c $3.5: 908$

LIBRARY

UNIVERSITY OF CALIFORNIA

DAVIS 



\section{Digitized by the Internet Archive in 2007 with funding from Microsoft Corporation}


DEPARTMENT OF COMMERCE AND LABOR

\section{BUREAU OF THE CENSUS}

E. DANA DURAND, DIRECTOR

\section{SPECIAL REPORTS}

\section{FISHERIES}

\section{OF THE UNITED STATES}

\section{8}




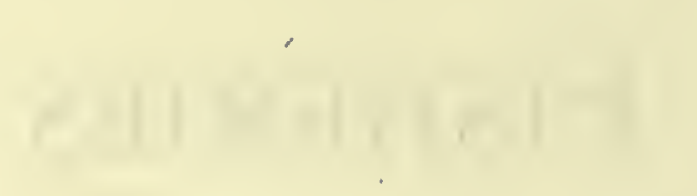

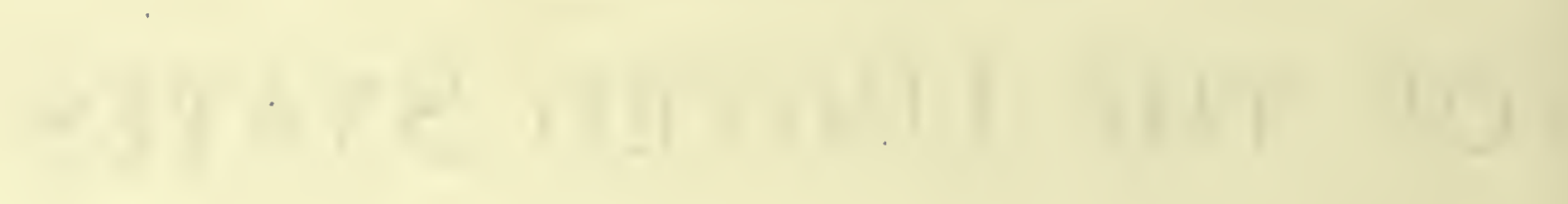




\section{CONTENTS.}

\section{CHAPTER I.}

INTronuCTION.

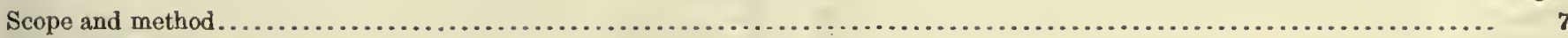

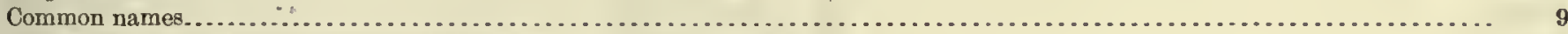

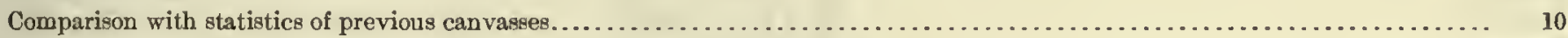

CHAPTER II.

Summary of STATIETICs.

Fisheries of the United States, by states: 1908

\section{CHAPTER III.}

Pergong Employed, Salarieg, and Wages.

Persons employed....

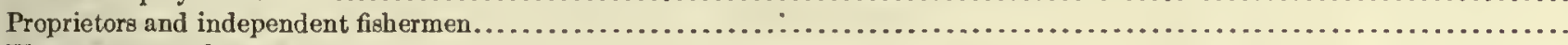

Wage-earners and wages.

Comparison with prior censuses.

\section{CHAPTER IV.}

Capttal and Equipment.

Vessels and boats.

Vessels and boats, by divisions.

Apparatus of capture.

Shore and accessory property and cash

Table 1.-Equipment and other capital: 1908.

Table 2.-Apparatus of capture: 1908.

Table 3.-Number, tonnage, and value of vessels and boats: 1908

CHAPTER V.

Pronucts.

Table 1.--Products, by general classes: 1908 and 1900 to 1904 .

Table 2.-Products, by species and by geographic divisions: 1908 .

Table 3.-Product, by class of fiseries, apparatus of capture, and geographic divison

Table 4.-Products, by species and by apparatus of capture: 1908.

Table 5.-Products-Detail summary, by states and by species: 1908

Table 6.-Products, by apparatus of capture and by states: 1908 .

CHAPTER VI.

Products of the Principal Fisherieg in Detall.

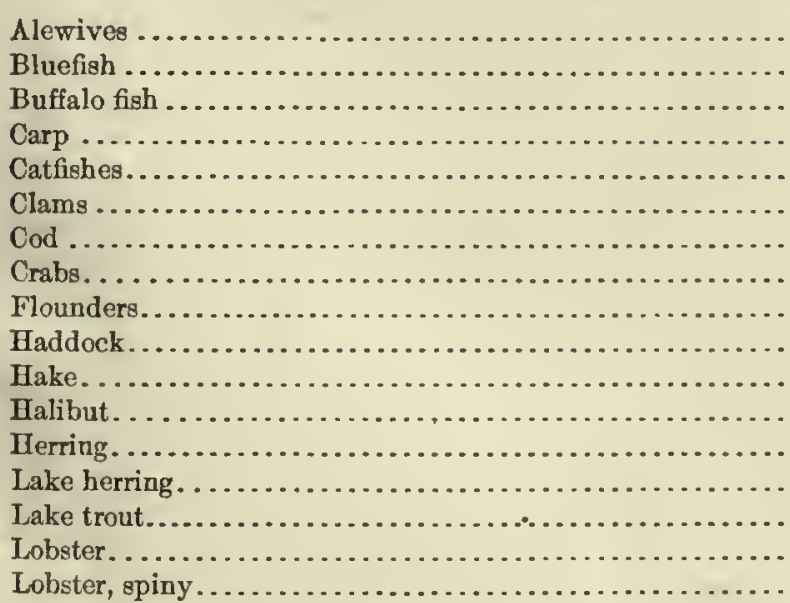

Page.

47

48

48

49

51

52

52

54

56

56

57

57

58

59

60

61

62
Mackerel

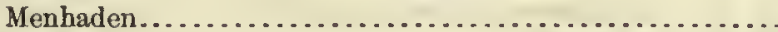

Mullets.....

65

Pike perches.................................. 68

Pollack.................................. $\quad 69$

Salmon................................... 69

Shad..................................... 71

Shrimp and prawn ................................... 72

Skins..................................... 73

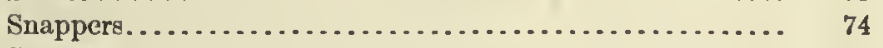
Sponge...................................... 74

Squeteague................................... 74

Sturgeons................................... 75

Whale products...................................... 76

Whitefish..................................... $\quad 77$ 
CHAPTER VII.

Fisheries, BY States.

Alabama.

\begin{tabular}{|c|c|}
\hline 79 & lisisour \\
\hline 82 & 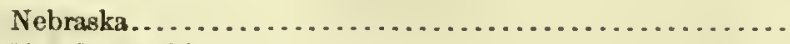 \\
\hline 84 & 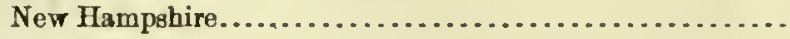 \\
\hline 91 & 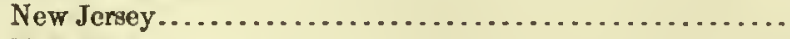 \\
\hline 96 & 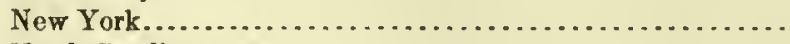 \\
\hline 100 & . \\
\hline 110 & Ohio. \\
\hline 113 & $\ldots \ldots \ldots \ldots \ldots$ \\
\hline 120 & . \\
\hline 124 & 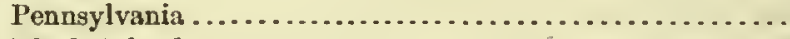 \\
\hline 126 & $\ldots \ldots \ldots \ldots \ldots \ldots$ \\
\hline 127 & 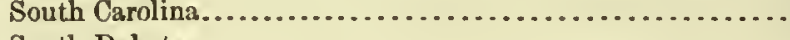 \\
\hline 130 & 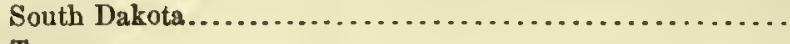 \\
\hline 138 & 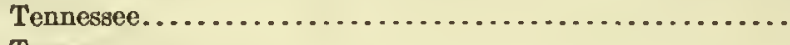 \\
\hline 145 & 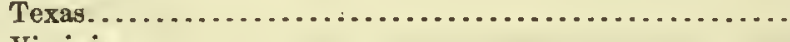 \\
\hline 152 & ( \\
\hline 165 & 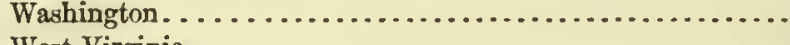 \\
\hline 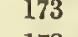 & nia.................................. \\
\hline 178 & \\
\hline
\end{tabular}

Arkansas.

Nebraska

California.

New Hampshire.

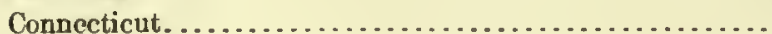

Delaware...

Florida.

(

Illinois.

Indian

Iowa.

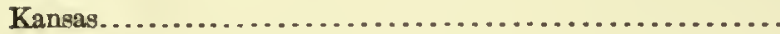

Kentucky

Louisiana.

Maine. .

Maryland . . . - .

Massachusetts.

Michigan.

Minnesota.

Mississippi

\section{CHAPTER VIII.}

Comparison with earlier canvasers.

Canning and Preserving.

Statistics, by geographic divisions.

Products, by kind.

Salmon.

Sardines.

Cod...

Oysters.

Shrimp and prawn.

Table 1.-Fish and oysters-value of food producta: 1908

Table 2.-Fish and oysters--products, by geographic divisions, method of treatment, and kind: 1908.

CHAPTER IX.

Comparison with domestic production

EXPORTA AND IMPQRTA.

Comparison of exports and imports.

Exports.

Imports .

Table 1.-Exports of domestic fishery products: 1908, 1900, and 1890.

Table 2.-Value of exports of domestic fishery products, by country to which exported: 1908, 1900, and 1890

Table 3.--Imports of fishery products, by kind and country from which imported: 1908, 1900, and 1890

Table 4.-Value of imports of fishery products, by country from which imported: 1908 , 1900, and 1890.

\section{APPENDICES.}

Appendix A.-The fisheries of Alaska in 1908.

Appendix B.-Schedules:

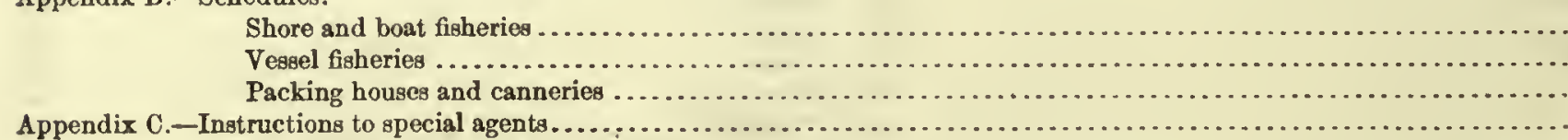

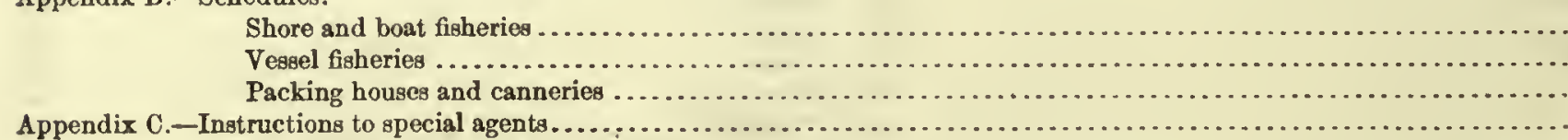

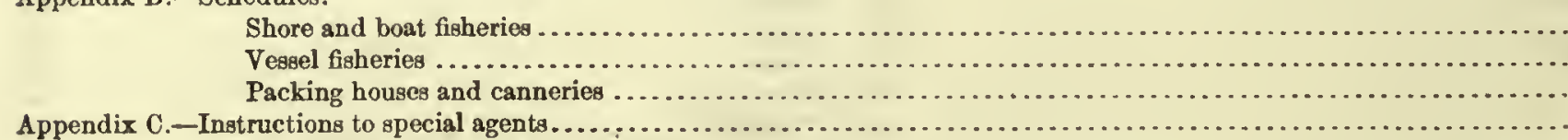

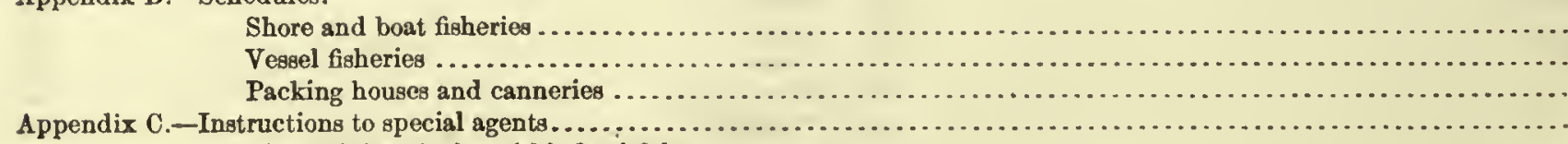

List and description of kinds of fish 


\section{LETTER OF TRANSMITTAL.}

Sir:

DEPARTMENT OF COMMERCE AND LABOR,

Bureau of the Census, Washington, D. C., July 27, 1911.

The act of Congress of June 7, 1906, provides that the Bureau of the Census shall take decennially, in cooperation with the Burcau of Fisheries, a census of the fishing industry of the United States.

I have the honor to submit herewith the report on the fisheries of the United States for the calendar year 1908 , which has been prepared in conformity with the requirements of this law. The report presents statistics concerning the capital invested in the industry, the number and tonnage of vessels and boats employed, the character of the apparatus used in catching fish, the number of persons employed, salaries and wages paid, and the quantity and value of the different varieties of products. Statistics of this character are collected from time to time by the Bureau of Fisheries, and as far as possible the census data have been compared with those compiled by that bureau. In order to preserve this comparability and also to comply with the requirements of the law, the Bureau of Fisheries was consulted in regard to the preparation of the schedules, and several employees of that bureau were detailed for work in the Bureau of the Census. These employees rendered valuable assistance, both in the office and in the field. The statistics were collected and the report was prepared under the supervision of Mr. William M. Steuart, chief statistician for manufactures.

Very respectfully,
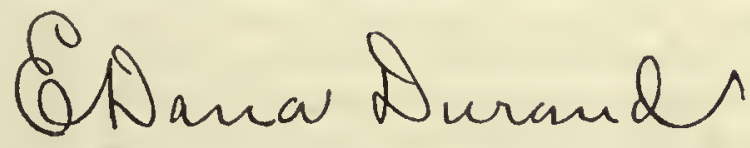

Director of the Census.

Hon. Ciiarles Nagel,

Secretary of Commerce and Labor. 



\title{
FISHERIES OF THE UNITED STATES.
}

\author{
CHAPTER I.
}

\section{INTRODUCTION.}

Scope and method.-The present report on the fisheries of the United States relates to the commercial fisheries of continental United States for the calendar year 1908, and is based on a canvass of these fisheries made by the Bureau of the Census in cooperation with the Bureau of Fisheries. A summary of the statistics of the fisheries of Alaska is given in the appendix on page 297, and in some of the tables in the chapter on canning and preserving figures for Alaska are included. The report is designed to cover shore fisheries, i. e., those carried on from shore or from boats of less than 5 tons; vessel fisheries, i. e., those conducted by vessels of 5 tons and over; the operations of vessels engaged in transporting fish from the fishing grounds, but not including vessels engaged in transporting fish from port to port as regular freight; and the business of packing and canning houses. The report does not cover the operations of individuals, clubs, etc., catching fish for their own consumption or for sport, or the business of those who deal in fish products simply as merchandise. The statisties are for the business year most nearly conforming to the year ending December 31, 1908; such data as relate to a fixed time, as cash on hand and value of property, relate to the beginning of the business year reported. The statistics as to the products include, besides the quantity and value of fish products proper, the number or quantity and value of aquatic mammals, reptiles, shellfish, sponges, etc., taken during the year.

The canvass was begun in January and finished in August of 1909. In order that it might be made thoroughly and rapidly, the entire country was divided into districts, to each of which one or more special agents were assigned, about 40 agents in all being employed. The Census Bureau was greatly assisted by the cooperation of the various state fish commissions and game wardens, with whom close relations were maintained. The agents were furnished with lists containing the names of fishing vessels and the names and addresses of the owners. They were instructed, however, not to confine their investigation to the names on these lists, which were prepared in some cases from records several years old, but to be constantly on the alert to discover vessels and establishments engaged in the fishing industry which were not listed. In addition to securing the information called for in the schedules each agent was required to obtain such other information as might prove valuable in determining the general condition and tendencies of the industry in the section of the country which he was canvassing.

A census of fisheries is attended perhaps with more difficulties than one of any other industry canvassed by the Bureau of the Census. Calling, as it does, for the number of persons employed and the investment in vessels, outfits, boats, and apparatus of capture both ashore and afloat, as well as the quantity and value of all commercial products of the seas, lakes, and rivers, it requires, in order that it be exhaustive, that a return be secured not only from all proprietors and firms engaged in the fishing business, but also from all independent fishermen who fish for profit. With respect to the vessel fisheries the problem was comparatively simple and the returns may be considered substantially accurate. All fishing craft of 5 tons or over are required to be documented, and as the names and home ports of these vessels are matters of record, and as such vessels are well known to the principal fishermen and fish dealers living in the district in which they operate, they and their owners could, as a rule, readily be located and canvassed. Moreover, the vessel fishermen usually make a regular business of fishing and keep books of record showing the species, amount, and value of the catch as well as other data called for in the schedules. The canvass is likewise essentially complete for the shore and boat fisheries so far as the operations of companies, firms, and individuals employing wage-earners are concerned, for these are, as a rule, located at the fishing centers and are known in the fish markets of their respective districts. The problem of securing reports from the independent fishermen, those who fish alone and do not employ others, was, however, especially difficult. These fishermen are scattered all along the coast, inlets, and waterways, many of them away from general routes of travel, and are consequently difficult of access. Their occupation takes them away from home much of the time, either in fishing or in transporting their catch to market; hence, with the corps of agents available for the work, it became a physical impossibility to make a personal canvass of each and every fisherman. within a reasonable period of time, as in order to do this an agent would have had to make repeated trips to the same 
locality to reach fishermen who were away at the time of former visits. In such cases the agent usually was able to secure satisfactory information from persons who were familiar with the operations of the fishermen. In addition to the difficulty just indicated in any canvass of the fisheries, a source of error arises in connection with the shore and boat fisheries from the fact that many of the shore and boat fishermen do not keep records of the catch, but give the information to the best of their recollection.

The extent to which the independent fishermen-that is, those fishing solely on their own accountfigure in the returns can be seen by referring to the statisties for Alabama. Although from these statistics the total number of independent fishermen in Alabama can not be ascertained, it appears from the figures that all the 77 fishermen on interior waters and more than 600 of the 647 engaged in the shore and boat fisheries of the Gulf were independent fishermen, showing that in the aggregate over 70 per cent of the total number employed in the fisheries of the state belonged to this class. This fact throws some light upon the conditions which were met, and indicates to some extent the difficulties attending an accurate canvass.

With almost invariable courtesy the fish dealers and principal fishermen in the different cities and towns visited assisted the agents engaged in the canvass by giving them the names and locations of the independent fishermen in the surrounding territory. The agents were likewise aided by the inspectors, fish and game wardens, and other state oflicials conversant with the fishing industry in the several states, who supplied the names of all proprietors, firms, or indopendent fishermen within their spheres of observation. Through these various channels and by constant inquiry of each fisherman reporting as to other unlisted independent fishermen in the neighborhood, it was possible for the agent to extend the canvass until it is believed that reports were secured from practically all commercial fishermen. In particular, a number of schedules were secured from fishermen who, although they had followed this occupation for a number of years, claimed they had never before been canvassed. The canvass did not cover Colorado, Idaho, Montana, Nevada, North Dakota, New Mexico, Utah, or Vermont, as the commercial fisheries, if any, which existed in these states were of minor importance.

Under these conditions it is probable that some apparent inconsistencies will appear from the comparison of the statistics with those compiled by the Bureau of Fisheries. Such inconsistencies as have been detected in the analysis of the data are of minor importance and are no indication that the statistics compiled by either office are wrong. The totals compiled by both offices can be safely accepted as representing the magnitude of the fishing industry of the United States, or the particular section of the country to which they pertain.
Three schedules were used in securing the dataone for the shore and boat fisherics, one for the vessel fisheries, and one for the canning and packing houses. The tables relating to the fishcries were prepared from the information secured on the first two schedules mentioned above.

In the statistical presentation the entire country is divided into five main divisions, as follows: Atlantic coast, Gulf of Mexico, Pacific coast, Great Lakes, and the Mississippi River and its tributaries. In connection with this division, which corresponds, gencrally speaking, to the principal bodies of water which bound the greater part of the United States and the large river system which occupies the great central valley, it will be noted that a fow states have fisheries in more than one division, as, for example, New York and Pennsylvania, which have fisheries in both the Atlantic coast and the Great Lakes divisions; Florida, which has fisheries on the Atlantic coast and also on the Gulf of Mexico; and Louisiana, which is represented in the Gulf fisheries as well as in those of the Mississippi. For purposes of comparison with previous statistics, the fisheries of the Atlantic coast are shown in a few tables in three divisions - those of the New England states, the Middle Atlantic states, and the South Atlantic states, respectively. The last-named group includes North Carolina, South Carolina, Georgia, and the east coast of Florida, and the Middle Atlantic division, all the Atlantic coast states from New York to Virginia, inclusive. In most of the states a distribution has been made according to the waters in which fishing was prosecuted; thus in Wisconsin separate statistics are presented for the fisheries of Lake Superior, Lake Michigan, and the Mississippi River and its tributaries. In Washington and in Oregon the fisheries of the Columbia River and its tributaries have been classed as a separate district, all the other waters in each of these states constituting a single district. In New York there are four divisions or fishing districts-Long Island Sound, all other waters of the Atlantic coast, Lake Erie, and Lake Ontario. On account of their importance, separate statistics are also given for the fisheries of Chesapeake Bay and its tributaries, which include portions of the fisheries of Delaware, Maryland, and Virginia, and the Susquehanna River fisheries of Pennsylvania and Maryland.

The catch has been credited to the port from which the fisherman sails, and therefore is not always credited to the state from whose waters it was taken. For example, California fishermen bring some of their eatch from Alaskan waters, and Connecticut oystermen take a great many oyster's from Rhode Island beds and from the New York waters of Long Island Sound.

Some 40 different kinds of apparatus of capture, including various forms of nets, pots, traps, lines, dredges, harpoons, and sponge apparatus, were used, and the tables show the principal forms employed in each division and class of fisheries. 
In order to show the total meat or marketable product of all fish, crustaceans, mollusks, and aquatic animals, it has been found desirable to reduce all to the common unit of a pound, although, in the trade, certain products are usually handled on the basis of bushels, barrels, or gallons. Where these species are treated separately the common trade unit of measurement for the species or product is used. In the general tables the quantities shown for the shell-bearing mollusks are based on the amount of meat contained, the figures used for estimating the meat contents being as follows: Hard clams and surf clams or skimmers, 8 pounds of meat per bushel, soft and razor clams, cockles, winkles, and mussels, 10 pounds of meat per bushel; oysters, 7 pounds of meat per bushel; and scallops, 6 pounds of meat per bushel.

The statistics of establishments engaged in canning and preserving fish and in the manufacture of various by-products have been classified by districts and states, by principal species used, and by method of treatment, whether boned, canned, salted, smoked, dried, or frozen. On account of the great value of the output of the canneries and salteries of Alaska, the statistics of that territory as reported by the Bureau of Fisheries have been included in some of the tables in the chapter on canning and preserving.

Common names.--The confusion in connection with the common names of fishes has naturally caused more or less difficulty in tabulating statistics of fisheries for the entire country. In some instances a single species of fish is known by a number of different names in the same section as well as in different sections of the country, and it also frequently happens that a single name will represent different species of fish in different localities. It is the exception, perhaps, rather than the rule, in the case of fishes usually taken in the commercial fisheries, to find a species that is not known by more than one common name. Such names as "herring," "trout," and "perch," are frequently applied by fishermen and others in various localities to species to which they do not properly belong, or which require that the name be supplemented with some qualifying word in order to be clearly understood. Even the familiar and generally well-understood name "shad" is, in Nortl Carolina, sometimes applied to the menhaden. In this report an effort has been made to list each species under a correct and well-established common name in the general tables, and at the same time in the tables for each state to use, so far as consistent, names which are applied locally.

Under "Albacore, or horse mackerel," are included the horse mackerel of the Atlantic coast, the tuna of California (Thunnus thynnus), and related species usually known as albacore. In the tables for California "albacore and tuna" includes Thunnus thynnus and related species, while the name "horse mackerel" is applied to Trachumes picturatus, as is the custom locally. The name "alewife" or "alewives" has been used exclusively to designate Pomolobus pseidoharengus $^{\prime}$ and $P$. xstivalis, although these species are very generally known in Chesapeake Bay, Albemarle Sound, and elsewhere in the Middle and South Atlantic states as herring, and in the New England states as alewives and bluebacks, respectively. The name "herring" has been used to designate Clupea harengus on the Atlantic coast and $C$. pallasii on the Pacific coast, while the various species of lake herring, Leucich thys artedi, L. hoyi, and other species of Leucichthys, which are locally known as herring in the Great Lakes region, have been designated as "lake herring;" and L. hoyi sometimes as "cliub," or "kieye." Under "bream and sunfish" are included various species of Lepomis and Eupomotis. The name "perch" is used in the tables for Washington, Oregon, and California for the viviparous perches, Cymatogaster aggregatus, Embiotoca jacksoni, Damalichthys argyrosomus, and other Embiotocidæ or surf-fishes. The name "surf-fish" is also applied to certain species of this family, and all the species tabulated under the head "viviparous perch" are in fact surf-fishes. "Drum, fresh-water" or "drum or sheepshead" is used for Aplodinotus grunniens, and "drum, saltwater" for Pogonias cromis and Sciznops ocellatus. "Channel bass" is also used as a designation for this latter species. "Sheepshead" is the term used to designate Archosargus probatocephalus. The name "halibut" is used exclusively for Hippoglossus hippoglossus, while the bastard halibut (Paralichthys californicus) of California is not shown separately, but is included with flounders. "Hickory shad" is applied to Pomolobus mediocris in waters on the Atlantic coast, and to P. chrysochloris in rivers of the Mississippi Valley. "Shad" is not applied in this report to any species except Alosa sapidissima, and $A$. ohiensis, and Brevoortia tyrrannus is given only as "menhaden." "Jewfish" is applied to Garrupa nigrita on the Atlantic coast, and to Stereolepis gigas on the Pacific coast. The names "kingfish" and "whiting" are used for various species of Menticirrhus on the Atlantic coast, while in Florida "kingfish" applies to Scomberomorus cavalla, but in the summary tables for the United States the two names are combined as a single designation for the various species of Menticirrhus, the kingfish on the Pacific coast being an entirely different species. Merluccius bilinearis in the New England and Middle Atlantic states is frequently known by the name "whiting," but in this report that species has been designated as "silver hake." The name "pigfish," and in Virginia the name "hogfish," designate Orthopristis chrysopterus, and in the summary tables for the entire country the two names combined represent this species, while in the tables for Florida "hogfish" is Lachnolaimus maximus, which is included among the miscellancous species in the summary statistics. In the statistics for Maine and Massachusetts the name "catfish" designates Anarhichas lupus, while 
in the statistics for other states "catfish" represents the various species of Siluridæ commonly known by that name. The name "pompano" on the Atlantic coast designates Trachinotus carolinus, the common pompano, but in the statistics for California this name represents Palometa simillima, which is one of the butterfishes, and is included with the butterfishes in the summary statistics.

Comparison with statistics of previous canvasses.Statistics of fishing industries for 1880 and 1889 were included in the reports of the Tenth and Eleventh censuses. Statistical reports on fisheries have also been issued fronı time to time by the Bureau of Fisheries in which only certain sections of the country are considered in any one year. The seven districts into which the United States has been divided for this purpose and the years for which statistics have been published are as follows: New England states, 188s, 1898, 1902, and 1905; Middle Atlantic states, 1888, 1892, 1897, 1901, and 1904; South Atlantic states, 1888, 1897, and 1902; Gulf states, 1888, 1890, 1897, and 1902; Pacific states, 1888, 1892, 1895, 1899, and 1904; Great Lakes $1885,1890,1899$, and 1903; and the Mississippi River and its tributaries, 1894,1899 , and 1903 . These reports show in detuil the number of persons engaged in the fisheries; the investment in fishing vessels, transporting vessels, boats, various apparatus of capture, and shore and accessory property, and the amount of cash capital; and the amount and value of products by species taken and by apparatus used. In the following table are presented the comparable statistics for the United States (exclusive of Alaska) for the censuses of 1908, 1889 , and 1880 , and a consolidation from selected reports of the Bureau of Fisheries made for the several districts mentioned above from 1900 to 1904. For the purpose of comparison the statistics as to the number of persons employed are confined to fishermen, exclusive of shoresmen, while those relating to the capital employed are confined to that invested in vessels and their outfits, boats, and apparatus of capture, and do not include capital invested in shore and accessory property or cash capital.

It will be observed that the items for each canvass show an increase over the corresponding figures for the last preceding canvass, except that the number of fishermen for the period 1900-1904 exceeds the number for 1908; the number of vessels shown for 1889 exceeds that for either of the subsequent canvasses; and the tonnage of vessels shows a decrease at each canvass, as compared with the preceding one.

In 1880 the investment in vessels formed 47 per cent of the total reported, and the investment in boats 12 per cent, while in 1908 the investment in vessels shows a decrease in relative importance to 41 per cent of the total, and that in boats an increase to 21 per cent. The proportion represented by investment in apparatus of capture and outfit shows but little variation41 per cent in 1880 and $3 S$ per cent in 1908 . The ratio of the capital invested to the value of products has progressively increased, the capital invested in vessels, boats, and apparatus of capture being equivalent to 63 per cent of the value of products in 1908 , compared with 53 per cent in 1880 .

\begin{tabular}{|c|c|c|c|c|}
\hline 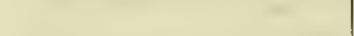 & 1908 & $1900-1904^{1}$ & 1889 & 1880 \\
\hline $\begin{array}{l}\text { Number of fishermen, exclusiva } \\
\text { of shoresmen......................... }\end{array}$ & 141,031 & 151,561 & 134,923 & - $\quad 95,684$ \\
\hline $\begin{array}{l}\text { Capltal, not including shore and } \\
\text { accessory property and cash... }\end{array}$ & $\$ 34,099,000$ & $828,590,000$ & $323,328,000$ & $\$ 19,801,000$ \\
\hline 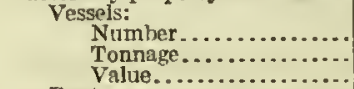 & $\begin{array}{r}6,933 \\
126,4.53 \\
\$ 13,806,000\end{array}$ & $\begin{array}{r}6,740 \\
130,432 \\
311,297,000\end{array}$ & $\begin{array}{r}7,209 \\
157,209 \\
\$ 1,343,000\end{array}$ & $\begin{array}{r}6,605 \\
208,298 \\
\$ 9,357,000\end{array}$ \\
\hline 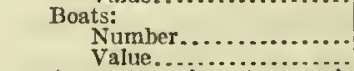 & $\begin{array}{r}83,548 \\
\$ 7,269,000\end{array}$ & $\begin{array}{r}80,516 \\
\$ 5,179,000\end{array}$ & $\begin{array}{r}79,539 \\
\$ 4,734,000\end{array}$ & $\begin{array}{r}41,804 \\
\$ 2,405,000\end{array}$ \\
\hline $\begin{array}{c}\text { Apparatus of capture and } \\
\text { outfit..................... }\end{array}$ & $\$ 13,025,000$ & $\$ 12,115,000$ & $\$ 8,251,000$ & $\$ 8,138,000$ \\
\hline 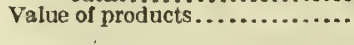 & $854,031,000$ & $\$ 49,398,000$ & $\$ 42,904,000$ & $\$ 37,789,000$ \\
\hline
\end{tabular}

1 Combined statistlcs for tha New England states, South Atlantic states, and Crulf states for 1902; Great Lakes and Mississippl Rlver and Its trlbutarles for 1903; Middile Atlantlc states and Pacific coast states for 1904; and minor Interlor waters for 1900-
1903 .

The following table shows the value of products of the specified fisheries for certain years:

\begin{tabular}{|c|c|c|c|c|}
\hline \multirow{2}{*}{ CLASS OF FISHERIES. } & \multicolumn{4}{|c|}{ VALUE OF PRODUCTS. } \\
\hline & 1908 & $1900-1904^{3}$ & 1889 & 1880 \\
\hline & \multicolumn{4}{|c|}{ A MOUNT. } \\
\hline Total..... & $854,031,000$ & $\$ 49,398,000$ & $\$ 42,780,000$ & $839,885,000$ \\
\hline \multirow[t]{2}{*}{ 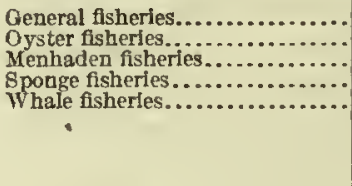 } & $\begin{array}{r}36,382,000 \\
15,713,000 \\
893,000 \\
545,000 \\
497,000\end{array}$ & $\begin{array}{r}30,101,000 \\
16,681,000 \\
1,426,000 \\
364,000 \\
824,000\end{array}$ & $\begin{array}{r}25,689,000 \\
13,294,000 \\
1,818,000 \\
282,000 \\
1,698,000\end{array}$ & $\begin{array}{r}21,840,000 \\
13,404,000 \\
2,117,000 \\
201,000 \\
2,323,000\end{array}$ \\
\hline & \multicolumn{4}{|c|}{ PER CENT DISTRIBUTION. } \\
\hline Total.................... & 100 & 100 & 100 & 100 \\
\hline 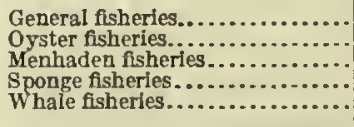 & $\begin{array}{r}67 \\
29 \\
2 \\
1 \\
1\end{array}$ & $\begin{array}{r}61 \\
34 \\
3 \\
1 \\
2\end{array}$ & $\begin{array}{r}60 \\
31 \\
4 \\
1 \\
4\end{array}$ & $\begin{array}{r}57 \\
31 \\
5 \\
1 \\
5\end{array}$ \\
\hline
\end{tabular}

1 Comblned statlstics for the New England states, South Atlantlc states, and Gulf states for 1902; Great Lakes and Mississippi RIver and its tributaries for 1903; Middle Atlantic states and Paclfic coast states for 1904; and minor Interior waters for $1900-1903$.

The decline in the value of products of the whale and menhaden fisheries is marked, while large gains are shown for the value of products of the general fisheries and the sponge fisheries. The oyster fisheries show a general increase in value of products, although a larger value was reported for the period from 1900-1904 than for either 1908 or 1889. 


\section{CHAPTER II.}

\section{SUMMARY OF STATISTICS.}

The general statistics for the United States and for the five divisions are summarized in the following table:

\begin{tabular}{|c|c|c|c|c|c|c|c|c|c|c|c|}
\hline & \multirow[b]{2}{*}{ Total. } & \multirow[b]{2}{*}{$\begin{array}{l}\text { Atlantic } \\
\text { coast } \\
\text { divislon. }\end{array}$} & \multirow[b]{2}{*}{$\begin{array}{l}\text { Gulf of } \\
\text { Mexico } \\
\text { dlvision. }\end{array}$} & \multirow[b]{2}{*}{$\begin{array}{l}\text { Pacific } \\
\text { coast } \\
\text { division. }\end{array}$} & \multirow[b]{2}{*}{$\begin{array}{c}\text { Mississippi } \\
\text { River } \\
\text { dlvision. }\end{array}$} & \multirow[b]{2}{*}{$\begin{array}{c}\text { Great } \\
\text { Lakes } \\
\text { divislon. }\end{array}$} & \multicolumn{5}{|c|}{ PER CENT OE TOTAL. } \\
\hline & & & & & & & $\begin{array}{l}\text { Atlantic } \\
\text { coast } \\
\text { divlsion. }\end{array}$ & $\begin{array}{l}\text { Gulf of } \\
\text { Mexico } \\
\text { division. }\end{array}$ & $\begin{array}{c}\text { Pacific } \\
\text { coast } \\
\text { division. }\end{array}$ & $\begin{array}{l}\text { Mississip- } \\
\text { pi River } \\
\text { divislon. }\end{array}$ & $\begin{array}{c}\text { Great } \\
\text { Lakes } \\
\text { divislon. }\end{array}$ \\
\hline 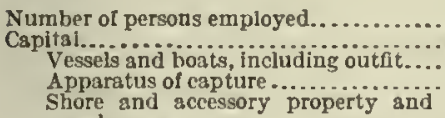 & $\begin{array}{r}143,881 \\
\$ 42,021,000 \\
25,101,000 \\
8,999,000\end{array}$ & $\begin{array}{r}94,281 \\
825,398,000 \\
16,553,000 \\
3,822,000\end{array}$ & $\begin{array}{r}15,481 \\
\$ 3,901,000 \\
2,805,000 \\
374,000\end{array}$ & $\begin{array}{r}13,855 \\
\$ 6,468,000 \\
3,544,000 \\
2,459,000\end{array}$ & $\begin{array}{r}11,731 \\
\$ 1,440,000 \\
547,000 \\
514,000\end{array}$ & $\begin{array}{r}8,533 \\
\$ 4,814,000 \\
1,651,000 \\
1,831,000\end{array}$ & $\begin{array}{l}66 \\
60 \\
66 \\
42\end{array}$ & $\begin{array}{r}11 \\
9 \\
11 \\
4\end{array}$ & $\begin{array}{l}10 \\
15 \\
14 \\
27\end{array}$ & $\begin{array}{l}8 \\
3 \\
2 \\
6\end{array}$ & $\begin{array}{r}6 \\
11 \\
20\end{array}$ \\
\hline 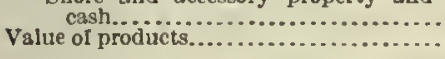 & $\begin{array}{r}7,921,000 \\
54,031,000\end{array}$ & $\begin{array}{r}5,023,000 \\
35,474,000\end{array}$ & $\begin{array}{r}722,000 \\
4,825,000\end{array}$ & $\begin{array}{r}465,000 \\
6,839,000\end{array}$ & $\begin{array}{r}379,000 \\
3,125,000\end{array}$ & $\begin{array}{l}1,332,000 \\
3,767,000\end{array}$ & $\begin{array}{l}63 \\
66\end{array}$ & $\begin{array}{l}9 \\
9\end{array}$ & $\begin{array}{r}6 \\
13\end{array}$ & 5 & $\begin{array}{r}17 \\
7\end{array}$ \\
\hline
\end{tabular}

The fisheries of the Atlantic coast division contributed nearly two-thirds of the total number of persons employed, the value of products, the capital invested in ressels and boats, and that invested in shore and accessory property, together with cash capital, though they represented a somewhat smaller proportion of the capital invested in apparatus of capture.

On account of the relatively large investment in apparatus of capture in the Pacific coast and the Great Lakes divisions, in the former chiefly in the form of the wheels and slides used in the salmon fisheries and in the latter chiefly in the form of pound nets and traps, these two divisions rank second and third, respectively, in the amount of capital employed. The investment in vessels reported for the Pacific coast division is also relatively large, as is the investment in accessory property, together with cash capital, reported for the Great Lakes division. In the value of products reported the Pacific coast fisheries rank next to those of the Atlantic coast.

Because of the prominence of the fisheries of the New England states, chiefly on account of the deep-sea fisheries, and of the Middle Atlantic states, on account of the oyster fisheries, a summary of the statisties of the Atlantic coast division by state groups is here given.

\begin{tabular}{|c|c|c|c|c|c|c|c|}
\hline \multirow{2}{*}{. } & \multirow{2}{*}{$\begin{array}{l}\text { Atlantic } \\
\text { coast } \\
\text { dlvision. }\end{array}$} & \multirow{2}{*}{$\begin{array}{l}\text { New } \\
\text { England } \\
\text { states. }\end{array}$} & \multirow{2}{*}{$\begin{array}{l}\text { Middle } \\
\text { A tlantic } \\
\text { states. }\end{array}$} & \multirow{2}{*}{$\begin{array}{l}\text { South } \\
\text { Atiantic } \\
\text { states. }\end{array}$} & \multicolumn{3}{|c|}{ PER CENT OF TOTAL. } \\
\hline & & & & & $\begin{array}{l}\text { New } \\
\text { England } \\
\text { states. }\end{array}$ & $\begin{array}{l}\text { Middle } \\
\text { Atlantic } \\
\text { states. }\end{array}$ & $\begin{array}{l}\text { South } \\
\text { Atlantio } \\
\text { states. }\end{array}$ \\
\hline 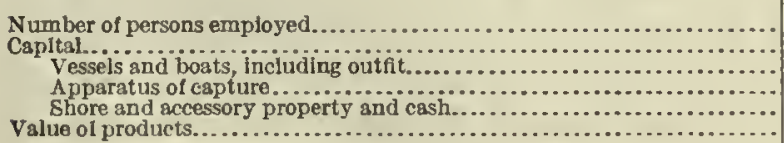 & $\begin{array}{r}94,281 \\
\$ 25,398,000 \\
16,553,000 \\
3,822,000 \\
5,023,000 \\
35,474,000\end{array}$ & $\begin{array}{r}22,157 \\
\$ 11,970,000 \\
8,201,000 \\
1,675,000 \\
2,094,000 \\
15,139,000\end{array}$ & $\begin{array}{r}54,163 \\
\$ 11,105,000 \\
7,280,000 \\
1,578,000 \\
2,248,000 \\
16,302,000\end{array}$ & $\begin{array}{r}17,961 \\
\$ 2,324,000 \\
1,073,000 \\
569,000 \\
682,000 \\
4,034,000\end{array}$ & $\begin{array}{l}24 \\
47 \\
50 \\
44 \\
42 \\
43\end{array}$ & $\begin{array}{l}57 \\
44 \\
44 \\
41 \\
45 \\
40\end{array}$ & $\begin{array}{r}19 \\
9 \\
6 \\
15 \\
14 \\
11\end{array}$ \\
\hline
\end{tabular}

Chesapeake Bay is the most important fishing ground on the Atlantic coast. The fishermen of the Chesapeake Bay fisheries, including those of its tributary waters, formed more than one-third of the total number employed in the Atlantic coast fisheries in 1908, and the value of the products of the Chesa- peake Bay fisheries constituted more than one-fifth of the value of all products of the Atlantic coast fisheries. As the fisheries of Chesapeake Bay and its tributaries cover portions of four states, a summary of the statistics, by states, is given in the following table: 


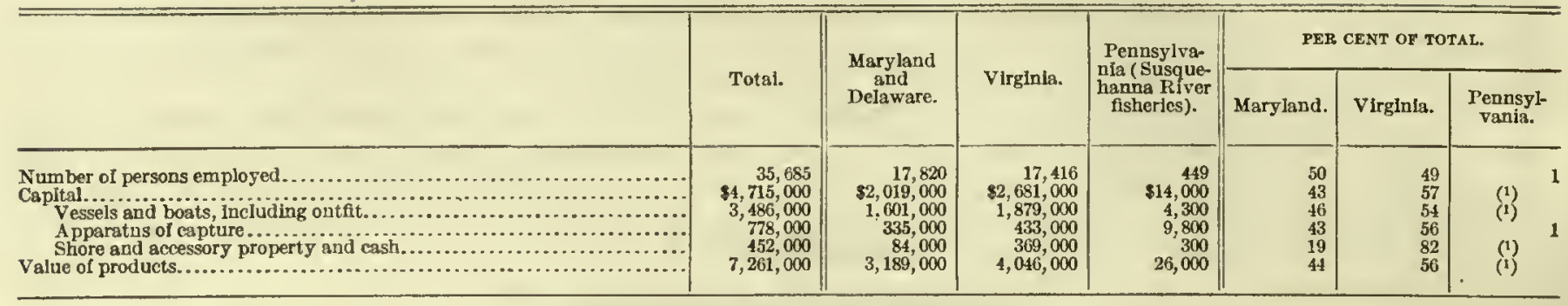

1 Less than 1 per cent.

With the exception of the number of persons employed, Virginia leads Maryland in every respect. The number of persons employed in the Chesapeake Bay fisheries is larger than the number reported for any of the other divisions of the Atlantic coast waters. Of the total capital employed, 74 per cent represents the value of vessels and boats, including outfits, 17 per cent the value of apparatus of capture, and 10 per cent the value of shore and accessory property and cash, the investment in vessels, boats, and outfits being the largest proportionately reported for any district or subdivision. The products of the Delaware fisheries which were conducted on tributaries of Chesapeake Bay consisted principally of shad. Fourteen fishermen, using boats and apparatus of capture valued at $\$ 400$, took products valued at $\$ 2,100$.

The following table is a summary of the general statistics for the fisheries of the Great Lakes and their tributary waters, classified according to the six principal bodies of water comprising the division, namely: Lake Superior, Lake Michigan, Lake Huron, Lake St. Clair and the St. Clair and Detroit Rivers, Lake Erie, and Lake Ontario, with which are included the Niagara and St. Lawrence Rivers:

\begin{tabular}{|c|c|c|c|c|c|c|c|c|c|c|c|c|c|}
\hline & \multirow[b]{2}{*}{ Total. } & \multirow[b]{2}{*}{$\begin{array}{l}\text { Lake } \\
\text { Superior. }\end{array}$} & \multirow[b]{2}{*}{$\begin{array}{l}\text { Lake } \\
\text { Michigan. }\end{array}$} & \multirow[b]{2}{*}{$\begin{array}{l}\text { Lake } \\
\text { Huron. }\end{array}$} & \multirow[b]{2}{*}{$\begin{array}{l}\text { Lake St. } \\
\text { Clair and } \\
\text { St. Clair } \\
\text { and } \\
\text { Detroit } \\
\text { Rivers. }\end{array}$} & \multirow[b]{2}{*}{$\begin{array}{l}\text { Lake } \\
\text { Erie. }\end{array}$} & \multirow[b]{2}{*}{$\begin{array}{c}\text { Lake } \\
\text { Ontario, } \\
\text { Including } \\
\text { Nlagara } \\
\text { and St. } \\
\text { Lawrence } \\
\text { Rlvers. }\end{array}$} & \multicolumn{6}{|c|}{ PER CENT OF TOTAL. } \\
\hline & & & & & & & & $\begin{array}{l}\text { Lake } \\
\text { Supe- } \\
\text { ríor. }\end{array}$ & $\begin{array}{l}\text { Lake } \\
\text { Milchl- } \\
\text { gan. }\end{array}$ & $\begin{array}{l}\text { Lake } \\
\text { Huron. }\end{array}$ & $\begin{array}{c}\text { Lake } \\
\text { St. Clair } \\
\text { and St. } \\
\text { Clair } \\
\text { and } \\
\text { Detroit } \\
\text { Rivers. }\end{array}$ & \begin{tabular}{|l|} 
\\
Lake \\
Erie.
\end{tabular} & $\begin{array}{l}\text { Lake } \\
\text { Ontarlo, } \\
\text { including } \\
\text { Niagara } \\
\text { and St. } \\
\text { Lawrence } \\
\text { Rivers. }\end{array}$ \\
\hline 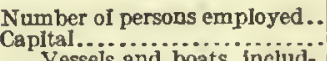 & $\begin{array}{r}8,533 \\
34,814,000\end{array}$ & $\begin{array}{r}786 \\
\$ 391,000\end{array}$ & $\begin{array}{r}2,706 \\
\$ 1,965,000\end{array}$ & $\begin{array}{r}1,382 \\
\$ 733,000\end{array}$ & $\begin{array}{r}221 \\
\$ 46,000\end{array}$ & $\begin{array}{r}3,142 \\
\$ 1,644,000\end{array}$ & $\$ 35,000$ & $\begin{array}{l}9 \\
8\end{array}$ & $\begin{array}{l}32 \\
41\end{array}$ & $\begin{array}{l}16 \\
15\end{array}$ & $\begin{array}{l}3 \\
1\end{array}$ & $\begin{array}{l}37 \\
34\end{array}$ & $\begin{array}{l}3 \\
1\end{array}$ \\
\hline $\begin{array}{l}\text { Vessels and boats, includ- } \\
\text { ing outfit } \\
\text { Apparatus of capture.......... }\end{array}$ & $\begin{array}{l}1,651,000 \\
1,831,000\end{array}$ & $\begin{array}{l}149,000 \\
159,000\end{array}$ & $\begin{array}{l}692,000 \\
753,000\end{array}$ & $\begin{array}{l}185,000 \\
281,000\end{array}$ & $\begin{array}{r}10,000 \\
8,000\end{array}$ & $\begin{array}{l}603,000 \\
615,000\end{array}$ & $\begin{array}{l}11,000 \\
16,000\end{array}$ & $\begin{array}{l}9 \\
9\end{array}$ & $\begin{array}{l}42 \\
41\end{array}$ & $\begin{array}{l}11 \\
15\end{array}$ & (1) 1 & $\begin{array}{l}37 \\
34\end{array}$ & $\begin{array}{l}1 \\
1\end{array}$ \\
\hline $\begin{array}{c}\text { erty and cash............... } \\
\text { Value of products............. }\end{array}$ & $\begin{array}{l}1,332,000 \\
3,767,000\end{array}$ & $\begin{array}{r}83,000 \\
342,000\end{array}$ & $\begin{array}{r}519,000 \\
1,554,000\end{array}$ & $\begin{array}{l}267,000 \\
486,000\end{array}$ & $\begin{array}{l}28,000 \\
32,000\end{array}$ & $\begin{array}{r}426,000 \\
1,280,000\end{array}$ & $\begin{array}{r}7,900 \\
74,000\end{array}$ & $\begin{array}{l}6 \\
9\end{array}$ & $\begin{array}{l}39 \\
41\end{array}$ & $\begin{array}{l}20 \\
13\end{array}$ & $\begin{array}{l}2 \\
1\end{array}$ & $\begin{array}{l}32 \\
34\end{array}$ & $\begin{array}{l}1 \\
2\end{array}$ \\
\hline
\end{tabular}

${ }^{1}$ Less than 1 per cent.

Ranked according to the value of fishery products, Lake Michigan was first, with Lake Erie, Lake Huron, Lake Superior, Lake Ontario, and Lake St. Clair and its adjacent rivers following in the order named, the first two named reporting three-fourths of the total. The order was the same in respect to the amount of capital employed in the fisheries, except that Lake St.
Clair and its adjacent rivers ontranked Lake Ontario; and, as in the case of value of products, three-fourths of the total capital of the division was reported for Lakes Michigan and Erie. A larger number of persons employed was reported from Lake Erie than from Iake Michigan; otherwise, the lakes follow the same order in respect to this item as in the case of value of products. 
SUMMARY-FISHERIES OF THE UNITED STATES, BY STATES : $1908 .{ }^{1}$

\begin{tabular}{|c|c|c|c|c|c|c|c|c|}
\hline \multirow{2}{*}{ STATE. } & \multirow{2}{*}{$\begin{array}{c}\text { Number of } \\
\text { persons } \\
\text { employed. }\end{array}$} & \multicolumn{2}{|c|}{ VESSELS. } & \multicolumn{2}{|c|}{ noATs. } & \multirow{2}{*}{$\begin{array}{c}\text { Value of } \\
\text { apparatus } \\
\text { of capture. }\end{array}$} & \multirow{2}{*}{$\begin{array}{l}\text { Value of } \\
\text { accessory } \\
\text { property } \\
\text { and cash. }\end{array}$} & \multirow{2}{*}{$\begin{array}{l}\text { Value of } \\
\text { products. }\end{array}$} \\
\hline & & Number. & $\begin{array}{l}\text { Value, In- } \\
\text { cluding } \\
\text { outfit. }\end{array}$ & Number. & Value. & & & \\
\hline Total....................... & 143,881 & 6,933 & $\$ 17,831,000$ & 83,549 & $\$ 7,269,000$ & $88,999,000$ & $\$ 7,921,000$ & $\$ 54,031,000$ \\
\hline 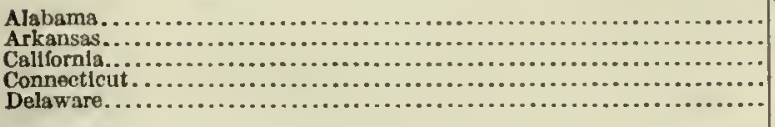 & $\begin{array}{r}972 \\
998 \\
4,129 \\
2,147 \\
1,756\end{array}$ & $\begin{array}{r}61 \\
6 \\
60 \\
243 \\
65\end{array}$ & $\begin{array}{r}130,000 \\
8,100 \\
573,000 \\
994,000 \\
334,000\end{array}$ & $\begin{array}{r}670 \\
1,154 \\
2,121 \\
1,069 \\
792\end{array}$ & $\begin{array}{r}34,000 \\
37,000 \\
493,000 \\
118,000 \\
38,000\end{array}$ & $\begin{array}{r}23,000 \\
31,000 \\
502,000 \\
84,000 \\
63,000\end{array}$ & $\begin{array}{r}82,000 \\
13,000 \\
91,000 \\
1,086,000 \\
9,500\end{array}$ & $\begin{array}{r}387,000 \\
207,000 \\
1,970,000 \\
2,982,000 \\
541,000\end{array}$ \\
\hline 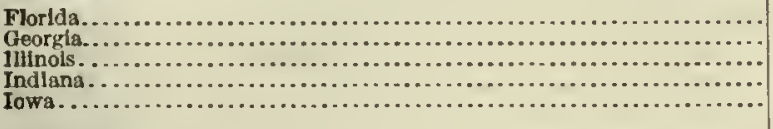 & $\begin{array}{r}9,212 \\
2,525 \\
4,439 \\
986 \\
786\end{array}$ & $\begin{array}{r}327 \\
88 \\
17 \\
2 \\
\cdots\end{array}$ & $\begin{array}{r}846,000 \\
90,000 \\
47,000 \\
7,700 \\
\cdots\end{array}$ & $\begin{array}{l}5,702 \\
2,791 \\
4,222 \\
937 \\
832\end{array}$ & $\begin{array}{r}575,000 \\
79,000 \\
234,000 \\
16,000 \\
38,000\end{array}$ & $\begin{array}{r}326,000 \\
55,000 \\
272,000 \\
28,000 \\
29,000\end{array}$ & $\begin{array}{r}668,000 \\
185,000 \\
295,000 \\
22,000 \\
11,000\end{array}$ & $\begin{array}{r}3,389,000 \\
701,000 \\
1,436,000 \\
223,000 \\
215,000\end{array}$ \\
\hline 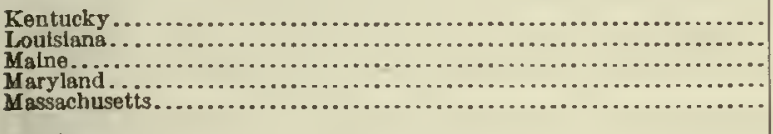 & $\begin{array}{r}5555 \\
5,795 \\
6,861 \\
18,392 \\
11,577\end{array}$ & $\begin{array}{r}222 \\
575 \\
1,107 \\
671\end{array}$ & $\begin{array}{r}441,000 \\
1,007,000 \\
1,001,000 \\
4,282,000\end{array}$ & $\begin{array}{r}511 \\
4,469 \\
6,969 \\
8,493 \\
3,694\end{array}$ & $\begin{array}{r}11,000 \\
354,000 \\
662,000 \\
644,000 \\
477,000\end{array}$ & $\begin{array}{r}21,000 \\
95,000 \\
576,000 \\
369,000 \\
775,000\end{array}$ & $\begin{array}{r}6,600 \\
40,000 \\
166,000 \\
86,000 \\
215,000\end{array}$ & $\begin{array}{r}110,000 \\
1,569,000 \\
3,257,000 \\
3,306,000 \\
7,095,000\end{array}$ \\
\hline 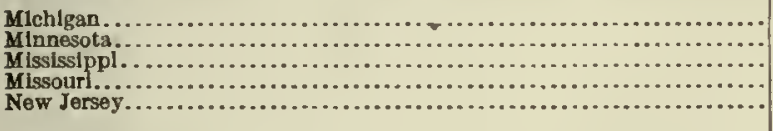 & $\begin{array}{r}3,472 \\
934 \\
2,037 \\
906 \\
7,231\end{array}$ & $\begin{array}{r}110 \\
4 \\
206 \\
435\end{array}$ & $\begin{array}{r}327,000 \\
16,000 \\
372,000 \\
709,000\end{array}$ & $\begin{array}{r}1,647 \\
689 \\
1,144 \\
785 \\
3,843\end{array}$ & $\begin{array}{r}267,000 \\
36,000 \\
46,000 \\
25,000 \\
391,000\end{array}$ & $\begin{array}{r}821,000 \\
43,000 \\
58,000 \\
39,000 \\
345,000\end{array}$ & $\begin{array}{r}599,000 \\
33,000 \\
46,000 \\
27,000 \\
269,000\end{array}$ & $\begin{array}{r}1,473,000 \\
192,000 \\
556,000 \\
271,000 \\
3,069,000\end{array}$ \\
\hline 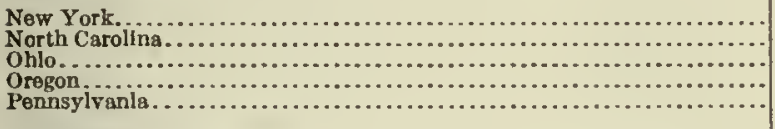 & $\begin{array}{l}6,775 \\
9,681 \\
2,054 \\
4,772 \\
1,250\end{array}$ & $\begin{array}{r}643 \\
299 \\
54 \\
44 \\
66\end{array}$ & $\begin{array}{r}1,750,000 \\
282,000 \\
215,000 \\
140,000 \\
254,000\end{array}$ & $\begin{array}{r}3,131 \\
4,984 \\
1,083 \\
2,312 \\
333\end{array}$ & $\begin{array}{r}308,000 \\
251,000 \\
141,000 \\
367,000 \\
26,000\end{array}$ & $\begin{array}{l}362,000 \\
367,000 \\
423,000 \\
795,000 \\
114,000\end{array}$ & $\begin{array}{r}1,413,000 \\
370,000 \\
343,000 \\
65,000 \\
87,000\end{array}$ & $\begin{array}{r}4,594,000 \\
1,776,000 \\
840,000 \\
1,356,000 \\
513,000\end{array}$ \\
\hline 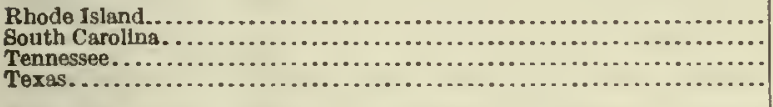 & $\begin{array}{r}1,493 \\
2,559 \\
427 \\
1,780\end{array}$ & $\begin{array}{l}138 \\
108 \\
157\end{array}$ & $\begin{array}{r}515,000 \\
50,000 \\
269,000\end{array}$ & $\begin{array}{r}815 \\
1,719 \\
399 \\
991\end{array}$ & $\begin{array}{r}133,000 \\
42,000 \\
9,400 \\
117,000\end{array}$ & $\begin{array}{r}230,000 \\
16,000 \\
27,000 \\
41,000\end{array}$ & $\begin{array}{r}627,000 \\
5,400 \\
13,000 \\
26,000\end{array}$ & $\begin{array}{r}1,752,000 \\
288,000 \\
112,000 \\
446,000\end{array}$ \\
\hline 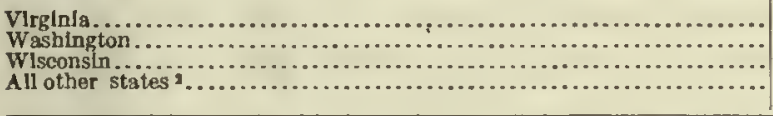 & $\begin{array}{r}20,066 \\
4,954 \\
2,011 \\
349\end{array}$ & $\begin{array}{r}946 \\
190 \\
89\end{array}$ & $\left|\begin{array}{r}1,332,000 \\
1,594,000 \\
244,000 \\
\cdots\end{array}\right|$ & $\begin{array}{r}10,942 \\
2,798 \\
1,200 \\
308\end{array}$ & $\begin{array}{r}733,000 \\
377,000 \\
173,000 \\
18,000\end{array}$ & $\begin{array}{r}485,000 \\
1,162,000 \\
407,000 \\
17,000\end{array}$ & $\begin{array}{r}434,000 \\
309,000 \\
276,000 \\
3,900\end{array}$ & $\begin{array}{r}4,716,000 \\
3,513,000 \\
1,067,000 \\
110,000\end{array}$ \\
\hline
\end{tabular}

1 Exclusive of Alaska.

Includes Kansas, Nebraska, New Hampshire, Oklahoma, South Dakota, and West Virginla. 


\section{OHAPTER III.}

\section{PERSONS EMPLOYED, SALARIES, AND WAGES.}

Persons employed.-The census was intended to include a report of all persons actually engaged in commercial fishing, whether on vessels, in boats, or on the shore.

The instructions to the special agents in regard to the enumeration of the persons employed were in part as follows:

Proprietors, firm members, and independent fishermen.-Stockholders of corporations should not be reported unless they are also employees of the company. A person fishing on shares, delivering a part of the catch to another person and selling the remainder, should not be considered as an independent fisherman; in this case the person to whom a part of the catch was delivered should be considered the proprietor. It is desired to show in the report the total number of persons engaged in fishing. For this reason it is necessary to indicate whether the proprietor was actually engaged in fishing. In the great majority of cases the proprietor will be found to be so engaged, but in cases where he is not, this fact should be indicated in the space provided. If the ownership of the vessel is in shares, a number of which are held by parties who take no part in its management, these parties should be reported as "shareholders." Persons reported in inquiries 2,3 , and 4 should not be duplicated when more than one schedule is secured for operations carried on under the same ownership.

Salaried employees.-There will probably be comparatively few cases where it will be necessary to answer this inquiry. It applies only to large companies having a managing office in which records of the fishing are kept by salaried employees. Persons reported in this inquiry should not be reported on another schedule.

Vessel crew.-The regular crew, including the fishermen on the vessel, should be reported as "vessel crew." If the captain or any other member of the crew has been reported as a proprietor, he should not be reported here. Where fishermen are working on shares, it will be necessary to estimate the annual wages. Where board is provided for fishermen as part compeneation, the value of provisions thus used should not be included in wages, but should be reported separately as provided for in the schedule.

The number of shoresmen reported represents only persons employed on shore in direct connection with the fisheries, and does not include those employed in secondary handling of fishery products in canneries, packing houses, and other establishments. For these reasons the number of persons reported as shoresmen is not comparable in all cases with the number shown by the Bureau of Fisheries in its various annual reports, which includes those employed in fish-packing and canning establishments. The statistics for the canneries and packing houses are given in Chapter VIII.

\begin{tabular}{|c|c|c|c|c|c|c|c|}
\hline \multirow[b]{3}{*}{ DIVISION AND CIASS. } & \multicolumn{7}{|c|}{ PERSONS EMPLOYED: 1908.} \\
\hline & \multicolumn{4}{|c|}{ Number. } & \multicolumn{3}{|c|}{ Salaries and wages. } \\
\hline & Total. & $\begin{array}{l}\text { Proprie- } \\
\text { tors and } \\
\text { independ- } \\
\text { ent fisher- } \\
\text { men. }\end{array}$ & $\begin{array}{l}\text { Salaried } \\
\text { employ- } \\
\text { ees. }\end{array}$ & $\begin{array}{l}\text { Wage- } \\
\text { earners. }\end{array}$ & Total. & Salaries. & Wages. \\
\hline United States.................. & 143,881 & 172,030 & 350 & 71,501 & $\$ 16,377,000$ & $\$ 319,000$ & $316,058,000$ \\
\hline 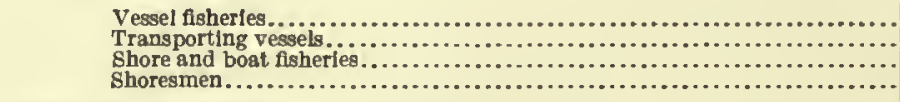 & $\begin{array}{r}31,879 \\
4,508 \\
104,644 \\
2,850\end{array}$ & $\begin{array}{r}4,248 \\
1,050 \\
66,732 \\
\end{array}$ & $\begin{array}{r}231 \\
23 \\
96 \\
\cdots \\
\end{array}$ & $\begin{array}{r}27,400 \\
3,435 \\
37,816 \\
2,850 \\
\end{array}$ & $\begin{array}{r}8,230,000 \\
943,000 \\
6,449,000 \\
755,000 \\
\end{array}$ & $\begin{array}{r}220,000 \\
20,000 \\
79,000 \\
\end{array}$ & $\begin{array}{r}8,010,000 \\
923,000 \\
6,370,000 \\
755,000 \\
\end{array}$ \\
\hline 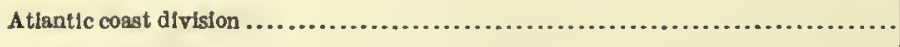 & 94,281 & 45,659 & 219 & 48,403 & $9,904,000$ & 184,000 & $9,720,000$ \\
\hline 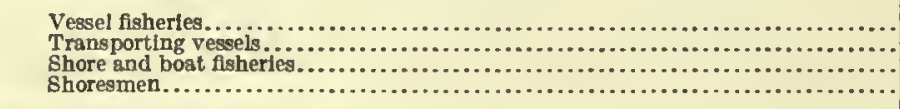 & $\begin{array}{r}24,631 \\
3,595 \\
64,301 \\
1,754\end{array}$ & $\begin{array}{r}3,469 \\
974 \\
41,216 \\
\cdots \\
\cdots\end{array}$ & $\begin{array}{r}169 \\
5 \\
45 \\
\cdots\end{array}$ & $\begin{array}{r}20,993 \\
2,616 \\
23,040 \\
1,754\end{array}$ & $\begin{array}{r}5,715,000 \\
618,000 \\
3,152,000 \\
418,000\end{array}$ & $\begin{array}{r}156,000 \\
4,100 \\
23,000 \\
\end{array}$ & $\begin{array}{r}5,559,000 \\
614,000 \\
3,128,000 \\
418,000\end{array}$ \\
\hline 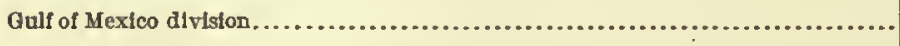 & 15,481 & 6,896 & 52 & 9,533 & $2,349,000$ & 67,000 & $2,292,000$ \\
\hline 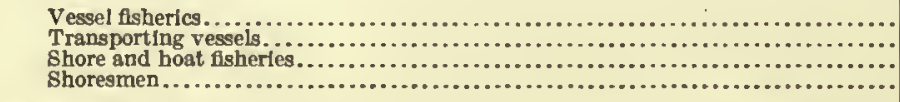 & $\begin{array}{r}3,970 \\
396 \\
10,577 \\
538\end{array}$ & $\begin{array}{r}352 \\
36 \\
6,508 \\
\cdots\end{array}$ & $\begin{array}{r}26 \\
18 \\
8\end{array}$ & $\begin{array}{r}3,592 \\
342 \\
5,061 \\
538\end{array}$ & $\begin{array}{r}1,040,000 \\
134,000 \\
1,042,000 \\
134,000\end{array}$ & $\begin{array}{r}35,000 \\
10,000 \\
5,700\end{array}$ & $\begin{array}{r}1,004,000 \\
117,000 \\
1,036,000 \\
134,000\end{array}$ \\
\hline 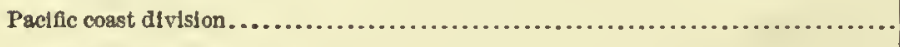 & 13,855 & 6,904 & 39 & 6,912 & $2,264,000$ & 51,000 & $2,213,000$ \\
\hline 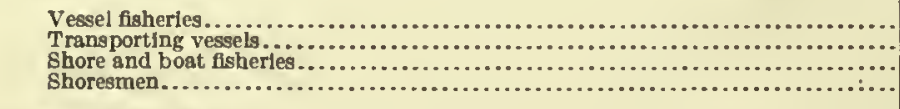 & $\begin{array}{r}1,754 \\
368 \\
11,626 \\
107\end{array}$ & $\begin{array}{r}96 \\
19 \\
6,789 \\
\cdots\end{array}$ & \begin{tabular}{r|r}
15 \\
24 \\
2.
\end{tabular} & $\begin{array}{r}1,643 \\
349 \\
4,813 \\
107\end{array}$ & $\begin{array}{r}600,000 \\
140,000 \\
1,175,000 \\
49,000\end{array}$ & $\begin{array}{r}14,000 \\
37,0000 \\
\cdots\end{array}$ & $\begin{array}{r}886,000 \\
140,000 \\
1,138,000 \\
49,000\end{array}$ \\
\hline 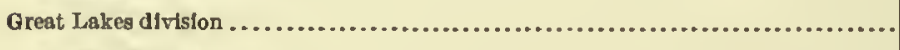 & 8,533 & 4,402 & 25 & 4,106 & $1,345,000$ & 18,000 & $1,327,000$ \\
\hline 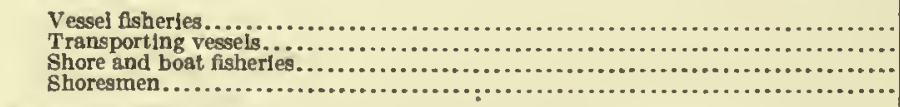 & $\begin{array}{r}1,494 \\
78 \\
6,600 \\
361\end{array}$ & $\begin{array}{r}325 \\
10 \\
4,067 \\
\cdots\end{array}$ & $\begin{array}{c}15 \\
10 \\
\cdots+\cdots\end{array}$ & $\begin{array}{r}1,154 \\
68 \\
2,523 \\
361\end{array}$ & $\begin{array}{r}566,000 \\
30,000 \\
623,000 \\
127,000\end{array}$ & $\begin{array}{r}10,000 \\
8,200 \\
\beta\end{array}$ & $\begin{array}{r}556,000 \\
30,000 \\
615,000 \\
127,000\end{array}$ \\
\hline 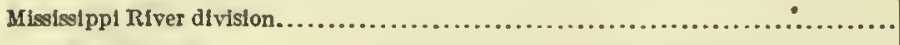 & 11,731 & 9,169 & 15 & 2,547 & 515,000 & 9,000 & 506,000 \\
\hline 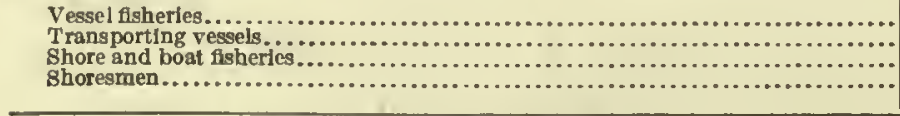 & $\begin{array}{r}30 \\
71 \\
11,540 \\
90\end{array}$ & $\begin{array}{r}6 \\
11 \\
9,152 \\
\cdots\end{array}$ & $\mid \begin{array}{r}6 \\
\cdots \\
\cdots+\cdots\end{array}$ & $\begin{array}{r}18 \\
60 \\
2,379 \\
90\end{array}$ & $\begin{array}{r}9,300 \\
21,000 \\
457,000 \\
27,000\end{array}$ & $\begin{array}{r}4,200 \\
4,800 \\
\cdots\end{array}$ & $\begin{array}{r}5,100 \\
21,000 \\
453,000 \\
27,000\end{array}$ \\
\hline
\end{tabular}


The inquiry called for the number of proprietors, firm members, and individual fishermen to be reported separately, and also for a separate report of the salaried employees, such as officers, managers, and clerks. The wage-earmers were returned as (a) vessel fishermen, (b) shore and boat fishermen, and $(c)$ shoresmen. An estimate was also obtrined of the cost of provisions supplied to employees, which is shown separately and also included in the amount shown for salaries or wages.

The preceding table summarizes the statistics for persons employed and salaries and wages paid, by geographic divisions and by the main branclies of the industry:

Of the total number of persons engaged in the fishing industry in the United States in 1908, 25 per cent were employed on fishing and transporting vessels, 73 per cent in the shore and boat fisheries, and 2 per cent as shoresmen, directly connected with the catching of fish. In addition to the foregoing there were 2,952 proprietors not engaged in fishing.

\begin{tabular}{|c|c|c|c|c|c|c|c|}
\hline \multirow{3}{*}{ DIVISION AND CLASS. } & \multicolumn{7}{|c|}{ PERSONS EMPLOYED: 1908.} \\
\hline & \multicolumn{4}{|c|}{ Per cent distribution. } & \multicolumn{3}{|c|}{ Per cent of total. } \\
\hline & Total. & $\begin{array}{l}\text { Proprietors } \\
\text { and inde- } \\
\text { pendent } \\
\text { asbermen. }\end{array}$ & $\begin{array}{l}\text { Salaried } \\
\text { employ- } \\
\text { ees. }\end{array}$ & $\begin{array}{l}\text { Wage- } \\
\text { earners. }\end{array}$ & $\begin{array}{l}\text { Proprietors } \\
\text { and inde- } \\
\text { pendent } \\
\text { fishermen. }\end{array}$ & $\begin{array}{l}\text { Salaried } \\
\text { employ- } \\
\text { ees. }\end{array}$ & $\begin{array}{l}\text { Wage- } \\
\text { earners. }\end{array}$ \\
\hline 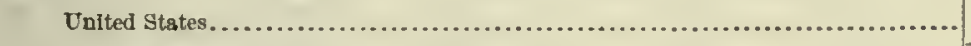 & 100 & 100 & 100 & 100 & 50 & (1) & 50 \\
\hline 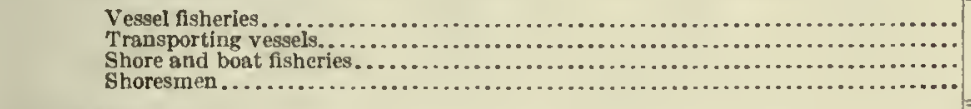 & $\begin{array}{r}22 \\
3 \\
73 \\
2 \\
\end{array}$ & $\begin{array}{r}6 \\
1 \\
93 \\
\end{array}$ & $\begin{array}{r}66 \\
7 \\
27 \\
2+\cdots \\
\end{array}$ & $\begin{array}{r}38 \\
5 \\
53 \\
4\end{array}$ & $\begin{array}{r}13 \\
23 \\
64 \\
-\ldots . .6 .6 \\
\end{array}$ & $\begin{array}{l}1 \\
1 \\
1\end{array}$ & $\begin{array}{r}86 \\
76 \\
36 \\
100\end{array}$ \\
\hline 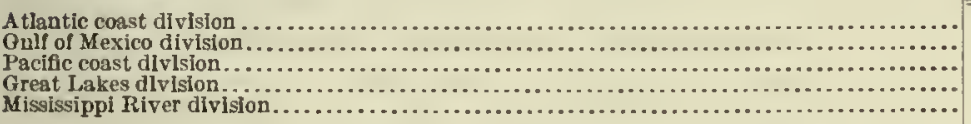 & $\begin{array}{r}66 \\
11 \\
10 \\
6 \\
8\end{array}$ & $\begin{array}{r}63 \\
8 \\
10 \\
6 \\
13\end{array}$ & $\begin{array}{r}63 \\
15 \\
11 \\
7 \\
4\end{array}$ & $\begin{array}{r}68 \\
13 \\
10 \\
6 \\
4\end{array}$ & \begin{tabular}{|l}
48 \\
38 \\
50 \\
52 \\
78
\end{tabular} & $\begin{array}{l}(1) \\
\text { (1) } \\
(3) \\
13 \\
2\end{array}$ & $\begin{array}{l}51 \\
62 \\
50 \\
48 \\
22\end{array}$ \\
\hline
\end{tabular}

The Atlantic coast division was by far the most important in the United States, giving occupation to 66 per cent of all the persons engaged in fishing. The next in importance of the fisheries districts was the Gulf of Mexico division, where 11 per cent of the total number were employed. The Pacific coast division, the Mississippi River division, and the Great Lakes division follow in the order named. The next table gives the distribution of persons employed in the Atlantic coast division, according to groups of states.

More than one-fourth of the total number of persons engaged in fishing in the Atlantic coast division in 1908 were employed in the vessel fisheries and on transporting vessels, and more than two-thirds in the shore and boat fisheries, while less than 2 per cent were shoresmen. In vessel fisheries and on transporting vessels combined, over four-fifths of the persons employed were wage-earners, as compared with only a little more than one-third of those employed in the shore and boat fisheries.

Each of the three groups of states comprising the Atlantic coast division employed more fishermen than any one of the four other geographic divisions into which the country is divided. More than one-half of the fishermen of the Atlantic coast division were employed in the fisheries of the Middle Atlantic states, nearly one-fourth in those of the New England states, and about one-fifth in those of the South Atlantic states.

In New England the vessel fisheries predominated, a fact which was not true of any other group of states for which statisties are presented. It follows that in this group of states the total number of wage-earners and salaried employees was large, as compared with the total number of proprietors and independent fishermen. From the excess of the number of proprietors and independent fishermen over the number of wageearners in the shore and boat fisheries it is evident that there were more than 6,000 independent fishermen.

In the Middle Atlantic states over 70 per cent of the persons employed were in the shore and boat fisheries. In the South Atlantic states the number of persons employed in the vessel fisheries was relatively small. Only 1,973 persons, or 11 per cent of the total number, were on fishing and transporting vessels. 


\begin{tabular}{|c|c|c|c|c|c|c|c|}
\hline \multirow{3}{*}{ BTATE GROUP AND CLASS. } & \multicolumn{7}{|c|}{ PERSONS EMPLOYED IN ATLANTIC COAST DIVISLON: 1908.} \\
\hline & \multicolumn{4}{|c|}{ Number. } & \multicolumn{3}{|c|}{ Salaries and wages. } \\
\hline & Total. & $\begin{array}{l}\text { Proprietors } \\
\text { snd inde- } \\
\text { pendent } \\
\text { fishermen. }\end{array}$ & $\begin{array}{c}\text { Salaried } \\
\text { employees. }\end{array}$ & $\begin{array}{l}\text { Wage- } \\
\text { earners. }\end{array}$ & Total. & Salaries. & Wages. \\
\hline Atlantic cosst divislon ............ & 94,221 & 45,659 & 219 & 48,403 & $89,904,000$ & $\$ 184,000$ & $\$ 9,720,000$ \\
\hline 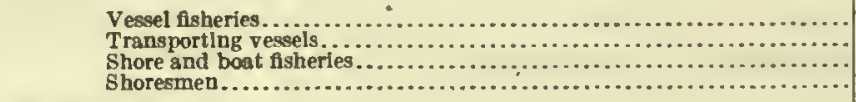 & $\begin{array}{r}24,631 \\
3,595 \\
64,301 \\
1,754 \\
\end{array}$ & $\begin{array}{r}3,469 \\
974 \\
41,216\end{array}$ & $\begin{array}{r}169 \\
5 \\
45 \\
- \\
\end{array}$ & $\begin{array}{r}20,993 \\
2,616 \\
23,040 \\
1,754 \\
\end{array}$ & $\begin{array}{r}5,715,000 \\
618,000 \\
3,152,000 \\
418,000\end{array}$ & $\begin{array}{r}156,000 \\
4,100 \\
23,000 \\
\end{array}$ & $\begin{array}{r}5,559,000 \\
614,000 \\
3,128,000 \\
418,000\end{array}$ \\
\hline New England states................ & 22,157 & 9,740 & 85 & 12,332 & $4,296,000$ & 90,000 & $4,206,000$ \\
\hline $\begin{array}{l}\text { Vessel fisherles } \ldots \ldots \ldots \\
\begin{array}{l}\text { Transporting vessels } \\
\text { Shore and boat fisheries }\end{array} \\
\text { Shoresmen }\end{array}$ & $\begin{array}{r}10,652 \\
535 \\
10,583 \\
387\end{array}$ & $\begin{array}{r}1,219 \\
92 \\
8,429 \\
\end{array}$ & $\begin{array}{r}72 \\
2 \\
11\end{array}$ & $\begin{array}{r}9,361 \\
441 \\
2,143 \\
387\end{array}$ & $\begin{array}{r}3,420,000 \\
208,000 \\
513,000 \\
155,000\end{array}$ & $\begin{array}{r}80,000 \\
2,300 \\
7,700 \\
\cdots\end{array}$ & $\begin{array}{r}3,340,000 \\
206,000 \\
505,000 \\
155,000\end{array}$ \\
\hline 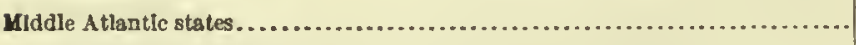 & 54,163 & 26,550 & 102 & 27,511 & $4,459,000$ & 75,000 & $4,385,000$ \\
\hline 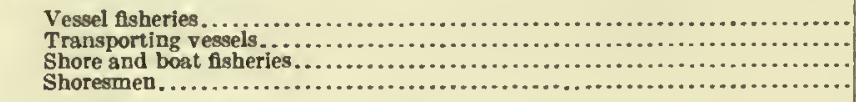 & $\begin{array}{r}12,474 \\
2,592 \\
38,153 \\
944\end{array}$ & $\begin{array}{r}2,118 \\
766 \\
23,666\end{array}$ & $\begin{array}{r}77 \\
3 \\
22\end{array}$ & $\begin{array}{r}10,279 \\
1,823 \\
14,465 \\
944\end{array}$ & $\begin{array}{r}2,076,000 \\
356,000 \\
1,822,000 \\
205,000\end{array}$ & $\begin{array}{r}61,000 \\
1,000 \\
12,000 \\
\cdots\end{array}$ & $\begin{array}{r}2,015,000 \\
354,000 \\
1,810,000 \\
205,000\end{array}$ \\
\hline South Atlantje states.................. & 17,961 & 9,369 & 32 & 8,560 & $1,148,000$ & 19,000 & $1,129,000$ \\
\hline 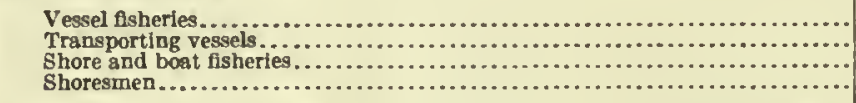 & $\begin{array}{r}1,505 \\
468 \\
15,565 \\
423\end{array}$ & $\begin{array}{r}132 \\
116 \\
\quad 9,121 \\
-\quad r+\end{array}$ & $\begin{array}{l}20 \\
12\end{array}$ & $\begin{array}{r}1,333 \\
352 \\
6,432 \\
423\end{array}$ & $\begin{array}{r}219,000 \\
54,000 \\
816,000 \\
58,000\end{array}$ & $\begin{array}{c}16,000 \\
3,500 \\
\ldots \ldots\end{array}$ & $\begin{array}{r}203,000 \\
54,000 \\
813,000 \\
58,000\end{array}$ \\
\hline
\end{tabular}

\begin{tabular}{|c|c|c|c|c|c|c|c|}
\hline \multirow{3}{*}{ GTATE GBOUP AND CLASS. } & \multicolumn{7}{|c|}{ PERSONS EMPLOYED IN ATLANTIC COAST DIVISION: 1908-contlnued. } \\
\hline & \multicolumn{4}{|c|}{ Per cent distribution. } & \multicolumn{3}{|c|}{ Per cent of total. } \\
\hline & Total. & $\begin{array}{l}\text { Proprle- } \\
\text { tors and } \\
\text { lndepend- } \\
\text { ent fisher- } \\
\text { men. }\end{array}$ & $\begin{array}{l}\text { Salaried } \\
\text { employ- } \\
\text { ees. }\end{array}$ & $\begin{array}{l}\text { Wage } \\
\text { earners. }\end{array}$ & $\begin{array}{l}\text { Proprie- } \\
\text { tors and } \\
\text { Indepentent } \\
\text { fishermen. }\end{array}$ & $\begin{array}{l}\text { Salaried } \\
\text { employ- } \\
\text { ees. }\end{array}$ & $\begin{array}{l}\text { Wage } \\
\text { earners. }\end{array}$ \\
\hline Atlantle coast divlslon . . . . . . . . . . . . . . . . . . . . & 100 & 100 & 100 & 100 & 48 & (') & 51 \\
\hline 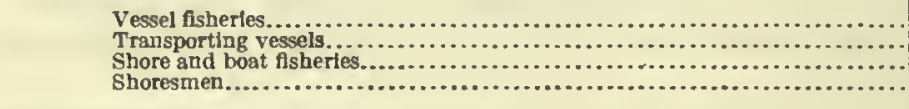 & $\begin{array}{r}26 \\
4 \\
68 \\
2\end{array}$ & $\begin{array}{r}8 \\
2 \\
90 \\
9 .+1\end{array}$ & $\begin{array}{r}77 \\
2 \\
21\end{array}$ & $\begin{array}{r}43 \\
5 \\
4 \\
4\end{array}$ & $\begin{array}{l}14 \\
27 \\
64\end{array}$ & $\begin{array}{l}1 \\
(1)^{1} \\
\cdots\end{array}$ & $\begin{array}{r}85 \\
73 \\
36 \\
100\end{array}$ \\
\hline 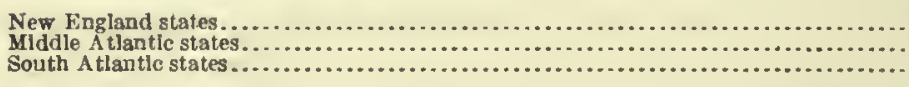 & $\begin{array}{l}23 \\
57 \\
19\end{array}$ & $\begin{array}{l}21 \\
58 \\
21\end{array}$ & $\begin{array}{l}39 \\
47 \\
15\end{array}$ & $\begin{array}{l}25 \\
57 \\
18\end{array}$ & $\begin{array}{l}44 \\
49 \\
52\end{array}$ & $\begin{array}{l}\text { (1) } \\
\text { (1) } \\
\text { (1) }\end{array}$ & $\begin{array}{l}58 \\
51 \\
48\end{array}$ \\
\hline
\end{tabular}

1 Less than 1 per cent.

The following tabular statement shows the number of persons engaged in the several classes of employment connected with the fislieries of Chesapeake Bay, the chief fishing ground of the Middle Atlantic states, and their distribution by states:

\begin{tabular}{|c|c|c|c|c|}
\hline \multirow[b]{2}{*}{ Class. } & \multicolumn{4}{|c|}{$\begin{array}{l}\text { PERSONS EMPLOYED IN CHESAPEAKE } \\
\text { BAY DISTRICT: } 1908 .\end{array}$} \\
\hline & Total. & $\begin{array}{l}\text { Maryland } \\
\text { and Del- } \\
\text { aware. }\end{array}$ & Vlrginia. & $\begin{array}{l}\text { Pennsyl- } \\
\text { vania } \\
\text { (Susque- } \\
\text { hanna } \\
\text { RIver } \\
\text { flsherles). }\end{array}$ \\
\hline Total............. & 35,685 & 17,820 & 17,416 & 449 \\
\hline 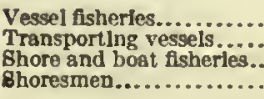 & $\begin{array}{r}7,016 \\
1,953 \\
26,486 \\
230\end{array}$ & $\begin{array}{r}4,046 \\
975 \\
12,723 \\
76\end{array}$ & $\begin{array}{r}2,970 \\
978 \\
13,314 \\
154\end{array}$ & $\cdots$ \\
\hline
\end{tabular}

The persons engaged in these fisheries were about equally divided between Maryland and Virginia, the few which are credited to Pennsylvania being engaged on the Susquehanna River. The shore and boat fisl- eries greatly predominated, reporting over 70 per cent of the total persons employed.

As already indicated, fishing on the Great Lakes gave occupation to fewer people than fishing in any other of the main geograplic divisions of the country. The distribution of the persons employed among the various lakes and rivers of the Great Lakes division is shown below:

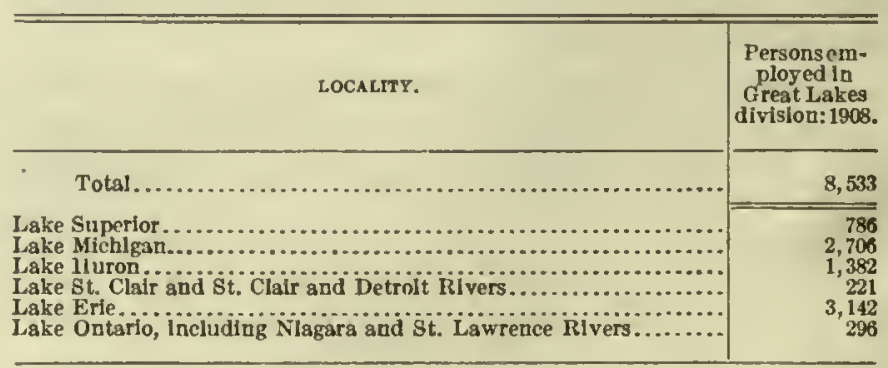

Proprietors and independent fishermen.-Slightly more than one-half of the persons engaged in the fisheries of the United States in 1908 were proprietors 
and independent fishermen. Nenrly two-tlirds of this class were reported from the Atlantic coast division, the Mississippi River division ranking second with a little more than one-eighth, followed by the Pacific coast, the Gulf of Mexico, and the Great Lakes, in the order named. The greatest percentage of proprietors and independent fishermen appears invariably in slore and boat fisheries. This is natural, as it was to be expected that independent fishermen would preponderate in the class of fisheries wherein the capital required and cost of operation are not great.

The largest proportion which the proprietors and independent fishermen formed of the total number of persons employed is shown for the Mississippi River division, where more than three-fourths were of this class. The number is smallest, relatively, in the Gulf of Mexico division, but even there it exceeds one-third.

The salaried employees are almost a neghibible quantity, amounting to only two-tenths of 1 per cent for tho United States as a whole.

Wage-earners and wages.-The number of wageearners in this report is the total number employed at any time during the year. The wages returned on the schedules were not those of the average fisherman, nor for any uniform period throughout the country, nor were they such as might have been secured if employment had been continuous.

In many cases remuneration is not wholly in money wages, but consists either altogether or in part in a shaie of the catch, the share being given usually as 50 per cent of the catch after certain expenses are deducted.

It was impossible in most cases to obtain from the returns the net share of the catch going to the fisherman. This share land sometimes been calculated weekly by the employing fisherman from slips which had been at once destroyed. In many cases an estimate, made either by the employer or by the special agent upon information furnished, had to serve the purpose. These estimates, however, are believed to be substantially representative of the income received.

Some inland fishermen work for wages, with apparatus and board furnished; otbers are paid by the bushel or according to the weight of their catch. In some coast fisheries men were given $\$ 25$ a month and board while employed, the value of the board being calculated at $\$ 10$ a montlı. When board was furnished in addition to wages it is included in the earnings given here. The earnings were frequently pieced out in other industries or occupations, as, for instance, in hunting or trapping, or perhaps in farming; for in some sections there are farmers who, being located near rivers, set seines and trawls, employing for this purpose men who, when not thus occupied, do farm work.

The nationality of the fishermen may possibly have something to do with the variations in the earnings in the various sections of the country. On the Gulf of
Mexico and Southern Atlantic coasts there has been little change in the nationality of the fishermen. Off the coast of Maine the fishermen are practically all natives. On some sections of the Massachusetts coast a great number of the deep-sea fishermen are Portuguese and natives of Nova Scotia. In other localities in this state the shore and boat fishories are carried on largely by Italians. A considerable number of fishermen in Rhode Island aro Greeks. From New Jersey there wero reported a number of Swedes, Norwegians, and Finns engaged in the vessel fisheries. In addition to Americans-Finns, Norwegians, Swedes, Slavonians, Greeks, Italians, Chinese, and Japanese are engaged in the fishery industries of the Pacific coast.

Most of the vessels of the New England fisheries make a number of voyages to the fishing grounds in the course of a year. In some instances the crews were engaged all the year round in one kind of fisheries or another, whereas in others the catch was confined to one or two kinds of fish and the season was accordingly limited. For some of the Middle Atlantic states the coast fisherman's average season was given as six months. The oyster season lasts from September to May, when the crab season begins. The shad season starts in December in the South when the shad enters the rivers to spawn, and the season is successively later and later northward. Drift or rip fishing off the Massachusetts coast lasts from January 1 to Oetober, and hand line-fishing from the side of the vessel extends to the end of the calendar year.

It will be noted that for the United States as a whole the earnings considered relatively to the number of wage-earners are greatest for the fishermen employed upon vessels. This is due to various causes, annong them being a greater continuity of employment. In some instances vessels engaged in fishing during the fishing scason were employed in freighting or excursion business for the rest of the year. Thus the crew was employed for the entire year and the wages reported represented the year's work, as it was impossible to obtain an estimate of the amount that should be cliarged to fishing. In the shore and boat fisheries, on the other hand, there are intervals of unemployment, and the earnings can be supplemented, if need be, by work in other occupations. Moreover, the number of fishermen employed on vessels is more readily ascertainable; if there are no records, then the estimates can be more closely based on fact. The records for the shore and boat fisheries are likely to be scattered; and as the statistics were taken some months after the close of the calendar year 1908 , it is probable that the numbers reported were not always perfectly accurate.

The earnings of the men employed on transporting vessels ranked second. Their high relative earnings also may be explained by the more accurate methods of establishing the figures and the more nearly continuous employment observed in connection with vessel fisheries. The earnings of shoresmen ranked 
third, while shore and boat fishermen earned, relatively to their numbers, less than those employed in any other branch of the industry.

It was, moreover, true of every main geographic division, shown in the table on page 14, that the gross wages paid in the slore and boat fisheries relatively to the numbers given employment at any time of the year, however short the term of employment, ranked lowest among the four classes of fisheries. In three of the five divisions-the Atlantie, Pacific, and Great Lakes-such relative earnings were greatest for wageearners in vessel fisheries; and in two-the Gulf of Mexico and Mississippi River divisions-they were greatest for wage-earners on transporting vessels.

The earnings of wage-earners on the Atlantic coast were, relative to their numbers, less than those for any other main geographic division except the Mississippi River division. Notwithstanding this fact, such relative earnings in the Now England states were larger than for any of the main geographic divisions. The reason for this is that in these states a large majority of the fishermen are employed upon vessels, while in the Middle Atlantic and South Atlantic states the majority are engaged in shore and boat fisheries.

Comparison with prior censuses.-Comparative statisties for the number of fishermen (not including shoresmen), as reported at the present census and at the censuses of 1890 and 1880, are given in the follow ing table. It should be noted, however, that the figures for 1889 , obtained in the census of 1890 , do not include persons for whom fishing was a transient occupation, and that those for 1880 do not include the inland waters, excepting the Great Lakes. For these reasons any comparison of the different years is of doubtful value. Possibly fisheries of minor importance were carried on in Colorado, Idaho, Montana, Nevada, North Dakota, Utah, and Vermont in interior waters not directly tributary to any of the large divisions, and were not included in the canvass of 1908 .

It would appear that at the eensus of 1890 a number of fishermen not now classed as commercial fisher- men were included. In 1908 the Atlantic coast states, including Florida, reported 11,172 fewer fishermen than in 1889 , but 15,647 more than in 1880 ; while the Pacific coast states in 1908 reported a total which is 3,169 more than in 1889 and 8,135 more than in 1880 . The states bordering on the Gulf of Mexico, exclusive of Florida, but including the entire states of Louisiana and Mississippi, employed in $1908,7,308$ more than in 1889 and 7,766 more than in 1880 .

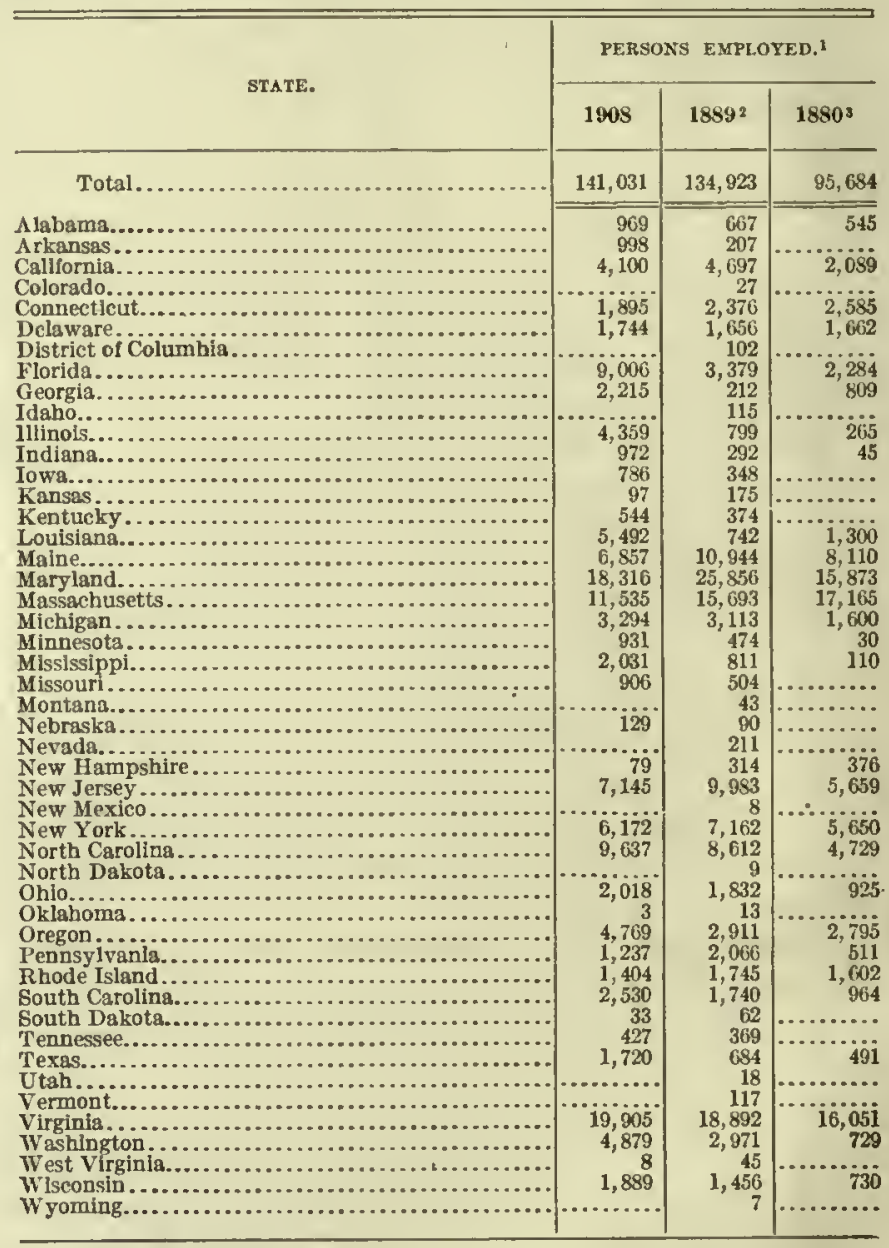

1 Not including shoresmen.

Not including transicnt fishermen. 


\section{CHAPTER IV.}

\section{CAPITAL AND EQUIPMENT.}

Although it is impossible to collect satisfactory statisties in regard to capital investerl in the fishing industry, it was considered necessary to include in the schedule an inquiry on this subject. The number and value of the different elasses of vessels, boats, and apparatus of eapture were reported separately. The value of land, buildings, maehinery, tools, implements, and other fixed capital, as well as cash on hand, materials in stock, and the various other items of live capital, were returned as separate items of investment. The instructions for the inquiry given on the sehedule were as follows:

The answer must show the total amount of capital, both owned and borrowed. All the items of fixed and live capital may be taken at the amounts carried on the books. If land or buildings are rented or vessels are chartered, that fact should be stated and the value given. The value of all items of live capital, bills receivable, unsettled ledger accounts, materials, products, and cash on hand, etc., should be given as of the beginning of the business year reported.

The total eapital invested in the commercial fisheries of the United States, as compiled from the answers to this inquiry, amounted to $\$ 42,021,000$, of which 57 per cent was invested in vessel fisheries and 43 per cent in shore and boat fisheries. The following tabular statement gives the leading items of capital:

\begin{tabular}{|c|c|c|c|}
\hline \multirow[b]{2}{*}{ CLASS OF INVESTMENT. } & \multicolumn{3}{|c|}{ CAPITAL: 1908.} \\
\hline & Total. & $\begin{array}{c}\begin{array}{c}\text { Vessel } \\
\text { fisheries. }\end{array}\end{array}$ & $\begin{array}{c}\text { Shore and } \\
\text { boat } \\
\text { fisheries. }\end{array}$ \\
\hline Total... & $\$ 42,021,000$ & $\$ 24,030,000$ & $\$ 17,991,000$ \\
\hline 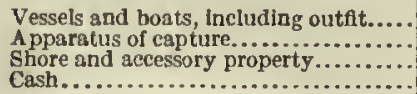 & $\begin{array}{r}25,101,000 \\
8,999,000 \\
5,342,000 \\
2,579,000\end{array}$ & $\begin{array}{r}17,823,000 \\
2,203,000 \\
2,345,000 \\
1,658,000\end{array}$ & $\begin{array}{l}7,277,000 \\
6,796,000 \\
2,997,000 \\
921,000\end{array}$ \\
\hline
\end{tabular}

Shore and accessory property includes wharf property, fish depots, house boats, shelters built near or upon fishing grounds, and unused apparatus of eapture; it does not include investments in preserving or canning establishments. Cash consists of the current funds employed in the business.

In the ease of both classes of fisheries the craft used was the largest item of investment. The capital invested in the vessels, including outfits, of the vessel fisheries was nearly equal to the entire investment in shore and boat fisheries and more than twice the capital reported as invested in boats by the shore and boat fisheries. The apparatus of capture used by the shore and boat fisheries, however, had a value over three times as great as that used by the vessel fisheries. The investment in shore and accessory property was larger for the shore and boat fisheries, but a larger amount of cash was reported for the vessel fisheries. The amount represented by shore and accessory property and cash combined did not differ materially for the two classes of fisheries.

The capital invested in the Atlantic coast division exceeded that of all the other divisions combined, being 60 per cent of the total. In the case of nearly every item more than one-half of the total for the United States was reported for this geograplic division.

The Great Lakes division is the only one in which there was less capital invested in vessels and boats than in apparatus of capture. In this district the amount reported for shore and accessory property and eash was relatively high.

The capital invested is presented by main geographic divisions in Table 1 on page 22 and by states on page 13. Those states reporting an amount in excess of $\$ 2,000,000$ are shown in the following tabular statement in the order of rank. The nine states given had invested a total capital of $\$ 27,227,000$, or 65 per cent of the total investment in the industry.

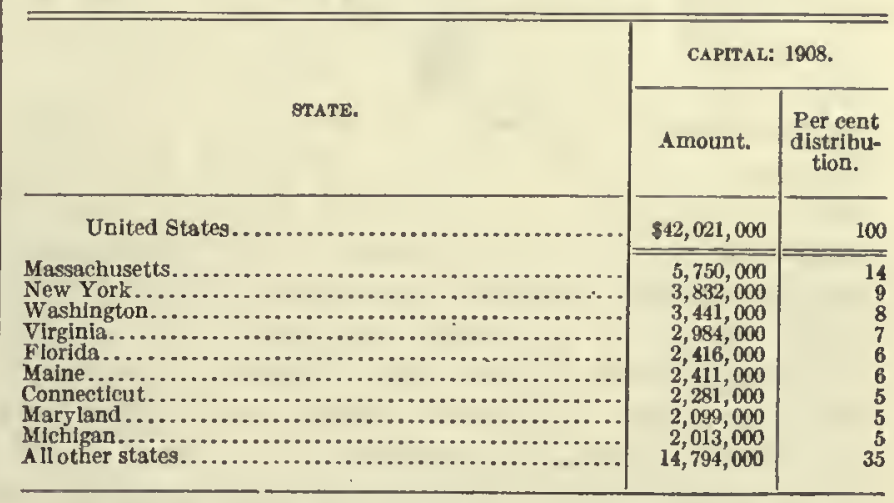

Vessels and boats.-Table 3 on page 23 gives in detail the statistics of vessels and boats for the United States as a whole, and for the main geographic divisions. The value of vessels, outfits of vessels, and boats employed in the fisheries of the United States amounted to $\$ 25,101,000$, or 60 per cent of the total capital.

The distinction between vessels and boats is one of tonnage. The term "vessel" is applied to all craft of 5 tons register or over, whether or not they are registered as required by the navigation laws of the 
United States. All craft of less than 5 tons are classified as boats.

Outfit includes provisions for the crew, and salt, brit, ice, and other articles used in the taking and preserving of the product, but does not include boats carried by the vessels and such articles as repair tools, nautical instruments, hawsers, anchors, or charts. As these are considered a part of the vessel, their value is included in the value of the vessels.

The subclass bearing the designation "Other," which is shown in the tables under the heads of both vessels and boats, includes scows and barges and all unrigged or towed craft of 5 tons or more register in the class of ressels and of less than 5 tons in the class of boats. It does not include house boats, floating wharves, or any sort of moored craft used only as living quarters, as warehouses, or as docks. Such items are included under "Shore and accessory property."

The investment in vessels was $\$ 13,806,000$, or 55 per cent of the total investment in craft, including outfits, and the investment in their outfits, $\$ 4,026,000$, or 16 per cent, together making a total of $\$ 17,832,000$ pertaining to vessel fisheries, or 71 per cent of the value of all floating equipment. 'The investment in boats, which was $\$ 7,269,000$, or 29 per cent of the total, represents the share of the shore and boat fisheries in this kind of equipment. Boats carried on vessels must not be confused with boats used in the shore and boat fisheries. The value of the former is includer in the value of the vessels.

Vessels are of two classes, those engaged in fishing and those engaged in transporting the product to port or to market. Fishing vessels had a value of $\$ 11,276,000$, or 82 per cent of the total for vessels and 54 per cent of the total for all craft. The value of outfits was much larger for the fishing vessels, as transporting vessels carry no bait and remain away from port a shorter period. Including outfits, the fishing vessels had a total value of $\$ 14,849,000$, of which the value of outfits constituted 24 per cent; and the transporting vessels a total value of $\$ 2,982,000$, of which the value of outfits constituted 15 per cent. Fishing vessels and their outfits formed 59 per cent of the investment in vessels, outfits, and boats, and transporting vessels 12 per cent.

The classification of vessels and boats according to means of propulsion is of special interest as showing the extent to which power craft are used. The vessels reported under the head "Steam and motor" were mainly steam vessels, and the boats so reported principally gasoline and naphtha launches.

Of the $\$ 21,075,000$ invested in vessels and boats, not including outfits, 55 per cent represents the value of craft propelled by engines, 39 per cent the value of sailing boats and vessels, 4 per cent the value of rowboats, and 2 per cent the value of other boats and vessels.
Vessels and boats, by divisions.-The Atlantic coast division is credited with 66 per cent of the total investment in ressels and boats. Of the $\$ 16,553,000$ so invested there, 58 per cent was in vessels, 17 per cent in outfits, and 25 per cent in boats. The percentages for vessels and outfits are larger than in any other division, and that for boats is smaller.

The value of the steam and motor vessels in use in the Atlantic coast division was 50 per cent of the total for all vessels in the division, but their number and tonnage formed only 34 per cent and 29 per cent, respectively, of the corresponding totals. Although 69 per cent of the steam tonnage of all vessels in the United States fisheries was reported from the Atlantic coast division, the proportions of the total number, tonnage, and value were higher for sailing vessels, indicating a greatel relative use of the latter in these waters. The value of steam vessels, not including outfits, exceeded that of sailing vessels among fishing vessels in this division, but not among transporting vessels.

Steam and motor boats of the Atlantic coast division, although forming only 16 per cent of all boats in number, contributed 60 per cent of the total value of boats for that division. Of the value of all craft in the Atlantic coast division, $\$ 7,324,000$, or 53 per cent, represents the value of craft equipped with steam or other power; $\$ 5,833,000$, or 42 per cent, that of sailing craft; $\$ 484,000$, or 4 per cent, rowboats; and $\$ 90,000$, or less than one-tenth of 1 per cent, scows or barges.

'The Pacific const division ranked next to the Atlantic coast division in the amount invested in vessels, outfits, and boats, although it reported only 14 per cent of the total for the United States. Steam vessels were in general use, forming 72 per cent of all vessels and contributing 83 per cent of the entire value.

In the Gulf of Mexico division the investment in vessels, outfits, and boats amounted to $\$ 2,805,000$, which was 11 per cent of that for the United States. The proportion represented by transporting vessels was 16 per cent, which was greater than in the country as a whole.

The capital invested in vessels and boats in the Great Lakes division $(\$ 1,651,000$, or 7 per cent of the total) was distributed as follows: vessels, 52 per cent; outfits, 11 per cent; and boats, 37 per cent. With one exception, all vessels were operated by steam or motor power. Of the value of boats on the Great Lakes, 81 per cent is eredited to power craft, while steam or motor craft represents 92 per cent of the total investment in craft, not including outfit.

The investment of the fisheries of the Mississippi River and its tributaries in vessels and boats $(\$ 547,000$, including outfits), was 2 per cent of the total so invested in the United States. This is the only division in which the value of the boats exceeded that of the vessels. Steam and motor craft contributed 61 per 
cent of the value of all boats and 65 per cent of the value of all craft of the Mississippi River division, which, exclusive of outfits, was $\$ 528,000$.

The amount invested in vessels in the United States as a whole was divided between fishing vessels and transporting vessels in the proportion of 82 per cent and 18 per cent, respectively. In the Atlantic coast division the proportion of the total vessel investment represented by fishing vessels was 83 per cent; in the Gulf of Mexico, 78 per cent; in the Pacific coast, 73 per cent; in the Great Lakes, 91 per cent; and in the fisheries of the Mississippi River and its tributaries, 19 per cent.

The average tonnage of vessels was slightly over 18 tons, the average for steam vessels being 16 tons, and for sailing vessels 20 tons. The following tabular statement gives the average tonnage of the several classes of vessels for the United States and for the five geographic divisions:

\begin{tabular}{|c|c|c|c|c|c|c|}
\hline \multirow[b]{2}{*}{ CH.ABS OF VESSEI. } & \multicolumn{6}{|c|}{ AVERAOE TONNAGE OF VESSEL. } \\
\hline & $\begin{array}{l}\text { United } \\
\text { States. }\end{array}$ & $\begin{array}{l}\text { Atlan- } \\
\text { tle } \\
\text { coast } \\
\text { dlvi- } \\
\text { slon. }\end{array}$ & $\begin{array}{c}\text { Gulf of } \\
\text { Mexico } \\
\text { dlin- } \\
\text { sion. }\end{array}$ & $\begin{array}{l}\text { Pacific } \\
\text { coast } \\
\text { divi- } \\
\text { slon. }\end{array}$ & $\begin{array}{l}\text { Great } \\
\text { Lakes } \\
\text { div1- } \\
\text { slon. }\end{array}$ & $\begin{array}{l}\text { Missls- } \\
\text { slppi } \\
\text { iflver } \\
\text { div1- } \\
\text { slon. }\end{array}$ \\
\hline $\begin{array}{l}\text { FIshlng vessels: } \\
\text { Stean } \ldots \ldots \ldots \ldots \ldots \\
\text { Sall } \ldots \ldots \ldots \ldots \ldots \ldots\end{array}$ & $\begin{array}{l}17 \\
20\end{array}$ & $\begin{array}{l}16 \\
20\end{array}$ & $\begin{array}{r}9 \\
14\end{array}$ & $\begin{array}{r}43 \\
125\end{array}$ & 14 & $?$ \\
\hline 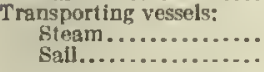 & $\begin{array}{l}12 \\
21\end{array}$ & ${ }_{17}^{11}$ & $\begin{array}{l}15 \\
11\end{array}$ & $\begin{array}{r}13 \\
667\end{array}$ & 14 & $\begin{array}{r}12 \\
7\end{array}$ \\
\hline
\end{tabular}

Apparatus of capture.-The total investment in apparatus of capture was $\$ 8,999,000$. Detailed statistics for each class of fisheries are given in Table 2 on page 22.

In point of value, pound nets, trap nets, and weirs were the most important class of apparatus of capture, having a total value of $\$ 3,000,000$, which is 33 per cent of the value of all apparatus of capture used. The value of the pound net varied greatly according to its size, ranging from less than $\$ 100$ to over $\$ 2,000$ for some in use in the Pacific coast division. They were most numerous in the Atlantic coast fisheries. Gill nets were in extensive and general use, ranking second in value among all apparatus of capture.

Next in importance to gill nets were seines, valued at $\$ 937,000$, of which $\$ 286,000$ represents the value of 466 purse seines and $\$ 652,000$ that of 7,530 haul and other seines. By far the greater number of the seines used and all but 9 per cent of the purse seines were reported by the fisheries of the Atlantic coast.

Fyke and hoop nets ranked fourth in value. Although used in large numbers in every division, they were most prominent in the fisheries of the Mississippi River and its tributaries, which con- tributed 66 per cent of the number and 56 per cent of the value of all fyke and hoop nets used in this country.

The value of all classes of nets used in the fisheries of the United States amounted to $\$ 7,315,000$, or 81 per cent of the value of all apparatus of capture.

Of apparatus other than nets, the most important as measured by value were hand, trawl, and set lines. The Atlantic coast division led in this kind of apparatus, reporting $\$ 367,000$, or 77 per cent of the value of all lines used.

Pots and traps of various kinds, which had a total value of $\$ 457,000$, were for the most part employed $i_{11}$ the lobster and eel fisheries of the Atlantic coast. The few lobster pots and traps shown for the Pacific coast fisheries were used in the spring lobster catch. Practically all the eel pots and traps belonged to the Atlantic coast fisheries.

Dredges, tongs, rakes, etc., were used most extensively in the Atlantic coast and Gulf of Mexico fisheries. This class of apparatus was also used to a small extent in the mussel-shell industry of the Mississippi River division and in the molluscan fisheries of the Pacific coast.

Other apparatus of capture included the wheels and slides of the Pacific coast fisheries, the fishing machines of North Carolina, and the sponge apparatus of the Gulf of Mexico sponge fisheries.

The following tabular statement gives the amount invested in apparatus of capture, by states, arranged in the order of the value of apparatus reported:

\begin{tabular}{|c|c|}
\hline STATE. & $\begin{array}{l}\text { Value ol appa } \\
\text { ratus ol cap- } \\
\text { ture: } 1908 .\end{array}$ \\
\hline United States.. & $\$ 8,999,000$ \\
\hline Washington.............. & $1,162,000$ \\
\hline Milehlgan.......................... & 821,000 \\
\hline 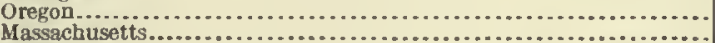 & 795,000 \\
\hline & 576,000 \\
\hline 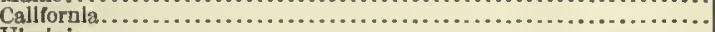 & 502,000 \\
\hline 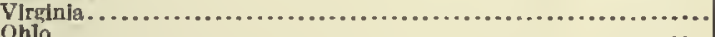 & 485,000 \\
\hline $\begin{array}{l}\text { Ohlo } \\
\text { W lsconsin }\end{array}$ & $\begin{array}{l}423,000 \\
407,000\end{array}$ \\
\hline Maryland & 369,000 \\
\hline 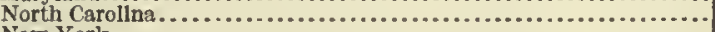 & 367,000 \\
\hline 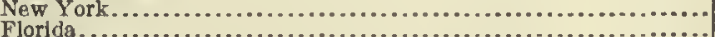 & 362,000 \\
\hline 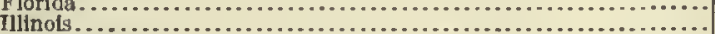 & 326,000 \\
\hline Rhode Isiand...$\cdots \cdots$ & 230,000 \\
\hline 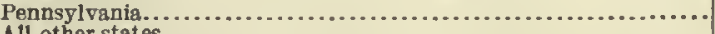 & 114,000 \\
\hline All other states. & $1,014,000$ \\
\hline
\end{tabular}

The table on page 22 gives statistics concerning the different kinds of apparatus of capture as reported for the vessel and for the shore and boat fisheries, respectively.

Shore and accessory property and cash.-The distribution of the capital invested in shore and accessory property and cash is shown by geographic divisions in the table following. 
TABLE 1.-EQUIPMENT AND OTHER CAPITAL: 1908.

\begin{tabular}{|c|c|c|c|c|c|c|c|c|c|c|c|c|c|c|c|c|c|}
\hline \multirow[b]{2}{*}{$\begin{array}{l}\text { CLASS OF } \\
\text { INVESTMENT. }\end{array}$} & \multicolumn{2}{|c|}{ UNITED STATES. } & \multicolumn{2}{|c|}{$\begin{array}{l}\text { ATLANTIC COAST } \\
\text { DIVISION. }\end{array}$} & \multicolumn{2}{|c|}{$\begin{array}{l}\text { GULF OF MEXICO } \\
\text { DIVISION. }\end{array}$} & \multicolumn{2}{|c|}{$\begin{array}{l}\text { PACIFIC COAST } \\
\text { DIVISTON. }\end{array}$} & \multicolumn{2}{|c|}{$\begin{array}{c}\text { MISSISSIPPI } \\
\text { RIVER DIVIBION. }\end{array}$} & \multicolumn{2}{|c|}{$\begin{array}{l}\text { GREAT LAKES } \\
\text { DIVISION. }\end{array}$} & \multicolumn{5}{|c|}{ PER CENT OP TOTAL. } \\
\hline & Amount. & $\begin{array}{l}\text { Per } \\
\text { cent } \\
\text { dis- } \\
\text { cribu- } \\
\text { tion. }\end{array}$ & Amount. & $\begin{array}{c}\text { Per } \\
\text { cent } \\
\text { dis- } \\
\text { tribu- } \\
\text { tlon. }\end{array}$ & Amount. & $\begin{array}{c}\text { Per } \\
\text { cent } \\
\text { dls- } \\
\text { tribu- } \\
\text { tion. }\end{array}$ & Amount. & $\begin{array}{c}\text { Per } \\
\text { cent } \\
\text { diss- } \\
\text { tribu- } \\
\text { tion. }\end{array}$ & Amount. & $\begin{array}{c}\text { Per } \\
\text { cent } \\
\text { dis- } \\
\text { tribu- } \\
\text { tion. }\end{array}$ & Amount. & $\mid$\begin{tabular}{c|} 
Per \\
cent \\
dis- \\
tribu- \\
tlon.
\end{tabular} & $\begin{array}{l}\text { Atlan- } \\
\text { tle } \\
\text { coast } \\
\text { divi- } \\
\text { slon. }\end{array}$ & $\begin{array}{c}\text { Gulf } \\
\text { of } \\
\text { Mexico } \\
\text { divi- } \\
\text { sion. }\end{array}$ & $\begin{array}{l}\text { Pa- } \\
\text { cific } \\
\text { coast } \\
\text { divi- } \\
\text { slon. }\end{array}$ & $\begin{array}{l}\text { Missis- } \\
\text { sippl } \\
\text { Rlver } \\
\text { dlys- } \\
\text { sion. }\end{array}$ & $\begin{array}{l}\text { Great } \\
\text { Lakes } \\
\text { divi- } \\
\text { slon. }\end{array}$ \\
\hline Total... & $842,021,000$ & 100 & $825,398,000$ & 100 & $\$ 3,901,000$ & 100 & $\$ 5,468 ; 000$ & 100 & $\$ 1,440,000$ & 100 & $\$ 4,814,000$ & 100 & 60 & 9 & 15 & 3 & 11 \\
\hline 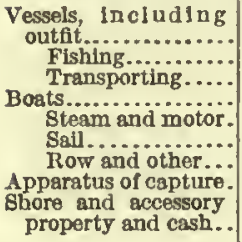 & $\begin{array}{r}17,831,000 \\
14,849,000 \\
2,982,000 \\
7,269,000 \\
4,016,000 \\
2,062,000 \\
1,190,000 \\
8,999,000\end{array}$ & $\begin{array}{r}42 \\
35 \\
7 \\
17 \\
10 \\
5 \\
3 \\
21\end{array}$ & $\begin{array}{r}12,449,000 \\
10,607,000 \\
1,842,000 \\
4,104,000 \\
2,471,000 \\
1,073,000 \\
560,000 \\
3,822,000\end{array}$ & $\begin{array}{r}49 \\
42 \\
7 \\
16 \\
10 \\
4 \\
2 \\
15\end{array}$ & $\begin{array}{r}1,964,000 \\
1,518,000 \\
447,000 \\
841,000 \\
207,000 \\
505,000 \\
129,000 \\
374,000\end{array}$ & $\begin{array}{r}50 \\
39 \\
11 \\
22 \\
5 \\
13 \\
3 \\
10\end{array}$ & $\begin{array}{r}2,307,000 \\
1,764,000 \\
543,000 \\
1,237,000 \\
552,000 \\
449,000 \\
236,000 \\
2,459,000\end{array}$ & $\begin{array}{r}36 \\
27 \\
8 \\
19 \\
9 \\
7 \\
4 \\
38\end{array}$ & $\begin{array}{r}77,000 \\
19,000 \\
58,000 \\
470,000 \\
289,000 \\
1,000 \\
180,000 \\
514,000\end{array}$ & $\begin{array}{r}5 \\
1 \\
4 \\
33 \\
20 \\
(1) \\
12 \\
36\end{array}$ & $\begin{array}{r}1,034,000 \\
942,000 \\
92,000 \\
617,000 \\
497,000 \\
35,000 \\
85,000 \\
1,831,000 \\
1,332,000\end{array}$ & $\begin{array}{r}21 \\
20 \\
2 \\
13 \\
10 \\
1 \\
2 \\
38\end{array}$ & $\begin{array}{l}70 \\
71 \\
62 \\
56 \\
62 \\
52 \\
47 \\
42\end{array}$ & $\begin{array}{r}11 \\
10 \\
15 \\
12 \\
5 \\
24 \\
11 \\
4\end{array}$ & $\begin{array}{l}13 \\
12 \\
18 \\
17 \\
14 \\
22 \\
20 \\
27\end{array}$ & $\begin{array}{r}\text { (1) } \\
2 \\
6 \\
7 \\
(1) \\
15 \\
15 \\
6 \\
5\end{array}$ & $\begin{array}{r}6 \\
6 \\
3 \\
8 \\
12 \\
2 \\
7 \\
20\end{array}$ \\
\hline
\end{tabular}

1 Less than 1 per cent.

TABLE 2.-APPARATUS OF CAPTURE: 1908.

\begin{tabular}{|c|c|c|c|c|c|c|}
\hline \multirow{2}{*}{ KIND. } & \multicolumn{2}{|c|}{ тотAL. } & \multicolumn{2}{|c|}{ VESSEL FISHERIES. } & \multicolumn{2}{|c|}{$\begin{array}{l}\text { SHORE AND BOAT } \\
\text { TISHERIES. }\end{array}$} \\
\hline & Number. & Value. & Number. & Value. & Number. & Value. \\
\hline Total.... & & $\$ 8,999,000$ & & $\$ 1,910,000$ & & $\$ 7,089,000$ \\
\hline Fyke and hoop nets..... & 81,191 & 504,000 & 4,390 & 19,000 & 76,801 & 485,000 \\
\hline 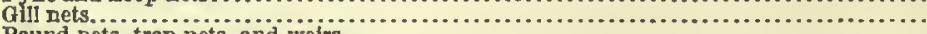 & 233,256 & $2,709,000$ & 111,093 & 779,000 & 122,163 & $1,930,000$ \\
\hline Pound nets, trap nets, and weirs............. & 16,104 & $3,000,000$ & 352 & 165,000 & 15,752 & $2,835,000$ \\
\hline 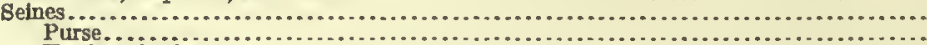 & 7,996 & $\begin{array}{l}037,000 \\
286,000\end{array}$ & $\begin{array}{r}1,111 \\
466\end{array}$ & $\begin{array}{l}342,000 \\
286,000\end{array}$ & 6,885 & 595,000 \\
\hline Haul, and other.............................. & 7,530 & 652,000 & 645 & 56,000 & 6,885 & 595,000 \\
\hline Trammel nets................. & 4,760 & 121,000 & 83 & 4,200 & 4,677 & 117,000 \\
\hline Other nets. & 13,027 & 44,000 & 24 & 7,200 & 13,003 & 37,000 \\
\hline Bag................................. & 176 & 5,500 & 3 & 100 & 173 & 5,400 \\
\hline 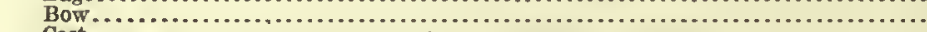 & 723 & 2,300 & ....... & ......... & 723 & 2,300 \\
\hline 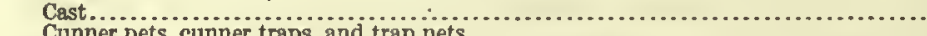 & 1,853 & 9,200 & $\ldots . .$. & ......... & 1,853 & 9,200 \\
\hline Cunner nets, cunner traps, and trap nets........................................... & 191 & 400 & $\cdots$ & $\because \ldots$ & 191 & 400 \\
\hline Dlp..................................... & 5,796 & 10,000 & ${ }_{10}^{2}$ & (1) 7,100 & 5,794 & 10,000 \\
\hline 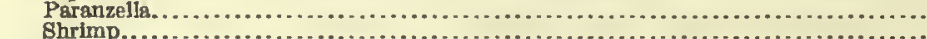 & 20 & 7,200 & & 7,100 & $\begin{array}{r}1 \\
9\end{array}$ & 100 \\
\hline 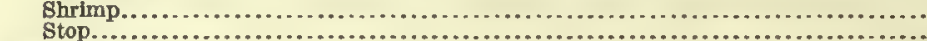 & 4, 25 & $\begin{array}{r}8,800 \\
400\end{array}$ & & $\cdots$ & $\begin{array}{r}4,243 \\
25\end{array}$ & 8,800 \\
\hline 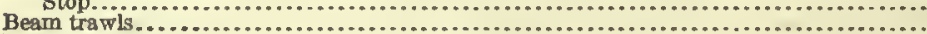 & 169 & 4,900 & 106 & $\because 3,500$ & 63 & 1,500 \\
\hline Harpoons, spears, etc..................... & ......... & 16,000 & ..... & 11,000 & & 4,600 \\
\hline 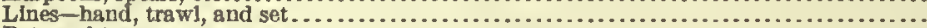 & .......... & 476,000 & & 353,000 & & 122,000 \\
\hline Pots and traps. & 464,002 & 457,000 & 28,568 & 40,000 & 435,434 & 417,000 \\
\hline Eel pots and traps.......................... & $\begin{array}{r}32,172 \\
270\end{array}$ & 25,000 & 3,769 & 4,200 & 28,403 & 20,000 \\
\hline otter, mink and muskrat traps.......... & $\begin{array}{l}270,251 \\
133,185\end{array}$ & $\begin{array}{r}376,000 \\
28,000\end{array}$ & 22,787 & (1) 35,000 & $\begin{array}{l}247,464 \\
133,173\end{array}$ & $\begin{array}{r}341,000 \\
28,000\end{array}$ \\
\hline Other pots and traps. & 28,394 & 29,000 & 2,000 & 1,200 & 26,394 & 28,000 \\
\hline 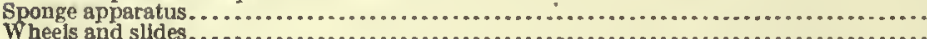 & ….......... & 76,000 & ........ & 55,000 & .......... & 22,000 \\
\hline 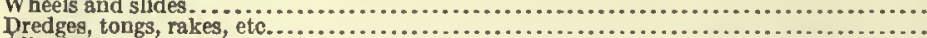 & 69 & $\begin{array}{l}237,000 \\
375,000\end{array}$ & & $\dddot{1 i 8,000}$ & 69 & $\begin{array}{l}237,000 \\
257,000\end{array}$ \\
\hline All other & & 41,000 & & 12,000 & & 29,000 \\
\hline
\end{tabular}


TABLE 3.-NUMBER, TONNAGE, AND VAlUE OF VESSELS AND BOATS: 1908.

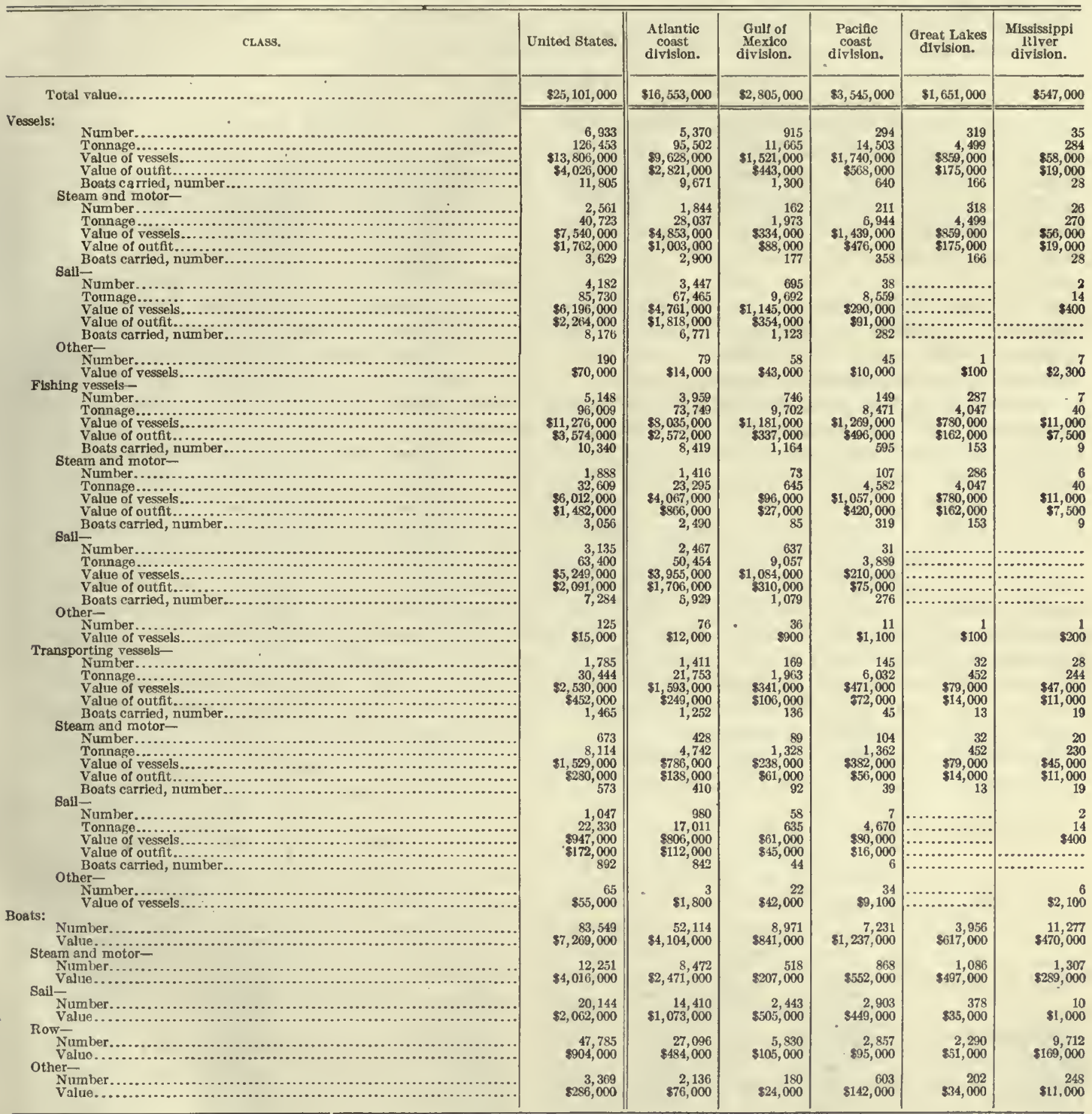




\section{CHAPTER V.}

\section{PRODUCTS.}

The value of the fishery products in $190 \mathrm{~s}$ is the largest yet recorded, and is in harmony with the slow but steady growth revealed by previous canvasses made under the direetion of the Bureau of Fisheries or by the Bureau of the Census. Comparative figures as to the total value of products for 1908 and prior years lave been given in Chapter I of this report. Table 1, on page 26 , is a comparative summary of the quantity and value of the products at the present census and as reported by the Bureau of Fisheries for the period 1900-1904, grouped according to general elasses.

The increase has been more or less general for those items which are shown separately for both periods. There were decreases both in quantity and value for menhaden and whale products and a decrease in value for oysters, although the quantity of this product shows an increase. Under the hear "All other products" for the period 1900-1904 are included products which were reported separately in 1908 . The total products show an increase in value over those for the earlier years of 9 per cent, the value of the fish products reported increasing 17 per cent and that of crustaceans 25 per cent. Mollusks show a slight decrease in value, amounting to 3 per cent, and the whale products a large decrease, amounting to 39 per cent.

The following statement shows the distribution of the chief products of the fisheries as reported in 1908:

\begin{tabular}{|c|c|c|c|c|}
\hline \multirow{3}{*}{ GuAS8. } & \multicolumn{4}{|c|}{ FISHERY PRODUCTS: 1908.} \\
\hline & \multicolumn{2}{|c|}{ Quantity. } & \multicolumn{2}{|c|}{ Value. } \\
\hline & Pounds. & $\begin{array}{l}\text { Per cent } \\
\text { distribu- } \\
\text { tlon. }\end{array}$ & Amouat. & $\begin{array}{l}\text { Per cent } \\
\text { dlstrlbu- } \\
\text { tlon. }\end{array}$ \\
\hline Total...................... & $1,893,454,000$ & 100 & $\$ 54,031,000$ & 100 \\
\hline 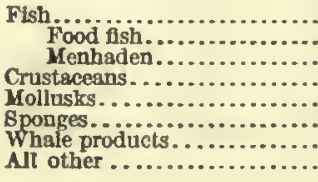 & $\begin{array}{r}1,441,317,000 \\
1,046,541,000 \\
394,776,000 \\
96,225,000 \\
347,799,000 \\
622,000 \\
4,028,000 \\
3,462,000\end{array}$ & $\begin{array}{r}76 \\
55 \\
21 \\
5 \\
18 \\
\text { (1) } \\
\text { (1) } \\
\text { (1) }\end{array}$ & $\begin{array}{r}30,247,000 \\
29,354,000 \\
893,000 \\
3,466,000 \\
18,752,000 \\
545,000 \\
497,000 \\
523,000\end{array}$ & $\begin{array}{r}56 \\
54 \\
2 \\
6 \\
35 \\
1 \\
1 \\
1\end{array}$ \\
\hline
\end{tabular}

Fish proper formed more than three-fourths of the quantity (76 per eent) and more than half the value (56 per cent) of the entire product. Menliaden alone contributed more than one-fourth of the total quantity but less than one-thirtieth of the total value of fish. On account of the great importance of the oyster fisheries mollusks were the most important product outside of fish proper, both in quantity and in value, forming 18 per cent of the total quantity and 35 per cent of the total value of the fishery products.
Table 2, on page 26, gives statistics showing the products by species for the United States and for the several geographic divisions. The value of the product taken by the fisheries of the Atlantic const division is nearly double that of all the rest of the country combined, being 66 per cent of the total for the United States. The Pacifie coast division ranked next in the value of its eatch, with 13 per cent of the total. The Gulf of Mexico, the Great Lakes, and the Mississippi River divisions contributed, respectively, 9 per cent, 7 per cent, and 6 per cent of the total value. The oyster product leads all other species in value, contributing 29 per cent of the total value of products. Salmon ranked next to oysters in the value of the eatch, being the leading species of fish in this respect. A catch valued at $\$ 2,000,000$ or over is also reported for cod and shad, while lobsters, clams, squeteague, laalibut, haddock, and carp each show a product in excess of $\$ 1,000,000$ in value. In the first of the following tables the 30 leading species, including all for which the reported product liad a value in excess of $\$ 400,000$, are ranked according to the value of the catch, and in the second the quantity and value of products are shown by states ranked according to value of product:

\begin{tabular}{|c|c|c|c|c|c|}
\hline \multirow{3}{*}{ Rank. } & \multirow{3}{*}{ SPECTES. } & \multicolumn{4}{|c|}{ FISHERY PRONUCTS: 1908.} \\
\hline & & \multicolumn{2}{|c|}{ Quantity. } & \multicolumn{2}{|c|}{ Value. } \\
\hline & & Pounds. & $\begin{array}{c}\text { Per } \\
\text { centdls- } \\
\text { trlbu- } \\
\text { tion. }\end{array}$ & Amount. & $\begin{array}{l}\text { Per } \\
\text { cent dis- } \\
\text { tribu- } \\
\text { tlon. }\end{array}$ \\
\hline & Total. & $1,893,454,000$ & 100 & $\$ 54,031,000$ & 100 \\
\hline 1 & Oysters... & $233,309,000$ & 12 & $15,713,000$ & 29 \\
\hline 2 & Salmon... & $90,417,000$ & 5 & $3,347,000$ & 6 \\
\hline 3 & Cod..... & $110,054,000$ & 6 & $2,914,000$ & 5 \\
\hline 4 & Shad.......................... & $27,641,000$ & 1 & $2,113,000$ & 4 \\
\hline 5 & 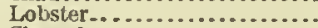 & $15,279,000$ & 1 & $1,931,000$ & 4 \\
\hline 6 & Clams ${ }^{1}, \ldots \ldots \ldots \ldots \ldots \ldots$ & $16,717,000$ & 1 & $1,896,000$ & 4 \\
\hline 7 & 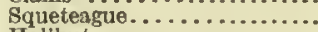 & $49,869,000$ & 3 & $1,776,000$ & 8 \\
\hline 8 & IIallbut...................... & $34,441,000$ & 2 & $1,562,000$ & 3 \\
\hline 9 & IJaddock .......................... & $59,987,000$ & 3 & $1,308,000$ & 2 \\
\hline 10 & Carp, German ................. & $42,763,000$ & 2 & $1,135,000$ & 2 \\
\hline 11 & Lake herring. . . . . . . . & $41,118,000$ & 2 & 889,000 & 2 \\
\hline 12 & Crabs ${ }^{2} . \ldots \ldots \ldots \ldots \ldots$ & $32,913,000$ & 3 & 812,000 & 2 \\
\hline 13 & Mullet............................ & $33,703,000$ & 2 & 908,000 & 2 \\
\hline 14 & Menhaden........ & $394,776,000$ & 21 & 893,000 & 2 \\
\hline 15 & 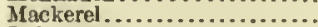 & $12,103,000$ & 1 & 848,000 & 2 \\
\hline 16 & Lake trout....................... & $12,024,000$ & 1 & 800,000 & 1 \\
\hline 17 & Herring, salt-water............... & $125,050,000$ & 7 & 796,000 & 1 \\
\hline 18 & 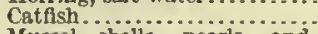 & $17,817,000$ & & 785,000 & 1 \\
\hline 19 & Mussel shells, pearls, and & & & & \\
\hline 20 & 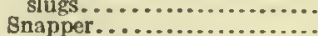 & $\begin{array}{l}81,869,000 \\
13,854,000\end{array}$ & $1_{1}^{4}$ & 692,000 & 1 \\
\hline 21 & Alewives........................ & $89,978,000$ & $\frac{1}{5}$ & 589,000 & \\
\hline 22 & Flouoders .................... & $23,346,000$ & 1 & 588,000 & 1 \\
\hline 23 & Plke perch................. & $15,247,000$ & & 580,000 & $\hat{1}$ \\
\hline 24 & Sponges. . . . & 622,000 & & 545,000 & 1 \\
\hline 25 & Whitefish.$\ldots \ldots \ldots \ldots \ldots$ & $7,722,000$ & (2) & 524,000 & 1 \\
\hline 26 & Bluefish . . . . . . . . . . . . . . & $7,647,000$ & (8) & 506,000 & 1 \\
\hline 27 & Buffalo fish $\ldots \ldots \ldots \ldots \ldots \ldots$. & $16,729,000$ & 1 & 498,000 & 1 \\
\hline 28 & 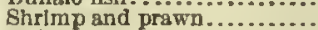 & $19,080,000$ & 1 & 494,000 & 1 \\
\hline 29 & llake......................... & $34,340,000$ & 2 & 464,000 & \\
\hline 30 & Pollack ..................... & $29,462,000$ & $\overline{2}$ & 402,000 & 1 \\
\hline & All other........................ & $183,574,000$ & 10 & $6,872,000$ & 13 \\
\hline
\end{tabular}




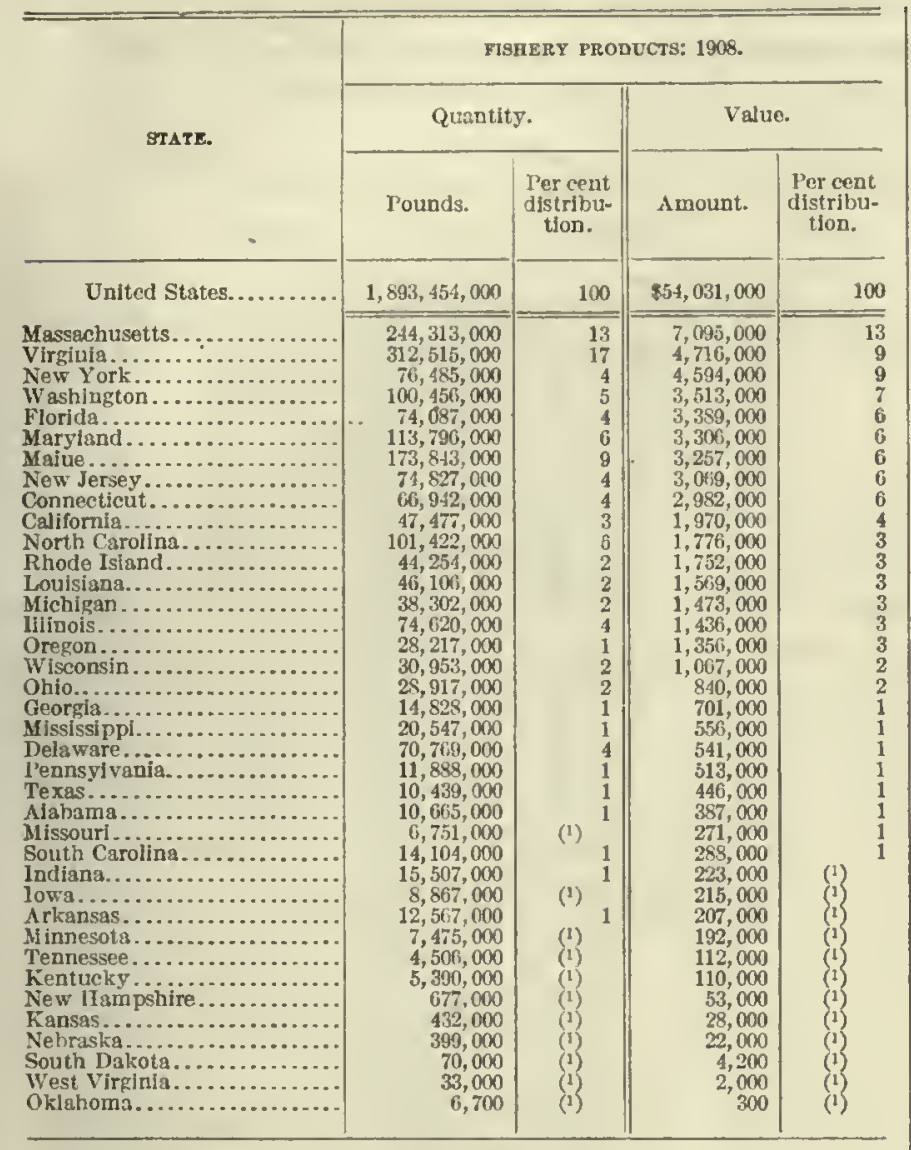

${ }^{1}$ Less than 1 per cent.

Statistics are shown separately for over a hundred species of fish proper, and in addition for about 50 specics of crustaceans, mollusks, aquatic mammals, and other products. Many of the products are brought in from the fishing grounds in a salted condition or are smoked by the fishermen and are so reported.

The quantity and value of the catch taken by each class of apparatus of capture is shown in Table 3, on page 29, for the United States and for each of the main geographic divisions into which it is divided. The table also shows the catch taken by each class of apparatus in the vessel fisheries and in the shore and boat fisheries.

Table 4, on page 30 , shows the products by species and by apparatus of capture.

Ranked in order of value, the catch with dredges, tongs, rakes, etc., is first in importance, representing 35 per cent of the total value of products. Lines rankerl next, 17 per cent of the total value of products being taken by this form of apparatus, followed by gill nets with 14 per cent, seines with 11 per cent, and pound and trap nets and weirs with 10 per cent of the total. Wheels and slides are of course used only in the shore and boat fisheries and whaling apparatus only in the vessel fisheries. With these exceptions all classes of apparatus were employed in both classes of fisheries, although fyke and hoop nets, pound and trap nets, pots and traps, and gill nets pertain more particularly to the shore and boat fisheries. On the other hand, the catch by lines in vessel fisheries was ncarly three times in value that of the shore and boat fisheries.

Since the bulk of the oyster product comes from the Atlantic coast, a greater proportion of the total product, 45 per cent, was taken by dredges, tongs, etc., in that division than in any other. The line catch represents 18 per cent of the total value of products for the Atlantic coast fisheries. For both these classes of apparatus the catch of the vessel fisheries excecded that of the shore and boat fisheries, although the total value of products was larger for the latter class of fisheries.

In the Gulf of Mexico division dredges and tongs, lines, seines, gill nets, and sponge apparatus were the leading forms of apparatus of capture. In the Pacific coast fisheries gill nets were the most important, contributing 34 per cent of the total value of products. Nearly all the catch with this apparatus was reported for the shore and boat fisheries.

In the Great Lakes division 54 per cent of the total value of products was taken with gill nets and 29 per cent witl pound and trap nets. Nearly three-fourths of the gill-net catch was taken in the vessel fisheries, while the pound and trap net catch was taken mainly in the shore and boat fisheries.

For the fisheries of the Mississippi River and its tributarics, the catch with seines represented 29 per cent of the value of all products, that with fyke and hoop nets 23 per cent, and that with dredges, tongs, etc., comprising chiefly crowfoot dredges employed in mussel fisheries, 22 per cent.

Table 5, on page 34 , is a detailed presentation of the products by states and by species. The quantity of each species marketed by the fishermen in a salted or smoked condition is shown with the understanding that, except when otherwise stated, the product is fresh. Table 6 , on page 44 , gives the quantity and value of the catch, by apparatus of capture and by states. 
TABLE 1.-PRODUCTS, BY GENERAL CLASSES: 1908 AND 1900 TO 1904.

\begin{tabular}{|c|c|c|c|c|}
\hline \multirow{3}{*}{ CLASS AND EPECTES. } & \multicolumn{4}{|c|}{ FISIIERY PRODUCTS. } \\
\hline & \multicolumn{2}{|c|}{1908} & \multicolumn{2}{|c|}{$1900-19041$} \\
\hline & $\begin{array}{l}\text { Quantity } \\
\text { (pounds). }\end{array}$ & Value. & $\begin{array}{l}\text { Quantity } \\
\text { (pounds). }\end{array}$ & Value. \\
\hline Totai......... & $1,893,454,000$ & $\$ 54,031,000$ & $1,919,862,000$ & $\$ 49,398,000$ \\
\hline Fish............. & $1,441,317,000$ & $30,247,000$ & $1,538,39 f, 000$ & $25,758,000$ \\
\hline 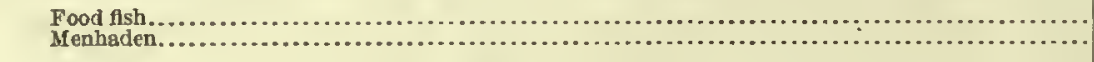 & $\begin{array}{r}1,046,541,000 \\
394,776,000\end{array}$ & $\begin{array}{r}29,354,000 \\
893,000\end{array}$ & $\begin{array}{l}989,275,000 \\
549,121,000\end{array}$ & $\begin{array}{r}24,332,000 \\
1,426,000\end{array}$ \\
\hline Crustaceans............................ & $96,225,000$ & $3,466,000$ & $77,813,000$ & $2,764,000$ \\
\hline 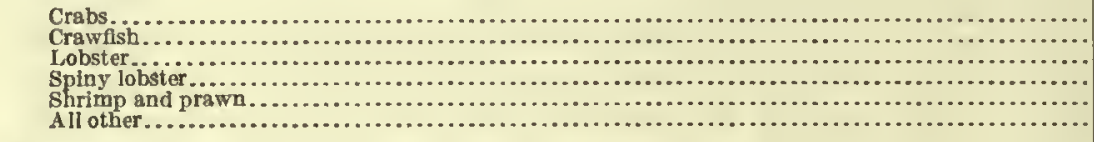 & $\begin{array}{r}52,913,000 \\
666,000 \\
15,279,000 \\
573,000 \\
19,080,000 \\
7,713,000\end{array}$ & $\begin{array}{r}912,000 \\
34,000 \\
1,931,000 \\
69,000 \\
494,000 \\
226,000\end{array}$ & $\begin{array}{r}40,154,000 \\
503,000 \\
15,130,000 \\
1,078,000 \\
17,695,000 \\
3,253,000\end{array}$ & $\begin{array}{r}906,000 \\
24,000 \\
1,382,000 \\
43,000 \\
395,000 \\
613,000\end{array}$ \\
\hline Mollusks...................................... & $347,799,000$ & $18,752,000$ & $290,891,000$ & $19,385,000$ \\
\hline 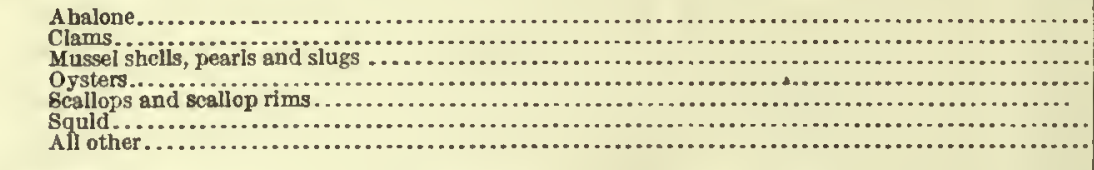 & $\begin{array}{r}1,005,000 \\
16,717,000 \\
81,869,000 \\
233,309,000 \\
2,432,000 \\
2,562,000 \\
9,905,000\end{array}$ & $\begin{array}{r}16,000 \\
1,896,000 \\
692,000 \\
15,713,000 \\
317,000 \\
43,000 \\
775,000\end{array}$ & $\begin{array}{r}825,000 \\
19,083,000 \\
51,851,000 \\
204,118,000 \\
1,551,000 \\
5,922,000 \\
7,535,000\end{array}$ & $\begin{array}{r}9,200 \\
1,820,000 \\
530,000 \\
16,681,000 \\
279,000 \\
43,000 \\
523,000\end{array}$ \\
\hline 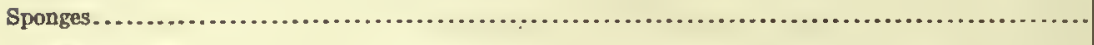 & 622,000 & 545,000 & 347,000 & 364,000 \\
\hline Whale products...... & $4,028,000$ & 497,000 & $5,576,000$ & 816,000 \\
\hline 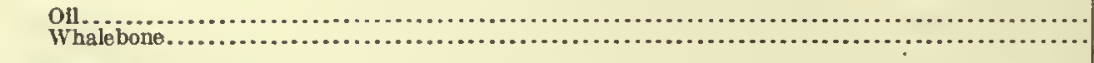 & $\begin{array}{r}3,964,000 \\
63,000\end{array}$ & $\begin{array}{l}282,000 \\
215,000\end{array}$ & $\begin{array}{r}5,462,000 \\
114,000\end{array}$ & $\begin{array}{l}311,000 \\
505,000\end{array}$ \\
\hline Hides, pelts, and skins.... & 602,000 & 325,000 & 353,000 & 59,000 \\
\hline 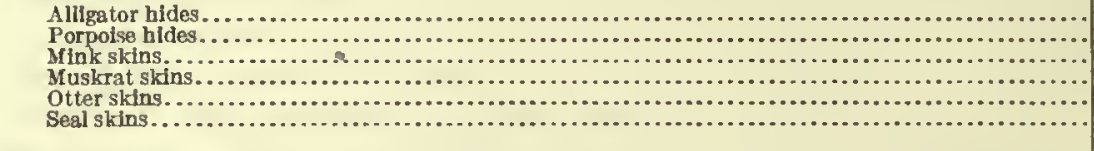 & $\begin{array}{r}372,000 \\
48,000 \\
22,000 \\
149,000 \\
7,600 \\
3,100\end{array}$ & $\begin{array}{r}61,000 \\
1,000 \\
89,000 \\
136,000 \\
30,000 \\
8,200\end{array}$ & 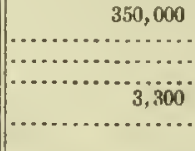 & $\begin{array}{l}\left(^{6}\right)^{41,000} \\
\left(^{6}\right) \\
\left({ }^{6}\right) \\
{ }_{(6)} 18,000\end{array}$ \\
\hline 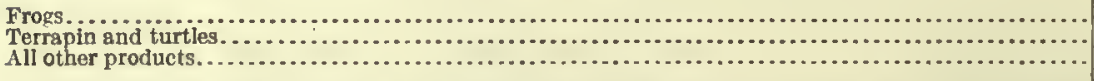 & $\begin{array}{r}259,000 \\
1,457,000 \\
1,145,000\end{array}$ & $\begin{array}{r}42,000 \\
122,000 \\
35,000\end{array}$ & $\begin{array}{r}1,409,0000 \\
5,078,0000\end{array}$ & (") 114,000 \\
\hline
\end{tabular}

1 Comblned statistics for the Naw England, South Atiantle, and Gulf states for 1902; Pacinc coaststates for 1904; Mississippi River and Its tributarles, Mlddle Atlantic states, and the Great Lakes for 1903; and minor interior waters for 1900-1903.

2 Includes king crabs, valued at $\$ 23,000$; and spider and stone crabs, valued at $\$ 3,700$

Includes king crabs, valued at $\$ 8,900$; and shrimp shells, valuad at $\$ 4,400$.

Includes surf clams, valued at $\$ 21,000$; cockles, winkles, and conchs, valued at $\$ 35,000$; mussels, valued at $\$ 12,000$; and other shells, valued at $\$ 7,100$.

Includes mussels, valued at \$8,500; oyster and other shells, valued at $\$ 6,500$; and cockles, winkles, conchs, ete., valued at $\$ 7,600$.

- Not reported separately.

TABLE 2.-PRODUCTS, BY SPECIES AND BY GEOGRAPHIC DIVISIONS: 1908.

\begin{tabular}{|c|c|c|c|c|c|c|c|c|c|c|c|c|}
\hline \multirow{2}{*}{ SFECIFS. } & \multicolumn{2}{|c|}{ UNITED STATEQ. } & \multicolumn{2}{|c|}{$\begin{array}{l}\text { ATLANTIC COAST } \\
\text { DIVISION. }\end{array}$} & \multicolumn{2}{|c|}{$\begin{array}{l}\text { GULF OF MEXICO } \\
\text { DIVLSION. }\end{array}$} & \multicolumn{2}{|c|}{$\begin{array}{l}\text { PACIFIC COAST } \\
\text { DIVISION. }\end{array}$} & \multicolumn{2}{|c|}{$\begin{array}{l}\text { MISSISSIPPI RIVER } \\
\text { DIVISION. }\end{array}$} & \multicolumn{2}{|c|}{$\begin{array}{l}\text { GREAT LAKES } \\
\text { DIVISION. }\end{array}$} \\
\hline & $\begin{array}{l}\text { Quantity } \\
\text { (pounds). }\end{array}$ & Value. & $\begin{array}{l}\text { Quantity } \\
\text { (pounds). }\end{array}$ & Value. & $\begin{array}{l}\text { Quantity } \\
\text { (pounds). }\end{array}$ & Value. & $\begin{array}{l}\text { Quantity } \\
\text { (pounds). }\end{array}$ & Value. & $\begin{array}{l}\text { Quantity } \\
\text { (pounds). }\end{array}$ & Value. & $\begin{array}{l}\text { Quantity } \\
\text { (pounds). }\end{array}$ & Value. \\
\hline Total .......... & $1,893,454,000$ & $\$ 54,031,000$ & $1,344,665,000$ & $\$ 35,474,000$ & $117,723,000$ & $\$ 4,825,000$ & $176,150,000$ & $56,839,000$ & $148,254,000$ & $\$ 2,125,000$ & $106,032.000$ & $\$ 3,767,000$ \\
\hline $\begin{array}{l}\text { Fish: } \\
\text { Albacore, or horse } \\
\text { mackerel ....... } \\
\text { Alewives, fresh ... } \\
\text { Alewives, salted } \\
\text { Alewives, smoked. } \\
\text { A m her - fis h, or } \\
\text { jack-fish ........ }\end{array}$ & $\begin{array}{r}359,000 \\
80,945,000 \\
8,840,000 \\
193,000 \\
38,000\end{array}$ & $\begin{array}{r}12,000 \\
455,000 \\
130,000 \\
3,500 \\
1,600\end{array}$ & $\begin{array}{r}309,000 \\
80,941,000 \\
8,810,000 \\
193,000 \\
600\end{array}$ & $\begin{array}{r}11,000 \\
455,000 \\
130,000 \\
3,500 \\
\text { (1) }\end{array}$ & $\begin{array}{r}4,500 \\
\ldots \ldots \ldots \ldots \\
\cdots \ldots \ldots \ldots\end{array}$ & $\begin{array}{r}100 \\
\cdots \ldots \ldots \\
\cdots \ldots\end{array}$ & 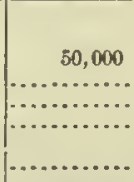 & $\begin{array}{r}\quad 800 \\
\ldots \ldots \ldots \\
\ldots \ldots \ldots\end{array}$ & 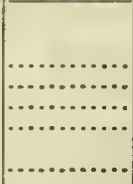 & 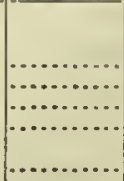 & & $\begin{array}{l}\cdots \\
\cdots \cdots \\
\cdots \cdots\end{array}$ \\
\hline $\begin{array}{l}\text { Anchories } \\
\text { Barracuda, fresh } \\
\text { Barracuda, salted } \\
\text { Black bass ....... } \\
\text { Biack cod ........ }\end{array}$ & $\begin{array}{r}220,000 \\
3,138,000 \\
112,000 \\
3,313,000 \\
209,000\end{array}$ & $\begin{array}{r}1,600 \\
87,000 \\
3,500 \\
255,000 \\
5,500\end{array}$ & $\ddot{i, 300}$ & 105,000 & 84,000 & $\begin{array}{r}3,100 \\
7,200 \\
\cdots\end{array}$ & $\begin{array}{r}220,000 \\
3,093,000 \\
112,000 \\
82,000 \\
209,000\end{array}$ & $\begin{array}{r}1,600 \\
84,000 \\
3,500 \\
8,200 \\
5,500\end{array}$ & 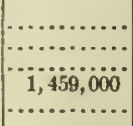 & i28,000 & $\begin{array}{r}45,000 \\
\cdots\end{array}$ & 6,100 \\
\hline $\begin{array}{l}\text { Biuefish, fresh .... } \\
\text { Bluefish, salted ... } \\
\text { Bonito ........... } \\
\text { Bream and sunish } \\
\text { Bufralo insh ....... }\end{array}$ & $\begin{array}{r}7,594,000 \\
52,000 \\
1,096,000 \\
4,738,000 \\
16,729,000\end{array}$ & $\begin{array}{r}504,000 \\
1,900 \\
39,000 \\
120,000 \\
495,000\end{array}$ & $\begin{array}{r}7,029,000 \\
1,400 \\
755,000 \\
1,656,000 \\
\ldots \ldots \ldots \ldots\end{array}$ & $\begin{array}{r}476,000 \\
100 \\
32,000 \\
52,000 \\
\ldots \ldots \ldots \ldots\end{array}$ & $\begin{array}{r}565,000 \\
51,000 \\
11,000 \\
185,000 \\
1,683,000\end{array}$ & $\begin{array}{r}28,000 \\
1,900 \\
900 \\
8,300 \\
43,000\end{array}$ & $\begin{array}{r}\cdots \cdots \\
\cdots 29,000 \\
\cdots \ldots \ldots \ldots \ldots \\
\cdots \cdots \cdots\end{array}$ & $\begin{array}{l}\cdots \\
6,100 \\
\cdots \cdots \cdots \cdots\end{array}$ & $\begin{array}{r}2,821,000 \\
15,040,000\end{array}$ & $\begin{array}{r}58,000 \\
455,000\end{array}$ & $\begin{array}{r}76,000 \\
6,200\end{array}$ & $\begin{array}{r}1,900 \\
200\end{array}$ \\
\hline 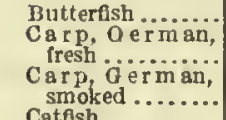 & $\begin{array}{r}6,855,000 \\
42,759,000 \\
4,500\end{array}$ & $\begin{array}{r}237,000 \\
1,135,000 \\
700\end{array}$ & $\begin{array}{l}6,749,000 \\
1,482,000\end{array}$ & $\begin{array}{r}223,000 \\
79,000\end{array}$ & $\begin{array}{r}16,000 \\
2,400\end{array}$ & 100 & $\begin{array}{r}89,000 \\
457,000\end{array}$ & $\begin{array}{r}13,000 \\
4,600\end{array}$ & $30,670,000$ & 858,000 & $\begin{array}{r}10,148,000 \\
4,500\end{array}$ & $\begin{array}{r}194,000 \\
700\end{array}$ \\
\hline $\begin{array}{l}\text { Cathsh ............. } \\
\text { Cobla ............ }\end{array}$ & $\begin{array}{r}17,817,000 \\
123,000\end{array}$ & $\begin{array}{r}785,000 \\
2,800\end{array}$ & $\begin{array}{r}3,528,000 \\
82,000\end{array}$ & $\begin{array}{r}132,000 \\
1,300\end{array}$ & $\begin{array}{r}3,984,000 \\
41,000\end{array}$ & $\begin{array}{r}143,000 \\
1,500\end{array}$ & $\begin{array}{r}1,270,000 \\
\ldots \ldots \ldots \ldots\end{array}$ & $\begin{array}{l}65,000 \\
\ldots \ldots\end{array}$ & $\begin{array}{r}8,073,000 \\
\ldots \ldots \ldots \ldots\end{array}$ & $\begin{array}{r}395,000 \\
\ldots \ldots \ldots \ldots\end{array}$ & $\begin{array}{r}963,000 \\
\ldots \ldots \ldots\end{array}$ & 50,000 \\
\hline
\end{tabular}


PRODUCTS.

TABLE 2.-PRODUCTS, BY SPECIES AND BY GEOGRAPHIC DIVISIONS: 1908-Continued.

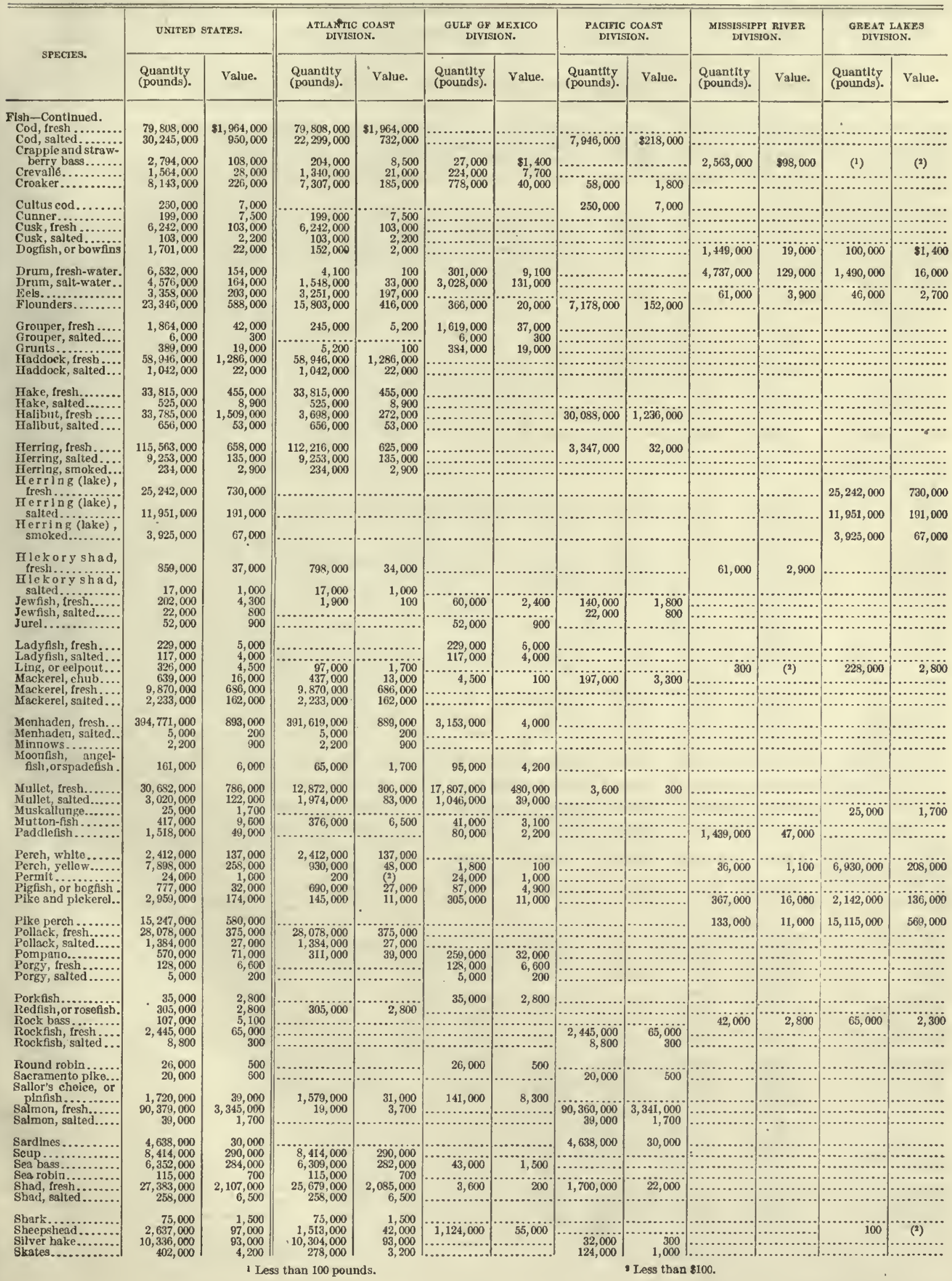


FISHERIES OF THE UNITED STATES, 1908.

TABLE 2.-PRODUCTS, BY SPECIES AND BY GEOGRAPHIC DIVISIONS: I908-Continued.

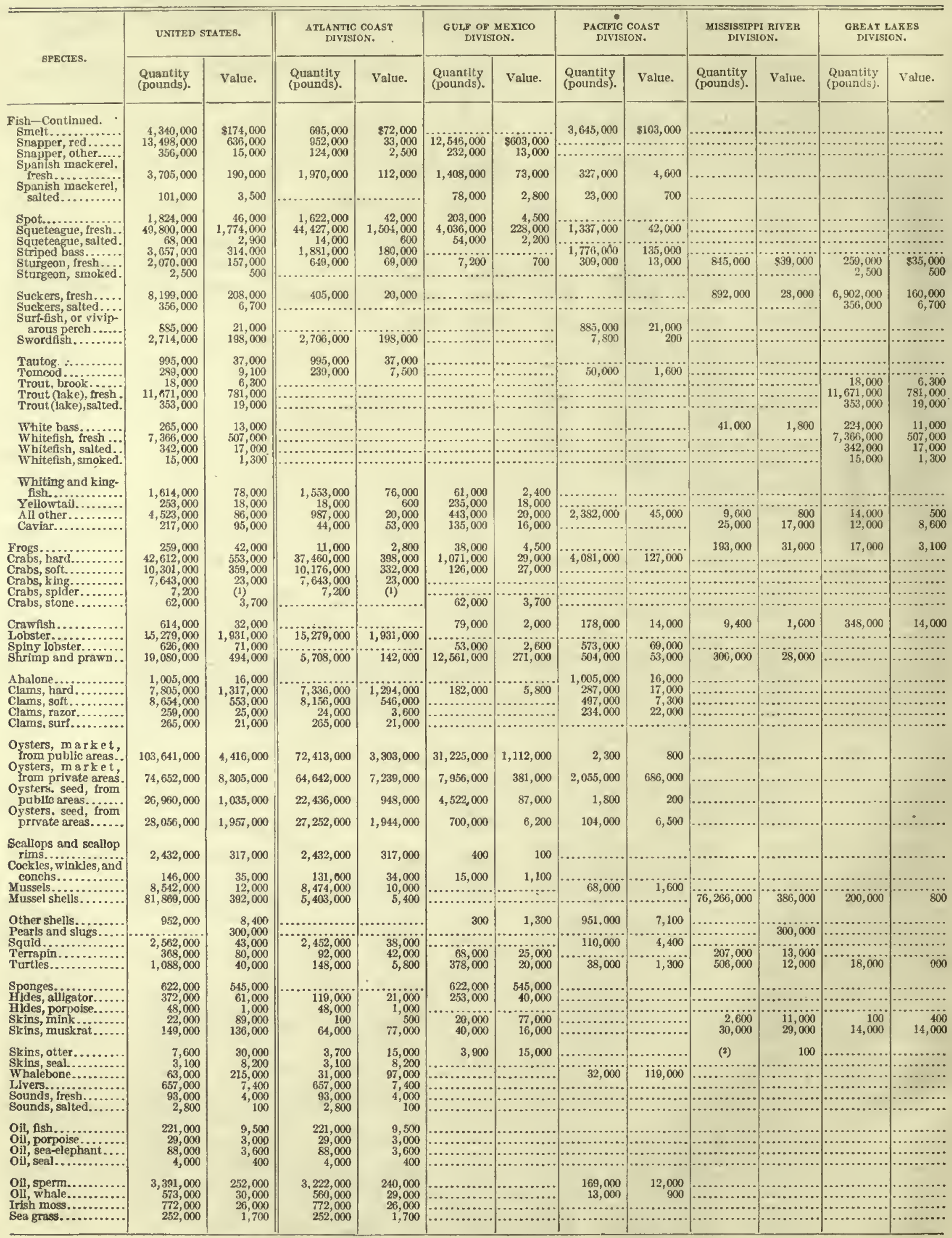


PRODUCTS.

TABLE 3.-PRODUCTS, BY CLASS OF FISHERIES, APPARATUS OF CAPTURE, AND GEOGRAPIIIC DIVISIONS: 1908.

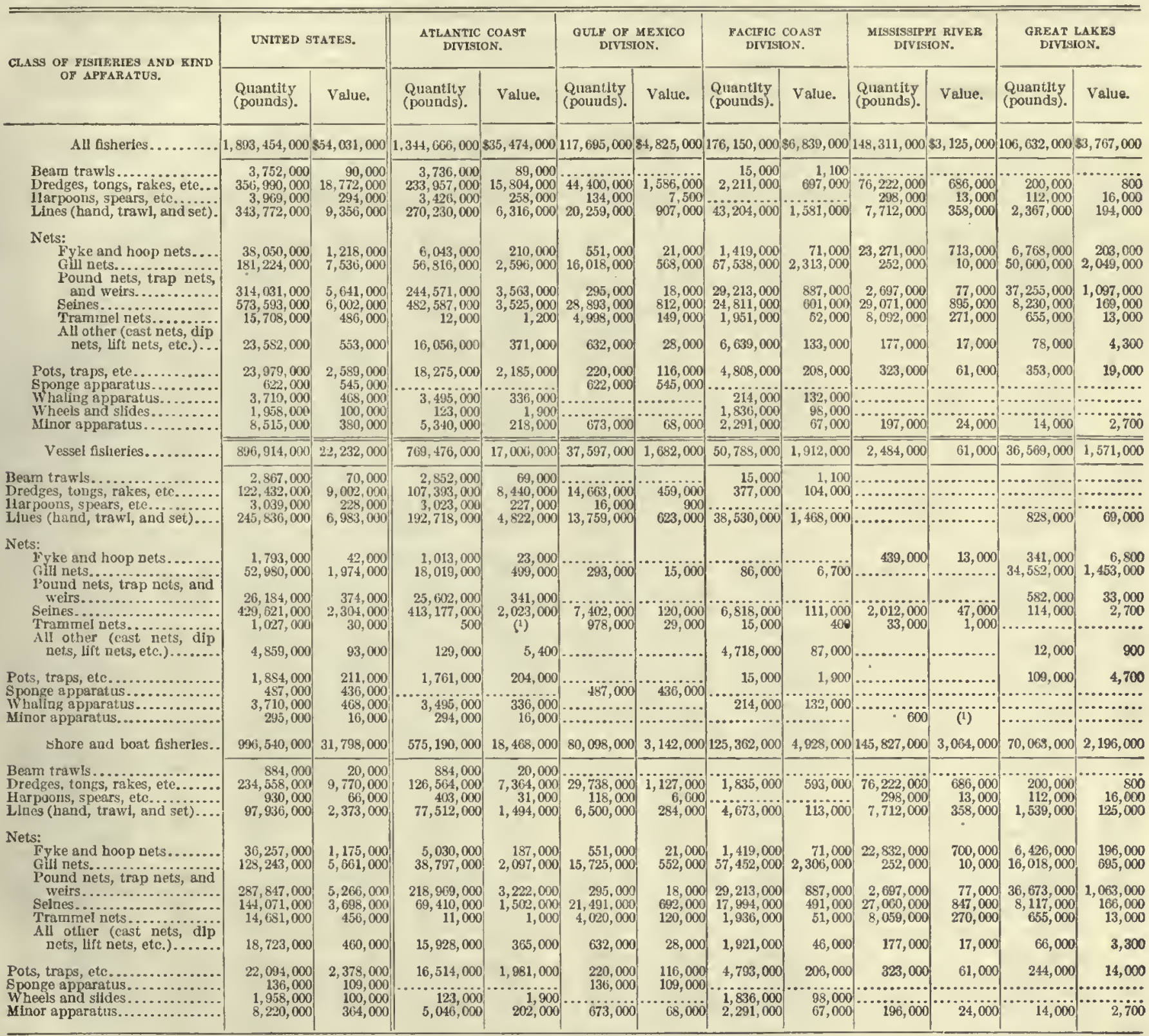

1 Less than $\$ 100$. 
TABLE 4.-PRODUCTS, BY SPECIES AND

\begin{tabular}{|c|c|c|c|c|c|c|c|c|c|c|c|}
\hline & \multirow{3}{*}{ SPECIES. } & \multirow{2}{*}{\multicolumn{2}{|c|}{ TOTAL }} & \multicolumn{8}{|c|}{ CAUGHT BY - } \\
\hline & & & & \multicolumn{2}{|c|}{ Lines. } & \multicolumn{2}{|c|}{ Gill nets. } & \multicolumn{2}{|c|}{ Seines. } & \multicolumn{2}{|c|}{$\begin{array}{l}\text { Pound nets, trap nets, } \\
\text { and weirs. }\end{array}$} \\
\hline & & $\begin{array}{l}\text { Quantity } \\
\text { (pounds). }\end{array}$ & Value. & $\begin{array}{l}\text { Quantity } \\
\text { (pounds). }\end{array}$ & Value. & $\begin{array}{l}\text { Quantity } \\
\text { (pounds). }\end{array}$ & Value. & $\begin{array}{l}\text { Quantity } \\
\text { (pounds). }\end{array}$ & Value. & $\begin{array}{l}\text { Quantity } \\
\text { (pounds). }\end{array}$ & Value. \\
\hline 1 & Total. & $1,803,454,000$ & $\$ 54,031,000$ & $343,960,000$ & $\$ 9,360,000$ & $181,224,000$ & $\$ 7,536,000$ & $573,405,000$ & $\$ 5,999,000$ & $314,031,000$ & $\$ 5,641,000$ \\
\hline $\begin{array}{l}2 \\
3 \\
4\end{array}$ & $\begin{array}{l}\text { Flsh: } \\
\text { Abseore, or horse mad } \\
\text { Alewives... ..... } \\
\text { Amber-fish (jackish). }\end{array}$ & $\begin{array}{r}359,000 \\
89,978,000 \\
38,000 \\
000\end{array}$ & $\begin{array}{r}12,000 \\
589,000 \\
1,600\end{array}$ & $\begin{array}{l}18,000 \\
400 \\
38,000\end{array}$ & (3) $\begin{array}{l}200 \\
1,600\end{array}$ & $\begin{array}{r}32,000 \\
2,211,000\end{array}$ & $\begin{array}{r}600 \\
20,000 \\
\cdots \\
\cdots\end{array}$ & $\begin{array}{r}500 \\
18,928,000 \\
\cdots\end{array}$ & (1) & $\begin{array}{r}309,000 \\
66,369,000 \\
100\end{array}$ & $\begin{array}{l}11,000 \\
372,000 \\
(2)\end{array}$ \\
\hline $\begin{array}{l}5 \\
6\end{array}$ & $\begin{array}{l}\text { Anchovies... } \\
\text { Barracuda... }\end{array}$ & $\begin{array}{r}220,000 \\
3,250,000\end{array}$ & $\begin{array}{r}1,600 \\
91,000\end{array}$ & $\ldots 91,000$ & 16,000 & $\begin{array}{r}55,000 \\
2,644,000\end{array}$ & 74,000 & $\begin{array}{r}165,000 \\
600\end{array}$ & $(2)$ & & \\
\hline $\begin{array}{l}7 \\
8\end{array}$ & $\begin{array}{l}\text { Black bass.. } \\
\text { Black cod... }\end{array}$ & $\begin{array}{l}3,313,000 \\
209,000\end{array}$ & $\begin{array}{r}255,000 \\
5,500\end{array}$ & $\begin{array}{r}1,264,000 \\
209,000\end{array}$ & $\begin{array}{r}92,000 \\
5,500\end{array}$ & 64,000 & 5,900 & $\begin{array}{l}1,288,000 \\
\ldots \ldots\end{array}$ & 102,000 & 77,000 & $\begin{array}{r}6,200 \\
\ldots \ldots\end{array}$ \\
\hline $\begin{array}{r}9 \\
10\end{array}$ & & $\begin{array}{l}7,647,000 \\
1,096,000\end{array}$ & $\begin{array}{r}506,000 \\
39,000\end{array}$ & $\begin{array}{r}3,781,000 \\
317,000\end{array}$ & $\begin{array}{r}307,000 \\
13,000\end{array}$ & $\begin{array}{l}2,029,000 \\
293,000\end{array}$ & $\begin{array}{r}109,000 \\
5,600\end{array}$ & $1,221,000$ & 54,000 & $\begin{array}{l}534,000 \\
474,000\end{array}$ & 33,000 \\
\hline 11 & Bream and sunfish & $\begin{array}{l}1,7,738,000 \\
4,000\end{array}$ & 120,000 & 175,000 & $\begin{array}{r}13,100 \\
7,100\end{array}$ & $\begin{array}{r}29,3,000 \\
\end{array}$ & 1,300 & $2,524,000$ & 67,000 & 197,000 & $\begin{array}{r}19,800 \\
6,400\end{array}$ \\
\hline $\begin{array}{l}12 \\
13 \\
14 \\
15 \\
16\end{array}$ & $\begin{array}{l}\text { Buffalo fish...... } \\
\text { Butterfish...... } \\
\text { Carp, German... } \\
\text { Cathish............ } \\
\text { Cobia.......... }\end{array}$ & $\begin{array}{r}16,729,000 \\
6,855,000 \\
42,763,000 \\
17,817,000 \\
123,000\end{array}$ & $\begin{array}{r}498,000 \\
237,000 \\
1,135,000 \\
785,000 \\
2,800\end{array}$ & $\begin{array}{r}812,000 \\
17,000 \\
1,062,000 \\
7,012,000 \\
100\end{array}$ & $\begin{array}{r}23,000 \\
800 \\
35,000 \\
290,000 \\
(2)\end{array}$ & $\begin{array}{r}131,000 \\
184,000 \\
894,000 \\
215,000 \\
52,000\end{array}$ & $\begin{array}{r}5,000 \\
8,000 \\
25,000 \\
11,000 \\
1,500\end{array}$ & $\begin{array}{r}7,138,000 \\
204,000 \\
24,162,000 \\
3,795,000 \\
71,000\end{array}$ & $\begin{array}{r}218,000 \\
14,000 \\
611,000 \\
151,000 \\
1,300\end{array}$ & $\begin{array}{r}828,000 \\
6,439,000 \\
1,224,000 \\
1,505,000\end{array}$ & $\begin{array}{r}29,000 \\
214,000 \\
28,000 \\
69,000\end{array}$ \\
\hline $\begin{array}{l}17 \\
18 \\
19 \\
20 \\
21\end{array}$ & 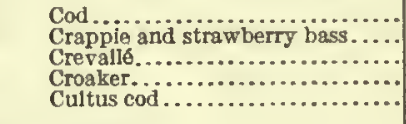 & $\begin{array}{r}110,054,000 \\
2,794,000 \\
1,564,000 \\
8,143,000 \\
250,000\end{array}$ & $\begin{array}{r}2,914,000 \\
108,000 \\
28,000 \\
226,000 \\
7,000\end{array}$ & $\mid \begin{array}{r}104,553,000 \\
372,000 \\
1,269,000 \\
934,000 \\
211,000\end{array}$ & $\begin{array}{r}2,787,000 \\
21,000 \\
20,000 \\
32,000 \\
5,900\end{array}$ & $\begin{array}{r}2,091,000 \\
2,800 \\
81,000 \\
428,000 \\
400\end{array}$ & $\begin{array}{r}47,000 \\
100 \\
2,600 \\
9,500 \\
(2)\end{array}$ & $\begin{array}{l}1,592,000 \\
1,132,000 \\
105,000 \\
1,421,000\end{array}$ & $\begin{array}{r}33,000 \\
42,000 \\
3,200 \\
48,000\end{array}$ & $\begin{array}{r}1,813,000 \\
78,000 \\
80,000 \\
5,071,000\end{array}$ & $\begin{array}{r}47,000 \\
3,200 \\
1,800 \\
130,000\end{array}$ \\
\hline $\begin{array}{l}22 \\
23\end{array}$ & $\begin{array}{l}\text { Cunner.............. } \\
\text { Cusk .............. }\end{array}$ & $\begin{array}{r}199,000 \\
6,344,000\end{array}$ & $\begin{array}{r}7,500 \\
105,000\end{array}$ & $\begin{array}{r}600 \\
6,344,000\end{array}$ & (2) & & & 1,000 & $\cdot 100$ & $\begin{array}{r}2,300 \\
\ldots \ldots\end{array}$ & 100 \\
\hline $\begin{array}{l}24 \\
25\end{array}$ & $\begin{array}{l}\text { Dogfish, or bowfin } \\
\text { Drum, fresh-wate }\end{array}$ & $\begin{array}{l}1,701,000 \\
6,532,000\end{array}$ & $\begin{array}{r}22,000 \\
154,000\end{array}$ & $\begin{array}{r}29,000 \\
812,000\end{array}$ & $\begin{array}{r}500 \\
29,000\end{array}$ & $\begin{array}{r}3,300 \\
29,000\end{array}$ & (2) 600 & 817,000 & 10,000 & in, & 900 \\
\hline & Druma, salt- & $4,576,000$ & 164,000 & 631,000 & 25,000 & 622,000 & 18,000 & $2,662,000$ & $\begin{array}{l}24,000 \\
96,000\end{array}$ & $\begin{array}{r}2,326,000 \\
165,000\end{array}$ & $\begin{array}{r}3,0,0 \times 0 \\
2,400\end{array}$ \\
\hline $\begin{array}{l}27 \\
28 \\
29 \\
30 \\
31\end{array}$ & & $\begin{array}{r}3,358,000 \\
23,346,000 \\
1,870,000 \\
339,000 \\
59,987,000\end{array}$ & $\begin{array}{r}203,000 \\
588,000 \\
42,000 \\
19,000 \\
1,308,000\end{array}$ & $\begin{array}{r}161,000 \\
4,017,000 \\
1,779,000 \\
281,000 \\
57,973,000\end{array}$ & $\begin{array}{r}8,800 \\
91,000 \\
38,000 \\
14,000 \\
1,260,000\end{array}$ & $\begin{array}{r}6,500 \\
820,000 \\
74,000 \\
86,000 \\
180,000\end{array}$ & $\begin{array}{r}500 \\
20,000 \\
3,500 \\
4,400 \\
4,100\end{array}$ & $\begin{array}{r}318,000 \\
1,645,000 \\
9,300 \\
12,000 \\
1,437,000\end{array}$ & $\begin{array}{r}12,000 \\
43,000 \\
400 \\
500 \\
33,000\end{array}$ & $\begin{array}{r}214,000 \\
4,369,000 \\
7,500 \\
10,000 \\
398,000\end{array}$ & $\begin{array}{r}12,000 \\
133,000 \\
400 \\
500 \\
11,000\end{array}$ \\
\hline $\begin{array}{l}32 \\
33\end{array}$ & $\begin{array}{l}\text { Hake........... } \\
\text { Ilalibut....... }\end{array}$ & $\begin{array}{l}34,340,000 \\
34,441,000\end{array}$ & $\begin{array}{r}464,000 \\
1,562,000\end{array}$ & $\begin{array}{l}33,633,000 \\
34,433,000\end{array}$ & $\begin{array}{r}458,000 \\
1,561,000\end{array}$ & 44,000 & 500 & $\begin{array}{r}70,000 \\
9,000\end{array}$ & $\begin{array}{r}1,100 \\
900\end{array}$ & 593,000 & 5,100 \\
\hline $\begin{array}{l}34 \\
35 \\
35\end{array}$ & & $125,050,000$ & 796,000 & & & $11,302,000$ & 218,000 & $33,988,000$ & 198,000 & $72,868,000$ & 336,000 \\
\hline $\begin{array}{l}35 \\
36\end{array}$ & $\begin{array}{l}\text { lerring (lake) ......... } \\
\text { Hickory shad........ }\end{array}$ & $\begin{array}{r}41,118,000 \\
876,000\end{array}$ & $\begin{array}{r}989,000 \\
38,000\end{array}$ & $\begin{array}{l}12,000 \\
17,000\end{array}$ & $\begin{array}{l}500 \\
800\end{array}$ & $\begin{array}{r}24,726,000 \\
267,000\end{array}$ & $\begin{array}{r}721,000 \\
10,000\end{array}$ & $\begin{array}{r}8,000 \\
278,000\end{array}$ & $\begin{array}{r}200 \\
12,000\end{array}$ & $\begin{array}{l}16,319,000 \\
237,000\end{array}$ & $\begin{array}{r}266,000 \\
12,000\end{array}$ \\
\hline $\begin{array}{l}37 \\
38\end{array}$ & $\begin{array}{l}\text { Jewfish } \ldots \ldots \ldots \ldots \ldots \ldots \ldots \ldots \\
\text { JureI } \ldots \ldots \ldots \ldots \ldots \ldots \ldots \ldots \ldots\end{array}$ & $\begin{array}{r}223,000 \\
52,000\end{array}$ & $\begin{array}{r}5,100 \\
900\end{array}$ & $\begin{array}{r}171,000 \\
8,800\end{array}$ & $\begin{array}{r}4,000 \\
400\end{array}$ & 35,000 & 700 & $\begin{array}{l}10,000 \\
32,000\end{array}$ & $\begin{array}{l}400 \\
400\end{array}$ & 100 & (2) \\
\hline & & 346,000 & 9,000 & & & 1,400 & 100 & 320,000 & 8,400 & & \\
\hline 41 & Jackerel, chub. & $\begin{array}{l}326,000 \\
639,000\end{array}$ & $\begin{array}{r}4,500 \\
16,000\end{array}$ & $\begin{array}{r}96,000 \\
7,000\end{array}$ & $\begin{array}{r}1,800 \\
200\end{array}$ & $\begin{array}{r}91,000 \\
173,000\end{array}$ & $\begin{array}{l}1,000 \\
3,100\end{array}$ & 290,000 & $\left(a^{3}\right), 900$ & $\begin{array}{l}102,000 \\
169,000\end{array}$ & $\begin{array}{l}1,300 \\
6,900\end{array}$ \\
\hline $\begin{array}{l}42 \\
43 \\
44\end{array}$ & & $\begin{array}{r}12,103,000 \\
394,776,000 \\
2,200\end{array}$ & $\begin{array}{r}848,000 \\
893,000 \\
900\end{array}$ & $\begin{array}{r}173,000 \\
100\end{array}$ & ${ }_{(9)}^{8,300}$ & $\begin{array}{l}2,809,000 \\
1,983,000\end{array}$ & $\begin{array}{r}180,000 \\
3,300\end{array}$ & $\begin{array}{r}8,174,000 \\
371,630,000 \\
2,200\end{array}$ & $\begin{array}{l}608,000 \\
822,000 \\
000\end{array}$ & $\begin{array}{r}943,000 \\
21,138,000\end{array}$ & $\begin{array}{l}42,000 \\
67,000\end{array}$ \\
\hline $\begin{array}{l}15 \\
46\end{array}$ & $\begin{array}{l}\text { Moonfsh, angel-fish, or spadefish. } \\
\text { Mullet................................. }\end{array}$ & $\begin{array}{r}161,000 \\
33,703,000\end{array}$ & $\begin{array}{r}6,000 \\
908,000\end{array}$ & 35,000 & $\begin{array}{r}{ }^{1} 100 \\
2,000\end{array}$ & $22,743,000$ & 593,000 & $\begin{array}{r}39,000 \\
7,444,000\end{array}$ & $\begin{array}{r}1,500 \\
235,000\end{array}$ & $\begin{array}{l}61,000 \\
88,000\end{array}$ & $\begin{array}{r}1,700 \\
3,300\end{array}$ \\
\hline${ }_{48}^{47}$ & Musk & 25,000 & , 700 & 19,000 & 1,200 & 2000 & & 800 & 100 & 100 & (2) \\
\hline (4) & & & & & & & 700 & & 30,0 & 16,000 & 600 \\
\hline & & & & & & & & & & & 39,0 \\
\hline 51 & jetion & $7,898,000$ & $00, \mathrm{ve}$ & 212,000 & 0,000 & $2,401,000$ & 90,000 & 510,000 & 26,000 & $2,502,000$ & 74,000 \\
\hline 52 & $\begin{array}{l}\text { Permit .... } \\
\text { PIgfish, or }\end{array}$ & $\begin{array}{r}24,000 \\
777,000\end{array}$ & $\begin{array}{r}1,000 \\
32,000\end{array}$ & $\begin{array}{r}2,600 \\
161,000\end{array}$ & $\begin{array}{r}100 \\
8,200\end{array}$ & $\begin{array}{r}8,800 \\
129,000\end{array}$ & $\begin{array}{r}300 \\
4,300\end{array}$ & $\begin{array}{r}5,700 \\
432,000\end{array}$ & $\begin{array}{r}200 \\
12,000\end{array}$ & & \\
\hline 54 & & & & & 16,000 & & 9,800 & & & & 74,000 \\
\hline $\begin{array}{l}55 \\
56\end{array}$ & & & & $\begin{array}{r}270,000 \\
20,164,000\end{array}$ & $\begin{array}{r}23,000 \\
309,000\end{array}$ & $\begin{array}{r}8,057,000 \\
501,000\end{array}$ & $\begin{array}{r}277,000 \\
6,000\end{array}$ & & & $\begin{array}{l}6,286,000 \\
1,893,000\end{array}$ & $\begin{array}{r}246,000 \\
26,000\end{array}$ \\
\hline 57 & & & .000 & & & 377,000 & 49,000 & 144,000 & 16,000 & 24,0 & 3,300 \\
\hline $\begin{array}{l}58 \\
59\end{array}$ & & & & & & & & & & & 300 \\
\hline 60 & & & & & 2,700 & 3,200 & & 200 & (2) & & \\
\hline 61 & 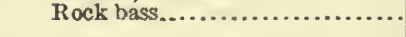 & 107,000 & 5,100 & 30,000 & 2,000 & & & 15,000 & 800 & 15,000 & 500 \\
\hline $\begin{array}{l}62 \\
63\end{array}$ & $\begin{array}{l}\text { Rockfish..... } \\
\text { Round robin. }\end{array}$ & $\begin{array}{r}2,454,000 \\
26,000\end{array}$ & $\begin{array}{r}66,000 \\
500\end{array}$ & $2,255,000$ & 58,000 & 59,000 & 1,200 & $\begin{array}{l}77,000 \\
22,000\end{array}$ & $\begin{array}{l}3,500 \\
400\end{array}$ & & \\
\hline 64 & & $\begin{array}{r}20,000 \\
1-000\end{array}$ & 500 & & & 20,000 & 300 & & & & \\
\hline $\begin{array}{l}65 \\
66\end{array}$ & $\begin{array}{l}\text { Sallor's cholce, or pin } \\
\text { Salmon............. }\end{array}$ & $\begin{array}{l}1,720,000 \\
90,417,000\end{array}$ & $\begin{array}{r}39,000 \\
3,347,000\end{array}$ & $\begin{array}{l}105,000 \\
301,000\end{array}$ & $\begin{array}{r}6,000 \\
11,000\end{array}$ & $\begin{array}{r}369,000 \\
46,219,000\end{array}$ & $\begin{array}{r}11,000 \\
1,941,000\end{array}$ & $\begin{array}{r}1,017,000 \\
13,290,000\end{array}$ & $\begin{array}{r}17,000 \\
415,000\end{array}$ & $\begin{array}{r}130,000 \\
28,744,000\end{array}$ & $\begin{array}{r}1,500 \\
882,000\end{array}$ \\
\hline 67 & & $4,638,000$ & & & & & 400 & & & & \\
\hline $\begin{array}{l}68 \\
69\end{array}$ & & & $\begin{array}{l}290,000 \\
284,000\end{array}$ & $\begin{array}{r}634,000 \\
5,550,000\end{array}$ & 23,000 & & $\begin{array}{r}400 \\
2.100\end{array}$ & & 000 & 5,9 & $\begin{array}{r}207,000 \\
23,000\end{array}$ \\
\hline 70 & & & 700 & & & $\begin{array}{r}40,000 \\
1,300\end{array}$ & & 1,000 & & 113,000 & \\
\hline & & $27,641,000$ & $2,113,000$ & 2,100 & 100 & $15,586,000$ & $1,28 \dot{4}, 000$ & $2,552,000$ & $172 ́, 000$ & $8,993,000$ & 619,000 \\
\hline
\end{tabular}

1 Includes bag nets, bow nets, cast nets, cockje nets and traps, crab nets, cunner nets and traps, dlp nets, paranzella nets, shrimp nets, stop nets, turtia nets, wheels and sildes, and beam trawls. 
BY APPARATUS OF CAPTURE: 1908.

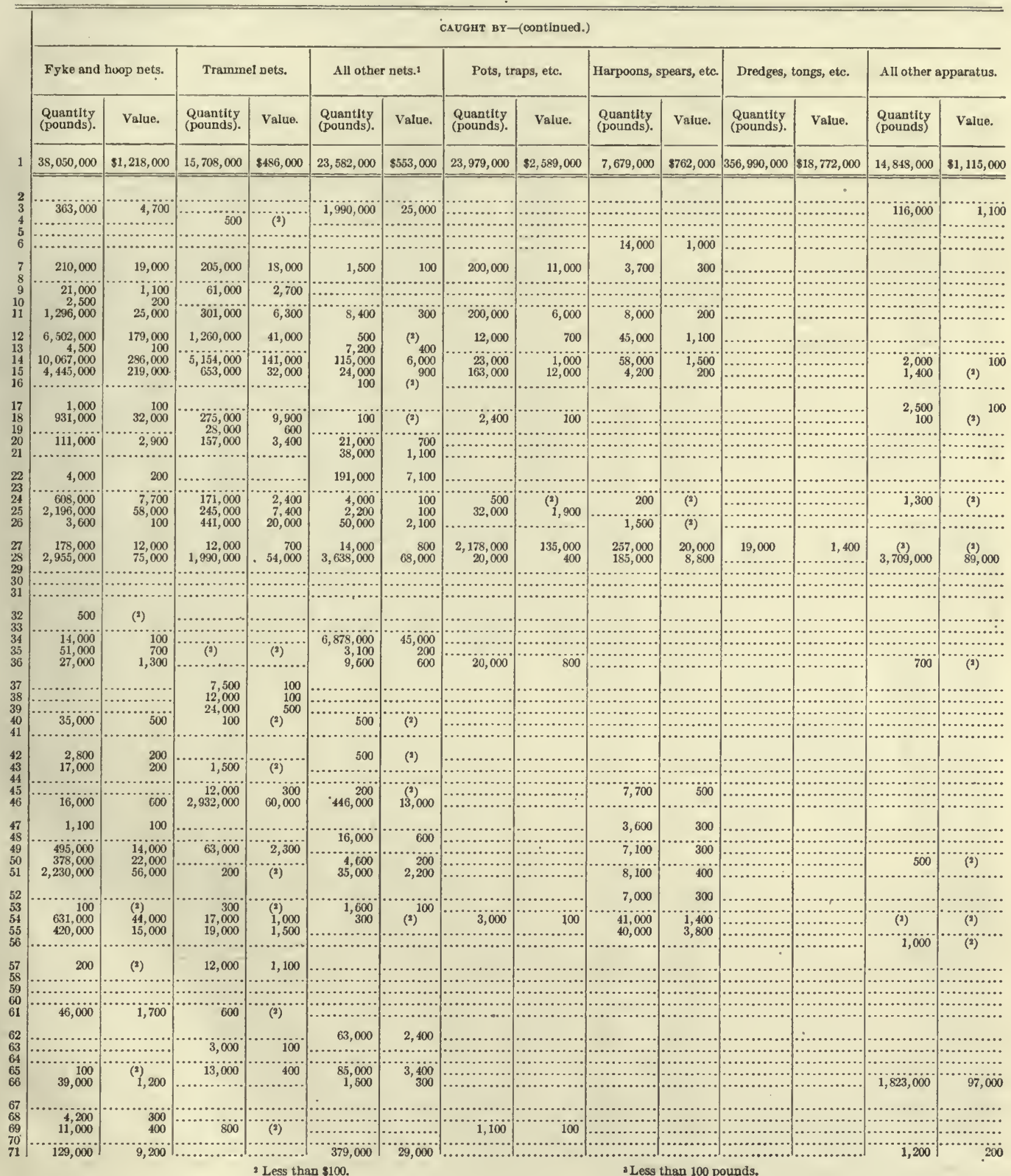


TABLE 4.-PRODUCTS, BY SPECIES AND BY

\begin{tabular}{|c|c|c|c|c|c|c|c|c|c|c|}
\hline \multirow{3}{*}{ SPECIES, } & \multirow{2}{*}{\multicolumn{2}{|c|}{ TOTAL. }} & \multicolumn{8}{|c|}{ CAUGHT 8Y- } \\
\hline & & & \multicolumn{2}{|c|}{ Lines. } & \multicolumn{2}{|c|}{ Gill nets. } & \multicolumn{2}{|c|}{ Selnes. } & \multicolumn{2}{|c|}{$\begin{array}{l}\text { Pound nets, trap nets, } \\
\text { and welrs. }\end{array}$} \\
\hline & $\begin{array}{l}\text { Quantlty } \\
\text { (pounds). }\end{array}$ & Value. & $\begin{array}{l}\text { Quantity } \\
\text { (pounds). }\end{array}$ & Value. & $\begin{array}{l}\text { Quantity } \\
\text { (pounds). }\end{array}$ & Value. & $\begin{array}{l}\text { Quantity } \\
\text { (pounds). }\end{array}$ & Value. & $\begin{array}{l}\text { Quantity } \\
\text { (pounds). }\end{array}$ & Value. \\
\hline 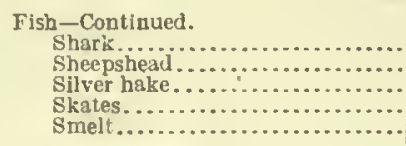 & $\begin{array}{r}75,000 \\
2,637,000 \\
10,336,000 \\
402,000 \\
4,340,000\end{array}$ & $\begin{array}{r}\$ 1,500 \\
97,000 \\
93,000 \\
4,200 \\
174,000\end{array}$ & $\begin{array}{r}72,000 \\
185,000 \\
974,000 \\
131,000 \\
102,000\end{array}$ & $\begin{array}{r}\$ 1,400 \\
12,000 \\
9,100 \\
900 \\
12,000\end{array}$ & $\begin{array}{r}611,000 \\
280,000 \\
6,400 \\
653,000\end{array}$ & $\begin{array}{r}\$ 18,000 \\
3,600 \\
100 \\
38,000\end{array}$ & $\begin{array}{r}1,361,000 \\
4,300 \\
12,000 \\
2,370,000\end{array}$ & $\begin{array}{l}8,3,000 \\
(2) \quad 100 \\
78,000\end{array}$ & $\begin{array}{r}2,200 \\
92,000 \\
9,068,000 \\
104,000 \\
118,000\end{array}$ & $\begin{array}{l}(2) \\
\$ 5,500 \\
80,000 \\
2,100 \\
15,000\end{array}$ \\
\hline 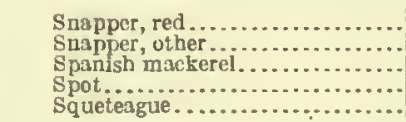 & $\begin{array}{r}13,498,000 \\
356,000 \\
3,806,000 \\
1,824,000 \\
49,869,000\end{array}$ & $\begin{array}{r}636,000 \\
15,000 \\
194,000 \\
46,000 \\
1,776,000\end{array}$ & $\begin{array}{r}13,498,000 \\
70,000 \\
367,000 \\
112,000 \\
2,038,000\end{array}$ & $\begin{array}{r}636,000 \\
4,400 \\
16,000 \\
5,000 \\
94,000\end{array}$ & $\begin{array}{r}186,000 \\
1,747,000 \\
333,000 \\
6,006,000\end{array}$ & $\begin{array}{r}7,500 \\
89,000 \\
99,200 \\
249,000\end{array}$ & $\begin{array}{r}76,000 \\
1,273,000 \\
805,000 \\
16,573,000\end{array}$ & $\begin{array}{r}1,900 \\
56,000 \\
18,000 \\
581,000\end{array}$ & $\begin{array}{r}5,800 \\
370,000 \\
431,000 \\
24,135,000\end{array}$ & $\begin{array}{r}5900 \\
29,000 \\
11,000 \\
807,000\end{array}$ \\
\hline 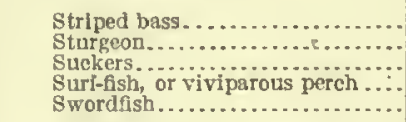 & $\begin{array}{r}3,657,000 \\
2,072,000 \\
8,555,000 \\
885,000 \\
2,714,000\end{array}$ & $\begin{array}{r}314,000 \\
157,000 \\
215,000 \\
21,000 \\
198,000\end{array}$ & $\begin{array}{r}59,000 \\
187,000 \\
26,000 \\
4,100 \\
7,800\end{array}$ & $\begin{array}{r}6,100 \\
17,000 \\
1,500 \\
100 \\
200\end{array}$ & $\begin{array}{r}2,053,000 \\
775,000 \\
702,000 \\
85,000\end{array}$ & $\begin{array}{r}164,000 \\
69,000 \\
21,000 \\
2,100\end{array}$ & $\begin{array}{l}554,000 \\
327,000 \\
645,000 \\
796,000\end{array}$ & $\begin{array}{l}52,000 \\
18,000 \\
20,000 \\
19,000\end{array}$ & $\begin{array}{r}718,000 \\
344,000 \\
4,577,000\end{array}$ & $\begin{array}{l}65,000 \\
32,000 \\
95,000\end{array}$ \\
\hline $\begin{array}{l}\text { Tautog ......... } \\
\text { Tomcod...... } \\
\text { Trout, brook. }\end{array}$ & $\begin{array}{r}995,000 \\
289,000 \\
18,000\end{array}$ & $\begin{array}{r}37,000 \\
9,100 \\
6,300\end{array}$ & $\begin{array}{r}530,000 \\
35,000 \\
18,000\end{array}$ & $\begin{array}{r}20,000 \\
1,000 \\
6,300\end{array}$ & $\begin{array}{l}4,800 \\
2,000\end{array}$ & $\begin{array}{l}200 \\
100\end{array}$ & $\begin{array}{l}35,000 \\
31,000\end{array}$ & $\begin{array}{r}1,400 \\
800\end{array}$ & $\begin{array}{r}408,000 \\
41,000\end{array}$ & $\begin{array}{r}14,000 \\
800\end{array}$ \\
\hline $\begin{array}{l}\text { Trout, lake............................. } \\
\text { White bass............................ }\end{array}$ & $\begin{array}{r}12,024,000 \\
265,000\end{array}$ & $\begin{array}{r}800,000 \\
13,000\end{array}$ & $\begin{array}{r}1,495,000 \\
13,000\end{array}$ & $\begin{array}{r}113,000 \\
800\end{array}$ & $\begin{array}{r}9,460,000 \\
1,400\end{array}$ & $\begin{array}{r}610,000 \\
100\end{array}$ & $\begin{array}{r}7,600 \\
8,400\end{array}$ & $\begin{array}{l}100 \\
400\end{array}$ & $1,057,000$ & 77,000 \\
\hline 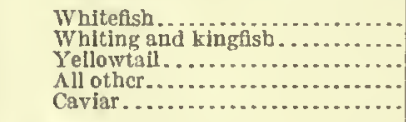 & $\begin{array}{r}7,722,000 \\
1,614,000 \\
253,000 \\
3,736,000 \\
217,000\end{array}$ & $\begin{array}{r}524,000 \\
78,000 \\
18,000 \\
86,000 \\
95,000\end{array}$ & $\begin{array}{r}5,600 \\
429,000 \\
88,000 \\
1,854,000 \\
5,500\end{array}$ & $\begin{array}{r}400 \\
29,000 \\
7,800 \\
41,000 \\
4,400\end{array}$ & $\begin{array}{r}4,927,000 \\
557,000 \\
56,000 \\
490.000 \\
125,000\end{array}$ & $\begin{array}{r}315,000 \\
21,000 \\
5,500 \\
16,000 \\
55,000\end{array}$ & $\begin{array}{r}13,000 \\
477,000 \\
93,000 \\
597,000 \\
63,000\end{array}$ & $\begin{array}{r}800 \\
17,000 \\
4,200 \\
15,000 \\
18,000\end{array}$ & $\begin{array}{r}2,736,000 \\
127,000 \\
8,000 \\
67,000 \\
12,000\end{array}$ & $\begin{array}{r}204,000 \\
9,800 \\
800 \\
1,000 \\
11,000\end{array}$ \\
\hline $\begin{array}{l}\text { Frogs } \\
\text { Crabs, hard. } \\
\text { Crabs, solt... }\end{array}$ & $\begin{array}{r}259,000 \\
42,612,000 \\
10,301,000\end{array}$ & $\begin{array}{r}42,000 \\
553,000 \\
359,000\end{array}$ & $\begin{array}{r}26,545,000 \\
165,000\end{array}$ & $\begin{array}{r}287,000 \\
11,000\end{array}$ & $\begin{array}{r}6,600 \\
700\end{array}$ & (2) 200 & $\begin{array}{r}244,000 \\
113,000\end{array}$ & $\begin{array}{r}5,300 \\
15,000\end{array}$ & 218,000 & 1,400 \\
\hline $\begin{array}{l}\text { Crabs, king ........ } \\
\text { Crabs splder..... }\end{array}$ & $\begin{array}{r}7,643,000 \\
7,200\end{array}$ & $(3), 000$ & & & & & 580,000 & 700 & $4,639,000$ & 18,000 \\
\hline Crabs, stone........ & 62,000 & 3,700 & 40,000 & 2,600 & 6,800 & 400 & & .... & 900 & 100 \\
\hline $\begin{array}{l}\text { Crawfish } \\
\text { Lobster }\end{array}$ & $\begin{array}{r}614,000 \\
15,279,000\end{array}$ & $\begin{array}{r}32,000 \\
1,931,000\end{array}$ & 1,800 & 100 & 500 & 100 & 500 & (2) & 6,900 & 900 \\
\hline 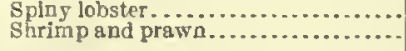 & $\begin{array}{r}626,000 \\
19,080,000\end{array}$ & $\begin{array}{r}71,000 \\
494,000\end{array}$ & (अ) & & 13,000 & 600 & $17,194,000$ & 385,000 & $\begin{array}{l}1,800 \\
1,000\end{array}$ & $\begin{array}{l}100 \\
200\end{array}$ \\
\hline 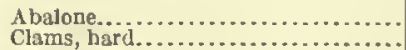 & $\begin{array}{l}\mathbf{1}, 005,000 \\
\mathbf{7}, 805,000\end{array}$ & $\begin{array}{r}16,000 \\
1,317,000\end{array}$ & & & & & & & & \\
\hline 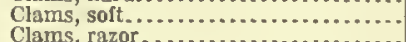 & $8,654,000$ & 553,000 & & & & & & ....... & …............ & $\cdots .$. \\
\hline Clams, surf............................. & 265,000 & 21,000 & & $\cdots \cdot$ & & & & & & \\
\hline $\begin{array}{l}\text { Oysters, market, Irom public areas... } \\
\text { Oysters, market, from privato areas. }\end{array}$ & $\begin{array}{r}103,641,000 \\
74,652,000\end{array}$ & $\begin{array}{l}4,416,000 \\
8,305,000\end{array}$ & & ' & & & & & & \\
\hline Oysters, seed, lrom pubilic areas...... & $26,960,000$ & $1,035,000$ & & 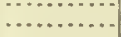 & & & & & & \\
\hline $\begin{array}{l}\text { Oysters, seed, from private areas...... } \\
\text { Scallops and scallop rims.................. }\end{array}$ & $\begin{array}{r}28,056,000 \\
2,432,000\end{array}$ & $\begin{array}{r}1,957,000 \\
317,000\end{array}$ & & & & & & & & \\
\hline 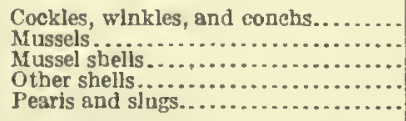 & $\begin{array}{r}146,000 \\
8,542,000 \\
81,869,000 \\
952,000\end{array}$ & $\begin{array}{r}35,000 \\
12,000 \\
392,000 \\
8,400 \\
300,000\end{array}$ & & & 300 & 1,300 & & & & \\
\hline $\begin{array}{l}\text { Squid..... } \\
\text { Terrapin.. }\end{array}$ & $\begin{array}{r}2,562,000 \\
368,000\end{array}$ & $\begin{array}{l}43,000 \\
80,000\end{array}$ & 121,000 & 2,200 & $\begin{array}{l}2,000 \\
6,800\end{array}$ & $\begin{array}{r}100 \\
2,700\end{array}$ & $\begin{array}{l}120,000 \\
109,000\end{array}$ & $\begin{array}{r}4,600 \\
43,000\end{array}$ & $\begin{array}{r}2,293,000 \\
3,300\end{array}$ & $\begin{array}{r}35,000 \\
2,200\end{array}$ \\
\hline $\begin{array}{l}\text { Turtles............................. } \\
\text { 8ponges. }\end{array}$ & $\begin{array}{l}1,088,000 \\
6222,000\end{array}$ & $\begin{array}{r}40,000 \\
545,000\end{array}$ & 47,000 & 2,100 & 128,000 & 11,000 & 281,000 & 7,600 & 41,000 & 700 \\
\hline 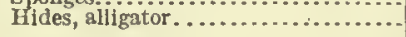 & 372,000 & 61,000 & & & & & (3) & (2) & & \\
\hline Hides, porpoise.... & 48,000 & 1,000 & & & & & 48,000 & 1,000 & & \\
\hline $\begin{array}{l}\text { Skins } \\
\text { Skins }\end{array}$ & $\begin{array}{r}22,000 \\
149,000\end{array}$ & $\begin{array}{r}89,000 \\
136,000\end{array}$ & & & & & & & [..., &.. \\
\hline $\begin{array}{l}\text { Sklns, otter. } \\
\text { Skins, seal. }\end{array}$ & $\begin{array}{l}7,600 \\
3,100\end{array}$ & $\begin{array}{r}30,000 \\
8,200\end{array}$ & & & & & & & (3) & \\
\hline Whalebo & & 215,000 & & & & & & & & \\
\hline & 657,000 & 7,400 & 653,000 & 7,300 & 4,000 & (a) & & & & \\
\hline & 96,000 & 4,100 & 96,000 & 4,100 & & & & & & \\
\hline 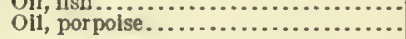 & $\begin{array}{r}221,000 \\
29,000\end{array}$ & $\begin{array}{l}9,500 \\
3,000\end{array}$ & 221,000 & 9,500 & & & 21,000 & 2,200 & & \\
\hline OI1, sea-elepbant.................. & 88,000 & 3,600 & & & & & 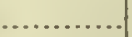 & & & \\
\hline $\begin{array}{l}\text { Oil, seal........... } \\
\text { oll, sperm...... }\end{array}$ & $\begin{array}{r}4,000 \\
3,391,000\end{array}$ & 252,000 & & & & & & & & \\
\hline Oil, whale & 573,000 & 30,000 & & & & & & & & \\
\hline & & & & & & & & & & \\
\hline Ses grass. & 282,000 & 1,700 & & & & & & & & \\
\hline
\end{tabular}

1 Ineludes bag nets, bow nets, cast nets, cockle nets and traps, crab nets, cunner nets and traps, dip nets, paranzells nets, shrimp nets, stop nets, turtle nets, wheels and silles, and beaw nets, c 
APPARATUS OF CAPTURE: 1908-Continued.

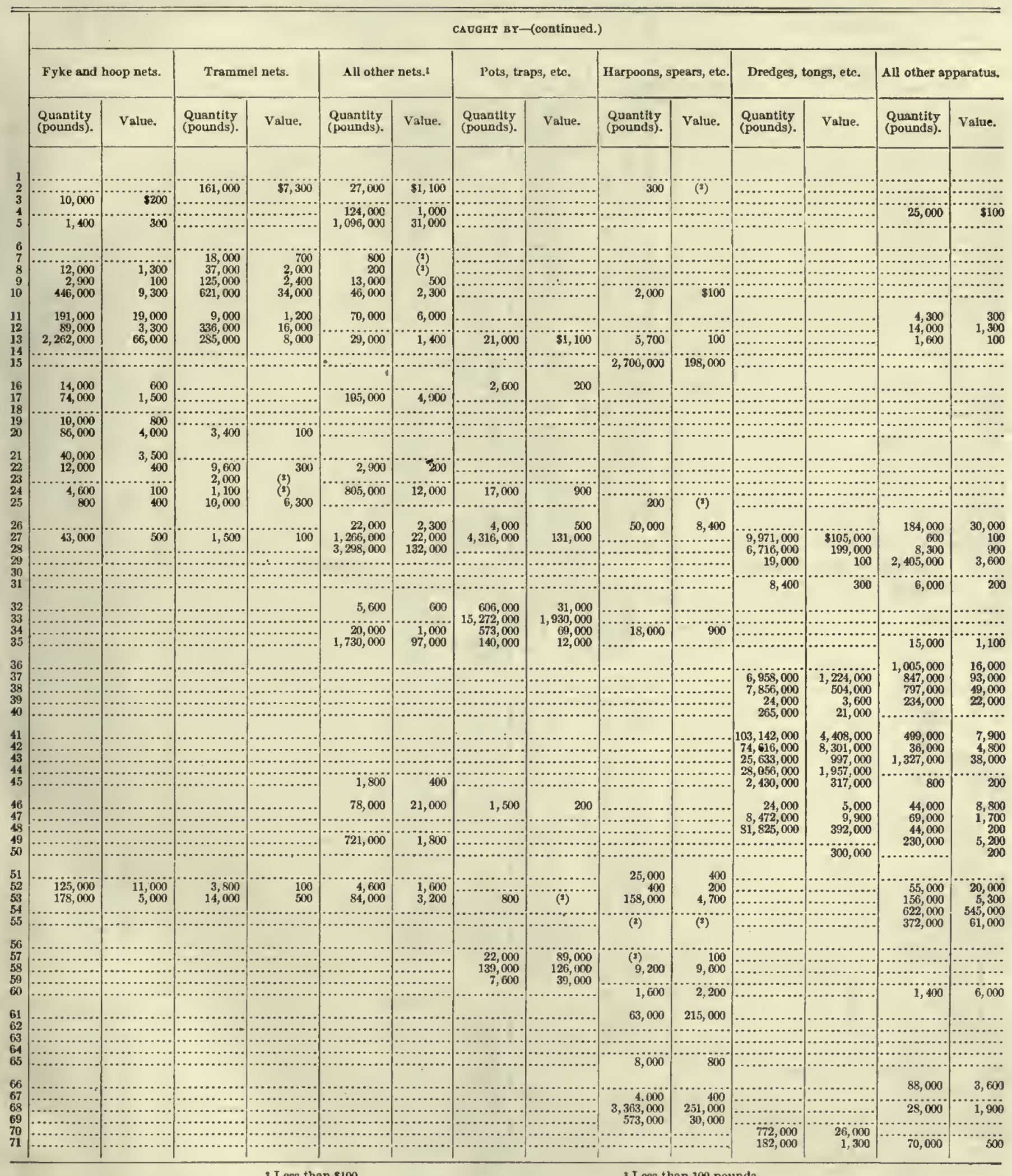


TABLE 5.-PRODUCTS-DETAIL SUMMARY, BY STATES AND BY SPECIES: 1908.

\begin{tabular}{|c|c|c|}
\hline SPECIES AND STATE. & $\begin{array}{l}\text { Quantity } \\
\text { (pounds). }\end{array}$ & Value. \\
\hline $\begin{array}{c}\text { ALL SPECIES. } \\
\text { Unlted States................ }\end{array}$ & $1,893,454,000$ & $\$ 54,031,000$ \\
\hline Alabama.. & $10,665,000$ & 387,000 \\
\hline Arkansas... & $12,667,000$ & 207,000 \\
\hline $\begin{array}{l}\text { Californis......... } \\
\text { Connectleut..... }\end{array}$ & $47,477,000$ & $1,970,000$ \\
\hline $\begin{array}{l}\text { Connectleut...... } \\
\text { Delaware........ }\end{array}$ & & $2,982,000$ \\
\hline Florlda.......... & $74,087,000$ & $3,389,000$ \\
\hline $\begin{array}{l}\text { Georgla } . \ldots \ldots \\
\text { Illinols........... }\end{array}$ & $14,828,000$ & 701,000 \\
\hline $\begin{array}{l}\text { Illinols............. } \\
\text { Indiana.......... }\end{array}$ & $74,620,000$ & $1,436,000$ \\
\hline $\begin{array}{l}\text { Indiana........... } \\
\text { Iowa............ }\end{array}$ & $\begin{array}{r}15,507,000 \\
8,867,000\end{array}$ & $\begin{array}{l}223,000 \\
215,000\end{array}$ \\
\hline Kansas.............. & $\begin{array}{r}8,00 \\
432,000\end{array}$ & 28,000 \\
\hline Kentucky........ & $5,390,000$ & 110,000 \\
\hline Louislana........ & $46,106,000$ & $1,569,000$ \\
\hline $\begin{array}{l}\text { Maine............ } \\
\text { Maryland....... }\end{array}$ & $173,843,000$ & $3,257,000$ \\
\hline & $113,796,000$ & $3,306,000$ \\
\hline $\begin{array}{l}\text { Massachusetts. } \\
\text { Mlchigan....... }\end{array}$ & $38,302,000$ & $1,473,000$ \\
\hline Minnesota Mississippi......... & $7,475,000$ & 192,000 \\
\hline $\begin{array}{l}\text { Mississippi........ } \\
\text { Missouri........ }\end{array}$ & $20,547,000$ & 556,000 \\
\hline $\begin{array}{l}\text { Missouri........... } \\
\text { Nebraska........ }\end{array}$ & $\begin{array}{r}6,751,000 \\
399,000\end{array}$ & $\begin{array}{r}271,000 \\
22,000\end{array}$ \\
\hline $\begin{array}{l}\text { Nebraska....jï... } \\
\text { New Hampshire.. }\end{array}$ & 677,000 & 53,000 \\
\hline New Jersey...... & $74,827,000$ & $3,069,000$ \\
\hline New York....... & $76,485,000$ & $4,594,000$ \\
\hline $\begin{array}{l}\text { North Carolina... } \\
\text { Ohilo............ }\end{array}$ & $101,422,000$ & $1,776,000$ \\
\hline $\begin{array}{l}\text { Ohilo } \\
\text { Oklahoma........... }\end{array}$ & $\begin{array}{r}28,917,000 \\
6,700\end{array}$ & $\begin{array}{r}840,000 \\
300\end{array}$ \\
\hline Qregon.......... & $28,217,000$ & $1,356,000$ \\
\hline $\begin{array}{l}\text { Pennsylvania..... } \\
\text { Rhode Island..... }\end{array}$ & $11,888,000$ & 513,000 \\
\hline $\begin{array}{l}\text { Rhode Island.... } \\
\text { South Caroling... }\end{array}$ & $44,254,000$ & $1,752,000$ \\
\hline $\begin{array}{l}\text { South Carolina... } \\
\text { South Dakota... }\end{array}$ & $\begin{array}{r}14,104,000 \\
70,000\end{array}$ & $\begin{array}{r}288,000 \\
4,200\end{array}$ \\
\hline Tennesseo......... & $4,506,000$ & $\begin{array}{r}4,200 \\
112,000\end{array}$ \\
\hline Texas.............. & $10,439,000$ & 446,000 \\
\hline Vlrglnia........................ & $312,515,000$ & $4,716,000$ \\
\hline $\begin{array}{l}\text { Washington } \\
\text { West Virginla }\end{array}$ & $\begin{array}{r}100,456,000 \\
33,000\end{array}$ & $\begin{array}{r}3,513,000 \\
2,000\end{array}$ \\
\hline 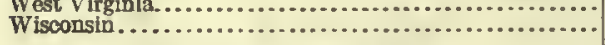 & $30,953,000$ & $1,067,000$ \\
\hline ALBACORE, OR HORSE MACKEREL. & & \\
\hline United States. & 359,000 & 12,000 \\
\hline Calltomla. & 50,000 & 800 \\
\hline Massachuse & 92,000 & 5,400 \\
\hline New Jersey ..................... & 207,000 & 5,600 \\
\hline New York.......................... & 10,000 & 400 \\
\hline ALEWTVES. & & \\
\hline Unlted States. & $89,978,000$ & 589,000 \\
\hline Fresh........ & $80,945,000$ & 455,000 \\
\hline $\begin{array}{l}\text { Salted.................. } \\
\text { Smoked.............. }\end{array}$ & $\begin{array}{r}8,840,000 \\
193,000\end{array}$ & $\begin{array}{r}130,000 \\
3,500\end{array}$ \\
\hline Connecticut. & & \\
\hline Delaware... & $\begin{array}{r}1,020,000 \\
794,000\end{array}$ & $\begin{array}{r}12,000 \\
8,400\end{array}$ \\
\hline Florlda.... & $1,224,000$ & 5,500 \\
\hline Georgla.... & 32,000 & 1,000 \\
\hline Maine................. & $2,085,000$ & 18,000 \\
\hline Fresh............. & $1,781,000$ & 12,000 \\
\hline $\begin{array}{l}\text { Salted............... } \\
\text { Smoked............ }\end{array}$ & $\begin{array}{l}112,000 \\
192,000\end{array}$ & 2,000 \\
\hline 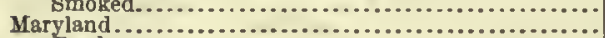 & $\begin{array}{r}192,000 \\
28,805,000\end{array}$ & $\begin{array}{r}3,400 \\
\end{array}$ \\
\hline 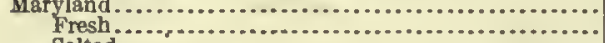 & $\begin{array}{l}28,805,000 \\
24,451,000\end{array}$ & $\begin{array}{r}157,000 \\
98,000\end{array}$ \\
\hline Salted......................................... & $4,354,000$ & . $\quad 59,000$ \\
\hline Massachusetts...................... & $4,062,000$ & 45,000 \\
\hline Fresh $\ldots . . . \ldots \ldots \ldots \ldots \ldots \ldots \ldots$ & $3,038,000$ & 29,000 \\
\hline 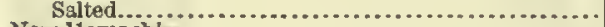 & $1,024,000$ & . 15,000 \\
\hline New l1ampshire................................... & 121,000 & 1,800 \\
\hline 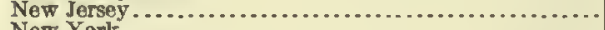 & $1,309,000$ & 12,000 \\
\hline 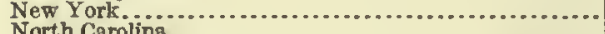 & 654,000 & 7,100 \\
\hline North Carolina........................................... & $10,928,000$ & 140,000 \\
\hline 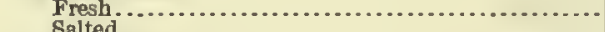 & $7,724,000$ & 88,000 \\
\hline 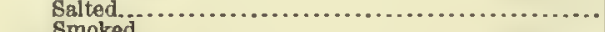 & $3,203,000$ & 52,000 \\
\hline 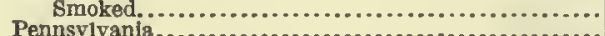 & $\begin{array}{r}1,200 \\
767,000\end{array}$ & \\
\hline 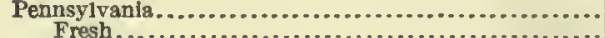 & $\begin{array}{l}767,000 \\
619,000\end{array}$ & 6,400 \\
\hline 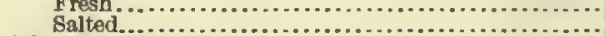 & 148,000 & $\begin{array}{l}5,300 \\
1,100\end{array}$ \\
\hline Rhode Island ........................................ & 288,000 & 4,600 \\
\hline VIrginla & $37,885,000$ & 171,000 \\
\hline AMNER-PISH (JACKFISH). & & \\
\hline United States.................................... & 38,000 & 1,600 \\
\hline Florida. & 38,000 & 1,600 \\
\hline 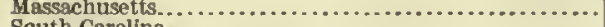 & 100 & (1) \\
\hline South Carolina........................................ & 500 & (1) \\
\hline United States.................. & 220,000 & 1,600 \\
\hline 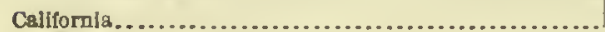 & 220,000 & \\
\hline
\end{tabular}

Less than 8100.

220,000

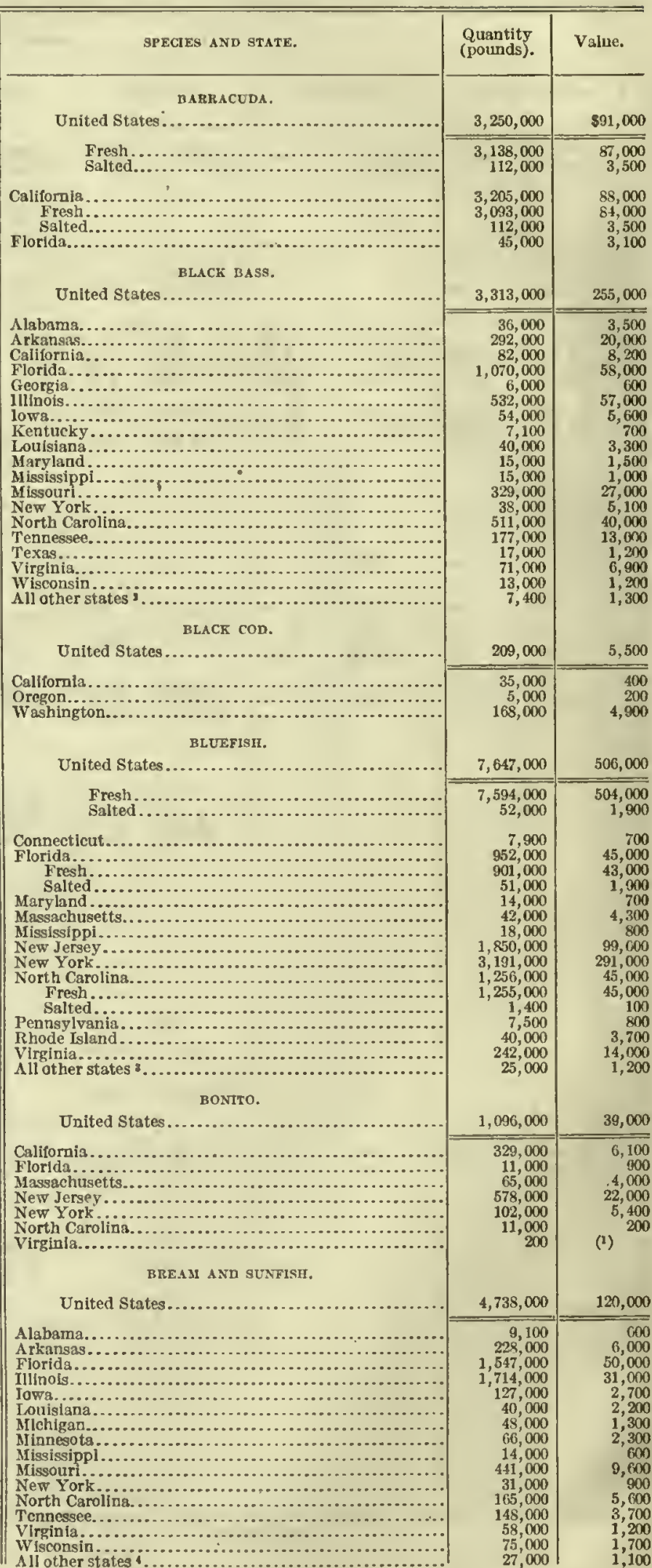

Includes Delaware, Georg1a, Indiana, Kansas, Kentucky, Maryland, Ohlo, South Carolina, and Texas. 
PRODUCTS.

TABle 5.-PRODUCTS-DETAIL SUMMARY BY STATES AND BY SPECIES: 1908-Continued.

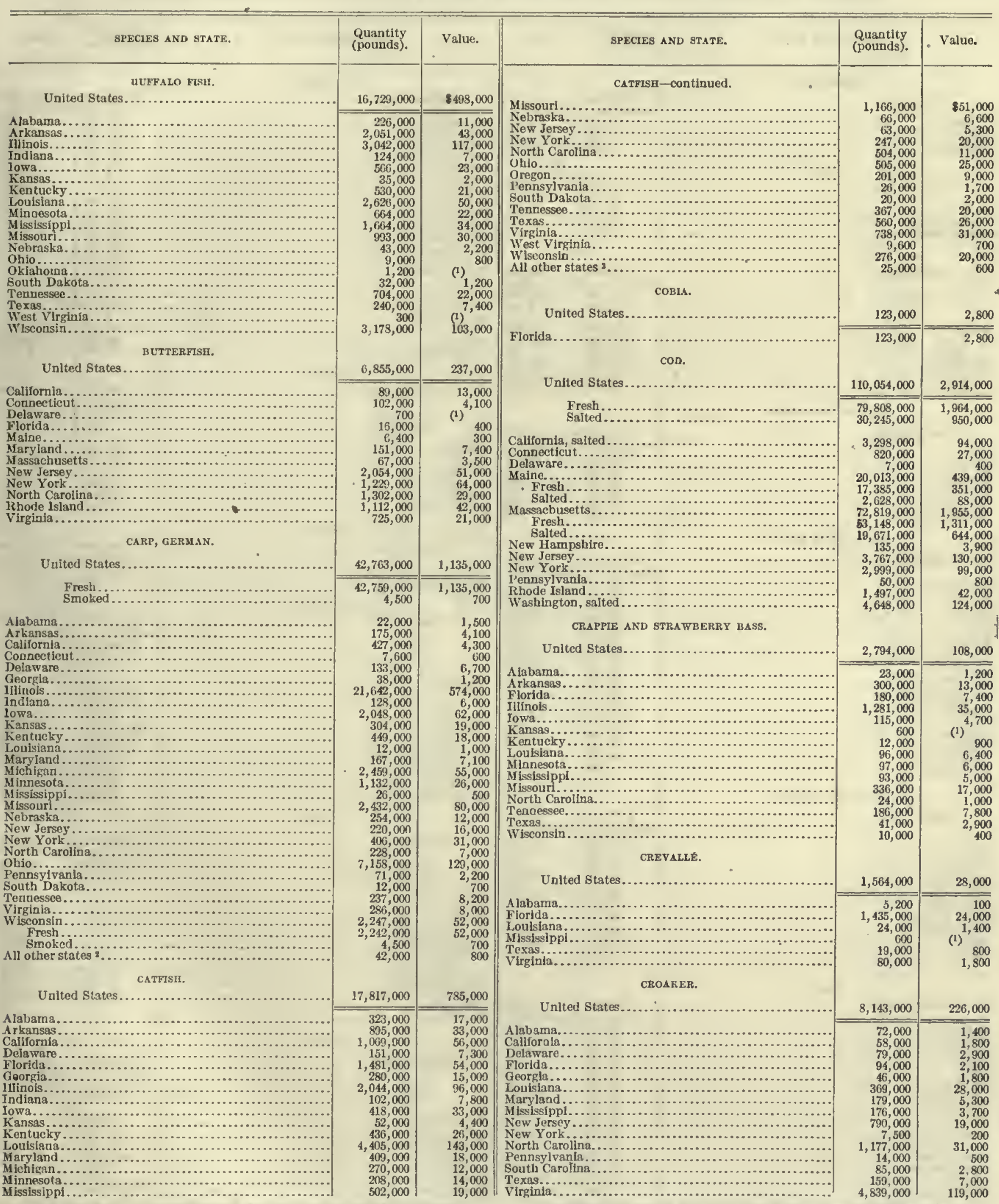

${ }^{I}$ Less than $\$ 100 . \quad 2$ Includes Florida, Oregon, Texas, and West Virginia.

- Includes Connecticut, Oklahoma, Rhode Island, and South Carolina. 
TABLF 5.-PRODUCTS-DETAII SUMMARY BY STATES AND BY SPECIES: 1908-Continued.

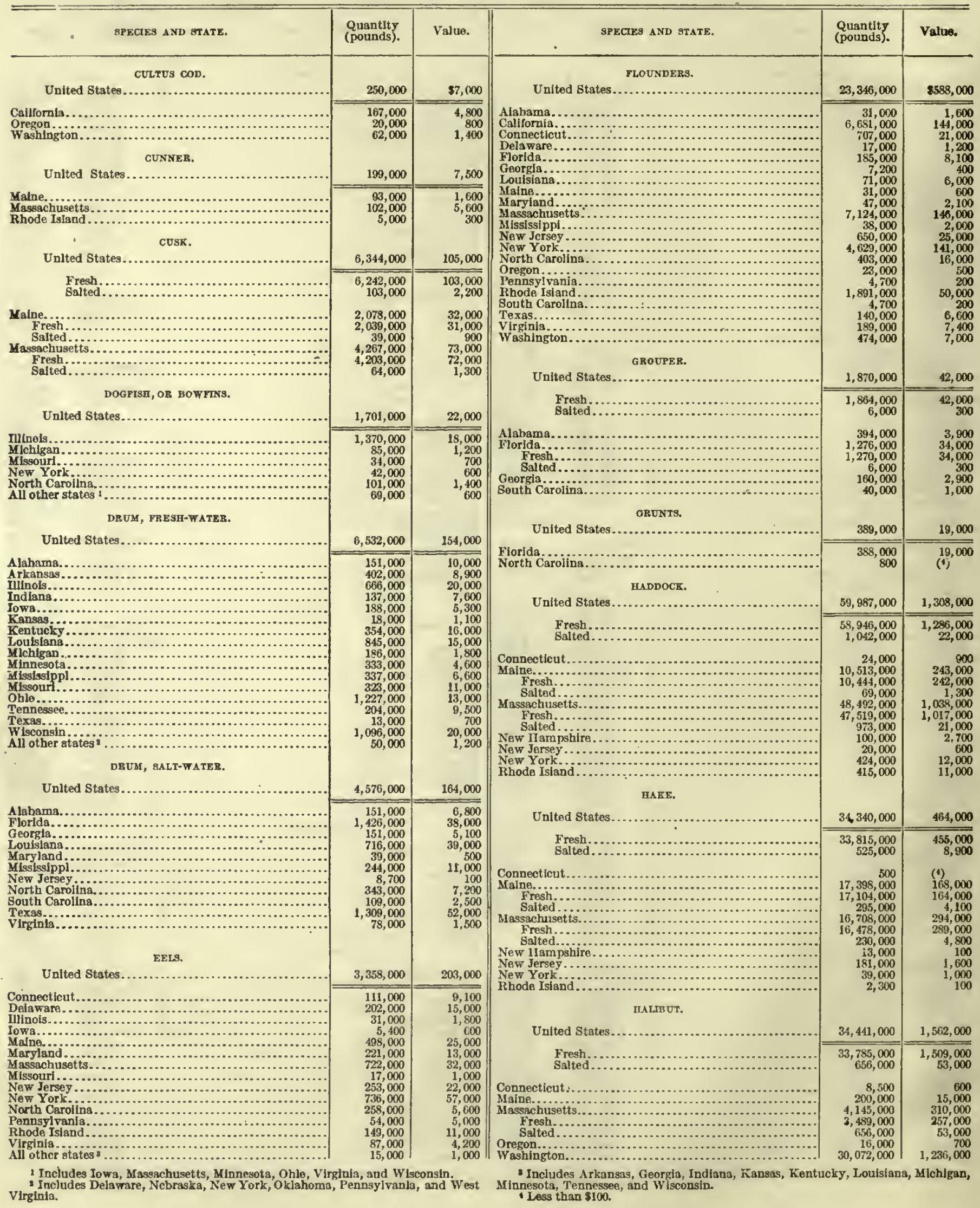


PRODUCTS.

TABLE 5.-PRODUCTS-DETAIL SUMMARY BY STATES AND BY SPECIES: 1908-Continued.

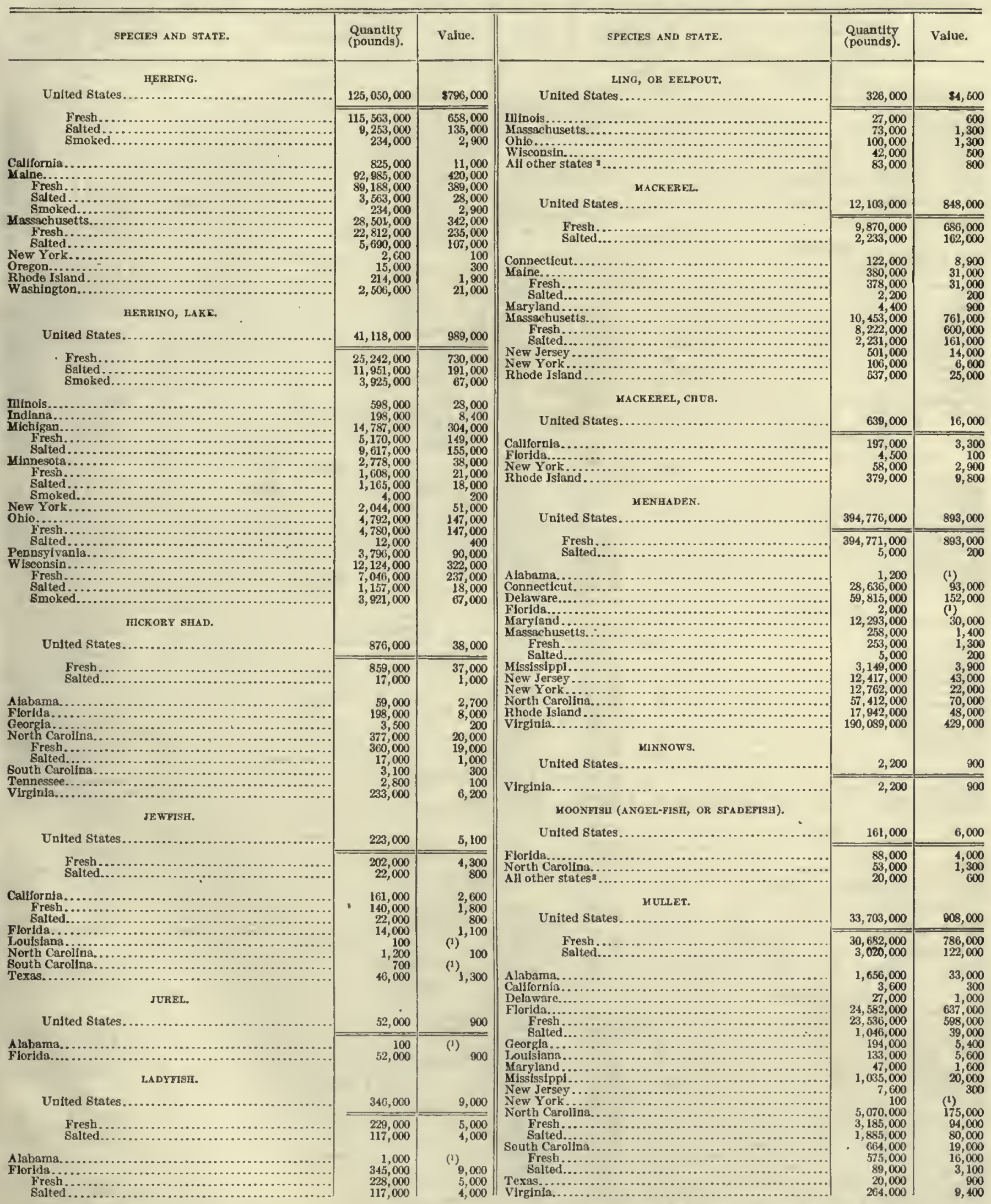

I Less than \$100.
2 Includes Indiana, Kansas, Michigan, New York, and Pennsyivania.

- Includes Afabama, L.ouisiana, Mtssissippl, and Virginta. 
TABle 5.-PRODUCTS-DETAIL SUMMARY BY STATES AND BY SPECIES: 1908-Continued.

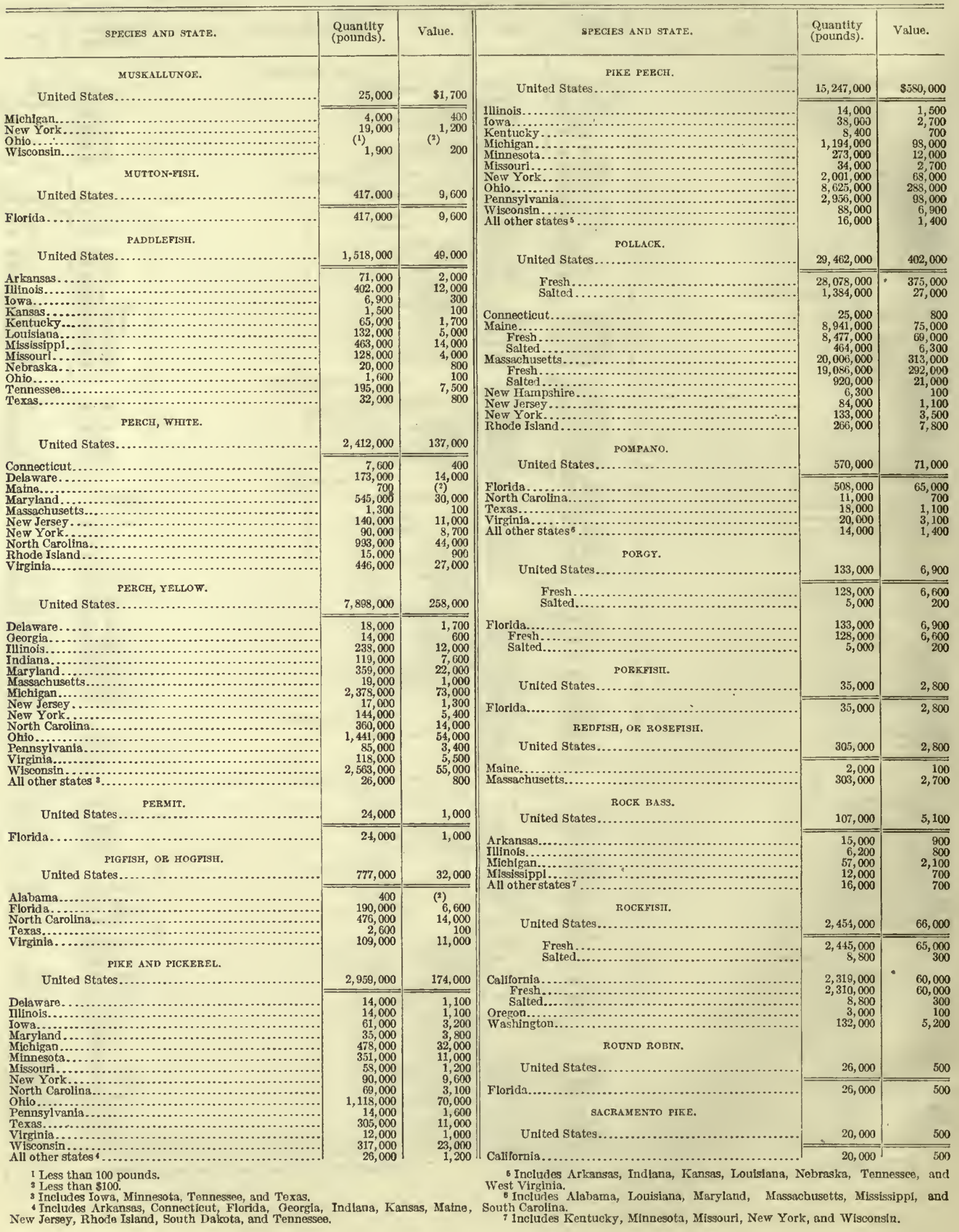


PRODUCTS.

TAnLE 5.-PRODUCTS-DETAII, SUMMARY BY STATES AND BY SPECIES: 1908-Continued.

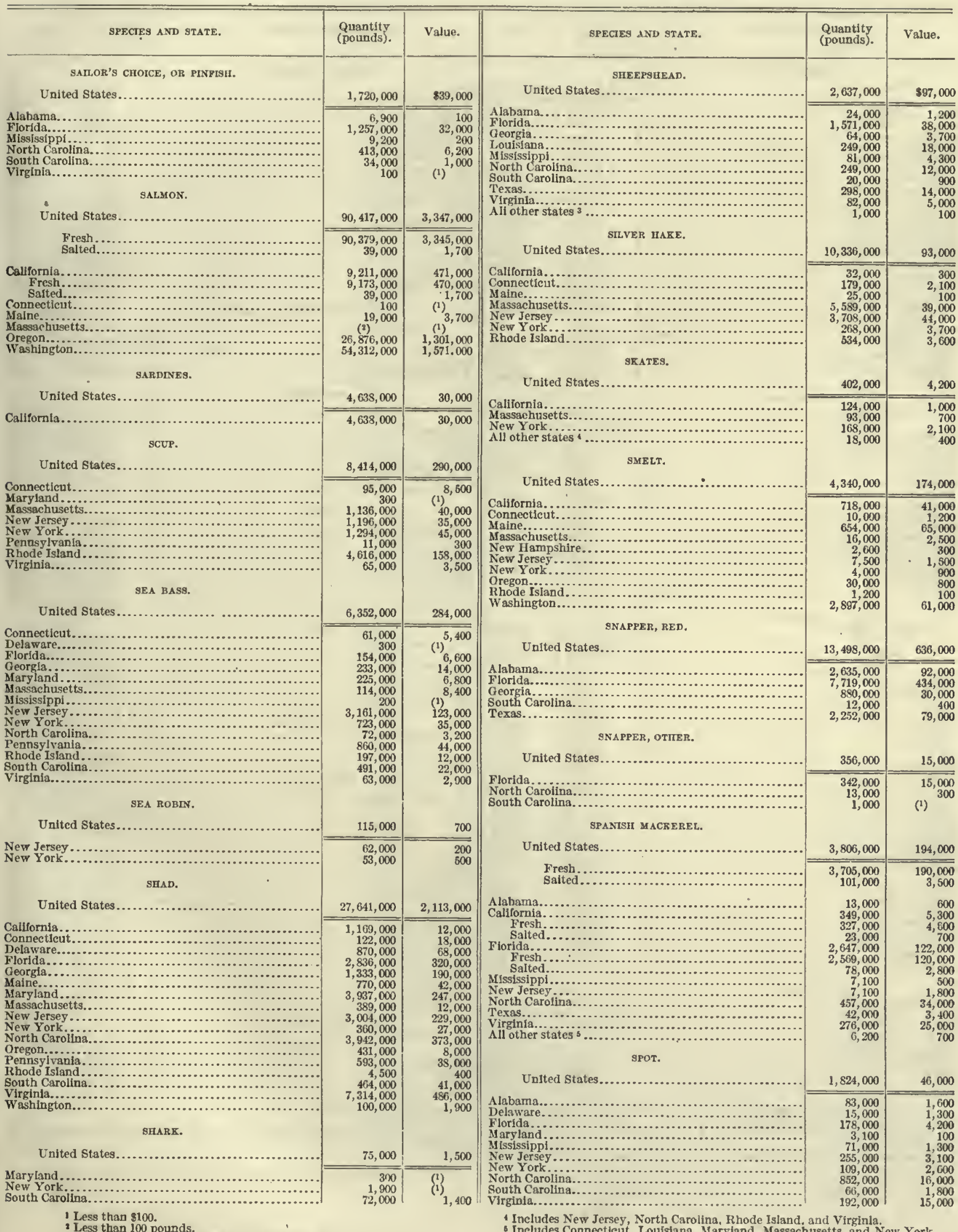

Less than 100 pounds.
Includes Delaware, Mary land, New Jersey, and New York.

Includes Connectleut, Louisiana, Maryland, Massachusetts, and New York. 
TABLE 5.-PRODUCTS-DETAIL SUMMARY BY STATES AND BY SPECIES: 1908-Continued.

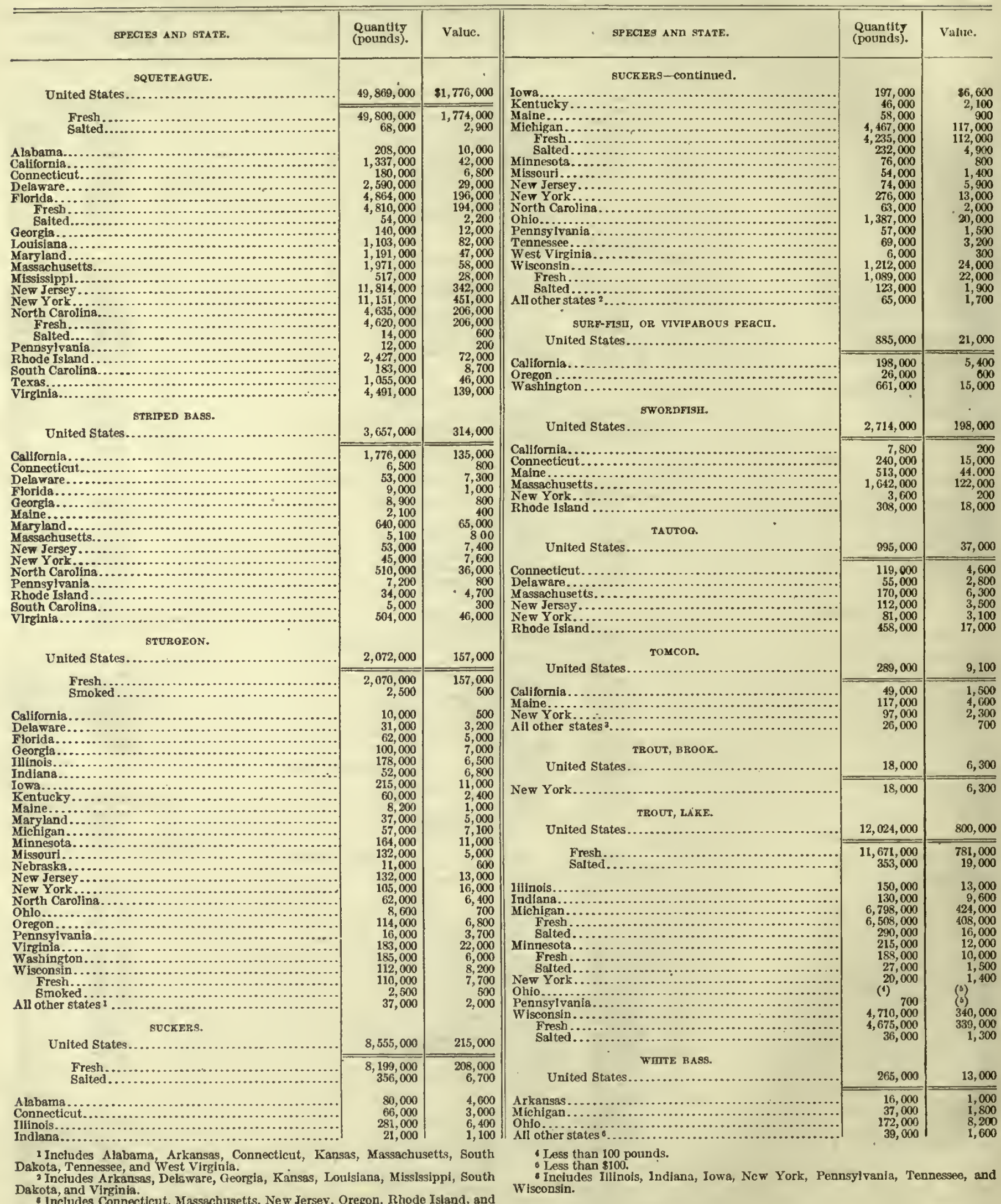


PRODUCTS.

TABLE 5.-PRODUCTS-DETAIL SUMMARY BY STATES AND BY SPECIES: 1908-Continued.

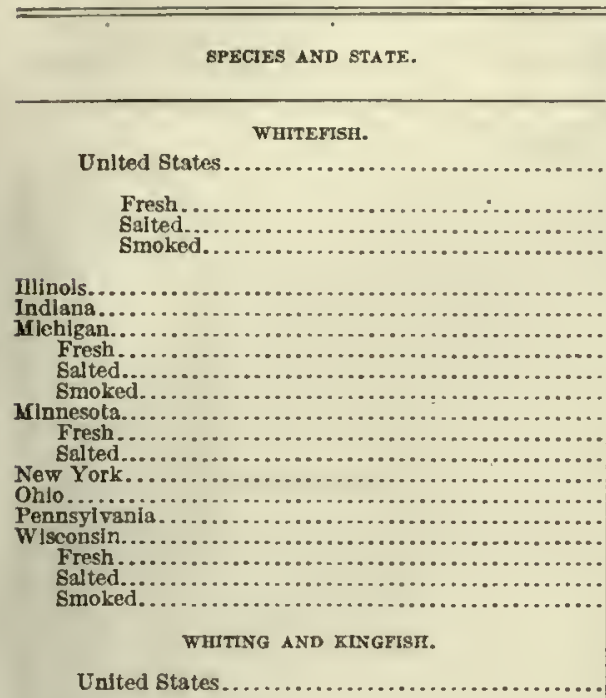

Florida.

New Jersey

North Carolins

Bouth Carolina.

Teras.

All other stätes

\section{YELLOWTAIL.}

United States.

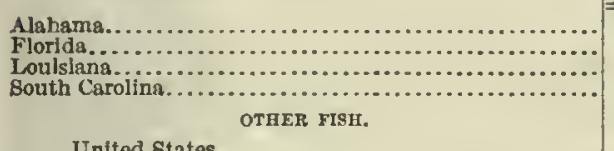

United States.

Calliornia

Connectieut.

Florlda.....

Maryland...

Massachusetts.

New York.

Wregoning......

All other states

Caviar.

Unlted States

$\mid$\begin{tabular}{c}
$\begin{array}{c}\text { Quantity } \\
\text { (pounds). }\end{array} \mid$ Value. \\
\hline
\end{tabular}

$\begin{array}{r}7,722,000 \\ \hline\end{array}$

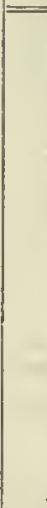

\begin{tabular}{rr|}
\hline $7,366,000$ \\
342,000 & 507,000 \\
15,000 & 17,000 \\
14,000 & 1,300 \\
52,000 & 800 \\
$4,772,000$ & 5,000 \\
$4,490,000$ & 339,000 \\
270,000 & 323,000 \\
13,000 & 15,000 \\
242,000 & 1,200 \\
241,000 & 11,000 \\
1,000 & 11000 \\
179,000 & 15,000 \\
732,000 & 60,000 \\
455,000 & 37,000 \\
$1,274,000$ & 56,000 \\
$1,202,000$ & 55,000 \\
71,000 & 1,500 \\
1,900 & 100 \\
& \\
$1,614,000$ & 78,000 \\
\hline
\end{tabular}

\begin{tabular}{|r|r|}
\hline 230,000 & 78,000 \\
98,000 & 8,600 \\
25,000 & 9,400 \\
34,000 & 3,400 \\
817,000 & 4,900 \\
274,000 & 28,000 \\
9,900 & 17,000 \\
95,000 & 500 \\
22,000 & 4,800 \\
& 1,200 \\
&
\end{tabular}

\begin{tabular}{r|r}
253,000 & 15,000 \\
\hline 1,100 & $(2)$ \\
170,000 & 14,000 \\
64,000 & 3,200
\end{tabular}

\begin{tabular}{|r|r|}
170,000 & $(2)$ \\
64,000 & 14,000 \\
17,000 & 3,200 \\
& 600 \\
$4,522,000$ & 101,000 \\
\hline
\end{tabular}

\begin{tabular}{|r|r|}
$4,522,000$ & 101,000 \\
\hline $2,372,000$ & 45,000 \\
12,000 & 700 \\
366,000 & 18,000 \\
150,000 & 5,000 \\
25,000 & 1,200 \\
599,000 & 8,000 \\
242,000 & 5,800 \\
36,000 & 1,000 \\
660,000 & 15,000 \\
60,000 & 1,600 \\
& \\
217,000 & 95,000
\end{tabular}

Arkansas.

Delaware.

Florida.

Ilino:

Loulsiana....

Maryland

Mississippi

New Jersey

Pennsylvania.

Tennesse

Texas...

Viscinia...

All other states i

United States.

FROGS.

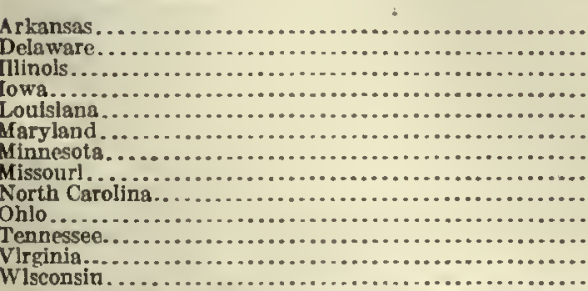

\begin{tabular}{|r|r|}
\hline 800 & 700 \\
3,100 & 3,900 \\
135,000 & 16,000 \\
1,300 & 800 \\
8,600 & 5,300 \\
5,500 & 4,400 \\
8,100 & 11,000 \\
3,500 & 1,200 \\
4,100 & 4,000 \\
9,700 & 10,000 \\
8,100 & 7,500 \\
3,200 & 500 \\
3,700 & 700 \\
22,000 & 27,000 \\
900 & 600 \\
2,000 & 1,200 \\
& \\
259,000 & 42,000 \\
\hline 27,000 & 4,000 \\
1,900 & 700 \\
25,000 & 6,800 \\
2,500 & 300 \\
35,000 & 4,500 \\
1,000 & 500 \\
66,000 & 7,900 \\
67,000 & 11,000 \\
5,400 & 900 \\
4,000 & 600 \\
5,000 & 1,000 \\
3,000 & 700 \\
14,000 & 2,600 \\
\hline
\end{tabular}

1 Ineludes Alabama, Delaware, Maryland, Mississlppl, and Rhode Island.

3 Less than $\$ 100$.

\begin{tabular}{|c|c|c|}
\hline SPECTES AND STATE. & $\begin{array}{l}\text { Quanlity } \\
\text { (poinds). }\end{array}$ & Value. \\
\hline United States. & $42,612,000$ & $\$ 553,000$ \\
\hline 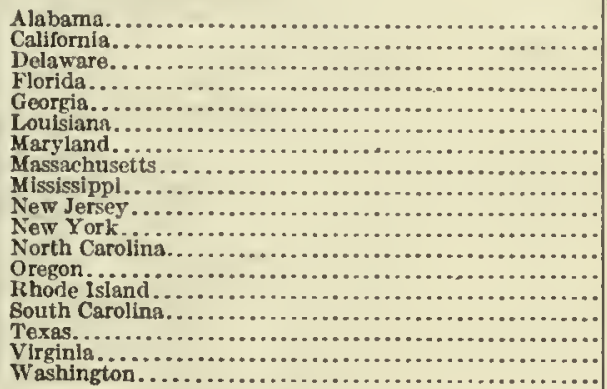 & $\begin{array}{r}246,000 \\
1,702,000 \\
57,000 \\
148,000 \\
196,000 \\
244,000 \\
12,786,000 \\
121,000 \\
380,000 \\
282,000 \\
580,000 \\
113,000 \\
200,000 \\
146,000 \\
33,000 \\
199,000 \\
23,001,000 \\
2,179,000\end{array}$ & $\begin{array}{r}6,100 \\
69,000 \\
600 \\
2,900 \\
7,500 \\
7,800 \\
124,000 \\
2,400 \\
9,800 \\
9,100 \\
7,400 \\
1,100 \\
6,900 \\
2,900 \\
900 \\
4,800 \\
239,000 \\
51,000\end{array}$ \\
\hline CRABS, sort. & & \\
\hline United States. & $10,301,000$ & 359,000 \\
\hline 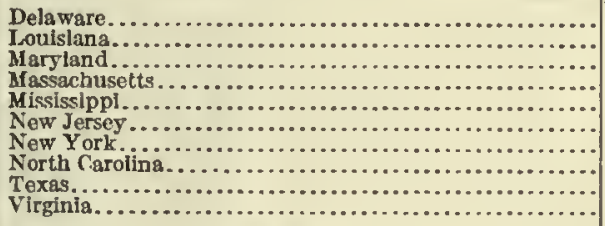 & $\begin{array}{r}142,000 \\
78,000 \\
7,587,000 \\
1,800 \\
47,000 \\
63,000 \\
22,000 \\
277,000 \\
600 \\
2,082,000\end{array}$ & $\begin{array}{r}8,400 \\
21,000 \\
195,000 \\
200 \\
5,600 \\
6,200 \\
2,300 \\
33,000 \\
200 \\
87,000\end{array}$ \\
\hline CRABS, KTNG. & & \\
\hline United States. & $7,6 \pm 3,000$ & 23,000 \\
\hline 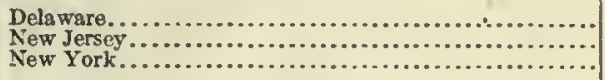 & $\begin{array}{r}2,980,000 \\
4,607,000 \\
56,000\end{array}$ & $\begin{array}{r}4,300 \\
18,000 \\
100\end{array}$ \\
\hline CRABS, STONE. & & \\
\hline United States.. & 62,000 & 3,700 \\
\hline $\begin{array}{l}\text { Florida.......................... } \\
\text { CEAwFtsh. }\end{array}$ & 62,000 & 3,700 \\
\hline Uniled Stales.................. & 614,000 & $3 \dot{2}, 000$ \\
\hline $\begin{array}{c}\text { Loulsiana } \\
\text { Oregon } \text { LIsconsin }_{\text {Wonsters. }}\end{array}$ & $\begin{array}{r}88,000 \\
178,000 \\
348,000\end{array}$ & $\begin{array}{r}3,600 \\
14,000 \\
14,000\end{array}$ \\
\hline Unlted States.................................... & $15,279,000$ & $1,931,000$ \\
\hline 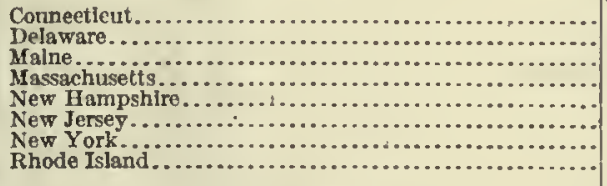 & $\begin{array}{r}661,000 \\
5,500 \\
9,929,000 \\
2,455,000 \\
264,000 \\
115,000 \\
423,000 \\
1,425,000\end{array}$ & $\begin{array}{r}84,000 \\
800 \\
1,269,000 \\
307,000 \\
43,000 \\
16,000 \\
57,000 \\
152,000\end{array}$ \\
\hline 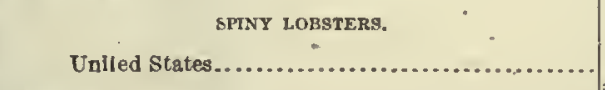 & 626,000 & 71,000 \\
\hline 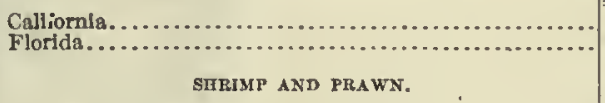 & $\begin{array}{r}573,000 \\
53,000\end{array}$ & $\begin{array}{r}69,000 \\
2,600\end{array}$ \\
\hline 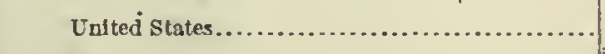 & $19,080,000$ & 494,000 \\
\hline 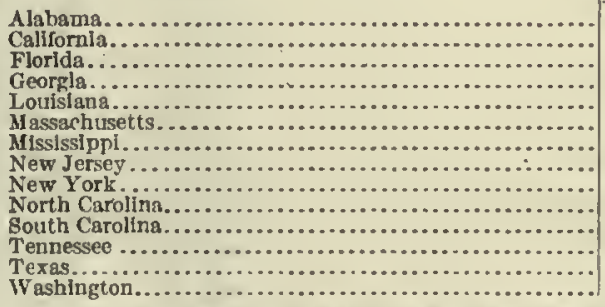 & $\begin{array}{r}37,000 \\
258,000 \\
4,353,000 \\
528,000 \\
8,581,000 \\
5,800 \\
4,121,000 \\
4,900 \\
1,500 \\
371,000 \\
452,000 \\
1,700 \\
118,000 \\
247,000\end{array}$ & $\begin{array}{r}1,200 \\
31,000 \\
92,000 \\
19,000 \\
213,000 \\
1,300 \\
81,000 \\
1,000 \\
600 \\
9,000 \\
19,000 \\
200 \\
4,400 \\
22,000\end{array}$ \\
\hline
\end{tabular}

Ineludes Alabama, Indiana, Illinols, Kansas, Malne, Miehigan, Mississlppl, New Jersey, North Carolina, Ohlo, Rhode Island, Texas, and Virginla.

- Ineludes Indlana, Malne, Minnesota, Missour, North Carolina, and Ohlo. 
TABLE 5.-PRODUCTS-DETAIL SUMMARY BY STATES AND BY SPECIES: 1908-Continued.

\begin{tabular}{|c|c|c|c|c|c|}
\hline SPECTES AND STATE. & $\begin{array}{l}\text { Quantity } \\
\text { (pounds). }\end{array}$ & Valuo. & SPECIES AND STATE. & $\begin{array}{l}\text { Quantily } \\
\text { (pounds). }\end{array}$ & Value. \\
\hline \multicolumn{6}{|l|}{ ABALONE. } \\
\hline United Stales... & $1,005,000$ & $\$ 16.000$ & Maryland ........... & $43,624,000$ & $\$ 2,228,000$ \\
\hline \multirow{4}{*}{ 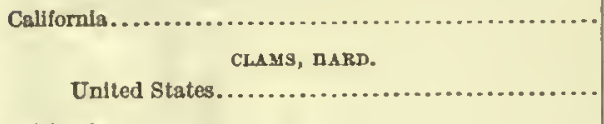 } & \multirow{3}{*}{$1,005,000$} & \multirow{2}{*}{16,000} & From pubilic äeas..... & \multirow{4}{*}{$\begin{array}{r}39,718,000 \\
1,094,000 \\
2,812,000 \\
1,084,000 \\
868,000\end{array}$} & \multirow{4}{*}{$\begin{array}{r}2,127,000 \\
2,041,000 \\
86,000 \\
101,000 \\
218,000 \\
203,000\end{array}$} \\
\hline & & & From private areas... & & \\
\hline & & & $\begin{array}{l}\text { Seed, from public areas ... } \\
\text { Massachusetts ................. }\end{array}$ & & \\
\hline & $7,805,000$ & $1,317,000$ & Market................. & & \\
\hline $\begin{array}{l}\text { California.... } \\
\text { Conneetleut. }\end{array}$ & 132,000 & 4,500 & $\begin{array}{l}\text { From public } \\
\text { From prival }\end{array}$ & $\begin{array}{r}4,900 \\
863,000\end{array}$ & 202,900 \\
\hline 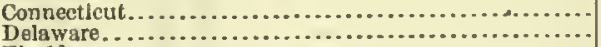 & $\begin{array}{r}100,000 \\
6,900\end{array}$ & $\begin{array}{r}20,000 \\
1,300\end{array}$ & 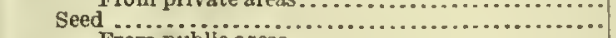 & 210,000 & 15,000 \\
\hline 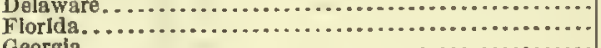 & 239,000 & 15,000 & From public areas...... & 43,000 & $\begin{array}{r}3,100 \\
12\end{array}$ \\
\hline 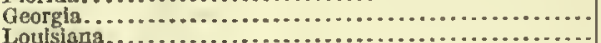 & 43,000 & 9,400 & $\begin{array}{l}\text { From private a } \\
\text { Mississippl, market... }\end{array}$ & $\begin{array}{r}173,000 \\
7,473,000\end{array}$ & $\begin{array}{r}12,000 \\
295,000\end{array}$ \\
\hline 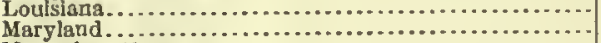 & 82,000 & 16,000 & From public areas.... & $7,423,000$ & 292,000 \\
\hline 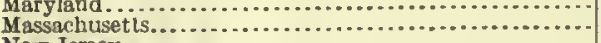 & $1,119,000$ & 189,000 & From private areas... & 50,000 & 3,800 \\
\hline Now Jersey ................. & $2,184,000$ & 318,000 & 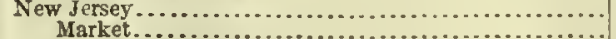 & $\begin{array}{r}18,105,000 \\
6,437,000\end{array}$ & $\begin{array}{r}1,369,000 \\
884,000\end{array}$ \\
\hline 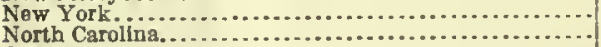 & $\begin{array}{l}809,000 \\
726,000\end{array}$ & $\begin{array}{r}223,000 \\
82,000\end{array}$ & From pubilic areis.... & $\begin{array}{l}0,437,000 \\
107,000\end{array}$ & $\begin{array}{r}834,000 \\
12,000\end{array}$ \\
\hline 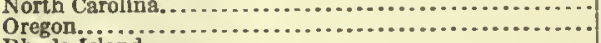 & & $\begin{array}{r}82,000 \\
100\end{array}$ & From private areas..... & $6,330,000$ & 872,000 \\
\hline 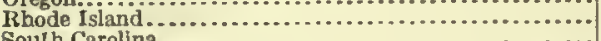 & 162,000 & 39,000 & 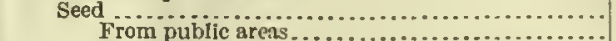 & $11,668,000$ & 485,000 \\
\hline 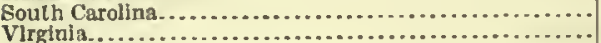 & $\begin{array}{r}76,000 \\
969,000\end{array}$ & $\begin{array}{r}6,300 \\
380,000\end{array}$ & $\begin{array}{l}\text { From public arens...... } \\
\text { From private areas.... }\end{array}$ & $\begin{array}{l}5,402,000 \\
6,266,000\end{array}$ & \\
\hline 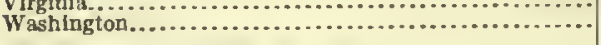 & 155,000 & 13,000 & New York.......... & $17,244,000$ & $2,553,000$ \\
\hline 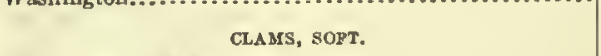 & & & $\begin{array}{l}\text { Market.......................... } \\
\text { From public areas... }\end{array}$ & $\begin{array}{l}12,946,000 \\
151,000\end{array}$ & $2,173,000$ \\
\hline Unlted States.......... & $8,654,000$ & 553,000 & From private areas... & $12,795,000$ & $2,155,000$ \\
\hline & $0,004,000$ & $=$ & - Seed $\quad$ From public area...... & $\begin{array}{l}4,298,000 \\
628,000\end{array}$ & $\begin{array}{r}381,000 \\
45,000\end{array}$ \\
\hline ............. & 468,000 & 5,300 & Fro & $3,670,000$ & 336,000 \\
\hline (n.................. & $5,061,000$ & $\begin{array}{r}5,500 \\
251,000\end{array}$ & $\begin{array}{l}\text { North Carolina...... } \\
\text { Market. }\end{array}$ & $6,690,000$ & 236,000 \\
\hline 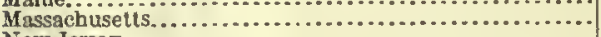 & $1,916,000$ & 186,000 & From pubilic areas....... & $5,209,000$ & 220,000 \\
\hline arsey & 205,000 & 11, 000 & From private areas..... & 66,000 & 7,300 \\
\hline $\begin{array}{l}\text { New York................... } \\
\text { Oregon.................... }\end{array}$ & $\begin{array}{r}656,000 \\
30,000\end{array}$ & $\begin{array}{r}54,000 \\
2,000\end{array}$ & Seed from public greas & 415,000 & 8,800 \\
\hline 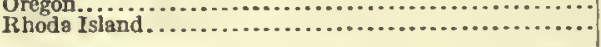 & 275,000 & 38,000 & $\begin{array}{l}\text { From public areas...... } \\
\text { From private areas... }\end{array}$ & $\begin{array}{r}401,000 \\
14,000\end{array}$ & $\begin{array}{r}8,500 \\
300\end{array}$ \\
\hline CLAMS, RAZOF & & & 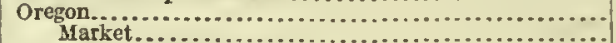 & $\begin{array}{l}9,100 \\
7,300\end{array}$ & 4,200 \\
\hline United States............ & 259,000 & 25,000 & From public & 2,300 & 800 \\
\hline nuselts................ & 24,000 & 3,000 & Seed, from publ & $\begin{array}{l}5,000 \\
1,800\end{array}$ & $\begin{array}{r}3,200 \\
200\end{array}$ \\
\hline 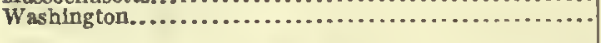 & 234,000 & 22,000 & $\begin{array}{l}\text { Pennsylvania........ } \\
\text { Market, from pi }\end{array}$ & $\begin{array}{l}1,938,000 \\
906,000\end{array}$ & $\begin{array}{l}176,000 \\
134,000\end{array}$ \\
\hline CLAMS, SURF & & & ublic areas.... & $1,032,000$ & 42,000 \\
\hline United States............ & 265,000 & 21,000 & 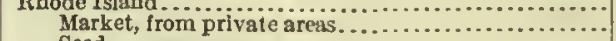 & $\begin{array}{l}8,002,000 \\
8,564,000\end{array}$ & 967,000 \\
\hline New Jersey & 99,000 & 7,000 & Fro & $\begin{array}{l}38,000 \\
21,000\end{array}$ & $\begin{array}{l}2,500 \\
\mathbf{I}, 500\end{array}$ \\
\hline & 167,000 & 14,000 & From priva & 18,000 & 1,000 \\
\hline OYSTERs. & & & $\begin{array}{l}\text { South Carolina, mar } \\
\text { From public are }\end{array}$ & $\begin{array}{l}10,942,000 \\
10,331,000\end{array}$ & $\begin{array}{l}137,000 \\
129,000\end{array}$ \\
\hline Untted States.............. & $233,309,000$ & $15,713,000$ & From private a & 610,000 & 8,000 \\
\hline Market............ & $178,293,000$ & $12,721,000$ & Market..... & $3,428,000$ & 167,000 \\
\hline From public areas. & $103,641,000$ & $4,416,000$ & From publi & $3,404,000$ & 166,000 \\
\hline From private areas. & $74,652,000$ & $8,305,000$ & $\begin{array}{l}\text { From pri } \\
\text { seed, from pu }\end{array}$ & $\begin{array}{l}24,000 \\
52,000\end{array}$ & $\begin{array}{r}1,200 \\
600\end{array}$ \\
\hline From public areas..... & $\begin{array}{l}55,016,000 \\
26,960,000\end{array}$ & $\begin{array}{l}2,992,000 \\
1,035,000\end{array}$ & Virginia........... & $35,525,000$ & $2,348,000$ \\
\hline From privale areas.... & $28,056,000$ & $1,957,000$ & Market...... & $\begin{array}{r}25,705,000 \\
9,581,000\end{array}$ & $\begin{array}{l}1,967,000 \\
645,000\end{array}$ \\
\hline Alabama................... & $4,132,000$ & 173,000 & From privat & $16,124,000$ & $1,322,000$ \\
\hline lic areas & & 000 & Seed......... Fubilic & $\begin{array}{l}9,820,000 \\
9,252,000\end{array}$ & $\begin{array}{l}381,000 \\
357,000\end{array}$ \\
\hline lic areas....... & $\begin{array}{r}3,314,000 \\
440,000\end{array}$ & $\begin{array}{r}132,000 \\
37,000\end{array}$ & From private areas ................. & $\begin{array}{r}9,252,000 \\
568,000\end{array}$ & $\begin{array}{r}35,, 000 \\
24,000\end{array}$ \\
\hline blle areas................... & 378,000 & 4,100 & Washington $\ldots \ldots \ldots$ & $1,425,000$ & 332,000 \\
\hline ket, from privale areas ............ & 729,000 & 337,000 & Market, from private areas...... & $1,321,000$ & 346,000 \\
\hline Connecticut.................................... & $27,636,000$ & $2,583,000$ & Seed, from private areas................ & 104,000 & 6,500 \\
\hline $\begin{array}{l}\text { Market........................ } \\
\text { From public areas...... }\end{array}$ & $\begin{array}{r}9,762,000 \\
44,000\end{array}$ & $\begin{array}{r}1,168,000 \\
4,400\end{array}$ & SCALLOPS AND SCALLOP RIMS. & & \\
\hline private areas...... & $9,718,000$ & $1,163,000$ & & & \\
\hline $\begin{array}{l}\text { Seed........ } \\
\text { From p }\end{array}$ & $\begin{array}{l}4,000 \\
8,000\end{array}$ & $\begin{array}{r}1,415,000 \\
99,000\end{array}$ & United States............ & $2,432,000$ & 317,000 \\
\hline ale areas..... & 6,000 & $1,317,000$ & Florida.. & 400 & 100 \\
\hline Delaware... & 2 , & 169,000 & & $1,257,000$ & 96,000 \\
\hline Marke & 1,0 & 000 & husetts.......... & 502,000 & 120,000 \\
\hline public areas .... & & 10,000 & w York .............. & 650,000 & 98,000 \\
\hline From privale areas..... & & 102,000 & 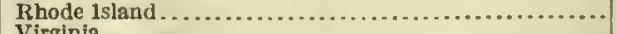 & 4,000 & 600 \\
\hline Seed... & $1,352,000$ & $\begin{array}{l}57,000 \\
53,000\end{array}$ & Virginia....$\ldots \ldots \ldots \ldots \ldots \ldots \ldots \ldots \ldots$ & 19,000 & 2,400 \\
\hline areas............................................. & $\begin{array}{r}1,343,000 \\
49,000\end{array}$ & $\begin{array}{r}53,000 \\
3,500\end{array}$ & COCKLES, WINKLES, AND CONCUS. & & \\
\hline Florida, in & $7,467,000$ & $-296,000$ & & & \\
\hline From & $7,327,000$ & 284,000 & Uniled States. & 146,000 & 35,000 \\
\hline $\begin{array}{l}\text { From p } \\
\text { Georgia... }\end{array}$ & $\begin{array}{r}141,000 \\
10,214,000\end{array}$ & $\begin{array}{r}12,000 \\
339,000\end{array}$ & Florida.... & 15,000 & 1,000 \\
\hline Market. & $10,053,000$ & 334,000 & Louisiana....... & 200 & \\
\hline blic areas...... & $3,484,000$ & 121,000 & Massachusetts............. & 130,000 & 34,000 \\
\hline private areas..... & $6,669,000$ & $\begin{array}{r}213,000 \\
4,600\end{array}$ & Rhode Island ............. & $\mathbf{1 , 5 0 0}$ & 200 \\
\hline bilic areas......... & $\begin{array}{r}161,000 \\
63,000\end{array}$ & $\begin{array}{l}4,600 \\
1,800\end{array}$ & MUSSELS. & & \\
\hline te areas...... & $\begin{array}{r}98,000 \\
\end{array}$ & 2,800 & Unlted States... & $8,5.42,000$ & 12,000 \\
\hline $\begin{array}{l}\text { Louisiana... } \\
\text { Markct. }\end{array}$ & $\begin{array}{l}25,553,000 \\
20,762,000\end{array}$ & $\begin{array}{l}763,000 \\
675,000\end{array}$ & & $0,02 a, 000$ & \\
\hline lic areas............ & $13,363,000$ & 341,000 & California..... & 68,000 & 1,600 \\
\hline From privale areas............. & $7,399,000$ & 334,000 & Connecticut... & 200 & 200 \\
\hline Seed....$\ldots \ldots \ldots \ldots \ldots \ldots$ & $4,791,000$ & 88,000 & husetts. . & $\begin{array}{r}1,100 \\
257,000\end{array}$ & $\begin{array}{r}100 \\
100\end{array}$ \\
\hline $\begin{array}{l}\text { From public areas............ } \\
\text { From private areas......... }\end{array}$ & $\begin{array}{l}4,091,000 \\
700,000\end{array}$ & $\begin{array}{r}82,000 \\
6,200\end{array}$ & $\begin{array}{l}\mathrm{w} \text { J Jersey ......... } \\
\text { w York....... }\end{array}$ & $8,175,000$ & 8,200 \\
\hline Maine, market, from public areas ............... & 1,000 & 200 & Rhode Island................ & 3,500 & 100 \\
\hline & & & $\cos +2$ & & \\
\hline
\end{tabular}


PRODUCTS.

TABLE 5.-PRODUCTS-DETAIL SUMMARY BY STATES AND BY SPECIES: 1908-Continued.

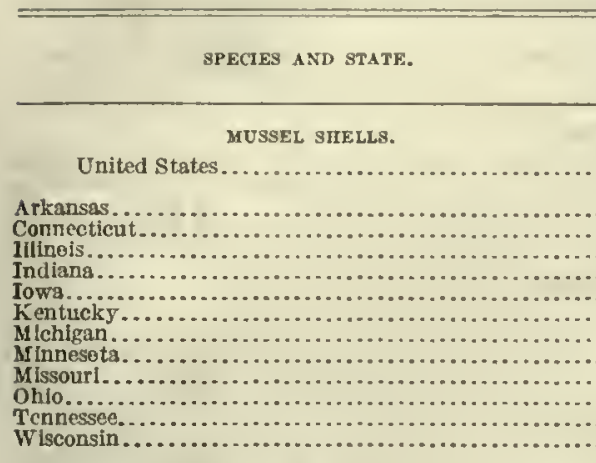

OTHER SHELLS.

United States.

California

Florida.

United States.

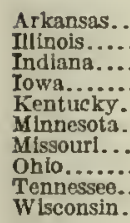

SQUTD.

Callfornia.

Connecticut.

Maine...

Maryland....

New Jersey.

Rhodo Island

TERRAPIN.

United States.

Alabama

Delaware.

Florida.

Georgla

Louislana

Maryland.

M ississippl.

New Jersey.

North Carolin

South

Texas...

$$
\text { United States................. }
$$

Californta.

Delaware.

Florida.

Iilnois.

Lowa

Maine.

Minnesota.

North Carolina.

Ohio.

Teras.....

Virginia

Ail other states?

Unlted States.

SPONGES.

Florida.

I, Lss than $\$ 100$.
Includes Alabama, Arkansas, feorgia, Kontucky, Maryland, Massachusotts,

\begin{tabular}{|c|c|}
\hline $\begin{array}{l}\text { Quantity } \\
\text { (pounds). }\end{array}$ & Value. \\
\hline & \\
\hline $81,869,000$ & $\$ 392,000$ \\
\hline $8,060,000$ & 42,000 \\
\hline $5,403,000$ & 5,400 \\
\hline $39,809,000$ & 184,000 \\
\hline $14,431,000$ & 81,000 \\
\hline $4,699,000$ & 33,000 \\
\hline $3,413,000$ & 18,000 \\
\hline 200,000 & 800 \\
\hline 767,000 & 4,700 \\
\hline 170,000 & 1,000 \\
\hline $1,597,000$ & 6,600 \\
\hline $2,170,000$ & 9,400 \\
\hline $1,150,000$ & 6,900 \\
\hline 952,000 & 8,400 \\
\hline $\begin{array}{r}951,000 \\
300\end{array}$ & $\begin{array}{l}7,100 \\
1,300\end{array}$ \\
\hline … & $\$ 300,000$ \\
\hline & 28,000 \\
\hline & 170,000 \\
\hline & 74,000 \\
\hline & 11,000 \\
\hline & 1,900 \\
\hline & 3,700 \\
\hline & 600 \\
\hline$\ldots \ldots$ & 400 \\
\hline & $\begin{array}{l}4,200 \\
5,400\end{array}$ \\
\hline $2,562,000$ & 43,000 \\
\hline 110,000 & 4,400 \\
\hline 21,000 & 400 \\
\hline 6,100 & (1) \\
\hline $\begin{array}{r}6,900 \\
837,000\end{array}$ & $\begin{array}{r}200 \\
20,000\end{array}$ \\
\hline $\begin{array}{r}1,837,000 \\
100,000\end{array}$ & 3,100 \\
\hline 189,000 & 8,100 \\
\hline 292,000 & 6,600 \\
\hline 368,000 & 80,000 \\
\hline & \\
\hline 4,400 & 300 \\
\hline $\begin{array}{r}2,900 \\
21,000\end{array}$ & 1,900 \\
\hline $\begin{array}{l}21,000 \\
41,000\end{array}$ & $\begin{array}{r}9,400 \\
21,000\end{array}$ \\
\hline 205,000 & 13,000 \\
\hline 41,000 & 21,000 \\
\hline 9,200 & 4,900 \\
\hline 5,100 & 1,200 \\
\hline 1,900 & 100 \\
\hline 1,100 & 1,000 \\
\hline 7,700 & 1,800 \\
\hline $\begin{array}{l}12,000 \\
15,000\end{array}$ & $\begin{array}{l}2,400 \\
1,600\end{array}$ \\
\hline 400 & 400 \\
\hline $1,088,000$ & 40,000 \\
\hline 38,000 & 1,300 \\
\hline 54,000 & 2,500 \\
\hline 165,009 & 11,000 \\
\hline 300,000 & 8,100 \\
\hline 93,000 & 1,800 \\
\hline 215,000 & 7,800 \\
\hline 1,400 & 600 \\
\hline 25,000 & 600 \\
\hline 23,000 & 700 \\
\hline 18,000 & 900 \\
\hline $\begin{array}{l}20,000 \\
24,000\end{array}$ & 1,000 \\
\hline $\begin{array}{l}24,000 \\
44,000\end{array}$ & 500 \\
\hline 63,000 & $\begin{array}{l}1,000 \\
1,700\end{array}$ \\
\hline & \\
\hline 622,000 & 545,000 \\
\hline 622,000 & 545,000 \\
\hline
\end{tabular}
Mississippl, Missouri, Now Jersey, and New York.

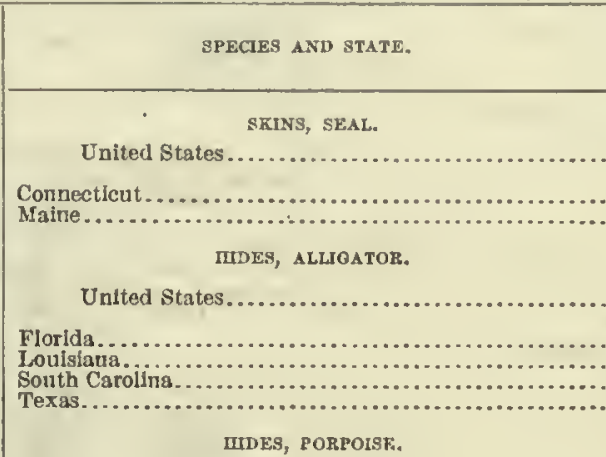

United Statcs.

North Carolina.

United Stgtes. SKrNs, MrNk.

Illinois...

Louisiana...

Minnesota.

All other states 3

SEINS, MUSKRAT.

United States.

Delaware

Illino

Iowaisiana

Mraryland.

Mfichigan

MI issouri.

New Jersey.

New York.

North Carejina

Ohio..

Visconsi

IDES, RORPOISF,

skINs, otrer.

United States.

Florida..

Louisians.

Lut other stai...

WHALEBONE.

Untted States.

California.

Connecticut.

Morth Carolina....

United States LIVERS.

Maine.

Massachio....

United States sounds.

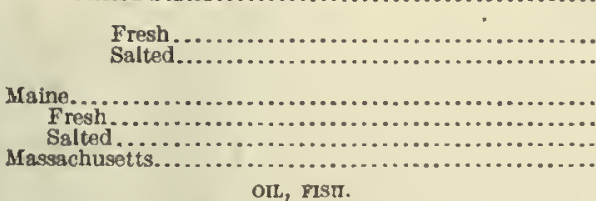

\begin{tabular}{r|r}
$\begin{array}{r}\text { Quantity } \\
\text { (pounds): }\end{array}$ & Value. \\
\hline 3,100 & $\$ 8,200$ \\
\hline 1,400 & 6,000 \\
1,600 & 2,200
\end{tabular}

$372,000 \quad 61,000$

\begin{tabular}{r|r}
\hline 254,000 & 48,000 \\
110,000 & 11,000 \\
100 & $(1)$ \\
7,000 & 1,400 \\
&
\end{tabular}

48,000

48,000

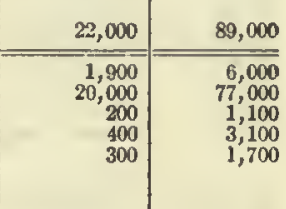

$149,000 \quad 136,000$

22,000
17,000 $\quad \begin{aligned} & 24,000 \\ & 14,000\end{aligned}$

1,400
40,000

$\begin{array}{ll}40,000 & 16,000 \\ 38,000 & 50,000\end{array}$

300

1,700

9,800
3,000

3,000
100

100
14,000

14,000
300
1,000

400
1,200

12,000
2,300

(c) 2,300

800
14,000

3,000
600

$7,600 \quad 30,000$

\begin{tabular}{r|r}
5,700 & 21,000 \\
700 & 3,600
\end{tabular}

\begin{tabular}{r|r} 
& 700 \\
1,100 & 3,600 \\
& 4,700 \\
& 300
\end{tabular}

$32,000=\frac{215,000}{119,000}$

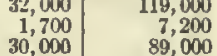

8000000
200

$657,000 \quad 7,400$

\begin{tabular}{r|r}
52,000 & 500 \\
605,000 & 6,900
\end{tabular}

$96,000 \quad 4,100$

\begin{tabular}{r|r}
96,000 & 4,100 \\
\hline 93,000 & 4,000 \\
2,800 & 100 \\
23,000 & 1,000 \\
20,000 & 900 \\
2,800 & 100 \\
73,000 & 3,100 \\
221,000 & \\
\hline 83,000 & 9,500 \\
\hline 138,000 & 3,600 \\
29,000 & 5,900 \\
\hline 8,000 & 3,000 \\
21,000 & 8,200
\end{tabular}

Maine.

Maine.

Iassaehusetts.

United Stateg OIh, PORPOISE.

Includes Iowa, North Carol!na, Onio, Texas, Virginia, and Wisconsin.

1 Ineludes Arkansas, Maryland, Missouri, North Carolina, and Virginia.

- Less than 100 pounds. 
TABLE 5.-PRODUCTS-DETAIL SUMMARY BY STATES AND BY SPECIES: 1908-Continued.

\begin{tabular}{|c|c|c|c|c|c|}
\hline SPECIES AND STATE. & $\begin{array}{l}\text { Quantity } \\
\text { (pounds). }\end{array}$ & Value. & SPECIES AND STATE. & $\begin{array}{l}\text { Quantity } \\
\text { (ponods). }\end{array}$ & Value. \\
\hline OL, SEA-ELEPHANT. & & & OIL, WHALE. & & \\
\hline United States... & 88,000 & $\$ 3,600$ & United States.............. & 573,000 & $\$ 30,000$ \\
\hline Connectlcut...................... & 88,000 & 3,600 & 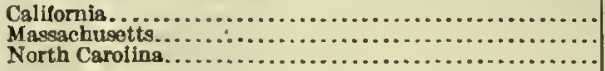 & $\begin{array}{r}13,000 \\
553,000 \\
7,500\end{array}$ & $\begin{array}{r}900 \\
28,000 \\
400\end{array}$ \\
\hline United States.................... & & 400 & IRISII Moss. & & \\
\hline Maine.............. & 4,000 & 400 & United States.............. & 772,000 & 26,000 \\
\hline $\begin{array}{l}\text { orL, BPERM. } \\
\text { Unlted States............... }\end{array}$ & $3,391,000$ & 252,000 & 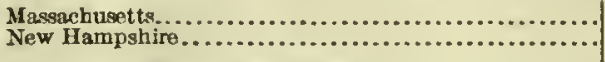 & $\begin{array}{r}737,000 \\
35,000\end{array}$ & $\begin{array}{r}25,000 \\
1,400\end{array}$ \\
\hline 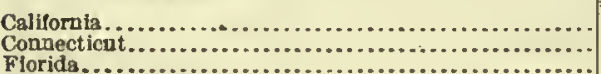 & $\begin{array}{r}169,000 \\
280,000 \\
28,000\end{array}$ & $\begin{array}{r}12,000 \\
20,000 \\
1,900\end{array}$ & $\begin{array}{c}\text { SEA GRASS. } \\
\text { Unlted States........................ }\end{array}$ & 252,000 & 1,700 \\
\hline 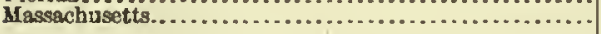 & $2,913,000$ & 218,000 & Maryland.... & 252,000 & 1,700 \\
\hline
\end{tabular}

Table 6.-PRODUCTS, BY apPaRATUS OF CAPTURE AND BY STATES: 1908.

\begin{tabular}{|c|c|c|c|c|c|}
\hline \multirow{2}{*}{ OS AND STATE. } & \multicolumn{2}{|c|}{ FISHERY PRODUCTS: 1908.} & \multirow[b]{2}{*}{ KIND OF APPARATUS AND STATE. } & \multicolumn{2}{|c|}{ PISHERY PRODUCTS: 1908.} \\
\hline & $\begin{array}{l}\text { Quantity } \\
\text { (pounds). }\end{array}$ & Valuc. & & $\begin{array}{l}\text { Quantity } \\
\text { (pounds). }\end{array}$ & Valuc. \\
\hline 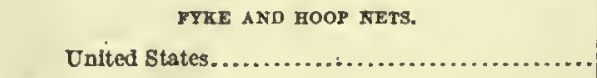 & $38,050,000$ & $\$ 1,218,000$ & 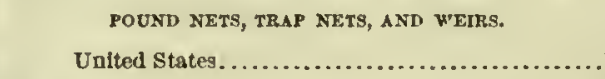 & $314,031,000$ & $\$ 5,641,000$ \\
\hline Alabama... & 386,000 & 24,000 & Arkansas... & 275,000 & 7,100 \\
\hline Arkansas..... & $2,286,000$ & 53,000 & Connecticut... & $1,629,000$ & 43,000 \\
\hline Calliormla & $1,218,000$ & 62,000 & Delawrare.......... & 11,000 & 400 \\
\hline $\begin{array}{l}\text { Connecticut.... } \\
\text { Delaware..... }\end{array}$ & $\begin{array}{l}112,000 \\
165,000\end{array}$ & $\begin{array}{l}3,000 \\
7,300\end{array}$ & 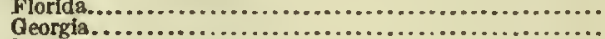 & $\begin{array}{l}295,000 \\
277,000\end{array}$ & $\begin{array}{l}18,000 \\
14,000\end{array}$ \\
\hline Florida......... & 4,000 & 300 & Illinols............. & 32,000 & 1,200 \\
\hline Georgia...... & 8,600 & 400 & Indlana..... & 293,000 & 18,000 \\
\hline Illinois......... & $11,370,000$ & 330,000 & Iows........... & 321,000 & 11,000 \\
\hline Indlana..... & $\begin{array}{l}284,000 \\
625,000\end{array}$ & $\begin{array}{l}16,000 \\
30,000\end{array}$ & Louisiana............ & $\begin{array}{r}36,000 \\
69,621,000\end{array}$ & 357,000 \\
\hline Kentucky..... & $1,122,000$ & 47,000 & 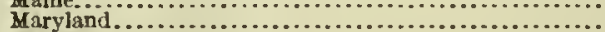 & $27,105,000$ & $\begin{array}{l}357,000 \\
321,000\end{array}$ \\
\hline Ioutsiana...... & $1,758,000$ & 32,000 & Massachusetts.. & $18,641,000$ & 266,000 \\
\hline Maryland.... & 769,000 & 39,000 & Mlchigan..... & $19,299,000$ & 550,000 \\
\hline Massachusetts & 52,000 & 2,200 & Minnesota... & $1,198,000$ & 44,000 \\
\hline Muchigan................ & $2,556,000$ & 94,000 & Mississippi... & 61,000 & 1,200 \\
\hline Minnesota.............. & 51,000 & 2,800 & Missouri..... & 26,000 & 1,100 \\
\hline Míssisslppl.. & $1,766,000$ & 10,000 & New Jersey. & $30,285,000$ & 539,000 \\
\hline Missouri...... & $2,538,000^{\circ}$ & 88,000 & New Y ork. & $11,006,000$ & 417,000 \\
\hline New Jersey............ & 449,000 & 22,000 & North Carolir & $14,040,000$ & 391,000 \\
\hline New York............ & $2,951,000$ & 86,000 & Ohlo......... & $9,783,000$ & 308,000 \\
\hline North Carolina. & 231,000 & 8,600 & Oregon............ & 353,000 & 18,000 \\
\hline Ohlo ........................ & $1,714,000$ & 51,000 & Pennsylvanla... & 322,000 & 13,000 \\
\hline $\begin{array}{l}\text { Oregon..................... } \\
\text { Pennsyilvania...... }\end{array}$ & 201,000 & 9,000 & $\begin{array}{l}\text { Rhode 1stand... } \\
\text { Tennessee..... }\end{array}$ & $19,406,000$ & 388,000 \\
\hline Rhode Island. & 241,000 & 5,800 & Virginia.... & $52,500,000$ & 833,000 \\
\hline Tennessee... & $1,159,000$ & 45,000 & Washington & $28,860,000$ & 868,000 \\
\hline Texas....... & 72,000 & 2,600 & Wisconsin.... & $8,089,000$ & 208,000 \\
\hline Virginia.... & $1,279,000$ & 47,000 & All other atates.... & 129,000 & 2,200 \\
\hline 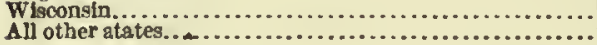 & $\begin{array}{r}2,449,000 \\
229,000\end{array}$ & $\begin{array}{l}54,000 \\
15,000\end{array}$ & & & \\
\hline & & & United States. & $573,405,000$ & $5,999,000$ \\
\hline & & & Alabama. & 150,000 & 4,400 \\
\hline & - & & Arkansag.... & 692,000 & 21,000 \\
\hline GILI, NETS. & & & Calliornla........ & $6,892,000$ & 116,000 \\
\hline United States. . & $181,224,000$ & $7,536,000$ & & $\begin{array}{l}29,398,000 \\
64,091,000\end{array}$ & $\begin{array}{l}116,000 \\
219,000\end{array}$ \\
\hline & & & & $20,400,000$ & 606,000 \\
\hline Alabama... & 35,000 & 1,200 & & 549,000 & 38,000 \\
\hline Callfornia... & $18,427,000$ & 769,000 & lliknols... & $15,945,000$ & 460,000 \\
\hline Connectlcut. & 180,000 & 20,000 & Indiana.. & 70,000 & 4,200 \\
\hline Delaware. & $1,075,000$ & 85,000 & & $1,877,000$ & 68,000 \\
\hline Florlda.. & $29,803,000$ & $1,133,000$ & tucky.. & 247,000 & 12,000 \\
\hline Georgia.. & $1,721.000$ & 213,000 & Loulsiana.. & $12,496,000$ & 400,000 \\
\hline IIlinols... & 962,000 & 51,000 & Madne.. & $27,877,000$ & 171,000 \\
\hline Indiana.. & 285,000 & 18,000 & Marylan & $17,983,000$ & 128,000 \\
\hline & 24,000 & 900 & iusetts. & $25,397,000$ & 806,000 \\
\hline Maine... & $1,404,000$ & 56,000 & Michigan... & $2,051,000$ & 55,000 \\
\hline Maryland & $3,038,000$ & 174,000 & & $1,884,000$ & 53,000 \\
\hline & 14,88 & & & $8,118,000$ & 108,000 \\
\hline Michigan.. & $13,240,000$ & 715,000 & & $1,915,000$ & 68,000 \\
\hline Minnesota.. & $2,991,000$ & 50,000 & Jersey. & $9,649,000$ & 108,000 \\
\hline & $4,515,000$ & 310,000 & York. & $18,178,000$ & 327,000 \\
\hline $\mathrm{Ner}$ & $7,412,000$ & 246.000 & North Carolin & $71,069,000$ & 591,000 \\
\hline Carolina... & $7,733,000$ & 376,000 & & $5,781,000$ & 105,000 \\
\hline Ohio... & $9,400,000$ & 336,000 & Oregon... & $2,387,000$ & 152,000 \\
\hline & $22,849,000$ & $1,076,000$ & Pennsylvanin. & 722,000 & 22,000 \\
\hline & $7,659,000$ & 235,000 & Rhode Jsiand.... & $10,648,000$ & 40,000 \\
\hline 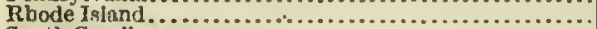 & 593,000 & 21,000 & South Carolina... & 567,000 & 16,000 \\
\hline South Carolina.... & 566.000 & 43,000 & Tennessee........ & 223,000 & R. 700 \\
\hline & 151,000 & 7,000 & & $3,055,000$ & 153,000 \\
\hline 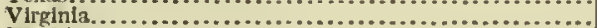 & $3,489,000$ & 205,000 & Virginia....... & $191,633.000$ & 531,000 \\
\hline 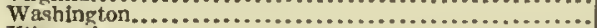 & $16,262,000$ & 468,000 & Washingtor... & $14,932.000$ & 333,000 \\
\hline Wisconsin........... & $12,481,000$ & 533.000 & Wisconsin...... & $4,995,000$ & 143,000 \\
\hline 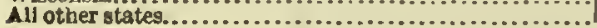 & 44,000 & 1,400 & 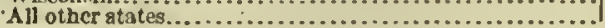 & 325,000 & 18,000 \\
\hline
\end{tabular}


PRODUCTS.

TABLE 6.-PRODUCTS, BY APPARATUS OF CAPTURE AND BY STATES: 1908-Continued.

\begin{tabular}{|c|c|c|c|c|c|}
\hline \multirow[b]{2}{*}{ KIND OF APPARATUS AND STATE. } & \multicolumn{2}{|c|}{ MSUERY PRODUCTS: 1908.} & \multirow[b]{2}{*}{ KIND OF APPARATUS AND STATE. } & \multicolumn{2}{|c|}{ FSIIEYY PRODUCT: 1908.} \\
\hline & $\begin{array}{l}\text { Quantity } \\
\text { (pounds). }\end{array}$ & Value. & & $\begin{array}{l}\text { Quantlty } \\
\text { (pounds). }\end{array}$ & Value. \\
\hline TRAMMEL & & & WNES (BAND, TRAWL, AND B & & \\
\hline United Stat & $15,708,000$ & 8486,000 & Kentucky. & 598,000 & 530,000 \\
\hline Alabama..... & $2,271,000$ & 58,000 & Maine..... & $\begin{array}{r}5,329,000 \\
55,287,000\end{array}$ & $\begin{array}{l}203,000 \\
953,000\end{array}$ \\
\hline Arkansas...... & 129,000 & 3,900 & Maryland...... & $11,491,000$ & 124,000 \\
\hline $\begin{array}{l}\text { California........ } \\
\text { Florida......... }\end{array}$ & $1,951,000$ & 52,000 & Massachuset ts. & $161,858,000$ & $3,930,000$ \\
\hline $\begin{array}{l}\text { Illinols............. } \\
\text { Illing }\end{array}$ & $\begin{array}{r}792,000 \\
5,100,000\end{array}$ & $\begin{array}{r}27,000 \\
151,000\end{array}$ & $\begin{array}{l}\text { Michigan...... } \\
\text { Minnesota... }\end{array}$ & $\begin{array}{l}855,000 \\
426,000\end{array}$ & $\begin{array}{l}52,000 \\
22,000\end{array}$ \\
\hline Iowa............. & $1,087,000$ & 46,000 & Mississippi... & $1,022,000$ & $\begin{array}{l}22,000 \\
40,000\end{array}$ \\
\hline $\begin{array}{l}\text { Kentucky....... } \\
\text { Loulslana....... }\end{array}$ & & $\begin{array}{r}400 \\
5.800\end{array}$ & Mlssouri.... & 970,000 & 46,000 \\
\hline Maryland..... & $\begin{array}{l}71,000 \\
12,000\end{array}$ & $\begin{array}{l}5,800 \\
1,200\end{array}$ & $\begin{array}{l}\text { New Jersey.. } \\
\text { New York.. }\end{array}$ & $8,382,000$ & 332,000 \\
\hline Mlnisesota .......... & 42,000 & 900 & Nortb Carolina & $\begin{array}{r}7,752,000 \\
574,000\end{array}$ & $\begin{array}{r}442,000 \\
21,000\end{array}$ \\
\hline Mississippl . . . . . . . & $1,839,000$ & 57,000 & Ohio............ & 118,000 & 7,700 \\
\hline $\begin{array}{l}\text { Mflssoutl...... } \\
\text { Ohjo........ }\end{array}$ & $\begin{array}{r}1,052,000 \\
489,000\end{array}$ & $\begin{array}{r}10,000 \\
9,400\end{array}$ & Oregon $\ldots . . . . . .$. & $\begin{array}{r}54,000 \\
\end{array}$ & 2,200 \\
\hline Tennessee..... & 275,000 & $\begin{array}{l}9,400 \\
7,600\end{array}$ & Rhode Island. & $\begin{array}{r}970,000 \\
1,828,000\end{array}$ & $\begin{array}{l}49,000 \\
55,000\end{array}$ \\
\hline Texas............ & 79,000 & 4,000 & South Carolina & $1,388,000$ & 50,000 \\
\hline $\begin{array}{l}\text { Wisconsin ....... } \\
\text { All other states.. }\end{array}$ & $\begin{array}{l}261,000 \\
249,000\end{array}$ & $\begin{array}{r}7,200 \\
15,000\end{array}$ & $\begin{array}{l}\text { Tennessee..... } \\
\text { Texas......... }\end{array}$ & $\begin{array}{r}540,000 \\
2,712,000\end{array}$ & $\begin{array}{r}32,000 \\
101,000\end{array}$ \\
\hline & & & Vlrginia........... & $15,106,000$ & $\begin{array}{l}101,000 \\
190,000\end{array}$ \\
\hline OTHER & & & $\begin{array}{l}\text { Washington } \\
\text { Wlsconsin }\end{array}$ & $35,013,000$ & $1,368,000$ \\
\hline United St & $23,582,000$ & 553,000 & All other states. & $\begin{array}{r}1,133,000 \\
314,000\end{array}$ & $\begin{array}{l}92,000 \\
13,000\end{array}$ \\
\hline $\begin{array}{l}\text { Arkansas....... } \\
\text { Californla....... }\end{array}$ & 5,000 & 100 & POTS ANn Tr & & \\
\hline Delaware... & 160,000 & 11,000 & United & $23,979,000$ & $2,589,000$ \\
\hline Florlda....... & $\begin{array}{l}754,000 \\
197,000\end{array}$ & $\begin{array}{r}25,000 \\
9,400\end{array}$ & Alabama.. & 107,000 & n \\
\hline Illinois......... & 35,000 & 1,800 & California... & $2,270,000$ & $\begin{array}{r}6,100 \\
137,000\end{array}$ \\
\hline $\begin{array}{l}\text { Indlana........ } \\
\text { Loulsiana.... }\end{array}$ & $\begin{array}{r}12,000 \\
404,000\end{array}$ & $\begin{array}{r}900 \\
83.000\end{array}$ & Connecticut. & 712,000 & 89,000 \\
\hline $\begin{array}{l}\text { Lominiana...... } \\
\text { Malne........ }\end{array}$ & $2,422,000$ & 35,000 & $\begin{array}{l}\text { Delaware.... } \\
\text { Florida...... }\end{array}$ & $\begin{array}{l}196,000 \\
522,000\end{array}$ & $\begin{array}{l}37,000 \\
47,000\end{array}$ \\
\hline Maryland..... & $2,853,000$ & 63,000 & Georgla..... & $\begin{array}{r}522,000 \\
5,700\end{array}$ & $\begin{array}{r}47,000 \\
4,100\end{array}$ \\
\hline Massachusett & $6,949,000$ & 87,000 & Illinols..... & 32,000 & 21,000 \\
\hline Minnesota. ........ & $\begin{array}{r}3,100 \\
102000\end{array}$ & 300 & Iowa....... & 1,500 & 1,200 \\
\hline $\begin{array}{l}\text { Mississpppi.......... } \\
\text { New Jersey....... }\end{array}$ & $\begin{array}{l}102,000 \\
117,000\end{array}$ & $\begin{array}{r}2,700 \\
10,000\end{array}$ & Louisiana.. & 142,000 & 100,000 \\
\hline New York.... & 144,000 & $\begin{array}{r}10,000 \\
9,300\end{array}$ & $\begin{array}{l}\text { Maine...... } \\
\text { Maryland... }\end{array}$ & & $\begin{array}{r}1,291,000 \\
60,000\end{array}$ \\
\hline North Carolina. & 920,000 & 57,000 & Massachusetts & $2,830,000$ & $\begin{array}{r}60,000 \\
325,000\end{array}$ \\
\hline $\begin{array}{l}\text { Ohlo............. } \\
\text { Pennsyivanin.. }\end{array}$ & $\begin{array}{r}19,000 \\
205,000\end{array}$ & $\begin{array}{r}1,000 \\
12,000\end{array}$ & Michigan.... & 300 & 400 \\
\hline South Carollna. & 552,000 & $\begin{array}{l}12,000 \\
25,000\end{array}$ & $\begin{array}{l}\text { Minnesota... } \\
\text { Mississippi... }\end{array}$ & $\begin{array}{r}5,700 \\
138,000\end{array}$ & 2,800 \\
\hline Texas........ & 251,000 & 7,200 & Missour..... & $\begin{array}{r}133,000 \\
10,000\end{array}$ & $\begin{array}{l}11,000 \\
15,000\end{array}$ \\
\hline Virginia....... & 828,000 & 29,000 & New Jersey... & 302,000 & 34,000 \\
\hline $\begin{array}{l}\text { Washington.... } \\
\text { Wisconsin ..... }\end{array}$ & $\begin{array}{r}900,000 \\
11,000\end{array}$ & 12,000 & New York....... & 915,000 & 95,000 \\
\hline wiscousin..... & 11,000 & 600 & $\begin{array}{l}\text { North Carolina.. } \\
\text { Ohio .................. }\end{array}$ & $\begin{array}{r}244,000 \\
4,500\end{array}$ & $\begin{array}{l}6,500 \\
4,500\end{array}$ \\
\hline EAM 1 & & & Oregon ................ & 359,000 & 20,000 \\
\hline United States. & $3,752,000$ & 90,000 & $\begin{array}{l}\text { Pennsylvanla.. } \\
\text { Rhode Island... }\end{array}$ & $\begin{array}{r}61,000 \\
1,670,000\end{array}$ & $\begin{array}{r}5,400 \\
163,000\end{array}$ \\
\hline Massachusetts & 72,000 & 66,000 & Tennessee.......... & 1,700 & 200 \\
\hline & 268,000 & 9,400 & $\begin{array}{l}\text { Virginia.............. } \\
\text { Washington........ }\end{array}$ & $\begin{array}{r}48,000 \\
2,179,000\end{array}$ & $\begin{array}{r}2,500 \\
51,000\end{array}$ \\
\hline Rhode Island. & 496,000 & 14,000 & Wisconsin.......... & $2,179,000$ & $\begin{array}{l}51,000 \\
15,000\end{array}$ \\
\hline 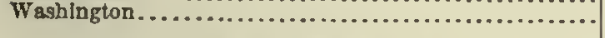 & 15,000 & 1,100 & All other states............................................ & 284,000 & 44,000 \\
\hline IUAROONS, SPEARS, ETC. & & & WHEELS AND SLIDES. & & \\
\hline United Sta & $7,679,000$ & 762,000 & United Stat & $1,958,000$ & 100,000 \\
\hline Alabanta & 14,000 & 700 & North Carolina. & 123,000 & 1,900 \\
\hline ....... & & 1,600 & Oregon............ & $1,355,000$ & 72,000 \\
\hline $\begin{array}{l}\text { California } \\
\text { Connectic }\end{array}$ & 214,000 & $\begin{array}{r}132,000 \\
43,000\end{array}$ & Washington...... & 481,000 & 26,000 \\
\hline Dela & 23,000 & $\begin{array}{r}43,000 \\
2,000\end{array}$ & DEEDGES, TONGS, RAKES, ETC. & & \\
\hline $\begin{array}{l}\text { Fiorl } \\
\text { Geor }\end{array}$ & 119,000 & 6,100 & & & \\
\hline $\begin{array}{l}\text { Georgí........... } \\
\text { Illinols............. }\end{array}$ & $\begin{array}{r}2,200 \\
68,000\end{array}$ & $\begin{array}{r}100 \\
1,800\end{array}$ & United Stat & $356,990,000$ & $18,772,000$ \\
\hline $\begin{array}{l}\text { Iowa } \\
\text { Maln }\end{array}$ & 55,000 & 1,400 & Alabama.... & $4,132,000$ & 173,000 \\
\hline $\begin{array}{l}\text { Maln } \\
\text { Mary }\end{array}$ & 539,000 & 48,000 & Arkan & & 70 \\
\hline Mass & $5,262,000$ & 465,000 & $\begin{array}{l}\text { Callornla....... } \\
\text { Connecticut... }\end{array}$ & $\begin{array}{r}729,000 \\
33,189,000\end{array}$ & $\begin{array}{r}337,000 \\
2,614,000\end{array}$ \\
\hline AIsch & 100,00 & 5,800 & Delaware............. & $\begin{array}{r}33,189,000 \\
2.441,000\end{array}$ & $\begin{array}{r}2,614,000 \\
170,000\end{array}$ \\
\hline & 46,00 & 1,000 & Flor & $7,506,000$ & $\begin{array}{l}170,000 \\
304,000\end{array}$ \\
\hline Miss! & 28,0 & 1,500 & ia........ & $10,257,000$ & 348,000 \\
\hline Miss & 22,000 & 3,600 & 1llinois............. & 39,80 & 355,000 \\
\hline & $\begin{array}{r}9,200 \\
108,000\end{array}$ & 800 & Indlana............ & $14,431,000$ & 155,000 \\
\hline & 108,000 & 8,800 & ....... & $4,699,000$ & 44,000 \\
\hline Nor & 51,000 & 2,800 & weky..... & 3,413 & 20,000 \\
\hline 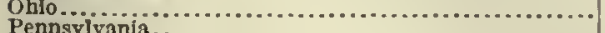 & 9,2 & 9,700 & $\operatorname{lan} 3 . . .$. & 25,55 & 763,000 \\
\hline e & $\begin{array}{r}6,00 \\
325,00\end{array}$ & 500 & & $6.310,000$ & 347.000 \\
\hline 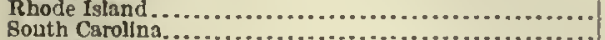 & $\begin{array}{r}325,00 \\
3,90\end{array}$ & 19,000 & land.... & 50,250, & $2,393,000$ \\
\hline $\begin{array}{l}\text { Boul } \\
\text { Ten }\end{array}$ & $\begin{array}{r}3,9 \\
64,0\end{array}$ & 200 & usetts...... & 5,363 & 741,000 \\
\hline$\ldots \ldots \ldots$ & $\begin{array}{l}64,00 \\
31,00\end{array}$ & 2,600 & 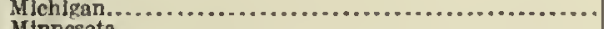 & & 800 \\
\hline $\begin{array}{l}\text { Texas...... } \\
\text { Wisconsin. }\end{array}$ & 31,000 & 1,700 & & $-743,000$ & 8,300 \\
\hline Wisconsin. & 25,000 & 1,000 & 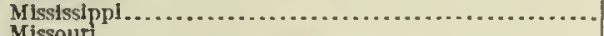 & $7,473,000$ & 295,000 \\
\hline LINES (IIAND, TRAFL, AND SET). & & & 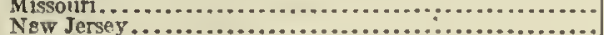 & $\begin{array}{r}170,000 \\
21,049,000\end{array}$ & $\begin{array}{r}1,600 \\
1,703,000\end{array}$ \\
\hline & & & 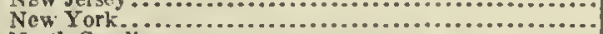 & $27,749,000$ & $2,954,000$ \\
\hline United States.. & $343,960,000$ & $9,360,000$ & n.............................. & $5,907,000$ & 307,000 \\
\hline Alabama. & $3,553,000$ & 120,000 & ' & $\begin{array}{r}1,597,000 \\
58,000\end{array}$ & $\begin{array}{l}7,000 \\
7,200\end{array}$ \\
\hline & & & n....................... & $1,938,0$ & 176,000 \\
\hline & $8,136,000$ & 212,000 & land....... & $8,767,000$ & $1,008,000$ \\
\hline 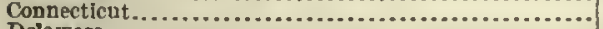 & $1,100,000$ & 41,000 & 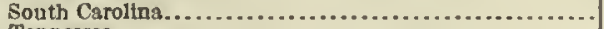 & $11,014,000$ & 143,000 \\
\hline (1) & 206,000 & 6,100 & essee.......... & $2,170,000$ & 14,000 \\
\hline rida..... & $12,747,000$ & 617,000 & is........ & $3,468,000$ & 167,000 \\
\hline$\cdots \cdots \cdots$ & $1,810,000$ & $\mathbf{7 4}, 000$ & Virginis.......... & $45,954,000$ & $2,781,000$ \\
\hline (................................... & $1,242,000$ & 56,000 & (n)....................... & $1,425,000$ & 352,000 \\
\hline 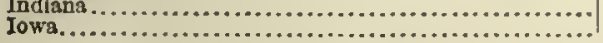 & $\begin{array}{l}132,000 \\
200,000\end{array}$ & $\begin{array}{l}11,000 \\
12,000\end{array}$ & $\begin{array}{l}\text { Wisconsin .............. } \\
\text { All other states...... }\end{array}$ & $\begin{array}{r}1,130,000 \\
35,000\end{array}$ & $\begin{array}{r}12,000 \\
1,400\end{array}$ \\
\hline
\end{tabular}


TABLE 6.-PRODUCTS, BY APPARATUS OF CAPTURE AND BY STATES: 1908-Continued.

\begin{tabular}{|c|c|c|c|c|c|}
\hline \multirow[b]{2}{*}{ EIND OF APPARATUS AND STATE. } & \multicolumn{2}{|c|}{ FISEERY PRODUCTS: 1908.} & \multirow[b]{2}{*}{ KTND OF APPARATUS AND STATE. } & \multicolumn{2}{|c|}{ FISHERY PRODUCTS: 1908.} \\
\hline & $\begin{array}{l}\text { Quantlty } \\
\text { (pounds). }\end{array}$ & Value. & & $\begin{array}{l}\text { Quantity } \\
\text { (pounds). }\end{array}$ & Value. \\
\hline MINOR APPARATUS. & & & MLYOR APPARATUS-continued. & & \\
\hline 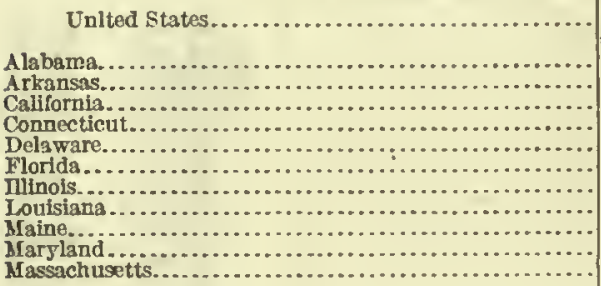 & $\begin{array}{r}9,138,000 \\
17,000 \\
19,000 \\
1,902,000 \\
89,000 \\
2,400,000 \\
1,145,000 \\
25,000 \\
292,000 \\
11,000 \\
74,000 \\
75,000\end{array}$ & $\begin{array}{r}\$ 925,000 \\
2,900 \\
33,000 \\
9,600 \\
3,600 \\
605,000 \\
6,800 \\
30,000 \\
400 \\
2,700 \\
14.000\end{array}$ & 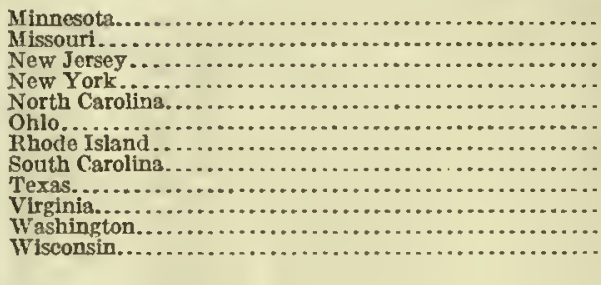 & $\begin{array}{r}86,000 \\
47,000 \\
70,000 \\
400 \\
530,000 \\
3,400 \\
280,000 \\
14,000 \\
20,000 \\
1,617,000 \\
389,000 \\
31,000\end{array}$ & $\begin{array}{r}87,000 \\
7,500 \\
9,900 \\
100 \\
14,000 \\
600 \\
39,000 \\
2,300 \\
2,100 \\
97,000 \\
34,000 \\
2,300\end{array}$ \\
\hline
\end{tabular}




\section{CHAPTER VI.}

\section{PRODUCTS OF THE PRINCIPAL FISHERIES IN DETAIL.}

Nearly seven-eighths of the value of fishery products of the United States in 1908 was represented by 30 kinds of products. Detailed statistics for these classes, and also for a few of the minor products of general interest, are presented in this eliapter. The products here considered are the following:

$\begin{array}{lll}\text { Alewives. } & \text { Herring. } & \text { Salmon. } \\ \text { Bluefish. } & \text { Lake herring. } & \text { Shad. } \\ \text { Buffalo fish. } & \text { Lake trout. } & \text { Shrimp and prawn. } \\ \text { Carp. } & \text { Lobster. } & \text { Skins. } \\ \text { Catfishes. } & \text { Lobster, spiny. } & \text { Snappers. } \\ \text { Clams. } & \text { Mackerel. } & \text { Sponges. } \\ \text { Cod. } & \text { Menhaden. } & \text { Squeteague. } \\ \text { Crabs. } & \text { Mullets. } & \text { Sturgeons. } \\ \text { Flounders. } & \text { Mussels. } & \text { Whale products. } \\ \text { Haddock. } & \text { Oysters. } & \text { Whitefish. } \\ \text { Hake. } & \text { Pike perches. } & \\ \text { Halibut. } & \text { Pollack. } & \end{array}$

Alewives (Pomolobus pseudoharengus and $P$. æstivalis).-These two species of fish are generally known indiscriminately as alewives, and are found in waters adjacent to the Atlantic Ocean. P.pseudoharengus is never found south of the Neuse River, in North Carolina. It is known along the Potomac as "branch herring," on Albemarle Sound as the "big-eyed herring" and the "wall-eyed herring," in New England as "alewife," and on the Connecticut River as "ellwife" and "ellwhop." It appears in the rivers three or four weeks earlier than the "glut herring" and the shad. P. xstivalis is found from the Carolinas to the coast of Maine. It is known in Chesapeake Bay and Albemarle Sound as "glut herring," in the Ogeechee River as "English herring," in the St. Jolnns River as "herring," and in Massachusetts and during the later runs in the Rappahannock as the "blueback." It is also known as "blackbelly," "sawbelly," and "kyack." This species is less abundant and much less valuable as a food fish than $P$. pseudoharengus. Both species average about a half pound in weight and from 8 to 10 inches in length. They are caught in nets, seines, weirs, ete., and besides being of great importance as food fish, are also used for bait. The name "alewife" is applied to the menhaden in Delaware, Maryland, and Virginia.

The value of the alewife catch in 1908 was $\$ 589,000$, and constituted 1 per cent of the total value of the fishery products of the United States. Over threefourths of this amount represented the value of fish disposed of fresh and 22 per cent the value of those which were salted, while the remainder was the value of a few which were smoked. Although alewives were taken in every state on the Atlantic coast except South Carolina, three states-Virginia, Maryland, and North Carolina-reported 80 per cent of the value and 86 per cent of the weight of the total alewife catch. The following tabular statement gives the statistics of the catch, by states:

\begin{tabular}{|c|c|c|c|c|}
\hline \multirow{3}{*}{ STATE. } & \multicolumn{4}{|c|}{ ALEFIFE PRODUCT: 1908.} \\
\hline & \multicolumn{2}{|c|}{ - Quantity. } & \multicolumn{2}{|c|}{ Value. } \\
\hline & Pounds. & $\begin{array}{l}\text { Per cent } \\
\text { distribu- } \\
\text { tion. }\end{array}$ & Amount. & $\begin{array}{l}\text { Per cent } \\
\text { distribu- } \\
\text { tion. }\end{array}$ \\
\hline Uंnited States..... & $89,978,000$ & 100 & 8589,000 & 100 \\
\hline 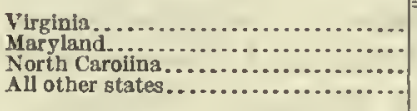 & $\begin{array}{l}37,885,000 \\
28,805,000 \\
10,928,000 \\
12,361,000\end{array}$ & \begin{tabular}{l|}
42 \\
32 \\
12 \\
14
\end{tabular} & $\begin{array}{l}171,000 \\
157,000 \\
140,000 \\
121,000\end{array}$ & $\begin{array}{l}29 \\
27 \\
24 \\
21\end{array}$ \\
\hline
\end{tabular}

In the following tabular statement are given comparative statistics of the catch of alewives for a series of years. Between 1892 and 1908 no figures for the entire product in any one year are available, but the returns for the New England states in 1898 have been combined with those for the Middle Atlantic and the South Atlantic states in 1897, while the results from the canvass of the New England states for 1905, the Middle Atlantic states for 1904, and the South Atlantic states for 1902 , have been similarly combined. This course has been followed in presenting the figures for other classes of products when returns are not available for the catch of all districts in any one year.

\begin{tabular}{|c|c|c|}
\hline \multirow[b]{2}{*}{ YEAR. } & \multicolumn{2}{|c|}{ ALEWLE PRODUCT. } \\
\hline & $\begin{array}{l}\text { Quantity } \\
\text { (pounds). }\end{array}$ & Value. \\
\hline 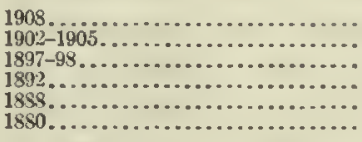 & $\begin{array}{l}89,978,000 \\
52,062,000 \\
59,027,000 \\
59,176,000 \\
56,158,000 \\
45,684,000\end{array}$ & $\begin{array}{r}5589,000 \\
474,000 \\
435,000 \\
555,000 \\
501,000 \\
527,000\end{array}$ \\
\hline
\end{tabular}

A considerable increase is apparent in the quentity of the product in 1908, as compared with that of previous years, At the same time there has been an increase in value, although this has not been commensurate with the increase in quantity. 
The eateh taken by the principal kinds of apparatus of capture was as follows:

\begin{tabular}{|c|c|c|c|c|}
\hline \multirow{3}{*}{ EWTD OY APPARATUS. } & \multicolumn{4}{|c|}{ ALSWTFE PRODUCT: 1908.} \\
\hline & \multicolumn{2}{|c|}{ Quantity. } & \multicolumn{2}{|c|}{ Value. } \\
\hline & Pounds. & $\begin{array}{l}\text { Per eent } \\
\text { distribu- } \\
\text { tion. }\end{array}$ & Amount. & $\begin{array}{l}\text { Per cent } \\
\text { distribu- } \\
\text { tlon. }\end{array}$ \\
\hline Total.............................. & $89,978,000$ & 100 & $\$ 589,000$ & 100 \\
\hline 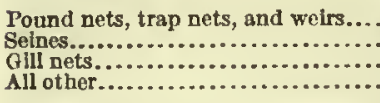 & $\begin{array}{r}66,369,000 \\
18,928,000 \\
2,211,000 \\
2,469,000\end{array}$ & $\begin{array}{r}74 \\
21 \\
2 \\
3\end{array}$ & $\begin{array}{r}372,000 \\
166,000 \\
20,000 \\
31,000\end{array}$ & $\begin{array}{r}63 \\
28 \\
3 \\
5\end{array}$ \\
\hline
\end{tabular}

Of the total alewife eateh, 74 per cent, or nearly three-fourths, representing 63 per cent, or a little less than two-thirds of the total value, was taken by pound nets, trap nets, and weirs, and 21 per cent, representing 28 per cent of the total value, by seines. Thus 95 per cent of the eatch, representing 91 per cent of the value, was taken by these two classes of apparatus.

Bluefish (Pomatomus saltatrix).-This fish is found on the Atlantic and the Gulf coasts. On the coast of the New England and Middle states it is generally called "bluefish;" in Rhode Island, "horse mackerel;" south of Cape Hatteras, "skip jack;" in North Carolina, Virginia, and Maryland, "tailor" and "greenfish;" and on the Gulf of Mexico, "bluefish." Young bluefish are called "snapping mackerel," "snappers," and "salt-water tailors" in Virginia and Maryland; "blue snappers" about New Bedford; and "skip mackerel" about New York. The bluefish varies in weight from 1 to 20 pounds, according to the season and locality, and large numbers are caught during the summer months with nets, traps, seines, and hand lines.

The name "bluefish" is also improperly applied to the squeteague from southern New Jersey to Virginia, to the black sea bass at Newport and New Bedford, to the "greenfish" on the California coast south of Monterey, and to the "bonito" in the markets.

The value of the bluefish catch in 1908 was $\$ 506,000$, or slightly less than 1 per cent of the value of all fishery products. This fish was taken in every coast state from Rhode Island to Texas, but only a small quantity was taken in the Gulf of Mexico. Of the total value of the catch, over one-half was reported by the fisheries of New York. Exeept for insignificant amounts salted in Florida and North Carolina, the catch was sold fresh. The following tabular statement gives the statisties of the bluefish catch for the leading states reporting this species:

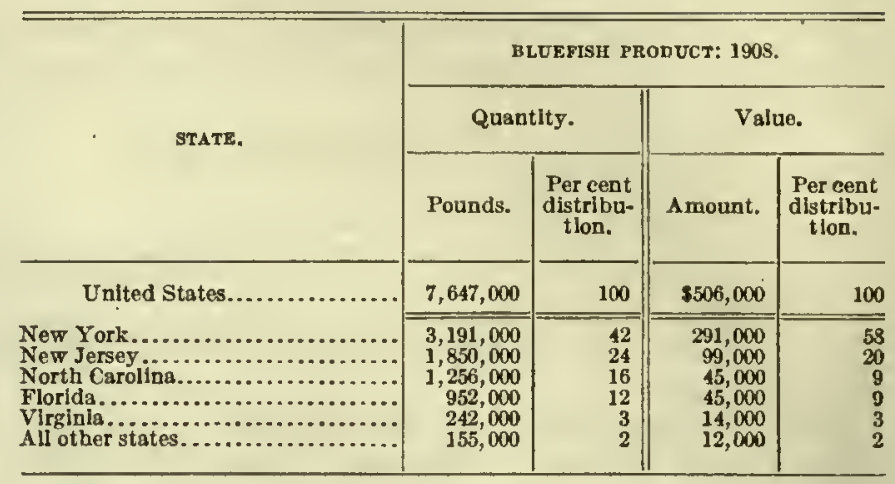

Statistics of the produet of the bluefish fisheries for previous years for which data are available are given in the following statement. The figures for the periods 1890-1892, 1897-98, and 1902-1904 were cbtained in the manner explained on page 47 .

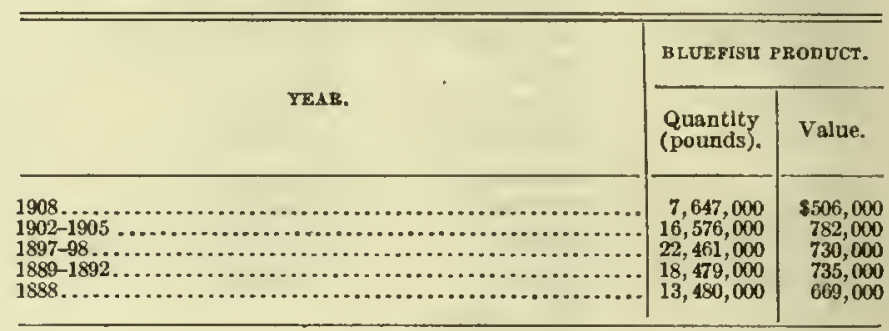

The quantity and value of the eateh of 1908 were the smallest on record. 'The distribution of the bluefish catch by apparatus of eapture was as follows:

\begin{tabular}{|c|c|c|c|c|}
\hline \multirow{3}{*}{ KIND OF APPARATUS. } & \multicolumn{4}{|c|}{ BLUEFISL PRODUCT: 1908.} \\
\hline & \multicolumn{2}{|c|}{ Quantity. } & \multicolumn{2}{|c|}{ Value. } \\
\hline & Pounds. & $\begin{array}{l}\text { Per cent } \\
\text { distribu- } \\
\text { tion. }\end{array}$ & Amount. & $\begin{array}{l}\text { Per cent } \\
\text { distribu- } \\
\text { tlon. }\end{array}$ \\
\hline Total............. & $7,647,000$ & 100 & $\$ 506,000$ & 100 \\
\hline 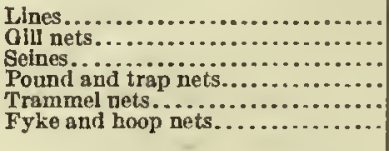 & $\begin{array}{r}3,781,000 \\
2,029,000 \\
1,221,000 \\
534,000 \\
61,000 \\
21,000\end{array}$ & $\begin{array}{r}49 \\
27 \\
16 \\
7 \\
1\end{array}$ & $\begin{array}{r}307,000 \\
109,000 \\
54,000 \\
33,000 \\
2,700 \\
1,100\end{array}$ & $\begin{array}{r}61 \\
22 \\
11 \\
7 \\
1\end{array}$ \\
\hline
\end{tabular}

Buffalo fish.-Under this general name are included three species, red or big-mouthed buffalo (Ictiobus cyprinella), black or mongrel buffalo (I. urus), and small-mouthed or white buffalo (I. bubalus). These fresh-water suckers, to which the name "buffalo carp" is sometimes erroneously applied, are found in the waters of the Mississippi Valley. They frequently weigh from 30 to 40 pounds and are eaught with nets and hand lines. The value of the eateh in 1908 was $\$ 498,000$, or less than 1 per cent of the total value of fishery products for the United States. In the fisher- 
ies of the Mississippi River and its tributaries, however, this fish ranked second in importance, contributing 15 per cent of the total value of the fishery products of that district. Ninety-one per cent of the total value of the buffalo-fish product represented that caught in the Mississippi River and its tributaries. The following tabular statement shows the catcl, by geographic divisions:

\begin{tabular}{|c|c|c|c|c|}
\hline \multirow{3}{*}{ Drvision. } & \multicolumn{4}{|c|}{ BUFTALO-FLSH PRODUCT: 1908.} \\
\hline & \multicolumn{2}{|c|}{ Quantity. } & \multicolumn{2}{|c|}{ Value. } \\
\hline & Pounds. & $\begin{array}{l}\text { Per cent } \\
\text { distrlbu- } \\
\text { tlon. }\end{array}$ & Amount. & $\begin{array}{l}\text { Per cent } \\
\text { distribu- } \\
\text { tlon. }\end{array}$ \\
\hline United States... & $16,729,000$ & 100 & $\$ 498,000$ & 100 \\
\hline 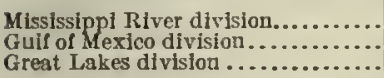 & $\begin{array}{r}15,040,000 \\
1,683,000 \\
6,200\end{array}$ & (1) ${ }^{90}$ & $\begin{array}{r}455,000 \\
43,000 \\
200\end{array}$ & (i) 9 \\
\hline
\end{tabular}

L Less than 1 per cent.

Ninetcen states reported a catch of buffalo fish. Statistics concerning the product of the leading states are given in the following tabular statement:

\begin{tabular}{|c|c|c|c|c|}
\hline \multirow{3}{*}{ STATE. } & \multicolumn{4}{|c|}{ - BUFFALO-FISII PRODUCT: 1908.} \\
\hline & \multicolumn{2}{|c|}{ Quantity. } & \multicolumn{2}{|c|}{ Valite. } \\
\hline & Pounds. & $\begin{array}{l}\text { Per cent } \\
\text { distribu- } \\
\text { tion. }\end{array}$ & Amount. & $\begin{array}{l}\text { Per cent } \\
\text { distribu- } \\
\text { tlon. }\end{array}$ \\
\hline United States.. & $16,729,000$ & 100 & $\$ 498,000$ & 100 \\
\hline 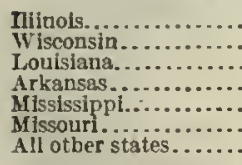 & $\begin{array}{r}3,042,000 \\
3,178,000 \\
2,626,000 \\
2,051,000 \\
1,604,000 \\
993,000 \\
3,175,000\end{array}$ & $\begin{array}{r}18 \\
19 \\
16 \\
12 \\
10 \\
6 \\
19\end{array}$ & $\begin{array}{r}117,000 \\
103,000 \\
50,000 \\
43,000 \\
34,000 \\
30,000 \\
121,000\end{array}$ & $\begin{array}{r}23 \\
21 \\
10 \\
9 \\
7 \\
6 \\
24\end{array}$ \\
\hline
\end{tabular}

The yield in 1908 was the most valuable on record, and, although smaller in quantity than those of some earlier years, it was larger than in 1903, a fact which indicates a recovery from the downward movement of the previous decade. Since the Mississippi River product represented $91 \mathrm{per}$ cent of the total value in 1908 and has always contributed at least this proportion, the catch of buffalo fish from that division affords a good basis of comparison between 1908 and previous years. Tho statistics concerning the catch of buffalo fish from the Mississippi River and its tributaries in $1894,1899,1903$, and 1908 are therefore given in the following tabular statement:

\begin{tabular}{|c|c|c|}
\hline YEAR. & \multicolumn{2}{|c|}{$\begin{array}{l}\text { BEFFALO-FISA PROD- } \\
\text { UCT OF THE MISSIS- } \\
\text { SIPPI RIVER DIVI- } \\
\text { SION. }\end{array}$} \\
\hline & $\begin{array}{l}\text { Quantity } \\
\text { (pounds). }\end{array}$ & Vaiue. \\
\hline $\begin{array}{l}1909 \ldots \ldots \ldots \ldots \\
1903 \ldots \ldots \ldots \ldots \\
1899 \ldots \ldots \ldots \ldots\end{array}$ & $\begin{array}{l}15,040,000 \\
11,492,000 \\
14,216,000 \\
17,584,000\end{array}$ & $\begin{array}{r}8455,000 \\
312,000 \\
350,000 \\
419,000\end{array}$ \\
\hline
\end{tabular}

During the entire period for which statistics are available the average price has been slowly but steadily increasing.

The following tabular statement gives the quantity and value of buffalo fish taken by the different kinds of apparatus:

\begin{tabular}{|c|c|c|c|c|}
\hline \multirow{3}{*}{ KIND OF APPARATUS. } & \multicolumn{4}{|c|}{ BUFPALO-FISII PRODUCT: 1908.} \\
\hline & \multicolumn{2}{|c|}{ Quantity. } & \multicolumn{2}{|c|}{ Vaiue. } \\
\hline & Pounds. & $\begin{array}{c}\text { Per cent } \\
\text { distribu- } \\
\text { tion. }\end{array}$ & Amount. & $\begin{array}{l}\text { Per cent } \\
\text { distribu- } \\
\text { tjon. }\end{array}$ \\
\hline Total.............. & $16,729,000$ & 100 & $\$ 498,000$ & 100 \\
\hline 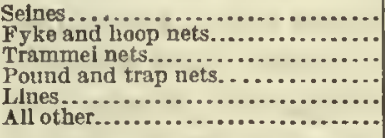 & $\begin{array}{r}7,138,000 \\
6,502,000 \\
1,260,000 \\
828,000 \\
812,000 \\
189,000\end{array}$ & $\begin{array}{r}43 \\
39 \\
8 \\
5 \\
5 \\
1\end{array}$ & $\begin{array}{r}218,000 \\
179,000 \\
41,000 \\
29,000 \\
23,000 \\
7,400\end{array}$ & $\begin{array}{r}44 \\
36 \\
8 \\
6 \\
5 \\
1\end{array}$ \\
\hline
\end{tabular}

Carp (Cyprinus carpio).-This fish, known as "German carp," is a fresh-water food fish of great interest to fish-culturists, and is found in ponds and streams in nearly every state of the union. As a result of domestication several varieties have arisen, of which the principal ones are the "scale carp," heavily scaled; the "mirror carp," with a few series of very large scales; and the "leather carp," which is scaleless. The size of the carp varies with the temperature and clearness of the water, the kind of bottom, the abundance and nature of the food supply, and in general with the conditions under which it lives. These fish live to a great age, and sometimes attain a weight of more than 40 pounds. The carp naturally thrives best in lakes, ponds, and sluggish streams, seeking quiet or stagnant waters. It spawns about June. It feeds largely on vegetable matter, insects and their larve, found on aquatic vegetation, forming its principal animal food. It will, however, eat practically anything it can get into its mouth, rooting about in the mud much in the same way as a pig; and it also, at times, feeds while swimming near the surface, eating insects and their larvæ and other floating substances. The carp is said to eat neither fish nor their spawn, but, on the other hand, young carp are preyed upon by bass and other predaceous fishes.

Certain species of carp, familiarly known as minnows, chubs, shiners, and dace, also are found in the fresh waters of tho United States, but the German carp (Cyprinus carpio) is not indigenous to this country. Originally a native of Central Asia, the carp was gradually introduced into Europe, and early in the thirteenth century was brought into Germany, whero it became a favorito food fish. It was not introduced into the United States with a view to propagation until 1877, when Mr. Hassel, of the United States Fish Commission, brought over a number of carp froin Germany for tho purpose of experimentation. Prior to that timo private individuals had brought specimens into the United States from Germany, without attracting any general attention. 
In the fall of 1879 a systematic distribution of young carp was begun, which was continued up to 1896. During that time nearly every state in the Union tried to cultivate this fish, and the attempt met with success in many states. The purpose of the Fish Commission, more especially, was to distribute this fish, which was believed to be a good food fish and which was hardy, casily and cheaply raised, and of great fecundity, in sections where conditions were not conducive to the growth of fish, the expectation being that natural ponds not suitable for other fish would be used or that artificial ponds would be constructed for its propagation. Although originally introduced therefore into private or restricted streams and waters, it was not long before the public waters began to be stocked-in some cases accidentally, by the overflowing of a carp pond or stream, and in other cases through the intentional introduction of the species, as in certain rivers in Illinois and Ohio.

The German carp product in 1908 amounted to $42,763,000$ pounds, valued at $\$ 1,135,000$, and constituted 2 per cent of the total quantity and of the total value of all fishery products. Of 38 states having fisheries of a commercial nature in 1908, 31 reported German carp. The following tabular statement gives the statistics of the carp product, by states ranked according to the value of the product, together with the per cent distribution of both the quantity and the value of the catch:

\begin{tabular}{|c|c|c|c|c|}
\hline \multirow{3}{*}{ BTATR. } & \multicolumn{4}{|c|}{ GERMAN-CARP PRODUCT: 1908.} \\
\hline & \multicolumn{2}{|c|}{ Quantity. } & \multicolumn{2}{|c|}{ Value. } \\
\hline & Pounds. & $\begin{array}{l}\text { Per cent } \\
\text { distribu- } \\
\text { tlon. }\end{array}$ & Amount. & $\begin{array}{l}\text { Per cent } \\
\text { distribu- } \\
\text { tion. }\end{array}$ \\
\hline United States.................. & $42,763,000$ & 100 & $\$ 1,135,000$ & 100 \\
\hline 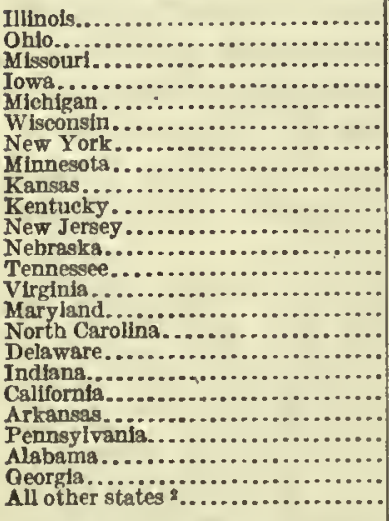 & $\begin{array}{r}21,642,000 \\
7,158,000 \\
2,432,000 \\
2,048,000 \\
2,459,000 \\
2,247,000 \\
406,000 \\
1,132,000 \\
304,000 \\
449,000 \\
220,000 \\
254,000 \\
237,000 \\
286,000 \\
167,000 \\
228,000 \\
133,000 \\
128,000 \\
427,000 \\
175,000 \\
71,000 \\
22,000 \\
38,000 \\
100,000\end{array}$ & \begin{tabular}{rr|}
51 \\
17 \\
6 \\
5 \\
6 \\
5 \\
1 \\
3 \\
1 \\
1 \\
1 \\
1 \\
1 \\
1 \\
(1) \\
1 \\
(1) \\
(1) \\
(1) \\
(1) \\
(1) \\
(1) \\
(1)
\end{tabular} & $\begin{array}{r}574,000 \\
129,000 \\
80,000 \\
62,000 \\
55,000 \\
52,000 \\
31,000 \\
26,000 \\
19,000 \\
18,000 \\
16,000 \\
12,000 \\
8,200 \\
8,000 \\
7,100 \\
7,000 \\
6,700 \\
6,000 \\
4,300 \\
4,100 \\
2,200 \\
1,500 \\
1,200 \\
3,600\end{array}$ & 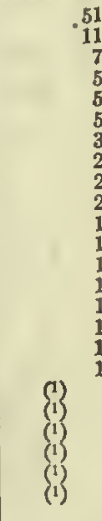 \\
\hline
\end{tabular}

1 Less than 1 per cent.
2 Includes Connectlcut, Florida, Louistana, Mississippi, Oregon, South Dakota, 'Includes Connectlcut,
Texas, and West Virginla.

The carp product of Illinois, most of which was from the Illinois River, exceeded that of all other states combined. Ohio ranked second, with a product of $7,158,000$ pounds, while Michigan, Missouri, Wisconsin, Iowa, and Minnesota each reported over $1,000,000$ pounds. The total German-carp product of these seven states amounted to nearly 20,000 tons, valued at $\$ 979,000$, and represented 91 per cent of the quantity and 86 per cent of the value of the Germancarp product of the United States.

The distribution of the German-carp product in 1908 , by groups of states, was as follows:

\begin{tabular}{|c|c|c|c|c|}
\hline \multirow{3}{*}{ STATE GROUP. } & \multicolumn{4}{|c|}{ GERMAN-CARP PRODUCT: 1908.} \\
\hline & \multicolumn{2}{|c|}{ Quantity. } & \multicolumn{2}{|c|}{ Vatue. } \\
\hline & Pounds. & $\begin{array}{l}\text { Per cent } \\
\text { distribu- } \\
\text { tion. }\end{array}$ & Amount. & $\begin{array}{l}\text { Per cent } \\
\text { distrlbn- } \\
\text { tion. }\end{array}$ \\
\hline United States................. & $42,763,000$ & 100 & $\$ 1,135,000$ & 100 \\
\hline 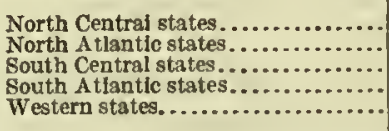 & $\begin{array}{r}39,818,000 \\
704,000 \\
924,000 \\
861,000 \\
457,000\end{array}$ & $\begin{array}{r}93 \\
2 \\
2 \\
2 \\
1\end{array}$ & $\begin{array}{r}1,017,000 \\
50,000 \\
33,000 \\
30,000 \\
4,600\end{array}$ & $\begin{array}{r}90 \\
4 \\
3 \\
3 \\
3\end{array}$ \\
\hline
\end{tabular}

1Less than 1 per cent.

As early as 1883 carp were taken in the waters of the Mississippi River and its tributaries and in the Great Lakes, but they were not handled by the fish dealers until some years later and had no extensive market until about 1895. In the report of the United States Fish Commission on the Great Lakes fisheries for 1892 , carp is not mentioned as a distinct species and, if caught and sold commercially at this time, was probably included under "Other fish." For 1893-94, however, the Bureau of Fislieries reported a considerable amount of this fish, and succeeding reports show a steadily increasing product, as the following comparative summary indicates:

\begin{tabular}{|c|c|c|}
\hline \multirow{2}{*}{ YEAR. } & \multicolumn{2}{|c|}{$\begin{array}{l}\text { GERMAN-CARP } \\
\text { PROdUCT. }\end{array}$} \\
\hline & $\begin{array}{l}\text { Quantity } \\
\text { (pounds). }\end{array}$ & Value. \\
\hline 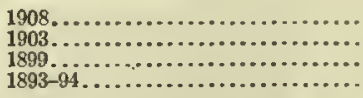 & $\begin{array}{r}42,763,000 \\
16,508,000 \\
15,543,000 \\
2,108,000\end{array}$ & $\begin{array}{r}81,135,000 \\
350,000 \\
342,000 \\
55,000\end{array}$ \\
\hline
\end{tabular}

Although this product is caught to some extent throughout the year, the largest part of the fishing is done in the spring and summer. A variety of apparatus is used in taking carp, but the bulk of the catch is made with seines, fyke and hoop nets, and trammel nets. The statistics of the catch by the various forms of apparatus are given in the following tabular statement: 


\begin{tabular}{|c|c|c|c|c|}
\hline \multirow{3}{*}{ KIND OF APPARATUS. } & \multicolumn{4}{|c|}{ OERMAN-CARP PRODUCT: 1908.} \\
\hline & \multicolumn{2}{|c|}{ Quantity. } & \multicolumn{2}{|c|}{ Vaine. } \\
\hline & Pounds. & $\begin{array}{l}\text { Per cent } \\
\text { distribu- } \\
\text { tlon. }\end{array}$ & Amount. & $\begin{array}{l}\text { Fer cent } \\
\text { distribu- } \\
\text { tion. }\end{array}$ \\
\hline Total........................ & $42,763,000$ & 100 & $\$ 1,135,000$ & 100 \\
\hline 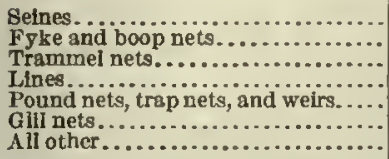 & $\begin{array}{r}24,162,000 \\
10,067,000 \\
5,154,000 \\
1,062,000 \\
1,224,000 \\
894,000 \\
199,000\end{array}$ & $\begin{array}{r}37 \\
24 \\
12 \\
2 \\
3 \\
2 \\
2\end{array}$ & $\begin{array}{r}611,000 \\
286,000 \\
141,000 \\
35,000 \\
28,000 \\
25,000 \\
8,500\end{array}$ & $\begin{array}{r}54 \\
25 \\
12 \\
3 \\
2 \\
2 \\
1\end{array}$ \\
\hline
\end{tabular}

1 Less than 1 per cent.

Catfishes (Siluridæx).-The American species include the sea catfishes of the Atlantic coast, the channel cats of all the rivers east of the Rocky Mountains, the horned pout, which is widely distributed through the brooks and ponds of the states, and the diminutive mad-toms. The different varieties are distinguished by the common names of "channel cat," "blue cat," "Mississippi cat," "mud cat," "flannel-mouth," "llorned pout," "bullhead," "minister," "goujon," "bashaw," "gaff-topsail," etc. They vary in length from 1 to 5 feet and in weight from 2 to 150 pounds, are caught by means of nets, traps, hand lines, and by jugging, and are used extensively for food.

The value of the catch in 1908 was $\$ 785,000$, or more than 1 per cent of the total value of the fishery products. Catfish are taken in all waters of the United States, but in 1908 nearly one-half of the total product came from the Mississippi River and its trib- utaries. In these waters catfish ranked third in value among fishery products, contributing 13 per cent of their total value. Of the 38 states included in the canvass of 1908 , all, with the exception of four of the New England states, reported this fish. The catches reported from Louisiana and Illinois greatly exceeded those from any of the other states, in both quantity and value, but the product was otherwise distributed with unusual equality. The weight and value of the catfish taken in the leading states and the per cent distribution of the value are given in the following tabular statement:

\begin{tabular}{|c|c|c|c|c|}
\hline \multirow{3}{*}{ STATE. } & \multicolumn{4}{|c|}{ CATFISE PRODUCT: 1908.} \\
\hline & \multicolumn{2}{|c|}{ Quantity. } & \multicolumn{2}{|c|}{ Value. } \\
\hline & Pounds. & $\begin{array}{l}\text { Per cent } \\
\text { distrl- } \\
\text { bution. }\end{array}$ & Amount. & $\begin{array}{l}\text { Per cent } \\
\text { distri- } \\
\text { bution. }\end{array}$ \\
\hline United States................. & $17,817,000$ & 100 & 3785,000 & 100 \\
\hline 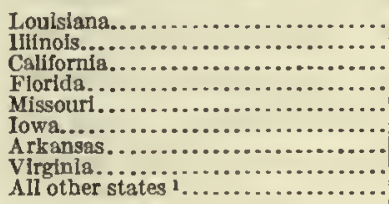 & $\begin{array}{r}4,405,000 \\
2,044,000 \\
1,069,000 \\
1,481,000 \\
1,166,000 \\
418,000 \\
895,000 \\
738,000 \\
5,602,000\end{array}$ & $\begin{array}{r}25 \\
11 \\
6 \\
8 \\
7 \\
2 \\
5 \\
4 \\
31\end{array}$ & $\begin{array}{r}143,000 \\
96,000 \\
56,000 \\
54,000 \\
51,000 \\
33,000 \\
33,000 \\
31,000 \\
288,000\end{array}$ & $\begin{array}{r}18 \\
12 \\
7 \\
7 \\
6 \\
4 \\
4 \\
4 \\
37\end{array}$ \\
\hline
\end{tabular}

1 Includes 20 states.

With the exception of the period 1889-1894, the product in 1908 was larger than that of any other year for which statistics are available, as shown by the following comparative statement giving the quantity and value for 1908 and previous canvasses:

\begin{tabular}{|c|c|c|c|c|c|c|c|c|}
\hline \multirow{3}{*}{ nIVIsION. } & \multicolumn{8}{|c|}{ CATFISH PRODUCT. } \\
\hline & \multicolumn{2}{|c|}{1908} & \multicolumn{2}{|c|}{$1902-1905$} & \multicolumn{2}{|c|}{$1897-1899$} & \multicolumn{2}{|c|}{$1889-1894$} \\
\hline & $\begin{array}{l}\text { Quantity } \\
\text { (pounds). }\end{array}$ & Value. & $\begin{array}{l}\text { Quantity } \\
\text { (pounds). }\end{array}$ & Value. & $\begin{array}{l}\text { Quantity } \\
\text { (pounds). }\end{array}$ & Value. & $\begin{array}{l}\text { Quantity } \\
\text { (pounds). }\end{array}$ & Value. \\
\hline United States.... & $17,817,000$ & $\$ 785,000$ & $12,120,000$ & $\$ 501,000$ & $14,953,000$ & 8554,000 & $22,673,000$ & $\$ 767,000$ \\
\hline 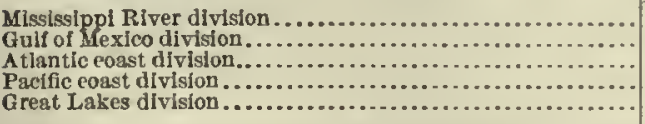 & $\begin{array}{r}8,073,000 \\
3,954,000 \\
3,528,000 \\
1,270,000 \\
903,000\end{array}$ & $\begin{array}{r}395,000 \\
143,000 \\
132,000 \\
65,000 \\
50,000\end{array}$ & $\begin{array}{r}5,192,000 \\
2,415,000 \\
2,838,000 \\
923,000 \\
752,000\end{array}$ & $\begin{array}{r}277,000 \\
73,000 \\
95,000 \\
27,000 \\
28,000\end{array}$ & $\begin{array}{r}7,648,000 \\
2,449,000 \\
2,047,000 \\
626,000 \\
2,183,000\end{array}$ & $\begin{array}{r}340,000 \\
58,000 \\
71,000 \\
16,000 \\
69,000\end{array}$ & $\begin{array}{r}14,727,000 \\
2,850,000 \\
3,166,000 \\
(1) \\
1,930,000\end{array}$ & $\begin{array}{r}533,000 \\
60,000 \\
113,000 \\
(1) \\
61,000\end{array}$ \\
\hline
\end{tabular}

1 None reported.

The value of the product of the Mississippi River and its tributaries constituted moro than 50 per cent of the value of the total catch of this fish in 1908, and the product of the Gulf of Mexico ranked next, with a value equal to 18 per cent of the total. The Atlantic coast and the Pacific coast divisions contributed, respectively, 17 per cent and 8 per cent of the total value, while the catch of the Great Lakes division represented only 6 per cent.

The following tabular statement presents the statistics of the catch, by the leading apparatus of capture:

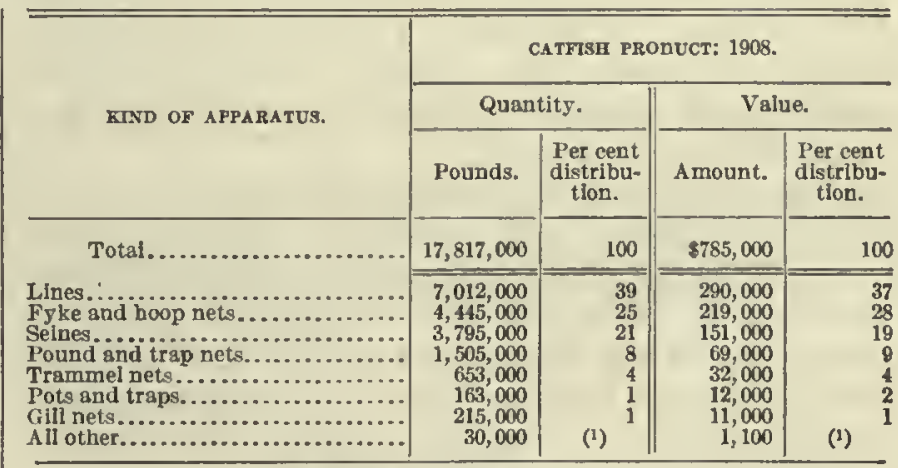

1 Less tban 1 per cent. 
Clams.- This term includes the hard clam, quahaug, or round clam (Venus mercenaria); soft or long clam (Mya arenaria); razor clam, or razor fish (Ensis americana); surf, sea, or lien clam (S pisula solidissima); and various' other species.

Clams are bivalvo mollusks largely used for food and bait, and are found on all our coasts. Various species, most of which are edible, are known as "soft clain," "long clam," "butterfish," "mananose," "nanninose," "squirt clam," "qualıaug," "hard clam," "surf clam," "sea clam," "hen clam," "beach clam," "dipper," "skimmer," "painted clam," "cuneata clam," "round clam," "little-neck clam," "gapers," "tellens," "flat clam," "razor clam," "razor fish," "knife-handle," and "bullnose." For the purposes of of the census, however, all species are classified as either hard, soft, razor, or surf clams.

The clam product of the United States in 1908 ranked sixth in value, amounting to $1,900,000$ bushels, valued at $\$ 1,917,000$. While the quantity of the hardshell variety but little exceeded that of the soft-shell, the value of the former was nearly two and one-half times that of the latter. The statistics of the clam product reported, by class of product, are given in the following tabular statement:

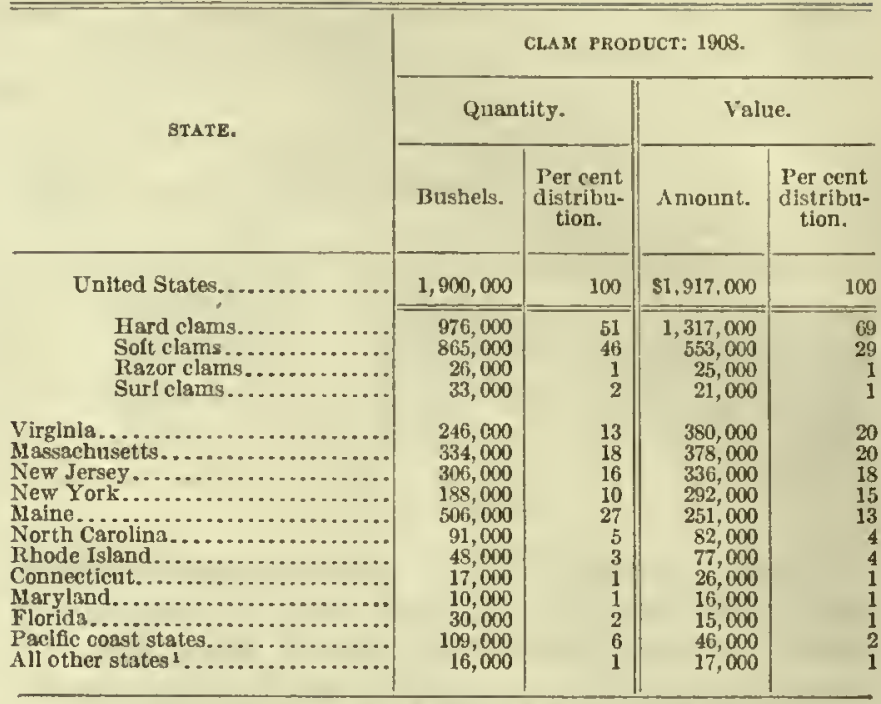

I Includes Delaware, Georgia, Louisiana, and Soth Carolina.

Hard clams were reported from all the Pacific coast states, from Florida and Louisiana on the Gulf of Mexico, and from all the Atlantic coast states except Maine and New Hampshire. The entire soft-clam product, with the exception of 1 per cent of the total, taken in California and Oregon, was from the North $\mathrm{At}$ lantic coast, none being reported south of New Jersey.

\begin{tabular}{|c|c|c|c|c|c|c|c|c|c|c|}
\hline \multirow{3}{*}{ STATE. } & \multicolumn{10}{|c|}{ CLAM PRODUCT: 1908.} \\
\hline & \multicolumn{2}{|c|}{ Total. } & \multicolumn{2}{|c|}{ II ard clams. } & \multicolumn{2}{|c|}{ Soft clsms. } & \multicolumn{2}{|c|}{ Razor clams. } & \multicolumn{2}{|c|}{ Surf clams. } \\
\hline & $\begin{array}{l}\text { Quantity } \\
\text { (bushels). }\end{array}$ & Value. & $\begin{array}{l}\text { Quantity } \\
\text { (bushels). }\end{array}$ & V alue. & $\begin{array}{l}\text { Quantity } \\
\text { (bushels). }\end{array}$ & Value. & $\begin{array}{l}\text { Quantity } \\
\text { (bushels). }\end{array}$ & Value. & $\begin{array}{l}\text { Quantity } \\
\text { (bushels). }\end{array}$ & Value. \\
\hline United States..... & $1,900,000$ & $\$ 1,917,000$ & 976,000 & $\$ 1,317,000$ & 865,000 & $\$ 553,000$ & 26,000 & $\$ 25,000$ & 33,000 & $\$ 21,000$ \\
\hline 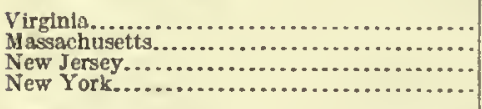 & $\begin{array}{l}246,000 \\
334,000 \\
306,000 \\
183,000\end{array}$ & $\begin{array}{l}380,000 \\
378,000 \\
336,000 \\
292,000\end{array}$ & $\begin{array}{l}246,000 \\
140,000 \\
273,000 \\
101,000\end{array}$ & $\begin{array}{l}380,000 \\
189,000 \\
318,000 \\
223,000\end{array}$ & $\begin{array}{r}192,000 \\
20,000 \\
66,000\end{array}$ & $\begin{array}{r}186,000 \\
11,000 \\
54,000\end{array}$ & $\begin{array}{r}2,400 \\
\end{array}$ & $\begin{array}{l}3,600 \\
0\end{array}$ & 12,000 & $\begin{array}{r}7,000 \\
14,000\end{array}$ \\
\hline 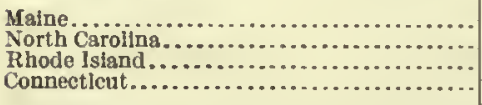 & $\begin{array}{r}506,000 \\
91,000 \\
48,000 \\
17,000\end{array}$ & $\begin{array}{r}251,000 \\
82,000 \\
77,000 \\
26,000\end{array}$ & $\begin{array}{r}9 i, 000 \\
20,000 \\
13,000\end{array}$ & $\begin{array}{l}82,000 \\
39,000 \\
20,000\end{array}$ & $\begin{array}{r}506,000 \\
28,000 \\
4,200\end{array}$ & $\begin{array}{r}251,000 \\
38,000 \\
5,500\end{array}$ & & & & (n.... \\
\hline 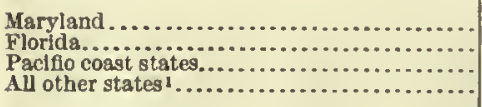 & $\begin{array}{r}10,000 \\
30,000 \\
109,000 \\
16,000\end{array}$ & $\begin{array}{l}16,000 \\
15,000 \\
46,000 \\
17,000\end{array}$ & $\begin{array}{l}10,000 \\
30,000 \\
36,000 \\
16,000\end{array}$ & $\begin{array}{l}16,000 \\
15,000 \\
17,000 \\
17,000\end{array}$ & 50,000 & 7,300 & 23,000 & 22,000 & & \\
\hline
\end{tabular}

1 Ineludes Delaware, Georgia, Loulsiana, and South Carolina.

Razor clams were reported from Washington and Massachusetts, and surf clams from New York and New Jersey. The statistics of the clam product, by states and varieties, are given in the above tabular statement, in which the states are ranked according to the value of their catch.

It is not possible to compare the statistics for the different varieties with those for previous years, owing to the fact that at the earlier canvasses in many instances no distinction of varictics was made. A comparison of the figures for the total clam product, however, shows a slight decrease in quantity since 1880, accompanied by an increase in value. The statistics for the various canvasses are as follows:

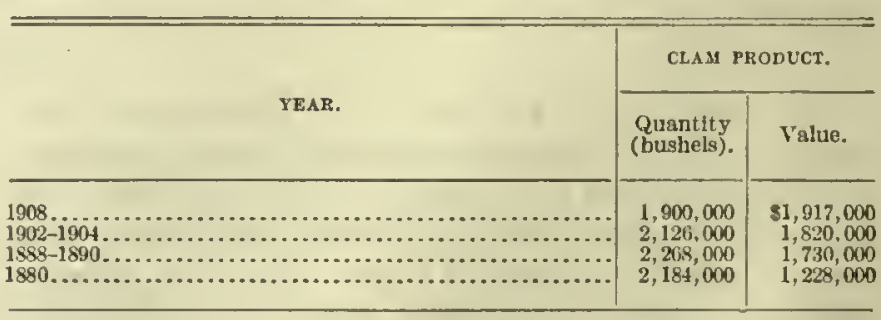

The cntire clam product was taken with tongs, dredges, and similar apparatus.

Cod (Gadus callarias).- The cod is caught most extensively along the coast of the Middle states, New England, and British America, and is not taken in the Atlantic Ocean south of New Jersey. It is most plenti- 
ful on the Grand Banks and off the coasts of Newfoundland and New Fngland. The weight varies from 3 to 75 pounds. The Alaska cod (G. macrocephalus) is found in the Pacific Ocean from Bering Sea to Oregon.

Of the fishery products of the United States in 1908, cod ranked third in value, the total product amounting to $109,453,000$ pounds, valued at $\$ 2,903,000$. The Atlantic coast states furnislied 93 per cent of this amount and the Pacific const states the remaining 7 per cent.

In the statement at top of next column is presented the per cent distribution by states of the quantity and the value of the cod product in 1908 .

On account of the lengtl of the trips made by vessels in the Pacific coast fisheries, often extending over a period of several months, the fish taken are salted on the ressels. In 1908 the Pacific coast catch was $7,946,000$ pounds, valued at $\$ 218,000$. Nassacliusetts and Maine furnished the entire amount of salted cod from the Atlantic coast. The amount salted in tliese two states is decreasing from year to year, while the amount marketed in a fresh condition is increasing. The total amount of salted cod was $30,245,000$ pounds, valued at $\$ 950,000$, or 27 per cent of the total quantity and 33 per cent of the total value of the United States cod product.

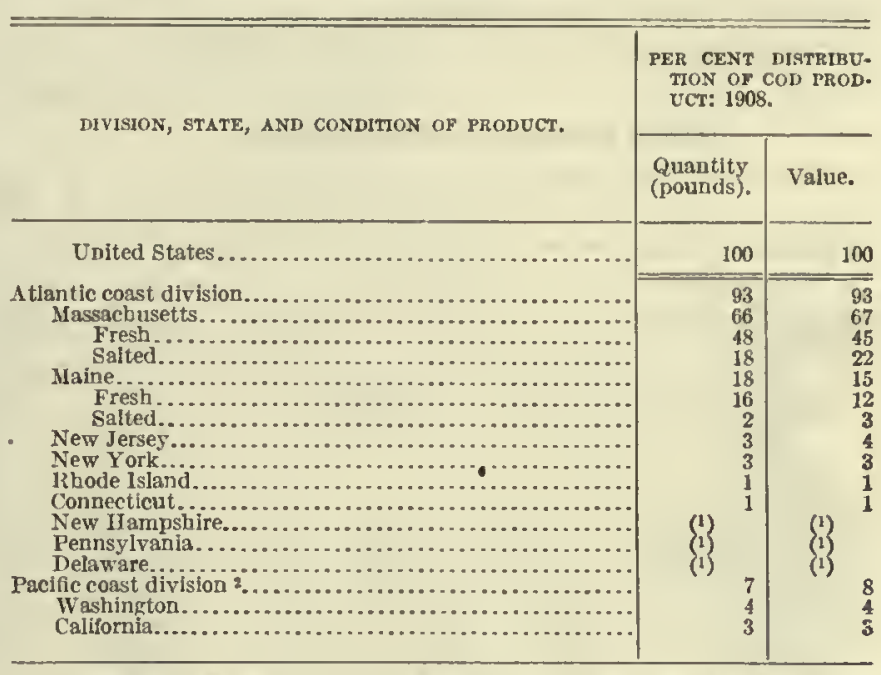

1 Less than 1 per cent. 2 All the cod product of this division was salted.

Fresh cod from the Atlantic coast fisheries represented 72 per cent of the total quantity and 67 per cent of the total value of the eatch. Massachusetts and Maine together furnished over four-fifths of the total cod product.

The comparative statistics of the cod product for 1888, 1902-1904, and 1908 are given in the following tabular statement:

\begin{tabular}{|c|c|c|c|c|c|c|c|c|c|c|c|c|}
\hline \multirow{4}{*}{$\begin{array}{c}\text { CONDITION OF PRODUCT AND } \\
\text { DIVISION. }\end{array}$} & \multicolumn{12}{|c|}{ COD PRODUCT. } \\
\hline & \multicolumn{4}{|c|}{1908} & \multicolumn{4}{|c|}{$1902-1904$} & \multicolumn{4}{|c|}{1888} \\
\hline & \multicolumn{2}{|c|}{ Quantity. } & \multicolumn{2}{|c|}{ Value. } & \multicolumn{2}{|c|}{ Quant!ty. } & \multicolumn{2}{|c|}{ Vaiue. } & \multicolumn{2}{|c|}{ Quantity. } & \multicolumn{2}{|c|}{ Value. } \\
\hline & Pounds. & $\begin{array}{l}\text { Per cent } \\
\text { distribu- } \\
\text { tion. }\end{array}$ & Amount. & $\begin{array}{l}\text { Per cent } \\
\text { distribu- } \\
\text { tion. }\end{array}$ & Pounds. & $\begin{array}{l}\text { Per cent } \\
\text { distribu- } \\
\text { tion. }\end{array}$ & Amount. & $\begin{array}{l}\text { Per cent } \\
\text { distribu- } \\
\text { tion. }\end{array}$ & Pounds. & $\begin{array}{l}\text { Per cent } \\
\text { distribu- } \\
\text { tion. }\end{array}$ & Amount. & $\begin{array}{l}\text { Per cent } \\
\text { distribu- } \\
\text { tion. }\end{array}$ \\
\hline Total.. & $110,054,000$ & 100 & $\$ 2,914,000$ & 100 & $98,383,000$ & 100 & $\$ 2,490,000$ & 100 & $119,545,000$ & 100 & $\$ 3,109,000$ & 100 \\
\hline Fresh $1 .$. & $79,808,000$ & 73 & $1,964,000$ & 67 & $55,338,000$ & 56 & $1,333,000$ & 54 & $38,517,000$ & 32 & 884,000 & 28 \\
\hline $\begin{array}{l}\text { Salted.................. } \\
\quad \text { Atlantic coost........ } \\
\quad \text { Pacific coast......... }\end{array}$ & $\begin{array}{r}30,24.5,000 \\
22,299,000 \\
7,946,000\end{array}$ & $\begin{array}{r}27 \\
20 \\
7\end{array}$ & $\begin{array}{l}950,000 \\
732,000 \\
218,000\end{array}$ & $\begin{array}{r}33 \\
25 \\
8\end{array}$ & $\begin{array}{r}43,045,000 \\
35,350,000 \\
7,695,000\end{array}$ & $\begin{array}{r}44 \\
36 \\
8\end{array}$ & $\begin{array}{r}1,157,000 \\
963,000 \\
194,000\end{array}$ & $\begin{array}{r}46 \\
39 \\
8\end{array}$ & $\begin{array}{r}81,028,000 \\
80,788,000 \\
239,000\end{array}$ & $\begin{array}{r}68 \\
68 \\
(2)\end{array}$ & $\begin{array}{r}2,225,000 \\
2,214,000 \\
11,000\end{array}$ & (2) $^{72}$ \\
\hline
\end{tabular}

A comparison of the totals for 1908 with thcse for 1902-1904 shows that there has been an increase, but that the yield reported at the last canvass was not equal to that of 1888. There was a heavy increase in the amount brought into market fresh and a corresponding decrease in the amount salted. The figures for Washington show an increase since the last canvass and those for California a decrease, while the result was an increase for the Pacific coast division as a whole. The cod taken by the Connecticut and Delaware fisheries formed but a small fraction of the total, but the value of the eatch in the former state in 1908 was nearly four times as great as that in 1902 , and in the latter the quantity caught was nearly nine times as great as in 1904. New Jersey, New York, and Rhode Island more than doubled their catch. New Hampshire and Maryland were the only states on the Atlantic coast showing a decrease. The distribution of the cod taken in 1888, 1902-1904, and 1908 is given in the next tabular statement:

As the cod habitually feeds on the bottom, practically the entire catch was taken with trawls and hand lines, though a few were taken in pound nets, gill nets, and other trawls. 


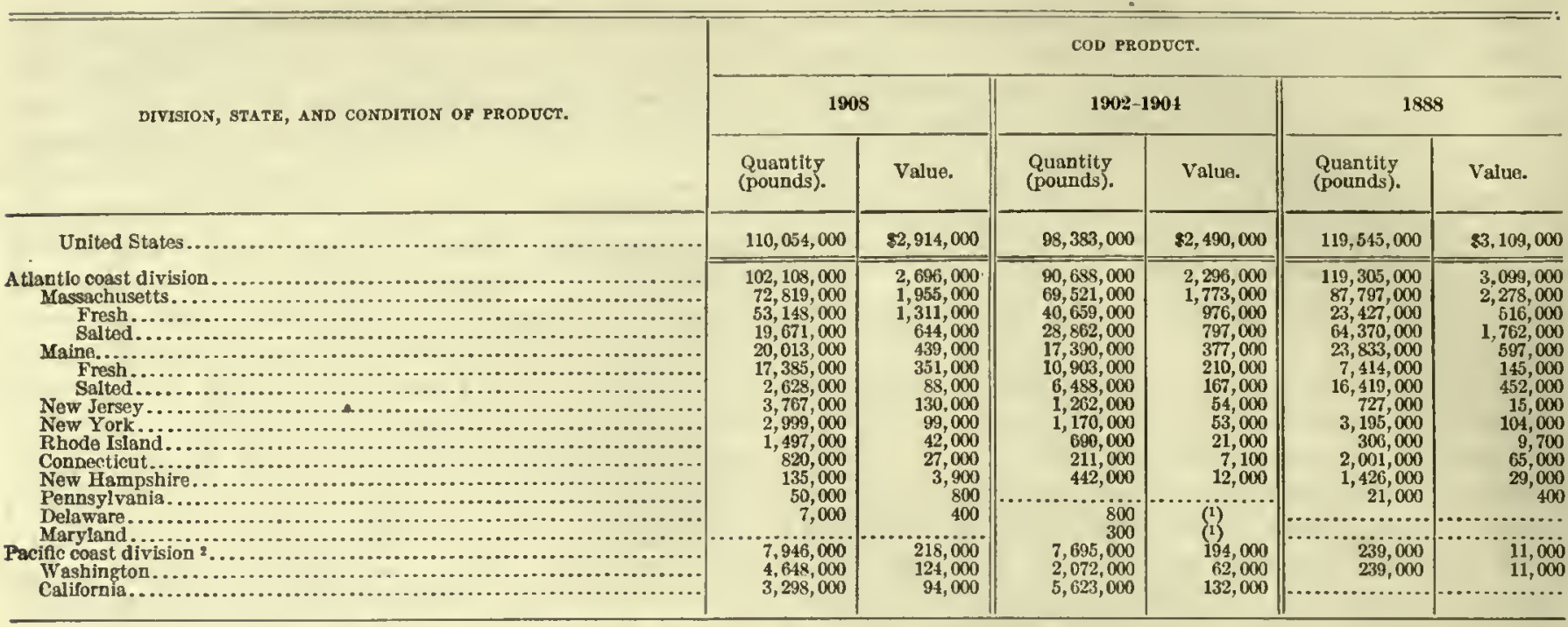

2 All the cod product of this divislon was salted.

Crabs.-Crabs are decapod crustaceans, found along all the coasts of the United States. The different species vary much in size, habit, and use, and are distinguished by the adjectives "blue," "fiddler," "green," "hermit," "jonah," "kelp," "lady," "'mud," "oyster," "red," "rock," "sand," "sea," "soldier," "spider," "stone," etc. The common edible crab has names applied by the catchers, describing the different conditions of the shell. While shedding they are known as "comer," "buster," "peeler," and "shedder;" while growing a new shell, as "soft-shell," "paper-shell," and "buckler."

Crabs are used for food, bait, and fertilizer. King crabs are sold for the latter purpose and the product is known as "cancerine."

Although for the purposes of this report crabs are divided into only five classes, a number of varioties were taken, most of which are included under "hard crabs" or "soft crabs." The most important species included under these heads are the blue crab of the Atlantic coast and the Pacific coast erabs. The terms "hard" and "soft" are applied to crabs to designate the condition of the shell rather than to differentiate species. The common blue crab of the Atlantic coast sherls its shell several times annually, and since commercially only two stages are recognized, it may be classed as either "hard" or "soft." No soft crabs were reported from the Pacific coast. In addition to the liard and soft varieties, those shown separately here are the "king crab," "spider crab," and "stone crab."

The erab product in 1908, comprising hard, soft, king, spider, and stone crabs, aggregated $60,626,000$ pounds, and had a value of $\$ 938,000$. The following tabular statement shows the distribution of the quantity and the value of the hard and soft crab product, as reported for 1908 , for groups of states:

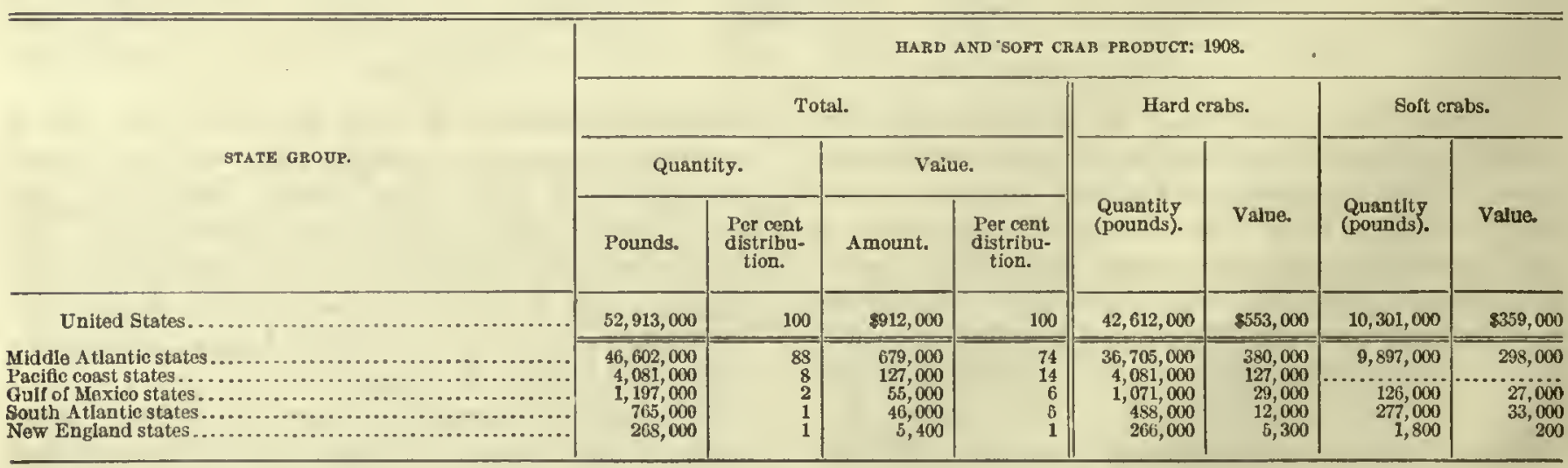

The statistics of the crab product for 1908 , by states and varieties, are given in tho next table.

The Virginia fisheries supplied more than one-half of the total quantity of hard erabs and the Maryland fisheries considerably more than one-fourth. In the soft-crab output Virginia and Maryland again took the lead, but the order is reversed, Maryland reporting three-fourths of the total weight and Virginia onefifth. No soft crabs whatever were reported from the Pacific coast states. The combined weight of hard and soft crabs was $52,913,000$ pounds and the combined value $\$ 912,000$. When the two varieties are thus 
considered together, the products of Virginia and Maryland are very nearly equal in value, that of the Virginia product being $\$ 326,000$ and that of the Maryland product $\$ 319,000$. These two states together contributed 71 per cent and the Middle Atlantic states, as a group, 74 per cent of the total value of the hard and soft crab product.

\begin{tabular}{|c|c|c|c|c|c|c|c|c|}
\hline \multirow{4}{*}{ BTATE. } & \multicolumn{8}{|c|}{ CRAR PRODUCT: 1908.} \\
\hline & \multicolumn{4}{|c|}{ Total. } & \multicolumn{2}{|c|}{ Uard crabs. } & \multicolumn{2}{|c|}{ Soft crabs. } \\
\hline & \multicolumn{2}{|c|}{ Quantlty. } & \multicolumn{2}{|c|}{ Value. } & \multirow[b]{2}{*}{$\begin{array}{l}\text { Quantity } \\
\text { (pounds). }\end{array}$} & \multirow[b]{2}{*}{ Value. } & \multirow[b]{2}{*}{$\begin{array}{l}\text { Quantity } \\
\text { (pounds). }\end{array}$} & \multirow[b]{2}{*}{ Value. } \\
\hline & Pounds. & $\begin{array}{l}\text { Per cent } \\
\text { distribu- } \\
\text { tion. }\end{array}$ & Amount. & $\begin{array}{l}\text { Per cent } \\
\text { distrlbu- } \\
\text { tlon. }\end{array}$ & & & & \\
\hline United States........... & $160,626,000$ & 100 & $1 \$ 938,000$ & 100 & $42,612,000$ & $\$ 553,000$ & $10,301,000$ & $\$ 359,000$ \\
\hline 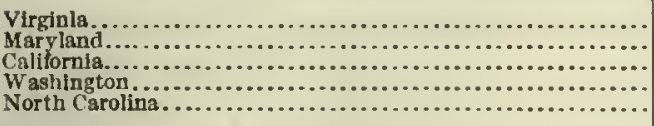 & $\begin{array}{r}25,083,000 \\
20,373,000 \\
1,702,000 \\
2,179,000 \\
390,000\end{array}$ & $\begin{array}{r}41 \\
34 \\
3 \\
4 \\
1\end{array}$ & $\begin{array}{r}326,000 \\
319,000 \\
69,000 \\
51,000 \\
34,000\end{array}$ & $\begin{array}{r}35 \\
34 \\
7 \\
5 \\
4\end{array}$ & $\begin{array}{r}23,001,000 \\
12,786,000 \\
1,702,000 \\
2,179,000 \\
113,000\end{array}$ & $\begin{array}{r}239,000 \\
124,000 \\
69,000 \\
51,000 \\
1,100\end{array}$ & $\begin{array}{r}2,082,000 \\
7,587,000 \\
\cdots, \ldots, \ldots, \ldots \\
277,000\end{array}$ & $\begin{array}{r}87,000 \\
195,000 \\
\cdots \\
\cdots\end{array}$ \\
\hline 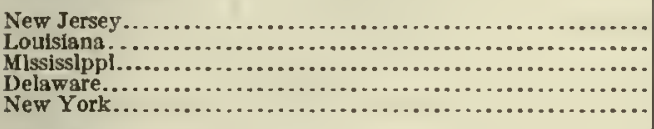 & $\begin{array}{r}4,952,000 \\
322,000 \\
426,000 \\
3,178,000 \\
665,000\end{array}$ & $\begin{array}{r}8 \\
1 \\
1 \\
5 \\
1\end{array}$ & $\begin{array}{r}34,000 \\
29,000 \\
15,000 \\
\times 13,000 \\
19,800\end{array}$ & $\begin{array}{l}4 \\
3 \\
2 \\
1 \\
1\end{array}$ & $\begin{array}{r}282,000 \\
244,000 \\
380,000 \\
57,000 \\
580,000\end{array}$ & $\begin{array}{r}9,100 \\
7,800 \\
9,800 \\
600 \\
7,400\end{array}$ & $\begin{array}{r}63,000 \\
78,000 \\
47,000 \\
142,000 \\
22,000\end{array}$ & $\begin{array}{r}6,200 \\
21,000 \\
5,600 \\
8,400 \\
2,300\end{array}$ \\
\hline 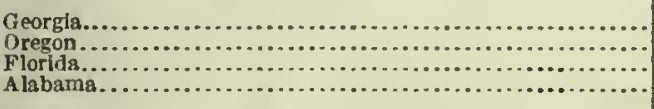 & $\begin{array}{r}196,000 \\
200,000 \\
211,000 \\
246,000\end{array}$ & $\left(\begin{array}{l}6 \\
6 \\
3 \\
3\end{array}\right)$ & $\begin{array}{r}7,500 \\
6,900 \\
6,500 \\
6,100\end{array}$ & $\begin{array}{l}1 \\
1 \\
1 \\
1\end{array}$ & $\begin{array}{l}196,000 \\
200,000 \\
148,000 \\
246,000\end{array}$ & $\begin{array}{l}7,500 \\
6,900 \\
2,900 \\
6,100\end{array}$ & 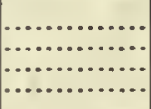 & (n) \\
\hline 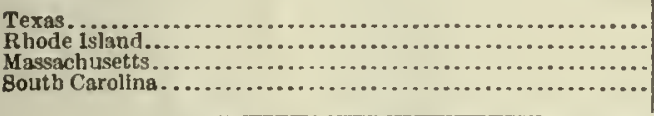 & $\begin{array}{r}200,000 \\
146,000 \\
122,000 \\
33,000\end{array}$ & $\left.\begin{array}{l}3 \\
3 \\
3 \\
3 \\
3\end{array}\right)$ & $\begin{array}{r}5,000 \\
2,900 \\
2,600 \\
900\end{array}$ & $\left.\begin{array}{l}(3) \\
(5) \\
3\end{array}\right)$ & $\begin{array}{r}199,000 \\
146,000 \\
121,000 \\
33,000\end{array}$ & $\begin{array}{r}4,800 \\
2,900 \\
2,400 \\
900\end{array}$ & $\begin{array}{r}600 \\
1,800 \\
1,80 \ldots\end{array}$ & $\begin{array}{l}200 \\
200 \\
200\end{array}$ \\
\hline
\end{tabular}

1 Includes 7,643,000 pounds of king crabs, valued at $\$ 23,000 ; 62,000$ pounds of stone crabs, valued at $\$ 3,700$; and 7,200 pounds of splder crabs. Includes $4,607,000$ pounds of king crabs, valued at $\$ 18,000$.

Includes $2,980,000$ pounds of king crabs, valued at $\$ 1,300$.
Includes 63,000 pounds of king and splder crabs, valued at $\$ 100$.

The statistics of the liard and soft crab product, for the years for which returns are available, are given in the following tabular stateinent:

\begin{tabular}{|c|c|c|c|c|c|c|}
\hline \multirow{3}{*}{ DIVISION AND YEAR. } & \multicolumn{6}{|c|}{ - HARD AND SOFT CRAB PRODUCT. } \\
\hline & \multicolumn{2}{|c|}{ Total. } & \multicolumn{2}{|c|}{ Hard crabs. } & \multicolumn{2}{|c|}{ Soft crabs. } \\
\hline & $\begin{array}{l}\text { Quantity } \\
\text { (pounds). }\end{array}$ & Value. & $\begin{array}{l}\text { Quantity } \\
\text { (pounds). }\end{array}$ & Value. & $\begin{array}{l}\text { Quantity } \\
\text { (pounds). }\end{array}$ & Value. \\
\hline $\begin{array}{r}\text { United States: } \\
1908.1905 . \\
1902-1909 . \\
1889-1892 . \\
1880 \ldots . . .\end{array}$ & $\begin{array}{r}52,913,000 \\
40.218,000 \\
16,004,000 \\
7,711,000 \\
\end{array}$ & $\begin{array}{l}\$ 912,000 \\
906,000 \\
566,000 \\
338,000\end{array}$ & \begin{tabular}{|c}
$42,612,000$ \\
$32,061,000$ \\
$19,770,000$ \\
$(2)$
\end{tabular} & $\begin{array}{r}3553,000 \\
578,000 \\
1213,000 \\
\quad(3) \\
\end{array}$ & $\begin{array}{r}10,301,000 \\
8,156,000 \\
16,029,000 \\
(2)\end{array}$ & $\begin{array}{r}\$ 359,000 \\
328,000 \\
1346,000 \\
(?)\end{array}$ \\
\hline 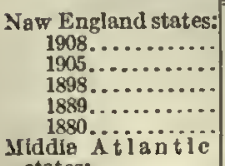 & $\begin{array}{r}268,000 \\
80,000 \\
\cdot 13,000 \\
13,000 \\
(2)\end{array}$ & $\begin{array}{l}5,400 \\
2,300 \\
2,200 \\
1,400 \\
(2)\end{array}$ & $\begin{array}{r}266,000 \\
73,000 \\
7,900 \\
(3) \\
(3)\end{array}$ & $\begin{array}{l}5,300 \\
1,100 \\
600 \\
(3) \\
(3)\end{array}$ & $\begin{array}{l}1,800 \\
6,600 \\
5,000 \\
(2) \\
\text { (2) }\end{array}$ & $\begin{array}{l}200 \\
1,200 \\
1,700 \\
(3) \\
\text { (3) }\end{array}$ \\
\hline 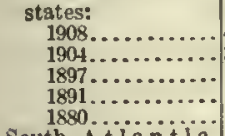 & $\begin{array}{r}46,602,000 \\
31,975,000 \\
17,226,000 \\
11,635,000 \\
7,026,000\end{array}$ & $\begin{array}{l}679,000 \\
675,000 \\
337,000 \\
426,000 \\
313,000\end{array}$ & $\mid \begin{array}{c}36,705,000 \\
24,057,000 \\
11,523,000 \\
5,751,000 \\
(3)\end{array}$ & $\left|\begin{array}{c}380,000 \\
366,000 \\
85,000 \\
87,000 \\
(3)\end{array}\right|$ & $\begin{array}{c}9,897,000 \\
7,919,000 \\
5,703,000 \\
5,884,000 \\
\left({ }^{3}\right)\end{array}$ & $\begin{array}{l}298,000 \\
309,000 \\
252,000 \\
339,000 \\
\left({ }^{\circ}\right)\end{array}$ \\
\hline $\begin{array}{l}\text { South } \mathrm{A} i \mathrm{i} \text { in } \mathrm{i} I \mathrm{c} \\
\text { states: }\end{array}$ & & & & & & \\
\hline $\begin{array}{r}1908 \ldots \ldots \ldots \\
1902 \ldots \ldots \ldots \\
1891 \ldots \ldots \ldots \\
1880 \ldots \ldots\end{array}$ & $\begin{array}{r}765,000 \\
386,000 \\
193,000 \\
60,000\end{array}$ & $\begin{array}{l}46,000 \\
19,000 \\
4,200 \\
1,300\end{array}$ & $\begin{array}{l}488,000 \\
185,000 \\
(3) \\
(3)\end{array}$ & $\begin{array}{l}12,000 \\
4,400 \\
\text { (1) } \\
\text { (3) }\end{array}$ & $\begin{array}{l}277,000 \\
200,000 \\
(3) \\
(3)\end{array}$ & $\begin{array}{l}33,000 \\
15,000 \\
\text { (?) }\end{array}$ \\
\hline $\begin{array}{l}\text { Gulfor Mexico states: } \\
\text { 1908 }\end{array}$ & & & & & & \\
\hline 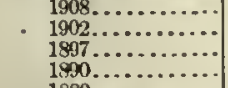 & $\begin{array}{l}1,197,000 \\
1,697,000 \\
1,780,000 \\
1,219,000\end{array}$ & $\begin{array}{l}55,000 \\
28,000 \\
22,000 \\
26,000\end{array}$ & $\begin{array}{l}1,071,000 \\
1,666,000 \\
1,759,000 \\
1,074,000\end{array}$ & $\begin{array}{l}29,000 \\
25,000 \\
21,000 \\
19,000\end{array}$ & $\begin{array}{r}126,000 \\
31,000 \\
21,000 \\
144,000\end{array}$ & $\begin{array}{r}27,000 \\
2,900 \\
1,700 \\
7,300\end{array}$ \\
\hline $\begin{array}{r}1880 \ldots . . . . . . . . . . \\
\text { Paciflc coast states: }\end{array}$ & 324,000 & 8,100 & (3) & (a) & (3) & \\
\hline $\begin{array}{l}1908, \ldots \ldots \ldots \ldots \\
1904 \ldots \ldots \ldots\end{array}$ & $\begin{array}{l}4,081,000 \\
6,080,000\end{array}$ & $\begin{array}{l}127,000 \\
182,000\end{array}$ & $\begin{array}{l}4,081,000 \\
6,080,000\end{array}$ & $\begin{array}{l}127,000 \\
182,000\end{array}$ & $\mid \ldots \ldots \ldots . . .$. & (n....... \\
\hline & $\begin{array}{l}4,062,000 \\
2,752,000\end{array}$ & $\begin{array}{r}100,0 \\
67,0\end{array}$ & $\begin{array}{l}4,002,000 \\
2,752,000\end{array}$ & $\begin{array}{r}100,000 \\
67,000\end{array}$ & & (n....... \\
\hline & $2,945,000$ & 107,0 & $2,945,000$ & 107,000 & & .... \\
\hline & 300,400 & 15,000 & 300,000 & 15,000 & & \\
\hline
\end{tabular}
1 Not inciuding the New England states and the South Atlantic states.
2 Not raported.
The crab fisheries show a great increase in productivity. As compared with the product of hard and soft crabs in 1908 , amounting to $52,913,000$ pounds, valued at $\$ 912,000$, the figures for 1880 are small, the product being only $7,711,000$ pounds, valued at $\$ 338,000$. Virginia and Maryland are the states reporting the largest quantities in 1880, as well as in 1908, but New York and New Jersey followed closely, and the value of New Jersey's product in 1880 was greater than that of all the remaining states of the Atlantic seaboard and the Gulf combined. No figures covering the whole United States are available for any single year of the intervening period, but the composite figures show the increase to be general. The increase in value shows greater fluctuations than the increase in the quantity of the product.

The king crab or horseshoe crab is used for bait and hog feed, but most extensively for fertilizer purposes. The following tabular statement shows the product for certain specified years:

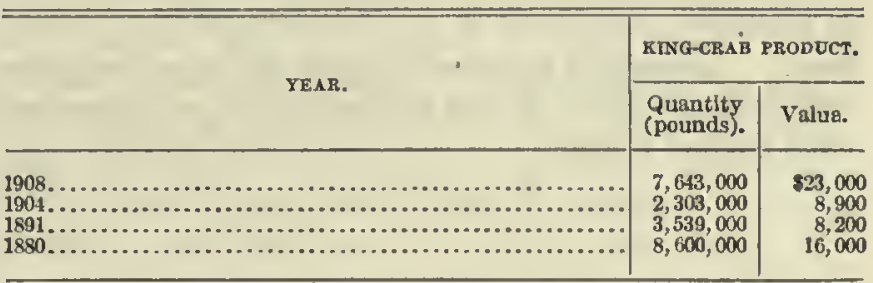

All king crabs reported wore taken from the Atlantic Ocean along the Middle Atlantic states, two-thirds of the quantity coming from New Jersey. 
The most common method of taking hard crabs is with meat-baited lines, hand or set, and a dip net in which the crab is caught when hauled to the surface. Two-thirds of the soft-crab catch is taken with dredges. King crabs were formerly all eaught by hand or with forks on the beach, but the great bulk are now taken in pound nets.

Flounders (Pleuronectidx).-The family of flounders is composed of the turbots, the halibuts, the plaices, and probably the soles. Since the halibuts are considered separately they are not here included under flounders.

The name flounder is variously applied to the flat fishes found on all the coasts of the United States, and known as "American sole," "bastard halibut," "Monterey halibut," "winter flounder," "starry flounder," "rough limanda," "diamond flounder," "long-finned sole," "sand dab," "rough dab," "Greenland turbot," "pole flounder," "craig flounder," "spotted sand flounder," etc. They vary in size and shape, and are sold for both food and bait. The catch is taken in weirs, nets, beam trawls, and seines, and with hand lines and gaffs.

The catch of flounders in 1908 was valued at $\$ 588,000$, and represented a little over 1 per cent of the total fishery product. It was derived from the fisheries of 21 states, including every coast state except New Hampshire. Massachusetts, California, and New York, however, reported 79 per cent of the weight and 73 per cent of the value of the total, and this, combined with the product of Rhode Island, New Jersey, and Connecticut, represents 93 per cent of the total weight and 90 per cent of the total value. The statistics of the product for the more important states are as follows:

\begin{tabular}{|c|c|c|c|c|}
\hline \multirow{3}{*}{ STATE. } & \multicolumn{4}{|c|}{ FLOUNDER PRODUCT: 1908.} \\
\hline & \multicolumn{2}{|c|}{ Quantity. } & \multicolumn{2}{|c|}{ Value. } \\
\hline & Pounds. & $\begin{array}{l}\text { Per cent } \\
\text { distribu- } \\
\text { tion. }\end{array}$ & Amount. & $\begin{array}{l}\text { Per cent } \\
\text { distribu- } \\
\text { tion. }\end{array}$ \\
\hline United States................. & $23,346,000$ & 100 & $\$ 588,000$ & 100 \\
\hline 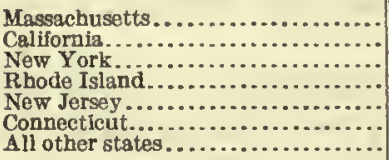 & $\begin{array}{r}7,124,000 \\
6,681,000 \\
4,629,000 \\
1,891,000 \\
650,000 \\
707,000 \\
1,664,000\end{array}$ & $\begin{array}{r}31 \\
29 \\
20 \\
8 \\
3 \\
3 \\
7\end{array}$ & $\begin{array}{r}146,000 \\
144,000 \\
141,000 \\
50,000 \\
25,000 \\
21,000 \\
60,000\end{array}$ & $\begin{array}{r}25 \\
24 \\
24 \\
9 \\
4 \\
4 \\
10\end{array}$ \\
\hline
\end{tabular}

Comparative figures of the product of flounders, so far as available, are given in the following tabular statement. A marked increase appears in both the quantity and the value of the catch in 1908, as compared with earlier years.

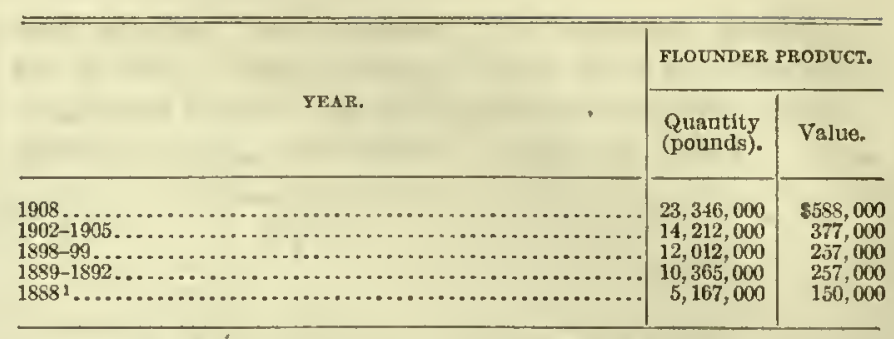

1 Exclusive of the product of the Pacific coast states.

Flounders were caught with a variety of apparatus of capture, and the quantity and value of the catch taken with the different kinds of apparatus are given in the following tabular statement:

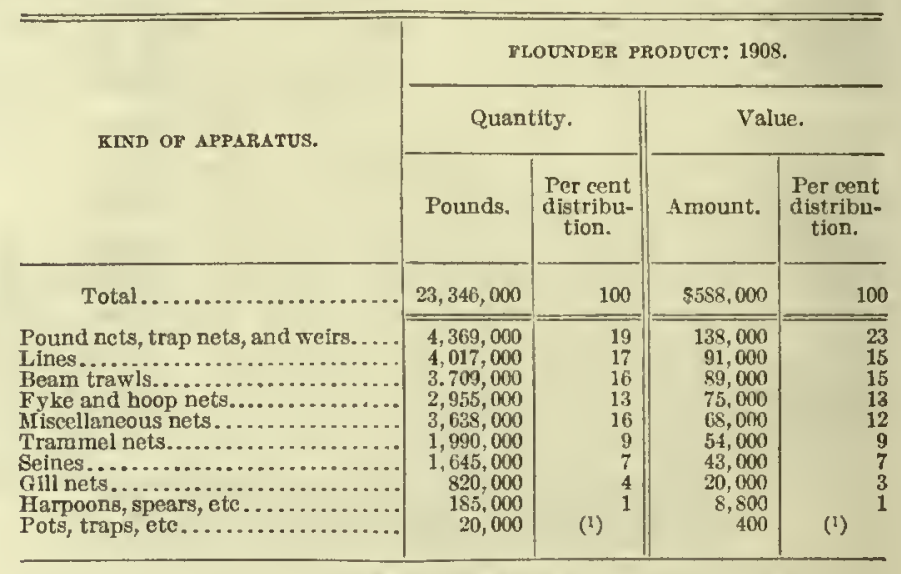

1 Less than 1 per cent.

Haddock (Melanogrammus æglifinus).-The haddock is a food fish found in the Atlantic Ocean north of the Delaware capes; it is called "dickie" in some localities. The average weight is from 4 to 6 pounds. It is extensively used as a fresh food fish, and is also salted, pickled, and dried. When slack-salted and smoked it is sold under the name of "haddie."

The catch in 1908 , valued at $\$ 1,308,000$, represented 2 per cent of the total value of the fishery products of the United States and 4 per cent of the value of the food fish. In the product from the Atlantic const this fish ranked seventh with respect to value, and represented 4 per cent of the total value. The catch was sold fresh, with the exception of $1,042,000$ pounds, valued at $\$ 22,000$, which were salted. The first tabular statement following gives the statisties of the weight and value of the haddock eatch, by states.

The value of the catch of haddock in 1908 exceeded that of any year for which statistics are available, but the quantity was less than in 1904-5. Comparative figures are given in the second tabular statement following for 1908 and earlier years. 


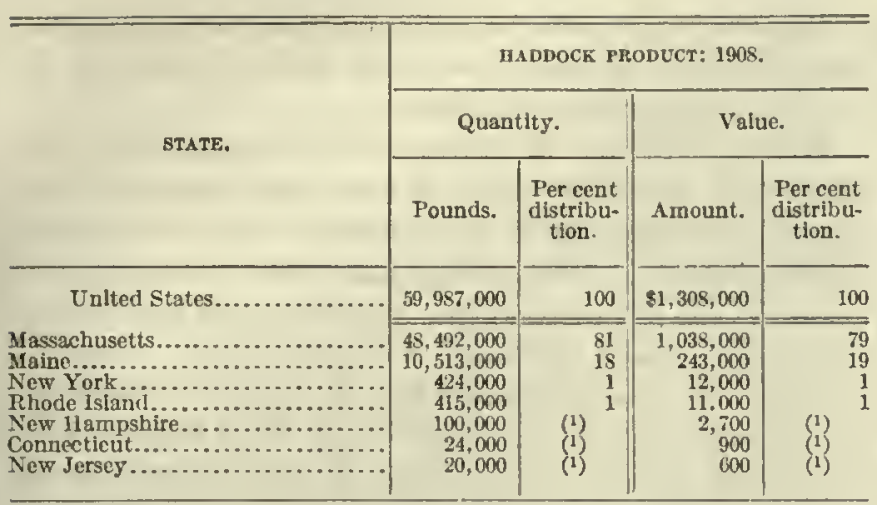

Less than 1 per cent.

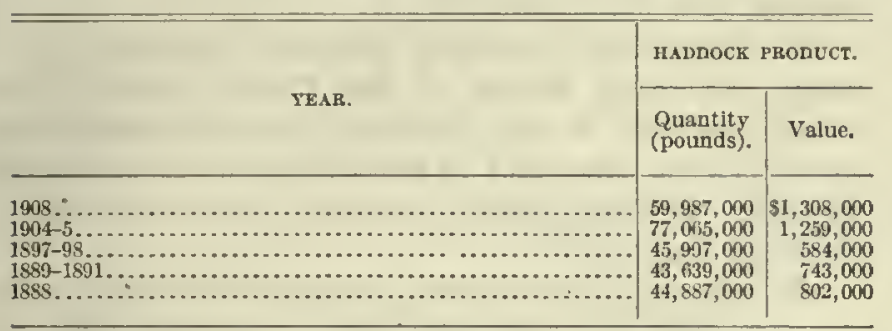

The catch was practically all taken with lines, only about 2 per cent being taken with seines and 1 per cent with pound nets, trap nets, and gill nets.

Hake (Urophycis).-The species included under this head are not true hakes, but comprise different varieties of food fish found off the Atlantic coast from Newfoundland to Cape Hatteras, which are variously known as "old English liake," "squirrel hake," "white hake," "ling," "king hake," "codling," ctc. "They are often prepared under the trade name of "boneless fish." The average length is from $1 \frac{1}{2}$ to 2 feet and the average weight from 3 to 8 pounds.

The value of the hake catch in 1908 was $\$ 464,000$. All the product reported was sold fresh except 525,000 pounds, valued at $\$ 8,900$, which were salted. The hake was taken only in the fisheries of the North Atlantic states, and practically the entire product was from Massachusetts and Maine, as shown in the following tabular statement:

\begin{tabular}{|c|c|c|c|c|}
\hline \multirow{3}{*}{ STATE. } & \multicolumn{4}{|c|}{ HAKE PRODUCT: 1908.} \\
\hline & \multicolumn{2}{|c|}{ Quantity. } & \multicolumn{2}{|c|}{ Value. } \\
\hline & Pounds. & $\begin{array}{l}\text { Per cent } \\
\text { distribu- } \\
\text { tlon. }\end{array}$ & Amount. & $\begin{array}{l}\text { Per cent } \\
\text { distribu- } \\
\text { tion. }\end{array}$ \\
\hline United States.. & $34,340,000$ & 100 & $\$ 464,000$ & 100 \\
\hline 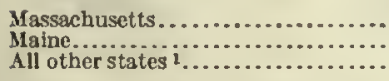 & $\begin{array}{r}16,708,000 \\
17,398,000 \\
233,000\end{array}$ & $\begin{array}{r}49 \\
51 \\
1\end{array}$ & $\begin{array}{r}294,000 \\
168,000 \\
2,700\end{array}$ & $\begin{array}{r}63 \\
36 \\
1\end{array}$ \\
\hline
\end{tabular}

1 Includes New Jersey, New York, New Hampshire, Connecticut, and Rhode Island.

Except for the greater proximity of the Massachusetts fisheries to the markets, no reason is apparent for the fact that the average value of the Massachusetts catch was so much greater than that of the Maine eatch.

That the value of the hake product has increased substantially during recent years is indicated by the following tabular statement, giving statistics for years for which returns are available:

\begin{tabular}{|c|c|c|}
\hline \multirow{2}{*}{ YEAR. } & \multicolumn{2}{|c|}{ HAKE PRODUCT. } \\
\hline & $\begin{array}{l}\text { Quantity } \\
\text { (pounds). }\end{array}$ & Value. \\
\hline 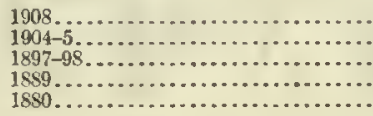 & $\begin{array}{l}34,340,000 \\
35,929,000 \\
37,278,000 \\
14,816,000 \\
30,657,000\end{array}$ & $\begin{array}{r}\$ 464,000 \\
419,000 \\
302,000 \\
16,000 \\
196,000\end{array}$ \\
\hline
\end{tabular}

During the earlier years for which statistics are given, large quantities were salted; in 1898 several million pounds were salted, but in 1908 practically the entire product was sold fresh.

The catch was taken principally with lines, the capture with other apparatus not exceeding 2 per cent of the total.

Hake sounds used in the manufacture of isinglass have been included in the statistics of sounds, which are given on page 43.

Halibut (Hippoglossus hippoglossus).--The halibut, the largest and most valuable of the flat fishes, is found in the North Atlantic and Pacific Oceans. It is one of the largest species used for food, sometimes weighing over 300 pounds, but the average weight is from 50 to 75 pounds. There are three grades of halibut. The "white," which has its underside immaculate, is considered best and brings the lighest price; the "gray" is blotched on the underside, and sells for a third less; the "sour" is tainted, and brings only about one-fourth as much as the "white." Small young fish, weighing from 10 to 20 pounds, are called "chickens," and are much sought after by epicures. Halibut are sold fresh and are also eured and smoked, while the napes are piekled. An oil used for currying purposes is made from the head, and the residue is used as a fertilizer under the name of "ehum."

Halibut was the eighth in value among all the fishery products and the fifth among fish proper. In 1908 its value, $\$ 1,562,000$, formed 3 per cent of that reported for the entire fishery produet and 5 per cont of that for fish proper. In the Pacific coast division, from which about six-seventlss of the catch was taken, it ranked next after salmon, and comprised 18 per cent of the fishery product. Nearly all of the catch of the Pacific coast states came from the fisheries of Washington. The value per pound was so much higher on the Atlantic seaboard, that the produet of the Atlantic coast states, although forming 
only about one-eighth of the total halibut catch in quantity, contributed one-fifth of its total value. The statistics of the catch reported by the different states are as follows:

\begin{tabular}{|c|c|c|c|c|}
\hline \multirow{3}{*}{ STATE. } & \multicolumn{4}{|c|}{ HALIBUT PRODUCT: 1908.} \\
\hline & \multicolumn{2}{|c|}{ Quantity. } & \multicolumn{2}{|c|}{ Value. } \\
\hline & Pounds. & $\begin{array}{l}\text { Per cent } \\
\text { distrihu- } \\
\text { tlon. }\end{array}$ & Amount. & $\begin{array}{l}\text { Per cent } \\
\text { distrihu- } \\
\text { tion. }\end{array}$ \\
\hline United States.................. & $34,441,000$ & .100 & $\$ 1,562,000$ & - 100 \\
\hline 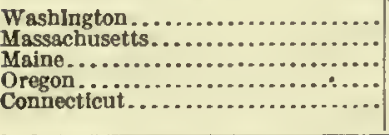 & $\begin{array}{r}30,072,000 \\
4,145,000 \\
200,000 \\
16,000 \\
8,500\end{array}$ & (1) $\begin{array}{r}87 \\
12 \\
(1)\end{array}$ & $\begin{array}{r}1,236,000 \\
310,000 \\
15,000 \\
700 \\
600\end{array}$ & $\begin{array}{l}(1) \\
(1)\end{array}$ \\
\hline
\end{tabular}

1 Less than 1 per cent.

The catch in 1908 was nearly twice as great in weight and value as that of any previous year. The most notable features of the statistics for 1908, as compared with those for prior canvasses, are the decrease in the catch of the New England fisheries and the increase in that of the Pacific coast fisheries. The following tabular statement gives the quantity and value of the catch for the various years for which returns are available:

\begin{tabular}{|c|c|c|c|c|c|c|}
\hline \multirow{3}{*}{ TEAR. } & \multicolumn{6}{|c|}{ HALIBUT PRODUCT. } \\
\hline & \multicolumn{2}{|c|}{ Total. } & \multicolumn{2}{|c|}{$\begin{array}{l}\text { Atlantic coast } \\
\text { division. }\end{array}$} & \multicolumn{2}{|c|}{$\begin{array}{l}\text { Paciffc coast } \\
\text { divlsion. }\end{array}$} \\
\hline & $\begin{array}{l}\text { Qnantity } \\
\text { (pounds). }\end{array}$ & Value. & $\begin{array}{l}\text { Quantity } \\
\text { (pounds). }\end{array}$ & Value. & $\begin{array}{l}\text { Quantity } \\
\text { (pounds). }\end{array}$ & Value. \\
\hline $\begin{array}{l}1908 \ldots \ldots \ldots \\
1904-5 . \ldots \ldots \\
1898-99 \ldots \ldots \\
1890-1992 \ldots \\
1888 . \ldots \ldots\end{array}$ & $\begin{array}{l}34,441,000 \\
15,807,000 \\
17,706,000 \\
11,391,000 \\
12,819,000\end{array}$ & $\begin{array}{r}\$ 1,562,000 \\
597,000 \\
762,000 \\
874,000 \\
727,000\end{array}$ & $\begin{array}{r}4,354,000 \\
3,716,000 \\
10,828,000 \\
9,288,000 \\
11,599,000\end{array}$ & $\begin{array}{r}\$ 326,000 \\
238,000 \\
570,000 \\
827,000 \\
695,000\end{array}$ & $\begin{array}{r}30,088,000 \\
12,091,000 \\
6,878,000 \\
2,103,000 \\
1,220,000\end{array}$ & $\begin{array}{r}\$ 1,236,000 \\
359,000 \\
193,000 \\
47,000 \\
32,000\end{array}$ \\
\hline
\end{tabular}

With the exception of 656,000 pounds of salted halibut, valued at $\$ 53,000$, all the output in 1908 was sold fresh. All the salted halibut product was reported by tho fisheries of Massachusetts. In previous years much larger quantities were salted in the Massachusetts fisheries, as is shown by the following tabular statement giving the statistics for certain years for which detailed reports were made:

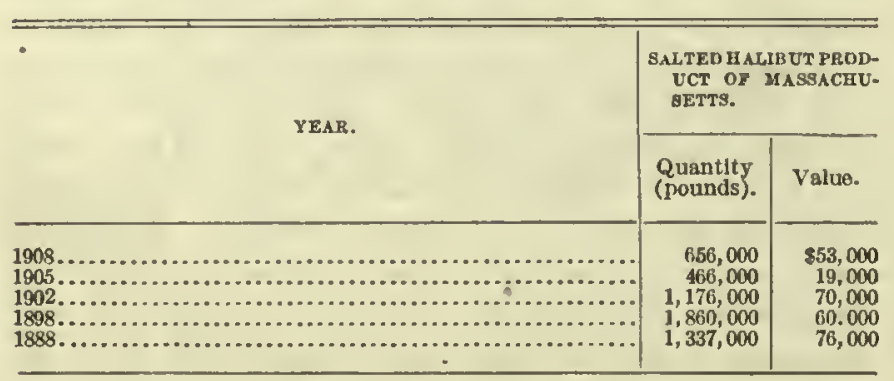

With the exception of 9,000 pounds, valued at $\$ 900$, taken in other trawls, the entire halibut catch of the country was made with lines.

Herring (Clupea harengus).-The herring is a very important food fish found in the north Atlantic as far south as Sandy Hook; it is never found in brackish or fresh waters. "Sperling" and "brit" denote differences in the age of the fish. Trade names are "Digby chicken," "hard herring," "bloaters," etc. Herring weigh from one-half pound to one pound, and average in length about 10 inches. As a food fish they are used fresh, salted, pickled, smoked, and canned. They are also used extensively for bait in the cod, haddock, halibut, and hake fisheries.

The California herring is an allied species found along the entire length of the Pacific coast. The name "herring" is also applied to the Gulf menhaden on the Texas coast and to the menhaden in southerm Florida. The hickory shad is called "thread herring" in North Carolina.

The herring catch in 1908 amounted to $125,050,000$ pounds, valued at $\$ 796,000$. Of this amount, 92 per cent was marketed fresh, and the balance, 8 per cent, was salted or smoked. Maine and Massachusetts fishermen captured 97 per cent of the total quantity, which represents 96 per cent of the total value. All of the salted product was reported from Maine and Massachusetts, and all of the smoked product from Maine. The statistics of the herring catch, by states ranked in the order of the value of their products, are given in the following tabular statement:

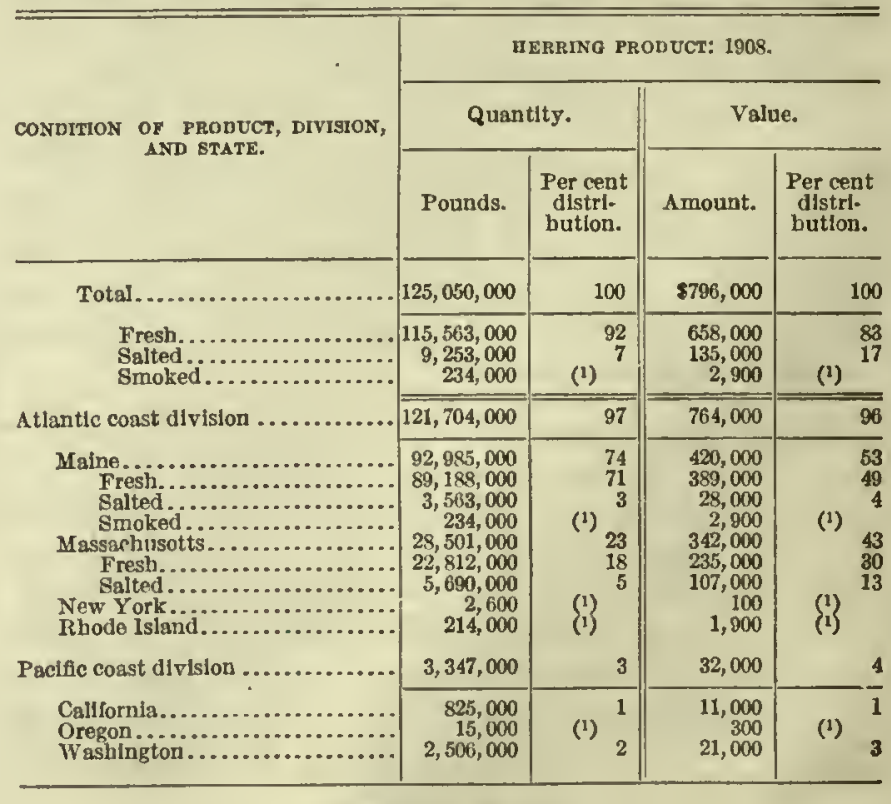

1 Less than 1 per cent.

The following tabular statement shows the quantity and value of the herring catch in specified years: 


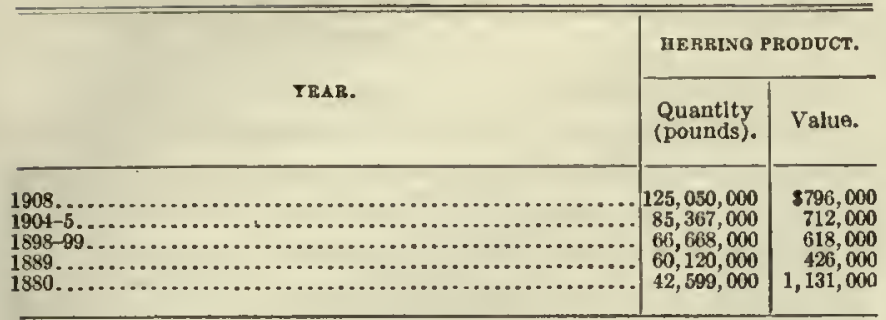

A large number of vessels engage in the winter herring fishery off the west coast of Newfoundland. The greater part of the catch was taken with pound nets, trap nets, and weirs. The distribution of the product by apparatus of capture was as follows:

\begin{tabular}{|c|c|c|c|c|}
\hline \multirow{3}{*}{ KIND OF APPARATUS. } & \multicolumn{4}{|c|}{ UERRINO PRODUCT: 1908.} \\
\hline & \multicolumn{2}{|c|}{ Quantity. } & \multicolumn{2}{|c|}{ Value. } \\
\hline & Pounds. & $\begin{array}{l}\text { Per cent } \\
\text { distribu- } \\
\text { tlon. }\end{array}$ & Amount. & $\begin{array}{l}\text { Per cent } \\
\text { distribu- } \\
\text { tion. }\end{array}$ \\
\hline Total... & $125,050,000$ & 100 & $\$ 796,000$ & 100 \\
\hline 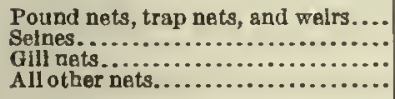 & $\begin{array}{r}72,868,000 \\
33,988,000 \\
11,302,000 \\
6,892,000\end{array}$ & $\begin{array}{r}58 \\
27 \\
9 \\
6\end{array}$ & $\begin{array}{r}336,000 \\
198,000 \\
218,000 \\
45,000\end{array}$ & $\begin{array}{r}42 \\
25 \\
27 \\
6\end{array}$ \\
\hline
\end{tabular}

Lake herring (Leucichthys).-The ciscoes, or lake herrings, are members of the whitefish family found in the Great Lakes and neighboring waters. There are various species popularly known as herring, with or without qualifying names, the common form (L. artedi) being most important.
Lake herring has always been the leading species from the Great Lakes, and in 1908 the value of the catch was $\$ 989,000$, or 26 per cent of the total value of the fishery products of this division. Of the total value of the United States product it contributed 2 per cent, and of the value of fish proper 3 per cent. Considerably over one-half of the entire catch was made in Lake Michigan, where this fish represented over one-half of the weight and one-third of the value of the total product.

The following tabular statement gives the quantity and value of the catch, distributed by fishing grounds:

\begin{tabular}{|c|c|c|c|c|}
\hline \multirow{3}{*}{ FISUINO GROUND. } & \multicolumn{4}{|c|}{ LAKE-HERRINO PRODUCT: 1908.} \\
\hline & \multicolumn{2}{|c|}{ Quantity. } & \multicolumn{2}{|c|}{ Value. } \\
\hline & Pounds. & $\begin{array}{c}\text { Per cent } \\
\text { distribu- } \\
\text { tlon. }\end{array}$ & A mount. & $\begin{array}{c}\text { Per cent } \\
\text { distribil- } \\
\text { tion. }\end{array}$ \\
\hline Total............. & $41,118,000$ & 100 & $\$ 989,000$ & 100 \\
\hline 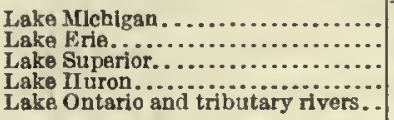 & $\begin{array}{r}21,059,000 \\
10,000,000 \\
5,361,000 \\
4,064,000 \\
35,000\end{array}$ & $\left(\begin{array}{l}51 \\
26 \\
13 \\
10\end{array}\right.$ & $\begin{array}{r}551,000 \\
286,000 \\
78,000 \\
72,000 \\
1,700\end{array}$ & $\begin{array}{r}56 \\
29 \\
8 \\
7\end{array}$ \\
\hline
\end{tabular}

Nearly five-eighths of the quantity of the product was reported as marketed fresh, the remainder being salted or smoked. The following tabular statement gives the statistics of the catch according to the condition in which it was marketed, the states being ranked according to the value of their catch:

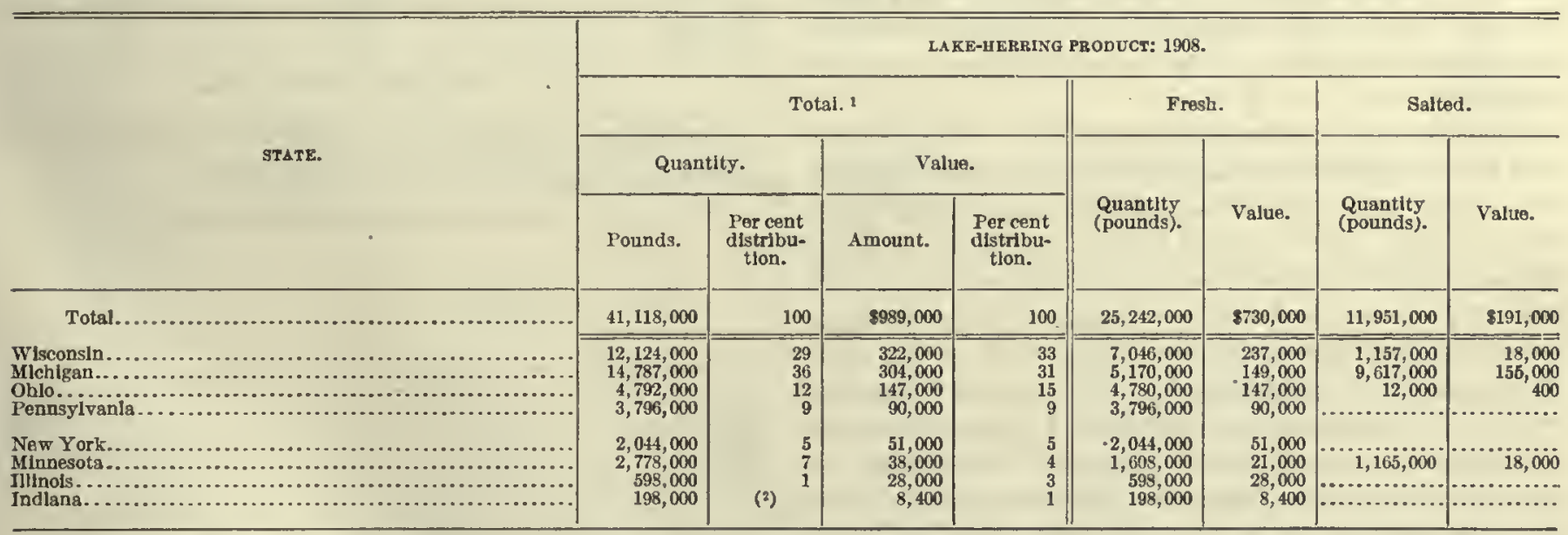

1. Includes $3,925.000$ pounds of smoked lake berrlng, valued at $\$ 67,000$, distrlbuted as follows: Wisconsin, $3,921,000$ pounds, valued at $\$ 67,000$, and Minnesota, 4,000 pounds, valued at $\$ 200$.

Less than 1 per cont.

Every state bordering on the Great Lakes shared in the catch, but Wisconsin and Michigan took far greater quantities than any others, the Michigan catch being the largest and the Wisconsin catch of the greatest value. The higher value of the Wisconsin product was due to the fact that more than one-half was sold fresh, while only about one-third of the Michigan product was so marketed. The bulk of the salted herring was from Michigan, and nearly all the smoked product was from Wisconsin.

Comparative figures for certain years are given in the following tabular statement: 


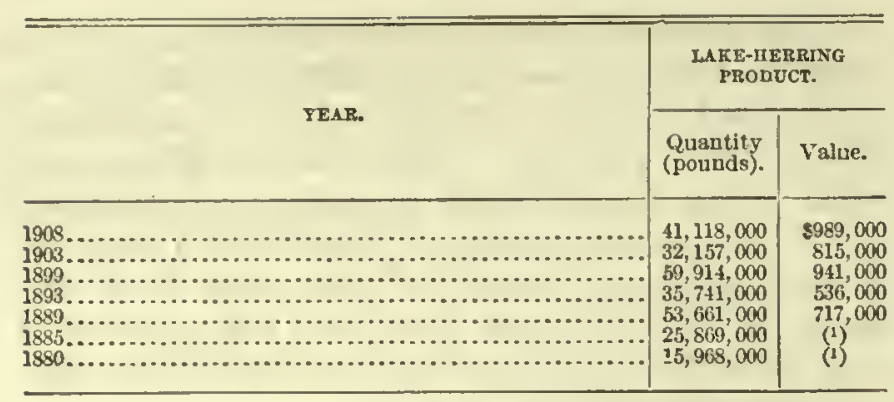

1 Kiot reported.

Although the value of the product was greater in 1908 than in any previous year, the quantity of the catch of that year was exceeded in 1889 and 1899 .

Besides the herring salted and smoked by the fishermen, a considerable quantity was canned by establishments located mainly in Wisconsin and Michigan. The total output of lake herring from such faetories in 1908 was valued at $\$ 480,000$, and was distributed as follows: Smoked, $\$ 426,000$; salted, $\$ 16,000$; pickled, $\$ 4,600$; and frozen, $\$ 33,000$.

The largest part of the catch, 73 per cent, was made with gill nets, 27 per cent was taken with pound and trap nets, and less than 1 per cent with other apparatus.

Lake trout.-The common lake trout (Cristivomer namaycush) is found in the Great Lakes and in the smaller lakes of the Northern states. In different loealities these fish vary greatly in color, size, and shape, and are known by the local names "salmon trout," "namaycush," "togue," "tuladi," "Mackinaw trout," "lake salmon," "black trout," "reef trout," "longe," etc. The "siscowet" (C. siscowet) is another species of lake trout. It is found principally in Lake Superior.

The lake trout was caught only in the Great Lakes, and the value reported for this species in 1908 was $\$ 800,000$, or 21 per cent of the total value of the products from these waters. Of the total value of the United States fishery products this fish contributed somewhat more than 1 per cent, and of that of fish proper nearly 3 per cent. It was taken by the fisheries of every state bordering the Great Lakes, but 53 per cent of the total value of the product was reported by the fisheries of Michigan and 43 per cent by those of Wisconsin. In both Michigan and Wisconsin lake trout ranked first in value among the fishery products, contributing 29 per cent of the total value of the catch in the former state and 32 per cent in the latter. The following tabular statement gives the statistics of the catch, by states:

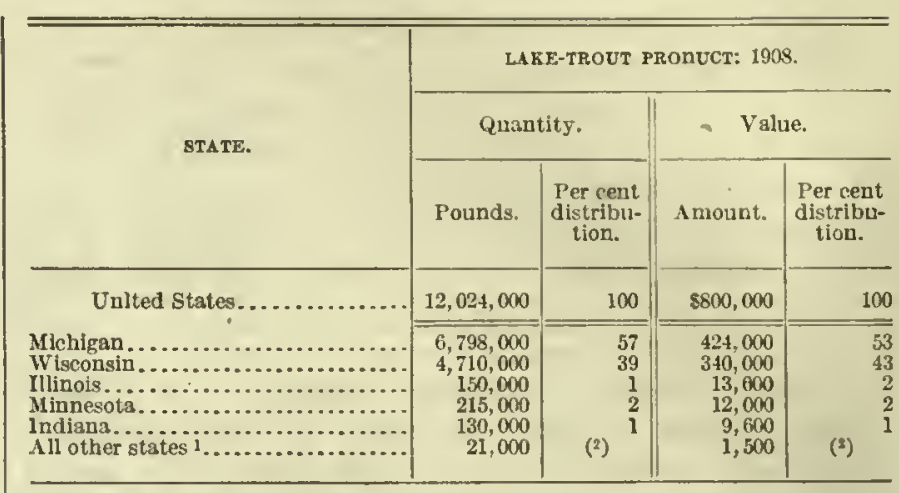

1 Includes New York, Pennsylvanla, and Ohio. " Less than 1 per cent.

Next to lake herring, lake trout was the most valuable species taken in the Great Lakes.

Of the total value reported for this species, $\$ 546,000$ was reported from Lake Michigan, this amount constituting 35 per cent of the total value of the products of this lake, and being exceeded only by the value reported for the lake-herring product.

The clistribution of the quantity and value of the catch by fishing grounds was as follows:

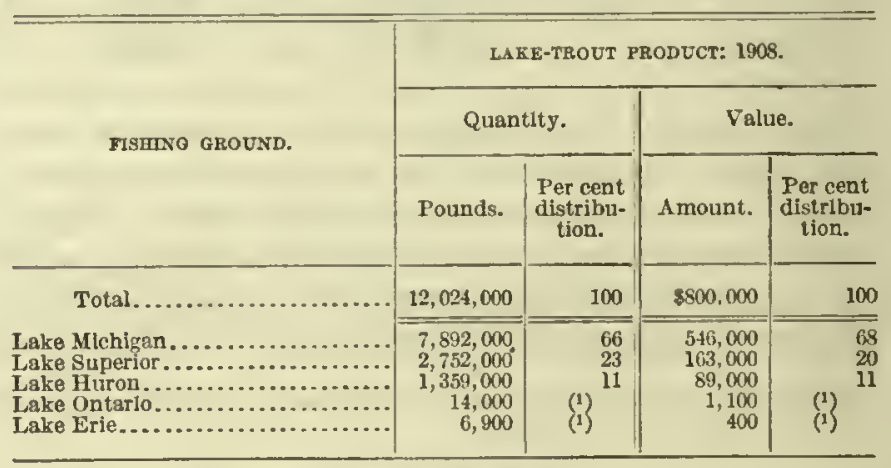

1 Less than 1 per cent.

Comparative figures for previous canvasses are given in the following tabular statement:

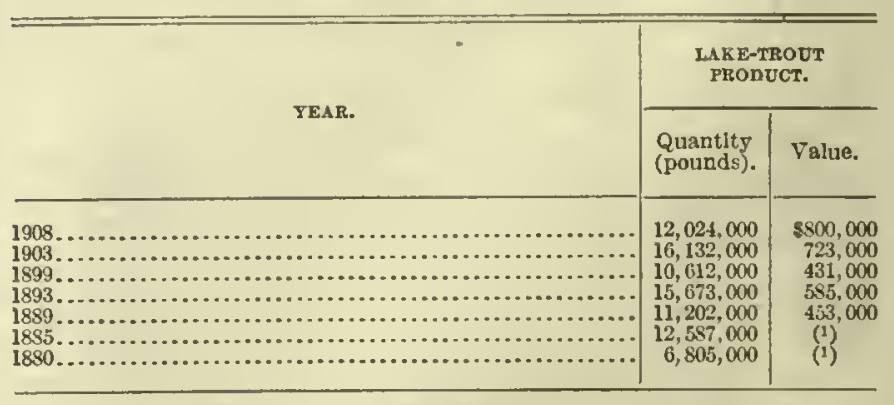

1 Not reported.

The quantity of the catch in 1908 was smaller than that reported at several previous canvasses, but its value has never been exceeded. All of the 1908 prod- 
nct was sold fresh except 353,000 pounds, valued at $\$ 19,000$, which were salted.

The bulk of the value of the lake-trout catch, 76 per cent, represents the value of the catch made with gill nots; 14 per cent, that of the catch with lines; 10 per cent, that of the catch with pound and trap nets; and a small amount, that of the catch with fyke and hoop nets and seines. The following tabular statement gives the statistics of the catch, by apparatus of capture:

\begin{tabular}{|c|c|c|c|c|}
\hline \multirow{3}{*}{ KIND OF APPARATUG. } & \multicolumn{4}{|c|}{ LARF-TROUT PRODUCT: 1908.} \\
\hline & \multicolumn{2}{|c|}{ Quantity. } & \multicolumn{2}{|c|}{ Value. } \\
\hline & Pounds. & $\begin{array}{l}\text { Per cent } \\
\text { distribu- } \\
\text { tion. }\end{array}$ & Amount. & $\begin{array}{l}\text { Per rent } \\
\text { distribu- } \\
\text { tion. }\end{array}$ \\
\hline Total......... & $12,024,000$ & 100 & $\$ 300,000$ & 100 \\
\hline 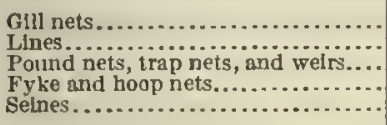 & $\begin{array}{r}9,460,000 \\
1,495,000 \\
1,057,000 \\
10,000 \\
1,600\end{array}$ & $\begin{array}{r}79 \\
12 \\
\text { (1) } \\
\text { (1) }\end{array}$ & $\begin{array}{r}610,000 \\
113,000 \\
77,000 \\
800 \\
100\end{array}$ & (1) 10 \\
\hline
\end{tabular}

1 Less than 1 per cent.

Lobster (Homarus americanus).--The lobster, a decapod crustacean of great economic importance, is found on the Atlantic coast from Delaware to Labrador. It averages about 11 inches in length and about 2 pounds in weight, but the size varies with localities and seasons. It is caught in pots and traps especially constructed for the purpose.

The value of the lobster product in $1908, \$ 1,931,000$, placed it first among all crustaceans, second only to the oyster among marine invertebrates, and fifth among the entirc fishery products of the United States. The catch, by states, is given in the following tabular statement. It will bo noted that the order of rank according to value follows more or less closely the geographical order from north to south.

\begin{tabular}{|c|c|c|c|c|}
\hline \multirow{3}{*}{ STATE. } & \multicolumn{4}{|c|}{ LOBSTER PRODUCT: 1908.} \\
\hline & \multicolumn{2}{|c|}{ Quantity. } & \multicolumn{2}{|c|}{ Value. } \\
\hline & Pounds. & $\begin{array}{l}\text { Per cent } \\
\text { distribu- } \\
\text { tion. }\end{array}$ & Amount. & $\begin{array}{l}\text { Per cent } \\
\text { distribu- } \\
\text { tion. }\end{array}$ \\
\hline United States................. & $15,279,000$ & 100 & $\$ 1,931,000$ & 100 \\
\hline 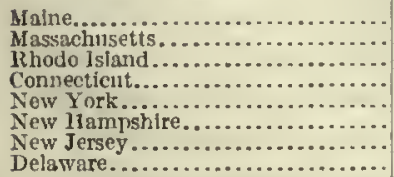 & $\begin{array}{r}9,929,000 \\
2,455,000 \\
1,425,000 \\
661,000 \\
423,000 \\
264,000 \\
115,000 \\
5,500\end{array}$ & $\begin{array}{r}65 \\
16 \\
9 \\
4 \\
3 \\
2 \\
1\end{array}$ & $\begin{array}{r}1,269,000 \\
307,000 \\
152,000 \\
81,000 \\
57,000 \\
43,000 \\
16,000 \\
800\end{array}$ & $\begin{array}{r}66 \\
16 \\
8 \\
4 \\
3 \\
2 \\
1\end{array}$ \\
\hline
\end{tabular}

The lobster product was essentially a New England product, the catch of the Middle Atlantic states forming less than 4 per cent of the total. The Maine lob- ster eatch represented nearly 40 per cent of the value of all fishery products of that state.

In the following comparative statement for the New England states and the Middle Atlantic states, respectively, statisties are given of the quantity and value of the catch for those years covered by previous canvasses. The largest product shown for any period is that of over thirty million pounds reported in 18891891, the greater part of which came from the New England states. By comparing the returns from the New England states for 1880 with those for 1908 a decrease of 26 per cent in the quantity of the catch and an increase of 292 per cent in its value are shown.

\begin{tabular}{|c|c|c|}
\hline \multirow[b]{2}{*}{ STATE GROUP AND YEAR. } & \multicolumn{2}{|c|}{ LOBSTER PRONUCT. } \\
\hline & $\begin{array}{l}\text { Quantity } \\
\text { (pounds). }\end{array}$ & Value. \\
\hline 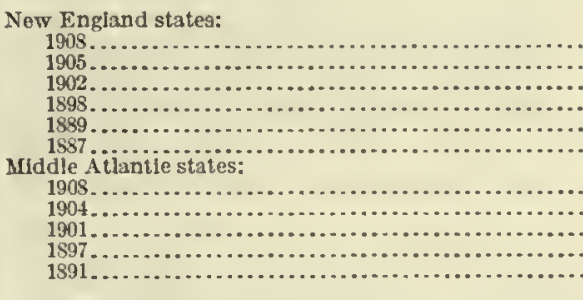 & $\begin{array}{r}14,735,000 \\
11,524,000 \\
14,756,000 \\
14,662,000 \\
30,450,000 \\
27,674,000 \\
545,000 \\
874,000 \\
252,000 \\
485,000 \\
339,000\end{array}$ & $\begin{array}{r}\$ 1,857,000 \\
1,319,000 \\
1,337,000 \\
1,277,000 \\
834,000 \\
732,000\end{array}$ \\
\hline
\end{tabular}

To a certain extent the growth of the lebster fishery under the protection of restrictive laws is directly connected with the history of the lobster-canning industry of Maine, first started in 1842. At first the lobsters used for canning varied in weight from 3 to 10 pounds, but gradually, owing to the high price obtainable for fresh lobsters, the weight fell until lobsters weighing as low as three-fourths of a pound were employed. As a result of the very perceptible diminution in the anmual product caused by this destruction of the young, canneries were in 1879 prohibited from packing lobsters except from April 1 to August 1, while in 1883 it was mado illegal to can lobsters less than 9 inches in length. The canning season was subsequently shortened by law until in 1891 it was limited to the weeks between April 20 and June 1. The last blow to the canning business, which had been rapidly declining, was given in 1895, when the minimum length for canning was fixed at $10 \frac{1}{2}$ inches. Since this legislation was passed the industry has disappeared from Maine. As carly as 1884 every state interested had passed laws to regulate and protect the lobster fishery. At about the same time artificial propagation was begun by the United States Fish Commission in an endeavor to check the diminution and possibly increase the supply; but so far these efforts have met witl little success. In no state can lobsters shorter than 9 inches now be taken, while in all the states the destruction of the female 
carrying eggs is prohibited. Not only are the fry and larvæ artificially liatclied and liberated, but the young lobsters are protected through the fourti or fifth larva stages, in order to insure them against the many dangers they encounter during the earlier period of their existence.

Since the lobster-canning business in the United States has ceased, the importation of lobsters has greatly increased. The following tabular statement shows the importation of lobsters, canned and uncanned, for 1890,1900 , and 1908 , for the fiscal years ending June 30:

\begin{tabular}{|c|c|c|c|c|c|}
\hline \multirow{3}{*}{ BOURCE. } & \multicolumn{5}{|c|}{ IMPORTS OP LOBSTERS. } \\
\hline & \multicolumn{2}{|c|}{1908} & \multicolumn{2}{|c|}{1900} & \multirow{2}{*}{$\frac{1890}{\text { Value. }}$} \\
\hline & $\begin{array}{l}\text { Quantity } \\
\text { (pounds). }\end{array}$ & Value. & $\begin{array}{l}\text { Quantity } \\
\text { (pounds). }\end{array}$ & Value. & \\
\hline Total.............. & $8,213,000$ & $\$ 1,401,000$ & $7,497,000$ & $\$ 931,000$ & $\$ 568,000$ \\
\hline $\begin{array}{l}\text { Brltish Arrica................ } \\
\text { Canada... ....... } \\
\text { Newfoundland and Labrador. } \\
\text { All other sources............... }\end{array}$ & $\begin{array}{r}136,000 \\
8,064,000 \\
5,300 \\
7,700\end{array}$ & $\begin{array}{r}23,000 \\
1,375,000 \\
1,500 \\
1,800\end{array}$ & $\begin{array}{r}144,000 \\
7,329,000 \\
17,000 \\
7,100\end{array}$ & $\begin{array}{r}11,000 \\
915,000 \\
3,400 \\
1,400\end{array}$ & $\begin{array}{r}491,000 \\
76,000 \\
800\end{array}$ \\
\hline
\end{tabular}

The entire catch was made in pots or traps. The lobsters are taken from the traps and put into floating cages called cars, where they are kept until enough are gathered to warrant shipment. They are marketed either alive or boiled. On account of the higher price received for the former the dealers often keep them until sold in "live-cars," which are similar to those used by the fishermen but much larger. Dealers often build large pounds sometimes covering a number of acres, where lobsters are fed until a satisfactory price may be obtained.

Lobster, spiny.-Closely allied to the American lobster is the spiny or rock lobster, often called crawfish or crayfish, found on the coast of California from Monterey to San Diego, and also along the Gulf coast of Florida. Its flesh is coarser and less tender than that of the eastern lobster, but its characteristics and habits are similar. The spiny lobster is more active, however, swimming more rapidly through the water and more often escaping from the ordinary lobster pots.

The total catch in the United States in 1908 was 626,000 pounds, valued at $\$ 71,000$, which was a little more than half the quantity caught in 1902-1904, but about equal to the normal catch for the past ten years. This fishery has reached much larger proportions in California than in Florida. In 1908, 573,000 pounds, valued at $\$ 69,000$, were caught in California and only 53,000 pounds, valued at $\$ 2,600$, in Florida. The statistics of the catch of California and of Florida for those years for which returns are available are given in the following tabular statement:

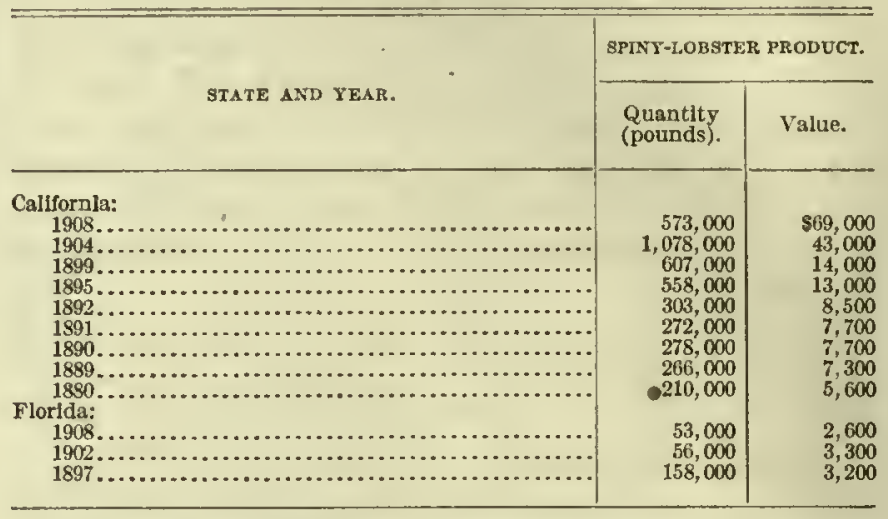

In California the spiny-lobster product increased steadily from 1880 to 1899 . In 1904 there was an abnormal catch, but in 1908 the total catch, while greater than that in $\mathbf{1 8 9 5}$, was slightly less than the catch in 1899.

The entire catch in the state of California in 1908 was made with traps. Formerly set nets were used extensively, especially by the Japanese fishermen, but with great damage to the industry, for if small lobsters under legal size were caught in these nets, it was almost impossible to remove them without seriously maiming or crippling them. As early as 1894 the several counties in California where these lobsters were caught had made local provisions prohibiting the sale or catching of lobsters from May 15 to July 15, and fixing 1 pound as the minimum weight. They are now protected by state laws establishing a closed season from February 15 to September 15 and limiting the size to be caught.

The California spiny lobster is canned as well as sold fresh.

Mackerel (Scomber scombrus). - The mackerel is found in the north Atlantic south as far as Cape Hatteras. It ranges from 9 to 18 inches in length and from one-half pound to 3 pounds in weight, and is caught in purse seines, pound nets, weirs, gill nets, etc., and with hook and line. Small mackerel are known as "spikes" when from 5 to 6 inches in length, as "blinkers" when from 7 to 8 inches in lengtll, and as "tinkers" when 9 inches in length.

The catch in 1908 amounted to $12,103,000$ pounds, valued at $\$ \$ 48,000$. Four-fifths of this quantity was marketed fresh and the remaining one-fifth was salted. All of the salted mackerel, except a small amount reported from Maine, was taken by the vessel fisheries of Massachusetts. The following tabular statement gives the statistics of the catch, by states: 


\begin{tabular}{|c|c|c|c|c|}
\hline \multirow{3}{*}{ CONDITION OF PRODUCT AND STATE. } & \multicolumn{4}{|c|}{ MACKEREL PRODUCT: 1908.} \\
\hline & \multicolumn{2}{|c|}{ Quantity. } & \multicolumn{2}{|c|}{ Value. } \\
\hline & Pounds. & $\begin{array}{l}\text { Per cent } \\
\text { distribu- } \\
\text { tion. }\end{array}$ & Amount. & $\begin{array}{l}\text { Per cent } \\
\text { distribu- } \\
\text { tion. }\end{array}$ \\
\hline Unlted States.. & $12,103,000$ & 100 & $\$ 818,000$ & 100 \\
\hline 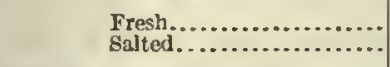 & $\begin{array}{l}9,870,000 \\
2,233,000\end{array}$ & $\begin{array}{l}82 \\
18\end{array}$ & $\begin{array}{l}686,000 \\
162,000\end{array}$ & $\begin{array}{l}81 \\
19\end{array}$ \\
\hline 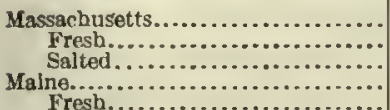 & $\begin{array}{r}10,453,000 \\
8,222,000 \\
2,231,000 \\
380,000 \\
378,000\end{array}$ & $\begin{array}{r}86 \\
68 \\
18 \\
3 \\
3\end{array}$ & $\begin{array}{r}761,000 \\
60,000 \\
161,000 \\
31,000 \\
31,000\end{array}$ & $\begin{array}{r}90 \\
71 \\
19 \\
4 \\
4\end{array}$ \\
\hline Salted........ & $\begin{array}{l}3 / 8,200 \\
2,200\end{array}$ & (1) 3 & & (') \\
\hline Rhode Island...................... & 537,000 & & 25,000 & 3 \\
\hline $\begin{array}{l}\text { Now Jersey } \\
\text { Connectient } \ldots \ldots \ldots, \ldots, \ldots, \ldots, \ldots, \ldots, \ldots\end{array}$ & $\begin{array}{l}501,000 \\
122,000\end{array}$ & $\begin{array}{l}4 \\
1\end{array}$ & $\begin{array}{r}14,000 \\
8,900\end{array}$ & 1 \\
\hline New York.................................. & 106,000 & & 6,600 & \\
\hline Maryland................................ & 4,400 & (1) & 900 & (1) \\
\hline
\end{tabular}

1 Les: than 1 per cent.

The quantity and value of the mackerel catch for prior years, so far as statistics are available, are given in the following tabular statement:

\begin{tabular}{|c|c|c|}
\hline \multirow{2}{*}{ YEAR. } & \multicolumn{2}{|c|}{ MACKERFL PRODUCT. } \\
\hline & $\begin{array}{l}\text { Quantity } \\
\text { (pounds). }\end{array}$ & Value. \\
\hline 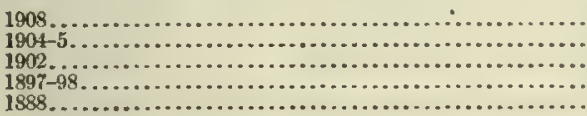 & $\begin{array}{r}12,103,000 \\
16,324,000 \\
20,359,000 \\
8,960,000 \\
16,212,000\end{array}$ & $\begin{array}{r}\$ 848,000 \\
1,107,000 \\
1,137,000 \\
491,000 \\
1,109,000\end{array}$ \\
\hline
\end{tabular}

The data given for 1902 are for the New England states alone, there being no statistics for the Middle Atlantic states for that year. The catch of the Middle Atlantic states, however, is of slight relative importance, having constituted, in the years for which figures are available, only about 2 per cent of the total.

About 72 per cent of the total value of the mackerel product represented the value of the catch with seines, 22 per cent the value of that made with gill nets, 5 per cent the value of that with pound nets, trap nets, and weirs, and 1 per cent the value of the capture with lines.

The statistics for the chub mackerel (Scomber japonicus) and the Spanish mackerel (Scomberomorus maculatus) are not included in the foregoing presentation. The catch of the chub mackerel in 1908 amounted to 639,000 pounds, valued at $\$ 16,000$, the greater part of which was taken by Rhode Island fishermen. While this species closely resembles the common mackerel, and is an excellent food fish, the average price in 1908 was much lower than that of the common mackerel. The catch of Spanish mackerel was $3,806,000$ pounds, valued at $\$ 194,000$, the greater part of which was reported from Florida.

Menhaden (Brevoortia tyrannus). - The menhaden is a fish of the herring family, found along the Atlantic seaboard from Maine to Florida. It is known by a great many local names, the most common being "pogy," "hardhead," "hardhead shad," "bony fish," "whitefish," "mossbunker," "'bunker," "cheboy," "marshbanker," "alewife," "oldwife," "ellwife," "pilcher," "green-tail," "bug-fish," "bug-shad," "bughead," "fat-back," "ycllowtail," "shiner," "herring," etc. The average length of menhaden is from 10 to 12 inches, and the average weight from two-thirds of a pound to 1 pound. They are caught in purse seines, haul seines, gill nets, set nets, and weirs. Their economic importance is due mainly to the oil and guano which are produced from them; they are also used as bait for mackerel, cod, halibut, haddock, and sea bass. As a food fish they are sold fresh, salted, and canned. "Fish meal," a food for domestic animals, is also made from them.

The menhaden is the most abundant fish found anywhere in the waters of the United States and forms one of the principal fishery products. The total catch in 1908 was $394,776,000$ pounds, which quantity represented one-fifth of the weight of all fishery products of the country, and was nearly 70 per cent greater than the weight of the fishery product next in rank. In value, however, this fish ranked fourteenth, contributing $\$ 893,000$ in 1908 , or only 2 per cent of the value of all fishery products. The catch, by states, is given in the following tabular statement, in which the states are ranked according to the value of their respective products:

\begin{tabular}{|c|c|c|c|c|}
\hline \multirow{3}{*}{ - STATE. } & \multicolumn{4}{|c|}{ MENHADEN PRODUCT: 1908.} \\
\hline & \multicolumn{2}{|c|}{ Quantity. } & \multicolumn{2}{|c|}{ Value. } \\
\hline & Pounds. & $\begin{array}{l}\text { Per cent } \\
\text { distribu. } \\
\text { tlon. }\end{array}$ & Amount. & $\begin{array}{l}\text { Per cent } \\
\text { distribu- } \\
\text { tion. }\end{array}$ \\
\hline United States.............. & $394,776,000$ & 100 & 8893,000 & 100 \\
\hline 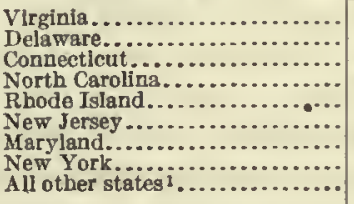 & $\begin{array}{r}190,089,000 \\
59,815,000 \\
28,636,000 \\
57,412,000 \\
17,942,000 \\
12,417,000 \\
12,293,000 \\
12,762,000 \\
3,411,000\end{array}$ & $\begin{array}{r}48 \\
15 \\
7 \\
15 \\
5 \\
3 \\
3 \\
3 \\
1\end{array}$ & $\begin{array}{r}429,000 \\
152,000 \\
93,000 \\
70,000 \\
48,000 \\
43,000 \\
30,000 \\
22,000 \\
5,400\end{array}$ & $\begin{array}{r}48 \\
17 \\
10 \\
8 \\
5 \\
5 \\
3 \\
2 \\
1\end{array}$ \\
\hline
\end{tabular}

1 Includes Alabama, Florlda, Massachusetts, and Mlssissippl.

In 1908 menhaden fishing was pursued along the Atlantic coast from Massachusetts to North Carolina, and a small quantity of the fish was also taken in the Gulf of Mexico off the coast of Florida. The menhaden is very irregular in its movements. Some years it goes as far north as Nova Scotia, and several menhaden factories are situated in Maine ready to be operated when the fish appear on that coast. In 1908 these factories were not operated. In 1900 this fish was found along the const of Texas, but none was taken in that locality in 1908. Menhaden approach the coast waters upon the advent of warm weather and remain until the water cools. They are seen as 
early as March in Chesapeake Bay, but not until much later in the more northern waters. They usually leave the colder waters of the North early in September, but are found around Cape IIatteras as late as January.

It is impossible to give thoroughly comparable data for former years for the United States as a whole, but composite statistics are given in the following tabular statement for the years 1880, 1889-1891, 1901-2, and 1908:

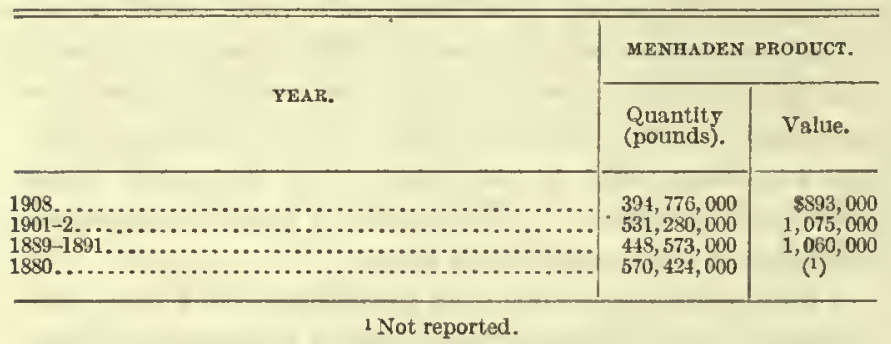

This fishery appears to have been less profitable in 1908 than in former years.

Purse and haul seines were the principal forms of apparatus of capture used in this fishery, these two alone taking 94 per cent of the total quantity in 1908 . Pound nets, trap nets, and gill nets took 6 per cent of the product, while all other apparatus cont ributed less than 1 per cent. The following tabular statement gives the distribution of the product by apparatus of capture:

\begin{tabular}{|c|c|c|c|c|}
\hline \multirow{3}{*}{ KIND OF APPARATUS. } & \multicolumn{4}{|c|}{ MENHADEN PRODUCT: 1908.} \\
\hline & \multicolumn{2}{|c|}{ Quantity. } & \multicolumn{2}{|c|}{ Value. } \\
\hline & Pounds. & $\begin{array}{l}\text { Per cent } \\
\text { distribu- } \\
\text { tion. }\end{array}$ & Amount. " & $\begin{array}{l}\text { Per cent } \\
\text { dlstribu- } \\
\text { tion. }\end{array}$ \\
\hline Total.................... & $394,776,000$ & 100 & $\$ 893,000$ & 100 \\
\hline 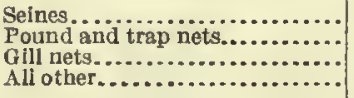 & $\begin{array}{r}371,636,000 \\
21,138,000 \\
1,983,000 \\
18,000\end{array}$ & $\begin{array}{r}94 \\
5 \\
1 \\
\text { (1) }\end{array}$ & $\begin{array}{r}822,000 \\
67,000 \\
3,300 \\
200\end{array}$ & (1) $\begin{array}{r}92 \\
8\end{array}$ \\
\hline
\end{tabular}

I Less than 1 per cent.

Mullets (Mugil cephalus and M. curema).-Two species of mullet, known as the striped mullet and the white mullet, figure among the fishery products of the United States. The striped mullet is found on the Atlantic coast from Cape Cod to Florida and on the coast of southern California, ascending streams; and the white mullet, on the Atlantic coast from Cape Cod southward. Local names are "bluefish mummichog," "jumping mullet," "sand mullet," "fat-back," "silver mullet," "big-eyed mullet," "blue-back mullet," "Liza," and "Josea." M. cephalus is the most important food fish of the South, and greatly surpasses M. curema both in numbers and in economic importance. It averages about 1 foot in length and 1 pound in weight, but sometimes reaches a weight of from 4 to 5 pounds and a length of 2 feet. It is caught in haul seines, gill nets, cast nets, pound nets, etc., and is sold fresh and salted; the roe is also very valuable food, and is sold fresh, salted, smoked, and dried.

Mullet in 1908 ranked thirteenth in value among the fishery products of the United States. Its value, including that of roe, was $\$ 908,000$, forming 2 per cent of the value of the entire fishery product and 3 per cent of the value of the fish product proper. In the Gulf of Mexico fisheries, from which over half of the total was obtained, it ranked fourth in value and represented 11 per cent of the total value of products reported for these fisheries. The following tabular statement gives the mullet catch by states, which are arranged according to the value of their product:

\begin{tabular}{|c|c|c|c|c|}
\hline \multirow{3}{*}{ STATE. } & \multicolumn{4}{|c|}{ YULLET PRODUCT: 1908.} \\
\hline & \multicolumn{2}{|c|}{ Quantity. } & \multicolumn{2}{|c|}{ Value. } \\
\hline & Pounds. & $\begin{array}{c}\text { Per cent } \\
\text { distri- } \\
\text { bution. }\end{array}$ & Amount. & $\begin{array}{l}\text { Per cent } \\
\text { distri- } \\
\text { bution. }\end{array}$ \\
\hline United States................ & $33,703,000$ & 100 & $\$ 908,000$ & 100 \\
\hline 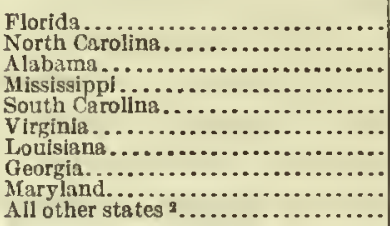 & $\begin{array}{r}24,582,000 \\
5,070,000 \\
1,656,000 \\
1,035,000 \\
664,000 \\
264,000 \\
133,000 \\
194,000 \\
47,000 \\
59,000\end{array}$ & $\begin{array}{rr}73 \\
15 \\
5 \\
3 \\
2 \\
\\
1 \\
\text { (1) } \\
\text { (1) } \\
\text { (1) }\end{array}$ & $\begin{array}{r}637,000 \\
175,000 \\
33,000 \\
20,000 \\
19,000 \\
9,100 \\
5,600 \\
5,400 \\
1,600 \\
2,600\end{array}$ & $\begin{array}{r}70 \\
19 \\
4 \\
2 \\
2 \\
1 \\
1 \\
1\end{array}$ \\
\hline
\end{tabular}

1 Less than 1 per cent.

2 Includes Delaware, Texas, New Jersey, California, and New York.

Florida, in which state mullet was the leading product, furnislied the bulk of the catch.

The mullet reported as salted amounted to $3,020,000$ pounds, with a value of $\$ 122,000$, of which $1,855,000$ pounds, valued at $\$ \$ 0,000$, were from North Carolina; $1,046,000$ pounds, valued at $\$ 39,000$, from Florida; and $\$ 9,000$ pounds, valued at $\$ 3,100$, from South Carolina. The balance was marketed fresh. Included with this salted mullet are 135,000 pounds of salted roe, valued at $\$ 15,000$.

The value of the total mullet product in 1908 was greater than that for any previous year, although the quantity was exceeded in 1902-1904. The following tabular statement gives the yield for those years for which statistics are available:

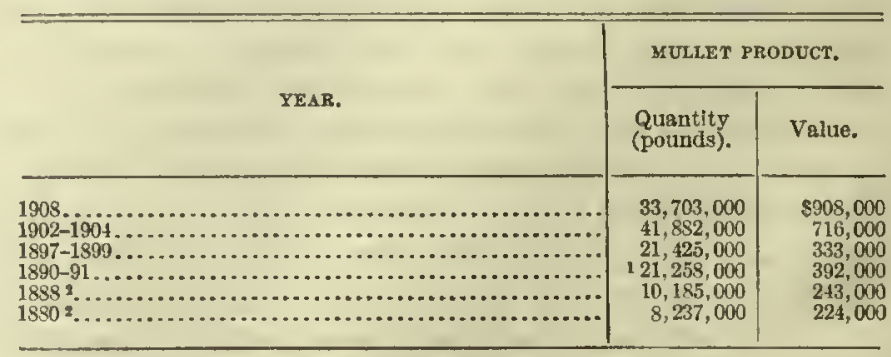

1 Exclusive of the product of the Pacific coast division, for which the quantity was not reported.

Erclusive of the product of the Paclfic coast division.

The quantity and value of the salted mullet-roe product for certain years are given in the following tabular statement: 


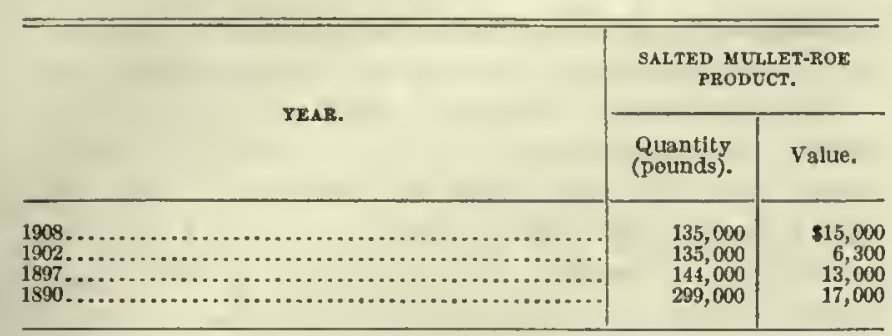

Gill nets took two-thirds of the mullet caught and seines almost one-fourth.

Mussels.-The black, thin-shelled salt-water mussel (Mytilus edulis) is found on the Atlantic coast as far south as North Carolina and on the Pacific coast north of Monterey. The shells are used as a cultch for young oysters, as paint holders, and as ornaments. Large quantities of another genus (Modiola) are sold to farmers along the New Jersey and Long Island coasts for fertilizer. The fresh-water mussels (Union$i d x$ ) are of much value as food for animals and birds, and the shells are used in making pearl buttons.

Mussels appear among the products of 17 states. In the case of the salt-water product the quantity of the catch is reported on the contained meat basis, while for the fresh-water varicties, which are taken primarily for the shells and pearls, the quantity represents the weight of shells. The salt-water product, which is the product referred to in this report under the head of "Mussels," is included in the returns of six statesCalifornia, Connecticut, Massachusetts, New Jersey, New York, and Rhode Island. Connecticut was the only one of these states reporting also the fresh-water varicties. The remaining 11 states which had mussel fisheries obtained their product entirely from the fresh waters of the Mississippi River and its tributaries. The meat of the salt-water product is sold for bait to fishermen and for fertilizer to farmers, and is also pickled and sold as an article of food. The shell of the salt-water mussel is utilized to a certain extent in the manufacture of buttons and mother-of-pearl articles, but no record of this shell product enters into the returns given in the present report. The statistics of the salt-water product are given in the following tabular' statement:

\begin{tabular}{|c|c|c|c|c|}
\hline \multirow{3}{*}{ STATE. } & \multicolumn{4}{|c|}{ SUUSEI PRODUCT: $190 S$. } \\
\hline & \multicolumn{2}{|c|}{ Quantity. } & \multicolumn{2}{|c|}{ Value. } \\
\hline & Pounds. & $\begin{array}{l}\text { Per cent } \\
\text { distribu- } \\
\text { tíen. }\end{array}$ & Amount. & $\begin{array}{l}\text { Per cent } \\
\text { distribu- } \\
\text { tion. }\end{array}$ \\
\hline United States.. & $8,542,000$ & 100 & $\$ 12,000$ & 100 \\
\hline $\begin{array}{l}\text { New York.......... } \\
\text { California........... } \\
\text { New Jersey........... } \\
\text { Connecticut....... } \\
\text { Rhode lsiand...... } \\
\text { Massachusetts...... }\end{array}$ & $\begin{array}{r}8,175,000 \\
68,000 \\
287,000 \\
7,200 \\
3,500 \\
1,100\end{array}$ & $\begin{array}{l}\quad 96 \\
1 \\
\text { (1) } \\
\text { (1) } \\
\text { (1) } \\
\text { (1) }\end{array}$ & $\begin{array}{r}8,200 \\
1,600 \\
1,400 \\
200 \\
100 \\
100\end{array}$ & $\begin{array}{r}68 \\
13 \\
12 \\
2 \\
1 \\
1\end{array}$ \\
\hline
\end{tabular}

1 Less than 1 per cent. $76786^{\circ}-11 \longrightarrow 5$
The products of the fresh-water mussel-shell fisheries were as follows:

\begin{tabular}{|c|c|c|c|c|}
\hline \multirow{3}{*}{ STATE. } & \multicolumn{4}{|c|}{ MUSSELSHELL PBODUCT: 1908.} \\
\hline & \multirow{2}{*}{$\begin{array}{l}\text { Quantity } \\
\text { (pounds). }\end{array}$} & \multicolumn{3}{|c|}{ Value. } \\
\hline & & Total. & Shells. & $\begin{array}{l}\text { Pearls } \\
\text { and } \\
\text { slugs. }\end{array}$ \\
\hline United States.............. & $81,869,000$ & $\$ 692,000$ & $\$ 392,000$ & $\$ 300,000$ \\
\hline 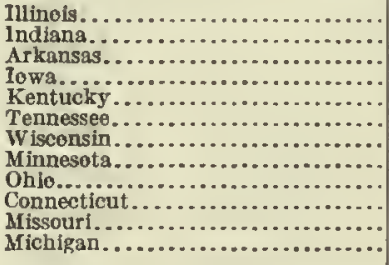 & $\begin{array}{r}39,809,000 \\
14,431,000 \\
8,060,000 \\
4,699,000 \\
3,413,000 \\
2,170,000 \\
1,150,000 \\
767,000 \\
1,697,000 \\
6,403,000 \\
170,000 \\
200,000\end{array}$ & $\begin{array}{r}355,000 \\
155,000 \\
70,000 \\
44,000 \\
20,000 \\
14,000 \\
12,000 \\
8,400 \\
7,000 \\
5,400 \\
1,600 \\
800\end{array}$ & $\begin{array}{r}184,000 \\
81,000 \\
42,000 \\
33,000 \\
18,000 \\
9,400 \\
6,900 \\
4,700 \\
6,600 \\
5,400 \\
1,000 \\
800\end{array}$ & $\begin{array}{r}170,000 \\
74,000 \\
28,000 \\
11,000 \\
1,900 \\
4,200 \\
5,400 \\
3,700 \\
400 \\
\ldots . . . . \\
600\end{array}$ \\
\hline
\end{tabular}

Illinois reported 52 per cent of the total value of the mussel-shell product and considerably more than one-half of the value of the pearl output. Indiana was next in order, contributing a product valued at 22 per cent of the total. The fisheries of the Ohio River and its tributaries, during 1908, were more prolific than those of the Mississippi River proper. Of the total value of the Illinois product, $\$ 114,000$ came from the Ohio River, which, added to the value of the yield from Indiana, Ohio, Kentucky, and Tennessee, made a total of $\$ 309,000$ as the value of the mussel-shell product of this river and its tributaries. The Illinois River produced shells valued at $\$ 139,000$, which leaves a balance of $\$ 239,000$ as the value of those reported from the Mississippi and its other tributaries. Considerably over half the value of pearls reported $(\$ 154,000)$ was from the Ohio River district, as compared with a value of $\$ 146,000$ reported from the Mississippi River district, including the fisheries of the Illinois River. Of shells, however, the Mississippi River district, including the Illinois River, produced a quantity valued at $\$ 230,000$, compared with the product of the Ohio River district, which had a value of $\$ 156,000$. In the Ohio River district the mussel product was much more valuable than that of all other fishery products combined, and in the Mississippi River district it was second only to carp.

The total shell product for 1908 shows an increase of 72 per cent in quantity and 81 per cent in value, compared with 1899 , when the quantity was $47,648,000$ pounds, valued at $\$ 216,000$. The yield of pearls was not reported in 1899. In the returns of sliells for that year only five states were represented-Illinois, Iowa, Minnesota, Missouri, and Wisconsin. The Illinois product has had a marked growth from $8,910,000$ pounds in 1899 to $39,809,000$ pounds in 1908. The Minnesota output, too, was much larger in 1908 than 1899. In the other three states, however, there lias been a pronounced decrease. Iowa in 1899 produced 
$20,354,000$ pounds of shells and Wisconsin $16,260,000$ pounds. In 1908 these two states produced, respectively, 4,699,000 and $1,150,000$ pounds. In 1894 the industry was barely started, and the total product was only 196,000 pounds, valued at $\$ 2,700$. Of this, Iowa supplied 148,000 pounds and Illinois the balance.

Pearling has uniformly preceded traffic in shells. In hunting for pearls the fishers wade in the shallow waters, feeling for the mussels with their feet or looking for them through a water telescope, and gather them by liand when found. In deeper water, garden rakes, to which are attached small bag nets, are used from small boats. Tongs are also an implement of common use. As the quantity of pearls taken becomes less and the excitement of hunting for them consequently subsides, the fishermen begin to look to the shells for their main remuneration. They then adopt more systematic methods, making use of the crowfoot dredge. This implement consists of an iron bar to which iron hooks with from two to four prongs are attached at intervals. As the bar is dragged downstream, the mussels, which lio with their valves open upstream, close tightly upon the prongs as soon as touched. Most of the boats are fitted with motors to propel them upstream, while to make the best use of the current downstream a device called a mule is attached. The latter consists of a square of canvas stretched on a frame and let into the water from the prow of the boat, so that it presents a broad surface for the current to act upon.

The decrease in the quantity of the mussel shells taken in the Iowa and Wisconsin fisheries means that the pearl industry in those states is in danger. Manufacturers have been interested in schemes for providing a future supply, either by protective legislation, which shall promote natural increase, or by an attempt at private culture. The latter plan, however, has not been more than considered. The especially discouraging feature is that at least 10 years are required to grow most of the varieties to commercial size, during which period the mollusk is beset with many dangers, both from the fish which prey on it and from the physiographical conditions which surround it. The only experiments in private culture have been in the growth of pearls within the mussel, not of the mussel itself. These attempts have not yet passed beyond the experimental stage. The enactment of protective legislation also presents its problems. Because of the different size of various species at maturity no uniform restriction as to minimum size can be preseribed, and if a specific size for each variety were established it would be impossible, owing to the close resemblance between nearly all of the different species, for any but biologists to do the gathering. Furthermore, as the spawning time is very irregular and uncertain, the proper period for a closed season is difficult to determine. The state of Illinois, however, has enacted legislation establishing a closed season from October 1 to April 1 and has set limits to the eapacity of apparatus used.

The importance of mussel shells dates from 1891, when a German opened a button factory at Muscatine, Iowa, modeled after those in Germany. His attention had been directed to this country by tariff regulations and attracted to this section of the United States by the abundance of shells left after the operations of pearl fishers. Previous to this an attempt to establish such a factory had been made in Tennessee, but had failed. The rapidity of the development of this industry is shown by the fact that at the close of 1897,13 factories had been opened, while during the first six months of 1898,36 others were established in Iowa, Wisconsin, and Illinois.

Pearl fishing was followed throughout the Mississippi Valley by the Indians and by the early settlers in a sinall way, but the first excitement in recent years was in 1878 in Ohio. Since that time at regular intervals "crazes" have developed in one section or another. Among these "crazes" may be mentioned that in Wisconsin begimning in 1889 and later extending down the river, that in Arkansas in 1895, that on the Clinch River in Tennessee in 1901, that on the Wabash in 1903, and that on the Illinois River in 1906. At the height of the excitement in Arkansas it is estimated that 10,000 persons were engaged in pearl fishing. The shells of the mussels were a waste product until the opening of the button factories. Now the shells are the important product of the industry, while pearls furnish the speculative element.

Oyster (Ostrea virginica).-Oysters ranked first in value among all fishery products of the United States in 1908 , with a total product of $33,330,000$ bushels, valued at $\$ 15,713,000$, or 29 per cent of the value of all fishery products. Of the total oyster product, market oysters represented 77 per cent in quantity and 81 per cent in value. Although oysters from private beds formed but 44 per cent of the total quantity, yet culture enlances the value to such an extent that their total value was greater than that of the product from public areas. In the case of private areas the ownership often lies in the state. In some states, however, it is considered a part of the riparian property of the landowners, and in others-Connecticut and New York, for example-oyster ground have been sold outright and the state has no further claim thereon.

The statistics for 1908 of market and seed oysters from public and private areas are given in the next tabular statement.

The oyster industry was reported for every state on both the Atlantic and Pacifie coasts, with the exception of New Hampshire. The greatest production was from the beds of Long Island Sound and Chesapeake Bay. Whilo Connecticut ranked first in tho value of this product, there was little difference in the value of the output of the states of Connecticut, New York, Virginia, and Maryland, each of which yielded 
oysters valued at over $\$ 2,000,000$. Oysters were the principal fishery product in 15 of the 21 states in which oyster fisheries were carried on, viz, Alabama, Connecticut, Delaware, Georgia, Louisiana, Maryland, Mississippi, New Jersey, New York, North Carolina, Pennsylvania, Rhode Island, South Carolina, Texas, and Virginia.

\begin{tabular}{|c|c|c|c|c|}
\hline \multirow{3}{*}{ KIND AND AREA. } & \multicolumn{4}{|c|}{ OYSTER PRODUCT: 1968.} \\
\hline & \multicolumn{2}{|c|}{ Qnantity. } & \multicolumn{2}{|c|}{ Value. } \\
\hline & Bushels. & $\begin{array}{l}\text { Per cent } \\
\text { distribu- } \\
\text { tion. }\end{array}$ & Amount. & $\begin{array}{l}\text { Per eent } \\
\text { distribu- } \\
\text { tion. }\end{array}$ \\
\hline Total....................... & $33,330,000$ & -100 & $315,713,000$ & 100 \\
\hline Market oysters....... & $25,470,000$ & 76 & $12,721,000$ & 81 \\
\hline $\begin{array}{l}\text { From publie areas. .............. } \\
\text { From private areas ............ }\end{array}$ & $\begin{array}{l}14,806,000 \\
10,665,000\end{array}$ & $\begin{array}{l}44 \\
32\end{array}$ & $\begin{array}{l}4,416,000 \\
8,305,000\end{array}$ & $\begin{array}{l}28 \\
53\end{array}$ \\
\hline Seed oysters... & $7,859,000$ & 24 & $2,992,000$ & 19 \\
\hline $\begin{array}{l}\text { From publle areas.............. } \\
\text { From private areas } . . . . . . . . .\end{array}$ & $\begin{array}{l}3,851,000 \\
4,008,000\end{array}$ & $\begin{array}{l}12 \\
12\end{array}$ & $\begin{array}{l}1,035,000 \\
1,957,000\end{array}$ & $\begin{array}{r}7 \\
12\end{array}$ \\
\hline
\end{tabular}

The greatest yield of oysters from natural or public beds was in Chesapeake Bay, the combined product of Maryland and Virginia from public areas representing 47 per cent of the quantity and 58 per cent of the value of the total product from public areas. In Virginia the cultivation of oyster beds was also carried on extensively, and in fact over 57 per cent of the value of all oysters produced in Virginia was contributed by private arcas. In Massachusetts, Rhode Island, Connecticut, New York, New Jersey, Virginia, Georgia, and the Pacific coast states, the majority of the oysters were dredged from private areas, while in Maine, Maryland, North Carolina, South Carolina, Florida, and the Gulf states, the oysters were taken mostly from public beds. Of the product of Pennsylvania and Delaware the larger part was taken from public areas, but the product from private areas had a greater value.

The statistics of the quantity and value of both market and seed oysters, by states ranked according to the amount reported, are given in the following table:

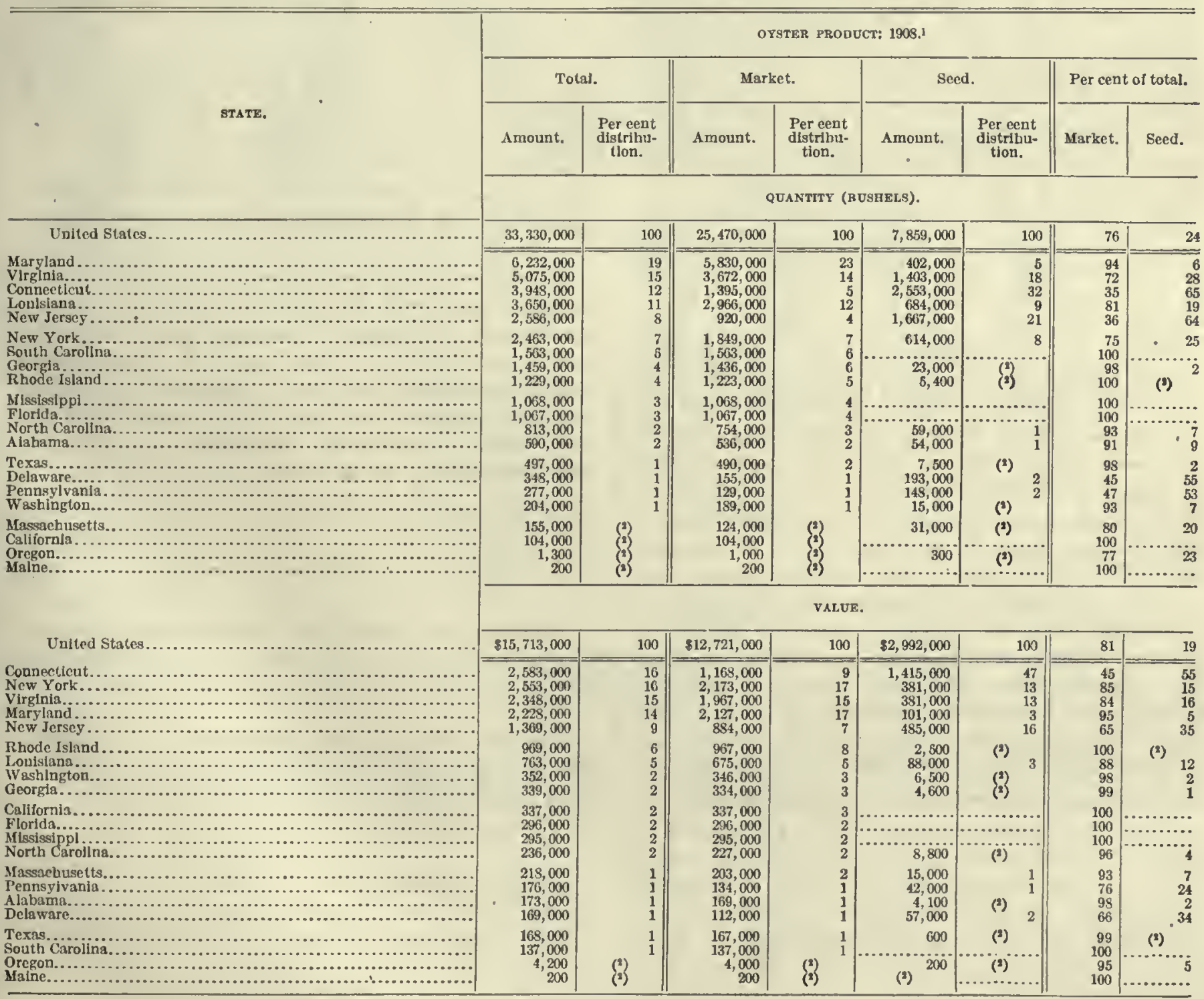


The following tabular statement gives comparative statistics for 1908 and earlier years, by geographic divisions:

\begin{tabular}{|c|c|c|c|c|c|c|c|c|}
\hline \multirow{3}{*}{ DIVISION. } & \multicolumn{8}{|c|}{ OYSTER PRODUCT. } \\
\hline & \multicolumn{2}{|c|}{1908} & \multicolumn{2}{|c|}{$1897-19011$} & \multicolumn{2}{|c|}{$1889-1892$ ? } & \multicolumn{2}{|c|}{1880} \\
\hline & $\begin{array}{l}\text { Quantity } \\
\text { (bnshels). }\end{array}$ & Value. & $\begin{array}{l}\text { Quantity } \\
\text { (hushels). }\end{array}$ & 'Valne. & $\begin{array}{l}\text { Quantity } \\
\text { (bushels). }\end{array}$ & Value. & $\begin{array}{l}\text { Quantity } \\
\text { (bushels). }\end{array}$ & Value. \\
\hline United States.. & $33,330,000$ & $\$ 15,713,000$ & $26,910,000$ & $\$ 14,375,000$ & $28,264,000$ & $\$ 16,152,000$ & $22,195,000$ & $\$ 9,035,000$ \\
\hline Atlantic coast division.... & $27,268,000$ & $13,434,000$ & $24,011,000$ & $12,583,000$ & $24,979,000$ & $14,507,000$ & $21,602,000$ & $8,712,000$ \\
\hline $\begin{array}{l}\text { New England atates........ } \\
\text { Middle Atlantic states...... } \\
\text { South Atlantic states...... }\end{array}$ & $\begin{array}{r}5,332,000 \\
16,982,000 \\
4,364,000\end{array}$ & $\begin{array}{r}3,771,000 \\
8,812,000 \\
821,000\end{array}$ & $\begin{array}{r}2,649,000 \\
19,750,000 \\
1,612,000\end{array}$ & $\begin{array}{r}1,911,000 \\
10,288,000 \\
385,000 \\
\end{array}$ & $\begin{array}{r}1,726,000 \\
21,346,000 \\
1,192,000\end{array}$ & $\begin{array}{r}1,393,000 \\
12,403,000 \\
254,000\end{array}$ & $\begin{array}{r}537,000 \\
20,756,000 \\
310,000\end{array}$ & $\begin{array}{r}655,000 \\
10,932,000 \\
120,000\end{array}$ \\
\hline $\begin{array}{l}\text { Oulf of Mexico division.... } \\
\text { Pacific coast division...... }\end{array}$ & $\begin{array}{r}6,343,000 \\
309,000\end{array}$ & $\begin{array}{r}1,586,000 \\
694,000\end{array}$ & $\begin{array}{r}2,380,000 \\
519,000\end{array}$ & $\begin{array}{r}749,000 \\
1,043,000\end{array}$ & $\begin{array}{l}2,941,000 \\
3,592,000\end{array}$ & $\begin{array}{l}796,000 \\
849,000\end{array}$ & $\begin{array}{r}579,000 \\
15,000\end{array}$ & $\begin{array}{r}313,000 \\
10,000\end{array}$ \\
\hline
\end{tabular}

1 Combined statistics for South Atlantie atates and Gulf of Mexico, 1897; New England atates, 1898; Pacific coast states, 1899 ; and Middle Atlantic atates, 1900-1901. - Combined statistics for New England atates, 1889; Gulf of Mexico, 1890; Middie Atlantic and Sonth $\Lambda$ tlantic states, $1891 ;$ snd Pacific coast states, 1892.

A marked increase is apparent in the product of the New England and of the South Atlantic states and a decrease in that of the Middle Atlantic states. In 1880 the product of the Middle Atlantic states formed 94 per cent of the total quantity, while in $1908^{\circ}$ it formed but 51 per cent. The product of the New England states, on the other hand, progressively increased in quantity, representing 16 per cent of the total in 1908, as compared with 2 per cent in 1880 , while the proportion represented by the product of the South Atlantic states increased from 1 per cent of the total quantity in 1880 to 13 per cent in 1908 .

Pike perches (Stizostedion vitreum and S. canadense).The "wall-eyed pike" (S. vitreum) is known as "glass eye," "pike perch," "yellow pike," "dory," and "blue pike" on the Great Lakes, and as "salmon," "jack," "okow," "blowfish," and "green pike" in other localities. It is an excellent food fish and sometimes reaches a weight of 20 pounds. The sauger, or sandperch ( $S$. canadense), which is smaller and less important as a food fish, is especially abundant in the Great Lakes. The catch of pike perch in 1908 amounted to $15,247,000$ pounds, valued at $\$ 580,000$. Of the total amount, $15,115,000$ pounds, valued at $\$ 569,000$, were taken in the Great Lakes, and the balance, all of which was of the wall-eyed species, was caught in the Mississippi River or its tributaries.

This fish was taken in 17 states, but almost 97 per cent of the total quantity was caught in Ohio, Pennsylvania, New York, and Michigan. Ohio alone is credited with 57 per cent of the total quantity and 50 per cent of the value. The statistics of the catch, by states ranked according to the value of the product, are given in the following tabular statement:

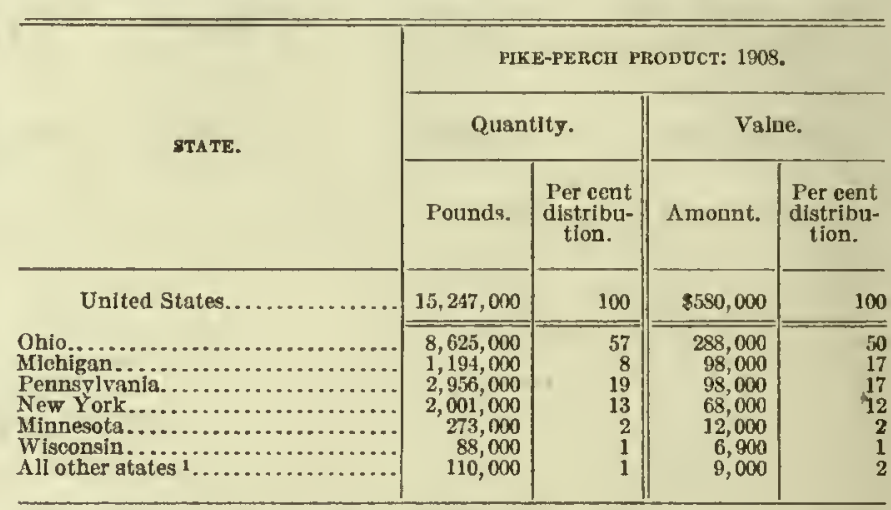

1 Includes Arizansas, Illinois, Indiana, Iowa, Kansas, Kentucky, Louisiana, Missouri, Nebrasks, Tennessee, and West Virginia.

As indicated by a comparison of the values for 1908 and previous years, this fish is growing rapidly in importance. No figures are available for the Mississippi River district in 1899 , but as the Great Lakes furnish practically the entire amount, the figures would be changed very little by the addition of the river catch. The statistics of the catch for previous years are given in the following tabular statement:

\begin{tabular}{|c|c|c|}
\hline \multirow{2}{*}{ YEAR. } & \multicolumn{2}{|c|}{$\begin{array}{l}\text { PIKE-PERCI PRODECT } \\
\text { OF THE GREAT LAKES. }\end{array}$} \\
\hline & $\begin{array}{l}\text { Quantity } \\
\text { (ponnds). }\end{array}$ & Value. \\
\hline $\begin{array}{l}1908 \ldots \ldots \ldots \ldots \ldots \ldots \ldots \ldots \\
1903 \ldots \ldots \ldots \ldots \ldots \ldots \ldots \ldots \ldots\end{array}$ & $\begin{array}{r}15,115,000 \\
9,998,000 \\
11,070,000\end{array}$ & $\begin{array}{r}8569,000 \\
407,000 \\
381,000\end{array}$ \\
\hline
\end{tabular}

This fish is taken principally in gill nets and pound nets, less than 6 per cent of the total quantity in 1908 being caught with other kinds of apparatus. 
Pollack (Pollachius virens).-The pollack, a food fish of importance, is found mainly off the New England coast. It sometimes appears as far south as Virginia. The average weight is about 10 pounds. The sounds are used in the manufacture of glue, the livers are sold in large quantities for the manufacture of oil, and the tongues nre cut out and sold fresh.

The pollack eatch in 1908 amounted to $29,462,000$ pounds, valued at $\$ 402,000$, less than 1 per cent of the total value for all fishery products and over 1 per cent of that for fish proper. The value of the catches of the fisheries of Massachusetts and Maine combined represented 97 per cent of the total. The statisties by states are given in the following tabular statement:

\begin{tabular}{|c|c|c|c|c|}
\hline \multirow{3}{*}{ STATE. } & \multicolumn{4}{|c|}{ POLLACK PRODUCT: 1908.} \\
\hline & \multicolumn{2}{|c|}{ Quantity. } & \multicolumn{2}{|c|}{ Value. } \\
\hline & Pounds. & $\begin{array}{l}\text { Per cent } \\
\text { distribu- } \\
\text { tion. }\end{array}$ & Amount. & $\begin{array}{l}\text { Per cent } \\
\text { distribu- } \\
\text { tlon. }\end{array}$ \\
\hline Ünited States................ & $29,462,000$ & 100 & $\$ 402,000$ & 100 \\
\hline 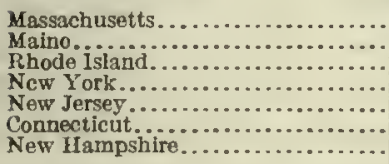 & $\begin{array}{r}20,006,000 \\
8,941,000 \\
266,000 \\
133,000 \\
84,000 \\
25,000 \\
6,300\end{array}$ & $\begin{array}{ll} & 68 \\
& 30 \\
(1) & 1 \\
(1) & \\
(1) & \end{array}$ & $\begin{array}{r}313,000 \\
75,000 \\
7,800 \\
3,500 \\
1,100 \\
800 \\
100\end{array}$ & $\begin{array}{rr} & 78 \\
& 19 \\
2 \\
(1) \\
(1) \\
(1)\end{array}$ \\
\hline
\end{tabular}

1 Less than 1 per cent.

The yield for 1908 shows a large increase in value, compared with the product of 1905 , but the weight was approximately the same for the two years. In both of these years, however, the product was much greater than in any other year for which statistics are available, as is shown by the following tabular statement:

\begin{tabular}{|c|c|c|}
\hline & \multicolumn{2}{|c|}{ POLLACK PRODUCT. } \\
\hline VEAK. & $\begin{array}{l}\text { Quantity } \\
\text { (pounds). }\end{array}$ & Vaiue. \\
\hline 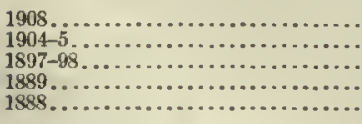 & $\begin{array}{r}29,462,000 \\
29,033,000 \\
9,448,000 \\
8,442,000 \\
6,125,000\end{array}$ & $\begin{array}{r}8402,000 \\
305,000 \\
65,000 \\
90,000 \\
67,000\end{array}$ \\
\hline
\end{tabular}

A small proportion of the pollack catch, less than 5 per cent of the total product, was salted by the fisherios in 1908, and a still smaller percentage was salted in 1905 .

The catch is taken principally in the vessel fisheries, and the most important apparatus used are lines. In 1908,68 per cent of the total quantity was taken with lines, 23 per cent with seines, and about 8 per cent with other kinds of apparatus.

Salmon.-The salmon of the Atlantic coast (Salmo salar) is found along the coast of the New England states. At different ages the fish are known as "parrs," "smolts," "grilse," "kelts," and "salmon." The adults weigh from 15 to 40 pounds. The landlocked salmon, or fresh-water salmon, or Sebago salmon ( $S$. sebago), is found, as the name implies, in fresh waters, generally landlocked. The steelhead (Salmo gairdneri) is found in coastal streams from San Francisco northward.

The blueback salmon (Oncorhynchus nerka) is found on the Pacific const from the Columbia River northward; and the California salmon, or chinook salmon, or quinnat (O. tschawytscha), is found from Monterey to Alaska. The dog salmon (O. Keta) ranges from the Sacramento River to Bering Strait; the humpbacked salmon, or lost salmon (O. gorbuscha), from the Sacramento River to Alaska; and the silver salmon or white salmon (O. kisutch) is found in all rivers from the Sacramento River to Bering Strait.

The following are improperly called salmon and are not included in the following tables under that name: The Californin yellow-tail (Seriola dorsalis) which is known as the "white salmon" on the Pacific coast; the chub (Ptychocheilus lucius) of the Colorado River is sometimes called salmon; "kelp salmon" is applied to the cabrilla (Paralabrax clathratus) at Monterey; "lake salmon" to the lake trout in the lakes of northern New York; and "salmon" and "jack salmon" to the wall-eyed pike in the streams of the South.

Next to oysters, salmon is the most important of the fishery products. Its value in 1908 was $\$ 3,347,000$, or 6 per cent of the total. It was first in importance among the different species of fish proper, and represented 11 per cent of their total value. Practically the entire catch was made on the Pacific coast, in which district salmon represented 49 per cent of the total value of fishery products. The statisties, by states, are given in the following tabular statement:

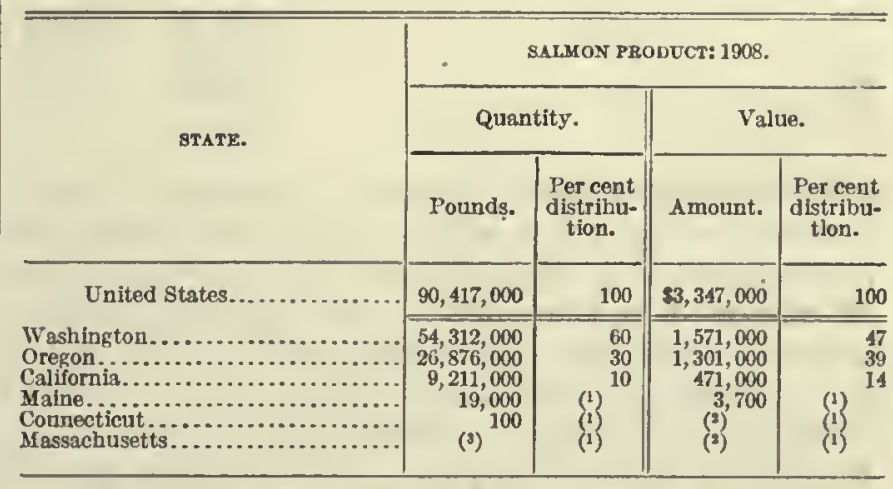

1 Less than 1 per cent. $\$$ Less than $\$ 100$. Less than 100 poinds.

The figures for the salmon product given here are for the product sold in the open market or to the canneries. The statisties for the product of the canneries and packing louses are given on page 283.

The statistics of the product of the Pacific coast states, classified according to variety, are as follows: 


\begin{tabular}{|c|c|c|c|c|c|c|c|c|}
\hline \multirow{3}{*}{ VARIETY. } & \multicolumn{8}{|c|}{ SALMON PRODUCT OF THE PACHFIC COAST STATES: 1908.} \\
\hline & \multicolumn{2}{|c|}{ Total. } & \multicolumn{2}{|c|}{ Californla. } & \multicolumn{2}{|c|}{ Óregon. } & \multicolumn{2}{|c|}{ Washington. } \\
\hline & $\begin{array}{l}\text { Quantlty } \\
\text { (pounds). }\end{array}$ & Value. & $\begin{array}{l}\text { Quantlty } \\
\text { (pounds). }\end{array}$ & Value. & $\begin{array}{l}\text { Quantity } \\
\text { (pounds). }\end{array}$ & Volue. & $\begin{array}{l}\text { Quantity } \\
\text { (pounds). }\end{array}$ & Value. \\
\hline Total.... & $90,398,000$ & $\$ 3,343,000$ & $9,211,000$ & $\$ 471,000$ & $26,876,000$ & $\$ 1,301,000$ & $54,312,000$ & $\$ 1,571,000$ \\
\hline 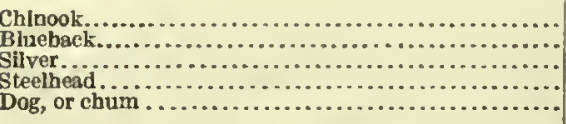 & $\begin{array}{r}39,359,000 \\
13,050,000 \\
19,144,000 \\
4,885,000 \\
13,960,000\end{array}$ & $\begin{array}{r}2,080,000 \\
538,000 \\
368,000 \\
234,000 \\
122,000\end{array}$ & $\begin{array}{r}8,846,000 \\
147,000 \\
141,000 \\
76,000 \\
\ldots . . .\end{array}$ & $\begin{array}{r}460,000 \\
4,900 \\
4,200 \\
2,800\end{array}$ & $\begin{array}{r}18,176,000 \\
403,000 \\
4,923,000 \\
2,469,000 \\
905,000\end{array}$ & $\begin{array}{r}1,056,000 \\
20,000 \\
109,000 \\
109,000 \\
7,000\end{array}$ & $\begin{array}{r}12,336,000 \\
12,501.000 \\
14,080,000 \\
2,339,000 \\
13,055,000\end{array}$ & $\begin{array}{l}565,000 \\
513,000 \\
255,000 \\
123,000 \\
115,000\end{array}$ \\
\hline
\end{tabular}

The species are ranked in the above statement according to total value; according to quantity the order is chinook, silver, dog or clium, blueback, and steelhead. The per cent distribution, by species, of the quantity and value is given below:

\begin{tabular}{|c|c|c|}
\hline \multirow[t]{2}{*}{ VARIETY. } & \multicolumn{2}{|c|}{$\begin{array}{l}\text { SALMON PRODUCT OP } \\
\text { THE PACTFIC COAST } \\
\text { QTATES: } 1908 \text { (PER } \\
\text { CENT DISTRIBU- } \\
\text { TION). }\end{array}$} \\
\hline & Quantity. & Valna. \\
\hline Total............ & 100 & 100 \\
\hline 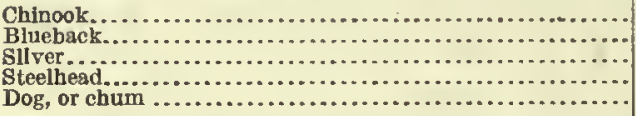 & $\begin{array}{r}44 \\
14 \\
21 \\
5 \\
15\end{array}$ & $\begin{array}{r}62 \\
16 \\
11 \\
7 \\
4\end{array}$ \\
\hline
\end{tabular}

The next tabular statement gives the statistics of the Pacific coast salmon catch for those years for which data are available.
The fluctuation to be noted in earlier years in the relative amount of the product reported for Oregon and Washington, respectively, is due to the peculiar habit of the principal species caught in Puget Sound in coming in greatest abundance every fourth year, and somewhat, perhaps, to an uncertainty in reporting results of operations on that portion of the Columbia River which forms the boundary between the two states. The great decrease in bulk shown for Washington in 1908, as compared with 1899, amounting to nearly 50 per cent, is in marked contrast to the slight increase in the Oregon product, while the contrast in the movement of the value since 1899 is also marked. In California there was a decrease in both quantity and value from 1888 to 1895 , but since then there has been a steady upward movement in value, although in 1908 the quantity of the catch shows a decrease from the high figures of 1904 .

\begin{tabular}{|c|c|c|c|c|c|c|c|c|}
\hline \multirow{3}{*}{ YEAR. } & \multicolumn{8}{|c|}{ SALMON PRODUCT OF PACTFIC COAST STATES. } \\
\hline & \multicolumn{2}{|c|}{ - Total. } & \multicolumn{2}{|c|}{ California. } & \multicolumn{2}{|c|}{ Oregon. } & \multicolumn{2}{|c|}{ Washington. } \\
\hline & $\begin{array}{l}\text { Qusntity } \\
\text { (pounds). }\end{array}$ & Value. & $\begin{array}{l}\text { Quantity } \\
\text { (pounds). }\end{array}$ & Value. & $\begin{array}{l}\text { Quantity } \\
\text { (pounds). }\end{array}$ & Value. & $\begin{array}{l}\text { Quantity } \\
\text { (pounds). }\end{array}$ & Value. \\
\hline 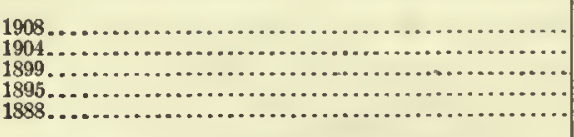 & $\begin{array}{r}90,398,000 \\
107,309,000 \\
130,005,000 \\
86,936,000 \\
48,807,000\end{array}$ & $\begin{array}{r}\$ 3,343,000 \\
3,549,000 \\
3,505,000 \\
2,447,000 \\
2,083,000\end{array}$ & $\begin{array}{r}9,211,000 \\
12,343,000 \\
7,283,000 \\
5,216,000 \\
8,539,000\end{array}$ & $\begin{array}{r}\$ 471,000 \\
456,000 \\
262,000 \\
154,000 \\
411,000\end{array}$ & $\begin{array}{l}26,876,000 \\
26,714,000 \\
21,374,000 \\
36,426,000 \\
23,948,000\end{array}$ & $\begin{array}{r}\$ 1,301,000 \\
1,151,000 \\
830,000 \\
1,230,000 \\
985,000\end{array}$ & $\begin{array}{r}54,312,000 \\
68,252,000 \\
101,348,000 \\
45,294,000 \\
16,320,000\end{array}$ & $\begin{array}{r}\$ 1,571,000 \\
1,943,000 \\
2,413,000 \\
1,063,000 \\
687,000\end{array}$ \\
\hline
\end{tabular}

The Alaska salmon product in 1908 , which is not included in the above presentation, was $198,953,000$ pounds, valued at $\$ 10,672,000$. This was practically all marketed in a preserved.condition, and the data therefor will be found in Chapter VIII, which relates to the packing and canning establishments.

Comparative figures for the salmon catch of New England as reported for prior years are as follows:

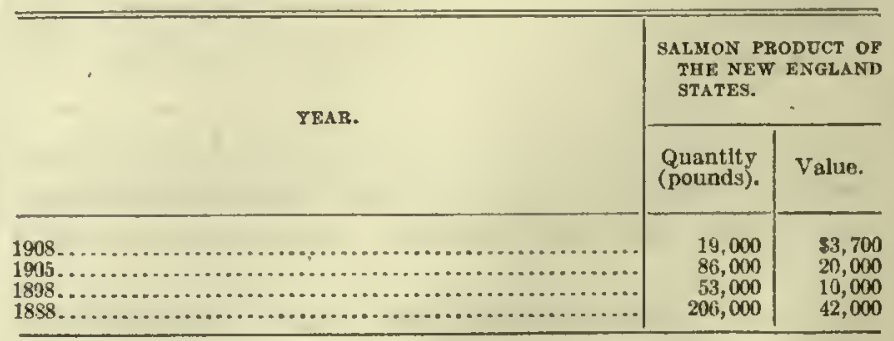


A summary of the statistics for the total salmon catch of the United States, obtained by combining the figures for the Alaska salmon product with those for the salmon product of continental United States, is given in the following tabular statement:

\begin{tabular}{|c|c|c|c|c|}
\hline \multirow{3}{*}{ DIVIsIoN. } & \multicolumn{4}{|c|}{$\begin{array}{l}\text { SALMON PRODUCT OF CONTINENTAL UNITED } \\
\text { STATES AND ALASKA: } 1908 \text {. }\end{array}$} \\
\hline & \multicolumn{2}{|c|}{ Quantity. } & \multicolumn{2}{|c|}{ Value. } \\
\hline & Pounds. & $\begin{array}{l}\text { Per cent } \\
\text { distri- } \\
\text { butlon. }\end{array}$ & Amount. & $\begin{array}{l}\text { Per cent } \\
\text { distri- } \\
\text { bution. }\end{array}$ \\
\hline United States.... & $289,370,000$ & 100 & $\$ 14,018,000$ & 100 \\
\hline Paclfic eoast.... & $289,351,000$ & 100 & $14,015,000$ & 100 \\
\hline $\begin{array}{l}\text { Alaska......................... } \\
\text { Pacific coust states......... }\end{array}$ & $\begin{array}{r}198,953,000 \\
90,398,000\end{array}$ & $\begin{array}{l}69 \\
31\end{array}$ & $\begin{array}{r}10,672,000 \\
3,343,000\end{array}$ & $\begin{array}{l}76 \\
24\end{array}$ \\
\hline New England states....... & 19,000 & (1) & 3,700 & (2) \\
\hline
\end{tabular}

. 1 Less than 1 per cent.

The distribution of the catch of salmon, exclusive of the Alaska product, by apparatus of capture, was as follows:

\begin{tabular}{|c|c|c|c|c|}
\hline \multirow{3}{*}{ KIND OP APPARATUS. } & \multicolumn{4}{|c|}{ SALMDN PRODUCT: 1908.} \\
\hline & \multicolumn{2}{|c|}{ Quantity. } & \multicolumn{2}{|c|}{ Value. } \\
\hline & Pouads. & $\begin{array}{c}\text { Per cent } \\
\text { distri- } \\
\text { butioa. }\end{array}$ & Amount. & $\begin{array}{l}\text { Per cent } \\
\text { distrl- } \\
\text { butlon. }\end{array}$ \\
\hline Total. & $90,417,000$ & 100 & $83,347,000$ & 100 \\
\hline 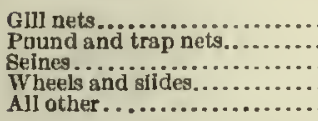 & $\begin{array}{r}40,219,000 \\
28,744,000 \\
13,290,000 \\
1,823,000 \\
342,000\end{array}$ & $\begin{array}{r}51 \\
32 \\
15 \\
2\end{array}$ & $\begin{array}{r}1,941,000 \\
882,000 \\
415,000 \\
97,000 \\
12,000\end{array}$ & $\begin{array}{l}58 \\
86 \\
12\end{array}$ \\
\hline
\end{tabular}

1 Less than 1 per cent.

Shad.-The common shar (Alosa sapidissima) is found on all the coasts of the United States and in some inland waters, the most important shad fisheries being in the rivers of the Atlantic slope. The average weight is about 4 pounds and the average length about 2 feet.

The names "mud shad," "gizzard shad," "winter shad," "stink shad," "hickory shad," and "whiteeyed shad" are applied to different species. The menhaden is called "hardhead shad" about Cape Arn, "bug-shad" in Virginia, and "yellow-tailed shad" from North Carolina to Florida.

Shad was fourth in value among the fishery products of the United States in 1908. Among fish proper it was surpassed in value only by salmon and cod, while in the Atlantic coast fisheries, cod is the only fish for which a greater value was reported. Shad is indigenous to the rivers of the Atlantic coast, and the transplanting of this species to the Pacific coast was among the early activities of the United States Fish Commission. The extent to which the undertaking succecded is shown in the tables which follow. The catch of shad in 1908 amounted to $27,641,000$ pounds, valued at $\$ 2,113,000$, or 4 per cent of the value of the entire fishery product and 7 per' cent of the value of fish proper. Shad was reported by 17 states, including all the Pacific coast and all Atlantic coast states, except New Hampshire. The statistics of the catch, by states ranked according to the value of their respective products, are given in the following tabular statement:

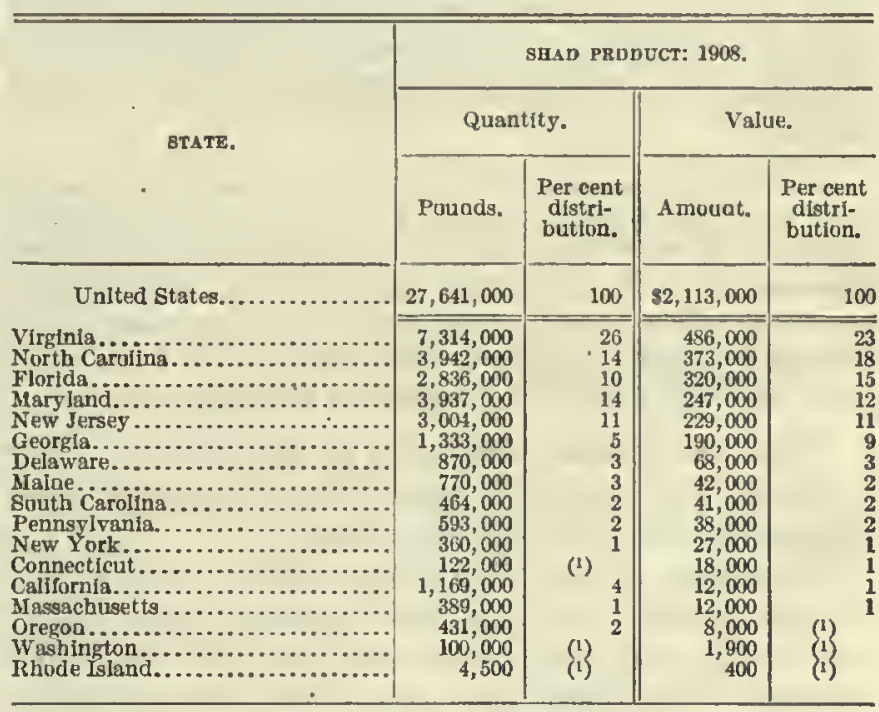

1 Less than 1 per ceat.

The first five states reported 78 per cent of the total value of this product. In all of these states shad ranked high in importance among the various species taken. In North Carolina it was first in value; in Virginia second, ranking next to oysters; in Maryland third; and in Florida and New Jersey fourth.

The distribution of the shad catch of 1908 , by divisions and state groups, was as follows:

\begin{tabular}{|c|c|c|c|c|}
\hline \multirow{3}{*}{ DIVLSION AND STATE GROUP. } & \multicolumn{4}{|c|}{ SHAD PRODUCT: 1908.} \\
\hline & \multicolumn{2}{|c|}{ Quantity. } & \multicolumn{2}{|c|}{ Value. } \\
\hline & Pounds. & $\begin{array}{l}\text { Per cent } \\
\text { distri- } \\
\text { bution. }\end{array}$ & Amount. & $\begin{array}{l}\text { Per cent } \\
\text { distri- } \\
\text { bution. }\end{array}$ \\
\hline Total.................... & $27,641,000$ & 100 & $\$ 2,113,000$ & 100 \\
\hline Atlantic coast division.. & $25,941,000$ & 94 & $2,092,000$ & 90 \\
\hline $\begin{array}{l}\text { Mlddle Atlantle states.......... } \\
\text { South Atlantic states.......... } \\
\text { New England states .......... }\end{array}$ & $\begin{array}{r}16,079,000 \\
8,572,000 \\
1,286,000\end{array}$ & $\begin{array}{r}58 \\
31 \\
5\end{array}$ & $\begin{array}{r}1,096,000 \\
923,000 \\
72,000\end{array}$ & 52 \\
\hline $\begin{array}{l}\text { Paclfic coast division } . . . . . . . . . . . \\
\text { Gulf of Mexico division . . . . . . }\end{array}$ & $\begin{array}{r}1,700,000 \\
3,600\end{array}$ & (1) 6 & $\begin{array}{r}22,000 \\
200\end{array}$ & ( \\
\hline
\end{tabular}

The quantity and value of the shad reported for 1908 and earlier years are given in the following tabular statement:

\begin{tabular}{|c|c|c|}
\hline \multirow[b]{2}{*}{ YEAR. } & \multicolumn{2}{|c|}{ SUAD PRODUCT. } \\
\hline & $\begin{array}{l}\text { Quantity } \\
\text { (pounds). }\end{array}$ & Value. \\
\hline 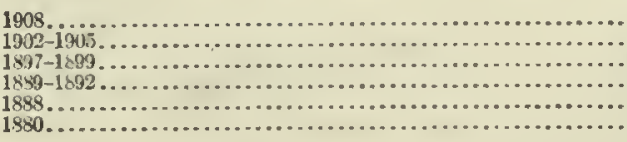 & $\begin{array}{l}27,641,000 \\
28,563,000 \\
49,787,000 \\
41,645,000 \\
35,737,000 \\
18,075,000\end{array}$ & $\begin{array}{r}\$ 2,113,000 \\
1,702,000 \\
1,520,000 \\
1,764,000 \\
1,672,000 \\
996,000\end{array}$ \\
\hline
\end{tabular}


The statistics show a marked decrease in quantity during the past decade, accompanied by an increase in value. Prior to 1897 , both quantity and value increased steadily, but in that year an unusually large catch demoralized the price and made the total value much lower than in years for which smaller quantities were reported. Concerning the increase in the shad product during these earlier years, the Report of the Commissioner of Fish and Fisheries for 1898 (p. 104) states:

There was a decrease in the yield in nearly every river on the coast until 1880, when the results of artificial propagation became apparent. * * * Since 1880 the aggregate yield has greatly increased. * * * It should be noted, however, that this largely increased yield has been accompanied and even surpassed by an increase in quantity and effectiveness of the apparatus of capture, but it was made possible by the results of artificial propagation.

When the shad fisheries were at the height of their activity, they employed nearly 25,000 men and used apparatus valued at over $\$ 2,000,000$.

The Middle Atlantic states have always supplied the greater proportion of the shad product, their contribution varying from more than one-half to threefourths of the total; and the South Atlantic states have been next in importance, with a fraction varying from one-fifth to one-third. In the New England states there has been little change from year to year.

The greater part of the shad product was sold fresh, although a considerable quantity was salted by the Chesapeake Bay fishermen and also by the fishermen of Maine and other states. Gill nets were the leading apparatus of capture, and in 1908 took a quantity representing 61 per cent of the total value. Pound and trap nets, used in the large estuaries, contributed 29 per cent of the total value, while the catch with seines represented 8 per cent, and that witl all other apparatus 2 per cent.

Shrimp and prawn.-The shrimp is a decapod crustacean found in large numbers on all our coasts and in many inland waters. The usual length is about 2 inches, but some attain a larger size. They are caught in dip nets, purse nets, etc., and are used for food and bait. The prawn is generally larger than the shrimp, often having a length of 7 inches.

The catch of shrimp and prawn in 1908 was 19,080,000 pounds, valued at $\$ 494,000$. The distribution, by states ranked according to the value of their product, is given in the following tabular statement:

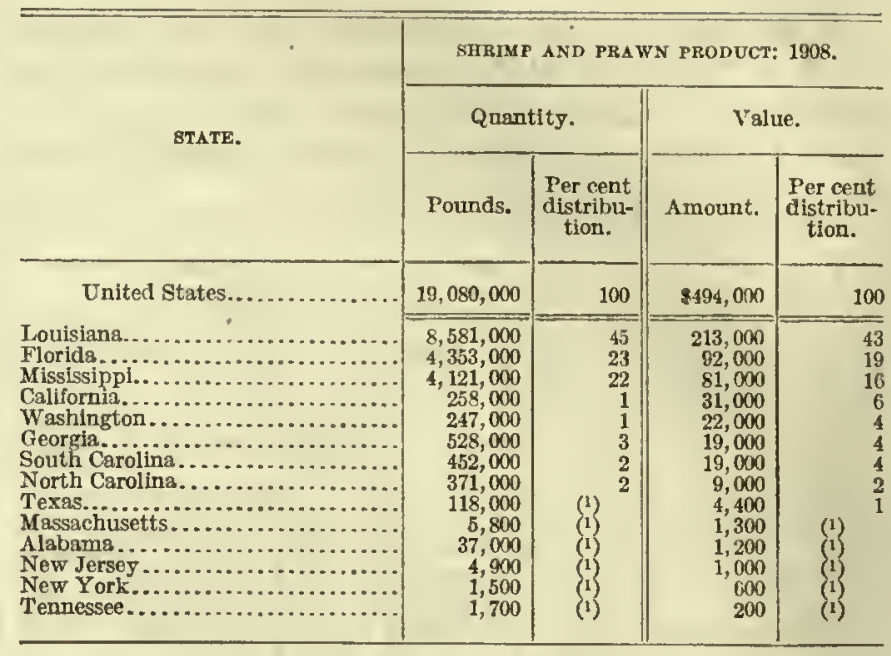

1 Less than 1 per cent.

The prawn catch included in the above was $4,706,000$ pounds, valued at $\$ 104,000$, and the shrimp catch $14,374,000$ pounds, valued at $\$ 390,000$. The distribution of the prawn product, by states, was as follows:

\begin{tabular}{|c|c|c|c|c|}
\hline \multirow{3}{*}{ stats. } & \multicolumn{4}{|c|}{ PRAWN PRODUCT: 1908.} \\
\hline & \multicolumn{2}{|c|}{ Quantity. } & \multicolumn{2}{|c|}{ Value. } \\
\hline & Pounds. & $\begin{array}{l}\text { Per cent } \\
\text { distribu- } \\
\text { tion. }\end{array}$ & Amount. & $\begin{array}{l}\text { Per cent } \\
\text { distribu- } \\
\text { tion. }\end{array}$ \\
\hline United States... & $4,706,000$ & 100 & $\$ 104,000$ & 100 \\
\hline 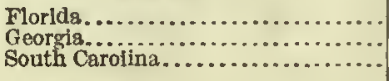 & $\begin{array}{r}4,152,000 \\
394,000 \\
160,000\end{array}$ & $\begin{array}{r}88 \\
8 \\
3\end{array}$ & $\begin{array}{r}84,000 \\
13,000 \\
7,300\end{array}$ & $\begin{array}{r}81 \\
12 \\
7\end{array}$ \\
\hline
\end{tabular}

By a subtraction of the foregoing figures from those presented for the same states in the tabular statement preceding, figures for the shrimp catch of these states are found to be as follows: Florida, 202,000 pounds, valued at $\$ 7,400$; Georgia, 134,000 pounds, valued at $\$ 6,700$; and South Carolina, 291,000 pounds, valued at $\$ 12,000$. In all the remaining states the total catch was composed of shrimp.

The bulk of the shrimp and prawn product came from the warm southern waters, and by far the largest portion from Louisiana. In both Louisiana and Mississippi shrimp and prawn ranked next to oysters in value among the fishery products.

The distribution of the shrimp and prawn catch, by divisions, is shown by the following tabular statement: 


\begin{tabular}{|c|c|c|c|c|}
\hline \multirow{3}{*}{ DIVISION. } & \multicolumn{4}{|c|}{ SIRIMP AND PRAWN PRODUCT: 1908.} \\
\hline & \multicolumn{2}{|c|}{ Quantity. } & \multicolumn{2}{|c|}{ Valuc. } \\
\hline & Pounds. & $\begin{array}{l}\text { Per cent } \\
\text { distribu- } \\
\text { tion. }\end{array}$ & Amount. & $\begin{array}{l}\text { Per cent } \\
\text { distribu- } \\
\text { tion. }\end{array}$ \\
\hline Total........ & $19,080,000$ & 100 & $\$ 494,000$ & 100 \\
\hline 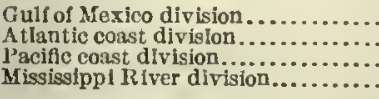 & $\begin{array}{r}12,561,000 \\
5,708,000 \\
504,000 \\
306,000\end{array}$ & $\begin{array}{r}66 \\
30 \\
3 \\
2\end{array}$ & $\begin{array}{r}271,000 \\
142,000 \\
53,000 \\
28,000\end{array}$ & $\begin{array}{r}55 \\
29 \\
11 \\
6\end{array}$ \\
\hline
\end{tabular}

In 1880 the shrimp and prawn product was $3,214,000$ pounds, valued at $\$ 209,000$; but in 1888 the product from the Gulf of Mexico and the Pacific coast divisions combined amounted to $13,398,000$ pounds, which is slightly in excess of the output of these two divisions in 1908. The price in 1888 was considerably lower than at present, for the value of the product of that year was $\$ 277,000$, compared with $\$ 324,000$ reported from the same divisions in 1908. Statistics of the product for the entire United States are not available for any one year prior to 1908 , but comparative data are presented for the several divisions for various years in the following tabular statement:

\begin{tabular}{|c|c|c|}
\hline \multirow{2}{*}{ DIVISTON AND YEAR. } & \multicolumn{2}{|c|}{$\begin{array}{l}\text { SURIMP AND PRAWN } \\
\text { PRODUCT. }\end{array}$} \\
\hline & $\begin{array}{l}\text { Quantity } \\
\text { (pounds). }\end{array}$ & Value. \\
\hline \multicolumn{3}{|l|}{ Gulf of Mexico divislon: } \\
\hline 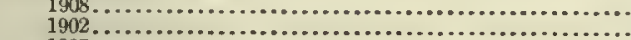 & $12,561,000$ & $\$ 271,000$ \\
\hline $1897 .$. & $\begin{aligned} 12,367,000 \\
6,791,000\end{aligned}$ & 199,000 \\
\hline $1390 . \ldots$ & $7,451,000$ & 109,000 \\
\hline \multicolumn{3}{|l|}{ 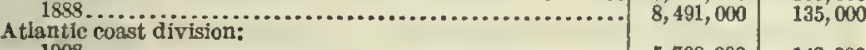 } \\
\hline Atranes ................... & $5,708,000$ & 142,000 \\
\hline $\begin{array}{l}1902-1904 \ldots \ldots \ldots \ldots \\
1889-1891 \ldots \ldots \ldots\end{array}$ & $3,825,000$ & 91,000 \\
\hline \multicolumn{3}{|l|}{ Pacific coast division: } \\
\hline $1908 . . . \ldots \ldots \ldots \ldots \ldots$ & $\begin{array}{r}504,000 \\
2,262,000\end{array}$ & 53,000 \\
\hline $1890 . . . .$. & $4,067,000$ & 113,000 \\
\hline & $5,461,000$ & 165,000 \\
\hline $\begin{array}{l}1892 \\
1888\end{array}$ & $5,315,000$ & 242,000 \\
\hline \multicolumn{3}{|l|}{ Mississippi River division: } \\
\hline & & \\
\hline 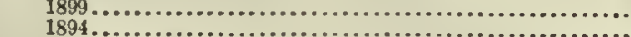 & 200,000 & 16,000 \\
\hline & & \\
\hline
\end{tabular}

In the Gulf of Mexico division a considerable portion of the catch is consumed by the canners and packers. In $1908,3,269,000$ pounds were canned, 342,000 pounds dried, and 79,000 pounds pickled. On the Pacific coast, in the flourishing days of the shrimp industry, the entire catch was taken by Chinese, and large quantities of dried shrimp were exported to China. The assiduity of the fishermen of this race is held responsible for the great decrease in the Pacific coast product noted above.

The bulk of the catch was made by shore and boat fisheries, except in Mississippi, where vessel fisheries took over 80 per cent of the product. Seines took more than 90 per cent of the catch, while 9 per cent of the total quantity was taken with other nets and less than 1 per cent with beam trawls and pots and traps.
Skins.-The fur skins reported in connection with the census of fisheries are those of the muskrat, mink, and otter. Although the value of such products is not large, compared with that of most of the distinctively fishery products, yet these industries give employment to a large number of men and are of considerable local importance. The aggregate value of the skins of these aquatic fur mammals reported was $\$ 255,000$, of which muskrats contributed $\$ 136,000$, or 53 per cent; mink $\$ 89,000$, or 35 per cent; and otter $\$ 30,000$, or 12 per cent.

The value of fur skins reported is given, by states, in the following tabular statement:

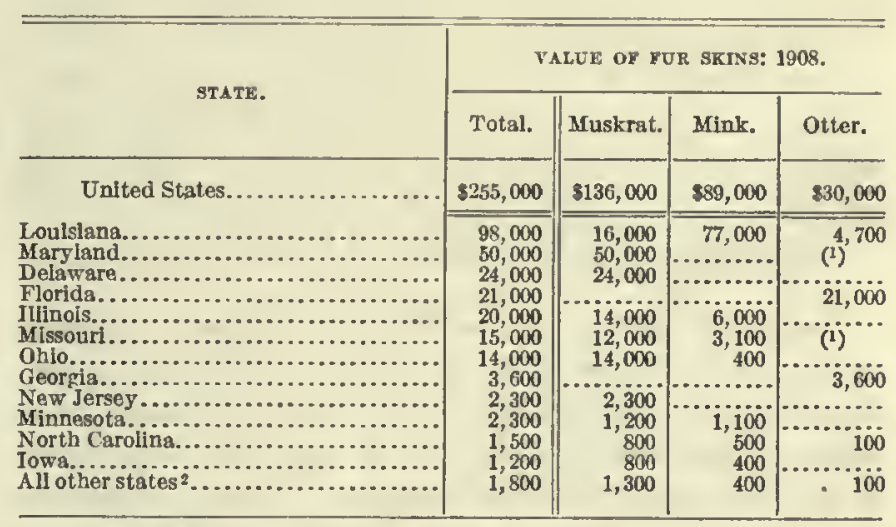

${ }^{1}$ Less than $\$ 100$.

2Ineludes W iseonsin, Mlehlgan, Vlrglnia, Arkansas, New York, and Texas.

The trapping of muskrats was reported in 14 states, and the number and value of the skins taken were as follows:

\begin{tabular}{|c|c|c|c|c|}
\hline \multirow{3}{*}{ STATE. } & \multicolumn{4}{|c|}{ MUSKRAT SKINS: 1908.} \\
\hline & \multicolumn{2}{|c|}{ Quantity. } & \multicolumn{2}{|c|}{ Value. } \\
\hline & Number. & $\begin{array}{l}\text { Per cent } \\
\text { distribu- } \\
\text { tion. }\end{array}$ & Amount. & $\begin{array}{l}\text { Per cent } \\
\text { distribu- } \\
\text { tion. }\end{array}$ \\
\hline United States....... & 457,000 & 100 & $\$ 136,000$ & 100 \\
\hline 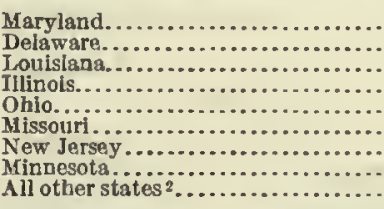 & $\begin{array}{r}115,000 \\
76,000 \\
119,000 \\
50,000 \\
41,000 \\
29,000 \\
9,100 \\
5,000 \\
11,000\end{array}$ & $\begin{array}{r}25 \\
17 \\
26 \\
11 \\
9 \\
6 \\
2 \\
1 \\
2\end{array}$ & $\begin{array}{r}50,000 \\
124,000 \\
16,000 \\
14,000 \\
14,000 \\
12,000 \\
2,300 \\
1,200 \\
2,900\end{array}$ & $\begin{array}{r}37 \\
18 \\
12 \\
10 \\
10 \\
9 \\
2 \\
1 \\
2\end{array}$ \\
\hline
\end{tabular}

1 Includes $\$ 3,800$, the value of 110,000 pounds of muskrat meat.

Includes North Carollna, Iowa, W Isconsin, Mlehigan, Virginla, and New York.

More than one-half of the value reported represented the product of the contiguous states of Delaware and Maryland. Although muskrats are trapped for the skins primarily, the meat also is marketed to a considerable extent. The sale of 110,000 pounds of muskrat meat was reported from Delaware, the value of which, $\$ 3,800$, has been included in the foregoing statement.

While ten states reported the trapping of mink, almost eight-ninths of the product was from Louisiana, as shown by the following tabular statement: 


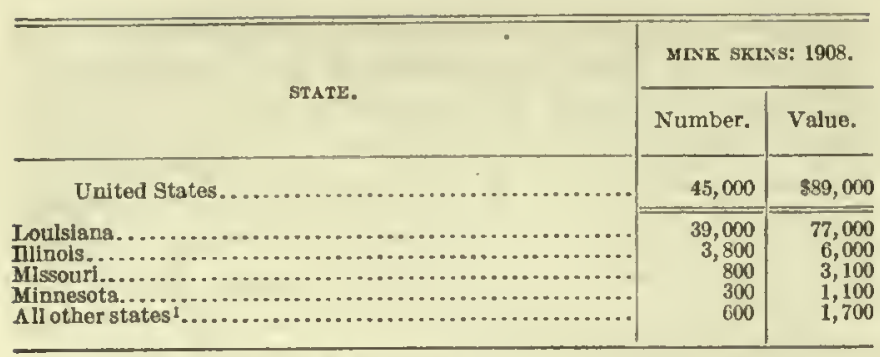

1 Includes North Carolina, Iowa, Wisconsin, Obio, Texas, and Virginla.

.The product of otter skins, by states, was as follows:

\begin{tabular}{|c|c|c|}
\hline \multirow{2}{*}{ STATE. } & \multicolumn{2}{|c|}{ OTIER SKINS: 1908.} \\
\hline & Number. & Value. \\
\hline United States............... & 3,800 & $\$ 30,000$ \\
\hline $\begin{array}{l}\text { Florida } \\
\text { Loulsana, } \\
\text { Georgla } \\
\text { All other states. }\end{array}$ & $\begin{array}{r}2,900 \\
600 \\
400 \\
(2)\end{array}$ & $\begin{array}{r}21,000 \\
4,700 \\
3,600 \\
300\end{array}$ \\
\hline
\end{tabular}

Includes North Carolina, Arkansas, Missouri, Vlrginla, and Maryland.

Less than 100 skins.

Snappers (Lutianidæ).-The red snapper (Lutianus aya), which is the most important of the snappers, is a large fish, bright red in color, and is found from Long Island southward, but in greatest abundance along the coasts of the Gulf states. The gray snapper, or mangrove snapper, also known in Florida as "lawyer," is a common species. The mutton snapper, dog snapper, or jocu, the schoolmaster, or caji, the silk snapper, and the lane snapper are all fishes of food value common in the West Indies and southern Florida.

The name is locally applied to other kinds of fish. The red grouper is called "brown snapper" and "redbellied snapper" in Florida. The rosefish is called "snapper" on the North Atlantic coast; the bluefish is called "snapper" and "blue snapper" on the New England coast; and the cod that live near the shore away from the ledges are called "black snappers."

The statistics of the catch of snappers as reported in $\mathbf{1 9 0 8}$ are given in the following tabular statement:

\begin{tabular}{|c|c|c|c|c|}
\hline \multirow{3}{*}{$\cdot$} & \multicolumn{4}{|c|}{ SNAPPER PRODUCT: 1908.} \\
\hline & \multicolumn{2}{|c|}{ Quantity. } & \multicolumn{2}{|c|}{ Value. } \\
\hline & Pounds. & $\begin{array}{c}\text { Per cent } \\
\text { distribu- } \\
\text { tlon. }\end{array}$ & Amount. & $\begin{array}{l}\text { Per cent } \\
\text { distribu- } \\
\text { tlon. }\end{array}$ \\
\hline United States. & $13,854,000$ & 100 & $\$ 651,000$ & 100 \\
\hline 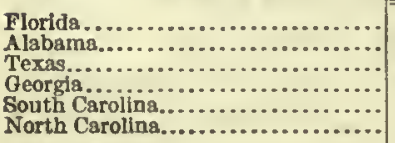 & $\begin{array}{r}8,061,000 \\
2,635,000 \\
2,252,000 \\
880,000 \\
14,000 \\
13,000\end{array}$ & $\begin{array}{r}58 \\
19 \\
16 \\
6 \\
(1)^{(1)}\end{array}$ & $\begin{array}{r}449,000 \\
92,000 \\
79,000 \\
30,000 \\
400 \\
300\end{array}$ & $\begin{array}{r}69 \\
14 \\
12 \\
\text { (1) } \\
\text { (1) }\end{array}$ \\
\hline
\end{tabular}

1 Less than 1 per cent.

The red-snapper product of Florida, Alabama, and Texas contributed over 98 per cent of the total value of the snappers caught in these states. The catch in the other states comprised 13,000 pounds, valued at
$\$ 300$, from North Carolina, and 1,000 pounds, valued at $\$ 30$, from South Carolina.

Comparative statistics of the entire snapper product for 1908 and former years, so far as data are available, are given in the following tabular statement:

\begin{tabular}{|c|c|c|}
\hline \multirow[b]{2}{*}{ YEAR. } & \multicolumn{2}{|c|}{ SNAPPER PRODUCT. } \\
\hline & $\begin{array}{l}\text { Qunntity } \\
\text { (pounds). }\end{array}$ & Value. \\
\hline 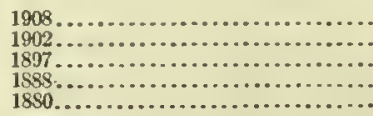 & $\begin{array}{r}13,854,000 \\
14,165,000 \\
6,313,000 \\
3,529,000 \\
1,483,000\end{array}$ & $\begin{array}{r}3651,000 \\
430,000 \\
206,000 \\
103,000 \\
67,000\end{array}$ \\
\hline
\end{tabular}

The statistics for 1902 show $13,764,000$ pounds of red snappers, valued at $\$ 418,000$, and 401,000 pounds of all other snappers, valued at $\$ 11,000$. In reports prior to 1902 no division is shown, and all snappers except the red were probably included under the head of miscellaneous fish.

The chief fishing ground is off the west coast of Florida. As these fish habitually feed along the ground in from 10 to 40 fathoms of water, lines are the only form of apparatus used in their capture.

Sponge.-The sponge which is of commercial value is found off the west coast of Florida, and the statistics in regard thereto are given in connection with those for the Florida fisheries on pages 103 and 104 of this report. The value of the sponge catch in 1908 was $\$ 545,000$.

Squeteague.-The common weakfish, or squeteague (Cynoscion regalis), is. found in abundance along the Atlantic coast from Cape Cod to Florida. It is known as "drummer" about Capo Cod; "yellowfin" about Buzzards Bay; "weakfish" in New York and New Jersey; "bluefish" in Delaware and Virginia; "gray trout," "sun trout," "shad trout," "sea trout," and "salt-water trout" in the Middle and South Atlantic states; and "squeteague," "squit," "chickwit," etc., in various places. It averages about $2 \frac{1}{2}$ pounds in weight, but some individuals attain a weight of 30 pounds. The spotted squeteague ( $C$. nebulosus) is found from New Jersey to Texas, and is somewhat larger than the other species. The California "bluefish" ( $C$. parvipinnis) and the great "white sea bass" of Califormia (C. nobilis) are other species of weakfish.

In 1908 squeteague were taken in all the Atlantic coast states south of Massachusetts, in all the Gulf states, and in California on the Pacific coast; but almost one-third of the catch was made off the New Jersey shores and along Delaware Bay. The entire product amounted to $49,869,000$ pounds, and was valued at $\$ 1,776,000$. Squeteague ranked seventh in value among all fishery products. Nearly the entire amount was sold fresh, the small quantities salted in North Carolina and Florida amounting to less than 1 per cent of the total product. The following tabular 
statement shows the statistics of the catch, by states ranked according to the value of their product:

\begin{tabular}{|c|c|c|c|c|}
\hline \multirow{3}{*}{ STATE. } & \multicolumn{4}{|c|}{ SQUETEAOUE PRODUCT: 1908.} \\
\hline & \multicolumn{2}{|c|}{ Quantity. } & \multicolumn{2}{|c|}{ Value. } \\
\hline & Pounds. & $\begin{array}{l}\text { Per cent } \\
\text { distribu- } \\
\text { tion. }\end{array}$ & Amount. & $\begin{array}{l}\text { Per cent } \\
\text { distribu- } \\
\text { tlon. }\end{array}$ \\
\hline United States........ & $49,869,000$ & 100 & $\$ 1,776,000$ & 100 \\
\hline 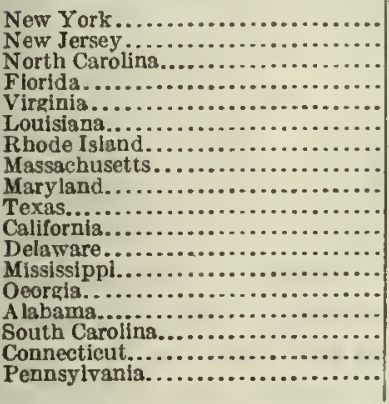 & $\begin{array}{r}11,151,000 \\
11,814,000 \\
4,635,000 \\
4,864,000 \\
4,491,000 \\
1,103,000 \\
2,427,000 \\
1,971,000 \\
1,191,000 \\
1,055,000 \\
1,337,000 \\
2,590,000 \\
517,000 \\
140,000 \\
208,000 \\
183,000 \\
180,000 \\
12,000\end{array}$ & 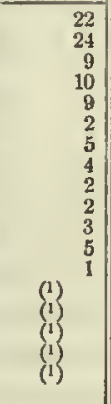 & $\begin{array}{r}451,000 \\
342,000 \\
206,000 \\
196,000 \\
139,000 \\
82,000 \\
72.000 \\
58,000 \\
47,000 \\
46,000 \\
42,000 \\
29,000 \\
28,000 \\
12,000 \\
10,000 \\
8,700 \\
6,800 \\
200\end{array}$ & $\begin{array}{r}25 \\
19 \\
12 \\
11 \\
8 \\
5 \\
4 \\
3 \\
3 \\
3 \\
2 \\
2 \\
2 \\
1 \\
1\end{array}$ \\
\hline
\end{tabular}

1 Less than 1 per cent.

Comparative figures for those years for which statistics are available are given in the following tabular statement:

\begin{tabular}{|c|c|c|}
\hline \multirow{2}{*}{ YEAR. } & \multicolumn{2}{|c|}{$\begin{array}{l}\text { BQUETEAGUE } \\
\text { PRODUCT. }\end{array}$} \\
\hline & $\begin{array}{l}\text { Quantity } \\
\text { (pounds). }\end{array}$ & Value. \\
\hline 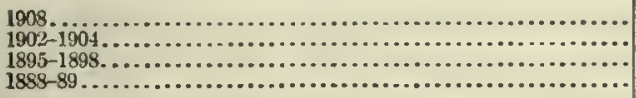 & $\begin{array}{l}49,869,000 \\
43,610,000 \\
31,971,000 \\
13,044,000\end{array}$ & $\begin{array}{r}\$ 1,776,000 \\
1,242,000 \\
733,000 \\
438,000\end{array}$ \\
\hline
\end{tabular}

Both the quantity and the value have increased since 1888-89, but except during the period from 1888-89 to 1895-1898 the rate of increase has been greater for the value than for the quantity.

Squeteague fishing begins in the latter part of April and lasts from six to eight weeks, until the schools begin to move off into deeper and cooler waters. Nearly one-lialf of the entire catch in 1908 was made in pound nets, trap nets, and weirs, and one-third in seines. The following tabular statement gives the statistics of the catch, by apparatus of capture, for 1908:

\begin{tabular}{|c|c|c|c|c|}
\hline \multirow{3}{*}{ KIND OF APPARATUS. } & \multicolumn{4}{|c|}{ SQUETEAGUE PRODUCT: 1908.} \\
\hline & \multicolumn{2}{|c|}{ Quantity. } & \multicolumn{2}{|c|}{ Value. } \\
\hline & Pounds. & $\begin{array}{l}\text { 'er cent } \\
\text { distri- } \\
\text { bution. }\end{array}$ & Amount. & $\begin{array}{l}\text { Per cent } \\
\text { distri- } \\
\text { bution. }\end{array}$ \\
\hline Total... & $49,869,000$ & 100 & $81,776,000$ & 100 \\
\hline 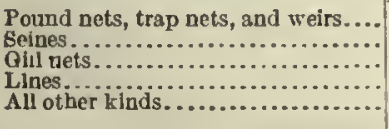 & $\begin{array}{r}24,135,000 \\
16,573,000 \\
6,006,000 \\
2,038,000 \\
1,115,000\end{array}$ & $\begin{array}{r}48 \\
33 \\
12 \\
4 \\
2\end{array}$ & $\begin{array}{r}807,000 \\
581,000 \\
249,000 \\
94,000 \\
45,000\end{array}$ & $\begin{array}{r}45 \\
33 \\
14 \\
5 \\
3\end{array}$ \\
\hline
\end{tabular}

Sturgeons (Acipenseridæ).-Sturgeons are found on the Atlantic and Pacific coasts and in many inland waters. The various species are known as "lake sturgeon," "white sturgeon," "shovelnose," etc. The Atlantic sturgeon attains a length of from 5 to 12 feet and a weight of from 400 to 500 pounds. They are sold fresh, pickled, and smoked, for food; caviar is manufactured from their eggs; the skin is made into leather; and the sounds are used in the manufacture of glue and isinglass. A valuable oil is sometimes obtained from the parts not used for food, and the refuse is used for fertilizing purposes.

These fishes were taken in 31 states and with the possible exception of catfish and carp were the most widely distributed fishes reported. The aggregate catch was $2,072,000$ pounds, valued at $\$ 157,000$. To these figures should be added those for the sturgeon caviar product which was reported separately and has been included in the statistics of caviar. The sturgeon caviar product was, in many cases, reported in conjunction with paddlefish eggs or caviar. For this reason the sturgeon caviar can not, in all cases, be segregated from that of the paddlefish. The paddlefish (Polyodon spathula), locally known as "spoonbill," "duckbill cat," and "shovelfish," is found in all the larger streams of the Mississippi Valley. It is a poor food fish, although the roe is used extensively for caviar. The production of sturgeon and paddlefish caviar was 79,000 pounds, valued at $\$ 79,000$, of which 69,000 pounds, valued at $\$ 70,000$, was from states reporting a catch of sturgeon and comprised, in the main, sturgeon caviar. The following tabular statement gives the statistics of the sturgeon catch by states and of the eaviar product for the same states, which are ranked according to the combined value of these products:

\begin{tabular}{|c|c|c|c|c|c|}
\hline \multirow{3}{*}{$\begin{array}{c}\text { STATE. } \\
.\end{array}$} & \multicolumn{5}{|c|}{ STURGEON AND CAVIAR PRODUCT: 1908.} \\
\hline & \multirow{2}{*}{$\begin{array}{l}\text { Total } \\
\text { value. }\end{array}$} & \multicolumn{2}{|c|}{ Sturgeon. } & \multicolumn{2}{|c|}{ Sturgeon caviar. 1} \\
\hline & & $\begin{array}{l}\text { Quentity } \\
\text { (pounds). }\end{array}$ & Value. & $\begin{array}{l}\text { Quantity } \\
\text { (pounds). }\end{array}$ & Value. \\
\hline United States.. & $\$ 228,000$ & $2,072,000$ & $\$ 157,000$ & 69,000 & $\$ 70,000$ \\
\hline Virginia.... & 49,000 & 183,000 & 22,000 & 22,000 & 27,000 \\
\hline New Jersey. & 23,000 & 132,000 & 13,000 & 0,700 & 10,000 \\
\hline New York.. & 23,000 & 105,000 & 16,000 & 8,100 & 7,500 \\
\hline lowa....... & 16,000 & 215,000 & 11,000 & 8,600 & 5,300 \\
\hline Maryland... & 16,000 & 37,000 & 5,000 & 8,100 & 11,000 \\
\hline Minnesota.. & 11,000 & 164,000 & 11,000 & 100 & 100 \\
\hline Wisconsin... & 8,800 & 112,000 & 8,200 & 900 & 600 \\
\hline Michigan.... & 8,000 & 57,000 & 7,100 & 1,200 & 900 \\
\hline lllinois..... & 7,300 & 178,000 & 6,500 & 1,300 & -800 \\
\hline Indiana....... & 7,200 & 62,000 & 6,800 & 300 & 400 \\
\hline Delawaro..... & 7,100 & 31,000 & 3,200 & 3,100 & 3,900 \\
\hline Georgia...... & 7,000 & 100,000 & 7,000 & ........ & ....... \\
\hline Oregon......... & 6,800 & 114,000 & 6,800 & & $\ldots . . .$. \\
\hline North Carolina... & 6,400 & 62,000 & 6,400 & & \\
\hline Washington............ & 6,000 & 185,000 & 6,000 & …. & $\ldots . .$. \\
\hline Florida................... & 5,300 & 62,000 & 5,000 & 200 & 200 \\
\hline Missourj....... & 5,100 & 132,000 & 5,000 & 300 & 100 \\
\hline l'ennsylvania.. & 4,300 & 16,000 & 3,700 & 500 & 500 \\
\hline Kentucky..... & 2,400 & 60,000 & 2,400 & & \\
\hline 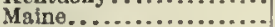 & 1,200 & 8,200 & 1,000 & 100 & 100 \\
\hline All other states ${ }^{2} . . . . .$. & 5,500 & 67,000 & 3,800 & 4,300 & 1,700 \\
\hline
\end{tabular}

I A small quantity of caviar from species other than sturgeon may be ineluded. 2 Includes California, Nebraska, Ohio, Alabama, Arkansas, Connectieut, Kansas, Massachusetts, South Dakota, Tennessee, and West Virginla. 
The following tabular statement, giving the distribution of the sturgeon catch by geographic divisions, shows that in quantity the product of the fisheries of the Mississippi River and its tributaries ranked first in 1908, while the catch of the Atlantic coast fisheries, more particularly that of the Middle Atlantic states, was of the greatest value.

\begin{tabular}{|c|c|c|c|c|}
\hline \multirow{3}{*}{ DTUSTON AND STATE OROUT. } & \multicolumn{4}{|c|}{ STUROEON PRODUCT: 1908.} \\
\hline & \multicolumn{2}{|c|}{ Quantity. } & \multicolumn{2}{|c|}{ Value. } \\
\hline & Pounds. & $\begin{array}{c}\text { Per cent } \\
\text { distribu- } \\
\text { tion. }\end{array}$ & Amount. & $\begin{array}{c}\text { Per cent } \\
\text { distrihu- } \\
\text { tion. }\end{array}$ \\
\hline United States... & $2,072,000$ & 100 & $\$ 157,000$ & 100 \\
\hline Atlantic coast division.......... & 649,000 & 31 & 69,000 & 44 \\
\hline $\begin{array}{l}\text { Middle Atlantic states .......... } \\
\text { South Atlantic states .......... } \\
\text { New England states ........... }\end{array}$ & $\begin{array}{r}418,000 \\
217,000 \\
14,000\end{array}$ & $\begin{array}{r}20 \\
10 \\
1\end{array}$ & $\begin{array}{r}49,000 \\
18,000 \\
1,500\end{array}$ & $\begin{array}{l}31 \\
11 \\
1\end{array}$ \\
\hline 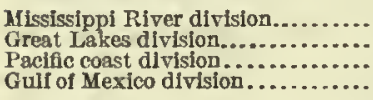 & $\begin{array}{r}845,000 \\
262,000 \\
309,000 \\
7,200\end{array}$ & $\begin{array}{r}41 \\
13 \\
15 \\
1\end{array}$ & $\begin{array}{r}39,000 \\
36,000 \\
\mathbf{1 3}, 000 \\
700\end{array}$ & $\begin{array}{r}24 \\
23 \\
9 \\
1\end{array}$ \\
\hline
\end{tabular}

Returns are not available for the country as a whole for a series of years, but figures for the various geographic divisions and groups of states are as follows:

\begin{tabular}{|c|c|c|}
\hline \multirow{2}{*}{ STATE OROUP OR DIVLSTON AND YEAR. } & \multicolumn{2}{|c|}{ STURGEON PRODUCT. } \\
\hline & $\begin{array}{l}\text { Quantity } \\
\text { (pounds). }\end{array}$ & Value. \\
\hline \multicolumn{3}{|l|}{ New England states: } \\
\hline & & \\
\hline 1905. & 21,000 & 1,600 \\
\hline & 18,000 & 1,300 \\
\hline 1898................. & 21,000 & 800 \\
\hline \multicolumn{3}{|l|}{ Mddle Atiantic states: } \\
\hline $1908 \ldots \ldots \ldots \ldots \ldots$ & 418,000 & 49,000 \\
\hline $\begin{array}{l}1904 . . \\
1897 .\end{array}$ & $\begin{array}{r}677,000 \\
2.308,000\end{array}$ & 42,000 \\
\hline $1891 \ldots \ldots \ldots \ldots \ldots$ & $2,636,000$ & 66,000 \\
\hline \multicolumn{3}{|l|}{ South Atlantic states: } \\
\hline $19022 \ldots \ldots+\cdots$ & 218,000 & $\begin{array}{l}18,000 \\
11,000\end{array}$ \\
\hline $1897 \ldots \ldots \ldots \ldots \ldots$ & 930,000 & 25,000 \\
\hline \multicolumn{3}{|l|}{ Gulf of Mexico division:" } \\
\hline $1908 . . . \ldots \ldots \ldots \ldots \ldots \ldots$ & & \\
\hline $1902 \ldots \ldots \ldots \ldots \ldots \ldots$ & $\begin{array}{r}467,000 \\
30\end{array}$ & 14,000 \\
\hline \multicolumn{3}{|l|}{ Oreat Lakes division: } \\
\hline $\begin{array}{l}1908 \ldots \ldots \ldots \ldots \ldots \\
1903\end{array}$ & 262,000 & 36,000 \\
\hline $1899 \ldots \ldots \ldots \ldots \ldots \ldots \ldots$ & $\begin{array}{r}619,000 \\
1082,00\end{array}$ & 40,000 \\
\hline $1893 \ldots \ldots \ldots . . . . . . . . . . . .$. & $1,427,000$ & $\begin{array}{l}51,000 \\
50,000\end{array}$ \\
\hline \multicolumn{3}{|l|}{ 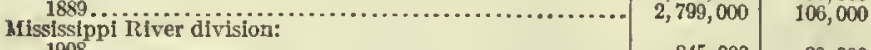 } \\
\hline $1908 . \ldots \ldots \ldots \ldots \ldots \ldots \ldots \ldots \ldots \ldots \ldots$ & 845,000 & \\
\hline & $2,250,000$ & 63,000 \\
\hline \multicolumn{3}{|l|}{ Pacific coast division: } \\
\hline 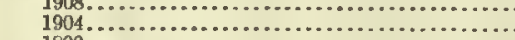 & $\begin{array}{l}309,000 \\
138,000\end{array}$ & $\begin{array}{r}13,000 \\
4,300\end{array}$ \\
\hline ................. & 295,000 & 15,000 \\
\hline $\begin{array}{rl}1895 & 18 \\
189 & \end{array}$ & $3,140,000$ & $\begin{array}{l}80,000 \\
56,000\end{array}$ \\
\hline & $3,775,000$ & \\
\hline
\end{tabular}

The following tabular statement, which shows the distribution of the catch by apparatus of capture, indicates that various appliances were used in taking the product:

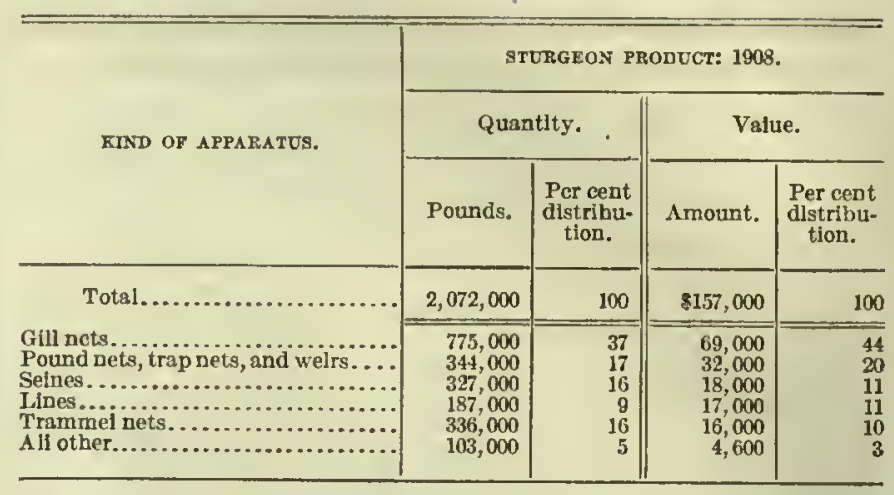

Whate products.-The value of the whale products reported amounted to $\$ 497,000$. These products consisted of 63,000 pounds of whalebone, valued at $\$ 215,000$, and 529,000 gallons of oil, valued at $\$ 282,000$. Of the latter, 452,000 gallons, valued at $\$ 252,000$, was sperm oil, and 76,000 gallons, valued at $\$ 30,000$, whale oil. In 1908 the entire amount from the Pacific coast was reported from the whaling fleet sailing from San Francisco, although in years past a small amount of whale products has been reported from Washington. The home port of the Atlantic whaling fleet, with the exception of a few vessels from Provincetown, is New Bedford, Mass. In 1908 nine whales were stranded on Ponce Park Beach, Fla, from which the oil was extracted; one was caught off Cape Lookout, N. C.; and a number were taken by two vessels sailing from Connecticut ports.

In the following tabular statement, which shows the quantity and value of whale products in 1908, the figures for Florida, North Carolina, and Connecticut are combined under the head "All other states:"

\begin{tabular}{|c|c|c|c|c|c|c|c|}
\hline \multirow{4}{*}{$\begin{array}{l}\text { DIVISION AND } \\
\text { STATE. }\end{array}$} & \multicolumn{7}{|c|}{ WHALE PRODUCTS: 1908.} \\
\hline & \multirow{3}{*}{$\begin{array}{l}\text { Totai } \\
\text { value. }\end{array}$} & \multicolumn{3}{|c|}{ Whalcbonc. } & \multicolumn{3}{|c|}{ Whale oil. } \\
\hline & & \multirow[b]{2}{*}{$\begin{array}{c}\text { Quan- } \\
\text { tity } \\
\text { (pounds). }\end{array}$} & \multicolumn{2}{|c|}{ Value. } & \multirow[b]{2}{*}{$\begin{array}{l}\text { Quail- } \\
\text { tity } \\
\text { (gal- } \\
\text { lons). }\end{array}$} & \multicolumn{2}{|c|}{ Vaine. } \\
\hline & & & Amount. & $\begin{array}{c}\text { Per } \\
\text { cent } \\
\text { distri- } \\
\text { bution. }\end{array}$ & & Amount. & $\begin{array}{c}\text { Per } \\
\text { cent } \\
\text { dlstri- } \\
\text { bution. }\end{array}$ \\
\hline Unitcd States.. & $\$ 497,000$ & 63,000 & $\$ 215,000$ & 100 & 529,000 & 3282,000 & 100 \\
\hline $\begin{array}{l}\text { Atiantic coast divi- } \\
\text { sion............... } \\
\text { Massachusetts } \\
\text { All other states } \\
\text { Pacific coast diví. } \\
\text { sion............... }\end{array}$ & $\begin{array}{r}365,000 \\
336,000 \\
30,000 \\
132,000\end{array}$ & $\begin{array}{r}31,000 \\
30,000 \\
1,900\end{array}$ & $\begin{array}{r}97,000 \\
89,000 \\
7,600 \\
119,000\end{array}$ & $\begin{array}{r}45 \\
41 \\
4\end{array}$ & $\begin{array}{r}594,000 \\
462,000 \\
42,000 \\
24,000\end{array}$ & $\begin{array}{r}269,000 \\
247,000 \\
22,000 \\
13,000\end{array}$ & $\begin{array}{r}95 \\
88 \\
8\end{array}$ \\
\hline
\end{tabular}

No statistics are available for the country as a whole between 1888 and 1908, but by combining the Pacific coast statistics for 1899 with those of the New England states for 1898, and making a similar combination for 1904 and 1905, comparative data are secured sufficient to indicate the general trend of the whaling industry. 
The following statement giving the value of the whale products for specified years shows that there has been a gradual decline:

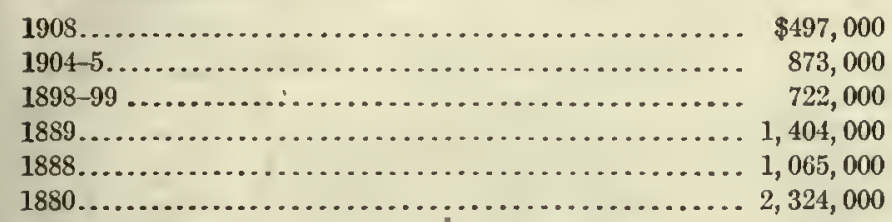

For the Pacific const states the period from 18901892 was the high-water mark of the whale fisheries. The statistics for the Pacific whaling fleet for certain years from 1880 to 1908 are given in the following tabular statement:

\begin{tabular}{|c|c|c|c|c|c|}
\hline \multirow{3}{*}{ YEAR. } & \multicolumn{5}{|c|}{ WHALE PRODUCTS TAKEN BY PACIFIC FLEET. } \\
\hline & \multirow{2}{*}{$\begin{array}{l}\text { Total } \\
\text { value. }\end{array}$} & \multicolumn{2}{|c|}{ Whalebone. } & \multicolumn{2}{|c|}{ Whale oll. } \\
\hline & & $\begin{array}{l}\text { Quantity } \\
\text { (pounds). }\end{array}$ & Value. & $\begin{array}{l}\text { Quantity } \\
\text { (gallons). }\end{array}$ & Value. \\
\hline 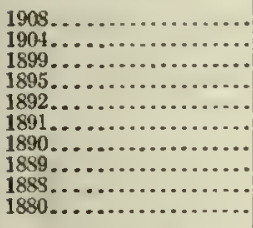 & $\begin{array}{r}\$ 132,000 \\
434,000 \\
457,000 \\
307,000 \\
999,000 \\
1,190,000 \\
736,000 \\
582,000 \\
691,000 \\
202,000\end{array}$ & $\begin{array}{r}32,000 \\
95,000 \\
207,000 \\
99,000 \\
197,000 \\
224,000 \\
170,000 \\
120,000 \\
197,000 \\
(1)\end{array}$ & $\begin{array}{r}\$ 119,000 \\
415,000 \\
436,000 \\
287,000 \\
937,000 \\
1,119,000 \\
680,000 \\
520,000 \\
586,000 \\
\text { (3) }\end{array}$ & $\begin{array}{r}24,000 \\
43,000 \\
70,000 \\
73,000 \\
210,000 \\
235,000 \\
298,000 \\
201,000 \\
292,000 \\
\left({ }^{1}\right)\end{array}$ & $\begin{array}{r}\$ 13,000 \\
18,000 \\
20,000 \\
20,000 \\
62,000 \\
71,000 \\
105,000 \\
62,000 \\
105,000 \\
(9)\end{array}$ \\
\hline
\end{tabular}

1 Not reported.

2 Not reported separately.

The comparative statistics of the catch of the Atlantic fleet are as follows:

\begin{tabular}{|c|c|c|c|c|c|}
\hline \multirow{3}{*}{ YEAR. } & \multicolumn{5}{|c|}{ WHALE PRODUCTS TAKEN BY ATLANTIC FLEET. } \\
\hline & \multirow{2}{*}{$\begin{array}{l}\text { Total } \\
\text { value. }\end{array}$} & \multicolumn{2}{|c|}{ Whalebone. } & \multicolumn{2}{|c|}{ Whale oll. } \\
\hline & & $\begin{array}{l}\text { Quantity } \\
\text { (pounds). }\end{array}$ & Value. & $\begin{array}{l}\text { Quantlty } \\
\text { (gallons). }\end{array}$ & Value. \\
\hline 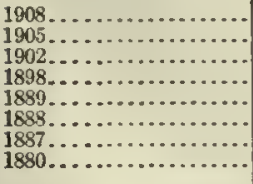 & $\begin{array}{r}\$ 365,000 \\
440,000 \\
383,000 \\
265,000 \\
821,000 \\
680,000 \\
1,034,000 \\
2,122,000\end{array}$ & $\begin{array}{r}31,000 \\
56,000 \\
19,000 \\
27,000 \\
98,000 \\
125,000 \\
223,000 \\
\text { (I) }\end{array}$ & $\begin{array}{r}\$ 97,000 \\
193,000 \\
90,000 \\
66,000 \\
320,000 \\
341,000 \\
569,000 \\
(3)\end{array}$ & $\begin{array}{l}504,000 \\
524,000 \\
685,000 \\
416,000 \\
864,000 \\
646,000 \\
930,000 \\
\left(^{(}\right)\end{array}$ & $\begin{array}{l}\$ 269,000 \\
247,000 \\
293,000 \\
199,000 \\
501,000 \\
339,000 \\
465,000 \\
(3)\end{array}$ \\
\hline
\end{tabular}

The average value per gallon of the product of whale oil in 1908, on both the Atlantic and Pacific coasts, was the highest reported at any time. Sperm oil contributed the greater portion of the value. reported for whale oil, and in 1908 was valued at 50 per cent more a gallon than other kinds of whale oil. It is derived exclusively from the sperm whale and is used chiefly as a lubricator. In previous reports sperm oil was not segregated from other kinds of whale oil.

Whalebone, or baleen, is chiefly used by whip makers, dressmakers, and corset manufacturers. It varies in color and fineness and is received from the vessels in lengths varying from 1 to 15 feet.

Ambergris, another product of the whale, while very valuable in the preparation of fine perfumery, is a very uncertain product. It is sometimes found floating out at sea and sometimes along the shore. None was reported in 1908. In 1905, 94 pounds, valued at $\$ 17,000$, were reported from Massachusetts, and in 1889,37 pounds, valued at $\$ 7,750$. In 1878 a vessel of New Bedford reported 136 pounds that sold for $\$ 23,000$, and in 1858 another New Bedford vessel secured 600 pounds of ambergris, valued at $\$ 10,500$. The total quantity reported by the American whaling fleet from 1836 to 1880 was 1,668 pounds.

Whitefish (Coregonus). - Whitefishes are among the most important fresh-water fishes of America. The common whitefish (C. clupeaformis) is the most valuable species of all, although the others are highly esteemed as food. It is found in the Great Lakes region and is known as "humpback," "bowback," and "highback" whitefish; it is known also as "Otsego bass" in the neighborhood of Otsego Lake, N. Y. Other species of economic importance are the Rocky Mountain whitefish (C. williamsoni) and the Menominee whitefish ( $C$. quadrilateralis), also known locally as "round whitefish," "frostfish," "shadwaiter," "pilot fish," "chivey," "blackback," etc. Coregonus albus is the common whitefish of Lake Erie.

There are included under this name the bluefin (Leucichthys nigripinnis) and the longjaw (L. prognathus), commercially classed with the whitefishes, although they belong to the same genus as the lake herring.

The name is locally applied to the bluefish on the Hudson; to the menhaden in western Connecticut; to the tilefish in California; and to the beluga by whalers.

The whitefish catch is confined to the Great Lakes, Lake of the Woods, and Rainy Lake. In value it ranked fourth among the fishery products in those waters with a catch in 1908 valued at $\$ 524,000$, which is less than 1 per cent of the total value of the United States fishery product, but 14 per cent of the value of the product of the Great Lakes. Every state bordering on the Great Lakes shared in the catch of whitefish, but nearly two-thirds of the total value was contributed by the fish reported from Michigan. In that state whitefish ranked second in value, representing 23 per cent of the total value.

The distribution of the catch, by states ranked according to the value of their product, is given in the following tabular statement:

\begin{tabular}{|c|c|c|c|c|}
\hline \multirow{3}{*}{ STATE. } & \multicolumn{4}{|c|}{ WHITEFISH PRODUCX: 1908.} \\
\hline & \multicolumn{2}{|c|}{ Quantlity. } & \multicolumn{2}{|c|}{ Value. } \\
\hline & Pounds. & $\begin{array}{l}\text { Per cent } \\
\text { distribu- } \\
\text { tion. }\end{array}$ & Amount. & $\begin{array}{l}\text { Per cent } \\
\text { distribu- } \\
\text { tion. }\end{array}$ \\
\hline United States............ & $7,722,000$ & 100 & $\$ 524,000$ & 100 \\
\hline 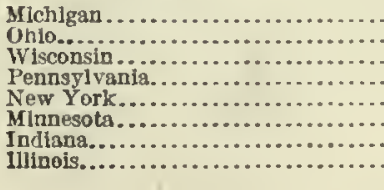 & $\begin{array}{r}4,772,000 \\
732,000 \\
1,274,000 \\
455,000 \\
179,000 \\
242,000 \\
52,000 \\
14,000\end{array}$ & $\begin{array}{r}62 \\
9 \\
17 \\
6 \\
2 \\
3 \\
1 \\
\text { (1) }\end{array}$ & $\begin{array}{r}339,000 \\
60,000 \\
56,000 \\
37,000 \\
15,000 \\
11,000 \\
5,000 \\
800\end{array}$ & $\begin{array}{r}65 \\
11 \\
11 \\
7 \\
3 \\
2 \\
1\end{array}$ \\
\hline
\end{tabular}

! Less than 1 per cont. 
In addition to the whitefish product included in the above statement, there were reported 2,300 pounds of caviar prepared from whitefish roe, valued at $\$ 200$, which are included in the statistics for caviar.

The distribution of the catch by fishing grounds was as follows:

\begin{tabular}{|c|c|c|c|c|}
\hline \multirow{3}{*}{ FISHUNG GROUND. } & \multicolumn{4}{|c|}{ WHITEFTSH PRODUCT: 1909.} \\
\hline & \multicolumn{2}{|c|}{ Quantity. } & \multicolumn{2}{|c|}{ Valuo. } \\
\hline & Pounds. & $\begin{array}{l}\text { Por cent } \\
\text { distribu- } \\
\text { tion. }\end{array}$ & Amount. & $\begin{array}{l}\text { Per cent } \\
\text { distrlbu- } \\
\text { tion. }\end{array}$ \\
\hline 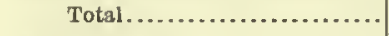 & $7,722,000$ & 100 & $\$ 524,000$ & 100 \\
\hline 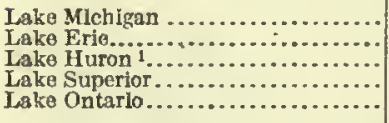 & $\begin{array}{r}3,553,000 \\
1,504,000 \\
1,469,000 \\
1,140,000 \\
56,000\end{array}$ & $\begin{array}{r}46 \\
19 \\
19 \\
15 \\
1\end{array}$ & $\begin{array}{r}241,000 \\
122,000 \\
91,000 \\
65,000 \\
5,400\end{array}$ & $\begin{array}{r}46 \\
23 \\
17 \\
12 \\
1\end{array}$ \\
\hline
\end{tabular}

1 Includos Lake St. Clair.

Nearly all the whitefish product was marketerl fresh, but 342,000 pounds, valued at $\$ 17,000$, were reported salted and 15,000 pounds, valued at $\$ 1,300$, were smoked. The combined value of the salted and smoked product formed only 3 per cent of the total value of the catch.

Although in some cases the returns specified the allied varieties as Menominee, longjaw, etc., in the majority of cases the catch was reported as whitefish without segregation, and hence, the returns can not be depended upon as showing the entire catch of specific varieties. For 5,680,000 pounds of whitefish, valued at $\$ 447,000$, or 85 per cent of the total value, the variety was specified.

The catches of the longjaw, bluefin, and Menominee whitefishes reported separately (chiefly from Michigan and Wisconsin, with small quantities from Minnesota and Illinois), were as follows:

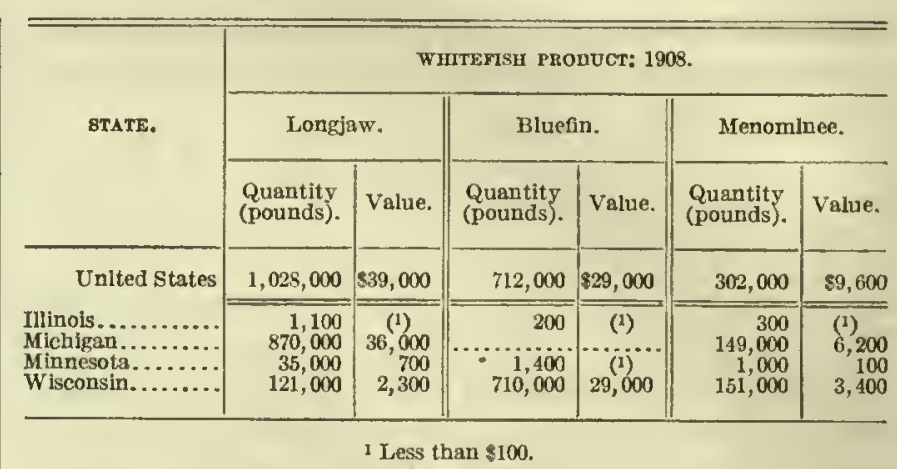

The yield of whitefish in 1908 shows a continuation of the recovery shown in 1903 from the downward movement which had culminated in 1899, yet the catch was little more than one-third as heavy as in 1880. The statisties for those years for which figures are available are given in the following tabular statement:

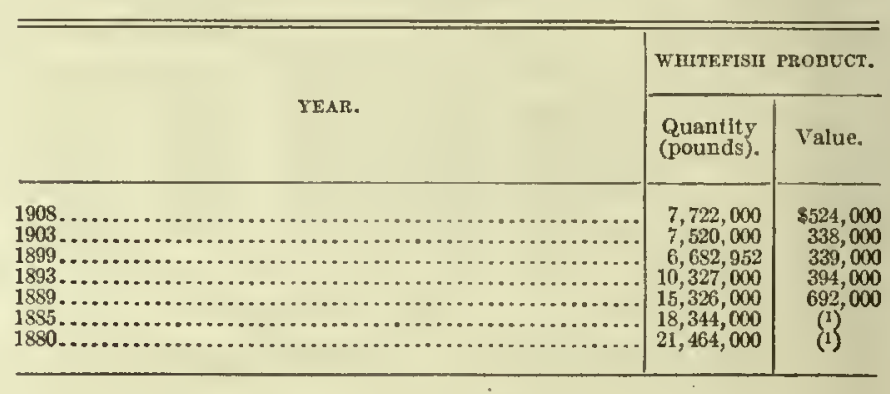

1 Not reported.

Gill nets, pound nots, and trap nets took nearly all of the catch. The proportion of the total value credited to gill nets was 60 per cent and that credited to pound and trap nets 39 per cent; while fyke and hoop nets, seines, and lines took less than 1 per cent of the total. 


\section{CHAPTER VII.}

\section{FISHERIES, BY STATES.}

\section{ALABAMA.}

The state of Alabama lias the shortest coast line of any of the states bordering on the Gulf of Mexico, and its fishing interests, whether measured by the number of fishermen, capital invested, or products, are the least of any of the Gulf states. Among the states engaged in fishing in 1908, Alabama ranked twentyfourth in the value of all products, second in the red snapper fisheries, and sixteenth in the oyster industry. The oyster industry was by far the most important fishing industry of the state and contributed nearly 45 per cent to the total value of all fishery products in 1908. The other fisheries with products exceeding $\$ 10,000$ in value for the year were, in the order of value of products, the red snapper, mullet, catfish, buffalo fish, squeteaguc, and fresh-water drum fisheries. The chicf fishing grounds are Mobile Bay, Mississippi Sound, and the Gulf of Mexico; commercial fishing is also conducted in the Mobile, Alabama, and Tombigbee Rivers. All of the foregoing together constitute the Gulf of Mexico district. The only other fishing ground of the state is the Tennessee River.

The following statement shows the principal items of the Alabama fisheries in 1908:

Number of persons employed...................

Capital:

Vessels and boats, including outfit............\$164,000

Apparatus of capture...................... 23,000

Shore and accessory property and cash ......... 82,000

Value of products........................ 387,000

Comparison with previous canvasses.-The rapid growth of this industry in Alabama during the past 20 years is shown in the following tabular statement:

\begin{tabular}{|c|c|c|c|c|c|c|}
\hline \multirow[b]{2}{*}{ TEAR. } & \multirow{2}{*}{$\begin{array}{l}\text { Persons } \\
\text { em- } \\
\text { ployed, } \\
\text { exclu- } \\
\text { slye of } \\
\text { shores- } \\
\text { men. }\end{array}$} & \multicolumn{3}{|c|}{ VALUE OF EQUIPMENT. } & \multicolumn{2}{|c|}{ PRODUCTS. } \\
\hline & & Total. & $\begin{array}{c}\text { Vessels } \\
\text { and } \\
\text { boats, in- } \\
\text { cluding } \\
\text { outat. }\end{array}$ & $\begin{array}{c}\text { Appara- } \\
\text { tus of } \\
\text { eapture. }\end{array}$ & $\begin{array}{l}\text { Quantity } \\
\text { (pounds). }\end{array}$ & Value. \\
\hline $\begin{array}{l}1908 \ldots \ldots \ldots \ldots \ldots \\
1902 \ldots \ldots \ldots \ldots \ldots \ldots \\
1897 \ldots \ldots \ldots \ldots \ldots \ldots \ldots \\
1889 \ldots \ldots \ldots \ldots \ldots\end{array}$ & $\begin{array}{l}969 \\
714 \\
593 \\
496\end{array}$ & $\begin{array}{r}\mathbf{8 1 8 7 , 0 0 0} \\
136,000 \\
73,000 \\
\mathbf{5 8 , 0 0 0}\end{array}$ & $\mid \begin{array}{r}8164,000 \\
127,000 \\
64,000 \\
47,000\end{array}$ & $\begin{array}{r}823,000 \\
8,200 \\
9,200 \\
12,000\end{array}$ & $\begin{array}{r}10,665,000 \\
9,351,000 \\
4,699,000 \\
4,560,000\end{array}$ & $\begin{array}{l}\$ 387,000 \\
267,000 \\
134,000 \\
147,000\end{array}$ \\
\hline
\end{tabular}

The increase has been continuous except in the cases of the value of the product from 1889 to 1897 and the investment in apparatus from 1889 to 1902 . The gain in the latter from 1902 to 1908 was due largely to the increased use of trammel nets.
Persons employed.-The distribution of the persons employed in 1908 is given below:

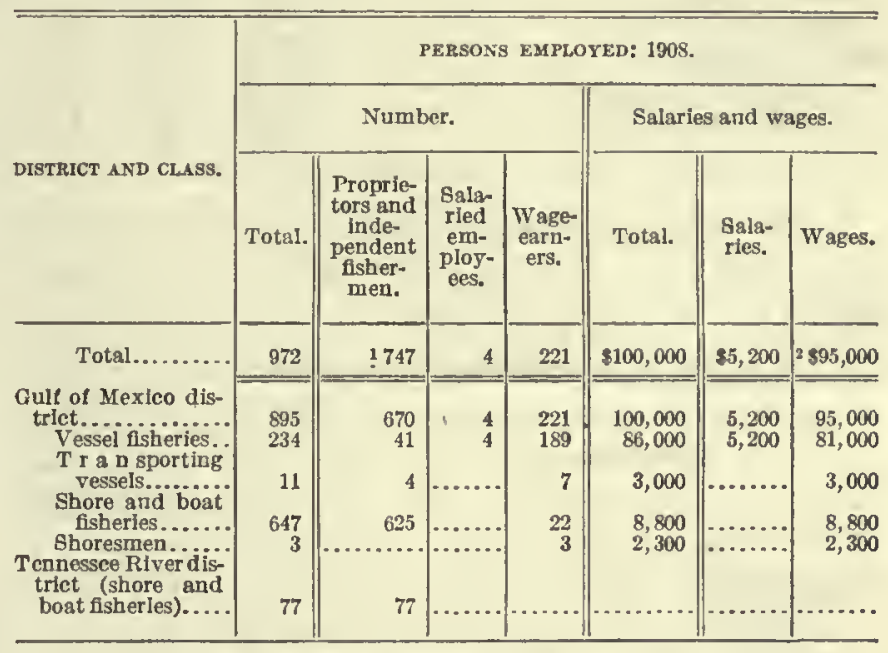

I Exclusive of seven proprtetors not fishing.

2 Includes provisions furnished to the value of $\$ 21,000$.

Nearly all of the fishermen were employed in the Gulf district, only 77 fishing on the Tennessec River. It will be noted that all of the latter were independent fishermen. Nearly all of the fishermen engaged in the shore and boat fisheries of the Gulf district were also independent fishermen, only 22 wage-earners being employed by the 625 proprietors and independent fishermen of the shore and boat fisheries of that district. At least 600 of the persons employed in the shore and boat fisheries of the Gulf district and at least 677 , or nearly 70 per cent, of the 972 persons employed in the fishing industry of the state must have been independent fishermen.

Of the persons employed in the Gulf district, more than 72 per cent were in the shore and boat fisheries. In 1908 the number of persons employed in vessel fisheries was 234 , and on transporting ressels 11 , as compared with 254 and 19, respectively, in 1902. The number of men engaged in the shore and boat fisheries of the Gulf and its immediate tributaries was 647 in 1908, compared with 441 in 1902 . There lias thus been a small decrease in the number of men employed in the vessel fisheries and a large increase in the number employed in the shore and boat fisheries.

Equipment and other capital.-The tabular statement following gives statistics of the fishing equipment comprised in vessels, boats, and apparatus of capture, and of other capital. 


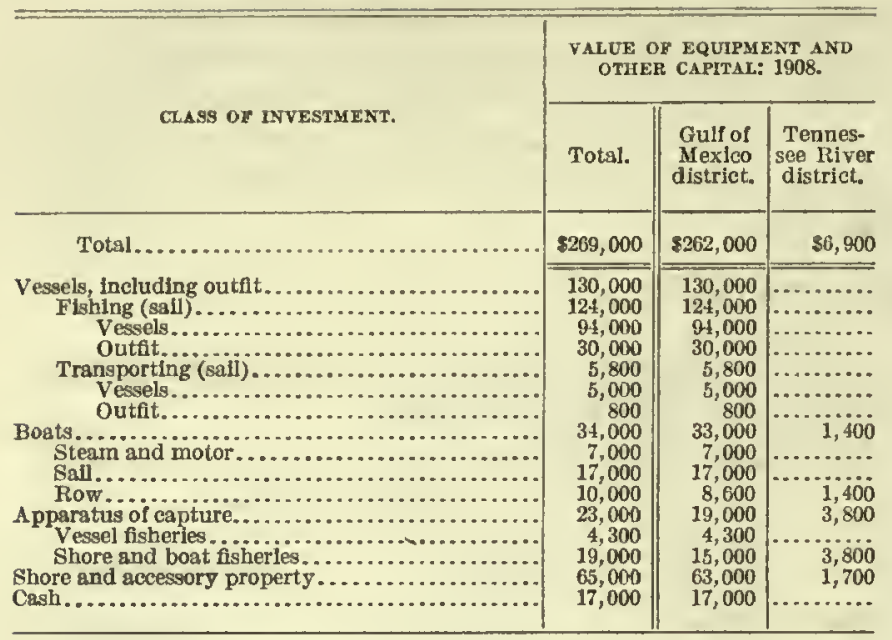

In the following tabular statement the number and tonnage of the vessels and the number of the boats used in the fisheries of Alabama in 1908 are shown:

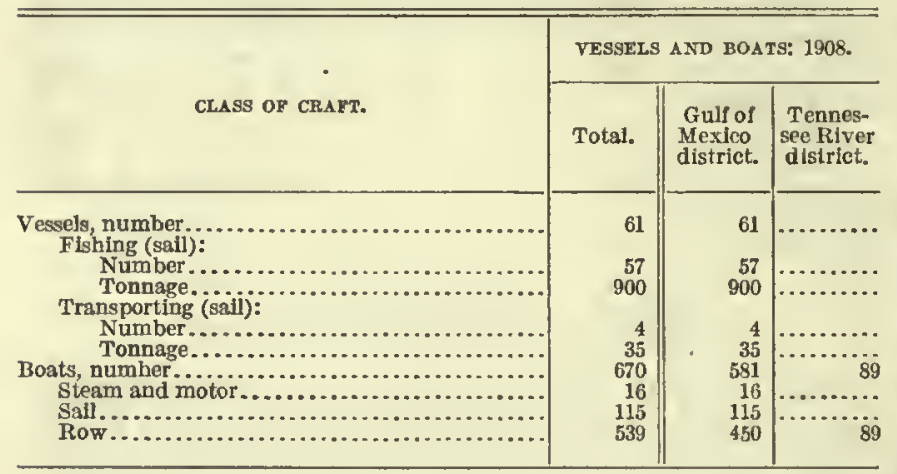

The number of the various kinds of apparatus used. was as follows:

\begin{tabular}{|c|c|c|c|c|c|}
\hline \multirow{3}{*}{ KIND. } & \multicolumn{5}{|c|}{ APPARATUS OP CAPTURE: 1908.} \\
\hline & \multirow{2}{*}{ Total. } & \multicolumn{2}{|c|}{$\begin{array}{c}\text { Distributed by dis- } \\
\text { triets. }\end{array}$} & \multicolumn{2}{|c|}{$\begin{array}{l}\text { Distribution by } \\
\text { class of fisherles. }\end{array}$} \\
\hline & & $\begin{array}{l}\text { Gulf of } \\
\text { Mexileo } \\
\text { district. }\end{array}$ & $\begin{array}{l}\text { Tennes- } \\
\text { see River } \\
\text { district. }\end{array}$ & $\begin{array}{c}\text { Vessel } \\
\text { fisherles. }\end{array}$ & $\begin{array}{l}\text { Shore } \\
\text { and hoat } \\
\text { fisheries. }\end{array}$ \\
\hline 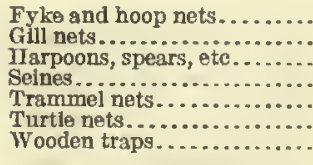 & $\begin{array}{r}891 \\
1 \\
57 \\
9 \\
200 \\
30 \\
27\end{array}$ & $\begin{array}{r}235 \\
1 \\
57 \\
9 \\
200 \\
30\end{array}$ & $\begin{array}{l}656 \\
\cdots \cdots \\
\cdots \cdots \\
\cdots \cdots\end{array}$ & $\begin{array}{r}1 \\
22 \\
6 \\
35\end{array}$ & $\begin{array}{r}891 \\
33 \\
3 \\
165 \\
30 \\
27\end{array}$ \\
\hline
\end{tabular}

All of the sail craft and motor boats were employed in the fisheries of the Gulf coast, rowboats alone being reported for the Tennessee River. The apparatus used in the Tennessee River fisheries was confined to fyke and hoop nets, wooden traps, and. lines.

The total investment in fishing and transporting vessels and their outfit was $\$ 130,000$, while the investment in boats aggregated $\$ 34,000$, of which all but $\$ 1,400$ pertained to the shore and boat fisheries of the Gulf of Mexico district. The number of vessels reported. as engaged in fishing and transporting liad decreased by 16 since 1902, but their value, including the value of the outfit, increased by $\$ 14,000$. The number of boats used in the fisheries of the Gulf coast and the rivers immediately tributary to the Gulf increased by 264 , and their value increased by $\$ 21,000$.

The investment in apparatus of capture for the shore and boat fisheries of the Gulf district largely exceeded that for the vessel fisheries, but the combined investment in floating craft and apparatus of capture by the vessel fisheries was $\$ 134,000$, while for the shore and boat fisheries of the Gulf district it was only $\$ 47,000$. Wooden traps were reported as in use only in the fisheries of the Tennessee River, which also show the majority of fyke and hoop nets. The shore and boat fisheries of the Gulf district employed the largest number of trammel nets. The value of fishing apparatus on vessels and boats fishing in the Gulf and its immediate tributaries was reported as $\$ 8,200$ in 1902 .

In the fisheries of the Gulf district 62 per cent of the capital was invested in floating craft and 7 per cent in apparatus of capture, while in the fisheries of the Tennessee River only 20 per cent was invested in floating craft and 55 per cent in apparatus of capture.

Products, by species. - The fishery products of the state were distributed by species and apparatus of eapture as shown in the table on page 82 . Oysters easily ranked first, with nearly 45 per cent of the total value. Red snapper, mullet, catfish, and buffalo fish followed in the order named.

Products, by fishing grounds.-The following tabular statement shows the distribution of the chief species by fishing grounds:

\begin{tabular}{|c|c|c|c|}
\hline \multirow[b]{2}{*}{ SPECIES. } & \multicolumn{3}{|c|}{ VALUE OF PRODUCTS: 1908.} \\
\hline & Total. & $\begin{array}{l}\text { Gulf of } \\
\text { Mexico. } \\
\text { district. }\end{array}$ & $\begin{array}{l}\text { Tennes- } \\
\text { see River } \\
\text { dIstrjct. }\end{array}$ \\
\hline Total $\ldots . . . . . . . . . . . .$. & $\$ 387,000$ & $\$ 358,000$ & $\$ 29,000$ \\
\hline 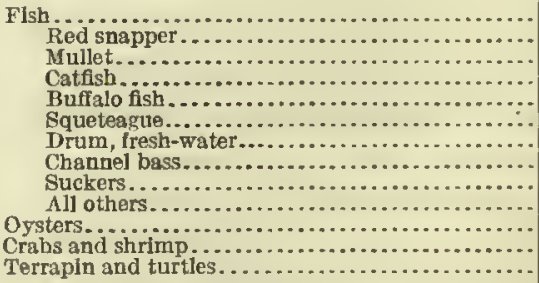 & $\begin{array}{r}206,000 \\
92,000 \\
33,000 \\
17,000 \\
11,000 \\
10,000 \\
10,000 \\
5,500 \\
4,600 \\
23,000 \\
173,000 \\
7,300 \\
600\end{array}$ & $\begin{array}{r}177,000 \\
92,000 \\
33,000 \\
9,600 \\
7,600 \\
10,000 \\
1,400 \\
5,500 \\
18,000 \\
173,000 \\
7,300 \\
600\end{array}$ & $\begin{array}{r}29,000 \\
7, \ldots \ldots \\
7,200 \\
3,200 \\
8,800 \\
4,600 \\
5,000 \\
\ldots \ldots \ldots\end{array}$ \\
\hline
\end{tabular}

The fisheries of the Gulf district are credited with 93 per cent of the total catch. In that district the value of the products was nearly evenly divided between fish and oysters, while in the Tennessee River district fish constituted the entire product. The principal species taken in the Gulf district were, in the order of value, oysters, red snapper, mullet, and squeteague. The first two named formed 74 per cent of the total catch of the Gulf district. The clief species caught in the Tennessee River, in the order of value, were freshwater drum, catfish, suckers, and buffalo fish. 
Products, by class of fisheries.-The distribution of products between the vessel fisheries and the shore and boat fiskeries is shown in the following tabular statement:

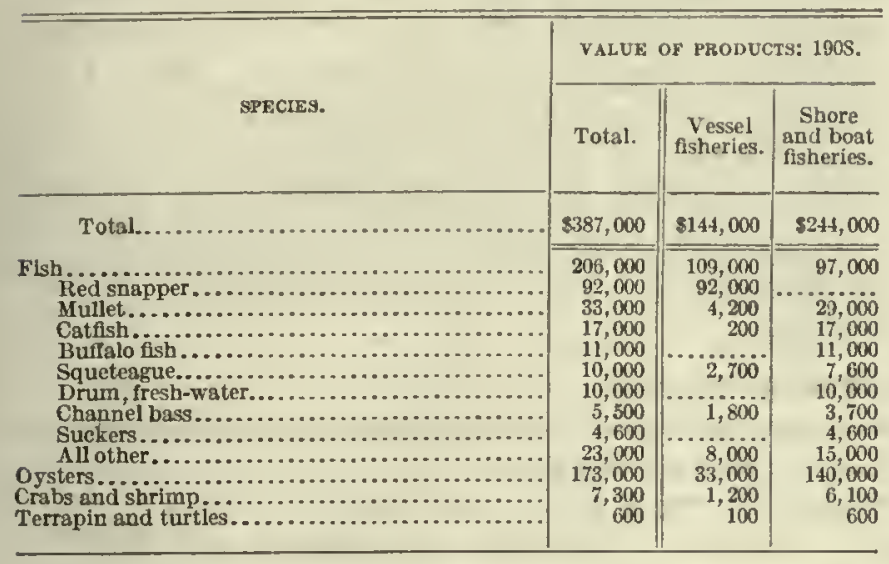

The fish products proper amounted in the aggregate to $6,232,000$ pounds, or 58 per cent of the total weight of fishery products, and were valued at $\$ 206,000$, or 53 per cent of the total value. The value of the fish products constituted 40 per cent of the total in the case of the shore and boat fisheries, and 76 per cent in the ease of the vessel fisheries. The products of the vessel fisheries were chiefly red snapper and oysters, all other products amounting to only 13 per cent.

The combined catch of the shore and boat fisheries aggregated $6,312,000$ pounds, having a value of $\$ 244,000$. Of this eateh, 93 per cent in quantity and 88 per cent in value was from the Gulf distriet.

Of the products of the shore and boat fisheries for the state, the oyster eateh formed 57 per cent in value.

Products, by apparatus of capture.-The product eaught by means of tongs, representing the oyster catch, contributed a larger percentage of the total products, as measured by value, than the product caught by any other class of apparatus, and formed nearly two-thirds of the shore and boat products of the Gulf district; while the eateh of lines contributed more than two-thirds of the total for the vcssel fisheries, and that of fyke nets nearly one-half of the total for the Tennessee River. Seines were used to a comparatively small extent, and gill nets still less and only in the rossel fisheries. The eatch in wooden traps, all in the Tennessee River, was a substantial one, aggregating 107,000 pounds. The following tabular statement shows the value and distribution of the catch, by the various kinds of apparatus:

$$
76786^{\circ}-11-6
$$

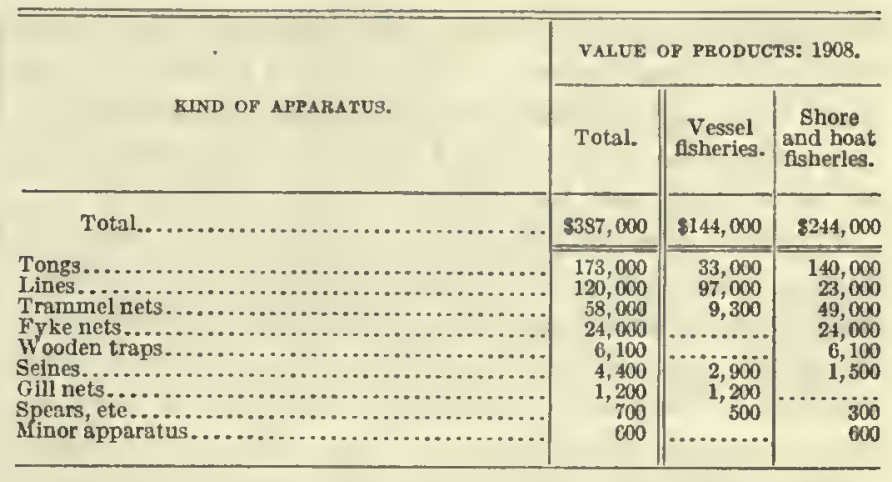

Oysters.-The product of the oyster fishery was 590,000 bushels, valued at $\$ 173,000$, which was 45 per cent of the total value of all products. The oyster catch included 54,000 bushels of seed oysters, having a value of $\$ 4,100$, and 536,000 bushels of market oysters, having a value of $\$ 169,000$. All of the seed oysters were from public areas, and of the market oysters 12 per ecnt were from private areas and 88 per cent from public areas. The value of the oysters from private areas formed 22 per cent of the total value of market oysters and their average value was 59 cents per bushel, compared with 28 cents per bushel for oysters from public areas. The oyster product of 1908 shows a large increase over the figures for 1902, in which year the total product reported amounted to 347,000 bushels, valued at $\$ 120,000$. The increase in quantity of oysters, exclusive of seed oysters, was 189,000 bushels, or 54 per cent, and the increase in value $\$ 49,000$, or 41 per cent. The gain was confined almost entirely to the product from the public areas, the product from the private areas increasing only 17 per cent in quantity and decreasing 5 per cent in value. Oysters ean be taken from the public reefs at any time, the demand alone governing the fishermen in this particular. Tongs are the only apparatus allowed for taking oysters, and the quantity of oysters permitted per single boat is limited to 3,500 bushels per week. No oysters measuring less than $2 \frac{1}{2}$ inches from hinge to mouth ean be taken.

Red snapper.-The red snapper was" the most important of the kinds of fish caught, and in 1908 constituted nearly one-fourth of all products both in quantity and in value. It is a deep-sea fish, the fishing being done with lines in from 20 to 75 fathoms of water, and the eateh figures solely in the vessel fisheries. This fishery centers at Mobile, and the vessels go as far east as Tampa, Fla., and as far west as the Mexican coast.

Mullet.-The mullet ranked next in importance in 1908, and formed 16 per cent of the total quantity of 
the products, although its value formed only 9 per cent of the total value. It is chiefly a product of the shore and boat fisheries, and is caught almost entirely in trammel nets, less than 4 per cent being caught in seines and gill nets in 1908 .

Catfish.-The catfish ranked third in the order of value. The figures for this fish represent both the fresh-water and the salt-water varieties, and practically all of the catch was reported by the shore and boat fisheries. They are caught with a variety of apparatus-trammel nets, fyke nets, lines, seines, and traps.

Other products.-The buffalo fish, squeteague, and fresh-water drum were important products of about equal commercial value. The buffalo fish and the drum were cauglit in the Tennessee River and the freshwater tributaries of the Gulf, while the squeteague was reported by both the shore and the vessel fisheries of the Gulf district. Hickory shad and carp were reported solely from the Tennessee River, and groupers and shrimp solely by the vessel fisheries. Black bass, sturgeon, and sunfish were taken in the shore and boat fisheries of the Gulf district as well as in the Tennessee River, and the remainder of the enumerated products were taken in the vessel fisheries and in the shore and boat fisheries of the Gulf of Mexico district.

ALABAMA-FISHERY PRODUCTS: 1908.

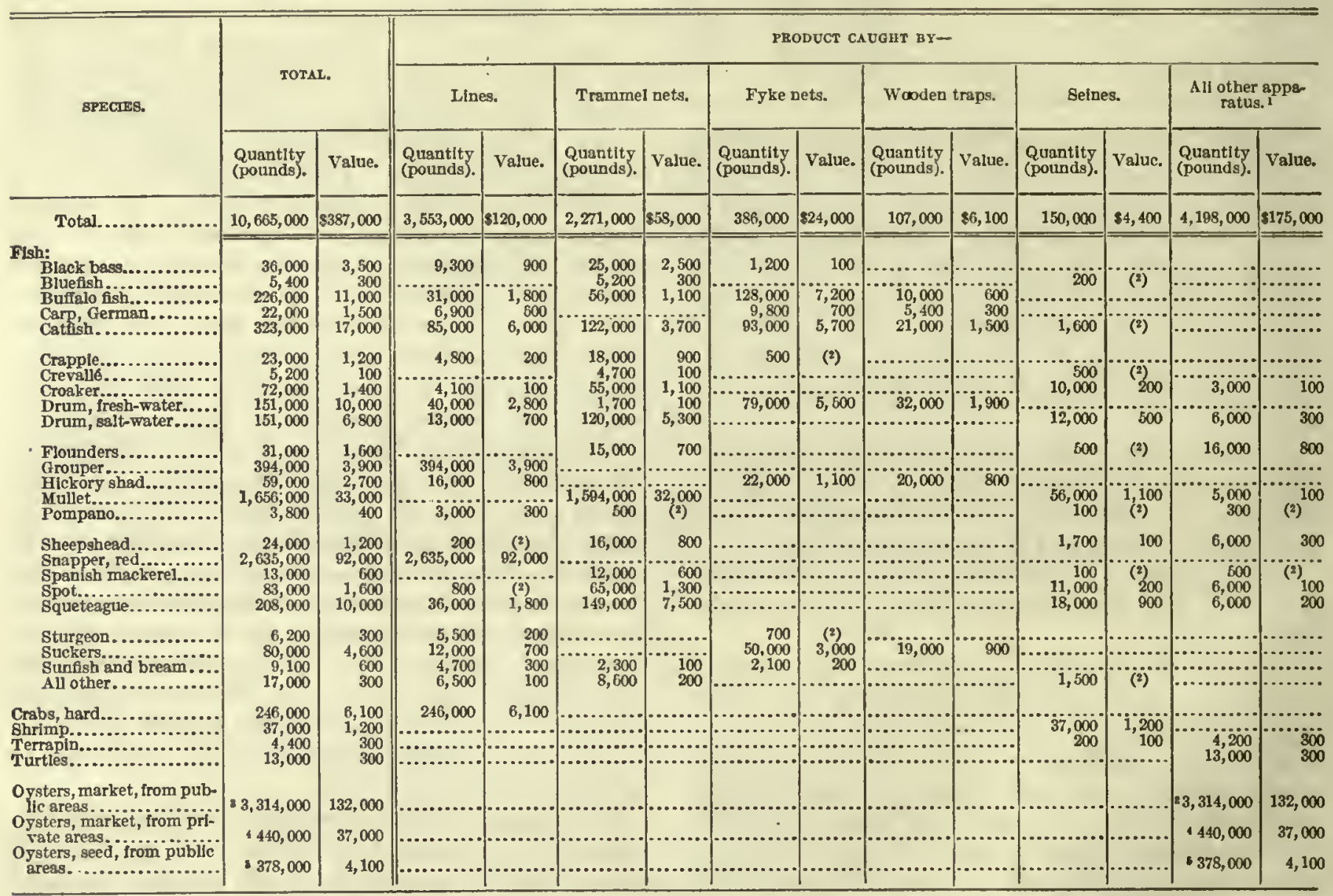

1 Includes apparatus, with catch, as follows: Tongs, 4,132,000 pounds, valued at $\$ 173,000$; gill nets, 35,000 pounds, valued at $\$ 1,200$; spears, etc., 14,000 pounds, valued at $\$ 700 ;$ and minor apparatus, 17,000 pounds, valued at $\$ c 00$. Less than $\$ 100$.
a

63,000 bushels.

s4,000 bushels.

\section{ARKANSAS.}

The fishing grounds of Arkansas are principally the Mississippi River; its tributaries, the Arkansas, White, St. Francis, Ouachita, Black, and Cache Rivers; and Big Lake. Buffalo fish and catfish were the leading species of fish caught, while mussel shells, together with pearls and slugs, almost equaled in importance these two fish products combined. The following statement gives a gencral summary of the state's fisheries for 1908:
Number of persons employed. 998 Capital:

Vessels and boats, including outfit............. $\$ 45,000$

Apparatus of capture...................... 31,000

Shore and accessory property.................. 13,000 Value of products......................... 207,000

Comparison with previous canvasses.-A comparison of the figures for 1908 with those for previous years shows a considerable increase in the fishery investments and products. The following tabular statement gives a summary of the fisheries of Arkansas for 1894, 1899, and 1908: 


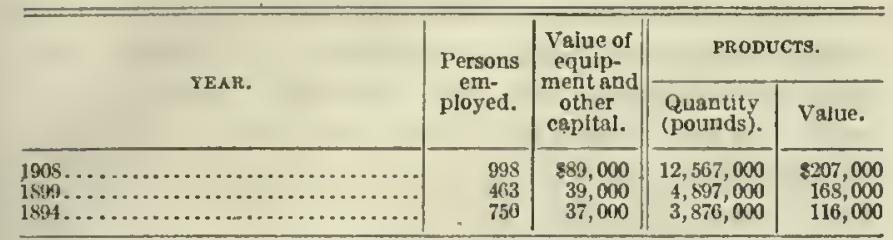

It will bo noticed that the rate of increase in the quantity of products between 1899 and 1908 is much higher than the rate for the value of products. This clisproportion is in large part due to the development of the mussel fisheries, the products of which amounted to $8,060,000$ pounds in 1908 , whereas none at all were reported in 1899. While mussel shells add greatly to the total weight of the state's fisliery products, they are of relatively small value. Exclusive of the mussel fishery, the quantity of products declined from $4,897,000$ pounds to $4,507,000$ pounds, and their value from $\$ 168,000$ to $\$ 137,000$.

Persons employed. - The data as to the persons employed in the fisheries of the state during 1908 are as follows:

\begin{tabular}{|c|c|c|c|c|}
\hline \multirow{3}{*}{ CLAS8. } & \multicolumn{4}{|c|}{ PERSONS EMPLOYED: 1908.} \\
\hline & \multicolumn{3}{|c|}{ Number. } & \multirow[b]{2}{*}{ Wages. } \\
\hline & Total. & $\begin{array}{l}\text { Proprie- } \\
\text { tors and } \\
\text { independ- } \\
\text { ent fish- } \\
\text { ermen. }\end{array}$ & $\begin{array}{l}\text { Wage- } \\
\text { earners. }\end{array}$ & \\
\hline Total .................. & 998 & 861 & 137 & $\$ 20,000$ \\
\hline 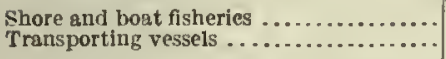 & $\begin{array}{r}981 \\
17\end{array}$ & $\begin{array}{r}855 \\
6\end{array}$ & $\begin{array}{r}126 \\
11\end{array}$ & $\begin{array}{r}16,000 \\
3,500\end{array}$ \\
\hline
\end{tabular}

1 Fxclusive of thrce proprietors not flshing.

The industry is carried on largely by independent fishermen, only a few of the fishermen employing helpers. A large proportion of the 137 wage-earners were employed by a few proprietors on Big Lakc, and the small total of wages paid suggests the intermittent character of much of the employment.

Equipment and other capital. - Statistics as to the number and value of the different kinds of equipment employed, and the amount of other capital invested, are presented in the following tabular statement:

\begin{tabular}{|c|c|c|}
\hline \multirow{2}{*}{ CLASS OF INVESTMENT. } & \multicolumn{2}{|c|}{$\begin{array}{l}\text { EQUIP MENT AND } \\
\text { OTHER CAPITAL: } \\
1908 .\end{array}$} \\
\hline & Number. & Value. \\
\hline Total........ & …..... & $\$ 89,000$ \\
\hline Transporting vessels (steam and motor), Including outfit.. & & 8,100 \\
\hline Véssels & $\begin{array}{r}6 \\
36\end{array}$ & 6,600 \\
\hline Outfit........ & & 1,500 \\
\hline $\begin{array}{l}\text { Boats....................... } \\
\text { Steam and motor.... }\end{array}$ & 1,154 & 37,000 \\
\hline $\begin{array}{l}\text { Steam and motor } \ldots \ldots \ldots \ldots \ldots \ldots \ldots \ldots \ldots \\
\text { Row... }\end{array}$ & 1,037 & $\begin{array}{l}18,000 \\
19,000\end{array}$ \\
\hline A pparatus of capture (shore and boat nisheries) & & 31,000 \\
\hline 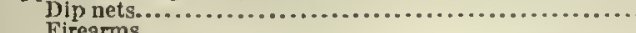 & 5 & -........... \\
\hline 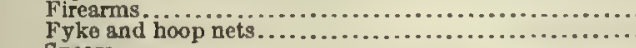 & 3,638 & (n........... \\
\hline $\begin{array}{l}\text { Spears................... } \\
\text { Pound nets.............. }\end{array}$ & $\begin{array}{r}46 \\
127\end{array}$ & (........... \\
\hline Seines ............. & 37 & …............ \\
\hline 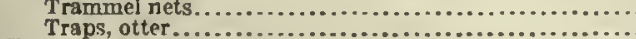 & ${ }_{10}^{21}$ & …......... \\
\hline Shore and accessory property...... & & $\cdots i 3,000$ \\
\hline
\end{tabular}

The value of vessels and boats together made up one-half of the investment. As would be expected in river fisheries, no sailing eraft were reported. Of the apparatus of capture, fyke and hoop nets were most numerous, with a value greater than that of all other kinds of apparatus combined.

Products, by species.-The table on page 84 gives the quantity and value of the products of the Arkansas fisheries, distributed by species and by apparatus of capture.

Fifteen species of fish were reported, besides frogs, turtles, mussel shells, and pearls and slugs. Mussel shells and pearls and slugs made up one-third of the total value of products. The catch of buffalo fish was the most important among the fish, and catfish and black bass were next in order. These four species contributed 80 per cent of the total value of products. In 1899 also buffalo fish and catfish were the leading species. Black bass, however, was one of the minor species in 1899. Crappie, fifth in importance in 1908, stood third in 1899, while paddlefish and caviar, although of little importance in 1908, stood fourth in 1899.

Products, by fishing grounds. - The distribution of the products by fishing grounds is given below:

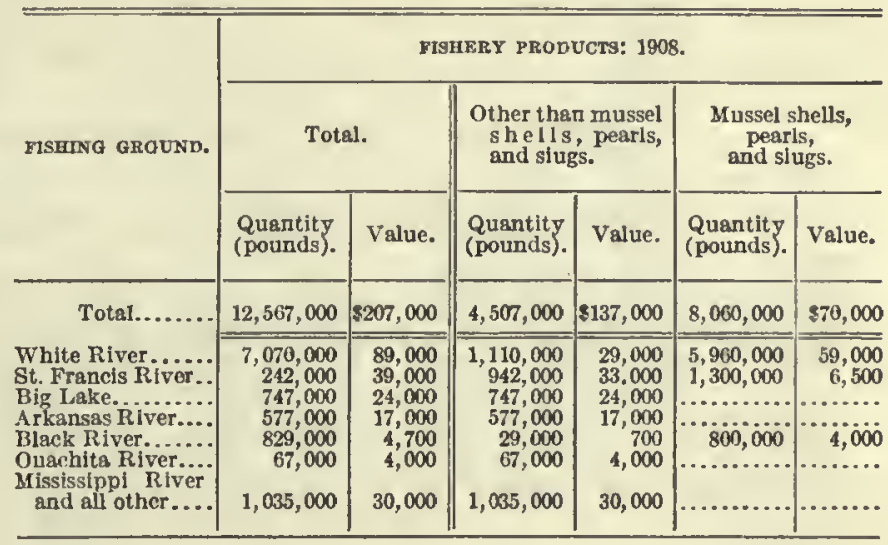

The fisleries of the White River were the most important in the state, measured by value of products, and the mussel fisheries contributed the larger part of the product. Only two other rivers, the St. Francis and the Black, reported mussel fisheries.

Products, by apparatus of capture.-In 1908 crowfoot dredges, fyke nets, lines, and seines together were credited with 93 per cent of the total value of products, ranking in importance in the order named. In 1899 crowfoot dredges were not reported, and the leading kinds of apparatus used were, in the order of importance, seines, fyke nets, and set lines. In 1899 seines took 37 per cent in value of the total product, while in 1908 they took only 15 per cent of the fish proper. This decrease is counterbalanced by the increases in the catcl of fyke nets and lines, as shown by the tabular statement following. 


\begin{tabular}{|c|c|c|c|c|}
\hline \multirow{3}{*}{ YEAR. } & \multicolumn{4}{|c|}{ PRODUCTS CAUGHT BY- } \\
\hline & \multicolumn{2}{|c|}{ Fyke nets. } & \multicolumn{2}{|c|}{ Lines. } \\
\hline & $\begin{array}{l}\text { Quantity } \\
\text { (pounds). }\end{array}$ & Value. & $\begin{array}{l}\text { Quantity } \\
\text { (pounds). }\end{array}$ & Value. \\
\hline $\begin{array}{l}1908 \ldots \\
1899 \ldots\end{array}$ & $\begin{array}{l}2,286,000 \\
1,40 ;, 000\end{array}$ & $\begin{array}{r}\$ 53,000 \\
45,000\end{array}$ & $\begin{array}{r}1,081,000 \\
682,000\end{array}$ & $\begin{array}{r}\$ 48,000 \\
30,000\end{array}$ \\
\hline
\end{tabular}

Buffalo fish.-In 1908 the buffalo-fish catch represented 21 per cent of the total value of products, compared with 31 per cent in 1899 . The product of this species has decreased slightly in quantity and still more in value. The gain over 1894, however, is substantial, as is shown by the following tabular statement:

\begin{tabular}{|c|c|c|c|c|}
\hline \multirow[t]{2}{*}{ - } & \multirow{2}{*}{ YXAR. } & \multirow[b]{2}{*}{ • } & \multicolumn{2}{|c|}{$\begin{array}{l}\text { B UFFALO-FTSH, } \\
\text { PRODUCT. }\end{array}$} \\
\hline & & & $\begin{array}{l}\text { Quantity } \\
\text { (pounds). }\end{array}$ & Value. \\
\hline $\begin{array}{l}1908 . . \\
1899 . .\end{array}$ & & & $\begin{array}{l}2,051,000 \\
2,389,000 \\
1,626,000\end{array}$ & $\begin{array}{r}\$ 43,000 \\
53,000 \\
31,000\end{array}$ \\
\hline
\end{tabular}

Catfish-Catfish contributed 16 per cent of the total value of products in 1908, as compared with approximately 25 per cent in 1899. Although the catch has increased since 1899 , the value has decreased. The following tabular statement gives the product for 1894, 1899, and 1908:

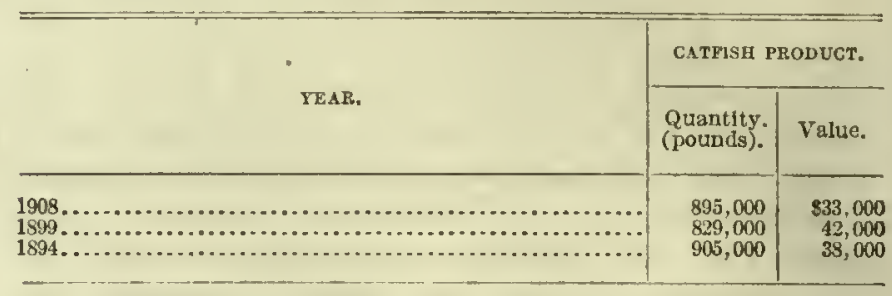

Other leading products. - In 1908 the value of the black bass caught, $\$ 20,000$, formed 10 per cent of the entire value of the fishery products of the state, the quantity being much larger than in 1899, when its value was $\$ 10,000$. The catch of crappie in 1908 was approximately 25 per cent heavier than in 1899 , but of about the same value. The total catch of fresh-water drum lias increased one-third in quantity and one-seventh in value since 1899.

ARKANSAS-FISHERY PRODUCTS: 1908.

\begin{tabular}{|c|c|c|c|c|c|c|c|c|c|c|c|c|c|c|}
\hline \multirow{3}{*}{ SPECIES. } & \multirow{2}{*}{\multicolumn{2}{|c|}{ TotaL. }} & \multicolumn{12}{|c|}{ PRODUCT CAUGHT BY- } \\
\hline & & & \multicolumn{2}{|c|}{ Fyke nets. } & \multicolumn{2}{|c|}{ Lines. } & \multicolumn{2}{|c|}{ Seines. } & \multicolumn{2}{|c|}{ Pound nets. } & \multicolumn{2}{|c|}{ Trammel nets. } & \multicolumn{2}{|c|}{ All other apparatus.1 } \\
\hline & $\begin{array}{l}\text { Quantity } \\
\text { (pounds). }\end{array}$ & Value. & $\begin{array}{l}\text { Quantity } \\
\text { (pounds). }\end{array}$ & Value. & $\begin{array}{l}\text { Quantity } \\
\text { (pounds). }\end{array}$ & Value. & $\begin{array}{l}\text { Quantlty } \\
\text { (pounds). }\end{array}$ & Value. & $\begin{array}{l}\text { Quantity } \\
\text { (pounds). }\end{array}$ & Value. & $\begin{array}{l}\text { Quantity } \\
\text { (pounds). }\end{array}$ & Value. & $\begin{array}{l}\text { Quantity } \\
\text { (pounds). }\end{array}$ & Value. \\
\hline Total........... & $12,567,000$ & 3207,000 & $2,286,000$ & $\$ 53,000$ & $1,081,000$ & $\$ 48,000$ & 692,000 & $\$ 21,000$ & 275,000 & 87,100 & 129,000 & $\$ 3,900$ & $8,105,000$ & $\$ 74,000$ \\
\hline $\begin{array}{l}\text { Fish: } \\
\text { Black bass........ } \\
\text { Bream, or sunisish. } \\
\text { Buffalo fish........ } \\
\text { Carp, German.... } \\
\text { Catfish........... }\end{array}$ & $\begin{array}{r}292,000 \\
228,000 \\
2,061,000 \\
176,000 \\
895,000\end{array}$ & $\begin{array}{r}20,000 \\
6,000 \\
43,000 \\
4,100 \\
33,000\end{array}$ & $\begin{array}{r}7,000 \\
70,000 \\
1,496,000 \\
102,000 \\
216,000\end{array}$ & $\begin{array}{r}500 \\
1,600 \\
32,000 \\
2,400 \\
7,100\end{array}$ & $\begin{array}{r}222,000 \\
44,000 \\
73,000 \\
23,000 \\
535,000\end{array}$ & $\begin{array}{r}15,000 \\
1,600 \\
1,800 \\
700 \\
20,000\end{array}$ & $\begin{array}{r}21,000 \\
72,000 \\
287,000 \\
29,000 \\
105,000\end{array}$ & $\begin{array}{r}1,400 \\
2,000 \\
6,100 \\
600 \\
4,100\end{array}$ & $\begin{array}{r}20,000 \\
27,000 \\
142,000 \\
8,500 \\
25,000\end{array}$ & $\begin{array}{r}1,400 \\
600 \\
2,500 \\
100 \\
900\end{array}$ & $\begin{array}{l}18,000 \\
15,000 \\
44,000 \\
10,000 \\
14,000\end{array}$ & $\begin{array}{r}1,300 \\
300 \\
800 \\
200 \\
400\end{array}$ & $\begin{array}{r}3,700 \\
8,500 \\
700\end{array}$ & $\begin{array}{l}300 \\
\cdots \ldots 0 \\
\left.{ }^{2}\right)^{200}\end{array}$ \\
\hline $\begin{array}{l}\text { Crapple .......... } \\
\text { Drum,fresh-water } \\
\text { Paddlefish....... } \\
\text { Caviar and pad- } \\
\text { dlofish eggs..... }\end{array}$ & $\begin{array}{r}300,000 \\
402,000 \\
71,000 \\
800\end{array}$ & $\begin{array}{r}13,000 \\
8,900 \\
2,000 \\
700\end{array}$ & $\begin{array}{r}71,000 \\
284,000 \\
19,000\end{array}$ & $\begin{array}{r}2,800 \\
6,000 \\
500\end{array}$ & $\begin{array}{r}104,000 \\
55,000 \\
\ldots \ldots\end{array}$ & $\begin{array}{r}5,100 \\
1,700 \\
\cdots \ldots\end{array}$ & $\begin{array}{l}58,000 \\
55,000 \\
52,000\end{array}$ & $\begin{array}{r}2,700 \\
1,100 \\
1,500 \\
700\end{array}$ & $\begin{array}{r}42,000 \\
7,700 \\
\cdots\end{array}$ & $\begin{array}{r}1,500 \\
100 \\
\ldots \ldots \ldots\end{array}$ & $\begin{array}{r}25,000 \\
800\end{array}$ & $\begin{array}{c}900 \\
(?) \\
(2)\end{array}$ & $\because$ & \\
\hline $\begin{array}{r}\text { Pike.............. } \\
\text { Pike perch (wall- } \\
\text { eyed)............ }\end{array}$ & 14,000 & 300 & 3,400 & 100 & 6,000 & 100 & 1,000 & $(2)$ & 2,600 & 100 & 1,200 & $(2)$ & & \\
\hline $\begin{array}{l}\text { Rock bass............ } \\
\text { Spekers......... }\end{array}$ & $\begin{array}{r}1,300 \\
15,000 \\
12,000\end{array}$ & $\begin{array}{l}100 \\
900 \\
200\end{array}$ & $\begin{array}{r}1,900 \\
12,000\end{array}$ & 100 & $\begin{array}{l}1,300 \\
4,000\end{array}$ & $\begin{array}{l}100 \\
200\end{array}$ & $\ddot{9}, \ddot{2000}$ & 900 & & & & & & \\
\hline $\begin{array}{l}\text { White bass........ } \\
\text { All other......... }\end{array}$ & $\begin{array}{r}16,000 \\
2,000\end{array}$ & $\begin{array}{l}1,000 \\
(2)\end{array}$ & $\begin{array}{r}12,000 \\
4,000 \\
\ldots \ldots .\end{array}$ & 200 & $\begin{array}{r}12,000 \\
2,000\end{array}$ & $\begin{array}{c}800 \\
(2)\end{array}$ & $\ldots \ldots \ldots$ & ....... & $\cdots$ & & & & & \\
\hline $\begin{array}{l}\text { Frogs................. } \\
\text { Turtles ................ } \\
\text { Mussel shells ......... } \\
\text { Pearls and slugs...... }\end{array}$ & $\begin{array}{r}27,000 \\
6,000 \\
8,000,000 \\
\end{array}$ & $\begin{array}{r}4,000 \\
100 \\
42,000 \\
28,000\end{array}$ & & & $\cdots$ & & $\ddot{1}, 000$ & (i) & & & & & $\begin{array}{r}27,000 \\
5,000 \\
8,060,000\end{array}$ & $\begin{array}{r}4,000 \\
100 \\
42,000\end{array}$ \\
\hline Skins, otter........... & $\left({ }^{2}\right)^{\prime}$ & $\begin{array}{r}28,000 \\
100\end{array}$ & & & & & & & & & & & $\cdots(3)$ & $\begin{array}{r}28,000 \\
100\end{array}$ \\
\hline
\end{tabular}

I Includes apparatus, with cateh, as follows: Crowfoot dredges, $8,060,000$ pounds, valued at $\$ 70,000$; frearms, 19,000 pounds, valuod at $\$ 2,900$; harpoons, spears, ete. 20,000 pounds, valued at $\$ 1,600 ;$ dip nets and traps, 5,000 pounds, valued at $\$ 200$. Less than $\$ 100$

\section{CALIFORNIA.}

In the value of products from fisheries, California ranked second among the Pacific coast states both at the canvass of 1904 and at that of 1908 . Sea fishing is carried on along practically the entire const line of the state, but the river or inland fisheries are confined almost exclusively to the rivers flowing into San Francisco Bay, the largest and most productive of which is tho Sacramento. Humboldt Bay is next in importance as a fishing ground, the salmon catch being the principal product. The following tabular statement gives a summary of the industry for 1908:

Number of persons employed................ 4, 129 Capital:

Vessels and boats, including outfit............. \$1,066,000

Apparatus of capture..................... 502,000

Shore and accessory property and cash.......... 91,000

Value of products......................... 1,970,000 
Comparison with previous canvasses.-The statistics reported for the years 1904 and 1899 are not in all respects comparable with the returns for 1908 , on account of the inclusion in the earlicr canvasses of the capital and number of persons employed in the canneries and packing houses with the data for the fisheries. The following figures, however, which are exclusive of statistics for shoresmen, capital invested in shore and accessory property, and cash capital, may be considered as comparable:

\begin{tabular}{|c|c|c|c|c|c|c|}
\hline \multirow[b]{2}{*}{ YEAR. } & \multirow{2}{*}{$\begin{array}{l}\text { Persons } \\
\text { em- } \\
\text { ployed, } \\
\text { exclut- } \\
\text { sive of } \\
\text { shores- } \\
\text { men. }\end{array}$} & \multicolumn{3}{|c|}{ VALUE OF EQUTPMENT. } & \multicolumn{2}{|c|}{ Pronccts. } \\
\hline & & Total. & $\begin{array}{c}\text { Vessels and } \\
\text { boats, } \\
\text { ncluding } \\
\text { outfit. }\end{array}$ & $\begin{array}{l}\text { Apparar } \\
\text { tus of } \\
\text { capture. }\end{array}$ & $\begin{array}{l}\text { Quantity } \\
\text { (pounds). }\end{array}$ & Value. \\
\hline $\begin{array}{l}1908 \ldots . . . \\
1904 \ldots . . . \\
1899 \ldots . .\end{array}$ & $\begin{array}{l}4,100 \\
4,406 \\
3,480\end{array}$ & $\begin{array}{r}81,568,000 \\
1,489,000 \\
1,574,000\end{array}$ & $\begin{array}{r}\$ 1,066,000 \\
1,128,000 \\
1,325,000\end{array}$ & $\begin{array}{r}\$ 502,000 \\
360,000 \\
250,000\end{array}$ & $\begin{array}{l}47,477,000 \\
52,110,000 \\
74,559,000\end{array}$ & $\begin{array}{r}\$ 1,970,000 \\
2,523,000 \\
2,551,000\end{array}$ \\
\hline
\end{tabular}

In 1908, as compared with 1904, the number of persons employed, exclusive of shoresmen, shows a decrease of 7 per cent and the capital invested in floating craft and fishing equipment an increase of 5 per cent, while the value of products shows a material loss of 22 per cent, the larger portion of which ean be attributed to the decrease in the value of products of the oyster industry. From 1899 to 1904 there was an increase of 27 per cent in the number of persons employed, and decreases of 5 per cent in the capital invested and of 1 per cent in the value of products.

Persons employed.-The number of persons employed and the salaries and wages paid during the year 1908 in each branch of the industry were as follows:

\begin{tabular}{|c|c|c|c|c|c|c|c|}
\hline \multirow[b]{3}{*}{ chass. } & \multicolumn{7}{|c|}{ PERSONS EMPLOYED: 1908.} \\
\hline & \multicolumn{4}{|c|}{ Numider. } & \multicolumn{3}{|c|}{ Salaries and wages. } \\
\hline & Total. & $\begin{array}{l}\text { Proprie- } \\
\text { tors and } \\
\text { inde- } \\
\text { pendent } \\
\text { fisher- } \\
\text { men. }\end{array}$ & $\begin{array}{l}\text { Sala- } \\
\text { ried } \\
\text { em- } \\
\text { ploy- } \\
\text { ees. }\end{array}$ & $\begin{array}{l}\text { Wage- } \\
\text { earn- } \\
\text { ers. }\end{array}$ & Total. & $\begin{array}{l}\text { Sala- } \\
\text { ries. }\end{array}$ & Wages. \\
\hline Total......... & 4,129 & 12,622 & 41 & 1,406 & $\$ 5562,000$ & $\$ 26,000$ & $2 \$ 536,000$ \\
\hline $\begin{array}{l}\text { Vessel fisheries....... } \\
\text { Transporting vessels } \\
\text { Shore and boat fish- } \\
\text { eries................ } \\
\text { Shoresmen.......... }\end{array}$ & $\begin{array}{r}645 \\
135 \\
3,320 \\
29\end{array}$ & 2,589 & $\begin{array}{l}11 \\
29\end{array}$ & $\begin{array}{l}618 \\
128\end{array}$ & $\begin{array}{r}275,000 \\
17,000\end{array}$ & $\begin{array}{r}1,200 \\
\cdots \\
25,000\end{array}$ & $\begin{array}{r}214,000 \\
55,000 \\
250,000 \\
17,000\end{array}$ \\
\hline
\end{tabular}

Of the 4,129 persons engaged in fishing, 16 per cent were connected with the vessel fisheries, 80 per cent with the shore and boat fisheries, and 3 per cent with the transporting vessels, while only 1 per cent were employed exclusively as shoresmen. Of the total number of proprietors and independent fishermen, 99 per cent were reported by the shore and boat fisheries. These fisheries, however, employed only 49 per cent of the total number of wage-earners, while the vessel fisheries employed 41 per cent. The vessel fisheries and the shore and boat fisheries are not comparable with respect to the number of proprietors and independent fishermen, inasmuch as many of the vessels are owned by corporations, while the percentage of the shore and boat fisheries conducted by corporations is very small.

Only 29 of the shoresmen were reported as being directly connected with the fisheries. It must be borne in mind that this number does not include employees working in canneries, packing houses, or fisl markets.

Equipment and other capital.-The description and value of vessels and boats engaged in the fisheries of the state and the value of apparatus used, together with the amount of other capital invested in 1908, are given in the following tabular statement:

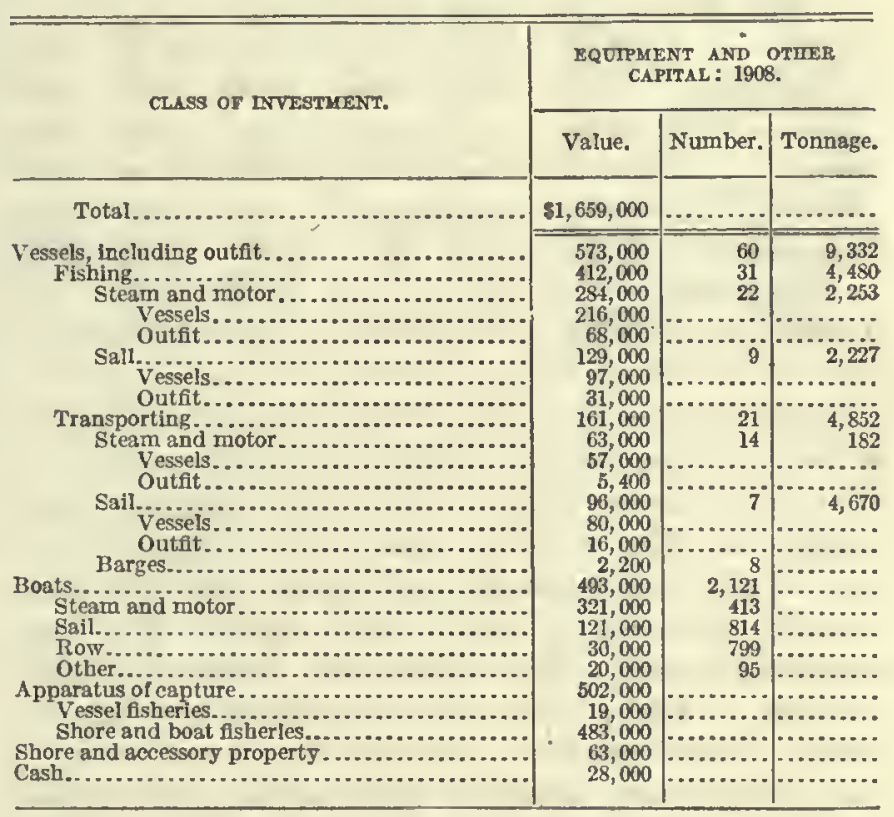

The number of the various kinds of apparatus of capture used was as follows:

\begin{tabular}{|c|c|c|c|}
\hline \multirow{3}{*}{ KIND. } & \multicolumn{3}{|c|}{ APPARATUS OF CAFTURE: 1908.} \\
\hline & \multirow[b]{2}{*}{ Total. } & \multicolumn{2}{|c|}{ Used in- } \\
\hline & & $\begin{array}{l}\text { Vessel } \\
\text { fisheries. }\end{array}$ & $\begin{array}{l}\text { Shore } \\
\text { and boat } \\
\text { fisheries. }\end{array}$ \\
\hline 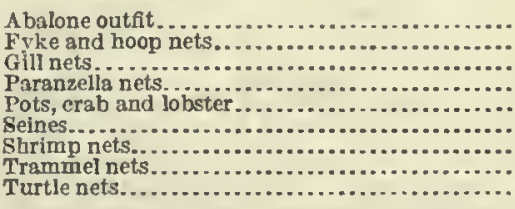 & $\begin{array}{r}1,56 \\
1,580 \\
3,550 \\
20 \\
2,874 \\
146 \\
295 \\
2,637 \\
57\end{array}$ & $\begin{array}{r}19 \\
19 \\
30 \\
5 \\
15\end{array}$ & $\begin{array}{r}56 \\
1,580 \\
3,531 \\
1 \\
2,844 \\
141 \\
295 \\
2,522 \\
57\end{array}$ \\
\hline
\end{tabular}

Products, by species.-Table 1 , on page 89 , shows the quantity and value of the fishery products of the state, by species and by apparatus of capture.

A comparison of the chicf species included in the catch reported by the Bureau of Fisheries for 1899 
and 1904 and in that reported at the present census, as given in the following tabular statement, is of interest as showing the fluctuations in the fishery products:

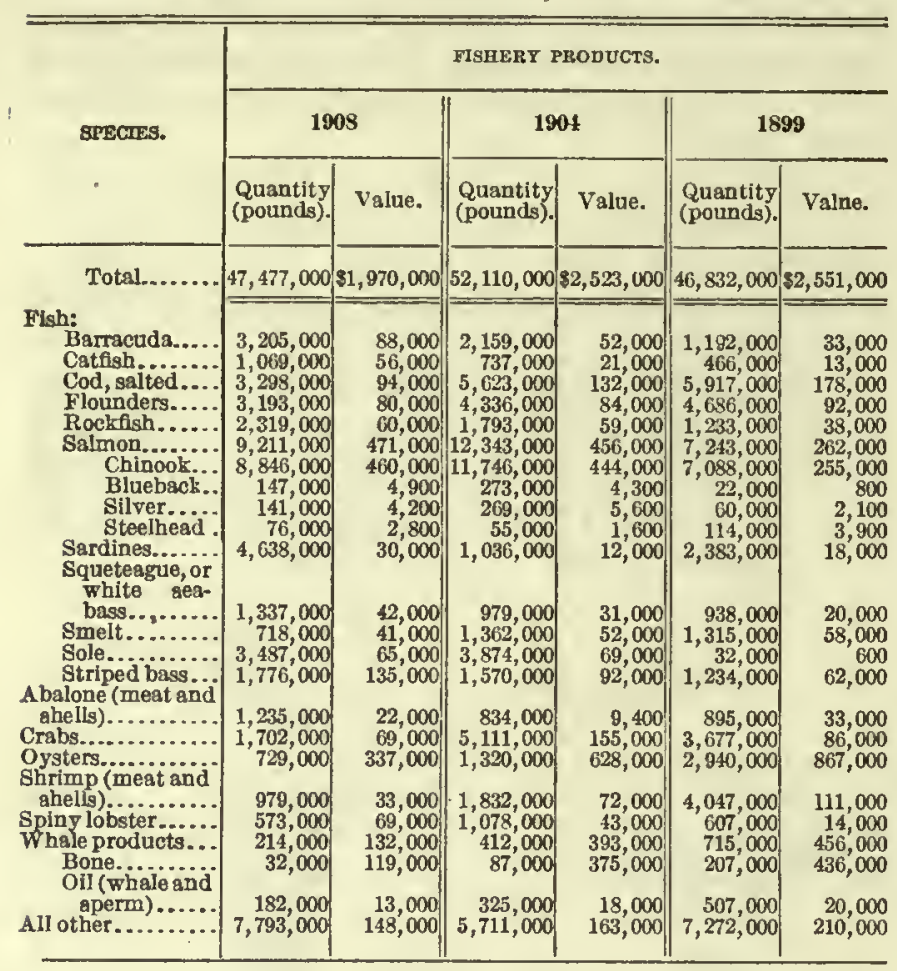

Although the total value of products in 1908 shows a material decrease, as compared with the values for the prior years, the value of the salmon catch increased. The value of this catch formed 24 per cent of the total value of products in 1908, compared with 10 per cent in 1899 . Other species that have increased notably are striped bass, barracuda, spiny lobsters, rockfish, catfish, and squeteague, or white sea bass. Whale products, on the other hand, show a large and steady decrease, both actual and proportionate, and cod, smelt, and shrimp decreased in a loss degree.

Products, by fishing grounds.-The following tabular statement shows the quantity and value of products taken by the shore and boat fisheries from the different waters of the state:

\begin{tabular}{|c|c|c|c|c|}
\hline \multirow{3}{*}{ IISHING GROUND. } & \multicolumn{4}{|c|}{$\begin{array}{l}\text { PRODUCTS OF SHORE AND BOAT FISHERIES: } \\
1908 .\end{array}$} \\
\hline & \multicolumn{2}{|c|}{ Quantity. } & \multicolumn{2}{|c|}{ Value. } \\
\hline & Pounds. & $\begin{array}{l}\text { Per cent } \\
\text { distribu- } \\
\text { tíon. }\end{array}$ & Amount. & $\begin{array}{l}\text { Per cent } \\
\text { distribu- } \\
\text { tion. }\end{array}$ \\
\hline Total... & $36,860,000$ & 100. & $\$ 1,627,000$ & 100 \\
\hline 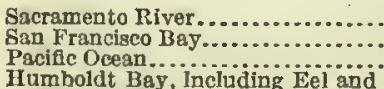 & $\begin{array}{r}11,643,000 \\
3,522,000 \\
8,552,000\end{array}$ & $\begin{array}{l}32 \\
10 \\
23\end{array}$ & $\begin{array}{l}617,000 \\
431,000 \\
249,000\end{array}$ & $\begin{array}{l}38 \\
26 \\
15\end{array}$ \\
\hline 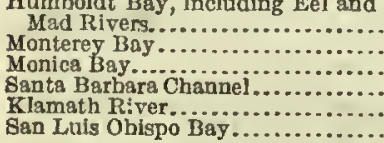 & $\begin{array}{r}2,888,000 \\
5,248,000 \\
2,574,000 \\
1,635,000 \\
433,000 \\
464,000\end{array}$ & $\begin{array}{r}8 \\
14 \\
7 \\
4 \\
1 \\
1\end{array}$ & $\begin{array}{r}96,000 \\
89,000 \\
67,000 \\
62,000 \\
8,900 \\
6,200\end{array}$ & $\begin{array}{l}6 \\
6 \\
4 \\
4 \\
1\end{array}$ \\
\hline
\end{tabular}

1 Less than 1 per cent.
Of the total products taken by the shore and boat fisheries in 1908, products from the Sacramento River formed 32 per cent in quantity and 38 per cent in value. Salmon was the principal species caught in this river and amounted to $7,292,000$ pounds. Striped bass was next in importance, the quantity reported being $1,690,000$ pounds. Other species taken were' as follows: Catfish, 1,068,000 pounds; shad, 1,055,000 pounds; carp, 425,000 pounds; black bass, 82,000 pounds; pike, 20,000 pounds; and sturgeon, 10,000 pounds. The total catch taken from the Sacramento River and the product of salmon, striped bass, catfish, shad, carp, and black bass for that river show substantial gains since 1904.

San Francisco Bay was second in rank according to the value of products, although the quantity of products taken from the Pacific Ocean was greater. This is due largely to the fact that much of the ocean product does not compare in value with the salmon and other choice species taken in the bay. The oyster product of San Francisco Bay also affected the relative value of the catch to a large extent. Herring was the principal species taken in the bay fisheries, the weight of the catch amounting to 450,000 pounds. Smelt ranked next in respect to quantity, with 278,000 pounds, and sea bass followed, with 271,000 pounds. Rockfish, striped bass, and sardines were also taken in considerable quantities.

In Humboldt Bay and its tributaries there were taken, besides salmon, the following: Smelt, 132,000 pounds; flounders, 112,000 pounds; herring, 26,000 pounds; rockfish, 63,000 pounds; and crabs, 1,411,000 pounds. Hard and soft clams also were marketed in considerable quantities.

The sardine catch of Monterey Bay amounted to $1,782,000$ pounds, and was valued at $\$ 8,900$. The low value per pound of sardines causes the average value per pound of the products of this bay to be lower than that for any other waters of the state, with the exception of San Luis Obispo Bay. More than two-thirds of the abalone catch of the state is credited to Monterey Bay. Other products were rockfish, 1,850,000 pounds; barracuda, 383,000 pounds; sea bass, 365,000 pounds; and squid, 110,000 pounds.

Products, by class of fisheries.-The next tabular statement shows the leading products ranked according to valuc, and their distribution between the vessel and the shore and boat fisheries.

The vessel fisheries of California are of minor importance, compared with the shore and boat fisheries, their product contributing in 1908 only 17 per cent to the total value of the fishery products of the state.

Table 3 , on page 91 , shows the product of the vessel fisheries by species and by apparatus of capture. Ranked according to the value of products, whaling apparatus was of first importance among the various kinds of apparatus of capture used by the vessel fisheries, and it was followed by lines, paranzella nets, 
seines, dredges, tongs, etc., and gill nets, in the order named.

\begin{tabular}{|c|c|c|c|}
\hline \multirow[b]{2}{*}{ SPECIES. } & \multicolumn{3}{|c|}{ VALUE OP PRONUCTS: 1908.} \\
\hline & Total. & $\begin{array}{c}\text { Vessel } \\
\text { fisberies. }\end{array}$ & $\begin{array}{c}\text { Shore and } \\
\text { bost } \\
\text { flsheries. }\end{array}$ \\
\hline Total... & $\$ 1,970,000$ & 8343,000 & $\$ 1,627,000$ \\
\hline Flsh........ & $1,292,000$ & 209,000 & $1,083,000$ \\
\hline Salmon..... & 471,000 & $\ldots \ldots+\ldots . . . . .$. & 471,000 \\
\hline Chinook... & 460,000 & ............ & 460,000 \\
\hline Blueback... & 4,900 & a........... & 4,900 \\
\hline Silver........ & 4,200 & .............. & 4,200 \\
\hline Steelhead.... & 2,800 & & 2,800 \\
\hline striped bass... & 135,000 & (n............. & 135,000 \\
\hline Cod........... & 94,000 & 94,000 & \\
\hline Barracuda... & 88,000 & 900 & 87,000 \\
\hline Flounders................................. & 80,000 & 10,000 & 69,000 \\
\hline 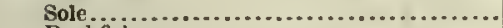 & 65,000 & 60,000 & 4,400 \\
\hline Rockfish..... & 60,000 & 6,100 & 54,000 \\
\hline 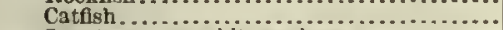 & 56,000 & & 56,000 \\
\hline Squeteague, or white sea-hass ............... & 42,000 & 400 & 42,000 \\
\hline smelt. $\ldots \ldots \ldots \ldots \ldots \ldots \ldots \ldots \ldots \ldots$ & 41,000 & & 41,000 \\
\hline 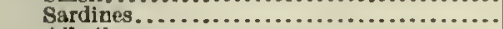 & 30,000 & 14,000 & 16,000 \\
\hline 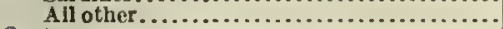 & 131,000 & 22,000 & 109,000 \\
\hline Oysters....................... & 337,000 & (1) & 337,000 \\
\hline Whale products (bone and oil) $\ldots . \ldots \ldots \ldots \ldots \ldots$. & 132,000 & 132,000 & \\
\hline 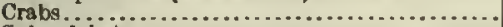 & 69,000 & 200 & 68,000 \\
\hline Splny lobster....................................... & 69,000 & 1,900 & 67,000 \\
\hline 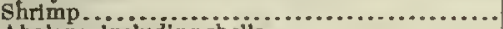 & 31,000 & ............. & 31,000 \\
\hline 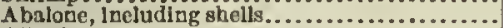 & 22,000 & .............. & 22,000 \\
\hline 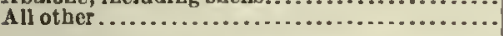 & 19,000 & & 19,000 \\
\hline
\end{tabular}

1 The oyster eatch of one vessel is included with that of the shore and boat fisheries.

The products of the shore and boat fisheries of the state were valued at $\$ 1,627,000$ in 1908 , compared with $\$ 1,864,000$ in 1904 , a decrease of 13 per cent. In 1908 these products formed 83 per cent of the total product of the state, and in 1904,74 percent. Table 2 , on page 90 , gives the products of the shore and boat fisheries by species and by apparatus of capture. All of the salmon catclı of the state was made by the shore and boat fisheries. It was necessary to credit the entire oyster catch to this class of fisheries in order to avoid disclosing the operations of one company operating an oyster vessel.

Products, by apparatus of capture.-The following tabular statement shows the catch by eacl kind of apparatus for each class of fisheries:

\begin{tabular}{|c|c|c|c|}
\hline \multirow[b]{2}{*}{ KIND OF APPARATUS. } & \multicolumn{3}{|c|}{ VALUE OF PRODUCTS: 1908.} \\
\hline & Total. & $\begin{array}{c}\text { Vessel } \\
\text { fisheries. }\end{array}$ & $\begin{array}{l}\text { Shore and } \\
\text { boat } \\
\text { fisheries. }\end{array}$ \\
\hline Total........... & $\$ 1,970,000$ & $\$ 343,000$ & $\$ 1,627,000$ \\
\hline 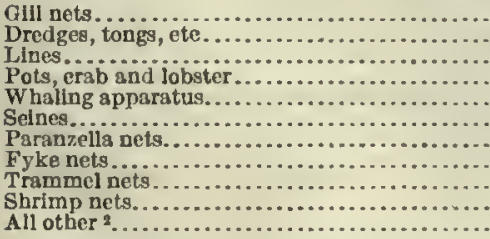 & $\begin{array}{r}769,000 \\
337,000 \\
212,000 \\
137,000 \\
132,000 \\
116,000 \\
87,000 \\
62,000 \\
52,000 \\
33,000 \\
34,000\end{array}$ & $\begin{array}{r}6,000 \\
101,000 \\
1,900 \\
132,000 \\
15,000 \\
87,000 \\
400 \\
4\end{array}$ & $\begin{array}{r}763,000 \\
337,000 \\
111,000 \\
135,000 \\
101,000 \\
100 \\
62,000 \\
51,000 \\
33,000 \\
34,000\end{array}$ \\
\hline
\end{tabular}

1 The cateh of ono vessel is included, with that of tho shoro and boat fisherles. 2 Includes apparatus, with value of cateh, as lollows: Abalone outfit, $\$ 22,000$; turtle nets, $\$ 1,300 ;$ and mlnor apparatus, $\$ 11,000$.
Judged by the value of products taken, gill nets led among the various kinds of apparatus used in the fisheries of the state. The largest catch made with these nets was chinook salmon, which had a value of $\$ 409,000$, or 53 per cent of the total value of the product taken by this apparatus. Barracuda, sea bass, smelt, and striped bass were also largely caught in gill nets.

Dredges, tongs, etc., which ranked second in the value of the products taken, were used exclusively in the oyster fisheries.

Third in importance were hand, trawl, and set lines. Some species are taken only by line fishing, cod being among the most notable of these both in quantity and value. Black cod, redfish, sea trout, and swordfish are other species the entire product of which was caught by lines. The quantity and value reported for each of these species are much less than for cod.

The seine catch of chinook salmon was the greatest in value among the products taken by seines, although the weight of the seine sardine catch was more than five times as great, namely, 4,552,000 pounds, representing 66 per cent of the total weight of the seine catch. Smelt to the value of $\$ 13,000$ were caught with seines. In the case of every other species the catch by this apparatus was of minor importance.

The paranzella net is peculiar to the fishing of California, none having been reported in use in any other state. Sole was the principal species caught with this kind of apparatus, representing 69 per cent of the quantity and 69 per cent of the value of the entire paranzella catch. Whitefish, flounders, kingfish, and skates were also taken in considerable quantities.

Catfish formed the principal catch with fyke nets, while flounders were practically the only species caught with trammel nets.

Salmon.-In 1908 salmon stood first both in quantity and in value among the species taken in California waters. The state ranked third in the country both in the quantity and in the value of the catch of salmon. Chinook was the principal kind taken, forming 96 per cent of the total yield of salmon in 1908 and representing 23 per cent of the total value of fishery products of the state. There was an increase in the quantity and in the value of this product sold fresh, as compared with the catch for 1904 reported by the Bureau of Fisheries, but a decrease in the salted product resulted in a decrease in the total quantity of chinook taken. The total value, however, increased slightly.

The next tabular statement shows the quantity and value of the salmon taken from the different waters of the state.

The Sacramento River is the principal fishing ground for salmon. Of the total quantity, 79 per 
cent was taken from that river. Humboldt Bay and tributaries were next in importance, being credited with 12 per cent of the total cateh. Klamath River, Monterey Bay, and San Francisco Bay ranked in the order named as to the quantity taken, but in respect to value the catch from Monterey Bay exceeded that from the Klamath River. The lower value per pound of the Klamath River catch may be attributed to the cost of shipping the product from Klamath River to San Franeisco or to other markets.

\begin{tabular}{|c|c|c|c|}
\hline \multirow{2}{*}{ MSHING GROUND. } & \multirow{2}{*}{ - } & \multicolumn{2}{|c|}{ SALMON: 1908.} \\
\hline & & $\begin{array}{l}\text { Quantity } \\
\text { (pounds). }\end{array}$ & Value. \\
\hline Total............. & & $9,211,000$ & $\$ 471,000$ \\
\hline 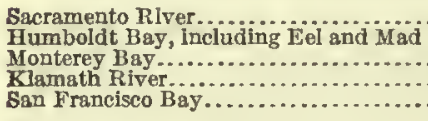 & 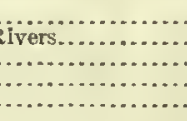 & $\begin{array}{r}7,292,000 \\
1,120,000 \\
335,000 \\
433,000 \\
31,000\end{array}$ & $\begin{array}{r}412,000 \\
37,000 \\
12,000 \\
8,900 \\
1,700\end{array}$ \\
\hline
\end{tabular}

Striped bass.-In value of the catch striped bass ranked second among the species reported for California, although larger quantities of sardines, sole, cod, barracuda, flounders, and rockfish were caught. The quantity of striped bass reported for 1908 was greater by 205,000 pounds, or 13 per cent, than that reported for 1904, while the value was greater by $\$ 43,000$, or 47 per cent.

Cod.-This species, third in value of product, was reported only by vessel fisheries, and was taken largely off the coast of Alaska. Six vessels with a total net tonnage of 1,889 were engaged in this fishery in 1908 . None of this product was reported as being sold fresh, all being salted before the ressels returned from the fishing grounds. The catch for 1908 was less by 2,325,000 pounds, or 41 per cent, than that reported for 1904, when the amount was 5,623,000 pounds, valued at $\$ 132,000$.

Barracuda.-Barracuda increased both in quantity and in value from 1904 to 1908 . The product sold fresh increased in weight $1,150,000$ pounds, or 59 por cent, and in value $\$ 40,000$, or 90 per cent. The salted product, however, showed a considerable decrease, the loss in weight being 104,000 pounds, or 48 per cent, and that in value $\$ 4,100$, or 54 per cent.

Flounders and sole.-In the group of flat fishes, both flounders and sole showed decreases, as compared with 1904. In 1908 the catch of sole was greater than that of flounders, but the value of the latter was greater. The reports of 1904 show a product of $4,336,000$ pounds of flounders, valued at $\$ 84,000$, while in 1908 the product was only $3,193,000$ pounds, valued at $\$ 80,000$. The decrease amounted to 26 per cent in quantity and 5 per cent in value. No salted product was reported by Califormia fishermen in 1908 . The quantity of sole caught in 1904 was $3,874,000$ pounds, and in $1908,3,487,000$ pounds, a dccrease of 386,000 pounds, or 10 per cent. The value of the catch during the period indicated fell from $\$ 69,000$ to $\$ 65,000$, a decrease of 6 per cent.

Oysters.-The oyster industry, while of considerable importanee, has decreased gradually from 1899 to 1908. It is difficult adequately to explain this decrease. There is no doubt that the year 1908 was a poor one, some beds not yielding more than 10 per cent of the usual catch. All of the oysters reported at the present census were taken from private beds and used for market purposes only. All seed oysters planted during the year were shipped from eastern beds for that purpose. No attempt was made at the present census to show separately the yield of eastern and of native species.

Crustaceans. - Crabs show a decrease between 1904 and 1908 of 67 per cent in quantity and 56 por cent in value. Spiny lobsters decreased in quantity during the same period 47 per cent, but the value increased 60 per eent. The decrease in the shrimp product was 47 per cent in quantity and 54 per cent in value.

Abalone.-The abalone industry in the United States is confined to California and is materially increasing in importance. In 1904 the total product was valued at $\$ 9,400$, while in 1908 the value was $\$ 22,000$, an increase of 134 per cent.

Whate products. - Whale products constituted the principal products of the vessel fisheries of California, but showed a decrease in value from 1904 to 1908 of $\$ 261,000$, or 66 per cent. Indeed, there has becn a steady decrease in whale products for several years. In 1904 the Bureau of Fisheries reported 87,000 pounds of whalebone, valued at $\$ 375,000$, and 43,000 gallons of oil, valued at $\$ 18,000$. The whaling fleet comprised seven vessels, of 2,328 tons net register.

Sea lions.-An industry of considerable importance is the capture of sea lions, which are sold alive for exhibition purposes. As but one fishery of this class was reported, the product is included in the group of "All other," to avoid the disclosure of individual operations. 
TABLE 1.-CALIFORNIA-FISHERY PRODUCTS: $190 \mathrm{~S}$.

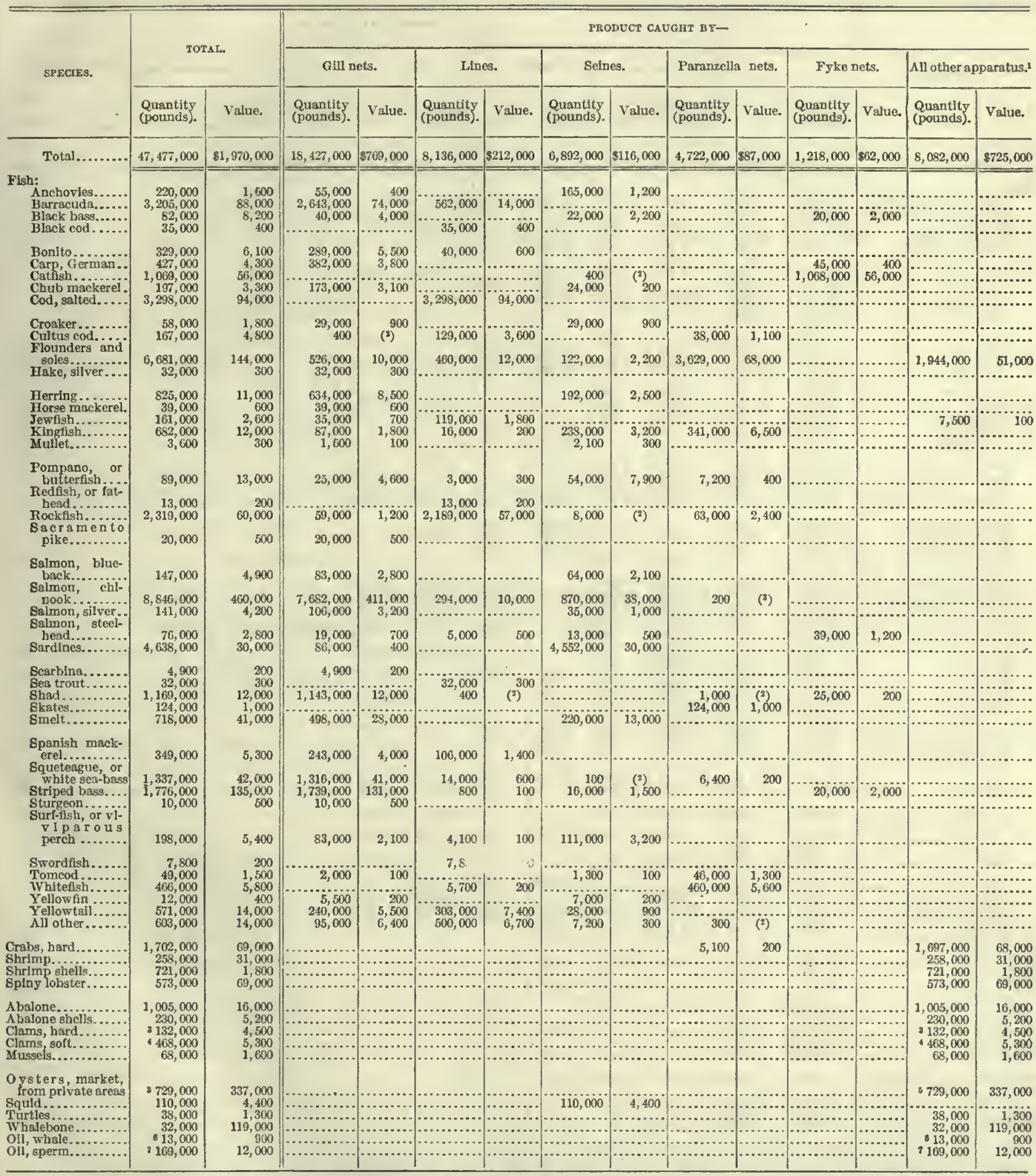

1 Includes apparatus, with eatch, as follows: Dredges, tongs, etc., 729,000 pounds, valued at $\$ 337,000 ;$ pots, 2,270,000 pounds, valued at $\$ 137,000 ;$ whaling apparatns,

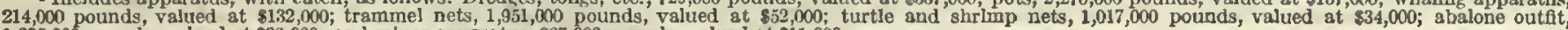
$1,235,000$ pounds, valued at $\$ 22,000$; and minor apparatus, 067,000 pounds, valued at $\$ 11,000$

Less than $\$ 100$.

16,000 bushels. 
TABLE 2.-CALIFORNIA-PRODUCTS OF SHORE AND BOAT FISHERIES: 1908.

\begin{tabular}{|c|c|c|c|c|c|c|c|c|c|c|c|c|c|c|}
\hline \multirow{3}{*}{ SPECIES. } & \multirow{2}{*}{\multicolumn{2}{|c|}{ TOTAL. }} & \multicolumn{12}{|c|}{ PRODUCT CAUGHT BY- } \\
\hline & & & \multicolumn{2}{|c|}{ GiII nets. } & \multicolumn{2}{|c|}{ Lines. } & \multicolumn{2}{|c|}{ Seines. } & \multicolumn{2}{|c|}{ Fyke nets. } & \multicolumn{2}{|c|}{ Paranzelia nets. } & \multicolumn{2}{|c|}{$\begin{array}{l}\text { All other appa- } \\
\text { ratus.1 }\end{array}$} \\
\hline & $\begin{array}{l}\text { Quantity } \\
\text { (pounds). }\end{array}$ & Value. & $\begin{array}{l}\text { Quantity } \\
\text { (pounds). }\end{array}$ & Value. & $\begin{array}{l}\text { Quantlty } \\
\text { (pounds) }\end{array}$ & Value. & $\begin{array}{l}\text { Quantlty } \\
\text { (pounds). }\end{array}$ & Value. & $\begin{array}{l}\text { Quantity } \\
\text { (pounds). }\end{array}$ & Value. & $\begin{array}{l}\text { Quantity } \\
\text { (pounds). }\end{array}$ & Value. & $\begin{array}{l}\text { Quantlty } \\
\text { (pounds). }\end{array}$ & Value. \\
\hline Total. . & $36,860,000$ & $\$ 1,627,000$ & $18,388,000$ & 8763,000 & $4,619,000$ & $\$ 111,000$ & $4,794,000$ & $\$ 101,000$ & $1,218,000$ & 862,000 & 4,000 & $\$ 100$ & $7,838,000$ & $\$ 591,000$ \\
\hline $\begin{array}{l}\text { Fish: } \\
\text { Albacore and tuna, fresh. } \\
\text { Albacoreand tuna, salted } \\
\text { Anchovies............... } \\
\text { Barracuda, fresh......... } \\
\text { Barracuda, sc.lted........ }\end{array}$ & $\begin{array}{r}510,000 \\
32,000 \\
220,000 \\
3,061,000 \\
112,000\end{array}$ & $\begin{array}{r}6,600 \\
900 \\
1,600 \\
83,000 \\
3,500\end{array}$ & \begin{tabular}{r}
42,000 \\
\hdashline 39,000 \\
$2,552,000$ \\
73,000
\end{tabular} & $\begin{array}{r}800 \\
71,000 \\
2,300\end{array}$ & $\begin{array}{r}468,000 \\
32,000 \\
309,000 \\
39,000\end{array}$ & $\begin{array}{r}5,800 \\
900 \\
7 \dddot{12,000} \\
1,200\end{array}$ & $\begin{array}{r}165,000 \\
\ldots \ldots \ldots \ldots\end{array}$ & $\mid \begin{array}{r}1,200 \\
\ldots \ldots \ldots \ldots\end{array}$ & $\cdots$ & & & & & $\begin{array}{l}\cdots \\
\cdots \cdots \\
\cdots \cdots \\
\cdots\end{array}$ \\
\hline 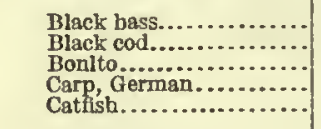 & $\begin{array}{r}82,000 \\
35,000 \\
329,000 \\
427,000 \\
1,069,000\end{array}$ & $\begin{array}{r}8,200 \\
400 \\
6,100 \\
4,300 \\
56,000\end{array}$ & $\mid \begin{array}{r}40,000 \\
\cdots 38900 \\
382,000 \\
\cdots\end{array}$ & $\begin{array}{r}4,000 \\
5,500 \\
3,800\end{array}$ & $\begin{array}{r}35,000 \\
40,000 \\
\ldots \ldots \ldots\end{array}$ & $\begin{array}{c}400 \\
600 \\
\cdots \cdots\end{array}$ & 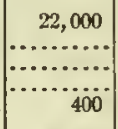 & 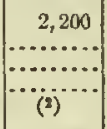 & $\begin{array}{r}20,000 \\
\cdots \\
45,000 \\
1,068,000\end{array}$ & $\mid \begin{array}{r}2,000 \\
\cdots \cdots \cdots \\
\cdots \cdots \\
56,000\end{array}$ & & & & $\begin{array}{l}\cdots \\
\cdots \cdots \\
\cdots \cdots \\
\cdots\end{array}$ \\
\hline 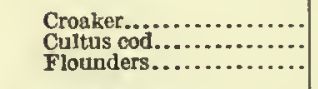 & $\begin{array}{r}58,000 \\
117,000 \\
2,7 \mathbf{7 4 1}, 000\end{array}$ & $\begin{array}{r}1,800 \\
3,200 \\
69,000\end{array}$ & $\begin{array}{r}29,000 \\
400 \\
400,000\end{array}$ & $\begin{array}{l}{ }^{900} \\
8,300\end{array}$ & $\begin{array}{l}117,000 \\
312,000\end{array}$ & $\begin{array}{l}3,200 \\
7,900\end{array}$ & $\begin{array}{r}29,000 \\
102,000\end{array}$ & 2,000 & $\cdots$ & & 2,300 & & $1,925,000$ & 51,000 \\
\hline 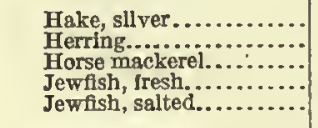 & $\begin{array}{r}32,000 \\
825,000 \\
39,000 \\
138,000 \\
22,000\end{array}$ & $\begin{array}{r}300 \\
11,000 \\
600 \\
1,700 \\
800\end{array}$ & $\begin{array}{r}32,000 \\
634,000 \\
39,000 \\
35,000 \\
\cdots\end{array}$ & $\begin{array}{r}300 \\
8,500 \\
600 \\
700 \\
\cdots\end{array}$ & $\begin{array}{l}96,000 \\
22,000\end{array}$ & $\begin{array}{r}\because, 000 \\
800\end{array}$ & $\begin{array}{c}192,000 \\
\cdots \ldots \ldots \\
\cdots\end{array}$ & $\mid \begin{array}{r}2,300 \\
\cdots \cdots \\
\cdots \cdots\end{array}$ & $\begin{array}{l}\cdots \\
\cdots \\
\cdots \\
\cdots\end{array}$ & & & & $\begin{array}{r}7,500 \\
\ldots\end{array}$ & (n) \\
\hline $\begin{array}{l}\text { Kingfish............... } \\
\text { Mackere1, chub ........... } \\
\text { Mullet.................... } \\
\text { Pompano .............. }\end{array}$ & $\begin{array}{r}337,000 \\
173,000 \\
3,600 \\
82,000\end{array}$ & $\begin{array}{r}5,100 \\
3,100 \\
300 \\
13,000\end{array}$ & $\begin{array}{r}87,000 \\
173,000 \\
1,600 \\
25,000\end{array}$ & $\begin{array}{r}1,800 \\
3,100 \\
100 \\
4,600\end{array}$ & $\begin{array}{r}16,000 \\
\cdots \\
3,000\end{array}$ & $\begin{array}{c}200 \\
300\end{array}$ & $\begin{array}{r}234,000 \\
2,100 \\
54,000\end{array}$ & $\begin{array}{r}3,100 \\
\mathbf{3 0 0} \\
7,900\end{array}$ & 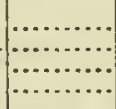 & & & & 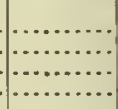 & , \\
\hline $\begin{array}{l}\text { Redfish, or lathead...... } \\
\text { Rockfish, fresh........... } \\
\text { Rockfish, salted......... } \\
\text { Sacramento pike........ }\end{array}$ & $\begin{array}{r}13,000 \\
2,131,000 \\
8,800 \\
20,000\end{array}$ & $\begin{array}{r}200 \\
54,000 \\
300 \\
500\end{array}$ & $\begin{array}{r}59,000 \\
20,000\end{array}$ & $\begin{array}{r}1,200 \\
500\end{array}$ & $\begin{array}{r}13,000 \\
2,064,000 \\
8,800 \\
\ldots \ldots \ldots\end{array}$ & $\begin{array}{r}200 \\
53,000 \\
300\end{array}$ & $\begin{array}{r}8,000 \\
\cdots . . .6 . \\
\cdots\end{array}$ & (2) & & & & & $\because$ & $\begin{array}{l}\cdots . . \\
\cdots \cdots \\
\cdots \cdots\end{array}$ \\
\hline $\begin{array}{l}\text { Salmon, blueback......... } \\
\text { Salmon, chlnook (fresi)... } \\
\text { Salmon, chinook (salted) } \\
\text { Salmon, sllver........... } \\
\text { Salmon, steelhead....... }\end{array}$ & $\begin{array}{r}147,000 \\
8,808,000 \\
39,000 \\
141,000 \\
76,000\end{array}$ & $\begin{array}{r}4,900 \\
458,000 \\
1,700 \\
4,200 \\
2,800\end{array}$ & $\begin{array}{r}83,000 \\
7,651,000 \\
31,000 \\
106,000 \\
19,000\end{array}$ & $\begin{array}{r}2,800 \\
409,000 \\
1,400 \\
3,200 \\
700\end{array}$ & 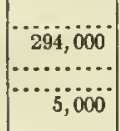 & $\mid \begin{array}{r}10,000 \\
\hdashline \ldots 00\end{array}$ & $\begin{array}{r}64,000 \\
863,000 \\
7,200 \\
35,000 \\
13,000\end{array}$ & $\begin{array}{r}2,100 \\
38,000 \\
300 \\
1,000 \\
500\end{array}$ & 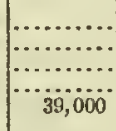 & 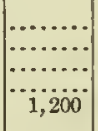 & $\begin{array}{c}200 \\
\cdots \cdots \\
\cdots \cdots \\
\cdots \cdots\end{array}$ & & 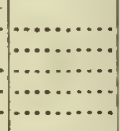 & 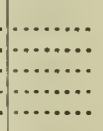 \\
\hline 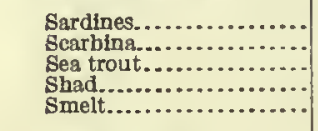 & $\begin{array}{r}2,567,000 \\
4,900 \\
32,000 \\
1,169,000 \\
718,000\end{array}$ & $\begin{array}{r}16,000 \\
200 \\
300 \\
12,000 \\
41,000\end{array}$ & \begin{tabular}{r}
86,000 \\
4,900 \\
\hdashline $1,193,000$ \\
498,000
\end{tabular} & $\begin{array}{r}400 \\
200 \\
\cdots 12,000 \\
28,000\end{array}$ & $\begin{array}{r}32,000 \\
400\end{array}$ & $\begin{array}{c}300 \\
(2) \\
\ldots \ldots\end{array}$ & $\begin{array}{r}2,482,000 \\
\cdots \ldots \ldots \ldots \\
\cdots \ldots \ldots \ldots \\
220,000\end{array}$ & $\begin{array}{r}15,000 \\
\cdots \ldots \ldots \\
\hdashline \ldots \ldots \\
\hdashline 13,000\end{array}$ & 25,000 & $\dddot{200}$ & $\ddot{1,000}$ & \begin{tabular}{l|}
$\cdots$ \\
$\cdots$ \\
$\cdots$
\end{tabular} & 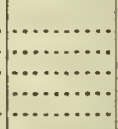 & 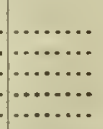 \\
\hline $\begin{array}{l}\text { Sole............................... } \\
\text { Spanish mackerel, fresh. } \\
\text { Spanish mackerel, salted. } \\
\text { Squeteague, or white sea- }\end{array}$ & $\begin{array}{r}222,000 \\
326,000 \\
23,000\end{array}$ & $\begin{array}{r}4,400 \\
4,600 \\
700\end{array}$ & $\begin{array}{r}126,000 \\
231,000 \\
13,000\end{array}$ & $\begin{array}{r}1,900 \\
3,600 \\
400\end{array}$ & $\begin{array}{l}73,000 \\
95,000 \\
10,000\end{array}$ & $\begin{array}{r}2,200 \\
1,100 \\
300\end{array}$ & 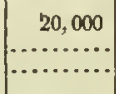 & $\begin{array}{c}200 \\
\cdots \cdots \\
\cdots \cdots\end{array}$ & & & & & $\begin{array}{r}3,000 \\
\cdots \cdots \\
\cdots\end{array}$ & $\begin{array}{r}100 \\
\cdots \\
\cdots\end{array}$ \\
\hline $\begin{array}{l}\text { Squeteague, or white sea- } \\
\text { bass................... } \\
\text { Striped bass............ }\end{array}$ & $\begin{array}{l}1,326,000 \\
1,776,000\end{array}$ & $\begin{array}{r}42,000 \\
135,000\end{array}$ & $\begin{array}{l}1,311,000 \\
1,739,000\end{array}$ & $\begin{array}{r}41,000 \\
131,000\end{array}$ & $\begin{array}{r}14,000 \\
800\end{array}$ & $\begin{array}{l}600 \\
100\end{array}$ & $\begin{array}{r}100 \\
16,000\end{array}$ & $\stackrel{(2)}{1,500}$ & 20,000 & 2,000 & & & $\because \cdots$ & $\cdots$ \\
\hline 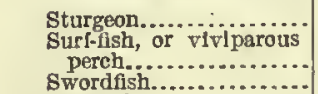 & $\begin{array}{r}10,000 \\
198,000 \\
7,800\end{array}$ & $\begin{array}{r}5,400 \\
200\end{array}$ & $\begin{array}{l}10,000 \\
83,000\end{array}$ & $\begin{array}{r}500 \\
2,100\end{array}$ & $\begin{array}{l}4,100 \\
7,800\end{array}$ & $\begin{array}{l}100 \\
200\end{array}$ & $\begin{array}{c}111,000 \\
\ldots\end{array}$ & $\begin{array}{r}3,200 \\
\ldots .\end{array}$ & & & & & & ....... \\
\hline Tomcod............................ & 3,600 & 300 & 2,000 & 100 & 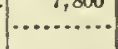 & & 1,300 & 100 & & & $\dddot{300}$ & $(2)^{\cdots}$ & & (n........ \\
\hline 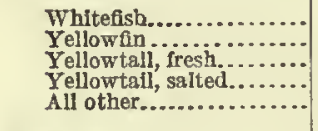 & $\begin{array}{r}5,700 \\
12,000 \\
564,000 \\
6,100 \\
44,000\end{array}$ & $\begin{array}{r}200 \\
400 \\
14,000 \\
200 \\
700\end{array}$ & $\mid \begin{array}{r}5,500 \\
240,000 \\
37,000\end{array}$ & $\begin{array}{r}200 \\
5,500 \\
300\end{array}$ & $\begin{array}{r}5,700 \\
290,000 \\
6,100 \\
\cdots\end{array}$ & $\mid \begin{array}{r}200 \\
7,200 \\
200 \\
\cdots\end{array}$ & $\begin{array}{r}7,000 \\
28,000 \\
7,000\end{array}$ & $\begin{array}{c}200 \\
900 \\
300\end{array}$ & & & $\ddot{300}$ & (2) & - $\ldots \ldots$ & (n.... \\
\hline 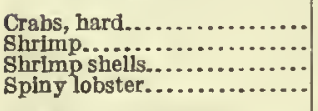 & $\begin{array}{r}1,697,000 \\
258,000 \\
721,000 \\
558,000\end{array}$ & $\begin{array}{r}68,000 \\
31,000 \\
1,800 \\
67,000\end{array}$ & $\begin{array}{l}\cdots \\
\cdots \\
\cdots\end{array}$ & . & & & & & & & & & $\begin{array}{r}1,697,000 \\
258,000 \\
721,000 \\
558,000\end{array}$ & $\begin{array}{r}68,000 \\
31,000 \\
1,800 \\
67,000\end{array}$ \\
\hline 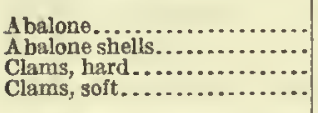 & $\begin{array}{r}1,005,000 \\
230,000 \\
8132,000 \\
468,000\end{array}$ & $\begin{array}{r}16,000 \\
5,200 \\
4,500 \\
5,300\end{array}$ & (n) & $\ldots \ldots$ & & & & & & & & & $\begin{array}{r}1,005,000 \\
230,000 \\
132,000 \\
468,000\end{array}$ & $\begin{array}{r}16,000 \\
5,200 \\
4,500 \\
5,300\end{array}$ \\
\hline $\begin{array}{l}\text { Mussels.................... } \\
\text { Oysters, market, from pri- }\end{array}$ & 68,000 & 1,600 & & & & & & & & & & & 68,000 & 1,600 \\
\hline 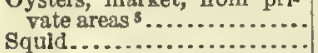 & $\begin{array}{r}729,000 \\
110,000\end{array}$ & $\begin{array}{r}337,000 \\
4,400\end{array}$ & & & & & iio, 000 & 4,400 & & & & & 729,000 & 337,000 \\
\hline 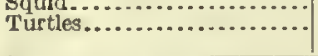 & 38,000 & 1,300 & & & & & 110, uou & 4,4000 & & & & & 38,000 & 1,300 \\
\hline
\end{tabular}

1 Includes apparatus, with catch, as follows: Dredges, tongs, etc., 729,000 pounds, valued at $\$ 337,000 ;$ pots, $2,255,000$ pounds, valued at $\$ 135,000 ;$ trammel nets, $1,936,000$

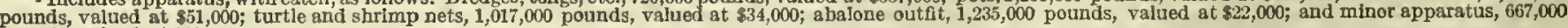
pounds, plued at s11,000;

- Includes the proluct of one establishment belonging to the vessel fisheries.

- 102,000 bushels. 
TABLE 3.-CALIFORNIA-PRODUCTS OF VESSEL FISHERIES: 1908.

\begin{tabular}{|c|c|c|c|c|c|c|c|c|c|c|c|c|}
\hline \multirow{3}{*}{ SPECTE8. } & \multirow{2}{*}{\multicolumn{2}{|c|}{ TOTAL." }} & \multicolumn{10}{|c|}{ PRODUCT CAUGHT BY- } \\
\hline & & & \multicolumn{2}{|c|}{ Lines. } & \multicolumn{2}{|c|}{ Paranzella nets. } & \multicolumn{2}{|c|}{ Selnos. } & \multicolumn{2}{|c|}{ Gill nets. } & \multicolumn{2}{|c|}{ All other apparatus. ${ }^{3}$} \\
\hline & $\begin{array}{l}\text { Quantity } \\
\text { (pounds). }\end{array}$ & Value. & $\begin{array}{l}\text { Quantity } \\
\text { (pounds). }\end{array}$ & Value. & $\begin{array}{l}\text { Quantity } \\
\text { (pounds). }\end{array}$ & Value. & $\begin{array}{l}\text { Quantity } \\
\text { (pounds). }\end{array}$ & Value. & $\begin{array}{l}\text { Quantlty } \\
\text { (pounds). }\end{array}$ & Value. & $\begin{array}{l}\text { Quantity } \\
\text { (pounds). }\end{array}$ & Value. \\
\hline Total.... & $10,617,000$ & $\$ 343,000$ & $3,517,000$ & $\$ 101,000$ & $4,718,000$ & $\$ 87,000$ & $2,098,000$ & $\$ 15,000$ & 39,000 & 86,000 & 244,000 & $\$ 134,000$ \\
\hline 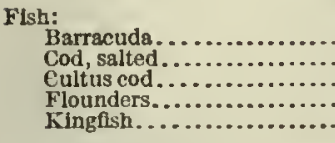 & $\begin{array}{r}31,000 \\
3,298,000 \\
50,000 \\
452,000 \\
345,000\end{array}$ & $\begin{array}{r}900 \\
94,000 \\
1,500 \\
10,000 \\
6,500\end{array}$ & $\begin{array}{r}13,000 \\
3,298,000 \\
12,000 \\
72,000\end{array}$ & $\begin{array}{r}400 \\
94,000 \\
400 \\
2,200\end{array}$ & $\begin{array}{r}38,000 \\
365,000 \\
341,000\end{array}$ & $\begin{array}{l}1,100 \\
7,700 \\
6,600\end{array}$ & 3,600 & $\dddot{100}$ & 18,000 & 500 & $\because 3,000$ & $\begin{array}{c}300 \\
\ldots \ldots\end{array}$ \\
\hline 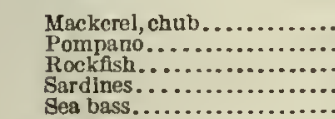 & $\begin{array}{r}24,000 \\
7,200 \\
179,000 \\
2,071,000 \\
12,000\end{array}$ & $\begin{array}{r}200 \\
400 \\
6,100 \\
14,000 \\
400\end{array}$ & 1116,000 & $3,700^{\circ}$ & $\begin{array}{r}7,200 \\
63,000\end{array}$ & $\begin{array}{r}400^{\circ} \\
2,400\end{array}$ & $\ddot{2}, 071,000$ & 14,000 & 5,200 & 200 & & \\
\hline 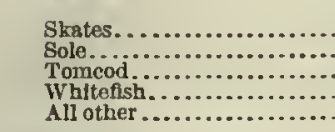 & $\begin{array}{r}124,000 \\
3,265,000 \\
46,000 \\
460,000 \\
19,000\end{array}$ & $\begin{array}{r}1,000 \\
60,000 \\
1,300 \\
5,600 \\
5,300\end{array}$ & $\begin{array}{l}3,400 \\
3,300\end{array}$ & $\begin{array}{l}100 \\
100 \\
\cdots \cdots \\
\text { (i) }\end{array}$ & $\begin{array}{r}124,000 \\
3,262,000 \\
46,000 \\
460,000\end{array}$ & $\begin{array}{r}1,000 \\
60,000 \\
1,300 \\
5,600\end{array}$ & & & 16,000 & $\dddot{5}, 200$ & & $\ldots . . .$. \\
\hline 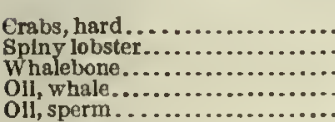 & $\begin{array}{r}5,100 \\
15,000 \\
32,000 \\
413,000 \\
169,000\end{array}$ & $\begin{array}{r}200 \\
1,900 \\
119,000 \\
900 \\
12,000\end{array}$ & & & $\begin{array}{l}5,100 \\
. . . . . .\end{array}$ & 200 & & & & & $\begin{array}{r}15,000 \\
32,000 \\
\quad 13.000 \\
-169,000\end{array}$ & $\begin{array}{r}1,900 \\
119,000 \\
900 \\
12,000\end{array}$ \\
\hline
\end{tabular}

1 Excluslve of the oystcr catch ol one establishment, which is Included under the shore and boat fisherles ln order to avold disclosing individual operatlons.

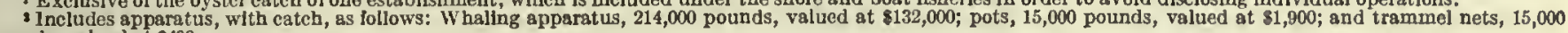
pounds, valued at $\$ 400$.

Less than $\$ 100$

$\uparrow 1,700$ gallons.

23,000 gallons.

\section{CONNECTICUT.}

In 1908 Connecticut ranked ninth among the states in the total value of fishery products, while it held first place in respect to the value of the oyster product and third place in respeet to the menhaden product. The oyster industry formed by " $a r$ the most important part of the fisheries of the state, and it was to this industry that the Connecticut fisheries owed their high rank. The principal fishing grounds are Long Island Sound and the Conneetieut River, but commercial fishing is also conducted to some extent on the Saugatuck, Housatonie, West, East, Indian, Four Mile, Mystic, and Paweatuck Rivers, as well as on some minor streams and inlets. A general summary of the fisheries of the state for 1908 is given in the following statement:

Number of persons employed.

2,147

Capital:

Vessels and boats, including outfit............. $\$ 1,112,000$

Apparatus of capture.................... 84,000

Shore and accessory property and cash.......... 1, 086, 000

Value of products........................ 2,982,000

Comparison with previous canvasses.-In comparing the number of persons employed in 1908 and the numbers employed in previous years, shoresmen are excluded, sinee the figures reported for shoresmen by the Bureau of Fislieries include those employed in packing and canning establishments and other shore industries connected with the fisheries.

The following tabular statemenit presents a comparative summary of the principal items of the Connecticut fisheries for a series of years:

\begin{tabular}{|c|c|c|c|c|c|c|}
\hline \multirow[b]{2}{*}{ YEAR. } & \multirow{2}{*}{$\begin{array}{c}\text { Per- } \\
\text { sons } \\
\text { em- } \\
\text { ployed, } \\
\text { exclu- } \\
\text { sive oo } \\
\text { shores- } \\
\text { men. }\end{array}$} & \multicolumn{3}{|c|}{ VALUE OF EQUTPMENT. } & \multicolumn{2}{|c|}{ PRonucts. } \\
\hline & & Total. & $\begin{array}{c}\text { Vessels } \\
\text { and boats, } \\
\text { Including } \\
\text { outfit. }\end{array}$ & $\begin{array}{c}\text { Appa- } \\
\text { rattus } \\
\text { of cap- } \\
\text { ture. }\end{array}$ & $\begin{array}{l}\text { Quantity } \\
\text { (pounds). }\end{array}$ & Value. \\
\hline $\begin{array}{l}1908 . \ldots \ldots \\
1905 \ldots \ldots \ldots \\
1902 . \ldots \ldots \\
1898 \ldots \ldots \ldots \\
1889 . \ldots \ldots\end{array}$ & $\begin{array}{l}1,895 \\
2,304 \\
1,865 \\
1,826 \\
2,314\end{array}$ & $\begin{array}{r}\$ 1,196,000 \\
1,077,000 \\
763,000 \\
718,000 \\
868,000\end{array}$ & $\begin{array}{r}\$ 1,112,000 \\
1,014,000 \\
698,000 \\
647,000 \\
761,000\end{array}$ & $\begin{array}{r}\$ 84,000 \\
63,000 \\
65,000 \\
71,000 \\
106,000\end{array}$ & $\begin{array}{l}66,942,000 \\
74,973,000 \\
37,832,000 \\
31,920,000 \\
92,672,000\end{array}$ & $\begin{array}{r}\$ 2,982,000 \\
3,174,000 \\
1,799,000 \\
1,560,000 \\
1,558,000\end{array}$ \\
\hline
\end{tabular}

The number of persons, exclusive of shoresmen, employed in the fisheries decreased considerably from 1889 to 1898 . In 1905 a relatively large number was returned, but the number reported in 1908 did not differ greatly from those for 1902 and 1898. In the report of the Bureau of Fisheries for the year 1898 the decrease from 1889 to 1898 is aseribed principally to the use of better equipment both in vessels and in apparatus of capture.

While there has been considerable fluctuation in the quantity of the product, the value inereased steadily from 1889 to 1905 , after which year a slight decrease occurred. The total value of equipment, which lias been advancing since 1898, was greater in 1908 than in any previous year for which statistics are available.

Persons employed.-The vessel fisheries gave employment directly to one-half of the persons employed in the fisheries of the state, and the majority of these employees were wage-earners. In the shore and boat fisheries, on the other liand, the wage-earners formed less than one-tenth of the persons engaged in fisheries of this class. All but two of the shoresmen were reported as connected with the vessel fisheries. 
The number, salaries, and wages of the persons employed in the fisheries of the state in 1908 were as follows:

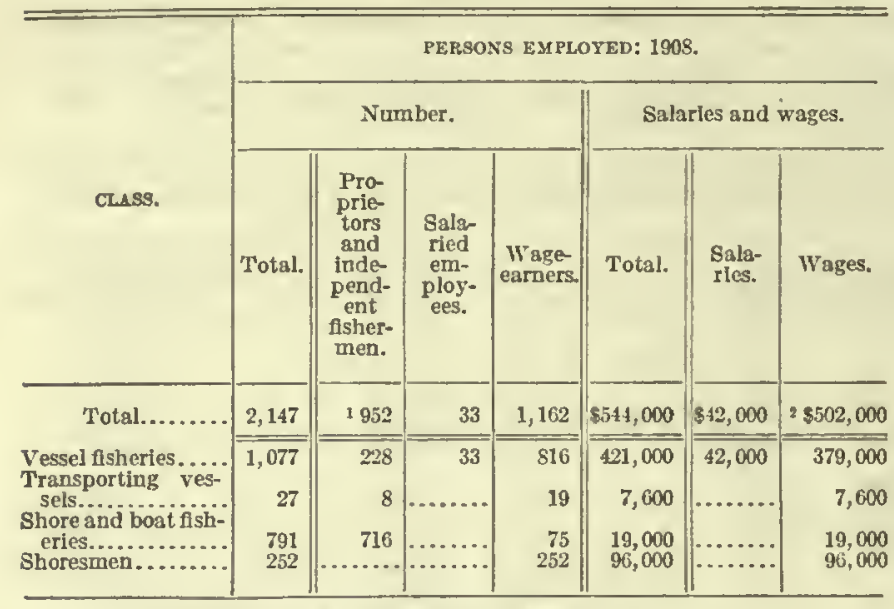

tExelusive of 24 proprietors not fishing.

Includes provisions furnlshed to the value of $\$ 09,000$.

Equipment and other capital. - The following tabular statement gives the description and value of vessels and boats, together with the value of apparatus of capture, and the amount of other capital employed for the year 1908:

\begin{tabular}{|c|c|c|c|}
\hline \multirow{2}{*}{ CLASS OF INVESTMENT. } & \multicolumn{3}{|c|}{$\begin{array}{l}\text { EQUIPMENT AND OTHER } \\
\text { CAPITAL: } 1908 \text {. }\end{array}$} \\
\hline & Value.. & Number. & Tonnage. \\
\hline Total........ & $\$ 2.281,000$ & & …… \\
\hline Vessel.s, Inclụding outfit. & 994,000 & 243 & $\overline{5,502}$ \\
\hline Fishing.................. & 973,000 & 227 & 5,384 \\
\hline $\begin{array}{l}\text { Steam and motor. } \\
\text { Vessels........ }\end{array}$ & 868,000 & & \\
\hline $\begin{array}{l}\text { Vessels.. } \\
\text { Outfit... }\end{array}$ & 160,000 & & \\
\hline Sall......... & 104,000 & $9 i$ & i,iig \\
\hline Vesseis... & 71,000 & & \\
\hline Outfit.......... & 33,000 & & ...... \\
\hline 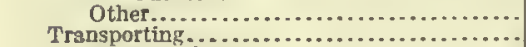 & $\begin{array}{l}1,100 \\
22,400\end{array}$ & $\begin{array}{r}4 \\
16\end{array}$ & iï \\
\hline 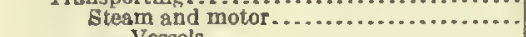 & 17,000 & & 69 \\
\hline Vessels .......... & $\begin{array}{r}13,000 \\
3,300\end{array}$ & & \\
\hline Sali........ & 3,700 & $\dddot{6}$ & 49 \\
\hline Vesseis. & 3,200 & & \\
\hline $\begin{array}{l}\text { Outfit... } \\
\text { Other....... }\end{array}$ & $\begin{array}{r}500 \\
1,500\end{array}$ & & \\
\hline Boats....................... & 118,000 & 1,069 & \\
\hline Steam and motor................... & 76,000 & 240 & ..... \\
\hline & 30,000 & 139 & \\
\hline Row & 12,000 & 680 & ....... \\
\hline Other................. & & 10 & \\
\hline Apparatus of capture. & 84,000 & & \\
\hline Vessel fisheries............. & 34,000 & & (............ \\
\hline Shore and boat fisheries............. & 49,000 & & -......... \\
\hline $\begin{array}{l}\text { Shore and accessory property....................... } \\
\text { Cash }\end{array}$ & $\begin{array}{l}513,000 \\
572,000\end{array}$ & & \\
\hline & & & \\
\hline
\end{tabular}

The investment in floating craft and apparatus of capture was $\$ 1,196,000$, or 52 per cent of the total capital invested, as compared with $\$ 1,086,000$, or 48 per cent, reported for shore and accessory property and cash capital.

The preeminence of the vessel fisheries is indicated by the ligh value of the vessels engaged in fishing and transporting. Of the total investment in 1908, $\$ 991,000$ represents the investment in fishing and transporting vessels with their outfit, and $\$ 118,000$ represents the investment in boats with their outfit.
Including apparatus of capture, the investments were $\$ 1,029,000$ for vessel fisheries and $\$ 167,000$ for shore and boat fisheries.

The number of vcssels reported as engaged in fishing and transporting in 1908 was 243, which is greater by 49 than the total number reported for 1902 . There was a corresponding difference in the value of vessels and their outfit for the two years named, the value in 1908 being greater by $\$ 367,000$ than in 1902 .

The investment in apparatus of capture for the shore and boat fisheries exceeded that for the vessel fisheries in 1908, although, as already shown, the capital invested in floating craft and apparatus of capture together was much greater for the vessel fisheries than for the shore and boat fisheries.

The various kinds of apparatus used were distributed between the vessel fisheries and the shore and boat fisheries as follows:

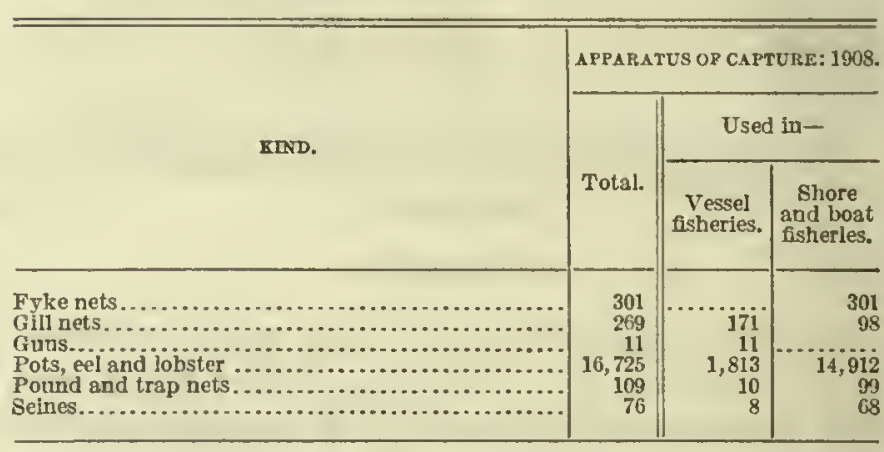

Products, by species.- The fishery products of the state are given, by species and by apparatus of capture, in Table 1 , on page 94.

A comparison with the statistics for former ycars shows, in general, an increase in the total of fishery products, duc chiefly to the growth of the oyster industry. Oysters, menhaden, and lobsters, shown separately in the table below, were the only products with a value forming more than $\mathbf{i}$ per cent of the total value of all fishery products in 1908.

\begin{tabular}{|c|c|c|c|c|c|}
\hline \multirow{2}{*}{ SPECTES. } & \multicolumn{5}{|c|}{ VALUE OF PRODUCTS. } \\
\hline & 1908 & 1905 & 1902 & 1898 & 1859 \\
\hline Total... & $\$ 2,982,000$ & $\$ 3,174,000$ & $\$ 1,799,000$ & $\$ 1,560,000$ & $\$ 1,558,000$ \\
\hline $\begin{array}{l}\text { Oysters...... } \\
\text { Menhaden... } \\
\text { I Aobster...... } \\
\text { All other.... }\end{array}$ & $\begin{array}{r}2,583,000 \\
93,000 \\
84,000 \\
221,000\end{array}$ & $\begin{array}{r}2,810,000 \\
72,000 \\
50,000 \\
236,000\end{array}$ & $\begin{array}{r}1,472,000 \\
48,000 \\
41,000 \\
239,000\end{array}$ & $\begin{array}{r}1,249,000 \\
26,000 \\
84,000 \\
200,000\end{array}$ & $\begin{array}{r}1,062,000 \\
101,000 \\
83,000 \\
312,000\end{array}$ \\
\hline
\end{tabular}

Products, by class of fisheries.-Table 2, page 95, shows in detail the products of the shore and boat fisheries, and Table 3, page 96, those of the vessel fisheries, by species and by apparatus of capture.

The value of the product for 1908 of the species showing a value of more than $\$ 10,000$ is given in the tabular statement following for all fisheries, and for the vessel fisheries and the shore and boat fisheries scparately. 


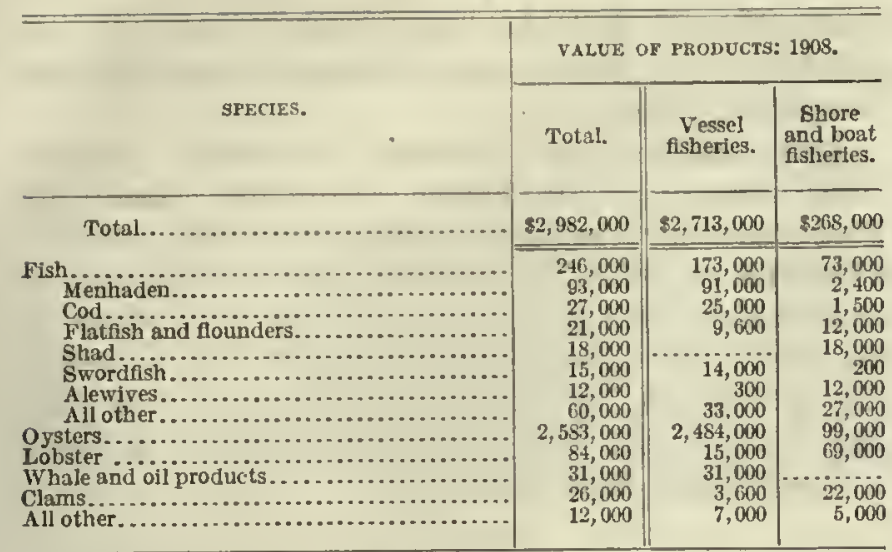

Products, by apparatus of capture.-The distribution of the total value of products according to the chief kinds of apparatus used is shown in the tabular statement below. Each kind of apparatus which is credited with $\approx$ total catch exceeding $\$ 10,000$ in value is given separately.

\begin{tabular}{|c|c|c|c|}
\hline \multirow[b]{2}{*}{ APPARATUS. } & \multicolumn{3}{|c|}{ VALUE OF PRODUCT: 1908.} \\
\hline & Total. & $\begin{array}{c}\text { Vessel } \\
\text { fisheries. }\end{array}$ & $\begin{array}{l}\text { Shore } \\
\text { and boat } \\
\text { fisheries. }\end{array}$ \\
\hline Total................ & $\$ 2,982,000$ & $\$ 2,713,000$ & $\$ 268,000$ \\
\hline 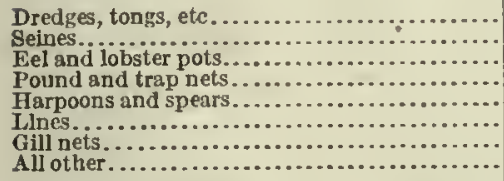 & $\begin{array}{r}2,614,000 \\
116,000 \\
89,000 \\
43,000 \\
43,000 \\
41,000 \\
20,000 \\
15,000\end{array}$ & $\begin{array}{r}2,488,000 \\
94,000 \\
15,000 \\
26,000 \\
42,000 \\
35,000 \\
4,300 \\
9,600\end{array}$ & $\begin{array}{r}126,000 \\
22,000 \\
73,000 \\
17,000 \\
1,300 \\
6,600 \\
16,000 \\
5,000\end{array}$ \\
\hline
\end{tabular}

Oysters.-From the table giving the comparison of the value of products for various years from 1889 to 1908 it is seen that the high mark of production reached in 1905 was due to the oyster industry, the total value of products other than oysters for that year being less than for 1908. In 1905 the value of the oyster product formed 89 per cent of the total, compared with 87 per cent in 1908, 82 per cent in 1902,80 per cent in 1898 , and.68 per cent in 1889 .

The statistics of the oyster product for 1908 , by source of supply, are shown in the following tabular statement:

\begin{tabular}{|c|c|c|c|c|}
\hline \multirow{3}{*}{ KIND AND SOURCE. } & \multicolumn{4}{|c|}{ OXSTER PRODUCT: 1908.} \\
\hline & \multicolumn{2}{|c|}{ Quantity. } & \multicolumn{2}{|c|}{ Value. } \\
\hline & Bushels. & $\begin{array}{l}\text { Per eent } \\
\text { distribu- } \\
\text { tion. }\end{array}$ & Amount. & $\begin{array}{l}\text { Per cent } \\
\text { distribu- } \\
\text { tlon. }\end{array}$ \\
\hline Total... & $3,948,000$ & 100 & $\$ 2,583,000$ & 100 \\
\hline $\begin{array}{l}\text { From publie areas.... } \\
\text { From private areas... }\end{array}$ & $\begin{array}{r}217,000 \\
3,731,000 \\
\end{array}$ & $\begin{array}{r}5 \\
95 \\
\end{array}$ & $\begin{array}{r}103,000 \\
2,480,000 \\
\end{array}$ & $\begin{array}{r}4 \\
96 \\
\end{array}$ \\
\hline Market oysters.............. & $1,395,000$ & 35 & $1,168,000$ & 45 \\
\hline $\begin{array}{l}\text { From publie areas... } \\
\text { From private areas.. }\end{array}$ & $\begin{array}{r}6,300 \\
1,388,000\end{array}$ & (1) 35 & $\begin{array}{r}4,400 \\
1,163,000\end{array}$ & (i) 45 \\
\hline Seed oysters.... & $2,553,000$ & 65 & $1,415,000$ & 55 \\
\hline 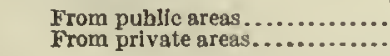 & $\begin{array}{r}211,000 \\
2,342,000\end{array}$ & $\begin{array}{r}5 \\
59\end{array}$ & $\begin{array}{r}99,000 \\
1,317,000\end{array}$ & 51 \\
\hline
\end{tabular}

1 Less than 1 per cent.
Connecticut was the first of the Northern states to cultivate the oyster successfully. In localities farther to the south warm weather usually prevails in the early summer months when the oysters spawn and a good "set" usually results, but in Connecticut oyster culture is hazardous because of the uncertainty of the "set" of the young oyster, an abundant "set" being the exception. Hundreds of thousands of bushels of shells have been deposited on the private grounds for the purpose of furnishing suitable material to which diminutive oysters may cling, but in rather more than half of the years this work has been profitless because of the destruction of the "set" by adverse weather conditions. The season of 1908 was considered a prosperous one by the fishermen, the bivalves being large and of a superior quality and the demand being such as to keep prices at a remunerative figure. The average price of market oysters per bushel was 84 cents and of seed oysters 55 cents.

The returns show that a considerable portion of the product was taken by Connecticut fishermen from beds outside of the state, mainly from the New York side of Long Island Sound and from the waters of Rhode Island and Massachusetts. A total of $1,270,000$ bushels, valued at $\$ 1,090,000$, was so reported. It was distributed as follows: From Rhode Island waters, 720,000 bushels, valued at $\$ 590,000$; from New York waters, 511,000 bushels, valued at $\$ 453,000$; and from Massachusetts waters, 40,000 bushels, valued at $\$ 47,000$.

Oyster fishing is conducted principally from vessels. In 1908 only about 4 per cent of the value of the total catch was credited to the shore and boat fisheries. Only 3 per cent of the product of the vessel fisheries was taken from the public areas, as compared with about 60 per cent in the case of the shore and boat fisheries.

Menhaden.-In 1908 the menhaden catch of Connecticut ranked next to the oyster product in value, and was surpassed in value only by the catches of that species in Virginia, Delaware, and North Carolina.

Lobsters.--The value of the yield of lobsters, which ranked third among the fishery products of the state in 1908, was greater than in any previous year for which data are available. It was more than double the value for 1902, and slightly greater than the values for 1898 and 1889. The quantity in 1908, however, was only 661,000 pounds, as compared with $1,501,000$ pounds in 1889, which represents a decrease of 56 per cent.

Whate and kindred products.-The whale and oil products reached higher figures in 1908 than in any previous year for which a canvass was made since 1880 , when the value of these products reported amounted to $\$ 53,000$. The total yield for 1908 included 49,000 gallons of sperm oil and sea-elephant oil and 1,700 pounds of whalebone. 
Other products.-Among the minor products was shad, the catch of which increased steadily from 1889 up to 1905 , when it was reported as 485,000 pounds, valued at $\$ 38,000$. The catch in 1908 was comparatively small, amounting to only 122,000 pounds, valued at $\$ 18,000$. The entire product of that year was taken from the Connecticut River, with the exception of a small quantity, valued at $\$ 700$, which was caught in traps in Long Island Sound near the mouth of the river named.

Other fish, such as alewives, carp, eels, perch, pickerel, striped bass, and suckers, aggregating $\$ 17,000$ in value, were caught in the Connecticut River. The total value of the fish obtained from this river was $\$ 34,000$. The greater part of the smelt were from the Saugatuck River.

Many fish that were formerly numerous in Connecticut waters are no longer abundant. Less than $\$ 700$ worth of bluefish were eaught in 1908 , while in 1898 the value of this product was $\$ 33,000$, and it ranked third in value among the fishery products of the state. The value of the halibut catch, which was $\$ 20,000$ in 1889 , fell to $\$ 600$ in 1908 . In 1898 the value of sea bass taken amounted to $\$ 12,000$, compared with $\$ 5,400$ in 1908.

TABLE 1.-CONNECTICUT-FISHERY PRODUCTS: 1908.

\begin{tabular}{|c|c|c|c|c|c|c|c|c|c|c|c|c|c|c|}
\hline \multirow{3}{*}{ SPECrES. } & \multirow{2}{*}{\multicolumn{2}{|c|}{ TOTAL. }} & \multicolumn{12}{|c|}{ PRODUCT CAUGHT BY- } \\
\hline & & & \multicolumn{2}{|c|}{ Seines. } & \multicolumn{2}{|c|}{$\begin{array}{l}\text { Pound and trap } \\
\text { nets. }\end{array}$} & \multicolumn{2}{|c|}{ Lines. } & \multicolumn{2}{|c|}{ Gill nets. } & \multicolumn{2}{|c|}{ Fyke neta. } & \multicolumn{2}{|c|}{ All other apparatus. ${ }^{2}$} \\
\hline & $\begin{array}{l}\text { Quantity } \\
\text { (pounds). }\end{array}$ & Value. & $\begin{array}{l}\text { Quantity } \\
\text { (pounds). }\end{array}$ & Value. & $\begin{array}{c}\text { Quantity } \\
\text { (peunds) }\end{array}$ & Value. & $\begin{array}{l}\text { Quantity } \\
\text { (pounds) }\end{array}$ & Value. & $\begin{array}{l}\text { Quantity } \\
\text { (pounds). }\end{array}$ & Value. & $\begin{array}{l}\text { Quantity } \\
\text { (pounds). }\end{array}$ & Value. & $\begin{array}{l}\text { Quant1ty } \\
\text { (peunds). }\end{array}$ & Value. \\
\hline Total. . & $66,942,000$ & $\$ 2,982,000$ & $29,398,000$ & $\$ 116,000$ & $1,629,000$ & $\$ 43,000$ & $1,100,000$ & 841,000 & 180,000 & $\$ 20,000$ & 112,000 & $\$ 5,000$ & $34,523,000$ & $\$ 2,756,000$ \\
\hline 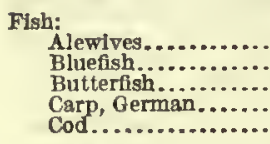 & $\begin{array}{r}1,025,000 \\
7,900 \\
102,000 \\
7,600 \\
820,000\end{array}$ & $\begin{array}{r}12,000 \\
700 \\
4,100 \\
600 \\
27,000\end{array}$ & $\begin{array}{r}858,000 \\
1,000 \\
7,400\end{array}$ & $\begin{array}{r}10,000 \\
100 \\
600 \\
6 \ldots\end{array}$ & $\begin{array}{r}154,000 \\
600 \\
102,000 \\
\cdots 1 \ddot{2}, \ldots 00\end{array}$ & $\begin{array}{l}1,500 \\
100 \\
4,100\end{array}$ & 809,000 & 26,000 & 4,500 & (2) & $\begin{array}{r}8,200 \\
500 \\
200\end{array}$ & $\begin{array}{l}300 \\
\left({ }^{2}\right) \\
\cdots \\
(2)\end{array}$ & & \\
\hline 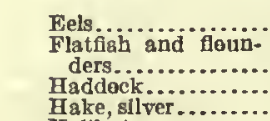 & $\begin{array}{r}111,000 \\
707,000 \\
24,000 \\
179,000\end{array}$ & $\begin{array}{r}9,100 \\
21,000 \\
900 \\
2,100\end{array}$ & $\begin{array}{l}36,000 \\
62,000\end{array}$ & $\begin{array}{l}2,500 \\
1,900\end{array}$ & $\begin{array}{r}7,900 \\
508,000 \\
170, \ldots 00\end{array}$ & $\begin{array}{r}15,000 \\
\cdots, 100\end{array}$ & $\begin{array}{l}81,000 \\
24,000\end{array}$ & $\begin{array}{r}2,900 \\
900\end{array}$ & & & 56,000 & 1,800 & $\begin{array}{r}60,000 \\
200\end{array}$ & 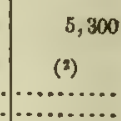 \\
\hline Hallbut................ & 8,500 & & & & 100,000 & 2,800 & 8,500 & 600 & & & & & & (n.......... \\
\hline $\begin{array}{l}\text { Mackerel............. } \\
\text { Menhaden............. } \\
\text { Perch, white.......... } \\
\text { Pickerel............... } \\
\text { Pollack............. }\end{array}$ & $\begin{array}{r}122,000 \\
28,636,000 \\
7,600 \\
2,500 \\
25,000\end{array}$ & $\begin{array}{r}8,900 \\
93,000 \\
400 \\
200 \\
800\end{array}$ & $\begin{array}{r}27,000 \\
28,316,000 \\
5,400 \\
1,500 \\
4,500\end{array}$ & $\begin{array}{r}2,700 \\
92,000 \\
300 \\
100 \\
200\end{array}$ & $\begin{array}{r}6,600 \\
310,000\end{array}$ & $\begin{array}{l}300 \\
900\end{array}$ & 23,000 & 1,500 & $\begin{array}{l}66,000 \\
2,800 \\
(2)\end{array}$ & $\begin{array}{l}4,300 \\
(2) \\
(2)\end{array}$ & $\begin{array}{l}6,800 \\
2,200 \\
1,000\end{array}$ & $\begin{array}{l}(2) \\
200 \\
100\end{array}$ & & (n........ \\
\hline $\begin{array}{l}\text { Scup.................. } \\
\text { Sea bass.............. } \\
\text { Shad ................ } \\
\text { Shiner............. }\end{array}$ & $\begin{array}{r}95,000 \\
61,000 \\
122,000 \\
5,500 \\
10\end{array}$ & $\begin{array}{r}8,500 \\
5.400 \\
18,000 \\
400 \\
\end{array}$ & $\begin{array}{r}5,000 \\
5,500\end{array}$ & 800 & $\begin{array}{r}95,000 \\
1,000 \\
7,200 \\
\cdots, \ldots\end{array}$ & $\begin{array}{r}8,500 \\
100 \\
900\end{array}$ & 38,000 & 5,200 & 107,000 & 16,000 & 2,700 & 400 & 1,100 & \\
\hline Smelt.................. & 10,000 & 1,200 & 8,600 & 1,100 & 1,500 & 100 & ........... & ..... & & & ..... & & .......... & (............ \\
\hline 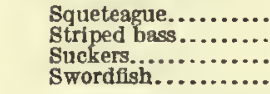 & $\begin{array}{r}180,000 \\
6,500 \\
66,000 \\
240,000\end{array}$ & $\begin{array}{r}6,800 \\
800 \\
3,000 \\
15,000\end{array}$ & $\begin{array}{r}12,000 \\
1,800 \\
42,000\end{array}$ & $\begin{array}{r}600 \\
200 \\
2,000\end{array}$ & $\begin{array}{r}163,000 \\
3,000 \\
\ldots \ldots \ldots\end{array}$ & $\begin{array}{r}6,000 \\
300\end{array}$ & 5,500 & 300 & $\begin{array}{l}400 \\
100\end{array}$ & ${ }_{(2)}^{100}$ & $\begin{array}{r}1,400 \\
23,000\end{array}$ & $\begin{array}{l}200 \\
900\end{array}$ & 240,000 & $\because 30,000$ \\
\hline 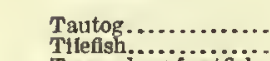 & $\begin{array}{r}119,000 \\
4.700\end{array}$ & $\begin{array}{r}4,600 \\
100\end{array}$ & & & 57,000 & 2,100 & $\begin{array}{r}62,000 \\
4,700\end{array}$ & $\begin{array}{r}2,400 \\
100\end{array}$ & & & & & 100 & (2) \\
\hline $\begin{array}{l}\text { Tomeod, or frostifish. } \\
\text { All other ............ }\end{array}$ & $\begin{array}{l}1,800 \\
5,000\end{array}$ & $\begin{array}{l}100 \\
300\end{array}$ & $\begin{array}{l}3,300 \\
2,000\end{array}$ & 100 & $\cdots 900$ & $\cdots_{100}$ & & & 100 & (2) & 400 & $(2)^{00}$ & & …...... \\
\hline 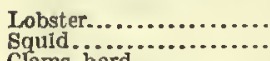 & $\begin{array}{r}661,000 \\
21,000\end{array}$ & 84,000 & & & $\stackrel{(3)}{21,000}$ & $\stackrel{(2)}{400}^{-1}$ & & & & & & & $\begin{array}{r}661,000 \\
\cdots . .\end{array}$ & $\begin{array}{l}84,000 \\
\ldots \ldots . .\end{array}$ \\
\hline 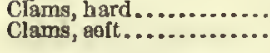 & 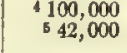 & $\begin{array}{r}20,000 \\
5,500\end{array}$ & & & & & & & & & & & $\begin{array}{r}1100,000 \\
542,000\end{array}$ & $\begin{array}{r}20,000 \\
5,500\end{array}$ \\
\hline $\begin{array}{l}\text { Oyaters, market, from } \\
\text { public areas......... } \\
\text { pysters, market, from }\end{array}$ & 844,000 & 4,400 & & & & & & & & & & & - 44,000 & 4.400 \\
\hline $\begin{array}{l}\text { private areas.......... } \\
\text { o ysters, seed, Irom pub- }\end{array}$ & $79,718,000$ & $1,163,000$ & & & & & & & & & & & $79,718,000$ & $1,103,000$ \\
\hline $\begin{array}{l}\text { ic areas............ } \\
\text { oysters, seed, from pri- }\end{array}$ & $81,478,000$ & 99,000 & & & & & & & & & & & $81,478,000$ & 99,000 \\
\hline 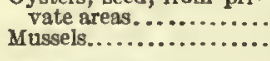 & $\begin{array}{r}16,396,000 \\
107,200\end{array}$ & $\begin{array}{r}1,317,000 \\
200\end{array}$ & & & & & & & & & & & $\begin{array}{r}016,396,000 \\
107,200\end{array}$ & $1,317,000$ \\
\hline Musscl ahells.............. & $\begin{array}{r}115,403,000 \\
1288,000\end{array}$ & $\begin{array}{r}5,400 \\
3,600\end{array}$ & & & & & & & & & & & in $5,403,000$ & $\begin{array}{r}5,400 \\
3,600\end{array}$ \\
\hline $\begin{array}{l}\text { Oil, whale and aperm..... } \\
\text { Fur-geal akins................. }\end{array}$ & $\begin{array}{r}13280,000 \\
111,400\end{array}$ & $\begin{array}{r}20,000 \\
6,000\end{array}$ & ............... & (............ & ….......... & (n..... & $\ldots . . .$. & & & & & & $\begin{array}{r}13280,000 \\
141,400\end{array}$ & $\begin{array}{r}20,000 \\
6,000\end{array}$ \\
\hline Whalebone................... & 1,700 & 7,200 & & & & & & & & & & & 1,700 & 7,200 \\
\hline
\end{tabular}

1 Includes apparatus, with catch, as follows: Dredges, tongs, etc., $33,189,000$ pounds, valued at $\$ 2,614,000$; pots, eel and lobster, 712,000 pounds, valued at $\$ 89,000$; harpoons, apears, otc., 533,000 pounds, valued at $\$ 48,000$; firearms, 88,000 pounds, valued at $\$ 3,600$; and minor apparatus, 1,400 pounds, valued at $\$ 6,000$.

2 less than $\$ 100$.

Less than 100 pounds. 13,000 bushels. 
FISHERIES, BY STATES.

TABLE 2.-CONNECTICUT-PRODUCTS OF SHORE AND BOAT FISHERIES: 1908.

\begin{tabular}{|c|c|c|c|c|c|c|c|c|c|c|c|c|c|c|}
\hline \multirow{3}{*}{ BPECIES. } & \multirow{2}{*}{\multicolumn{2}{|c|}{ TOTAL. }} & \multicolumn{8}{|c|}{ PRODUCT CAUGHT BY- } & \multicolumn{2}{|l|}{$\cdot$} & & \\
\hline & & & \multicolumn{2}{|c|}{ Selnes. } & \multicolumn{2}{|c|}{$\begin{array}{l}\text { Pound and trap } \\
\text { nets. }\end{array}$} & \multicolumn{2}{|c|}{ Gill nets. } & \multicolumn{2}{|c|}{ Lines. } & \multicolumn{2}{|c|}{ Fyke nets. } & \multicolumn{2}{|c|}{$\begin{array}{l}\text { All other appa- } \\
\text { ratus. }\end{array}$} \\
\hline & $\begin{array}{l}\text { Quantity } \\
\text { (pounds). }\end{array}$ & Value. & $\begin{array}{l}\text { Quantity } \\
\text { (pounds). }\end{array}$ & Value. & $\begin{array}{l}\text { Quantity } \\
\text { (pounds). }\end{array}$ & Value. & $\begin{array}{l}\text { Quantity } \\
\text { (pounds). }\end{array}$ & Value. & $\begin{array}{l}\text { Quantity } \\
\text { (pounds). }\end{array}$ & Value. & $\begin{array}{l}\text { Quantity } \\
\text { (pounds). }\end{array}$ & Value. & $\begin{array}{l}\text { Quantity } \\
\text { (pounds). }\end{array}$ & Value. \\
\hline Total.. & $9,162,000$ & $\$ 268,000$ & $1,107,000$ & $\$ 22,000$ & 918,000 & $\$ 17,000$ & 115,000 & $\$ 16,000$ & 163,000 & $\$ 6,600$ & 112,000 & $\$ 5,000$ & $6,748,000$ & 8201,000 \\
\hline 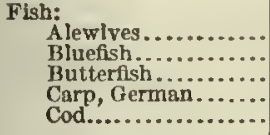 & $\begin{array}{r}992,000 \\
7,200 \\
31,000 \\
7,000 \\
42,000\end{array}$ & $\begin{array}{r}12,000 \\
600 \\
1,300 \\
600 \\
1,500\end{array}$ & $\begin{array}{r}858,000 \\
300 \\
7,400 \\
7.6\end{array}$ & $\begin{array}{c}10,000 \\
(3) \\
600\end{array}$ & $\begin{array}{r}120,000 \\
600 \\
31,000 \\
\ldots, 800\end{array}$ & $\begin{array}{r}1,200 \\
100 \\
1,300 \\
\because 200\end{array}$ & $\begin{array}{c}4,500 \\
\cdots\end{array}$ & (घ) & $\begin{array}{c}5,800 \\
\ldots 7,000\end{array}$ & $\begin{array}{r}500 \\
17,400 \\
1,400\end{array}$ & $\begin{array}{r}8,200 \\
500 \\
200 \\
200\end{array}$ & $\begin{array}{l}300 \\
(2) \\
(2)\end{array}$ & & $\begin{array}{l}\cdots \cdots \\
\cdots \cdots \\
\cdots \cdots \\
\cdots \cdots\end{array}$ \\
\hline Flats............. & 110,000 & 9,000 & 36,000 & 2,500 & 6,700 & 400 & & & & & 6,600 & 800 & 60,000 & 5,300 \\
\hline ders Hake, silver............... & $\begin{array}{r}404,000 \\
49,000\end{array}$ & $\begin{array}{r}12,000 \\
500\end{array}$ & $\begin{array}{r}62,000 \\
\ldots \ldots\end{array}$ & $\begin{array}{l}1,900 \\
\ldots \ldots\end{array}$ & $\begin{array}{r}254,000 \\
49,000\end{array}$ & $\begin{array}{r}7,000 \\
500\end{array}$ & & & $\begin{array}{c}32,000 \\
\cdots\end{array}$ & $\begin{array}{l}1,000 \\
\cdots\end{array}$ & $\begin{array}{c}56,000 \\
\cdots\end{array}$ & 1,800 & 200 & $\begin{array}{l}(2) \\
\cdots \cdots\end{array}$ \\
\hline 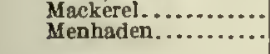 & $\begin{array}{r}8,300 \\
374,000\end{array}$ & $\begin{array}{r}600 \\
2,400\end{array}$ & 58,000 & 1,400 & $\begin{array}{r}2,600 \\
306,000\end{array}$ & $\begin{array}{l}100 \\
900\end{array}$ & $2,80_{0}$ & (2) & $\begin{array}{c}5,700 \\
\cdots \cdots \cdots\end{array}$ & $\begin{array}{r}500 \\
\cdots \cdots\end{array}$ & 6,600 & & & \\
\hline $\begin{array}{l}\text { Perch................. } \\
\text { Pickerel............... } \\
\text { Pollack.............. }\end{array}$ & $\begin{array}{r}7,600 \\
2,500 \\
15,000\end{array}$ & $\begin{array}{l}400 \\
200 \\
400\end{array}$ & $\begin{array}{l}5,400 \\
1,000\end{array}$ & $\begin{array}{l}300 \\
100\end{array}$ & & & (ग) & (3) & a $\cdots \cdots \cdots$ & $\begin{array}{l}\cdots \cdots \\
400\end{array}$ & $\begin{array}{l}2,200 \\
1,000 \\
\ldots\end{array}$ & $\begin{array}{l}200 \\
100 \\
\ldots\end{array}$ & & \\
\hline 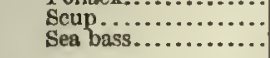 & $\begin{array}{r}3,900 \\
9,000\end{array}$ & $\begin{array}{l}400 \\
600\end{array}$ & & & $\begin{array}{l}3,900 \\
1,000\end{array}$ & 100 & & & 8,000 & 500 & (n....... & $\begin{array}{l}\cdots \\
\cdots \cdots \\
\cdots \cdots\end{array}$ & $\begin{array}{l}-1 \\
\cdots \cdots \\
\cdots \cdots\end{array}$ & (a............. \\
\hline 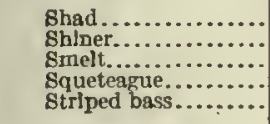 & $\begin{array}{r}122,000 \\
5,500 \\
10,000 \\
106,000 \\
4,700\end{array}$ & $\begin{array}{r}18,000 \\
400 \\
1,200 \\
3,900 \\
700\end{array}$ & $\begin{array}{r}5,600 \\
5,500 \\
8,600 \\
12,000 \\
1,800\end{array}$ & $\begin{array}{r}800 \\
400 \\
1,100 \\
600 \\
200\end{array}$ & $\begin{array}{r}7,200 \\
\cdots, 300 \\
89 ; 000 \\
1,200\end{array}$ & $\begin{array}{r}900 \\
100 \\
3,100 \\
200\end{array}$ & $\begin{array}{r}107,000 \\
\cdots \cdots \cdots \\
\cdots \cdots \\
\cdots \cdots \\
400\end{array}$ & $\mid \begin{array}{r}16,000 \\
\cdots \cdots \\
\cdots \cdots \\
\cdots \cdots \\
100\end{array}$ & 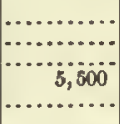 & $\begin{array}{l}\cdots \ldots \\
300 \\
\cdots \cdots\end{array}$ & $\begin{array}{r}2,700 \\
\cdots \cdots \cdots \cdots \\
\cdots \cdots \cdots \\
1,400\end{array}$ & $\begin{array}{c}400 \\
\cdots \\
\cdots\end{array}$ & 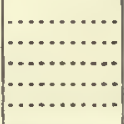 & 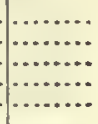 \\
\hline $\begin{array}{l}\text { Suckers................ } \\
\text { Swordfish............ }\end{array}$ & $\begin{array}{r}66,000 \\
2,800\end{array}$ & $\begin{array}{r}3,000 \\
200\end{array}$ & $\begin{array}{c}42,000 \\
\cdots \ldots \ldots\end{array}$ & 2,000 & ......... & … & 100 & $\begin{array}{l}(2) \\
\ldots \ldots\end{array}$ & & & 23,000 & $\begin{array}{c}900 \\
\cdots\end{array}$ & 2,800 & 200 \\
\hline $\begin{array}{l}\text { Tautog } \\
\text { Tomcod, or frostish. }\end{array}$ & $\begin{array}{r}77,000 \\
1,800\end{array}$ & $\begin{array}{r}2,800 \\
100\end{array}$ & 1,500 & 100 & 22,000 & 800 & & & 54,000 & $\mid \begin{array}{r}2,100 \\
\ldots \ldots \ldots\end{array}$ & $\cdots \cdots \cdots$ & & & $\ldots \ldots$ \\
\hline All other............ & 5,000 & 300 & 2,000 & 100 & 900 & 100 & 100 & $(2)$ & (n)........... & ........... & 2,100 & 100 & ............... & $\cdots$ \\
\hline 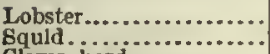 & $\begin{array}{r}544,000 \\
15,000\end{array}$ & 69,000 & & $\cdots$ & $\stackrel{(2)}{15,000}$ & $\stackrel{(2)}{300}$ & & & & & & & $\begin{array}{r}544,000 \\
\cdots \cdots\end{array}$ & $\begin{array}{r}69,000 \\
\cdots\end{array}$ \\
\hline Clams, hard ............... & $\begin{array}{l}484,000 \\
541,000\end{array}$ & 17,000 & & & $\ldots \ldots \ldots \ldots$ & ......... & $\ldots \ldots \ldots \ldots$ & $\ldots$ & $\ldots \ldots$ & & $\ldots \ldots \ldots$ & & 484,000 & 17,000 \\
\hline Clams, solt.................... & 41,000 & 3,400 & & & & & & & & & ........ & ......... & 41,000 & 3,400 \\
\hline Oysters, market, from & - 36,000 & 3,400 & & & & & & & & & & & 36,000 & 3,400 \\
\hline $\begin{array}{l}\text { Oysters, markct, from } \\
\text { private areas........... } \\
\text { oysters, seed, from pub- }\end{array}$ & 287,000 & 38,000 & & & & & & & & & & & 2887,000 & 38,000 \\
\hline $\begin{array}{l}\text { Oysters, seed, from pub- } \\
\text { lic areas............... } \\
\text { Oysters, seed, from prl- }\end{array}$ & 651,000 & 43,000 & & & & & & & & & & & 651,000 & 43,000 \\
\hline $\begin{array}{l}\text { Oysters, seed, from pri- } \\
\text { vate areas.............. }\end{array}$ & 179,000 & 15,000 & & & & & & & & & & & 179,000 & 15,000 \\
\hline $\begin{array}{l}\text { Mussels.................. } \\
\text { Mussel shells............ }\end{array}$ & I2 $4,863,000$ & $\stackrel{(3)}{4,700}$ & & & & & & & & & & & $\begin{array}{r}10500 \\
114,863,000\end{array}$ & $\stackrel{(2)}{4,700}$ \\
\hline
\end{tabular}

Ineludes apparatus, with catch, as follows: Dredges, tongs, etc., $6,141,000$ pounds, valued at $\$ 126,000$; pots, 593,000 pounds, valued at $\$ 73,000$; harpoons, spears, etc., 14,000 pounds, valised at $\$ 1,300$.

2 Less than $\$ 100$. 
TABLE 3.-CONNECTICUT-PRODUCTS OF VESSEL FISHERIES: 1908.

\begin{tabular}{|c|c|c|c|c|c|c|c|c|c|c|}
\hline \multirow{3}{*}{ SPECIES. } & \multirow{2}{*}{\multicolumn{2}{|c|}{ ToTAL. }} & \multicolumn{8}{|c|}{ PRODUCT CAUGHT BY- } \\
\hline & & & \multicolumn{2}{|c|}{ Seines. } & \multicolumn{2}{|c|}{ Lines. } & \multicolumn{2}{|c|}{ Pound and trap nets. } & \multicolumn{2}{|c|}{ All other apparatus. ${ }^{1}$} \\
\hline & $\begin{array}{l}\text { Quantity } \\
\text { (pounds). }\end{array}$ & Value. & $\begin{array}{l}\text { Quantity } \\
\text { (pounds). }\end{array}$ & Value. & $\begin{array}{l}\text { Quantity } \\
\text { (pounds). }\end{array}$ & Value. & $\begin{array}{l}\text { Quantity } \\
\text { (pounds). }\end{array}$ & Value. & $\begin{array}{l}\text { Quantity } \\
\text { (pounds). }\end{array}$ & Value. \\
\hline Total. $\ldots \ldots \ldots \ldots \ldots \ldots$ & $57,780,000$ & $\$ 2,713,000$ & $28,290,000$ & $\$ 94,000$ & 937,000 & $\$ 35,000$ & 711,000 & $\$ 26,000$ & $27,8+1,000$ & $\$ 2,559,000$ \\
\hline 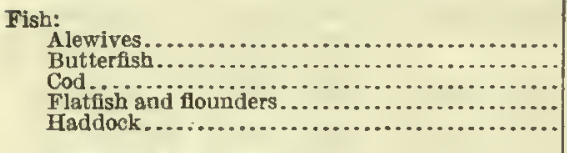 & $\begin{array}{r}34,000 \\
71,000 \\
778,000 \\
303,000 \\
24,000\end{array}$ & $\begin{array}{r}300 \\
2,800 \\
25,000 \\
9,600 \\
900\end{array}$ & & & $\begin{array}{r}772,000 \\
48,000 \\
24,000\end{array}$ & $\begin{array}{r}25,000 \\
2,000 \\
900\end{array}$ & $\begin{array}{r}34,000 \\
71,000 \\
6,000 \\
255,000 \\
\ldots \ldots \ldots\end{array}$ & $\begin{array}{r}300 \\
2,800 \\
200 \\
7,700\end{array}$ & & $\begin{array}{l}\cdots \\
\cdots \\
\cdots \cdots \\
\cdots \cdots\end{array}$ \\
\hline 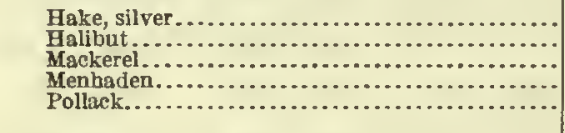 & $\begin{array}{r}130,000 \\
8,500 \\
114,000 \\
28,262,000 \\
10,000\end{array}$ & $\begin{array}{r}1,600 \\
600 \\
8,200 \\
91,000 \\
400\end{array}$ & $\begin{array}{r}27,000 \\
28,258,000 \\
4,500\end{array}$ & $\begin{array}{r}2,700 \\
91,000 \\
200\end{array}$ & $\begin{array}{r}8,500 \\
17,000 \\
\ldots, 500\end{array}$ & $\begin{array}{c}600 \\
1,000 \\
2000\end{array}$ & $\begin{array}{r}130,000 \\
\quad 4,000 \\
4,000 \\
\ldots\end{array}$ & $\begin{array}{c}1,600 \\
\ldots \ldots \ldots \\
\left(^{2}\right)^{200}\end{array}$ & 66,000 & $\begin{array}{l}\ldots \ldots \\
4,300 \\
\cdots \ldots\end{array}$ \\
\hline 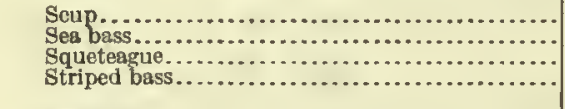 & $\begin{array}{r}91,000 \\
52,000 \\
74,000 \\
1,800\end{array}$ & $\begin{array}{r}8,400 \\
4,800 \\
2,900 \\
100\end{array}$ & ( & & $\begin{array}{r}50,000 \\
\ldots \ldots \ldots \\
\ldots . . .6 .\end{array}$ & $\begin{array}{r}4,700 \\
\cdots, \ldots \ldots \\
\cdots \ldots . .6\end{array}$ & $\begin{array}{r}91,000 \\
74,000 \\
1,800\end{array}$ & $\begin{array}{r}8,400 \\
2,900 \\
100\end{array}$ & 1,100 & 100 \\
\hline 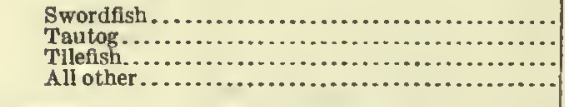 & $\begin{array}{r}237,000 \\
42,000 \\
4,700 \\
1,900\end{array}$ & $\begin{array}{r}14,000 \\
1,700 \\
100 \\
100\end{array}$ & 700 & 100 & $\begin{array}{r}7,500 \\
4,700 \\
\ldots .\end{array}$ & $\begin{array}{r}300 \\
100 \\
\ldots \ldots\end{array}$ & $\begin{array}{r}34,000 \\
1,200\end{array}$ & $\begin{array}{r}1,400 \\
100\end{array}$ & $\begin{array}{r}237,000 \\
100\end{array}$ & $\begin{array}{l}14,000 \\
\quad(2) \\
\cdots \cdots\end{array}$ \\
\hline 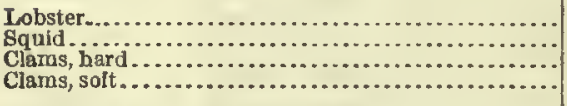 & $\begin{array}{r}117,000 \\
6,000 \\
16,000 \\
\$ 800\end{array}$ & $\begin{array}{r}15,000 \\
100 \\
3,500 \\
100\end{array}$ & & & & & 6,000 & $\begin{array}{l}100 \\
\ldots \ldots \\
\ldots . .\end{array}$ & $\begin{array}{r}117,000 \\
\because 16,000 \\
1800\end{array}$ & $\begin{array}{r}15,000 \\
3,500 \\
100\end{array}$ \\
\hline 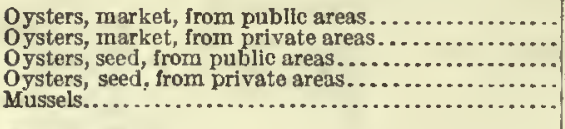 & $\begin{array}{r}68,400 \\
69,431,000 \\
7827,000 \\
816,217,000 \\
96,700\end{array}$ & $\begin{array}{r}1,000 \\
1,125,000 \\
56,000 \\
1,302,000 \\
200\end{array}$ & & & & & & & $\begin{array}{r}58,400 \\
9,431,000 \\
7827,000 \\
16,217,000 \\
96,700\end{array}$ & $\begin{array}{r}1,000 \\
1,125,000 \\
56,000 \\
1,302,000 \\
200\end{array}$ \\
\hline 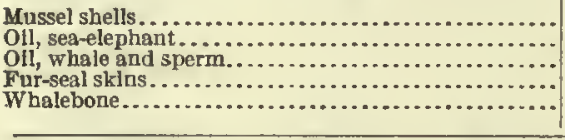 & $\begin{array}{r}10540,000 \\
1188,000 \\
12280,000 \\
131,400 \\
1,700\end{array}$ & $\begin{array}{r}600 \\
3,600 \\
20,000 \\
6,000 \\
7,200\end{array}$ & & & & ... & 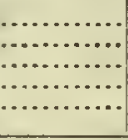 & & $\begin{array}{r}10540,000 \\
1188,000 \\
12280,000 \\
181,400 \\
1,700\end{array}$ & $\begin{array}{r}600 \\
3,600 \\
20,000 \\
6,000 \\
7,200\end{array}$ \\
\hline
\end{tabular}

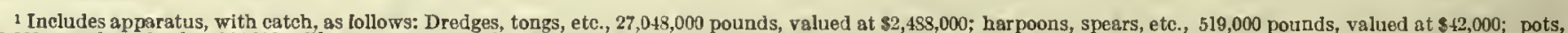

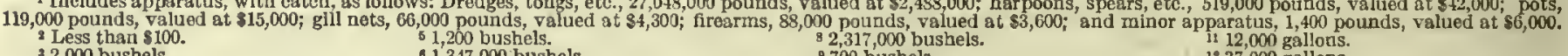
2,000 bushels.
100 bushels. s 1,200 bushels.
i $1,347,000$ bushels.
118,000 bushels. $8,317,000$ bushels
2700 bushels. 109,000 bushels.
Comparison with previous canvasses.-The following tabular statement shows the principal statisties of the fisheries of Delaware for 1908, in comparison with those reported by the Bureau of Fisheries for 1897 and 1904:

\begin{tabular}{|c|c|c|c|c|c|c|}
\hline \multirow[b]{2}{*}{ YEAR. } & \multirow{2}{*}{$\begin{array}{l}\text { Persons } \\
\text { em- } \\
\text { ployed, } \\
\text { exclusive } \\
\text { of } \\
\text { shores- } \\
\text { men. }\end{array}$} & \multicolumn{3}{|c|}{ VALUE OF EQUIPMENT. } & \multicolumn{2}{|c|}{ PRODUCTS. } \\
\hline & & Total. & $\begin{array}{c}\text { Vessels } \\
\text { and } \\
\text { boats, } \\
\text { including } \\
\text { outfit. }\end{array}$ & $\begin{array}{l}\text { Appara- } \\
\text { tus of } \\
\text { capturc. }\end{array}$ & $\begin{array}{l}\text { Quantity } \\
\text { (pounds). }\end{array}$ & Value. \\
\hline $\begin{array}{l}1908 \ldots \ldots \ldots \ldots \ldots \\
1904 . \ldots \ldots \ldots \ldots \ldots \\
1897 . \ldots \ldots \ldots \ldots\end{array}$ & $\begin{array}{l}1,744 \\
1,495 \\
2,008\end{array}$ & $\begin{array}{r}\$ 435,000 \\
104,000 \\
123,000\end{array}$ & $\begin{array}{r}8372,000 \\
69,000 \\
77,000\end{array}$ & $\begin{array}{r}\$ 63,000 \\
35,000 \\
46,000\end{array}$ & $\begin{array}{r}70,769,000 \\
5,608,000 \\
8,648,000\end{array}$ & $\begin{array}{r}8541,000 \\
260,000 \\
252,000\end{array}$ \\
\hline
\end{tabular}

1]ncludes menhaden $(59,815,000$ pounds, valued at $\$ 152,000)$. This fish was reported separately in 1904 and in 1897.

Persons employed.-The report of the Bureau of Fisheries for the year 1904 showed 1,495 persons employed in the fisheries of Delaware, not including shoresmen. The distribution of the persons employed in 1908 was as follows: 


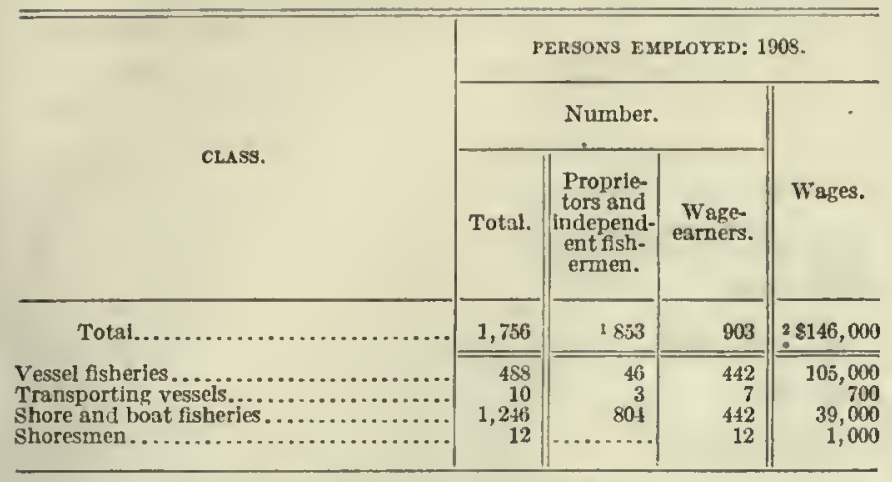

2 Includes provisions furnished to the value of $\$ 15,000$.

Over 70 per eent of the total number were employed in the shore and boat fisheries, and more than onehalf of the total number were wage-earners, independent fishcrmen being relatively not so numerous in this state as in the Soutl Atlantic and the Gulf states. Althougl the number of persons fishing on their own account and not employing any wage-earners is not aseertainable, yet it is apparent that of the 804 proprietors and independent fishermen engaged in shore and boat fisheries, one-half or more were independent fishermen. Of the 442 wage-carners in the vessel fisheries, 266 , or more than one-half, were employed in the menhaden fisheries.

Equipment and other capital.-The following tabular statement slows the capital invested in the industry and its distribution, by class of investment, together with the number and tonnage of the vessels and the number of the boats:

\begin{tabular}{|c|c|c|c|}
\hline \multirow{2}{*}{ CLASS OF INVESTMENT. } & \multicolumn{3}{|c|}{$\begin{array}{l}\text { EQUTPMENT AND OTIIER } \\
\text { CAPTTAL: 1908. }\end{array}$} \\
\hline & Value. & Number. & Tonnage. \\
\hline Total..... & $\$ 444,000$ & $\mid \ldots \ldots \ldots . .$. & ............ \\
\hline Vessels, including outfit... & 334,000 & 65 & 1,629 \\
\hline $\begin{array}{l}\text { Fishing.................... } \\
\text { Steam and motor. }\end{array}$ & $\begin{array}{l}329,000 \\
277,000\end{array}$ & 61 & 1,578 \\
\hline Vessels....... & 233,000 & & \\
\hline Sall......... & 44,000 & & \\
\hline 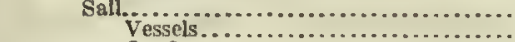 & $\begin{array}{l}52.000 \\
42.000\end{array}$ & 49 & 437 \\
\hline Outfit...................... & 10,000 & & \\
\hline Transporting (saii).............. & 5,400 & 4 & 51 \\
\hline 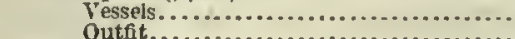 & 4,900 & & \\
\hline Boats.............................. & 38,000 & 792 & \\
\hline Steam and motor........................... & 25,000 & 116 & \\
\hline 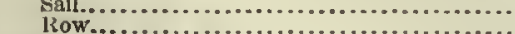 & $\begin{array}{r}3,500 \\
0,500\end{array}$ & 62 & \\
\hline A pparatus of capture & 63,500 & & \\
\hline Vessel fisheries ............. & 24,000 & & $\cdots$ \\
\hline Shore and boat fisheries.................. & 38,000 & & \\
\hline Shore and accessory property ................... & 9,500 & & \\
\hline
\end{tabular}

More than one-half of the capital was invested in steam ressels. Of the 12 reported, 11, with a total tonnage of 1,136 , were employed in menhaden fisheries, and 1 , of 5 tons, in oyster dredging.

The total investment in vessels, both fishing and transporting, aggregated $\$ 334,000$, the investment in boats $\$ 38,000$, and the investment in apparatus of eapture $\$ 63,000$. Of the latter, $\$ 24,000$ pertained to vessel fisheries and $\$ 38,000$ to shore and boat fisheries.
The investment in fishing and transporting vessels and in apparatus of capture for vessels aggregated $\$ 358,000$, of which 93 per eent represents the value of vessels and 7 per cent that of apparatus of capture. In the shore and boat fisheries the investment in boats "and apparatus of capturo combined was $\$ 77,000$, an amount which was about equally divided. The number of each kind of apparatus used was as follows:

\begin{tabular}{|c|c|c|}
\hline Bow nets............ & Muskrat traps...... & 16,461 \\
\hline Cast nets............. & Pound nets........ & 9 \\
\hline Dip nets............. & Seines............... & 261 \\
\hline Eel and lobster pots. $\therefore . .3,167$ & Spears.............. & 113 \\
\hline Fyke and hoop nets.... 1,806 & Stop nets........... & 15 \\
\hline Gill nets............ 865 & Turtle nets. ........... & 13 \\
\hline
\end{tabular}

All of the apparatus enumerated above, except 1 gill net and 23 seines, was used in shore and boat fisheries.

Products, by species.-Table 1, on page 99, gives the weight and value of the fishery product of the state, distributed by speeies and by apparatus of capture.

The product of the menhaden fisheries was the most important, if measured by market values, for, although the total value of the oyster product was greater, onethird of the latter represented seed oysters and but two-thirds market oysters. In quantity the menhaden catch largely exceeded that of all other fishery products, amounting in net weight to nearly $60,000,000$ pounds, compared with about $11,000,000$ pounds for all other fishery products. Even if the oyster catch is considered on the basis of gross weight at an average of 80 pounds per bushel, instead of on the basis of contained meat, the menhaden catch is still in excess of all other products in the ratio of approximately 30,000 net tons to 19,000 net tons.

Products, by class of fisheries.-Table 2, on page 99, gives the products of the vessel fisheries, distributed according to apparatus of capture. The vessel fishery products were limited practically to menhaden and oysters. With the exception of the products of the menhaden and oyster fisheries which are shown in Table 2, and the small amount of shad and squeteague shown in the same table, all the products given in Table 1, on page 99, were reported by the shore and boat fisheries. Of these species, the portions belonging to the shore and boat fisheries were as follows: Menhaden, 54,000 pounds, valued at $\$ 2,400$; shad, 868,000 pounds, valued at $\$ 68,000$; squeteague, $2,587,000$ pounds, valued at $\$ 29,000$; market oysters from public areas, 159,000 pounds (representing 23,000 bushels), valued at $\$ 8,400$; market oysters from private areas, 28,000 pounds (representing 4,000 bushels), valued at $\$ 1,000$; and seed oysters from public areas, 338,000 pounds (representing 48,000 bushels), valued at $\$ 12,000$. The total products of the shore and boat fisheries in 1908 were $9,092,000$ pounds, having a value of $\$ 244,000$. Of these products, $4,327,000$ pounds, having a value of $\$ 69,000$, were caught with seines; $1,073,000$ pounds, having a value of 
$\$ 85,000$, with gill nets; and 531,000 pounds, having a value of $\$ 23,000$, with dredges and tongs, and the remainder with the other forms of apparatus as specified in Table 1, page 99. The chief products of the shore and boat fisheries were in the order of value: shad, $\$ 68,000$; squeteague, $\$ 29,000$; muskrats and muskrat skins, $\$ 24,000$; oysters, $\$ 21,000$; eels, $\$ 15,000$; and white perch, $\$ 14,000$.

The distribution of the catch by chief products and by class of fisheries was as follows:

\begin{tabular}{|c|c|c|c|}
\hline \multirow[b]{2}{*}{ SPECIES, } & \multicolumn{3}{|c|}{ VALUE OF PRODUCTS: 1908.} \\
\hline & Total. & $\begin{array}{c}\text { Vessel } \\
\text { fisherles. }\end{array}$ & $\begin{array}{l}\text { Shore } \\
\text { and boat } \\
\text { fisherles. }\end{array}$ \\
\hline Total... & $\$ 541,000$ & $\$ 297,000$ & $\$ 244,000$ \\
\hline Fish........... & 328,000 & 150,000 & 179,000 \\
\hline Menhaden...... & 152,000 & 149,000 & 2,400 \\
\hline Shad............ & 68,000 & 100 & 68,000 \\
\hline Squeteague...... & 29,000 & 200 & 29,000 \\
\hline Eels................ & 15,000 & & 15,000 \\
\hline Perch, white ....... & 14,000 & & 14,000 \\
\hline Alewives......... & 8,400 & & 8,400 \\
\hline Catfish.................... & 7,300 & ............. & 7,300 \\
\hline 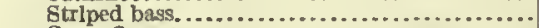 & 7,300 & ............ & 7,300 \\
\hline Carp, German..... & 6,700 & & 6,700 \\
\hline All other.......... & 20,000 & & 20,000 \\
\hline 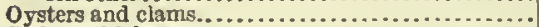 & 170,000 & 147,000 & 23,000 \\
\hline 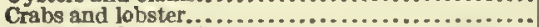 & 14,000 & & 14,000 \\
\hline Turtles and terrapin................................. & 4,500 & ............. & 4,500 \\
\hline 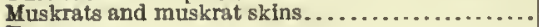 & 24,000 & & 24,000 \\
\hline Frogs........................................... & 700 & & 700 \\
\hline
\end{tabular}

Products, by apparatus of capture.-The total value of the fishery products was distributed according to apparatus of capture as follows:

\begin{tabular}{|c|c|c|c|}
\hline \multirow[b]{2}{*}{ KIND OF APPARATUS. } & \multicolumn{3}{|c|}{ VALUE OF PRODUCTS: 1908.} \\
\hline & Total. & $\begin{array}{c}\text { Vessel } \\
\text { fisherles. }\end{array}$ & $\begin{array}{l}\text { Shore } \\
\text { and boat } \\
\text { fisherles. }\end{array}$ \\
\hline Total. & $\$ 541,000$ & $\$ 297,000$ & $\$ 244,000$ \\
\hline Selnes.................... & 219,000 & 150,000 & 69,000 \\
\hline 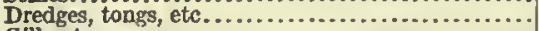 & 170,000 & 147,000 & 23,000 \\
\hline 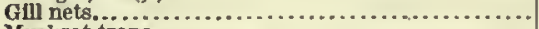 & 85,000 & 100 & 55,000 \\
\hline 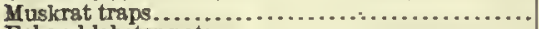 & 24,000 & & 24,000 \\
\hline 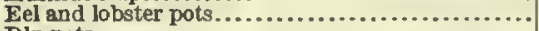 & 14,000 & $\ldots \ldots \ldots$ & 14,000 \\
\hline Dlp nets $\ldots \ldots \ldots \ldots \ldots \ldots \ldots \ldots \ldots \ldots$ & 8,400 & ........... & 8,400 \\
\hline 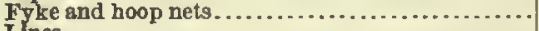 & 7,300 & ............ & 7,300 \\
\hline $\begin{array}{l}\text { Lines } \\
\text { All other }\end{array}$ & $\begin{array}{l}6,100 \\
8,400\end{array}$ & $\cdots \cdots \cdots$ & $\begin{array}{l}6,100 \\
8,400\end{array}$ \\
\hline All other........................ & & & \\
\hline
\end{tabular}

The catch in seines led in value and constituted nine-tenths of all products in quantity. The chief species caught in this way were menhaden and squeteague. The products taken by dredges and tongs consisted almost entirely of oysters. Shad, sturgeon, and striped bass were the leading species taken with gill nets; and catfish and carp the leading species taken with fyke and hoop nets.

Oysters.-The oyster yicld was 348,000 bushels, valued at $\$ 169,000$, and contributed 31 per cent of the value of all products. Of the total quantity, 155,000 bushels were market oysters, chiefly from private areas, and 193,000 bushels seed oysters, almost entirely from public areas. The distribution of the oyster product is shown by the following tabular statement:

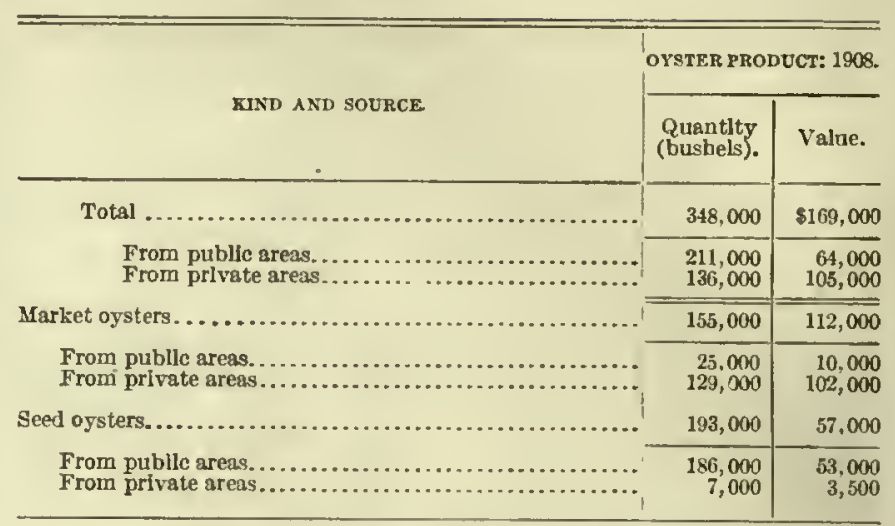

Oysters from private areas averaged much higher in value than those from public areas, the market oysters from private areas having an average value of 79 cents per bushel, compared with 40 cents for those from public areas. Of the market oysters, 83 per cent, in quantity, were from private areas, while 96 per cent of the seed oysters were from public areas and but 4 per cent from private areas.

Other shellfish.-The clam product consisted of 900 bushels of hard clams, of a value of $\$ 1,300$, while the lobster product, likewise small, amounted to 5,500 pounds, valued at $\$ 800$. The crab catch, it should be noted, included a large quantity of king or horseshoe crabs, which are used chiefly as fertilizers. The food crabs comprised soft-shell crabs, valued at $\$ 8,400$, and hard-shell crabs, valued at $\$ 600$.

Squeteague and shad.--The squeteaguc, or sea trout, is the most abundant of the food fishes, and in quantity the catch formed nearly one-half of them. In value, however, it was greatly exceeded by shad, which represented nearly two-fifths of the value of all food-fish products, although only one-cighth of their quantity. The bulk of the squeteague catch was made with seines and the bulk of the shad catch with gill nets.

Muskrats.-The muskrat industry was important, inasmuch as it not only contributed products of a considerable amount but furnished employment, in whole or in part, to a large number of men. The animal is trapped chiefly for its skin. The meat, however, is used to a considerable extent, the sale of 110,000 pounds, valued at $\$ 3, \$ 00$, being reported in 1908 . The value of this meat has been included in the sum of $\$ 24,000$ shown in the tables as the value of muskrat skins. The method of reporting muskrats varied greatly. In most cases the number or weight of the skins was reported and their value, regardless of whether they were sold alone and the carcasses discarded, or the animals were sold entirc, or the skins and carcasses were marketed separately. Hence for the purpose of tabulation the total value in the general tables has been credited to the skins. The average value of a muskrat carcass was 5 cents and of a skin from 25 to 30 cents. 
FISHERIES, BY STATES.

TABLE 1.-DELAWARE-FISHERY PRODUCTS: 1908.

\begin{tabular}{|c|c|c|c|c|c|c|c|c|c|c|c|c|c|c|}
\hline \multirow{3}{*}{ SPECIES. } & \multicolumn{2}{|c|}{ TOTAL. } & \multicolumn{12}{|c|}{ PRODUCT CAUGHT BY- } \\
\hline & \multirow{2}{*}{$\begin{array}{l}\text { Quantity } \\
\text { (pounds). }\end{array}$} & \multirow{2}{*}{ Value. } & \multicolumn{2}{|c|}{ Scines. } & \multicolumn{2}{|c|}{ Gill nets. } & \multicolumn{2}{|c|}{$\begin{array}{l}\text { Fyke and hoop } \\
\text { nets. }\end{array}$} & \multicolumn{2}{|c|}{ Lines. } & \multicolumn{2}{|c|}{ Yound nets. } & \multicolumn{2}{|c|}{$\begin{array}{l}\text { All other appa- } \\
\text { ratus.1 }\end{array}$} \\
\hline & & & $\begin{array}{l}\text { Quantity } \\
\text { (poutuds). }\end{array}$ & Value. & $\begin{array}{l}\text { Quantity } \\
\text { (pounds). }\end{array}$ & Value. & $\begin{array}{l}\text { Quantity } \\
\text { (pounds). }\end{array}$ & Value. & $\begin{array}{l}\text { Quantlty } \\
\text { (pounds). }\end{array}$ & Value. & $\begin{array}{c}\text { Quantlty } \\
\text { (pounds). }\end{array}$ & Value. & $\begin{array}{l}\text { Quantity } \\
\text { (pounds). }\end{array}$ & Value. \\
\hline Total.. & $70,769,000$ & $\$ 541,000$ & $64,091,000$ & $\$ 219,000$ & $1,075,000$ & 885,000 & 165,000 & 57,300 & 206,000 & 86,100 & 11,000 & $\$ 400$ & $5,220,000$ & $\$ 224,000$ \\
\hline 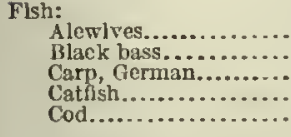 & $\begin{array}{r}794,000 \\
2,100 \\
133,000 \\
151,000 \\
7,000\end{array}$ & $\begin{array}{r}8,400 \\
200 \\
6,700 \\
7,300 \\
400\end{array}$ & $\begin{array}{r}705,000 \\
700 \\
84,000 \\
56,000\end{array}$ & $\begin{array}{l}7,300 \\
100 \\
4,200 \\
2,900\end{array}$ & $\begin{array}{r}59,000 \\
300 \\
26,000 \\
4,800\end{array}$ & $\begin{array}{r}800 \\
(8) \\
1,300 \\
200\end{array}$ & $\begin{array}{l}25,000 \\
400 \\
21,000 \\
81,000\end{array}$ & $\begin{array}{r}200 \\
(\stackrel{2}{(2)} \\
1,100 \\
3,800\end{array}$ & \begin{tabular}{r}
700 \\
\hdashline, 900 \\
7,000
\end{tabular} & $\begin{array}{l}100 \\
100 \\
400\end{array}$ & 4,500 & 100 & 5,7000 & $\begin{array}{l}\cdots . . \\
100 \\
300\end{array}$ \\
\hline 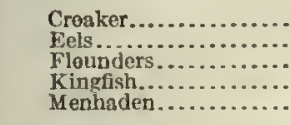 & $\begin{array}{r}79,000 \\
202,000 \\
17,000 \\
1,800 \\
59,815,000\end{array}$ & $\begin{array}{r}2.900 \\
15,000 \\
1,200 \\
300 \\
152,000\end{array}$ & $\begin{array}{r}55,000 \\
23,000 \\
11.000 \\
1,800 \\
59,815,000\end{array}$ & $\begin{array}{r}1,700 \\
1,000 \\
800 \\
200 \\
152,000\end{array}$ & $\begin{array}{r}7,900 \\
6,000\end{array}$ & $\begin{array}{l}400 \\
400 \\
\ldots \ldots\end{array}$ & $7,600^{\circ}$ & 500 & 15,000 & 700 & 100 & (i) & $17 i, 000$ & $\begin{array}{l}13,000 \\
\ldots \ldots . . \\
\cdots \ldots . . .\end{array}$ \\
\hline 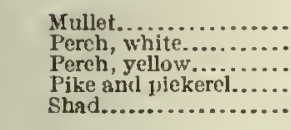 & $\begin{array}{r}27,090 \\
173,000 \\
18,000 \\
11,000 \\
870,000\end{array}$ & $\begin{array}{r}1,000 \\
14,000 \\
1,700 \\
1,100 \\
68.000\end{array}$ & $\begin{array}{r}17,000 \\
138,000 \\
17,000 \\
8,200 \\
10,000\end{array}$ & $\begin{array}{r}600 \\
11,000 \\
1,600 \\
800 \\
700\end{array}$ & $\begin{array}{r}6,700 \\
24,000 \\
3 \times 300 \\
859,000\end{array}$ & $\begin{array}{r}300 \\
2,000 \\
\cdots(3) \\
67,000\end{array}$ & $\begin{array}{r}3,400 \\
6,200 \\
600 \\
400\end{array}$ & $\begin{array}{l}200 \\
500 \\
(2) \\
(3)\end{array}$ & $\begin{array}{l}2,500 \\
2,500\end{array}$ & $\begin{array}{c}200 \\
300\end{array}$ & 3,000 & 200 & & (.... \\
\hline $\begin{array}{l}\text { Spot................ } \\
\text { Squeteague, or ses trout } \\
\text { Striped bass........... } \\
\text { Sturgeon................. }\end{array}$ & $\begin{array}{r}15,000 \\
2,590,000 \\
53,000 \\
31,000\end{array}$ & $\begin{array}{r}1,300 \\
29,000 \\
7,300 \\
3,200\end{array}$ & $\begin{array}{r}5,500 \\
2,467,000 \\
23,000\end{array}$ & $\begin{array}{r}400 \\
27,000 \\
3,000\end{array}$ & $\begin{array}{r}9,400 \\
5,000 \\
29,000 \\
31,000\end{array}$ & $\begin{array}{r}900 \\
300 \\
4,200 \\
3,200\end{array}$ & 1,0000 & 100 & $\begin{array}{r}114,000 \\
100\end{array}$ & $(2)$ & $1,500^{\circ}$ & 100 & & $\ddot{0}$ \\
\hline 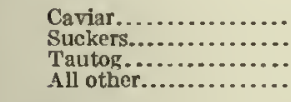 & $\begin{array}{r}3,100 \\
9,900 \\
55.000 \\
5,300\end{array}$ & $\begin{array}{r}3,900 \\
300 \\
2,800 \\
100\end{array}$ & 6,600 & 200 & $\begin{array}{r}3,100 \\
300\end{array}$ & $\begin{array}{c}3,900 \\
(2)\end{array}$ & $2,500^{\circ}$ & ioo" & $\begin{array}{r}500 \\
55,000 \\
300\end{array}$ & $\begin{array}{l}(8) \\
2,800 \\
(2)\end{array}$ & 200 & (2) & & $\begin{array}{l}\cdots \\
\cdots \\
\ldots\end{array}$ \\
\hline 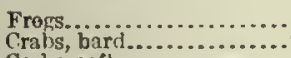 & $\begin{array}{r}1,900 \\
57.000\end{array}$ & $\begin{array}{l}700 \\
600\end{array}$ & 55,000 & & 500 & (1) & & & 1,000 & (2) & & & $\begin{array}{r}1,900 \\
\cdots\end{array}$ & $\begin{array}{r}700 \\
\ldots . .\end{array}$ \\
\hline 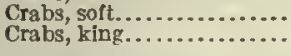 & $\begin{array}{r}142,000 \\
2,930,000\end{array}$ & $\begin{array}{l}8,400 \\
4,300\end{array}$ & $\begin{array}{r}1,000 \\
580,000\end{array}$ & ${ }_{700}^{(2)}$ & 700 & (2) & & & & & & & $\begin{array}{r}140,000 \\
2,400,000\end{array}$ & $\begin{array}{l}8,400 \\
3,600\end{array}$ \\
\hline 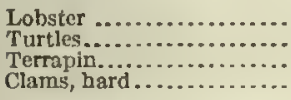 & $\begin{array}{r}5.500 \\
54,000 \\
2,900 \\
86,900\end{array}$ & $\begin{array}{r}800 \\
2,500 \\
1,000 \\
1,300\end{array}$ & $\begin{array}{r}4,700 \\
200\end{array}$ & 200 & & & 15,000 & 800 & 5,200 & 200 & & & $\begin{array}{r}5,500 \\
29,000 \\
2,700 \\
\mathbf{8} 6,900\end{array}$ & $\begin{array}{r}600 \\
1,400 \\
1,700 \\
1,300\end{array}$ \\
\hline $\begin{array}{l}\text { Oysters, market, from pub- } \\
\text { lie areas......................... }\end{array}$ & 4177,000 & 10,000 & & & & & & & & & & & 4177,000 & 10,000 \\
\hline $\begin{array}{l}\text { Oysters, masket, from pri- } \\
\text { vate areas................. }\end{array}$ & 6905,000 & 102,000 & & & & & & & & & & & 6905,000 & 102,000 \\
\hline $\begin{array}{l}\text { Oysters, seed, from public } \\
\text { areas................................. }\end{array}$ & $81,303,000$ & 53,000 & & & & & & & & & & & $\bullet 1,303,000$ & 53,000 \\
\hline $\begin{array}{l}\text { Oysters, seed, from prlvate } \\
\text { areas................................ }\end{array}$ & & 3,500 & & & & & & & & & & & & 3,500 \\
\hline Skins, muskrat............. & 22,000 & 24,000 & & & & & & & & & & & 822,000 & 24,000 \\
\hline
\end{tabular}

1 ncludes apparatus, with cateh, as follows: Dredges, tongs, etc., $2,441,000$ pounds, valued at $\$ 170,000 ;$ muskrat traps, 22,000 pounds, valued at $\$ 24,000$; eel and 10 bster

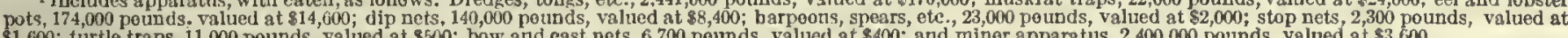

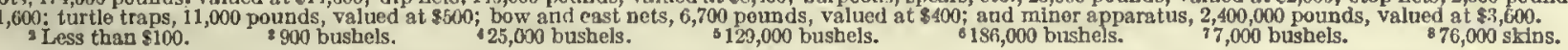

TABLE 2.-DELAWARE-PRODUCTS OF VESSEL FISHERIES: 1908.

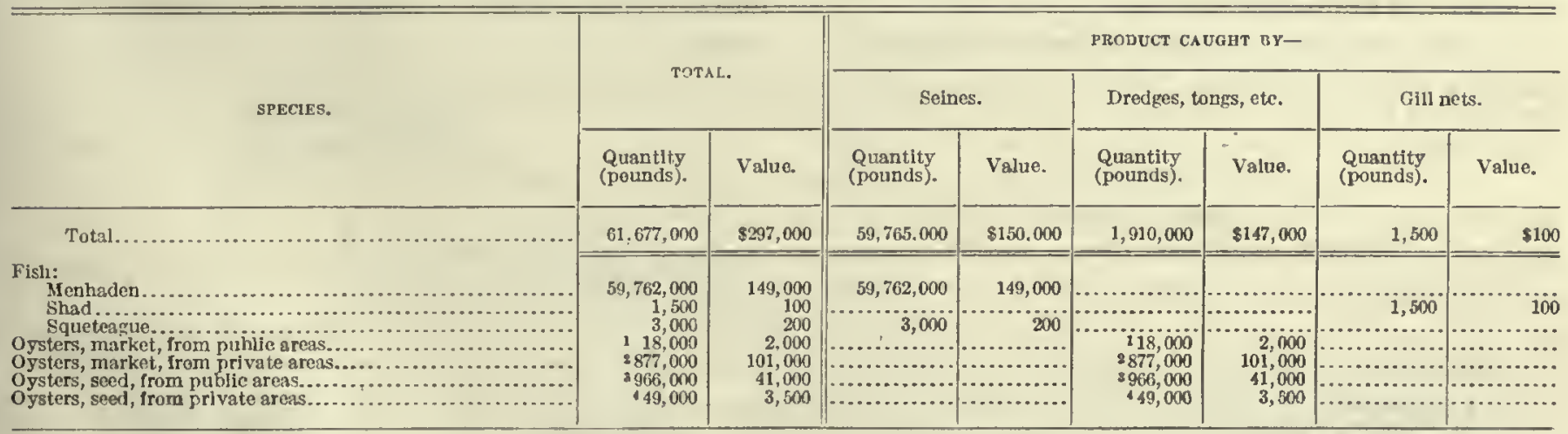




\section{FLORIDA.}

During the last three decades the fisheries of Florida have grown steadily in the value of their products, and in 1908 the state held fifth rank in this respect. It has a natural monopoly of the sponge fisheries of the United States, contributed two-thirds, in value, of the mullet product, and was surpassed in the value of its shad product only by Virginia and North Carolina.

Florida has the longest coast line of any state in the Union, measuring about 450 miles on the Atlantic Ocean and 675 miles on the Gulf of Mexico. The Atlantic coast is remarkably free from indentation, but is bordered throughout almost its entire length by sand reefs that inclose long lagoons, sounds, and bays (often misnamed rivers), in which fish abound. The principal fishing grounds on this coast are the following waters, in geographical order: St. Marys, St. Johns, and Matanzas Rivers, Lake George, Mosquito Lagoon, Indian River, Biscayne Bay, St. Lucie River, and Lake Worth.

The Gulf coast, like the Atlantic coast, is low, but it is much less regular and is intersected by the estuaries of a number of rivers and by numerous bays, sounds, and lagoons. Following the indentations, the western coast line of Florida measures approximately 2,810 miles. Nearly all of the shore fishing on this coast, as along the eastern coast, is pursued in the shallow waters shut in from the open sea by keys and lowland spits. The principal indentations along the Gulf coast where commercial fishing is carried on are the following: The bays known as Pensacola, Escambia, Chootawhatchee, St. Andrews, and St. Joseph, St. Vincent Sound, Apalachicola Bay, St. George's Sound, Waccassassee, Clearwater, Tampa, Hillsboro, and Sarasota Bays, Charlotte Harbor, and Gasparilla and San Carlos Bays. Among the rivers the Apalachicola, Withlacoochee, Homosassa, Anclote, and Manatee are the principal fishing grounds.

The following table presents a general summary of the statistics of the fishing industry of the state for 1908:

Number of persons employed.

Capital:

Vessels and boats, including outfit...........\$1, 421,000

Apparatus of capture.................... $\quad 326,000$

Shore and accessory property and cash......... 668,000 Value of products....................... $3,389,000$

Comparison with previous canvasses.-If the figures are compared with those reported for former years, a steady increase in the importance of the fishing industry of the state is observed. A comparison with such preceding years for which figures are available is given below, the number of shoresmen and the investment in shore and accessory property and cash capital being excluded:

\begin{tabular}{|c|c|c|c|c|c|c|}
\hline \multirow[b]{2}{*}{$\begin{array}{l}\text { DISTRICT AND } \\
\text { YEAR. }\end{array}$} & \multirow{2}{*}{$\begin{array}{l}\text { Per- } \\
\text { sonsem- } \\
\text { ployed, } \\
\text { exclu- } \\
\text { sive of } \\
\text { shores- } \\
\text { men. }\end{array}$} & \multicolumn{3}{|c|}{ VALUE OF EQUTPMENT. } & \multicolumn{2}{|c|}{ PRONUCT8. } \\
\hline & & Total. & $\begin{array}{c}\text { Vessels } \\
\text { and boats } \\
\text { inchuding } \\
\text { outfit. }\end{array}$ & $\begin{array}{l}\text { Appara- } \\
\text { tus of } \\
\text { eapture. }\end{array}$ & $\begin{array}{l}\text { Quantity. } \\
\text { (pounds). }\end{array}$ & Value. \\
\hline $\begin{array}{r}\text { Total: } \\
1908 . . . \\
1902 . . \\
1897 . . \\
1890 . .\end{array}$ & $\begin{array}{l}9,006 \\
7,846 \\
5,658 \\
4,776 \\
\end{array}$ & $\begin{array}{r}31,747,000 \\
1,298,000 \\
708,000 \\
769,000 \\
\end{array}$ & $\begin{array}{r}\$ 1,421,000 \\
1,126,000 \\
620,000 \\
682,000 \\
\end{array}$ & $\begin{array}{r}\$ 326,000 \\
172,000 \\
88,000 \\
87,000 \\
\end{array}$ & $\begin{array}{l}74,087,000 \\
67,704,000 \\
34,138,000 \\
34,882,000\end{array}$ & $\begin{array}{l}83,359,000 \\
1,940,000 \\
1,081,000 \\
1,284,000\end{array}$ \\
\hline 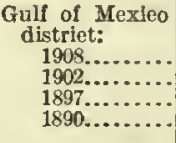 & $\begin{array}{r}5,850 \\
5,579 \\
4,607 \\
+3,602\end{array}$ & $\begin{array}{r}1,338,000 \\
1,139,000 \\
6511,000 \\
699,000\end{array}$ & $\begin{array}{r}1,143,000 \\
1,041,000 \\
596,000 \\
650,000\end{array}$ & $\begin{array}{r}195,000 \\
95,000 \\
54,000 \\
50,000\end{array}$ & $\begin{array}{l}37,566,000 \\
48,120,000 \\
28,255,000 \\
27,419,000\end{array}$ & $\begin{array}{r}2,120,000 \\
1,462,000 \\
945,000 \\
1,064,000\end{array}$ \\
\hline 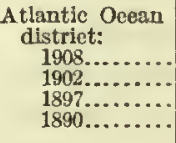 & $\begin{array}{r}3,156 \\
2,267 \\
991 \\
1,174\end{array}$ & $\begin{array}{r}409,000 \\
159,000 \\
57,000 \\
70,000\end{array}$ & $\begin{array}{r}278,000 \\
82,000 \\
24,000 \\
32,000\end{array}$ & $\begin{array}{r}131,000 \\
77,000 \\
33,000 \\
38,000\end{array}$ & $\begin{array}{r}36,521,000 \\
19,584,000 \\
5,883,000 \\
7,462,000\end{array}$ & $\begin{array}{r}1,269,000 \\
478,000 \\
136,000 \\
220,000\end{array}$ \\
\hline
\end{tabular}

Persons employed. - The total number of persons employed in the fisheries of the state in 1908 was 9,212 , or, exclusive of shoresmen, 9,006 .

The following tabular statement shows the distribution of the persons employed, as reported at the census of 1908 .

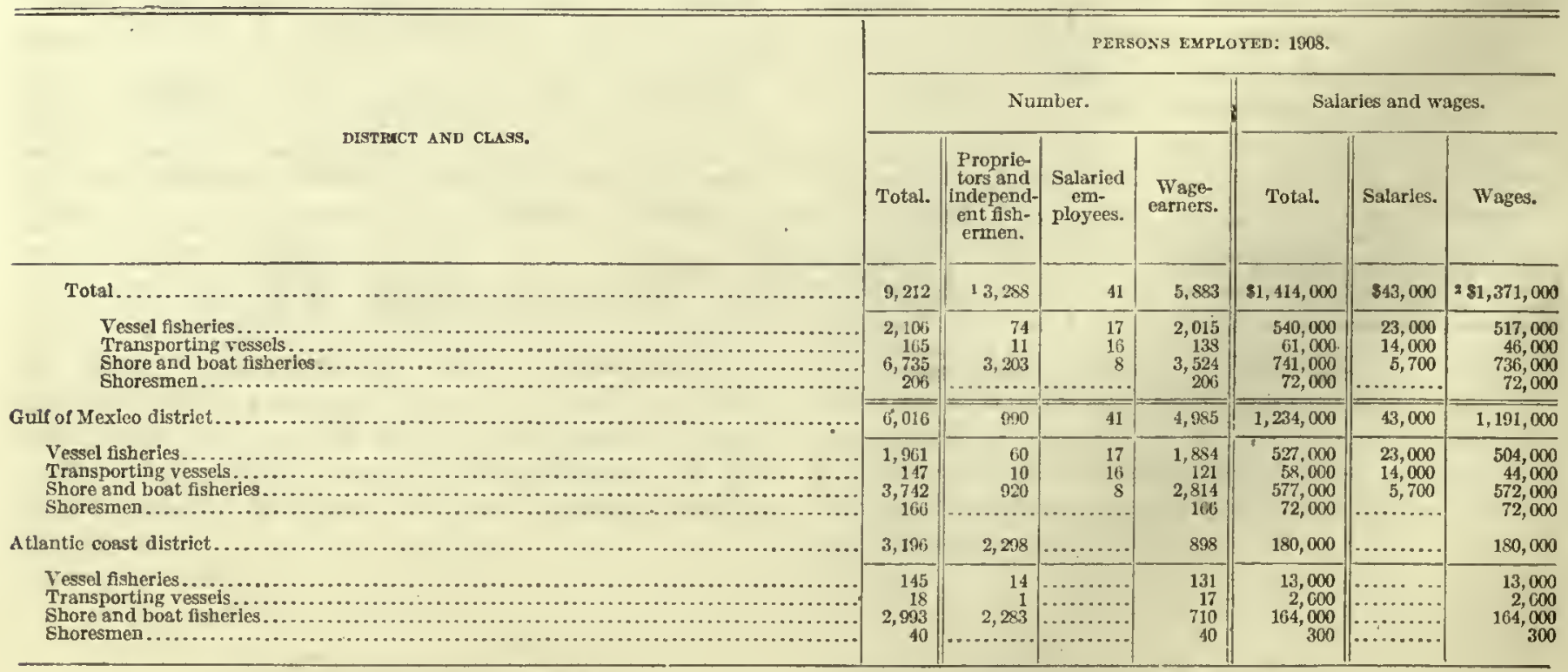


The Gulf coast fisheries employed nearly two-thirds of all the fishermen of the state and 93 per cent of those engaged in the ressel fisheries.

The fishermen engaged in the shore and boat fisheries of the Atlantic coast were to a large extent independent fishermen, only 710 wage-earners being employed by the 2,283 persons classed as proprietors and independent fishermen in the returns of these fisheries. On the other hand, a large majority of the fishermen employed in the shore and boat fisheries of the Gulf were wage-earners. Of those engaged in the Atlantic coast fisheries, nearly 94 per cent were in the shore and boat fisheries, while only 62 per cent of those engaged in the Gulf fisheries belonged to this class.

Equipment and other capital.-The following table gives the value of the equipment in vessels, boats, and apparatus of capture and the amount of other capital employed:

\begin{tabular}{|c|c|c|c|}
\hline \multirow{2}{*}{ CLASS OF INVESTMENT. } & \multicolumn{3}{|c|}{$\begin{array}{l}\text { VALUE OF EQUTPMENT AND OTHER } \\
\text { CAPITAL: } 1908 .\end{array}$} \\
\hline & Total. & $\begin{array}{l}\text { Gulf of } \\
\text { Mexico } \\
\text { district. }\end{array}$ & $\begin{array}{l}\text { Atlantic } \\
\text { coast } \\
\text { district. }\end{array}$ \\
\hline Total.. & $\$ 2,416,000$ & $\$ 1,884,000$ & $\$ 531,000$ \\
\hline Vessels, Including outfit. & 816,000 & 798,000 & 48,000 \\
\hline Fishing................. & 680,000 & 645,000 & 36,000 \\
\hline Stearn and motor... & 29,000 & 9,900 & 19,000 \\
\hline Vessels.......... & 25,000 & 9,100 & 16.000 \\
\hline Outfit...... & 4,300 & 800 & 3,400 \\
\hline Sail ............ & 651,000 & 635,000 & 17,000 \\
\hline $\begin{array}{l}\text { Vessels.... } \\
\text { Outfit.... }\end{array}$ & $\begin{array}{l}487.000 \\
165.000\end{array}$ & $\begin{array}{l}472,000 \\
163,000\end{array}$ & $\begin{array}{r}15,000 \\
1,700\end{array}$ \\
\hline Transporting......... & 166,000 & 154,000 & 12,000 \\
\hline Steam and motor... & 78,000 & 69,000 & 8,600 \\
\hline Vessels........................... & 60,000 & 54,000 & 6,600 \\
\hline Outfit.............................. & 18,000 & 16,000 & 2,000 \\
\hline Sail _..... & $\begin{array}{l}88,000 \\
47,000\end{array}$ & 84,000 & 3,800 \\
\hline (n. & $\begin{array}{l}47,000 \\
41,000\end{array}$ & $\begin{array}{l}44,000 \\
41,000\end{array}$ & $\begin{array}{r}3,300 \\
500\end{array}$ \\
\hline 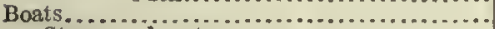 & 575,000 & 345,000 & 230,000 \\
\hline Steam and motor.............. & 289,000 & 112,000 & 167,000 \\
\hline Sail ....................... & 192,000 & 166,000 & 26,000 \\
\hline Row ......... & 79,000 & 44,000 & 35,000 \\
\hline Diving....... & 22,000 & 22,000 & \\
\hline 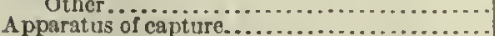 & $\begin{array}{r}1.300 \\
326.000\end{array}$ & 195000 & $\begin{array}{r}1,300 \\
131,000\end{array}$ \\
\hline Vessel fisheries................... & $\begin{array}{r}326,000 \\
64,000\end{array}$ & 59,000 & 5,300 \\
\hline 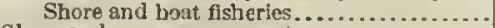 & 262,000 & 136,000 & 126,000 \\
\hline Shore and accessory property................ & 460,000 & 347,000 & 122,000 \\
\hline 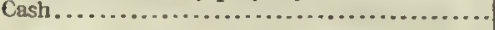 & 200,000 & 200,000 & 200 \\
\hline
\end{tabular}

The following table gives the statistics in respect to the number and tonnage of the vessels and the number of the boats used in the fisheries:

\begin{tabular}{|c|c|c|c|}
\hline \multirow[b]{2}{*}{ CLASS OF CRAFT. } & \multicolumn{3}{|c|}{ VESSELS AND BOATS: 1908.} \\
\hline & Total. & $\begin{array}{l}\text { Qull of } \\
\text { Mexleo } \\
\text { district. }\end{array}$ & $\begin{array}{l}\text { Atlantio } \\
\text { coast } \\
\text { district. }\end{array}$ \\
\hline 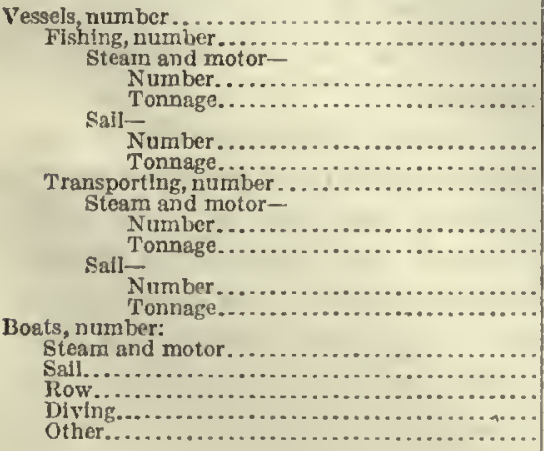 & $\begin{array}{r}327 \\
250 \\
12 \\
125 \\
238 \\
4,341 \\
77 \\
27 \\
316\end{array}$ & $\begin{array}{r}258 \\
221 \\
6 \\
67 \\
215 \\
4,049 \\
67 \\
22 \\
273\end{array}$ & $\begin{array}{r}39 \\
29 \\
6 \\
55 \\
23 \\
292 \\
10\end{array}$ \\
\hline
\end{tabular}

The total investment was $\$ 2,416,000$, of which $\$ 1,884,000$, or 78 per cent, was reported from the Gulf coast, and $\$ 531,000$, or 22 per cent, from the Atlantic coast. Not including the value of shore and accessory property and cash capital, the amount invested in the fishing industry of the state was $\$ 1,747,000$, compared with an investment of $\$ 1,298,000$ reported by the Bureau of Fisheries in 1902. The investment in fishing and transporting vessels was $\$ \$ 46,000$ and in boats $\$ 575,000$, making a total investment in floating craft of $\$ 1,421,000$. Of this amount, $\$ 1,143,000$, or 80 per cent, pertained to the Gulf fisheries.

The investment in apparatus of capture in the shore and boat fisheries of Florida largely exceeded that for the vessel fisheries. The total investment in floating craft was, however, greater for the vessel fisheries. The number of the various kinds of apparatus of capture employed is shown for each district and for each class of fisheries in the following tabular statement:

\begin{tabular}{|c|c|c|c|c|c|}
\hline \multirow{3}{*}{ KIND. } & \multicolumn{5}{|c|}{ APPARATUS OF CAPTUER: 1908.} \\
\hline & \multirow{2}{*}{ Total. } & \multicolumn{2}{|c|}{$\begin{array}{l}\text { Distributed by } \\
\text { distrlcts. }\end{array}$} & \multicolumn{2}{|c|}{$\begin{array}{l}\text { Distributed by } \\
\text { class of fisheries. }\end{array}$} \\
\hline & & $\begin{array}{l}\text { Gull of } \\
\text { Mexico } \\
\text { distrlct. }\end{array}$ & $\begin{array}{l}\text { Atlantic } \\
\text { coast } \\
\text { district. }\end{array}$ & $\begin{array}{l}\text { Vessel } \\
\text { fisheries. }\end{array}$ & $\begin{array}{c}\text { Shore } \\
\text { and boat } \\
\text { fisherles. }\end{array}$ \\
\hline 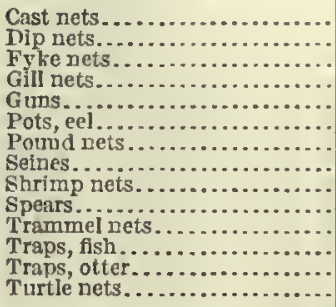 & $\begin{array}{r}402 \\
70 \\
10 \\
3,640 \\
364 \\
3 \\
26 \\
702 \\
3 \\
432 \\
140 \\
700 \\
5,962 \\
38\end{array}$ & $\begin{array}{r}55 \\
20 \\
10 \\
2,143 \\
135 \\
3 \\
26 \\
230 \\
3 \\
165 \\
140 \\
200 \\
3,712 \\
38\end{array}$ & 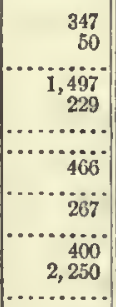 & 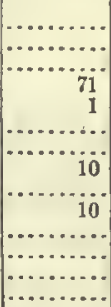 & $\begin{array}{r}402 \\
70 \\
10 \\
3,569 \\
363 \\
3 \\
26 \\
692 \\
3 \\
422 \\
140 \\
700 \\
5,962 \\
38\end{array}$ \\
\hline
\end{tabular}

Products, by species.-The fishery products of the state, distributed by species and by apparatus of capture, are given in Table 1, on page 106.

In 1908 the mullet fishery led in value of catch and was followed by the sponge fishery and the red snapper fishery. These three fisheries contributed nearly onelialf of the total value of products.

The total product of the state in 1908 was $74,087,000$ pounds, valued at $\$ 3,389,000$. Marked gains are shown over the total quantities as reported for earlier years.

Products, by fishing grounds.-The fishery product of the Gulf coast of Florida, distributed by species and by apparatus of eapture, is presented in Table 2, page 107.

The sponge fishery was the most important on the Gulf coast, having a total product of 622,000 pounds, valued at $\$ 545,000$. This constituted the entire sponge product of the United States, and represented 26 per cent of the total value of products of the Gulf coast fisheries of Florida. Following the sponge fislcry closely in the value of their product were the mullet and red snapper fisheries. The product of the 
red-snapper fisheries of the Gulf district was $7,659,000$ pounds, valued at $\$ 432,000$, which represented over 99 per cent of the total value reported for the red-snapper catch of the state, and 57 per cent in quantity and 68 per cent in value, of the total catch of the species reported for the United States.

Table 3, on page 108, gives the produets of the Atlantic coast fisheries of Florida, distributed by species and by apparatus of capture.

Measured by value of products, the shad fishery was the most important in the Atlantic coast district. All but 3,600 pounds of the shad catch of the state was taken in the Atlantic coast waters. The oyster product consisted entirely of market oysters. Prawn was an important item, the yield amounting to $4,152,000$ pounds, valued at $\$ \$ 4,000$, the entire product of the state being reported from this district. Shrimps, on the other hand, were reported from both the Atlantic coast and the Gulf of Mexico.

The value of products reported for 1908 , by principal species arranged in order of importance, is shown in the following table for the state as a whole and for the Gulf of Mexico and Atlantic coast fisheries.

\begin{tabular}{|c|c|c|c|}
\hline \multirow[b]{2}{*}{ SPECIES. } & \multicolumn{3}{|c|}{ VALUE OF PRODUCTS: 1908.} \\
\hline & Total. & $\begin{array}{l}\text { Gulf of } \\
\text { Mexico } \\
\text { district. }\end{array}$ & $\begin{array}{l}\text { A tlantic } \\
\text { coast } \\
\text { district. }\end{array}$ \\
\hline Total.................. & $\$ 3.389,000$ & $\$ 2,120,000$ & $\$ 1,269,000$ \\
\hline 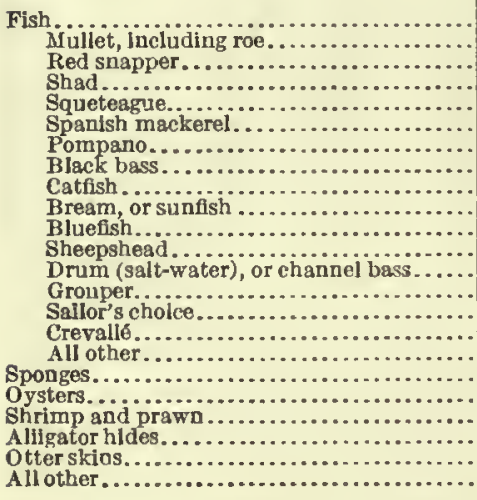 & $\begin{array}{r}2,337,000 \\
652,000 \\
434,000 \\
320,000 \\
196,000 \\
122,000 \\
65,000 \\
58,000 \\
54,000 \\
50,000 \\
45,000 \\
38,000 \\
38,000 \\
34,000 \\
32,000 \\
24,000 \\
174,000 \\
545,000 \\
296,000 \\
92,000 \\
48,000 \\
21,000 \\
50,000\end{array}$ & $\begin{array}{r}1,324,000 \\
475,000 \\
432,000 \\
200 \\
63,000 \\
71,000 \\
30,000 \\
2,500 \\
18,000 \\
5,800 \\
28,000 \\
17,000 \\
22,000 \\
33,000 \\
8,000 \\
5,300 \\
113,000 \\
545,000 \\
187,000 \\
400 \\
27,000 \\
10,000 \\
26,000\end{array}$ & $\begin{array}{r}1,013,000 \\
177,000 \\
2,400 \\
320,000 \\
133,000 \\
51,000 \\
35,000 \\
55,000 \\
36,000 \\
44,000 \\
17,000 \\
21,000 \\
16,000 \\
1,400 \\
24,000 \\
19,000 \\
61,000 \\
1709,000 \\
109,000 \\
91,000 \\
21,000 \\
11,000 \\
23,000\end{array}$ \\
\hline
\end{tabular}

In the fisheries of the Atlantic coast the value of shad, mullet, and squeteague constituted about onehalf of the total value of products; and in the fisheries of the Gulf the value of sponges, mullet, and red snapper constituted more than two-thirds of the total value of products.

Products, by class of fisheries.-The products of the shore and boat fisheries for 1908 are shown in detail, by species and by apparatus of capture, in Table 4, on page 109.

The total eatch of the shore and boat fisheries was $63,992,000$ pounds, or 86 per cent of the total for the state, and its valuo was $\$ 2,459,000$, or 73 per cent of the total for the state. Among the shore and boat fisheries the mullet fishery was the most important, contributing 26 per cent of the total value of products; shad ranked second, with 13 per cent of the total value; and oysters third, with 12 per cent.

The distribution between the vesscl fisheries and the shore and boat fisheries of the value reported for the leading species in 1908 is given below:

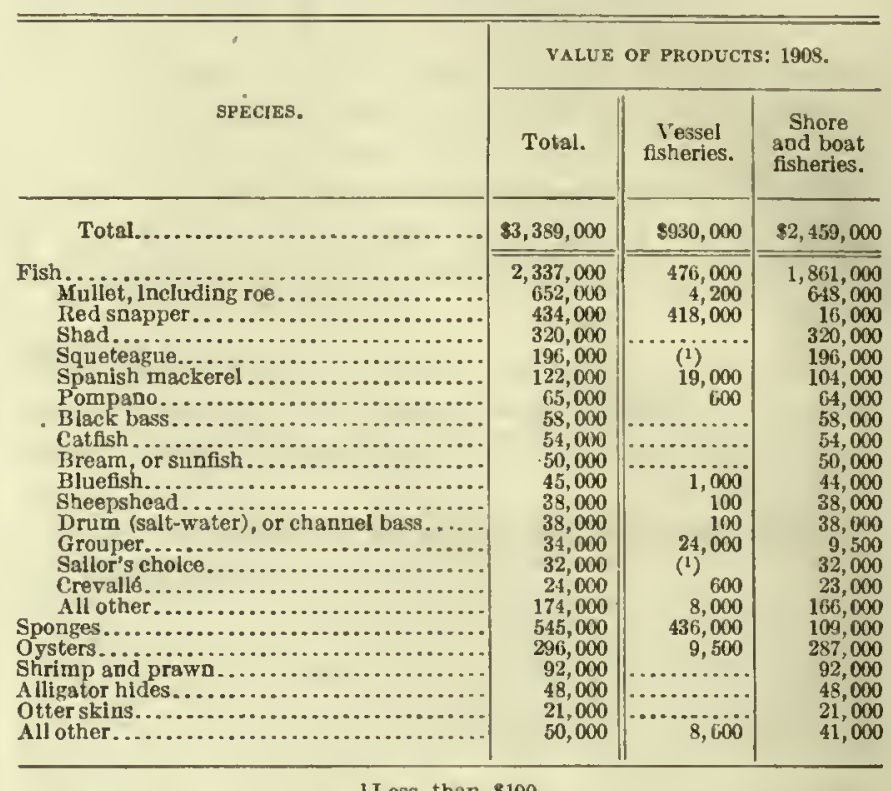

i Less than $\$ 100$.

The shore and boat fisheries of the Gulf waters had a total catch of $28,216,000$ pounds, valued at $\$ 1,215,000$, which represented 44 per cent in quantity and 49 per cent in value of the shore and boat catch of the state. Of the total products of the Gulf coast fisheries of the state, 75 per cent in quantity and 57 per cent in value were reported by the shore and boat fisheries. In the shore and boat fisheries of the Gulf the catch of mullet exceeded in value that of any other species, representing about one-third of the total value of all products of the fisheries in question. Oysters were next in value and sponges third.

The total eatch of the shore and boat fisheries in the waters tributary to the Atlantic Ocean was $35,776,000$ pounds, with a value of $\$ 1,244,000$, representing 56 per cent in quantity and 51 per cent in value of the shore and boat catch of the state. Of the total products of the Atlantic coast fisheries of the state, the shore and boat fisheries were credited with 98 per cent both in quantity and in value.

The products of the vessel fisheries for 1908 are presented in detail, by species and by apparatus of capture, in table 5, on page 110 .

The total catch of the vessel fisheries of Florida was $10,094,000$ pounds, valued at $\$ 930,000$, representing 14 per cent in quantity and 27 per cent in value of all fishery products of the state. In this class of fisheries the sponge product was the largest item in value, and snappers ranked second. The total of these two products was $\$ \$ 54,000$, or 92 per cent of the total value of the products of all vessel fisheries of the state. 
The sponge and red snapper products of the vessel fisheries of the Gulf coast together had a value of $\$ \$ 51,000$, or 94 per cent of the total for the fisheries in question. The total catch of the vessel fisheries in the Atlantic waters was 745,000 pounds, valued at $\$ 25,000$, which represents 7 per cent in quantity and 3 per cent in value of the total products of the vessel fisheries of the state. Of the total products of the Atlantic fisheries of the state, the products of the vessel fisheries formed 2 per cent both in quantity and in value.

Products, by apparatus of capture.-The distribution of the total value of products for 1908 by apparatus of capture is given in the following tabular statement for the state as a whole and for the vessel fisheries and the shore and boat fisheries, respectively:

\begin{tabular}{|c|c|c|c|}
\hline \multirow[b]{2}{*}{ KIND OF APPARATUS. } & \multicolumn{3}{|c|}{ VALUE OF PRODUCTS: 1908.} \\
\hline & Total. & $\begin{array}{l}\text { Vessel } \\
\text { fisheries. }\end{array}$ & $\begin{array}{l}\text { Shore and } \\
\text { boat } \\
\text { fisheries. }\end{array}$ \\
\hline Total. & $\$ 3,389,000$ & 5930,000 & $\$ 2,459,000$ \\
\hline 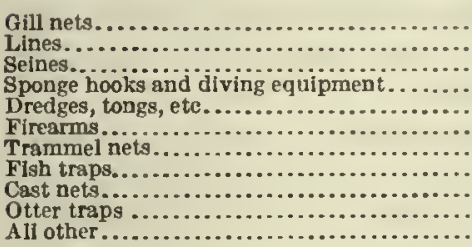 & $\begin{array}{r}1,133,000 \\
617,000 \\
606,000 \\
545,000 \\
304,000 \\
43,000 \\
27,000 \\
25,000 \\
23,000 \\
21,000 \\
38,000\end{array}$ & 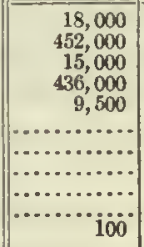 & $\begin{array}{r}1,115,000 \\
165,000 \\
591,000 \\
109,000 \\
295,000 \\
48,000 \\
27,000 \\
25,000 \\
23,000 \\
21,000 \\
38,000\end{array}$ \\
\hline
\end{tabular}

The value of the products caught by gill nets forms a larger percentage of the total value than that for any other apparatus of capture. This class of apparatus was used to a greater or less extent in the capture of nearly all of the numerous species of fish proper reported, although 70 per cent of the total value of the gill-net catch represents the combined value of mullet and shad. The use of gill nets was practically confined to the shore and boat fisheries. The next lighest value of products was reported for the catch by lines. The red snapper, which constituted 70 per cent of the total line catch in value, was taken exclusively with lines.

The following tabular statement shows the total value of fishery products, distributed by apparatus of capture, for the state and for the Gulf and the Atlantic coast waters, respectively:

\begin{tabular}{|c|c|c|c|}
\hline \multirow[b]{2}{*}{ KIND OF APPARATUS. } & \multicolumn{3}{|c|}{ VALUE OF PRODUCTS: 1908.} \\
\hline & Total. & $\begin{array}{l}\text { Guli of } \\
\text { Mexico } \\
\text { district. }\end{array}$ & $\begin{array}{l}\text { Atlantle } \\
\text { coast } \\
\text { dlstrict. }\end{array}$ \\
\hline Total...... & $\$ 3,389,000$ & $\$ 2,120,000$ & $\$ 1,269,000$ \\
\hline 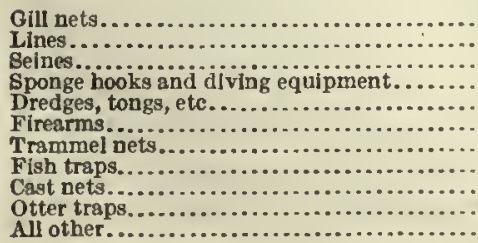 & $\begin{array}{r}, 133,000 \\
617,000 \\
606,000 \\
545,000 \\
304,000 \\
48,000 \\
27,000 \\
25,000 \\
23,000 \\
21,000 \\
38,000 \\
\end{array}$ & $\begin{array}{r}559,000 \\
534,000 \\
193,000 \\
545,000 \\
187,000 \\
27,000 \\
27,000 \\
6,500 \\
1,500 \\
10,000 \\
29,000\end{array}$ & $\begin{array}{r}574,000 \\
83,000 \\
414,000 \\
117,000 \\
21,000 \\
19,000 \\
22,000 \\
11,000 \\
9,000\end{array}$ \\
\hline
\end{tabular}

Mullet.-While the total product of the state's mullet fishery in 1908 , including roe $(24,716,000$ pounds), was considerably less than the eatch of 1902 $(32,289,000$ pounds), it was larger than for any other year for which statistics are available. The increase in the price per pound was sufficient, however, to raise the total value of the product from $\$ 473,000$ in 1902 to $\$ 652,000$ in 1908 , an increase in value of 38 per cent, compared with a decrease in weight of 24 per cent. Mullet contributed only 19 per cent of the value of the state's fishery products in 1908, but constituted onethird of the aggregate weight of all such products. Practically all of the mullet was taken in the shore and boat fisheries, less than 1 per cent being the product of vessel fisheries. Seventy-two per cent of the total value of this product was reported for the Gulf fisheries.

The principal apparatus of capture employed in the mullet fishery was gill nets, by means of which mullet valued at $\$ 542,000$ was caught, representing 83 per cent of the total value of the state's mullet catch. Seines ranked next, the value of the amount taken in this way forming 14 per cent of the total value reported for this species. The remaining 2 per cent represents the catch by means of trammel nets, cast nets, and dip nets.

Of the mullet product, 1,046,000 pounds, valued at $\$ 39,000$, was reported as having been salted, and 135,000 pounds consisted of mullet roe, valued at $\$ 15,000$.

Sponges.-As already indicated, the sponge fishery belongs exclusively to the Gulf coast district. It is subject to marked fluctuations from year to year, and for a few years following 1900 it appeared to be on a decline. The statistics for 1908, however, show a large increase both in quantity and in value of product; the quantity exceeded that reported for any prior year, and the value was exceeded only by that reported for the year 1900. The average prices per pound for the different grades and for the product as a whole are, however, lower than they have been for a number of years for which statistics are available. As the sponge fisheries of Florida represent the entire industry in the United States, the statisties in regard to the persons employed, the equipment in vessels, boats, and apparatus, and the capital are herewith presented.

In 1908 there were employed in the sponge fisheries 143 sailing vessels, which aggregated 2,200 tons and were valued at $\$ 186,000$. These vessels carried 88 diving boats and 367 other boats. The investment in outfit was $\$ 103,000$. The total investment in vessels, boats, and their outfit was $\$ 337,000$ for the vessel fisheries. In the shore and boat sponge fisheries, 567 additional boats of all kinds, valued at $\$ 102,000$, were used. Their value, added to the foregoing, makes a total investment of $\$ 439,000$ in vessels, boats, and outfits in connection with the sponge industry. The 567 boats employed in the shore and boat sponge fisheries consisted of 2 motor boats, 175 sailboats, 356 
rowboats, and 34 diving boats. In the sponge fisheries as a whole, 122 diving boats, having a value of $\$ 40,000$, were used.

Pcrsons employed in the sponge fisheries in 1908, exclusive of 172 proprietors not fishing, formed a total of 2,097 , distributed as follows: 125 proprietors and independent fishermen; 1 salaried employee; and 1,971 wage-earners, who received $\$ 437,000$ in wages (including provisions furnished to the value of \$132,000). The persons reported for the vessel fisheries, exclusive of 90 proprietors not fishing, numbered 1,466 , and comprised 32 proprietors and independent fishermen, 1 salaried employee, and 1,433 wage-earners, receiving wages to the amount of $\$ 343,000$ (including provisions furnished to the value of $\$ 95,000$ ). In the shore and boat fisheries 631 persons were employed, of whom 93 were proprietors (exclusive of 82 not fishing), and 538 wage-earners, who received wages to the amount of $\$ 93,000$ (inclusive of provisions to the value of $\$ 37,000$ ).

The total investment in apparatus of capture was $\$ 78,000$, which comprised hooks and diving apparatus to the value of $\$ 76,000$, and nets, and other fishing apparatus to the value of $\$ 1,300$, reported by certain of the vessel sponge fishers who had a fish catch. Of the total investment in the sponge industry in apparatus of capture, $\$ 55,000$ was credited to the vessel fisheries and $\$ 22,000$ to the shore and boat fisheries. The investment in shore and accessory property for the sponge fisheries was $\$ 4,900$, practically all of which was reported by the shore and boat fisheries.

In the following tabular statement the sponge catch for 1908 is shown in detail, classified according to kind or grade of product, and according to apparatus of capture, whether taken by hooks or with diving apparatus:

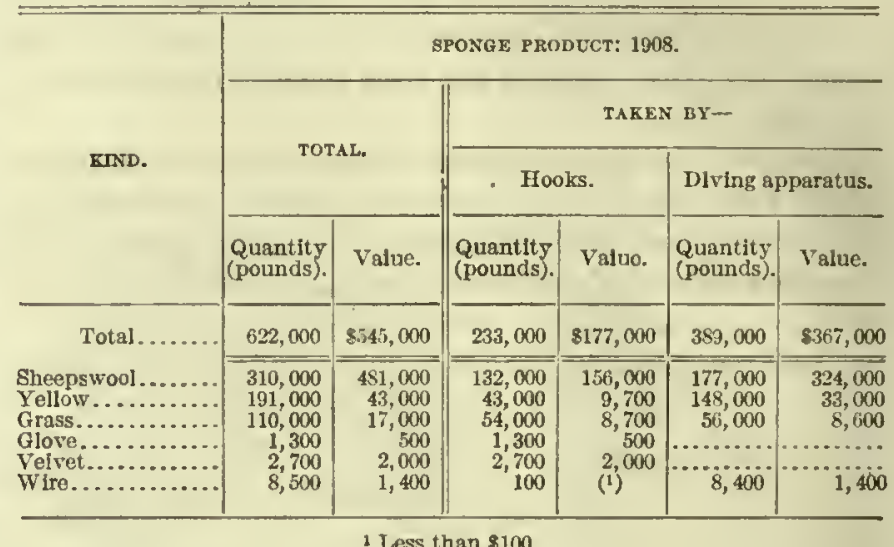

The catch with diving apparatus represented approximately two-thirds of the total value, and the catch with hooks one-third.

In the following tabular statement the quantity and value of the sponge product for 1908 are compared with the figures for a series of years as reported by the Bureau of Fisheries:

\begin{tabular}{|c|c|c|c|c|c|c|c|c|c|c|}
\hline \multirow{3}{*}{ TEAR. } & \multicolumn{10}{|c|}{ SPONGE PRODUCT. } \\
\hline & \multicolumn{2}{|c|}{ Total. } & \multicolumn{2}{|c|}{ Sheepswool. } & \multicolumn{2}{|c|}{ Yellow. } & \multicolumn{2}{|c|}{ Grass. } & \multicolumn{2}{|c|}{ All other. } \\
\hline & $\begin{array}{l}\text { Quantlty } \\
\text { (pounds). }\end{array}$ & Value. & $\begin{array}{l}\text { Quantity } \\
\text { (pounds). }\end{array}$ & Value. & $\begin{array}{l}\text { Quantity } \\
\text { (pounds). }\end{array}$ & Value. & $\begin{array}{l}\text { Quantity } \\
\text { (pounds). }\end{array}$ & Value. & $\begin{array}{l}\text { Quantity } \\
\text { (pounds). }\end{array}$ & Value. \\
\hline 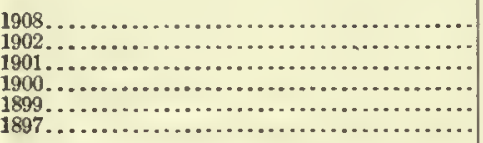 & $\begin{array}{l}622,000 \\
347,000 \\
396,000 \\
418,000 \\
334,000 \\
332,000\end{array}$ & $\begin{array}{r}\$ 545,000 \\
364,000 \\
493,000 \\
568,000 \\
368,000 \\
286,000\end{array}$ & $\begin{array}{l}310,000 \\
134,000 \\
203,000 \\
181,000 \\
154,000 \\
157,000\end{array}$ & $\begin{array}{r}8481,000 \\
298,000 \\
423,000 \\
483,000 \\
332,000 \\
241,000\end{array}$ & $\begin{array}{r}191,000 \\
57,000 \\
63,000 \\
74,000 \\
56,000 \\
32,000\end{array}$ & $\begin{array}{r}843,000 \\
31,000 \\
39,000 \\
44,000 \\
16,000 \\
13,000\end{array}$ & $\begin{array}{r}110,000 \\
141,000 \\
109,000 \\
143,000 \\
77,000 \\
129,000\end{array}$ & $\begin{array}{r}\$ 17,000 \\
30,000 \\
24,000 \\
33,000 \\
14,000 \\
\quad 29,000\end{array}$ & $\begin{array}{l}12,000 \\
16,000 \\
22,000 \\
19,000 \\
18,000 \\
13,000\end{array}$ & $\begin{array}{r}\$ 4,000 \\
5,800 \\
6,700 \\
7,100 \\
5,000 \\
3,200\end{array}$ \\
\hline 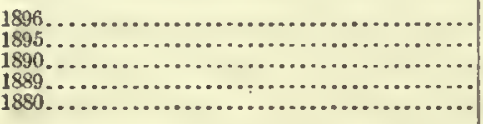 & $\begin{array}{l}236,000 \\
306,000 \\
367,000 \\
317,000 \\
207,000\end{array}$ & $\begin{array}{l}273,000 \\
387,000 \\
439,000 \\
381,000 \\
201,000\end{array}$ & $\begin{array}{l}150,000 \\
231,000 \\
(1) \\
(1) \\
(1)\end{array}$ & $\begin{array}{l}248,000 \\
363,000 \\
(1) \\
(1)\end{array}$ & $\begin{array}{l}24,000 \\
30,000 \\
\text { (1) } \\
\text { (1) }\end{array}$ & $\begin{array}{l}9,300 \\
12,000 \\
(1) \\
1 \\
(1)\end{array}$ & $\begin{array}{l}45,000 \\
21,000 \\
(1) \\
(1) \\
(1)\end{array}$ & $\begin{array}{l}12,000 \\
5,500 \\
(1) \\
(1) \\
(1)\end{array}$ & $\begin{array}{l}18,000 \\
24,000 \\
\text { (1) } \\
\text { (1) } \\
(1)\end{array}$ & 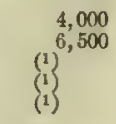 \\
\hline
\end{tabular}

1 Not reported separately.

Red snapper.-The red-snapper fishery has increased steadily in importance, as shown by the following tabular statement of the product for a number of years:
The increase in both quantity and value of product since 1880 is remarkable, while the average value per pound for 1908 represents a great advance over that for the earlier years shown. This fishery was confined almost entirely to the Gulf waters, and the catch was made exclusively with lines.

Shad.-The shad fishery was by far the most inportant of the Atlantic coast district, contributing 25 per cent of the value of all products of these waters in 1908 . Shad ranked third in value among the fish of the state, representing 9 per cent of the value of all products. Compared with the catch for 1902 , which was 1,819 ,000 pounds, valued at $\$ 125,000$, the product of 1908 shows an increase of 56 per cent in quantity and of 
156 per cent in value. The value of the products of this fishery has increased remarkably, having been only $\$ 20,000$ in 1880 and only $\$ 42,000$ in 1890 . In value of the shad catch in 1908 Florida was surpassed only by Virginia and North Carolina, although in respect to quantity Maryland and New Jersey ranked alead of it. The entire catch was made in the shore and boat fisheries with gill nets and seines.

Oysters.-In respect to the value of products the oyster fishery of Florida holds fifth place among the fisheries of the state. The total product in 1908 was $1,067,000$ bushels, valued at $\$ 296,000$, or 9 per cent of the total value of the fishery products of the state. About one-third of the value of the products was reported from the Atlantic coast waters and the remainder from the Gulf waters. The oyster fishery was conducted principally by the shore and boat fisheries, which reported 97 per cent of the total value of the oyster product. "Compared with 1902 the product of Florida shows a decrease of 737,000 bushels, or 41 per cent, in quantity, and of $\$ 69,000$, or 19 per cent, in value. It is noteworthy that this decrease has taken place entirely in the Atlantic coast district, where the value of the oyster catch decreased from $\$ 220,000$ in 1902 to $\$ 109,000$ in 1908 , while on the Gulf const there was an increase from $\$ 124,000$ in 1902 to $\$ 1 \$ 7,000$ in 1908 .

Squeteague.-The squeteague, or sea trout, ranks next to the oyster in respect to value of product. In $1908,4,864,000$ pounds of this fish, having a value of $\$ 196,000$, were caught, as compared with only $2,757,000$ pounds, having a value of $\$ 73,000$, in 1902 . About two-thirds of the catch was taken in the Atlantic const fisheries, and practically all in the shore and boat fish- eries. The catch was made principally with gill nets and seines. The product includes 54,000 pounds reported as sold salted.

Alligators.-Among the important fishery industries of Florida, though the value of the product is comparatively small, is the alligator industry. About three-fourths of all the alligators killed in the United States in 1908 were killed in Florida, the product aggregating 51,000 hides, valued $\$ 48,000$. This represents a large increase over 1902 , when only 31,000 hides, valued at $\$ 18,000$, were secured. No data are given for this industry in the 1880 report of the Bureau of Fisheries. In the 1890 report it was estimated that not less than 2,500,000 alligators were killed between 1880 and 1890 , and it was stated that the numbers had been greatly reduced because of the nonmigratory habits and the remarkably slow growth of the animal, and because of the killing of many alligators before they had reached the reproductive age. The product of the Gulf coast alone in 1890 was 49,000 alligator hides, valued at $\$ 35,000$, and 84,000 alligator feet, valued at $\$ 4,200$. No data were compiled by the Bureau of Fisheries for the Atlantic coast. In 1908 hides valued at $\$ 27,000$, or 56 per cent of the total value of alligator products, were secured from the Gulf coast rivers, and hides valued at $\$ 21,000$ from the Atlantic coast rivers.

Otters.-The otter-skin product of the state is a substantial one and in 1908 formed more than twothirds of the otter-skin eatch of the entire country. The total for the state was 2,900 skins, having a value of $\$ 21,000$, compared with 3,300 skins, having a value of $\$ 18,000$, in 1902 . Thus, while the quantity docreased, the value increased. 
TABLE 1.-FLORIDA-FISHERY PRODUCTS: 1908.

\begin{tabular}{|c|c|c|c|c|c|c|c|c|c|c|c|c|c|c|}
\hline \multirow{3}{*}{ SPECIES. } & \multirow{2}{*}{\multicolumn{2}{|c|}{ TOTAL. }} & \multicolumn{12}{|c|}{ PBODUCT CAUGHT HY- } \\
\hline & & & \multicolumn{2}{|c|}{ Gill nets. } & \multicolumn{2}{|c|}{ Lines. } & \multicolumn{2}{|c|}{ Selnes. } & \multicolumn{2}{|c|}{ Trammel nets. } & \multicolumn{2}{|c|}{ Cast nets. } & \multicolumn{2}{|c|}{$\begin{array}{l}\text { All other appa- } \\
\text { ratus.1 }\end{array}$} \\
\hline & $\begin{array}{l}\text { Quantlty } \\
\text { (pounds). }\end{array}$ & Value. & $\begin{array}{l}\text { Quantity } \\
\text { (pounds). }\end{array}$ & Value. & $\begin{array}{c}\text { Quantity } \\
\text { (pounds). }\end{array}$ & Value. & $\begin{array}{c}\text { Quantity } \\
\text { (pounds). }\end{array}$ & Value. & $\begin{array}{l}\text { Quantity } \\
\text { (pounds). }\end{array}$ & Value. & $\begin{array}{l}\text { Quantity } \\
\text { (pounds). }\end{array}$ & Value. & $\begin{array}{l}\text { Quantity } \\
\text { (pounds). }\end{array}$ & Value. \\
\hline Total. & $74,087,000$ & $\$ 3,389,000$ & $29,803,000$ & $\$ 1,133,000$ & $12,747,000$ & $\$ 617,000$ & $20,400,000$ & 8606,000 & 792,000 & $\$ 27,000$ & 653,000 & $\$ 23,000$ & $9,691,000$ & 8982,000 \\
\hline $\begin{array}{l}\text { Fish: } \\
\text { Alewives............ } \\
\text { Amber-fish......... } \\
\text { Angel-fish......... } \\
\text { Barracuda......... } \\
\text { Black bass......... }\end{array}$ & $\begin{array}{r}1,224,000 \\
38,000 \\
70,000 \\
45,000 \\
1,070,000\end{array}$ & $\begin{array}{r}5,500 \\
1,600 \\
3,100 \\
3,100 \\
58,000\end{array}$ & $\begin{array}{r}33,000 \\
700 \\
2,500\end{array}$ & $\begin{array}{l}1,600 \\
(2)_{200}\end{array}$ & $\begin{array}{r}38,000 \\
1,100 \\
30,000 \\
467,000\end{array}$ & $\begin{array}{r}1,600 \\
100 \\
2,300 \\
27,000\end{array}$ & $\begin{array}{r}1,224,000 \\
22,000 \\
600 \\
376,000\end{array}$ & $\begin{array}{c}5,500 \\
700 \\
(2) \\
19,000\end{array}$ & 4,5000 & (a) 100 & 1,300 & $\ddot{100}$ & $\begin{array}{r}9,800 \\
14,000 \\
218,000\end{array}$ & $\begin{array}{r}600 \\
1,000 \\
12,000\end{array}$ \\
\hline $\begin{array}{l}\text { Bluefish ...... } \\
\text { Bonito...... }\end{array}$ & $\begin{array}{r}952,000 \\
11,000\end{array}$ & 45,000 & 340,000 & 18,000 & $\begin{array}{l}84,000 \\
11,000\end{array}$ & $\begin{array}{r}4,800 \\
900\end{array}$ & $\begin{array}{l}485,000 \\
200\end{array}$ & 20,000 & 42,000 & 1,900 & & & & \\
\hline $\begin{array}{l}\text { Bonito, or unfish.: } \\
\text { Bream, orsterfish........ }\end{array}$ & $\begin{array}{r}11,000 \\
1,547,000 \\
16,000\end{array}$ & $\begin{array}{r}50,000 \\
400\end{array}$ & 13,000 & $\begin{array}{l}600 \\
100\end{array}$ & 16,000 & 900 & $\begin{array}{r}1,215,000 \\
11,000\end{array}$ & 38,000 & & & 20300 & $100^{\circ}$ & 299,000 & 10,000 \\
\hline & $\begin{array}{r}16,000 \\
1,481,000\end{array}$ & 54,000 & $\begin{array}{r}5,700 \\
500\end{array}$ & $(2)^{100}$ & 259,000 & $8,700^{\circ}$ & $\begin{array}{r}11,000 \\
977,000\end{array}$ & 27,000 & 200 & (2) & & & 244,000 & 17,000 \\
\hline 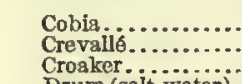 & $\begin{array}{r}123,000 \\
1,435,000 \\
94,000\end{array}$ & $\begin{array}{r}2,800 \\
24,000 \\
2,100\end{array}$ & $\begin{array}{l}52,000 \\
81,000 \\
15,000\end{array}$ & $\begin{array}{r}1,500 \\
2,600 \\
400\end{array}$ & $\begin{array}{r}100 \\
1,250,000 \\
2,500\end{array}$ & $\begin{array}{r}(2) \\
19,000 \\
100\end{array}$ & $\begin{array}{l}71,000 \\
81,000 \\
73,000\end{array}$ & $\begin{array}{l}1,300 \\
2,300 \\
1,500\end{array}$ & $\dddot{23}, 000$ & & $\dddot{3}, 000$ & 100 & & \\
\hline $\begin{array}{l}\text { Drum (sait-water), } \\
\text { or channel hass. } \\
\text { Flounders......... }\end{array}$ & $\begin{array}{r}1,426,000 \\
185,000\end{array}$ & $\begin{array}{r}38,000 \\
8,100\end{array}$ & $\begin{array}{r}514,000 \\
49,000\end{array}$ & $\begin{array}{r}15,000 \\
1,900\end{array}$ & $\begin{array}{r}121,000 \\
100\end{array}$ & $\begin{array}{l}2,900 \\
(3)\end{array}$ & $\begin{array}{r}641,000 \\
55,000\end{array}$ & $\begin{array}{r}14,000 \\
2,200\end{array}$ & $\begin{array}{r}109,000 \\
7,500\end{array}$ & $\begin{array}{r}4,100 \\
400\end{array}$ & $\begin{array}{r}41,000 \\
1,000\end{array}$ & $\begin{array}{r}1,600 \\
100\end{array}$ & 72,000 & 3,000 \\
\hline $\begin{array}{l}\text { Grouper........ } \\
\text { Grunts...... }\end{array}$ & $\begin{array}{r}1,276,000 \\
388,000 \\
198,000\end{array}$ & $\begin{array}{r}34,000 \\
19,000 \\
8000\end{array}$ & $\begin{array}{r}74,000 \\
86,000 \\
72,000\end{array}$ & $\begin{array}{l}3,500 \\
4,400 \\
6,900\end{array}$ & $\begin{array}{r}1,185,000 \\
281,000\end{array}$ & $\begin{array}{l}30,000 \\
14,000\end{array}$ & $\begin{array}{r}9,300 \\
11,000\end{array}$ & $\begin{array}{r}400 \\
500\end{array}$ & & & & & $\begin{array}{r}8,000 \\
10,000\end{array}$ & $\begin{array}{l}400 \\
500\end{array}$ \\
\hline $\begin{array}{l}\text { Hickory s. } \\
\text { Hogfish.. } \\
\text { Jewfish.. }\end{array}$ & $\begin{array}{r}198,000 \\
81,000 \\
14,000\end{array}$ & $\begin{array}{l}8,000 \\
4,800\end{array}$ & $\begin{array}{r}172,000 \\
15,000\end{array}$ & $\begin{array}{l}6,900 \\
900\end{array}$ & 57,000 & 3,500 & $\begin{array}{r}27,000 \\
4,200\end{array}$ & $1, \frac{100}{200}$ & & & & ….... & 4,300 & 300 \\
\hline $\begin{array}{l}\text { Jurel......... } \\
\text { Ladyfish... }\end{array}$ & $\begin{array}{r}52,000 \\
345,000\end{array}$ & $\begin{array}{r}900 \\
9,000\end{array}$ & 1400 & & 8,800 & 400 & $\begin{array}{r}32,000 \\
320,000\end{array}$ & $\begin{array}{r}400 \\
8.400\end{array}$ & $\begin{array}{l}12,000 \\
24,000\end{array}$ & $\begin{array}{l}100 \\
500\end{array}$ & & & 100 & (2) \\
\hline $\begin{array}{l}\text { Lady } \\
\text { Marge } \\
\text { Moon }\end{array}$ & $\begin{array}{r}340,090 \\
3,500 \\
18,000\end{array}$ & $\begin{array}{l}9,000 \\
300\end{array}$ & $\begin{array}{l}1,400 \\
1,900\end{array}$ & 200 & 1,300 & 100 & & 8,400 & & & & & 300 & (2) \\
\hline $\begin{array}{l}\text { Moonfish............ } \\
\text { Mullet.............. }\end{array}$ & $\begin{array}{r}18,000 \\
24,582,000\end{array}$ & 637,000 & $\begin{array}{r}6,000 \\
20,892,000\end{array}$ & $\begin{array}{r}300 \\
534,000\end{array}$ & & & $\begin{array}{r}11,000 \\
3,117,000\end{array}$ & $\begin{array}{r}67,000 \\
8700\end{array}$ & $\begin{array}{r}1,500 \\
361,000\end{array}$ & 10,000 & 197,000 & 3,100 & 15,000 & 300 \\
\hline $\begin{array}{l}\text { Mullet roe......... } \\
\text { Mutton-fish....... }\end{array}$ & $\begin{array}{l}135,000 \\
417,000\end{array}$ & $\begin{array}{r}15,000 \\
9,600\end{array}$ & $\begin{array}{l}86,000 \\
52,000\end{array}$ & $\begin{array}{r}8,300 \\
800\end{array}$ & 61,000 & 3,900 & $\begin{array}{r}49,000 \\
288,000\end{array}$ & $\begin{array}{l}7,100 \\
4,300\end{array}$ & & & 16,000 & 600 & & \\
\hline Pers & 24,000 & 1,00 & 8,800 & 300 & 2,600 & 100 & 5,700 & 200 & ........ & & 10,0000 & 000 & 7,000 & 300 \\
\hline 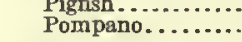 & $\begin{array}{l}109,000 \\
508,000\end{array}$ & $\begin{array}{r}1,800 \\
65,000\end{array}$ & $\begin{array}{r}6,800 \\
374,000\end{array}$ & 49,000 & $\begin{array}{r}600 \\
5,100\end{array}$ & $\stackrel{(2)}{1,000}$ & $\begin{array}{l}100,000 \\
120,000\end{array}$ & $\begin{array}{r}1,500 \\
14,000\end{array}$ & $8,000^{\circ}$ & 800 & 1,200 & (2) & & \\
\hline Porgy, or scup.... & $\begin{array}{r}133,000 \\
35,000\end{array}$ & $\begin{array}{l}6,900 \\
2,800\end{array}$ & $\begin{array}{l}16,000 \\
16,000\end{array}$ & $\begin{array}{r}900 \\
300\end{array}$ & $\begin{array}{r}110,000 \\
15,000\end{array}$ & $\begin{array}{l}5,700 \\
1,200\end{array}$ & 4,600 & 100 & & & & & 2,600 & 200 \\
\hline Round rohin & $\begin{array}{l}35,000 \\
26,00\end{array}$ & $\begin{array}{l}2,800 \\
500\end{array}$ & & & & & $\cdots 22,000$ & $400^{\circ}$ & $\dddot{3}, 000$ & $100^{\circ}$ & & & & \\
\hline $\begin{array}{l}\text { Sallor's cholce..... } \\
\text { Sardines........... }\end{array}$ & $\begin{array}{r}1,257,000 \\
22,000\end{array}$ & $\begin{array}{r}32,000 \\
1,100\end{array}$ & 328,000 & 11,000 & 60,000 & 4,700 & $\begin{array}{r}776,000 \\
22,000\end{array}$ & $\begin{array}{r}13,000 \\
1,100\end{array}$ & 6,000 & 200 & 85,000 & 3,400 & $1,700^{\circ}$ & 100 \\
\hline Sea hass............ & 154,000 & 6,600 & 28,000 & 1,000 & 47,000 & 3,100 & 78,000 & 2,500 & 700 & (a) & ........ & ..... & ....... & .... \\
\hline & $\begin{array}{l}2,800,000 \\
1,571,000\end{array}$ & $\begin{array}{r}320,000 \\
38,000\end{array}$ & $\begin{array}{r}2,168,000 \\
553,000\end{array}$ & $\begin{array}{r}256,000 \\
15,000\end{array}$ & 38,000 & 1,200 & 876,000 & 18,000 & 82,000 & $\dddot{3}, 200$ & $\dddot{22}, 000$ & $\dddot{900}$ & 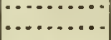 & \\
\hline $\begin{array}{l}\text { Snapper, red........ } \\
\text { Snapper, other.... }\end{array}$ & $\begin{array}{r}7,719,000 \\
342,000\end{array}$ & $\begin{array}{r}434,000 \\
15,000\end{array}$ & 186,000 & 7,500 & $\begin{array}{r}7,719,000 \\
56,000\end{array}$ & $\begin{array}{r}434,000 \\
4,100\end{array}$ & $76,000^{\circ}$ & $\dddot{1}, 900$ & 18,000 & 700 & $\dddot{800}$ & (i) & 3,800 & $\because 300$ \\
\hline Spanlsh mackerel.. & $2,647,000$ & 122,000 & $1,248,000$ & 63,000 & 235,000 & 12,000 & $1,146,000$ & 46,000 & 19,000 & 1,000 & & & & \\
\hline $\begin{array}{l}\text { Spot.. } \\
\text { Squet }\end{array}$ & $\begin{array}{r}18,000 \\
4,864,000\end{array}$ & $\begin{array}{r}4,200 \\
196,000\end{array}$ & $\begin{array}{r}32,000 \\
1,985,000\end{array}$ & $\begin{array}{l}1,000 \\
95,000\end{array}$ & $\begin{array}{r}1,000 \\
85,000\end{array}$ & $\begin{array}{l}(2) \\
4,600\end{array}$ & $\begin{array}{r}123,000 \\
2,728,000\end{array} \mid$ & $\begin{array}{r}2,500 \\
94,000\end{array}$ & $\begin{array}{r}9,500 \\
56,000\end{array}$ & 2,800 & $\begin{array}{l}12,000 \\
10,000\end{array}$ & $\begin{array}{l}400 \\
700\end{array}$ & & (...... \\
\hline $\begin{array}{l}\text { Straw berry bass, } \\
\text { or crapple........ } \\
\text { Strlped bass...... }\end{array}$ & - $\quad 180,000$ & 7,400 & 1,200 & 100 & & & 177,000 & 7,300 & & & & & 2,000 & 100 \\
\hline Sturgeon.......... & 62000 & 5,000 & 62,000 & 5,000 & & & & & & & & & & \\
\hline Cavla & 02,000 & & Ua, wous & 0 , vor & & & & & & & & & & \\
\hline or king- & 200 & 200 & 200 & 200 & & & & & & & & & & \\
\hline $\begin{array}{l}\text { fish. } \\
\text { Yellov }\end{array}$ & $\begin{array}{l}230,000 \\
170,000\end{array}$ & $\begin{array}{r}8,600 \\
14,000\end{array}$ & $\begin{array}{l}42,000 \\
56,000\end{array}$ & $\begin{array}{l}1,500 \\
5,500\end{array}$ & $\begin{array}{l}37,000 \\
73,000\end{array}$ & $\begin{array}{l}1,500 \\
7,300\end{array}$ & $\begin{array}{r}151,000 \\
32,000\end{array}$ & $\begin{array}{r}.5,500 \\
900\end{array}$ & 1000 & & 1,200 & 100 & & \\
\hline All other................ & 350,000 & 17,000 & 38,000 & 1,800 & 262,000 & 12,000 & $\mathbf{4 7}, 000$ & 2,600 & 1,000 & & & & $\begin{array}{l}\quad \\
3,200\end{array}$ & 100 \\
\hline Crahs, hard.. & 148,000 & 2,900 & & & 66,000 & 1,900 & 5,000 & 100 & & & & & 77,000 & 900 \\
\hline 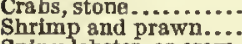 & $\begin{array}{r}62,000 \\
4,353,000\end{array}$ & $\begin{array}{r}3,700 \\
92,000\end{array}$ & 6,800 & 400 & & 2,600 & $4,106,000$ & 32,000 & & & 240,000 & 9,000 & $\begin{array}{r}15,000 \\
8,000\end{array}$ & $\begin{array}{l}700 \\
400\end{array}$ \\
\hline $\begin{array}{l}\text { Spiny lobster, or craw- } \\
\text { fish........................... }\end{array}$ & 53,000 & 2,600 & 13,000 & 600 & & & & & & & 20,000 & 1,000 & 20,000 & 1,000 \\
\hline $\begin{array}{l}\text { Terrapin......... } \\
\text { Turtles........ }\end{array}$ & $\begin{array}{r}21,000 \\
163,000\end{array}$ & $\begin{array}{r}9,400 \\
11,000\end{array}$ & $\begin{array}{r}6,600 \\
126,000\end{array}$ & $\begin{array}{r}2,600 \\
11,000\end{array}$ & 3,000 & 100 & $\begin{array}{l}10,000 \\
26,000\end{array}$ & $\begin{array}{r}5,000 \\
700\end{array}$ & & & & & $\begin{array}{l}3,800 \\
5,100\end{array}$ & $\begin{array}{r}1,800 \\
100\end{array}$ \\
\hline $\begin{array}{l}\text { Tortolse shell................................. } \\
\text { Sponges. }\end{array}$ & 622,000 & $\begin{array}{r}1,300 \\
545,000\end{array}$ & 300 & 1,300 & & & & & & & & & 622,000 & $\ddot{5} 4 \bar{s}^{\circ}, 0000$ \\
\hline $\begin{array}{l}\text { Conchs ........ } \\
\text { Clams, hird. }\end{array}$ & $\begin{array}{r}15,000 \\
4230,000\end{array}$ & $\begin{array}{l}21,000 \\
15,000\end{array}$ & & & & & & & & & & & $\begin{array}{r}15,000 \\
4239,000\end{array}$ & 1,000 \\
\hline ret, from & $167.37 \mathrm{mon}$ & 284,000 & & & & & & & & & & & 37.327 .000 & 284000 \\
\hline $\begin{array}{l}\text { pysters, market, from } \\
\text { private areas................... }\end{array}$ & B 141,000 & 12,000 & & & & & & & & & & & 8141,000 & 12,000 \\
\hline Scallops & 7400 & 10 & & & & & & & & & & & 7400 & 100 \\
\hline & & & & & & & & & & & & & & \\
\hline $\begin{array}{l}\text { Skins, otter... } \\
\text { Oil, sperm.... }\end{array}$ & $\begin{array}{l}1028,000 \\
28,00\end{array}$ & $\begin{array}{r}21,900 \\
1,900\end{array}$ & & & & & & & & & & & $\begin{array}{r}105,7000 \\
10,000\end{array}$ & $\begin{array}{r}21,000 \\
1,900\end{array}$ \\
\hline
\end{tabular}

1 Includes apparatus, with catch, as follows: Sponge hooks and diving apparatus, 622,000 pounds, valued at $\$ 545,000$; dredges, tongs, etc., $7,506,000$ pounds, valued at \$304,000; firearms, 254,000 pounds, valued at \$48,000; ish traps, 517,000 pounds, valued at \$25,000; otter traps, 5,700 pounds, valued at \$21,000; pound nets, 295,000 pounds, valued at $\$ 18,000$; spears, 119,000 pounds, valued at $\$ 6,100$; dip nets, 92,000 pounds, valued, at $\$ 1,200$; shrimp nets, 8,000 pounds, valued at $\$ 400$; fyke nets, 4,000 pounds, valued at $\$ 300:$ and minor apparatus, 268,000 pounds, valued at $\$ 12,000$.

? Less than $\$ 100$.

Includes pearls,

1,047,000 hushels.

20,000 bushe
50 gallons.
- 51,000 hides.

2,900 sklns.
io 3,800 gallons. 
TABLE 2.-FLORIDA-FISHERY PRODUCTS OF GULF OF MEXICO DISTRICT: 1908.

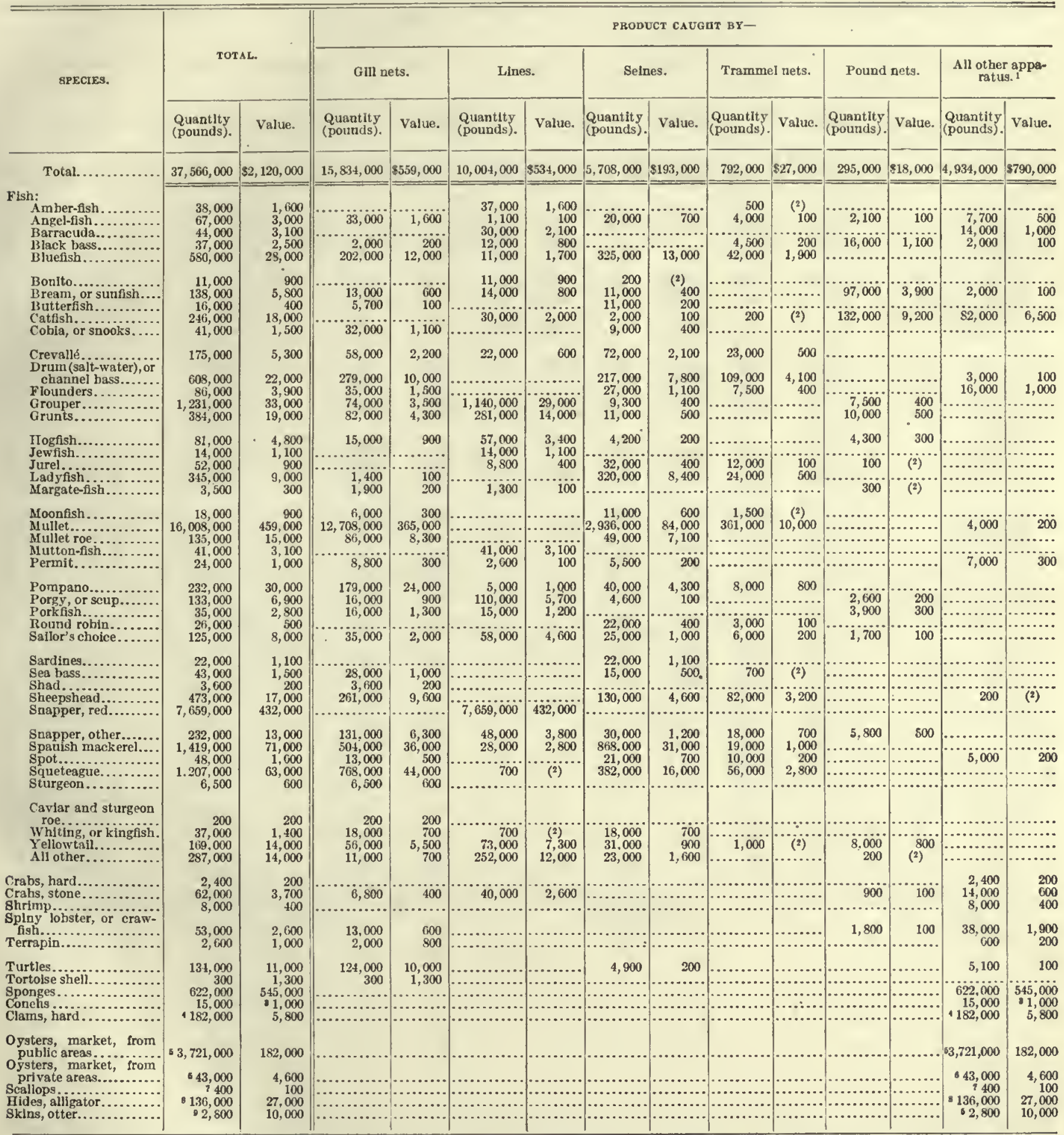

1 Includes apparatus, with catch, as follows: Sponge hooks and diving apparatus, 622,000 pounds, valued at $\$ 545,000 ;$ dredges, tongs, etc., $3,773,000$ pounds, valued at

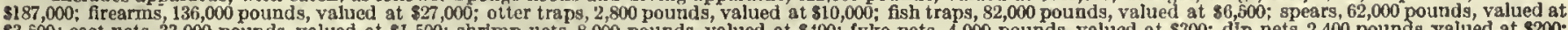

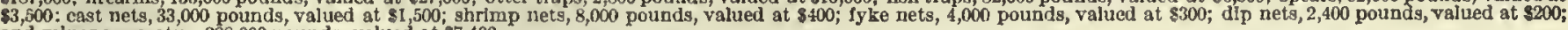
and minor apparatus, 208,000 pounds, valued at $\$ 7,400$. 
TABLE 3.-FLORIDA-FISHERY PRODUCTS OF ATLANTIC COAST DISTRICT: 1908.

\begin{tabular}{|c|c|c|c|c|c|c|c|c|c|c|c|c|c|c|}
\hline \multirow{3}{*}{ SPECIES. } & \multirow{2}{*}{\multicolumn{2}{|c|}{ tọtal. }} & \multicolumn{12}{|c|}{ PronuCt CAUGHT BY- } \\
\hline & & & \multicolumn{2}{|c|}{ Gill nets. } & \multicolumn{2}{|c|}{ Lines. } & \multicolumn{2}{|c|}{ Selnes. } & \multicolumn{2}{|c|}{ Flsh traps. } & \multicolumn{2}{|c|}{ Cast nets. } & \multicolumn{2}{|c|}{$\begin{array}{l}\text { All other appa- } \\
\text { ratus. } .^{1}\end{array}$} \\
\hline & $\begin{array}{l}\text { Quantity } \\
\text { (pounds). }\end{array}$ & Value. & $\begin{array}{l}\text { Quantity } \\
\text { (pounds). }\end{array}$ & Value. & $\begin{array}{r}\text { Quantity } \\
\text { (pounds) }\end{array}$ & Value. & $\begin{array}{l}\text { Quantity } \\
\text { (pounds). }\end{array}$ & Value. & $\begin{array}{l}\text { Quantity } \\
\text { (pounds). }\end{array}$ & Value. & $\begin{array}{l}\text { Quantity } \\
\text { (pounds). }\end{array}$ & Value. & $\begin{array}{l}\text { Quantity } \\
\text { (pounds). }\end{array}$ & Value. \\
\hline Total. . & $36,521,000$ & $\$ 1,260,000$ & $13,969,000$ & $\$ 574,000$ & $2,743,000$ & $\$ 83,000$ & $14,692,000$ & $\$ 414,000$ & 435,000 & $\$ 19,000$ & 620,000 & $\$ 22,000$ & $4,061,000$ & $\$ 158,000$ \\
\hline 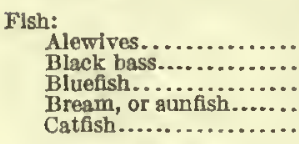 & $\begin{array}{r}1,220,000 \\
1,034,000 \\
372,000 \\
1,409,000 \\
1,235,000\end{array}$ & $\begin{array}{r}5,400 \\
56,000 \\
17,000 \\
44,000 \\
36,000\end{array}$ & $\begin{array}{r}139,000 \\
500 \\
\$ 500\end{array}$ & $\begin{array}{l}(2) \\
6,200 \\
(2)\end{array}$ & $\begin{array}{r}756,000 \\
73,000 \\
2,300 \\
229,000\end{array}$ & $\begin{array}{r}26,000 \\
3,100 \\
100 \\
6,700\end{array}$ & $\begin{array}{r}1,220,000 \\
376,000 \\
160,000 \\
1,204,000 \\
975,000\end{array}$ & $\begin{array}{r}5,400 \\
19,000 \\
7,400 \\
38,000 \\
27,000\end{array}$ & $\begin{array}{r}200,000 \\
200,000 \\
30,000\end{array}$ & $\begin{array}{r}11,000 \\
6,000 \\
1,600\end{array}$ & 2,300 & $\begin{array}{l}1000 \\
100\end{array}$ & & \\
\hline $\begin{array}{l}\text { Cobla, or sergeant-fish.. } \\
\text { Crevalle.................. } \\
\text { Crosker }\end{array}$ & $\begin{array}{r}82,000 \\
1,200,000 \\
92,000\end{array}$ & $\begin{array}{r}1,300 \\
19,000 \\
2,000\end{array}$ & $\begin{array}{l}20,000 \\
23,000 \\
15,000\end{array}$ & $\begin{array}{l}400 \\
500 \\
400\end{array}$ & $\begin{array}{r}100 \\
1,228,000 \\
2,500\end{array}$ & $\begin{array}{r}{ }^{(2)} \\
18,000 \\
100\end{array}$ & $\begin{array}{r}62,000 \\
8,700 \\
71,000\end{array}$ & $\begin{array}{r}900 \\
200 \\
1,400\end{array}$ & & & $\begin{array}{r}100 \\
3,000\end{array}$ & $\begin{array}{l}\text { (9) } \\
\cdots \ldots\end{array}$ & $\ldots$ & \\
\hline $\begin{array}{l}\text { Drum (salt-water), or } \\
\text { channel bass........... } \\
\text { Flounders............ }\end{array}$ & $\begin{array}{r}818,000 \\
99,000\end{array}$ & $\begin{array}{r}16,000 \\
4,100\end{array}$ & $\begin{array}{r}235,000 \\
14,000\end{array}$ & $\begin{array}{r}4,600 \\
500\end{array}$ & $\begin{array}{r}121,000 \\
100\end{array}$ & $\begin{array}{c}2,900 \\
(2)\end{array}$ & $\begin{array}{r}424,000 \\
28,000\end{array}$ & $\begin{array}{l}6,700 \\
1,100\end{array}$ & & & $\begin{array}{r}38,000 \\
100\end{array}$ & $\begin{array}{l}1,500 \\
\text { (ग) }\end{array}$ & 57,000 & $\because, 600$ \\
\hline 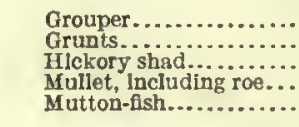 & $\begin{array}{r}45,000 \\
4,400 \\
198,000 \\
8,573,000 \\
376,000\end{array}$ & $\begin{array}{r}1,400 \\
100 \\
8,000 \\
177,000 \\
6,500\end{array}$ & $\begin{array}{r}17,000 \\
172,000 \\
8,184,000 \\
52,000\end{array}$ & $\begin{array}{r}100 \\
6,900 \\
169,000 \\
800\end{array}$ & $\begin{array}{r}45,000 \\
200\end{array}$ & 1,400 & $\begin{array}{r}27,000 \\
181,000 \\
288,000\end{array}$ & $\begin{array}{l}19 ; \\
1,100 \\
3,000 \\
4,300\end{array}$ & & & $\begin{array}{r}193,000 \\
16,000\end{array}$ & $\begin{array}{r}4,900 \\
600\end{array}$ & 15,000 & $\ddot{3} 00$ \\
\hline 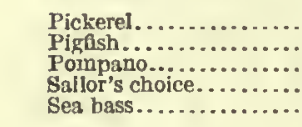 & $\begin{array}{r}3,000 \\
105,000 \\
276,000 \\
1,132,000 \\
110,000\end{array}$ & $\begin{array}{r}100 \\
1,800 \\
35,000 \\
24,000 \\
5,100\end{array}$ & $\begin{array}{r}6,800 \\
195,000 \\
294,000\end{array}$ & $\begin{array}{r}2000 \\
25,000 \\
8,800\end{array}$ & $\begin{array}{r}600 \\
100 \\
3.000 \\
47,000\end{array}$ & $\begin{array}{l}3,3 \\
100 \\
3,100\end{array}$ & $\begin{array}{r}97,000 \\
851,000 \\
754,000 \\
64,000\end{array}$ & $\begin{array}{r}1,500 \\
9,600 \\
12,000 \\
2,000\end{array}$ & 3,000 & 100 & $\begin{array}{r}1,200 \\
85,000 \\
8 \ldots \ldots\end{array}$ & 3,400 & & $\begin{array}{l}\cdots \\
\cdots \cdots \\
\cdots \cdots\end{array}$ \\
\hline 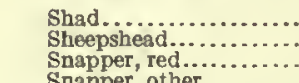 & $\begin{array}{l}2,833,000 \\
1,098,000 \\
60,000\end{array}$ & $\begin{array}{r}320,000 \\
21,000 \\
2,400\end{array}$ & $\begin{array}{r}2,164,000 \\
291,000\end{array}$ & $\begin{array}{r}255,000 \\
5,700\end{array}$ & $\begin{array}{l}38,000 \\
60,000\end{array}$ & $\begin{array}{l}1,2000 \\
2,400\end{array}$ & $\begin{array}{l}668,000 \\
746,000\end{array}$ & $\begin{array}{l}64,000 \\
13,000\end{array}$ & & & 22,000 & 8000 & & \\
\hline Snapper, other............ & 110,000 & 2,200 & 55,000 & 1,200 & 8,100 & 200 & 46,000 & 700 & & & 800 & (i) & & \\
\hline 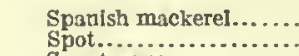 & $\begin{array}{r}1,228,000 \\
130,000\end{array}$ & $\begin{array}{r}51,000 \\
2,600\end{array}$ & $\begin{array}{r}744,000 \\
20,000\end{array}$ & $\begin{array}{r}27,000 \\
500\end{array}$ & $\begin{array}{r}207,000 \\
1,000\end{array}$ & $\begin{array}{l}9,300 \\
(2)\end{array}$ & $\begin{array}{l}278,000 \\
102,000\end{array}$ & $\begin{array}{r}15,000 \\
1,700\end{array}$ & & & 7,300 & 300 & & \\
\hline 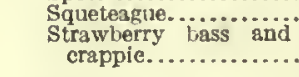 & $\begin{array}{r}3,657,000 \\
180,000\end{array}$ & $\begin{array}{r}133,000 \\
7,400\end{array}$ & $\begin{array}{r}1,217,000 \\
1,200\end{array}$ & $\begin{array}{r}51,000 \\
100\end{array}$ & 84,000 & 4,600 & $\begin{array}{r}2,346,000 \\
177,000\end{array}$ & $\begin{array}{r}77,000 \\
7,300\end{array}$ & 2,000 & 100 . & 10,000 & 700 & & \\
\hline 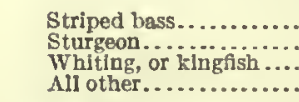 & $\begin{array}{r}9,000 \\
55,000 \\
194,000 \\
75,000\end{array}$ & $\begin{array}{l}1,000 \\
4,400 \\
7,200 \\
2,600\end{array}$ & $\begin{array}{r}9,000 \\
55,000 \\
24,000 \\
29,000\end{array}$ & $\begin{array}{r}1,000 \\
4.400 \\
600 \\
1,100\end{array}$ & $\begin{array}{l}36,000 \\
10,000\end{array}$ & $\dddot{1} 1,300$ & $\begin{array}{r}133,0000 \\
36,000\end{array}$ & $\begin{array}{l}4,900 \\
1,200\end{array}$ & & & 1,200 & 700 & $\ldots .$. & $\ddot{\because}$ \\
\hline 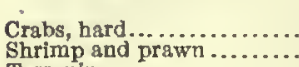 & $\begin{array}{r}146,000 \\
4,346,000\end{array}$ & $\begin{array}{r}2,700 \\
91,000\end{array}$ & & & 66,000 & 1,900 & $\begin{array}{r}5,000 \\
4,106,000\end{array}$ & $\begin{array}{r}100 \\
82,000\end{array}$ & & & $240,000^{\circ}$ & $\dddot{9}, \ddot{0000}$ & 75,000 & $\begin{array}{r}800 \\
\ldots \ldots\end{array}$ \\
\hline & $\begin{array}{r}18,000 \\
29,000\end{array}$ & 8,500 & $\begin{array}{r}4,600 \\
2,300\end{array}$ & "i, & 5,000 & 100 & $\begin{array}{l}10,000 \\
21,000\end{array}$ & $\begin{array}{r}5,000 \\
500\end{array}$ & & & & & 3,200 & 1,000 \\
\hline irom pub- & 857,000 & 9,400 & & & & & & & & & & & 57,000 & 9,400 \\
\hline te from pub- & $43,606,000$ & 101,000 & & & & & & & & & & & $43,606,000$ & 101,000 \\
\hline et, irom pri- & $\begin{array}{r}598,000 \\
8119,000\end{array}$ & $\begin{array}{r}7,600 \\
21,000\end{array}$ & & & & & & & & & & & . 98,000 & 7,600 \\
\hline 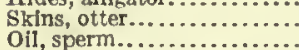 & $\begin{array}{r}73,000 \\
828,000\end{array}$ & $\begin{array}{l}11,000 \\
1,900\end{array}$ & & & & & & & & & & & $\begin{array}{r}119,000 \\
73,000 \\
828,000\end{array}$ & $\begin{array}{l}21,000 \\
11,000\end{array}$ \\
\hline Oil, sperm...................... & 28,000 & 1,900 & & & & & & & & & & & 28,000 & 1,900 \\
\hline
\end{tabular}

1 Includes apparatus with catch, as follows: Dredges, tongs, etc. $3,732,000$ pounds, valued at $\$ 117,000$; firearms, 119,000 pounds, valued at $\$ 21,000$; otter traps, 3,000 pounds, valued at $\$ 11,000$; spears, 57,000 pounds, valued at $\$ 2,600 ;$ dip nats, 90,000 pounds, valued at $\$ 1,000$; and minor apparatus, 60,000 pounds, valued at $\$ 5,000$. I I ess than $\$ 100$. 515,000 busheis. 
TABLE 4.-FLORIDA-PRODUCTS OF' SHORE AND BOAT FISHERIES: 1908.

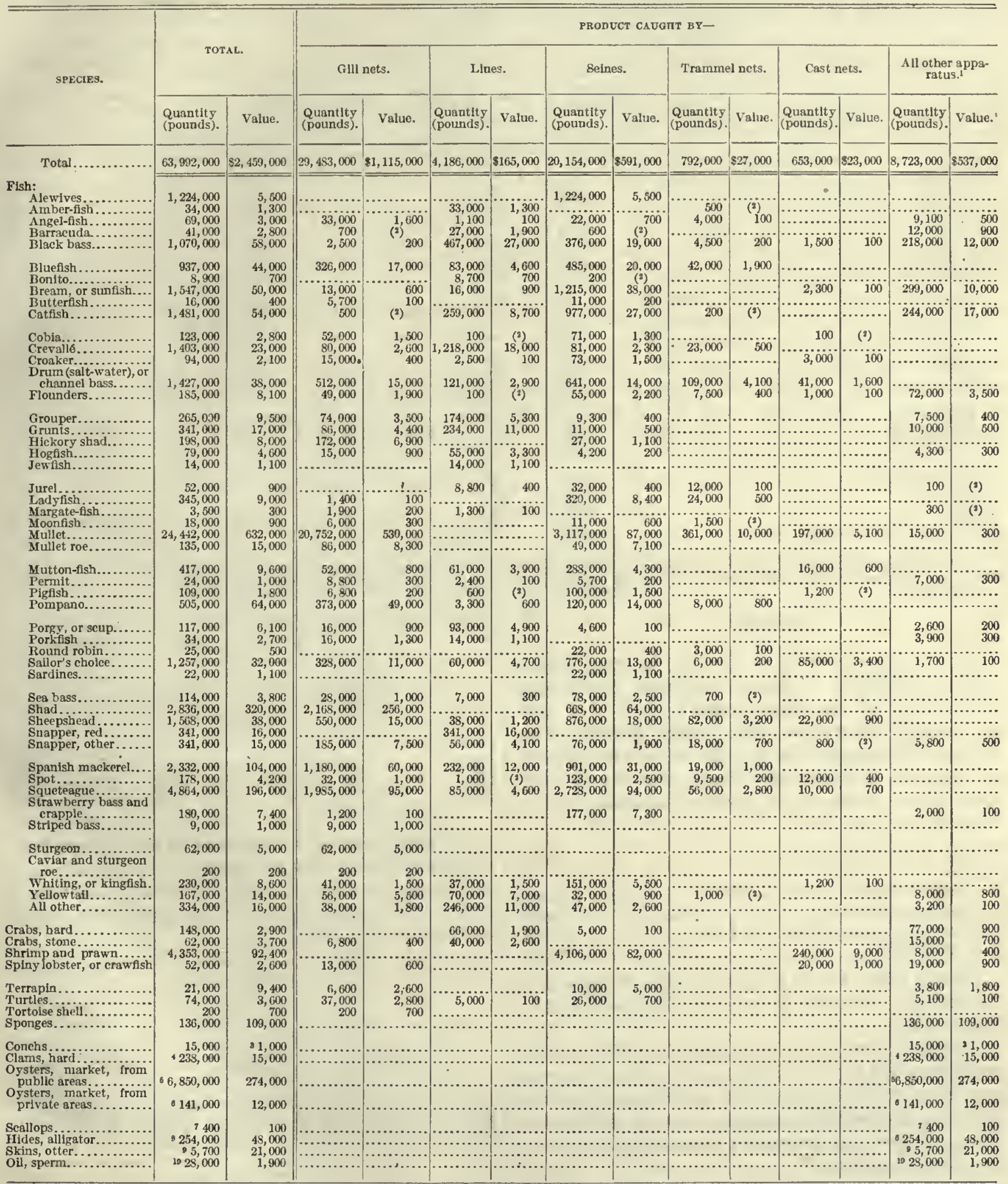

1 Includes apparatus, with catch, as follows: Dredges, tongs, etc, 7,029,000 pounds, valued at $\$ 295,000 ;$ sponge hooks und diving apparatus, 136,000 pounds, valued at

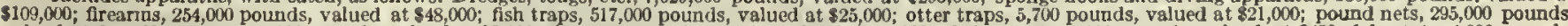

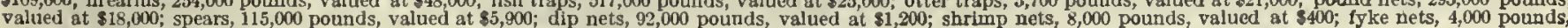
valued at $\$ 300$; and minor apparatus, 267,000 pounds, valued at $\$ 12,000$.

6979,000 bushels. 750 gallons.
$\$ 51,000$ bldes. ${ }_{10}, 2,900$ skins. 
TABLE 5.-FLORIDA-PRODUCTS OF VESSEL FISHERIES: I908.

\begin{tabular}{|c|c|c|c|c|c|c|c|c|}
\hline \multirow{3}{*}{ SPECIES. } & \multirow{2}{*}{\multicolumn{2}{|c|}{ TOTAL. }} & \multicolumn{6}{|c|}{ PRODUCT CAUGuT BY- } \\
\hline & & & \multicolumn{2}{|c|}{ GIIl nets. } & \multicolumn{2}{|c|}{ Lines. } & \multicolumn{2}{|c|}{ All other apparatus. ${ }^{1}$} \\
\hline & $\begin{array}{l}\text { Quantity } \\
\text { (pounds). }\end{array}$ & Value. & $\begin{array}{l}\text { Quantity } \\
\text { (pounds). }\end{array}$ & Value. & $\begin{array}{l}\text { Quantlty } \\
\text { (pounds). }\end{array}$ & Value. & $\begin{array}{l}\text { Quantity } \\
\text { (pounds). }\end{array}$ & Value. \\
\hline Total....... & $10,094,000$ & $\$ 930,000$ & 320,000 & $\$ 18,000$ & $8,561,000$ & $\$ 452,000$ & $1,214,000$ & $\$ 460,000$ \\
\hline 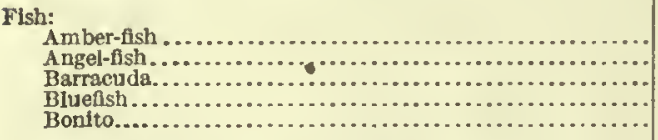 & $\begin{array}{r}4,100 \\
1,200 \\
3,800 \\
15,000 \\
2,200\end{array}$ & $\begin{array}{r}200 \\
100 \\
300 \\
1,000 \\
200\end{array}$ & 14,000 & (a) & $\begin{array}{r}4,100 \\
2,100 \\
1,100 \\
2,200\end{array}$ & $\begin{array}{r}200 \\
100 \\
200 \\
200\end{array}$ & $\begin{array}{r}1,700 \\
\ldots \ldots \\
\cdots\end{array}$ & (2) \\
\hline 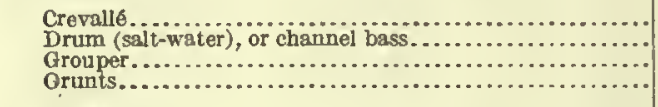 & $\begin{array}{r}32,000 \\
1,500 \\
1,005,000 \\
47,000\end{array}$ & $\begin{array}{r}600 \\
100 \\
24,000 \\
2,200\end{array}$ & $\begin{array}{r}500 \\
1,500 \\
\cdots \cdots\end{array}$ & $\begin{array}{l}\text { (2) } 100 \\
100 \\
\cdots \cdots\end{array}$ & $\begin{array}{r}31,000 \\
1,005,000 \\
47,000\end{array}$ & $\begin{array}{r}600 \\
24,000 \\
2,200\end{array}$ & & \\
\hline 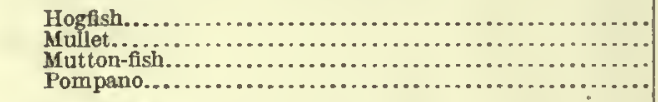 & $\begin{array}{r}1,900 \\
140,000 \\
600 \\
3,200\end{array}$ & $\begin{array}{r}100 \\
4,200 \\
100 \\
600\end{array}$ & 140,000 & 300 & $\begin{array}{r}1,900 \\
600 \\
1,800\end{array}$ & $\begin{array}{l}100 \\
100 \\
400\end{array}$ & & \\
\hline 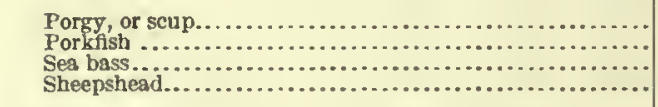 & $\begin{array}{r}16,000 \\
1,000 \\
40,000 \\
2,500\end{array}$ & $\begin{array}{r}500 \\
100 \\
2,800 \\
100\end{array}$ & 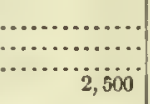 & 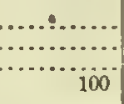 & $\begin{array}{r}16,000 \\
1,000 \\
40,000 \\
\ldots\end{array}$ & $\begin{array}{r}500 \\
100 \\
2,800 \\
\end{array}$ & & ( \\
\hline 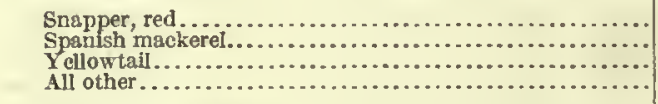 & $\begin{array}{r}7,378,000 \\
315,000 \\
3,000 \\
19,000\end{array}$ & $\begin{array}{r}418,000 \\
19,000 \\
400 \\
900\end{array}$ & 2, 500 & $\begin{array}{r}3,500 \\
100\end{array}$ & $\begin{array}{r}7,378,000 \\
2,400 \\
3,600 \\
17,000\end{array}$ & $\begin{array}{r}418,000 \\
200 \\
400 \\
800\end{array}$ & $\begin{array}{r}246,000 \\
\cdots \ldots \ldots \ldots \\
\cdots\end{array}$ & $\begin{array}{r}15,000 \\
\ldots \ldots \ldots\end{array}$ \\
\hline 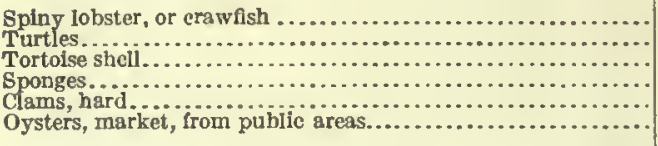 & $\begin{array}{r}1,100 \\
89,000 \\
200 \\
487,000 \\
11,200 \\
477,000\end{array}$ & $\begin{array}{r}100 \\
7,700 \\
700 \\
436,000 \\
100 \\
9,500\end{array}$ & $\begin{array}{r}89,000 \\
200 \\
\ldots \ldots \ldots\end{array}$ & $\begin{array}{r}7,700 \\
700 \\
\ldots \ldots\end{array}$ & 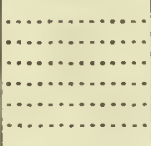 & 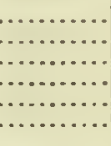 & $\begin{array}{r}1,100 \\
4.7 \% \\
437,000 \\
11,200 \\
477,000\end{array}$ & $\begin{array}{r}\cdot 100 \\
436,000 \\
100 \\
9,500\end{array}$ \\
\hline
\end{tabular}

1 Includes apparatus, with catch, as follows: Sponge hooks and diving apparatus, 487,000 pounds, valued at $\$ 436,000$; selnes, 246,000 pounds, valued at $\$ 15,000 ;$ dredges, tongs, etc. 477,000 pounds, valued at $\$ 9,500 ;$ spears and hooks, 3,500 pounds, valued at $\$ 200$; and minor apparatus, 1,600 pounds, valucd at $\$ 100$.
2 Less than $\$ 100$.

\section{GEORGIA.}

The fishery products of Georgia in 1908 had a value of $\$ 701,000$. Oysters contributed nearly half of the value of the entire product, while shad and red snapper followed as other leading species. The principal fishing grounds are the Savannah, the $\mathrm{Al}$ tamaha, and the Ogeechee Rivers, and the outlying ocean areas. Following is a general summary of the statistics:

Number of persons employed .................... Capital:

Vessels and boats, including outfit............. $\$ 169,000$

Apparatus of capture........................ 55,000

Shore and accessory property and cash.......... 185, 000

Value of products....................... 701,000

Though this industry is relatively. one of the minor industries of the state, it appears to be increasing in importance.

Comparison with previous canvasses.-The census report for 1880 stated that the sea fisheries of Georgia were at that time almost wholly undeveloped, but the following comparative summary shows that there has been a decided and progressive increase since then in practically every item:

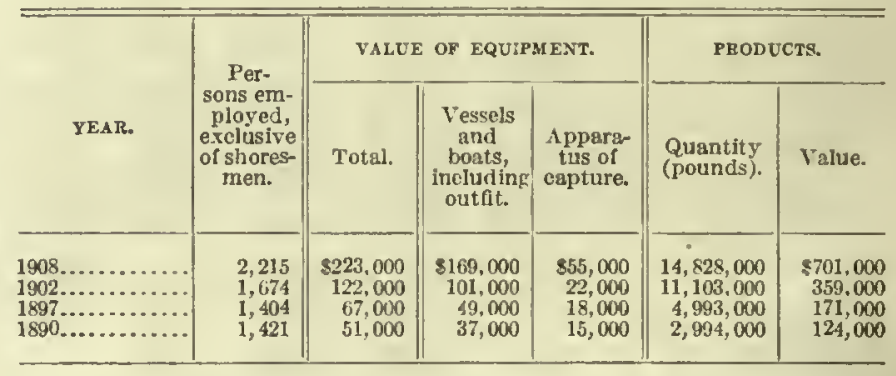

The uniformity of development in the Georgia fisheries since 1890 is well demonstrated by the following comparative statement of the quantities and values of the chief species at each of the periods for which statistics are at hand:

\begin{tabular}{|c|c|c|c|c|c|c|}
\hline \multirow{3}{*}{ YEAR. } & \multicolumn{6}{|c|}{ FISHERY PRODUCTS. } \\
\hline & \multicolumn{2}{|c|}{ Oysters. } & \multicolumn{2}{|c|}{ Shad. } & \multicolumn{2}{|c|}{ Red snapper. } \\
\hline & $\begin{array}{l}\text { Quantity } \\
\text { (pounds). }\end{array}$ & Value. & $\begin{array}{l}\text { Quantity } \\
\text { (pounds). }\end{array}$ & Value. & $\begin{array}{l}\text { Quantity } \\
\text { (pounds). }\end{array}$ & Value. \\
\hline $\begin{array}{l}1908 \ldots \ldots \ldots \\
1902 \ldots \ldots \ldots \ldots \\
1897 \ldots \ldots \ldots \ldots \\
1890 \ldots \ldots \ldots \ldots\end{array}$ & $\begin{array}{r}10,214,000 \\
8,568,000 \\
3,406,000 \\
1,570,000\end{array}$ & $\begin{array}{r}8339,000 \\
220,000 \\
87,000 \\
41,000\end{array}$ & $\begin{array}{r}1,333.000 \\
1.029,000 \\
788,000 \\
400,000\end{array}$ & $\begin{array}{r}\$ 190,000 \\
75,000 \\
47,000 \\
31,000\end{array}$ & $\begin{array}{l}880,000 \\
125,000 \\
(1) \\
(1)\end{array}$ & $\begin{array}{l}830,000 \\
7,500 \\
(1)^{1} \\
(1)\end{array}$ \\
\hline
\end{tabular}

1 Not reported separatcly. 
The increase in the catch has not been so rapid in the case of shad as in that of some other varieties, but there has been a marked increase in the price since 1902. Red snappers were not mentioned in the report for 1897 , but they occupied the third place in 1908.

Persons employed.-The statistics in regard to the number of persons employed in the fisheries of Georgia are given in the following tabular statement:

\begin{tabular}{|c|c|c|c|c|c|c|c|}
\hline \multirow[b]{3}{*}{ Class. } & \multicolumn{7}{|c|}{ PERSONS EMPLOYED: 1908.} \\
\hline & \multicolumn{4}{|c|}{ Number. } & \multicolumn{3}{|c|}{ Salarles and wages. } \\
\hline & Total. & $\begin{array}{l}\text { Pro- } \\
\text { prietors } \\
\text { and in- } \\
\text { depend- } \\
\text { ent fish- } \\
\text { ermen. }\end{array}$ & $\begin{array}{c}\text { Sala- } \\
\text { ried } \\
\text { em- } \\
\text { ployees. }\end{array}$ & $\begin{array}{l}\text { Wage } \\
\text { earn- } \\
\text { ers. }\end{array}$ & Total. & $\begin{array}{l}\text { Sala- } \\
\text { ries. }\end{array}$ & Wages. \\
\hline Total.... & 2,525 & 1634 & 29 & 1,862 & $\$ 338,000$ & $\$ 17,000$ & $\$ 320,000$ \\
\hline $\begin{array}{l}\text { Vessel fisherles...... } \\
\text { Transporting vessels. }\end{array}$ & $\begin{array}{r}395 \\
7\end{array}$ & 14 & 18 & $\begin{array}{r}363 \\
7\end{array}$ & $\begin{array}{r}87,000 \\
1,400\end{array}$ & 14,000 & $\begin{array}{r}73,000 \\
1,400\end{array}$ \\
\hline $\begin{array}{l}\text { Shore and boat flsh- } \\
\text { eries............... } \\
\text { Shoresmen.......... }\end{array}$ & $\begin{array}{r}1,813 \\
310\end{array}$ & 620 & 11 & $\begin{array}{r}1,182 \\
310\end{array}$ & $\begin{array}{r}201,000 \\
49,000\end{array}$ & $\begin{array}{r}3,500 \\
\ldots \ldots \ldots\end{array}$ & $\begin{array}{r}197,000 \\
49,000\end{array}$ \\
\hline
\end{tabular}

1 Exclusive of 11 proprietors not fishing.

The seven persons employed on transporting vessels were connected with vessel fishery interests, while all the shoresmen were connected with the shore and boat fisheries. The comparison therefore shows a total of 2,123 persons for the shore and boat fisheries and of 402 for the vessel fisheries. The intermittent character of much of the employment is manifest from the low average individual wage.

Equipment and other capital.-The following table presents statistics in regard to the capital invested in the industry:

\begin{tabular}{|c|c|c|c|}
\hline \multirow{2}{*}{ CLASS OF INVESTMENT. } & \multicolumn{3}{|c|}{$\begin{array}{l}\text { EQUIPMENT AND OTHER } \\
\text { CAPITAL: } 1908 .\end{array}$} \\
\hline & Value. & Number. & Tonnage. \\
\hline Total...... & $\$ 408,000$ & & ...... \\
\hline Vessels, Including ontfit... & 90,000 & 88 & 1,301 \\
\hline Fishing..................... & 85,000 & 86 & 1,255 \\
\hline Steam................... & 24,000 & 15 & 155 \\
\hline Vessels........................................ & 20,000 & ..... & $\ldots . . . . .$. \\
\hline Outfit............................. & 3,700 & $\cdots \cdots$ & (n........... \\
\hline 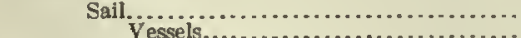 & $\begin{array}{l}61,000 \\
59,000\end{array}$ & 71 & 1,100 \\
\hline Outfit............................. & $\begin{array}{r}39,000 \\
2,000\end{array}$ & & $\ldots \ldots$ \\
\hline Transporting (saii) $\ldots \ldots \ldots \ldots \ldots \ldots \ldots \ldots$ & 4,200 & $\ddot{2}$ & 46 \\
\hline 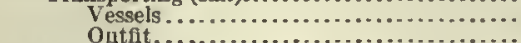 & 4,000 & & (.......... \\
\hline 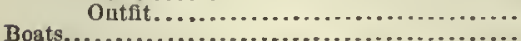 & 79.000 & & \\
\hline 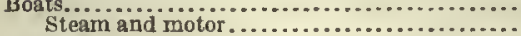 & $\begin{array}{l}79,000 \\
36,000\end{array}$ & ̈i34 & $\ldots \ldots \ldots$ \\
\hline 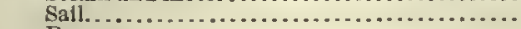 & 24,000 & 596 & ........... \\
\hline Row. & 19,000 & 2,059 & ............ \\
\hline other..................................... & 700 & 2 & ............ \\
\hline 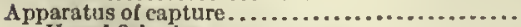 & 55,000 & ........... & \\
\hline 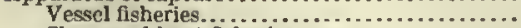 & 3,100 & ............. & ............. \\
\hline 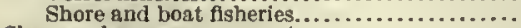 & 51,000 & ............ & $\ldots .$. \\
\hline Shore and accessory property................... & 185,000 & $\ldots \ldots \ldots$ & ...... \\
\hline 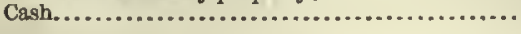 & 500 & (........... & \\
\hline
\end{tabular}

Of the total investment, $\$ 130,000$ was credited to vessel fisheries and $\$ 278,000$ to shore and boat fisheries.
The item showing the largest value is shore and accessory property, which was valued at $\$ 185,000$. Of this amount, $\$ 37,000$ belonged to vessel fishery interests and $\$ 148,000$ to those of shore and boat fisheries. Craft of various kinds made up the next largest item, the value exclusive of outfits being $\$ 163,000$. To this the value of vessels contributed $\$ 84,000$ and that of boats $\$ 79,000$. The entire amount of cash capital reported was from the shore and boat fisheries. That none was reported by the vessel fisheries is due partly to their close association with canneries whose accounts carry the items of capital. Sailing vessels were more important than steam vessels in number, tonnage, and value, but the greater part of the investment in outfits pertained to steam craft. Steam and motor boats, although less than one-fourth as numerous as sailboats, exceeded them in average value by more than 50 per cent. The bulk of the apparatus of eapture was used in shore and boat fisheries, the largest investment being in gill nets. Lines and dredges, tongs, etc., were the only kinds of apparatus reported for the vessel fisheries. The number of the various kinds of apparatus in use in the shore and boat fisheries in 1908 was as follows:

Cast nets........................................ 333

Fyke and hoop nets........................... 51

Gill nets......................................... 982

Pound nets................................... 12

Seines.................................. 123

Spears..................................... 7

Stop nets.................................... 6

Traps, catfish.................................... 150

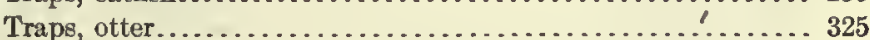

Products, by species.-The quantity and value of the products of the Georgia fisheries are given, by species and by apparatus of capture, in the table on page 113. The value of the oyster product formed 48 per cent of that of all products. Shad and red snappers ranked second and third, respectively, in value of catch. All other species amounted to $2,401,000$ pounds, valued at $\$ 142,000$. Only three of theseprawn, catfish, and sea bass-appear in quantities exceeding 200,000 pounds, while terrapin was the only one for which a value above $\$ 20,000$ was reported. The three leading species-oysters, shad, and red snappers-have contributed the bulk of the increase both in the quantity and in the value of fishery products since 1880 , although their gain has been relatively no greater than that of the less important species.

Products, by class of fisheries. - The following tabular statement gives the product of vessel fisheries by species. The fish were taken by lines, and the oyster product (amounting to $4,509,000$ pounds, valued at $\$ 117,000)$ was taken by dredges, tongs, etc. 


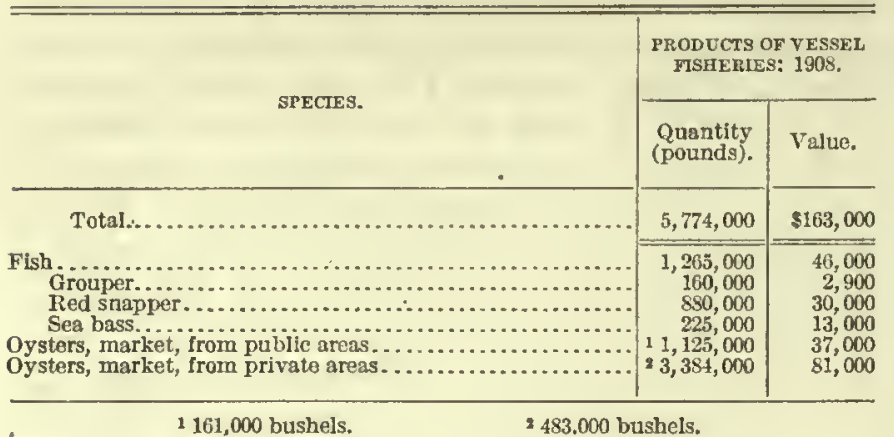

If the items given in the foregoing tabular statement be deducted from the table on page 113, the latter may be used as a table of the shore and boat fisheries. Groupers and red snappers were taken solely in the vessel fisheries, and only sea bass and market oysters appear in the catch of both vessel fisheries and shore and boat fisheries. The distribution of the products appearing in both the vessel and the shore and boat fisheries is shown in the following tabular statement:

\begin{tabular}{|c|c|c|}
\hline \multirow[t]{2}{*}{ SPECIES AND CLASS OP PISHERIES.. } & \multicolumn{2}{|c|}{$\begin{array}{l}\text { PRODUCTS COMMON TO } \\
\text { VESSEL FISHERIES } \\
\text { AND SHORE AND } \\
\text { BOAT TISHERIES: } \\
1908 \text {. }\end{array}$} \\
\hline & $\begin{array}{l}\text { Quantity } \\
\text { (pounds). }\end{array}$ & Value. \\
\hline 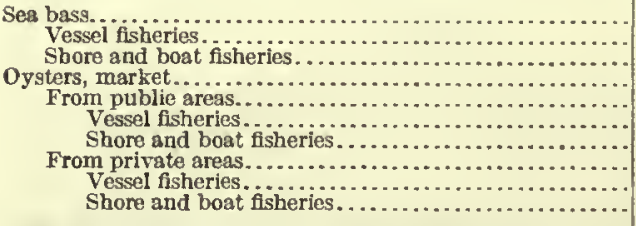 & $\begin{array}{r}233,000 \\
225,000 \\
8,000 \\
10,053,000 \\
13,484,000 \\
1,125,000 \\
32,359,000 \\
6,569,000 \\
3,384,000 \\
3,185,000\end{array}$ & $\begin{array}{r}\$ 14,000 \\
13,000 \\
334,000 \\
121,000 \\
37,000 \\
84,000 \\
213,000 \\
81,000 \\
133,000\end{array}$ \\
\hline $\begin{array}{l}337,000 \text { bushels. } \\
\text { 938,000 bushels. }\end{array}$ & $\begin{array}{l}483,000 \text { bus } \\
645,000 \text { bus }\end{array}$ & Is. \\
\hline
\end{tabular}

Practically all of the sea bass was taken by vessel fisheries. The large factor in the catch of both classes of fisheries was market oysters, of which the vessel fisheries reported 644,000 bushels, valued at $\$ 117,000$, and the shore and boat fisheries 792,000 bushels, valued at $\$ 217,000$.

Products, by apparatus of capture.-As oysters represented the greater part of the weight and value of the Georgia fishery product, dredges, tongs, etc., were tho leading forms of apparatus of capture. Except for hard clams, valued at $\$ 9,000$, the entire product taken with dredges, tongs, etc., consisted of oysters. All the clams reported were taken by the shore and boat fisheries.

On the basis of weight of catch, lines were next in importance, with a catch of $1,810,000$ pounds, valued at $\$ 74,000$, followed by gill nets, with $\Omega$ catch of $1,721,000$ pounds, valued at $\$ 213,000$. On the basis of value of catch, the order is reversed. The total product of Georgia fisheries, exchusive of the eatch by dredges and tongs, was 4,571,000 pounds, having a value of $\$ 353,000$. Of this quantity, lines and gill nets took $3,532,000$ pounds, valued at $\$ 287,000$, and all the remaining varieties of apparatus $1,040,000$ pounds, valued at $\$ 66,000$. Among the produets caught by lines the red snapper held first rank, with a weight of 880,000 pounds and a value of $\$ 30,000$. Sea bass and groupers also stood high in the list. The gill-net capture, all by shore and boat fisheries, was chiefly shad. The principal eatch with seines consisted of prawn, on the basis of quantity, and terrapin, on the basis of value.

Oysters.-Oysters were of greater relative importance in 1902 than in either 1890 or 1897 , as will be seen by reference to the tabular statement on page 110. Between 1902 and 1908 the oyster industry made large gains, but the increase for that period was not so great as that for the previous five years. The rapid development made during the latter period and the few years preceding was largely the result of the market created by new canneries. Such was the growth that the Commissioner of Fisheries stated in his report for 1902, in regard to Georgia, that there was very little cloubt that in years to come private oyster culture would have to be resorted to on a large scale in this state if the oyster supply were to be maintained. $^{1}$ Private oyster culture had been well started at that time, but no statistics of its extent were presented. The growth of this enterprise is indicated by the table on page 113, which shows that in 1908 the product from the private areas was much larger than that from public areas, amounting to a total of 952,000 bushels, as compared with only 507,000 bushels from the public areas. Except for the results of private culture, the oyster industry apparently would have shown a loss instead of a gain since 1902, as the product from public areas decreased from $1,224,000$ bushels in 1902 to 507,000 bushels in 1908 . In considering these figures, however, allowance must be made for the fact that while no returns were made for private areas separately in 1902, a considerable product therefrom appears in the totals for that year.

In each class of fisheries in 1908 oysters from private areas exceeded those from public areas both in quantity and in value.

'Statistics of the Fisheries of the South Atlantic States, 1902, p. 387 . 
GEORGIA-FISHERY PRODUCTS: 1908.

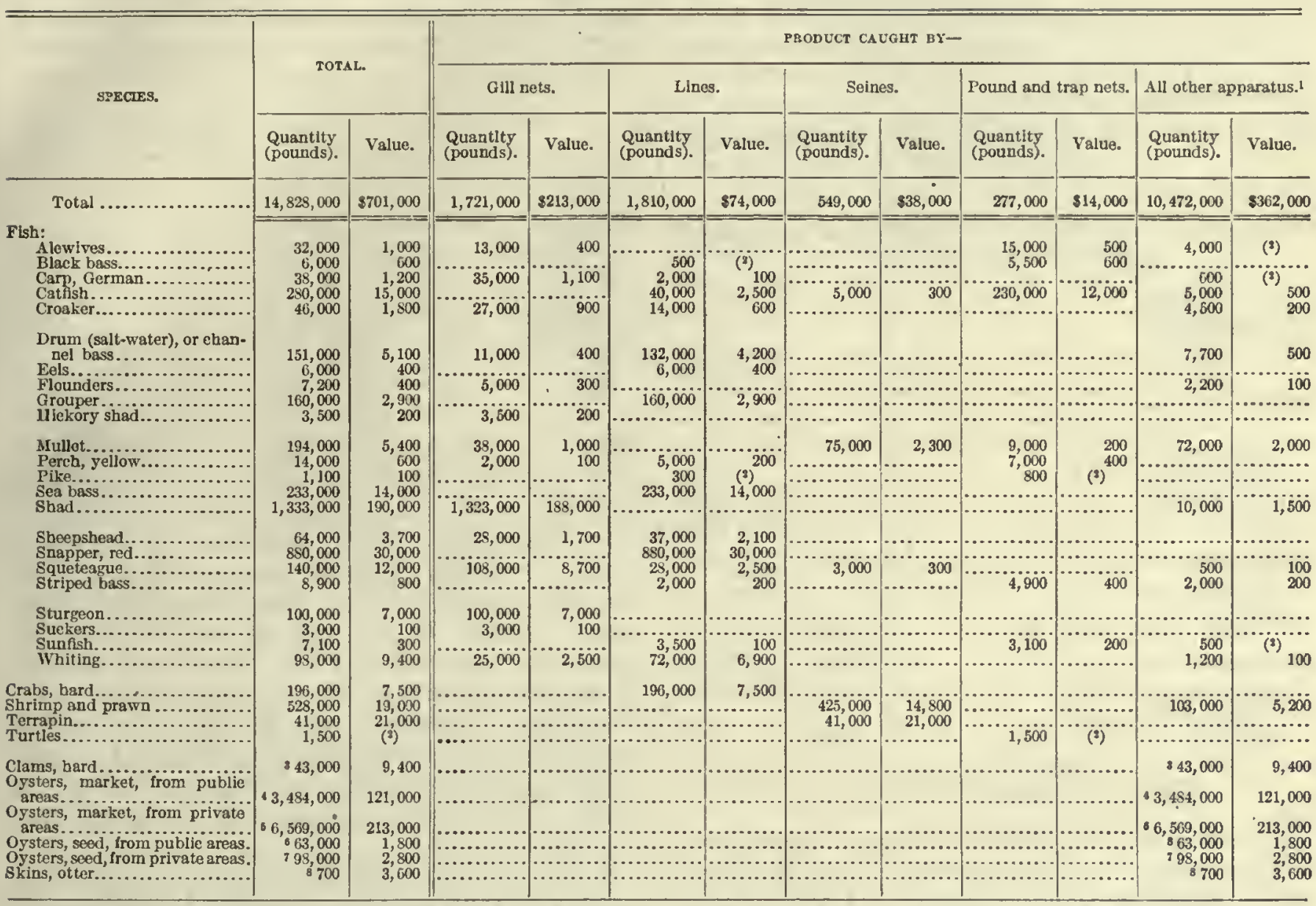

1 Ineludes apparatus, with eatch, as follows: Dredges, tongs, ete. $10,257,000$ pounds, valued at $\$ 348,000 ;$ cast nets, 187,000 pounds, valued at $\$ 7,900 ;$ otter traps, 700 pounds,

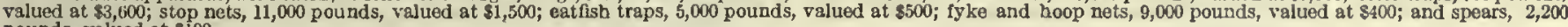
pounds, valued at $\$ 100$.

I I ss than $\$ 100$.

498,000 bushels. 638,000 bushels.
8,000 bushels.
7 14,000 bushels.

\section{ILLINOIS.}

In fishery products Illinois ranked fifteenth among the states in 1908. The catch of this state included a great variety of species, but the German carp represented considerably more than one-third and the products of the mussel fisheries almost one-fourth of the total, measured by value of products. The fishing grounds of the state are the Mississiippi and Ohio Rivers with their tributaries, and Lake Michigan.

The following statement is a general summary of the statistics for 1908:

Number of persons employed

Capital:

Vessels and boats, including outfit.............. $\$ 281,000$

Apparatus of capture..................... 272,000

Shore and accessory property and cash........... 295,000

Value of products..................... 1,436,000

Comparison with previous canvasses.-During the five years preceding 1908 a great impetus was given the fisheries of Illinois. The increase in the catch of German carp and in the quantity of mussel products obtained was marked. Many other species showed heavy increases and a few species were reported for the first time at the census of 1908 . The increase was general throughout all the fisheries of the state.

The main statistics for 1908 and for 1899 , as reported by the Bureau of Fisheries, are as follows:

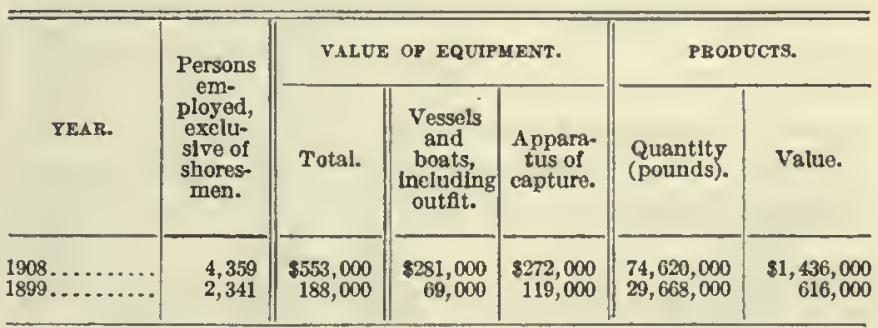

Persons employed.-The following table gives the statistics of the persons employed in the fisheries of Illinois, by district, class of fisheries, and condition of employment. The districts into which the fisheries are grouped are those of the Mississippi River and its tributaries, the Ohio River and its tributaries, and Lako Michigan. The district first mentioned includes the Illinois River, which furnished 60 per cent of the total products for the state. 


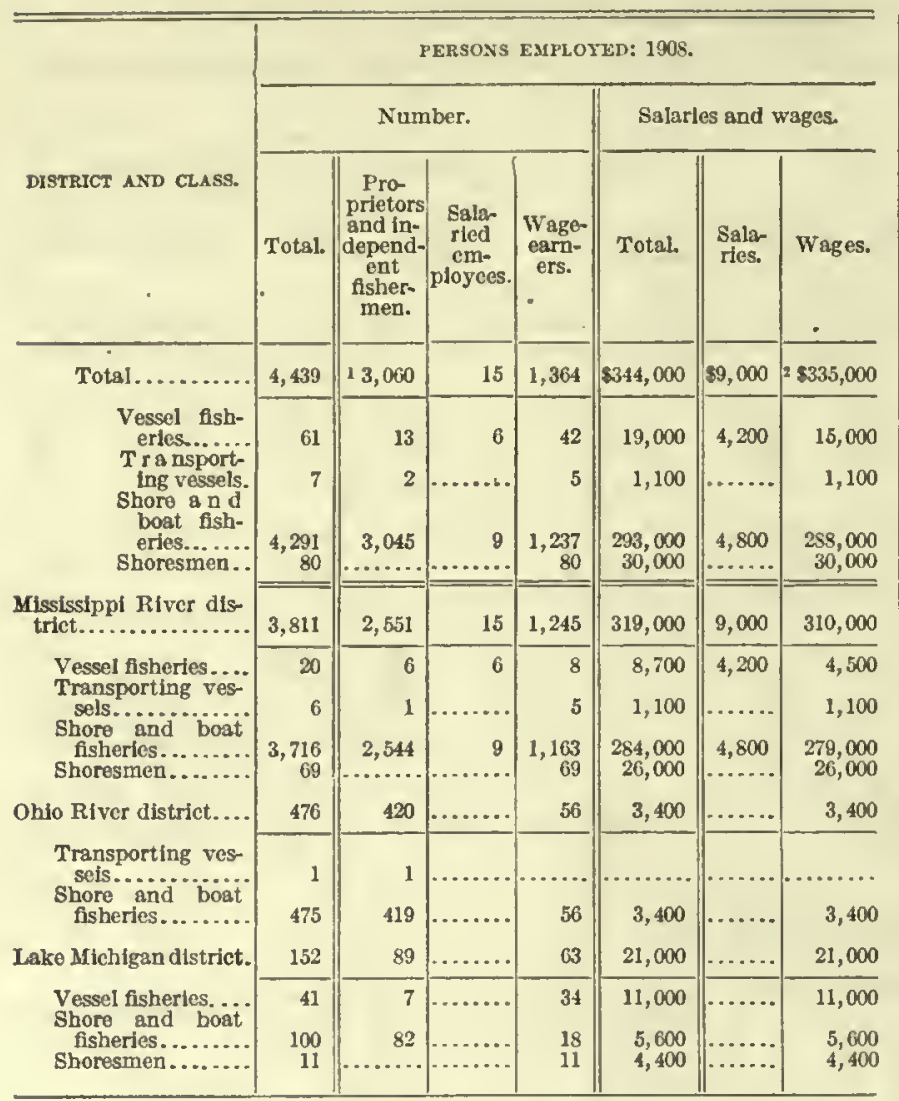

Exclusive of 24 proprietors not fishing.
Includes provlsions furnished to the value of $\$ 16,000$.

The fisheries of the Illinois River gave employment in the aggregate to 2,497 persons, or more than onehalf of the total number for the state. Of these, 1,504 were proprietors and independent fishermen, 6 were salaried employees, and 987 were wage-earners.

Equipment and other capital.-The distribution among the three districts of the value of equipment and other capital employed in the Illinois fisheries is shown in the following table:

\begin{tabular}{|c|c|c|c|c|}
\hline \multirow[b]{2}{*}{ CLASS OF INVESTMENT. } & \multicolumn{4}{|c|}{$\begin{array}{l}\text { VALUE OF EQUIPMENT AND OTHER } \\
\text { CAPITAL: } 1908 .\end{array}$} \\
\hline & Total. & $\begin{array}{l}\text { Missis- } \\
\text { sippl } \\
\text { River } \\
\text { district. }\end{array}$ & $\begin{array}{l}\text { Ohio } \\
\text { liver } \\
\text { district. }\end{array}$ & $\begin{array}{c}\text { Lake } \\
\text { Michl- } \\
\text { gan } \\
\text { district. }\end{array}$ \\
\hline Total... & 5849,000 & $\$ 747,000$ & $\$ 19,000$ & $\$ 83,000$ \\
\hline Vessels, including outfit.......... & 47,000 & 21,000 & 1,200 & 25,000 \\
\hline $\begin{array}{l}\text { Flshing (steam and motor). } \\
\text { Yessels }\end{array}$ & $\begin{array}{l}43,000 \\
33,000\end{array}$ & 18,000 & & 25,000 \\
\hline Out6t.................... & 9,800 & 7,500 & & $\begin{array}{r}23,000 \\
2,400\end{array}$ \\
\hline Transporting......... & 4,600 & 3,300 & $\dddot{1}, 200$ & 2,300 \\
\hline Steam and motor. & 3,400 & 2,600 & 800 & \\
\hline Vesscls....... & 2,900 & $\overline{2}, 100$ & 800 & \\
\hline & 500 & 500 & & \\
\hline 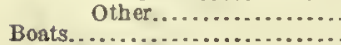 & 1,200 & 700 & $\begin{array}{r}400 \\
5,500\end{array}$ & \\
\hline Steam and motor.... & 155,000 & 148,000 & 1,400 & 5,100 \\
\hline $\begin{array}{l}\text { Sail.................... } \\
\text { Row.............. }\end{array}$ & 69,000 & 64000 & $\because$ ¿ion & 400 \\
\hline Other................. & 10,000 & 9,100 & & 1,000 \\
\hline A pparatus of capture. & 272,000 & 239,000 & $\ddot{8}, 900$ & 24,000 \\
\hline Vessel fisherfes............... & 23,000 & 5,300 & & 18,000 \\
\hline $\begin{array}{l}\text { Shore and hoat fisheries... } \\
\text { Shore and accessory property }\end{array}$ & 249,000 & 234,000 & 8,900 & 6,700 \\
\hline 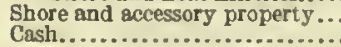 & 153,000 & 130,000 & 3,400 & 19,000 \\
\hline Cash.................................. & 142,000 & 135,000 & & 7,000 \\
\hline
\end{tabular}

The number and tonnage of the vessels and the number of boats reported for 1908 and the distribu- tion by districts is given in the following tabular statement:

\begin{tabular}{|c|c|c|c|c|}
\hline \multirow[b]{2}{*}{ CLASS OF CRAFT. } & \multicolumn{4}{|c|}{ VESSELS AND DOATS: 1908.} \\
\hline & Total. & $\begin{array}{l}\text { Missts- } \\
\text { slppl } \\
\text { River } \\
\text { distriet. }\end{array}$ & $\begin{array}{c}\text { Ohlo } \\
\text { RIver } \\
\text { distriet. }\end{array}$ & $\begin{array}{c}\text { Lake } \\
\text { Michl- } \\
\text { gan } \\
\text { distrlct. }\end{array}$ \\
\hline \multirow{6}{*}{ 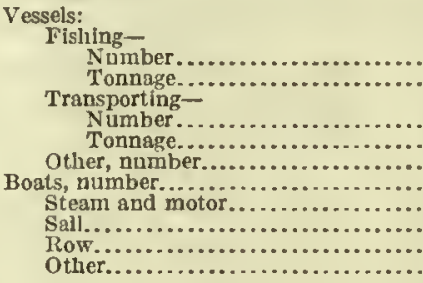 } & 12 & 5 & & 7 \\
\hline & $\begin{array}{r}3 \\
23\end{array}$ & $\begin{array}{r}29 \\
2 \\
13\end{array}$ & $\frac{1}{5}$ & 98 \\
\hline & 2 & $\frac{1}{3}$ & 1 & \\
\hline & 624 & ${ }^{0,004}$ & 12 & \\
\hline & $\begin{array}{r}8 \\
3,374\end{array}$ & $\dddot{2}, 8,80$ & 300 & $\begin{array}{r}8 \\
54\end{array}$ \\
\hline & & & & \\
\hline
\end{tabular}

The value of apparatus of eapture, of floating equipment, and that of shore and accessory property, combined with cash, each represents about a third of the total investment. Of the investment in shore and accessory property, $\$ 126,000$ pertained to shore and boat fisheries and $\$ 26,000$ to vessel fisheries and transporting vessels. Of the cash capital, $\$ 115,000$ was reported by the shore and boat fisheries and $\$ 27,000$ by the vessel fisheries. The total investment of the shore and boat fisheries was $\$ 725,000$, and that of vessel fisheries and transporting vessels was $\$ 124,000$.

Of the investment in floating equipment exclusive of outfits, $\$ 190,000$, or over 70 per cent, represents steam and motor boats.

The Illinois River fisheries employed $\$ 551,000$, or nearly two-thirds of the total capital for the state.

The number and distribution of the various kinds of apparatus of capture, as reported for 1908, were as follows:

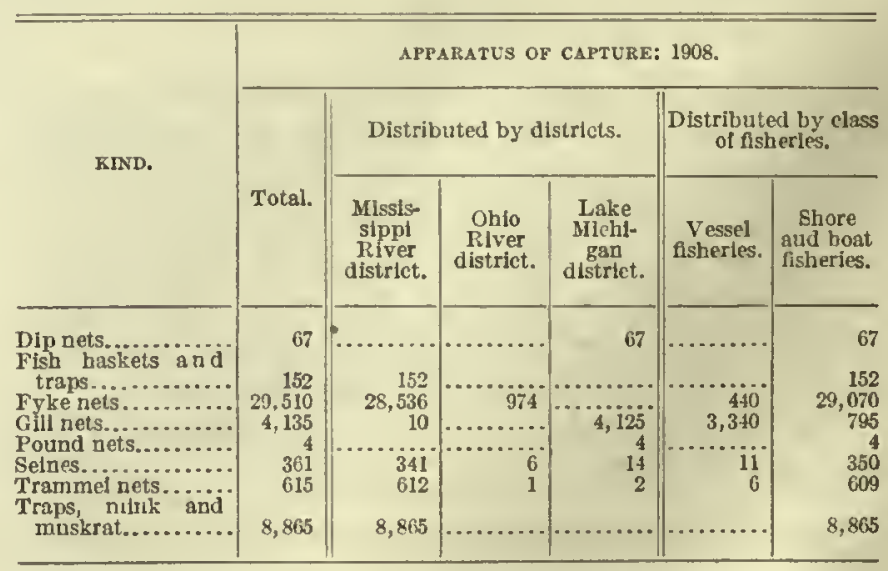

Products, by species.-The quantity and value of the fishery products of the state are given, by species and by apparatus of eapture, in Table 1, on page 117 .

The carp and mussel fisheries ranked far above all of the others in value and together contributed 65 per cent of the total value of the fishing product for the state.

Products, by fishing grounds.-Tables 2, 3, and 4, on pages 118 and 119 show the products, by species and 
apparatus of capture, for the Mississippi River, the Ohio River, and the Lake Michigan districts, respectively.

The following table shows the distribution of the value of the clief products for the fishery districts of tlie state:

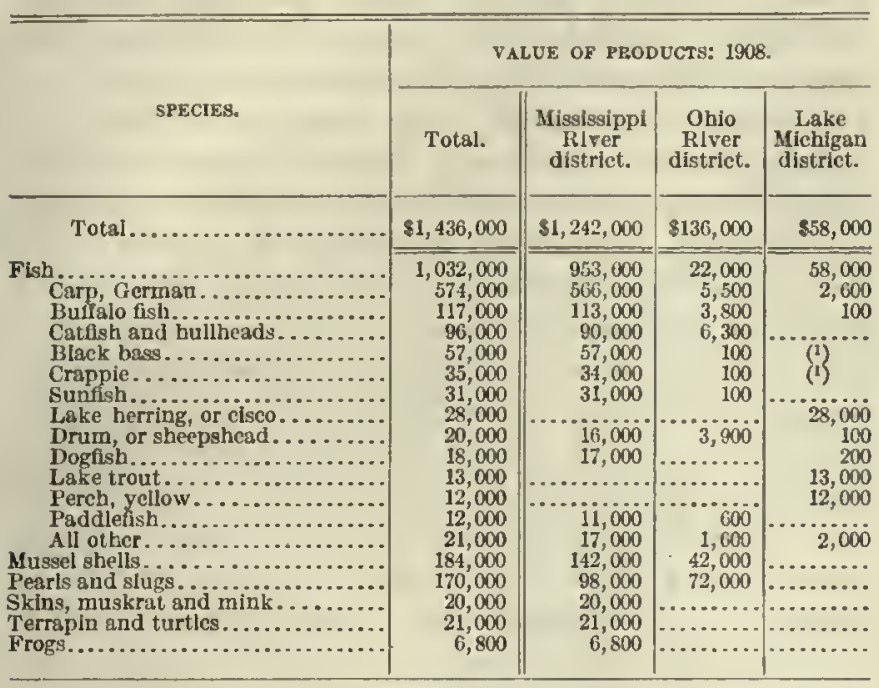

1 Less than $\$ 100$.

The most important tributary of the Mississippi River is the Illinois River. In 1894 the fishery product of the Illinois River was about 3,000 tons, valued at $\$ 162,000$, and formed about one-half of the yield of the Mississippi River district. In 1899 it formed about two-thirds, amounting to 7,000 tons, valued at $\$ 382,000$, and in 1908 it formed more than seven-tenths, amounting to 23,000 tons, valued at $\$ \$ 60,000$. The chief product of the Illinois River is German carp. The carp from this river in 1908 formed nenly three-fourths of the carp product for the state, and was valued at $\$ 412,000$, which is nearly as large as the combined value of all the other fishery products of this river.

The mussel products of the Illinois River were valued at $\$ 139,000$, or nearly 58 per cent of the value of the mussel products of the Mississippi River distriet, and nearly 40 per cent of the value of the mussel products of the state.

The fisheries of the Ohio River district have increased to a considerable extent, as is shown by the following comparative statement:

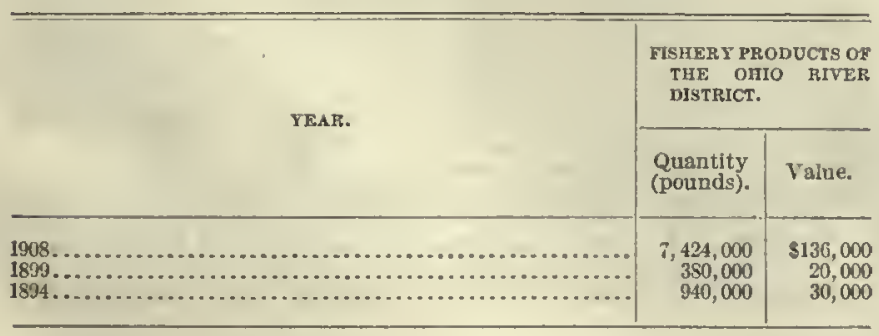

Prior to 1908 no mussel product entered into the total for this district. The extent of such products in 1908 accounts almost entirely for the large gains shown for that year, as compared with the earlier years. Carp, moreover, which in 1908 contributed one-fourth of the value of the fish product, formed only a small part of the product at each of the previous canvasses. In 1899 and in 1894 drum, buffalo fish, and catfish were leading species.

The increase in the products of the lake fisheries since the last canvass has been relatively large, as is shown in the following tabular statement:

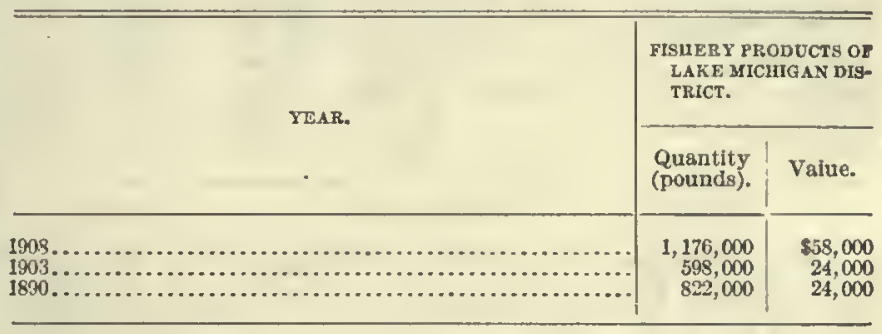

Products, by class of fisheries. - The distribution of the product between the vessel fisheries and the shore and boat fisheries by districts is shown in the following tabular statement:

\begin{tabular}{|c|c|c|c|c|}
\hline \multirow{3}{*}{ DISTRICT AND CLASS OF FISUERIES. } & \multicolumn{4}{|c|}{ FSUERY PRODUCTS: 1908.} \\
\hline & \multicolumn{2}{|c|}{ Quantity. } & \multicolumn{2}{|c|}{ Value. } \\
\hline & Pounds. & $\begin{array}{l}\text { Per cent } \\
\text { distrl- } \\
\text { butlon. }\end{array}$ & Amonnt. & $\begin{array}{c}\text { Per cant } \\
\text { distri- } \\
\text { butlon. }\end{array}$ \\
\hline Total......... & $74,620,000$ & 100 & $\$ 1,430,000$ & 100 \\
\hline Vessei fisheries..... & $2,983,000$ & 4 & 89,000 & 6 \\
\hline $\begin{array}{l}\text { Misslssippl River district ....... } \\
\text { Lake Michigan district. . ...... }\end{array}$ & $\begin{array}{r}2,484,000 \\
500,000\end{array}$ & 3 & $\begin{array}{l}61,000 \\
28,000\end{array}$ & $\begin{array}{l}4 \\
2\end{array}$ \\
\hline Shora and boat fisheries........... & $71,636,000$ & 96 & $1,347,000$ & 94 \\
\hline $\begin{array}{l}\text { Mlssissippl Rlver district....... } \\
\text { Ohio RIfer district............ } \\
\text { Laka Mlchigan district........ }\end{array}$ & $\begin{array}{r}63,536,000 \\
7,424,000 \\
677,000\end{array}$ & $\begin{array}{r}85 \\
10 \\
1\end{array}$ & $\begin{array}{r}1,181,000 \\
136,000 \\
30,000\end{array}$ & $\begin{array}{r}82 \\
9 \\
2\end{array}$ \\
\hline
\end{tabular}

The catch of the shore and boat fisheries comprised all but a small portion of the entire state product.

The products, by species and apparatus of capture, are given for the vessel fisheries in Table 5, on page 119 , and for the shore and boat fisheries in Table 6, on page 120 . The former table also distributes the products between the two districts which had vessel fisheries-the Mississippi River and the Lake Michigan districts.

By deducting the products of the vessel fisheries of the Mississippi River and Lake Michigan districts, as given in Table 5, on page 119 , from the corresponding items for all fishery products of those districts, as given in Tables 2 and 4, respectively, on pages 118 and 119, the specific products of the shore and boat fisheries of each of these districts can be ascertained. All of the products of the Olio River district, presented in Table 3 , bclong to the shore and boat fisheries. 
Products, by apparatus of capture.-'The distribution by apparatus of capture of the products of chief value for the respective districts is given in the following tabular statement:

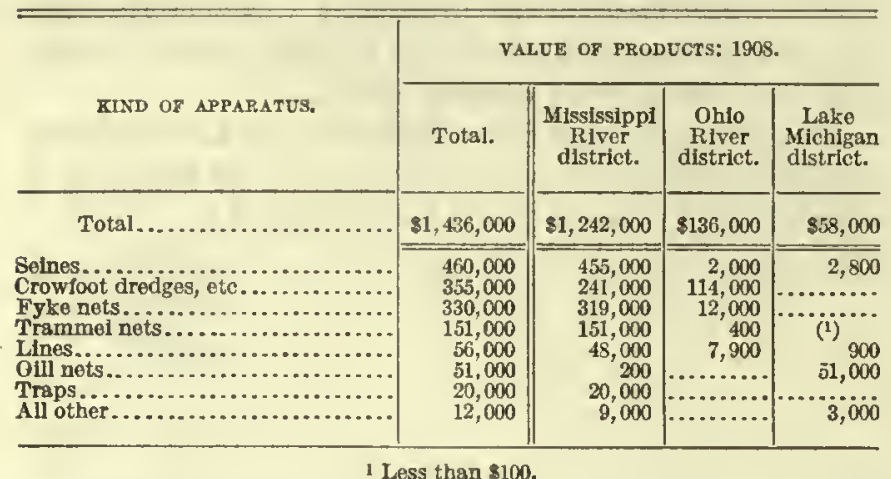

Crowfoot dredges, which are employed in the mussel fisheries, had the largest yield in weight and the second in value, while seines had the largest in value and the second in weight. Fyke nets were third in both weight and value of catch. Products valued at about 80 per cent of the total value of fishery products were taken by these three classes of apparatus. Gill-net fishing is practically confined to Lake Michigan, where nearly nine-tenths of the product for 1908 was taken in nets of this class.

German carp.-The value of the catch of German carp, $\$ 574,000$, formed 40 per cent of the value of the entire fishery product of the state, and was considerably more than the combined value of all of the other food fishes. The carp taken weighed 11,000 short tons, or more than one and one-half times the weight of all other food fishes taken in the state. A carp product was reported by every district, but much the largest amount was taken in the Mississippi River district. Of the total for that district, 7,700 tons, valued at $\$ 412,000$, were taken in the Illinois River.

Approximately three-fourths of the carp reported at previous canvasses as caught in the Mississippi River district came from the Illinois River. One-half or more of the growth in the fishery product of the state can be credited to the growth in the catch of carp. In 1894 buffalo, catfish, and fresh-water drum had a heavier and more valuable yield than carp, but in 1899 carp led for the first time.

\begin{tabular}{|c|c|c|c|}
\hline & \multirow{2}{*}{ YEAR. } & \multicolumn{2}{|c|}{$\begin{array}{l}\text { GERMAN-CARP } \\
\text { PRODUCT. }\end{array}$} \\
\hline & & $\begin{array}{l}\text { Quantity } \\
\text { (pounds). }\end{array}$ & Value. \\
\hline $\begin{array}{l}1908 \ldots \\
1903 \ldots \\
1899 . . \\
1894 \ldots\end{array}$ & 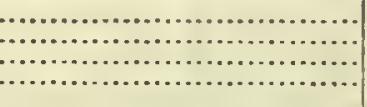 & $\begin{array}{r}21,642,000 \\
7,650,000 \\
9,896,000 \\
860,000\end{array}$ & $\begin{array}{r}\$ 574,000 \\
176,000 \\
244,000 \\
21,000\end{array}$ \\
\hline
\end{tabular}

The German carp was introduced into the Illinois River as late as 1880. At first it was despised, and when a fish of this speeies was caught inadvertently it was generally thrown back into the river. These early years of unmolested opportunity, given to a fish of such fecundity and hardihoorl, produced large results later. Much hostility was manifested toward the carp by sportsmen, and no demand for it as a food was apparent for some years after its introduction. But the Illinois commission began a vigorous defense of the carp and conducted what was almost a campaign of education, instructing sportsmen in the habits of the carp and fish dealers in its food value. Recipes for preparing the flesh for table use and for making jellies and other delicacies were published, testimony as to the epicurean qualities of these preparations was collected and printed, menus containing carp served in various ways at famous hostelries were lithographed and distributed, and statistics of the production and consumption of the fish in other countries were made known. In a relatively short time fishermen turned their attention to the carp, and as early as 1899 the weight of the carp taken was nearly equal to that of all other food fishes combined.

Carp are taken with a great variety of apparatus, although one-half of the catch was with seines. Contrary to the general impression, lines are efficacious in their capture, and of the commercial product, carp to the value of $\$ 17,000$ were so taken.

Mussels. - The mussel fisheries had a product second in value to that of carp. The value of the shells, pearls, and slugs obtained in the state amounted to $\$ 355,000$, or 25 per cent of the value of all products. Of this amount, $\$ 114,000$ is credited to the fisheries of the Ohio River district and $\$ 241,000$ to those of the Mississippi River district. The value of the products of the Illinois River, amounting to $\$ 139,000$, formed the larger portion of the value reported for the Mississippi River district. The increase in the yield of mussels was even more rapid than that in the catcls of carp. The product in 1894, 1899, and 1908 was as follows:

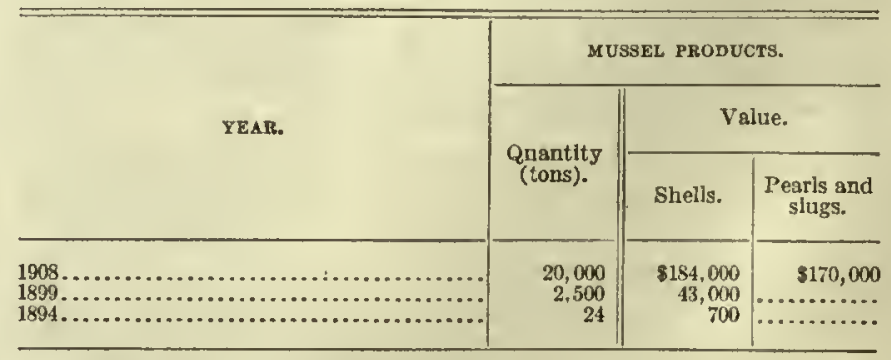

Buffalo fish.--The buffalo fish, which led before carp attained first place, ranked second in value among the 
food fishes in 1908, and its value formed 8 per-cent of the total value of products. Buffalo fish are taken in all districts, but 90 per cent of the catch in 1908 was from the Mississippi River district. The yield of buffalo fish decreased in quantity, but a recovery in prices arrested the decrease in the value of the catch. Buffalo fish are taken principally with scines and fyke nets.

The product for 1894, 1899, and 1908 is shown below:

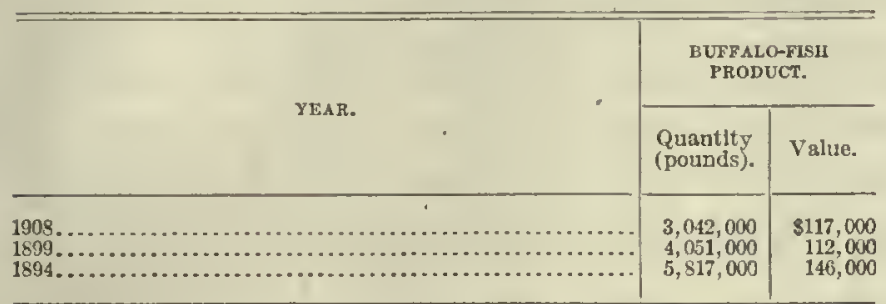

Catfish.-Catfish was fourth in importance, and the product for 1908 and prior years is shown in the next column.

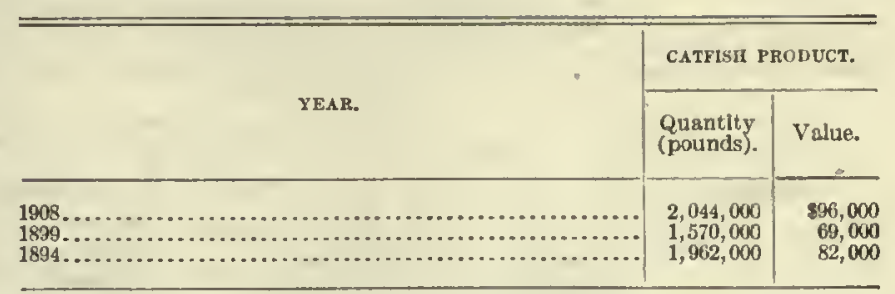

Black bass.--Black bass is a valuable food fish that is taken chiefly in the Mississippi River district. Nearly one-half of the catch is by seines. 'That there has bcen a notable increase in the quantity caught is shown by the following tabular statement:

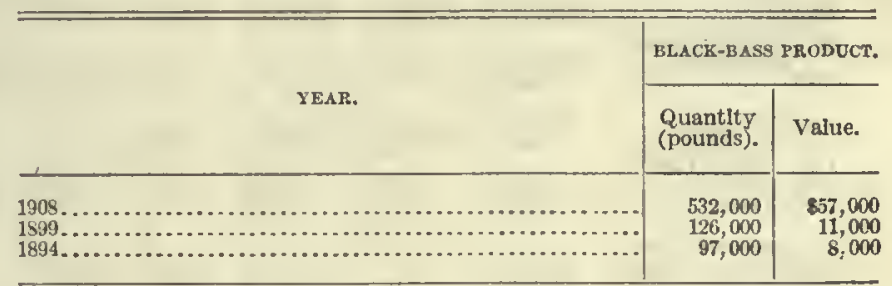

TABLE 1.-ILLINOIS-FISHERY PRODUCTS: 1908.

\begin{tabular}{|c|c|c|c|c|c|c|c|c|c|c|c|c|c|c|}
\hline \multirow{3}{*}{ SPECIES. } & \multirow{2}{*}{\multicolumn{2}{|c|}{ TOTAL. }} & \multicolumn{12}{|c|}{ PRODUCT CAUOHT BY- } \\
\hline & & & \multicolumn{2}{|c|}{ Scines. } & \multicolumn{2}{|c|}{ Fyke nets. } & \multicolumn{2}{|c|}{ Trammel nets. } & \multicolumn{2}{|c|}{ Lines. } & \multicolumn{2}{|c|}{ Gill nets. } & \multicolumn{2}{|c|}{$\begin{array}{l}\text { All other appa } \\
\text { ratus. }{ }^{1}\end{array}$} \\
\hline & $\begin{array}{l}\text { Quantity } \\
\text { (pounds). }\end{array}$ & Value. & $\begin{array}{l}\text { Quantity } \\
\text { (pounds). }\end{array}$ & Value. & $\begin{array}{l}\text { Quantity } \\
\text { (pounds). }\end{array}$ & Value. & $\begin{array}{l}\text { Quantity } \\
\text { (pounds). }\end{array}$ & Value. & $\begin{array}{l}\text { Quantity } \\
\text { (pounds). }\end{array}$ & Vaine. & $\begin{array}{l}\text { Quantity } \\
\text { (pounds). }\end{array}$ & Value. & $\begin{array}{l}\text { Quantity } \\
\text { (pounds). }\end{array}$ & Value. \\
\hline Total... & $74,620,000$ & $\$ 1,436,000$ & $15,945,000$ & $\$ 460,000$ & $11,370,000$ & $\$ 330,000$ & $5,100,000$ & $\$ 151,000$ & $1,242,000$ & $\$ 56,000$ & 962,000 & $\$ 51,000$ & $40,001,000$ & $\$ 387,000$ \\
\hline $\begin{array}{l}\text { Fish: } \\
\text { Black bass............ } \\
\text { Buffalo fish......... } \\
\text { Carp, German..... } \\
\text { Catfish and bull- }\end{array}$ & $\begin{array}{r}532,000 \\
3,042,000 \\
21,642,000\end{array}$ & $\begin{array}{r}57,000 \\
117,000 \\
574,000\end{array}$ & $\begin{array}{r}220,000 \\
1,227,000 \\
10,957,000\end{array}$ & $\begin{array}{r}25,000 \\
49,000 \\
291,000\end{array}$ & $\begin{array}{r}100,000 \\
1,153,000 \\
6,891,000\end{array}$ & $\begin{array}{r}9,900 \\
44,000 \\
185,000\end{array}$ & $\begin{array}{r}114,000 \\
598,000 \\
3,175,000\end{array}$ & $\begin{array}{l}11,000 \\
22,000 \\
81,000\end{array}$ & $\begin{array}{r}98,000 \\
62,000 \\
604,000\end{array}$ & $\begin{array}{r}11,000 \\
2,400 \\
17,000\end{array}$ & $\begin{array}{r}300 \\
1,800 \\
2,200\end{array}$ & $\begin{array}{l}(2) \\
100 \\
100\end{array}$ & $\begin{array}{r}200 \\
800 \\
13,000\end{array}$ & $\stackrel{(2)}{(2)}_{400}$ \\
\hline $\begin{array}{c}\text { heads................ } \\
\text { Crappie........... }\end{array}$ & $\begin{array}{l}2,044,000 \\
1,281,000\end{array}$ & $\begin{array}{l}96,000 \\
35,000\end{array}$ & $\begin{array}{l}811,000 \\
575,000\end{array}$ & $\begin{array}{l}34.000 \\
16,000\end{array}$ & $\begin{array}{l}625,000 \\
515,000\end{array}$ & $\begin{array}{l}29,000 \\
13,000\end{array}$ & $\begin{array}{l}319,000 \\
174,000\end{array}$ & $\begin{array}{r}15,000 \\
5,000\end{array}$ & $\begin{array}{r}283,000 \\
16,000\end{array}$ & $\begin{array}{r}17,000 \\
700\end{array}$ & $\begin{array}{r}500 \\
-\quad 200\end{array}$ & $\begin{array}{l}(2) \\
(2)\end{array}$ & $\begin{array}{r}5,400 \\
400\end{array}$ & $\left(3^{200}\right.$ \\
\hline $\begin{array}{l}\text { Dogfish............ } \\
\text { Drum (fresh-water), }\end{array}$ & $1,370,000$ & 18,000 & 702,000 & 9,100 & 485,000 & 6,000 & 162,000 & 2,200 & 20,000 & 300 & 400 & (2) & 500 & $\left({ }^{2}\right)$ \\
\hline $\begin{array}{l}\text { or sheepshead..... } \\
\text { Eels.............. } \\
\text { Lake herring, or cisco. } \\
\text { Lake trout........... }\end{array}$ & $\begin{array}{r}666,000 \\
31,000 \\
508,000 \\
150,000\end{array}$ & $\begin{array}{r}20,000 \\
1,800 \\
28.000 \\
13,000\end{array}$ & $\begin{array}{r}167,000 \\
7,200 \\
\cdots\end{array}$ & $\begin{array}{r}4,700 \\
400\end{array}$ & $\begin{array}{r}312,000 \\
12,000\end{array}$ & $\begin{array}{r}9,700 \\
600 \\
\cdots \cdots \\
\cdots\end{array}$ & $\begin{array}{l}106,000 \\
6,500 \\
\text { (3) }\end{array}$ & $\begin{array}{c}2,800 \\
300 \\
(2) \\
\cdots \cdots\end{array}$ & $\begin{array}{r}76,000 \\
5,400 \\
300 \\
100\end{array}$ & $\begin{array}{l}2,800 \\
500 \\
(2) \\
(3)\end{array}$ & $\begin{array}{r}1,800 \\
573,000 \\
148,000\end{array}$ & $\begin{array}{r}100 \\
27,000 \\
12,000\end{array}$ & $\begin{array}{r}2,700 \\
100 \\
24,000 \\
2,300\end{array}$ & $\begin{array}{l}100 \\
(2)^{800} \\
200\end{array}$ \\
\hline $\begin{array}{l}\text { Ling, or celpout ..... } \\
\text { Paddlefish.......... }\end{array}$ & $\begin{array}{r}27,000 \\
402,000\end{array}$ & $\begin{array}{r}600 \\
12,000\end{array}$ & 289,000 & 8,700 & 84,000 & 2,300 & 30,000 & $\ddot{1}, 100$ & $\begin{array}{l}500 \\
400\end{array}$ & (2) & & 500 & 1,000 & (2) \\
\hline $\begin{array}{l}\text { Perch, yellow.... } \\
\text { Pike and pickerel... }\end{array}$ & $\begin{array}{r}238,000 \\
14,000\end{array}$ & $\begin{array}{r}12,000 \\
1,100\end{array}$ & 5,000 & 300 & 2,300 & 200 & $\begin{array}{r}200 \\
2,600\end{array}$ & ${ }^{(2)} 200$ & $\begin{array}{r}21,000 \\
3,400\end{array}$ & $\begin{array}{l}900 \\
300\end{array}$ & $\begin{array}{r}193,000 \\
400\end{array}$ & $\begin{array}{c}10,000 \\
(2)\end{array}$ & $\begin{array}{r}25,000 \\
200\end{array}$ & $\begin{array}{l}1,400 \\
(2)\end{array}$ \\
\hline $\begin{array}{l}\text { Plke perch (wall - } \\
\text { eyed pike)......... } \\
\text { Rock bass.......... } \\
\text { Sturgoon and caviar }\end{array}$ & $\begin{array}{r}14,000 \\
6,200\end{array}$ & $\begin{array}{r}1,500 \\
800\end{array}$ & $\begin{array}{r}1,700 \\
400\end{array}$ & $\left(^{100}\right.$ & $\begin{array}{l}900 \\
900\end{array}$ & $\begin{array}{l}100 \\
100\end{array}$ & $\begin{array}{l}400 \\
600\end{array}$ & $\left(\begin{array}{l}2 \\
(3)\end{array}\right)$ & $\begin{array}{r}11,000 \\
4,200\end{array}$ & $\begin{array}{r}1,300 \\
600\end{array}$ & ${ }_{100}^{(2)}$ & $\left(\begin{array}{l}2 \\
2\end{array}\right)$ & $\cdots \cdots \cdot \cdot \cdot$ & $\therefore$ \\
\hline $\begin{array}{l}\text { and sturgeon eggs } 4 . \\
\text { suckers................ }\end{array}$ & $\begin{array}{r}180,000 \\
-281,000\end{array}$ & $\begin{array}{l}7,300 \\
6,400\end{array}$ & $\begin{array}{l}45,000 \\
72,000\end{array}$ & $\begin{array}{l}1,600 \\
1,300\end{array}$ & $\begin{array}{r}30,000 \\
128,000\end{array}$ & $\begin{array}{r}800 \\
3,000\end{array}$ & $\begin{array}{l}79,000 \\
74,000\end{array}$ & $\begin{array}{l}3,800 \\
1,800\end{array}$ & $\begin{array}{r}26,000 \\
1,400\end{array}$ & $\begin{array}{l}1,100 \\
(2)\end{array}$ & 2,000 & $\stackrel{(2)}{100}$ & 2,200 & 100 \\
\hline $\begin{array}{l}\text { Sunfish, or brearn.... } \\
\text { Whitc bass.......... } \\
\text { Whitefish .......... } \\
\text { All other......... }\end{array}$ & $\begin{array}{r}1,714,000 \\
6,900 \\
13,000 \\
2,900\end{array}$ & $\begin{array}{r}31,000 \\
300 \\
800 \\
100\end{array}$ & $\begin{array}{r}606,000 \\
2,500\end{array}$ & $\begin{array}{r}13,000 \\
100\end{array}$ & $\begin{array}{r}767,000 \\
1,200\end{array}$ & $\begin{array}{r}13,000 \\
100 \\
\ldots .\end{array}$ & $\begin{array}{r}241,000 \\
2,800\end{array}$ & $\begin{array}{l}4,600 \\
(2)\end{array}$ & $\begin{array}{r}0,500 \\
200\end{array}$ & $\begin{array}{l}300 \\
\left({ }^{2}\right)\end{array}$ & $\begin{array}{r}200 \\
100 \\
9,300 \\
1,600\end{array}$ & $\begin{array}{l}(2) \\
(2) \\
500 \\
100\end{array}$ & $\begin{array}{r}200 \\
3,500 \\
1,300\end{array}$ & $\begin{array}{l}(2) \\
(2)\end{array}$ \\
\hline Frogs....................... & $\begin{array}{r}25,000 \\
205,000\end{array}$ & $\begin{array}{r}6,800 \\
13,000\end{array}$ & 79,000 & 3,000 & 123,000 & 10,000 & $3.800^{\circ}$ & 100 & & & & & 25,000 & $\begin{array}{r}6,800 \\
\ldots .\end{array}$ \\
\hline 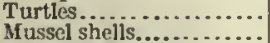 & $\begin{array}{r}396,000 \\
39,809,000\end{array}$ & $\begin{array}{r}8,100 \\
184,000\end{array}$ & 88,000 & 2,400 & 141,000 & 3,700 & 11,000 & 300 & & & 200 & (2) & $\begin{array}{r}66,000 \\
39,809,000\end{array}$ & $\begin{array}{r}1,700 \\
184,000\end{array}$ \\
\hline Pearls and slugs. ......... & (as, ous, wo & 170,000 & 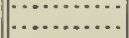 & an...... & 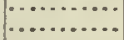 & (n........... & an. & …..... & $\cdots$ & $\cdots$ & $\cdots . . .8$. & & & 170,000 \\
\hline $\begin{array}{l}\text { Skins, mink ............ } \\
\text { Skins, muskrat......... }\end{array}$ & $\begin{array}{r}81,000 \\
617,000\end{array}$ & $\begin{array}{r}6,000 \\
14,000\end{array}$ & (n.... & & & & & & & & & & $\begin{array}{r}81,900 \\
617,000\end{array}$ & $\begin{array}{r}6,000 \\
14,000\end{array}$ \\
\hline
\end{tabular}

1 Includes apparatus, with catch, as follows: Crowfoot dredges, etc., 30,800,000 pounds, valued at $\$ 55,000 ;$ traps, 19,000 pounds, valued at $\$ 20,000 ;$ dip nets, 35,000 Dounds,

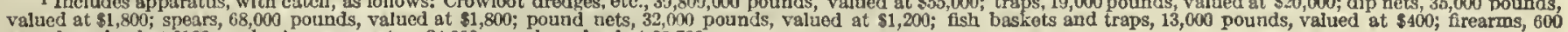
pounds, valued at $\$ 100$; and minor apparatus, 24,000 pounds, valued at $\$ 5,700$.

2 Iess than $\$ 100$.

4 Includes 1,300 pound of caviar and sturgeon eggs, valued at $\$ 800$. 
TABLE 2.-ILLINOIS-FISHERY PRODUCTS OF MISSISSIPPI RIVER DISTRICT: 1908.

\begin{tabular}{|c|c|c|c|c|c|c|c|c|c|c|c|c|c|c|}
\hline \multirow{3}{*}{ SPECIES. } & \multirow{2}{*}{\multicolumn{2}{|c|}{ TOTAL. }} & \multicolumn{12}{|c|}{ PRODUCT CAUGHT BY- } \\
\hline & & & \multicolumn{2}{|c|}{ Selnes. } & \multicolumn{2}{|c|}{ Fyke nets. } & \multicolumn{2}{|c|}{ Tranimel nets. } & \multicolumn{2}{|c|}{ Lines. } & \multicolumn{2}{|c|}{ Gill uets. } & \multicolumn{2}{|c|}{$\begin{array}{l}\text { All other appa- } \\
\text { ratus. } 1\end{array}$} \\
\hline & $\begin{array}{l}\text { Quantity } \\
\text { (pounds). }\end{array}$ & Value. & $\begin{array}{l}\text { Quantity } \\
\text { (pounds). }\end{array}$ & Value. & $\begin{array}{l}\text { Quantity } \\
\text { (pounds). }\end{array}$ & Value. & $\begin{array}{l}\text { Quantity } \\
\text { (pounds). }\end{array}$ & Value. & $\begin{array}{l}\text { Quantity } \\
\text { (pounds). }\end{array}$ & Vaine. & $\begin{array}{l}\text { Quantity } \\
\text { (pounds). }\end{array}$ & Value. & $\begin{array}{l}\text { Quantity } \\
\text { (pounds). }\end{array}$ & Value. \\
\hline Total... & $66,020,000$ & $\$ 1,242,000$ & $15,766,000$ & $\$ 455,000$ & $11,088,000$ & $\$ 319,000$ & $5,088,000$ & $\$ 151,000$ & $1,059,000$ & $\$ 48,000$ & 7,000 & $\$ 200$ & $33,012,000$ & $\$ 270,000$ \\
\hline $\begin{array}{l}\text { Fish: } \\
\text { Blaek hass........... } \\
\text { Buffalo fish........ } \\
\text { Carr, German .... } \\
\text { Cathsh and buil- } \\
\text { heads.................... }\end{array}$ & $\begin{array}{r}532,000 \\
2,919,000 \\
21,390,000 \\
1,943,000\end{array}$ & $\begin{array}{r}57,000 \\
113,000 \\
566,000\end{array}$ & $\begin{array}{r}220,000 \\
1,214,000 \\
10,830,000\end{array}$ & $\begin{array}{r}25,000 \\
48,000 \\
258,000 \\
34,000\end{array}$ & $\begin{array}{r}100,000 \\
1,094,000 \\
6,804,000\end{array}$ & $\begin{array}{r}9,800 \\
11,000 \\
181,000 \\
28,000\end{array}$ & $\begin{array}{r}114.000 \\
590,000 \\
3,175,000 \\
319,000\end{array}$ & $\begin{array}{l}11,000 \\
21,000 \\
81,000 \\
15,000\end{array}$ & $\begin{array}{r}98,000 \\
49,000 \\
571,000 \\
212,000\end{array}$ & $\begin{array}{r}11,000 \\
1,900 \\
15,000 \\
13,000\end{array}$ & $\begin{array}{r}300 \\
1,800 \\
2,000 \\
600\end{array}$ & $\begin{array}{l}\text { (2) } \\
100 \\
(2) \\
(2)\end{array}$ & $\begin{array}{r}200 \\
300 \\
8,000 \\
5,400\end{array}$ & $\begin{array}{l}\text { (3) } \\
\text { (3) } \\
300 \\
200\end{array}$ \\
\hline 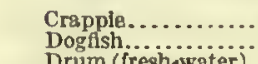 & $\begin{array}{l}1,279,060 \\
1,359,060\end{array}$ & $\begin{array}{l}34,000 \\
17,000\end{array}$ & $\begin{array}{l}575,000 \\
692,000\end{array}$ & $\begin{array}{r}16,000 \\
9,000\end{array}$ & $\begin{array}{l}514,000 \\
485,000\end{array}$ & $\begin{array}{r}13,000 \\
6,000\end{array}$ & $\begin{array}{l}174,000 \\
162,000\end{array}$ & $\begin{array}{l}5,000 \\
2,200\end{array}$ & $\begin{array}{l}16,000 \\
20,000\end{array}$ & $\begin{array}{l}700 \\
300\end{array}$ & $\begin{array}{l}200 \\
400\end{array}$ & $\left(\begin{array}{l}\text { (2) } \\
(3)\end{array}\right)$ & $\begin{array}{l}400 \\
500\end{array}$ & (3) \\
\hline $\begin{array}{l}\text { or sheepshead...... } \\
\text { Eels.................... }\end{array}$ & $\begin{array}{r}569,000 \\
30,000\end{array}$ & $\begin{array}{r}16,000 \\
1,800\end{array}$ & $\begin{array}{r}156,000 \\
7,200\end{array}$ & $\begin{array}{r}4,300 \\
400\end{array}$ & $\begin{array}{r}259,000 \\
12,000\end{array}$ & $\begin{array}{r}7,400 \\
600\end{array}$ & $\begin{array}{r}106,000 \\
6,500\end{array}$ & $\begin{array}{r}2,800 \\
300\end{array}$ & $\begin{array}{r}48,000 \\
5,300\end{array}$ & $\begin{array}{r}1,600 \\
500\end{array}$ & 500 & (a) & 300 & (2) \\
\hline $\begin{array}{l}\text { Paddleftsh } \\
\text { Plke and plekerei.... } \\
\text { Plke perch (wall- }\end{array}$ & $\begin{array}{r}374,000 \\
13,000\end{array}$ & $\begin{array}{r}11,000 \\
1,100\end{array}$ & $\begin{array}{r}283,000 \\
5,000\end{array}$ & $\begin{array}{r}8,000 \\
300\end{array}$ & $\begin{array}{r}62,000 \\
2,300\end{array}$ & $\begin{array}{r}1,800 \\
200\end{array}$ & $\begin{array}{r}30,000 \\
2,600\end{array}$ & $\begin{array}{r}1,100 \\
200\end{array}$ & $\begin{array}{r}400 \\
3,400\end{array}$ & (3) 300 & & & & \\
\hline $\begin{array}{r}\text { eyed pike }) . . . . . \\
\text { Rock bass.......... }\end{array}$ & $\begin{array}{r}12,000 \\
4,800\end{array}$ & $\begin{array}{r}1,400 \\
700\end{array}$ & $\begin{array}{r}1,700 \\
300\end{array}$ & $\left(3^{100}\right.$ & $\begin{array}{l}300 \\
100\end{array}$ & $\left.\begin{array}{l}(3) \\
(3)\end{array}\right)$ & $\begin{array}{l}400 \\
200\end{array}$ & (9) & $\begin{array}{l}9,900 \\
4,200\end{array}$ & $\begin{array}{r}1,200 \\
600\end{array}$ & 1000 & (i) & & \\
\hline 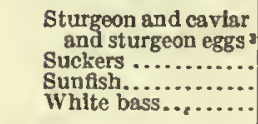 & $\begin{array}{r}161,000 \\
240,000 \\
1,712,000 \\
6,900\end{array}$ & $\begin{array}{r}6,900 \\
5,100 \\
31,000 \\
300\end{array}$ & $\begin{array}{r}45,000 \\
67,000 \\
696,000 \\
2,600\end{array}$ & $\begin{array}{r}1,600 \\
1,200 \\
13,000 \\
100\end{array}$ & $\begin{array}{r}25,000 \\
99,000 \\
766,000 \\
1,200\end{array}$ & $\begin{array}{r}700 \\
2,200 \\
13,000 \\
100\end{array}$ & $\begin{array}{r}79,000 \\
72,000 \\
211,000 \\
2,800\end{array}$ & $\begin{array}{l}3,800 \\
1,800 \\
4,600 \\
\text { (3) }\end{array}$ & $\begin{array}{r}11,000 \\
1,400 \\
9,500 \\
200\end{array}$ & $\begin{array}{c}800 \\
(3) \\
300 \\
(3)\end{array}$ & $\begin{array}{l}200 \\
500 \\
200 \\
100\end{array}$ & $\begin{array}{l}(2) \\
\text { (2) } \\
\text { (2) } \\
\text { (3) }\end{array}$ & $\begin{array}{l}1000 \\
200\end{array}$ & $\begin{array}{l}(3) \\
\text { (3) }\end{array}$ \\
\hline 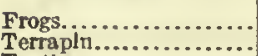 & $\begin{array}{r}25,000 \\
205,000\end{array}$ & $\begin{array}{r}6,800 \\
13,000\end{array}$ & 79,000 & 3,000 & 123,000 & 10,000 & 3,800 & 100 & & & & & 25,000 & 6,800 \\
\hline 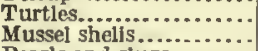 & $\begin{array}{r}306,000 \\
32,887,000\end{array}$ & $\begin{array}{r}8,100 \\
142,000\end{array}$ & 88,000 & 2,400 & 141,000 & 3,700 & 11,000 & 300 & & & $200^{\circ}$ & (3) & $32,887,000$ & $\begin{array}{r}1,700 \\
142,000\end{array}$ \\
\hline $\begin{array}{l}\text { Pearls an } \\
\text { Skins, m! }\end{array}$ & $\because 1,900^{\circ}$ & $\begin{array}{r}98,000 \\
6,000\end{array}$ & & & & & & & & & & & $\because 1.900$ & $\begin{array}{r}98,000 \\
6,000\end{array}$ \\
\hline Skins, muskrat. & $\begin{array}{l}b \\
17,000\end{array}$ & 14,000 & & & & & & & & & & & $\therefore 17,000$ & 14,000 \\
\hline
\end{tabular}

1 Ineludes apparatus, with cateh, as follows: Crowloot dredges, ete, , 32,897,000 pounds, valued at $\$ 2: 11,000 ;$ traps, 19,000 pounds, valued at $\$ 20,000 ;$ spears, 67,000 pounds, valued at $\$ 1,800$; fish baskets or traps, 13,000 pounds, valued at $\$ 400$; firearms, 600 pounds, valued at $\$ 100$; and minor apparatus, 24,000 pounds, valued et $\$ 6,700$.

Ineludes 1,300 pounds of caviar and sturgeon eggs, valued at $\$ 800$. $5,0,200$ skins.

TABLE 3.-HLINOIS-FISHERY PRODUCTS OF ,OHIO RIVER DISTRICT: 1908.

\begin{tabular}{|c|c|c|c|c|c|c|c|c|c|c|c|c|}
\hline \multirow{3}{*}{ SPECIES. } & \multirow{2}{*}{\multicolumn{2}{|c|}{ Total. }} & \multicolumn{10}{|c|}{ PRODUCT CAU } \\
\hline & & & \multicolumn{2}{|c|}{ Seines. } & \multicolumn{2}{|c|}{ Fyke nets. } & \multicolumn{2}{|c|}{ Trammel nets. } & \multicolumn{2}{|c|}{ Lines. } & \multicolumn{2}{|c|}{ Crowfoot dredges, ete } \\
\hline & $\begin{array}{l}\text { Quantity } \\
\text { (pounds). }\end{array}$ & Value. & $\begin{array}{l}\text { Quantity } \\
\text { (pounds). }\end{array}$ & Value. & $\begin{array}{l}\text { Quantity } \\
\text { (pounds). }\end{array}$ & Value. & $\begin{array}{l}\text { Quantity } \\
\text { (pounds). }\end{array}$ & Value. & $\begin{array}{l}\text { Quantity } \\
\text { (pounds). }\end{array}$ & Value. & $\begin{array}{l}\text { Quantity. } \\
\text { (pounds). }\end{array}$ & Value. \\
\hline Total......... & $7,424,000$ & $\$ 136,000$ & 47,000 & $\$ 2,000$ & 282,000 & $\$ 12,000$ & 11,000 & $\$ 400$ & 162,000 & $\$ 7,900$ & $6,922,000$ & $\$ 114,000$ \\
\hline 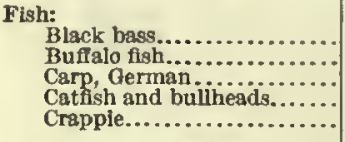 & $\begin{array}{r}600 \\
91,000 \\
132,000 \\
100,000 \\
1,600\end{array}$ & $\begin{array}{r}100 \\
3,800 \\
5,500 \\
6,300 \\
100\end{array}$ & $\begin{array}{r}10,0000 \\
12,000 \\
6,000 \\
500\end{array}$ & $\begin{array}{l}400 \\
500 \\
400 \\
(1)^{\circ}\end{array}$ & $\begin{array}{r}600 \\
59,000 \\
86,000 \\
24,000 \\
1,100\end{array}$ & $\begin{array}{r}100 \\
2,500 \\
3,600 \\
1,600 \\
100\end{array}$ & $\begin{array}{r}\because \ddot{7}, \ddot{800} \\
400 \\
\cdots\end{array}$ & (1) $300^{\circ}$ & $\begin{array}{r}13,000 \\
33,000 \\
70,000 \\
\cdots\end{array}$ & $\begin{array}{r}600 \\
1,400 \\
4,300 \\
\cdots \cdots\end{array}$ & $\cdots$ & $\begin{array}{l}-1 \\
\cdots \cdots\end{array}$ \\
\hline 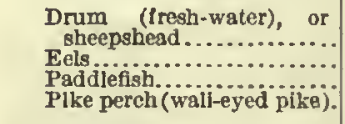 & $\begin{array}{r}93,000 \\
100 \\
28,000 \\
2,000\end{array}$ & $\begin{array}{l}3,900 \\
(1) \\
600 \\
100\end{array}$ & $\begin{array}{l}10,000 \\
6,100 \\
6 \ldots\end{array}$ & $\begin{array}{r}400 \\
100 \\
\cdots \cdots\end{array}$ & $\begin{array}{r}53,000 \\
\dddot{22}, 0000 \\
600\end{array}$ & $\begin{array}{l}2,200 \\
\left.{ }^{1}\right)\end{array}$ & $\begin{array}{r}500 \\
\cdots \\
\cdots\end{array}$ & $\begin{array}{l}(1) \\
\cdots\end{array}$ & $\begin{array}{r}29,000 \\
100 \\
\hdashline, 400\end{array}$ & ${ }^{1,200}{ }^{200}$ & & \\
\hline 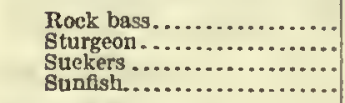 & $\begin{array}{r}1,300 \\
19,000 \\
32,000 \\
1,500\end{array}$ & $\begin{array}{r}100 \\
400 \\
1,000 \\
100\end{array}$ & $\begin{array}{r}100 \\
1,600 \\
200\end{array}$ & $\begin{array}{l}\text { (1) } \\
\text { (i) } \\
\text { (1) }\end{array}$ & $\begin{array}{r}800 \\
4,400 \\
29,000 \\
1,300\end{array}$ & $\begin{array}{l}100 \\
100 \\
900 \\
100\end{array}$ & $\begin{array}{r}400 \\
\ldots, 000 \\
\ldots \ldots \ldots\end{array}$ & (1) & 15,000 & $\begin{array}{l}300 \\
2 \ldots\end{array}$ & & (n..... \\
\hline $\begin{array}{l}\text { Mussel shells.................... } \\
\text { Pearls and sliggs................ }\end{array}$ & $\begin{array}{r}6,922,000 \\
\ldots \ldots \ldots \ldots\end{array}$ & $\begin{array}{l}42,000 \\
72,000\end{array}$ & & 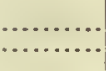 & & & & & & & $6,922,000$ & $\begin{array}{l}42,000 \\
72,000\end{array}$ \\
\hline
\end{tabular}


FISHERIES, BY STATES.

TABLE 4.-ILLINOIS-FISHERY PRODUCTS OF LAKE MICHIGAN DISTRICT: 1908.

\begin{tabular}{|c|c|c|c|c|c|c|c|c|c|c|}
\hline \multirow{3}{*}{ SPECLES. } & \multirow{2}{*}{\multicolumn{2}{|c|}{ TOTAL. }} & \multicolumn{8}{|c|}{ PRODUCT CAUGIT DY- } \\
\hline & & & \multicolumn{2}{|c|}{ Selnes. } & \multicolumn{2}{|c|}{ Gill nets. } & \multicolumn{2}{|c|}{ Dip nets. } & \multicolumn{2}{|c|}{ All other apparatus. 1} \\
\hline & $\begin{array}{l}\text { Quantity } \\
\text { (pounds). }\end{array}$ & Value. & $\begin{array}{l}\text { Quantity } \\
\text { (pounds). }\end{array}$ & Value. & $\begin{array}{l}\text { Quantlty } \\
\text { (pounds). }\end{array}$ & Value. & $\begin{array}{l}\text { Quautity } \\
\text { (pounds). }\end{array}$ & Value. & $\begin{array}{l}\text { Quantity } \\
\text { (pounds). }\end{array}$ & Value. \\
\hline Total............... & $1,176,000$ & $\$ 58,000$ & 132,000 & $\$ 2,800$ & 955,000 & $\$ 51,000$ & 35,000 & $\$ 1,800$ & 54,000 & $\$ 2,200$ \\
\hline 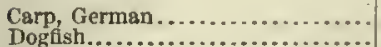 & $\begin{array}{r}120,000 \\
10,000\end{array}$ & $\begin{array}{r}2,600 \\
200\end{array}$ & $\begin{array}{r}115,000 \\
10,000\end{array}$ & $\begin{array}{r}2,500 \\
200\end{array}$ & 200 & (3) & 4,400 & 100 & 400 & (2) \\
\hline 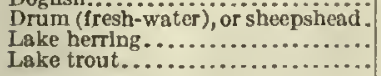 & $\begin{array}{r}3,700 \\
598,040 \\
150,000\end{array}$ & $\begin{array}{r}100 \\
28,000 \\
13,000\end{array}$ & \begin{tabular}{l}
\multicolumn{1}{r}{$10,0 \mathrm{w}$} \\
$\ldots \ldots \ldots \ldots \ldots$ \\
$\ldots \ldots \ldots \ldots$
\end{tabular} & $\ldots \ldots \ldots \ldots$. & $\begin{array}{r}1,300 \\
573,000 \\
148,000\end{array}$ & $\begin{array}{l}(1) \\
27,000 \\
12,000\end{array}$ & $\begin{array}{l}2,000 \\
1,400\end{array}$ & $\begin{array}{l}100 \\
100\end{array}$ & $\begin{array}{r}4000 \\
23,000 \\
2,400\end{array}$ & (i) $\begin{array}{l}700 \\
200\end{array}$ \\
\hline 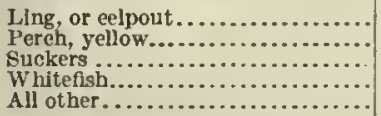 & $\begin{array}{r}27,000 \\
238,000 \\
8,500 \\
13,000 \\
6,100\end{array}$ & $\begin{array}{r}600 \\
12,000 \\
300 \\
800 \\
300\end{array}$ & $\ddot{4}, \ddot{0000}$ & 100 & $\begin{array}{r}26,000 \\
193,000 \\
2,400 \\
9,300 \\
2,000\end{array}$ & $\begin{array}{r}500 \\
10,000 \\
100 \\
500 \\
100\end{array}$ & $\begin{array}{r}500 \\
24,000 \\
800 \\
2,000\end{array}$ & 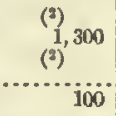 & $\begin{array}{r}1,000 \\
22,000 \\
1,200 \\
3,500 \\
100\end{array}$ & $\begin{array}{ll}\text { (') } & \\
\text { (') } & 900 \\
\text { (') } & 300\end{array}$ \\
\hline
\end{tabular}

1 Includes apparatus, with catch, as follows: Pound nets, 32,000 pounds, valued at $\$ 1,200$; and Ines, 21,000 pounds, valued at $\$ 900$.

Less than $\$ 100$.

TABLE 5.-IILINOIS-PRODUCTS OF VESSEL FISHERIES: 1908.

\begin{tabular}{|c|c|c|c|c|c|c|c|c|c|c|c|c|}
\hline \multirow{3}{*}{ SPECIES AND DISTRICT. } & \multirow{2}{*}{\multicolumn{2}{|c|}{ TOTAL. }} & \multicolumn{10}{|c|}{ PRODUCT CAUGHT BY- } \\
\hline & & & \multicolumn{2}{|c|}{ Selnes. } & \multicolumn{2}{|c|}{ GIII nets. } & \multicolumn{2}{|c|}{ Fyke nets. } & \multicolumn{2}{|c|}{ Trammel nets. } & \multicolumn{2}{|c|}{$\begin{array}{l}\text { All other appa- } \\
\text { ratus.1 }\end{array}$} \\
\hline & $\begin{array}{l}\text { Quantlty } \\
\text { (pounds). }\end{array}$ & Value. & $\begin{array}{l}\text { Quantity } \\
\text { (pounds). }\end{array}$ & Vajue. & $\begin{array}{l}\text { Quantlty } \\
\text { (pounds). }\end{array}$ & Value. & $\begin{array}{l}\text { Quantity } \\
\text { (pounds). }\end{array}$ & Value. & $\begin{array}{l}\text { Quantlty } \\
\text { (pounds). }\end{array}$ & Value. & $\begin{array}{l}\text { Quantlty } \\
\text { (pounds). }\end{array}$ & Value. \\
\hline Total........ & $2,983,000$ & $\$ 89,000$ & $2,012,000$ & $\$ 7,000$ & 495,000 & $\$ 28,000$ & 439,000 & $\$ 13,000$ & 33,000 & $\$ 1,000$ & 4,700 & $\$ 200$ \\
\hline 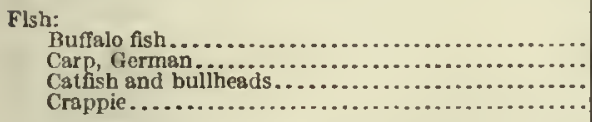 & $\begin{array}{r}204,000 \\
1,975,000 \\
121,000 \\
51,000\end{array}$ & $\begin{array}{r}7,500 \\
46,000 \\
3,500 \\
1,400\end{array}$ & $\begin{array}{r}173,000 \\
1,632,000 \\
101,000 \\
34,000\end{array}$ & $\begin{array}{r}6,200 \\
36,000 \\
2,600 \\
900\end{array}$ & ( & $\mid \begin{array}{ll}\cdots \\
\cdots \cdots \\
\cdots \cdots\end{array}$ & $\begin{array}{r}28,000 \\
323,000 \\
19,000 \\
17,000\end{array}$ & $\begin{array}{r}1,100 \\
9,100 \\
800 \\
500\end{array}$ & $\begin{array}{r}4,000 \\
20,000 \\
2,000 \\
600\end{array}$ & $\begin{array}{l}100 \\
600 \\
100 \\
(2)\end{array}$ & & \\
\hline 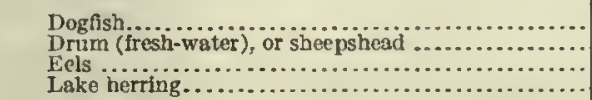 & $\begin{array}{r}30,000 \\
13,000 \\
5,000 \\
321,000\end{array}$ & $\begin{array}{r}400 \\
400 \\
200 \\
16,000\end{array}$ & $\begin{array}{r}4,500 \\
9,700 \\
3,000 \\
\end{array}$ & $\begin{array}{l}100 \\
300 \\
200\end{array}$ & $32 i, 000$ & 16,000 & $\begin{array}{r}25,000 \\
2,700 \\
1,000\end{array}$ & $\begin{array}{l}300 \\
100 \\
100\end{array}$ & $\begin{array}{l}1,000 \\
1,000 \\
1,000\end{array}$ & $\begin{array}{l}\text { (?) } \\
\text { (3) }\end{array}$ & $\cdots$ & $\cdots$ \\
\hline 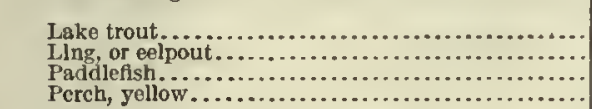 & $\begin{array}{r}119,000 \\
25,000 \\
4,700 \\
27,000\end{array}$ & $\begin{array}{r}10,000 \\
500 \\
100 \\
1,300\end{array}$ & $\cdots$ & $\cdots \cdots$ & $\begin{array}{r}119,000 \\
25,000 \\
23,000\end{array}$ & $\begin{array}{r}10,000 \\
500 \\
1,100\end{array}$ & $\ddot{1, i 000}$ & $\dddot{(3)}$ & $400^{\circ}$ & (3) & 100 & (ग) \\
\hline 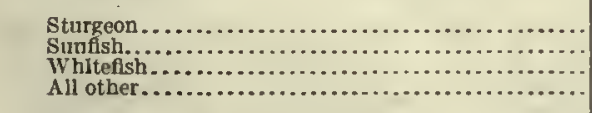 & $\begin{array}{r}12,000 \\
50,000 \\
6,200 \\
6,800\end{array}$ & $\begin{array}{r}400 \\
1,200 \\
300 \\
200\end{array}$ & $\begin{array}{r}11,000 \\
30,000 \\
\cdots 2,600\end{array}$ & $\begin{array}{c}300 \\
700 \\
100\end{array}$ & $\begin{array}{r}6,200 \\
1,300\end{array}$ & $\begin{array}{r}300 \\
100\end{array}$ & $\begin{array}{r}400 \\
19,000 \\
\cdots \\
2,500\end{array}$ & $\begin{array}{l}\left({ }^{2}\right) \\
500 \\
\cdots \\
100\end{array}$ & $\begin{array}{r}400 \\
600 \\
400\end{array}$ & $\begin{array}{l}\text { (2) } \\
\text { (2) } \\
\text { (2) }\end{array}$ & & \\
\hline $\begin{array}{l}\text { Frogs. } \\
\text { Terrapin...... }\end{array}$ & $\begin{array}{r}600 \\
9,600\end{array}$ & $\stackrel{(2)}{200}$ & 8,000 & 200 & & & 200 & $\ddot{(z)}$ & 1,400 & $\dddot{(2)}$ & 600 & (2) \\
\hline Mississlpp! Rlver dlstrict... & $2,484,000$ & 61,000 & $2,012,000$ & 47,000 & & & 439,000 & 13,000 & 33,000 & 1,000 & 600 & (2) \\
\hline 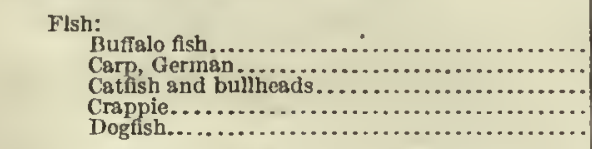 & $\begin{array}{r}204,000 \\
1,975,000 \\
121,000 \\
51,000 \\
30,000\end{array}$ & $\begin{array}{r}7,500 \\
46,000 \\
3,500 \\
1,400 \\
400\end{array}$ & $\begin{array}{r}173,000 \\
1,632,000 \\
101,000 \\
34,000 \\
4,500\end{array}$ & $\begin{array}{r}6,200 \\
36,000 \\
2,600 \\
900 \\
100\end{array}$ & 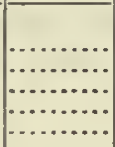 & 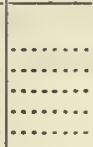 & $\begin{array}{r}28,000 \\
323,000 \\
19,000 \\
17,000 \\
25,000\end{array}$ & $\begin{array}{r}1,100 \\
9,100 \\
800 \\
500 \\
300\end{array}$ & $\begin{array}{r}4,000 \\
20,000 \\
2,000 \\
600 \\
1,000\end{array}$ & $\begin{array}{l}100 \\
600 \\
100 \\
(3)\end{array}$ & 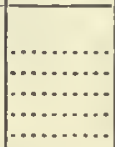 & \\
\hline 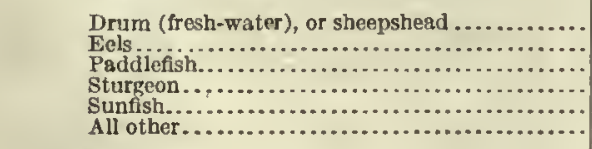 & $\begin{array}{r}13,000 \\
5,000 \\
4,700 \\
12,000 \\
50,000 \\
5,500\end{array}$ & $\begin{array}{r}400 \\
200 \\
100 \\
400 \\
1,200 \\
200\end{array}$ & $\begin{array}{r}9,700 \\
3,000 \\
3,200 \\
11,000 \\
30,000 \\
2,600\end{array}$ & $\begin{array}{l}300 \\
200 \\
100 \\
300 \\
700 \\
100\end{array}$ & $|\cdots \cdots \cdots \cdot|$ & $\mid \begin{array}{ll}\ldots \ldots \\
\cdots \cdots \\
\cdots \cdots \\
\cdots \cdots\end{array}$ & $\begin{array}{r}2,700 \\
1,000 \\
1,100 \\
400 \\
19,000 \\
2,500\end{array}$ & $\begin{array}{l}100 \\
100 \\
(2)- \\
(2) \\
100\end{array}$ & $\begin{array}{r}1,000 \\
1,000 \\
400 \\
400 \\
600 \\
400\end{array}$ & $\begin{array}{l}(2) \\
100 \\
(2) \\
(3) \\
(3)\end{array}$ & 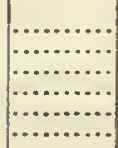 & $\begin{array}{l}\cdots \cdots \\
\cdots \cdots \\
\cdots \cdots \\
\cdots \cdots\end{array}$ \\
\hline 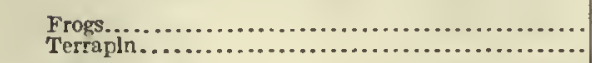 & $\begin{array}{r}600 \\
9,600\end{array}$ & (?) 200 & 8,000 & $200^{\circ}$ & & & 200 & $(3)$ & $i, 400$ & $(3)$ & 600 & (3) \\
\hline Lake Mlchlgan district............ & 500,000 & 28,000 & $\ldots \ldots \ldots \ldots$ & $\ldots \ldots$ & 495,000 & 28,000 & -......... & & . $\ldots \ldots \ldots \ldots$ & $\ldots \ldots$ & 4,100 & 200 \\
\hline 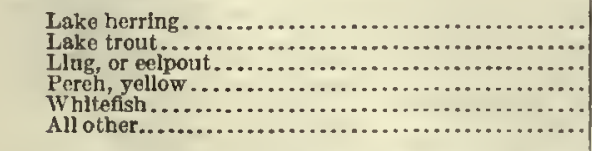 & $\begin{array}{r}321,000 \\
119,000 \\
25,000 \\
27,000 \\
6,200 \\
1,300\end{array}$ & $\begin{array}{r}16,000 \\
10,000 \\
500 \\
1,300 \\
300 \\
100\end{array}$ & 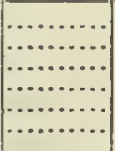 & 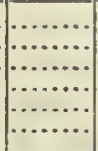 & $\begin{array}{r}321,000 \\
119,000 \\
25,000 \\
23,000 \\
6,300 \\
1,300\end{array}$ & $\begin{array}{r}16,000 \\
10,000 \\
500 \\
1,100 \\
300 \\
100\end{array}$ & & 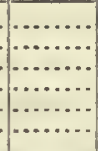 & & {$\left[\begin{array}{l}\cdots \\
\cdots \\
\cdots \\
\cdots \\
\cdots \\
\cdots\end{array}\right.$} & $\begin{array}{r}100 \\
4,000\end{array}$ & 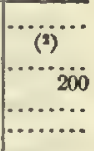 \\
\hline
\end{tabular}

1 Includes apparatus, with cateh, as follows: Lines, 4,100 pounds, valued at \$200; and minor apparatus, 600 pounds, valued at less than $\$ 100 . \quad 9$ Less than $\$ 100$. 
TABLE 6.-ILLINOIS-PRODUCTS OF SHORE AND BOAT FISHERIES: 1908.

\begin{tabular}{|c|c|c|c|c|c|c|c|c|c|c|c|c|c|c|}
\hline \multirow{3}{*}{ SPECIES. } & \multirow{2}{*}{\multicolumn{2}{|c|}{ TOTAL. }} & \multicolumn{12}{|c|}{ PRODUCT CAUOIT RY- } \\
\hline & & & \multicolumn{2}{|c|}{ Selnes. } & \multicolumn{2}{|c|}{ Fyke nets. } & \multicolumn{2}{|c|}{ Trammel nets. } & \multicolumn{2}{|c|}{ Lines. } & \multicolumn{2}{|c|}{ Gill nets. } & \multicolumn{2}{|c|}{$\begin{array}{l}\text { All other sppa- } \\
\text { ratus.? }\end{array}$} \\
\hline & $\begin{array}{l}\text { Quantity } \\
\text { (pounds). }\end{array}$ & Value. & $\begin{array}{l}\text { Quantity } \\
\text { (pounds). }\end{array}$ & Value. & $\begin{array}{l}\text { Quantlty } \\
\text { (pounds). }\end{array}$ & Value. & $\begin{array}{l}\text { Quantity } \\
\text { (pounds). }\end{array}$ & Value. & $\begin{array}{l}\text { Quantlty } \\
\text { (potwnds). }\end{array}$ & Value. & $\begin{array}{l}\text { Quentity } \\
\text { (pounds). }\end{array}$ & Value. & $\begin{array}{l}\text { Quantity } \\
\text { (pounds). }\end{array}$ & Value. \\
\hline Total... & $71,636,000$ & $\$ 1,347,000$ & $13,933,000$ & $\$ 412,000$ & $10,931,000$ & $\$ 318,000$ & $5,067,000$ & $\$ 150,000$ & $1,238,000$ & $\$ 56,000$ & 467,000 & $\$ 24,000$ & $40,001,000$ & $\$ 387,000$ \\
\hline $\begin{array}{l}\text { Fish: } \\
\text { Black bass............ } \\
\text { Buffalo fish.......... } \\
\text { Carp, German ...... } \\
\text { Cattash and hulliheads }\end{array}$ & $\begin{array}{r}532,000 \\
2,838,000 \\
19,607,000 \\
1,922,000\end{array}$ & $\begin{array}{r}57,000 \\
109,000 \\
529,000 \\
92,000\end{array}$ & $\begin{array}{r}220,000 \\
1,054,000 \\
9,325,000 \\
710,000\end{array}$ & $\begin{array}{r}25,000 \\
42,000 \\
255,000 \\
32,000\end{array}$ & $\begin{array}{r}100,000 \\
1,125,000 \\
6,568.000 \\
607,000\end{array}$ & $\begin{array}{r}9,900 \\
43,000 \\
176,000 \\
28,000\end{array}$ & $\begin{array}{r}114,000 \\
594,000 \\
3,155,000 \\
317,000\end{array}$ & $\begin{array}{l}11,000 \\
21,000 \\
80,000 \\
15,000\end{array}$ & $\begin{array}{r}98,000 \\
62,000 \\
604,000 \\
283,000\end{array}$ & $\begin{array}{r}11,000 \\
2,400 \\
17,000 \\
17,000\end{array}$ & $\begin{array}{r}300 \\
1,800 \\
2,200 \\
500\end{array}$ & $\begin{array}{l}(2) \\
100 \\
100\end{array}$ & $\begin{array}{r}200 \\
800 \\
13,000 \\
5,400\end{array}$ & $\begin{array}{l}(2) \\
(2) \\
400 \\
200\end{array}$ \\
\hline $\begin{array}{l}\text { Crapple.............. } \\
\text { Dogush ............. } \\
\text { Drum (fresh-water) }\end{array}$ & $\begin{array}{l}1,229,000 \\
1,339,000\end{array}$ & $\begin{array}{l}33,000 \\
17,000\end{array}$ & $\begin{array}{l}542,000 \\
698,000\end{array}$ & $\begin{array}{r}15,000 \\
9,100\end{array}$ & $\begin{array}{l}497,000 \\
460,000\end{array}$ & $\begin{array}{r}13,000 \\
5,700\end{array}$ & $\begin{array}{l}174,000 \\
161,000\end{array}$ & $\begin{array}{l}5,000 \\
2,100\end{array}$ & $\begin{array}{l}16,000 \\
20,000\end{array}$ & $\begin{array}{l}700 \\
300\end{array}$ & $\begin{array}{l}200 \\
400\end{array}$ & $\begin{array}{l}\text { (') } \\
\text { (') }\end{array}$ & $\begin{array}{l}400 \\
500\end{array}$ & $\begin{array}{l}\text { (') } \\
\text { (') }\end{array}$ \\
\hline $\begin{array}{l}\text { or sheepshead..... } \\
\text { Eels. ................. } \\
\text { Lake herring....... }\end{array}$ & $\begin{array}{r}652,000 \\
26,000 \\
278,000\end{array}$ & $\begin{array}{r}20,000 \\
1,500 \\
13,000\end{array}$ & $\begin{array}{r}157,000 \\
4,200 \\
\ldots \ldots\end{array}$ & $\begin{array}{r}4,400 \\
200\end{array}$ & $\begin{array}{r}309,000 \\
11,000 \\
\ldots \ldots \ldots\end{array}$ & $\begin{array}{r}9,600 \\
500 \\
\cdots\end{array}$ & $\begin{array}{l}105,000 \\
5,500 \\
(2)\end{array}$ & $\begin{array}{l}2,800 \\
300 \\
(1)\end{array}$ & $\begin{array}{r}76,000 \\
5,400 \\
300\end{array}$ & $\begin{array}{c}2,800 \\
500 \\
\left({ }^{2}\right)\end{array}$ & $\begin{array}{r}1,800 \\
\cdots 232,000\end{array}$ & $\begin{array}{r}100 \\
132,000\end{array}$ & $\begin{array}{r}2,700 \\
100 \\
25,000\end{array}$ & ${ }^{(2)} 700$ \\
\hline $\begin{array}{l}\text { Lake trout.......... } \\
\text { Ling, or eelpout..... } \\
\text { Paddlefish.......... }\end{array}$ & $\begin{array}{r}32,000 \\
2,400 \\
395,000\end{array}$ & $\begin{array}{r}2,500 \\
100 \\
12,000\end{array}$ & 286,000 & 8,600 & 83,000 & 2,200 & 29,000 & 1,100 & $\begin{array}{l}500 \\
400\end{array}$ & (2) & $\begin{array}{r}29,000 \\
1,000\end{array}$ & $\begin{array}{c}2,300 \\
(8)\end{array}$ & $\begin{array}{l}2,300 \\
1,000\end{array}$ & ()$^{200}$ \\
\hline $\begin{array}{l}\text { Perch, yellow......... } \\
\text { Plke and pickerei... }\end{array}$ & $\begin{array}{r}211,000 \\
13,000\end{array}$ & $\begin{array}{r}11,000 \\
1,100\end{array}$ & 4,800 & 300 & 2,200 & 200 & $\begin{array}{r}29,000 \\
2,400\end{array}$ & ${ }_{200}^{1}$ & $\begin{array}{r}17,000 \\
3,400\end{array}$ & 700 & 169,000 & 8,900 & $\begin{array}{r}25,000 \\
200\end{array}$ & ${ }_{(2)}^{1,400}$ \\
\hline $\begin{array}{l}\text { Plke perch (wall- } \\
\text { eyed)................ } \\
\text { Rock bass......... }\end{array}$ & $\begin{array}{r}14,000 \\
6,200\end{array}$ & $\begin{array}{r}1,500 \\
800\end{array}$ & $\begin{array}{r}1,700 \\
400\end{array}$ & ()$^{100}$ & $\begin{array}{l}900 \\
900\end{array}$ & $\begin{array}{l}100 \\
100\end{array}$ & $\begin{array}{l}400 \\
600\end{array}$ & (2) & $\begin{array}{r}11,000 \\
4,200\end{array}$ & $\begin{array}{r}1,300 \\
600\end{array}$ & ${ }^{(2)}{ }_{100}$ & (2) & & \\
\hline $\begin{array}{l}\text { Sturgeon and cavlar } \\
\text { and sturgeon eggs. } \\
\text { Suckers, including }\end{array}$ & 168,000 & 7,000 & 34,000 & 1,300 & 29,000 & 800 & 78,000 & 3,800 & 26,000 & 1,100 & 200 & $\left({ }^{2}\right)$ & & . \\
\hline mullet................ & 276,000 & 6,300 & 70,000 & 1,300 & 126,000 & 3,000 & 74,000 & 1,800 & 1.400 & (') & 2,900 & 100 & 2,200 & 100 \\
\hline $\begin{array}{l}\text { Sunfish......... } \\
\text { Whilte bass..... }\end{array}$ & $\begin{array}{r}1,664,000 \\
6,900\end{array}$ & $\begin{array}{r}29,000 \\
300\end{array}$ & $\begin{array}{r}666,000 \\
2,600\end{array}$ & $\begin{array}{r}12,000 \\
100\end{array}$ & $\begin{array}{r}748,000 \\
1,200\end{array}$ & $\begin{array}{r}12,000 \\
100\end{array}$ & $\begin{array}{r}240,000 \\
2,800\end{array}$ & $\begin{array}{l}4,600 \\
(2)\end{array}$ & $\begin{array}{r}9,500 \\
200\end{array}$ & $\begin{array}{l}300 \\
\left({ }^{3}\right)\end{array}$ & $\begin{array}{l}200 \\
100\end{array}$ & (1) & 200 & (2) \\
\hline $\begin{array}{l}\text { Whitensh.............. } \\
\text { All other.......... }\end{array}$ & $\begin{array}{l}6,600 \\
1,700\end{array}$ & $\begin{array}{l}500 \\
100\end{array}$ & $\ldots \ldots \ldots$ & ........... & .............. & ........... & $\ldots \ldots \ldots$ & ............ & . & $\ldots \ldots$ & $\begin{array}{r}3,100 \\
400\end{array}$ & $\begin{array}{l}200 \\
\left({ }^{2}\right)\end{array}$ & $\begin{array}{l}3,300 \\
1,300\end{array}$ & $(3)$ \\
\hline Frogs........... & 24,000 & 6,800 & & & & & & & & & & & 24,000 & 6,800 \\
\hline $\begin{array}{l}\text { Terrapin............. } \\
\text { Turtles............. }\end{array}$ & $\begin{array}{l}196,000 \\
306,000\end{array}$ & $\begin{array}{r}13,000 \\
8,100\end{array}$ & $\begin{array}{l}71,000 \\
88,000\end{array}$ & $\begin{array}{l}2,800 \\
2,400\end{array}$ & $\begin{array}{l}122,000 \\
141,000\end{array}$ & $\begin{array}{r}10,000 \\
3,700\end{array}$ & $\begin{array}{r}2,400 \\
11,000\end{array}$ & $\begin{array}{l}100 \\
300\end{array}$ & & & 200 & $(3)$ & 66,000 & 1,700 \\
\hline 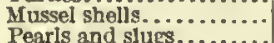 & $39,809,000$ & 184,000 & .............. & & & & & & & & & & $39,809,000$ & 184.000 \\
\hline $\begin{array}{l}\text { Pearls and slugs...... } \\
\text { Skins, mink........ }\end{array}$ & $\cdots, 900$ & $\begin{array}{r}170,000 \\
6,000\end{array}$ & (n.......... & & ... & & & 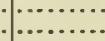 & & & & & 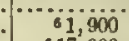 & $\begin{array}{r}170,000 \\
6,000\end{array}$ \\
\hline Skins, muskrat........ & 17,000 & 14,000 & & & & & & & & & & & 617,000 & 14,000 \\
\hline
\end{tabular}

1 Includes apparatus, with catch, as follows: Crowfoot dredges, etc., $39,809,000$ pounds, valued at $\$ 355,000$; traps, 19,000 pounds, valued at $\$ 20,000$; dip nets, 35,000

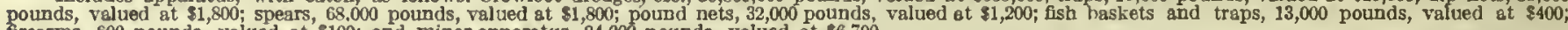
frearms, 600 pounds, valued at $\$ 100$; and minor apparatus, 24,000 pounds, valued at $\$ 6,700$.

2 Less than $\$ 100$.

Includes 1,300 pounds of cavlar and sturgeon eggs, valued at $\$ 800$.
las than 100 pounds.

\section{INDIANA.}

The fisheries of the northern part of Indiana are carried on in Lake Michigan, and those of the southern part in the Ohio River and its tributaries, the Wabash, White, and otlier rivers. The extent of the industry in this state is briefty indicated in the following statement:

Number of persons employed..................... $\quad 986$ Capital:

Vessels and boats, including outfit................. $\$ 23,000$

Apparatus of capture....................... 28, 000

Shore and accessory property and cash............ 22, 000 Value of products.......................... 223, 000

Comparison with previous canvasses. - $\mathrm{A}$ comparison of the returns of this census with those of earlier canvasses shows that there has been a reaction from the decrease in the products which was apparent in both fishery districts of Indiana in 1899 . This reaction is due almost entirely to the recent development of the mussel fisheries. The following tabular statement compares the figures for 1908 with the figures reported for former years:

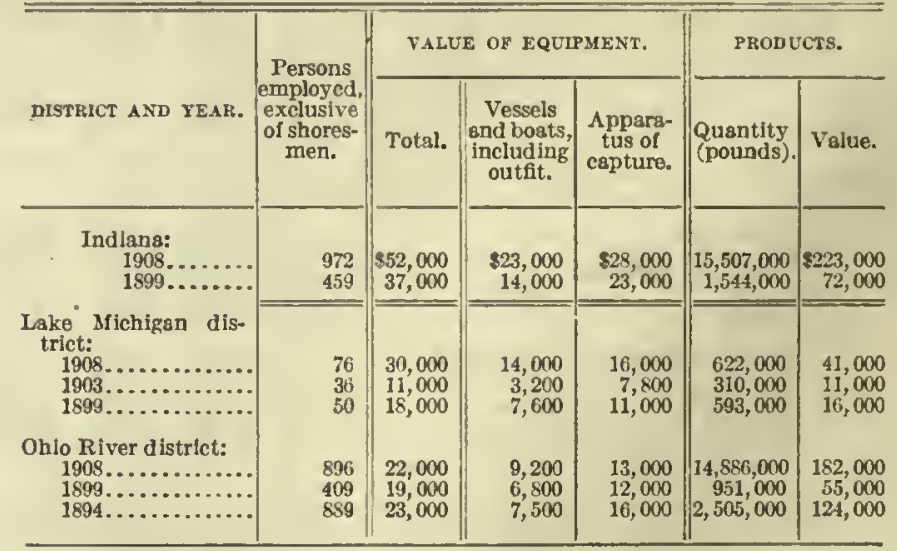

Persons employed.-The statistics of the persons employed in the fisheries of the state are given in the following tabular statement. The greater number were independent fishermen. The low average wages paid to all classes of wage-earners in the Ohio River district and to those employed in the shore and boat fisheries of Lake Michigan indicate the incidental or intermittent character of the employment. 


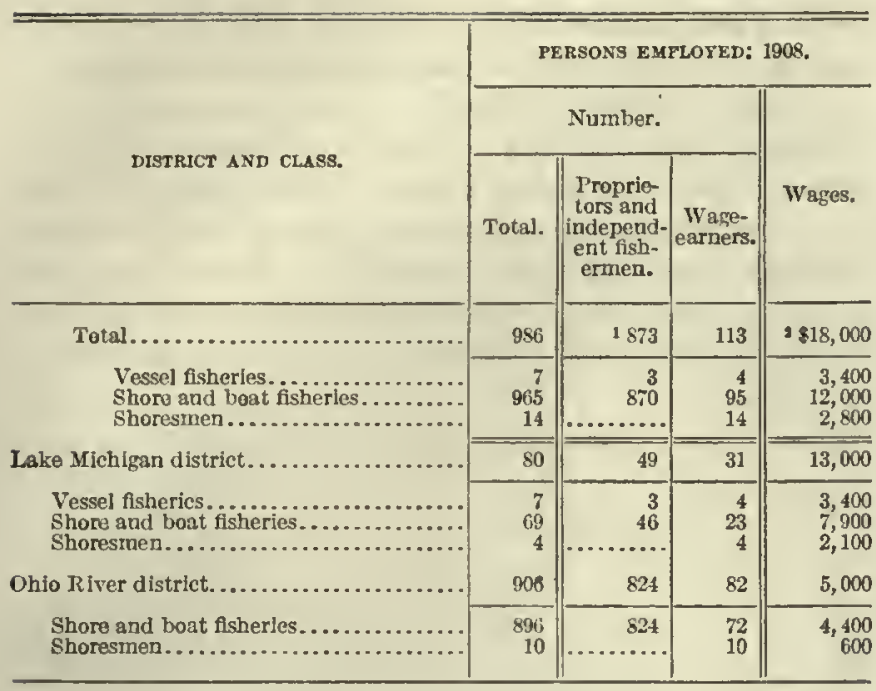

1 Exclusive of four proprictors not fishing.

Includes provisions furnished to the value of $\$ 1,200$.

Equipment and other capital. -The next tabular statement gives the value of the investment in the Incliana fisheries, with its distribution between the Lake Michigan and the Olio River districts.

\begin{tabular}{|c|c|c|c|}
\hline \multirow{2}{*}{ CLASS OF INVESTMENT. } & \multicolumn{3}{|c|}{$\begin{array}{l}\text { VALUE OF EQUIPMENT AND OTHER } \\
\text { CAPITAL: } 1908 \text {. }\end{array}$} \\
\hline & Total. & $\begin{array}{l}\text { Lake Michi- } \\
\text { gan district. }\end{array}$ & $\begin{array}{l}\text { Ohlo Rlver } \\
\text { district. }\end{array}$ \\
\hline Total................ & $\$ 74,000$ & $\$ 51,000$ & $\$ 24,000$ \\
\hline 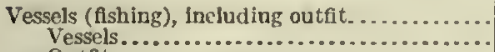 & $\begin{array}{l}7,700 \\
6,700\end{array}$ & $\begin{array}{l}7,700 \\
6,700\end{array}$ & \\
\hline Outfit............... & 1,000 & 1,000 & \\
\hline $\begin{array}{l}\text { Beats................... } \\
\text { Stcam and motor.. }\end{array}$ & 16,000 & 6,400 & 9,200 \\
\hline 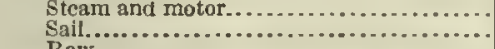 & $\begin{array}{r}6,800 \\
500\end{array}$ & $\begin{array}{r}4,300 \\
500\end{array}$ & 2,500 \\
\hline Row.........., & 7,200 & 600 & 6,600 \\
\hline pparatus of cap & 1,100 & 1,100 & (1) \\
\hline $\begin{array}{l}\text { pparatus of capture. ........... } \\
\text { Vessel fisheries.......... }\end{array}$ & $\begin{array}{r}28,000 \\
3,200\end{array}$ & $\begin{array}{r}16,000 \\
3,200\end{array}$ & 13,000 \\
\hline $\begin{array}{l}\text { Shore and boat fisheries....................... } \\
\text { Shoro and accessory preperty............. }\end{array}$ & 25,000 & 13,000 & 13,000 \\
\hline 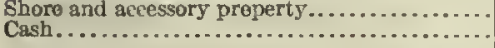 & 18,000 & 16,000 & 1,700 \\
\hline 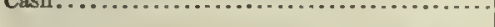 & 4,900 & 4,800 & \\
\hline
\end{tabular}

1 Less than $\$ 100$.

The statistics of the number and tonnage of vessels and the number of boats are as follows:

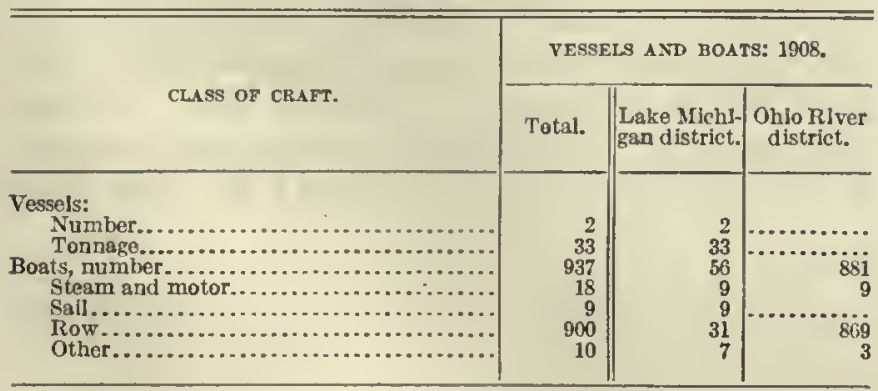

The value of shore and accessory property in 1908 amounted to $\$ 4,600$ for vessel fisheries and $\$ 13,000$ for shore and boat fisheries, while the amount of cash reported for vessel fisheries was $\$ 800$ and for shoro and boat fisheries $\$ 4,100$. The total capital credited to vessel fisheries was therefore $\$ 16,000$ and to shore and boat fisheries $\$ 58,000$.

Apparatus of capture represented more than a third of the entire investment. The number of the kinds of apparatus was as follows:

Dip nets....................................... 25

Fyke nets....................................... 919

Gill nets..................................... 809

Pound nets................................... 37

Seines....................................., 30

The pound nets and gill nets were used wholly in Lake Michigan. All except 192 of the gill nets were used in the shore and bont fisheries.

Products, by species.-The products, by species and apparatus of capture, for all fisheries of the state are shown in Table 1 , on page 123 . The entire product was taken by the shore and boat fisheries, with the exception of 3,000 pounds of herring, valued at $\$ 100$, and 112,000 pounds of trout, valued at $\$ 8,000$, which were taken by the vessel fisheries of Lake Michigan. The mussel fishery furnished the bulk of the product. The catch of fish proper amounted to only $1,076,000$ pounds, or 7 per cent of the total, and was valued at $\$ 69,000$, or only 31 per cent of the total. These figures, however, represent an increase over the food fish caught in 1903 of approximately 66 per cent in weight and 125 per cent in value.

Products, by fishing grounds.-The fishery products of the Ohio River and its tributaries, by species and by apparatus of capture, are given in Table 2, on page 123 , and those of Lake Michigan are similarly given in Table 3, on page 123.

The fisheries of the Ohio River district were all of the shore and boat class. The entire product of mussels, pearls, and slugs came from these waters, contributing 85 per cent of the total value for the district. The fish product proper of this district amounted to 455,000 pounds, valued at $\$ 27,000$, and consisted chiefly of catfish, buffalo fish, drum, and German carp, ranking in value in the order named.

All of the Lake Michigan product was food fish, while in the Ohio River district only 15 per cent of the value represented food fish. In the lake fisheries trout, lake herring, yellow perch, sturgeon (including caviar), and whitefish were the leading species and formed 91 per cent of the lake catch.

The chief products, ranked in the order of the value reported for the state, are given in the following table, by districts:

\begin{tabular}{|c|c|c|c|}
\hline \multirow{2}{*}{ SFECIES. } & \multicolumn{3}{|c|}{ VALUE OF PRODUCTS: 1908.} \\
\hline & Total. & $\begin{array}{l}\text { Ohlo Rlver } \\
\text { district. }\end{array}$ & $\begin{array}{l}\text { Lake Mlchi- } \\
\text { gan district. }\end{array}$ \\
\hline Total... & $\$ 223,000$ & $\$ 182,000$ & $\$ 41,000$ \\
\hline Fish: & & & \\
\hline 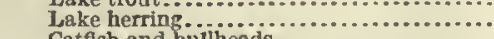 & 8,400 & & $\begin{array}{l}9,600 \\
8,400\end{array}$ \\
\hline Catfish and bnllheads .................... & $\begin{array}{r}7,800 \\
7,600\end{array}$ & 7,600 & 100 \\
\hline Drum ('resh-water), or shecpshead ........ & 7,600 & $\dddot{6}, \ddot{2} \ddot{0} 0$ & 1,400 \\
\hline Sturgeon and caviar.................. & 7,200 & 800 & 6,300 \\
\hline Buftalo fish............. & 7,000 & 6,900 & 100 \\
\hline Carp, German ....... & 6,000 & 5,000 & 1,000 \\
\hline Whitefish........... & 5,000 & $\cdots \cdots . . . .$. & 5,000 \\
\hline 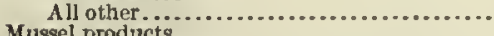 & 2,400 & 155,000 & 1,400 \\
\hline 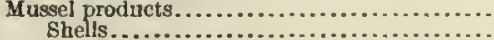 & $\begin{array}{r}135,000 \\
81,000\end{array}$ & 81,000 & $\cdots \cdots$. \\
\hline Pearls and slugs...... & 74,000 & 74,000 & ................. \\
\hline
\end{tabular}


Products, by apparatus of capture.-The distribution of the total value of products, according to apparatus of capture, for the state and for each district, was as follows:

\begin{tabular}{|c|c|c|c|}
\hline \multirow[b]{2}{*}{ FUND OF APPARATUS. } & \multicolumn{3}{|c|}{ VALUE OF PRODUCTS: 1908.} \\
\hline & Total. & $\begin{array}{c}\text { Ohio River } \\
\text { district. }\end{array}$ & $\begin{array}{l}\text { Lake Michi- } \\
\text { gan district. }\end{array}$ \\
\hline Total........................ & $\$ 223,000$ & $\$ 182,000$ & $\$ 41,000$ \\
\hline 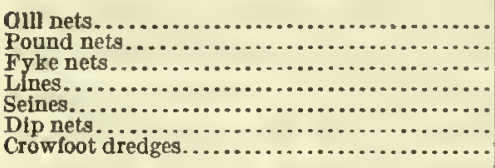 & $\begin{array}{r}18,000 \\
18,000 \\
16,000 \\
11,000 \\
4,200 \\
155,000 \\
\end{array}$ & $\begin{array}{r}16,000 \\
7,400 \\
3,700 \\
155,000\end{array}$ & 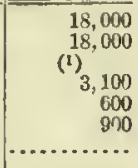 \\
\hline
\end{tabular}

1 Less than $\$ 100$

The product taken by crowfoot dredges largely exceeded the catch with all other forms of apparatus, comprising $14,431,000$ pounds of mussel shells, which had a value, including pearls and slugs, of $\$ 155,000$.

Mussel products.-The mussel fishery of the state has developed since 1903 and is responsible for almost the entire gain in the value of the fishery products of the Ohio River district since that date. The large value of the pearls and slugs is noteworthy, nearly equaling that of the mussel shells and exceeding the aggregate value of all food fish.

Lake trout.-The lake-trout catch was larger than that of any otherspecies of fish reported for 1908. Over four-fifths of the catch was taken in the vessel fisheries, in which this species contributed the entire amount, with the exception of 3,000 pounds of lake herring. Trout were taken almost entirely with gill nets. The following comparative statement shows the catch for stated years:

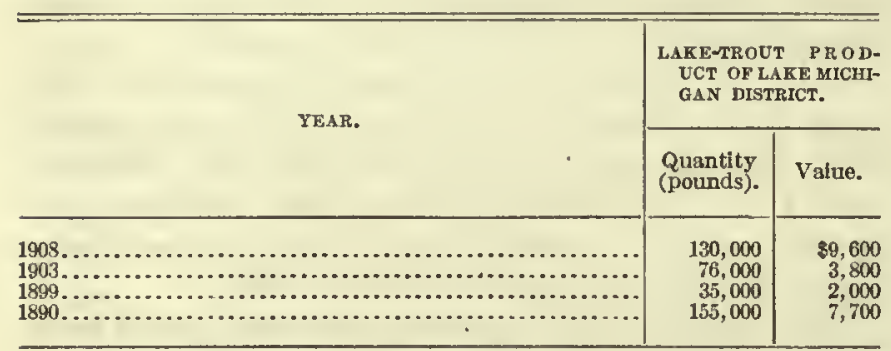

Lake herring.-Lake herring ranked second in value among the food fishes in 1908. The value of the prod- uct in 1890 was $\$ 3,200$; in $1899, \$ 7,200$; and in 1903 only $\$ 2,300$. 'By 1908 it had incroased to $\$ 8,400$.

Catfish.-Catfish and bullheads ranked next to lake herring in value in 1908. The Ohio River district furnished almost the entire catch. Over one-half of the catch was taken with fyke nets and most of the remainder with lines. Catfish formerly led in quantity and in value, but a great decline in both these respects was shown in 1908, as is indicated by the following tabular statement:

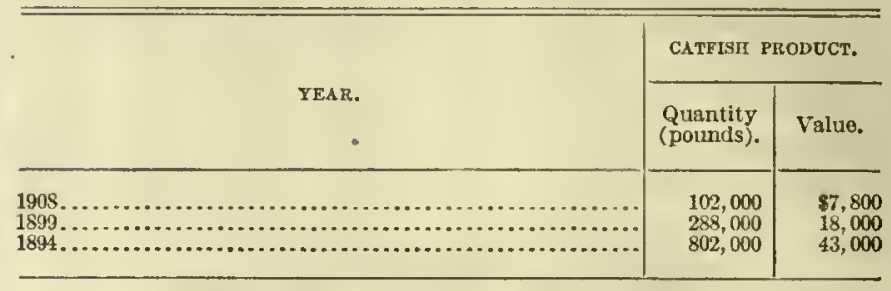

Yellow perch.-Yellow perch, with a catch of practically the same value as that of catfish, was a product of the shore and boat fisheries of Lake Michigan. The greater part of the catch was taken with gill nets, although considerable quantities were caught in pound nets. This species was taken in greater quantities in 1899 than in 1908 , but the value was no greater in the earlier year.

Other products.-Drum and sturgeon were taken in both districts, the former mostly in the Ohio River district and the latter mostly in Lake Michigan. The catch of fresh-water drum decreased at about the same rate as that of catfish. The value of the yicld from the Oliio River district alone was $\$ 20,000$ in 1894 , but by 1899 it had dropped to $\$ 11,000$, while in 1908 the value of the catch for the whole state was only $\$ 7,600$. The quantity has decreased in much the same proportions. The yield of the sturgeon product has been fluctuating, the lake catch being valued at $\$ 2,800$ in $1890, \$ 800$ in $1899, \$ 300$ in 1903 , and $\$ 6,300$ in 1908 .

The buffalo-fish product was valued at only a little less than that of either of the foregoing species. Nearly the whole catch was from the Ohio River and two-thirds was taken by fyke nets. The catch of buffalo fish shows a decrease in value from $\$ 17,000$ in 1894 to $\$ 7,700$ in 1899 and to $\$ 7,000$ in 1908 . German carp increased in weight and in value reported from $\$ 1,100$ in 1894 to $\$ 2,300$ in 1899 and to $\$ 6,000$ in 1908 . 
TABLE 1.-INDIANA-FISHERY PRODUCTS: 1908.

\begin{tabular}{|c|c|c|c|c|c|c|c|c|c|c|c|c|c|c|}
\hline \multirow{3}{*}{ SPECDES. } & \multirow{2}{*}{\multicolumn{2}{|c|}{ TOTAL.1 }} & \multicolumn{12}{|c|}{ PRODUCT CAUGRT BY- } \\
\hline & & & \multicolumn{2}{|c|}{ GIII nets.I } & \multicolumn{2}{|c|}{ Pound nets. } & \multicolumn{2}{|c|}{ Fyke nets. } & \multicolumn{2}{|c|}{ Lines. } & \multicolumn{2}{|c|}{ Selnes. } & \multicolumn{2}{|c|}{$\begin{array}{l}\text { Crowloot dredges } \\
\text { and dip nets.s }\end{array}$} \\
\hline & $\begin{array}{l}\text { Quantity } \\
\text { (pounds). }\end{array}$ & Value. & $\begin{array}{l}\text { Quantity } \\
\text { (pounds). }\end{array}$ & Value. & $\begin{array}{l}\text { Quantity } \\
\text { (pounds). }\end{array}$ & Value. & $\begin{array}{l}\text { Quantity } \\
\text { (pounds). }\end{array}$ & Value. & $\begin{array}{l}\text { Quantity } \\
\text { (pounds). }\end{array}$ & Velue. & $\begin{array}{l}\text { Quantlty } \\
\text { (pounds). }\end{array}$ & Value. & $\begin{array}{l}\text { Quantlty } \\
\text { (pounds). }\end{array}$ & Value. \\
\hline Total................... & $15,507,000$ & $\$ 223,000$ & 285,000 & $\$ 18,000$ & 293,000 & $\$ 18,000$ & 284,000 & 816,000 & 132,000 & $\$ 11,000$ & 70,000 & 84,200 & $14,443,000$ & $\$ 156,000$ \\
\hline $\begin{array}{l}\text { Fish: } \\
\text { Buffalo fish............... } \\
\text { Carp, German .......... } \\
\text { Catfish and buliheads... }\end{array}$ & $\begin{array}{l}124,000 \\
128,000 \\
102,000\end{array}$ & $\begin{array}{l}7,000 \\
6,000 \\
7,800\end{array}$ & & & $\begin{array}{r}3,400 \\
16,000 \\
1,300\end{array}$ & $\begin{array}{l}100 \\
500 \\
100\end{array}$ & $\begin{array}{l}83,000 \\
75,000 \\
59,000\end{array}$ & $\begin{array}{l}4,500 \\
3,400 \\
4,500\end{array}$ & $\begin{array}{r}27,000 \\
6,700 \\
37,000\end{array}$ & $\begin{array}{r}1,700 \\
500 \\
2,800\end{array}$ & $\begin{array}{r}11,000 \\
30,600 \\
4,600\end{array}$ & $\begin{array}{r}600 \\
1,600 \\
300\end{array}$ & 200 & $(3)$ \\
\hline $\begin{array}{l}\text { Drum (fresh - water), or } \\
\text { sheepshead.............. } \\
\text { Lake herring } . \ldots \ldots \ldots \ldots \ldots \\
\text { Lake trout............ }\end{array}$ & $\begin{array}{l}137,000 \\
198,000 \\
130,000\end{array}$ & $\begin{array}{l}7,600 \\
8,400 \\
9,600\end{array}$ & $\begin{array}{r}400 \\
79,000 \\
124,000\end{array}$ & $\begin{array}{l}\left({ }^{3}\right) \\
3,300 \\
9,200\end{array}$ & $\begin{array}{r}33,000 \\
118,000 \\
5,200\end{array}$ & $\begin{array}{r}1,300 \\
4,900 \\
500\end{array}$ & $\begin{array}{r}57,000 \\
\cdots \cdots \\
\cdots \cdots \\
\cdots\end{array}$ & $\begin{array}{c}3,200 \\
\cdots \cdots \\
\cdots\end{array}$ & $\begin{array}{r}32,000 \\
300\end{array}$ & $\begin{array}{l}2,000 \\
(\delta)\end{array}$ & $\begin{array}{r}14,000 \\
200\end{array}$ & $\begin{array}{l}1,000 \\
(3)\end{array}$ & $\begin{array}{r}200 \\
1,700 \\
.\end{array}$ & ${ }^{(3)}{ }_{1}$ \\
\hline 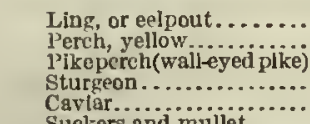 & $\begin{array}{r}1,700 \\
119,000 \\
3,100 \\
52,000 \\
300\end{array}$ & $\begin{array}{r}100 \\
7,600 \\
300 \\
6,800 \\
400\end{array}$ & $\begin{array}{r}300 \\
66,000 \\
3,700 \\
7, \ldots 00\end{array}$ & $\begin{array}{r}\left({ }^{(3)}\right. \\
4,400 \\
400 \\
400\end{array}$ & $\begin{array}{r}1,100 \\
40,000 \\
100 \\
16,000 \\
300\end{array}$ & $\begin{array}{l}(\stackrel{3}{)}) \\
2,300 \\
2,800 \\
200\end{array}$ & $\begin{array}{r}\cdots, 200 \\
2,200 \\
700\end{array}$ & 300 & $\begin{array}{r}300 \\
3,300 \\
200 \\
25,000\end{array}$ & $\begin{array}{l}\quad{ }^{3)} \\
300 \\
{ }^{(8)} \\
3,300 \\
\cdots \cdots\end{array}$ & $\begin{array}{r}300 \\
600 \\
7,200 \\
\hdashline 70\end{array}$ & $\begin{array}{l}\left({ }^{3}\right) \\
100 \\
300\end{array}$ & $\begin{array}{l}9,000 \\
\cdots \cdots\end{array}$ & \\
\hline Suckers and mullet...... & & & 1,800 & 100 & 10,000 & 400 & 7,100 & 500 & $\cdots \cdots \cdots$ & $\cdots \ldots$ & 1,700 & 200 & (4) & (3) \\
\hline $\begin{array}{l}\text { Trout, rainbow.......... } \\
\text { Trout, perch............. } \\
\text { White bass. }\end{array}$ & $\begin{array}{l}2,700 \\
1,000 \\
4,500\end{array}$ & $\begin{array}{l}300 \\
100 \\
400\end{array}$ & an..... & & $\begin{array}{r}2,700 \\
4,500\end{array}$ & 300 & & & & & & & . & \\
\hline 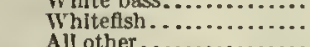 & $\begin{array}{r}4,000 \\
600\end{array}$ & $\begin{array}{r}5,000 \\
100\end{array}$ & $\ddot{9}, 300$ & 1,100 & $\begin{array}{r}4,500 \\
42,000 \\
500\end{array}$ & $\begin{array}{r}400 \\
3,900\end{array}$ & & & ........ & & & & $\ldots \ldots \ldots$ & \\
\hline $\begin{array}{r}\text { All other............... } \\
\text { Mrussel shells............... }\end{array}$ & $\begin{array}{r}600 \\
14,431,000\end{array}$ & $\begin{array}{r}100 \\
81.000\end{array}$ & 100 & $(3)$ & 500 & 100 & & & . . . n........ & .......... & anc...... & & $\cdots \ldots \ldots . . . .$. & ............ \\
\hline $\begin{array}{l}\text { Arussel shells.................... } \\
\text { Pearls and slugs.............. }\end{array}$ & $\begin{array}{l}14,431,000 \\
\ldots \ldots \ldots \ldots \ldots\end{array}$ & $\begin{array}{l}81,000 \\
74,000\end{array}$ & & & ....... & & & & & & ( $\ldots \ldots \ldots \ldots$ & $\ldots \ldots$ & $\begin{array}{l}14,431,000 \\
\cdots \ldots \ldots \ldots \ldots .\end{array}$ & $\begin{array}{l}81,000 \\
74,000\end{array}$ \\
\hline
\end{tabular}

3 All from the shore and boat fisheries, except 115,000 pounds, valued at $\$ 8,100$, taken in the vessel fisheries with gil! nets. This quantity comprised 3,000 pounds of lake berring, valued at $\$ 100$, and 112,000 pounds of trout, valued at $\$ 8,000$.

crowfoot dredges were used only in taking mussels.

8 Less than 100 pounds.

TABLE 2.-INDIANA-FISHERY PRODUCTS OF OHIO RIVER DISTRICT: 1908.

\begin{tabular}{|c|c|c|c|c|c|c|c|c|}
\hline \multirow{3}{*}{ SPECIES. } & \multirow{2}{*}{\multicolumn{2}{|c|}{ TOTAL. }} & \multicolumn{6}{|c|}{ PronUCT CAUOUT BY- } \\
\hline & & & \multicolumn{2}{|c|}{ Fyke nets. } & \multicolumn{2}{|c|}{ Lines. } & \multicolumn{2}{|c|}{$\begin{array}{l}\text { Selnes and crow loot } \\
\text { dredges.1 }\end{array}$} \\
\hline & $\begin{array}{l}\text { Quantity } \\
\text { (pounds). }\end{array}$ & Value. & $\begin{array}{l}\text { Quantity } \\
\text { (pounds). }\end{array}$ & Value. & $\begin{array}{l}\text { Quantity } \\
\text { (pounds). }\end{array}$ & Value. & $\begin{array}{l}\text { Quantity } \\
\text { (pounds). }\end{array}$ & Value. \\
\hline Total... & $14,886,000$ & $\$ 182,000$ & 284,000 & $\$ 16,000$ & 113,000 & $\$ 7,400$ & $14,489,000$ & $\$ 158,000$ \\
\hline 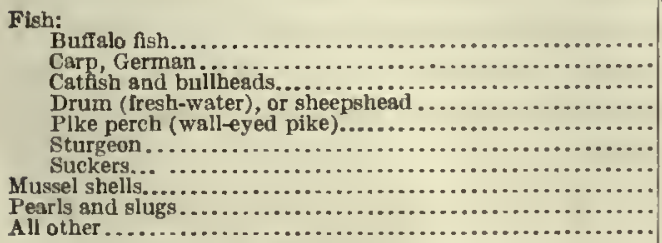 & $\begin{array}{r}121,000 \\
100,000 \\
101,000 \\
104,000 \\
3,000 \\
17,000 \\
8,600 \\
14,431,000 \\
\ldots \ldots \ldots\end{array}$ & $\begin{array}{r}6,900 \\
5,000 \\
7,600 \\
6,200 \\
300 \\
800 \\
600 \\
81,000 \\
74,000 \\
(8)\end{array}$ & $\begin{array}{r}83,000 \\
75,000 \\
59,000 \\
57,000 \\
2,200 \\
700 \\
6,900 \\
7 . \ldots .\end{array}$ & $\begin{array}{r}4,500 \\
3,400 \\
4,500 \\
3,200 \\
300 \\
\text { (2) } 500 \\
3 \\
\text { (ग) }\end{array}$ & 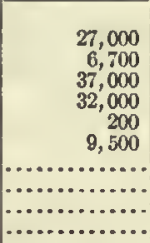 & 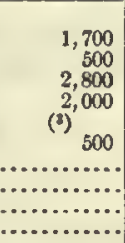 & $\begin{array}{r}11,000 \\
19,000 \\
4,600 \\
14,000 \\
600 \\
7,200 \\
1,700 \\
114,431,000 \\
\hdashline \ldots \ldots\end{array}$ & $\begin{array}{r}600 \\
1,100 \\
300 \\
1,000 \\
100 \\
300 \\
200 \\
81,000 \\
74,000 \\
\ldots \ldots\end{array}$ \\
\hline
\end{tabular}

1 Crow foot dredges were used only In taking mussels. 2 Less than $\$ 100$. 3 Includes 60,000 pounds of mussel shells, valued at 3500 , from the Kankakee River.

TABLE 3.-INDIANA-FISHERY PRODUCTS OF LAKE MICHIGAN DISTRICT: 1908.

\begin{tabular}{|c|c|c|c|c|c|c|c|c|}
\hline \multirow{3}{*}{ SPECIES. } & \multirow{2}{*}{\multicolumn{2}{|c|}{ TOTAL.1 }} & \multicolumn{6}{|c|}{ PRODUCT CAUOHT BY- } \\
\hline & & & \multicolumn{2}{|c|}{ Gill nets. } & \multicolumn{2}{|c|}{ Pound nets. } & \multicolumn{2}{|c|}{ AI other apparatus.3 } \\
\hline & $\begin{array}{l}\text { Quantity } \\
\text { (pounds). }\end{array}$ & Value. & $\begin{array}{l}\text { Quantity } \\
\text { (pounds). }\end{array}$ & Value. & $\begin{array}{l}\text { Qunntity } \\
\text { (pounds). }\end{array}$ & Value. & $\begin{array}{l}\text { Quantity } \\
\text { (pounds). }\end{array}$ & Value. \\
\hline Total................. & 622,000 & $\$ 41,000$ & 285,000 & $\$ 18,000$ & 293,000 & $\$ 18,000$ & 43,000 & 84,700 \\
\hline 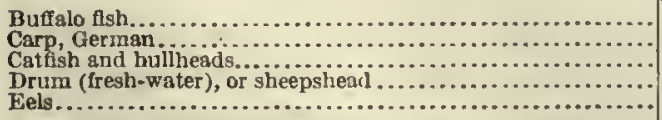 & $\begin{array}{r}3,700 \\
27,000 \\
1,300 \\
33,000 \\
400\end{array}$ & $\begin{array}{r}100 \\
1,000 \\
100 \\
1,400 \\
100\end{array}$ & (n) & 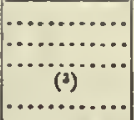 & $\begin{array}{r}3,500 \\
16,000 \\
1,300 \\
33,000 \\
400\end{array}$ & $\begin{array}{r}100 \\
800 \\
100 \\
1,300 \\
100\end{array}$ & $\begin{array}{r}200 \\
12,000 \\
4000 \\
40 .\end{array}$ & ${ }^{(3)} 600$ \\
\hline 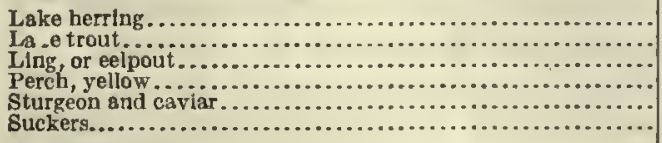 & $\begin{array}{r}198,000 \\
130,000 \\
1,700 \\
119,000 \\
35,000 \\
12,000\end{array}$ & $\begin{array}{r}8,400 \\
9,500 \\
100 \\
7,600 \\
6,300 \\
500\end{array}$ & $\begin{array}{r}79,000 \\
124,000 \\
300 \\
66,000 \\
3,700 \\
1,800\end{array}$ & $\begin{array}{r}3,300 \\
9,200 \\
\left({ }^{3}\right) \\
4,400 \\
400 \\
100\end{array}$ & $\begin{array}{r}118,000 \\
5,200 \\
1,100 \\
40,000 \\
16,000 \\
10,000\end{array}$ & $\begin{array}{r}4,900 \\
500 \\
2,300 \\
3,200 \\
400\end{array}$ & $\begin{array}{r}1,900 \\
300 \\
300 \\
13,000 \\
15,000 \\
200\end{array}$ & 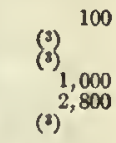 \\
\hline 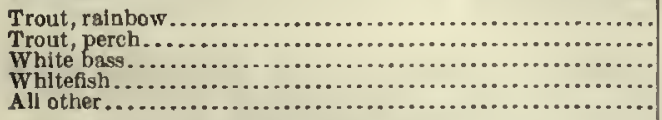 & $\begin{array}{r}2,700 \\
1,000 \\
4,500 \\
52,000 \\
300\end{array}$ & $\begin{array}{r}300 \\
100 \\
400 \\
5,000 \\
\left.()^{3}\right)^{-}\end{array}$ & $\begin{array}{r}9,300 \\
100\end{array}$ & ${ }_{(2)}^{1,100}$ & $\begin{array}{r}2,700 \\
\therefore, 300 \\
4,500 \\
43,000 \\
200\end{array}$ & $\begin{array}{c}300 \\
400 \\
3,900 \\
(3)\end{array}$ & $\begin{array}{c}1,000 \\
\text { (ग) }^{\prime}\end{array}$ & $\begin{array}{l}100 \\
{ }_{(\eta)}\end{array}$ \\
\hline
\end{tabular}

1 All from the shore and boat fisheries, except 115,000 pounds, valued at $\$ 8,100$, taken in the vessel fisheries with gl!l nets. This quantity coniprised 3,000 pounds of lake herring valued at $\$ 100$, and 112,000 pounds of lake trout, valued at $\$ 8,000$.

Includes apparatus, with catch, as follows: Lines, 19,000 pounds, valued at $\$ 3,100$; dip nets, 12,000 pounds, valued at $\$ 900$; and selnes, 12,000 pounds, valued at $\$ 600$.
Less than $\$ 100$. 
IOWA.

In 1908 Iowa held a relatively unimportant place among the states in which commercial fishing was carried on. It was, however, fourth among the states represented in the fisheries of the Mississippi River and its tributaries. The Mississippi and Missouri Rivers are the waters of chief importance in or bordering on this state, and the commercial fisheries of the state were practically confined to them. Small quantities of mussel shells were taken from the Iowa and Wapsipinicon Rivers, but the state laws prohibit the taking of fish in any of the interior rivers or lakes except by means of hook and line. No vessels were employed in the fisheries of the state. A summary of the statistics for 1908 is given in the following statement:

Number of persons employed....................... $\quad 786$ Capital:

Boats............................... \$38, 000

Apparatus of capture...................... 29,000

Shore and accessory property ................. 11, 000

Value of products......................... 215,000

Comparison with previous canvasses.-The following tabular statement gives a comparison of the leading statistics for 1908 with those for 1894 and 1899, as shown in the reports of the Bureau of Fisheries:

\begin{tabular}{|c|c|c|c|c|c|c|}
\hline \multirow[b]{2}{*}{ YEAR. } & \multirow{2}{*}{$\begin{array}{l}\text { Persons } \\
\text { em- } \\
\text { ployed, } \\
\text { exciusive } \\
\text { of shores- } \\
\text { men. }\end{array}$} & \multicolumn{3}{|c|}{ VALUE OF EQUTPMENT. } & \multicolumn{2}{|c|}{ PRODUCTS. } \\
\hline & & Total. & Boats. & $\begin{array}{l}\text { A ppara- } \\
\text { tus of } \\
\text { capture. }\end{array}$ & $\begin{array}{l}\text { Quantlty } \\
\text { (pounds). }\end{array}$ & Value. \\
\hline $\begin{array}{l}1908 \ldots \ldots . \\
1899 \ldots \ldots . \\
1894 \ldots \ldots\end{array}$ & $\begin{array}{r}786 \\
1,161 \\
944\end{array}$ & $\begin{array}{r}866,000 \\
50,000 \\
39,000\end{array}$ & $\begin{array}{r}\$ 38,000 \\
17,000 \\
15,000\end{array}$ & $\begin{array}{r}\$ 29,000 \\
33,000 \\
25,000\end{array}$ & $\begin{array}{r}8,867,000 \\
123,902,000 \\
4,080,000\end{array}$ & $\begin{array}{r}\$ 215,000 \\
208,000 \\
125,000\end{array}$ \\
\hline
\end{tabular}

1 Includes $20,354,000$ pounds of mussel shells.

From 1894 to 1899 there were fairly large increases in the number of persons employed, the total value of equipment, and the value of boats and of apparatus of capture. Fewer persons were employed in 1908 than in either of the other years for which a canvass was made, a fact which was due to the discontinuance of commercial fishing along the Skunk, Des Moines, and Big Sioux Rivers and in the lakes reported as fishing grounds in the former years.

The value reported for apparatus of capture was lower in 1908 than in 1899. The decrease did not, however, bring the value for 1908 as low as that reported in 1894; nor did it result in a reduction in the total value of equipment between 1899 and 1908, the tendency in that direction being more than offset by an increase in the value of boats.

The great changes in the quantity of products reflect the rise and decline of the mussel-shell industry rather than the development of the-general fisheries of the state. If mussel shells, pearls, and slugs are eliminated from consideration, the weight of products as reported in 1894,1899 , and 1908 was, respectively, $3,932,000$ pounds, $3,548,000$ pounds, and 4,167,000 pounds, and the corresponding values were $\$ 123,000$, $\$ 110,000$, and $\$ 170,000$. There were, therefore, in the case of products exclusive of mussel shells, decreases in both quantity and value in 1899 , as compared with 1894; but from 1899 to 1908 there were increases which more than counterbalanced the preceding losses.

Persons employed.-The following tabular statement shows, for the state as a whole and for the two main fishing distriets, the distribution of the persons employed, according to their relation to the industry:

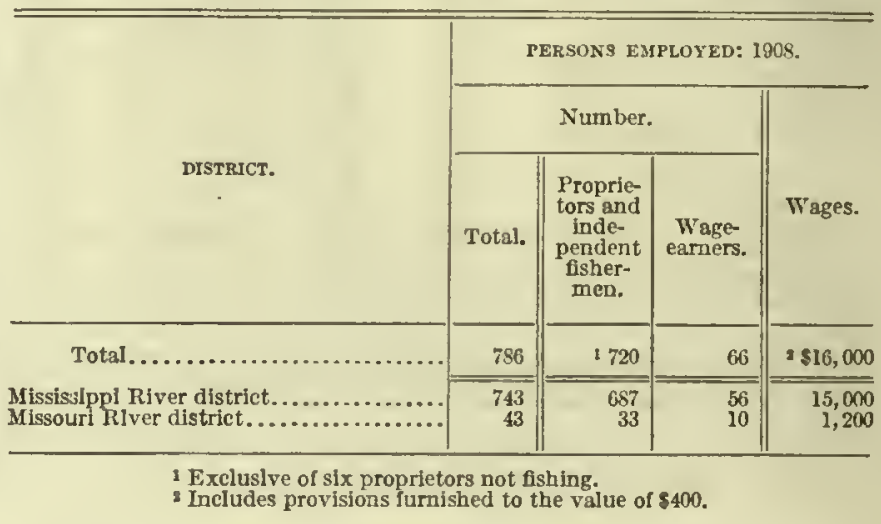

In 1908, 95 per cent of the Iowa fishermen were employed in the basin of the Mississippi River. Of the total number, only 66 , or less than 9 per cent, were wage-earners. The amount paid in wages was $\$ 16,000$. There were no salaried employees reported.

Equipment and other capital.-The following tabular statement gives the value of the fishing equipment and other items of capital for the state in 1908, and its distribution between the Mississippi River and the Missouri River districts:

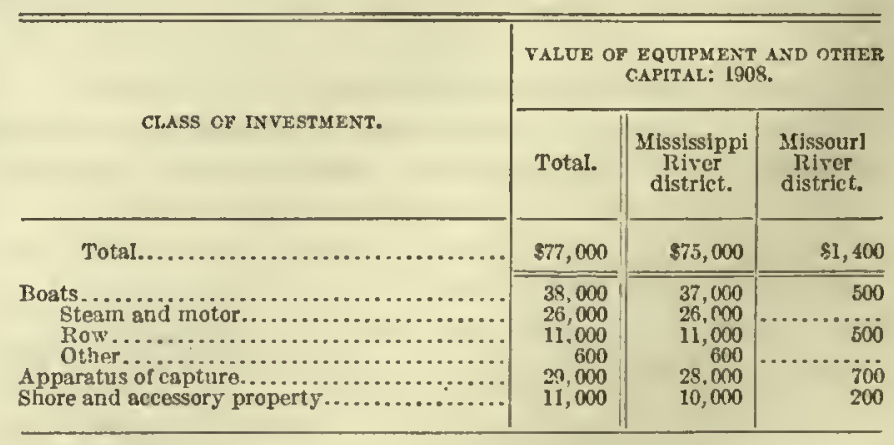

More than 97 per cent of the capital was invested in the Mississippi River district. The investment in boats formed 49 per cent of the total capital; the investment in apparatus of capture, 38 per cent; and that in shore and accessory property, 14 per cent. Power boats represented one-third of all the capital employed.

The number of the various kinds of apparatus used are shown in the next tabular statement. 


\begin{tabular}{|c|c|c|c|}
\hline \multirow[b]{2}{*}{ KIND. } & \multicolumn{3}{|c|}{ APPARATUS OF CAPTURE: 1908.} \\
\hline & Total. & $\begin{array}{l}\text { Mrississippl } \\
\text { River } \\
\text { distrlet. }\end{array}$ & $\begin{array}{l}\text { Missourl } \\
\text { River } \\
\text { district. }\end{array}$ \\
\hline 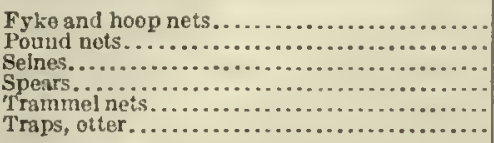 & $\begin{array}{r}2,455 \\
403 \\
163 \\
129 \\
257 \\
748\end{array}$ & $\begin{array}{r}2,389 \\
403 \\
158 \\
129 \\
243 \\
748\end{array}$ & $\begin{array}{l}66 \\
10 \\
\text { ii } \\
\cdots\end{array}$ \\
\hline
\end{tabular}

Products, by species. - Table 1, on page 126, shows the fishery products of the state in 1908, by species and by apparatus of capture.

Products, by fishing grounds.-Over 95 per cent of the value was from the Mississippi River district. The Missouri River products, aggregating 143,000 pounds, of a value of $\$ 9,300$, are given in Table 2 , on page 126 , by species and by apparatus of capture; and by deducting the specific items from the corresponding itoms in the general state table, the products in detail of the Mississippi River district are readily ascertainable.

The distribution by districts of the chief products, ranked according to value, is given in the following tabular statement:

\begin{tabular}{|c|c|c|c|}
\hline \multirow[b]{2}{*}{ SPECIES. } & \multicolumn{3}{|c|}{ YALUE OP PRODCCTS: 1908.} \\
\hline & Total. & $\begin{array}{l}\text { Mississippl } \\
\text { River } \\
\text { district. }\end{array}$ & $\begin{array}{l}\text { Missourl } \\
\text { River } \\
\text { district. }\end{array}$ \\
\hline Total........ & $\$ 215,000$ & $\$ 205,000$ & $\$ 9,300$ \\
\hline 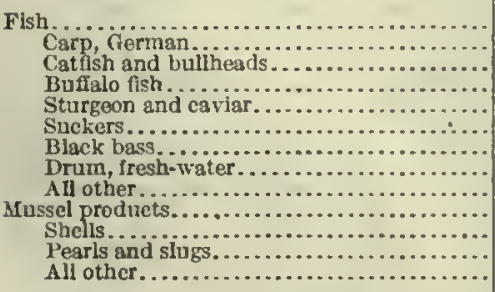 & $\begin{array}{r}167,000 \\
62,000 \\
33,000 \\
23,000 \\
16,000 \\
6,600 \\
5,600 \\
5,300 \\
15,000 \\
44,000 \\
33,000 \\
11,000 \\
3,300\end{array}$ & $\begin{array}{r}158,000 \\
57,000 \\
31,000 \\
22,000 \\
16,000 \\
6,600 \\
5,600 \\
5,200 \\
14,000 \\
44,000 \\
33,000 \\
11,000 \\
3,300\end{array}$ & 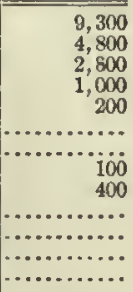 \\
\hline
\end{tabular}

Products, by apparatus of capture.-The following tabular statement shows the distribution of the value of products by waters and according to the kind of apparatus used in making the cateh:

\begin{tabular}{|c|c|c|c|}
\hline \multirow[b]{2}{*}{ KND OF APPARATUS. } & \multicolumn{3}{|c|}{ VALCE OP PRODUCTS: 1908.} \\
\hline & Total. & $\begin{array}{l}\text { Mississippl } \\
\text { River } \\
\text { district. }\end{array}$ & $\begin{array}{l}\text { MIJssourl } \\
\text { River } \\
\text { district. }\end{array}$ \\
\hline Total......................................... & $\$ 215,000$ & $\$ 205,000$ & $\$ 9,300$ \\
\hline 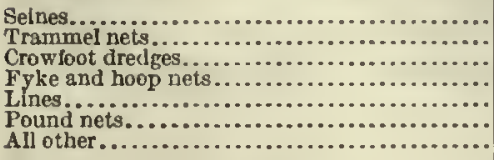 & $\begin{array}{r}68,000 \\
46,000 \\
44,000 \\
30,000 \\
12,000 \\
11,000 \\
2,000\end{array}$ & $\begin{array}{r}64,000 \\
43,000 \\
44,000 \\
28,000 \\
11,000 \\
11,000 \\
2,000\end{array}$ & $\begin{array}{r}3,300 \\
2,900 \\
1,1,100 \\
1,500 \\
\cdots \ldots .\end{array}$ \\
\hline
\end{tabular}

As shown by the table on page 126 , seines were used in the capture of every spccies of fish proper caught in any of the waters of the state, with the exception of eels, and the catch by seines represented 32 per cent of the total value of all products caught.
Trammel nets, with which fishery products aggregating 21 per cent of the total value for the state were cauglit, were also employed in taking a great number of species; but the catch with crowfoot dredges, ranking next and representing 20 per cent of the total value, consisted exclusively of mussel products.

Mussel products.-The comparison of the weight and value of several general classes of the products of the Iowa fisheries for 1894,1899 , and 1908, given in the following tabular statement, is of special interest, as showing the phenomenal growth of the mussel industry between 1894 and 1899 and its rapid decline since:

\begin{tabular}{|c|c|c|c|c|c|c|c|c|}
\hline \multirow{3}{*}{ YEAR. } & \multicolumn{8}{|c|}{ FISHERY PRODUCTS. } \\
\hline & \multicolumn{2}{|c|}{ Total. } & \multicolumn{2}{|c|}{ Fish. } & \multicolumn{2}{|c|}{$\begin{array}{l}\text { Mussel shells, } \\
\text { pearls, and slugs. }\end{array}$} & \multicolumn{2}{|c|}{$\begin{array}{c}\text { All other prod- } \\
\text { vets. }\end{array}$} \\
\hline & $\begin{array}{c}\text { Quan- } \\
\text { tity } \\
\text { (pounds). }\end{array}$ & Value. & $\begin{array}{c}\text { Quan- } \\
\text { tity } \\
\text { (pounds). }\end{array}$ & Value. & $\begin{array}{c}\text { Quan- } \\
\text { tity } \\
\text { (ponnds). }\end{array}$ & Value. & $\begin{array}{c}\text { Quan- } \\
\text { tity } \\
\text { (pounds). }\end{array}$ & Value. \\
\hline $\begin{array}{l}1908 . . . \\
1899 . . . \\
1894 . .\end{array}$ & $\begin{array}{r}8,867,000 \\
23,902,000 \\
4,080,000\end{array}$ & $\begin{array}{r}\$ 215,000 \\
208,000 \\
125,000\end{array}$ & $\begin{array}{l}4,071,000 \\
3,3 r 9,000 \\
3,932,000\end{array}$ & $\begin{array}{r}\$ 167,000 \\
110,000 \\
123,000\end{array}$ & $\begin{array}{r}4,699,000 \\
20,354,000 \\
148,000\end{array}$ & $\begin{array}{r}\$ 44,000 \\
97,000 \\
2,100\end{array}$ & $\begin{array}{r}97,000 \\
18,000 \\
\ldots \ldots\end{array}$ & $\begin{array}{r}\$ 3,300 \\
400 \\
\ldots \ldots . . .\end{array}$ \\
\hline
\end{tabular}

1 Includes frogs, turtles, and skins.

In $1899,10,000$ tons of mussel shells were dredged in the Iowa fisheries, while in 1894 only 74 tons were reported. Since 1899 , however, the beds appear to have become gradually exhausted, and in 1908 only 2,300 tons were obtained. The value of the mussel product, which in 1894 was only $\$ 2,100$, or less than 2 per cent of the value of the fishery produets of the state, was $\$ 97,000$ in 1899 , or nearly 47 per cent of the total of all products in that year. By 1908 the value of the mussel shells had fallen to $\$ 44,000$, or 20 per cent of the total value of fishery products. Nevertheless, at the last canvass of the states having fisheries along the Mississippi and its tributaries, only three-Arkansas, Illinois, and Indiana-reported a greater value of mussel-shell product than Iowa. Among the fishery products of Iowa at that date the value of the product of the mussel-shell industry was exceeded only by that of the carp catch.

Other leading products.- The German carp was the leading variety of fish in 1908, the value of the catch forming 29 per cent of the total value of products and being nearly twice as great as the value of the species next in importance-catfish and bullheads. From 1899 to 1908 the carp product increased from $1,039,000$ pounds, valued at $\$ 23,000$, to $2,048,000$ pounds, valued at $\$ 62,000$; that is, the product nearly doubled in weight and nearly tripled in value.

Catfish, buffalo fish, and fresh-water drun were each reported in sinaller quantities in 1908 than in 1899 , but increases oceurred in the quantity and value of the suckers and black bass caught. The catch of sturgeon, however, gained greatly between the two canvasses, increasing from 44,000 pounds, valued at $\$ 1,400$, to 223,000 pounds, valued at $\$ 16,000$. 
TABLE 1.-IOWA-FISHERY PRODUCTS: 1908.

\begin{tabular}{|c|c|c|c|c|c|c|c|c|c|c|c|c|c|c|}
\hline \multirow{3}{*}{ SPECJES. } & \multicolumn{2}{|c|}{ TOTAL. } & \multicolumn{12}{|c|}{ PRODUCT CAUGDT BY- } \\
\hline & \multirow{2}{*}{$\begin{array}{l}\text { Qnantity } \\
\text { (pounds). }\end{array}$} & \multirow{2}{*}{ Value. } & \multicolumn{2}{|c|}{ Selnes. } & \multicolumn{2}{|c|}{ Trammel nets. } & \multicolumn{2}{|c|}{$\begin{array}{l}\text { Fyko and hoop } \\
\text { nets. }\end{array}$} & \multicolumn{2}{|c|}{ Lines. } & \multicolumn{2}{|c|}{ Pound nets. } & \multicolumn{2}{|c|}{$\begin{array}{l}\text { All other appar } \\
\text { ratus.1 }\end{array}$} \\
\hline & & & $\begin{array}{l}\text { Quantity } \\
\text { (pounds). }\end{array}$ & Value. & $\begin{array}{l}\text { Quantity } \\
\text { (pounds). }\end{array}$ & Value. & $\begin{array}{l}\text { Quantity } \\
\text { (pounds). }\end{array}$ & Value. & $\begin{array}{l}\text { Quantity } \\
\text { (pounds). }\end{array}$ & Value. & $\begin{array}{l}\text { Quantity } \\
\text { (pounds). }\end{array}$ & Value. & $\begin{array}{l}\text { Quantity } \\
\text { (pounds). }\end{array}$ & Value. \\
\hline Total.. & $8,867,000$ & $\$ 215,000$ & $1,877,000$ & $\$ 68,000$ & $1,087,000$ & $\$ 46,000$ & 625,000 & $\$ 30,000$ & 200,000 & $\$ 12,000$ & 321,000 & $\$ 11,000$ & $4,756,000$ & $\$ 47,000$ \\
\hline 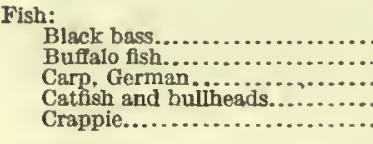 & $\begin{array}{r}54,000 \\
566,000 \\
2,048,000 \\
418,000 \\
115,000\end{array}$ & $\begin{array}{r}5,600 \\
23,000 \\
62,000 \\
33,000 \\
4,700\end{array}$ & $\begin{array}{r}40,000 \\
222,000 \\
1,004,000 \\
182,000 \\
89,000\end{array}$ & $\begin{array}{r}4,200 \\
8,400 \\
29,000 \\
11,000 \\
3,600\end{array}$ & $\begin{array}{r}5,400 \\
112,000 \\
562,000 \\
18,000 \\
9,800\end{array}$ & $\begin{array}{r}600 \\
1,800 \\
18,000 \\
1,700 \\
400\end{array}$ & $\begin{array}{r}1,200 \\
159,000 \\
265,000 \\
109,000 \\
8,500\end{array}$ & $\begin{array}{r}100 \\
6,900 \\
8,600 \\
11,000 \\
400\end{array}$ & $\begin{array}{r}4,300 \\
17,000 \\
6.5,000 \\
74,000 \\
100\end{array}$ & $\begin{array}{r}400 \\
700 \\
2,100 \\
7,400 \\
(2)\end{array}$ & $\begin{array}{r}2,800 \\
54,000 \\
150,000 \\
35,000 \\
7,500\end{array}$ & $\begin{array}{r}300 \\
2,000 \\
4,300 \\
2,300 \\
300\end{array}$ & $\begin{array}{l}1,500 \\
2,000\end{array}$ & $\begin{array}{l}100 \\
100\end{array}$ \\
\hline 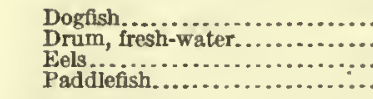 & $\begin{array}{r}7,800 \\
188,000 \\
5,400 \\
6,900\end{array}$ & $\begin{array}{r}100 \\
5,300 \\
600 \\
300\end{array}$ & $\begin{array}{r}7,800 \\
89,000 \\
-5,600\end{array}$ & $\begin{array}{r}100 \\
2,400 \\
\because \because 300\end{array}$ & $\begin{array}{r}47,000 \\
1,300\end{array}$ & $\begin{array}{l}1,300 \\
100\end{array}$ & $\begin{array}{r}15,000 \\
800\end{array}$ & $\begin{array}{l}500 \\
100\end{array}$ & $\begin{array}{r}20,000 \\
4,400\end{array}$ & $\begin{array}{l}700 \\
500\end{array}$ & $\begin{array}{r}19,000 \\
300\end{array}$ & $\begin{array}{l}400 \\
(\text { (2) }\end{array}$ & & \\
\hline 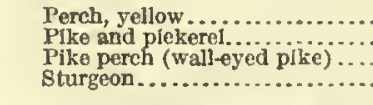 & $\begin{array}{r}12,000 \\
61,000 \\
38,000 \\
215,000\end{array}$ & $\begin{array}{r}300 \\
3,200 \\
2,700 \\
11,000\end{array}$ & $\begin{array}{r}8,200 \\
40,000 \\
25,000 \\
20,000\end{array}$ & $\begin{array}{r}200 \\
2,100 \\
1,800 \\
1,100\end{array}$ & $\begin{array}{r}5,600 \\
4,200 \\
184,000\end{array}$ & $\begin{array}{r}300 \\
400 \\
9,500\end{array}$ & $\begin{array}{r}900 \\
1,600 \\
1,600 \\
300\end{array}$ & $\begin{array}{l}(2) \\
100 \\
100 \\
(3)\end{array}$ & $\begin{array}{l}2,000 \\
2,600 \\
8,700\end{array}$ & $\begin{array}{l}100 \\
200 \\
600\end{array}$ & $\begin{array}{r}2,400 \\
12,000 \\
4,300 \\
800\end{array}$ & $\begin{array}{r}100 \\
600 \\
330 \\
(2)\end{array}$ & & \\
\hline 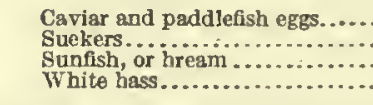 & $\begin{array}{r}8,600 \\
197,000 \\
12,000 \\
4,700\end{array}$ & $\begin{array}{r}5,300 \\
6,600 \\
2,700 \\
300\end{array}$ & $\begin{array}{r}200 \\
13,000 \\
107,000 \\
4,200\end{array}$ & $\begin{array}{r}100 \\
300 \\
2,200 \\
300\end{array}$ & $\begin{array}{r}8,400 \\
125,000 \\
5,000\end{array}$ & $\begin{array}{r}5,200 \\
4,300 \\
200\end{array}$ & $\begin{array}{r}52,000 \\
3,000\end{array}$ & $\begin{array}{r}2,000 \\
100\end{array}$ & 500 & (2) & $\begin{array}{r}6,200 \\
12,000\end{array}$ & $\begin{array}{l}100 \\
300\end{array}$ & & \\
\hline 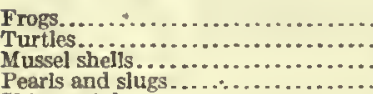 & $\begin{array}{r}2,500 \\
93,000 \\
4,699,000 \\
\hdashline \ldots . .\end{array}$ & $\begin{array}{r}300 \\
1,800 \\
33,000 \\
11,000\end{array}$ & 21,000 & 400 & & & 7,400 & 100 & 800 & (2) & 15,000 & 300 & $\begin{array}{r}2,500 \\
49,000 \\
4,699,000\end{array}$ & $\begin{array}{r}300 \\
1,000 \\
33,000 \\
11,000\end{array}$ \\
\hline 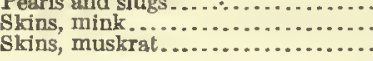 & $\begin{array}{r}3100 \\
41,400\end{array}$ & $\begin{array}{r}11,000 \\
400 \\
800\end{array}$ & & & & & & & & & & & 1,400 & $\begin{array}{r}400 \\
800\end{array}$ \\
\hline
\end{tabular}

1 Includes apparatus, with catch, as follows: Crowfoot dredges, 4,699,000 pounds, valued at $\$ 44,000$; hooks, spears, etc., 55,000 pounds, valued ai $\$ 1,400$; and mink and

muskrat traps, 1,500 pounds, valued at $\$ 1,200$.
2 Less than $\$ 100$. 100 skins.

TABLE 2.-IOWA-FISHERY PRODUCTS OF MISSOURI RIVER DISTRICT: 1908.

\begin{tabular}{|c|c|c|c|c|c|c|c|c|c|c|}
\hline \multirow{3}{*}{ SPECIES. } & \multicolumn{2}{|c|}{ TOTAL. } & \multicolumn{8}{|c|}{ PRODUCT CAUGHT BY- } \\
\hline & \multirow{2}{*}{$\begin{array}{l}\text { Quantity } \\
\text { (pounds). }\end{array}$} & \multirow[b]{2}{*}{ Value. } & \multicolumn{2}{|c|}{ Seines. } & \multicolumn{2}{|c|}{ Tramamel nets. } & \multicolumn{2}{|c|}{ Fyke and hoop nets. } & \multicolumn{2}{|c|}{ Ilnes. } \\
\hline & & & $\begin{array}{l}\text { Quantity } \\
\text { (pounds). }\end{array}$ & $\begin{array}{c}\text { Value. } \\
\text { ह }\end{array}$ & $\begin{array}{l}\text { Quantlty } \\
\text { (pounds). }\end{array}$ & Value. & $\begin{array}{l}\text { Quantity } \\
\text { (pounds). }\end{array}$ & Value. & $\begin{array}{l}\text { Quantity } \\
\text { (pounds). }\end{array}$ & Value. \\
\hline Total..... & 143,000 & $\$ 9,300$ & 56,000 & $\$ 3,300$ & 48,000 & $\$ 2,900$ & 21,000 & $\$ 1,600$ & 18,000 & $\$ 1, \$ 00$ \\
\hline 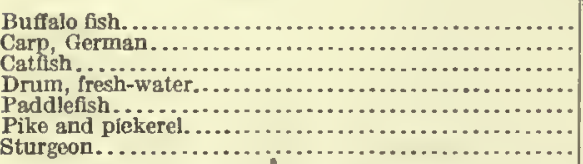 & $\begin{array}{r}16,000 \\
89,000 \\
27,000 \\
1,400 \\
6,900 \\
600 \\
3,100\end{array}$ & $\begin{array}{r}1,000 \\
4,500 \\
2,800 \\
100 \\
300 \\
100 \\
200\end{array}$ & $\begin{array}{r}6,000 \\
36,000 \\
7,000 \\
600 \\
5,600 \\
400 \\
700\end{array}$ & $\begin{array}{l}300 \\
1,900 \\
(100 \\
(1) \\
(100 \\
(1)\end{array}$ & $\begin{array}{r}5,800 \\
35,000 \\
5,000 \\
500 \\
1,300 \\
200 \\
400\end{array}$ & $\begin{array}{l}400 \\
1,000 \\
500 \\
(1) \\
(100 \\
\text { (1) }\end{array}$ & $\begin{array}{r}2,000 \\
12,000 \\
6,800 \\
300 \\
\cdots \\
\cdots\end{array}$ & 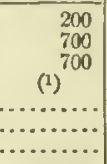 & 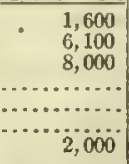 & 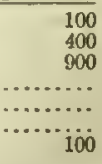 \\
\hline
\end{tabular}

1 Less than $\$ 100$.

KANSAS.

The fishing industry is not important in Kansas, and commercial fishing in 1908, which was entirely of the shore and boat class, was confined to the Missouri River and to the part of the Kansas River near its mouth. The principal statisties of the fisheries of the state are summarized in the following statement:

Number of persons employed..................... 97 Capital:

Boats.................................. $\$ 3,200$

A pparatus of capture...................... 3,900

Shore and accessory property and cash.......... 2,200

Value of products.......................... 28,000

Comparison with previous canvasses. $-\Lambda$ comparison of the statisties for 1908 and those for former years, which were secured by the Bureau of Fisheries, is presented in the following tabular statement. There was a deerease in the number of persons engaged in the industry, but an increase of over 100 per cent in the value of the equipment and in the value of the produet.

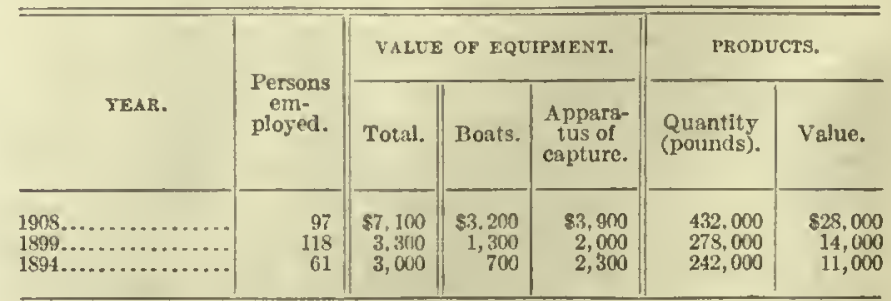

Persons employcd. - Of the 97 persons employed in the fisheries of Kransas, 90 were proprietors and inde- 
pendent fishermon. The seven wage-carners received, including provisions furnished, the sum of $\$ 400$.

Equipment and other capital.-The value of the equipment and other capital reported for the Kansas fisheries in 1908, and the number of the various kinds of boats used, are shown in the following tabular statement:

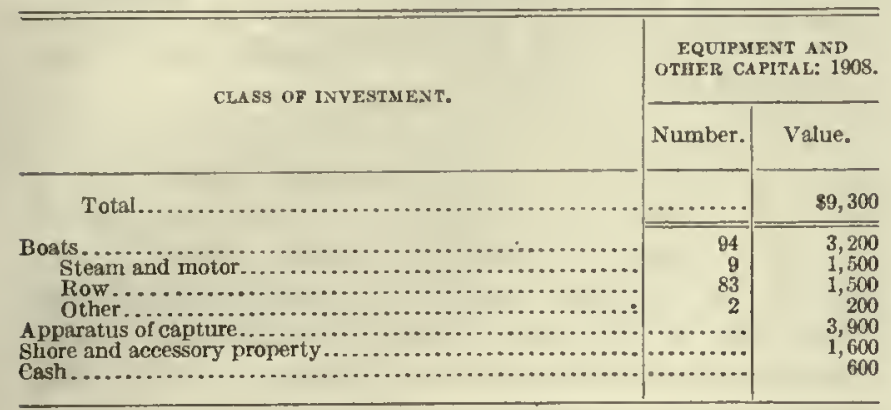

The total investment in apparatus of capture was $\$ 3,900$, of which amount $\$ 2,900$ represented the value of 620 fyke and hoop nets, which were by far the most important forms of apparatus. There were 32 trammel nets and 17 seines reported.
Products.-The total product, which amounted to 432,000 pounds, valued at $\$ 28,000$, is shown in detail, by species and by apparatus of capture, in the following table.

German carp formed by far the most important fishery product, the total catch in 1908 being 304,000 pounds, valued at $\$ 19,000$, or 70 per cent of the quantity and 68 per cent of the value of all fishery products of the state. The quantity and value reported for this fish have increased to a great extent since 1894 , when the catch was 19,000 pounds and the value $\$ 600$.

Catfish, on the other hand, showed a large decrease, the total cateh in 1908 being only 52,000 pounds, valued at $\$ 4,400$, compared with 95,000 pounds, valued at $\$ 6,100$, in 1899 . Buffalo fish also showed a decrease between 1899, when the catch was 52,000 pounds, valued at $\$ 2,200$, and 1908 , when it was 35,000 pounds, valued at $\$ 2,000$.

Fyke and hoop nets, trammel nets, and seines were the chief forms of apparatus of capture used, German carp representing most of the value of the catch in each case.

KANSAS-FISHERY PRODUCTS: 1908.

\begin{tabular}{|c|c|c|c|c|c|c|c|c|c|c|}
\hline \multirow{3}{*}{ SPECIES. } & \multirow{2}{*}{\multicolumn{2}{|c|}{ TOTAL. }} & \multicolumn{8}{|c|}{ PRODUCT CAUGHT BY- } \\
\hline & & & \multicolumn{2}{|c|}{ Fyke and hoop nets. } & \multicolumn{2}{|c|}{ Trammel nets. } & \multicolumn{2}{|c|}{ Scines. } & \multicolumn{2}{|c|}{ Lines. } \\
\hline & $\begin{array}{l}\text { Quantity } \\
\text { (pounds). }\end{array}$ & Valuo. & $\begin{array}{l}\text { Quantity } \\
\text { (pounds). }\end{array}$ & Value. & $\begin{array}{l}\text { Quantity } \\
\text { (pounds). }\end{array}$ & Value. & $\begin{array}{l}\text { Quantity } \\
\text { (pounds). }\end{array}$ & Valtue. & $\begin{array}{l}\text { Quantity } \\
\text { (pounds). }\end{array}$ & Value. \\
\hline Total. . & . 432,000 & 828,000 & 154,000 & $\$ 10,000$ & 125,000 & $\$ 8,000$ & 124,000 & $\$ 7,700$ & 30,000 & $\$ 2,400$ \\
\hline 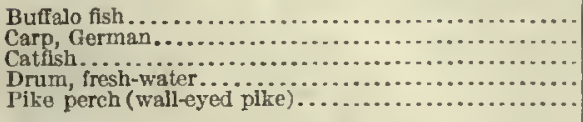 & $\begin{array}{r}35,000 \\
304,000 \\
52,000 \\
18,000 \\
6,600\end{array}$ & $\begin{array}{r}2,000 \\
19,000 \\
4,400 \\
1,100 \\
500\end{array}$ & $\begin{array}{r}13,000 \\
112,000 \\
16,000 \\
5,200 \\
1,700\end{array}$ & $\begin{array}{r}700 \\
7,200 \\
1,300 \\
300 \\
100\end{array}$ & $\begin{array}{r}12,000 \\
89,000 \\
11,000 \\
6,800 \\
2,700\end{array}$ & $\begin{array}{r}700 \\
5,600 \\
900 \\
400 \\
200\end{array}$ & $\begin{array}{r}11,000 \\
89,000 \\
12,000 \\
5,200 \\
2,200\end{array}$ & $\begin{array}{r}600 \\
5,400 \\
900 \\
300 \\
200\end{array}$ & $\begin{array}{r}14,000 \\
14,000 \\
1,000\end{array}$ & $\begin{array}{r}900 \\
1,300 \\
100\end{array}$ \\
\hline 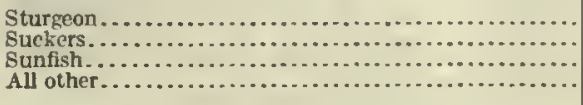 & $\begin{array}{l}7,300 \\
1,900 \\
2,300 \\
4,000\end{array}$ & $\begin{array}{l}400 \\
100 \\
100 \\
300\end{array}$ & $\begin{array}{r}2,800 \\
800 \\
1,000 \\
1,000\end{array}$ & $(1)^{200}$ & $\begin{array}{r}1,800 \\
700 \\
600 \\
1,000\end{array}$ & $\stackrel{(1)}{11}_{100}^{100}$ & $\begin{array}{r}1,600 \\
400 \\
500 \\
2,200\end{array}$ & $(1)^{100}$ & $\begin{array}{rl} & 1,100 \\
20 & 200 \\
2 & \end{array}$ & ${ }^{100}$ \\
\hline
\end{tabular}

1 Less than $\$ 100$.

KENTUCKY.

The fisheries of Kentucky, all of which are of the shore and boat class, fall into two main divisions, those of the Mississippi River and its small tributaries in the western part of the state and those of the Ohio River and its tributaries, including the Tennessee and the Cumberland Rivers. In respect to quantity, mussel shells, buffalo fish, and German carp were the leading products, in the order named, while in respect to value, catfish, buffalo fish, and German carp led, in the order named. The mussel shell and pearl industry is of recent development. The following statement gives a summary of the industry for 1908:

Number of persons employed........................ Capital:

Boats................................ $\$ 11,000$

Apparatus of capture......................... 21,000

Shore and accessory property .................. 6,600

Value of products....................... 110,000

Comparison with previous canvasses. - $\mathrm{A}$ comparison of the industry in 1908 with certain earlier years, for 
which statistics collected by the Bureau of Fisheries are available, is given in the following tabular statement:

\begin{tabular}{|c|c|c|c|c|c|c|}
\hline \multirow[b]{2}{*}{ YEAR. } & \multirow{2}{*}{$\begin{array}{c}\text { Persons } \\
\text { em- } \\
\text { ployed, } \\
\text { exclusive } \\
\text { of shores- } \\
\text { men. }\end{array}$} & \multicolumn{3}{|c|}{ VAIUE OF EQUIPMENT. } & \multicolumn{2}{|c|}{ PRODUCTS. } \\
\hline & & Total. & $\begin{array}{c}\text { Vessels } \\
\text { and } \\
\text { hoats, in- } \\
\text { cluding } \\
\text { outfit. }\end{array}$ & $\begin{array}{l}\text { Appara } \\
\text { tus of } \\
\text { capture. }\end{array}$ & $\begin{array}{l}\text { Quantity } \\
\text { (pounds). }\end{array}$ & Value. \\
\hline $\begin{array}{l}1908 \ldots \ldots \ldots \ldots \\
1899 \ldots \ldots \ldots \ldots \\
1894 \ldots \ldots \ldots\end{array}$ & $\begin{array}{l}544 \\
551 \\
587\end{array}$ & $\begin{array}{l}\$ 32,000 \\
30,000 \\
33,000\end{array}$ & $\begin{array}{r}\$ 11,000 \\
10,000 \\
10,000\end{array}$ & $\begin{array}{r}\$ 21,000 \\
19,000 \\
23,000\end{array}$ & $\begin{array}{l}5,390,000 \\
1,753,000 \\
2,274,000\end{array}$ & $\begin{array}{r}\$ 110,000 \\
79,000 \\
90,000\end{array}$ \\
\hline
\end{tabular}

The large increase shown for 1908 in quantity of product was due almost entirely to the mussel fisheries, which were not reported in the preceding canvasses.

Persons employed.-The following tabular statement gives the statistics of the persons employed in the Kentucky fisheries in 1908:

\begin{tabular}{|c|c|c|c|c|}
\hline \multirow{3}{*}{ DISTRICT AND CLASS. } & \multicolumn{4}{|c|}{ PERSONS EMPLOYED: 1908.} \\
\hline & \multicolumn{3}{|c|}{ Number. } & \multirow[b]{2}{*}{ Wages. } \\
\hline & Total. & $\begin{array}{l}\text { Proprietors } \\
\text { and inde- } \\
\text { pendent } \\
\text { fishermen. }\end{array}$ & $\begin{array}{l}\text { Wage- } \\
\text { earners. }\end{array}$ & \\
\hline Total.......... & 555 & 452 & 103 & $\$ 6,600$ \\
\hline Mississippl Rlver district.... & 87 & 79 & 8 & 600 \\
\hline 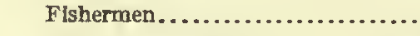 & 87 & 79 & 8 & 600 \\
\hline Ohio River district............ & 469 & 373 & 95 & 5,900 \\
\hline 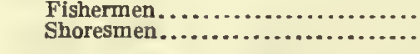 & $\begin{array}{r}457 \\
11\end{array}$ & $\begin{aligned} & 373 \\
\ldots \ldots & \end{aligned}$ & $\begin{array}{l}84 \\
11\end{array}$ & $\begin{array}{r}15,400 \\
600\end{array}$ \\
\hline
\end{tabular}

1 Includes provisions furnished to the value of $\$ 400$.

The fishing was done on a small scale, and the prevailing type of person engaged in this pursuit was the independent fisherman. All the shoresmon and a large proportion of the other wage-earners were employed in the mussel industry. The small amount paid in wages indicates that the wage-earners were engaged in the fisheries only a part of the time.

Equipment and other capital.-The value of the equipment and the amount of other capital employed are shown below:

\begin{tabular}{|c|c|c|c|}
\hline \multirow{2}{*}{ CLASS OF INVESTMENT. } & \multicolumn{3}{|c|}{$\begin{array}{l}\text { VALUE OF EQUIPMENT AND } \\
\text { OTHER CAPITAL: } 1908 .\end{array}$} \\
\hline & Total. & $\begin{array}{c}\text { Ohio } \\
\text { River } \\
\text { district. }\end{array}$ & $\begin{array}{l}\text { Mississippi } \\
\text { River } \\
\text { district. }\end{array}$ \\
\hline Total....... & $\$ 39,000$ & $\$ 29,000$ & $\$ 9,400$ \\
\hline 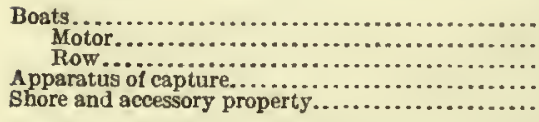 & $\begin{array}{r}11,000 \\
4,500 \\
6,600 \\
21,000 \\
6,600\end{array}$ & $\begin{array}{r}8,300 \\
3,600 \\
4,700 \\
16,000 \\
4,400\end{array}$ & $\begin{array}{r}2,800 \\
1,900 \\
4,400 \\
2,200\end{array}$ \\
\hline
\end{tabular}

Boats constituted somewhat less than one-third of the total investment and apparatus of capture more than one-half. For the entire state 479 rowboats and 32 motor boats were reported, 399 of the former and 26 of the latter being used in the Ohio River district. Fyke and hoop nets largely predominated among the apparatus of capture, 2,513 being used in the Ohio River district and 767 in the Mississippi River district. Thirty-six seines and one trammel net were reported for the Ohio River district and four seines and one trammel net for the Mississippi River district.

Products, by species.-The products for 1908 were distributed by species and apparatus of capture as shown in Table 1, on page 129. Thirteen species of fish were reported, besides turtles and mussels. Five of the products together represented more than nine-tenths of the total, both in weight and value. In order of value they were catfish, buffalo fish, mussel products (including shells and pearls), German carp, and fresh-water drum. In 1899 musscls were not reported and the German carp was of minor importance, but catfish, buffalo fish, and drum led in the order named, and together contributed nearly 73 per cent of the total product, both in weight and in value.

Products, by fishing grounds.-Table 2, on page 129, gives in detail the fishery products of the state from the Ohio River and its tributaries, and Table 3, on page 130, those from the Mississippi River and its tributaries other than the Ohio River.

In the Ohio River district the leading species were, in the order of their value, the mussel, catfish, buffalo fish, fresh-watcr drum, and carp, which together formed 91 per cent of the total value of products. The most important fishing grounds in this district are those of the Ohio River. The products of the Mississippi River district constituted about onc-third in quantity of the total product of the state, exclusive of mussel shells. Catfish, buffalo fish, carp, and drum formed the bulk of the catch and contributed over 93 per cent of the total for the district, both in weight and in value.

Products, by apparatus of capture.-Crowfoot dredges, used exclusively for mussels, took more than 63 per cent of the product. In value, however, the catch by crowfoot dredges was exceeded by the catch by fyke and hoop nets and that by lines. The product taken by fyke and hoop nets contributed 43 per cent of the total value, and that taken by lines over 27 per cent. In the Mississippi River district 96 per cent of the total quantity was taken by these two forms of apparatus, and in the Olio River district 23 per cent of the total. Nearly all the seine catch was from the Ohio River fisheries. More than one-half of the catch by lines consisted of catfish, and more than half of the catfish catch was taken by lines.

Catfish.-The catch of catfish represented in 1908 nearly 24 per cent of the total value of the fishery products of the state. The yield was slightly larger, 
in respect to both quantity and value, than in 1899, although its relative importance was somewhat greater at the earlicr date, when it contributed 26 per cent of the value of the total fishery yield of the state. Two-thirds of the value of this species was from the Ohio River district, and one-third from the Mississippi River district.

Buffalo fish.-This product in 1908 was credited with about 20 per cent of the total value of the catch. The species showed a substantial increase in both quantity and value over the figures for 1899, but declined somewhat in relative importance. Of the value of the catch of buffalo fish, 71 per cent was reported from the Ohio River district.

Mussel products.-Mussel shells, together with pearls and slugs, ranked third in value of products, and contributed 18 per cent of the total value of products. The mussel product, which in 1908 appears for the first time in the statistics of the commercial fisheries of Kentucky, was entirely from the Ohio River district.

German carp.-This fish has advanced from the position of a minor species, with a value of $\$ 3,100$ in 1899 , to fourth rank in 1908 , with a value of $\$ 18,000$, onc-sixth of the total for the state. The Ohio River district reported the greater portion of the catch.

Fresh-water dmum.-This is the only important species which shows a decrease in quantity and value since 1899. In that year 391,000 pounds were taken, valued at $\$ 19,000$, or 24 per cent of the total value of products for the state. Four-fifths of the drum catch was from the Ohio River district.

TABLE 1.-KENTUCKY-FISHERY PRODUCTS: 1908.

\begin{tabular}{|c|c|c|c|c|c|c|c|c|c|c|c|c|}
\hline \multirow{3}{*}{ SPECIES. } & \multirow{2}{*}{\multicolumn{2}{|c|}{ TOTAL. }} & \multicolumn{10}{|c|}{ PRODUCT CAUGHT BY- } \\
\hline & & & \multicolumn{2}{|c|}{ Fyke and boop nets. } & \multicolumn{2}{|c|}{ Llnes. } & \multicolumn{2}{|c|}{ Crowfoot dredges. } & \multicolumn{2}{|c|}{ Selnes. } & \multicolumn{2}{|c|}{ Trammel nets. } \\
\hline & $\begin{array}{l}\text { Quantity } \\
\text { (pounds). }\end{array}$ & Value. & $\begin{array}{l}\text { Quantity } \\
\text { (pounds). }\end{array}$ & Value. & $\begin{array}{l}\text { Quantlty } \\
\text { (pounds). }\end{array}$ & Value. & $\begin{array}{l}\text { Quantity } \\
\text { (pounds). }\end{array}$ & Value. & $\begin{array}{l}\text { Quantity } \\
\text { (pounds). }\end{array}$ & Value. & $\begin{array}{l}\text { Quantity } \\
\text { (pounds). }\end{array}$ & Value. \\
\hline Total............ & $5,390,000$ & $\$ 110,000$ & $1,122,000$ & $\$ 47,000$ & 598,000 & $\$ 30,000$ & $3,413,000$ & $\$ 20,000$ & 247,000 & $\$ 12,000$ & 9,600 & $\$ 400$ \\
\hline 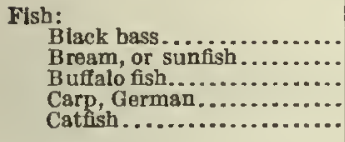 & $\begin{array}{r}7,100 \\
4,300 \\
530,000 \\
449,000 \\
436,000\end{array}$ & $\begin{array}{r}700 \\
200 \\
21,000 \\
18,000 \\
26,000\end{array}$ & $\begin{array}{r}1,600 \\
700 \\
392,000 \\
305,000 \\
120,000\end{array}$ & $\begin{array}{r}(1)^{200} \\
15,000 \\
12,000 \\
8,000\end{array}$ & $\begin{array}{r}2,700 \\
100 \\
76,000 \\
78,000 \\
295,000\end{array}$ & $\begin{array}{r}300 \\
(1) \\
3,300 \\
3,200 \\
17,000\end{array}$ & 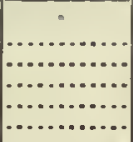 & 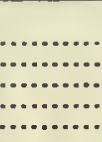 & $\begin{array}{r}2,600 \\
3,200 \\
61,000 \\
61,000 \\
21,000\end{array}$ & $\begin{array}{r}200 \\
100 \\
2,600 \\
2,700 \\
1,200\end{array}$ & $\begin{array}{r}200 \\
300 \\
1,000 \\
5,000 \\
\ldots \ldots\end{array}$ & $\begin{array}{l}\text { (1) } \\
11 \\
1\end{array}{ }_{200}$ \\
\hline 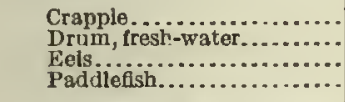 & $\begin{array}{r}12,000 \\
354,000 \\
300 \\
65,000\end{array}$ & $\begin{array}{r}900 \\
16,000 \\
(1) \\
1,700\end{array}$ & $\begin{array}{r}1,800 \\
197,000 \\
53,000\end{array}$ & $\begin{array}{r}100 \\
8,000 \\
1,300\end{array}$ & $\begin{array}{r}700 \\
20,000 \\
300\end{array}$ & $\begin{array}{l}\text { (1) } \\
5,700 \\
\text { (i) }\end{array}$ & & & $\begin{array}{r}9,300 \\
36,000 \\
11,000\end{array}$ & $\begin{array}{r}600 \\
2,400 \\
400\end{array}$ & $\begin{array}{r}700 \\
2,000 \\
2\end{array}$ & $\begin{array}{l}100 \\
100 \\
\cdots \\
\cdots\end{array}$ \\
\hline $\begin{array}{l}\text { Plke perch (wall-eyed plke). } \\
\text { Rock bass and white bass... } \\
\text { Sturgeon, shovelnose........ } \\
\text { Suckers................... }\end{array}$ & $\begin{array}{r}8,400 \\
2,200 \\
60,000 \\
46,000\end{array}$ & $\begin{array}{r}700 \\
200 \\
2,400 \\
2,100\end{array}$ & $\begin{array}{r}5,100 \\
1,100 \\
10,000 \\
34,000\end{array}$ & $\begin{array}{r}500 \\
100 \\
500 \\
1,300\end{array}$ & $\begin{array}{r}2,600 \\
800 \\
21,000 \\
\ldots \ldots \ldots\end{array}$ & $\begin{array}{r}200 \\
100 \\
600 \\
\cdots\end{array}$ & (n) & & $\begin{array}{r}300 \\
300 \\
29,000 \\
12,000\end{array}$ & $\begin{array}{l}(1) \\
1,300 \\
800\end{array}$ & \begin{tabular}{r}
\multicolumn{1}{r}{400} \\
$\ldots \ldots \ldots \ldots$ \\
$\cdots \ldots \ldots \ldots$
\end{tabular} & $\begin{array}{c}(n) \\
\cdots \ldots \ldots \ldots \\
\cdots \ldots \ldots \ldots\end{array}$ \\
\hline 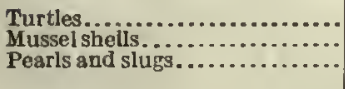 & $\begin{array}{r}1,900 \\
3,413,000 \\
\cdots\end{array}$ & $\begin{array}{r}(1) \\
18,000 \\
1,900\end{array}$ & 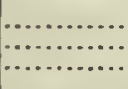 & ........... & $\begin{array}{l}1,900 \\
\ldots \ldots\end{array}$ & $\begin{array}{c}(1) \\
\cdots \cdots \\
\cdots \cdots\end{array}$ & $\ddot{3,4 i 3,000}$ & $\begin{array}{r}18,000 \\
1,900\end{array}$ & {$\left[\begin{array}{c}\cdots \ldots \ldots \ldots \\
\cdots \ldots \ldots \ldots \ldots\end{array}\right.$} & ............... & (n) & \\
\hline
\end{tabular}

1 Less than $\$ 100$.

TABLE 2.-KENTUCKY-FISHERY PRODUCTS OF OHIO RIVER DISTRICT: 1908.

\begin{tabular}{|c|c|c|c|c|c|c|c|c|c|c|c|c|}
\hline \multirow{3}{*}{ SPECIES. } & \multirow{2}{*}{\multicolumn{2}{|c|}{ TOTAL. }} & \multicolumn{10}{|c|}{ PRONUCT CAUOHT BY- } \\
\hline & & & \multicolumn{2}{|c|}{ Fy ke and hoop nets. } & \multicolumn{2}{|c|}{ Lines. } & \multicolumn{2}{|c|}{ Crowfoot dredges. } & \multicolumn{2}{|c|}{ Selnes. } & \multicolumn{2}{|c|}{ Trammel nets. } \\
\hline & $\begin{array}{l}\text { Quantlty } \\
\text { (pounds). }\end{array}$ & Value. & $\begin{array}{l}\text { Quantity } \\
\text { (pounds). }\end{array}$ & Value. & $\begin{array}{l}\text { Quantity } \\
\text { (pounds). }\end{array}$ & Value. & $\begin{array}{l}\text { Quantlty } \\
\text { (pounds). }\end{array}$ & Valué. & $\begin{array}{l}\text { Quantity } \\
\text { (pounds). }\end{array}$ & Value. & $\begin{array}{l}\text { Quantlty } \\
\text { (pounds). }\end{array}$ & Value. \\
\hline Total.................... & $4,765,000$ & $\$ 87,000$ & 719,000 & 534,000 & 397,000 & $\$ 21,000$ & $3,413,000$ & $\$ 20,000$ & 231,000 & $\$ 12,000$ & 4,000 & $\$ 200$ \\
\hline 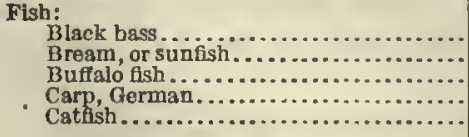 & $\begin{array}{r}6,200 \\
2,000 \\
345,000 \\
289,000 \\
273,000\end{array}$ & $\begin{array}{r}600 \\
100 \\
15,000 \\
13,000 \\
17,000\end{array}$ & $\begin{array}{r}1,600 \\
500 \\
216,000 \\
177,000 \\
101,000\end{array}$ & $\begin{array}{r}200 \\
(1) \\
9,800 \\
7,800 \\
6,900\end{array}$ & $\begin{array}{r}2,700 \\
100 \\
70,000 \\
51,000 \\
152,000\end{array}$ & $\begin{array}{c}300 \\
(1) \\
3,100 \\
2,300 \\
9,300\end{array}$ & 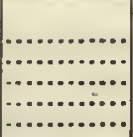 & 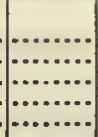 & $\begin{array}{r}1,900 \\
2,300 \\
58,000 \\
59,000 \\
20,000\end{array}$ & $\begin{array}{r}200 \\
100 \\
2,600 \\
2,600 \\
1,100\end{array}$ & $\begin{array}{r} \\
1,000 \\
2,000 \\
\cdots\end{array}$ & (i) 100 \\
\hline 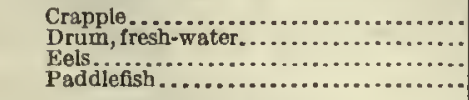 & $\begin{array}{r}6,800 \\
281,000 \\
100 \\
37,000\end{array}$ & $\begin{array}{r}800 \\
14,000 \\
(1) \\
1,000\end{array}$ & $\begin{array}{r}1,200 \\
143,000 \\
20,000\end{array}$ & $\begin{array}{r}100 \\
6,600 \\
700\end{array}$ & $\begin{array}{r}100 \\
101,000 \\
100\end{array}$ & $\begin{array}{l}(1) \\
5,200 \\
(1)\end{array}$ & (n. & & $\begin{array}{r}5,400 \\
35,000 \\
8,000\end{array}$ & $\begin{array}{r}400 \\
2,400 \\
300\end{array}$ & $\begin{array}{r}\ldots, 000 \\
\cdots \ldots \ldots \ldots\end{array}$ & $\begin{array}{ll}(1) \\
\cdots \cdots\end{array}$ \\
\hline 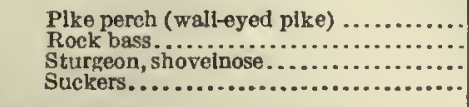 & $\begin{array}{r}6,800 \\
1,400 \\
58,000 \\
46,000\end{array}$ & $\begin{array}{r}600 \\
100 \\
2,400 \\
2,100\end{array}$ & $\begin{array}{r}4,600 \\
10,000 \\
34,000\end{array}$ & $\begin{array}{r}400 \\
100 \\
500 \\
1,300\end{array}$ & $\begin{array}{r}1,900 \\
400 \\
19,000\end{array}$ & $\begin{array}{c}100 \\
600\end{array}$ & 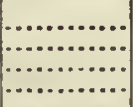 & $\mid \cdots \cdots$ & $\begin{array}{r}300 \\
200 \\
29,000 \\
12,000\end{array}$ & 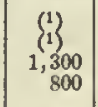 & 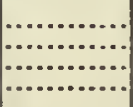 & $\mid \begin{array}{l}-1 \\
\cdots \\
\cdots\end{array}$ \\
\hline 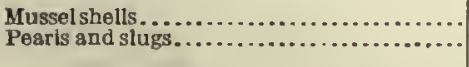 & $\begin{array}{r}3,413,000 \\
\cdots\end{array}$ & $\begin{array}{r}18,000 \\
1,900\end{array}$ & $\begin{array}{l}\cdots \cdots \\
\cdots \cdots\end{array}$ & & & & $\begin{array}{r}3,413,000 \\
\ldots \ldots \ldots \ldots\end{array}$ & $\begin{array}{r}18,000 \\
1,900\end{array}$ & ......... & & & \\
\hline
\end{tabular}


TABLE 3.-KENTUCKY-FISHERY PRODUCTS OF MISSISSIPPI RIVER DISTRICT: 1908.

\begin{tabular}{|c|c|c|c|c|c|c|c|c|c|c|}
\hline \multirow{3}{*}{ SPECLES. } & \multirow{2}{*}{\multicolumn{2}{|c|}{ TOTAL. }} & \multicolumn{8}{|c|}{ PRODUCT CAUGIT BY-- } \\
\hline & & & \multicolumn{2}{|c|}{ Fyke and hoop nets. } & \multicolumn{2}{|c|}{ Lines. } & \multicolumn{2}{|c|}{ Seines. } & \multicolumn{2}{|c|}{ Trammel nets. } \\
\hline & $\begin{array}{l}\text { Quantity } \\
\text { (pounds). }\end{array}$ & Value. & $\begin{array}{l}\text { Quantity } \\
\text { (pounds). }\end{array}$ & Value. & $\begin{array}{l}\text { Quantity } \\
\text { (pounds). }\end{array}$ & Value. & $\begin{array}{l}\text { Quantity } \\
\text { (pounds). }\end{array}$ & Valure. & $\begin{array}{l}\text { Quantity } \\
\text { (pounds). }\end{array}$ & Value. \\
\hline Total............ & 625,000 & $\$ 23,000$ & 402,000 & $\$ 13,000$ & 201,000 & $\$ 9,400$ & 16,000 & $\$ 700$ & 5,600 & $\$ 200$ \\
\hline 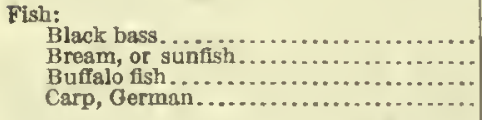 & $\begin{array}{r}1,000 \\
1,400 \\
185,000 \\
161,000\end{array}$ & $\begin{array}{r}100 \\
100 \\
6,000 \\
5,200\end{array}$ & $\begin{array}{l}200 \\
176,000 \\
128,000\end{array}$ & $\begin{array}{l}\text { (i) } \\
5,700 \\
4,100\end{array}$ & $\begin{array}{r}6,000 \\
28,000\end{array}$ & $\begin{array}{r}200 \\
200\end{array}$ & $\begin{array}{r}700 \\
900 \\
3,000 \\
2,400\end{array}$ & $\begin{array}{l}100 \\
100 \\
100\end{array}$ & $\begin{array}{r}200 \\
300 \\
3,000\end{array}$ & $\begin{array}{l}(1) \\
(1) \\
100\end{array}$ \\
\hline 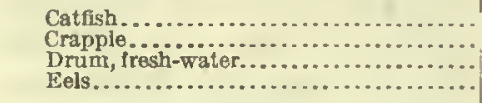 & $\begin{array}{r}163,000 \\
5,700 \\
74,000 \\
200\end{array}$ & $\begin{array}{l}8,800 \\
300 \\
1,900 \\
(1)\end{array}$ & $\begin{array}{r}19,000 \\
500 \\
53,000\end{array}$ & $\begin{array}{l}1,100 \\
(1) \\
1,400\end{array}$ & $\begin{array}{r}143,000 \\
600 \\
19,000 \\
200\end{array}$ & $\begin{array}{l}7,700 \\
\text { (1) } \\
\text { (1) }\end{array}$ & $\begin{array}{r}1,100 \\
3,900 \\
700\end{array}$ & $(1)^{200}$ & $\begin{array}{r}700 \\
1,000\end{array}$ & (1) 100 \\
\hline 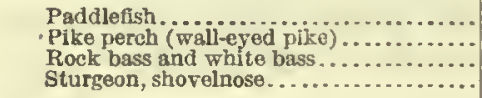 & $\begin{array}{r}28,000 \\
1,600 \\
800 \\
2,000\end{array}$ & $\begin{array}{l}700 \\
100 \\
100 \\
100\end{array}$ & $\begin{array}{r}25,000 \\
600 \\
300\end{array}$ & $\begin{array}{l}(1)^{600} \\
(1)^{2} \\
. \ldots . .\end{array}$ & $\begin{array}{r}600 \\
400 \\
2.000\end{array}$ & $\left.{ }^{(1)}\right)_{100}$ & $\begin{array}{r}3,300 \\
100 \\
\ldots \ldots\end{array}$ & $\begin{array}{r}100 \\
{ }_{(i)}\end{array}$ & $400^{\circ}$ & (i) \\
\hline Turtles................. & 1,900 & (i) & & & 1,900 & (1) & & & & \\
\hline
\end{tabular}

1 Less than $\$ 100$

LOUISIANA.

Of the states bordering upon the Gulf of Mexico, Louisiana in 1908 was second in the extent of her fisheries, ranking next to Florida. In addition to the Gulf fisheries Louisiana has fisheries along the Missis sippi River and its tributaries, chief among which is the Red River. A large local trade in fish and oysters has its center at New Orleans, and there are in addition small wholesale markets for fish at New Orleans and Morgan City, and for oysters at Morgan City and Houma.

The following statement presents a summary of the chief statistics for the state's fisheries in 1908:

Number of persons employed .................. $\quad 5,795$ Capital:

Vesscls and boats, including outfit........... $\$ 794,000$

Apparatus of capture........................ $\quad 95,000$

Shore and accessory property and cash........ 40,000 Value of products........................... 1,569,000

Comparison with previous canvasses. -No statistics concerning the fisheries of Louisiana for years previous to 1908 apply to the entire state, but since the value of the product of the Gulf fisheries constituted, in 1908, 92 per cent of the total value for the state, the statistics compiled at different times for this branch of the state's fisheries represent fairly the development in the state as a whole.

The following tabular statement gives a comparative summary of the principal statistics of the fisheries of the Gulf district of Louisiana for the canvasses of 1890,1897 , and 1908, and those of the Mississippi River district of the state for 1899 and 1908:

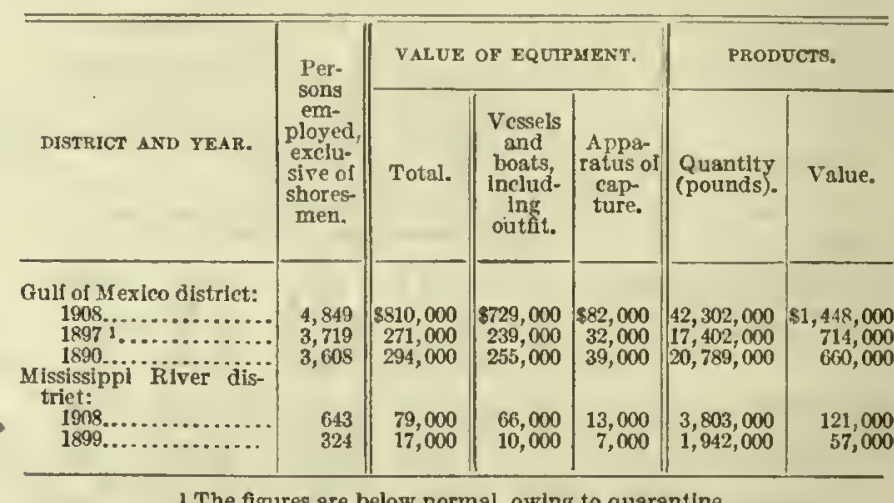

1 The figures are below normal, owing to quarantine.

In Louisiana, as in other states bordering on this body of water, the fisheries of the Gulf of Mexico show an increase in recent years in each of the items covered by the tabular statement, with the exception that in 1897 , owing to the fact that a quarantine was in force for a large part of the year, fishing operations were curtailed and the capital and quantity of product reported were less than in 1890. In the Mississippi River fisheries the amount of capital invested in equipment increased 365 per cent between 1899 and 1908, and in each of the other items there was an increase of more than 86 per cent. In the Gulf district the gain in quantity of product has been much greater than the gain in value; in the Mississippi River district quantity has increased but very little faster than value.

Persons employed.-The statistics of the persons employed in the Louisiana fisheries in 1908 are as follows: 


\begin{tabular}{|c|c|c|c|c|c|c|c|}
\hline \multirow[b]{3}{*}{ DISTRICT AND CZAS9. } & \multicolumn{7}{|c|}{ PERSONS EMPLOYED: $190 \%$. } \\
\hline & \multicolumn{4}{|c|}{ Number. } & \multicolumn{3}{|c|}{ Salarles and wages. } \\
\hline & Total. & $\begin{array}{l}\text { Proprle- } \\
\text { tors and } \\
\text { inde- } \\
\text { pendent } \\
\text { fisher- } \\
\text { men. }\end{array}$ & $\begin{array}{l}\text { Sala } \\
\text { ried } \\
\text { em- } \\
\text { ployees. }\end{array}$ & $\begin{array}{l}\text { Wage- } \\
\text { earn- } \\
\text { ers. }\end{array}$ & Total. & $\begin{array}{l}\text { Sala- } \\
\text { ries. }\end{array}$ & Wages. \\
\hline Total........ & 5,795 & 12,963 & 2 & 2,830 & $\$ 570,000$ & 81,700 & 28568,000 \\
\hline $\begin{array}{l}\text { Oulf of Mexico dis- } \\
\text { trict..................... }\end{array}$ & 5,152 & 2,472 & 2 & 2,678 & 536,000 & 1,700 & 535,000 \\
\hline $\begin{array}{l}\text { Vessel fisheries. } \\
\text { Transporting }\end{array}$ & 503 & 72 & & & & & 98,000 \\
\hline $\begin{array}{l}\text { Shoree and boat } \\
\text { fsheries..... } \\
\text { Shoresmen..... }\end{array}$ & $\begin{array}{r}4,166 \\
303\end{array}$ & 2,381 & 2 & $\begin{array}{r}159 \\
1,785 \\
303\end{array}$ & $\begin{array}{r}51,000 \\
341,000 \\
45,000\end{array}$ & 1,700 & $\begin{array}{r}49,000 \\
341,000 \\
45,000\end{array}$ \\
\hline $\begin{array}{c}\text { Mississippl RIver } \\
\text { district................. }\end{array}$ & 643 & 491 & & 152 & 33,000 & & 33,000 \\
\hline $\begin{array}{l}\text { Transporting } \\
\text { vessels... } \\
\text { Shore and boat } \\
\text { fisheries }\end{array}$ & $\begin{array}{r}34 \\
609\end{array}$ & $\begin{array}{r}1 \\
490\end{array}$ & & $\begin{array}{r}33 \\
119\end{array}$ & $\begin{array}{l}10,000 \\
23,000\end{array}$ & & 10,000 \\
\hline
\end{tabular}

I Exclusive of 73 proprietors not fishing.

Includes provisions furnished to the value of $\$ 145,000$.

The persons employed in the shore and boat fisheries, including 244 shoresmen, outnumbered those employed in the vessel fisheries, including 59 shoresmen, the total figures being 5,019 and 562, respectively. The total number employed in transporting vessels was 214. The number of wage-earners was smaller than the number of proprietors and independent fishermen. The shore and boat fisheries are credited with 2,871 of the 2,963 proprietors and independent fishermen actually engaged in fishing, and with 2,148 of the 2,832 employees. In vessel fisheries employees outnumbered proprietors and independent fishermen, the ratio being about 6 to 1 , and for transporting vessels the ratio was nearly 10 to 1 ; but in shore and boat fisheries proprietors and independent fishermen were more numerous than wage-earners, in the ratio of 4 to 3. The wages and salaries paid equaled 36 per cent of the value of the sproducts.

Equipment and other capital.-The following table gives statistics of the capital invested in Louisiana fisheries in 1908:

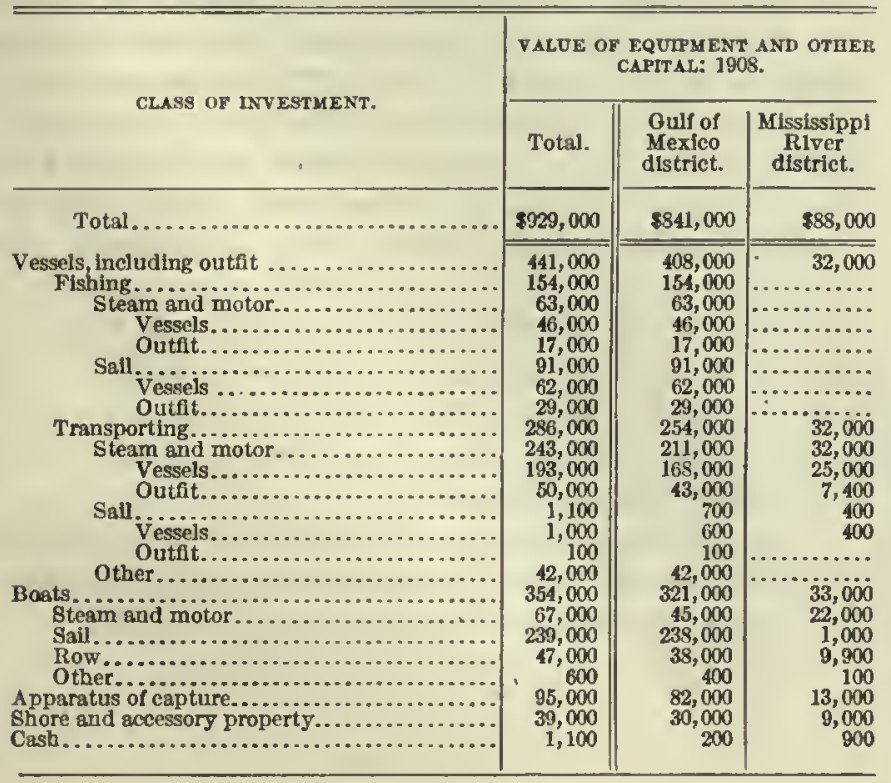

In 1908 slightly over half of the investment in Louisiana fisheries, or $\$ 479,000$, was in shore and boat fisheries. Transporting vessels accounted for $\$ 289,000$ of the capital, and fishing vessels for $\$ 162,000$. Of the value of shore and accessory property, $\$ 1,200$ pertained to vessel fisheries, $\$ 2,500$ to transporting vessels, and $\$ 35,000$ to shore and boat fisheries. Of the cash capital, $\$ 900$ was reported in connection with the shore and boat fisheries in the Mississippi River district, and $\$ 200$ in connection with transporting vessels in the Gulf district. Over 85 per cent of the total capital was invested in craft of various kinds and their outfits.

The number and tonnage of vessels and the number of boats were as follows:

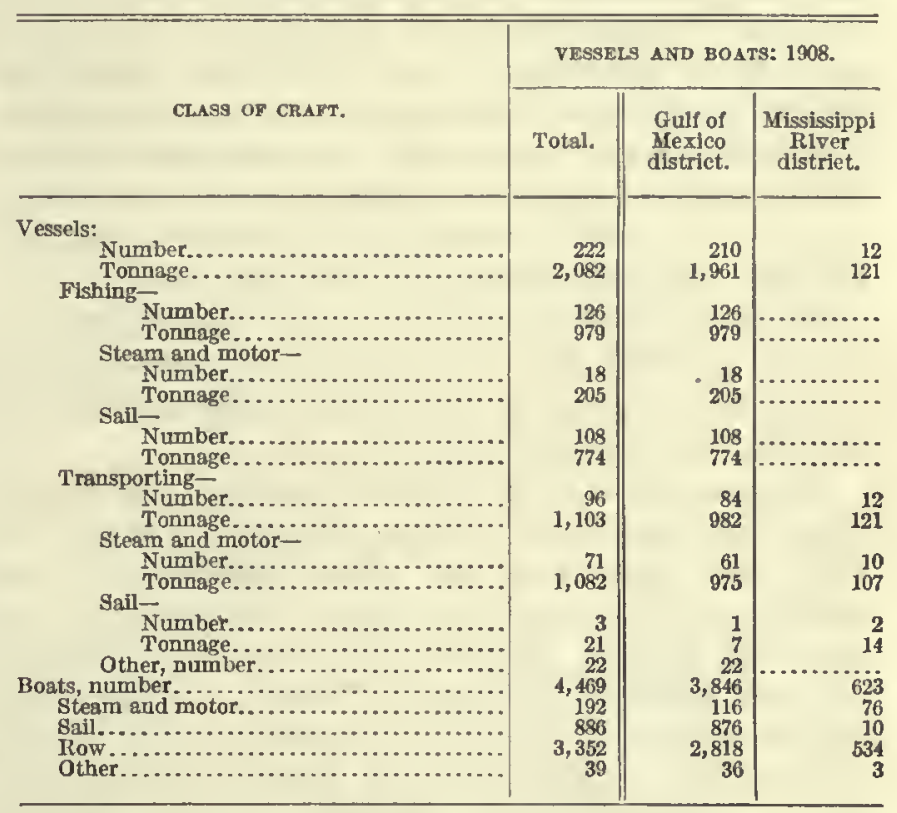

The number of the various kinds of apparatus used is shown in the following tabular statement:

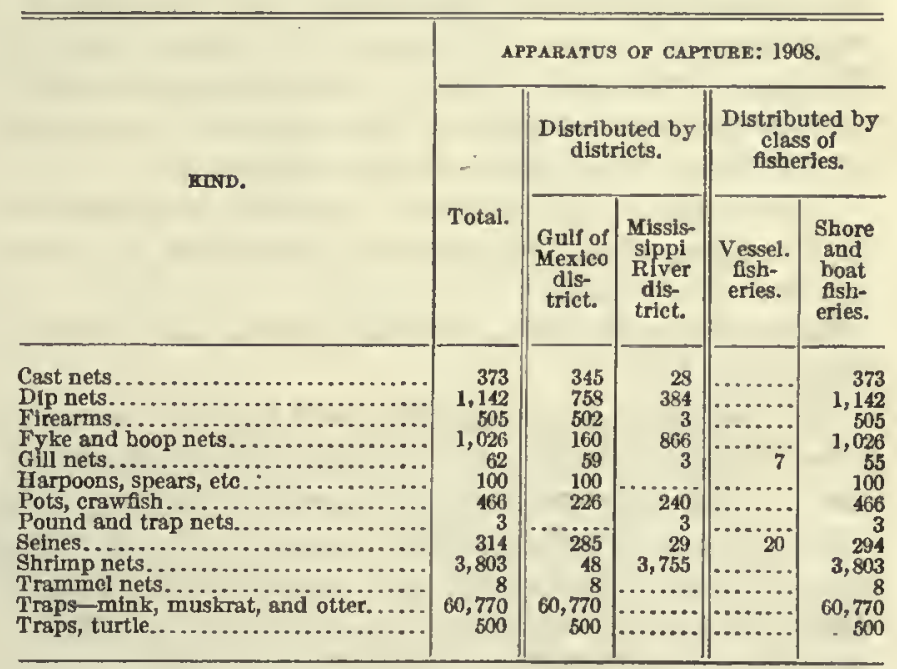

Products, by species.-Table 1, on page 135, gives statistics for 1908 of the quantity and value of the product of the Louisiana fisheries by species and by apparatus of capture. Forty-one species inade up 
this product. Oysters represented more than onebalf its weight and about half its value. Ranked according to value of product, shrimp, catfish, squeteague, and mink skins followed, in the order named, and together with oysters amounted to $39,662,000$ pounds, valued at $\$ 1,277,000$, or 86 per cent of the total weight and 81 per cent of the total value. In 1897 the four species of fish named were in the lead, and contributed about 80 per cent of the total weight and 83 per cent of the total value. Mink skins were not reported at the canvass of 1897 .

Products, by fishing grounds.-Table 2, on page 136, gives, by species and apparatus of capture, the weight and value of the products of the Louisiana fisheries in the Gulf of Mexico. Of the forty-odd species taken in Louisiana fisheries, 27 were reported exclusively from the Gulf of Mexico district. The value of the entire product of this district was $\$ 1,448,000$, while the value reported for these 27 species was $\$ 1,115,000$. Among the latter the oysters, as would be expected, were the most important, having a value of $\$ 763,000$. The next in value of the products reported only for the Gulf fisheries were squeteague and mink skins, valued at $\$ 82,000$ and $\$ 77,000$, respectively; while other important products were salt-water drum (channel bass), croakers, soft crabs, and terrapin, valued at $\$ 39,000$, $\$ 28,000, \$ 21,000$, and $\$ 21,000$, respectively.

The product reported by the fisheries of the Mississippi River and its tributaries, all of which are of the shore and boat class, had about one-eleventh the weight and one-twelf the value of that reported for the Gulf district. The distribution of the products of these fisheries is shown in Table 3 , on page 136 . Fifteen species comprised the river product, five of which-carp, crappie, eels, pike perch (wall-eyed), and suckers-were not found in the Gulf product. Catfish, buffalo fish, and shrimp, in the order named, were the most valuable species in the products of this district, furnishing a little more than three-fourths of both the weight and the value of the catch. Catfish and buffalo fish headed the list in 1899 also, together representing at that time three-fourths of the weight and two-thirds of the value of the products from the district.

The value of the different products reported for 1908 , arranged in the order of importance, is shown in the next tabular statement for the state as a whole and for the Gulf of Mexico and Mississippi River districts.

Of the species reported for both the Gulf and the river fisheries, shrimp and eatfish were the most valuable. The shrimp product reported by the Gulf district was valued at $\$ 196,000$ and the river product at only about one-twelfth as much, $\$ 17,000$; the catfish product of the Gulf district was valued at $\$ 89,000$ and the river product at $\$ 54,000$. The total value of the other species common to both districts, including caviar, was $\$ 90,000$, of which the Gulf fisheries contributed $\$ 47,000$ and the river fisheries $\$ 43,000$. In the case of three species-namely, black bass, freshwater drum, and paddlefish-the greater value came from the Mississippi River district, while in the case of the four remaining species-bream, buffalo fish, crawfish, and turtles-the product of the Gulf district represented the greater value.

\begin{tabular}{|c|c|c|c|}
\hline \multirow[b]{2}{*}{ SPECIES. } & \multicolumn{3}{|c|}{ VALUE OF PRODUCTS: 1908.} \\
\hline & Total. & $\begin{array}{l}\text { Gulf of } \\
\text { Mexico } \\
\text { district. }\end{array}$ & $\begin{array}{c}\text { Mississippl } \\
\text { River } \\
\text { distrlet. }\end{array}$ \\
\hline Total... & $\$ 1,569,000$ & $\$ 1,448,000$ & $\$ 121,000$ \\
\hline Fish........ & 419,000 & 316,000 & 103,000 \\
\hline Catfish. . & 143,000 & 89,000 & 54,000 \\
\hline Squetergue & 82,000 & 82,000 & \\
\hline Buffalo & 50,000 & - 28,000 & 22,000 \\
\hline Drum (salt-water), or channel bass..... & 39,000 & 39,000 & $\ldots \ldots \ldots \ldots$ \\
\hline 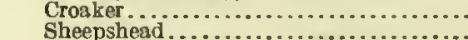 & $\begin{array}{l}28,000 \\
18,000\end{array}$ & $\begin{array}{l}28,000 \\
18,000\end{array}$ & (............... \\
\hline Drum, fresh-water............... & 15,000 & $\begin{array}{r}18,000 \\
6,900\end{array}$ & 8,400 \\
\hline All other.............. & 45,000 & 26,000 & 19,000 \\
\hline Oysters....... & 763,000 & 763,000 & \\
\hline 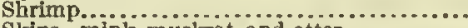 & 213,000 & 196,000 & 17,000 \\
\hline Skins-rnink, muskrat, and otter............ & 98,000 & 98,000 & ......... \\
\hline 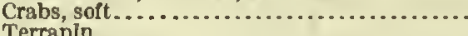 & 21,000 & 21,000 & ......... \\
\hline 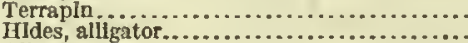 & $\begin{array}{l}21,000 \\
11,000\end{array}$ & $\begin{array}{l}21,000 \\
11,000\end{array}$ & ?...... \\
\hline All other & 24,000 & 22,000 & $i, 700$ \\
\hline
\end{tabular}

Products, by class of fisheries.-The products of the vessel fisheries of Louisiana are shown in Table 4, on page 137, by species and by apparatus of capture. These fisheries, all of which are in the Gulf of Mexico, are of small proportions, their products representing only 15 per cent of the total weight and 11 per cent of the total value for the state. Of the product of the vessel fisheries, oysters contributed 92 per cent in weight and 84 per cent in value; the remainder comprised 18 species, all of which were taken in the shore and boat fisheries of the Gulf., Shore and boat fisheries were common to both the Gulf of Mexico and the Mississippi River districts. This class of fisheries formed the most important branch not only of the Gulf fisheries but also of the fisheries of the state as a whole, furnishing a total product of $39,344,000$ pounds, valued at $\$ 1,395,000$, or nearly six times the quantity and over eight times the value of the product of the vessel fisheries. Statistics as to the products of the shore and boat fisheries of the Gulf fishing grounds are given in Table 5, on page 137. Seventy-seven per cent of the total weight and 81 per cent of the total value of the products of the Louisiana fisheries came from the shore and boat fisheries of the Gulf district. Hence the leading species for this district were the same as those in the fisheries of the entire state. All the skins included in the state product were from the shore and boat fisheries of the Gulf district.

The following tabular statement shows the distribution, by species, of the value of products between the vessel fisheries and the shore and boat fisheries: 


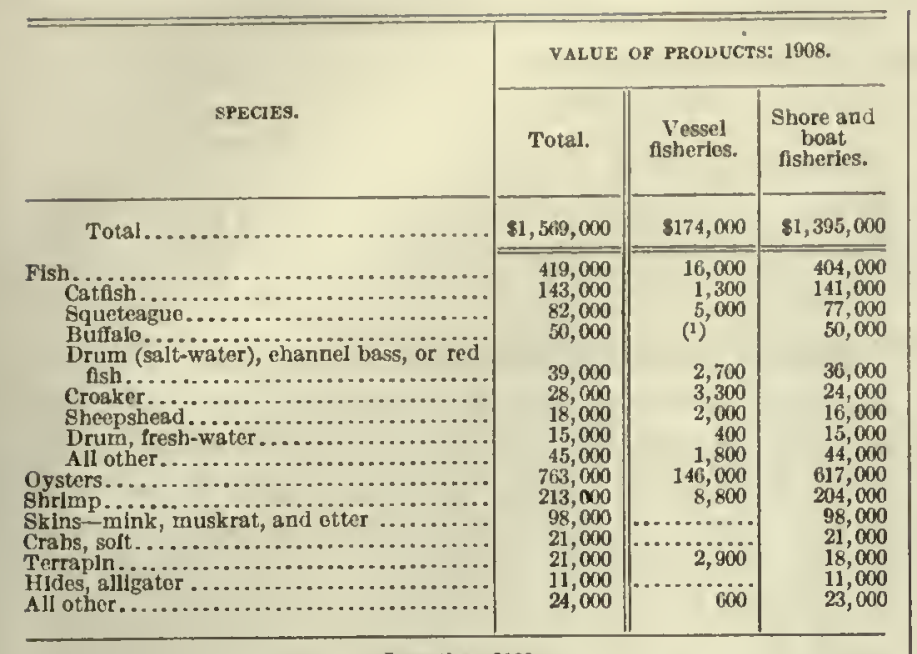

3 Less than $\$ 100$.

Products, by apparatus of capture. - The distribution of the total value of products by apparatus of capture for 1908 , for the state as a whole and for the two classes of fisheries, was as follows:

\begin{tabular}{|c|c|c|c|}
\hline \multirow[b]{2}{*}{ KIND OF APPARATUS, } & \multicolumn{3}{|c|}{ VALUE OP PRODUCTS: 1908.} \\
\hline & Total. & $\begin{array}{c}\text { Vessel } \\
\text { fisheries. }\end{array}$ & $\begin{array}{l}\text { Shore and } \\
\text { boat } \\
\text { fisheries. }\end{array}$ \\
\hline Total. . & $\$ 1,569,000$ & $\$ 174,000$ & $\$ 1,395,000$ \\
\hline 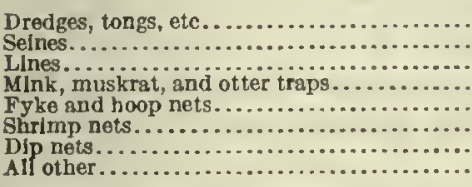 & $\begin{array}{r}763,000 \\
400,000 \\
203,000 \\
98,000 \\
32,000 \\
19,000 \\
15,000 \\
41,000\end{array}$ & 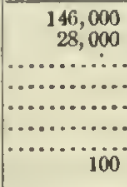 & $\begin{array}{r}617,000 \\
372,000 \\
203,000 \\
98,000 \\
32,000 \\
19,000 \\
15,000 \\
41,000\end{array}$ \\
\hline
\end{tabular}

Dredges, tongs, etc., were the principal apparatus of capture used in both elasses of fisheries of the Gulf district. Except for a very small quantity of periwinkles, oysters were the only species taken by this kind of apparatus. The proportions given below for oysters apply in full to the product taken with dredges, tongs, etc.

The weight and value of the product taken by seines marle them second in importance as an apparatus of capture in the entire state and in each branch of the Gulf fisheries. Seines were used for taking 30 species, chief of which were shrimp, squeteague (or sea trout), and buffalo fish. The value of the catch by this form of apparatus represented nine-tenths of the value of the shrimp taken in the state, more than two-thircls of the value of the squeteague, and more than one-half of the value of the buffalo fish. Practically all of the shrimp taken cither in the vessel fisheries or in the shore and boat fisheries of the Gulf district and practically all of the squeteague taken in the vessel fisheries were caught with seines. Of the squeteague product taken. by the shore and boat fisheries, 74 per cent of the quantity was taken by seines. In 1897 seines showed a product slightly heavier than that of tongs, but the value of the catch was not relatively as important as in 1908 .
Lines were third in importance as apparatus of eapture in the shore and boat fisheries of the Gulf district and in the fisheries of the state as a whole. They ranked first in the Mississippi River fisheries, but were not employed in the vessel fisheries. Twentytwo species made up the catch by lines for the state; yet one species, catfish, contributed 58 per cent of the value of this product, as well as 50 per cent of the value of the product of the shore and boat fisheries of the Gulf. In 1897 the total catch by lines was $3,150,000$ pounds, valued at $\$ 64,000$, almost threefifths as much as the quantity reported in 1908, but representing a value less than a third as great.

A great many other kinds of apparatus of capture were used to take the remainder of the product, which was valued at $\$ 203,000$ and represented about oneeighth of the value for the entire state. The most important of these kinds of apparatus were fyke and hoop nets, which took products valued at $\$ 32,000$, and shrimp nets and dip nets, which took products valued at $\$ 19,000$ and $\$ 15,000$, respectively. To minor apparatus $\$ 20,000$ was credited.

The following tabular statement shows the distribution of the total value of fishery products, by apparatus of capture, between the Gulf of Mexico and the Mississippi River districts:

\begin{tabular}{|c|c|c|c|}
\hline \multirow[b]{2}{*}{ KIND OF APFARATUS. } & \multicolumn{3}{|c|}{ VALUE OF PRONUCTS: 1908.} \\
\hline & Total. & $\begin{array}{l}\text { Gullof } \\
\text { Mexlco } \\
\text { district. }\end{array}$ & $\begin{array}{l}\text { Misslssippl } \\
\text { Rlver } \\
\text { district. }\end{array}$ \\
\hline Total.... & $\$ 1,569,000$ & $\$ 1,448,000$ & $\$ 121,000$ \\
\hline 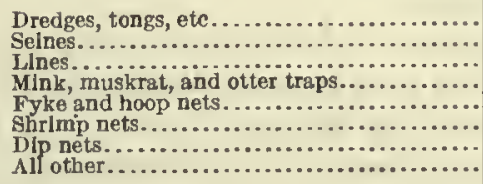 & $\begin{array}{r}763,000 \\
400,000 \\
203,000 \\
98,000 \\
32,000 \\
19,000 \\
11,000 \\
11,000\end{array}$ & $\begin{array}{r}763,000 \\
383,000 \\
141,000 \\
98,000 \\
7,800 \\
1,500 \\
15,000 \\
39,000\end{array}$ & $\begin{array}{r}17,000 \\
61,000 \\
24,000 \\
17,000 \\
2,200\end{array}$ \\
\hline
\end{tabular}

Oysters.-In 1908 the Louisiana oyster product amounted to $3,650,000$ bushels, or, computed on the basis of contained meat, 25,553,000 pounds, valued at $\$ 763,000$. That this product represents a remarkable growth over previous years is shown by the following tabular statement:

\begin{tabular}{|c|c|c|c|c|}
\hline \multirow{3}{*}{ YEAR. } & \multicolumn{4}{|c|}{ OYSTER PRONUCT. } \\
\hline & \multirow{2}{*}{$\begin{array}{l}\text { Quantity } \\
\text { (bushels). }\end{array}$} & \multirow{2}{*}{ Value. } & \multicolumn{2}{|c|}{$\begin{array}{l}\text { Per cent of total for } \\
\text { all fishery produets. }\end{array}$} \\
\hline & & & $\begin{array}{l}\text { Quantity } \\
\text { (bushels). }\end{array}$ & Value. \\
\hline 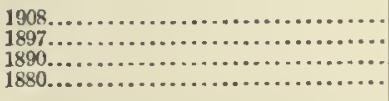 & $\begin{array}{r}3,650,000 \\
959,000 \\
842,000 \\
295,000\end{array}$ & $\begin{array}{r}3763,000 \\
433,000 \\
300,000 \\
200,000\end{array}$ & $\begin{array}{l}55 \\
39 \\
28 \\
29\end{array}$ & $\begin{array}{l}49 \\
61 \\
45 \\
51\end{array}$ \\
\hline
\end{tabular}

The gain in the quantity of oysters between 1897 and 1908 constitutes two-thirds of the gain in the entire fisliery product of the state, while for the period from 
1880 to 1908 it constitutes about three-fifths of the total gain. The price of oysters, however, has fallen to such an extent that, although the quantity in 1908 was more than three and one-half times as large as in 1897 and about four and one-half times as large as in 1890 , the value of the product increased only 76 per cent in the former period and 154 per cent in the latter.

Oysters were reported only from the Gulf district. Here the shore and boat fisheries took 2,763,000 bushels, valued at $\$ 617,000$, and the vessel fisheries 888,000 bushels, valued at $\$ 146,000$. While the "relaying" of oysters in salt water in order to improve their flavor was quite extensive in 1880, according to the Geographical Review of the Fisheries, ${ }^{1}$ very little oyster planting was done at that date. Although the planting seems to have reached a considerable extent by 1897 , the first collected data are those of the present census. In 1908 over one-third of the market oysters came from private areas. As the price of oysters from private areas, owing to their superior flaver, is much higher than that of oysters from public areas, the product from the former areas, though much smaller in quantity, was nearly as valuable as the product from the latter. In the case of seed oysters conditions were reversed, the yield of the public areas, which formed only about sixsevenths of the quantity of seed oysters, representing thirteen-fourteenths of the value.

The practice of relaying mature oysters to improve their flaver probably accounts in part for the high average price of the seed oysters taken from the public areas in the shore and boat fisheries, as compared with the price of the seed oysters in the same class of fisheries taken from private areas.

Shrimp.-Ninety-six per cent of the shrimp taken and 88 per cent of their value were credited to the shore and boat fisheries of the Gulf of Mexico district. Of the remaining product, the fisheries of the Mississippi River and its tributaries furnished a little more than two-fifths of the weight and nearly two-thirds of the value. The growth in the shrimp product within the period for which statistics are available has been very irregular, as is shown in the following tabular statement:

'The Fisheries and Fishery Industries of the United States, section 2, p. 580 .

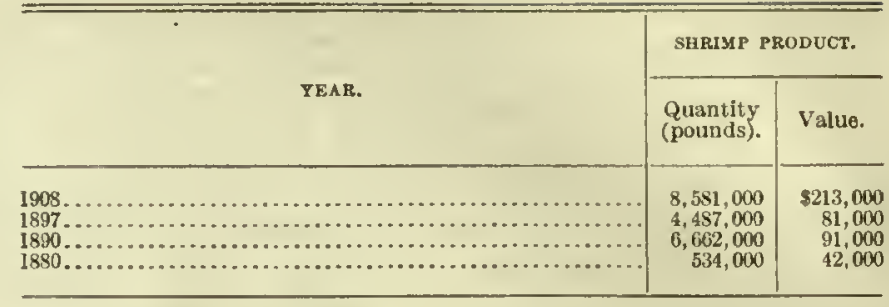

Catfish.-In order of value catfish rankel third in the state as a whole and in the Gulf district, and first in the Mississippi River district, where it contributed 39 per cent of the quantity and 45 per cent of the value of the entire preduct. More than one-third of the value of the entire catfish haul came from the Mississippi River fisheries, and with the exception of a very small quantity reported by vessel fisheries all of the remainder was from the shore and boat fisheries of the Gulf. The species has shared in the general increase shown by the products of the Louisiana fisheries. In 1880 it was not reported separately, but was included in "Other species;" in 1897 the yield was 1,950,000 pounds, valued at $\$ 47,000$; and in 1908 the product was more than twice as large and more than three times as valuable.

Squeteague, or sea trout.-This species was taken only in the Gulf district, 92 per cent of the quantity and 94 per cent of the value being reported by the shore and beat fishermen. The weight of the catch taken has nearly doubled, and its value has trebled since 1897 . In 1880 the squeteague was included under the head of "Other species."

Buffalo fish.-Buffalo fish, like catfish, were taken but little in vessel fisheries. In 1908 they ranked third among the fishery products of the state and second among the products of the Mississippi River district. Over half of the weight of the buffale-fish catch was reported by the Mississippi River district, but the Gulf shore and boat catch, less by about 40,000 pounds, had a greater value. In 1880 buffalo fish were included under the head of "Other species," and in 1897 they furnished a product which had only about one-eighth of the weight and one-tenth of the value of that of 1908 .

Mink skins.-This product, which ranked fifth with respect to value at the census of 1908 , was not reported at prior canvasses. 
FISHERIES, BY STATES.

TABLE 1.-LOUISIANA-FISHERY PRODUCTS: 1908.

\begin{tabular}{|c|c|c|c|c|c|c|c|c|c|c|c|c|c|c|}
\hline \multirow{3}{*}{ SPECIES. } & \multirow{2}{*}{\multicolumn{2}{|c|}{ TOTAL. }} & \multicolumn{12}{|c|}{ PRODUCT CAUGUT BY- } \\
\hline & & & \multicolumn{2}{|c|}{ Selnes. } & \multicolumn{2}{|c|}{ Lines. } & \multicolumn{2}{|c|}{$\begin{array}{c}\text { Fyke and hoop } \\
\text { nets. }\end{array}$} & \multicolumn{2}{|c|}{ Tramrnel nets. } & \multicolumn{2}{|c|}{ Gill nets. } & \multicolumn{2}{|c|}{$\begin{array}{c}\text { All other appa- } \\
\text { ratus. }\end{array}$} \\
\hline & $\begin{array}{l}\text { Quantity } \\
\text { (pounds). }\end{array}$ & Value. & $\begin{array}{l}\text { Quantity } \\
\text { (pouads). }\end{array}$ & Value. & $\begin{array}{l}\text { Quantlty } \\
\text { (pounds). }\end{array}$ & Value. & $\begin{array}{l}\text { Quantity } \\
\text { (pounds). }\end{array}$ & Value. & $\begin{array}{l}\text { Quantity } \\
\text { (pounds). }\end{array}$ & Value. & $\begin{array}{l}\text { Quantity } \\
\text { (pounds). }\end{array}$ & Value. & $\begin{array}{l}\text { Qnantity } \\
\text { (pounds). }\end{array}$ & Value. \\
\hline Total......... & $46,106,000$ & $81,569,000$ & $12,496,000$ & $\$ 100,000$ & $5,329,000$ & $\$ 203,000$ & $1,758,000$ & $\$ 32,000$ & 71,000 & $\$ 5,800$ & 24,000 & $\$ 800$ & $26,427,000$ & 3928,000 \\
\hline 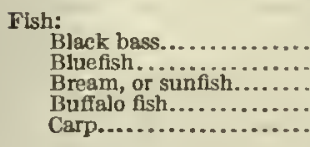 & $\begin{array}{r}40,000 \\
2,800 \\
40,000 \\
2,626,000 \\
12,000\end{array}$ & $\begin{array}{r}3,300 \\
100 \\
2,200 \\
50,000 \\
1,000\end{array}$ & $\begin{array}{r}9,700 \\
2,700 \\
21,000 \\
1,226,000 \\
10,000\end{array}$ & $\begin{array}{r}800 \\
100 \\
1,200 \\
29,000 \\
800\end{array}$ & $\begin{array}{r}30,000 \\
20,000 \\
372,000 \\
2,000\end{array}$ & $\begin{array}{r}2,500 \\
1,000 \\
5,900 \\
200\end{array}$ & 998,000 & 15,000 & & & & & 30,000 & ( \\
\hline 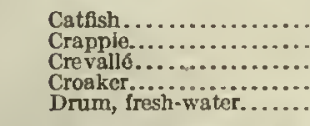 & $\begin{array}{r}4,405,000 \\
96,000 \\
24,000 \\
369,000 \\
845,000\end{array}$ & $\begin{array}{r}143,000 \\
6,400 \\
1,400 \\
28,000 \\
15,000\end{array}$ & $\begin{array}{r}442,000 \\
7,000 \\
5,100 \\
259,000 \\
118,000\end{array}$ & $\begin{array}{r}14,000 \\
400 \\
100 \\
18,000 \\
3,600\end{array}$ & $\begin{array}{r}3,617,000 \\
88,000 \\
19,000 \\
108,000 \\
311,000\end{array}$ & $\begin{array}{r}118,000 \\
6,000 \\
1,300 \\
9,000 \\
5,600\end{array}$ & $\begin{array}{r}339,000 \\
\cdots \ldots \ldots \ldots \\
\cdots \\
\hdashline 15,000\end{array}$ & $\mid \begin{array}{c}10,000 \\
\cdots \ldots \ldots \\
\cdots \\
\cdots, 100\end{array}$ & 2,200 & 200 & $\begin{array}{r}1,000 \\
\ldots \ldots \\
1,100\end{array}$ & (3) & $\begin{array}{r}6,200 \\
\cdots \cdots \cdots \\
100\end{array}$ & $\begin{array}{r}200 \\
\cdots \cdots \\
\cdots \cdots\end{array}$ \\
\hline 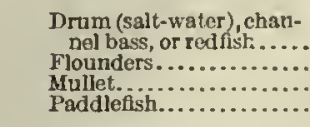 & $\begin{array}{r}716,000 \\
71,000 \\
133,000 \\
132,000\end{array}$ & $\begin{array}{r}39,000 \\
6,000 \\
5,600 \\
5,000\end{array}$ & $\begin{array}{r}538,000 \\
16,000 \\
106,000 \\
99,000\end{array}$ & $\begin{array}{r}27,000 \\
1,100 \\
3,900 \\
3,700\end{array}$ & $\begin{array}{r}156,000 \\
38,000 \\
20,000 \\
21,000\end{array}$ & $\begin{array}{r}11,000 \\
3,500 \\
1,400 \\
800\end{array}$ & 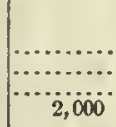 & 100 & $\begin{array}{r}16,000 \\
16,000 \\
3,200\end{array}$ & $\begin{array}{r}1,400 \\
1,400 \\
200\end{array}$ & $\begin{array}{r}5,400 \\
100 \\
1,700 \\
10,000\end{array}$ & $\begin{array}{l}200 \\
(3) \\
(3) \\
400\end{array}$ & $\begin{array}{r}200 \\
\cdots, 600\end{array}$ & $\begin{array}{c}\text { (घ) } \\
\ldots \ldots \\
\cdots\end{array}$ \\
\hline 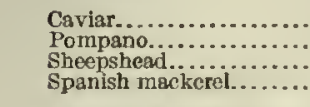 & $\begin{array}{r}5,500 \\
1,100 \\
249,000 \\
4,900\end{array}$ & $\begin{array}{r}4,400 \\
100 \\
18,000 \\
500\end{array}$ & $\begin{array}{r}5,500 \\
1,100 \\
185,000 \\
4,900\end{array}$ & $\begin{array}{r}4,400 \\
100 \\
12,000 \\
500\end{array}$ & 61,000 & ( & $\therefore$ & & $\ddot{2}, 200$ & 200 & ........ & $(8)$ & $\mid \begin{array}{l}\cdots \\
\cdots \ldots 0\end{array}$ & $\left\{\begin{array}{l}\cdots \\
\cdots \cdots \\
\cdots \cdots\end{array}\right.$ \\
\hline 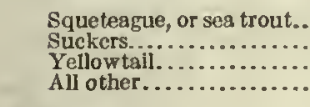 & $\begin{array}{r}1,103,000 \\
5,000 \\
64,000 \\
152,000\end{array}$ & $\begin{array}{r}82,000 \\
100 \\
3,200 \\
5,100\end{array}$ & $\begin{array}{r}840,000 \\
64,000 \\
1,700\end{array}$ & $\begin{array}{r}56,000 \\
3,200 \\
100\end{array}$ & $\begin{array}{r}232,000 \\
\cdots \\
151,000\end{array}$ & $\begin{array}{r}23,000 \\
2,000 \\
5,00\end{array}$ & 5,000 & 100 & 27,000 & \begin{tabular}{|c|}
2,200 \\
$\ldots \ldots \ldots$ \\
$\ldots \ldots \ldots$ \\
$\cdots \ldots$
\end{tabular} & $\begin{array}{r}3,900 \\
\cdots \\
\cdots \\
100\end{array}$ & 200 & $\mid \begin{array}{l}\mid \\
\cdots \cdots \cdots \\
\cdots \cdots \cdots \\
\cdots \cdots \cdots\end{array}$ & $\begin{array}{l}\cdots \ldots \ldots \\
\cdots \ldots \ldots \ldots \\
\cdots \ldots \ldots \ldots\end{array}$ \\
\hline 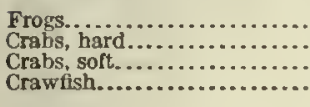 & $\begin{array}{r}38,000 \\
244,000 \\
78,000 \\
88,000\end{array}$ & $\begin{array}{r}4,500 \\
7,800 \\
21,000 \\
3,600\end{array}$ & $\begin{array}{r}80,000 \\
39,000 \\
\cdots\end{array}$ & $\begin{array}{r}3,300 \\
12,000 \\
\end{array}$ & $\begin{array}{r}60,000 \\
1,800\end{array}$ & $\begin{array}{r}1,600 \\
100\end{array}$ & $\therefore$ & & 1,500 & $\begin{array}{r}100 \\
\cdots \\
\cdots\end{array}$ & & & $\begin{array}{r}38,000 \\
102,000 \\
40,000 \\
86,000\end{array}$ & $\begin{array}{l}4,500 \\
2,900 \\
9,600 \\
3,500\end{array}$ \\
\hline 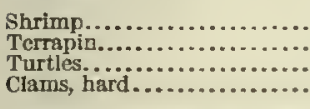 & $\begin{array}{r}8,581,000 \\
41,000 \\
215,000 \\
100\end{array}$ & $\begin{array}{r}213,000 \\
21,000 \\
7,800 \\
(8)\end{array}$ & $\begin{array}{r}8,346,000 \\
12,000 \\
58,000 \\
\cdots\end{array}$ & $\begin{array}{r}194,000 \\
9,500 \\
1,600\end{array}$ & ${ }_{21,000}$ & $\cdots$ & $\mid \begin{array}{l}\cdots \ldots \\
\cdots \cdots \\
\cdots \cdots\end{array}$ & & $\because \ldots \ldots$ & $\ddot{200}$ & & & $\begin{array}{r}236,000 \\
29,000 \\
133,000 \\
100\end{array}$ & $\begin{array}{l}19,000 \\
12,000 \\
4,800 \\
\text { (s) }\end{array}$ \\
\hline $\begin{array}{l}\text { Oysters, market, from public } \\
\text { areas....................... } \\
\text { Oysters, market, from pri- } \\
\text { vate areas }\end{array}$ & $\begin{array}{l}13,363,000 \\
17,399,000\end{array}$ & 341,000 & & & & & & & & & & & $13,363,000$ & 341,000 \\
\hline 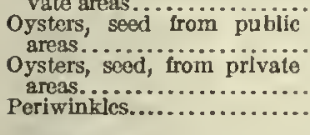 & $\begin{array}{r}7,399,000 \\
4,091,000 \\
700,000 \\
200\end{array}$ & $\begin{array}{r}334.000 \\
82,000 \\
6,200 \\
(2)\end{array}$ & & & & & & & & & & & $\mid \begin{array}{r}7,399,000 \\
64,091,000 \\
700,000 \\
200\end{array}$ & $\begin{array}{l}334,000 \\
82,000 \\
6,200 \\
(2)\end{array}$ \\
\hline 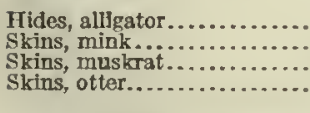 & $\begin{array}{r}110,000 \\
820,000 \\
40,000 \\
101,100\end{array}$ & $\begin{array}{r}11,000 \\
77,000 \\
16,000 \\
4,700\end{array}$ & ( & (n. & $\cdots$ & & & & & & & & $\begin{array}{r}7110,000 \\
20,000 \\
40,000 \\
101,100\end{array}$ & $\begin{array}{r}11,000 \\
77,000 \\
16,000 \\
4,700\end{array}$ \\
\hline
\end{tabular}

1 Includes apparatus, with eatch, as follows: Dredges, tongs, ete., 25,553,000 pounds, valued at 3763,000 ; mink, muskrat, and otter traps, 60,000 pounds, ralued at $\$ 98,000$.

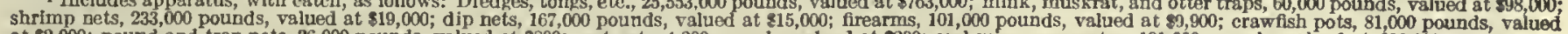

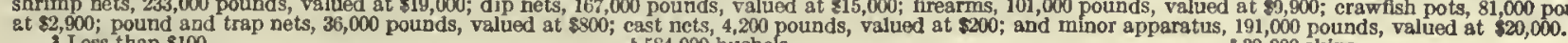

$\$$ Less than $\$ 100$.

$1,909,000$ bushels.
$1,057,000$ bushels.

584,000 bushels.

122,000 hides.
119,000 skins. 
TABLE 2.-LOUISIANA-FISHERY PRODUCTS OF GULF OF MEXICO DISTRICT: 1908.

\begin{tabular}{|c|c|c|c|c|c|c|c|c|c|c|c|c|c|c|}
\hline \multirow{3}{*}{ SPECIES. } & \multirow{2}{*}{\multicolumn{2}{|c|}{ TOTAL. }} & \multicolumn{12}{|c|}{ PRODUCT CAUOHT BY- } \\
\hline & & & \multicolumn{2}{|c|}{ Seines. } & \multicolumn{2}{|c|}{. Lines. } & \multicolumn{2}{|c|}{$\begin{array}{c}\text { Fyke and hoop } \\
\text { nets. }\end{array}$} & \multicolumn{2}{|c|}{ Trammel nets. } & \multicolumn{2}{|c|}{ Gill nets. } & \multicolumn{2}{|c|}{ Al] other apparatus. 1} \\
\hline & $\begin{array}{l}\text { Quantity } \\
\text { (pounds). }\end{array}$ & Value. & $\begin{array}{l}\text { Quantity } \\
\text { (pounds). }\end{array}$ & Value. & $\begin{array}{l}\text { Quantity } \\
\text { (pounds). }\end{array}$ & Value. & $\begin{array}{l}\text { Quantlty } \\
\text { (pounds). }\end{array}$ & Value, & $\begin{array}{l}\text { Qunntity } \\
\text { (pounds). }\end{array}$ & Value. & $\begin{array}{l}\text { Quantity } \\
\text { (pounds). }\end{array}$ & Value. & $\begin{array}{l}\text { Quantity } \\
\text { (pounds). }\end{array}$ & Value. \\
\hline Total. & $42,302,000$ & $\$ 1,448,000$ & $12,114,000$ & $\$ 383,000$ & $3,592,000$ & $\$ 141,000$ & 296,000 & $\$ 7,800$ & 71,000 & 85,800 & 14,000 & 8000 & $26,216,000$ & $\$ 909,000$ \\
\hline 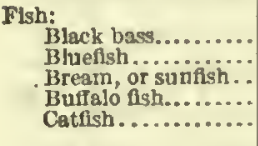 & $\begin{array}{r}12,000 \\
2,800 \\
35,000 \\
1,293,000 \\
2,037,000\end{array}$ & $\begin{array}{r}1,100 \\
100 \\
1,900 \\
28,000 \\
89,000\end{array}$ & $\begin{array}{r}8,800 \\
2,800 \\
21,000 \\
1,022,000 \\
362,000\end{array}$ & $\begin{array}{r}800 \\
100 \\
1,200 \\
23,000 \\
11,000\end{array}$ & $\begin{array}{r}3,700 \\
15,000 \\
254,000 \\
2,343,000\end{array}$ & $\begin{array}{r}300 \\
700 \\
4,400 \\
71,000\end{array}$ & 232,000 & $\begin{array}{r}300^{\circ} \\
6,700\end{array}$ & & & 1,000 & 100 & 200 & (2)....... \\
\hline 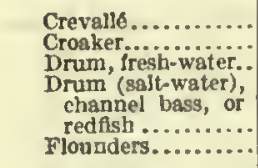 & $\begin{array}{r}24,000 \\
369,000 \\
265,000 \\
\\
716,000 \\
71,000\end{array}$ & $\begin{array}{r}1,400 \\
28,000 \\
6,900\end{array}$ & $\begin{array}{r}5,100 \\
259,000 \\
116,000\end{array}$ & $\begin{array}{r}100 \\
18,000 \\
3,600\end{array}$ & $\begin{array}{r}19,000 \\
108,000 \\
102,000\end{array}$ & $\begin{array}{l}1,300 \\
9,000 \\
2,500\end{array}$ & 47,000 & $800^{\circ}$ & $\begin{array}{l}16,000 \\
16,000\end{array}$ & $\begin{array}{l}1,400 \\
1,400\end{array}$ & $\begin{array}{l}\cdots \\
1,100\end{array}$ & $\begin{array}{l}\text { (3) } \\
2000 \\
\text { (2) }\end{array}$ & 200 & $(2) \cdots$ \\
\hline $\begin{array}{l}\text { Mullet................ } \\
\text { Paddlefishs............ }\end{array}$ & $\begin{array}{r}133,000 \\
48,000\end{array}$ & $\begin{array}{l}5,600 \\
1,400\end{array}$ & $\begin{array}{r}106,000 \\
27,000\end{array}$ & $\begin{array}{r}3,800 \\
500\end{array}$ & $\begin{array}{l}20,000 \\
21,000\end{array}$ & $\begin{array}{r}1,400 \\
800\end{array}$ & & & 3,200 & 200 & 1,700 & (2) & 2,500 & 100 \\
\hline $\begin{array}{l}\text { Pompano............. } \\
\text { Sheepshead......... }\end{array}$ & $\begin{array}{r}1,100 \\
249,000\end{array}$ & $\begin{array}{r}100 \\
18,000\end{array}$ & $\begin{array}{r}1,100 \\
185,000\end{array}$ & $\begin{array}{r}100 \\
12,000\end{array}$ & 61,000 & $\dddot{5}, 900$ & & & $2,200^{\circ}$ & 2000 & 60 & (a)" & 200 & (a) \\
\hline $\begin{array}{l}\text { Spanlsb mackerel... } \\
\text { Squeteague, or sea }\end{array}$ & 4,900 & 500 & 4,900 & 500 & & & & & & & & & & \\
\hline Me, of sea. & $\begin{array}{r}1,103,000 \\
64,000\end{array}$ & $\begin{array}{r}82,000 \\
3,200\end{array}$ & $\begin{array}{r}840,000 \\
64,000\end{array}$ & $\begin{array}{r}56,000 \\
3,200\end{array}$ & 232,000 & 23,000 & & & 27,000 & 2,200 & 3,900 & & & \\
\hline All other............... & 142,000 & 1,300 & 1,700 & 100 & 140,000 & $\ddot{4}, 200$ & $\ldots .$. & & (........... & (......... & 100 & (2) & …........... & (n......... \\
\hline 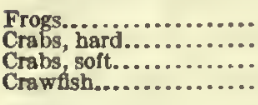 & $\begin{array}{r}38,000 \\
244,000 \\
78,000 \\
79,000\end{array}$ & $\begin{array}{r}4,500 \\
7,800 \\
21,000 \\
2,000\end{array}$ & $\begin{array}{l}80,000 \\
39,000\end{array}$ & $\begin{array}{r}3,300 \\
12,000 \\
\ldots\end{array}$ & 1,800 & 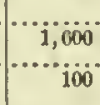 & & & 1,500 & 100 & & & $\begin{array}{r}38,000 \\
102,000 \\
40,000 \\
77,000\end{array}$ & $\begin{array}{l}4,500 \\
2,900 \\
9,600 \\
2,000\end{array}$ \\
\hline 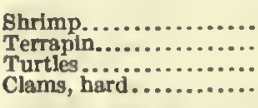 & $\begin{array}{r}8,415,000 \\
41,000 \\
211,000 \\
100\end{array}$ & $\begin{array}{r}196,000 \\
21,000 \\
7,700 \\
(3)\end{array}$ & $\begin{array}{r}8,346,000 \\
12,000 \\
58,000\end{array}$ & $\begin{array}{r}194,000 \\
9,500 \\
1,600\end{array}$ & "i7,0000 & i,ioo & & $\because \because$ & 2,000 & 200 & & & $\begin{array}{r}70,000 \\
29,000 \\
133,000 \\
100\end{array}$ & $\begin{array}{l}2,100 \\
12,000 \\
4,800 \\
(2)\end{array}$ \\
\hline $\begin{array}{l}\text { Oysters, market, from } \\
\text { public areas........ }\end{array}$ & $13,363,000$ & 341,000 & & & & & & & & & & & $213,363,000$ & 341,000 \\
\hline 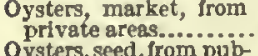 & $47,399,000$ & 334,000 & & & & & & & & & & & 1 7,399,000 & 334,000 \\
\hline $\begin{array}{l}\text { Oysters, seed, from pub- } \\
\text { lic areas........... } \\
\text { oysters, seed irom pri- }\end{array}$ & $4,091,000$ & 82,000 & & & & & & & & & & & $\cdot 4,001,090$ & 82,000 \\
\hline $\begin{array}{l}\text { vate areas............................. } \\
\text { Periwinkles. }\end{array}$ & $\begin{aligned}-700,000 \\
200\end{aligned}$ & $\begin{array}{l}6,200 \\
\left({ }^{2}\right)\end{array}$ & & & & & & & & & & & - 700,000 & $\left(\begin{array}{l}6,200 \\
(2)\end{array}\right.$ \\
\hline 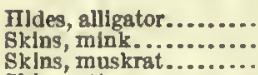 & $\begin{array}{r}7110,000 \\
820,000 \\
840,000\end{array}$ & $\begin{array}{l}11,000 \\
77,000 \\
16,000\end{array}$ & & & & & & & & & & & $\begin{array}{r}\quad 110,000 \\
820,000 \\
040,000\end{array}$ & $\begin{array}{l}11,000 \\
77,000 \\
16,000\end{array}$ \\
\hline 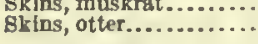 & 10 1,100 & $\begin{array}{r}16,000 \\
4,700\end{array}$ & & & & & & & & & & & 301,100 & 4,700 \\
\hline
\end{tabular}

1 Ineludes apparatus, with catch, as follows: Dredges, tongs, ete., 25,553,000 pounds, valued at $\$ 703,000 ;$ mlnk, muskrat, and otter traps, 60,000 pounds, valued at $\$ 98,000 ;$

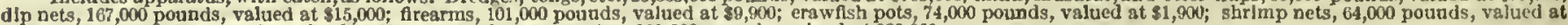 $\$ 1,500$; cast nets, 4,200 pounds, valued at $\$ 200$; and minor apparatus, 191,000 pounds, valued at $\$ 20,000$
2 Less than $\$ 100$.
$1,000,000$ bushels.
- 584,000 bushels.
39,000 skins.
119,000 sklas.
722,000 bides.
ut 600 skins.

TABLE 3.-LOUISIANA-FISHERY PRODUCTS OF MISSISSIPPI RIVER DISTRICT: 1908.'

\begin{tabular}{|c|c|c|c|c|c|c|c|c|c|c|c|c|}
\hline \multirow{3}{*}{ ERECTES. } & \multirow{2}{*}{\multicolumn{2}{|c|}{ TOTAL. }} & \multicolumn{10}{|c|}{ PRODUCT CAUCHT BY- } \\
\hline & & & \multicolumn{2}{|c|}{ Lines. } & \multicolumn{2}{|c|}{ Fyke and hoop nets. } & \multicolumn{2}{|c|}{ Selnes. } & \multicolumn{2}{|c|}{ Gill nets. } & \multicolumn{2}{|c|}{ All other apparatus.2 } \\
\hline & $\begin{array}{l}\text { Quantity } \\
\text { (pounds). }\end{array}$ & Value. & $\begin{array}{l}\text { Quantity } \\
\text { (pounds). }\end{array}$ & Value. & $\begin{array}{l}\text { Quantity } \\
\text { (pounds). }\end{array}$ & Value. & $\begin{array}{l}\text { Quantity } \\
\text { (pounds). }\end{array}$ & Value. & $\begin{array}{l}\text { Quantity } \\
\text { (pounds). }\end{array}$ & Value. & $\begin{array}{l}\text { Quantity } \\
\text { (pounds). }\end{array}$ & Value. \\
\hline Total.................... & $3,803,000$ & $\$ 121,000$ & $1,738,000$ & $\$ 61,000$ & $1,463,000$ & $\$ 24,000$ & 382,000 & $\$ 17,000$ & 10,000 & $\$ 400$ & 211,000 & $\$ 19,000$ \\
\hline 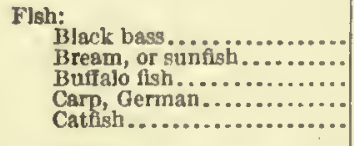 & $\begin{array}{r}28,000 \\
5,000 \\
1,333,000 \\
12,000 \\
1,467,000\end{array}$ & $\begin{array}{r}2,200 \\
200 \\
22,000 \\
1,000 \\
54,000\end{array}$ & $\begin{array}{r}26,000 \\
5,000 \\
118,000 \\
2,000 \\
1,274,000\end{array}$ & $\begin{array}{r}2,200 \\
200 \\
1,500 \\
200 \\
47,000\end{array}$ & $\begin{array}{l}{ }_{981}, 000 \\
\text { ioco, } 000\end{array}$ & 15,000 & $\begin{array}{r}1,000 \\
204,000 \\
10,000 \\
80,000\end{array}$ & $\begin{array}{r}100 \\
5,200 \\
800 \\
2,800\end{array}$ & & & 0,000 & 600 \\
\hline 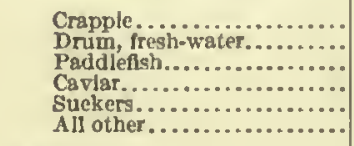 & $\begin{array}{r}96,000 \\
580,000 \\
84,000 \\
5,500 \\
5,000 \\
10,000\end{array}$ & $\begin{array}{r}6,400 \\
8,400 \\
3,600 \\
4,400 \\
100 \\
800\end{array}$ & $\begin{array}{r}88,000 \\
209,000 \\
\cdots \ldots \ldots \ldots \\
\cdots \ldots \ldots \ldots\end{array}$ & 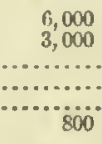 & $\begin{array}{r}368,000 \\
2,000 \\
\cdots \ldots \\
5,000\end{array}$ & $\begin{array}{r}5, \begin{array}{r}300 \\
100\end{array} \\
100\end{array}$ & $\begin{array}{r}7,000 \\
2,000 \\
72,000 \\
5,500 \\
\cdots \ldots . .\end{array}$ & $\begin{array}{l}(2)^{400} \\
3,2100 \\
4,400 \\
.\end{array}$ & $\begin{array}{l}10,000 \\
\cdots \cdots\end{array}$ & $\begin{array}{l}400 \\
\ldots \ldots \\
\ldots \ldots\end{array}$ & & 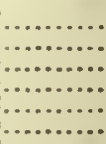 \\
\hline 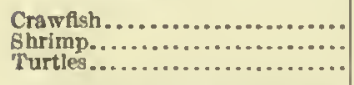 & $\begin{array}{r}9,400 \\
166,000 \\
4,000\end{array}$ & $\begin{array}{r}1,600 \\
17,000 \\
100\end{array}$ & $\cdots \cdots \cdots$ & 100 & & & & & & & $\begin{array}{r}9,400 \\
108,000 \\
\cdots\end{array}$ & $\begin{array}{r}1,600 \\
17,000 \\
.\end{array}$ \\
\hline
\end{tabular}

1 All taken in the shore and bont fisheriog.

2 Includes apparatus, with eateh, as follows: Shrimp nets, 169,000 pounds, valued at $\$ 17,000$; craw ish pots, 6,200 pounds, valued at $\$ 1,000$; and pound and i rap nets, 36,000 pounds, valued at $\$ 800$

3 Less than 8100 
FISHERIES, BY STATES.

'TARLF 4.-LOUISIANA-PRODUCTS OF' VESSEL FISIIERIES: 1908.

\begin{tabular}{|c|c|c|c|c|c|c|c|c|}
\hline \multirow{3}{*}{ SPECIES. } & \multirow{2}{*}{\multicolumn{2}{|c|}{ TOTAL }} & \multicolumn{6}{|c|}{ PRODUCT CAEGHT nY- } \\
\hline & & & \multicolumn{2}{|c|}{ Dreuges, tongs, elc. } & \multicolumn{2}{|c|}{ Selnes. } & \multicolumn{2}{|c|}{ (1111 nets } \\
\hline & $\begin{array}{l}\text { Quantlty } \\
\text { (pounds). }\end{array}$ & Value. & $\begin{array}{l}\text { Quantity } \\
\text { (pounds). }\end{array}$ & Value. & $\begin{array}{l}\text { Quantity } \\
\text { (pounds). }\end{array}$ & Value. & $\begin{array}{l}\text { Quantity } \\
\text { (pounds). }\end{array}$ & Value. \\
\hline 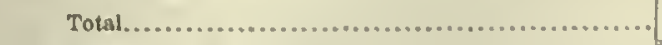 & $0,7+2,000$ & $\$ 174,000$ & $0.215,010$ & $\$ 140,0100$ & $.845,000$ & 198,000 & 1,300 & $\$ 100$ \\
\hline 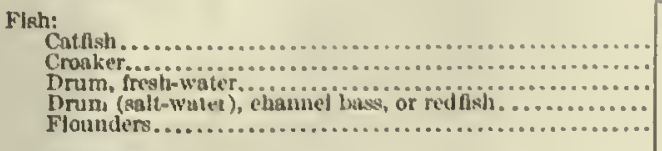 & $\begin{array}{r}18,000 \\
50,000 \\
18,000 \\
58,000 \\
2,800\end{array}$ & $\begin{array}{r}1,300 \\
3,300 \\
400 \\
2,700 \\
200\end{array}$ & (n. & 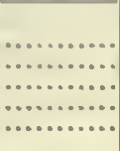 & $\begin{array}{r}48,000 \\
49,000 \\
18,000 \\
87,000 \\
2,800\end{array}$ & $\begin{array}{r}1,300 \\
3,300 \\
400 \\
2,(00) \\
200\end{array}$ & $\begin{array}{l}\text { (1) } \\
\text { (1) } \\
\text { (1) }\end{array}$ & $\begin{array}{l}(3) \\
(3)\end{array}$ \\
\hline 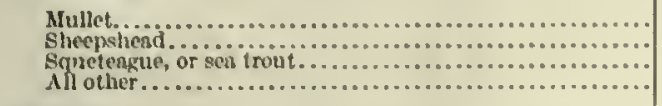 & $\begin{array}{r}15,000 \\
32,000 \\
92,000 \\
2,100\end{array}$ & $\begin{array}{r}500 \\
2,000 \\
8,000 \\
100\end{array}$ & 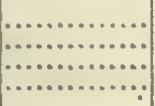 & $\begin{array}{ll}\cdots \cdots \cdots \\
\cdots \cdots \cdots \cdots \\
\cdots \cdots \cdots\end{array}$ & $\begin{array}{r}13,000 \\
32,060 \\
92,000 \\
2,100\end{array}$ & $\begin{array}{r}800 \\
2,000 \\
8,000 \\
100\end{array}$ & $\begin{array}{l}200 \\
100 \\
400\end{array}$ & $\left\{\begin{array}{l}3 \\
3 \\
3 \\
3\end{array}\right)$ \\
\hline 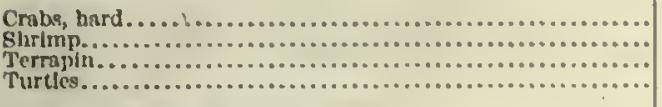 & $\begin{array}{r}4,100 \\
205,0 \times 0 \\
3,000 \\
17,000\end{array}$ & $\begin{array}{r}300 \\
8,800 \\
2,000 \\
300\end{array}$ & 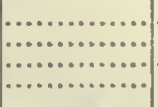 & (n........... & $\begin{array}{r}1,100 \\
205,000 \\
3,000 \\
17,000\end{array}$ & $\begin{array}{r}300 \\
8,800 \\
2,000 \\
300\end{array}$ & 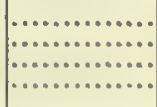 & ( $\cdots \cdots \cdots \cdots$ \\
\hline 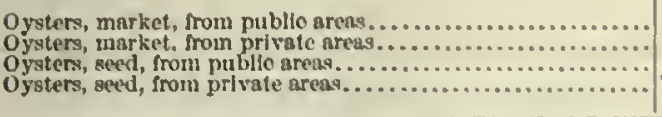 & $\begin{array}{r}3,559,000 \\
1,878,000 \\
1,011,000 \\
0.08,000\end{array}$ & $\begin{array}{r}81,000 \\
56,000 \\
8,100 \\
600\end{array}$ & $\begin{array}{r}1,5,50,000 \\
1,578,000 \\
1,011,000 \\
08,000\end{array}$ & $\begin{array}{r}81,000 \\
50,000 \\
8,100 \\
800\end{array}$ & 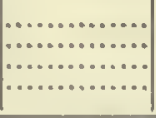 & ${ }_{1}, \ldots, \cdots, \cdots, \cdots$ & $\mid \begin{array}{l}\ldots \ldots \ldots \\
\cdots \ldots \ldots \ldots \ldots \ldots \ldots\end{array}$ & 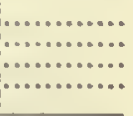 \\
\hline
\end{tabular}

TABLE 5.-LOUISIANA-PRODUCTS OF SHORE AND BOAT FISHERIES OF GULF OF MEXICO DISTRICT: 1908.

\begin{tabular}{|c|c|c|c|c|c|c|c|c|c|c|c|c|c|c|}
\hline \multirow{3}{*}{ SPECGES. } & \multirow{2}{*}{\multicolumn{2}{|c|}{ тотАL. }} & \multicolumn{12}{|c|}{ PRODUCT CAUGHT RY- } \\
\hline & & & \multicolumn{2}{|c|}{ Selnes. } & \multicolumn{2}{|c|}{ Lines. } & \multicolumn{2}{|c|}{$\begin{array}{l}\text { Fyke and hoop } \\
\text { nets. }\end{array}$} & \multicolumn{2}{|c|}{ Trammel nets. } & \multicolumn{2}{|c|}{ Gill nets. } & \multicolumn{2}{|c|}{$\begin{array}{l}\text { All other appa- } \\
\text { ratus. }\end{array}$} \\
\hline & $\begin{array}{l}\text { Quanclty } \\
\text { (1)unds). }\end{array}$ & Value. & $\begin{array}{l}\text { Quanilty } \\
\text { (pounds). }\end{array}$ & Value. & $\begin{array}{l}\text { Qusulity } \\
\text { (pounds). }\end{array}$ & Value. & $\begin{array}{l}\text { Quantity } \\
\text { (jounds). }\end{array}$ & Value. & $\begin{array}{l}\text { Quantity } \\
\text { (pounds). }\end{array}$ & Value. & $\begin{array}{l}\text { Quantity } \\
\text { (pounds). }\end{array}$ & Value. & $\begin{array}{l}\text { Quanlity } \\
\text { (pounds). }\end{array}$ & Value. \\
\hline Total.. & $35,5+1,000$ & $\$ 1,274,000$ & $11,568,000$ & $\$ 355,000$ & $3,592,000$ & 3141,000 & 290,000 & 37,800 & 71,000 & 85,800 & 13,000 & $\sin 0$ & $20,001,000$ & $\sin (3,000$ \\
\hline 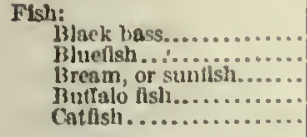 & $\begin{array}{r}12,000 \\
2,100 \\
35,000 \\
1,293.000 \\
2,889,000\end{array}$ & $\begin{array}{r}1,100 \\
100 \\
1,900 \\
28,000 \\
88,010\end{array}$ & $\begin{array}{r}8,800 \\
2,100 \\
23,(100 \\
1,022,000 \\
313,000\end{array}$ & $\begin{array}{r}800 \\
100 \\
1,200 \\
23,000 \\
10,000\end{array}$ & $\begin{array}{r}3,700 \\
i s, 000 \\
254,000 \\
2,343,000\end{array}$ & $\begin{array}{r}300 \\
\cdots, 700 \\
41,000 \\
71,000\end{array}$ & $\begin{array}{r}17,000 \\
232,000\end{array}$ & $\begin{array}{r}3, \ldots 0 \\
0,700\end{array}$ & & & $1,0000^{\circ}$ & (i) & a............. & $\cdots \cdots$ \\
\hline 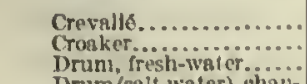 & $\begin{array}{r}24,000 \\
320,000 \\
248,000\end{array}$ & $\begin{array}{r}1,400 \\
24,000 \\
6,500\end{array}$ & $\begin{array}{r}5,100 \\
209,000 \\
06,000\end{array}$ & $\begin{array}{r}100 \\
13,000 \\
3,100\end{array}$ & $\begin{array}{r}19,000 \\
108,000 \\
102,000\end{array}$ & $\begin{array}{l}1,300 \\
8,0100 \\
2,600\end{array}$ & 蒋, 000 & $\cdots 800^{\circ}$ & $\ddot{2}, \ddot{2} \ddot{0} 0$ & 200 & $\begin{array}{l}1,100 \\
1,100\end{array}$ & $(3)$ & 100 & (i) \\
\hline $\begin{array}{l}\text { Drum (salt-water), than- } \\
\text { nel bass, ox redilish.... } \\
\text { Flounders.................. }\end{array}$ & $\begin{array}{l}0.58,010 \\
t i s, 000\end{array}$ & $\begin{array}{r}38,000 \\
3,800\end{array}$ & $\begin{array}{r}481,000 \\
13,000\end{array}$ & 24,0000 & $\begin{array}{r}150,000 \\
38,000\end{array}$ & $\begin{array}{r}11,000 \\
3,500\end{array}$ & & & $\begin{array}{l}10,000 \\
10,000\end{array}$ & $\begin{array}{l}1,400 \\
1,400\end{array}$ & $\begin{array}{r}1,800 \\
100\end{array}$ & $(3)^{200}$ & 200 & ( $)$ \\
\hline Mullet. & $\begin{array}{r}118,000 \\
48,000\end{array}$ & $\begin{array}{l}5,100 \\
1,400\end{array}$ & $\begin{array}{l}21,000 \\
27,000\end{array}$ & $\begin{array}{r}3,400 \\
500\end{array}$ & $\begin{array}{l}20,000 \\
21,000\end{array}$ & $\begin{array}{l}1,400 \\
800\end{array}$ & & & 3,200 & 200 & 1,800 & (3) & 2,800 & 100 \\
\hline $\begin{array}{l}\text { Pounpano................. } \\
\text { Sheepshera.............. }\end{array}$ & 217,000 & $\begin{array}{r}100 \\
16,000\end{array}$ & $\begin{array}{r}800 \\
153,000\end{array}$ & $\begin{array}{r}100 \\
10,000\end{array}$ & 61,000 & 3,000 & & & $\dddot{2}, 200$ & $200^{\circ}$ & $\sin 0^{\circ}$ & (i) & 300 & (i) \\
\hline $\begin{array}{l}\text { Emanish mackerel........ } \\
\text { squeteagne, or sea trout. } \\
\text { Yellowtall................ }\end{array}$ & $\begin{array}{r}4,000 \\
1.011,000 \\
64,000\end{array}$ & $\begin{array}{r}400 \\
77,000 \\
3,200\end{array}$ & $\begin{aligned} 4,000 \\
799,000 \\
04,000\end{aligned}$ & $\begin{array}{r}400 \\
51,0100 \\
3,200\end{array}$ & 232,000 & 23,000 & & & $\ddot{2} \ddot{2}, 000$ & 2,300 & 3,000 & 2000 & & ...... \\
\hline All other................. & 142,000 & 4,300 & 1,600 & 100 & "iio, 0000 & $\dddot{4}, 200$ & & & 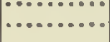 & & (a) & (i) & ......... & $\cdots \ldots \ldots$ \\
\hline 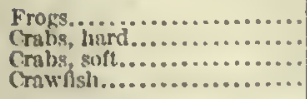 & $\begin{array}{r}38,000 \\
240,000 \\
78,000 \\
79,000\end{array}$ & $\begin{array}{r}4,500 \\
7,500 \\
21,000 \\
2,000\end{array}$ & $\begin{array}{r}70,000 \\
39,000 \\
\ldots .\end{array}$ & $\begin{array}{r}r, 0000 \\
12,000 \\
\ldots \ldots \ldots\end{array}$ & ${ }^{10,000}$ & ${ }_{100}$ & & & $1,300^{\circ}$ & $100^{\circ}$ & & & $\begin{array}{r}38,000 \\
102,000 \\
40,000 \\
77,000\end{array}$ & $\begin{array}{l}4,800 \\
2,900 \\
8,000 \\
2,000\end{array}$ \\
\hline 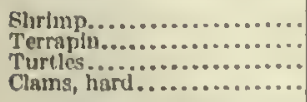 & $\begin{array}{r}8.210,000 \\
38,000 \\
104,000 \\
100\end{array}$ & $\begin{array}{l}187,000 \\
18,000 \\
77400 \\
\text { (i) }\end{array}$ & $\begin{array}{r}8,141,000 \\
8,000 \\
41,000\end{array}$ & $\begin{array}{r}185,000 \\
0,700 \\
1,200\end{array}$ & ${ }^{\cdots} \mathrm{i},{ }^{\prime}, \ldots 000^{\circ}$ & $i, i 00$ & & & 2,600 & $200^{\circ}$ & & & $\begin{array}{r}70,000 \\
29,000 \\
133,000 \\
100\end{array}$ & $\begin{array}{l}2,100 \\
12,000 \\
4,800 \\
(1)\end{array}$ \\
\hline $\begin{array}{l}\text { Oysters, market, from pub- } \\
\text { lic areas. }\end{array}$ & $19,805,000$ & 260,000 & & & .. & & & & & & & & $\cdot 9,805,0 \times 0$ & 200,000 \\
\hline $\begin{array}{l}\text { Oysters, market, from prj- } \\
\text { vato areas.............. }\end{array}$ & o $8,821,000$ & 278,000 & & & & & & & & & & & $3,821,000$ & 278,000 \\
\hline $\begin{array}{l}\text { Oysters, seed, from puble } \\
\text { areas. } \\
\text { oysters, sced, trom private }\end{array}$ & $3,050,000$ & 74,000 & & & & & & & & & & & $\cdot 3,050,000$ & 74,000 \\
\hline 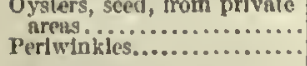 & 1032,000 & (2) $^{85}, 600$ & & & & & & & & & & & $\begin{array}{r}10032,000 \\
200\end{array}$ & $\begin{array}{l}5,600 \\
(3)\end{array}$ \\
\hline 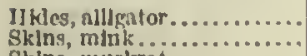 & $\begin{array}{r}8110,000 \\
020,000\end{array}$ & $\begin{array}{l}11,000 \\
77,000\end{array}$ & & & & & & & & & & & $\begin{array}{l}8110,000 \\
80,000\end{array}$ & $\begin{array}{l}11,000 \\
77,000\end{array}$ \\
\hline 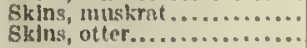 & $\begin{aligned} 10.40,(00) \\
\text { 11], } 100\end{aligned}$ & $\begin{aligned} 16,000 \\
4,700\end{aligned}$ & & & & & & & & & & & $\begin{array}{rl}10 & 40,000 \\
& 11 \\
1 & 100\end{array}$ & $\begin{aligned} 16,0(0) \\
4,700\end{aligned}$ \\
\hline
\end{tabular}

1 Inelides apparatus, with cateh, as follows: Dredges, Longs, eto., 10,338,000 pounds, valued at s017,000; inink, muskrat, and otter inaps, fo,000 patmds, valued at

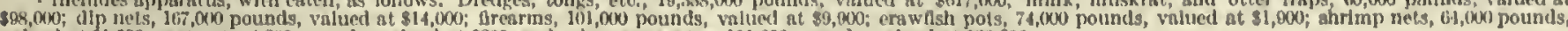

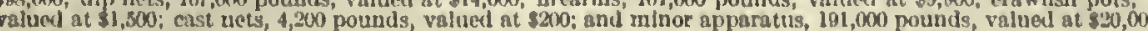

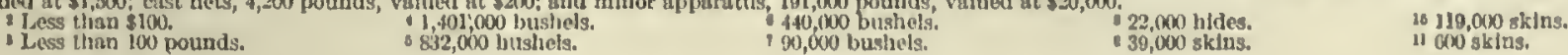


MAINE.

The fishing industry of Maine is confined to sea and shore fisheries along the Atlantic coast; but because of the peculiarly ragged and uneven coast line and the many outlying islands, the state possesses special advantages among the states in which commercial fishing is carried on. In the total value of fishery products Maine ranked second among the New England states in 1908 and seventh among all the states; in the value of lobsters, soft clams, and herring caught it ranked first, and in the value of cod, haddock, and hake second.

The following statement presents a summary of the most important statistics for the fisheries of Maine in 1908:

Number of persons employed.......................

6,861

Capital:

Vessels and boats, including outfit.............\$1, 669,000

Apparatus of capture...................... $\quad 576,000$

Shore and accessory property and cash.......... $\quad 166,000$

Value of products......................... 3, 257,000

Comparison with previous canvasses. -The principal statistics of the Maine fisheries for 1908, in comparison with the returns for certain earlier years for which canvasses were made, are given in the following tabular statement:

\begin{tabular}{|c|c|c|c|c|c|c|}
\hline \multirow[b]{2}{*}{ YEAR. } & \multirow{2}{*}{$\begin{array}{l}\text { Persons } \\
\text { em- } \\
\text { ployed, } \\
\text { exclustre } \\
\text { of shores- } \\
\text { men. }\end{array}$} & \multicolumn{3}{|c|}{ VALUE OF EQUTPMENT. } & \multicolumn{2}{|c|}{ PRODUCTS. } \\
\hline & & Total. & $\begin{array}{l}\text { Vessels and } \\
\text { boats, } \\
\text { lneluding } \\
\text { outfit. }\end{array}$ & $\begin{array}{l}\text { Appara- } \\
\text { tus of } \\
\text { capture. }\end{array}$ & $\begin{array}{l}\text { Quantlty } \\
\text { (pounds). }\end{array}$ & Value. \\
\hline $\begin{array}{l}1908 \ldots \ldots \\
1905 \ldots \ldots \\
1902 \ldots . . \\
1898 \ldots . \\
1889 \ldots\end{array}$ & $\begin{array}{l}6,857 \\
7,442 \\
9,207 \\
8,717 \\
8,885\end{array}$ & $\begin{array}{r}\$ 2,245,000 \\
1,606,000 \\
1,732,000 \\
1,434,000 \\
1,475,000\end{array}$ & $\begin{array}{r}81,669,000 \\
1,179,000 \\
1,255,000 \\
1,006,000 \\
1,051,000\end{array}$ & $\begin{array}{r}\mathbf{5} 576,000 \\
428,000 \\
476,000 \\
429,000 \\
424,000\end{array}$ & $\begin{array}{l}173,843,000 \\
124,724,000 \\
242,390,000 \\
123,405,000 \\
129,560,000\end{array}$ & $\begin{array}{r}83,257,000 \\
2,386,000 \\
2,919,000 \\
2,655,000 \\
2,111,000\end{array}$ \\
\hline
\end{tabular}

The total investment in equipment-ressels and their outfits, boats, and apparatus of capture-increased by more than 50 per cent from 1889 to 1908 , being $\$ 1,475,000$ at the earlier date and $\$ 2,245,000$ at the latter. An increase in each of the items helped to make up the increase in the total, the value of the apparatus of capture increasing from $\$ 424,000$ to $\$ 576,000$ and the value of vessels and boats from $\$ 1,051,000$ to $\$ 1,669,000$. The increase in these items, however, was not uninterrupted, for the value of apparatus of capture fell in 1905 below the values reported for 1898 and 1902, and the value of vessels and boats in 1898 was less than in 1889, and in 1905 less than in 1902 . It may be noted that the investment in 1880 was $\$ 1,814,000$, which is larger than that reported at any subsequent canvass prior to 1908 .

In the report for 1880 the values of the separate products as sold by the fishermen are not given. The following tabular statement, however, presents statistics showing the value of the leading products for the years $1908,1902,1898$, and 1889 , arranged in the order of their value in 1908 :

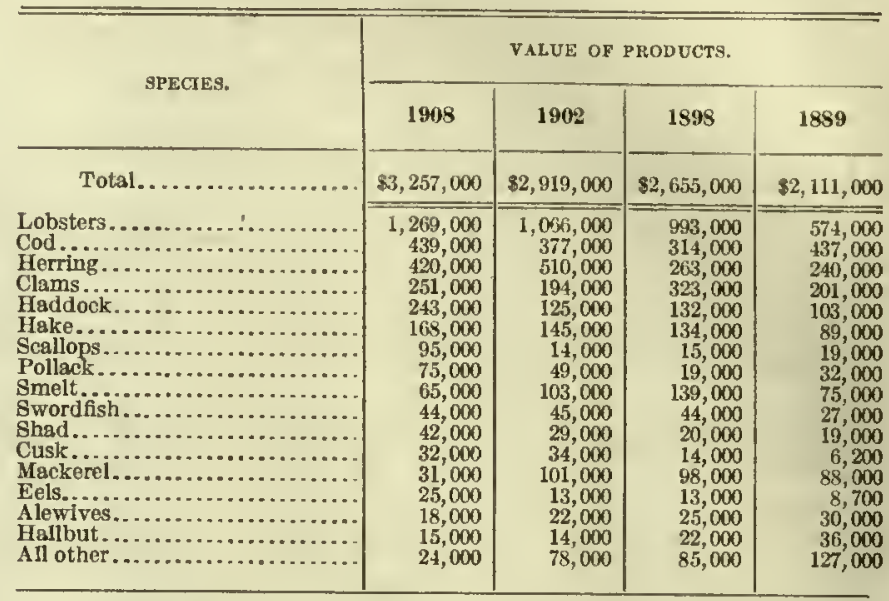

In each of the years for which statisties are shown, lobsters, cod, herring, clams, haddock, and hake constituted the six principal fishery products of the state, except that in 1898 smelt rankerl fifth and haddock seventh. These six species contributed 78 per cent of the aggregate value of the fishery product of the state in 1889,81 per cent in 1898,83 per cent in 1902 , and 86 per cent in 1908 .

The value of the lobster product increased about 73 per cent from 1889 to 1898 and 28 per cent from 1898 to 1908 . The cod prorluct decreased in value about 28 per cent from 1889 to 1898 , but during the following ten years recovered this loss, so that in 1908 the value was about the same as in 1889 . The value of the herring catch in 1908 showed a decrease of about 18 per cent, as compared with 1902 , but an increase of about 60 per cent, as compared with 1898 or 1889. The value of the clan product in 1908 was 29 per cent greater than in 1902 and 25 per cent greater than in 1889, but was less than in 1898 . The haddock eatch fluctuated in value througlout the period covered by the statistics, although in 1908 the value was more than twice as great as in 1889 and nearly twice as great as in 1902 . The value of hake showed an increase at each canvass.

Of the less important varieties, shad alone shows an increase in value at each successive canvass. Alewives declined steadily in value, while scallops and halibut decreased in value until 1902, and then gained. Pollack and eels show increases from 1902 to 1908; smelt, swordfish, cusk, and mackerel show declines. The most marked decline is in the value of the mackerel catch, which decreased 69 per cent between 1902 and 1908.

Persons employed.-The total number of persons employed in the fisheries of the state in 1908 was 6,861 , distributed as follows: 


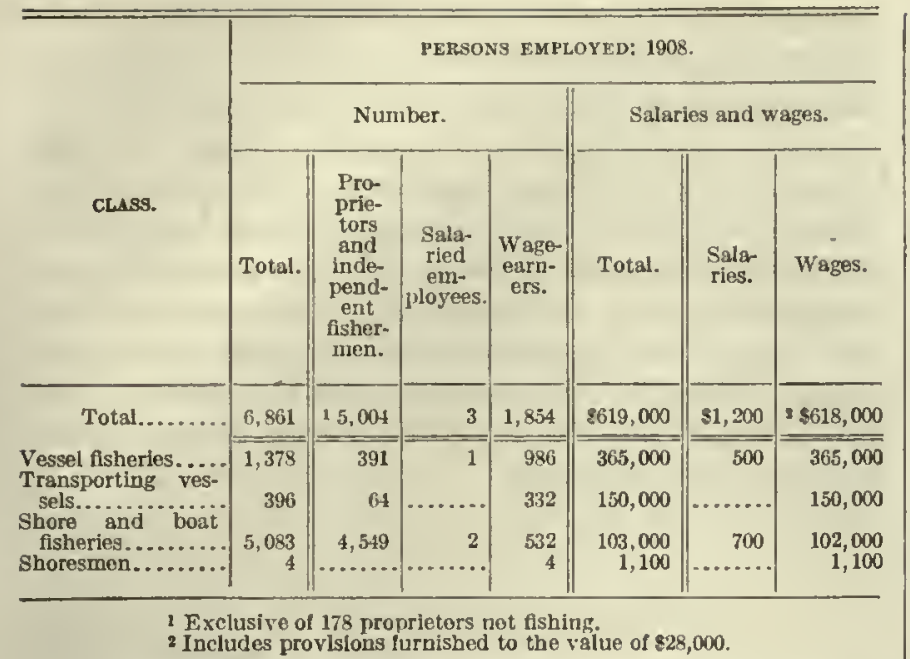

Nearly three-fourths of the persons employed in fishing industries in the state were engaged in the shore and boat fisheries, and nearly nine-tenths of those engaged in the shore and boat fisheries were proprietors and independent fishermen. Of the total number engaged in the shore and boat fisheries, 534, or 11 per cent, were employed by others. The following tabular statement shows the number of persons employed, exclusive of slioresmen, in the fisheries of Maine during the years named:

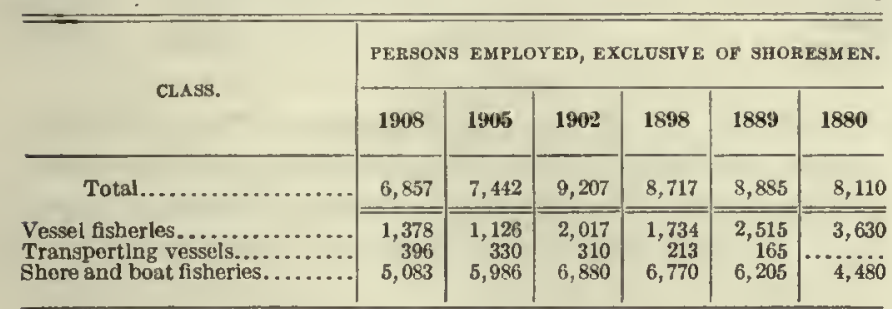

There has been a general, though to some extent interrupted, decrease since 1880 in the number of persons employed. The total number employed was smallest in 1908, and the number employed in shore and boat fisheries was smaller in that year than at any other time since 1880. Both for the fisheries of the state as a whole and for the shore and boat fisheries the largest number of persons employed was reported in 1902. For vessel fisheries the largest number of employees was reported in 1880 and the smallest number in 1905, although the number in 1902 was larger than that at any canvass since 1889. Contrary to the general tendency toward a decrease in the number of persons employed apparent in each of the other branches of the industry, the number employed on transporting vessels shows a small increase from year to year.

Equipment and other capital.-The following table gives statistics of the equipment and of other capital employed:

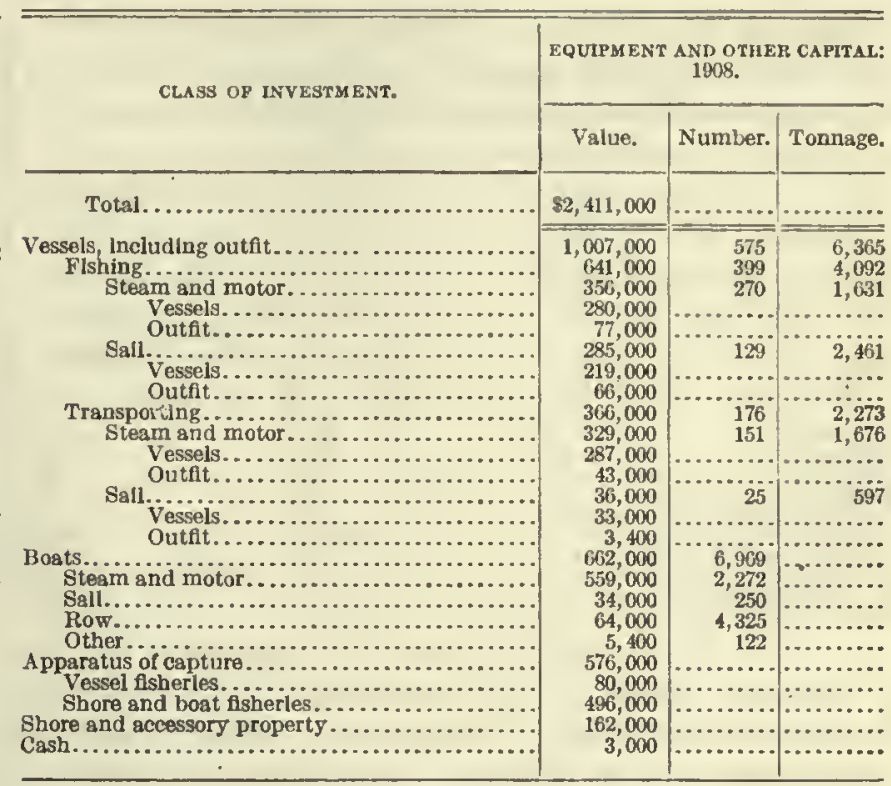

In 1908 the total investment in vessels, boats, and apparatus of capture was $\$ 2,245,000$. Of this amount, $\$ 1,007,000$ represented the investment in vessels and their outfits and $\$ 662,000$ the investment in boats.

A prominent feature of the Maine fisheries is the large number of small craft. The value of the boats employed in 1908 represented 27 per cent of all capital invested, the value of steam and motor boats alone forming 23 per cent. The investment in power craft of all kinds, including vessels and boats with their outfits, aggregated $\$ 1,245,000$, or 52 per cent of all capital invested.

The statistics for boats show a material increase in the number and a large increase in the value, as compared with the returns for earlier years made by the Bureau of Fisheries. The increase in value seems to be due to the increasing use of motor boats of small tonnage. For 1905 the report of the Bureau of Fisheries showed only 798 gasoline boats (including one steamer), with a value of $\$ 233,000$, while in 1908 the steam and motor boats numbered 2,272, with a total value of $\$ 559,000$. The capital invested in craft and apparatus of capture together was nearly equal for the two classes of fisheries, aggregating $\$ 1,087,000$ for the vessel fisheries and $\$ 1,158,000$ for the shore and boat fisheries.

Lobster and eel pots, which constituted the principal apparatus used in the lobster industry, far exceeded in number any other kind of apparatus used in the fishing industries of Maine. Pound and trap nets were used principally in the shore and boat fisheries, no pound nets and only 11 trap nets being used in the vessel fisheries. Of the 511 seines used, 412 were reported for the shore and boat fisheries. 
The following tabular statement shows the number of various kinds of apparatus reported. No returns were made of the number of lines, dredges, tongs, etc.

\begin{tabular}{|c|c|c|c|}
\hline \multirow{3}{*}{ KLND. } & \multicolumn{3}{|c|}{ APPARATUS OF CAPTURE: 1908.} \\
\hline & \multirow[b]{2}{*}{ Total. } & \multicolumn{2}{|c|}{ Used in- } \\
\hline & & $\begin{array}{c}\text { Vessel } \\
\text { fisberies. }\end{array}$ & $\begin{array}{l}\text { Shore and } \\
\text { boat } \\
\text { fisheries. }\end{array}$ \\
\hline 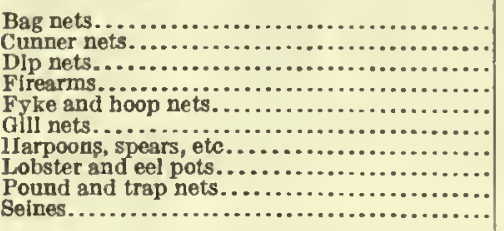 & $\begin{array}{r}156 \\
11 \\
657 \\
6 \\
4 \\
1,980 \\
550 \\
176,365 \\
655 \\
511\end{array}$ & $\begin{array}{r}71 i \\
475 \\
15,594 \\
11 \\
99\end{array}$ & $\begin{array}{r}153 \\
11 \\
655 \\
6 \\
4 \\
1,269 \\
80 \\
160,771 \\
644 \\
412\end{array}$ \\
\hline
\end{tabular}

Products, by species.-The fisheries of the state of Maine yielded, in $1908,173,843,000$ pounds of products, with a value of $\$ 3,257,000$. Along the coast sunken ledges and rocks, the habitat of various marine animals that serve as food for many of the most important food fishes, are the resort of the cod, haddock, hake and other species known as "ground fish." The rocky character of the coast makes it especially suitable for the growth of lobsters, and the breeding of them is carried on in practically every locality along the coast and has become by far the most important branch of the fishing industry of the state. In 1908 the lobster product contributed 39 per cent of the total value of all fishery products of the state. In point of value the cod product ranked next, but this furnished only 13 per cent of the value of all fishery products, or little more than one-third as much as the lobster product. Herring ranked third in value, the large number of these fish caught being utilized mainly in sardine canneries and smokehouses. The softclam industry is also important and its products ranked fourth in value among those of the fisheries of the state; but oysters thus far have not been successfully propagated in the waters of Maine. The other important classes of product, in order of value reported, were haddock, hake, scallop, pollack, and smelt. The products distributed by species and by apparatus of capture are shown in Table 1, on page 143.

Products, by class of fisheries.-The distribution of the value of products between the vessel fisheries and the shore and boat fisheries is given in the next tabular statement.

The products in detail, by species and apparatus of capture, are presented for the vessel fisheries in Table 3 , on page 145 , and for the shore and boat fisheries in Table 2, on page 144 .

The vessel fisheries, while of considerable importance, are much less extensive than the shore and boat fisheries. In 1908 the catch reported for the former was $52,724,000$ pounds, valued at $\$ 898,000$, or about 30 per cent of the total quantity and 28 per cent of the total value for the state. The shore and boat fisheries reported a catch of $121,119,000$ pounds, valued at $\$ 2,359,000$, or about 70 per cent of the total quantity and 72 per cent of the total value for the state.

In the vessel fisheries the combined catch of cod, herring, haddock, hake, swordfish, and lobsters was valued at $\$ 742,000$, or 83 per cent of the total value of the products of those fisheries. In the shore and boat fisheries the value of the lobster catch represented 48 per cent of the total value. The value of the fish proper constituted 80 per cent of the total value in the case of vessel fisheries and 39 per cent in the case of shore and boat fisheries.

\begin{tabular}{|c|c|c|c|}
\hline \multirow[b]{2}{*}{ SPECIES. } & \multicolumn{3}{|c|}{ VALUE OF PRODUCtS: 1908.} \\
\hline & Total. & $\begin{array}{c}\text { Vessel } \\
\text { fisheries. }\end{array}$ & $\begin{array}{l}\text { Shore and } \\
\text { boat } \\
\text { fisherles. }\end{array}$ \\
\hline Total.. & $83,257,000$ & 8898,000 & $\$ 2,359,000$ \\
\hline Fish... & $1,631,000$ & 717,000 & 914,000 \\
\hline cod...... & 439,000 & 238,000 & 201,000 \\
\hline Herring. & 420,000 & 95,000 & 325,000 \\
\hline Haddoek. & 243,000 & 133,000 & 111,000 \\
\hline Hake.... & 168,000 & 100,000 & 68,000 \\
\hline Pollack. & 75,000 & 36,000 & 30,000 \\
\hline Smelt....... & 65,000 & 2,400 & 63,000 \\
\hline Swordfish.. & 44,000 & 43,000 & 600 \\
\hline Sbad........ & 42,000 & 10,000 & 32,000 \\
\hline Mackerei.... & $\begin{array}{l}32,000 \\
31,000\end{array}$ & 24,000 & 8,000 \\
\hline $\begin{array}{l}\text { Mackerel..... } \\
\text { Eels......... }\end{array}$ & $\begin{array}{l}31,000 \\
25,00\end{array}$ & $\begin{array}{r}19,000 \\
3,700\end{array}$ & 12,000 \\
\hline Alewives..... & $\begin{array}{l}25,000 \\
18,000\end{array}$ & $\begin{array}{l}3,600 \\
1,500\end{array}$ & $\begin{array}{l}21,000 \\
16,000\end{array}$ \\
\hline .................... & 15,000 & 11,000 & 3,700 \\
\hline All other.... & 14,000 & 700 & 13,000 \\
\hline Iobster ......... & $1,269,000$ & 134,000 & $1,136,000$ \\
\hline Clams.............. & 251,000 & 4,300 & 247,000 \\
\hline 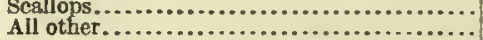 & $\begin{array}{r}95,000 \\
9,600\end{array}$ & 38,000 & 58,000 \\
\hline & & & \\
\hline
\end{tabular}

Products, by apparatus of capture.-The following tabular statement shows the distribution of the value of the fishery products taken by each kind of apparatus for the state as a whole and for each class of fisheries:

\begin{tabular}{|c|c|c|c|}
\hline \multirow[b]{2}{*}{ EIND OF APPARATUS. } & \multicolumn{3}{|c|}{ VALUE OF PRONUCTS: 1908.} \\
\hline & Total. & $\begin{array}{c}\text { Vessel } \\
\text { fisherles. }\end{array}$ & $\begin{array}{l}\text { Shore and } \\
\text { boat } \\
\text { fisheries. }\end{array}$ \\
\hline Total........................... & $\$ 3,257,000$ & $\$ 898,000$ & $\$ 2,359,000$ \\
\hline 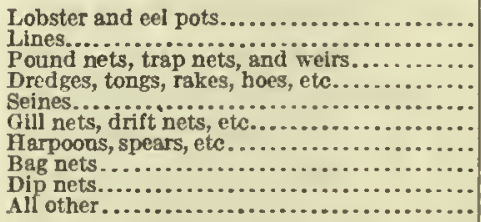 & $\begin{array}{r}1,290,000 \\
953,000 \\
357,000 \\
347,000 \\
171,000 \\
56,000 \\
48,000 \\
22,000 \\
12,000 \\
2,200\end{array}$ & $\begin{array}{r}137,000 \\
529,000 \\
11,000 \\
42,000 \\
108,000 \\
27,000 \\
43,000 \\
600 \\
300 \\
400\end{array}$ & $\begin{array}{r}1,153,000 \\
424,000 \\
346,000 \\
305,000 \\
63,000 \\
29,000 \\
5,300 \\
21,000 \\
12,000 \\
1,800\end{array}$ \\
\hline
\end{tabular}

In consequence of the fact that the lobster is the most important product of the fisheries of Maine, the products caught by means of eel and lobster pots show the largest value. Lines ranked second in value of the catch. They are used very generally along the coast of Maine, and nearly all the important species of fish, except herring, shacl, and such large fish as sturgeon and swordfish, are caught by this apparatus.

Pound nets, trap nets, and weirs followed lines in importance as apparatus of capture. All of these 
were used principally in the shore and boat fisheries, only about 3 per cent of the value of the product taken by them in 1908 coming from vessel fisheries. Herring contributed more than four-fifths of the value of the catch by these forms of apparatus.

Dredges, tongs, rakes, hoes, and similar'apparatus ranked fourth in importance as measured by the value of the product taken; although used to some extent in vessel fisheries, they were employed chiefly in shore and boat fisheries for taking clams. All of the scallops taken in the state, valued at $\$ 95,000$, and a few oysters were also secured by apparatus of this kind.

Seines were used extensively in the vessel fisheries, which reported nearly two-thirds of the total value of the catch made by this apparatus. The principal species caught by seines were herring, pollack, smelt, mackerel, and shad.

Gill nets and drift nets were used to nearly the same extent in vessel fisheries and shore and boat fisheries. The total catch taken by these nets weighed $1,404,000$ pounds and was valued at $\$ 56,000$. It included mackerel, herring, shad, cod, and smelt, with a combined value of $\$ 52,000$, and six other species aggregating in value $\$ 3,600$.

The principal species taken with harpoons and spears was the swordfish. By these implements were also captured seals, from which came skins and oil; porpoises, taken for their oil; and eels.

Lobster.-Measured by value of products lobster wers the most important fishery product of the state in 1908, and, although the weight of the total catch was less than in 1902 , by $2,234,000$ pounds, or 18 per cent, its value was greater by $\$ 203,000$, or 16 per cent. It is interesting to note that the total catch in 1880 was $14,234,000$ pounds - a much larger quantity than in 1908 -but its value to the fishermen was only $\$ 269,000$. Lobsters are taken principally in the shore and boat fisheries. In 1908 this class of fisheries reported $8,898,000$ pounds, valued at $\$ 1,136,000$, whereas only $1,031,000$ pounds, with a value of $\$ 134,000$, were taken in the vessel fisheries.

Cod.- The catch of cod ranked next to the lobster product in value and was the largest in quantity reported for any of the so-called "ground fish" (cod, haddock, hake, halibut, pollack, and cusk). In all, $20,013,000$ pounds of cod were caught, with a value of $\$ 439,000$, or 13 per cent of the value of all fishery products of the state. The catch in 1908 represents an increase of about 15 per cent in weight and nearly 17 per cent in value orer the catch in 1902 , which amounted to $17,390,000$ pounds, valued at $\$ 377,000$. The product of 1908 was almost equally divided between the vessel and the shore and boat fisheries, the quantity taken in the former being $9,951,000$ pounds and that taken in the latter $10,063,000$ pounds, or only 1 per cent more. Yet the value of the lesser catch of the vessel fisheries, $\$ 238,000$, was 15 per cent greater than the value of the catch from the shore and boat fisheries, which was $\$ 201,000$. It is of interest to note in this connection that in 1902 the Bureau of Fisheries reported a large difference in the amount of cod taken in shore and boat fisheries as compared with vessel fisheries, the product of the latter being $12,621,000$ pounds, valued at $\$ 286,000$, and that of the former only $4,769,000$ pounds, valued at $\$ 91,000$. Nearly 87 per cent of the catch was sold fresh and the remainder was salted. Practically the entire product was taken by hand and trawl lines.

Herring.-Herring fishing is important in the state of Maine, and this fish in 1908 ranked first among the fishery products of the state in quantity and third in value. The value of the product represented $13 \mathrm{per}$ cent of the value of the aggregate product for the state. Since 1902 there has been a decrease of $69,419,000$ pounds, or nearly 43 per cent, in the total catch, and of $\$ 90,000$, or nearly 18 per cent, in its value. The herring fishery is principally a shore fishery; in $1908,75,638,000$ pounds of herring were taken in the shore and boat fisheries, with a value of $\$ 325,000$, or over 77 per cent of the total value of the herring taken in Maine. Ninety-six per cent of the catch was sold fresh and the remainder salted or smoked. The greater part of the total quantity$66,826,000$ pounds, valued at $\$ 287,000$, or over 68 per cent of the total value of herring-was taken in pound nets, trap nets, and weirs. About 27 per cent of the value represents the value of the catch made with seines. Herring, as already stated, are utilized mainly in sardine canneries and smokehouses, but they are also to some extent sold salted and are used for bait in trawl and hand-line fishing.

Clams.-For the clam product a considerable increase in value is shown in the last few years, and in 1908 it stood in this respect next to herring. In this report both the fresh clams sold for food and for canning and the salted clams sold for bait are included under the term "soft clams." The total yield of clams in 1908 was $5,061,000$ pounds; valued at $\$ 251,000$; in $1905,3,729,000$ pounds, valued at $\$ 135,000$; and in $1902,5,547,000$ pounds, valued at $\$ 194,000$. There was a decline in the product from 1902 to 1905 , amounting to 33 per cent in quantity and nearly 31 per cent in value, but an increase from 1905 to 1908 made the total quantity in 1908 less than 9 per cent smaller than in 1902 and the total value 29 per cent more. Clams ranked third in value among the products of the shore and boat fisheries, less than 2 per cent of the clam product being taken in the vessel fisheries.

Haddock. - In value of the catch the haddock ranked next to the cod among the "ground fish," and fifth among all species of the state. The catch was slightly larger in the vessel fislieries than in the shore and boat fisheries and proportionately more valuable. It was practically all sold fresh. Since 1902 there has been 
an increase of 50 per cent in the quantity of the catch of this fish together with an increase of nearly 95 per cent in the value. Lines were the principal kind of apparatus used in the capture of haddock.

Hake.-The hake wrs an important species of "ground fish" taken in Maine, and in quantity reported ranked next to the cod in 1908 and third among all the species taken in the state. The most prolific hake fishing grounds in the United States are off the coast of Maine, and more than 50 per cont of the hake caught in the United States comes from there. The fishermen usually dress these fish before selling them. Formerly the sounds were very valuable for the manufacture of glue, and although their value for this purpose has decreased, the custom of dressing the hake, begun before the Civil War, has continued. The value of the hake product in 1908 formed 5 per cent of the value of all fishery products of Maine. Compared with the 1902 product that of 1908 represented a decrease of 7 per cent in quantity but an increase of nearly 16 per cent in value. The hake was taken in the vessel fisheries to a greater extent than in the shore and boat fisheries, the total quantity caught by vessels in 1908 constituting about 60 per cent of all hake caught in the state. Lines were the leading apparatus of capture employed.

Scallops.-Although scallops have been taken in the other New England states for a number of years, the industry is comparatively new in Maine. The water in which they are taken is of great depth, and for this reason scallop fishing was not much carried on in this state. During the past few years, however, the advent of motor boats for dragging and of the motor engines and drum for hoisting the dredge has overcome the difficulties due to the deep water and led to a marked increase in product. In 1908 scallops stood seventh in value among the species taken in the state. Exclusive of 18,000 pounds of scallop rims, with a value of $\$ 100$, the total product in 1908 was $1,239,000$ pounds, with a value of $\$ 95,000$. In 1905 the total quantity was 416,000 pounds, valued at $\$ 52,000$, and in $1902,115,000$ pounds, valued at $\$ 14,000$. The product of the shore and boat fisheries amounted to 766,000 pounds, valued at $\$ 58,000$. The entire catch was made by dredges, tongs, rakes, hoes, and similar apparatus.

Pollack.-The value of the catch of pollack increased from $\$ 49,000$ in 1902 to $\$ 75,000$ in 1908 , or more than 53 per cent. The value of the product in 1908 amounted to four times the value of that of 1898 . This fish is reported in nearly equal quantities by the vessel fisheries and the shore and boat fisheries, and is taken principally by means of lines and seines.

Smelt.-Although the catch of smelt represented but 2 per cent of the value of the fishery products of the state in 1908, smelt fishing is regarded as important because it furnishes employment to a large number of men in the fall and winter months. In the fall principally seines are used in taking the catch, but in the winter the fish are taken through the ice with lines and the fishing grounds are usually some distance up the rivers. Since 1902 there has been a decrease of 42 per cent in the quantity of the catch and 37 per cent in its value. There has been a slight increase since 1905, however, in both quantity and value. Over 96 per cent of the value of the catch was reported by the shore and boat fisheries. Other apparatus besides seines and lines used in capturing this fish are bag nets, pound nets, trap nets, weirs, and to a less extent, dip nets, gill nets, and drift nets. The figures given for smelt in the columns headed "All other apparatus" in Table 1, on page 143, represent the catch in bag nets.

Mackerel.-The mackerel was formerly very abundant in the waters of Maine, but the catch for 1908 was only 380,000 pounds. The value of the catch was $\$ 31,000$, a decrease of 69 per cent since 1902 , when it was $\$ 101,000$.

Salmon.-Salmon fishing also has been decreasing in importance yearly, the catch in 1908 being 72 per cent less in value than that in 1902. The salmon is a migratory fish and formerly came to the Maine waters to spawn, but it is asserted that, owing to tha pollution of the waters, it is now impossible for the fish to reach the spawning beds in the fresh water. 
FISHERIES, BY STATES.

TABle 1.-MAINE-Fishery PRODUCTS: 1908.

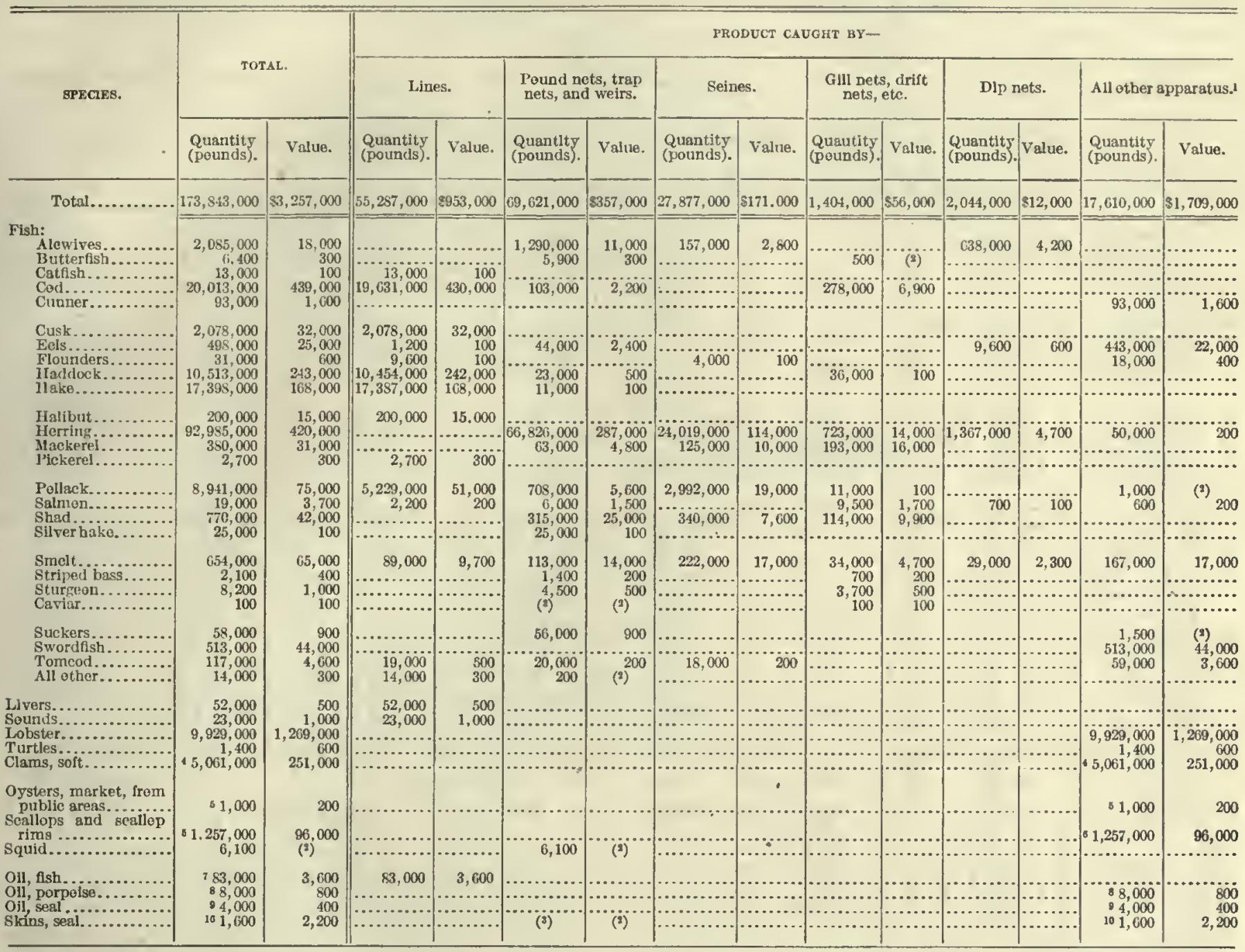

1 Includes apparatus, with catch, as follows: Lobster and eel pots, 10,361,000 pounds, valued at $\$ 1,290,000 ;$ dredges, tongs, etc., 6,310,000 paunds, valued at $\$ 347,000$;

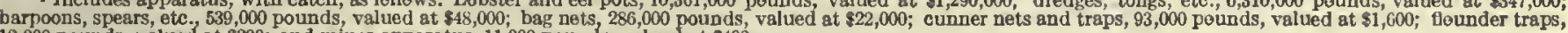
10,000 pounds, valued at $\$ 200$; and miner apparatus, 11,000 peunds, valued at $\$ 400$ 
TABLE 2.-MAINE-PRODUCTS OF SHORE AND BOAT FISHERIES: 1908.

\begin{tabular}{|c|c|c|c|c|c|c|c|c|c|c|c|c|c|c|}
\hline \multirow{3}{*}{ SPECIES. } & \multirow{2}{*}{\multicolumn{2}{|c|}{ TOTAL. }} & \multicolumn{12}{|c|}{ PRODUCT CAUGHT BY- } \\
\hline & & & \multicolumn{2}{|c|}{ Lines. } & \multicolumn{2}{|c|}{$\begin{array}{l}\text { Pound nets, trap } \\
\text { nets, and weirs. }\end{array}$} & \multicolumn{2}{|c|}{ Seines. } & \multicolumn{2}{|c|}{$\begin{array}{l}\text { Gill nets, drift } \\
\text { nets, etc. }\end{array}$} & \multicolumn{2}{|c|}{ Dip nets. } & \multicolumn{2}{|c|}{ All other apparatus. } \\
\hline & $\begin{array}{l}\text { Quantity } \\
\text { (pounds). }\end{array}$ & Value. & $\begin{array}{l}\text { Quantity } \\
\text { (pounds). }\end{array}$ & Value. & $\begin{array}{l}\text { Quantity } \\
\text { (pounds). }\end{array}$ & Value. & $\begin{array}{l}\text { Quantity } \\
\text { (pounds). }\end{array}$ & Value. & $\begin{array}{l}\text { Quantity } \\
\text { (pounds). }\end{array}$ & Value. & $\begin{array}{l}\text { Quantity } \\
\text { (pounds). }\end{array}$ & Valt & $\begin{array}{l}\text { Quantity } \\
\text { (pounds). }\end{array}$ & Value. \\
\hline Total... & $121,119,000$ & $\$ 2,359,000$ & $25,461,000$ & $\$ 424,000$ & $68,200,000$ & $\$ 346,000$ & $9,562,000$ & $\$ 63,000$ & 538,000 & $\$ 29,000$ & $1,956,000$ & $\$ 12,000$ & $15,403,000$ & $\$ 1,486,000$ \\
\hline $\begin{array}{l}\text { Fish: } \\
\text { Alewives, tresh .... } \\
\text { Alewives, salted } \\
\text { Alewives, smoked. } \\
\text { Butterfish........ } \\
\text { Catfish............ }\end{array}$ & $\begin{array}{r}\mathbf{1}, 751,000 \\
112,000 \\
192,000 \\
\mathbf{5}, 900 \\
\mathbf{5}, 800\end{array}$ & $\begin{array}{r}11,000 \\
2,000 \\
3,400 \\
300 \\
100\end{array}$ & ( & $\mid \begin{array}{c}\cdots \\
\cdots \\
\cdots\end{array}$ & $\begin{array}{r}1,052,000 \\
64,000 \\
174,000 \\
5,400 \\
\ldots \ldots \ldots . . .\end{array}$ & $\begin{array}{r}6,600 \\
1,500 \\
2,700 \\
300 \\
\cdots\end{array}$ & 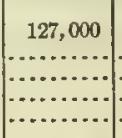 & $\begin{aligned} 1,300 \\
\cdots \cdots \\
\cdots \cdots \\
\cdots \cdots \\
\cdots \cdots \\
\cdots\end{aligned}$ & 500 & $\mid \begin{array}{c}\cdots \\
\cdots \\
\cdots\end{array}$ & $\begin{array}{r}572,000 \\
48,000 \\
18,000 \\
\ldots \ldots\end{array}$ & $\begin{array}{r}2,900 \\
600 \\
700 \\
\cdots\end{array}$ & 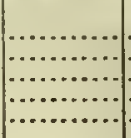 & $\begin{array}{l}\cdots \cdots \cdots \\
\cdots \cdots \cdots \\
\cdots \cdots \cdots\end{array}$ \\
\hline $\begin{array}{l}\text { Cod, fresh ........ } \\
\text { Cod, salted....... } \\
\text { Cunner........... } \\
\text { Cusk, fresh ....... } \\
\text { Cusk, salted...... }\end{array}$ & $\begin{array}{r}9,896,000 \\
167,000 \\
90,000 \\
520,000 \\
4,100\end{array}$ & $\begin{array}{r}196,000 \\
5,500 \\
1,600 \\
\mathbf{7}, 900 \\
100\end{array}$ & $\begin{array}{r}9,588,000 \\
167,000 \\
520,000 \\
4,100\end{array}$ & $\begin{array}{r}188,000 \\
5,500 \\
7,900 \\
100\end{array}$ & 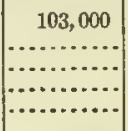 & 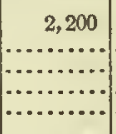 & $\begin{array}{l}\ldots . \\
\cdots \\
\cdots \\
\cdots \\
\cdots\end{array}$ & $\begin{array}{l}\cdots \\
\cdots \\
\cdots \\
\cdots\end{array}$ & $\mid \begin{array}{c}204,000 \\
\cdots \cdots \\
\cdots \cdots \\
\cdots \cdots \\
\cdots \cdots \\
\cdots\end{array}$ & $\begin{array}{r}5,200 \\
\cdots \ldots \ldots . \\
\cdots \ldots \ldots \\
\cdots \ldots \ldots \\
\cdots \ldots\end{array}$ & & & 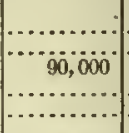 & 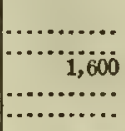 \\
\hline $\begin{array}{l}\text { Eels.............. } \\
\text { Flounders ........ } \\
\text { Haddoek, fresh... } \\
\text { Haddock, sal ted.. } \\
\text { Hake, fresh....... } \\
\text { Hake, salted...... }\end{array}$ & $\begin{array}{r}414,000 \\
31,000 \\
4,753,000 \\
48,000 \\
6,947,000 \\
245,000\end{array}$ & $\begin{array}{r}21,000 \\
600 \\
110,000 \\
1,000 \\
64,000 \\
3,500\end{array}$ & $\begin{array}{r}1,200 \\
9,600 \\
4,694,000 \\
48,000 \\
6,937,000 \\
245,000\end{array}$ & $\begin{array}{r}100 \\
100 \\
108,000 \\
1,000 \\
64,000 \\
3,600\end{array}$ & $\begin{array}{r}44,000 \\
\ldots \ldots, 000 \\
23,00 \\
11,000 \\
\cdots \ldots \ldots\end{array}$ & $\begin{array}{r}2,400 \\
\cdots, \ldots 00 \\
1000\end{array}$ & 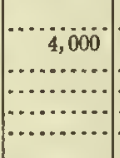 & $\begin{array}{l}100 \\
\cdots \cdots \\
\cdots \cdots \\
\cdots \cdots\end{array}$ & $\mid \begin{array}{c}36,000 \\
\cdots \cdots \\
\cdots \cdots\end{array}$ & $\begin{array}{c}1,000 \\
\cdots \cdots \\
\cdots \cdots \\
\cdots\end{array}$ & $\begin{array}{c}9,600 \\
\cdots \ldots . . . \\
\cdots \ldots . . . \\
\cdots \cdots . . . \\
\cdots\end{array}$ & $\begin{array}{l}600 \\
\cdots \cdots \\
\cdots \cdots \\
\cdots \cdots \\
\cdots \cdots \\
\end{array}$ & 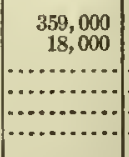 & 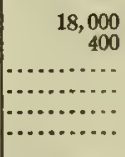 \\
\hline $\begin{array}{l}\text { Hallbut. ......... } \\
\text { Herring, fresh .... } \\
\text { Herring, salted ... } \\
\text { Herring, smoked. }\end{array}$ & $\begin{array}{r}47,000 \\
74,552,000 \\
851,000 \\
234,000\end{array}$ & $\begin{array}{r}3,700 \\
316,000 \\
6,200 \\
2,900\end{array}$ & $\begin{array}{l}47,000 \\
\ldots \ldots \ldots \\
\ldots \ldots \ldots \\
\ldots \ldots\end{array}$ & 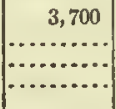 & $\begin{array}{r}65,217,000 \\
40,000 \\
234,000\end{array}$ & $\begin{array}{r}276,000 \\
300 \\
2,900\end{array}$ & $\mid \begin{array}{r}7,944,000 \\
811,000 \\
\ldots \ldots \ldots \ldots\end{array}$ & $\begin{array}{r}34,000 \\
5,900\end{array}$ & 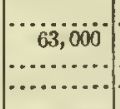 & $\begin{array}{c}400 \\
\ldots \ldots \ldots \\
\cdots \ldots . . \\
\ldots\end{array}$ & 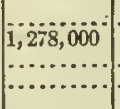 & $\begin{array}{r}\ldots, 300 \\
\cdots \ldots \ldots \\
\cdots\end{array}$ & 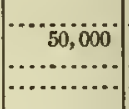 & 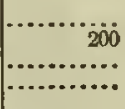 \\
\hline $\begin{array}{l}\text { Mackerel, fresh ... } \\
\text { Mackerel, salted... } \\
\text { Pickerel........ } \\
\text { Pollack, fresh..... } \\
\text { Pollack, salted.... }\end{array}$ & $\begin{array}{r}155,000 \\
2,200 \\
2,700 \\
3,770,000 \\
448,000\end{array}$ & $\begin{array}{r}12,000 \\
200 \\
300 \\
33,000 \\
6,000\end{array}$ & $\begin{array}{r}2,700 \\
2,873,000 \\
216,000\end{array}$ & $\begin{array}{r}300 \\
27,000 \\
3,300\end{array}$ & \begin{tabular}{r}
61,000 \\
$\ldots \ldots \ldots \ldots$ \\
\hdashline$\ldots 70,000$ \\
33,000
\end{tabular} & $\begin{array}{r}4,700 \\
\cdots \ldots \ldots \\
4,700 \\
900\end{array}$ & $\begin{array}{r}33,000 \\
2,200 \\
\ldots 21 \%, 000 \\
200,000\end{array}$ & $\begin{array}{r}2,600 \\
200 \\
\ldots, \ldots, 0 \\
1,400 \\
1,800\end{array}$ & $\begin{array}{r}61,000 \\
\ldots \ldots \ldots \ldots \\
11,0,000 \\
\ldots \ldots \ldots \ldots\end{array}$ & 5,000 & & & 1,000 & (i) \\
\hline $\begin{array}{l}\text { Salmon.......... } \\
\text { Shad, fresh....... } \\
\text { Silver hake....... } \\
\text { Smelt .......... } \\
\text { Striped bass...... }\end{array}$ & $\begin{array}{r}19,000 \\
370,000 \\
17,000 \\
624,000 \\
2,100\end{array}$ & $\begin{array}{r}3,700 \\
32,000 \\
100 \\
63,000 \\
400\end{array}$ & $\begin{array}{r}2,200 \\
\cdots \\
\cdots \\
89,000 \\
\cdots\end{array}$ & 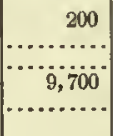 & $\begin{array}{r}6,000 \\
246,000 \\
17,000 \\
113,000 \\
1,400\end{array}$ & $\begin{array}{r}1,500 \\
22,000 \\
100 \\
14,000 \\
200\end{array}$ & $\begin{array}{r}10,000 \\
198,000 \\
\cdots\end{array}$ & $\begin{array}{r}200 \\
15,000 \\
\cdots \ldots\end{array}$ & $\begin{array}{r}9,500 \\
114,000 \\
39,000 \\
700\end{array}$ & $\begin{array}{r}1,700 \\
9,900 \\
\because 4,700 \\
200\end{array}$ & $\begin{array}{r}329,000 \\
\cdots\end{array}$ & 2,300 & $\left.\mid \begin{array}{r}\cdots \\
\cdots\end{array}\right] \ldots \ldots$ & $\begin{array}{r}200 \\
\cdots \cdots \\
\cdots \\
\cdots \\
\cdots\end{array}$ \\
\hline $\begin{array}{l}\text { Sturgeon .......... } \\
\text { Caviar........... } \\
\text { Suckers......... } \\
\text { Swordfish ......... } \\
\text { Tomeod......... } \\
\text { All other......... }\end{array}$ & $\begin{array}{r}8,200 \\
100 \\
57,000 \\
8,000 \\
100,000 \\
800\end{array}$ & $\begin{array}{r}1,000 \\
100 \\
900 \\
600 \\
4,100 \\
100\end{array}$ & $\begin{array}{r}8,000 \\
600\end{array}$ & $(2)^{200}$ & $\begin{array}{l}4,500 \\
(3) \\
55,000 \\
20,000 \\
200\end{array}$ & $\begin{array}{c}500 \\
(2)_{900} \\
900 \\
200\end{array}$ & 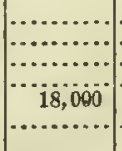 & 200 & $\begin{array}{r}3,700 \\
100 \\
\ldots\end{array}$ & $\begin{array}{r}500 \\
100 \\
\end{array}$ & $\because$ & & $\begin{array}{r}1,500 \\
8,000 \\
53,000\end{array}$ & $\begin{array}{r}(2) \\
600 \\
3,500 \\
\cdots \ldots\end{array}$ \\
\hline 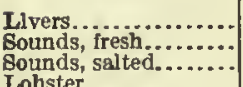 & $\begin{array}{r}800 \\
1,100 \\
2,800\end{array}$ & (3) 100 & $\begin{array}{r}800 \\
1,100 \\
2,800\end{array}$ & $\begin{array}{r}\text { (3) } \\
100 \\
100\end{array}$ & {$\left[\begin{array}{c}n \\
\cdots \cdots \cdots \cdots\end{array}\right.$} & & & & & & & - & 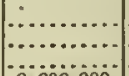 & (n. \\
\hline $\begin{array}{l}\text { Lohster................. } \\
\text { Turtles................ }\end{array}$ & $\begin{array}{r}8,898,000 \\
1,400\end{array}$ & $\begin{array}{r}1,136,000 \\
600\end{array}$ & (n) & & …........... & & & & & & & & $\begin{array}{r}8,898,000 \\
1,400\end{array}$ & $1,136,000$ \\
\hline $\begin{array}{l}\text { Clams, soit............ } \\
\text { Oysters, market, from }\end{array}$ & $4,961,000$ & 247,000 & & & & & & & & & & & $44,961,000$ & 247,000 \\
\hline $\begin{array}{l}\text { publle areas........ } \\
\text { Scallops and scallop }\end{array}$ & 1,000 & 200 & & & & & & & & & & & 1,000 & 200 \\
\hline 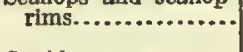 & C 784,000 & 58,000 & & & & & & & & & & & C 784,000 & 58,000 \\
\hline $\begin{array}{l}\text { Squid................ } \\
\text { oil, porpoise .......... } \\
\text { Oil, seal.............. } \\
\text { Skins, seal.......... }\end{array}$ & $\begin{array}{r}5,300 \\
78,000 \\
84,000 \\
=1,600\end{array}$ & $\begin{array}{l}\text { (3) } 800 \\
400 \\
2,200\end{array}$ & 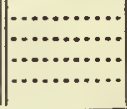 & & 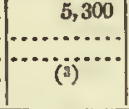 & $\begin{array}{c}\left({ }^{2}\right) \\
\ldots \ldots \\
\cdots \cdots \\
\cdots\end{array}$ & $\cdots \cdots$ & & & & $\cdots$ & $\begin{array}{c}\cdots \cdots \\
\cdots \cdots \\
\cdots \cdots\end{array}$ & $\begin{array}{l}88,000 \\
84,000 \\
-1,600\end{array}$ & $\begin{array}{r}800 \\
400 \\
2,200\end{array}$ \\
\hline
\end{tabular}

1 Includes apparatus, with catch, as follows: Lobster and eel pots, $9,246,000$ pounds, valued at $\$ 1,153,000$; dredges, tongs, etc., $5,746,000$ pounds, valued at $\$ 305,000$; bag

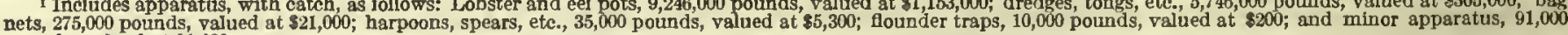
pounds, valued at $\$ 1,600$.

3 Less than $\$ 100$

Iess than 100 pounds.

1496,000 bushels.

- 98,400 gallons.

- 500 gallons.

200 bushels. 
FISHERIES, BY STATES.

TARLE 3.-MAINE-PRODUCTS OF VESSEL FISHERIES: 1908.

\begin{tabular}{|c|c|c|c|c|c|c|c|c|c|c|c|c|}
\hline \multirow{3}{*}{ SPECIES. } & \multirow{2}{*}{\multicolumn{2}{|c|}{ TOTAL. }} & \multicolumn{10}{|c|}{ PRODUCT CAUOHT BY- } \\
\hline & & & \multicolumn{2}{|c|}{ Lines. } & \multicolumn{2}{|c|}{ Selnes. } & \multicolumn{2}{|c|}{$\begin{array}{l}\text { Glll nets, drift } \\
\text { ncts, etc. }\end{array}$} & \multicolumn{2}{|c|}{$\begin{array}{l}\text { Pound nets, trap } \\
\text { nets, and wejrs. }\end{array}$} & \multicolumn{2}{|c|}{$\begin{array}{l}\text { All other \&ppar } \\
\text { ratus. }\end{array}$} \\
\hline & $\begin{array}{l}\text { Quantity } \\
\text { (pounds). }\end{array}$ & Value. & $\begin{array}{l}\text { Quantlty } \\
\text { (pounds). }\end{array}$ & Value. & $\begin{array}{l}\text { Quantity } \\
\text { (pounds). }\end{array}$ & Value. & $\begin{array}{l}\text { Quantity } \\
\text { (pounds). }\end{array}$ & Value. & $\begin{array}{l}\text { Quantity } \\
\text { (pounds). }\end{array}$ & Value. & $\begin{array}{l}\text { Quantlty } \\
\text { (pounds). }\end{array}$ & Value. \\
\hline Total... & $52,724,000$ & $\$ 898,000$ & $29,826,000$ & $\$ 529,000$ & $18,315,000$ & $\$ 108,000$ & 866,000 & $\$ 27,000$ & $1,422,000$ & $\$ 11,000$ & $2,295,000$ & 8223,000 \\
\hline 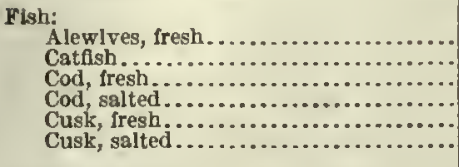 & $\begin{array}{r}30,000 \\
7,000 \\
7,489,000 \\
2,461,000 \\
1,519,000 \\
35,000\end{array}$ & $\begin{array}{r}1,500 \\
100 \\
155,000 \\
83,000 \\
23,000 \\
800\end{array}$ & $\begin{array}{r}7,000 \\
7,415,000 \\
2,461,000 \\
1,519,000 \\
35,000\end{array}$ & $\begin{array}{r}153,000 \\
83,000 \\
23,000 \\
800\end{array}$ & 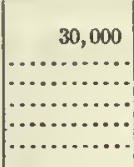 & $\begin{array}{l}1,500 \\
\ldots \ldots \ldots \\
\cdots \cdots \\
\cdots \cdots\end{array}$ & $\mid \begin{array}{c}\cdots \\
74,000 \\
\cdots \cdots \cdots \\
\cdots \cdots \cdots \\
\cdots\end{array}$ & $\begin{array}{l}1,700 \\
\cdots \cdots \\
\cdots \cdots\end{array}$ & $\mid \begin{array}{ll}\cdots \\
\cdots \cdots \\
\cdots \cdots \\
\cdots \cdots\end{array}$ & $\begin{array}{ll}\cdots \cdots \\
\cdots \cdots \\
\cdots \cdots \\
\cdots \cdots \\
\cdots \cdots\end{array}$ & 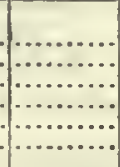 & $\mid \begin{array}{ll}\cdots \cdots \cdots \\
\cdots \cdots \cdots \\
\cdots \cdots \cdots \\
\cdots \cdots\end{array}$ \\
\hline 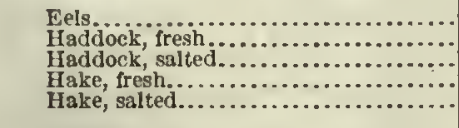 & $\begin{array}{r}84,000 \\
5,691,000 \\
21,000 \\
10,156,000 \\
50,000\end{array}$ & $\begin{array}{r}3,700 \\
132,000 \\
300 \\
99,000 \\
700\end{array}$ & $\begin{array}{r}5,691,000 \\
21,000 \\
10,156,000 \\
50,000\end{array}$ & $\begin{array}{r}132,000 \\
300 \\
99,000 \\
700\end{array}$ & (n) & & & & & (n. & 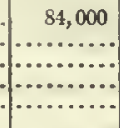 & $\begin{array}{r}3,700 \\
\cdots \cdots \cdots \\
\cdots \cdots \cdots \\
\cdots \cdots \cdots\end{array}$ \\
\hline 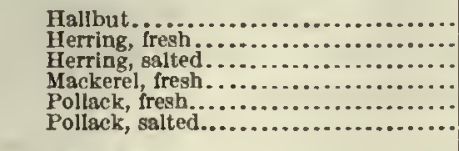 & $\begin{array}{r}153,000 \\
14,635,000 \\
2,711,000 \\
224,000 \\
4,707,000 \\
16,000\end{array}$ & $\begin{array}{r}11,000 \\
73,000 \\
22,000 \\
19,000 \\
36,000 \\
300\end{array}$ & $\begin{array}{r}153,000 \\
\cdots \ldots \ldots \ldots \\
\cdots \\
2,125,000 \\
16,000\end{array}$ & $\left\{\begin{array}{r}11,000 \\
\cdots \ldots \ldots \\
20,000 \\
3000\end{array}\right.$ & $\begin{array}{r}13,040,000 \\
2,224,000 \\
90,000 \\
2,577,000 \\
\ldots \ldots \ldots \ldots\end{array}$ & $\begin{array}{r}59,000 \\
15,000 \\
7,200 \\
16,000 \\
\ldots \ldots \ldots\end{array}$ & $\mid \begin{array}{r}212,000 \\
448,000 \\
132,000 \\
\cdots \cdots \cdots \\
\cdots \cdots\end{array}$ & $\begin{array}{r}6,400 \\
7,400 \\
11,000 \\
\cdots \cdots\end{array}$ & $\mid \begin{array}{r}1,335,000 \\
1,600 \\
5,600 \\
\cdots\end{array}$ & $\begin{array}{r}7,700 \\
100 \\
100 \\
\cdots\end{array}$ & $\mid \begin{array}{r}40,000 \\
40,000 \\
\cdots\end{array}$ & $\begin{array}{r}200 \\
200 \\
\cdots\end{array}$ \\
\hline 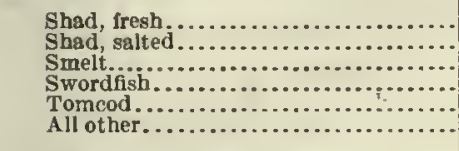 & $\begin{array}{r}141,000 \\
258,000 \\
29,000 \\
505,000 \\
17,000 \\
26,000\end{array}$ & $\begin{array}{r}3,800 \\
6,500 \\
2,400 \\
43,000 \\
500 \\
300\end{array}$ & 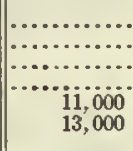 & $\mid \begin{array}{r}\cdots \ldots \ldots \ldots \\
\cdots \cdots \ldots \\
\cdots \cdots \\
300 \\
200\end{array}$ & \begin{tabular}{r}
72,000 \\
258,000 \\
24,000 \\
$\ldots \ldots \ldots$ \\
\hdashline$\ldots \ldots$ \\
$\cdots$
\end{tabular} & $\begin{array}{r}1,000 \\
6,500 \\
2,000 \\
\cdots \ldots \ldots \\
\cdots \ldots \ldots \\
\cdots \ldots\end{array}$ & 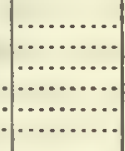 & 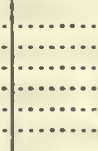 & 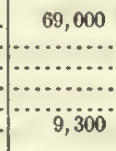 & $\begin{array}{r}2,800 \\
\cdots \ldots \ldots \\
\cdots \ldots \ldots \\
\cdots \cdots \\
\cdots \\
100\end{array}$ & $\begin{array}{r}\ldots \ldots \ldots \\
505,000 \\
6,000 \\
3,000\end{array}$ & $\begin{array}{c}400 \\
43,000 \\
200 \\
(3)\end{array}$ \\
\hline 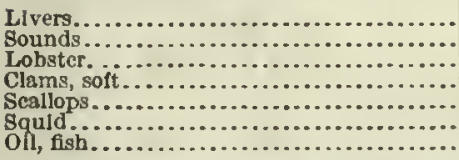 & $\begin{array}{r}51,000 \\
19,000 \\
1,031,000 \\
100,000 \\
4473,000 \\
800 \\
\quad 83,000\end{array}$ & $\begin{array}{r}500 \\
800 \\
134,000 \\
4,300 \\
38,000 \\
(2) \\
3,600\end{array}$ & 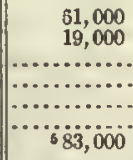 & 3,600 & $\begin{array}{l}\cdots \cdots \\
\cdots \cdots \cdots \\
\cdots \cdots \\
\cdots \cdots \\
\cdots \cdots\end{array}$ & & $\ldots$ & & $\begin{array}{ll}\cdots \ldots \ldots \\
\cdots \cdots \\
\cdots \cdots\end{array}$ & $\mid \begin{array}{l}\cdots \\
\cdots \\
\cdots \\
\cdots\end{array}$ & $\mid \begin{array}{l}1,031,000 \\
100,000 \\
473,000 \\
\ldots \ldots \ldots \ldots\end{array}$ & $\begin{array}{r}134,000 \\
4,300 \\
38,000 \\
\ldots\end{array}$ \\
\hline
\end{tabular}

1 Includes apparatus, with catch, as follows: Lobster and eel pots, 1,115,000 pounds, valued at \$137,000; harpoons, spears, etc., 505,000 pounds, valued at \$43,000; dredges,

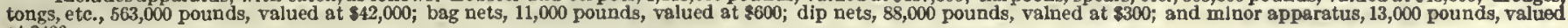
at $\$ 400$.

Less than $\$ 100$.

10,000 gallons.

\section{MARYLAND.}

In respect to fisheries Maryland stands high among the states, ranking fifth in 1908 , with a product valued at $\$ 3,306,000$. Likewise the fisheries of Maryland rank high among the industries of the state. Chesapeake Bay and its tributary streams, the Potomac, Susquehanna, Patuxent, Choptank, Nanticoke, and lesser rivers, form the greatest oyster area in the world. In 1908 the value of the oyster product constituted two-thirds of the total value of the fishery product of the state.

The fishing grounds of Maryland are naturally divided into two districts comprising those of the Atlantic Ocean and those of Chesapeake Bay and its tributary waters. As the water front of thestate on Chesapeake Bay and its tributaries is much more extensive than the Atlantic water front, the Chesapeake Bay fisheries are much more important than those of the Atlantic Ocean, which in 1908 contributed only 4 per cent of the total value of fishery products for the state.

The following statement gives a general summary of the statistics of the state's fisheries for 1908:

Number of persons employed ..................

18,392 Capital:

Vessels and boats, including outfit.

$\$ 1,644,000$

Apparatus of capture 369,000

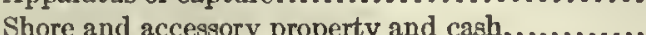

86,000

Value of products......................... $3,306,000$
459,000 gallons.

611,000 gallons.

Comparison with previous canvasses. - A comparison of the general statistics for different years shows considerable fluctuations. The following tabular statement gives the number of persons employed, exclusive of shoresmen, the capital invested, and the products, as shown by the census returns for 1880 and 1908 and the reports of the Bureau of Fisheries for 1891, 1897, and 1904:

\begin{tabular}{|c|c|c|c|c|c|c|}
\hline \multirow[b]{2}{*}{ YEAR. } & \multirow{2}{*}{$\begin{array}{l}\text { Persons } \\
\text { em- } \\
\text { ployed, } \\
\text { exclusive } \\
\text { of shores- } \\
\text { men. }\end{array}$} & \multicolumn{3}{|c|}{ VALUE OP EQUTPMENT. } & \multicolumn{2}{|c|}{ PBonucts. } \\
\hline & & Total. & $\begin{array}{c}\text { Vessels } \\
\text { and boats, } \\
\text { including } \\
\text { outfit. }\end{array}$ & $\begin{array}{l}\text { Appara- } \\
\text { tus of } \\
\text { capture. }\end{array}$ & $\begin{array}{l}\text { Quantlty } \\
\text { (pounds). }\end{array}$ & Valua. \\
\hline $\begin{array}{l}1908 \ldots \ldots \\
1904 \ldots \ldots \\
1897 \ldots \ldots \\
1891 \ldots \ldots \\
1880 \ldots\end{array}$ & $\begin{array}{l}18,316 \\
20,054 \\
26,627 \\
28,209 \\
15,873\end{array}$ & $\begin{array}{r}2,013,000 \\
1,870,000 \\
2,303,000 \\
2,913,000 \\
2,234,000\end{array}$ & $\begin{array}{r}\$ 1,644,000 \\
1,534,000 \\
1,907,000 \\
2,418,000 \\
1,930,000\end{array}$ & $\begin{array}{r}\$ 369,000 \\
336,000 \\
396,000 \\
495,000 \\
297,000\end{array}$ & $\begin{array}{r}113,796,000 \\
81,129,000 \\
88,588,000 \\
141,178,000 \\
95,713,000\end{array}$ & $\begin{array}{r}\$ 3,306,000 \\
3,337,000 \\
3,617,000 \\
6,461,000 \\
5,222,000\end{array}$ \\
\hline
\end{tabular}

Persons employed.-The statistics of the persons employed in the fisheries of the state in 1908 are shown in the next tabular statement.

All the shoresmen were connected with shore and boat fisheries. In this class of fisheries 13,326 persons were employed, as compared with only 4,046 persons in vessel fisheries and 1,020 on transporting vessels. Wage-earners outnumbered proprietors and independent fishermen by only a small percentage. The 9,948 salaried employees and wage-earners were paid in cash and provisions $\$ 1,036,000$, an amount equal to 31 per cent of the value of the fishery products. 


\begin{tabular}{|c|c|c|c|c|c|c|c|}
\hline \multirow{3}{*}{ DISTRICT AND CLSSS. } & \multicolumn{7}{|c|}{ PERSONS EMPLOYED: 1908.} \\
\hline & \multicolumn{4}{|c|}{ Number. } & \multicolumn{3}{|c|}{ Salarles and wages. } \\
\hline & Total. & $\begin{array}{l}\text { Proprietors } \\
\text { and la- } \\
\text { dependent } \\
\text { fishermen. }\end{array}$ & $\begin{array}{l}\text { Salaried } \\
\text { employees. }\end{array}$ & $\begin{array}{l}\text { Wage: } \\
\text { earners. }\end{array}$ & Total. & Salarles. & Wages. \\
\hline Total............................... & 18,392 & 18,444 & 6 & 9,942 & $\$ 1,036,000$ & $\$ 1,000$ & $281,035,000$ \\
\hline 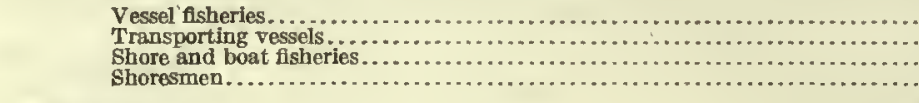 & $\begin{array}{r}4,046 \\
1,020 \\
13,250 \\
76\end{array}$ & $\begin{array}{r}607 \\
305 \\
7,532 \\
\ldots\end{array}$ & $(\cdots \cdots$ & $\begin{array}{r}3,439 \\
715 \\
5,712 \\
76\end{array}$ & $\begin{array}{r}374,000 \\
101,000 \\
557,000 \\
5,200\end{array}$ & 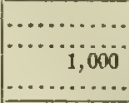 & $\begin{array}{r}374,000 \\
101,000 \\
556,000 \\
5,200\end{array}$ \\
\hline Chesapeske Bay district............................. & 17,806 & 8,154 & 6 & 9,646 & 991,000 & 1,000 & 990,000 \\
\hline 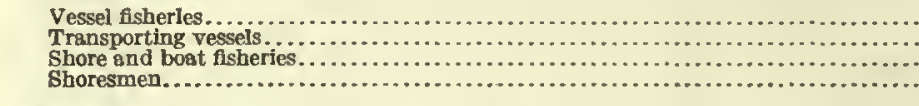 & $\begin{array}{r}4,046 \\
975 \\
12,709 \\
76\end{array}$ & $\begin{array}{r}607 \\
276 \\
7,271 \\
\cdots+\cdots\end{array}$ & $(\cdots \cdots+\cdots$ & $\begin{array}{r}3,439 \\
699 \\
5,432 \\
76\end{array}$ & $\begin{array}{r}374,000 \\
99,000 \\
513,000 \\
5,200\end{array}$ & 1,o00 & $\begin{array}{r}374,000 \\
99,000 \\
512,000 \\
6,200\end{array}$ \\
\hline Atlantlc Ocean district............... & 686 & 290 & & 296 & 45,000 & $\ldots \ldots \ldots \ldots$ & 45,000 \\
\hline 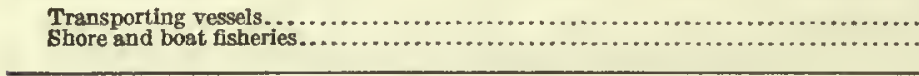 & $\begin{array}{r}45 \\
541\end{array}$ & 29 & ( $\cdots \cdots \cdots$ & $\begin{array}{r}16 \\
280\end{array}$ & $\begin{array}{r}1,200 \\
44,000\end{array}$ & & $\begin{array}{r}1,200 \\
44,000\end{array}$ \\
\hline
\end{tabular}

1 Excluslve of 367 proprietors not fishlng.

Equipment and other capital.--The following tables give the value of equipment and capital in 1908 as distributed among vessels, boats, apparatus of capture, shore and accessory property, and cash, for the state as a whole and for the Atlantic Ocean and Chesapeake Bay districts separately:

\begin{tabular}{|c|c|c|c|}
\hline \multirow{2}{*}{ CLASS OT INVESTMENT. } & \multicolumn{3}{|c|}{$\begin{array}{l}\text { VALUE OF EQUTPUENT AND OTHER } \\
\text { CAPITAL: } 1908 .\end{array}$} \\
\hline & Total. & $\begin{array}{l}\text { Chesa- } \\
\text { peake Bay } \\
\text { district. }\end{array}$ & $\begin{array}{l}\text { Atlartic } \\
\text { Ocean } \\
\text { district. }\end{array}$ \\
\hline Total....... & $\$ 2,099,000$ & $\$ 2,019,000$ & $\$ 80,000$ \\
\hline & $1,001,000$ & 985,000 & 15,000 \\
\hline Flshing..................... & 593,000 & 593,000 & $10,0 \times 0$ \\
\hline Steam and motor. & 65,000 & 65,000 & \\
\hline $\begin{array}{l}\text { Vessels........ } \\
\text { Outfit..... }\end{array}$ & 50,000 & 50,000 & \\
\hline $\begin{array}{l}\text { Outfit........... } \\
\text { Sail.............. }\end{array}$ & 15,000 & $\begin{array}{r}15,000 \\
50,000\end{array}$ & \\
\hline $\begin{array}{l}\text { Sail „.......... } \\
\text { Vessels. }\end{array}$ & $\begin{array}{l}528,000 \\
406,000\end{array}$ & $\begin{array}{l}528,000 \\
406,000\end{array}$ & ......... \\
\hline Outfit... & $\begin{array}{l}406,000 \\
122,000\end{array}$ & $\begin{array}{l}402,000 \\
122,000\end{array}$ & \\
\hline Transporting ............ & 408,000 & 392,000 & 15,000 \\
\hline Steam and motor.. & 24,000 & 23,000 & 1,100 \\
\hline Vessels......... & 22,000 & 21,000 & 1,000 \\
\hline Sail........ & $\begin{array}{r}2,100 \\
383,000\end{array}$ & $\begin{array}{r}2,000 \\
369,000\end{array}$ & 14,000 \\
\hline Vessels. & 343,000 & 330,000 & 13,000 \\
\hline Outfit.. & 40,000 & 39,000 & 1,000 \\
\hline Boats...................... & 644,000 & 615,000 & 28,000 \\
\hline Steam and motor... & 220,000 & 200,000 & 20,000 \\
\hline Sali................. & 384,000 & 378,000 & 5,200 \\
\hline Row... & 31,000 & 29,000 & 1,300 \\
\hline Other.............. & 9,300 & 8,000 & 1,300 \\
\hline Apparatus of capture........... & 369,000 & 335,000 & 34,000 \\
\hline $\begin{array}{l}\text { Vessel tisheries } \\
\text { Shore and hoat fisheries.............. }\end{array}$ & $\begin{array}{r}51,000 \\
318,000\end{array}$ & $\begin{array}{r}51,000 \\
284000\end{array}$ & 34000 \\
\hline Shore and accessory property.... & 80,000 & 77,000 & $\begin{array}{r}\$, 4,000 \\
2,400\end{array}$ \\
\hline 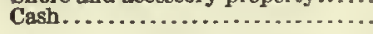 & 6,500 & 6,500 & \\
\hline
\end{tabular}

The statistics concerning the number and tonnage of vessels and the number of boats are shown in the first tabular statement following.

Of the total capital invested, $\$ 1,644,000$, or 78 per cent, represented the value of vessels and boats, including outfit. Of the remainder, the investment in apparatus of capture was the largest item, having a value of $\$ 369,000$, and this was followed by shore and accessory property, with a value of $\$ 80,000$. The distribution of the apparatus of capture by districts and by class of fisheries is shown in the second tabular statement following.
2 Includes provisions furnished to the value of $\$ 159,000$.

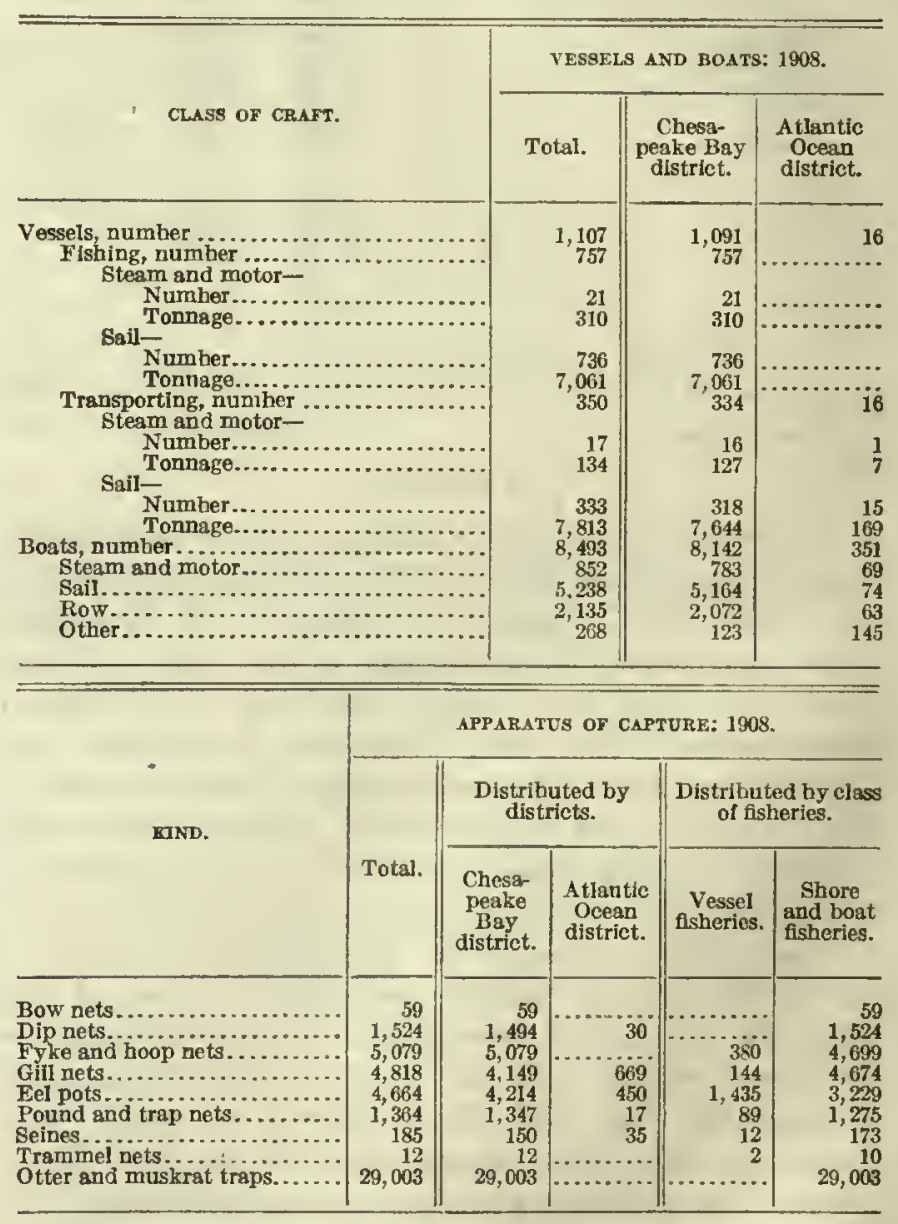

Products, by species.-The products are given, by species and by apparatus of capture, in Table 1 on page 149. Oysters ranked first both in quantity and in value. On the basis of quantity the species next in order were alewives, or river herring, with a product of nearly 29,000,000 pounds; crabs, with over $20,000,000$ pounds; menhaden, with over $12,000,000$ pounds; and shad, with nearly $4,000,000$ pounds. On the basis of value the leading species after oysters were crabs, shad, and alewives, in the order named. 
The heavy catch of menhaden stood relatively low in value, and was exceeded in this respect by striped bass, squeteague, and muskrat skins.

Products, by fishing grounds.- Table 2, on page 150, gives the products of the Maryland fisheries in the Chesapeake Bay district by species and by apparatus of capture, and Table 3 , on page 151 , gives similar statistics for the Maryland fisheries of the Atlantic Ocenn, all of which were of the shore and boat class. For the Chesapeake Bay district the leading products, in the order of value, were the same as those already noted for the statc, namely, oysters, crabs, shad, and alewives; while for the Atlantic Ocean fisheries the leading products with respect to value were squeteague, oysters, sturgeon (including caviar), and ycllow perch, in the order named.

\begin{tabular}{|c|c|c|c|c|c|}
\hline \multirow{3}{*}{ BPECIES. } & \multicolumn{5}{|c|}{ VALUE OF PRODUCTS: 1908.} \\
\hline & \multirow{2}{*}{ Total. } & \multicolumn{2}{|c|}{$\begin{array}{l}\text { Distributed by } \\
\text { distriets. }\end{array}$} & \multicolumn{2}{|c|}{$\begin{array}{c}\text { Distributed by class } \\
\text { of fisheries. }\end{array}$} \\
\hline & & $\begin{array}{c}\text { Chesa- } \\
\text { peake Bay } \\
\text { distriet. }\end{array}$ & $\begin{array}{l}\text { Atlantie } \\
\text { Ocean } \\
\text { distriet. }\end{array}$ & $\begin{array}{l}\text { Vessel } \\
\text { fisberies. }\end{array}$ & $\begin{array}{l}\text { Sbore } \\
\text { and boat } \\
\text { fisheries. }\end{array}$ \\
\hline Total ..... & $83,306,000$ & $\$ 3,187,000$ & $\$ 119,000$ & $\$ 767,000$ & $\$ 2,539,000$ \\
\hline $\begin{array}{l}\text { Fish } \\
\text { Shad } \\
\quad \text { Alewives, or river her- }\end{array}$ & $\begin{array}{l}684,000 \\
247,000\end{array}$ & $\begin{array}{l}592,000 \\
247,000\end{array}$ & $\begin{array}{l}92,000 \\
(i)\end{array}$ & $\begin{array}{l}67,000 \\
20,000\end{array}$ & $\begin{array}{l}618,000 \\
227,000\end{array}$ \\
\hline 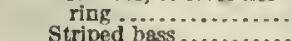 & 157,000 & 155,000 & 1,100 & 4,600 & 152,000 \\
\hline $\begin{array}{l}\text { Striped bass ............ } \\
\text { Squeteaguis, or sea trout. }\end{array}$ & 65,000 & 62,000 & 3,500 & 3,700 & 61,000 \\
\hline $\begin{array}{l}\text { Squeteaguh, or sea trout. } \\
\text { Perch, white .......... }\end{array}$ & 47,000 & 6,200 & 40,000 & 100 & 46,000 \\
\hline $\begin{array}{l}\text { Perch, white ............ } \\
\text { Menhaden ........... }\end{array}$ & $\begin{array}{l}30,000 \\
30,000\end{array}$ & $\begin{array}{l}28,000 \\
30,000\end{array}$ & $\begin{array}{r}2,100 \\
400\end{array}$ & $\begin{array}{r}1,500 \\
30,000\end{array}$ & $\begin{array}{r}29,000 \\
400\end{array}$ \\
\hline Perch, yellow ........ & 22,000 & 15,000 & 7,200 & 400 & 22,000 \\
\hline $\begin{array}{l}\text { Catfisb ............... } \\
\text { Stargeon, caviar, and }\end{array}$ & 18,000 & 18,000 & & 800 & 18,000 \\
\hline sturgeon eggs........ & 16,000 & 1,600 & 14,000 & & 16,000 \\
\hline Eels ..................... & 13,000 & 12,000 & 500 & 4,900 & 7,800 \\
\hline $\begin{array}{l}\text { All other....... } \\
\text { Oysters ............ }\end{array}$ & 40,000 & 17,000 & 22,000 & 1,300 & 38,000 \\
\hline $\begin{array}{l}\text { Oysters } \ldots . . . . . . . . . \\
\text { Market ....... }\end{array}$ & $2,228,000$ & $2,205,000$ & 24,000 & 686,000 & $1,543,000$ \\
\hline $\begin{array}{l}\text { Market..... } \\
\text { Seed ....... }\end{array}$ & $2,127,000$ & $2,113,000$ & 14,000 & 676,000 & $1,451,000$ \\
\hline 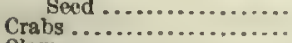 & 101,000 & 92,000 & 9.600 & 9,600 & 92,000 \\
\hline 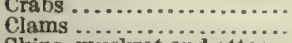 & $\begin{array}{r}319,000 \\
16.000\end{array}$ & 319,000 & 100 & 15,000 & 305,000 \\
\hline Skins, muskrat and otter.. & $\begin{array}{l}16,000 \\
50,000\end{array}$ & $\begin{array}{l}15,000 \\
50,000\end{array}$ & 1,400 & ?........ & 16,000 \\
\hline All other ${ }^{2} \ldots \ldots \ldots \ldots$.......... & 7,800 & 6,400 & 1,100 & & 27,800 \\
\hline
\end{tabular}

1. Less than $\$ 100$.

2 Ineludes produets valned as follows: Terrapln, $\$ 4,900$; Irogs, $\$ 500$; turtles, $\$ 400$; squid, \$200; and sea grass, $\$ 1,700$.

Products, by class of fisheries.-Table 4, on page 151, gives the products for 1908, by species and by apparatus of capture, for the vessel fisheries of the state, all of which are confined to the Chesapeake Bay district, and Table 5, on page 152, gives similar data for the shore and boat fisheries. In the latter the four leading species-oysters, crabs, shad, and alewives-aggregated $81,019,000$ pounds, or 94 per cent of the total product, and their combined value was $\$ 2,226,000$, or 88 per cent of the total. Oysters alone contributed 89 per cent to the total value of products of the vessel fisheries and 61 per cent to the total value of products of the shore and boat fisheries. Of the value of the Maryland oyster product, 31 per cent was reported by the vessel fisheries and 69 per cent by the shore and boat fisheries. Practically the entire catch of menhaden was made by vessels. With the exception of oysters and menhaden, the catch by vessels was small, compared with that of the shore and boat fisheries. The products of the shore and boat fisheries of the Chesapeake Bay district, which in the aggregate amounted to $83,247,000$ pounds, having a value of $\$ 2,420,000$, can readily be ascertained by subtracting the items of Table 4 from the corresponding items of Table 2 giving the total products of the Chesapeake Bay district.

The tabular statement immediately preceding shows the distribution of the value of products reported for the leading species between the vessel fisheries and the shore and boat fisheries.

Products, by apparatus of capture.--All but 5 per cent of the total products, increased by value, was taken with the five classes of apparatus specified in the following tabular statement:

\begin{tabular}{|c|c|c|}
\hline \multirow[b]{2}{*}{ KIND OF APPARATUS. } & \multicolumn{2}{|c|}{$\begin{array}{l}\text { VALUE OF } \\
\text { PRODUCTS: } 1908 .\end{array}$} \\
\hline & Amount. & $\begin{array}{l}\text { Per eent } \\
\text { distribu- } \\
\text { tlon. }\end{array}$ \\
\hline Total............ & $\$ 3,306,000$ & 100 \\
\hline 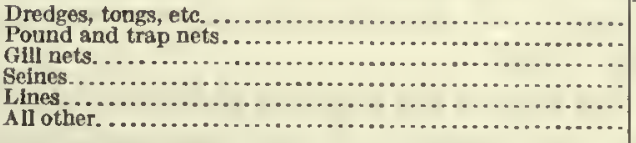 & $\begin{array}{r}2,393,000 \\
321,000 \\
174,000 \\
128,000 \\
124,000 \\
166,000\end{array}$ & $\begin{array}{r}72 \\
10 \\
5 \\
4 \\
4 \\
5\end{array}$ \\
\hline
\end{tabular}

On account of the large oyster catch, dredges, tongs, etc., are by far the most important apparatus of capture in both the vessel and the shore and boat fisheries of Chesapeake Bay; but in the Atlantic Ocean fisheries the largest catch was credited to pound and trap nets. For the fisheries of the state pound and trap nets are second in importance as apparatus of capture, and are used for taking a large number of species. Alcwives made up the bulk of the catch, contributing 82 per cent of the total weight and 32 per cent of the total value; shad stood second, following closely in value, although the weight of this product was only one-fifteenth as great as that of the alewife catch; and squeteague was third.

Oysters.-The oyster product of Maryland for 1908 was substantially greater than that for 1904 but less than that for 1897. The yield for 1904 was abnormally small, a fact attributed by some authorities to the two exceptionally cold winters just preceding, which killed many of the oysters. The value of the product, however, steadily decreased from $\$ 2,885,000$ in 1897 to $\$ 2,418,000$ in 1904 and to $\$ 2,228,000$ in 1908 . This decrease of $\$ 657,000$, or 23 per cent, in the value of the oyster product during the 11 years from 1897 to 1908 contrasts sharply with an increase of $\$ 345,000$, or 47 per cent, in the aggregate value of all other fishery products during the same period. From 1904 to 1908 , however, the decrease in the value of the oyster yield, which amounted to $\$ 189,000$, or 8 per 
cent, was at a rate only one-half as great as that of the decrease in the value of all other fishery products during this period, namely, 17 per cent. The percentage of the total value of fishery products which was represented by the value of oysters was lower in 1908 than in 1904,1897 , or 1880 , as is shown by the following tabular statement:

\begin{tabular}{|c|c|c|c|c|}
\hline \multirow{3}{*}{ TEAR. } & \multirow{3}{*}{$\begin{array}{l}\text { Total } \\
\text { value of } \\
\text { fishery } \\
\text { products. }\end{array}$} & \multicolumn{3}{|c|}{ OYSTER PRODUCT. } \\
\hline & & \multirow{2}{*}{$\begin{array}{l}\text { Quantity } \\
\text { (bushels). }\end{array}$} & \multicolumn{2}{|c|}{ Value. } \\
\hline & & & Amount. & $\begin{array}{l}\text { Per cent } \\
\text { of total. }\end{array}$ \\
\hline 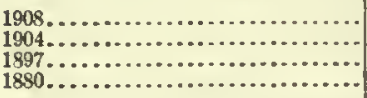 & $\begin{array}{r}\$ 3,306,000 \\
3,337,000 \\
3,617,000 \\
5,222,000\end{array}$ & $\begin{array}{r}6,232,000 \\
4,430,000 \\
7,255,000 \\
10,600,000\end{array}$ & $\begin{array}{r}\$ 2,228,000 \\
2,418,000 \\
2,885,000 \\
4,730,000\end{array}$ & $\begin{array}{l}67 \\
72 \\
80 \\
91\end{array}$ \\
\hline
\end{tabular}

Of the total oyster product of $1908,6,076,000$ bushels, valued at $\$ 2,142,000$, were furnished by public areas. Private areas produced only market oysters, and of these, only 156,000 bushels, valued at $\$ 86,000$. Private beds were of considerably more importance in 1904 , when they were credited with 465,000 bushels, valued at $\$ 302,000$. No record of the yield of private areas is given for 1897 .

Alewives.-The bulk of the catch of alewives, locally called herring, was reported by the shore and boat fisheries of Chesapeake Bay. The product was larger in 1908 than in any previous year, in both quantity and value, and its relative importance among the fishery products of the state was greater. The quantity of alewives sold fresh in 1908 was more than double that in 1897 , and the value more than a third higher. Compared with 1904, which was a poor year for this species, the increase shown for 1908 is much greater. The quantity sold salted has steadily decreased. On account of an increase in price, the value for 1908 was in excess of that for 1897, though less than the value reported for 1904 . The value of the total alewife catch has increased steadily since 1897 , from $\$ 123,000$ to $\$ 157,000$ in 1908 . The following tabular statement gives the alewife product for the most recent years for which figures are available:

\begin{tabular}{|c|c|c|c|c|c|c|}
\hline \multirow{3}{*}{ YEAR. } & \multicolumn{6}{|c|}{ ALEWTE PRODUCT. } \\
\hline & \multicolumn{2}{|c|}{ Total. } & \multicolumn{2}{|c|}{ Fresh. } & \multicolumn{2}{|c|}{ Salted. } \\
\hline & $\begin{array}{l}\text { Quantity } \\
\text { (pounds). }\end{array}$ & Value. & $\begin{array}{l}\text { Quantity } \\
\text { (pounds). }\end{array}$ & Value. & $\begin{array}{l}\text { Quantlty } \\
\text { (pounds). }\end{array}$ & Value. \\
\hline $\begin{array}{l}1908 \ldots \ldots \ldots \ldots \ldots \\
1904 \ldots \ldots \ldots \ldots \\
1897 \ldots \ldots \ldots \ldots \\
1880 \ldots \ldots \ldots \ldots\end{array}$ & $\begin{array}{r}28,805,000 \\
14,485,000 \\
17,136,000 \\
9,129,000\end{array}$ & $\begin{array}{r}\$ 157,000 \\
138,000 \\
123,000 \\
140,000\end{array}$ & $\begin{array}{r}24,451,000 \\
9,589,000 \\
11,727,000 \\
\ldots \ldots \ldots \ldots .\end{array}$ & $\begin{array}{r}598,000 \\
55,000 \\
73,000\end{array}$ & $\begin{array}{l}4,354,000 \\
4,896,000 \\
5,409,000 \\
\ldots \ldots \ldots . .\end{array}$ & $\begin{array}{r}\$ 59,000 \\
83,000 \\
51,000\end{array}$ \\
\hline
\end{tabular}

Crabs.- The heavy increase shown in the crab product from 1897 to 1904 did not continue up to 1908 . Although a gain of nearly $2,000,000$ pounds was reported from 1904 to 1908 , the value decreased by $\$ 39,000$. The quantity of crabs marketed in 1908 was considerably more than double that in 1897 , and the returns to the fishermen were 46 per cent greater.

\begin{tabular}{|c|c|c|c|c|c|c|}
\hline \multirow{3}{*}{ YEAR. } & \multicolumn{6}{|c|}{ CRAB PRODUCT. } \\
\hline & \multicolumn{2}{|c|}{ Total. } & \multicolumn{2}{|c|}{ Hard crabs. } & \multicolumn{2}{|c|}{ Soft crabs. } \\
\hline & $\begin{array}{l}\text { Quantity } \\
\text { (pounds). }\end{array}$ & Value. & $\begin{array}{l}\text { Quantity } \\
\text { (pounds). }\end{array}$ & Valuo. & $\begin{array}{l}\text { Quantity } \\
\text { (pounds). }\end{array}$ & Value. \\
\hline $\begin{array}{l}1908 \ldots \ldots . . . \\
1904 \ldots \ldots . . . \\
1897 \ldots \ldots \ldots\end{array}$ & $\begin{array}{r}20,373,000 \\
18,398,000 \\
9,449,000\end{array}$ & $\begin{array}{r}\$ 319,000 \\
359,000 \\
218,000\end{array}$ & $\begin{array}{r}12,786,000 \\
12,665,000 \\
5,833,000\end{array}$ & $\begin{array}{r}124,000 \\
169,000 \\
40,000\end{array}$ & $\begin{array}{l}7,587,000 \\
5,733,000 \\
4,116,000\end{array}$ & $\begin{array}{l}8195,000 \\
190,000 \\
178,000\end{array}$ \\
\hline
\end{tabular}

Menhaden.-The menhaden catch, though not relatively important on the basis of value, is conspicuous for quantity. In 1880 the quantity reported was $3,903,000$ pounds, valued at $\$ 12,000$; in $1897,353,000$ pounds, valued at $\$ 400$; in $1904,9,849,000$ pounds, valued at $\$ 20,000$; and in $1890,27,969,000$ pounds, valued at $\$ 57,000$. This species has such migratory habits that the catch for any particular year can not be taken as characteristic of the period or locality in question.

Shad.- The catch of shad has increased considerably since $1904,3,937,000$ pounds being taken in 1908 , as compared with $2,912,000$ pounds in the former year. The catch in 1897 , however, $5,800,000$ pounds, was far in excess of those in either of the later years. Scarcity and increasing demand, however, have raised the price, so that while the catch in 1904 was only lialf that of 1897 , its value was a trifle greater, the catch in 1904 being valued at $\$ 160,000$ and that in 1897 at $\$ 159,000$. The price has continued to increase, and the 1908 catch was valued at $\$ 247,000$.

Squeteague.-The catch of squeteague, or sea trout, reported principally by the Atlantic Ocean fisheries, was larger in 1908 and of greater value than in either 1904 or 1897 , as is shown by the following tabular statement:

\begin{tabular}{|c|c|c|}
\hline \multirow{2}{*}{ TEAR. } & \multicolumn{2}{|c|}{$\begin{array}{l}\text { SQUETEAGUE } \\
\text { PRODUCT. }\end{array}$} \\
\hline & $\begin{array}{l}\text { Quantity } \\
\text { (pounds). }\end{array}$ & Valuo. \\
\hline $\begin{array}{l}1908, \ldots \ldots \ldots \ldots \ldots \ldots \ldots \\
1904, \ldots \ldots \ldots \ldots\end{array}$ & $\begin{array}{r}1,191,000 \\
785,000 \\
597,000\end{array}$ & $\begin{array}{r}847,000 \\
23,000 \\
15,000\end{array}$ \\
\hline
\end{tabular}


FISHERIES, BY STATES.

TABLE 1.-MARYLAND-FISHERY PRODUCTS: 1908.

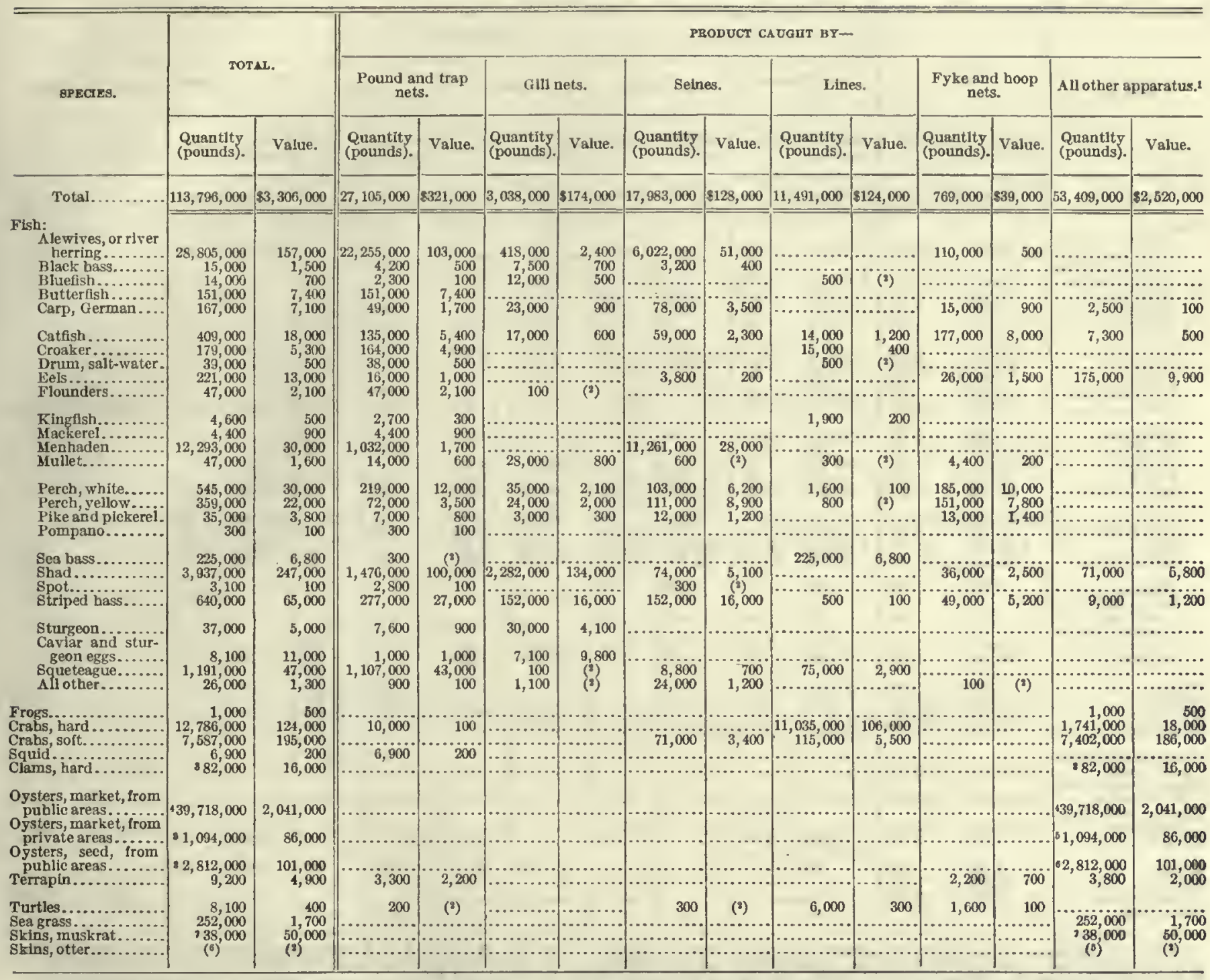

I Ineludes apparatus, with catch, as follows: Dredges, tongs, etc., 50,250,000 pounds, vahed at \$2,393,000; dip nets, 2,817,000 pounds, valued at 659,000; otter and muskrat

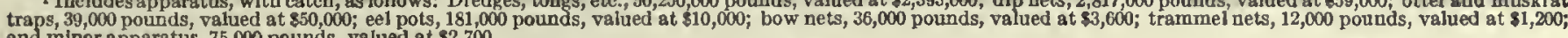
and minor apparatus, 75,000 pounds, valued at $\$ 2,700$

Less than $\$ 100$. 
FISHERIES OF THE UNITED STATES, 1908.

TABLE 2.-MARYLAND-FISHERY PRODUCTS OF CHESAPEAKE BAY DISTRICT: 1908.

\begin{tabular}{|c|c|c|c|c|c|c|c|c|c|c|c|c|c|c|}
\hline \multirow{3}{*}{ SPECIES. } & \multirow{2}{*}{\multicolumn{2}{|c|}{ TOTAL. }} & \multicolumn{12}{|c|}{ PRODUCT CAUGHT BY- } \\
\hline & & & \multicolumn{2}{|c|}{$\begin{array}{l}\text { Pound and trap } \\
\text { nets. }\end{array}$} & \multicolumn{2}{|c|}{ Gill nets. } & \multicolumn{2}{|c|}{ Seines. } & \multicolumn{2}{|c|}{ Lioes. } & \multicolumn{2}{|c|}{$\begin{array}{c}\text { Fyke and hoop } \\
\text { nets. }\end{array}$} & \multicolumn{2}{|c|}{ All other apparatus." } \\
\hline & $\begin{array}{l}\text { Quantity } \\
\text { (pounds). }\end{array}$ & Value. & $\begin{array}{l}\text { Quantity } \\
\text { (pounds). }\end{array}$ & Value. & $\begin{array}{l}\text { Quantity } \\
\text { (pounds). }\end{array}$ & Value. & $\begin{array}{l}\text { Quantity } \\
\text { (pounds). }\end{array}$ & Value. & $\begin{array}{l}\text { Quantity } \\
\text { (pounds). }\end{array}$ & Value. & $\begin{array}{l}\text { Quantity } \\
\text { (pounds). }\end{array}$ & Value. & $\begin{array}{l}\text { Quantity } \\
\text { (pounds). }\end{array}$ & Value. \\
\hline Total..... & $111,193,000$ & $\$ 3,187,000$ & $25,775,000$ & $\$ 268,000$ & $2,946,000$ & $\$ 156,000$ & $17,565,000$ & $\$ 116,000$ & $11,182,000$ & $\$ 114,000$ & 769,000 & 839,000 & $52,956,000$ & $\$ 2,494,000$ \\
\hline $\begin{array}{l}\text { Fish: } \\
\text { Alewives, or river } \\
\text { herring, fresh... } \\
\text { Alewives, or river } \\
\text { herring, salted.. } \\
\text { Black bass......... } \\
\text { Blucfish.......... } \\
\text { Butterfish......... }\end{array}$ & $\begin{array}{r}4,354,000 \\
15,000 \\
14,000 \\
5,800\end{array}$ & $\begin{array}{r}59,000 \\
1,500 \\
600 \\
200\end{array}$ & $\begin{array}{r}2,673,000 \\
4,200 \\
1,700 \\
5,800\end{array}$ & $\begin{array}{r}68,000 \\
35,000 \\
500 \\
100 \\
200\end{array}$ & $\begin{array}{r}418,000 \\
\\
200 \\
7,400 \\
12,000 \\
\ldots . . .\end{array}$ & $\begin{array}{l}2,400 \\
\left({ }^{2}\right) \\
700 \\
500 \\
.\end{array}$ & $\begin{array}{r}4,241,000 \\
1,680,000 \\
3,000 \\
\ldots \ldots \ldots \ldots\end{array}$ & $\begin{array}{r}26,000 \\
23,000 \\
400 \\
2\end{array}$ & 500 & & 110,000 & 500 & & $\begin{array}{l}\cdots \\
\cdots\end{array}$ \\
\hline $\begin{array}{l}\text { Carp, German..... } \\
\text { Cathsh............ } \\
\text { Croaker............ } \\
\text { Drum, sait-water. } \\
\text { Eeis............... }\end{array}$ & $\begin{array}{r}166,000 \\
409,000 \\
4,200 \\
25,000 \\
214,000\end{array}$ & $\begin{array}{r}7,100 \\
18,000 \\
100 \\
400 \\
12,000\end{array}$ & $\begin{array}{r}49,000 \\
135,000 \\
4,200 \\
24,000 \\
16,000\end{array}$ & $\begin{array}{r}1,700 \\
5,400 \\
100 \\
400 \\
1,000\end{array}$ & 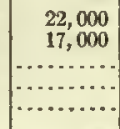 & $\begin{array}{r}900 \\
600 \\
\ldots \ldots\end{array}$ & $\begin{array}{r}77,000 \\
59,000 \\
\cdots, \ldots \ldots \\
3,800\end{array}$ & $\begin{array}{l}3,500 \\
2,300 \\
\cdots \cdots \\
\cdots \\
200\end{array}$ & $\begin{array}{l}14,000 \\
500\end{array}$ & $\begin{array}{l}1,200 \\
(2)\end{array}$ & $\begin{array}{r}15,000 \\
177,000 \\
\ldots \ldots \ldots\end{array}$ & $\begin{array}{r}900 \\
8,400 \\
\cdots \ldots \ldots \\
\cdots, \ldots, 300\end{array}$ & $\begin{array}{r}2,500 \\
7,300 \\
\cdots \\
\hdashline 169,000\end{array}$ & $\begin{array}{r}100 \\
500 \\
\cdots \\
\dddot{9}, 400\end{array}$ \\
\hline $\begin{array}{l}\text { Flounders........ } \\
\text { Kingfish........... } \\
\text { Menhade........ } \\
\text { Mullet............ } \\
\text { Perch, white...... }\end{array}$ & $\begin{array}{r}31,000 \\
2,500 \\
12,053,000 \\
20,000 \\
520,000\end{array}$ & $\begin{array}{r}1,600 \\
200 \\
30,000 \\
800 \\
28,000\end{array}$ & $\begin{array}{r}31,000 \\
600 \\
1,002,000 \\
14,000 \\
218,000\end{array}$ & $\begin{array}{r}1,600 \\
(2) \\
1,700 \\
600 \\
12,000\end{array}$ & $\begin{array}{r}100 \\
\cdots \cdots \\
\cdots \\
30,000 \\
30,00\end{array}$ & $\begin{array}{l}(3) \\
1,600\end{array}$ & $\begin{array}{r}11,051,000 \\
600 \\
85,000\end{array}$ & $\begin{array}{c}28,000 \\
(2) \\
4,400\end{array}$ & $\begin{array}{r}1,900 \\
300 \\
1,000\end{array}$ & ${ }^{(2)} 100$ & $\begin{array}{r}4,400 \\
185,000\end{array}$ & $\begin{array}{r}200 \\
10,000\end{array}$ & & (n.... \\
\hline $\begin{array}{l}\text { Perch, yellow..... } \\
\text { Pike and pickerei. } \\
\text { Shad............. } \\
\text { Striped bass..... }\end{array}$ & $\begin{array}{r}287,000 \\
31,000 \\
3,936,000 \\
604,000\end{array}$ & $\begin{array}{r}15,000 \\
3,400 \\
247,000 \\
62,000\end{array}$ & $\begin{array}{r}72,000 \\
7,000 \\
1,475,000 \\
276,000\end{array}$ & $\begin{array}{r}3,500 \\
800 \\
100,000 \\
27,000\end{array}$ & $\begin{array}{r}12,000 \\
1,800 \\
2,282,000 \\
140,000\end{array}$ & $\begin{array}{r}800 \\
200 \\
134,000 \\
14,000\end{array}$ & $\begin{array}{r}51,000 \\
9,000 \\
74,000 \\
130,000\end{array}$ & $\begin{array}{r}2,900 \\
1,000 \\
5,100 \\
14,000\end{array}$ & 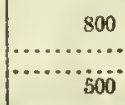 & $\begin{array}{l}(2) \\
\cdots \\
100\end{array}$ & $\begin{array}{r}151,000 \\
13,000 \\
35,000 \\
49,000\end{array}$ & $\begin{array}{l}7,800 \\
1,400 \\
2,500 \\
5,200\end{array}$ & $\begin{array}{r}71,000 \\
9,000\end{array}$ & $\begin{array}{l}5,800 \\
1,200\end{array}$ \\
\hline 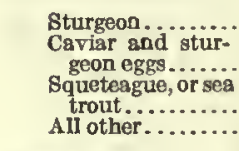 & $\begin{array}{r}188,000 \\
29,000\end{array}$ & $\begin{array}{l}6,200 \\
1,300\end{array}$ & $\begin{array}{r}170,000 \\
3,100\end{array}$ & $\begin{array}{r}5,200 \\
100\end{array}$ & $\begin{array}{r}1,400 \\
300\end{array}$ & $\begin{array}{l}100 \\
400 \\
(2) \\
(2)\end{array}$ & $\begin{array}{r}5,600 \\
24,000\end{array}$ & $\begin{array}{r}500 \\
1,200\end{array}$ & 13,000 & 400 & 100 & $(3)$ & & \\
\hline 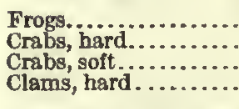 & $\begin{array}{r}1,000 \\
12,779,000 \\
7,587,000 \\
74,000\end{array}$ & $\begin{array}{r}500 \\
124,000 \\
195,000 \\
15,000\end{array}$ & $\begin{array}{r}8,400 \\
\hdashline\end{array}$ & (2) & & & 71,000 & 3,400 & $\begin{array}{r}11,032,000 \\
115,000\end{array}$ & $\begin{array}{r}106,000 \\
5,500\end{array}$ & & & $\begin{array}{r}1,000 \\
1,739,000 \\
7,402,000 \\
274,000\end{array}$ & $\begin{array}{r}500 \\
18,000 \\
186,000 \\
15,000\end{array}$ \\
\hline $\begin{array}{l}\text { Oysters, market, from } \\
\text { public areas.......... }\end{array}$ & $39,665,000$ & $2,036,000$ & & & & & & & & & & & $439,665,000$ & $2,036,000$ \\
\hline $\begin{array}{l}\text { Oysters, market, from } \\
\text { private areas........ } \\
\text { oysters, sced, from } \\
\text { public areas.......... } \\
\text { Terrapin.............. }\end{array}$ & $\begin{array}{r}81,012,000 \\
8,513,000 \\
7,600\end{array}$ & $\begin{array}{r}77,000 \\
92,000 \\
3,900\end{array}$ & 3,300 & 2,200 & & & & & & & 2,200 & 700 & $\begin{array}{r}51,012,000 \\
2,513,000 \\
2,100\end{array}$ & $\begin{array}{r}92,000 \\
1,000\end{array}$ \\
\hline 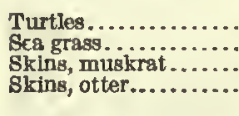 & $\begin{array}{r}5,100 \\
252,000 \\
738,000 \\
\text { (8) }\end{array}$ & $\begin{array}{r}200 \\
1,700 \\
50,000 \\
(2)\end{array}$ & $\begin{array}{r}200 \\
\ldots . . .\end{array}$ & (2) & & & $\begin{array}{r}300 \\
\ldots \ldots \ldots \\
\cdots \ldots \ldots\end{array}$ & (2) & $\begin{array}{r}3,000 \\
\ldots \ldots \ldots\end{array}$ & $\begin{array}{c}100 \\
\ldots \ldots\end{array}$ & $\begin{array}{r}1,600 \\
\cdots \ldots \ldots\end{array}$ & $\begin{array}{r}r \\
100 \\
\ldots \ldots\end{array}$ & $\begin{array}{c}252,000 \\
38,000 \\
(B)\end{array}$ & $\begin{array}{l}1,700 \\
50,000 \\
\left({ }^{2}\right)\end{array}$ \\
\hline
\end{tabular}

1 Includes apparatus, with catch, as follows: Dradges, toags, etc., $49,807,000$ pounds, valued at $\$ 2,368,000$; dip nets, $2,817,000$ pounds, valued at $\$ 59,000$; otter and musk

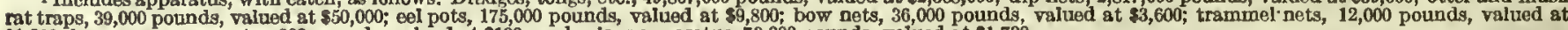
$\$ 1,200$; harpoons, spears, etc. 800 pornds, valued at $\$ 100$; and mloor apparatus, 73,000 pounds, valued at $\$ 1,700$. 
FISHERIES, BY STATES.

TABLE 3.-MARYLAND-FISHERY PRODUCTS OF ATLANTIC OCEAN DISTRICT: 1908.

\begin{tabular}{|c|c|c|c|c|c|c|c|c|c|c|c|c|}
\hline \multirow{3}{*}{ SPECIES. } & \multirow{2}{*}{\multicolumn{2}{|c|}{ TOTAL. }} & \multicolumn{10}{|c|}{ PBODDCT CAUGHT BT- } \\
\hline & & & \multicolumn{2}{|c|}{ Pound and trap nets. } & \multicolumn{2}{|c|}{ Gill nets. } & \multicolumn{2}{|c|}{ Seines. } & \multicolumn{2}{|c|}{ Llnes. } & \multicolumn{2}{|c|}{ All other apparatus. 1} \\
\hline & $\begin{array}{l}\text { Quantity } \\
\text { (pounds). }\end{array}$ & Value. & $\begin{array}{l}\text { Quantlty } \\
\text { (pounds). }\end{array}$ & Value. & $\begin{array}{l}\text { Quantity } \\
\text { (pounds). }\end{array}$ & Value. & $\begin{array}{l}\text { Quantity } \\
\text { (pounds). }\end{array}$ & Value. & $\begin{array}{l}\text { Quantity } \\
\text { (pounds). }\end{array}$ & Value. & $\begin{array}{l}\text { Quantity } \\
\text { (pounds). }\end{array}$ & Value. \\
\hline Total. . & $2,602,000$ & $\$ 119,000$ & $1,330.000$ & $\$ 53,000$ & 93,000 & $\$ 17,000$ & 418,000 & $\$ 12,000$ & 309,000 & $\$ 9,900$ & 453,000 & $\$ 27,000$ \\
\hline 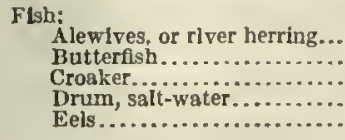 & $\begin{array}{r}106,000 \\
145,000 \\
175,000 \\
14,000 \\
6,200\end{array}$ & $\begin{array}{r}1,100 \\
7,200 \\
5,200 \\
100 \\
500\end{array}$ & $\begin{array}{r}5,000 \\
145,000 \\
160,000 \\
14,000 \\
\ldots\end{array}$ & $\begin{array}{r}100 \\
7,200 \\
4,800 \\
100\end{array}$ & & & $\begin{array}{l}101,000 \\
\ldots \ldots \ldots\end{array}$ & $\begin{array}{c}1,000 \\
\ldots \ldots \ldots \\
\cdots\end{array}$ & $i 5,000$ & "300 & $\begin{array}{l}\cdots \cdots \cdots \\
\cdots \cdots \cdots \\
6,200\end{array}$ & $\begin{array}{l}\cdots \cdots \cdots \\
\cdots \cdots \cdots \\
\cdots \cdots\end{array}$ \\
\hline 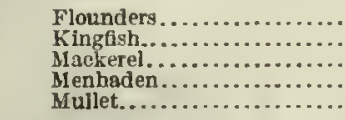 & $\begin{array}{r}16,000 \\
2,100 \\
4,400 \\
240,000 \\
27,000\end{array}$ & $\begin{array}{l}500 \\
300 \\
900 \\
400 \\
800\end{array}$ & $\begin{array}{r}16,000 \\
2,100 \\
4,400 \\
30,000 \\
.\end{array}$ & $\begin{array}{l}500 \\
300 \\
900 \\
100 \\
\cdots\end{array}$ & 27,000 & 800 & $\ddot{210}, 000$ & 400 & & & 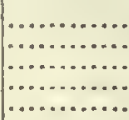 & n. \\
\hline $\begin{array}{l}\text { Perch, white................. } \\
\text { Perch, yellow............... } \\
\text { Plke........................ } \\
\text { Pormpano................ }\end{array}$ & $\begin{array}{r}25,000 \\
72,000 \\
3,700 \\
300\end{array}$ & $\begin{array}{r}2,400 \\
7,200 \\
400 \\
100\end{array}$ & $\begin{array}{r}900 \\
\ldots \ldots \ldots \cdots \\
300\end{array}$ & $\begin{array}{r}100 \\
\ldots \ldots \ldots \ldots \\
\cdots \cdots \\
100\end{array}$ & $\begin{array}{r}5,000 \\
12,000 \\
1,200 \\
\end{array}$ & $\begin{array}{r}500 \\
1,200 \\
100\end{array}$ & $\begin{array}{r}18,000 \\
60,000 \\
2,500 \\
6 .\end{array}$ & $\begin{array}{r}1,800 \\
6,000 \\
200 \\
\end{array}$ & \begin{aligned} \multicolumn{1}{c}{600} \\
$\cdots \cdots \cdots \cdots \\
\cdots \cdots \cdots \\
\cdots \cdots\end{aligned}$ & $\begin{array}{l}(2) \\
\cdots\end{array}$ & 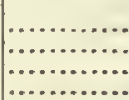 & $\begin{array}{l}\cdots \cdots \\
\cdots \cdots \cdots \\
\cdots \cdots\end{array}$ \\
\hline Sea bass ......................... & 225,000 & 6,800 & & & & & & & 225,000 & $\dddot{6}, 800$ & & \\
\hline $\begin{array}{l}\text { Strlped bass.................. } \\
\text { Sturgeon..................... } \\
\text { Caviar aud sturgeon eggs... } \\
\text { Squeteague, or trout......... } \\
\text { All other.................... }\end{array}$ & $\begin{array}{r}35,000 \\
31,000 \\
7,200 \\
1,002,000 \\
3,300\end{array}$ & $\begin{array}{r}3,500 \\
4,300 \\
10,000 \\
40,000 \\
200\end{array}$ & $\begin{array}{r}1,200 \\
2,400 \\
400 \\
937,000 \\
2,300\end{array}$ & $\begin{array}{r}100 \\
300 \\
600 \\
38,000 \\
100\end{array}$ & $\begin{array}{r}12,000 \\
28,000 \\
6,800 \\
200\end{array}$ & $\begin{array}{r}1,200 \\
4,000 \\
9,400 \\
9, \ldots\end{array}$ & $\begin{array}{r}22,000 \\
3,200 \\
900\end{array}$ & $\begin{array}{l}2,200 \\
{ }_{(3)}^{200}\end{array}$ & $\dddot{62,000}$ & $\dddot{2}, 500$ & & $\begin{array}{l}. \\
\because . \\
\cdots\end{array}$ \\
\hline 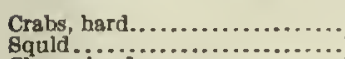 & $\begin{array}{r}6,500 \\
6,900\end{array}$ & $\begin{array}{l}100 \\
200\end{array}$ & $\begin{array}{l}1,500 \\
6,900\end{array}$ & ${ }^{(2)} 200$ & & & & ….... & 3,000 & ( $\left.{ }^{2}\right)$ & 2,000 & (2) \\
\hline 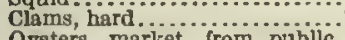 & 28,400 & 1,400 & & & & & & & & & 8,400 & 1,400 \\
\hline $\begin{array}{l}\text { Oysters, market, from publlc } \\
\text { areas......................... } \\
\text { Oysters, market from private }\end{array}$ & 43,000 & 4.700 & & & & & & & & & '53,000 & 4,700 \\
\hline 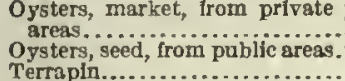 & $\begin{array}{r}82,000 \\
300,000 \\
1,600\end{array}$ & $\begin{array}{l}9,400 \\
9,600 \\
1,000\end{array}$ & (n........... & & & & & & & & $\begin{array}{r}82,000 \\
300,000 \\
1,600\end{array}$ & $\begin{array}{l}9,400 \\
9,600 \\
1,000\end{array}$ \\
\hline Turtles............................ & 3,000 & 200 & & & & & & & 3,000 & 200 & $\cdots \cdots$ & \\
\hline
\end{tabular}

1 Includes apparatus, with catch, as follows: Dredges, tongs, etc., 443,000 paunds, valued at $\$ 25,000$; eel pota, 6,200 pounds, valued at $\$ 500$; and minor apparatus, 1,600,

pounds, valued at $\$ 1,000$.
Less than $\$ 100$.

7,600 bushels.

12,000 bushels.

- 43,000 bushels.

TAble 4.-MARYLAND-PRODUCTS OF VESSEL FisheRIES: 1908.

\begin{tabular}{|c|c|c|c|c|c|c|c|c|c|c|c|c|}
\hline \multirow{3}{*}{ SPECIES. } & \multirow{2}{*}{\multicolumn{2}{|c|}{ TOTAL. }} & \multicolumn{10}{|c|}{ PRODUCT CAUGHT BY- } \\
\hline & & & \multicolumn{2}{|c|}{ Pound and trap nets. } & \multicolumn{2}{|c|}{ Gill nets. } & \multicolumn{2}{|c|}{ Seines. } & \multicolumn{2}{|c|}{ Fyke and hoop nets. } & \multicolumn{2}{|c|}{ Al] other apparatus. } \\
\hline & $\begin{array}{l}\text { Quantity } \\
\text { (pounds). }\end{array}$ & Value. & $\begin{array}{l}\text { Qnantlty } \\
\text { (pounds). }\end{array}$ & Vaine. & $\begin{array}{l}\text { Quantlty } \\
\text { (pounds). }\end{array}$ & Value. & $\begin{array}{l}\text { Quantity } \\
\text { (pounds). }\end{array}$ & Value. & $\begin{array}{l}\text { Quantlty } \\
\text { (pounds). }\end{array}$ & Vaiue. & $\begin{array}{l}\text { Quantlty } \\
\text { (pounds). }\end{array}$ & Valne. \\
\hline Total.. & $27,946,000$ & $s 767,000$ & $1,938,000$ & $\$ 21,000$ & 113,000 & 88,000 & $11,092,000$ & $\$ 31,000$ & 41,000 & $\$ 2,000$ & $14,762,000$ & $\$ 705,000$ \\
\hline 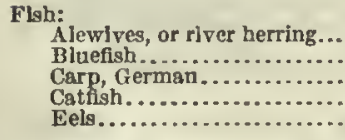 & $\begin{array}{r}778,000 \\
400 \\
18,000 \\
22,000 \\
84,000\end{array}$ & $\begin{array}{l}4,600 \\
(?) \\
600 \\
800 \\
4,900\end{array}$ & $\begin{array}{r}776,000 \\
400 \\
1,000 \\
2,200 \\
500\end{array}$ & $\begin{array}{l}4,500 \\
\text { (3) } \\
\text { (3) } 100 \\
(3)\end{array}$ & $\begin{array}{r}2,500 \\
1,000\end{array}$ & $\begin{array}{r}100 \\
100\end{array}$ & $\begin{array}{r}16,000 \\
1,000\end{array}$ & $(3)^{600}$ & $\begin{array}{r}16,000 \\
500\end{array}$ & (3) & $\begin{array}{r}1,700 \\
\mathbf{8 3}, 000\end{array}$ & $\begin{array}{r}100 \\
4,800\end{array}$ \\
\hline 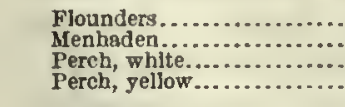 & $\begin{array}{r}4,400 \\
12,021,000 \\
28,000 \\
7,600\end{array}$ & $\begin{array}{r}200 \\
30,000 \\
1,500 \\
100\end{array}$ & $\begin{array}{r}4,400 \\
970,000 \\
6,600\end{array}$ & $\begin{array}{r}200 \\
1,000 \\
400 \\
\ldots\end{array}$ & 500 & & $\begin{array}{r}11,051,000 \\
8,000 \\
100\end{array}$ & $\begin{array}{l}28,000 \\
400\end{array}$ & $\begin{array}{r}14.000 \\
7,000\end{array}$ & $\begin{array}{l}700 \\
400\end{array}$ & 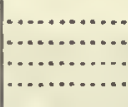 & ( \\
\hline 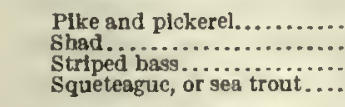 & $\begin{array}{r}4,600 \\
265,000 \\
36,000 \\
900\end{array}$ & $\begin{array}{r}500 \\
20,000 \\
3,700 \\
100\end{array}$ & $\begin{array}{r}500 \\
168,000 \\
9,300 \\
400\end{array}$ & $\begin{array}{r}100 \\
13,000 \\
800 \\
(2)^{8}\end{array}$ & $\begin{array}{r}97,000 \\
12,000 \\
\cdots\end{array}$ & $\begin{array}{r}6,500 \\
1,300 \\
\cdots \ldots \ldots\end{array}$ & $\begin{array}{r}300 \\
15,000 \\
500\end{array}$ & $\begin{array}{r}(3) \\
1,600 \\
100\end{array}$ & $\begin{array}{r}3,800 \\
200 \\
2 \times \cdots\end{array}$ & ${ }^{400}$ & 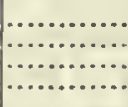 & n. \\
\hline 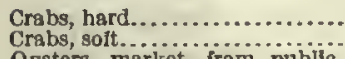 & $\begin{array}{l}480,000 \\
348,000\end{array}$ & $\begin{array}{l}6,200 \\
8,300\end{array}$ & & & & & & & & & $\begin{array}{l}480,000 \\
348,000\end{array}$ & $\begin{array}{l}6,200 \\
8,300\end{array}$ \\
\hline $\begin{array}{l}\text { Ogsters, market, from public } \\
\text { areas............................ } \\
\text { Oysters, inarket, from private }\end{array}$ & $213,391,000$ & 670,000 & & & & & & & & & $13,391,000$ & 670,000 \\
\hline areas...................... & $\begin{array}{r}490,000 \\
\quad 368,000\end{array}$ & $\begin{array}{l}6,400 \\
9,600\end{array}$ & & & & & & & & & $\begin{array}{r}90,000 \\
368,000\end{array}$ & $\begin{array}{l}6,400 \\
9,600\end{array}$ \\
\hline
\end{tabular}

I Includes apparatus, wlth catch, as follows: Dredges, tongs, etc., 14,574,000 pounds, valued at 8698,000 ; eel pots, 84,000 pounds, ralued at $\$ 4,900$; lines, 95,000 pounds, valued at $\$ 2,100$; and nets, 8,800 pounds, valued at $\$ 200$.

Less than $\$ 100$. 
TABLE 5.-MARYLAND-PRODUCTS OF SHORE AND BOAT FISHERIES: 1908.

\begin{tabular}{|c|c|c|c|c|c|c|c|c|c|c|c|c|c|c|}
\hline \multirow{3}{*}{ SPECIBS. } & \multirow{2}{*}{\multicolumn{2}{|c|}{ TOTAL. }} & \multicolumn{12}{|c|}{ PRODUCT CAUGHT BY- } \\
\hline & & & \multicolumn{2}{|c|}{$\begin{array}{l}\text { Pound and trap } \\
\text { nets. }\end{array}$} & \multicolumn{2}{|c|}{ Gill nets. } & \multicolumn{2}{|c|}{ Lines. } & \multicolumn{2}{|c|}{ Seines. } & \multicolumn{2}{|c|}{$\begin{array}{c}\text { Fyke and hoop } \\
\text { nets. }\end{array}$} & \multicolumn{2}{|c|}{ All other apparatus. } \\
\hline & $\begin{array}{l}\text { Quantity } \\
\text { (pounds). }\end{array}$ & Value. & $\begin{array}{l}\text { Quantity } \\
\text { (pounds). }\end{array}$ & Value. & $\begin{array}{l}\text { Quantity } \\
\text { (pounds). }\end{array}$ & Value. & $\begin{array}{l}\text { Qnantity } \\
\text { (pounds). }\end{array}$ & Value. & $\begin{array}{l}\text { Quantity } \\
\text { (pounds). }\end{array}$ & Value. & $\begin{array}{l}\text { Quantity } \\
\text { (pounds). }\end{array}$ & Value. & $\begin{array}{l}\text { Quantity } \\
\text { (pounds). }\end{array}$ & Value. \\
\hline Total.... & $85,850,000$ & $\$ 2,539,000$ & $25,167,000$ & $\$ 300,000$ & $2,926,000$ & $\$ 166,000$ & $11,396,000$ & $\$ 122,000$ & $6,891,000$ & $\$ 97,000$ & 728,000 & $\$ 37,000$ & $38,744,000$ & $\$ 1,817,000$ \\
\hline 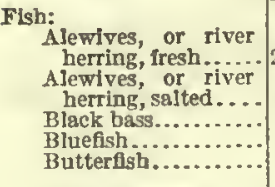 & $\begin{array}{r}23,673,000 \\
4,354,000 \\
15,000 \\
14,000 \\
151,000\end{array}$ & $\begin{array}{r}59,000 \\
1,500 \\
600 \\
7,400\end{array}$ & $\begin{array}{r}2,673,000 \\
4,200 \\
1,500 \\
151,000\end{array}$ & $\begin{array}{r}35,000 \\
500 \\
100 \\
7,400\end{array}$ & $\begin{array}{r}415,000 \\
200 \\
7,500 \\
12,000 \\
2\end{array}$ & $\begin{array}{l}2,300 \\
\left({ }^{2}\right) \\
700 \\
500\end{array}$ & $\ddot{500}$ & (3) & $\mid \begin{array}{r}4,342,000 \\
1,680,000 \\
3,200 \\
\ldots \ldots \ldots\end{array}$ & $\begin{array}{r}27,000 \\
23,000 \\
400 \\
\cdots\end{array}$ & 110,000 & 500 & & $\begin{array}{l}\ldots \\
\ldots \\
\cdots\end{array}$ \\
\hline 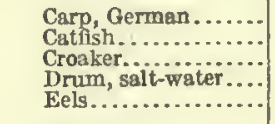 & $\begin{array}{r}149,000 \\
387,000 \\
179,000 \\
39,000 \\
137,000\end{array}$ & $\begin{array}{r}6,500 \\
18,000 \\
5,300 \\
300 \\
7,800\end{array}$ & $\begin{array}{r}48,000 \\
133,000 \\
164,000 \\
38,000 \\
16,000\end{array}$ & $\begin{array}{r}1,600 \\
5,400 \\
4,900 \\
500 \\
1,000\end{array}$ & $\begin{array}{r}23,000 \\
16,000 \\
\cdots \cdots \\
\cdots \\
\cdots\end{array}$ & $\begin{array}{r}900 \\
500 \\
\cdots \cdots \\
\cdots \cdots \\
\cdots \cdots \\
\cdots\end{array}$ & $\begin{array}{r}14,000 \\
15,000 \\
500 \\
\ldots\end{array}$ & $\begin{array}{l}1,200 \\
400 \\
(2)\end{array}$ & $\begin{array}{r}61,000 \\
58,000 \\
\cdots \ldots, \ldots \\
3,800 \\
3,80\end{array}$ & $\left|\begin{array}{r}2,900 \\
2,300 \\
\cdots \cdots \\
\cdots \\
200\end{array}\right|$ & $\begin{array}{r}15,000 \\
161,000 \\
\cdots \\
\cdots \\
25,000\end{array}$ & $\begin{array}{r}900 \\
7,800 \\
\cdots \cdots \\
\hdashline 1,500\end{array}$ & $\begin{array}{r}2,500 \\
5,600 \\
\cdots \ldots, \ldots \ldots \\
\cdots, \cdots, 000\end{array}$ & $\begin{array}{r}100 \\
400 \\
\end{array}$ \\
\hline 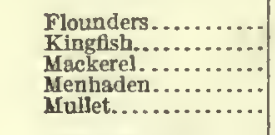 & $\begin{array}{r}42,000 \\
4,600 \\
4,400 \\
272,000 \\
47,000\end{array}$ & $\begin{array}{r}1,900 \\
500 \\
900 \\
400 \\
1,600\end{array}$ & $\begin{array}{r}42,000 \\
2,700 \\
4,400 \\
62,000 \\
14,000\end{array}$ & $\begin{array}{r}1,900 \\
300 \\
900 \\
100 \\
600\end{array}$ & $\begin{array}{r}100 \\
\cdots \ldots \ldots \ldots \\
\cdots \ldots \ldots \\
28,000\end{array}$ & 800 & 1,900 & $\begin{array}{l}200 \\
\ldots \ldots \\
(2)\end{array}$ & $\begin{array}{r}210,000 \\
600\end{array}$ & $(2)$ & 4,400 & 200 & $\begin{array}{l}\cdots \\
\cdots \\
\cdots \\
\cdots\end{array}$ & (n........ \\
\hline $\begin{array}{l}\text { Perch, whlte........ } \\
\text { Perch, yellow....... } \\
\text { Plke and pickerel.... } \\
\text { Pompano............. } \\
\text { Sea bass.............. } \\
\text { Shad............... }\end{array}$ & $\begin{array}{r}516,000 \\
351,000 \\
30,000 \\
300 \\
225,000 \\
3,672,000\end{array}$ & $\begin{array}{r}29,000 \\
22,000 \\
3,300 \\
100 \\
6,800 \\
227,000\end{array}$ & $\begin{array}{r}212,000 \\
72,000 \\
6,500 \\
300 \\
300 \\
1,308,000\end{array}$ & $\begin{array}{r}12,000 \\
3,500 \\
700 \\
100 \\
\left({ }^{2}\right) \\
86,000\end{array}$ & $\begin{array}{r}35,000 \\
24,000 \\
3,000 \\
\cdots \ldots . \\
\hdashline 2,185,000\end{array}$ & $\begin{array}{r}2,100 \\
1,900 \\
300 \\
127,000\end{array}$ & $\begin{array}{r}1,600 \\
800 \\
\cdots \cdots \\
\cdots \cdots \cdots \\
225,000 \\
\cdots \cdots\end{array}$ & 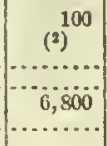 & $\begin{array}{r}95,000 \\
111,000 \\
11,000 \\
\ldots \ldots \ldots \\
77,000\end{array}$ & $\begin{array}{r}5,800 \\
8,900 \\
1,200 \\
\cdots \ldots \ldots \\
5,100\end{array} \mid$ & $\begin{array}{r}172,000 \\
144,000 \\
9,600 \\
\cdots \\
35,000\end{array}$ & $\begin{array}{r}9,400 \\
7,400 \\
1,100 \\
\cdots \cdots \\
2,500\end{array}$ & 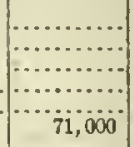 & ( \\
\hline $\begin{array}{l}\text { Spot.................. } \\
\text { Striped bass........... } \\
\text { Sturgeon............ }\end{array}$ & $\begin{array}{r}3,100 \\
604,000 \\
37,000\end{array}$ & $\begin{array}{r}100 \\
61,000 \\
5,000\end{array}$ & $\begin{array}{r}2,800 \\
268,000 \\
7,600\end{array}$ & $\begin{array}{r}100 \\
27,000 \\
900\end{array}$ & $\begin{array}{r}140,000 \\
30,000\end{array}$ & $\begin{array}{r}14,000 \\
4,100\end{array}$ & 500 & 100 & $\begin{array}{r}300 \\
137,000 \\
\ldots .\end{array}$ & $\left.14,{ }^{(2)}\right)$ & 48,000 & 5,200 & 9,000 & $\ddot{1}, 200$ \\
\hline 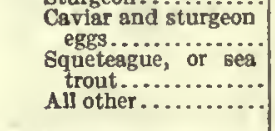 & $\begin{array}{r}8,100 \\
1,190,000 \\
26,000\end{array}$ & $\begin{array}{r}11,000 \\
46,000 \\
1,300\end{array}$ & $\begin{array}{r}1,000 \\
1,106,000 \\
900\end{array}$ & $\begin{array}{r}1,000 \\
43,000 \\
100\end{array}$ & $\begin{array}{r}7,100 \\
100 \\
1,100\end{array}$ & $\begin{array}{l}9,800 \\
(2) \\
(2)\end{array}$ & $\begin{array}{r}75,000 \\
\cdots \cdots\end{array}$ & 2,900 & $\begin{array}{r}8,300 \\
24,000\end{array}$ & $\begin{array}{r}600 \\
1,200\end{array}$ & 100 & (3) & n..... & $\cdots \cdots$ \\
\hline 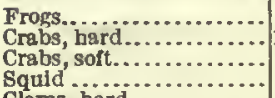 & $\begin{array}{r}1,000 \\
12,306,000 \\
7,239,000 \\
6,900\end{array}$ & $\begin{array}{r}500 \\
118,000 \\
187,000 \\
200\end{array}$ & 10,000 & 100 & & & $\begin{array}{r}10,940,000 \\
115,000 \\
\ldots . . . . .\end{array}$ & $\begin{array}{r}104,000 \\
5,500\end{array}$ & $\because 7,000$ & 3,400 & …'. & & $\begin{array}{r}1,000 \\
1,358,000 \\
7,054,000 \\
\ldots \ldots \ldots\end{array}$ & $\begin{array}{r}500 \\
14,000 \\
178,000 \\
\ldots\end{array}$ \\
\hline Clams, hard............. & 82,000 & 16,000 & & 200 & & & •...... & & & & & & 82,000 & $\because 16,000$ \\
\hline $\begin{array}{l}\text { Oysters, seed, from pub- } \\
\text { lio areas.................. } \\
\text { Terrapin................. }\end{array}$ & $\begin{array}{r}2,444,000 \\
9,200\end{array}$ & $\begin{array}{r}92,000 \\
4,900\end{array}$ & 3,300 & 2,200 & & & & & & & 2,200 & $\ddot{7000}$ & $\begin{array}{r}8,444,000 \\
3,800\end{array}$ & $\begin{array}{r}92,000 \\
2,000\end{array}$ \\
\hline $\begin{array}{l}\text { Turtles................... } \\
\text { Sea grass . } \\
\text { SkIns, muskrat............. } \\
\text { Skins, otter............. }\end{array}$ & $\begin{array}{r}8,100 \\
252,000 \\
38,000 \\
(8)\end{array}$ & $\begin{array}{l}1,700 \\
50,000 \\
(2)\end{array}$ & 200 & (2) & & & $\begin{array}{c}6,000 \\
\ldots \ldots \ldots\end{array}$ & 300 & 300 & $\left(\mathbf{(}^{2}\right)$ & $\begin{array}{r}1,600 \\
.\end{array}$ & $\begin{array}{r}100 \\
\cdots\end{array}$ & $\begin{array}{c}252,000 \\
738,000 \\
(8)\end{array}$ & $\begin{array}{l}1,700 \\
50,000 \\
(2)\end{array}$ \\
\hline
\end{tabular}

1 Includes apparatus, with catch, as follows: Dredges, tongs, etc., $35,676,000$ pounds, valued at $\$ 1,695,000 ;$ dip nets, $2,809,000$ pounds, valued at $\$ 59,000 ;$ otter and musk-

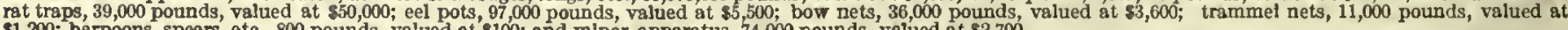

$\$ 1,200$; harpoons, spears, etc., 800 pounds, valued at $\$ 100$; and minor apparatus, 74,000 pounds, valued at $\$ 2,700$. $\$ 349,000$ bushels. $\quad ? 115,000$ skins.
2 Less than $\$ 100$. Less than 100 pounds.

\section{MASSACHUSETTS}

In the value of fishery products and in the amount of capital invested in the fishery industry Massachusetts ranked first among the states, while in the number of persons employed it ranked third, Virginia being first and Maryland second. Cod, haddock, and mackerel were the most important species taken, the catch of each of these being larger than that of the respective species in any other state. Massachusetts ranked first also in the catch of 15 other species or forms of fish product, and second in 10 others.

The preeminence of the state was due to the great importance of its vessel fisheries, the headquarters of which are located in a few ports, notably Gloucester and Boston. On this account statistics are presented separately for the counties in which these cities are situated, namely, Essex County and Suffolk County; the statistics for the rest of the state are presented under the head "All other counties." The Essex County district takes in the ports along the north shore of Massachusetts Bay, on Capo Ann, and north to the New Hampshire line, with Gloucester as the chief port. The Suffolk County district represents principally the city of Boston, while the group "All other counties" embraces the counties of Norfolk, Plymouth, Barnstable, Bristol, Dukes, and Nantucket, including the ports on the south shore of Massachusetts Bay, Cape Cod, and Buzzards Bay. A summary of the principal statistics for the state and for the several districts is given in the following tabular statement: 


\begin{tabular}{|c|c|c|c|c|}
\hline 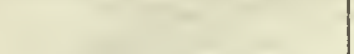 & Total. & $\begin{array}{c}\text { Essex } \\
\text { County. }\end{array}$ & $\begin{array}{l}\text { Suffolk } \\
\text { County. }\end{array}$ & $\begin{array}{l}\text { All other } \\
\text { countles. }\end{array}$ \\
\hline $\begin{array}{l}\text { Number of persons employed... } \\
\text { Capltal: }\end{array}$ & 11,577 & 4,725 & 2,305 & 4,547 \\
\hline $\begin{array}{l}\text { Vessels and boats, including } \\
\text { outfit } \\
\text { A pparatus of capture........................... }\end{array}$ & $\begin{array}{r}\$ 1,759,000 \\
775,000\end{array}$ & $\begin{array}{r}\$ 2,157,000 \\
320,000\end{array}$ & $\begin{array}{r}\$ 1,402,000 \\
165,000\end{array}$ & $\begin{array}{r}\$ 1,200,000 \\
290,000\end{array}$ \\
\hline Shore and accessory prop- & 800,000 & & & \\
\hline $\begin{array}{l}\text { erty and cash } \\
\text { Value of products...................... }\end{array}$ & $\begin{array}{r}215,000 \\
7,095,000\end{array}$ & $\begin{array}{r}35,000 \\
3,030,000\end{array}$ & $\begin{array}{r}46,000 \\
1,749,000\end{array}$ & $\begin{array}{r}134,000 \\
2,316,000\end{array}$ \\
\hline
\end{tabular}

The importance of Essex County in every item, except shore and accessory property and cash, is apparent.

Comparison with previous canvasses.-By examination of the statistics for $1889,1898,1902$, and 1905 presented in the following tabular statement, it will be seen that at each successive canvass, except that of 1898 , a larger value of products was reported than at the preceding canvass, but that for the other items the figures for 1908 are considerably less than those for
1889. During the past decade, however, there has been a gradual improvement in every respect, except that the number of persons employed and the weight of the catch decreased slightly from 1905 to 1908 .

\begin{tabular}{|c|c|c|c|c|c|c|}
\hline \multirow[b]{2}{*}{ YEAK. } & \multirow{2}{*}{$\begin{array}{c}\text { Persons } \\
\text { em- } \\
\text { ployed, } \\
\text { exclu- } \\
\text { sive of } \\
\text { shores- } \\
\text { men. }\end{array}$} & \multicolumn{3}{|c|}{ VALUE OF EQUTPMENT. } & \multicolumn{2}{|c|}{ PRODECTs. } \\
\hline & & Total. & $\begin{array}{l}\text { Vessels } \\
\text { and boasts, } \\
\text { including } \\
\text { outfit. }\end{array}$ & $\begin{array}{l}\text { A ppara } \\
\text { tus of } \\
\text { capture. }\end{array}$ & $\begin{array}{l}\text { Quantlty } \\
\text { (pounds). }\end{array}$ & Value. \\
\hline $\begin{array}{l}1908 \ldots \ldots \ldots \\
1905 \ldots \ldots \ldots \\
1902 \ldots \ldots \ldots \\
1898 \ldots \ldots \\
1889 . \ldots \ldots\end{array}$ & $\begin{array}{l}11,535 \\
12,618 \\
11,387 \\
10,341 \\
14,599\end{array}$ & $\begin{array}{r}\$ 5,534,000 \\
5,216,000 \\
4,742,000 \\
3,450,000 \\
5,903,000\end{array}$ & $\begin{array}{r}\$ 4,759,000 \\
4,453,000 \\
4,139,000 \\
2,894,000 \\
4,893,000\end{array}$ & $\begin{array}{r}\$ 775,000 \\
762,000 \\
603,000 \\
557,000 \\
1,010,000\end{array}$ & $\begin{array}{l}244,313,000 \\
255,654,000 \\
230,646,000 \\
202,258,000 \\
299,218,000\end{array}$ & $\begin{array}{r}87,095,000 \\
7,025,000 \\
6,482,000 \\
4,404,000 \\
5,858,000\end{array}$ \\
\hline
\end{tabular}

Persons employed.-The following table shows the distribution of the persons employed in the fisheries of Massachusetts, by districts and by class of service, for the state and for each county district:

\begin{tabular}{|c|c|c|c|c|c|c|c|}
\hline & \multicolumn{4}{|c|}{ Number. } & \multicolumn{3}{|c|}{ Salarles and wages. } \\
\hline 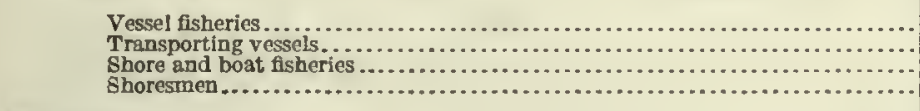 & $\begin{array}{r}7,568 \\
63 \\
3,904 \\
42 \\
\end{array}$ & $\begin{array}{r}468 \\
8 \\
2,665\end{array}$ & $\begin{array}{r}15 \\
2 \\
6\end{array}$ & $\begin{array}{r}7,085 \\
53 \\
1,233 \\
12 \\
\end{array}$ & $\begin{array}{r}2,408,000 \\
27,000 \\
294,000 \\
14,000 \\
\end{array}$ & $\begin{array}{r}14,000 \\
2,500 \\
3,000 \\
\end{array}$ & $\begin{array}{r}2,394,000 \\
25,000 \\
291,000 \\
14,000 \\
\end{array}$ \\
\hline Rssex County .................................. & 4,725 & 871 & 11 & 3,843 & $1,116,000$ & 11,000 & $1,105,000$ \\
\hline 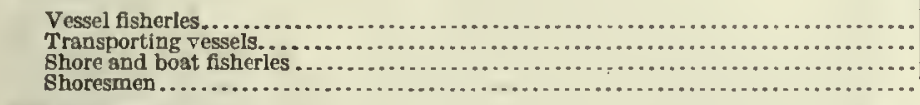 & $\begin{array}{r}3,727 \\
20 \\
973 \\
5\end{array}$ & $\begin{array}{r}125 \\
1 \\
745\end{array}$ & $\begin{array}{l}8 \\
2 \\
1\end{array}$ & $\begin{array}{r}3,594 \\
17 \\
227 \\
5\end{array}$ & $\begin{array}{r}1,054,000 \\
12,000 \\
49,000 \\
1,100\end{array}$ & $\begin{array}{r}7,500 \\
2,500 \\
700\end{array}$ & $\begin{array}{r}1,046,000 \\
9,300 \\
49,000 \\
1,100\end{array}$ \\
\hline All other counties................................................ & 4,547 & 1,964 & 7 & 2,576 & 824,000 & 4,100 & 820,000 \\
\hline $\begin{array}{l}\text { Vessel fisheries................... } \\
\text { Transportlng vessels............. } \\
\text { Shore and boat fisheries.......... } \\
\text { Shoresmen...................... }\end{array}$ & $\begin{array}{r}2,022 \\
16 \\
2,473 \\
36\end{array}$ & $\begin{array}{r}286 \\
5,673 \\
1,67\end{array}$ & $\begin{array}{c}2 \\
\dddot{5} \\
\cdots\end{array}$ & $\begin{array}{r}1,734 \\
11 \\
795 \\
36\end{array}$ & $\begin{array}{r}617,000 \\
2,100 \\
182,000 \\
12,000\end{array}$ & $\begin{array}{l}1,800 \\
2,300 \\
2,300\end{array}$ & $\begin{array}{r}616,000 \\
2,100 \\
190,000 \\
12,000\end{array}$ \\
\hline
\end{tabular}

1 Exclusive of 943 proprietors not fishing.

The number of persons employed in the fisheries of Massachusetts formed 8 per cent of the total number for the United States. Of the 42 shoresmen, 15 were employed in the vessel fisheries and the remaining 27 in the shore and boat fisheries. While in the country as a whole shore and boat fishermen outnumbered vessel fishermen in the proportion of about three to one, in Massachusetts the vessel fishermen were nearly twice as numerous as the shore and boat fishermen, forming 21 per cent of the total number of vessel fishermen in the United States. Independent fishermen throughout the country comprised 50 per cent of all persons engaged in fishing, but in Massachusetts wageearners constituted 73 per cent of the persons employed. This predominance of wage-earners was due to the
2 Includes provislons furnlshed to the value of $\$ 103,000$.

vessel fisheries, for in the shore and boat fisheries the number of proprietors and independent fishermen was more than twice the number of persons working for wages or salaries.

Essex County reported 28 per cent of the proprietors and independent fishermen and 46 per cent of the total number of employees in the state. Of the wageearnors in the vessel fisheries, Essex County had 51 per cent, but it had only 18 per cent of the wage-earners in the shore and boat fisheries. In the latter class of fisheries 64 per cent of the wage-earners were reported by the southern counties included under the head "All other counties."

Suffolk County showed the same predominance of wage-earners as Essex County, but the total number 
and the number in vessel fisheries were only about one-half as great. The number of wage-earners in the shore and boat fisheries was about the same in Suffolk County as in Essex County. Nearly threefourths (73 per cent) of the vessel fishermen were found in Essex and Suffolk Counties and nearly twothirds (63 per cent) of the shore and boat fishermen were found in the group comprising the other counties.

Equipment and other capital.-The following table gives, by county districts, the value of equipment and the amount of other capital employed in the fisheries of Massachusetts:

\begin{tabular}{|c|c|c|c|c|}
\hline \multirow{2}{*}{ CLASS OF INVESTMEAT, } & \multicolumn{4}{|c|}{$\begin{array}{l}\text { VALUE OF EQUIPMENT AND OTHER } \\
\text { CAPITAL: } 1908 .\end{array}$} \\
\hline & Total. & $\begin{array}{l}\text { Essex } \\
\text { County. }\end{array}$ & $\begin{array}{l}\text { Suffolk } \\
\text { County. }\end{array}$ & $\begin{array}{l}\text { All other } \\
\text { counties. }\end{array}$ \\
\hline Total.......... & $\$ 5,750,000$ & $\$ 2,513,000$ & $\$ 1,613,000$ & $\$ 1,624,000$ \\
\hline Vessels, including outfit. & $4,282,000$ & $2,068,000$ & $1,332,000$ & 882,000 \\
\hline Fishing................. & $4,204,000$ & $2,032,000$ & $1,301,000$ & 870,000 \\
\hline Steam and motor.. & 710,000 & 252,000 & 176,000 & 281,000 \\
\hline Vessels........ & 563,000 & 185,000 & 148,000 & 227,000 \\
\hline Outfit......... & 147,000 & 64,000 & 29,000 & 55,000 \\
\hline Sail........... & $3,494,000$ & $1,780,000$ & $1,125,000$ & 588,000 \\
\hline $\begin{array}{l}\text { Vessels............ } \\
\text { Outfit. . . . }\end{array}$ & $\begin{array}{l}2,293,000 \\
1,201,000\end{array}$ & $\begin{array}{r}1,215,000 \\
565,000\end{array}$ & $\begin{array}{l}746,000 \\
380,000\end{array}$ & $\begin{array}{l}332,000 \\
256,000\end{array}$ \\
\hline Other............... & 600 & & & 600 \\
\hline Transporting............. & 79,000 & 36,000 & 31,000 & 12,000 \\
\hline Steam and motor.... & 71,000 & 33,000 & 27,000 & 11,000 \\
\hline $\begin{array}{l}\text { Vessels............. } \\
\text { Outfit............ }\end{array}$ & 65,000 & 30,000 & 25,000 & 10,000 \\
\hline $\begin{array}{r}\text { Outfit.......... } \\
\text { Sail } \ldots \ldots \ldots \ldots \ldots \ldots\end{array}$ & 6,200 & 3,400 & 1,900 & 800 \\
\hline vansels.................. & 7,500 & $\begin{array}{l}2,100 \\
2,000\end{array}$ & $\begin{array}{l}4,100 \\
3,600\end{array}$ & 1,300 \\
\hline Outfit........ & 500 & 100 & 400 & 1,300 \\
\hline ................ & 477,000 & 90,000 & 70,000 & 318,000 \\
\hline $\begin{array}{l}\text { Steam and motor. ....... } \\
\text { Sail. }\end{array}$ & 376,000 & 67,000 & 65,000 & 244,000 \\
\hline Sail........... & 54,000 & 10,000 & 500 & 43,000 \\
\hline ( & 37,000 & 12,000 & 4,000 & 21,000 \\
\hline 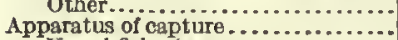 & $\begin{array}{r}10,000 \\
775,000\end{array}$ & 320,000 & 165,000 & $\begin{array}{l}10,000 \\
290,000\end{array}$ \\
\hline 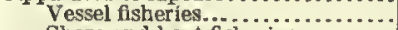 & 515,000 & 271,000 & 145,000 & 99,000 \\
\hline Shore and boat fisheries.......... & 260,000 & 49,000 & 20,000 & 192,000 \\
\hline Shore and accessory property........ & 164,000 & 30,000 & 7,800 & 127,000 \\
\hline Cash............................ & 51,000 & 5,700 & 38,000 & 7,400 \\
\hline
\end{tabular}

The investment of Massachusetts in the fishing industry was larger than that of any other state, comprising 14 per cent of the total for the United States. Practically three-fourths (74 per cent) of the total state investment was in fishing vessels and their outfits. The total'value of vessels and boats in this state was more than double that in the state next in rank, Virginia, and formed 19 per cent of the total investment in vessels and boats for the United States. In the value of boats alone and of apparatus of capture, however, Massachusetts was outranked by several states in which shore and boat fisheries were more prominent. Apparatus of capture represented 13 per cent of the Massachusetts investment, having a value higher than the value of boats and of shore and accessory property combined with cash capital.

The value of all sailing vessels, including outfits, was between four and five times that of steam vessels, being $\$ 3,501,000$, as compared with $\$ 781,000$. Among the boats, however, power-driven craft contributed 79 per cent of the total value.

The following table gives detailed statisties concerning the number and tonnage of vessels and the number of boats:

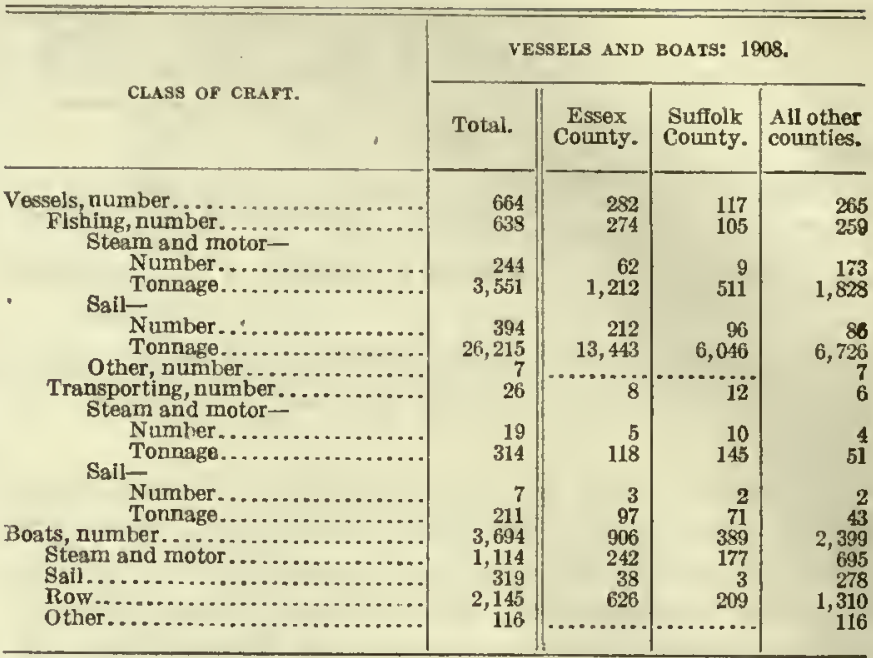

Of the investment in apparatus of capture, approximately two-thirds was in the vessel fisheries and onethird in the shore and boat fisheries. The distribution of the several kinds of apparatus by districts and by class of fisheries is given in the following tabular statement:

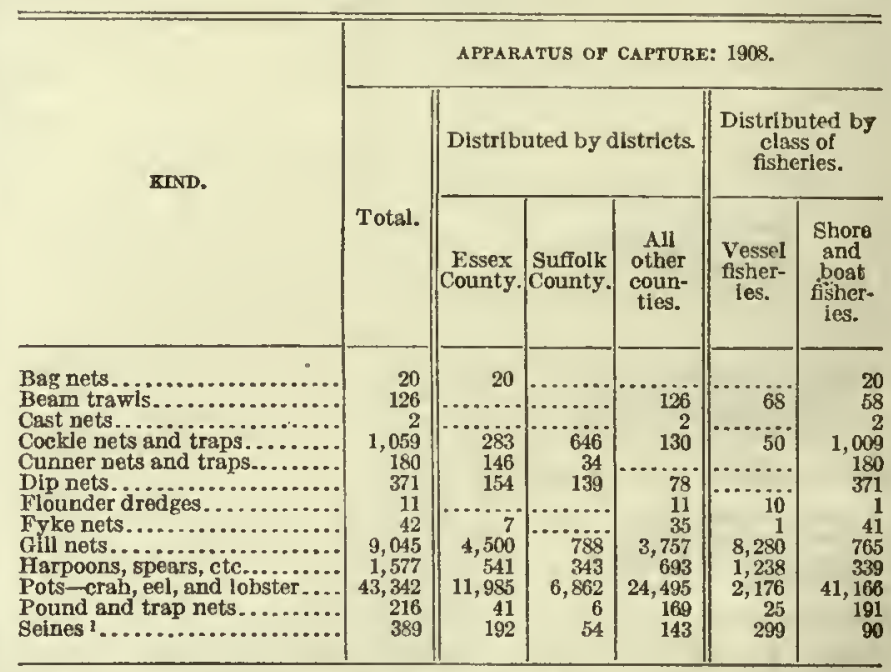

1 Includes otter trawls.

Products, by species. - Table 1, on page 159, gives the fishery products of the state, by species and by apparatus of capture.

Sixty distinct species were represented, the most important being cod, haddock, and mackerel, which together contributed 53 per cent of the value of all fishery products of the state. The cod and the haddock catch each exceeded a million dollars in value. For eight other products-clams (including all three varieties, hard, soft, and razor), herring, pollack, halibut, lobsters, sperm oil, hake, and oysters-values in excess of $\$ 200,000$ were reported. The value reported for the 11 species named formed 86 per cent of the total value of products. Flounders, swordfish, and scallops had values in excess of $\$ 100,000$.

Products, by county districts.-The fishery products, by principal species and by county districts, are given 
in Table 2 , on page 160 , where they are ranked according to the value reported for the state as a whole.

The value of the products was distributed among the districts as follows: Essex County, 43 per cent; Suffolk County, 25 per cent ; and "All other counties," 33 per cent. The products reported for "All other counties" were much more diversified than those of Essex and Suffolk Counties. Cod was the leading species with respect to value in Essex and Suffolk Counties. Mackerel ranked next to cod in value in Essex County, and haddock in Suffolk County. In the rest of the state whale products ranked first and cod second. Haddock and mackerel were important products in each district. All the oysters and whale products, and 57 per cent of the value of the clams, were reported by the southern counties grouped under the designation "All other counties."

Products, by class of fisheries.-Tables 3 and 4, on pages 161 and 162, give the products for the vessel fisheries and for the shore and boat fisheries, respectively, by species and by apparatus of capture. The values of the chief species of products for each class of fisheries were as follows:

\begin{tabular}{|c|c|c|c|}
\hline \multirow[b]{2}{*}{ SPECIES. } & \multicolumn{3}{|c|}{ VALUE OF PRODUCTS: 1908.} \\
\hline & Total. & $\begin{array}{c}\text { Vessel } \\
\text { fisheries. }\end{array}$ & $\begin{array}{l}\text { Shore and } \\
\text { boat } \\
\text { isheries. }\end{array}$ \\
\hline Total...... & $\$ 7,095,000$ & $\$ 5,497,000$ & $81,598,000$ \\
\hline 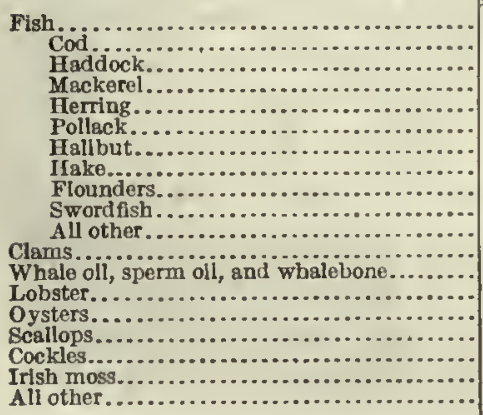 & $\begin{array}{r}5,637,000 \\
1,944,000 \\
1,038,000 \\
761,000 \\
342,000 \\
313,000 \\
310,000 \\
294,000 \\
146,000 \\
122,000 \\
367,000 \\
378,000 \\
336,000 \\
307,000 \\
218,000 \\
120,000 \\
34,000 \\
25,000 \\
40,000\end{array}$ & $\begin{array}{r}4,971,000 \\
1,81,000 \\
985,000 \\
742,000 \\
245,000 \\
265,000 \\
399,000 \\
281,000 \\
66,000 \\
121,000 \\
147,000 \\
14,000 \\
336,000 \\
14,000 \\
97,000 \\
14,000 \\
4,300\end{array}$ & $\begin{array}{r}666,000 \\
133,000 \\
52,000 \\
19,000 \\
97,000 \\
48,000 \\
1,700 \\
13,000 \\
81,000 \\
220,900 \\
365,000 \\
299,000 \\
121,000 \\
76,000 \\
29,000 \\
25,000 \\
21,000\end{array}$ \\
\hline
\end{tabular}

The products of the vessel fisheries represented 77 per cent of the total value, and those of the shore and boat fisheries 23 per cent. All the products shown separately in the table were reported for both classes of fisheries, with the exception of the whale products, which were confined to the vessel fisheries, and Irish moss, reported for the shore and boat fisheries only. Of the species not shown separately, 13 which were returned by the shore and boat fisheries were absent from the reports of vessel fisheries, and 12 appearing in the returns of the latter were not reported for the former. For the vessel fisheries the rank of the leading products with respect to value followed closely the order for the state as a whole - cod, haddock, and mackerel leading by a wide margin, with a combined value which formed 64 per cent of that of the total product of these fisheries. In the shore and boat fisheries, on the other hand, clams and lobsters led, with a value equal to 41 per cent of the total, and these were followed by cod, oysters, and herring.

Table 5, on page 163, gives the products of the vessel fisheries, by species and by county districts. The statistics of the vessel catch in cach district show the same general characteristics as those of the vessel catch of the state as a whole, except that for the Suffolk County district the value of the cod product is surpassed by that of haddock, while in the district designated as "All other counties" it was exceeded by that of the whale products.

Table 6 , on page 164 , gives the products of the shore and boat fisheries, by species and by county districts. In this class of fisheries conditions directly opposite to those appearing in the vessel fisheries exist, not only as to the rank of leading species, but also as to the importance of districts.

In the vessel fisheries Essex County contributed 47 per cent of the total value of products for the state; Suffolk County, 29 per cent; and "All other counties," 24 per cent. In the shore and boat fisheries, on the other liand, the district designated "All otlier counties" reported 63 per cent of the total value of products, while Essex County had 27 per cent and Suffolk County only 10 per cent. Only 14 species were taken in the Suffolk County shore and boat fisheries, of which four-lobsters, herring, cod, and flounderscontributed 70 per cent of the total value of the products. In Essex County twice that number of species were included in the shore and boat product, but 64 per cent of the value of this product represented the value of clams and lobsters. In the district designated "All other counties" 35 species made up the product. Although the quantities of cod, flounders, herring, haddock, pollack, and other important species reported were nearly as large or larger than those credited to the shore and boat fisheries of Essex or Suffolk County, the leading species were clams, lobsters, and oysters, which contributed 46 per cent of the total value of the products.

Products, by apparatus of capture.-The value of the catch, by each form of apparatus of capture, is given for the two classes of fisheries in the next tabular statement.

In the two classes of fisheries much the same apparatus was used, but the prominence of particular forms differed. Lines predominated in the ressel fisheries, while seines, gill nets, and whaling apparatus followed in importance in the order named. In the shore and boat fisheries the principal forms of apparatus, ranked according to the value of the catch, were dredges, tongs, etc.; pots and traps; lines; and pound nets, trap 
nets, and weirs. From this it will be seen that the leading kinds of apparatus in one class of fisheries were of minor importance in the other.

\begin{tabular}{|c|c|c|c|}
\hline \multirow[b]{2}{*}{ KLND OB APPARATUS. } & \multicolumn{3}{|c|}{ VALUE OZ PRODUCTS: 1908.} \\
\hline & Total. & $\begin{array}{l}\text { Vessel } \\
\text { fisberies. }\end{array}$ & $\begin{array}{l}\text { Shore and } \\
\text { boat } \\
\text { fisheries. }\end{array}$ \\
\hline Total............................... & $\$ 7,095,000$ & $\$ 5,497,000$ & $81,598,000$ \\
\hline 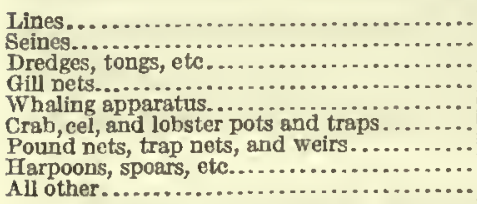 & $\begin{array}{r}3,930,000 \\
806,000 \\
741,000 \\
393,000 \\
336,000 \\
325,000 \\
266,000 \\
130,000 \\
169,000\end{array}$ & $\begin{array}{r}3,649,000 \\
754,000 \\
155,000 \\
384,000 \\
336,000 \\
15,000 \\
30,000 \\
122,000 \\
53,000\end{array}$ & $\begin{array}{r}281,000 \\
51,000 \\
586,000 \\
9,000 \\
310,000 \\
236,000 \\
7,800 \\
116,000\end{array}$ \\
\hline
\end{tabular}

The following tabular statement gives the value of the catch made with each form of apparatus of capture, by county districts:

\begin{tabular}{|c|c|c|c|c|}
\hline \multirow{2}{*}{ KIND OF APPARATUS. } & \multicolumn{4}{|c|}{ VALUE OP PRODUCTS: 1908.} \\
\hline & Total. & $\begin{array}{c}\text { Essex } \\
\text { County. }\end{array}$ & $\begin{array}{l}\text { Suffolk } \\
\text { County. }\end{array}$ & $\begin{array}{l}\text { All other } \\
\text { eounties. }\end{array}$ \\
\hline Total..... & $\$ 7,095,000$ & $\$ 3,030,000$ & $\$ 1,749,000$ & $\$ 2,316,000$ \\
\hline 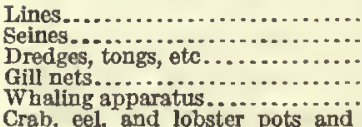 & $\begin{array}{r}3,930,000 \\
806,000 \\
741,000 \\
393,000 \\
336,000\end{array}$ & $\begin{array}{r}1,822,000 \\
539,000 \\
149,000 \\
276,000 \\
\ldots . . .\end{array}$ & $\begin{array}{r}1,410,000 \\
204,000 \\
14,000 \\
24,000\end{array}$ & $\begin{array}{r}698,000 \\
63,000 \\
578,000 \\
94,000 \\
336,000\end{array}$ \\
\hline 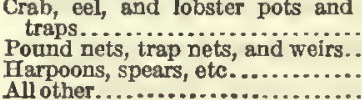 & $\begin{array}{l}325,000 \\
256,000 \\
130,000 \\
169,000\end{array}$ & $\begin{array}{r}121,000 \\
28,000 \\
63,000 \\
33,000\end{array}$ & $\begin{array}{l}35,000 \\
24,000 \\
39,000\end{array}$ & $\begin{array}{r}169,000 \\
238,000 \\
43,000\end{array}$ \\
\hline .......................... & 169,000 & 33,000 & 39,000 & 98,000 \\
\hline
\end{tabular}

The value of the line catch formed 55 per cent of the value of the total catch for the state and was the largest shown for any state, representing 42 per cent of the value of the total line catch of the United States. Although 30 species were taken with lines, 48 per cent of the value of the product taken in this way was contributed by cod. Nearly all of the cod, haddock, hake, and halibut and all of the cusk reported were taken by lines. The following tabular statement gives the value of the line catch, by principal species and by county districts:

\begin{tabular}{|c|c|c|c|c|}
\hline \multirow{2}{*}{ SPECIES. } & \multicolumn{4}{|c|}{ VALCE OF PRODUCT TAKEN WTIE LINES: 1908.} \\
\hline & Total. & $\begin{array}{c}\text { Essex } \\
\text { County. }\end{array}$ & $\begin{array}{l}\text { Suffolk } \\
\text { County. }\end{array}$ & $\begin{array}{l}\text { All other } \\
\text { countles. }\end{array}$ \\
\hline Total.... & $\$ 3,930,000$ & $\$ 1,822,000$ & $\$ 1,410,000$ & $\$ 698,000$ \\
\hline 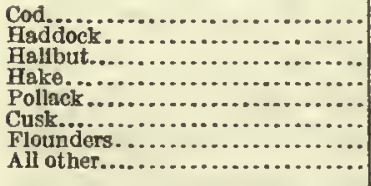 & $\begin{array}{r}1,876,000 \\
995,000 \\
309,000 \\
289,000 \\
250,000 \\
73,000 \\
61,000 \\
77,000\end{array}$ & $\begin{array}{r}1,035,000 \\
306,000 \\
229,000 \\
72,000 \\
131,000 \\
32,000 \\
2,500 \\
14,000\end{array}$ & $\begin{array}{r}531,000 \\
497,000 \\
61,000 \\
184,000 \\
54,000 \\
34,000 \\
27,000 \\
22,000\end{array}$ & $\begin{array}{r}310,000 \\
193,000 \\
20,000 \\
33,000 \\
65,000 \\
6,700 \\
31,000 \\
40,000\end{array}$ \\
\hline
\end{tabular}

The catch with seines represented only 11 per cent of the total value of products for the state, but ranked second to that with lines. The number of species captured by seines was 31 , of which mackerel contrib- uted 74 per cent of the total value of the catch by this form of apparatus. Essex County reported 67 per cent of the total value of the seine catch. The value of the seine product caught by vessel fisheries formed 94 per cent of the total value of product taken by this form of apparatus. The following tabular statement gives the value of the principal species captured by seines, for each county district:

\begin{tabular}{|c|c|c|c|c|}
\hline \multirow{2}{*}{ SPECIES. } & \multicolumn{4}{|c|}{ VALUE OF PRODUCT TAKEN IN SETNES: 1908.} \\
\hline & Total. & $\begin{array}{l}\text { Essex. } \\
\text { County. }\end{array}$ & $\begin{array}{l}\text { Suffolk } \\
\text { County. }\end{array}$ & $\begin{array}{l}\text { All other } \\
\text { counties. }\end{array}$ \\
\hline Total.... & 3806,000 & 8539,000 & 8204,000 & $\$ 63,000$ \\
\hline 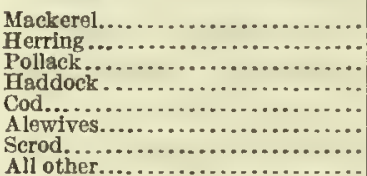 & $\begin{array}{r}594,000 \\
63,000 \\
42,000 \\
33,000 \\
22,000 \\
16,000 \\
11,000 \\
26,000\end{array}$ & $\begin{array}{r}435,000 \\
39,000 \\
36,000 \\
2,200 \\
17,000 \\
2,200 \\
8,500\end{array}$ & $\begin{array}{r}131,000 \\
16,000 \\
5,200 \\
30,000 \\
5,400 \\
\quad 11,000 \\
11,000\end{array}$ & $\begin{array}{r}28,000 \\
8,200 \\
400 \\
\ldots \ldots \ldots \\
114,000\end{array}$ \\
\hline
\end{tabular}

Dredges, tongs, etc., ranked third in the value of the product taken. The following tabular statement gives the value of the catch, by species and by county districts:

\begin{tabular}{|c|c|c|c|c|}
\hline \multirow{2}{*}{ SPECTES. } & \multicolumn{4}{|c|}{$\begin{array}{c}\text { VARUE OF PRODUCT TAKEN WITH DREDOES, } \\
\text { TONGS, ETC.: } 1908 .\end{array}$} \\
\hline & Total. & $\begin{array}{l}\text { Essex } \\
\text { County. }\end{array}$ & $\begin{array}{l}\text { Suffolk } \\
\text { County. }\end{array}$ & $\begin{array}{l}\text { All other } \\
\text { counties. }\end{array}$ \\
\hline Total.. & 8741,000 & $\$ 149,000$ & $\$ 14,000$ & $\$ 578,000$ \\
\hline Clams........ & 372,000 & 148,000 & 9,600 & 215,000 \\
\hline $\begin{array}{l}\text { Oysters...... } \\
\text { Scallops.... }\end{array}$ & $\begin{array}{l}218,000 \\
120,000\end{array}$ & $\ldots . . . . .$. & & $\begin{array}{l}218,000 \\
10,000\end{array}$ \\
\hline Irish mooss. . & 25,000 & 300 & & 25,000 \\
\hline & $\begin{array}{l}5,000 \\
200\end{array}$ & $\begin{array}{l}600 \\
200\end{array}$ & 4,400 & \\
\hline $\begin{array}{l}\text { Crabs, soft .............. } \\
\text { Mussels............... }\end{array}$ & 100 & 100 & & \\
\hline
\end{tabular}

Of the value of the product taken in this manner, 79 per cent was reported by the shore and boat fisheries. The amount returned by the vessel fisheries was entirely from the district designated "All other counties."

Gill nets took products valued at 6 per cent of the total, 87 per cent of the value representing that of herring and mackerel. The gill-net catch was reported principally by the vessel fisheries, and 70 per cent of the value was contributed by the Essex County district. The following tabular statement gives the value of the gill-net catch, by principal species and by county districts:

\begin{tabular}{|c|c|c|c|c|}
\hline \multirow[b]{2}{*}{ SPECIES. } & \multicolumn{4}{|c|}{ VALUE OF PRODUCT TAKEN IN GILL NETS: 1908.} \\
\hline & Total. & $\begin{array}{c}\text { Essex } \\
\text { County. }\end{array}$ & $\begin{array}{l}\text { Suffoik } \\
\text { County. }\end{array}$ & $\begin{array}{l}\text { All other } \\
\text { countles. }\end{array}$ \\
\hline Total.. & $\$ 393,000$ & 8276,000 & $\$ 24,000$ & $\$ 94,000$ \\
\hline \multirow{4}{*}{ 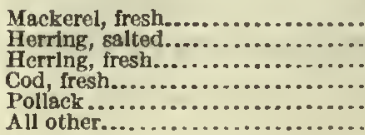 } & \multirow{4}{*}{$\begin{array}{r}146,000 \\
102,000 \\
93,000 \\
38,000 \\
6,400 \\
8,800\end{array}$} & \multirow{4}{*}{$\begin{array}{r}46,000 \\
102,000 \\
84,000 \\
34,000 \\
6,400 \\
3,000\end{array}$} & 16,000 & 84,000 \\
\hline & & & $\cdots$ & \\
\hline & & & $\begin{array}{l}6,430 \\
1,700\end{array}$ & $\begin{array}{l}2,100 \\
1,600\end{array}$ \\
\hline & & & & 3,800 \\
\hline
\end{tabular}


Principal species.-Table 7, on page 164, gives the yield of the more important species during earlier years for which complete statistics are available, together with the percentage of the total value of products formed by the value of each species. The species are ranked in the order of the value of the catch in 1908.

Cod.-The most important product of the Massachusetts fisheries was cod, which contributed 28 per cent of the total value in 1908 . The state catch of cod formed $6 b^{3}$ per cent of that of the United States. The quantity and value of the product were less in 1908 than in 1889, but greater than for any other year shown. Cod were taken chiefly by the vessel fisheries, which reported 93 per cent of the total value. Fiftythree per cent of the aggregate product was taken by the Essex County fishermen. Nearly the whole product, 97 per cent, was caught by lines.

Haddock.--Haddock ranked second in value, contributing 15 per cent of the total value of the Massachusetts product. The Massachusetts catch contributed 80 per cent of the total value of the haddock product of the United States and was taken almost wholly in the vessel fisheries. The catch increased in weight and value in the period from 1889 to 1905 , but prior to 1902 it was outranked in value by halibut and in 1902 by mackerel. Suffolk County had a larger product than Essex County, slightly over half of the total being taken in the former district. About the same proportion of haddock as of cod, 96 per cent of the total value, was taken with lines.

Mackerel.-The catch of this species, which stood third in value, contributed 11 per cent of the total value of the Massachusetts product, and represented 90 per cent of the value of the entire mackerel product of the United States. The 1908 catch was the smallest since 1898 , both in quantity and value. In 1902 mackerel ranked next to cod. Vessel fisheries took 97 per cent of the 1908 catch, on the basis of value, and of the value credited to this class of fisheries 65 per cent was reported by the Essex County district. Mackerel were taken mostly with seines, 78 per cent of the total value representing the value of the seine haul. Gill nets took most of the remainder, the catch with this form of apparatus representing 19 per cent of the total value.

Herring.-The value of the herring product constituted 5 per cent of the total value of products for the state, and 43 per cent of the total value of herring for the United States, Massachusetts ranking second to Maine in this respect. Both the weight and the value of the herring catch have fluctuated more or less at the various canvasses, but the percentage which the catch represents of the total value of products of the state has decreased steadily since 1898. Since 1905, despite a large increase in quantity, this fish has suffered a substantial decrease in value. Of the total value of the herring product, 72 per cent was reported by the vessel fisheries and 28 per cent by the shore and boat fisheries. Essex County furnished 74 per cent of the total value for the state. The largest catch of herring, representing 57 per cent of the total value, was made by gill nets. The catch with seines represented 18 per cent of the value, while nearly all the remaining value was credited to pound and trap nets and to dip nets in proportions approximately equal.

Pollack.-Pollack was another important species, the value of the Massachusetts catch constituting over three-fourths of the value of the total pollack product for the country. Nearly 85 per cent of the Massachusetts catch was made in vessel fisheries, while more than one-half of this total value came from the Essex County district. In value and in relative importance, pollack has increased rapidly and uniformly since 1898, although in 1908 the quantity taken was considerably less than in 1905 . Of the total value of the pollack product reported in 1908 , 80 per cent represented the value of the catch taken with lines.

Halibut.-The halibut catch showed an increase in both quantity and value in 1908 over 1905, but a marked falling off as compared with the returns for earlier years. In 1889 and 1898 it ranked next to cod, and not until the canvass of 1905 did it represent less than 10 per cent of the total value of products for the state. The catch of this state, though far below that of Washington, contributed 20 per cent of the total value of the halibut product of the United States and ranked second in importance. Halibut was practically a vessel fishery product. Only 6 per cent came from the southern counties of Massachusetts, 74 per cent being reported from Essex County. Nearly all of the product was taken with lines.

Hake.-The Massachusetts hake product represented 63 per cent of the total value of the hake catch for the United States. In spite of the great fluctuations in quantity, the value has steadily increased since 1889 . It is preeminently a vessel fishery product. Twentyfive per cent of the total value was reported by the Essex County district and 63 per cent by the Suffolk County district. Practically the entire catch was made by lines.

Catfish.-Catfish, or wolf fish, were taken to the value of $\$ 8,000$. Nearly the entire catch, amounting to 557,000 pounds, was taken with lines. The vessel fisheries were credited with 368,000 pounds, valued at $\$ 4,400$.

Clams.-Hard, soft, and razor clams were reported by the Massachusetts fisheries. The latter species were not taken in large quantities. For the other two species the values of the product reported were nearly the same. Clams were taken almost wholly in shore and boat fisheries. Fifty-seven per cent of 
the total value of the state product was from the district designated as "All other counties," Essex County being the source of nearly all the remainder.

Whale products.--The value of the whale oil, sperm oil, and whalebone reported from Massachusetts, about two-thirds of which represented the value of sperm oil alone, comprised 68 per cent of the total reported for the United States in 1908. Since 1889 the value of the whale products of the state has decreased more or less steadily, the year 1898 alone showing a smaller value than 1908 . These products, which were exclusively vessel fishery products, were taken principally by the New Bedford whaling fleets and were reported solely from the district "All other counties," of which they formed the leading product.

Lobster.-In the catch of lobster Massachusetts was second to Maine. The large increase in quantity and value in 1908 as compared with 1905 is worthy of note, compared with the gradual decrease in quantity and slight increase in value shown for prior canvasses. Over 95 per cent of the total value of the lobster product represented the value of lobster taken in shore and boat fisheries. Fifty per cent of the total value was contributed by counties included under the head "All otlier counties," while 39 per cent represented the value of the Essex County product.

Oysters.-Though taken in quantities sufficient to class them among the more important products of the Massachusetts fisheries, oysters were of far less importance than in states to the south. The quantity taken has increased steadily, but the value of the product has fluctuated greatly. Private beds furnished 96 per cent of the entire quantity. Of the total value of the oyster product, 45 per cent represented the value of the oysters taken in the vessel fisheries, and 55 per cent the value of those taken in the shore and boat fisheries. The entire product came from the southern counties. Forty thousand bushels of oysters, valued at $\$ 47,000$, were taken by Connecticut fishermen from waters of Massachusetts, but are included in the statistics for Connecticut. 
TABLE 1.-MASSACHUSETTS-FISHERY PRODUCTS: 1908.

\begin{tabular}{|c|c|c|c|c|c|c|c|c|c|c|c|c|}
\hline \multirow{3}{*}{ BPECTES. } & \multirow{2}{*}{\multicolumn{2}{|c|}{ TOTAL. }} & \multicolumn{4}{|c|}{ 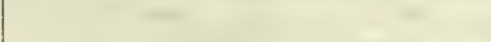 } & \multicolumn{6}{|c|}{ PRODUCT CAUGET BY- } \\
\hline & & & \multicolumn{2}{|c|}{ Lines. } & \multicolumn{2}{|c|}{ Seines.2 } & \multicolumn{2}{|c|}{ Oill nets. } & \multicolumn{2}{|c|}{$\begin{array}{l}\text { Pound aets, trap nets, } \\
\text { and weirs. }\end{array}$} & \multicolumn{2}{|c|}{ All other apparatus. } \\
\hline & $\begin{array}{l}\text { Quantity } \\
\text { (pounds). }\end{array}$ & Value. & $\begin{array}{l}\text { Quantity } \\
\text { (pounds). }\end{array}$ & Value. & $\begin{array}{l}\text { Quantity } \\
\text { (pounds). }\end{array}$ & Value. & $\begin{array}{l}\text { Quantity } \\
\text { (pouads). }\end{array}$ & Value. & $\begin{array}{l}\text { Quantity } \\
\text { (pounds). }\end{array}$ & Value. & $\begin{array}{l}\text { Quantity } \\
\text { (pounds). }\end{array}$ & Value. \\
\hline Total... & $244,313,000$ & $\$ 7,095,000$ & $161,888,000$ & $\$ 3,930,000$ & $25,397,000$ & $\$ 806,000$ & $14,885,000$ & $\$ 393,000$ & $18,641,000$ & $\$ 266,000$ & $23,503,000$ & $\$ 1,701,000$ \\
\hline 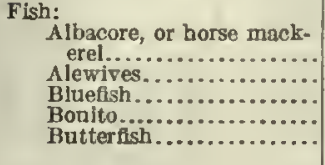 & $\begin{array}{r}92,000 \\
4,062,000 \\
42,000 \\
65,000 \\
67,000\end{array}$ & $\begin{array}{r}5,400 \\
45,000 \\
4,300 \\
4,000 \\
3,500\end{array}$ & $\begin{array}{r}11,000 \\
200 \\
300\end{array}$ & $(2)^{3}$ & $\begin{array}{r}1,693,000 \\
6,200 \\
7,400\end{array}$ & $\begin{array}{r}16,000 \\
600 \\
600\end{array}$ & $\begin{array}{r}25,000 \\
9,300 \\
3,200\end{array}$ & $\begin{array}{l}400 \\
1,400 \\
100\end{array}$ & $\begin{array}{r}92,000 \\
1,052,000 \\
15,000 \\
65,000 \\
57,000\end{array}$ & $\begin{array}{l}5,400 \\
7,000 \\
1,100 \\
3,900 \\
2,800\end{array}$ & $\begin{array}{c}1,292,000 \\
\ldots \ldots \ldots \ldots \ldots \\
\ldots \ldots \ldots \ldots\end{array}$ & $\begin{array}{r}20,000 \\
\cdots \ldots \ldots \ldots \\
\cdots \ldots \ldots\end{array}$ \\
\hline 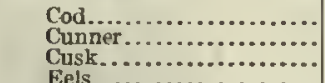 & $\begin{array}{r}72,819,000 \\
102,000 \\
4,267,000\end{array}$ & $\begin{array}{r}1,955,000 \\
5,6000 \\
73,000\end{array}$ & $\begin{array}{r}69,191,000 \\
600 \\
4,267,000\end{array}$ & $\begin{array}{l}1,876,000 \\
(8) \\
73,000\end{array}$ & $\begin{array}{r}1,590,000 \\
.\end{array}$ & $\begin{array}{r}33,000 \\
\cdots \cdots\end{array}$ & $\begin{array}{r}1,750,000 \\
\cdots \\
\cdots\end{array}$ & 38.000 & $\begin{array}{r}288,000 \\
2,300\end{array}$ & $\begin{array}{r}8,200 \\
100\end{array}$ & 99,000 & $\begin{array}{r}5,500 \\
\ldots \ldots\end{array}$ \\
\hline $\begin{array}{l}\text { Eels........................ } \\
\text { Flounders............... }\end{array}$ & $7,124,000$ & $\begin{array}{r}32,000 \\
146,000\end{array}$ & $\begin{array}{r}118,000 \\
3,105,000\end{array}$ & $\begin{array}{r}5,800 \\
61,000\end{array}$ & $\begin{array}{l}154,000 \\
342,000\end{array}$ & $\begin{array}{r}700 \\
5,700\end{array}$ & iii,000 & 2,600 & $\begin{array}{r}47,000 \\
616,000\end{array}$ & $\begin{array}{r}1,000 \\
12,000\end{array}$ & $\begin{array}{r}403,000 \\
2,950,000\end{array}$ & $\begin{array}{l}\dddot{2} 5,0000 \\
66,000\end{array}$ \\
\hline $\begin{array}{l}\text { Hadiock................ } \\
\text { Hake..................... } \\
\text { Halibut............... }\end{array}$ & $\begin{array}{r}48,492,000 \\
16,708,000 \\
4,145,000\end{array}$ & $\begin{array}{r}1,038,000 \\
294,000 \\
310,000\end{array}$ & $\begin{array}{r}46,649,000 \\
16,192,000 \\
4,136,000\end{array}$ & $\begin{array}{l}995,100 \\
289,000 \\
309,000\end{array}$ & $\begin{array}{r}1,436,000 \\
67,000 \\
9,600\end{array}$ & $\begin{array}{r}33,000 \\
1,000 \\
1,000\end{array}$ & $\begin{array}{r}104,000 \\
43,000\end{array}$ & $\begin{array}{r}1,300 \\
500\end{array}$ & $\begin{array}{l}303,000 \\
407,000\end{array}$ & $\begin{array}{l}8,600 \\
3,500\end{array}$ & & \\
\hline Herring.................. & $28,501,000$ & 342,000 & & & $7,554,000$ & 63,000 & $9,936,000$ & 195,000 & $5,536,000$ & 44,000 & $5,476,000$ & 40,000 \\
\hline 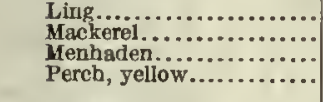 & $\begin{array}{r}73,000 \\
10,453,000 \\
258,000 \\
19,000\end{array}$ & $\begin{array}{r}1,300 \\
761,000 \\
1,400 \\
1,000\end{array}$ & $\begin{array}{r}73,000 \\
66,000 \\
\cdots \cdots\end{array}$ & $\begin{array}{r}1,300 \\
3,200 \\
\cdots \cdots \\
\cdots\end{array}$ & $\begin{array}{r}8,006,000 \\
253,000 \\
19,000\end{array}$ & $\begin{array}{r}594,000 \\
1,300 \\
1,000\end{array}$ & $\begin{array}{r}2,147,000 \\
\cdots \cdots \cdots \cdots \\
\cdots \cdots \cdots\end{array}$ & 146,000 & $\begin{array}{r}233,000 \\
5,000 \\
\ldots .\end{array}$ & $\begin{array}{r}18,000 \\
200\end{array}$ & 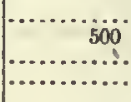 & (i) \\
\hline 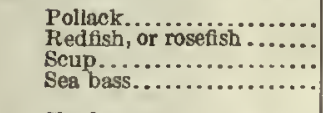 & $\begin{array}{r}20,006,000 \\
303,000 \\
1,136,000 \\
114,000\end{array}$ & $\begin{array}{r}313,000 \\
2,700 \\
40,000 \\
8,400\end{array}$ & $\begin{array}{r}14,668,000 \\
300,000 \\
329,000 \\
77,000\end{array}$ & $\begin{array}{r}250,000 \\
2,700 \\
12,000 \\
5,700\end{array}$ & $\begin{array}{r}3,816,000 \\
200 \\
800\end{array}$ & $\begin{array}{l}42,000 \\
(\Sigma) \\
(3) \\
\cdots\end{array}$ & $\begin{array}{r}565,000 \\
3,200 \\
13,000 \\
\ldots\end{array}$ & $\begin{array}{c}6,400 \\
(3) \\
400 \\
.\end{array}$ & $\begin{array}{r}957,000 \\
793,000 \\
37,000\end{array}$ & $\begin{array}{r}15,000 \\
27,000 \\
2,700\end{array}$ & 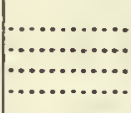 & $\mid \begin{array}{l}\ldots \ldots \ldots \\
\cdots \ldots \ldots \ldots\end{array}$ \\
\hline 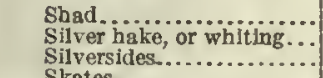 & $\begin{array}{r}389,000 \\
5,589,000 \\
3,500\end{array}$ & $\begin{array}{r}12,000 \\
39,000 \\
600\end{array}$ & $\ddot{021}, 000$ & $\ddot{8}, \ddot{300}$ & $\begin{array}{r}367,000 \\
1,000 \\
3,500\end{array}$ & $\begin{array}{c}11,000 \\
\left({ }^{8}\right) \\
600\end{array}$ & $\begin{array}{r}2,000 \\
125,000 \\
0\end{array}$ & $\begin{array}{r}100 \\
1,300\end{array}$ & $\begin{array}{r}20,000 \\
4,540,000\end{array}$ & $\begin{array}{r}700 \\
29,000\end{array}$ & & \\
\hline Skstes................... & 93,000 & 700 & 37,000 & 300 & 12,000 & 100 & 5,000 & $\dddot{100}$ & 14,000 & 200 & 25,000 & 100 \\
\hline $\begin{array}{l}\text { Smelt................... } \\
\text { Squeteague, or weakfish.. } \\
\text { Strjped bass............... } \\
\text { Sturgeon............... }\end{array}$ & $\begin{array}{r}16,000 \\
1,971,000 \\
5,100 \\
5,300\end{array}$ & $\begin{array}{r}2,500 \\
58,000 \\
800 \\
500\end{array}$ & $\begin{array}{r}13,000 \\
92,000 \\
2,900\end{array}$ & $\begin{array}{r}2,200 \\
2,000 \\
300 \\
3\end{array}$ & $\begin{array}{r}3,200 \\
1,000 \\
200\end{array}$ & $\begin{array}{l}(8)^{300} \\
(8)^{3 \cdots}\end{array}$ & $\begin{array}{l}30,000 \\
\cdots \cdots \\
\cdots \cdots\end{array}$ & $\begin{array}{l}400 \\
\cdots \cdots\end{array}$ & $\begin{array}{r}1,848,000 \\
200 \\
5,100\end{array}$ & $\begin{array}{l}56,000 \\
(2)_{500}\end{array}$ & 2,000 & 800 \\
\hline 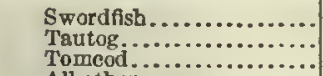 & $\begin{array}{r}1,642,000 \\
170,000 \\
7,000\end{array}$ & $\begin{array}{r}122,000 \\
6,300 \\
200\end{array}$ & $\begin{array}{r}149,000 \\
5,000\end{array}$ & $\begin{array}{r}5,600 \\
100\end{array}$ & 2,000 & 100 & & & $\begin{array}{l}21,000 \\
\cdots \ldots\end{array}$ & 700 & $\begin{array}{l}1,642,000 \\
\ldots \ldots \ldots \ldots \\
\ldots \ldots \ldots \ldots\end{array}$ & $\begin{array}{r}122,000 \\
\cdots \cdots \\
\cdots\end{array}$ \\
\hline 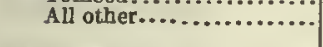 & 604,000 & 8,400 & 553,000 & 7,800 & 33,000 & 400 & $\ddot{9}, 100$ & $" 1000$ & $\ddot{8}, 000$ & $\cdots$ & 600 & $(a) \cdots$ \\
\hline 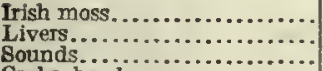 & $\begin{array}{r}737,000 \\
605,000 \\
73,000\end{array}$ & $\begin{array}{r}25,000 \\
6,900 \\
3,100\end{array}$ & $\begin{array}{r}601,000 \\
73,000\end{array}$ & $\begin{array}{l}6,800 \\
3,100\end{array}$ & & (n) & $\begin{array}{r}4,000 \\
\ldots \ldots\end{array}$ & (8) & & & $\begin{array}{l}737,000 \\
.\end{array}$ & $\begin{array}{l}25,000 \\
\ldots \ldots\end{array}$ \\
\hline & 121,000 & 2,400 & & 3,100 & 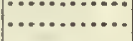 & $\cdots \cdots$ & & & & & $\ddot{121,000}$ & 2,400 \\
\hline Crabs, soft................... & 1,800 & 200 & & & & & & & & & 1,800 & \\
\hline 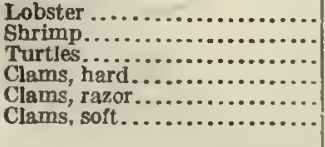 & $\begin{array}{r}2,455,000 \\
5,800 \\
1,300 \\
+1,119,000 \\
82,000 \\
1,916,000\end{array}$ & $\begin{array}{r}307,000 \\
1,300 \\
(3) \\
189,000 \\
3,600 \\
186,000\end{array}$ & & 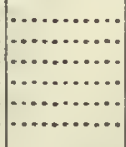 & 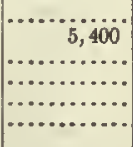 & 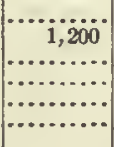 & & & $\begin{array}{r}200 \\
100\end{array}$ & $\mid \begin{array}{c}\left({ }^{2}\right) \\
(i) \\
\cdots \cdots \cdots \\
\cdots \cdots \cdots \\
\cdots \cdots \\
\cdots \cdots\end{array}$ & $\begin{array}{r}2,455,000 \\
400 \\
1,200 \\
+1,119,000 \\
24,000 \\
1,916,000\end{array}$ & $\begin{array}{r}307,000 \\
100 \\
189,000 \\
3,600 \\
186,000\end{array}$ \\
\hline 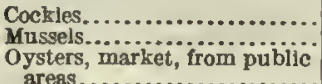 & $\begin{array}{r}130,000 \\
1,100\end{array}$ & $\begin{array}{r}34,000 \\
100\end{array}$ & & & & & & & & & $\begin{array}{r}730,000 \\
\quad 1,100\end{array}$ & $\begin{array}{r}34,000 \\
100\end{array}$ \\
\hline $\begin{array}{l}\text { areas. } \\
\text { oysters, market, from private } \\
\text { areas...................................... }\end{array}$ & $\begin{array}{r}4,900 \\
10863,000\end{array}$ & $\begin{array}{r}900 \\
202,000\end{array}$ & & & & & & & & & $\begin{array}{r}4,900 \\
10863,000\end{array}$ & $\begin{array}{r}900 \\
202,000\end{array}$ \\
\hline $\begin{array}{l}\text { Oysters, seed, from public } \\
\text { areas................................ } \\
\text { Oysters, seed, from private }\end{array}$ & if 43,000 & 3,100 & & & & & & & & & ut 43,000 & 3,100 \\
\hline $\begin{array}{l}\text { Oysters, seed, from private } \\
\text { areas......................................... }\end{array}$ & 12173,000 & 12,000 & & & & & & & & & 12173,000 & 12,000 \\
\hline 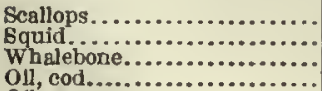 & $\begin{array}{r}18502,000 \\
1,837,000 \\
30,000 \\
14138,000\end{array}$ & $\begin{array}{r}120,000 \\
20,000 \\
89,000 \\
5,000\end{array}$ & $\begin{array}{r}121,000 \\
\cdots i 1338,000\end{array}$ & $\begin{array}{r}2,200 \\
5,900\end{array}$ & $\begin{array}{l}10,000 \\
\ldots \ldots \\
\ldots\end{array}$ & 200 & & & i, 680,000 & 17,000 & $\begin{array}{r}12502,000 \\
25,000 \\
30,000\end{array}$ & $\begin{array}{r}120,000 \\
400 \\
89,000\end{array}$ \\
\hline 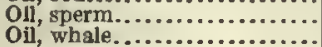 & $\begin{array}{r}15,913,000 \\
1653,000\end{array}$ & 218,000 & ............ & ............. & & & & & & & ii $2,913.000$ & $\ddot{218}, 0000$ \\
\hline & ${ }^{16} 553,000$ & 28,000 & & & & & & & & & ${ }^{16} 553,000$ & 28,000 \\
\hline
\end{tabular}

1 Includes otter trawls.

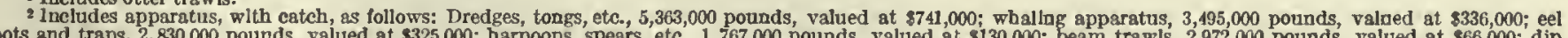

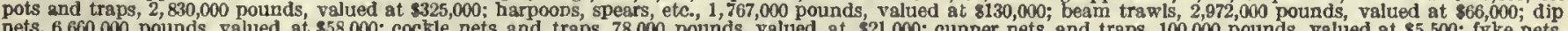

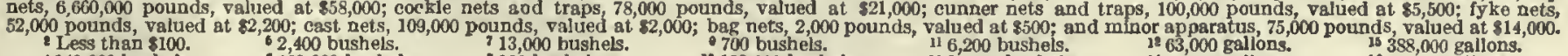

Less than $\$ 100$.

13,000 bushel.

10 700 bushels.

1225,000 busheis.

14 18,000 gallons.

10 74000 gallons. 
TABLE 2.-MASSACHUSETTS-FISHERY PRODUCTS, BY COUNTY DISTRICTS: I908.

\begin{tabular}{|c|c|c|c|c|c|c|c|c|}
\hline \multirow{2}{*}{ SPECTES. } & \multicolumn{2}{|c|}{ TOTAL. } & \multicolumn{2}{|c|}{ ESSEX COUNTY. } & \multicolumn{2}{|c|}{ SUFFOLK COUNTY. } & \multicolumn{2}{|c|}{ ALL OTHER COUNTIES. } \\
\hline & $\begin{array}{l}\text { Quantity } \\
\text { (pounds). }\end{array}$ & Value. & $\begin{array}{l}\text { Quantity } \\
\text { (pounds). }\end{array}$ & Value. & $\begin{array}{l}\text { Quantity } \\
\text { (pounds). }\end{array}$ & Value. & $\begin{array}{l}\text { Quantity } \\
\text { (pounds). }\end{array}$ & Value. \\
\hline Total........... & $244,313,000$ & $\$ 7,095,000$ & $106,007,000$ & $\$ 3,030,000$ & $76,030,000$ & $\$ 1,749,000$ & $62,276,000$ & $\$ 2,316,000$ \\
\hline 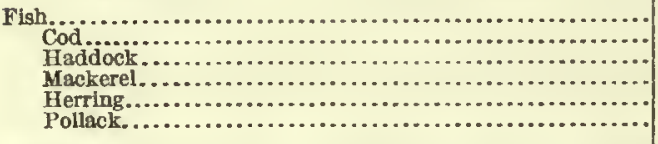 & $\begin{array}{r}230,066,000 \\
72,819,000 \\
48,492,000 \\
10,453,000 \\
28,501,000 \\
20,006,000\end{array}$ & $\begin{array}{r}5,637,000 \\
1,955,000 \\
1,038,000 \\
761,000 \\
342,000 \\
313,000\end{array}$ & $\begin{array}{r}103,005,000 \\
38,339,000 \\
14,770,000 \\
6,475,000 \\
17,342,000 \\
12,474,000\end{array}$ & $\begin{array}{r}2,736,000 \\
1,087,000 \\
309,000 \\
483,000 \\
252,000 \\
175,000\end{array}$ & $\begin{array}{r}75,117,000 \\
22,991,000 \\
24,511,000 \\
2,017,000 \\
6,441,000 \\
3,278,000\end{array}$ & $\begin{array}{r}1,680,000 \\
549,000 \\
527,000 \\
147,000 \\
47,000 \\
59,000\end{array}$ & $\begin{array}{r}51,944,000 \\
11,489,000 \\
9,211,000 \\
1,961,000 \\
4,718,000 \\
4,255,000\end{array}$ & $\begin{array}{r}1,221,000 \\
319,000 \\
202,000 \\
131,000 \\
43,000 \\
78,000\end{array}$ \\
\hline 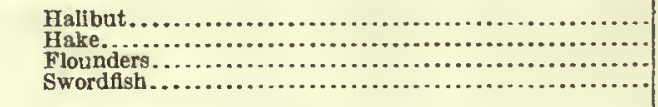 & $\begin{array}{r}4,145,000 \\
16,708,000 \\
7,124,000 \\
1,642,000\end{array}$ & $\begin{array}{l}310,000 \\
294,000 \\
146,000 \\
122,000\end{array}$ & $\begin{array}{r}3,230,000 \\
4,356,000 \\
338,000 \\
795,000\end{array}$ & $\begin{array}{r}229,000 \\
74,000 \\
4,300 \\
61,000\end{array}$ & $\begin{array}{r}682,000 \\
10,254,000 \\
1,394,000 \\
270,000\end{array}$ & $\begin{array}{r}62,000 \\
185,000 \\
29,000 \\
24,000\end{array}$ & $\begin{array}{r}233,000 \\
2,098,000 \\
5,391,000 \\
577,000\end{array}$ & $\begin{array}{r}20,000 \\
36,000 \\
113,000 \\
37,000\end{array}$ \\
\hline 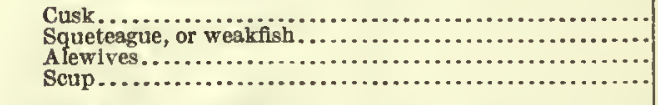 & $\begin{array}{l}4,267,000 \\
1,971,000 \\
4,062,000 \\
1,136,000\end{array}$ & $\begin{array}{l}73,000 \\
58,000 \\
45,000 \\
40,000\end{array}$ & $\begin{array}{r}1,845,000 \\
542,000 \\
3,000\end{array}$ & $\begin{array}{c}32,000 \\
3,300 \\
100\end{array}$ & $\begin{array}{c}2,029,000 \\
\cdots \ldots \ldots \ldots \\
\cdots, \ldots \ldots \ldots\end{array}$ & 34,000 & $\begin{array}{r}393,000 \\
1,971,000 \\
3,520,000 \\
1,133,000\end{array}$ & $\begin{array}{r}6,700 \\
58,000 \\
41,000 \\
40,000\end{array}$ \\
\hline 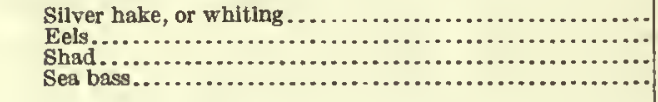 & $\begin{array}{r}5,589,000 \\
722,000 \\
389,000 \\
114,000\end{array}$ & $\begin{array}{r}39,000 \\
32,000 \\
12,000 \\
8,400\end{array}$ & $\begin{array}{l}1,503,000 \\
202,000 \\
308,000 \\
(1)\end{array}$ & $\begin{array}{r}4,000 \\
3,600 \\
7,900 \\
(3)\end{array}$ & $\begin{array}{r}712,000 \\
91,000 \\
10,000 \\
\end{array}$ & $\begin{array}{r}7,100 \\
5,500 \\
300 \\
\cdots\end{array}$ & $\begin{array}{r}3,374,000 \\
429,000 \\
72,000 \\
114,000\end{array}$ & $\begin{array}{r}28,000 \\
23,000 \\
3,300 \\
8,400\end{array}$ \\
\hline 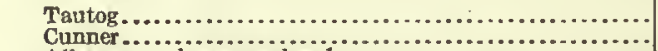 & $\begin{array}{l}170,000 \\
102,000\end{array}$ & $\begin{array}{l}6,300 \\
5,600\end{array}$ & $\begin{array}{r}800 \\
73,000\end{array}$ & ${ }_{4}^{(3)}, 000$ & 29,000 & 1,600 & 169,000 & $\begin{array}{r}6,300 \\
\cdots\end{array}$ \\
\hline 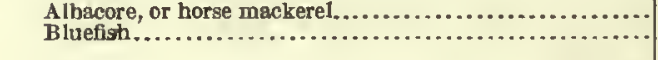 & $\begin{array}{l}92,000 \\
42,000\end{array}$ & $\begin{array}{l}5,400 \\
4,300\end{array}$ & $\begin{array}{r}8,800 \\
900\end{array}$ & $\begin{array}{l}300 \\
100\end{array}$ & .......... & ........ & $\begin{array}{l}83,000 \\
41,000\end{array}$ & $\begin{array}{l}3,100 \\
4,200\end{array}$ \\
\hline 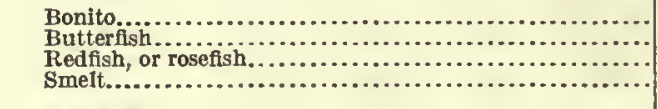 & $\begin{array}{r}65,000 \\
67,000 \\
303,000 \\
16,000\end{array}$ & $\begin{array}{l}4,000 \\
3,500 \\
2,700 \\
2,500\end{array}$ & $\begin{array}{r}200 \\
5,000 \\
162,000 \\
10,000\end{array}$ & $\begin{array}{r}(2) \\
1,600 \\
1,800\end{array}$ & $\begin{array}{r}6,900 \\
139,000 \\
500\end{array}$ & $\begin{array}{r}600 \\
1,100 \\
100\end{array}$ & $\begin{array}{r}65,000 \\
56,000 \\
2,000 \\
5,000\end{array}$ & $\begin{array}{r}4,000 \\
2,700 \\
(2) \quad 700\end{array}$ \\
\hline 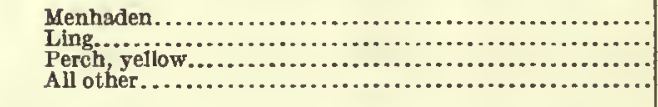 & $\begin{array}{r}258,000 \\
73,000 \\
19,000 \\
717,000\end{array}$ & $\begin{array}{r}1,400 \\
1,300 \\
1,000 \\
11,000\end{array}$ & $\begin{array}{r}3,300 \\
210,000\end{array}$ & $\ddot{3}, 2000$ & (n................ & 2,400 & $\begin{array}{r}255,000 \\
73,000 \\
19,000 \\
239,000\end{array}$ & $\begin{array}{l}1,400 \\
1,300 \\
1,000 \\
5,500\end{array}$ \\
\hline 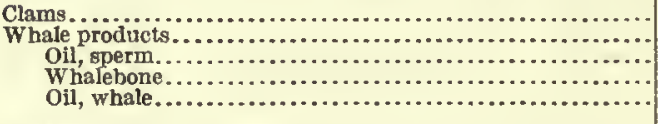 & $\begin{array}{r}3,060,000 \\
3,495,000 \\
+2,913,000 \\
30,000 \\
\quad 553,000\end{array}$ & $\begin{array}{r}378,000 \\
336,000 \\
218,000 \\
89,000 \\
28,000\end{array}$ & 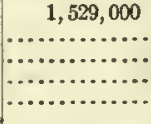 & $\begin{array}{l}153,000 \\
\cdots \ldots \ldots \ldots \\
\cdots \cdots \cdots\end{array}$ & $\begin{array}{r}124,000 \\
\cdots\end{array}$ & $\begin{array}{c}9,600 \\
\cdots \cdots \\
\cdots \\
\cdots\end{array}$ & $\begin{array}{r}1,407,000 \\
3,495,000 \\
+2,913,000 \\
30,000 \\
\quad 553,000\end{array}$ & $\begin{array}{r}215,000 \\
336,000 \\
218,000 \\
89,000 \\
28,000\end{array}$ \\
\hline 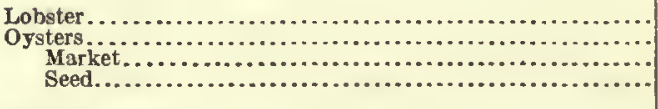 & $\begin{array}{l}2,455,000 \\
1,084,000 \\
8868,000 \\
7216,000\end{array}$ & $\begin{array}{r}307,000 \\
218,000 \\
203,000 \\
15,000\end{array}$ & 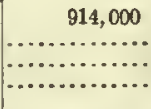 & $\begin{array}{l}120,000 \\
\cdots \cdots \cdots \\
\cdots \cdots \cdots \\
\cdots \cdots\end{array}$ & $\begin{array}{c}217,000 \\
\ldots \ldots\end{array}$ & 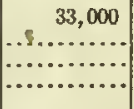 & $\begin{array}{l}1,324,000 \\
1,084,000 \\
8868,000 \\
7216,000\end{array}$ & $\begin{array}{r}154,000 \\
218,000 \\
203,000 \\
15,000\end{array}$ \\
\hline 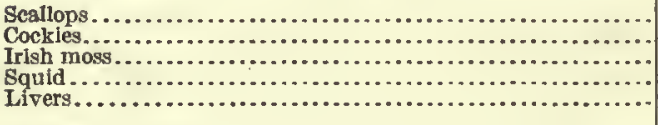 & $\begin{array}{r}502,000 \\
130,000 \\
737,000 \\
1,837,000 \\
605,000\end{array}$ & $\begin{array}{r}120,000 \\
34,000 \\
25,000 \\
20,000 \\
6,900\end{array}$ & $\begin{array}{r}41,000 \\
7,500 \\
132,000 \\
283,000\end{array}$ & $\begin{array}{r}11,000 \\
300 \\
2,400 \\
3,300\end{array}$ & $\begin{array}{r}69,000 \\
\cdots \cdots \\
310,000\end{array}$ & $\begin{array}{r}17,000 \\
\cdots \cdots \ldots . . . . . . \\
3,400 \\
\cdots \cdots\end{array}$ & $\begin{array}{r}8502,000 \\
821,000 \\
730,000 \\
1,705,000 \\
12,000\end{array}$ & $\begin{array}{r}120,000 \\
6,100 \\
25,000 \\
17,000 \\
100\end{array}$ \\
\hline 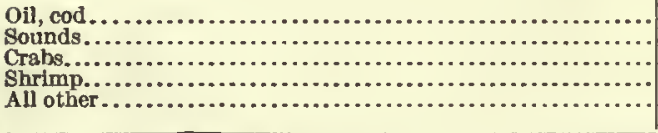 & $\begin{array}{r}138,000 \\
73,000 \\
122,000 \\
5,800 \\
2,400\end{array}$ & $\begin{array}{r}5,900 \\
3,100 \\
2,600 \\
1,300 \\
100\end{array}$ & $\begin{array}{r}79,000 \\
8,800 \\
6,300 \\
\because, 700 \\
\hdashline, 400\end{array}$ & $\begin{array}{r}3,400 \\
600 \\
200 \\
\cdots \ldots \\
100\end{array}$ & $\begin{array}{r}13,000 \\
64,000 \\
116,000\end{array}$ & $\begin{array}{r}600 \\
2,600 \\
2,300\end{array}$ & $\begin{array}{r}1846,000 \\
6,800 \\
60 . \\
\ldots \ldots\end{array}$ & $\begin{array}{r}2,000 \\
\ldots \ldots \\
(3)^{\cdots}, 300 \\
\ldots \ldots\end{array}$ \\
\hline $\begin{array}{l}\text { Less than } 100 \text { pounds. } \\
\text { Less than } \$ 100 \text {. }\end{array}$ & & $\begin{array}{l}74,000 \mathrm{~g} \\
124,000\end{array}$ & oushels. & $\begin{array}{l}: 31,000 \\
863,000\end{array}$ & $\begin{array}{l}\text { bushels. } \\
\text { gallons. }\end{array}$ & $\begin{array}{l}813, \\
1618,\end{array}$ & 00 bushels. & \\
\hline
\end{tabular}


FISHERIES, BY STATES.

TABLE 3.-HASSACHUSETTS-PRODUCTS OF VESSEL FISHERIES: 1908.

\begin{tabular}{|c|c|c|c|c|c|c|c|c|c|c|c|c|}
\hline \multirow{3}{*}{ SPECIES. } & \multirow{2}{*}{\multicolumn{2}{|c|}{ TOTAL. }} & \multicolumn{10}{|c|}{ PronUCT CAUGHT BY- } \\
\hline & & & \multicolumn{2}{|c|}{ Lines. } & \multicolumn{2}{|c|}{ Seines. ${ }^{1}$} & \multicolumn{2}{|c|}{ GIII nets. } & \multicolumn{2}{|c|}{$\begin{array}{l}\text { Pound nets, trap } \\
\text { Dets, and w'eirs. }\end{array}$} & \multicolumn{2}{|c|}{ All otber apparatus.? } \\
\hline & $\begin{array}{l}\text { Quantity } \\
\text { (pounds). }\end{array}$ & Value & $\begin{array}{l}\text { Quantlty } \\
\text { (pounds). }\end{array}$ & Value. & $\begin{array}{l}\text { Quantity } \\
\text { (pounds). }\end{array}$ & Value. & $\begin{array}{l}\text { Quantity } \\
\text { (pounds). }\end{array}$ & Value. & $\begin{array}{l}\text { Quantity } \\
\text { (pounds). }\end{array}$ & Value. & $\begin{array}{l}\text { Quantity } \\
\text { (pounds). }\end{array}$ & Value. \\
\hline Total..... & $193,839,000$ & $\$ 5,497,000$ & $149,523,000$ & $\$ 3,649,000$ & $20,124,000$ & $\$ 754,000$ & $14,585,000$ & $\$ 384,000$ & $1,403,000$ & $\$ 30,000$ & $8,204,000$ & $\$ 680.000$ \\
\hline $\begin{array}{l}\text { Fish: } \\
\text { Alewives........ } \\
\text { Bluefish ......... } \\
\text { Bonito } \\
\text { Butterfish....... }\end{array}$ & $\begin{array}{r}829,000 \\
24,000 \\
35,000 \\
29,000\end{array}$ & $\begin{array}{l}9,600 \\
2,700 \\
2,300 \\
1,800\end{array}$ & $\begin{array}{r}6,000 \\
200 \\
300\end{array}$ & $(3)$ & $\begin{array}{r}779,000 \\
6,200 \\
\cdots, 400\end{array}$ & $\begin{array}{r}9,000 \\
600 \\
600 \\
600\end{array}$ & $\begin{array}{r}25,000 \\
9,300 \\
-3,200\end{array}$ & $\begin{array}{r}400 \\
1,400 \\
100\end{array}$ & $\begin{array}{r}24,000 \\
2,800 \\
35,000 \\
18,000\end{array}$ & $\begin{array}{r}100 \\
200 \\
2,300 \\
1,100\end{array}$ & & \\
\hline 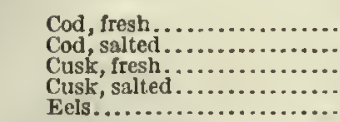 & $\begin{array}{r}48,124,000 \\
19,565,000 \\
4,145,000 \\
64,000 \\
55,000\end{array}$ & $\mid \begin{array}{r}1,183,000 \\
640,000 \\
71,000 \\
1,300 \\
2,500\end{array}$ & $\begin{array}{r}45,382,000 \\
19,565,000 \\
4,145,000 \\
64,000 \\
11,000\end{array}$ & $\begin{array}{r}1,123,000 \\
640,000 \\
71,000 \\
1,300 \\
200\end{array}$ & $1,073,000$ & $\begin{aligned} 25,000 \\
\cdots \cdots \cdots \\
\cdots \cdots\end{aligned}$ & 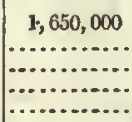 & 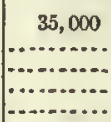 & $\begin{array}{r}19,000 \\
\ldots . . . . .\end{array}$ & 600 & $\dddot{40,000}$ & $\begin{array}{l}\ldots \ldots \ldots \ldots \\
\cdots \ldots \ldots . . . \\
2,100\end{array}$ \\
\hline 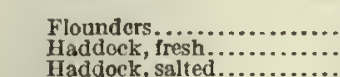 & $\begin{array}{r}3,402,000 \\
45,294,000 \\
973,000\end{array}$ & $\begin{array}{r}66,000 \\
965,000 \\
21,000\end{array}$ & $\begin{array}{r}818,000 \\
43,875,000 \\
973,000\end{array}$ & $\begin{array}{r}10,000 \\
932,000 \\
21,000\end{array}$ & $\begin{array}{r}327,000 \\
1,302,000\end{array}$ & $\begin{array}{r}5,500 \\
31,000\end{array}$ & $\begin{array}{r}65,000 \\
104,000\end{array}$ & $\begin{array}{l}1,100 \\
1,300\end{array}$ & $\begin{array}{l}61,000 \\
13,000\end{array}$ & $\begin{array}{r}1,200 \\
\quad 400\end{array}$ & $2,141,000$ & $\begin{array}{c}48,000 \\
\ldots \ldots\end{array}$ \\
\hline 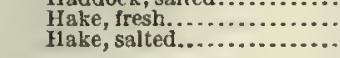 & $\begin{array}{r}15,521,000 \\
230,000\end{array}$ & $\begin{array}{r}276,000 \\
4,800\end{array}$ & $\begin{array}{r}15,412,000 \\
230,000\end{array}$ & $\begin{array}{r}275,000 \\
4,800\end{array}$ & $\because 7,000$ & 1,000 & 38,000 & 400 & 7,000 & 100 & & (n... \\
\hline $\begin{array}{l}\text { Hall but, fresh } \\
\text { Hali but, salted....... }\end{array}$ & $\begin{array}{r}3,470,000 \\
643,000\end{array}$ & $\begin{array}{r}255,000 \\
53,000\end{array}$ & $\begin{array}{r}3,460,000 \\
643,000\end{array}$ & $\begin{array}{r}254,000 \\
53,000\end{array}$ & 8,600 & 1,000 & & & & & & \\
\hline 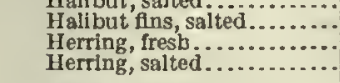 & $\begin{array}{r}13,000 \\
10,078,000 \\
5,616,000\end{array}$ & $\begin{array}{r}53,500 \\
500 \\
138,000 \\
108,000\end{array}$ & 13,000 & $\begin{array}{r}03,000 \\
500\end{array}$ & $5,139,000$ & $\begin{array}{r}43,000 \\
4,500\end{array}$ & $\begin{array}{l}4,593,000 \\
5,271,000\end{array}$ & $\begin{array}{r}92,000 \\
102,000\end{array}$ & 326,000 & 3,190 & & \\
\hline 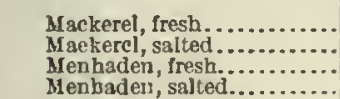 & $\begin{array}{r}7,967,000 \\
2,251,000 \\
253,000 \\
5,000\end{array}$ & $\begin{array}{r}580,000 \\
161,000 \\
1,300 \\
200\end{array}$ & 60,000 & $\begin{array}{r}2,900 \\
\cdots \cdots \\
\cdots\end{array}$ & $\begin{array}{r}5,775,000 \\
2,231,000 \\
253,000\end{array}$ & $\begin{array}{r}432,000 \\
161,000 \\
1,300\end{array}$ & $2,104,000$ & 142,000 & 28,000 & 2,500 & & $\ldots .$. \\
\hline Pollack, Iresh............... & $15,144,000$ & 241,000 & $12,086,000$ & 206,000 & $2,373,000$ & 29,000 & 547,000 & 6,100 & $\begin{array}{r}5,000 \\
138,000\end{array}$ & $\begin{array}{r}200 \\
2,400\end{array}$ & & \\
\hline h, or rosefish. & 293,000 & $\begin{array}{l}21,000 \\
2,600\end{array}$ & $\begin{array}{l}920,000 \\
290,000\end{array}$ & $\begin{array}{r}21,000 \\
2,600\end{array}$ & 200 & (3) & & (a) & & & & \\
\hline 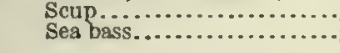 & $\begin{array}{r}308,000 \\
47,000\end{array}$ & $\begin{array}{r}11,000 \\
3,500\end{array}$ & $\begin{array}{r}166,000 \\
36,000\end{array}$ & $\begin{array}{l}6,000 \\
2,600\end{array}$ & 800 & (3) & 13,000 & 400 & $\begin{array}{r}128,000 \\
12,000\end{array}$ & $\begin{array}{r}4,700 \\
900\end{array}$ & & $\cdots$ \\
\hline $\begin{array}{l}\text { Shad ...................... } \\
\text { Sliver hake, or whiting..... }\end{array}$ & $\begin{array}{l}371,000 \\
578,000\end{array}$ & $\begin{array}{r}9,800 \\
4,400\end{array}$ & & & $\begin{array}{r}352,000 \\
4,000\end{array}$ & 9,100 & $\begin{array}{r}2,000 \\
125,000\end{array}$ & 100 & 16,000 & 600 & ........ & ........... \\
\hline & $\begin{array}{r}578,000 \\
74,000\end{array}$ & $\begin{array}{r}4,400 \\
500\end{array}$ & $\begin{array}{r}131,000 \\
37,000\end{array}$ & $\begin{array}{l}500 \\
300\end{array}$ & $\begin{array}{r}4,000 \\
12,000\end{array}$ & 100 & 125,000 & 1,300 & 318,000 & 2,600 & 25,000 & 100 \\
\hline Squeteague, or weakfish & 150,000 & 5,900 & 10,000 & 400 & & & 30,000 & $400^{\circ}$ & 110,000 & 5,100 & & \\
\hline $\begin{array}{l}\text { Striped bass.. } \\
\text { Sword fish }\end{array}$ & 2,100 & 200 & 2,100 & 200 & & & & & & & & \\
\hline & $\begin{array}{l}1,625,000 \\
24,000\end{array}$ & $\begin{array}{r}121,000 \\
900\end{array}$ & 24,000 & 900 & & & & & & & $1,625,000$ & 121,000 \\
\hline All other........ & 408,000 & 4,700 & 364,000 & 4,100 & 32,000 & 400 & 0,200 & $\ddot{1000}$ & $\dddot{2}, 200$ & 2000 & & $\ldots . . . . .$. \\
\hline $\begin{array}{l}\text { Ij vers............... } \\
\text { Sounds........... }\end{array}$ & $\begin{array}{r}590,000 \\
73,000\end{array}$ & $\begin{array}{l}6,700 \\
3,100\end{array}$ & $\begin{array}{r}586,000 \\
73,000\end{array}$ & 6,600 & & & 4,000 & (3) & 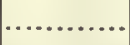 & & & ........ \\
\hline 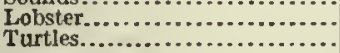 & $\begin{array}{r}123,000 \\
1,300\end{array}$ & $\begin{array}{l}14,000 \\
(8)\end{array}$ & & & & & & & & (1) & 123,000 & 14,000 \\
\hline 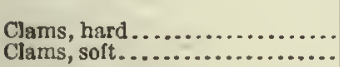 & $\begin{array}{l}185,000 \\
810,000\end{array}$ & $\begin{array}{r}13,000 \\
800\end{array}$ & & & & & & & & & $\begin{array}{l}485,000 \\
810,000\end{array}$ & 13,000 \\
\hline $\begin{array}{l}\text { Cockles...................... } \\
\text { Oysters, market, from public }\end{array}$ & 18,000 & 4,300 & & & & & & & & & - 18,000 & 4,300 \\
\hline $\begin{array}{l}\text { areas................................. } \\
\text { oysters, market, from private }\end{array}$ & 32,100 & 400 & & & & & & & & & 72,100 & 400 \\
\hline 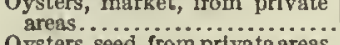 & - 449,000 & 96,000 & & & & & & & & & ${ }^{6} 449,000$ & 96,000 \\
\hline $\begin{array}{l}\text { Oysters, seed, from privata areas. } \\
\text { Scallops..................................... }\end{array}$ & $\begin{aligned} 18,000 \\
1152,000\end{aligned}$ & $\begin{array}{r}1,000 \\
44,000\end{array}$ & & & & & & & & & $\begin{array}{l}: 18,000 \\
10152,000\end{array}$ & $\begin{array}{r}1,000 \\
44,000\end{array}$ \\
\hline 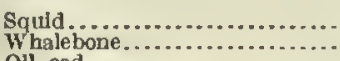 & $\begin{array}{r}172,000 \\
30,000 \\
\end{array}$ & $\begin{array}{r}2,500 \\
89,000\end{array}$ & & & 10,000 & 200 & & & 142,000 & 2,000 & $\begin{array}{l}20,000 \\
30,000\end{array}$ & 89,000 \\
\hline 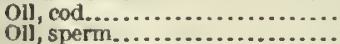 & $\begin{array}{r}\mathbf{1} 138,000 \\
22,913,000\end{array}$ & $\begin{array}{r}5,900 \\
218,000\end{array}$ & ii 138,000 & 3,900 & $\cdots$ & & & & & & i3 $2,913,000$ & 218,000 \\
\hline oll, whale & 18553,000 & 28,000 & & & & & & & & & 11553,000 & 28,000 \\
\hline
\end{tabular}

1 Includes otter trawls.

Includes apparatus, with catch, as follows: Wbaling apparatus, $3,495,000$ pounds, ralued at $\$ 336,000$; dredges, tongs, etc., 716,000 pounds, valued at $\$ 155,000$; harpoons,

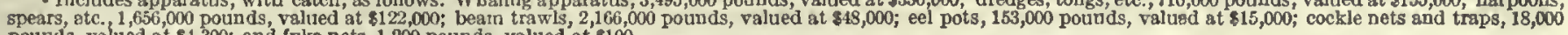
pounds, valued at $\$ 4,300$; and fyke nets, 1,200 pounds, valued at $\$ 100$.

- Less than $\$ 100$.

51,000 bushels.

1,800 bushels.

64,000 bushels.

64,000 bushels.
2,500 bushels.

10 19,000 gallons.

12 388,000 gallons.

$76786^{\circ}-11-11$ 
TABLE 4.-MASSACHUSETTS-PRODUCTS OF SHORE AND BOAT FISHERIES: 1908.

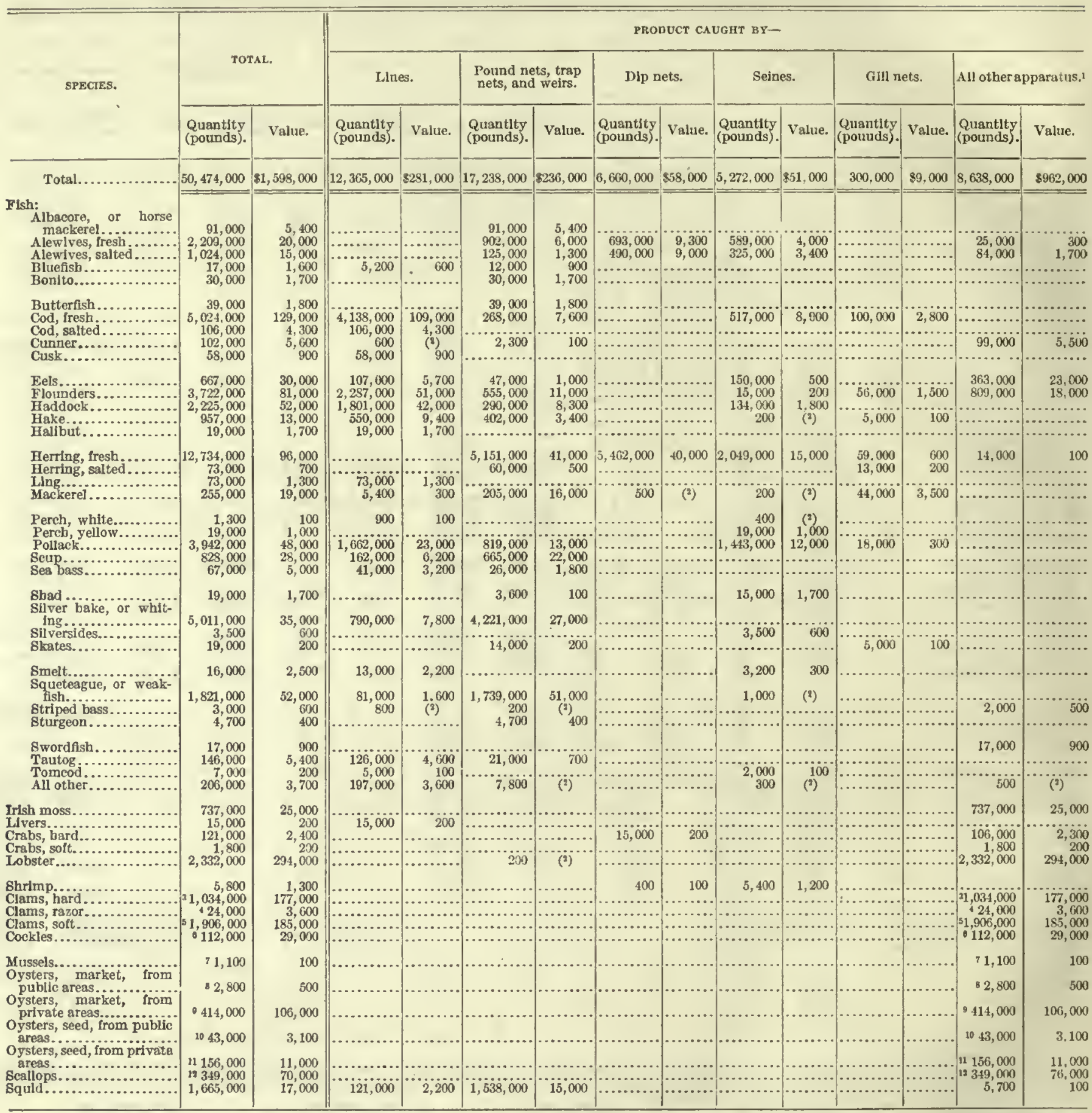

1 Includes apparatus, with catch, as follows: Dredges, tongs, etc., 4,617,000 pounds, valued at $\$ 586,000$; eel pots, 2,678,000 pounds, valued at $\$ 310,000 ;$ cockle

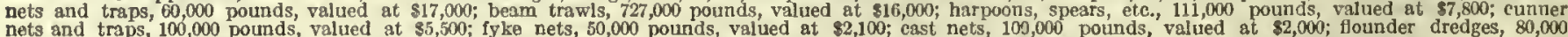

pounds, valued at $\$ 2,000$; bag nets, 2,000 pounds, valued at $\$ 500$; and minor apparatus, 75,000 pounds, valued at $\$ 14,000$.
Less than $\$ 100$.
191,000 bushels.
100 bushels.
2,400 bushels.
- 11,000 bushels.
8400 bushels.
100,200 bushels.
it 22,000 bushels.
is 44,000 gallons 
FISHERIES, BY STATES.

TABLE 5.-MASSACHUSETTS-PRODUCTS OF VESSEL FISHERIES, BY COUNTY DISTRICTS: 1908.

\begin{tabular}{|c|c|c|c|c|c|c|c|c|}
\hline \multirow{2}{*}{ SPECIES. } & \multicolumn{2}{|c|}{ TOTAL. } & \multicolumn{2}{|c|}{ ESSEX COUNTY. } & \multicolumn{2}{|c|}{ SUFFOLK COUNTY. } & \multicolumn{2}{|c|}{ ALL OTHER COUNTIES. } \\
\hline & $\begin{array}{l}\text { Quantlity } \\
\text { (pounds). }\end{array}$ & Value. & $\begin{array}{l}\text { Quantity } \\
\text { (pounds). }\end{array}$ & Value. & $\begin{array}{l}\text { Quantity } \\
\text { (pounds). }\end{array}$ & Value. & $\begin{array}{l}\text { Quantity } \\
\text { (pounds). }\end{array}$ & Value. \\
\hline Total..... & $193,839,000$ & $85,497,000$ & $91,160,000$ & $\$ 2,604,000$ & $67,269,000$ & $\$ 1,583,000$ & $35,411,000$ & $\$ 1,310,000$ \\
\hline 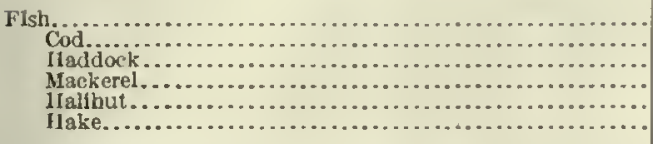 & $\begin{array}{r}188,512,000 \\
67,659,000 \\
46,268,000 \\
10,198,000 \\
4,126,000 \\
15,751,000\end{array}$ & $\begin{array}{r}4,971,000 \\
1,822,000 \\
985,000 \\
742,000 \\
309,000 \\
281,000\end{array}$ & $\begin{array}{r}90,741,000 \\
36,262,000 \\
14,317,000 \\
6,446,000 \\
3,230,000 \\
3,999,000\end{array}$ & $\begin{array}{r}2,595,000 \\
1,041,000 \\
300,000 \\
481 ; 000 \\
229,000 \\
71,000\end{array}$ & $\begin{array}{r}66,864,000 \\
21,926,000 \\
24,216,000 \\
2,017,000 \\
682,000 \\
10,254,000\end{array}$ & $\begin{array}{r}1,572,000 \\
521,000 \\
520,000 \\
147,000 \\
62,000 \\
185,000\end{array}$ & $\begin{array}{r}30,907,000 \\
9,501,000 \\
7,734,000 \\
1,735,000 \\
213,000 \\
1,498,000\end{array}$ & $\begin{array}{r}804,000 \\
260,000 \\
166,000 \\
114,000 \\
18,000 \\
25,000\end{array}$ \\
\hline 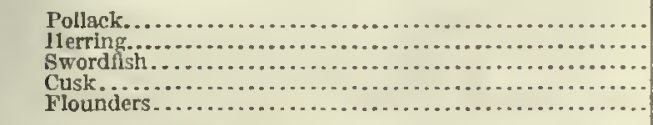 & $\begin{array}{r}16,064,000 \\
15,694,000 \\
1,625,000 \\
4,209,000 \\
3,402,000\end{array}$ & $\begin{array}{r}265,000 \\
245,000 \\
121,000 \\
72,000 \\
66,000\end{array}$ & $\begin{array}{r}9,914,000 \\
13,075,000 \\
788,000 \\
1,801,000 \\
137,000\end{array}$ & $\begin{array}{r}152,000 \\
216,000 \\
60,000 \\
32,000 \\
1,000\end{array}$ & $\begin{array}{r}3,081,000 \\
1,585,000 \\
270,000 \\
2,029,000 \\
387,000\end{array}$ & $\begin{array}{r}57,000 \\
16,000 \\
24,000 \\
34,000 \\
3,500\end{array}$ & $\begin{array}{r}3,069,000 \\
1,034,000 \\
567,000 \\
379,000 \\
2,878,000\end{array}$ & $\begin{array}{r}57,000 \\
12,000 \\
37,000 \\
6,400 \\
61,000\end{array}$ \\
\hline 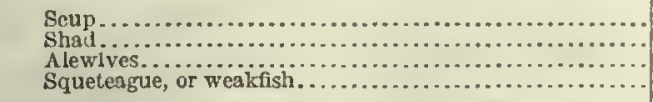 & $\begin{array}{l}308,000 \\
371,000 \\
829,000 \\
150,000\end{array}$ & $\begin{array}{r}11,000 \\
9,800 \\
9,600 \\
5,400\end{array}$ & $\begin{array}{r}2,800 \\
304,000 \\
25,000\end{array}$ & $\begin{array}{r}100 \\
7,800 \\
200\end{array}$ & io, & $\begin{array}{c}\cdots \\
300 \\
\cdots \cdots\end{array}$ & $\begin{array}{r}305,000 \\
56,000 \\
804,000 \\
150,000\end{array}$ & $\begin{array}{r}11,000 \\
1,700 \\
9,400 \\
5,900\end{array}$ \\
\hline 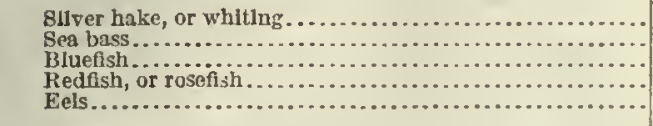 & $\begin{array}{r}578,000 \\
47,000 \\
24,000 \\
293,000 \\
55,000\end{array}$ & $\begin{array}{l}4,400 \\
3,500 \\
2,700 \\
2,600 \\
2,500\end{array}$ & $\begin{array}{r}148,000 \\
152,000 \\
600\end{array}$ & $\begin{array}{r}600 \\
(1,500 \\
(1)\end{array}$ & (3). & ( $\cdots \cdots \cdots \cdots$ & $\begin{array}{r}430,000 \\
47,000 \\
24,000 \\
2,000 \\
54,000\end{array}$ & $\begin{array}{r}3,800 \\
3,500 \\
2,700 \\
(1) \\
2,500\end{array}$ \\
\hline 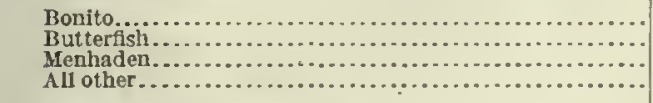 & $\begin{array}{r}35,000 \\
29,000 \\
258,000 \\
508,000\end{array}$ & $\begin{array}{l}2,300 \\
1,800 \\
1,400 \\
6,400\end{array}$ & $\begin{array}{r}1,400 \\
3,300 \\
133,000\end{array}$ & ${ }^{(1)} 1,600$ & 250,000 & 600 & $\begin{array}{r}35,000 \\
20,000 \\
255,000 \\
116,000\end{array}$ & $\begin{array}{l}2,300 \\
1,100 \\
1,400 \\
2,400\end{array}$ \\
\hline 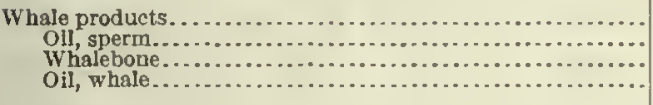 & $\begin{array}{r}3,495,000 \\
2,913,000 \\
30,000 \\
553,000\end{array}$ & $\begin{array}{r}336,000 \\
218,000 \\
89,000 \\
28,000\end{array}$ & 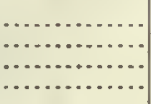 & & an. & 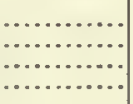 & $\begin{array}{r}3,495,000 \\
2,913,000 \\
30,000 \\
553,000\end{array}$ & $\begin{array}{r}336,000 \\
218,000 \\
89,000 \\
28,000\end{array}$ \\
\hline 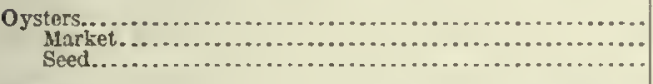 & $\begin{array}{r}468,000 \\
451,000 \\
18,000\end{array}$ & $\begin{array}{r}97,000 \\
96,000 \\
1,000\end{array}$ & & & & & $\begin{array}{r}468,000 \\
451,000 \\
18,000\end{array}$ & $\begin{array}{r}97,000 \\
96,000 \\
1,000\end{array}$ \\
\hline $\begin{array}{l}\text { Seallops } \\
\text { Irobster } \ldots \ldots \ldots \\
\text { Clams } \ldots \ldots\end{array}$ & $\begin{array}{r}152,000 \\
123,000 \\
995,000\end{array}$ & $\begin{array}{l}44,000 \\
14,000 \\
14,000\end{array}$ & 8,500 & 1,200 & & & $\begin{array}{r}152,000 \\
115,000 \\
795,000\end{array}$ & $\begin{array}{l}44,000 \\
12,000 \\
14,000\end{array}$ \\
\hline 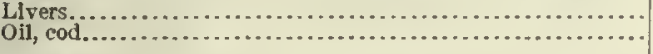 & $\begin{array}{r}590,000 \\
-138,000\end{array}$ & $\begin{array}{l}6,700 \\
5,900\end{array}$ & $\begin{array}{r}280,000 \\
79,000\end{array}$ & $\begin{array}{l}3,300 \\
3,400\end{array}$ & $\begin{array}{r}310,000 \\
13,000\end{array}$ & $\begin{array}{r}3,400 \\
600\end{array}$ & 46,000 & 2,000 \\
\hline 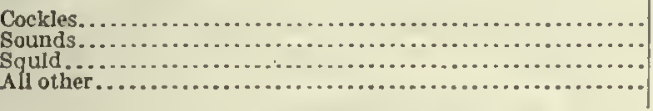 & $\begin{array}{r}18,000 \\
73,000 \\
172,000 \\
1,300\end{array}$ & $\begin{array}{l}4,300 \\
3,100 \\
2,500 \\
(1)\end{array}$ & $\begin{array}{r}8,800 \\
41,000 \\
1,300\end{array}$ & (1) 800 & $\begin{array}{r}18,000 \\
64,000 \\
\cdots\end{array}$ & $\begin{array}{c}4,300 \\
2,600 \\
\ldots \ldots \ldots \\
\cdots \ldots . .\end{array}$ & ${ }_{13 i, 000}$ & 1,800 \\
\hline $\begin{array}{l}1 \text { Less than } \$ 100 \text {. } \\
2388,000 \text { gallons. } \\
74,000 \text { gallons. }\end{array}$ & & $\begin{array}{l}164,000 \text { bush } \\
\text { 2,500 bushe } \\
19,000 \text { gallo }\end{array}$ & & & $\begin{array}{l}12,000 \\
18,000 \\
1,800 \mathrm{~b}\end{array}$ & $\begin{array}{l}\text { bushels. } \\
\text { gallons. } \\
\text { ushels. }\end{array}$ & & \\
\hline
\end{tabular}


TABLE 6. MASSACHUSETTS-PRODUCTS OF SHORE AND BOAT FISHERIES, BY COUNTY DISTRICTS: 1908.

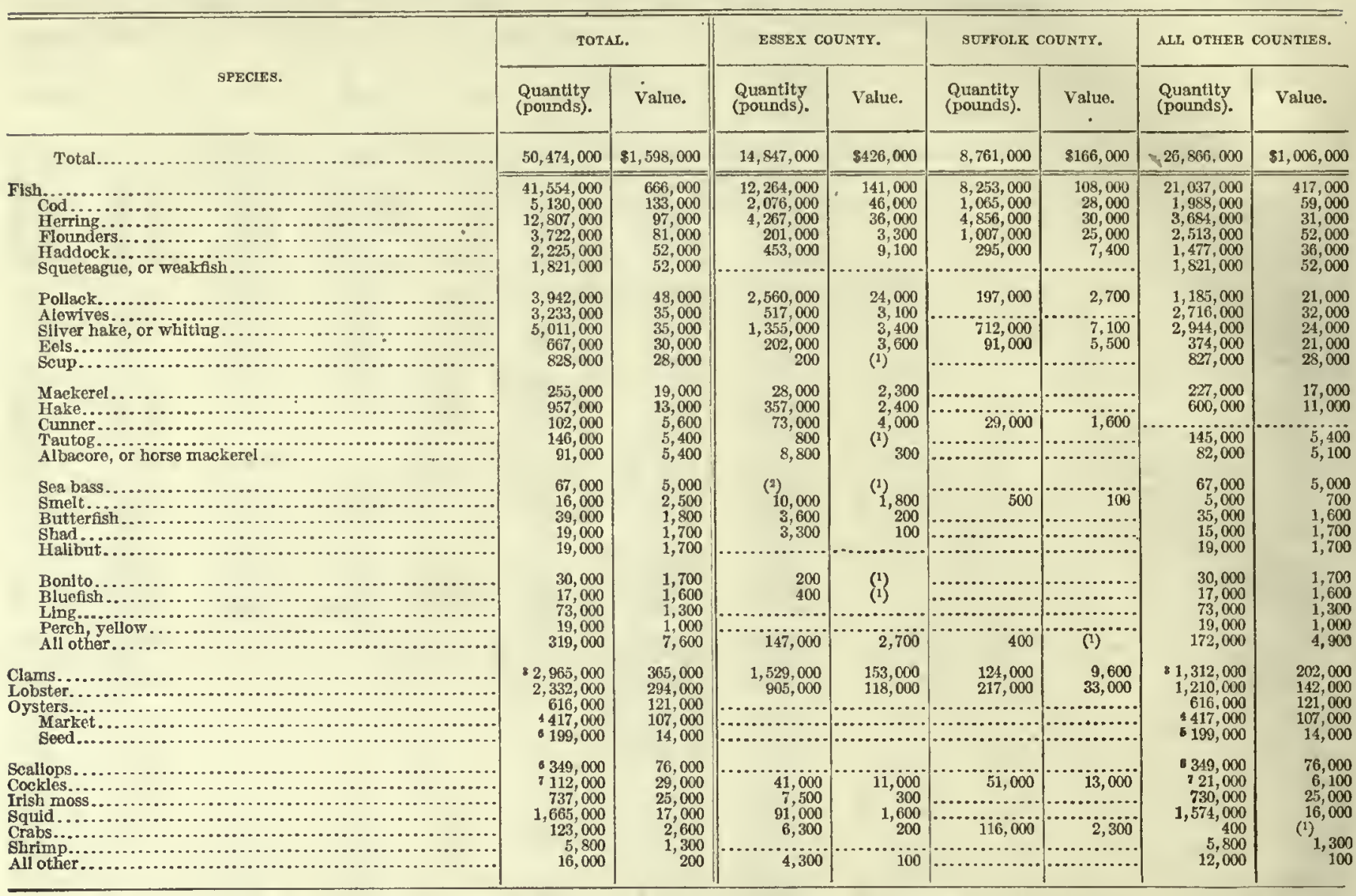

1 Less than $\$ 100$. Less than 100 pounds. 371,000 bushels.

460,000 busbels.

28,000 bushels.

44,000 gallons

11,000 gallons.

TABLE 7.-MASSACHUSETTS-FISHERY PRODUCTS: 1889, 1898, 1902, 1905, AND 1908.

\begin{tabular}{|c|c|c|c|c|c|c|c|c|c|c|c|c|c|c|c|}
\hline \multirow{2}{*}{ SPECIES. } & \multicolumn{2}{|c|}{1908} & \multicolumn{2}{|c|}{1905} & \multicolumn{2}{|c|}{1902} & \multicolumn{2}{|c|}{1898} & \multicolumn{2}{|c|}{1889} & \multicolumn{5}{|c|}{$\begin{array}{c}\text { PER CILNT DISTRIBUTION OF } \\
\text { VALUE. }\end{array}$} \\
\hline & $\begin{array}{l}\text { Quantlty } \\
\text { (pounds). }\end{array}$ & Value. & $\begin{array}{l}\text { Quantity } \\
\text { (pounds). }\end{array}$ & Vaiue. & $\begin{array}{l}\text { Quantity } \\
\text { (pounds). }\end{array}$ & Value. & $\begin{array}{l}\text { Quantity } \\
\text { (pounds). }\end{array}$ & Value. & $\begin{array}{l}\text { Quantity } \\
\text { (pounds). }\end{array}$ & Value. & 1908 & 1905 & 1902 & 1898 & 1889 \\
\hline Total.. & $244,313,000$ & $\$ 7,095,000$ & $255,654,000$ & $\$ 7,025,000$ & $230,646,000$ & $86,482,000$ & $202,258,000$ & $\$ 4,464,000$ & $299,218,000$ & $\$ 5,858,000$ & 100 & 100 & 100 & 100 & 100 \\
\hline $\begin{array}{l}\text { Cod............. } \\
\text { Haddock........ } \\
\text { Mackerei........ } \\
\text { Clams.......... }\end{array}$ & \begin{tabular}{|}
$72,819,000$ \\
$48,492,000$ \\
$10,453,000$ \\
$13,060,000$
\end{tabular} & $\begin{array}{r}1,955,000 \\
1,038,000 \\
761,000 \\
378,000\end{array}$ & $\begin{array}{r}62,263,000 \\
67,054,000 \\
14,104,000 \\
3,548,000\end{array}$ & $\begin{array}{r}1,689,000 \\
1,069,000 \\
966,000 \\
500,000\end{array}$ & $\begin{array}{r}69,521,000 \\
39,220,000 \\
17,624,000 \\
3,134,000\end{array}$ & $\begin{array}{r}1,773,000 \\
802,000 \\
981,000 \\
288,000\end{array}$ & $\begin{array}{r}71,315,000 \\
\mathbf{3 5}, 582,000 \\
\mathbf{6}, 703,000 \\
\mathbf{1}, 981,000\end{array}$ & $\begin{array}{r}1,407,000 \\
420,000 \\
362,000 \\
153,000\end{array}$ & $\begin{array}{r}76,342,000 \\
35,305,000 \\
6,687,000 \\
2,654,000\end{array}$ & $\begin{array}{r}2,013,000 \\
602,000 \\
585,000 \\
150,000\end{array}$ & $\begin{array}{r}28 \\
15 \\
11 \\
5\end{array}$ & $\begin{array}{r}24 \\
15 \\
14 \\
7\end{array}$ & $\begin{array}{r}27 \\
12 \\
15 \\
4\end{array}$ & $\begin{array}{r}32 \\
9 \\
8 \\
3\end{array}$ & $\begin{array}{r}34 \\
10 \\
10 \\
2\end{array}$ \\
\hline $\begin{array}{l}\text { Herring......... } \\
\text { Pollack ......... } \\
\text { Halibut........ } \\
\text { Lobster........ }\end{array}$ & $\begin{array}{r}28,501,000 \\
20,006,000 \\
4,145,000 \\
2,455,000\end{array}$ & $\begin{array}{l}342,000 \\
313,000 \\
310,000 \\
307,000\end{array}$ & $\begin{array}{r}18,364,000 \\
25,486,000 \\
3,513,000 \\
1,283,000\end{array}$ & $\begin{array}{l}382,000 \\
268,000 \\
218,000 \\
176,000\end{array}$ & $\begin{array}{r}29,235,000 \\
12,176,000 \\
12,156,000 \\
1,696,000\end{array}$ & $\begin{array}{l}401,000 \\
118,000 \\
649,000 \\
175,000\end{array}$ & $\begin{array}{r}22,363,000 \\
7,084,000 \\
10,523,000 \\
1,694,000\end{array}$ & $\begin{array}{r}333,000 \\
43,000 \\
547,000 \\
148,000\end{array}$ & $\begin{array}{l}9,931,000 \\
5,069,000 \\
9,888,000 \\
3,354,000\end{array}$ & $\begin{array}{r}91,000 \\
55,000 \\
661,000 \\
143,000\end{array}$ & $\begin{array}{l}5 \\
4 \\
4 \\
4 \\
4\end{array}$ & $\begin{array}{l}5 \\
4 \\
3 \\
3\end{array}$ & $\begin{array}{r}6 \\
2 \\
10 \\
3\end{array}$ & $\begin{array}{r}7 \\
1 \\
12 \\
3\end{array}$ & $\begin{array}{r}2 \\
1 \\
11 \\
3\end{array}$ \\
\hline $\begin{array}{l}\text { Hake............ } \\
\text { Oil, whale and }\end{array}$ & $16,708,000$ & 294,000 & $20,701,000$ & 258,000 & $14,358,000$ & 191,000 & $21,332,000$ & 164,000 & $6,354,000$ & 68,000 & 4 & 4 & 3 & 4 & 1 \\
\hline $\begin{array}{l}\text { sperm........ } \\
\text { Opsters........ } \\
\text { All other ....... }\end{array}$ & $\begin{array}{l}23,466,000 \\
81,084,000 \\
33,123,000\end{array}$ & $\begin{array}{l}247,000 \\
218,000 \\
932,000\end{array}$ & $\begin{array}{r}3,934,000 \\
996,000 \\
34,409,000\end{array}$ & $\begin{array}{r}247,000 \\
222,000 \\
1,030,000\end{array}$ & $\begin{array}{r}5,137,000 \\
724,000 \\
25,666,000\end{array}$ & $\begin{array}{l}293,000 \\
134,000 \\
677,000\end{array}$ & $\begin{array}{r}3,119,000 \\
709.000 \\
19,852,000\end{array}$ & $\begin{array}{l}199,000 \\
156,000 \\
532,000\end{array}$ & $\begin{array}{r}6,172,000 \\
259,000 \\
137,203,000\end{array}$ & $\begin{array}{r}489,000 \\
66,000 \\
931,000\end{array}$ & $\begin{array}{r}3 \\
3 \\
13 \\
\end{array}$ & $\begin{array}{r}4 \\
3 \\
15\end{array}$ & $\begin{array}{r}5 \\
2 \\
10\end{array}$ & $\begin{array}{r}5 \\
4 \\
12\end{array}$ & $\begin{array}{r}8 \\
1 \\
16\end{array}$ \\
\hline
\end{tabular}




\section{MICHIGAN.}

Miehigan is foremost among the Great Lakes states in value of fishery products. All the lakes, with the exeeption of Lake Ontario, touel upon the stato, but Lakes Michigan and IIuron contributed the larger percentage of the state yield.

The following statement presents a summary of the chief statisties for the fisheries of Michigan in 1908:

Number of persons employed.................... $\quad 3,472$ Capital:

Vessels and bonts, including outfit............ \$594,000

A pparatus of capture..................... 821,000

Shore and accessory property and cash.......... 599,000

Value of products....................... 1,473,000

Comparison with previous canvasses.-Since 1890 a considerable increase is manifest in the quantity and value of products. No statisties of comparative value are at hand for Michigan for years previous to 1890. With regard to the Great Lakes the Bureau of Fisheries stated, as a result of the investigation of 1885 , that, "considered as a whole, the fisheries were more prolifie in 1885 than they had ever previously been."

The statistics for the fisheries of the Great Lakes district in 1885 are, on the whole, very similar to those of 1890 and show figures very much in excess of those for 1880. Sinee signs of growth appear in the early statistics of the fisheries of this region, it may be inferred that the increase during the past 18 years indicates a movement extending over a much longer period. Reasons for this increase, as suggested in 1885 , include the increase in the number of persons engaged in the work, the use of a larger number of nets and other apparatus of capture, and more extensive artificial propagation. In addition to these forces, all of which were active in 1885 , favorable legislation has fostered the growth of the industry since 1890.

Michigan shares so largely in the catch from all but one of these lakes that what is true of the fisheries of the Great Lakes region in general may be considered equally true of the Michigan fisheries. The following comparative summary shows the principal statistics for the various canvasses from 1890 to 1908 , inclusive:

\begin{tabular}{|c|c|c|c|c|c|c|}
\hline \multirow[b]{2}{*}{ YEAR. } & \multirow{2}{*}{$\begin{array}{l}\text { Persons } \\
\text { em- } \\
\text { ployed, } \\
\text { exelu- } \\
\text { sive of } \\
\text { shores- } \\
\text { men. }\end{array}$} & \multicolumn{3}{|c|}{ VALUE OF EQUIPMENT. } & \multicolumn{2}{|c|}{ PRODUCTS. } \\
\hline & & Total. & $\begin{array}{c}\text { Vessels } \\
\text { and } \\
\text { boats, } \\
\text { ineluding } \\
\text { outfit. }\end{array}$ & $\begin{array}{l}\text { Appar } \\
\text { ratus of } \\
\text { capture. }\end{array}$ & $\begin{array}{l}\text { Quantity } \\
\text { (pounds). }\end{array}$ & Value. \\
\hline $\begin{array}{l}1908 \ldots \ldots \ldots \\
1903 \ldots \ldots \ldots \\
189 \ldots \ldots \ldots . . . . . \\
1890 \ldots \ldots . .\end{array}$ & $\begin{array}{l}3,294 \\
3,348 \\
2,968 \\
2,943\end{array}$ & $\begin{array}{r}81,415,000 \\
962,000 \\
824,000 \\
836,000\end{array}$ & $\begin{array}{r}\$ 594,000 \\
394,000 \\
299,000 \\
278,000\end{array}$ & $\begin{array}{r}\$ 821,000 \\
568,000 \\
524,000 \\
558,000\end{array}$ & $\begin{array}{l}38,302,000 \\
35,609,000 \\
32,369,000 \\
32,872,000\end{array}$ & $\begin{array}{r}\$ 1,473,000 \\
1,224,000 \\
894,000 \\
934,000\end{array}$ \\
\hline
\end{tabular}

Persons employed.-Statisties of the persons employed in the fisheries of Michigan in 1908 are given in the following table:

\begin{tabular}{|c|c|c|c|c|c|c|c|}
\hline \multirow[b]{3}{*}{ DISTRICT AND CLASS. } & \multicolumn{7}{|c|}{ PERSONG EMPLOYED: 1908.} \\
\hline & \multicolumn{4}{|c|}{ Number. } & \multicolumn{3}{|c|}{ Salaries and wages. } \\
\hline & Total & $\begin{array}{l}\text { Proprie- } \\
\text { tors and } \\
\text { lndepend- } \\
\text { ent fisher- } \\
\text { men. }\end{array}$ & $\begin{array}{c}\text { Salaried } \\
\text { employees. }\end{array}$ & $\begin{array}{l}\text { Wage- } \\
\text { earners. }\end{array}$ & Total. & Salaries. & Wages. \\
\hline Total.............................. & 3,472 & 11,698 & 8 & 1,766 & $\$ 533,000$ & $\$ 6,600$ & $2 \$ 527,000$ \\
\hline 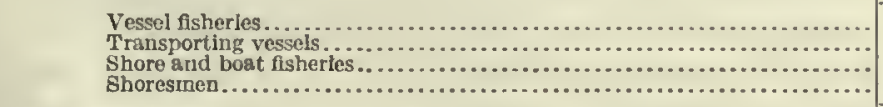 & $\begin{array}{r}501 \\
27 \\
2,766 \\
178 \\
\end{array}$ & $\begin{array}{r}117 \\
7 \\
1,574 \\
\cdots \cdots\end{array}$ & & $\begin{array}{r}379 \\
20 \\
1,189 \\
178 \\
\end{array}$ & $\begin{array}{r}174,000 \\
5,700 \\
289,000 \\
64,000 \\
\end{array}$ & $\begin{array}{r}3,900 \\
2,700 \\
\end{array}$ & $\begin{array}{r}170,000 \\
5,700 \\
286,000 \\
64,000 \\
\end{array}$ \\
\hline Lake Miehlgan dlstrict...................... & 1,268 & 553 & $\stackrel{1}{11}$ & 714 & 236,000 & 1,200 & 235,000 \\
\hline 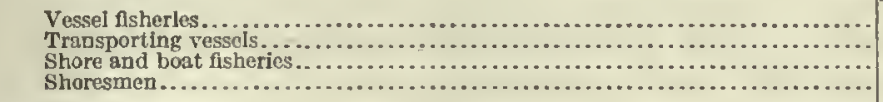 & $\begin{array}{r}311 \\
5 \\
873 \\
79\end{array}$ & $\begin{array}{r}98 \\
1 \\
454 \\
-1\end{array}$ & $\mid \begin{array}{c}\mid \\
\cdots \ldots \ldots \ldots \ldots \\
\cdots \ldots \ldots \ldots \\
\cdots \ldots \ldots\end{array}$ & $\begin{array}{r}212 \\
4 \\
419 \\
79\end{array}$ & $\begin{array}{r}100,000 \\
900 \\
108,000 \\
32,000\end{array}$ & 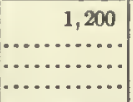 & $\begin{array}{r}99,000 \\
900 \\
103,000 \\
32,000\end{array}$ \\
\hline 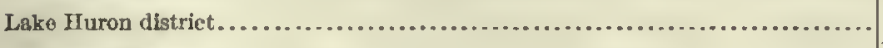 & 1,382 & 684 & 6 & 692 & 196,000 & 5,200 & 191,000 \\
\hline 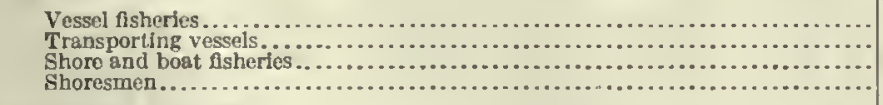 & $\begin{array}{r}131 \\
22 \\
1,148 \\
81\end{array}$ & $\begin{array}{r}14 \\
6 \\
664\end{array}$ & 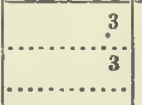 & $\begin{array}{r}114 \\
16 \\
481 \\
81\end{array}$ & $\begin{array}{r}51,000 \\
4,900 \\
115,000 \\
25,000\end{array}$ & $\begin{array}{r}2,500 \\
2,700 \\
2 \ldots+\ldots\end{array}$ & $\begin{array}{r}49,000 \\
4,900 \\
112,000 \\
25,000\end{array}$ \\
\hline 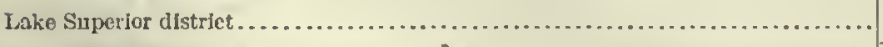 & 371 & 205 & 1 & 165 & 57,000 & 200 & 57,000 \\
\hline 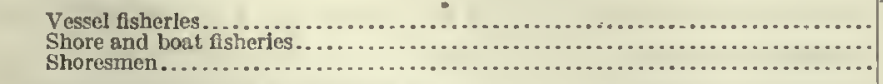 & $\begin{array}{r}59 \\
297 \\
15\end{array}$ & $\begin{array}{r}5 \\
200 \\
\cdots\end{array}$ & $\ldots \ldots$ & $\begin{array}{l}53 \\
97 \\
15\end{array}$ & $\begin{array}{r}23,000 \\
27,000 \\
7,000\end{array}$ & 200 & $\begin{array}{r}23,000 \\
27,000 \\
7,000\end{array}$ \\
\hline 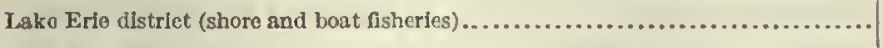 & 230 & 67 & (............ & 163 & 34,000 & ...... & 34,000 \\
\hline 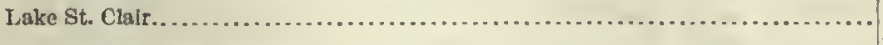 & 221 & 189 & (.............. & 32 & 11,000 & $\ldots$. & 11,000 \\
\hline 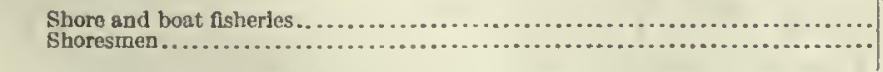 & $\begin{array}{r}218 \\
3\end{array}$ & 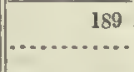 & $\mid \begin{array}{l}\ldots \ldots \ldots \\
\cdots \ldots \ldots\end{array}$ & $\begin{array}{r}29 \\
3\end{array}$ & $\begin{array}{r}10,000 \\
300\end{array}$ & …........... & $\begin{array}{r}10,000 \\
300\end{array}$ \\
\hline
\end{tabular}


The state had vessel fisheries in three of the Great Lakes-Lakes Michigan, Superior, and Huron-and 634 vessel fishermon and shoresmen were employed in connection with such fisheries. The number of shore and boat fishermen and their employees, including shoresmen, amounted to 2,811. Altliough Lake Michigan had a product about one-third larger than that of Lake Huron, the persons employed in fishing numbered 114 less.

Equipment and other capital.-Statistics concerning the investment in vessels, boats, and apparatus of capture, and the other capital employed in the fisheries of the state, are given in the following table, for the state and for the several lakes and their tributary waters:

\begin{tabular}{|c|c|c|c|c|c|c|}
\hline \multirow[b]{2}{*}{ CLASS OF INVESTMENT. } & \multicolumn{6}{|c|}{ VALUE OF EQUIPMENT AND OTHER CAPITAL: 1908.} \\
\hline & Total. & $\begin{array}{l}\text { Lake } \\
\text { Michi- } \\
\text { gan dis- } \\
\text { trict. }\end{array}$ & $\begin{array}{c}\text { Lake } \\
\text { II uron } \\
\text { district. }\end{array}$ & $\begin{array}{l}\text { Lake } \\
\text { Superior } \\
\text { district. }\end{array}$ & $\begin{array}{c}\text { Lake } \\
\text { Erie } \\
\text { district. }\end{array}$ & $\begin{array}{l}\text { Lake } \\
\text { St. Clair } \\
\text { district. }\end{array}$ \\
\hline Total... & $\$ 2,013,000$ & $\$ 897,000$ & $\$ 733,000$ & $\$ 226,000$ & $\$ 111,000$ & $\$ 46,000$ \\
\hline Vessels, including outfit. & 327,000 & 196,000 & 89,000 & 41,000 & & \\
\hline Fishing................ & & 192,000 & 72,000 & 41,000 & & \\
\hline & 242,000 & 151,000 & 55,000 & 36,000 & & \\
\hline Outa & 64,000 & 41,000 & 17,000 & 5,800 & & \\
\hline $\begin{array}{l}\text { Transporting. } \\
\text { Vessels... }\end{array}$ & 22,000 & $\begin{array}{r}4,100 \\
3,800\end{array}$ & 17,000 & & & \\
\hline Outfit.... & 1,800 & $\begin{array}{r}3,800 \\
400\end{array}$ & 1,500 & & & \\
\hline Boats.............................. & 267,000 & 106,000 & 96,000 & 35,000 & 19,000 & 10,000 \\
\hline Stear and motor.. & 217,000 & 97,000 & 71,000 & 29,000 & 14,000 & 5,900 \\
\hline $\begin{array}{l}\text { Sail................... } \\
\text { Row. }\end{array}$ & 24,000 & 3,100 & 18,000 & 3,200 & & \\
\hline & 21,000 & 5,500 & 5,100 & 3,200 & 2,700 & 4,200 \\
\hline $\begin{array}{l}\text { Other........................ } \\
\text { Apparatus opture... }\end{array}$ & $\begin{array}{r}5,200 \\
821,000\end{array}$ & $\begin{array}{r}400 \\
377,000\end{array}$ & $\begin{array}{r}1,700 \\
281.000\end{array}$ & $\begin{array}{r}200 \\
105,000\end{array}$ & 51,000 & 8,000 \\
\hline $\begin{array}{l}\text { Vessel fisherres..... } \\
\text { Shore and boat fish- }\end{array}$ & 319,000 & 192,000 & 81,000 & 46,000 & & \\
\hline $\begin{array}{l}\text { Shore and boat fish- } \\
\text { erjes................ }\end{array}$ & 502,000 & 185,000 & 200,000 & 58,000 & 51,000 & 8,000 \\
\hline $\begin{array}{c}\text { Shore and aocessory } \\
\text { property.................... }\end{array}$ & & & & & & \\
\hline 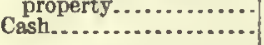 & 114,000 & 70,000 & 32,000 & 8,200 & 600 & $\begin{array}{r}2,0,600 \\
3,600\end{array}$ \\
\hline
\end{tabular}

The statement at top of next column gives detailed statistics of the number and tonnage of vessels and the number of boats.

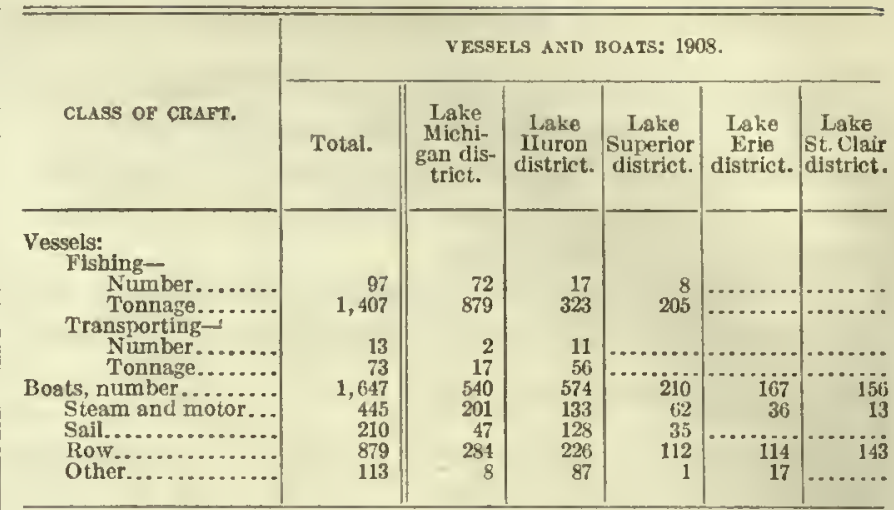

The shore and accessory property of the vessel fisheries was valued at $\$ 137,000$, that of the shore and boat fisheries at $\$ 344,000$, and that of transporting vessels at $\$ 3,500$. Of the cash eapital, $\$ 67,000$ is credited to the vessel fisheries, $\$ 46,000$ to the shore and boat fisheries, and $\$ 600$ to transporting vessels. The total investment comprised $\$ 829,000$ invested in vessel fisheries, $\$ 1,159,000$ in shore and boat fisheries, and $\$ 26,000$ in transporting vessels. No sailing vessels were used, and the number of sailboats was comparatively small.

Gill nets and pound and trap nets were the prineipal kinds of apparatus of capture. All of these nets were used in both classes of fisheries, but gill nets were used in vessel fisheries almost to the exclusion of other apparatus, while pound and trap nets were more generally used in shore and boat fisheries. The same conditions were apparent at all previous canvasses. On Lake Superior, however, gill nets were used in much greater numbers than pound and trap nets in shore and boat fisheries as well as in vessel fisheries.

The number of the various kinds of apparatus reported was as follows:

\begin{tabular}{|c|c|c|c|c|c|c|c|c|}
\hline \multirow{3}{*}{ EIND. } & \multicolumn{8}{|c|}{ APPARATUS OF CAPTURE: 1908.} \\
\hline & \multirow{2}{*}{ Total. } & \multicolumn{5}{|c|}{ Distributed by distriets. } & \multicolumn{2}{|c|}{$\begin{array}{l}\text { Distributed by ciass of } \\
\text { fisheries. }\end{array}$} \\
\hline & & $\begin{array}{l}\text { Lake } \\
\text { Michigan } \\
\text { district. }\end{array}$ & 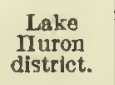 & $\begin{array}{l}\text { Lake } \\
\text { Superior } \\
\text { district. }\end{array}$ & $\begin{array}{c}\text { Lake } \\
\text { Erie } \\
\text { distrlet. }\end{array}$ & $\begin{array}{c}\text { Lake St. } \\
\text { Clair } \\
\text { district. }\end{array}$ & $\begin{array}{c}\text { Vessel } \\
\text { fisherfes. }\end{array}$ & $\begin{array}{l}\text { Shore and } \\
\text { boat } \\
\text { isherles. }\end{array}$ \\
\hline 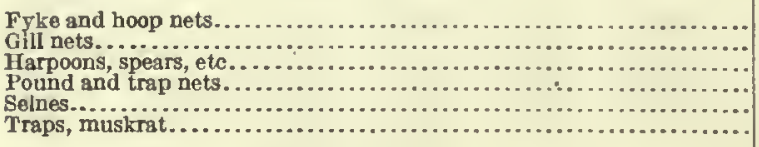 & $\begin{array}{r}1,069 \\
55,673 \\
553 \\
2,232 \\
120 \\
130\end{array}$ & $\begin{array}{r}37,688 \\
786 \\
3\end{array}$ & $\begin{array}{r}694 \\
10,341 \\
208 \\
1,116 \\
38\end{array}$ & $\begin{array}{r}8 \\
7,642 \\
\quad \ldots 93 \\
5\end{array}$ & $\begin{array}{r}361 \\
237 \\
50 \\
130\end{array}$ & $\begin{array}{r}6 \\
2 \\
345 \\
\hdashline 24\end{array}$ & $\begin{array}{r}\ldots . \\
36,783 \\
\cdots \\
3 . \\
35 \\
1\end{array}$ & $\begin{array}{r}1,069 \\
18,890 \\
553 \\
2,197 \\
119 \\
130\end{array}$ \\
\hline
\end{tabular}

Products, by species.-Table 1, on page 170, gives the weight and value of the product of the Michigan fisheries, by species and apparatus of capture for 1908 .

Twenty-three species were taken in the fisheries of Michigan. Lake trout ranked first, the value of this species, fresh and salted, forming 29 per cent of the value of all products of the state. Whitefish of all kinds, fresh, smoked, and salted, including the longjaw and Menominee varieties and also whitefish caviar, stood next to lake trout in importanee, its value forming 23 per cent of the value of all fishery products from the state; whitefish alone, fresh, salted, and smoked, contributed 20 per cent of the value of all produets. Lake herring were taken in greater quantities than trout and whitefish combined. The weight of this species formed 39 per cent of the weight of all fishery products, but its value formed only 21 per cent of the total value. Suckers, and the 
various pike perches combined, ranked next in value. The value of these five species formed 87 per cent of the value of the entire state fishery product.

Products, by fishing grounds.-Tables 2 to 6 , on pages 170 to 172 , give, by species and apparatus of capture, the quantities and values of the products of the Michigan fisheries in 1908 for Lakes Michigan, Huron, Superior, Erie, and St. Clair, respectively. The lakes ranked in the order named with respect to value of products. The following tabular statement gives the value of the chief species, for the state and for the respective lakes, ranked according to the value for the state as a whole:

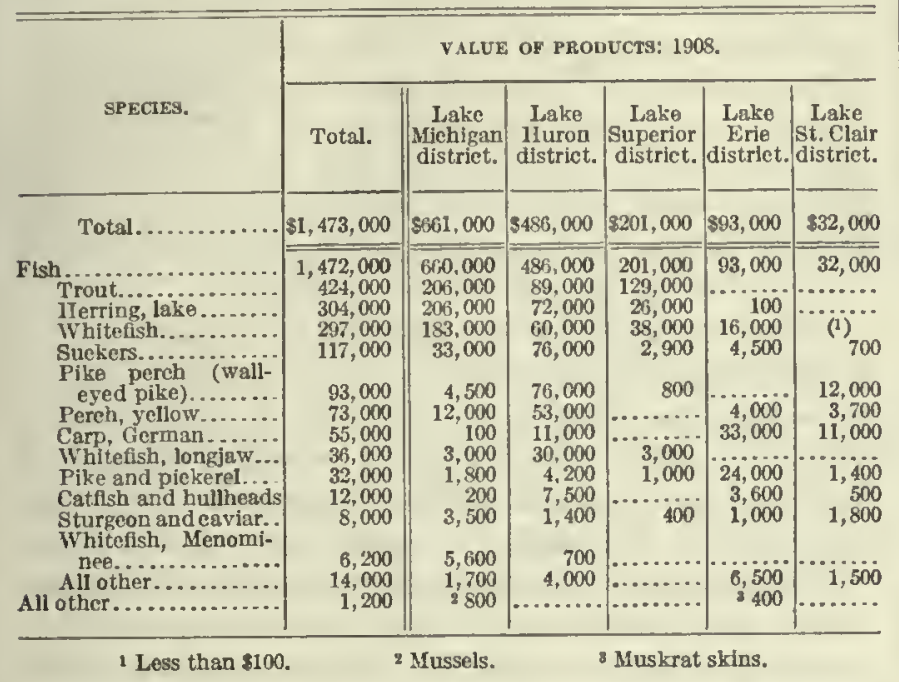

The fisheries in Lake Michigan furmished 45 per cent both of the weight and of the value of the entire Michigan product. The yield of Lake Huron was next to that of Lake Michigan, contributing 34 per cent of the weight and 33 per cent of the value of the catch of the entire state. Of the eight species taken in Lake Superior, trout was the most important, representing 47 per cent of the weight and 64 per cent of the value of the products of this lake. A similar preponderance of trout appeared in both the vessel fisheries and the shore and boat fisheries. Whitefish and herring made up the bulk of the remaining product in both classes of the Lake Superior fisheries.

Notwithstanding the fact that the Lake Erie fisheries of Michigan were all of the shore and boat class, 15 species of fish were taken. The eatch of this lake represented only 8 per cent of the quantity and 6 per cent of the value of the state product. No lake trout were reported as taken in the fisheries of Lake Erie and the lake herring taken formed only a negligible proportion of the product. The German carp, a minor species in the state as a whole, was the most important product of this lake, the Lake Erie catch of this species representing over one-half of the quantity and over one-third of the value of the total catch of Lake Erie for Michigan, and 69 per cent of the weight and 60 per cent of the value of the catch of this species in the state.
Lake St. Clair supplied about 2 per cent of the Michigan fishery product. Tho leading species was wall-eyed pike. German carp ranked next in value. These two species contributed 72 per cent of the weight and 71 per cent of the value of the total pro. duct of this lake.

Products, by class of fisheries.-Tables 7 and 8, on pages 172 and 173 , give the products taken in the vessel fisheries and the shore and boat fisheries of Michigan, respectively, by species and by apparatus of capture. The following tabular statement gives the value of the products, by class of fisheries and by species, ranked according to the value reported for the state as a whole:

\begin{tabular}{|c|c|c|c|}
\hline \multirow[b]{2}{*}{ SPECIES. } & \multicolumn{3}{|c|}{ VALUE OT PRODUCTS: 1908.} \\
\hline & Total. & $\begin{array}{c}\text { Vessel } \\
\text { fisheries. }\end{array}$ & $\begin{array}{l}\text { Shore and } \\
\text { hoat } \\
\text { fisheries. }\end{array}$ \\
\hline Total.................. & $\$ 1,473,000$ & $\$ 516,000$ & $\$ 957,000$ \\
\hline 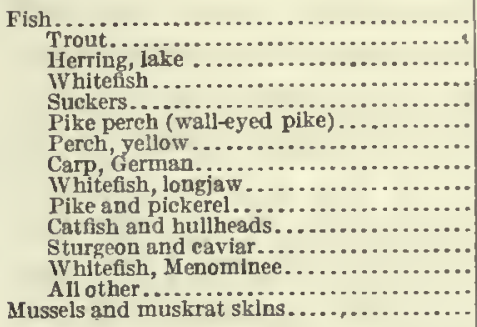 & $\begin{array}{r}1,472,000 \\
424,000 \\
304,000 \\
297,000 \\
117,000 \\
93,000 \\
73,000 \\
55,000 \\
36,000 \\
32,000 \\
12,000 \\
8,000 \\
6,200 \\
14,000 \\
1,200\end{array}$ & $\begin{array}{r}516,000 \\
266,000 \\
102,000 \\
110,000 \\
1,900 \\
800 \\
900 \\
\text { (1) } 3,000 \\
400 \\
100 \\
700 \\
\text { (1) } 800 \\
\end{array}$ & $\begin{array}{r}956,000 \\
158,000 \\
202,000 \\
187,000 \\
115,000 \\
93,000 \\
72,000 \\
55,000 \\
3,100 \\
32,000 \\
12,000 \\
7,300 \\
6,200 \\
13,000 \\
1,200\end{array}$ \\
\hline
\end{tabular}

Products, by apparatus of capture.-Pound nets and gill nets both took large shares of the total catch. The larger quantity is reported for pound nets, but gill nets are credited with the greater value of the product. Combined, these two linds of apparatus took a quantity representing 85 per cent of the total weight and 86 per cent of the total value.

The value of the catch, by kinds of apparatus, for the state and the respective lake districts, is given in the following tabular statement:

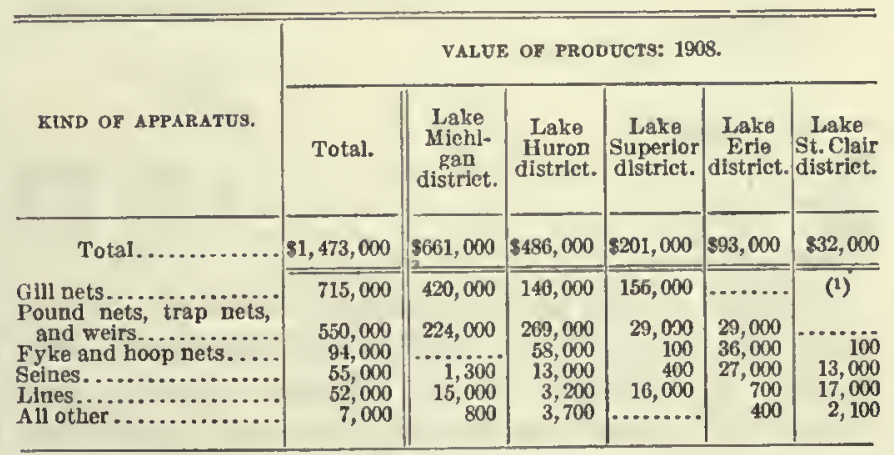

1 Less than $\$ 100$.

In Lake Superior gill nets were most important by a wide margin in both classes of fisheries and they were also the leading apparatus of capture in Lake Michigan, but in Lake Erie they were not used, and in Lake St. Clair they were used but little. Pound and trap nets, which were the most important apparatus of capture 
on Lake Huron, owe their prominence in part to their wide adaptability. Fyke and hoop nets, seines, and lines were next in order. Lake trout contributed more than half of the value of the gill-net catch, and whitefish and herring furnished the greater part of the remainder; while lake herring and whitefish composed more than one-half of the pound and trap net catch. Of the products taken with fyke and hoop nets, suckers were the leading species, but although the quantity of this species taken was more than double that of any other, except German carp, it contributed only a little more than a third of the value of the total product taken by this class of nets. Fyke and hoop nets were used to a greater extent in the shore and boat fisheries of Lake Huron than elsewhere, but they were of the greatest relative importance on Lake Erie. In Lakes Erie and St. Clair, as a result of the prevalence of carp, seines were among the most important forms of apparatus of capture used. Carp contributed 68 per cent of the value of the seine capture of the state. Of the value of the total line catch, 60 per cent represented lake trout. Every district and class of fisheries, except the vessel fisheries of Lake Hurori, reported products taken with lines.

Lake trout.-Three species-lake trout, whitefish, and lake herring-mado up approximately 70 per cent of the fishery product of Michigan. Lake trout furnished 29 per cent of the value, though only 18 per cent of the weight, of the state fishery product. About 4 per cent of the catch was salted, but the general practice in regard to this fish was to market it fresh.

The following tabular statement shows the quantity and value of the catch reported at the various canvasses from 1890 to 1908 , inclusive. Since 1903 a heavy decrease in quantity has taken place, but prices have been such as to keep the value very nearly the same.

\begin{tabular}{|c|c|c|}
\hline \multirow{2}{*}{ YEAR. } & \multicolumn{2}{|c|}{ LAKE-TROUT PRODUCT. } \\
\hline & $\begin{array}{l}\text { Quantity } \\
\text { (pounds). }\end{array}$ & Vaine. \\
\hline $\begin{array}{l}1908 \\
1903 \\
1899 \\
1890 \ldots \ldots\end{array}$ & $\begin{array}{l}6,798,000 \\
9,688,000 \\
6,691,000 \\
8,543,000\end{array}$ & $\begin{array}{l}\$ 424,000 \\
426,000 \\
260,000 \\
310,000\end{array}$ \\
\hline
\end{tabular}

Whitefish.-This product ranked second in value of catch among all fishery products of Michignn. Two species in addition to the common species were taken, and a small amount of caviar was made from the eggs. The totals given in the tabular statement presented below are for all of these species combined, including caviar. The great bulk of the catch was sold fresh, but a small percentage was salted and a very small amount smoked. The quantity taken by the shore and boat fisheries was about a fifth larger than that taken by the vessel fisheries, and brought slightly higher prices. This fish was taken in each of the five lakes, but considerably more than half came from Lake Michigan. Lakes Erie and St. Clair contributed but small proportions of the total. Whitefish has experienced a marked recovery from the downward movement apparent in 1899 and 1903, but the yield in 1908 was still far below that in 1890 with respect to quantity, although the demand made its value greater than the value reported for any previous year for which statistics are available. Comparative figures for the various canvasses beginning with 1890 are given below:

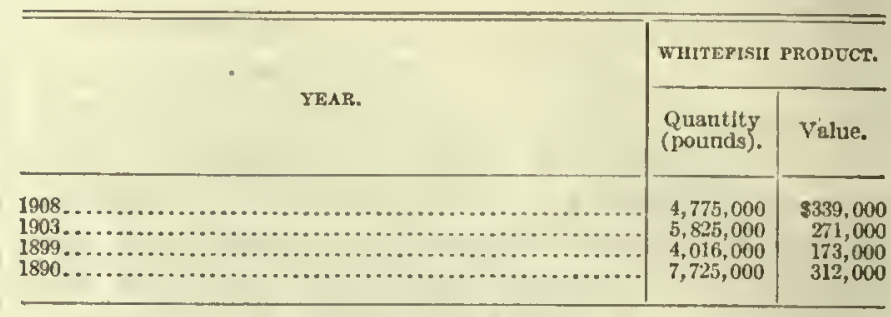

Lake hering.-'This fish was taken in greater quantities than lake trout and whitefish combined, but its value was less than that of cither of these species. Lake herring represented 39 per cent of the weight and 21 per cent of the value of the total product. Nearly two-thirds of the catch was salted, practically all of the salting being done by the shore and boat fishermen, who in 1908 treated over three-fourths of their lakeherring product in this way. This fish was not taken in Lake St. Clair, nor in more than a negligible quantity in Lake Erie.

The total lake-herring catch in 1908 exceeded in quantity and value that of any previous year for which statistics are available. The figures for the more recent canvasses are as follows:

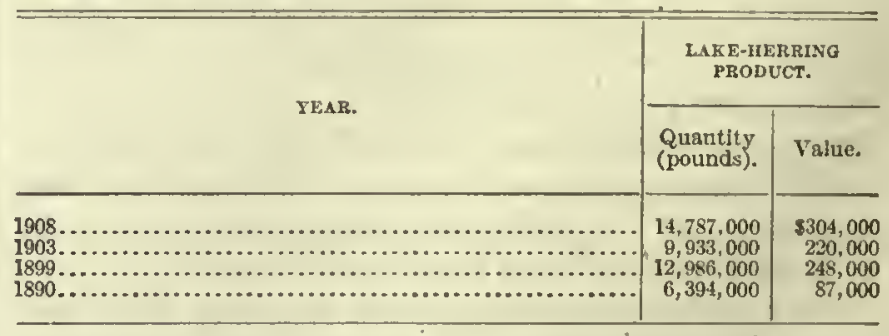

Suckers.-This species contributed 12 per cent of the weight and 8 per cent of the value of the state fishery product, the catch in 1908 being scarcely inferior to that of whitcfish in weight, but only about one-third as valuable. Only a small portion of the total product of this species was salted, and almost all of the quantity so treated came from Lake Michigan. Nearly seven-tentlis of the catch was made by pound and trap nets, and the bulk of the remainder was taken by fyke and hoop nets. This species has shown a steady incrense both in the weight and in the value of the yield, as indicated by the following tabular statement: 


\begin{tabular}{|c|c|c|}
\hline \multirow[b]{2}{*}{$\begin{array}{l}\text { YEAR. } \\
.\end{array}$} & \multicolumn{2}{|c|}{ SUCKER PRODUCT. } \\
\hline & $\begin{array}{l}\text { Quantity } \\
\text { (pounds). }\end{array}$ & Value. \\
\hline $\begin{array}{l}1908 \ldots \ldots \ldots \\
1903 \ldots \ldots \ldots \\
1899 \ldots \ldots\end{array}$ & $\begin{array}{l}4,467,000 \\
4,087,000 \\
1,775,000\end{array}$ & $\begin{array}{r}\$ 117,000 \\
85.000 \\
30,000\end{array}$ \\
\hline
\end{tabular}

Pike perehes.- Under this head are included tho blue pike, the sauger pike, and the wall-eyed pike, which is many times more important than the two first-named species in the catch of this state. The blue pike was taken only in the vessel fishories, while the others were taken almost exclusively in the shore and boat fisheries. All of the blue-pike product was from Lake Michigan, and all of the salted sauger pike came from the vessel fisheries of the same district. Most of the catch of fresl sauger pike was from Lake Erie. Aboutfour-fifths of the wall-eyed pikecamefrom Lake Huron, while most of the remainder was from Lake St. Clair, of which this is the leading product, measured by value. In Lake Huron this species was taken chicfly by pound and trap nets and in Lake St. Clair chiefly by lines. A greater quantity of sauger pilke was taken with fyke and hoop nets than with pound and trap nets, the only other class of apparatus for which product of any importance was reported. For the capture of blue pike gill nets were used exclusively. The yield of pike perch was less in 1908 than in any of the years for which a canvass has been made, but its value was exceeded only by that of the catch of 1903 . Figures for the various canvasses are presented in the following tabular statement:

\begin{tabular}{|c|c|c|}
\hline \multirow[b]{2}{*}{ YEAR. } & \multicolumn{2}{|c|}{ PIKE-PERCH PRODUCT. } \\
\hline & $\begin{array}{l}\text { Quantity } \\
\text { (pounds). }\end{array}$ & Value. \\
\hline $\begin{array}{l}1908 \ldots \ldots \ldots \ldots \ldots \ldots \\
1903 \ldots \ldots \ldots \\
1899 \ldots \ldots \ldots \ldots\end{array}$ & $\begin{array}{r}1,194,000 \\
2,318,000 \\
1,989,000 \\
12,690,000\end{array}$ & $\begin{array}{r}898,000 \\
127,000 \\
92,000 \\
187,000\end{array}$ \\
\hline
\end{tabular}

$Y$ ellow perch.-This species contributed about 5 per cent of the value of the state products, and was taken almost wholly by the shore and boat fisheries. Lake Huron furnished almost three-fourths of the total value of the yellow perch caught and Lake Michigan the greater part of the remainder. Over three-fourths of the Lake Huron product was taken with pound and trap nets, and fyke and hoop nets ranked next in importance among the kinds of apparatus used. 'In Lake Michigan gill nets took nearly as great a quantity as pound and trap nets, and the catcl was of greater value; all but a small part of the catch was taken by these two forms of apparatus: The yellowperch eatch has increased in value steadily, but the quantity taken in 1908, though greater than that taken in 1903, was much less than the catch in 1899 or 1890.

\begin{tabular}{|c|c|c|}
\hline \multirow{2}{*}{ TEAR. } & \multicolumn{2}{|c|}{$\begin{array}{l}\text { YELLOW-PERCII } \\
\text { PRODUCT. }\end{array}$} \\
\hline & $\begin{array}{l}\text { Qunntity } \\
\text { (pounds). }\end{array}$ & Value. \\
\hline $\begin{array}{l}1908 \ldots \ldots \ldots \ldots \ldots \\
1903 \ldots \ldots \ldots \ldots \ldots \ldots \ldots \ldots \ldots \\
1890 \ldots \ldots \ldots \ldots \ldots \ldots \ldots \ldots\end{array}$ & $\begin{array}{l}2,378,000 \\
2,257,000 \\
3,137,000 \\
3,029,000\end{array}$ & $\begin{array}{r}\$ 73,000 \\
53,000 \\
41,000 \\
40,000\end{array}$ \\
\hline
\end{tabular}

German carp.-This species is mentioned separately because it has risen from an inferior rank to one of prominence since the last canvass. Though contributing only 6 per cent of the quantity and 3 per cent of the value of the state product in 1908, German carp ranked seventh in value and the quantity caught was greater than that of yellow perch. It was not taken in Lake Superior, nol to any extent in Lake Michigan, but it contributed over one-half of the weight and over one-third of the value of the total fishery product reported for Lake Erie, to which lake over two-thirds of the weight of the Michigan capture of carp is credited. The shore and boat fislieries of Lake Huron reported about one-half of the weight and over one-half of the value of the product not taken in Lake Erie, while Lake St. Clair reported most of the remainder.

\begin{tabular}{|c|c|c|}
\hline \multirow{2}{*}{ TEAR. } & \multicolumn{2}{|c|}{$\begin{array}{l}\text { GERMAN-CARP } \\
\text { PRODUCT. }\end{array}$} \\
\hline & $\begin{array}{l}\text { Quantity } \\
\text { (pounds). }\end{array}$ & Value. \\
\hline $\begin{array}{l}1908 \ldots \ldots \ldots \ldots \ldots \ldots \\
1903 \ldots \ldots \ldots \ldots \ldots \ldots \ldots \\
1899 \ldots \ldots \ldots \ldots \ldots \ldots\end{array}$ & $\begin{array}{r}2,459,000 \\
580,000 \\
218,000\end{array}$ & $\begin{array}{r}855,000 \\
10,000 \\
4,300\end{array}$ \\
\hline
\end{tabular}


TABLE 1.-MICHIGAN-FISHERY PRODUCTS: 1908.

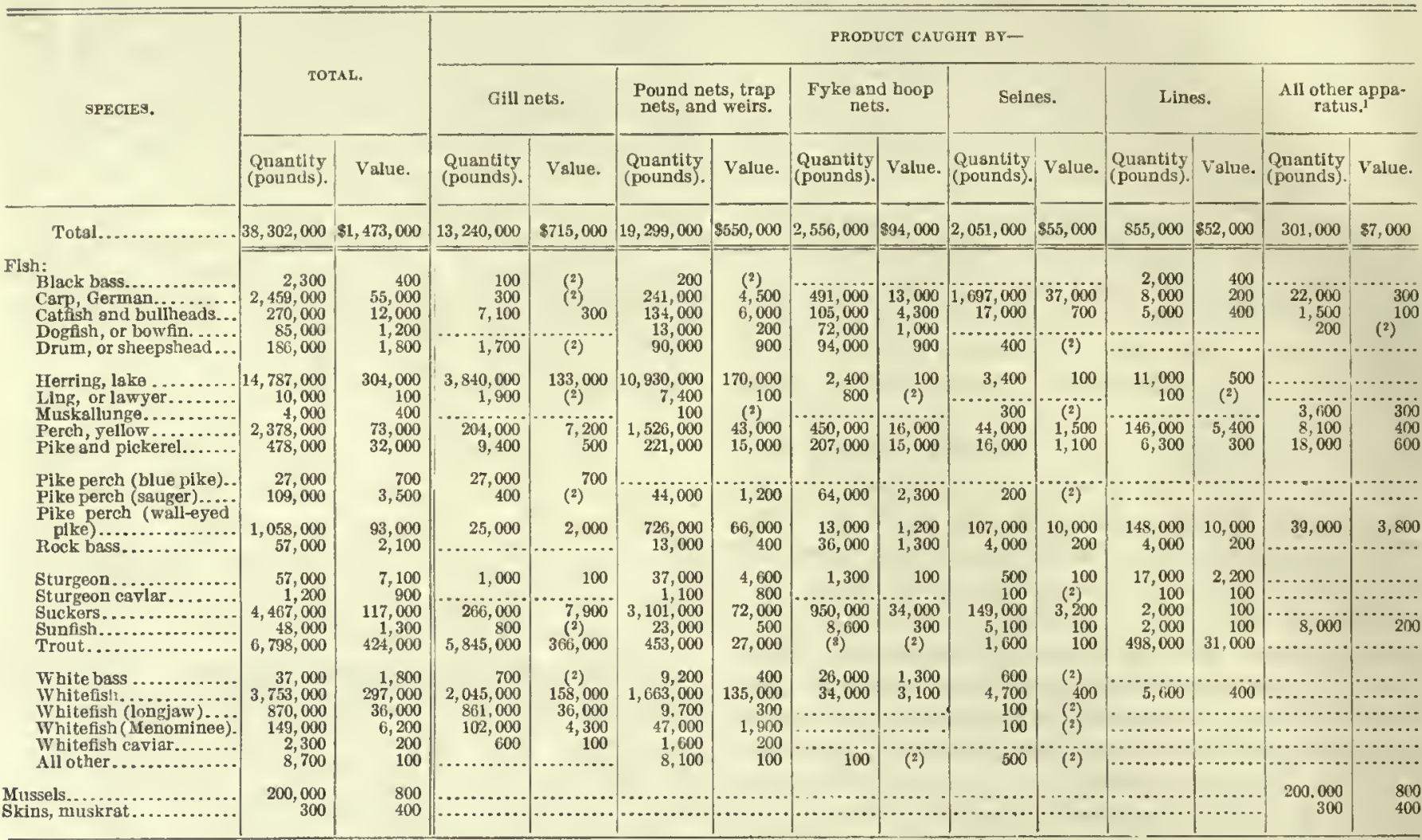

1 Includes apparatus, with catch, as follows: Harpoons, spears, etc., 100,000 pounds, valued at $\$ 5,800$; crow foot dredges, etc., 200,000 pounds, valued at $\$ 800$; and muskrat traps, 300 pounds, valued at $\$ 400$.

2 Less than $\$ 100$.
3 Less than 100 pounds.

TABLE 2.-MICHIGAN-FISHERY PRODUCTS OF LAKE MICHIGAN DISTRICT: 1908.

\begin{tabular}{|c|c|c|c|c|c|c|c|c|c|c|c|c|}
\hline \multirow{3}{*}{ SPECIES. } & \multirow{2}{*}{\multicolumn{2}{|c|}{ TOTAL. }} & \multicolumn{10}{|c|}{ PRODUCT CAUGHT BY- } \\
\hline & & & \multicolumn{2}{|c|}{ Gill nets. } & \multicolumn{2}{|c|}{$\begin{array}{c}\text { Pound nets, trap nets, } \\
\text { snd weirs. }\end{array}$} & \multicolumn{2}{|c|}{ Llnes. } & \multicolumn{2}{|c|}{ Selnes. } & \multicolumn{2}{|c|}{$\begin{array}{l}\text { Crowfoot dredges, } \\
\text { etc. }\end{array}$} \\
\hline & $\begin{array}{l}\text { Quantity } \\
\text { (pounds). }\end{array}$ & Value. & $\begin{array}{l}\text { Quantity } \\
\text { (pounds). }\end{array}$ & Value. & $\begin{array}{l}\text { Quantity } \\
\text { (pounds). }\end{array}$ & Value. & $\begin{array}{l}\text { Quantity } \\
\text { (pounds). }\end{array}$ & Value. & $\begin{array}{l}\text { Quantity } \\
\text { (pounds). }\end{array}$ & Value. & $\begin{array}{l}\text { Quantity } \\
\text { (pounds). }\end{array}$ & Value. \\
\hline Total........................ & $17,044,000$ & $\$ 661,000$ & $7,042,000$ & $\$ 420,000$ & $9,526,000$ & $\$ 224,000$ & 246,000 & $\$ 15,000$ & 31,000 & $\$ 1,300$ & 200,000 & 8800 \\
\hline 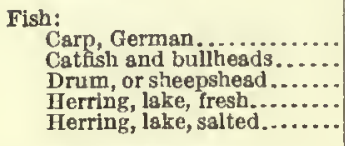 & $\begin{array}{r}3,800 \\
2,500 \\
24,000 \\
2,625,000 \\
6,479,000\end{array}$ & $\begin{array}{r}100 \\
200 \\
400 \\
108,000 \\
98,000\end{array}$ & $\begin{array}{r}300 \\
700 \\
1,700 \\
2,123,000 \\
12,000\end{array}$ & $\begin{array}{l}\text { (1) } \\
100 \\
\text { (1) } \\
102,000 \\
400\end{array}$ & $\begin{array}{r}3,500 \\
1,300 \\
22,000 \\
489,000 \\
6,467,000\end{array}$ & $\begin{array}{r}100 \\
100 \\
400 \\
5,200 \\
97,000\end{array}$ & 11,000 & 500 & 2,000 & (i) & & $\begin{array}{l}\cdots \\
\cdots \\
\cdots\end{array}$ \\
\hline 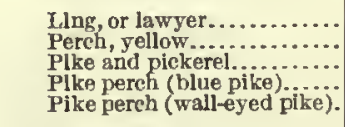 & $\begin{array}{r}8,300 \\
348,000 \\
21,000 \\
27,000 \\
52,000\end{array}$ & $\begin{array}{r}100 \\
12,000 \\
1,800 \\
700 \\
4,500\end{array}$ & $\begin{array}{r}1,900 \\
140,000 \\
1,700 \\
27,000 \\
1,600\end{array}$ & $\begin{array}{l}\text { (1) } \\
\mathbf{5}, 400 \\
100 \\
700 \\
100\end{array}$ & $\begin{array}{r}6,400 \\
143,000 \\
19,000 \\
50,000\end{array}$ & $\begin{array}{r}100 \\
4,600 \\
1,700 \\
4,400\end{array}$ & $\begin{array}{r}100 \\
59,000 \\
300 \\
\cdots\end{array}$ & $\begin{array}{l}\text { (i) } \\
1,900 \\
\text { (1) }\end{array}$ & $(2)$ & (I) 300 & $\begin{array}{l}\cdots \\
\cdots \\
\cdots\end{array}$ & $\begin{array}{l}\cdots \\
\cdots \\
\cdots\end{array}$ \\
\hline 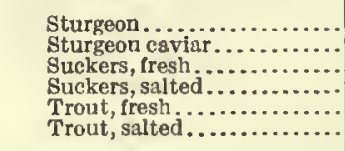 & $\begin{array}{r}21,000 \\
800 \\
1,223,000 \\
216,000 \\
3,214,000 \\
70,000\end{array}$ & $\begin{array}{r}2,800 \\
700 \\
28,000 \\
4,600 \\
203,000 \\
3,600\end{array}$ & $\begin{array}{r}600 \\
135,000 \\
67,000 \\
2,873,000 \\
65,000\end{array}$ & $\begin{array}{r}100 \\
4,400 \\
1,900 \\
180,000 \\
3,400\end{array}$ & $\begin{array}{r}20,000 \\
800 \\
1,070,000 \\
145,000 \\
172,000 \\
4,700\end{array}$ & $\begin{array}{r}2,700 \\
700 \\
23,000 \\
2,600 \\
10,000 \\
200\end{array}$ & $\begin{array}{l}(2) \\
2,000 \\
169,000 \\
\cdots \ldots \ldots\end{array}$ & $\begin{array}{c}\text { (1) } \\
100 \\
12,000\end{array}$ & $\begin{array}{r}16,000 \\
5,000 \\
1,000\end{array}$ & $\begin{array}{l}600 \\
100 \\
100\end{array}$ & (...... & $\begin{array}{l}\cdots \\
\cdots \\
\cdots \\
\cdots\end{array}$ \\
\hline $\begin{array}{l}\text { White bass .................. } \\
\text { Whitefish, fresh } \\
\text { Whitefish, salted............. } \\
\text { Whitefish (longjaw), fresh.. }\end{array}$ & $\begin{array}{r}2,000 \\
2,172,000 \\
137,000 \\
68,000\end{array}$ & $\begin{array}{r}100 \\
174,000 \\
8,600 \\
3,000\end{array}$ & $\begin{array}{r}700 \\
1,403,000 \\
35,000 \\
63,000\end{array}$ & $\begin{array}{r}(1) \\
112,000 \\
2,200 \\
2,800\end{array}$ & $\begin{array}{r}1,300 \\
763,000 \\
102,000 \\
4,200\end{array}$ & $\begin{array}{r}100 \\
62,000 \\
6,400 \\
200\end{array}$ & 5,600 & $4000^{\circ}$ & $\left({ }^{2}\right)$ & (1) & & $\because$ \\
\hline $\begin{array}{l}\text { Whitefish (Menominee), } \\
\text { fresh }\end{array}$ & 36,000 & 1,300 & 33,000 & 1,200 & 3,000 & 100 & & & & & & \\
\hline 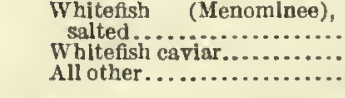 & $\begin{array}{r}91,000 \\
2,100 \\
1,300\end{array}$ & $\begin{array}{r}4,200 \\
200 \\
100\end{array}$ & $\begin{array}{r}54,000 \\
600 \\
400\end{array}$ & $\begin{array}{l}2,000 \\
100 \\
\text { (1) }\end{array}$ & $\begin{array}{r}37,000 \\
1,500 \\
900\end{array}$ & $\begin{array}{r}1,600 \\
100 \\
100\end{array}$ & & & & & $\begin{array}{l}\text { l......... } \\
\cdots \cdots \cdots\end{array}$ & (n........ \\
\hline Mussels......................... & 200,000 & 800 & & & & & & & & & 200,000 & 800 \\
\hline
\end{tabular}


TABLE 3.-MICHIGAN-FISHERY PRODUCTS OF LAKE HURON DISTRICT: 1908.

\begin{tabular}{|c|c|c|c|c|c|c|c|c|c|c|c|c|c|c|}
\hline \multirow{3}{*}{ SPECIES. } & \multirow{2}{*}{\multicolumn{2}{|c|}{ TOTAL. }} & \multicolumn{12}{|c|}{ PRODUCT CAUGHT BY- } \\
\hline & & & \multicolumn{2}{|c|}{$\begin{array}{l}\text { Pound nets, trap } \\
\text { nets, and weirs. }\end{array}$} & \multicolumn{2}{|c|}{ Gill nets. } & \multicolumn{2}{|c|}{$\begin{array}{l}\text { Fyke and hoop } \\
\text { nets. }\end{array}$} & \multicolumn{2}{|c|}{ Seines. } & \multicolumn{2}{|c|}{$\begin{array}{l}\text { Harpoons, spears, } \\
\text { etc. }\end{array}$} & \multicolumn{2}{|c|}{ Lines. } \\
\hline & $\begin{array}{l}\text { Quantity } \\
\text { (pounds). }\end{array}$ & Value. & $\begin{array}{l}\text { Quantity } \\
\text { (pounds). }\end{array}$ & Value. & $\begin{array}{l}\text { Quantity } \\
\text { (pounds). }\end{array}$ & Value. & $\begin{array}{l}\text { Quantity } \\
\text { (pounds). }\end{array}$ & Value. & $\begin{array}{l}\text { Quantity } \\
\text { (pounds). }\end{array}$ & Value. & $\begin{array}{l}\text { Quantity } \\
\text { (pounds). }\end{array}$ & Value. & $\begin{array}{l}\text { Quantity } \\
\text { (pounds). }\end{array}$ & Value. \\
\hline Tatal............ & $12,932,000$ & $\$ 4 S 6,000$ & $8,589,000$ & 3269,000 & $2,468,000$ & $\$ 140,000$ & $1,520,000$ & 858,000 & 264,000 & $\$ 13,000$ & 42,000 & $\$ 3,700$ & 50,000 & $\$ 3,200$ \\
\hline 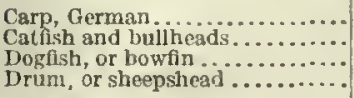 & $\begin{array}{r}407,000 \\
174,000 \\
82,000 \\
8,100\end{array}$ & $\begin{array}{r}11,000 \\
7,500 \\
1,200 \\
100\end{array}$ & $\begin{array}{r}149,000 \\
118,000 \\
13,000 \\
8,100\end{array}$ & $\begin{array}{r}2,900 \\
5,300 \\
200 \\
100\end{array}$ & $\begin{array}{c}(1) \\
6,300 \\
\cdots \cdots \cdots\end{array}$ & $\begin{array}{r}{ }^{(2)} \\
200 \\
\cdots \cdots \\
\cdots\end{array}$ & $\begin{array}{r}207,000 \\
39,000 \\
69,000\end{array}$ & $\begin{array}{l}7,500 \\
1,600 \\
1,000\end{array}$ & $\begin{array}{r}45,000 \\
10,000 \\
\cdots\end{array}$ & $\begin{array}{r}700 \\
400 \\
\cdots\end{array}$ & $\begin{array}{r}5,900 \\
200\end{array}$ & 200 & 600 & $\begin{array}{l}(2) \\
\cdots \cdots\end{array}$ \\
\hline $\begin{array}{l}\text { Herring, lake, fresh. ............... } \\
\text { Herring, lake, salted. ............. }\end{array}$ & $\begin{array}{l}1.239,000 \\
2,824,000\end{array}$ & $\begin{array}{l}21,000 \\
51,000\end{array}$ & $\begin{array}{l}1,121,000 \\
2,824,000\end{array}$ & $\begin{array}{l}16,000 \\
51,000\end{array}$ & $\begin{array}{r}115,000 \\
\ldots \ldots\end{array}$ & 4,800 & 1,900 & $\left({ }^{2}\right)$ & 1,400 & $\left({ }^{2}\right)$ & & & & \\
\hline $\begin{array}{l}\text { Perch, yellow ..................... } \\
\text { Pike and pickerel............... }\end{array}$ & $\begin{array}{r}1,805,000 \\
63,000\end{array}$ & $\begin{array}{r}53,000 \\
4,200\end{array}$ & $\begin{array}{r}1,362,000 \\
37,000\end{array}$ & $\begin{array}{r}37,000 \\
2,400\end{array}$ & $\begin{array}{r}64,000 \\
7,000\end{array}$ & 1,800 & $\begin{array}{r}342,000 \\
15,000\end{array}$ & $\begin{array}{r}13,000 \\
1,200\end{array}$ & $\begin{array}{r}32,000 \\
3,400\end{array}$ & 1,000 & 100 & $\dddot{(2)}$ & $\ddot{5}, 000$ & 2000 \\
\hline 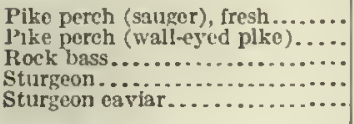 & $\begin{array}{r}3,500 \\
829,000 \\
48,000 \\
9,900 \\
300\end{array}$ & $\begin{array}{r}100 \\
76,000 \\
1,700 \\
1,200 \\
100\end{array}$ & $\begin{array}{r}3,100 \\
668,000 \\
13,000 \\
9,400 \\
300\end{array}$ & $\begin{array}{r}100 \\
61,000 \\
400 \\
1,200 \\
100\end{array}$ & $\begin{array}{r}100 \\
23,000 \\
400\end{array}$ & $\begin{array}{l}(\stackrel{2}{)} \\
1,800 \\
100\end{array}$ & $\begin{array}{r}200 \\
11,000 \\
36,000 \\
\cdots\end{array}$ & $\begin{array}{c}\stackrel{(2)}{ }^{1,100} \\
1,300 \\
\cdots, \cdots \\
\cdots, \cdots\end{array}$ & 91,000 & $\begin{array}{r}\left({ }^{2}\right) \\
8,700 \\
(2)\end{array}$ & 35,000 & 3,600 & & \\
\hline 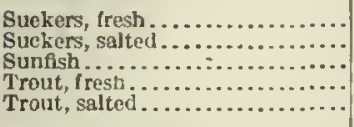 & $\begin{array}{r}2,566,000 \\
9,400 \\
34,000 \\
1,353,000 \\
5,800\end{array}$ & $\begin{array}{r}76,000 \\
200 \\
900 \\
89,000 \\
200\end{array}$ & $\begin{array}{r}1,645,000 \\
9,200 \\
23,000 \\
113,000 \\
3,900\end{array}$ & $\begin{array}{r}42,000 \\
200 \\
500 \\
6,800 \\
200\end{array}$ & $\begin{array}{r}53,000 \\
200 \\
800 \\
1,195,000 \\
2,000\end{array}$ & $\begin{array}{c}1,300 \\
(2) \\
79,000 \\
100\end{array}$ & $\begin{array}{c}789,000 \\
8,500 \\
(1) \\
\cdots\end{array}$ & $\begin{array}{c}31,000 \\
300 \\
(2)\end{array}$ & $\begin{array}{r}80,000 \\
1,100 \\
100\end{array}$ & $\begin{array}{c}1,600 \\
(2) \\
(2)\end{array}$ & $\begin{array}{l}\cdots \\
\therefore\end{array}$ & & 44,000 & 3,000 \\
\hline 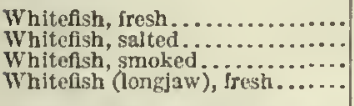 & $\begin{array}{r}693,000 \\
13,000 \\
13,000 \\
728,000\end{array}$ & $\begin{array}{r}58,000 \\
600 \\
1,200 \\
30,000\end{array}$ & $\begin{array}{r}447,000 \\
13,000 \\
7700\end{array}$ & $\begin{array}{r}39,000 \\
600 \\
(2)\end{array}$ & $\begin{array}{r}245,000 \\
100 \\
13,000 \\
727,000\end{array}$ & $\begin{array}{c}19,000 \\
(2) \\
1,200 \\
30,000\end{array}$ & 200 & (ग) & 200 & (') & & & & $\because$ \\
\hline 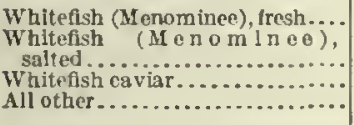 & $\begin{array}{r}19,000 \\
3,000 \\
100 \\
1,900\end{array}$ & ${ }_{(2)}^{100}$ & $\begin{array}{l}2,700 \\
100 \\
1,000\end{array}$ & $(3)^{100}$ & $\begin{array}{r}15,000 \\
300\end{array}$ & $\begin{array}{l}400 \\
(2)\end{array}$ & 900 & (3) & 100 & (2) & & & & \\
\hline
\end{tabular}

1 Less than 100 pounds.

2 Less than $\$ 100$.

TABLE 4.-MICHIGAN-FISHERY PRODUCTS OF LAKE SUPERIOR DISTRICT: 1908.

\begin{tabular}{|c|c|c|c|c|c|c|c|c|c|c|c|c|}
\hline \multirow{3}{*}{ SPECIES. } & \multirow{2}{*}{\multicolumn{2}{|c|}{ TOTAL. }} & \multicolumn{10}{|c|}{ PRONUCT CAUGHT BY- } \\
\hline & & & \multicolumn{2}{|c|}{ Gil1 nets. } & \multicolumn{2}{|c|}{$\begin{array}{l}\text { Pound nets, trap nets, } \\
\text { and weirs. }\end{array}$} & \multicolumn{2}{|c|}{ Lines. } & \multicolumn{2}{|c|}{ Seines. } & \multicolumn{2}{|c|}{ Fyke and hoop nets. } \\
\hline & $\begin{array}{l}\text { Quartity } \\
\text { (paunds). }\end{array}$ & Value. & $\begin{array}{l}\text { Quantity } \\
\text { (pounds). }\end{array}$ & Value. & $\begin{array}{l}\text { Quantity } \\
\text { (pounds). }\end{array}$ & Value. & $\begin{array}{l}\text { Quantity } \\
\text { (pounds). }\end{array}$ & Value. & $\begin{array}{l}\text { Quantity } \\
\text { (pounds). }\end{array}$ & Value. & $\begin{array}{l}\text { Quantity } \\
\text { (pounds). }\end{array}$ & Value. \\
\hline Total......... & $4,579,000$ & $\$ 201,000$ & $3,731,000$ & $\$ 156,000$ & $.554,000$ & $\$ 29,000$ & 286,000 & $\$ 16,000$ & 5,800 & $\$ 400$ & 2,100 & $\$ 100$ \\
\hline 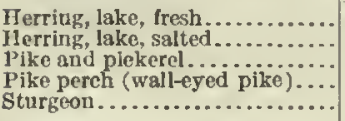 & $\begin{array}{r}1,304,000 \\
314,000 \\
24,000 \\
10,000 \\
4,200\end{array}$ & $\begin{array}{r}20,000 \\
6,000 \\
1,000 \\
800 \\
400\end{array}$ & $\begin{array}{r}1,277,000 \\
314,000 \\
200 \\
800\end{array}$ & $\begin{array}{c}19,000 \\
5,900 \\
(1) \\
100 \\
. \quad . . . . .\end{array}$ & $\begin{array}{r}27,000 \\
23,000 \\
7,600 \\
4,200\end{array}$ & $\begin{array}{r}600 \\
900 \\
600 \\
400\end{array}$ & $\begin{array}{l}\cdots \cdots \\
\cdots \cdots \\
\cdots \cdots\end{array}$ & (i) & $\begin{array}{l}200 \\
500\end{array}$ & (1) & $\begin{array}{r}r \\
1,300 \\
800 \\
\ldots\end{array}$ & $\begin{array}{l}\cdots \\
100 \\
100\end{array}$ \\
\hline 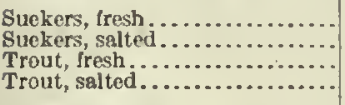 & $\begin{array}{r}154,000 \\
6,900 \\
1,941,000 \\
214,000\end{array}$ & $\begin{array}{r}2,800 \\
100 \\
117,000 \\
12,000\end{array}$ & $\begin{array}{r}9,200 \\
1,400 \\
1,525,000 \\
184,000\end{array}$ & $\begin{array}{l}300 \\
(1) \\
93,000 \\
10,000\end{array}$ & $\begin{array}{r}145,000 \\
5,500 \\
158,000 \\
1,500\end{array}$ & $\begin{array}{l}2,600 \\
100 \\
9,700 \\
(1)\end{array}$ & $\begin{array}{r}257,000 \\
29,000\end{array}$ & $\begin{array}{r}14,000 \\
1,700\end{array}$ & 500 & (i) & & 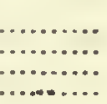 \\
\hline $\begin{array}{l}\text { Whitefish, fresh ............... } \\
\text { Whitefish, salted .............. } \\
\text { Whitefish (longjaw), fresh } \\
\text { Whitefish (longjaw), salted..... }\end{array}$ & $\begin{array}{r}513,000 \\
18,000 \\
68,000 \\
7,000\end{array}$ & $\begin{array}{r}37,000 \\
1,300 \\
2,800 \\
300\end{array}$ & $\begin{array}{r}342,000 \\
5,800 \\
63,000 \\
7,000\end{array}$ & $\begin{array}{r}23,000 \\
400 \\
2,6100 \\
300\end{array}$ & $\begin{array}{r}166,000 \\
12,000 \\
4.800\end{array}$ & $\begin{array}{r}13,000 \\
800 \\
100\end{array}$ & & & $\begin{array}{l}4,500 \\
100\end{array}$ & $\begin{array}{r}300 \\
3^{(1)}\end{array}$ & & $\begin{array}{l}\ldots \ldots \ldots \ldots \\
\cdots \ldots \ldots \ldots \\
\cdots \ldots \ldots \ldots \\
\cdots \ldots \ldots\end{array}$ \\
\hline
\end{tabular}


TABLE 5.-MICHIGAN-FISHERY PRODUCTS OF LAKE ERIE DISTRICT: 1908.

\begin{tabular}{|c|c|c|c|c|c|c|c|c|c|c|c|c|}
\hline \multirow{3}{*}{ SPECIES. } & \multirow{2}{*}{\multicolumn{2}{|c|}{ Total. }} & \multicolumn{10}{|c|}{ PRODUCT CAUGHT BY- } \\
\hline & & & \multicolumn{2}{|c|}{ Fykc and hoop nets. } & \multicolumn{2}{|c|}{$\begin{array}{l}\text { Pound nets, trap nets, } \\
\text { and weirs. }\end{array}$} & \multicolumn{2}{|c|}{ Seines. } & \multicolumn{2}{|c|}{ Lines. } & \multicolumn{2}{|c|}{ Mfuskrat traps. } \\
\hline & $\begin{array}{l}\text { Quantity } \\
\text { (pounds). }\end{array}$ & Value. & $\begin{array}{l}\text { Quantity } \\
\text { (pounds). }\end{array}$ & Value. & $\begin{array}{l}\text { Quantity } \\
\text { (pounds). }\end{array}$ & Value. & $\begin{array}{l}\text { Quantity } \\
\text { (pounds). }\end{array}$ & Value. & $\begin{array}{l}\text { Quantity } \\
\text { (pounds). }\end{array}$ & Value. & $\begin{array}{l}\text { Quantity } \\
\text { (pounds). }\end{array}$ & $\begin{array}{c}\text { Value. } \\
\text {. }\end{array}$ \\
\hline Total........ & $3,010,000$ & $\$ 93,000$ & $1,031,000$ & $\$ 36,000$ & 630,000 & $\$ 29,000$ & $1,343,000$ & $\$ 27,000$ & 5,000 & $\$ 700$ & 300 & $\$+00$ \\
\hline $\begin{array}{l}\text { Fish: } \\
\text { Carp, German } \ldots . . . . . . . . . . . \\
\text { Catfish and builheads....... } \\
\text { Drum, or sheepshead....... } \\
\text { Herring, lake.............. }\end{array}$ & $\begin{array}{r}1,684,000 \\
87,000 \\
154,000 \\
2,100\end{array}$ & $\begin{array}{r}33,000 \\
3,600 \\
1,300 \\
100\end{array}$ & $\begin{array}{r}284,000 \\
66,000 \\
94,000 \\
500\end{array}$ & $\begin{array}{l}5,700 \\
2,700 \\
900 \\
(1)\end{array}$ & $\begin{array}{r}88,000 \\
15,000 \\
60,000 \\
1,600\end{array}$ & $\begin{array}{r}1,500 \\
600 \\
400 \\
100\end{array}$ & $\begin{array}{r}1,311,000 \\
5,500 \\
400 \\
\ldots\end{array}$ & $\begin{array}{c}26,000 \\
200 \\
(1)^{2}\end{array}$ & $900^{\circ}$ & (1) & & $\begin{array}{l}\cdots \\
\cdots \\
\cdots\end{array}$ \\
\hline $\begin{array}{l}\text { Perch, yellow ............... } \\
\text { Pike and plekerei........... } \\
\text { Pike perch................. } \\
\text { Sturgeon................ }\end{array}$ & $\begin{array}{r}133,000 \\
338,000 \\
105,000 \\
9,000\end{array}$ & $\begin{array}{r}4,000 \\
24,000 \\
3,300 \\
1,000\end{array}$ & $\begin{array}{r}108,000 \\
189,000 \\
64,000 \\
1,300\end{array}$ & $\begin{array}{r}3,300 \\
14,000 \\
2,200 \\
100\end{array}$ & $\begin{array}{r}21,000 \\
142,000 \\
41,000 \\
3,600\end{array}$ & $\begin{array}{r}600 \\
9,900 \\
1,100 \\
300\end{array}$ & $\begin{array}{r}3,300 \\
6,100 \\
\cdots \cdots \cdots \\
\cdots \cdots\end{array}$ & $\begin{array}{r}100 \\
400 \\
\cdots \cdots\end{array}$ & $\dddot{4}, 100$ & 000 & 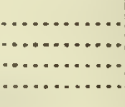 & $\begin{array}{l}\ldots \ldots \ldots \ldots \\
\cdots \ldots \ldots \ldots \\
\cdots \ldots \ldots \ldots \\
\cdots \ldots \ldots\end{array}$ \\
\hline 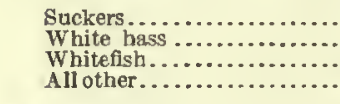 & $\begin{array}{r}258,000 \\
35,000 \\
193,000 \\
11,000\end{array}$ & $\begin{array}{r}4,500 \\
1,700 \\
16,000 \\
100\end{array}$ & $\begin{array}{r}160,000 \\
26,000 \\
34,000 \\
3,000\end{array}$ & $\begin{array}{l}2,900 \\
1,300 \\
3,100 \\
(1)\end{array}$ & $\begin{array}{r}82,000 \\
7,800 \\
159,000 \\
8,200\end{array}$ & $\begin{array}{r}1,300 \\
300 \\
13,000 \\
100\end{array}$ & $\begin{array}{r}16,000 \\
600 \\
\ldots \ldots . . .\end{array}$ & $\begin{array}{l}\text { (1) }^{300} \\
\cdots \cdots \cdots\end{array}$ & & & $\cdots \cdots$ & $\begin{array}{l}\ldots \ldots \ldots \\
\cdots \ldots \ldots \ldots \\
\cdots \cdots \cdots\end{array}$ \\
\hline Muskrat skins........ & 300 & 400 & & & & & & & & & 300 & 400 \\
\hline
\end{tabular}

3 Less than $\$ 100$.

21,000 skins.

TABLE 6.-MICHIGAN-FISHERY PRODUCTS OF LAKE ST. CLAIR DISTRICT: 1908. ${ }^{1}$

\begin{tabular}{|c|c|c|c|c|c|c|c|c|c|c|}
\hline \multirow{3}{*}{ SPECIES. } & \multirow{2}{*}{\multicolumn{2}{|c|}{ TотAL. }} & \multicolumn{8}{|c|}{ PRODUCT CAUGRT BY- } \\
\hline & & & \multicolumn{2}{|c|}{ Lines. } & \multicolumn{2}{|c|}{ Seines. } & \multicolumn{2}{|c|}{ Harpoons, spears, etc. } & \multicolumn{2}{|c|}{ Gill, tyke, and hoop nets. } \\
\hline & $\begin{array}{l}\text { Quantity } \\
\text { (pounds). }\end{array}$ & Value. & $\begin{array}{l}\text { Quantity } \\
\text { (pounds). }\end{array}$ & Value. & $\begin{array}{l}\text { Quantity } \\
\text { (pounds). }\end{array}$ & Value. & $\begin{array}{l}\text { Quantity } \\
\text { (pounds). }\end{array}$ & Value. & $\begin{array}{l}\text { Quantity } \\
\text { (pounds). }\end{array}$ & Value. \\
\hline Total.... & 737,000 & $\$ 32,000$ & 269,000 & $\$ 17,000$ & 408,000 & $\$ 13,000$ & 59,000 & $\$ 2,100$ & 2,600 & $\$ 100$ \\
\hline 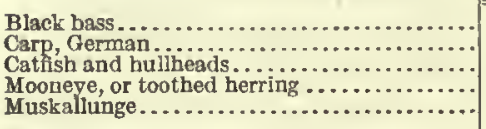 & $\begin{array}{r}2,000 \\
365,000 \\
6,000 \\
500 \\
3,900\end{array}$ & $\begin{array}{r}400 \\
11,000 \\
500 \\
(9) \\
400\end{array}$ & $\begin{array}{r}2,000 \\
8,000 \\
3,500 \\
\cdots \cdots \\
\cdots \cdots\end{array}$ & $\begin{array}{r}400 \\
200 \\
300 \\
\cdots \cdots \\
\cdots\end{array}$ & $\begin{array}{r}3+1,000 \\
800 \\
500 \\
300\end{array}$ & $\begin{array}{l}10,0000 \\
(2) \\
\text { (2) }\end{array}$ & $\begin{array}{r}16,000 \\
1,500 \\
3,600\end{array}$ & $\begin{array}{l}200 \\
100 \\
300\end{array}$ & 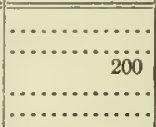 & (s) \\
\hline 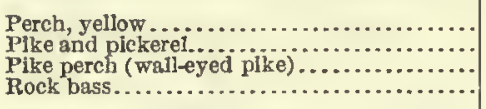 & $\begin{array}{r}92,000 \\
32,000 \\
167,000 \\
8,100\end{array}$ & $\begin{array}{r}3,700 \\
1,400 \\
12,000 \\
300\end{array}$ & $\begin{array}{r}82,000 \\
6,000 \\
148,000 \\
4,000\end{array}$ & $\begin{array}{r}3,300 \\
300 \\
10,000 \\
200\end{array}$ & $\begin{array}{r}2,000 \\
6,500 \\
15,000 \\
4,000\end{array}$ & $\begin{array}{r}100 \\
400 \\
1,200 \\
200\end{array}$ & $\begin{array}{r}8,000 \\
18,000 \\
3,500 \\
\end{array}$ & $\begin{array}{l}400 \\
600 \\
200\end{array}$ & $\begin{array}{r}1,300 \\
100\end{array}$ & 100 \\
\hline 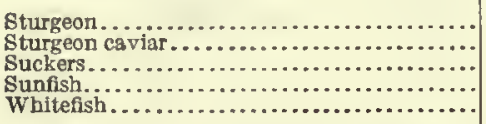 & $\begin{array}{r}13,000 \\
200 \\
34,000 \\
14,000 \\
(3)\end{array}$ & $\begin{array}{l}1,600 \\
100 \\
700 \\
400 \\
(2)\end{array}$ & $\begin{array}{r}13,000 \\
100 \\
2,000\end{array}$ & $\begin{array}{r}1,600 \\
100 \\
100\end{array}$ & $\begin{array}{r}400 \\
100 \\
33,000 \\
4,000\end{array}$ & $\begin{array}{l}(2) \\
600 \\
100\end{array}$ & … & ${ }_{200}$ & (s) & (2)..... \\
\hline
\end{tabular}

1 Al] taken in shore and boat fisheries.

Less than $\$ 100$

Less than 100 pounds.

TABLE 7.-MICHIGAN-PRODUCTS OF VESSEL FISHERIES: 1908.

\begin{tabular}{|c|c|c|c|c|c|c|c|c|c|c|}
\hline \multirow{3}{*}{ SPECIES. } & \multirow{2}{*}{\multicolumn{2}{|c|}{ TOTAL. }} & \multicolumn{8}{|c|}{ PRODUCT CAUGET BY- } \\
\hline & & & \multicolumn{2}{|c|}{ Gill nets. } & \multicolumn{2}{|c|}{$\begin{array}{l}\text { Pound nets, trap nets, } \\
\text { and weirs. }\end{array}$} & \multicolumn{2}{|c|}{ Lines. } & \multicolumn{2}{|c|}{ Selnes. } \\
\hline & $\begin{array}{l}\text { Quantity } \\
\text { (pounds). }\end{array}$ & Value. & $\begin{array}{l}\text { Quantity } \\
\text { (pounds). }\end{array}$ & Value. & $\begin{array}{l}\text { Quantity } \\
\text { (pounds). }\end{array}$ & Value. & $\begin{array}{l}\text { Quantity } \\
\text { (pounds). }\end{array}$ & Value. & $\begin{array}{l}\text { Quantity } \\
\text { (pounds). }\end{array}$ & Value. \\
\hline Total........... & $8,979,000$ & $\$ 516,000$ & $8,635,000$ & $\$ 497,000$ & 190,000 & 89,400 & 134,000 & $\$ 9,000$ & 20,000 & 8800 \\
\hline 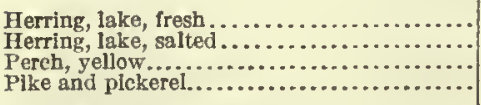 & $\begin{array}{r}2,403,000 \\
73,000 \\
26,000 \\
6,400\end{array}$ & $\begin{array}{r}100,000 \\
1,200 \\
900 \\
400\end{array}$ & $\begin{array}{r}2,365,000 \\
40,000 \\
21,000 \\
600\end{array}$ & $\begin{array}{r}99,000 \\
500 \\
800 \\
(1)^{8}\end{array}$ & $\begin{array}{r}33,000 \\
33,000 \\
1,400 \\
5,800\end{array}$ & $\begin{array}{r}800 \\
700 \\
(1) \\
400\end{array}$ & $\begin{array}{r}2,700 \\
4,000 \\
\ldots \ldots \ldots\end{array}$ & $\begin{array}{l}100 \\
100 \\
\cdots\end{array}$ & $\begin{array}{r}2,000 \\
400 \\
400\end{array}$ & $\begin{array}{l}100 \\
(1){ }^{\cdots} \\
\cdots\end{array}$ \\
\hline 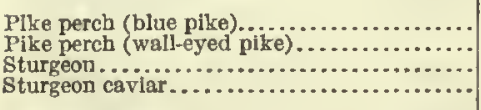 & $\begin{array}{r}27,000 \\
11,000 \\
5,100 \\
100\end{array}$ & $\begin{array}{l}700 \\
800 \\
600 \\
100\end{array}$ & $\begin{array}{r}27,000 \\
8,100 \\
\cdots \cdots \cdots\end{array}$ & $\begin{array}{r}700 \\
600 \\
\cdots\end{array}$ & $\begin{array}{r}3,200 \\
5,100 \\
100\end{array}$ & $\begin{array}{l}3000 \\
600 \\
100\end{array}$ & & & 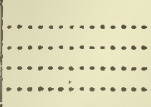 & (n) \\
\hline 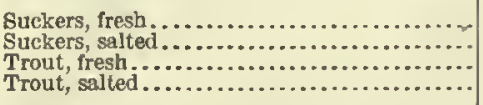 & $\begin{array}{r}61,000 \\
4,400 \\
4,079,000 \\
92,000\end{array}$ & $\begin{array}{r}1,800 \\
100 \\
261,000 \\
4,800\end{array}$ & $\begin{array}{r}22,000 \\
1,400 \\
3,932,000 \\
90,000\end{array}$ & $\begin{array}{r}251,000 \\
4,700\end{array}$ & $\begin{array}{r}24,000 \\
21,000^{-} \\
\cdots \ldots \ldots\end{array}$ & $\begin{array}{r}600 \\
\because 1,300\end{array}$ & $\begin{array}{r}126,000 \\
2,000\end{array}$ & $\begin{array}{r}8,600 \\
100\end{array}$ & $\begin{array}{r}15,000 \\
3,000 \\
\cdots \ldots\end{array}$ & $\begin{array}{r}600 \\
100 \\
\cdots\end{array}$ \\
\hline 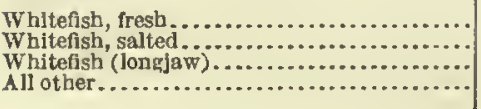 & $\begin{array}{r}1,369,000 \\
21,000 \\
794,000 \\
6,600\end{array}$ & $\begin{array}{r}108,000 \\
1,200 \\
33,000 \\
200\end{array}$ & $\begin{array}{r}1,314,000 \\
17,000 \\
794,000 \\
2,200\end{array}$ & $\begin{array}{r}104,000 \\
1,000 \\
33,000 \\
100\end{array}$ & $\begin{array}{r}55,000 \\
3,500 \\
\hdashline, 300\end{array}$ & $\begin{array}{r}4,300 \\
200 \\
\cdots \\
100\end{array}$ & 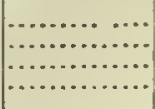 & 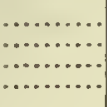 & 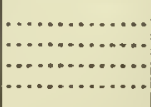 & $\begin{array}{c}\cdots \ldots \ldots \ldots \\
\cdots \ldots \ldots \ldots \\
\cdots \ldots \ldots \ldots \\
\cdots \ldots \ldots\end{array}$ \\
\hline
\end{tabular}


FISHERIES, BY STATES.

TABLE 8.-MICHIGAN-PRODUCTS OF SHORE AND BOAT FISHERIES: 1908.

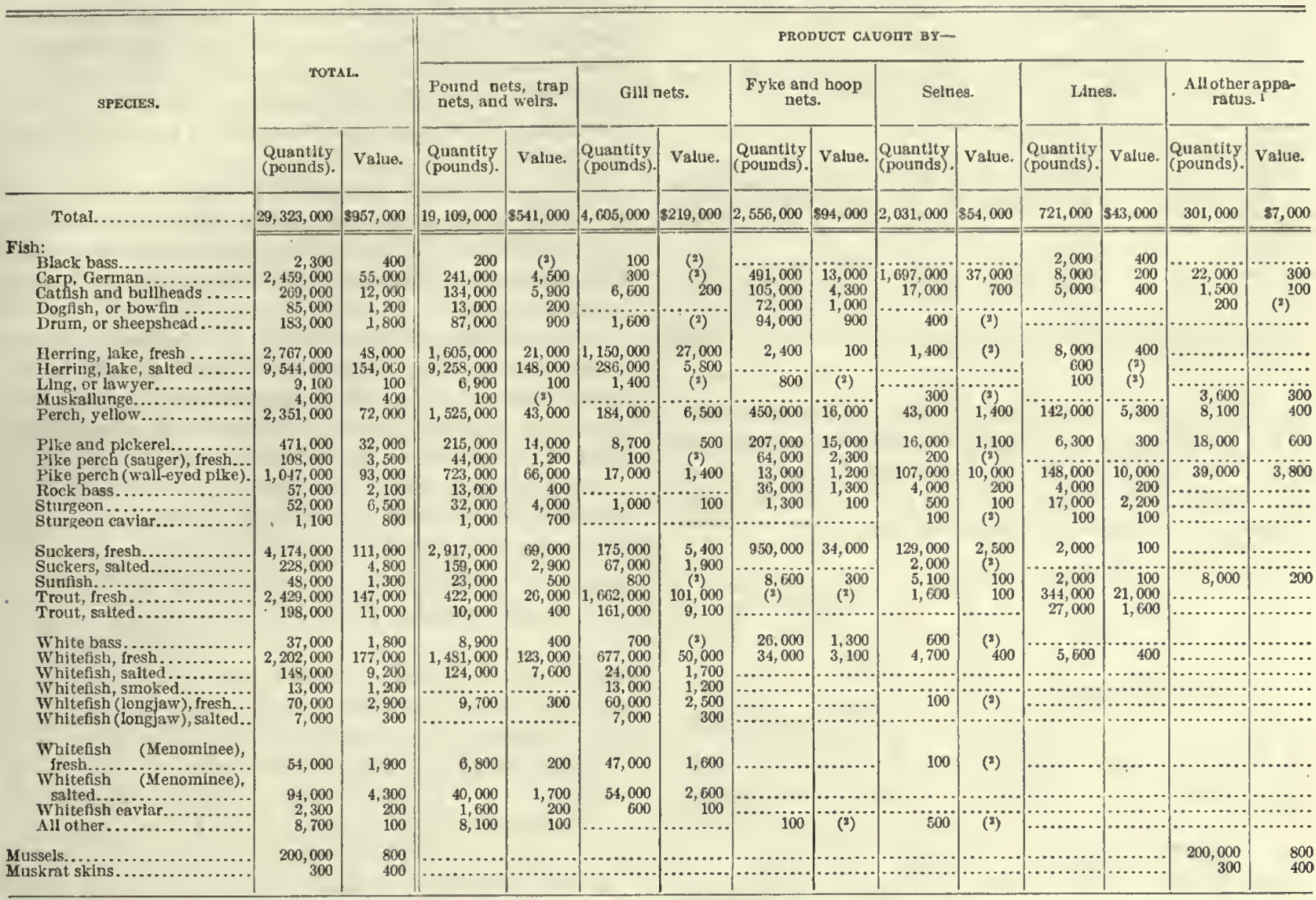

1 Includes apparatus, with catch. as follows: Harpoons, spears, etc., 100,000 pounds, valued at $\$ 5,800$; crowfoot dredges, etc., 200,000 pounds, valued at 8800 ; and muskrat traps, 300 pounds, valued at $\$ 400$.

\section{MINNESOTA.}

The chief fishing grounds of the state of Minnesota are the Mississippi River and Lake Superior. Commercial fishing is carried on to a considerable extent also in the numerous small lakes and rivers of the state, especially in the St. Croix and other tributaries of the Mississippi River, and in the Lake of the Woods and Rainy Lake, which are tributary to Hudson Bay.

No vessel fishery existed in the state in 1908, and the fisheries of Minnesota were entirely of the shore and boat class, although four vessels were engaged in transporting on the Lake Superior waters.

The following statement presents a summary of the chief statistics for the Minnesota fisheries in 1908:

Number of persons employed.....................

934

Capital:

Vessels and boats, including outfit. ............ $\$ 52,000$

Apparatus of capture.................... 43,000

Shore and accessory property and cash.......... 33, 000

Value of products.......................... 192,000

Comparison with previous canvasses.-Although legislation limiting the fishing on the interior waters to hand lines and spears lias caused a decided falling off in the products of the fisheries of this state since 1897 , about one-third of the value of the products of the state fisheries on the Mississippi River and its tributaries in 1908 represented the value of products from the interior lakes and rivers, a fact which indicates a revival of commercial fishing on these waters. During the past few years carp have multiplied to such an extent in the lakes and other interior waters that in certain cases the game wardens have issued to fishermen special licenses to seine the lakes for this fish.

The next comparative summary shows the changes that have taken place in the fisheries of the Lake Superior district since 1899 and in those on the smaller lakes and interior rivers since 1894. In the tabulation for 1908 the fisheries of the Lake of the Woods and Rainy Lake have been included with the Lake Superior fisheries, instead of with those of the Mississippi River and its tributaries.

A comparison of the statistics given in the summary shows that there has been a steady growth in the Lake Superior district, and that commercial fishing on the tributaries of the Mississippi is gradually recovering from the temporary setback caused by the passage of stringent laws. 


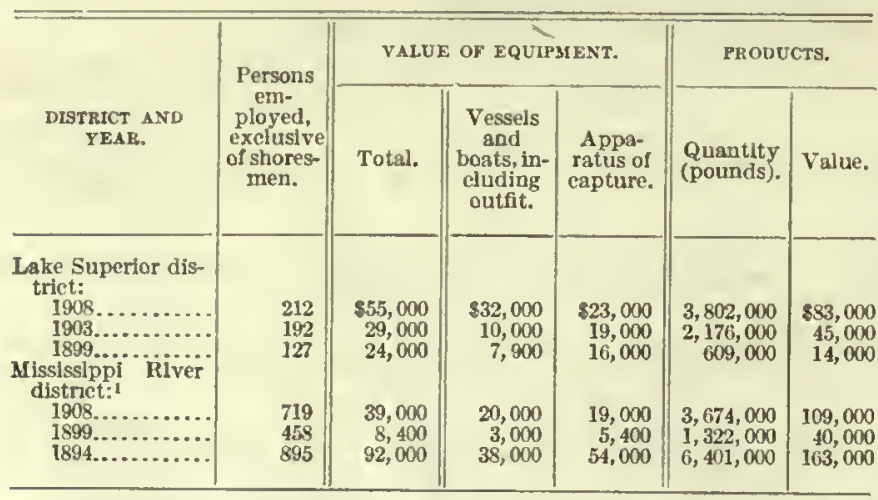

1 Lake of the Woods and Rainy Lake are ineluded in the Lake Superior dlstrict in 1908, and in the Mississlppi River district in 1894 and 1899.

Persons employed.-The following tabular statement gives the number and distribution of the persons $\mathrm{cm}-$ ployed in the fisheries of Minnesota in 1908. Over two-thirds of the total number were independent fishermen in the Mississippi River district.

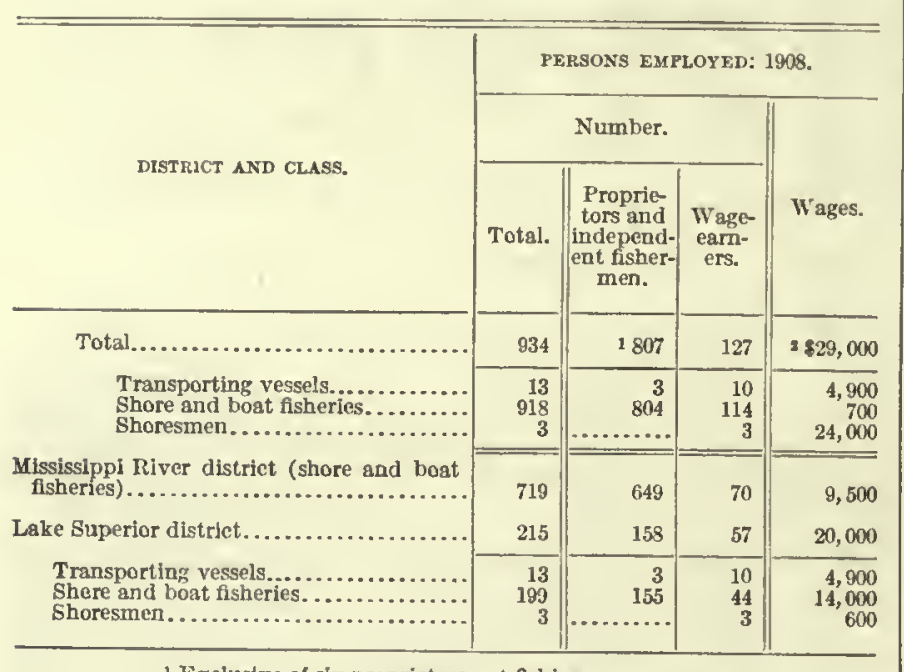

1 Exclusive of six proprietors not fishing.

3 Includes provisions furnished to the value of $\$ 4,200$.

Equipment and other capital.-The following tabular statement gives statistics of the investment of the state in fishcries, including the value of vessels, boats, and apparatus of capture, together with other capital employed in 1908:

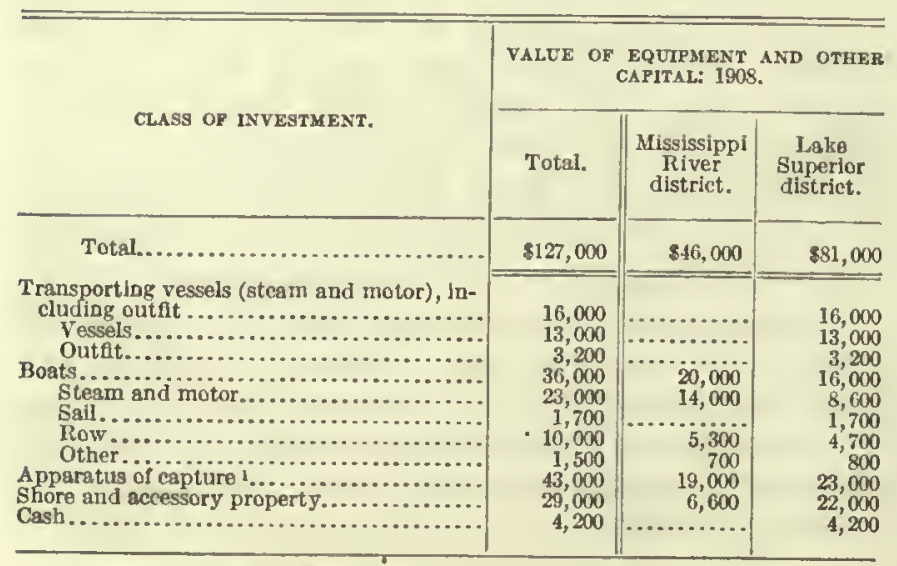

1 All reported by the shere and boat fisheries.
The four transporting vessels on the Lake Superior waters were steam and motor craft. The rowboats were divided between the Mississippi River and the Lake Superior fisheries in proportions about equal to the relative size of their respective total fleets. All of the sailing craft reported belonged to the Lake Superior district.

The value of the transporting vessels belonging to the Lake Superior district makes the investment in vessels and boats in that district much higher than that in the Mississippi River distriet, which had products of a greater value.

In the fisheries of the Lake Supcrior district 39 per cent of the capital was invested in floating craft, while 29 per cent was invested in apparatus of capture. A little over one-half of the investment in vessels and boats represented the value of transporting vessels.

The following tabular statement gives detailed statistics of the number of vessels and boats:

\begin{tabular}{|c|c|c|c|}
\hline \multirow[b]{2}{*}{ CLASS OF CRAFT. } & \multicolumn{3}{|c|}{ VESSELS ANO BOATS: 1908.} \\
\hline & Total. & $\begin{array}{l}\text { Mississippi } \\
\text { River } \\
\text { distriet. }\end{array}$ & $\begin{array}{l}\text { Lake } \\
\text { Superior } \\
\text { district. }\end{array}$ \\
\hline Total................. & 693 & 482 & 211 \\
\hline 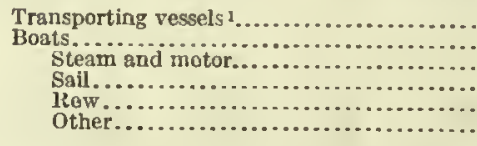 & $\begin{array}{r}4 \\
689 \\
82 \\
20 \\
577 \\
10\end{array}$ & \begin{tabular}{r}
$\dddot{482}$ \\
64 \\
\hdashline 132 \\
412 \\
6
\end{tabular} & $\begin{array}{r}4 \\
207 \\
18 \\
20 \\
165 \\
4\end{array}$ \\
\hline
\end{tabular}

A large increase is evident in the total value of the floating craft of the Lake Superior fisheries in 1908, as compared with 1899 , when the value was only $\$ 7,900$. In the carlier year this district had only 91 boats, none of which were motor boats, while in the later year there were 211 boats, of which 18 were power boats. In the Mississippi River district the value of the boats was only $\$ 3,000$ in 1899 , and in that year only 263 boats were reported, as compared with 482 in 1908 .

The total investment in apparatus of capture was $\$ 43,000$. The investment of the Lake Superior district in apparatus of capture exceeded that of the Mississippi River district, and was confined to gill nets, lines, and pound nets. In the interior waters of the statc, except for a few dip nets, only hand lines and spears were reported. In the following tabular statement detailed statistics concerning the number of various kinds of apparatus of capture are given:

\begin{tabular}{|c|c|c|c|}
\hline \multirow[b]{2}{*}{ KIND. } & \multicolumn{3}{|c|}{ APPARATUS OF CAPTURE: 1908.} \\
\hline & Total. & $\begin{array}{l}\text { Mississippi } \\
\text { River } \\
\text { district. }\end{array}$ & $\begin{array}{l}\text { Lake } \\
\text { Superior } \\
\text { distriet. }\end{array}$ \\
\hline 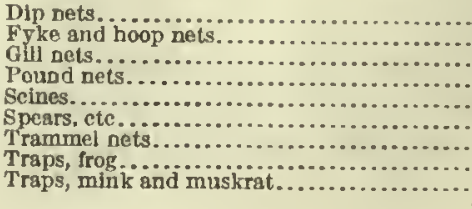 & $\begin{array}{r}34 \\
234 \\
1,288 \\
162 \\
86 \\
212 \\
6 \\
43 \\
1,980\end{array}$ & $\begin{array}{r}34 \\
234 \\
29 \\
77 \\
86 \\
212 \\
6 \\
43 \\
1,980\end{array}$ & 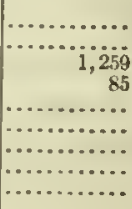 \\
\hline
\end{tabular}


Products, by species.-The fishery products of the state in 1908 are distributed by spceies and by apparatus of capture in Table 1, on page 177 . The total of $7,475,000$ pounds, valued at $\$ 192,000$, represents a large inerease over the products in 1899 , the latest year prior to 1908 for which complete data for the state as a whole are available. In 1899 the total yield, as reported by the Bureau of Fisheries, was only 1,931,000 pounds, with a value of $\$ 55,000$. The year 1899 , however, is an unfavorable year for comparison beeause of the fact that restrictive legislation recently passed had caused a temporary decline in the fishery activities of the state. A more correct coneeption of the rate of decrease may be obtained from a comparison of the figures for 1908 with those given in the report of the Bureau of Fisheries for 1894, which showed the fishery products of the Mississippi River district of the state alone in that year to be $6,401,000$ pounds.

The catch of fish proper in 1908 amounted in the aggregate to $6,616,000$ pounds, or 89 per cent of the total weight of all fishery products, and was valued at $\$ 173,000$, or 90 per cent of the total value of such products.

Products, by fishing grounds.-The products of the Mississippi River and its tributaries and those of the Lake Superior district for 1908 aro given in detail, by species and by apparatus of capture, in Tables 2 and 3, on pages 177 and 178 , respectively.

The eatch of the Mississippi River district amounted to $3,674,000$ pounds and had a value of $\$ 109,000$, while the eateh of the fisheries of Lake Superior amounted to $3,802,000$ pounds, valued at $\$ 83,000$. In the fisheries of the Mississippi River and its tributaries the value of fish proper constituted 82 per cent of the value of the total product, while in the Lake Superior clistrict the entire product was fish proper. Of the value of fish, 48 per cent was reported for the Lake Superior fisheries and 52 per eent for the Mississippi River fisheries. The most important product of the Mississippi River district was German earp, for which a value of $\$ 26,000$, or 24 per cent of the total for the district, was reported, although the value of the buffalo-fish product was nearly as great.

In the Lake Superior district herring was the principal product, with a value of $\$ 38,000$, or 46 per eent of the total value of the products of this distriet.

The next tabular statement gives the distribution of the value of fishery products, according to species and districts.

The quantity and value of the products taken by the fisheries of the Lake Superior waters show a gradual increase, according to the reports of the Bureau of Fisheries. The Lake Superior products amounted to 183,000 pounds, valued at $\$ 6,200$, in $1890 ; 609,000$ pounds, valued at $\$ 14,000$, in 1899 ; and $2,176,000$ pounds, valued at $\$ 45,000$, in 1903 .

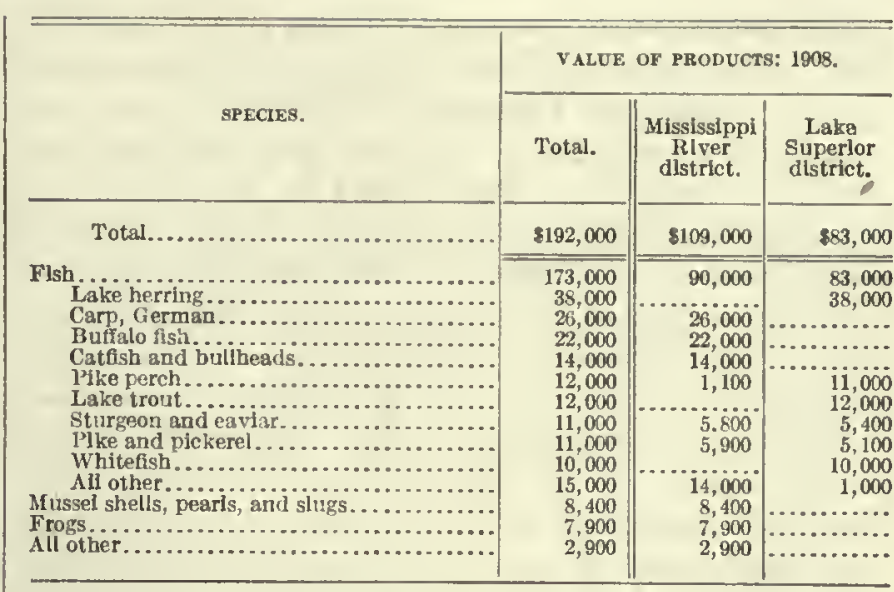

In the following tabular statement the distribution of the value of products of the Lake Superior district in 1908 is shown, by species and by waters:

\begin{tabular}{|c|c|c|c|c|}
\hline \multirow{2}{*}{ SPECIES. } & \multicolumn{4}{|c|}{$\begin{array}{l}\text { VALUE OF PRODUCTS OF LAKE SUPEKIOR } \\
\text { DISTRICT: } 1908 \text {. }\end{array}$} \\
\hline & Total. & $\begin{array}{c}\text { Lake } \\
\text { Supertor. }\end{array}$ & $\begin{array}{l}\text { Lake of } \\
\text { the } \\
\text { Woods. }\end{array}$ & $\begin{array}{l}\text { Rainy } \\
\text { Lake. }\end{array}$ \\
\hline Total....... & 883,000 & $\$ 50,000$ & $\$ 27,000$ & 86,200 \\
\hline 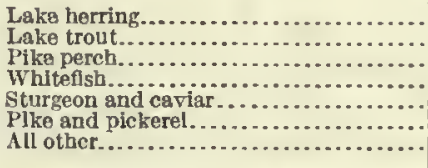 & $\begin{array}{r}38,000 \\
12,000 \\
11,000 \\
10,000 \\
5,400 \\
5,100 \\
1,000\end{array}$ & 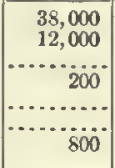 & $\begin{array}{r}9,500 \\
8,000 \\
5,000 \\
4,000\end{array}$ & $\begin{array}{r}1,400 \\
2,200 \\
300 \\
1,100 \\
200\end{array}$ \\
\hline
\end{tabular}

It appears that lake herring and lake trout were the only fish eaught in any considerable quantity in Lake Superior itself. All of the pike perch, sturgeon, pike, and pickerel, and nearly all of the whitefish reported for the Lake Superior district were obtained from the Lake of the Woods and Rainy Lake.

Products, by apparatus of capture.-The distribution of products, by kind of apparatus used and by fishery distriets, is given in the following tabular statement:

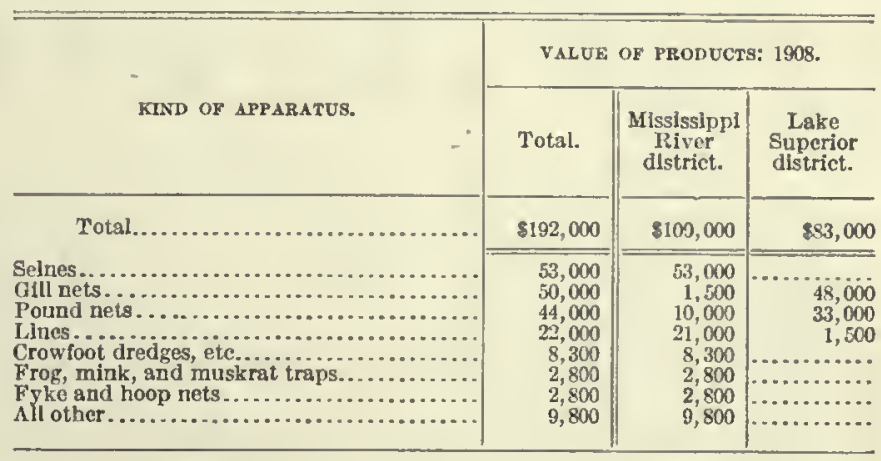

On the basis of the value of products taken, seines, gill nets, and pound nets were the most important forms of apparatus of eapture, the value of their catch together constituting three-fourths of the total value of all products. For the Lake Superior waters the 
products caught by means of gill nets and pound nets had a value equal to 98 per cent of that of all products. On the Mississippi River and its tributaries, on the other hand, the catch by gill nets was small and the catch by pound nets was valued at less than onefourth of the total value of products caught by pound nets in the state. Lines were the only other form of apparatus of capture used in the Lake Superior district. Only 7 per cent of the total value of the products caught by lines contributed to the catch from these waters. In the interior waters of the Mississippi River district, on the other hand, where only hand lines and spears were allowed by law, lines formed an important means of capture. Almost one-fifth of the value of the fishery products of the Mississippi River district represented the value of product caught by hand lines.

Principal species.-Lake herring, taken wholly in Lake Superior, formed the most important fishery product of the state, contributing 20 per cent of the value of all fishery products. A part of the lakeherring catch was sold fresh at a valuation of $\$ 21,000$, while the remainder, which was sold salted and smoked, brought $\$ 18,000$. This fish was caught entirely by means of gill nets.

The entire catches of German carp, buffalo fish, and catfish were taken in the Mississippi River and its tributaries. The buffalo fish and the catfish have been steadily declining in numbers during the past few years, and the carp has been taking a higher place in this state, as in the other states along the Mississippi and Missouri Rivers. No carp were caught in 1894 aud a quantity valued at only $\$ 900$ was taken in 1899 , while in 1908 over a million pounds, valued at $\$ 26,000$, were reported, and carp ranked second among the fishery products of the state.

Some pike perch were eaught in the tributary lakes of the Mississippi River, but over nine-tenths of the value reported for this fish was reported from the Lake Superior waters. All of the lake trout came from the Lake Superior fisheries. Sturgeon came from the Mississippi River and also from the Lake of the Woods and Rainy Lake, which, while included in the Lake Superior system, did not come under the statute prohibiting the taking of sturgeon from Lake Superior. The pike and pickerel caught were secured from the Lake of the Woods and Rainy Lake, and from the tributaries of the Mississippi River. The whitefish were caught in the Lake Superior waters only.

The mussel-shell and pearl industry has become an important branch of the Mississippi River fisheries during the past few years. The industry was not mentioned in the report of the Bureau of Fisheries for 1894 , and its product amounted to only $\$ 200$ in value in 1899 , but in 1908 produets valued at $\$ 8,400$ wero reported. The value of pearls and slugs secured incidentally in the pursuit of the mussel-shell industry represented $\$ 3,700$, or 44 per cent of the value of mussel-shell products in 1908 .

The frog industry, carried on in the tributary waters of the Mississippi, is also of recent development, having been started about 1895 . In 1899 a product of 92,000 pounds, valued at $\$ 9,600$, was reported, and in 1908 , 66,000 pounds, valued at $\$ 7,900$. The 1908 product, though somewhat smaller in quantity and value than that secured in 1899 , represented nearly 20 per cent of the total value of the capture in the United States and was surpassed only by the capture in Missouri. 
TABLE 1.-MINNESOTA-FISHERY PRODUCTS: 1908.

\begin{tabular}{|c|c|c|c|c|c|c|c|c|c|c|c|c|c|c|}
\hline \multirow{3}{*}{ SPECTES. } & \multirow{2}{*}{\multicolumn{2}{|c|}{ TOTAL. }} & \multicolumn{10}{|c|}{ PRODUCT CAUGHT BY- } & \multicolumn{2}{|r|}{. } \\
\hline & & & \multicolumn{2}{|c|}{ Seines. } & \multicolumn{2}{|c|}{ Gill nets. } & \multicolumn{2}{|c|}{ Pound nets. } & \multicolumn{2}{|c|}{ Llnes. } & \multicolumn{2}{|c|}{$\begin{array}{l}\text { Fyke and hoop } \\
\text { nets. }\end{array}$} & \multicolumn{2}{|c|}{$\begin{array}{l}\text { All other appa- } \\
\text { ratus.t }\end{array}$} \\
\hline & $\begin{array}{l}\text { Quantity } \\
\text { (pounds). }\end{array}$ & Value. & $\begin{array}{l}\text { Quantity } \\
\text { (pounds). }\end{array}$ & Value. & $\begin{array}{l}\text { Quantity } \\
\text { (pounds). }\end{array}$ & Value. & $\begin{array}{l}\text { Quantity } \\
\text { (pounds). }\end{array}$ & Value. & $\begin{array}{l}\text { Quantity } \\
\text { (pounds). }\end{array}$ & Value. & $\begin{array}{l}\text { Quantlty } \\
\text { (pounds). }\end{array}$ & Value. & $\begin{array}{l}\text { Quantlty } \\
\text { (pounds). }\end{array}$ & Value. \\
\hline Total. & $7,475,000$ & $\$ 192,000$ & $1,854,000$ & $\$ 53,000$ & $2,991,000$ & $\$ 50,000$ & $1,198,000$ & $\$ 44,000$ & 426,000 & 322,000 & 51,000 & $\$ 2,800$ & 926,000 & $\$ 21,000$ \\
\hline 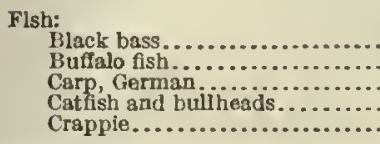 & $\begin{array}{r}1,900 \\
664,000 \\
1,132,000 \\
208,000 \\
97,000\end{array}$ & $\begin{array}{r}400 \\
22,000 \\
26,000 \\
14,000 \\
6,000\end{array}$ & $\begin{array}{r}1,500 \\
499,000 \\
1,027,000 \\
43,000 \\
2,300\end{array}$ & $\begin{array}{r}400 \\
16,000 \\
24,000 \\
2,800 \\
200\end{array}$ & $\begin{array}{r}4,100 \\
6,100 \\
700\end{array}$ & $\begin{array}{l}200 \\
200 \\
100\end{array}$ & $\begin{array}{r}146,000 \\
21,000 \\
4,000 \\
\end{array}$ & $\begin{array}{r}5,800 \\
500 \\
400 \\
\ldots .\end{array}$ & $\begin{array}{r}400 \\
900 \\
15,000 \\
140,000 \\
95,000\end{array}$ & $\begin{array}{c}(2) \\
(3) \\
400 \\
8,800 \\
5,800\end{array}$ & $\begin{array}{r}7,300 \\
15,000 \\
20,000 \\
\ldots \ldots\end{array}$ & $\begin{array}{r}300 \\
400 \\
1,800\end{array}$ & $\begin{array}{r}6,700 \\
48,000 \\
\cdots \\
\cdots\end{array}$ & $\begin{array}{r}200 \\
1,100 \\
\ldots \ldots\end{array}$ \\
\hline 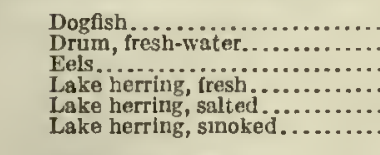 & $\begin{array}{r}1,200 \\
333,000 \\
800 \\
1,608,000 \\
1,165,000 \\
4,000\end{array}$ & $\begin{array}{r}\left({ }^{2}\right) \\
4,600 \\
100 \\
21,000 \\
18,000 \\
200\end{array}$ & $\begin{array}{r}1,200 \\
120,000 \\
\ldots \ldots \\
\cdots \cdots\end{array}$ & 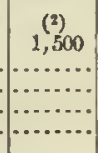 & $\begin{array}{r}1,000 \\
1,608,000 \\
1,165,000 \\
4,000\end{array}$ & $\begin{array}{r}(2) \\
21,000 \\
18,000 \\
200\end{array}$ & $\begin{array}{r}204,000 \\
\cdots \ldots \\
\cdots \cdots\end{array}$ & $\begin{array}{r}3,000 \\
\cdots \\
\cdots\end{array}$ & $\begin{array}{r}6,300 \\
500 \\
\ldots \ldots \ldots \\
\cdots \ldots \ldots \ldots \\
\ldots \ldots \ldots\end{array}$ & $\mid \begin{array}{c}100 \\
(2) \\
\cdots \cdots \ldots\end{array}$ & $\begin{array}{r}i, 500 \\
300 \\
\cdots \\
\cdots\end{array}$ & $\begin{array}{c}\left.\begin{array}{c}(2) \\
(3) \\
\cdots\end{array}\right] \\
\cdots \cdots \\
\cdots\end{array}$ & $\mid \begin{array}{l}\cdots \\
\cdots \\
\cdots\end{array} \ldots$ & $\mid \begin{array}{l}\cdots \\
\cdots \\
\cdots \\
\cdots\end{array}$ \\
\hline 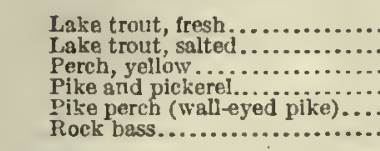 & $\begin{array}{r}188,000 \\
27,000 \\
7,400 \\
351,000 \\
273,000 \\
5,100\end{array}$ & $\begin{array}{r}10,000 \\
1,600 \\
200 \\
11,000 \\
12,000 \\
200\end{array}$ & $\begin{array}{r}1,400 \\
40,000 \\
\cdots . . .\end{array}$ & $\begin{array}{c}{ }^{(2)} \\
2,200 \\
\cdots\end{array}$ & $\begin{array}{r}138,000 \\
23,000 \\
\quad 8,000 \\
2,900\end{array}$ & $\begin{array}{c}7,600 \\
1,300 \\
300 \\
200\end{array}$ & $\begin{array}{r}25,000 \\
1,200 \\
210,000 \\
256,000 \\
\cdots\end{array}$ & $\begin{array}{r}1,400 \\
100 \\
\ldots \ldots \\
5,100 \\
11,000 \\
\ldots \ldots \ldots\end{array}$ & $\begin{array}{r}25,000 \\
3,100 \\
6,000 \\
63,000 \\
13,000 \\
5,100\end{array}$ & $\begin{array}{r}1,300 \\
200 \\
100 \\
2,300 \\
900 \\
200\end{array}$ & $\begin{array}{r}\mathbf{3}, \mathbf{9} 00 \\
\end{array}$ & 200 & $\begin{array}{r}25,000 \\
700\end{array}$ & 900 \\
\hline 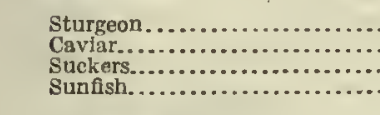 & $\begin{array}{r}164,000 \\
100 \\
76,000 \\
66,000\end{array}$ & $\begin{array}{r}11,000 \\
100 \\
800 \\
2,300\end{array}$ & $\begin{array}{r}94,000 \\
23,000 \\
16,000\end{array}$ & $\begin{array}{r}4,800 \\
400 \\
500\end{array}$ & $\begin{array}{r}13,000 \\
100 \\
5,000\end{array}$ & $\begin{array}{l}700 \\
100 \\
(2)\end{array}$ & $\begin{array}{r}55,000 \\
\ldots, 000 \\
43,000 \\
\cdots\end{array}$ & $\begin{array}{r}5,400 \\
\ldots \ldots \ldots \\
300\end{array}$ & $\begin{array}{r}1,000 \\
\ldots \ldots \\
50,000\end{array}$ & $\begin{array}{r}100 \\
\cdots \cdots \\
1,800\end{array}$ & 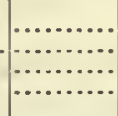 & & $\begin{array}{r}5,100 \\
\ldots . . .\end{array}$ & (2) \\
\hline 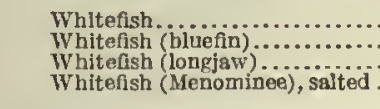 & $\begin{array}{r}205,000 \\
1,400 \\
35,000 \\
1,000\end{array}$ & $\begin{array}{c}10,000 \\
\left({ }^{2}\right) \\
700 \\
100\end{array}$ & & $\begin{array}{l}\cdots \cdots \cdots \\
\cdots \cdots \cdots \\
\cdots \cdots \cdots \\
\cdots \cdots \cdots\end{array}$ & $\begin{array}{l}4,900 \\
1,400 \\
4,000 \\
1,000\end{array}$ & $\begin{array}{l}300 \\
(2) \\
100 \\
100\end{array}$ & $\begin{array}{r}200,000 \\
31,000 \\
3 \ldots \ldots\end{array}$ & $\begin{array}{r}10,000 \\
600 \\
\cdots \cdots \cdots\end{array}$ & 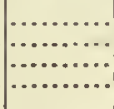 & $\mid \begin{array}{l}\cdots \\
\cdots \ldots \ldots \\
\cdots \ldots \ldots\end{array}$ & $\mid \begin{array}{l}\cdots \\
\cdots \ldots \ldots\end{array}$ & & & \\
\hline 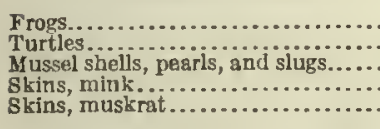 & $\begin{array}{r}66,000 \\
25,000 \\
767,000 \\
3200 \\
11,700\end{array}$ & $\begin{array}{l}7,900 \\
600 \\
8,400 \\
1,100 \\
1,200\end{array}$ & $\begin{array}{r}1 \\
15,000 \\
\cdots \cdots\end{array}$ & 400 & ... & $\mid \cdots \cdots$ & $\left(\begin{array}{ll}1,000 \\
\cdots \cdots \cdots\end{array}\right.$ & $\begin{array}{c}(2) \\
\cdots\end{array}$ & $\cdots \cdot$. & & $\begin{array}{l}2,900 \\
\ldots \ldots . . .\end{array}$ & $\begin{array}{c}100 \\
\ldots . . . \\
\ldots . .\end{array}$ & $\begin{array}{r}66,000 \\
6,000 \\
767,000 \\
8200 \\
+1,700\end{array}$ & $\begin{array}{l}7,900 \\
100 \\
8,400 \\
1,100 \\
1,200\end{array}$ \\
\hline
\end{tabular}

1 Includes apparatus, with catch, as follows: Crow foot dredges, etc., 743,000 pounds, valued at $\$ 8,300$; mink, muskrat, and trog traps, 5,700 pounds, valued at $\$ 2,800$;

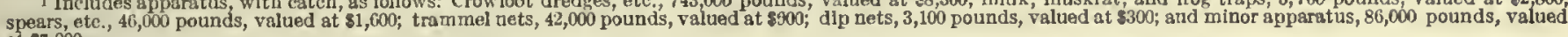
at $\$ 7,000$.

Less than $\$ 100$.

300 skins.

1 5,000 skins.

TABLE 2.-MINNESOTA-FISHERY PRODUCTS OF MISSISSIPPI RIVER DISTRICT: 1908.

\begin{tabular}{|c|c|c|c|c|c|c|c|c|c|c|c|c|c|c|}
\hline \multirow{3}{*}{ SPECIES. } & \multirow{2}{*}{\multicolumn{2}{|c|}{ TOTAL. }} & \multicolumn{12}{|c|}{ PRODUCT CAUGHT BY - } \\
\hline & & & \multicolumn{2}{|c|}{ Seines. } & \multicolumn{2}{|c|}{ Gill nets. } & \multicolumn{2}{|c|}{ Pound nets. } & \multicolumn{2}{|c|}{ Lines. } & \multicolumn{2}{|c|}{$\begin{array}{l}\text { Fyke and hoop } \\
\text { nets. }\end{array}$} & \multicolumn{2}{|c|}{$\begin{array}{l}\text { All nther appa- } \\
\text { ratus.1 }\end{array}$} \\
\hline & $\begin{array}{l}\text { Quantity } \\
\text { (pounds). }\end{array}$ & Value. & $\begin{array}{l}\text { Quantity } \\
\text { (pounds). }\end{array}$ & Value. & $\begin{array}{l}\text { Quantity } \\
\text { (pounds). }\end{array}$ & Value. & $\begin{array}{l}\text { Quantity } \\
\text { (pounds). }\end{array}$ & Value. & $\begin{array}{l}\text { Quantity } \\
\text { (pounds). }\end{array}$ & Value. & $\begin{array}{l}\text { Quantity } \\
\text { (pounds). }\end{array}$ & Value. & $\begin{array}{l}\text { Quantity } \\
\text { (pounds). }\end{array}$ & Value. \\
\hline Total. . & $3,674,000$ & 3109,000 & $1,884,000$ & $\$ 53,000$ & 28,000 & $\$ 1,500$ & 388,000 & $\$ 10,000$ & 398,000 & $\$ 21,000$ & 51,000 & $\$ 2,800$ & 926,000 & $\$ 21,000$ \\
\hline 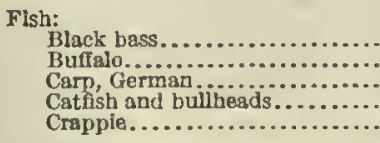 & $\begin{array}{r}1,900 \\
664,000 \\
1,132,000 \\
208,000 \\
97,000\end{array}$ & $\begin{array}{r}400 \\
22,000 \\
26,000 \\
14,000 \\
6,000\end{array}$ & $\begin{array}{r}1,500 \\
499,000 \\
1,027,000 \\
43,000 \\
2,300\end{array}$ & $\begin{array}{r}16,000 \\
24,000 \\
2,800 \\
200\end{array}$ & $\begin{array}{r}4,100 \\
6,100 \\
700 \\
\cdots\end{array}$ & $\begin{array}{l}200 \\
200 \\
100\end{array}$ & $\begin{array}{r}146,000 \\
21,000 \\
4,000 \\
\ldots\end{array}$ & $\begin{array}{r}5,800 \\
500 \\
400\end{array}$ & $\begin{array}{r}400 \\
900 \\
15,000 \\
140,000 \\
95,000\end{array}$ & $\begin{array}{l}(2) \\
(2) \\
400 \\
8,800 \\
5,800\end{array}$ & $\begin{array}{r}7,300 \\
15,000 \\
20,000 \\
\ldots \ldots\end{array}$ & $\begin{array}{r}300 \\
400 \\
1,800\end{array}$ & $\begin{array}{r}6,700 \\
48,000 \\
\cdots\end{array}$ & $\begin{array}{r}200 \\
1,100 \\
\ldots\end{array}$ \\
\hline 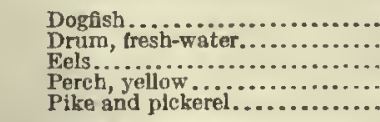 & $\begin{array}{r}1,200 \\
333,000 \\
800 \\
7,400 \\
138,000\end{array}$ & $\begin{array}{r}(2) \\
4,600 \\
100 \\
200 \\
5,900\end{array}$ & $\begin{array}{r}1,200 \\
120,000 \\
1,900 \\
40,000\end{array}$ & $\begin{array}{l}{ }^{(2)} \\
1,500 \\
{ }_{(2)}^{(2)} \\
2,200\end{array}$ & $\begin{array}{l}1,000 \\
3,3000\end{array}$ & $\begin{array}{c}(2) \\
\cdots \cdots \\
200\end{array}$ & $\mid \begin{array}{r}204,000 \\
2,100\end{array}$ & $\begin{array}{r}3,000 \\
100\end{array}$ & $\begin{array}{r}6,300 \\
800 \\
6,000 \\
63,000\end{array}$ & $\begin{array}{c}100 \\
\left({ }^{2}\right) \\
100 \\
2,300\end{array}$ & $\begin{array}{r}1,500 \\
300 \\
3,900\end{array}$ & $\begin{array}{l}(2) \\
200\end{array}$ & ( & 900 \\
\hline 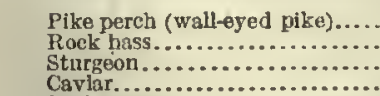 & $\begin{array}{r}15,000 \\
5,100 \\
109,000 \\
100\end{array}$ & $\begin{array}{r}1,100 \\
200 \\
5,700 \\
100\end{array}$ & 94,000 & 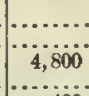 & $\begin{array}{r}900 \\
12,000 \\
100\end{array}$ & $\begin{array}{l}100 \\
600 \\
100\end{array}$ & $\cdots \cdots$ & $\dddot{000}$ & $\begin{array}{r}13,000 \\
5,100 \\
1,000 \\
-\end{array}$ & $\begin{array}{l}900 \\
200 \\
100\end{array}$ & & $\begin{array}{ll}\ldots \ldots & \ldots \\
\ldots \ldots & \ldots \\
\ldots \ldots & \ldots \\
\cdots & \ldots\end{array}$ & $\begin{array}{r}700 \\
500 \\
500\end{array}$ & $\begin{array}{l}\text { (2) } \\
(3)\end{array}$ \\
\hline 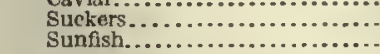 & $\begin{array}{l}35,000 \\
66,000\end{array}$ & $\begin{array}{r}600 \\
2,300\end{array}$ & $\begin{array}{l}23,000 \\
16,000\end{array}$ & $\begin{array}{l}400 \\
500\end{array}$ & n...... & & $\begin{array}{r}6,800 \\
0\end{array}$ & 100 & 50,000 & 1,800 & & & $\begin{array}{r}5,100 \\
\ldots \ldots\end{array}$ & 100 \\
\hline 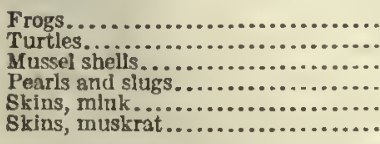 & $\begin{array}{r}66,000 \\
25,000 \\
767,000 \\
-9200 \\
1,700\end{array}$ & $\begin{array}{r}7,900 \\
600 \\
4,700 \\
3,700 \\
1,100 \\
1,200\end{array}$ & $\begin{array}{l}1, \ldots, 000 \\
\cdots \\
\cdots\end{array}$ & $\begin{array}{l}\cdots \\
\cdots \\
\cdots\end{array}$ & & & $\begin{array}{l}\dddot{1}, 000 \\
\cdots \ldots \ldots \\
\cdots \cdots \\
\cdots\end{array}$ & (3) & ......... & 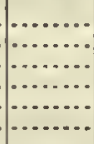 & $\begin{array}{r}2,900 \\
\cdots \\
\cdots\end{array}$ & 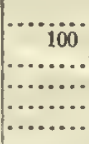 & $\begin{array}{r}66,000 \\
6,000 \\
767,000 \\
\cdots \\
1200 \\
11,700\end{array}$ & $\begin{array}{r}7,900 \\
100 \\
4,700 \\
3,700 \\
1,100 \\
1,200\end{array}$ \\
\hline
\end{tabular}

1 Includes apparatus, with eatch, as follows: Crowfoot dredges, etc., 743,000 pounds, valued at 39,$300 ;$ mink, muskrat, and frog traps, 5,700 pounds, valuad at 32,800

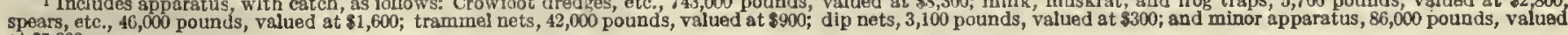
at $\$ 7,000$.

Less than $\$ 100$

: 300 skins.

45,000 strins. 
TABLE 3.-MINNESOTA-FISHERY PRODUCTS OF LAKE SUPERIOR DISTRICT: 1908.

\begin{tabular}{|c|c|c|c|c|c|c|c|c|}
\hline \multirow{3}{*}{ SPECIES. } & \multirow{2}{*}{\multicolumn{2}{|c|}{ rotal. }} & \multicolumn{6}{|c|}{ PRODUCT CAUGHT BY- } \\
\hline & & & \multicolumn{2}{|c|}{ Glll nets. } & \multicolumn{2}{|c|}{ Pound nets. } & \multicolumn{2}{|c|}{ Lines. } \\
\hline & $\begin{array}{l}\text { Quantity } \\
\text { (pounds). }\end{array}$ & Value. & $\begin{array}{l}\text { Quantity } \\
\text { (pounds). }\end{array}$ & Value. & $\begin{array}{l}\text { Quantity } \\
\text { (pounds). }\end{array}$ & Value. & $\begin{array}{l}\text { Quantity } \\
\text { (pounds). }\end{array}$ & Value. \\
\hline Total............. & $3,802,000$ & $\$ 83,000$ & $2,963,000$ & $\$ 48,000$ & 811,000 & $\$ 33,000$ & 28,000 & $\$ 1,500$ \\
\hline 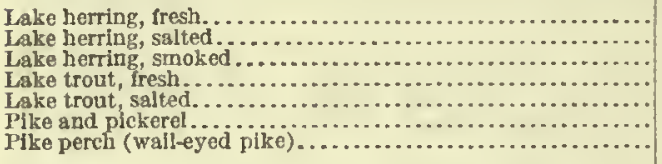 & $\begin{array}{r}1,608,000 \\
1,165,000 \\
4,000 \\
188,000 \\
27,000 \\
213,000 \\
258,000\end{array}$ & $\begin{array}{r}21,000 \\
18,000 \\
200 \\
10,000 \\
1,500 \\
5,100 \\
11,000\end{array}$ & $\begin{array}{r}1,605,000 \\
1,165,000 \\
4,000 \\
138,000 \\
23,000 \\
5,000 \\
2,000\end{array}$ & $\begin{array}{r}21,000 \\
18,000 \\
200 \\
7,500 \\
1,300 \\
100 \\
100\end{array}$ & $\begin{array}{r}25,000 \\
1,200 \\
208,000 \\
256,000\end{array}$ & $\begin{array}{r}1,400 \\
100 \\
5,090 \\
11,000\end{array}$ & $\begin{array}{r}25,000 \\
3,100 \\
\cdots\end{array}$ & $\begin{array}{r}r, 300 \\
200 \\
\cdots \cdots \cdots\end{array}$ \\
\hline 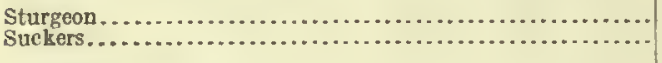 & $\begin{array}{l}54,000 \\
41,000\end{array}$ & $\begin{array}{r}5,400 \\
200\end{array}$ & $\begin{array}{l}1,000 \\
5,000\end{array}$ & $(1)^{100}$ & $\begin{array}{l}53,000 \\
36,000\end{array}$ & $\begin{array}{r}5.300 \\
200\end{array}$ & & \\
\hline 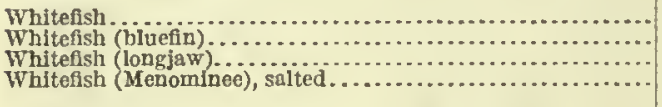 & $\begin{array}{r}205,000 \\
1,400 \\
35,000 \\
1,000\end{array}$ & $\begin{array}{l}10,000 \\
700 \\
100\end{array}$ & $\begin{array}{l}4,900 \\
1,400 \\
4,000 \\
1,000\end{array}$ & (1) $\begin{array}{l}300 \\
100 \\
100\end{array}$ & $\begin{array}{r}200,000 \\
3 i, 0000 \\
\cdots\end{array}$ & $\begin{array}{c}10,000 \\
1000 \\
\cdots \cdots\end{array}$ & & \\
\hline
\end{tabular}

1 Less than $\$ 100$.

MISSISSIPPI.

The fisheries of Mississippi may be grouped in two divisions, including, respectively, the fisheries of the Gulf of Mexico and those of the Mississippi River and its tributaries. Of the total value of the state product in 1908 , the Gulf fisheries contributed 82 per cent. Biloxi is a center for the wholesale dealers and the canners, and here oysters and shrimps are both canned and prepared for shipment fresh, in large quantities.

The following statement presents a summary of the chief statistics for the state fisheries in 1908:

Number of persons employed................ 2,037 Capital:

Vessels and boats, including outfit........... \$418, 000

Apparatus of capture ................. 58,000

Shore and accessory property and cash........ 46,000 Value of products......................... 556,000

Comparison with previous canvasses. - A slight falling off in the number of persons employed is shown for each district in 1908, as compared with the last canvass, as well as a decrease in the quantity and in the value of the product. An increase, however, is to be noted in the investment in equipment for each district.

The decline in the products of the Gulf fisheries in late years is not due entirely to natural causes, but is to be attributed, in part, to a recent decision of the Supreme Court of the United States, by which the jurisdiction of the oyster and other fishing grounds about Pear Island was transferred from Mississippi to Louisiana.

The following tabular statement presents for each district comparative statistics as to persons employed, value of equipment, and products, as returned at the canvass of 1908 and certain earlier canvasses:

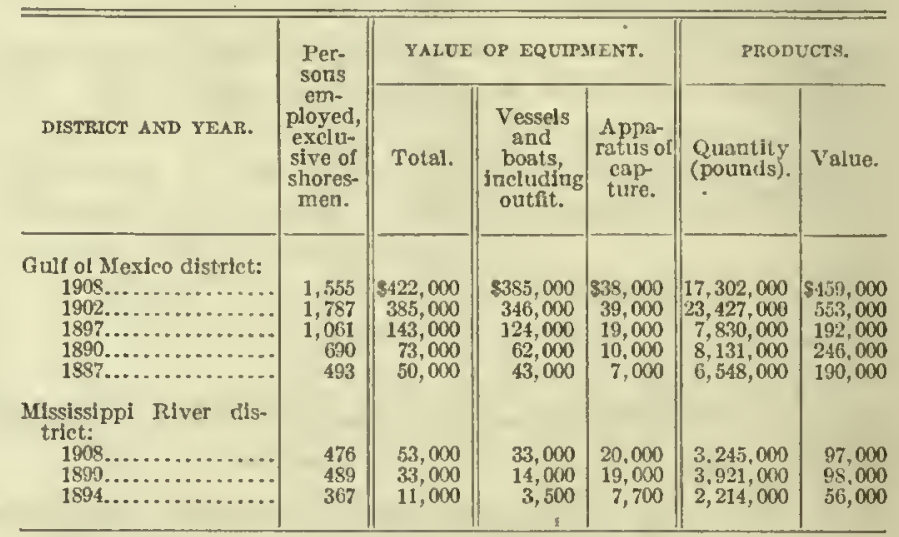

Persons employed.--The following table gives statistics of persons employed in the fisheries of Mississippi in 1908:

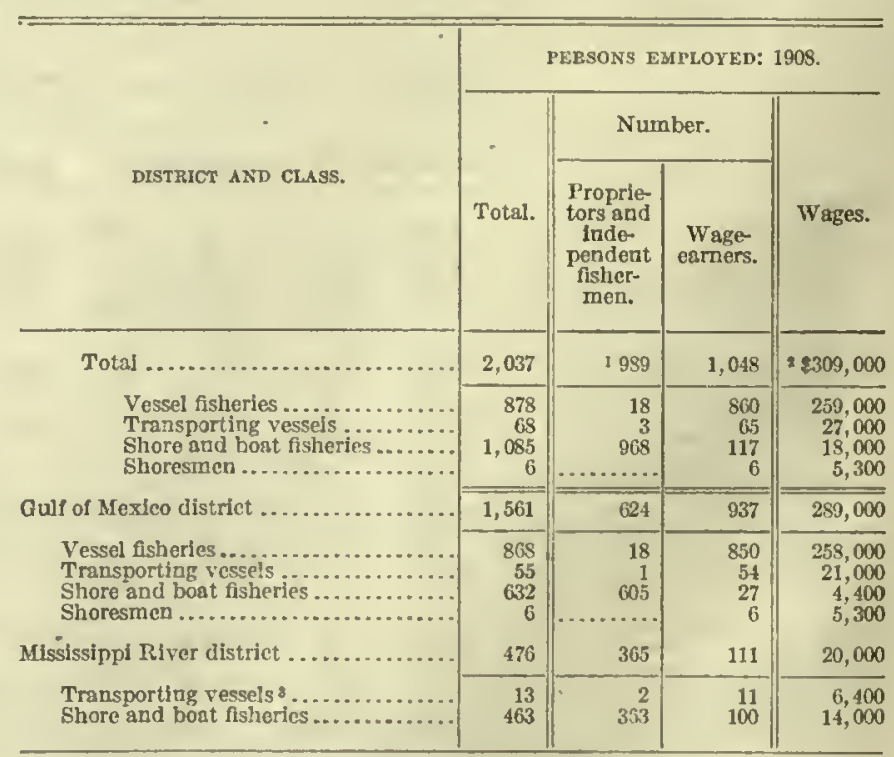

1 Exclusive of 47 proprictors not fishing.

a lncludes provistoons furnlshed to the value of $\$ 45,000$.
Inciudes crew of one vessel engaged in fishing. 
Wage-earners slightly outnumbered proprictors and independent fishermen. Of the wage-earners, 89 per cont were employed in the Gulf fisheries, and of the wage-earners in this district, 91 per cent were employed in the vessel fisheries. The low ratio of wageearners to proprietors and independent fishermen in the shore and boat fisheries, the absence of salaried employees, and the small average sumpaid to cmployees make plain the small scale on which this class of fisheries is conducted in Mississippi.

Equipment and other capital.-The following table shows the distribution of the investment in the fisheries of the state:

\begin{tabular}{|c|c|c|c|}
\hline \multirow{2}{*}{ CLASS OF INVESTMENT. } & \multicolumn{3}{|c|}{$\begin{array}{l}\text { VALUE OF EQUTPMENT ARD OTHER } \\
\text { CAPITAL: } 1908 .\end{array}$} \\
\hline & Total. & $\begin{array}{l}\text { Gull ol } \\
\text { Mexico } \\
\text { district. }\end{array}$ & $\begin{array}{l}\text { Mississippl } \\
\text { River } \\
\text { dlstrict. }\end{array}$ \\
\hline Total. & $\$ 522,000$ & $\$ 461,000$ & $\$ 61,000$ \\
\hline Vessels, Including outfit.. & 372,000 & 358,000 & 13,000 \\
\hline Fishing.................... & 326,000 & 326,000 & ........ \\
\hline Steam and motor.. & 4,400 & $\begin{array}{l}4,400 \\
3,700\end{array}$ & $\ldots \ldots \ldots$ \\
\hline $\begin{array}{l}\text { Vessels.. } \\
\text { Outfit... }\end{array}$ & $\begin{array}{r}3,700 \\
700\end{array}$ & $\begin{array}{r}3,700 \\
700\end{array}$ & $\cdots$ \\
\hline Sail ........ & 322,000 & 322,000 & $\because$ \\
\hline Vessels. & 275,000 & 275,000 & 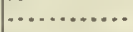 \\
\hline Outit & 47,000 & 47,000 & \\
\hline Transporting.......... & 45,000 & $\begin{array}{l}32,000 \\
17,000\end{array}$ & $\begin{array}{l}13,000 \\
13,000\end{array}$ \\
\hline Steam and motor... & 30,000 & $\begin{array}{l}17,000 \\
15,000\end{array}$ & $\begin{array}{l}13,000 \\
11,000\end{array}$ \\
\hline $\begin{array}{l}\text { Vessels.......... } \\
\text { Outfit......... }\end{array}$ & $\begin{array}{r}26,000 \\
4,200\end{array}$ & $\begin{array}{r}15,000 \\
2,400\end{array}$ & $\begin{array}{r}11,000 \\
1,800\end{array}$ \\
\hline Sail..... & 15,000 & 15,000 & \\
\hline Vesseis.... & 11,000 & 11,000 & ..... \\
\hline $\begin{array}{l}\text { Outfit..... } \\
\text { Other....... }\end{array}$ & 3,100 & 3,100 & \\
\hline Boats $\quad$ Other $\ldots \ldots \ldots \ldots$ & $\begin{array}{r}400 \\
46,000\end{array}$ & & 20,000 \\
\hline 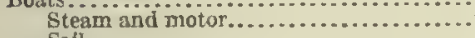 & 16,000 & 5,000 & 111,000 \\
\hline Sall.......... & 14,000 & 14,000 & \\
\hline $\begin{array}{l}\text { Row............... } \\
\text { Apparatus of capture... }\end{array}$ & 17,000 & 7,900 & 8,700 \\
\hline 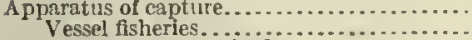 & 58,000 & 38,000 & 20,000 \\
\hline 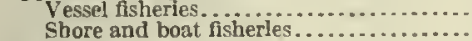 & 26,000 & 25,000 & $\begin{array}{r}1,400 \\
19,000\end{array}$ \\
\hline $\begin{array}{l}\text { Shore and boat fisherles..... } \\
\text { Shore and accessory property.... }\end{array}$ & 31,000 & 13,000 & $\begin{array}{r}19,000 \\
7,300\end{array}$ \\
\hline 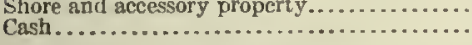 & $\begin{array}{l}34,000 \\
12,000\end{array}$ & $\begin{array}{l}27,000 \\
12,000\end{array}$ & 7,300 \\
\hline & & & \\
\hline
\end{tabular}

1 Includes the value of one vessel engaged la fishing.

Over three-fifths of the total investment in the fisheries of the state represented the value of the sail fishing vessels and their outfits. All the shore and accessory property and cash capital reported, with trifling exceptions, pertained to the shore and boat fisheries. The total investment was distributed in the following manner: $\$ 353,000$ in vessel fisheries; $\$ 45,000$ in transporting vessels and $\$ 124,000$ in shore and boat fisheries.

Detailed statisties of the number and tonnage of the vessels and the number of the boats are given in the next table.

In the vessel fisheries all but two of the craft were sailing vessels. Among transporting vessels steam and motor craft equal sailing craft in number, but the value of the former was more than double that of the latter. The fisheries of the Gulf of Mexico were credited with the entire investment in fishing vessels, except the value of one ressel of 11 tons engaged in fishing in the Missisippi River district. The transporting vessels used in the Gulf district were valued at $\$ 32,000$, and the boats used in the shore and boat fisheries of the same district were valued at $\$ 27,000$.

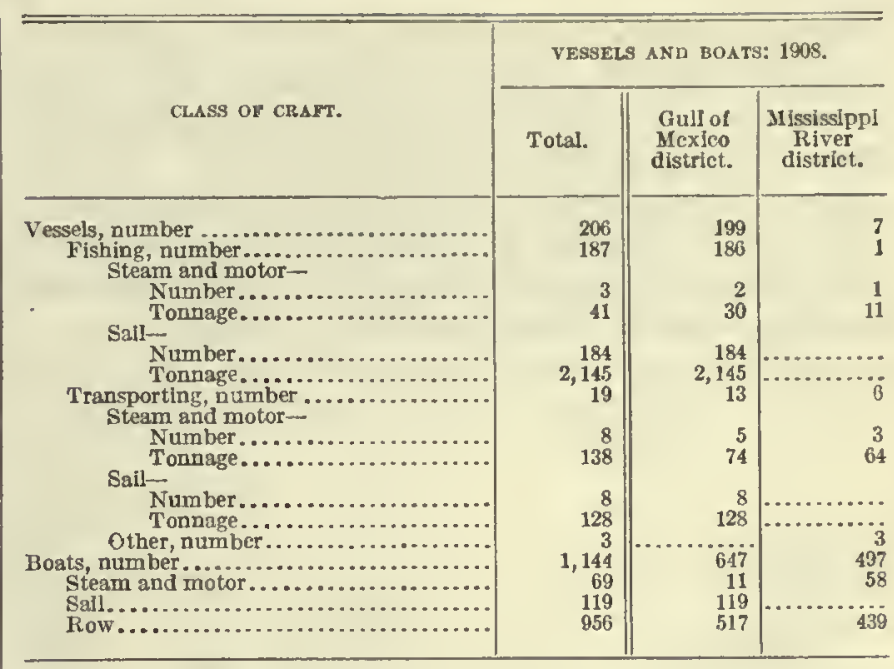

The following tabular statement gives details of the number of the principal kinds of apparatus of capture used:

\begin{tabular}{|c|c|c|c|c|c|}
\hline \multirow{3}{*}{ KIND. } & \multicolumn{5}{|c|}{ APPARATUS OF CAPTURE: 1908.} \\
\hline & \multirow{2}{*}{ Total. } & \multicolumn{2}{|c|}{$\begin{array}{l}\text { Distributed by } \\
\text { districts. }\end{array}$} & \multicolumn{2}{|c|}{$\begin{array}{l}\text { Distributed by class } \\
\text { of fisheries. }\end{array}$} \\
\hline & & $\begin{array}{l}\text { Gull of } \\
\text { Mlexico } \\
\text { district. }\end{array}$ & $\begin{array}{c}\text { Missis- } \\
\text { sippi } \\
\text { River } \\
\text { district. }\end{array}$ & $\begin{array}{l}\text { Vessel } \\
\text { fisheries. }\end{array}$ & $\begin{array}{l}\text { Sbore } \\
\text { and boat } \\
\text { fisheries. }\end{array}$ \\
\hline 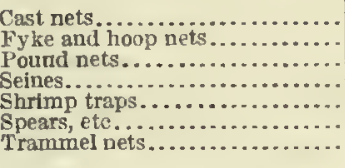 & $\begin{array}{r}71 \\
1,710 \\
2 \\
135 \\
1,150 \\
116 \\
136\end{array}$ & $\begin{array}{r}71 \\
\cdots+110 \\
110 \\
116 \\
135\end{array}$ & $\begin{array}{r}1,710 \\
2 \\
25 \\
1,150 \\
\cdots\end{array}$ & $\begin{array}{l}30 \\
\cdots \\
\cdots\end{array}$ & $\begin{array}{r}71 \\
1,680 \\
2 \\
45 \\
1,150 \\
116 \\
111\end{array}$ \\
\hline
\end{tabular}

Products, by species.-Table 1, on page 182, gives the quantity and value of the fishery products of Mississippi, by species and by apparatus of capture.

The greater portion of the product in 1908 consisted of mollusks and crustaceans. The oyster yield was more valuable than all the rest of the catch, and the shrimp product had a total value almost equal to half the value of all fish proper. The total fish catch amounted to $8,520,000$ pounds, valued at $\$ 164,000$. Buffalo fish and sea trout were the leading species, while mullet, catfish, and paddlefish followed.

Products, by fishing grounds.-Table 2, on page 183, shows, by species and by apparatus of capture, the weight and value of the product taken in the Gulf of Mexico district by Mississippi fishermen, and Table 3 gives similar detailed statistics for the Mississippi River distriet. The value reported for the principal species taken in the two districts is shown in the next tabular statement.

The fishery product from the Gulf of Mexico district contributed 82 per cent of the value of the total product of the state. Oysters ranked first, with a value forming 64 per cent of the total value of products from this district, and shrimp ranked second, with a value equal to 15 per cent of the total. Of fish proper, the 
catch reported for the Gulf of Mexico fisheries was $5,413,000$ pounds, valued at $\$ 78,000$. This value represents 17 per cent of the total value of the fishory products of the Gulf district, and is smaller than the corresponding value for the Mississippi River district. The bulk of the catch of fish proper was composed of two low-priced species, menhaden and mullet; but squeteague led in value, followed by mullet.

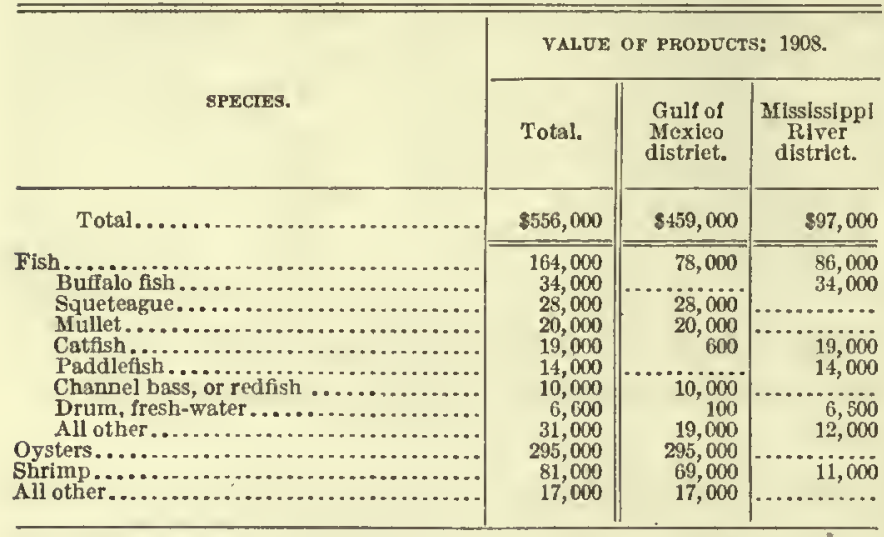

The value of the fishery product from the Mississippi River district amounted to 17 per cent of the value of the total state product. Except for a small shrimp catch, the entire product consisted of fish proper. The quantity of fish proper taken in this district was smaller than that taken in the Gulf district; which formed 64 per cent of the total weight, but, as already stated, the value of the river catch was greater. Buffalo fish was the leading species, contributing over one-half of the weight and over one-third of the value of the Mississippi River product. Catfish ranked next in quantity and value, and was closely followed by paddlefish and paddlefish caviar.

Products, by class of fisheries.-Table 4, on page 184, gives statistics of the weight and value, by species and by apparatus of capture, of the product taken by the vessol fisheries of Mississippi on the Gulf of Mexico, and Table 5, on page 184, gives similar statistics for the shore and boat fisheries of the same district. Oysters contributed 50 per cent of the value of the product taken by shore and boat fisheries of the Gulf district. The fish proper reported by this class of fisheries had a value of $\$ 50,000$, squeteague being the leacling fish with respect to value, and mullet ranking second. The catch of crabs made in the Gulf shore and boat fisheries, which comprised the entire crab product of Mississippi, ranked next to the mullet product in value.

The following tabular statement distributes the value of products reported for the state as a whole and for each class of fisheries, by species arranged in order of value:

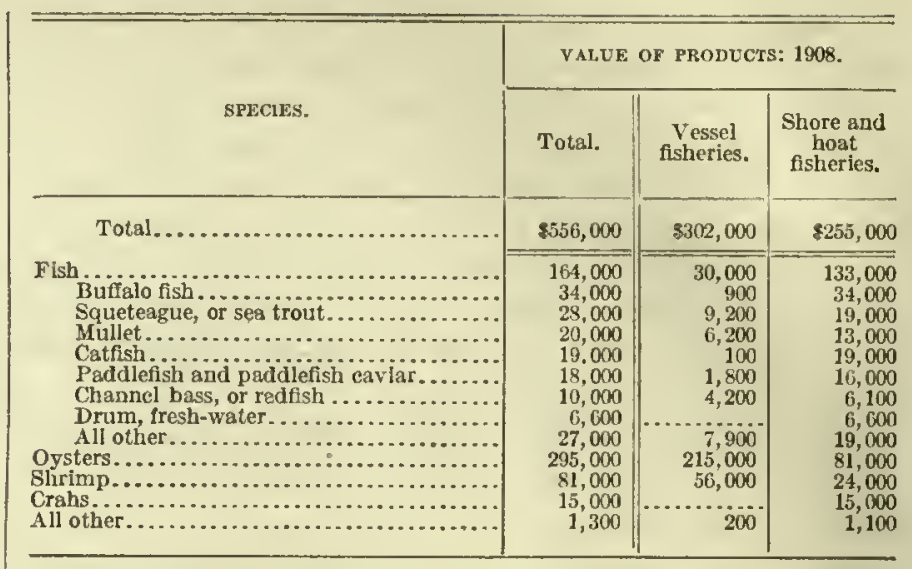

With the exception of one vessel of 11 tons, all of the Mississippi River fisheries were of the shore and boat class.

Products, by apparatus of capture.-Fyke and hoop nets, pound nots, and shrimp traps were used exclusively in the Mississippi River district, and cast nets, shrimp nets, and dredges and tongs, exclusively in the Gulf district, while seines, trammel nets, and lines were common to both districts.

The total value of products for the state, distributed by apparatus of capture and by fishery districts, is shown in the following tabular statement:

\begin{tabular}{|c|c|c|c|}
\hline \multirow[b]{2}{*}{ KIND OF APPARATUS. } & \multicolumn{3}{|c|}{ VALUE OF PRODUCTs: 1908.} \\
\hline & Total. & $\begin{array}{l}\text { Gulf of } \\
\text { Mexieo } \\
\text { district. }\end{array}$ & $\begin{array}{l}\text { Misslssippl } \\
\text { River } \\
\text { district. }\end{array}$ \\
\hline Total............ & $\$ 556,000$ & $\$ 459,000$ & $\$ 97,000$ \\
\hline 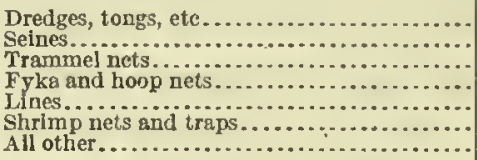 & $\begin{array}{r}295,000 \\
108,000 \\
57,000 \\
40,000 \\
40,000 \\
12,000 \\
4,700\end{array}$ & $\begin{array}{r}295,000 \\
82,000 \\
56,000 \\
21,000 \\
3,400\end{array}$ & $\begin{array}{r}26,000 \\
000 \\
40,000 \\
19,000 \\
12,000 \\
1,200\end{array}$ \\
\hline
\end{tabular}

The following tabular statement distributes the total value of products for the state as a whole and for each class of fisheries by apparatus of capture, arranged in the order of value of their catch:

\begin{tabular}{|c|c|c|c|}
\hline \multirow[b]{2}{*}{ KIND OF APPARATUS. } & \multicolumn{3}{|c|}{ VALUE OF PRODUCTS: 1908.} \\
\hline & Total. & $\begin{array}{c}\text { Vessel } \\
\text { fisherles. }\end{array}$ & $\begin{array}{l}\text { Shore and } \\
\text { boat } \\
\text { fisheries. }\end{array}$ \\
\hline 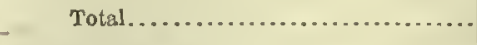 & $\$ 556,000$ & $\$ 302,000$ & $\$ 255,000$ \\
\hline 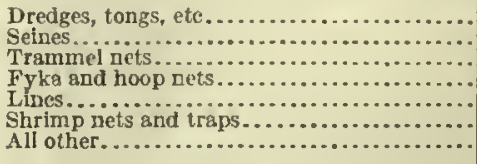 & $\begin{array}{r}295,000 \\
108,000 \\
57,000 \\
40,000 \\
40,000 \\
12,000 \\
4,700\end{array}$ & $\begin{array}{r}215,000 \\
67,000 \\
20,000 \\
\cdots \\
\cdots\end{array}$ & $\begin{array}{r}81,000 \\
40,000 \\
37,000 \\
40,000 \\
40,000 \\
12,000 \\
4,700\end{array}$ \\
\hline
\end{tabular}


Oysters.-The oyster product, all of which was taken in the Gulf of Mexico distriet, mostly by vessel fishermen, contributed 53 per cent of the value of the state fishery products. The oysters taken by the shore and boat fisheries brought a price considerably higher than that received for the product of the vessel fisheries, the average price being 46 eents per bushel for the former, as against 24 cents for tho latter. Oyster farming was followed to a very limited extent, less tlian 1 per cent of the total oyster product being from private areas. The entire oyster product in 1908 was much smaller than in 1902 , but compared with the yield in previous years, must be considered unusually large. The following statement gives statisties of the oyster product for 1908 and for previous canvasses:

\begin{tabular}{|c|c|c|}
\hline \multirow[b]{2}{*}{ YEAR. } & \multicolumn{2}{|c|}{ OYSTER PRODUCT. } \\
\hline & $\begin{array}{l}\text { Quantity } \\
\text { (bushels). }\end{array}$ & Value. \\
\hline 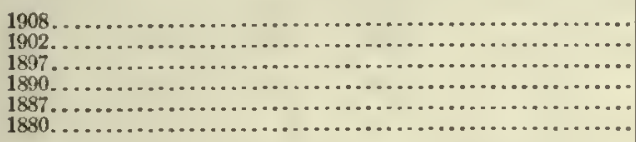 & $\begin{array}{r}1,068,000 \\
2,405,000 \\
630,000 \\
806,000 \\
581,000 \\
25,000\end{array}$ & $\begin{array}{r}\$ 295,000 \\
426,000 \\
111,000 \\
167,000 \\
119,000 \\
10,000\end{array}$ \\
\hline
\end{tabular}

Shrimp.-Shrimp are taken in Mississippi in larger quantities than in any other state except Louisiana. They represented 15 per cent of the total value of the state product, and were taken in both the Mississippi River and the Gulf of Mexico districts. Only 3 per cent of the total shrimp product was taken in the Mississippi River distriet, but this small portion contributed 14 per cent of the total value. The vessel fisheries of the Gulf took a quantity valued at 70 per cent of the total value for the state. The produet of the Gulf was taken almost exclusively with seines, while in the Mississippi River shrimp traps were the form of apparatus of capture used. In quantity the shrimp catel of 1908 shows a decrease compared with that of 1902 , but an increase over years prior thereto. In value, however, the slirimp product has increased steadily since 1890 , as is shown by the following tabular statement:

\begin{tabular}{|c|c|c|}
\hline \multirow{2}{*}{ YEAR. } & \multicolumn{2}{|c|}{$\begin{array}{l}\text { SHRIMP PRODUCT OF } \\
\text { GULF OF MEXICO } \\
\text { DISTRICT. }\end{array}$} \\
\hline & $\begin{array}{l}\text { Quantity } \\
\text { (pounds). }\end{array}$ & Value. \\
\hline 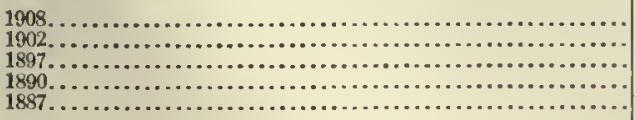 & $\begin{array}{r}3,983,000 \\
4,424,000 \\
1,903,000 \\
1,14,000 \\
1,145,000\end{array}$ & $\begin{array}{r}869,000 \\
58,000 \\
29,000 \\
13,000 \\
24,000\end{array}$ \\
\hline
\end{tabular}

Buffalo fish.-This fish was the leading speeies of fish proper, and was taken almost exclusively in the Mississippi River district, where it contributed 35 per cent of the value of the product. Fyke and hoop nets were the principal forms of apparatus of capture used. The catch of buffalo fish in 1908, although about double that of 1894, shows a decrease compared with 1899. Statistics of the catch of buffalo fish in the Mississippi River district for 1894, 1899, and 1908 are given in the following tabular statement:

\begin{tabular}{|c|c|c|}
\hline \multirow{2}{*}{.YEAR. } & \multicolumn{2}{|c|}{$\begin{array}{l}\text { BUFFALO-FISH PROD- } \\
\text { UCT OF MISSISSIPP } \\
\text { RIVER DISTRICT. }\end{array}$} \\
\hline & $\begin{array}{l}\text { Quantity } \\
\text { (pounds). }\end{array}$ & Value. \\
\hline 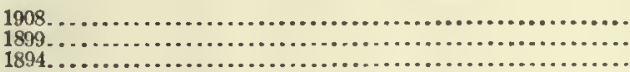 & $\begin{array}{r}1,664,000 \\
2,023,000 \\
848,000\end{array}$ & $\begin{array}{r}\$ 34,000 \\
34,000 \\
15,000\end{array}$ \\
\hline
\end{tabular}

Squeteague, or sea trout.-The catch of squeteague lias increased constantly in quantity, as reported at the various eanvasses, and of late years, in value, as is shown by the following tabular statement:

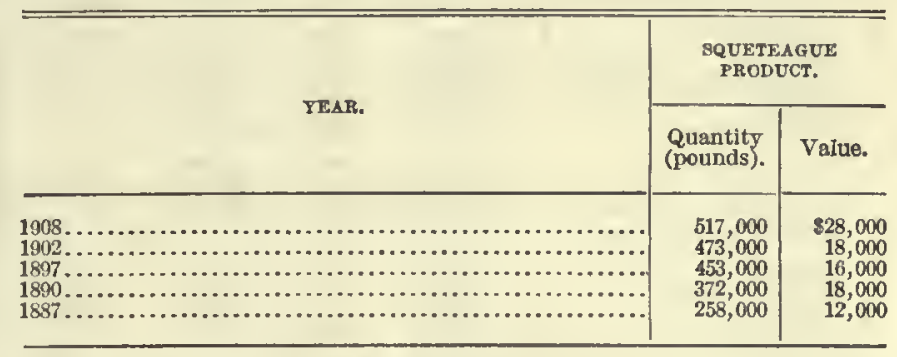

Other products.-Mullet contributed 4 per cent of the value of the state product. This species, almost the entire eatch of which was taken with trammel nets, ranked third in value among the fish produets proper of the state, and second among those of the Gulf district. During recent years the mullet product has increased greatly in both quantity and value, as is indicated by the following tabular statement:

\begin{tabular}{|c|c|c|c|}
\hline \multirow[b]{2}{*}{ YEAR. } & \multirow[b]{2}{*}{$r$} & \multicolumn{2}{|c|}{ MULLET PRODUCT. } \\
\hline & & $\begin{array}{l}\text { Quantity } \\
\text { (pounds). }\end{array}$ & Value. \\
\hline 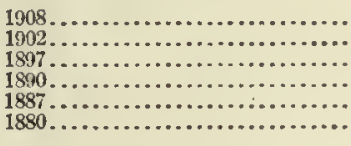 & 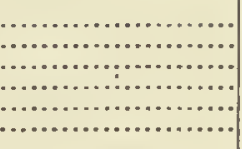 & $\begin{array}{r}1,035,000 \\
600,000 \\
241,000 \\
305,000 \\
233,000 \\
1,500\end{array}$ & $\begin{array}{r}\$ 20,000 \\
10,000 \\
2,900 \\
3,500 \\
2,600 \\
100\end{array}$ \\
\hline
\end{tabular}


Catfish were taken almost entirely by shore and boat fishermen, and practically all of the catch came from the Mississippi River district. They are caught chiefly with lines. The following tabular statement gives the statistics of the catch of the Mississippi River district as reported at the canvasses of 1894 , 1899, and 1908:

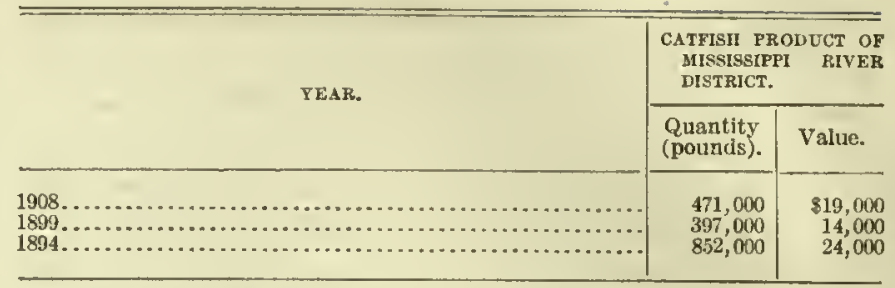

TABLE 1.-MISSISSIPPI-FISHERY PRODUCTS: 1908

\begin{tabular}{|c|c|c|c|c|c|c|c|c|c|c|c|c|}
\hline \multirow{3}{*}{ SPECIES. } & \multirow{2}{*}{\multicolumn{2}{|c|}{ TOTAL. }} & \multicolumn{10}{|c|}{ PRODUCT CAUGHT BY- } \\
\hline & & & \multicolumn{2}{|c|}{ Seines. } & \multicolumn{2}{|c|}{ Trammel nets. } & \multicolumn{2}{|c|}{ Fyke and hoop nets. } & \multicolumn{2}{|c|}{ Lines. } & \multicolumn{2}{|c|}{ All other apparatus. ${ }^{1}$} \\
\hline & $\begin{array}{l}\text { Quantity } \\
\text { (pounds). }\end{array}$ & Value. & $\begin{array}{l}\text { Quantity } \\
\text { (pounds). }\end{array}$ & Value. & $\begin{array}{l}\text { Quantity } \\
\text { (pounds). }\end{array}$ & Value. & $\begin{array}{l}\text { Quantity } \\
\text { (pounds). }\end{array}$ & Value. & $\begin{array}{l}\text { Quantity } \\
\text { (pounds). }\end{array}$ & Value. & $\begin{array}{l}\text { Quantity } \\
\text { (pounds). }\end{array}$ & Value. \\
\hline Total.. & $20,547,000$ & 8556,000 & $8,118,000$ & $\$ 108,000$ & $1,839,000$ & $\$ 57,000$ & $1,766,000$ & $\$ 40,000$ & $1,022,000$ & $\$ 40,000$ & $7,802,000$ & $\$ 312,000$ \\
\hline 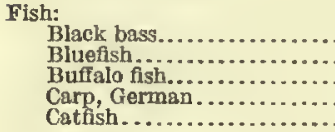 & $\begin{array}{r}15,000 \\
18,000 \\
1,664,000 \\
26,000 \\
502,000\end{array}$ & $\begin{array}{r}1,000 \\
800 \\
34,000 \\
500 \\
19,000\end{array}$ & $\begin{array}{r}2,000 \\
4,900 \\
421,000 \\
12,000 \\
54,000\end{array}$ & $\begin{array}{r}200 \\
200 \\
9,600 \\
300 \\
2,100\end{array}$ & $\begin{array}{r}200 \\
13,000 \\
12,000 \\
22,000\end{array}$ & $\begin{array}{r}(2) \\
600 \\
200 \\
600\end{array}$ & $\begin{array}{r}1,154,000 \\
14,000 \\
71,000\end{array}$ & $\begin{array}{r}23,000 \\
200 \\
3,100\end{array}$ & $\begin{array}{l}13,000 \\
(35) \\
35,000\end{array}$ & $\begin{array}{l}800 \\
(2) \\
700\end{array}$ & 42,000 & $\begin{array}{l}\cdots \\
\dddot{3} 00\end{array}$ \\
\hline 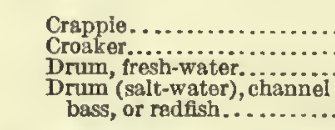 & $\begin{array}{r}89,000 \\
176,000 \\
337,000\end{array}$ & $\begin{array}{l}4,800 \\
3,700 \\
6,600\end{array}$ & $\begin{array}{l}28,000 \\
37,000 \\
59,000\end{array}$ & $\begin{array}{l}1,500 \\
700 \\
1,200 \\
1,800\end{array}$ & $\begin{array}{r}100 \\
100,000 \\
2,200 \\
185,000\end{array}$ & $\begin{array}{l}(2) \\
2,000 \\
(2) \\
8,200\end{array}$ & $\begin{array}{r}11,000 \\
244,000\end{array}$ & $\begin{array}{r}700 \\
\hdashline, 800\end{array}$ & $\begin{array}{l}50,000 \\
25,000 \\
18,000\end{array}$ & $\begin{array}{r}2,600 \\
600 \\
400 \\
800\end{array}$ & $\begin{array}{l}14,000 \\
13,000\end{array}$ & $\begin{array}{l}300 \\
200\end{array}$ \\
\hline $\begin{array}{l}\text { Flounders................... } \\
\text { Menhaden................. } \\
\text { Mullet..................... } \\
\text { Paddlefish .... } \\
\text { Caviar and paddiefish egg.. }\end{array}$ & $\begin{array}{r}38,000 \\
3,149,000 \\
1,035,000 \\
463,000 \\
4,100\end{array}$ & $\begin{array}{r}2,000 \\
3,900 \\
20,000 \\
14,000 \\
4,000\end{array}$ & $\begin{array}{r}2,300 \\
3,149,000 \\
41,000 \\
209,000 \\
3,900\end{array}$ & $\begin{array}{r}100 \\
3,900 \\
800 \\
6,800 \\
3,800\end{array}$ & $\begin{array}{r}7,200 \\
500 \\
973,000 \\
1,000\end{array}$ & $\begin{array}{l}300 \\
(2) \\
18,000 \\
\left({ }^{(2)}\right.\end{array}$ & 253,600 & 7,500 & 100 & ${ }^{(2)}$ & 22,000 & $\begin{array}{r}1,500 \\
400 \\
4 . .\end{array}$ \\
\hline 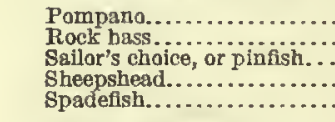 & $\begin{array}{r}4,600 \\
12,000 \\
9,200 \\
81,000 \\
6,900\end{array}$ & $\begin{array}{r}400 \\
700 \\
200 \\
4,300 \\
200\end{array}$ & $\begin{array}{l}1,900 \\
7,600 \\
2,400\end{array}$ & $\begin{array}{r}100 \\
(2) \\
400 \\
100\end{array}$ & $\begin{array}{r}3,300 \\
6,400 \\
58,000 \\
4,300\end{array}$ & $\begin{array}{r}300 \\
100 \\
3,000 \\
100\end{array}$ & & & $\begin{array}{r}200 \\
12,000 \\
600 \\
12,000 \\
100\end{array}$ & $\begin{array}{l}\text { (2) } 700 \\
(2) \\
(200 \\
(2)\end{array}$ & $\begin{array}{r}400 \\
2,500 \\
200\end{array}$ & (2) 100 \\
\hline 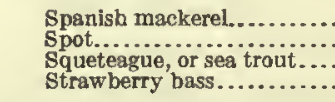 & $\begin{array}{r}7,100 \\
71,000 \\
517,000 \\
3,200\end{array}$ & $\begin{array}{r}500 \\
1,300 \\
28,000 \\
200\end{array}$ & $\begin{array}{l}1,400 \\
20,000 \\
80,000 \\
(2)\end{array}$ & $\begin{aligned} & 100 \\
& 400 \\
& 4,400 \\
&(2)\end{aligned}$ & $\begin{array}{r}5,400 \\
50,000 \\
383,000 \\
(2)\end{array}$ & $\begin{array}{r}400 \\
900 \\
21,000 \\
\left({ }^{2}\right)\end{array}$ & - & & $\begin{array}{r}400 \\
900 \\
50,000 \\
3,200\end{array}$ & $\begin{array}{l}(2) \\
(2) \\
2,800 \\
200\end{array}$ & $\begin{array}{r}200 \\
4,400\end{array}$ & 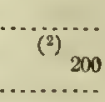 \\
\hline 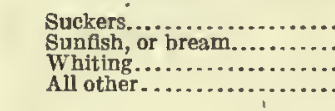 & $\begin{array}{r}20,000 \\
14,000 \\
12,000 \\
1,700\end{array}$ & $\begin{array}{l}400 \\
600 \\
400 \\
100\end{array}$ & $\begin{array}{r}4,200 \\
2,900 \\
500\end{array}$ & $\begin{array}{l}200 \\
100\end{array}$ & $\begin{array}{l}3,500 \\
7,300 \\
1,200\end{array}$ & $\begin{array}{l}100 \\
200 \\
100\end{array}$ & 19,000 & 400 & $\begin{array}{l}1,000 \\
6,500 \\
1,500 \\
200\end{array}$ & $\begin{array}{l}(2) \\
300 \\
(2) \\
(2)\end{array}$ & 100 & (i) \\
\hline 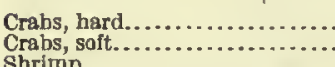 & $\begin{array}{r}380,000 \\
47,000\end{array}$ & $\begin{array}{r}9,800 \\
5,600 \\
81,000\end{array}$ & & 68000 & & & & & $\begin{array}{r}380,000 \\
47,000\end{array}$ & $\begin{array}{l}9,800 \\
5,600\end{array}$ & & \\
\hline 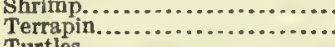 & $\begin{array}{r}4,121,000 \\
5,100\end{array}$ & $\begin{array}{r}81,000 \\
1,200\end{array}$ & $\begin{array}{r}3,925,000 \\
5,100\end{array}$ & $\begin{array}{r}68,000 \\
1,200\end{array}$ & & & & & & & 196,000 & 13,000 \\
\hline 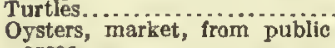 & 2,200 & 100 & 2,200 & 100 & & & & & & & & \\
\hline 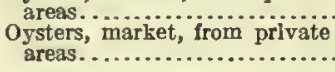 & $\begin{array}{r}4,423,000 \\
\quad 50,000\end{array}$ & $\begin{array}{r}292,000 \\
3,800\end{array}$ & & & & & & & & & $\begin{array}{r}4,423,000 \\
550,000\end{array}$ & $\begin{array}{r}292,000 \\
3,800\end{array}$ \\
\hline & & 0,0000 & & & & & & & & & 30,000 & 3,800 \\
\hline
\end{tabular}

1 Includes apparatus, with catch, as follows: Dradges, tongs, etc., $7,473,000$ pounds, valued at $\$ 295,000$; shrimp nets and traps, 178,000 pounds, valued at $\$ 12,000$; cast nets, 62,000 pounds, valued at $\$ 1,900 ;$ spears, etc., 28,000 pounds, valued at $\$ 1,500$; and pound nets, 61,000 pounds, valued at $\$ 1,200$.

Less than $\$ 100$.
I Iess than 100 pounds. $1,060,000$ busheis. 
FISHERIES, BY STATES.

TABLE 2.-MISSISSIPPI-FISHERY PRODUCTS OF GULF OF MEXICO DISTRICT: 1908.

\begin{tabular}{|c|c|c|c|c|c|c|c|c|c|c|c|c|}
\hline \multirow{3}{*}{ SPECTES. } & \multirow{2}{*}{\multicolumn{2}{|c|}{ TOTAL. }} & \multicolumn{9}{|c|}{ PRODUCT CAUGHT BY- } & \multirow{2}{*}{$\stackrel{-}{\text { pparatus.1 }}$} \\
\hline & & & \multicolumn{2}{|c|}{ Seines. } & \multicolumn{2}{|c|}{ Trammel nets. } & \multicolumn{2}{|c|}{ Lines. } & \multicolumn{2}{|c|}{ Cast nets. } & All other apparatus. 1 & \\
\hline & $\begin{array}{l}\text { Quantity } \\
\text { (pounds). }\end{array}$ & Value. & $\begin{array}{l}\text { Quantity } \\
\text { (pounds). }\end{array}$ & Value. & $\begin{array}{l}\text { Quantity } \\
\text { (pounds). }\end{array}$ & Value. & $\begin{array}{l}\text { Quantity } \\
\text { (pounds). }\end{array}$ & Value. & $\begin{array}{l}\text { Quantity } \\
\text { (pounds). }\end{array}$ & Value. & $\begin{array}{l}\text { Quantity } \\
\text { (pounds). }\end{array}$ & Value. \\
\hline Total................ & $17,302,000$ & $\$ 459,000$ & $7,331,000$ & $\$ 82,000$ & $1,818,000$ & $\$ 56,000$ & 550,000 & $\$ 21,000$ & 62,000 & $\$ 1,900$ & $7,541,000$ & $\$ 298,000$ \\
\hline 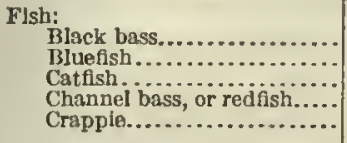 & $\begin{array}{r}1,700 \\
18,000 \\
31,000 \\
227,000 \\
2,100\end{array}$ & $\begin{array}{r}100 \\
800 \\
600 \\
10,000 \\
100\end{array}$ & $\begin{array}{r}4,000 \\
5,200 \\
38,000 \\
100\end{array}$ & $\begin{array}{l}200 \\
100 \\
1,700 \\
(2)\end{array}$ & $\begin{array}{r}200 \\
13,000 \\
14,000 \\
174,000 \\
100\end{array}$ & $\begin{array}{l}\left({ }^{2}\right) \\
600 \\
300 \\
7,900 \\
(3)\end{array}$ & $\begin{array}{r}1,500 \\
(2), 000 \\
12,000 \\
15,000 \\
1,900\end{array}$ & $\begin{array}{l}100 \\
(2) \\
300 \\
700 \\
100\end{array}$ & $\begin{array}{ll}\cdots \\
1,100\end{array}$ & $\ddot{100}$ & (n) & $\begin{array}{l}\cdots \cdots \cdots \\
\cdots \cdots \cdots \\
\cdots \cdots \cdots\end{array}$ \\
\hline 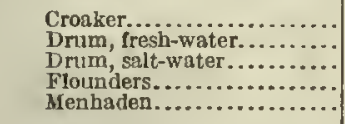 & $\begin{array}{r}176,000 \\
2,400 \\
17,000 \\
38,000 \\
3,149,000\end{array}$ & $\begin{array}{r}3,700 \\
100 \\
600 \\
2,000 \\
3,900\end{array}$ & $\begin{array}{r}37,000 \\
100 \\
3,000 \\
2,300 \\
3,149,000\end{array}$ & $\begin{array}{r}700 \\
(2)^{700} \\
100 \\
3,900\end{array}$ & $\begin{array}{r}100,000 \\
2,200 \\
11,000 \\
7,200 \\
500\end{array}$ & $\begin{array}{l}2,000 \\
(2) \\
400 \\
300 \\
\left.()^{2}\right)^{4}\end{array}$ & $\begin{array}{r}25,000 \\
200 \\
2,000 \\
100 \\
\ldots\end{array}$ & ${ }_{(2)}^{(2)} 100$ & $\begin{array}{r}14,000 \\
400 \\
100\end{array}$ & $\begin{array}{l}300 \\
(3) \cdots \\
(3)\end{array}$ & 28,000 & $\begin{array}{r}1,500 \\
\cdots \ldots \ldots . . .\end{array}$ \\
\hline 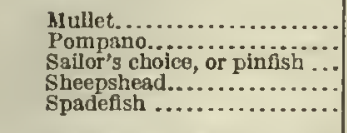 & $\begin{array}{r}1,035,000 \\
4,600 \\
9,200 \\
81,000 \\
6,900\end{array}$ & $\begin{array}{r}20,000 \\
400 \\
200 \\
4,300 \\
200\end{array}$ & $\begin{array}{r}41,000 \\
1,200 \\
1,900 \\
7,600 \\
2,400\end{array}$ & $\begin{array}{r}800 \\
100 \\
\left({ }^{2}\right) \\
400 \\
100\end{array}$ & $\begin{array}{r}973,000 \\
3,300 \\
6,400 \\
58,000 \\
4,300\end{array}$ & $\begin{array}{r}18,000 \\
300 \\
100 \\
3,000 \\
100\end{array}$ & $\begin{array}{r}200 \\
600 \\
12,000 \\
100\end{array}$ & $\begin{array}{l}(2) \\
(2) \\
(2)\end{array}$ & $\begin{array}{r}22,000 \\
2,500 \\
200\end{array}$ & $\begin{array}{l}400 \\
{ }_{(2)}{ }_{100} \\
\left({ }^{(2)}\right.\end{array}$ & 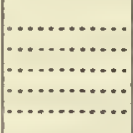 & (n. \\
\hline 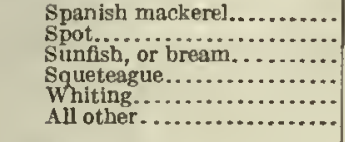 & $\begin{array}{r}7,100 \\
71,000 \\
5,300 \\
517,000 \\
12,000 \\
2,300\end{array}$ & $\begin{array}{r}500 \\
1,300 \\
200 \\
25,000 \\
400 \\
100\end{array}$ & $\begin{array}{r}1,400 \\
20,000 \\
1,200 \\
80,000 \\
2,900 \\
500\end{array}$ & $\begin{array}{l}100 \\
400 \\
(2) \\
4,400 \\
100 \\
(3)\end{array}$ & $\begin{array}{r}5,400 \\
50,000 \\
3,500 \\
383,000 \\
7,300 \\
1,400\end{array}$ & $\begin{array}{r}400 \\
900 \\
100 \\
21,000 \\
200 \\
100\end{array}$ & $\begin{array}{r}400 \\
900 \\
500 \\
50,000 \\
1,500 \\
400\end{array}$ & $\begin{array}{l}(3) \\
(3) \\
(3) \\
2,800 \\
(2) \\
(3)\end{array}$ & $\begin{array}{r}200 \\
100 \\
4,400 \\
\cdots \ldots \ldots \ldots\end{array}$ & 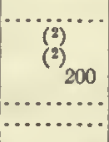 & 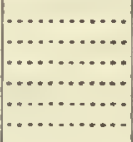 & 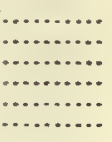 \\
\hline $\begin{array}{l}\text { Crabs, hard....................... } \\
\text { Crahs, soft.................... } \\
\text { Shrimn }\end{array}$ & $\begin{array}{r}380,000 \\
47,000 \\
3,983,000\end{array}$ & $\begin{array}{r}9,800 \\
5,600\end{array}$ & & & & & $\begin{array}{r}380,000 \\
.47,000\end{array}$ & $\begin{array}{l}9,800 \\
5,600\end{array}$ & & & & (n) \\
\hline 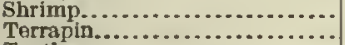 & $\begin{array}{r}3,983,000 \\
5,100\end{array}$ & $\begin{array}{r}69,000 \\
1,200\end{array}$ & $\begin{array}{r}3,925,000 \\
5,100\end{array}$ & $\begin{array}{r}68,000 \\
1,200\end{array}$ & n... & & …........... & n......... & 18,000 & 700 & $\begin{array}{r}40,000 \\
\ldots . .\end{array}$ & 800 \\
\hline $\begin{array}{l}\text { Turtles } \\
\text { Oysters market from public }\end{array}$ & 2,200 & 100 & 2,200 & 100 & & & & & (n........... & & (n) & (n) \\
\hline $\begin{array}{l}\text { areas.............................. } \\
\text { oysters, market, from private }\end{array}$ & $47,423,000$ & 292,000 & & & & & & & & & $7,423,000$ & 292,000 \\
\hline areas................................... & 50,000 & 3,800 & & & & & & & & & 550,000 & 3,800 \\
\hline
\end{tabular}

1 Includes apparatus, with catch, as follows: Dredges, tongs, etc., $7,473,000$ pounds, valued at $\$ 295,000$; spears, etc., 28,000 pounds, valued at $\$ 1,500$; and shrimp nets, 40,000 pounds, valued at $\$ 800$

2Less than $\$ 100$. "Less than 100 pounds. $\$ 1,060,000$ bushels. 7,100 bushels.

TABLE 3.-MISSISSIPPI-FISHERY PRODUCTS OF MISSISSIPPI RIVER DISTRICT: 1908.

\begin{tabular}{|c|c|c|c|c|c|c|c|c|c|c|c|c|}
\hline \multirow{3}{*}{ SPECIES. } & \multirow{2}{*}{\multicolumn{2}{|c|}{ TотAL. }} & \multicolumn{10}{|c|}{ PRODUCT CAUGIT BY- } \\
\hline & & & \multicolumn{2}{|c|}{ Fyke and hoop nets. } & \multicolumn{2}{|c|}{ Selnes. } & \multicolumn{2}{|c|}{ Lines. } & \multicolumn{2}{|c|}{ Pound nèts. } & \multicolumn{2}{|c|}{ Ali other apparotus. 1} \\
\hline & $\begin{array}{l}\text { Quantlty } \\
\text { (pounds). }\end{array}$ & Value. & $\begin{array}{l}\text { Quantity } \\
\text { (pounds). }\end{array}$ & Value. & $\begin{array}{l}\text { Quantity } \\
\text { (pounds). }\end{array}$ & Value. & $\begin{array}{l}\text { Quantity } \\
\text { (pounds). }\end{array}$ & Velue. & $\begin{array}{l}\text { Quantity } \\
\text { (pounds). }\end{array}$ & Value. & $\begin{array}{l}\text { Quantity } \\
\text { (pounds). }\end{array}$ & Velue. \\
\hline Total.... & $3,245,000$ & $\$ 97,000$ & $1,766,000$ & $\$ 40,000$ & 787,000 & $\$ 26,000$ & 472,000 & $\$ 19,000$ & 61,000 & $\$ 1,200$ & 159,000 & $\$ 12,000$ \\
\hline 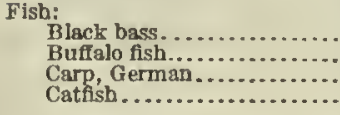 & $\begin{array}{r}13,000 \\
1,664,000 \\
26,000 \\
471,000\end{array}$ & $\begin{array}{r}900 \\
34,000 \\
500 \\
19,000\end{array}$ & $\begin{array}{r}1,154,000 \\
14,000 \\
71,000\end{array}$ & $\begin{array}{r}23,000 \\
200 \\
3,100\end{array}$ & $\begin{array}{r}2,000 \\
421,000 \\
12,000 \\
49,000\end{array}$ & $\begin{array}{r}200 \\
9,600 \\
300 \\
2,000\end{array}$ & $\begin{array}{r}11,000 \\
35,000 \\
338,000\end{array}$ & $\begin{array}{r}700 \\
700 \\
13,000\end{array}$ & $\begin{array}{l}42,000 \\
\cdots 6,000^{\circ}\end{array}$ & $\begin{array}{c}800 \\
2000\end{array}$ & 8,000 & $\begin{array}{r}200 \\
300\end{array}$ \\
\hline 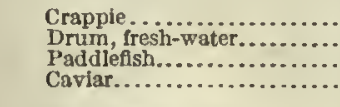 & $\begin{array}{r}87,000 \\
334,000 \\
463,000 \\
4,100\end{array}$ & $\begin{array}{r}4,700 \\
6,500 \\
14,000 \\
4,000\end{array}$ & $\begin{array}{r}11,000 \\
244,000 \\
253,000 \\
200\end{array}$ & $\begin{array}{r}700 \\
4,800 \\
7,500 \\
200\end{array}$ & $\begin{array}{r}28,000 \\
59,000 \\
209,000 \\
3,900\end{array}$ & $\begin{array}{l}1,500 \\
1,200 \\
6,800 \\
3,800\end{array}$ & $\begin{array}{r}49,000 \\
18,000 \\
\ldots\end{array}$ & $\begin{array}{r}2,500 \\
400 \\
\ldots . \ldots .\end{array}$ & 13,000 & 200 & $\ddot{1,000}$ & $(2)$ \\
\hline 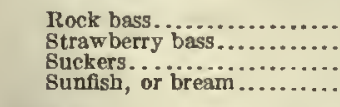 & $\begin{array}{r}12,000 \\
3,000 \\
20,000 \\
9,000\end{array}$ & $\begin{array}{l}700 \\
200 \\
400 \\
400\end{array}$ & ig,oö & $\ddot{400}$ & 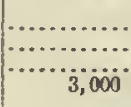 & …… & $\begin{array}{r}12,000 \\
3,000 \\
1,000 \\
6,000\end{array}$ & $\begin{array}{r}700 \\
200 \\
(3)^{200}\end{array}$ & & & (n....... & 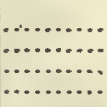 \\
\hline Shrimp......................... & 138,000 & 11,000 & & & & & & & & & 138,000 & 11,000 \\
\hline
\end{tabular}

1 Includes apparatus, with catch, as follows: Shrimp traps, 138,000 pounds, valued at \$11,000, and trammel nets, 21,000 pounds, valued at $\$ 600$.

2 Less than $\$ 100$. 
TABLE 1.-MISSISSIPPI-PRODUCTS OF VESSEL FISHERIES OF GULF OF MEXICO DISTRICT: 1909.

\begin{tabular}{|c|c|c|c|c|c|c|c|c|}
\hline \multirow{3}{*}{ SPECIES. } & \multirow{2}{*}{\multicolumn{2}{|c|}{ TOTAL. }} & \multicolumn{6}{|c|}{ PRODUCT CAUGHT HY- } \\
\hline & & & \multicolumn{2}{|c|}{ Dredges, tongs, etc. } & \multicolumn{2}{|c|}{ Seines. } & \multicolumn{2}{|c|}{ Trammel nets. } \\
\hline & $\begin{array}{l}\text { Quantity } \\
\text { (pounds). }\end{array}$ & Value. & $\begin{array}{l}\text { Quantity } \\
\text { (pounds). }\end{array}$ & Value. & $\begin{array}{l}\text { Quantlty } \\
\text { (pounds). }\end{array}$ & Value. & $\begin{array}{l}\text { Quantity } \\
\text { (pounds). }\end{array}$ & Value. \\
\hline Total....... & $13,188,000$ & $\$ 299,000$ & $6,244,000$ & $\$ 215,000$ & $6,288,000$ & $\$ 65,000$ & 657,000 & $\$ 20,000$ \\
\hline 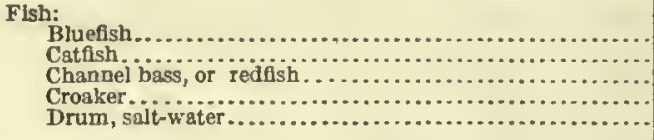 & $\begin{array}{r}13,000 \\
3,600 \\
100,000 \\
44,000 \\
5,500\end{array}$ & $\begin{array}{r}600 \\
100 \\
4,200 \\
800 \\
100\end{array}$ & & . n & $\begin{array}{r}3,800 \\
1,400 \\
20,000 \\
15,000 \\
1,500\end{array}$ & (1) $\begin{array}{r}200 \\
900 \\
300\end{array}$ & $\begin{array}{r}8,900 \\
2,200 \\
80,000 \\
29,000 \\
4,000\end{array}$ & $\begin{array}{r}400 \\
100 \\
3,400 \\
500 \\
100\end{array}$ \\
\hline 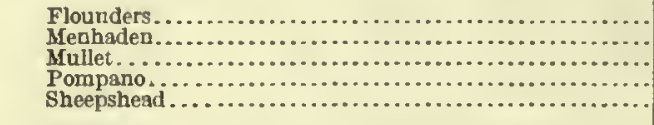 & $\begin{array}{r}5,700 \\
2,751,000 \\
353,000 \\
2,900 \\
22,000\end{array}$ & $\begin{array}{r}300 \\
3,400 \\
6,200 \\
300 \\
1,000\end{array}$ & & & $\begin{array}{r}1,202 \\
2,751,000 \\
24,000 \\
900 \\
3,800\end{array}$ & $\begin{array}{r}100 \\
3,400 \\
400 \\
100 \\
200\end{array}$ & $\begin{array}{r}4,600 \\
200 \\
329,000 \\
2,000 \\
18,000\end{array}$ & (1) $\begin{array}{r}200 \\
5,800 \\
200 \\
900\end{array}$ \\
\hline 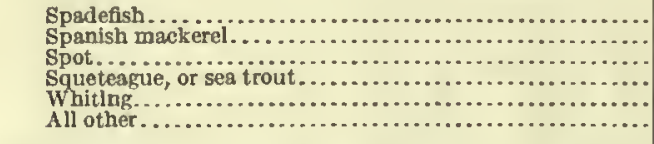 & $\begin{array}{r}5,500 \\
4,500 \\
43,000 \\
178,000 \\
4,400 \\
2,600\end{array}$ & $\begin{array}{r}100 \\
300 \\
800 \\
9,200 \\
100 \\
100\end{array}$ & 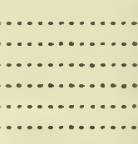 & . & $\begin{array}{r}2,100 \\
1,100 \\
15,000 \\
40,000 \\
1,400 \\
1,000\end{array}$ & $\begin{array}{l}\text { (1) } \\
100 \\
\quad 300 \\
2,200 \\
(1)\end{array}$ & $\begin{array}{r}3,400 \\
3,400 \\
28,000 \\
138,000 \\
3,000 \\
1,600\end{array}$ & $\begin{array}{r}100 \\
200 \\
500 \\
7,100 \\
\quad 100 \\
\end{array}$ \\
\hline 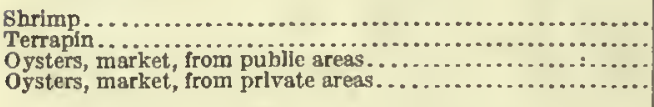 & $\begin{array}{r}3,405,000 \\
600 \\
26,226,000 \\
18,000\end{array}$ & $\begin{array}{r}56,000 \\
200 \\
214,000 \\
1,100\end{array}$ & $\begin{array}{r}26,226,000 \\
18,000\end{array}$ & $\begin{array}{r}214,000 \\
1,100\end{array}$ & $\begin{array}{r}3,405,000 \\
600 \\
\ldots \ldots \ldots \ldots \\
\ldots \ldots \ldots \ldots\end{array}$ & $\begin{array}{r}56,000 \\
200 \\
\ldots \ldots\end{array}$ & $\begin{array}{l}\cdots \\
\cdots \\
\cdots\end{array}$ & $\begin{array}{l}\cdots \cdots \cdots \\
\cdots \cdots \cdots \\
\cdots \cdots \cdots\end{array}$ \\
\hline
\end{tabular}

TABLE 5.-MISSISSIPPI-PRODUCTS OF SHORE AND BOAT FISHERIES OF GULF OF MEXICO DISTRICT: 1908.

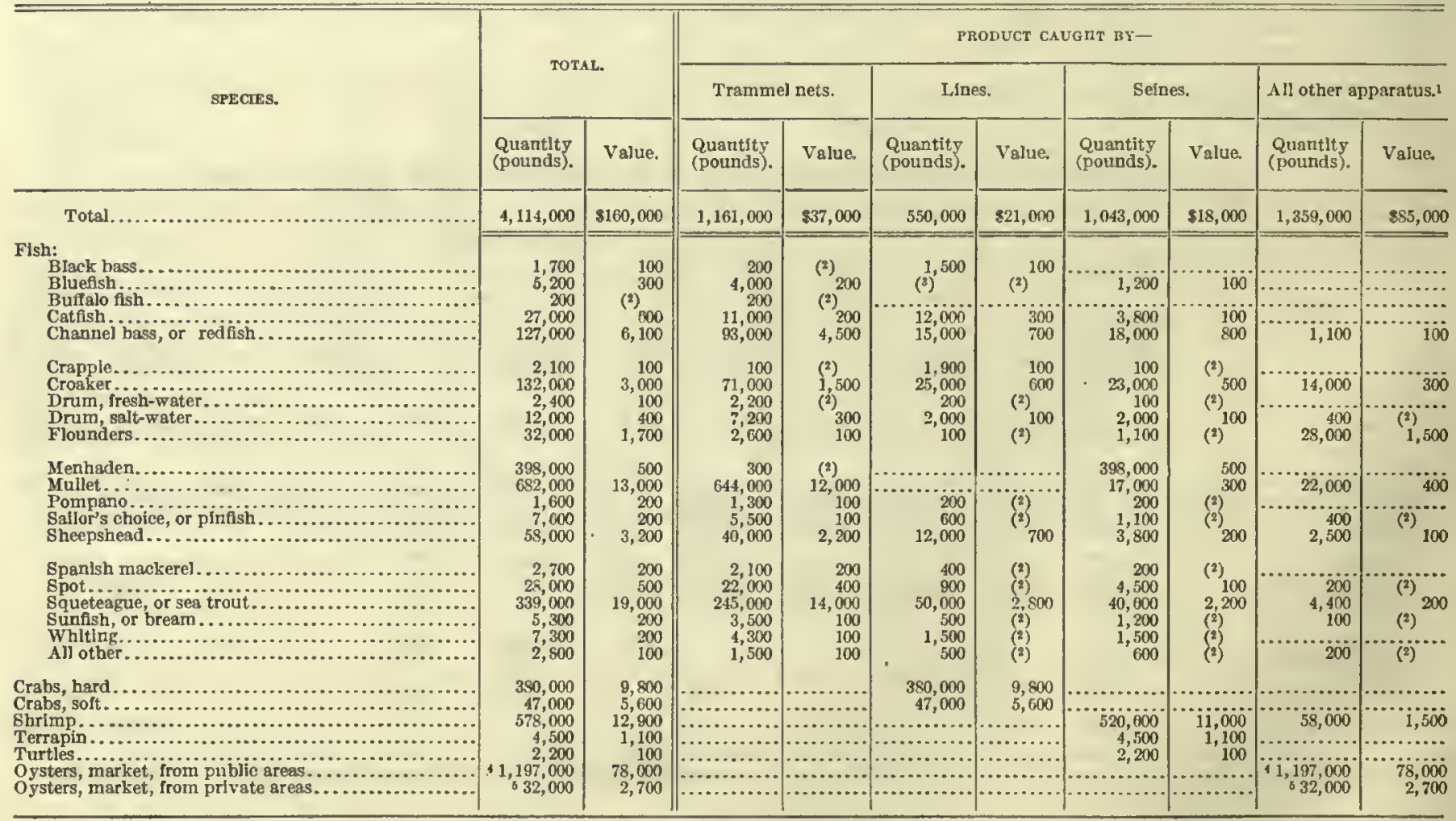

2 Ineludes apparatus, with catch, as follows: Dredges, tongs, ete., 1,229,000 pounds, valued at $\$ \$ 1,000$; east nets, 62,000 pounds, valued at $\$ 1,900$; spears, etc., 28,000 pounds, valued at $\$ 1,500 ;$ and shrimp nets, 40,000 pounds, valued at $\$ 300$. 
MISSOURI.

The fishing grounds of Missouri are the Mississippi, St. Francis, Missouri, Osage, and Gasconade Rivers and the Little River Overflow, as well as minor waters. They may be grouped in two districts, comprising, respectively, the Mississippi River with its tributaries, exclusive of the Missouri River, and the Missouri River with its tributaries. The fisheries of the state are all of the shore and boat class, no documented vessels being employed. The following is a general summary of the industry for 1908:

Number of persons employed.

Capital:

906

Boats............................... \$25,000

Apparatus of capture.................... 39,000

Shore and accessory property and cash $\ldots \ldots \ldots \ldots 27,000$

Value of products.......................... 271,000

Comparison with previous canvasses.-A comparison with the reports of the Bureau of Fisheries for former years shows considerable fluctuation in the number of persons employed, capital invested in equipment, and products. The following tabular statement gives such comparative figures for 1894, 1899, and 1908:

\begin{tabular}{|c|c|c|c|c|c|c|}
\hline \multirow[b]{2}{*}{ TEAR. } & \multirow{2}{*}{$\begin{array}{l}\text { Persons } \\
\text { em- } \\
\text { ployed, } \\
\text { exclusive } \\
\text { of shores- } \\
\text { men. }\end{array}$} & \multicolumn{3}{|c|}{ VALUE OF EQUTPMENT. } & \multicolumn{2}{|c|}{ PRODUCTS. } \\
\hline & & Total. & Boats. & $\begin{array}{l}\text { Appara- } \\
\text { tus of } \\
\text { capture. }\end{array}$ & $\begin{array}{l}\text { Quantity } \\
\text { (pounds). }\end{array}$ & Value. \\
\hline $\begin{array}{l}1908 \ldots . . \\
1899 \ldots \\
1894 \ldots\end{array}$ & $\begin{array}{r}906 \\
1,125 \\
567\end{array}$ & $\begin{array}{r}\$ 64,000 \\
52,000 \\
36,000\end{array}$ & $\begin{array}{r}\$ 25,000 \\
18,000 \\
11,000\end{array}$ & $\begin{array}{r}\$ 39,000 \\
34,000 \\
24,000\end{array}$ & $\begin{array}{l}6,751,000 \\
7,551,000 \\
3,822,000\end{array}$ & $\begin{array}{r}\$ 271,000 \\
211,000 \\
120,000\end{array}$ \\
\hline
\end{tabular}

Persons employed.-The distribution of the persons engaged in fishing in 1908 is given in the following tabular statement. Almost three-fourths of the total number were employed in the fisheries of the Mississippi River and its tributaries other than the Missouri River. This district reported an even larger proportion of the wage-earners:

\begin{tabular}{|c|c|c|c|c|}
\hline \multirow{3}{*}{ DISTRICT. } & \multicolumn{4}{|c|}{ PERSONS EMYLOYED: 1908.} \\
\hline & \multicolumn{3}{|c|}{ Number. } & \multirow[b]{2}{*}{ Wages. } \\
\hline & Total. & $\begin{array}{l}\text { Proprie- } \\
\text { tors and } \\
\text { inde- } \\
\text { pendent } \\
\text { flsher- } \\
\text { men. }\end{array}$ & $\begin{array}{l}\text { Wage- } \\
\text { earners. }\end{array}$ & \\
\hline Total... & 900 & 2746 & 160 & $\$ 21,000$ \\
\hline 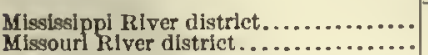 & $\begin{array}{l}669 \\
237\end{array}$ & $\begin{array}{l}533 \\
213\end{array}$ & $\begin{array}{r}136 \\
24\end{array}$ & $\begin{array}{r}19,000 \\
2,600\end{array}$ \\
\hline
\end{tabular}

1 Exclusite of seven proprietors not fishing.
Equipment and other capital.-The following tabular statement gives the value of the equipment and the amount of other capital employed in the industry, together with the distribution of the same between the Mississippi River and the Missouri River districts:

\begin{tabular}{|c|c|c|c|}
\hline \multirow[b]{2}{*}{ CLASS OF INVESTMENT. } & \multicolumn{3}{|c|}{$\begin{array}{l}\text { VALUE OF EQUIPMENT AND OTHEB } \\
\text { CAPITAL: } 1908 .\end{array}$} \\
\hline & Total. & $\begin{array}{l}\text { Misslsslppl } \\
\text { River } \\
\text { district. }\end{array}$ & $\begin{array}{l}\text { Missouri } \\
\text { River } \\
\text { district. }\end{array}$ \\
\hline Total............ & $\$ 91,000$ & $\$ 71,000$ & 820,000 \\
\hline 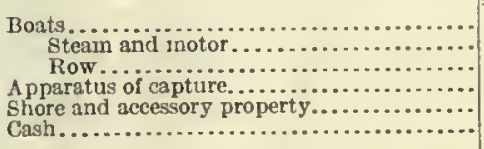 & $\begin{array}{l}25,000 \\
11,000 \\
14,000 \\
39,000 \\
12,000 \\
14,000\end{array}$ & $\begin{array}{r}20,000 \\
9,400 \\
10,000 \\
30,000 \\
9,800 \\
12,000\end{array}$ & $\begin{array}{l}5,800 \\
1,700 \\
4,100 \\
8,300 \\
2,700 \\
2,800\end{array}$ \\
\hline
\end{tabular}

The number of boats reported was 785 , which comprised 33 steam and motor and 526 row boats in the Mississippi River district and 9 steam and motor and 217 row boats in the Missouri River district.

The following tabular statement shows the number of the more important kinds of apparatus of capture used:

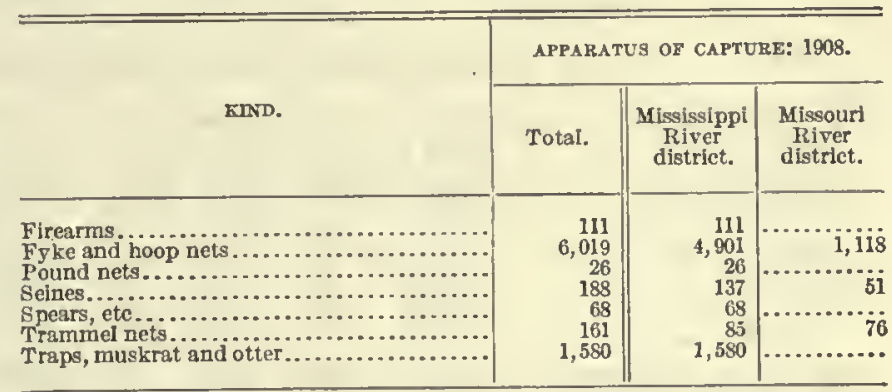

Apparatus of capture represented a little more than two-fifths of the capital invested, the balance being about equally divided between boats on the one hand and shore and accessory property and cash capital on the other.

Products.-The products of all fisheries of the state, distributed by species and apparatus of capture, are given in Table 1, on page 186. The German carp led in quantity and value, and was followerl by catfish, bullheads, and buffalo fish, the catches of these four species representing nearly three-fifths of the total value of products. The frog catch was of considerable importance, while muskrat, mink, and otter skins contributed nearly 6 per cent of the total value of products.

In Tables 2 and 3 , on page 187, the products are distributed by species and apparatus of capture for the two districts. The distribution of the principal 
products, by species and districts, is given in the following tabular statement:

\begin{tabular}{|c|c|c|c|}
\hline \multirow[b]{2}{*}{ SPECIES. } & \multicolumn{3}{|c|}{ VALUE OF PEODUCTS: 1908.} \\
\hline & Total. & $\begin{array}{c}\text { Mississippi } \\
\text { liver } \\
\text { district. }\end{array}$ & $\begin{array}{l}\text { Mlssouri } \\
\text { River } \\
\text { district. }\end{array}$ \\
\hline Total...... & $\$ 271,000$ & $\$ 197,000$ & $\$ 74,000$ \\
\hline 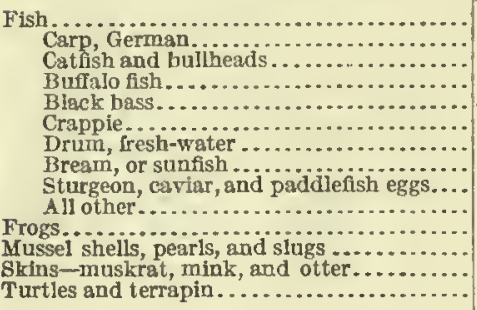 & $\begin{array}{r}241,000 \\
80,000 \\
51,000 \\
30,000 \\
27,000 \\
17,000 \\
11,000 \\
9,600 \\
5,100 \\
11,000 \\
11,000 \\
1,600 \\
15,000 \\
400\end{array}$ & $\begin{array}{r}105,000 \\
44,000 \\
37,000 \\
25,000 \\
27,000 \\
16,000 \\
5,900 \\
8,500 \\
1,400 \\
5,000 \\
11,000 \\
1,600 \\
15,000 \\
400\end{array}$ & $\begin{array}{r}74,000 \\
37,000 \\
15,000 \\
4,900 \\
100 \\
1,300 \\
5,500 \\
1,100 \\
3,700 \\
6,100 \\
\cdots \ldots . . . \\
\end{array}$ \\
\hline
\end{tabular}

The distribution of the value of the products according to apparatus of capture used was as follows:

\begin{tabular}{|c|c|c|c|}
\hline \multirow[b]{2}{*}{ KIND OF APPARATUS. } & \multicolumn{3}{|c|}{ VALUE OF ṔRODUCTS: 1908.} \\
\hline & Total. & $\begin{array}{l}\text { Mississippl } \\
\text { River } \\
\text { district. }\end{array}$ & $\begin{array}{l}\text { Missouri } \\
\text { River } \\
\text { district. }\end{array}$ \\
\hline Total............... & $\$ 271,000$ & $\$ 197,000$ & $\$ 74,000$ \\
\hline 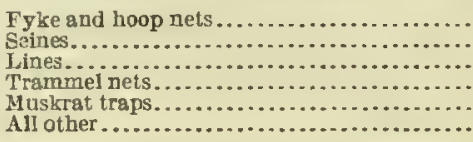 & $\begin{array}{l}88,000 \\
68,000 \\
46,000 \\
40,000 \\
15,000 \\
14,000\end{array}$ & $\begin{array}{l}65,000 \\
42,000 \\
40,000 \\
20,000 \\
15,000 \\
14,000\end{array}$ & $\begin{array}{r}23,000 \\
26,400 \\
5,000 \\
20,000 \\
2 . . .\end{array}$ \\
\hline
\end{tabular}

Fyke and hoop nets are credited with the largest catch for the Mississippi River district, and seines with the largest catch for the Missouri River district.

TABle 1.-MISSOURI-FISHERY PRODUCTS: 1908.

\begin{tabular}{|c|c|c|c|c|c|c|c|c|c|c|c|c|c|c|}
\hline \multirow{3}{*}{ SPECIES. } & \multirow{2}{*}{\multicolumn{2}{|c|}{ TOTAL. }} & \multicolumn{12}{|c|}{ PRODUCX CAUGITT BY- } \\
\hline & & & \multicolumn{2}{|c|}{$\begin{array}{c}\text { Fyke and hoop } \\
\text { nets. }\end{array}$} & \multicolumn{2}{|c|}{ Seines. } & \multicolumn{2}{|c|}{ Lines. } & \multicolumn{2}{|c|}{ Trammel nets. } & \multicolumn{2}{|c|}{ Pound nets. } & \multicolumn{2}{|c|}{$\begin{array}{l}\text { All other appa- } \\
\text { ratus. } 1\end{array}$} \\
\hline & $\begin{array}{l}\text { Quantity } \\
\text { (pounds). }\end{array}$ & Value. & $\begin{array}{l}\text { Quantity } \\
\text { (pounds). }\end{array}$ & Value. & $\begin{array}{l}\text { Quantity } \\
\text { (pounds). }\end{array}$ & Value. & $\begin{array}{l}\text { Quantity } \\
\text { (pounds). }\end{array}$ & Value. & $\begin{array}{l}\text { Quantity } \\
\text { (pounds). }\end{array}$ & Value. & $\begin{array}{l}\text { Quantity } \\
\text { (pounds). }\end{array}$ & Value. & $\begin{array}{l}\text { Quantity } \\
\text { (pounds). }\end{array}$ & Value. \\
\hline Total......... & $6,751,000$ & $\$ 271,000$ & $2,538,000$ & $\$ 88,000$ & $1,915,000$ & $\$ 68,000$ & 970,000 & $\$ 40,000$ & $1,052,000$ & $\$ 40,000$ & 26,000 & $\$ 1,100$ & 248,000 & $\$ 28,000$ \\
\hline 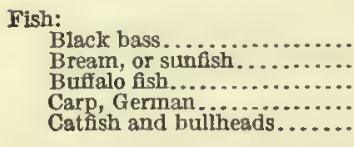 & $\begin{array}{r}329,000 \\
441,000 \\
993,000 \\
2,432,000 \\
1,166,000\end{array}$ & $\begin{array}{r}27,000 \\
9,600 \\
30,000 \\
80,000 \\
51,000\end{array}$ & $\begin{array}{r}43,000 \\
271,000 \\
476,000 \\
928,000 \\
378,000\end{array}$ & $\begin{array}{r}3,500 \\
5,800 \\
15,000 \\
31,000 \\
16,000\end{array}$ & $\begin{array}{r}61,000 \\
143,000 \\
299,000 \\
841,000 \\
200,000\end{array}$ & $\begin{array}{r}5,200 \\
2,900 \\
8,700 \\
26,000 \\
10,000\end{array}$ & $\begin{array}{r}201,000 \\
1,900 \\
38,000 \\
141,000 \\
482,000\end{array}$ & $\begin{array}{r}16,000 \\
100 \\
1,400 \\
5,100 \\
19,000\end{array}$ & $\begin{array}{r}24,000 \\
25,000 \\
173,000 \\
516,000 \\
104,000\end{array}$ & $\begin{array}{r}1,800 \\
800 \\
5,200 \\
18,000 \\
6,300\end{array}$ & $\begin{array}{l}7,0000 \\
5,000 \\
2,500\end{array}$ & $\begin{array}{r}200 \\
100 \\
100\end{array}$ & $\cdots \cdots$ & 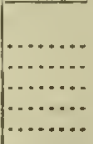 \\
\hline 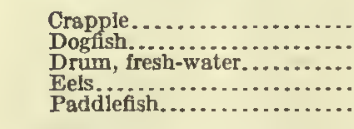 & $\begin{array}{r}336,000 \\
34,000 \\
323,000 \\
17,000 \\
128,000\end{array}$ & $\begin{array}{r}17,000 \\
700 \\
11,000 \\
1,000 \\
4,000\end{array}$ & $\begin{array}{r}152,000 \\
13,000 \\
145,000 \\
2,700 \\
49,000\end{array}$ & $\begin{array}{r}7,400 \\
300 \\
4,800 \\
200 \\
1,400\end{array}$ & $\begin{array}{r}137,000 \\
8,800 \\
71,000 \\
7,700 \\
51,000\end{array}$ & $\begin{array}{r}7,000 \\
200 \\
2,900 \\
400 \\
1,700\end{array}$ & $\begin{array}{r}3,000 \\
2,800 \\
44,000 \\
1,600 \\
400\end{array}$ & $\begin{array}{r}200 \\
100 \\
1,500 \\
100 \\
(ग)\end{array}$ & $\begin{array}{r}33,000 \\
8,500 \\
62,000 \\
4,900 \\
26,000\end{array}$ & $\begin{array}{r}1,700 \\
200 \\
2,300 \\
300 \\
900\end{array}$ & $\left\{\begin{array}{r}10,000 \\
500 \\
\cdots, 300 \\
1,500\end{array}\right.$ & $\begin{array}{c}600 \\
\cdots(2) \\
\cdots \cdots \\
(2)\end{array}$ & & 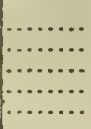 \\
\hline 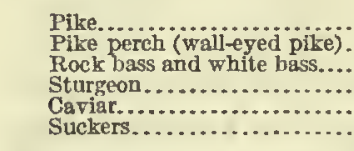 & $\begin{array}{r}58,000 \\
34,000 \\
300 \\
132,000 \\
300 \\
54,000\end{array}$ & $\begin{array}{l}1,200 \\
2,700 \\
(2) \\
5,000 \\
100 \\
1,400\end{array}$ & $\begin{array}{r}12,000 \\
9,200 \\
90,000 \\
400 \\
17,000\end{array}$ & \begin{tabular}{r}
300 \\
700 \\
\hdashline 1,600 \\
100 \\
400
\end{tabular} & $\begin{array}{r}5,800 \\
12,000 \\
300 \\
40,000 \\
16,000\end{array}$ & $\begin{array}{r}100 \\
1,000 \\
\left({ }^{2}\right) \\
1,500 \\
400\end{array}$ & $\begin{array}{r}41,000 \\
2,600 \\
\cdots, 100 \\
0,100 \\
1,000\end{array}$ & $\begin{array}{r}800 \\
200 \\
500 \\
\left({ }^{2}\right) \\
100\end{array}$ & $\begin{array}{r}11,000 \\
(8) \\
43,000 \\
(8) \\
19,000\end{array}$ & $\begin{array}{l}\left({ }^{2}\right) \\
800 \\
(\stackrel{2}{)}) \\
1,600 \\
\left({ }^{(}\right) \\
500\end{array}$ & & & 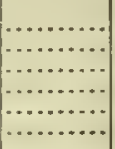 & (n. \\
\hline Frogs............................ & $\begin{array}{r}67,000 \\
1,900\end{array}$ & $\begin{array}{r}11,000 \\
100\end{array}$ & & & 800 & (2) & & & & & & & $\begin{array}{r}67,000 \\
1,100\end{array}$ & $\begin{array}{l}11,000 \\
(2)\end{array}$ \\
\hline 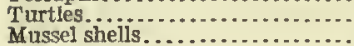 & $\begin{array}{r}23,000 \\
170,000\end{array}$ & $\begin{array}{r}400 \\
1,000\end{array}$ & 2,700 & 100 & 20,000 & 300 & & & $\begin{array}{r}800 \\
\ldots .6 .\end{array}$ & (⿳) & & & " 170,000 & $i, 000$ \\
\hline $\begin{array}{l}\text { Pearls and slugs.................. } \\
\text { Skins, mink and otter........... }\end{array}$ & $\because 400$ & $\begin{array}{r}600 \\
3,100\end{array}$ & & & & & & & & & & & $\$ 400$ & $\begin{array}{r}600 \\
3,100\end{array}$ \\
\hline gkins, muskrat......................... & 6,800 & 12,000 & & & & & & & & & & & 59,800 & 12,000 \\
\hline
\end{tabular}

1 Incindes apparatus, with cateh, as follows: Muskrat traps, etc., 10,000 pounds, valued at $\$ 15,000$; guns, 46,000 pounds, valued at $\$ 7,500$; spears, etc., 22,000 pounds,

valued at $\$ 3,600 ;$ and crowfoot dredges, 170,000 pounds, valued at $\$ 1,600$.
a Less than 100 pounds.
I than $\$ 100$. 
TABLE 2.-MISSOURI-FISHERY PRODUCTS OF MISSISSIPPI RIVER DISTRICT: 1908.

\begin{tabular}{|c|c|c|c|c|c|c|c|c|c|c|c|c|c|c|}
\hline \multirow{3}{*}{ SPECIES. } & \multirow{2}{*}{\multicolumn{2}{|c|}{ TOTAL. }} & \multicolumn{12}{|c|}{ PRODUCT CAUGHT RY- } \\
\hline & & & \multicolumn{2}{|c|}{$\begin{array}{c}\text { Fyke and hoop } \\
\text { uets. }\end{array}$} & \multicolumn{2}{|c|}{ Selnes. } & \multicolumn{2}{|c|}{ Lines. } & \multicolumn{2}{|c|}{ Trammel nets. } & \multicolumn{2}{|c|}{ Pound nets. } & \multicolumn{2}{|c|}{$\begin{array}{l}\text { All other appa- } \\
\text { ratus. }{ }^{-1}\end{array}$} \\
\hline & $\begin{array}{l}\text { Quantity } \\
\text { (pounds.) }\end{array}$ & Value. & $\begin{array}{l}\text { Quantity } \\
\text { (pounds). }\end{array}$ & Value. & $\begin{array}{l}\text { Quantity } \\
\text { (pounds). }\end{array}$ & Value. & $\begin{array}{l}\text { Quantity } \\
\text { (pounds). }\end{array}$ & Value. & $\begin{array}{l}\text { Quantity } \\
\text { (pounds). }\end{array}$ & Value. & $\begin{array}{l}\text { Quantity } \\
\text { (pounds). }\end{array}$ & Value. & $\begin{array}{l}\text { Quantity } \\
\text { (pounds). }\end{array}$ & Value. \\
\hline Total... & $5,448,000$ & $\$ 197,000$ & $2,148,000$ & $\$ 65,000$ & $1,450,000$ & $\$ 42,000$ & 893,000 & $\$ 40,000$ & 682,000 & 520,000 & 26,000 & $\$ 1,100$ & 248,000 & $\$ 28,000$ \\
\hline 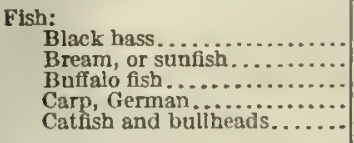 & $\begin{array}{r}328,000 \\
421,000 \\
894,000 \\
1,735,000 \\
987,000\end{array}$ & $\begin{array}{r}27,000 \\
8,500 \\
25,000 \\
44,000 \\
37,000\end{array}$ & $\begin{array}{r}42,000 \\
265,000 \\
448,000 \\
705,000 \\
330,000\end{array}$ & $\begin{array}{r}3,400 \\
5,400 \\
13,000 \\
19,000 \\
12,000\end{array}$ & $\begin{array}{r}61,000 \\
137,000 \\
256,000 \\
593,000 \\
137,000\end{array}$ & $\begin{array}{r}5,100 \\
2,600 \\
6,700 \\
13,000 \\
4,900\end{array}$ & $\begin{array}{r}201,000 \\
1,600 \\
35,000 \\
109,06 \hat{3} \\
460,000\end{array}$ & $\begin{array}{r}16,000 \\
100 \\
1,200 \\
3,100 \\
17,000\end{array}$ & $\begin{array}{r}24,000 \\
18,000 \\
148,000 \\
324,000 \\
58,000\end{array}$ & $\begin{array}{r}1,800 \\
400 \\
4,000 \\
8,000 \\
2,700\end{array}$ & $\begin{array}{l}7,000 \\
5,000 \\
2,500\end{array}$ & $\begin{array}{l}200 \\
100 \\
100\end{array}$ & & $\begin{array}{ll}\cdots \cdots \cdots \\
\cdots \cdots \cdots \\
\cdots \cdots \cdots \\
\cdots \cdots \cdots\end{array}$ \\
\hline 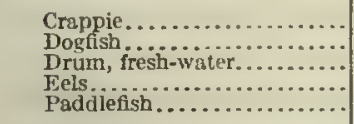 & $\begin{array}{r}313,000 \\
14,000 \\
233,000 \\
6,500 \\
94,000\end{array}$ & $\begin{array}{r}16,000 \\
300 \\
5,900 \\
300 \\
2,300\end{array}$ & $\begin{array}{r}146,000 \\
6,800 \\
118,000 \\
600 \\
41,000\end{array}$ & $\begin{array}{r}7,000 \\
200 \\
3,100 \\
(2) \\
1,000\end{array}$ & $\begin{array}{r}130,000 \\
2,500 \\
39,000 \\
3,700 \\
38,000\end{array}$ & $\begin{array}{l}6,600 \\
(1) \\
900 \\
200 \\
900\end{array}$ & $\begin{array}{r}2,100 \\
1,700 \\
38,000 \\
800 \\
\cdots\end{array}$ & $\begin{array}{l}100 \\
(2), 000 \\
(?)\end{array}$ & $\begin{array}{r}25,000 \\
3,100 \\
38,000 \\
1,400 \\
13,000\end{array}$ & $\begin{array}{r}1,300 \\
100 \\
900 \\
100 \\
300\end{array}$ & $\begin{array}{r}10,000 \\
\cdots \cdots \\
\cdots, 500\end{array}$ & $\begin{array}{r}\quad 600 \\
\cdots\left({ }^{2}\right) \\
\cdots \cdots \\
\cdots(3)\end{array}$ & & 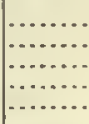 \\
\hline 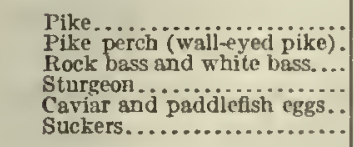 & $\begin{array}{r}58,000 \\
300 \\
300 \\
54,000 \\
300 \\
38,000\end{array}$ & $\begin{array}{l}1,200 \\
(2) \\
\text { (3) } \\
1,200 \\
100 \\
800\end{array}$ & $\begin{array}{r}12,000 \\
100 \\
18,000 \\
300 \\
13,000\end{array}$ & $\begin{array}{l}300 \\
(3) \\
400 \\
100 \\
300\end{array}$ & $\begin{array}{r}5,800 \\
200 \\
300 \\
15,000 \\
12,000\end{array}$ & $\begin{array}{l}100 \\
\left(\begin{array}{l}100 \\
(2) \\
300 \\
200\end{array}\right.\end{array}$ & $\begin{array}{l}41,000 \\
(3) \\
3,800 \\
(3) \\
100\end{array}$ & $\begin{array}{l}800 \\
(1) \\
100 \\
\text { (ग) }\end{array}$ & $\begin{array}{r}200 \\
100 \\
(3) \\
17,000 \\
(3) \\
14,000\end{array}$ & 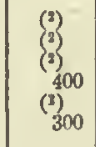 & 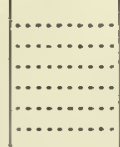 & & ............. & (1) \\
\hline 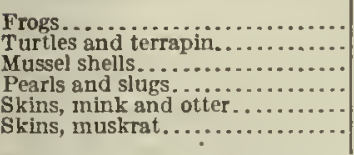 & $\begin{array}{r}67,000 \\
25,000 \\
170,000 \\
\quad+700 \\
\quad 9,800\end{array}$ & $\begin{array}{r}11,000 \\
400 \\
1,000 \\
600 \\
3,100 \\
12,000\end{array}$ & 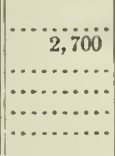 & $\ddot{100}$ & 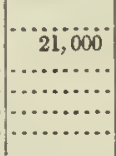 & 300 & an. & $\begin{array}{l}\ldots \\
\cdots \\
\cdots\end{array}$ & $\begin{array}{r}800 \\
\cdots \\
\cdots\end{array}$ & $\begin{array}{c}{ }^{\prime}(1) \\
\cdots \cdots \cdots \\
\cdots \cdots \cdots \\
\cdots \cdots \cdots\end{array}$ & ( & 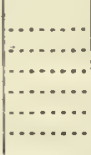 & $\begin{array}{r}67,000 \\
1,100 \\
170,000 \\
8,7400 \\
89,800\end{array}$ & $\begin{array}{r}11,000 \\
(3) \\
1,000 \\
600 \\
3,100 \\
12,000\end{array}$ \\
\hline
\end{tabular}

1 Includes apparatus, with eateh, as follows: Traps, muskrat, ete., 10,000 pounds, valued at $\$ 15,000$; guns, 46,000 pounds, valued at $\$ 7,500$; spears, ete., 22,000 pounds, alued at $\$ 3,600 ;$ and crowfoot dredges, 170,000 pounds, valued at $\$ 1,600$.

1800 skins. 829,000 skins.

TABLE 3.-MISSOURI-FISHERY PRODUCTS OF MISSOURI RIVER DISTRICT: 1908.

\begin{tabular}{|c|c|c|c|c|c|c|c|c|c|c|}
\hline \multirow{3}{*}{ SPECIES. } & \multirow{2}{*}{\multicolumn{2}{|c|}{ TOTAL. }} & \multicolumn{8}{|c|}{ PRODUCT CAUGHT BY- } \\
\hline & & & \multicolumn{2}{|c|}{ Seines. } & \multicolumn{2}{|c|}{ Fyke and hoop nets. } & \multicolumn{2}{|c|}{ Trammel nets. } & \multicolumn{2}{|c|}{ Lines. } \\
\hline & $\begin{array}{l}\text { Quantity } \\
\text { (pounds). }\end{array}$ & Value. & $\begin{array}{l}\text { Quantity } \\
\text { (pounds). }\end{array}$ & Value. & $\begin{array}{l}\text { Quantity } \\
\text { (pounds). }\end{array}$ & Value. & $\begin{array}{l}\text { Quantity } \\
\text { (pounds). }\end{array}$ & Value. & $\begin{array}{l}\text { Quantity } \\
\text { (pounds). }\end{array}$ & Value. \\
\hline Total...... & $1,303,000$ & $\$ 74,000$ & 465,000 & $\$ 26,000$ & 391,000 & $\$ 23,000$ & 370,000 & $\$ 20,000$ & 77,000 & $\$ 5,400$ \\
\hline 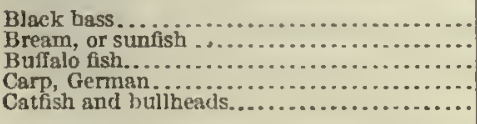 & $\begin{array}{r}1,300 \\
20,000 \\
99,000 \\
697,000 \\
179,000\end{array}$ & $\begin{array}{r}100 \\
1,100 \\
4,900 \\
37,000 \\
15,000\end{array}$ & $\begin{array}{r}700 \\
6,300 \\
43,000 \\
248,000 \\
63,000\end{array}$ & $\begin{array}{r}100 \\
300 \\
2,100 \\
13,000 \\
5,200\end{array}$ & $\begin{array}{r}400 \\
5,900 \\
28,000 \\
224,000 \\
47,000\end{array}$ & $\begin{array}{r}\text { (1) } \\
300 \\
1,500 \\
12,000 \\
4,100\end{array}$ & $\begin{array}{r}100 \\
7,800 \\
25,000 \\
192,000 \\
46,000\end{array}$ & $\begin{array}{r}{ }^{(1)} 400 \\
1,200 \\
10,000 \\
3,600\end{array}$ & $\begin{array}{r}100 \\
400 \\
3,500 \\
33,000 \\
23,000\end{array}$ & $\begin{array}{l}\text { (l) } \\
\text { (l) } 200 \\
2,000 \\
1,900\end{array}$ \\
\hline 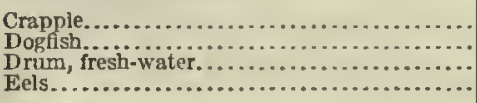 & $\begin{array}{l}23,000 \\
20,000 \\
90,000 \\
10,000\end{array}$ & $\begin{array}{r}1,300 \\
400 \\
5,500 \\
700\end{array}$ & $\begin{array}{r}6,900 \\
6,200 \\
33,000 \\
4,000\end{array}$ & $\begin{array}{r}400 \\
100 \\
1,900 \\
200\end{array}$ & $\begin{array}{r}6,500 \\
5,900 \\
27,000 \\
2,100\end{array}$ & $\begin{array}{r}400 \\
100 \\
1,700 \\
100\end{array}$ & $\begin{array}{r}8,800 \\
6,400 \\
24,000 \\
3,600\end{array}$ & $\begin{array}{r}500 \\
100 \\
1,400 \\
200\end{array}$ & $\begin{array}{r}900 \\
1,200 \\
5,900 \\
800\end{array}$ & (1) 100 \\
\hline 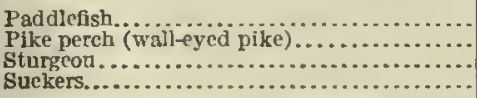 & $\begin{array}{l}35,000 \\
34,000 \\
78,000 \\
16,000\end{array}$ & $\begin{array}{r}1,700 \\
2,700 \\
3,700 \\
600\end{array}$ & $\begin{array}{r}13,000 \\
12,000 \\
25,000 \\
4,900\end{array}$ & $\begin{array}{r}700 \\
900 \\
1,200 \\
200\end{array}$ & $\begin{array}{r}7,900 \\
9,200 \\
22,000 \\
4,700\end{array}$ & $\begin{array}{r}300 \\
700 \\
1,100 \\
200\end{array}$ & $\begin{array}{r}13,000 \\
11,000 \\
26,000 \\
5,600\end{array}$ & $\begin{array}{r}600 \\
800 \\
1,200 \\
200\end{array}$ & $\begin{array}{r}400 \\
2,600 \\
5,300 \\
1,000\end{array}$ & (1) $\begin{array}{r}200 \\
400 \\
100\end{array}$ \\
\hline
\end{tabular}

1 Less than $\$ 100$. 


\section{NEBRASKA.}

In 1908 commercial fishing in this state was confined to shore and boat fishing in the Missouri River. The products comprised seven species, of which the chief was German carp. The other kinds of fish taken, named in the order of the value of the eatch, were catfish, buffalo fish, paddlefish, sturgeon, fresh-water drum, and pike perch, or wall-eyed pike. The following statement gives a summary of the principal statistics of the inclustry for 1908:

Number of persons employed.

Capital:

Boats............................... \$1,300

Apparatus of capture..................... 2,500

Shore and accessory property................... 600 Value of products......................... 22, 000

Comparison with previous canvasses.-While, in the number of persons employed, value of boats, and quantity of product, the figures for 1908 show decreases, as compared with previous eanvasses, there has been a decided inerease in the value of the apparatus of capture and in the value of the product. The following tabular statement gives the principal statisties for 1894, 1899, and 1908:

\begin{tabular}{|c|c|c|c|c|c|c|}
\hline \multirow{2}{*}{ YEAR. } & \multirow{2}{*}{$\begin{array}{c}\text { Persons } \\
\text { employed, } \\
\text { exelusive } \\
\text { of shores- } \\
\text { mez. }\end{array}$} & \multicolumn{3}{|c|}{ VALUE OF EQUIPMENT. } & \multicolumn{2}{|c|}{ PRODUCTS. } \\
\hline & & Total. & B oats. & $\begin{array}{l}\text { Appa- } \\
\text { ratus of } \\
\text { eapture. }\end{array}$ & $\begin{array}{l}\text { Quantity } \\
\text { (pounds). }\end{array}$ & Value. \\
\hline $\begin{array}{l}1908 \ldots \ldots \ldots \ldots \ldots \\
1899 \ldots \ldots \ldots \ldots \ldots \\
1894 \ldots \ldots \ldots \ldots \ldots\end{array}$ & $\begin{array}{r}129 \\
142 \\
76\end{array}$ & $\begin{array}{r}\$ 3,800 \\
3,300 \\
2,200\end{array}$ & $\begin{array}{r}\$ 1,300 \\
1,400 \\
600\end{array}$ & $\begin{array}{r}\$ 2,500 \\
1,900 \\
1,700\end{array}$ & $\begin{array}{l}399,000 \\
367,000 \\
340,000\end{array}$ & $\begin{array}{r}\$ 22,000 \\
16,000 \\
14,000\end{array}$ \\
\hline
\end{tabular}

Persons employed.-The Nebraska fisheries furnished employment for 129 persons in 1908. Of these, 115 were proprietors and independent fishermen and 14 were wage-earners. The wage-earners received $\$ 900$ in wages during the year.

Equipment and other capital.-The capital invested in the industry was distributed as follows: Rowboats, $\$ 1,300$; apparatus of capture, $\$ 2,500$; and shoro and accessory property, $\$ 600$.

There were 96 boats reported, and their value was slightly less than the value of boats reported in 1899 , but over twice that reported in 1894 . The total investment in apparatus of eapture in 1908 shows a considerable increase over the amount reported for this item in 1899.

In 1908, 38 seines, 217 fyke and hoop nets, 60 pots and traps, and 32 trammel nets were reported.

Products.-The fishery produets of the state, distributed by species and apparatus of eapture, are given in the following table.

The leading species was German carp, which represented 64 per cent of the weight of all the fishery products of Nebraska and 53 per eent of the total value. The catch of this fish has increased greatly within the past few years, as a quantity valued at only $\$ 100$ was caught in 1894, and none was reported in 1899. The eatfish product, 66,000 pounds, valued at $\$ 6,600$, was considerably smaller in quantity but somewhat larger in value than that reported in 1899 , which was $\$ 5,000$ pounds, valued at $\$ 6,100$. The eateh of buffalo fish, 43,000 pounds, was less than a third of that reported in $1899,138,000$ pounds; but a comparison of the respective values of the two catches, $\$ 2,200$ for that of 1908 and $\$ 4,900$ for that of 1899 , shows an increase in the average price per pound. The quantity of this fish reported in 1894 was 169,000 pounds, valued at $\$ 7,000$.

The eateh of sturgeon in 1908 was somewhat less in quantity and in value than in 1899 , while that of paddlefish was greater both in quantity and in value.

NEBRASKA-FISHERY PRODUCTS: 1908.

\begin{tabular}{|c|c|c|c|c|c|c|c|c|c|c|c|c|}
\hline \multirow{3}{*}{ SPECIES. } & \multirow{2}{*}{\multicolumn{2}{|c|}{ TOTAL. }} & \multicolumn{10}{|c|}{ PRODUCT CAUGMT BY- } \\
\hline & & & \multicolumn{2}{|c|}{ Seines. } & \multicolumn{2}{|c|}{ Trammel nets. } & \multicolumn{2}{|c|}{ Lines. } & \multicolumn{2}{|c|}{ Fyko and hoop nets. } & \multicolumn{2}{|c|}{ Flsh pots and traps. } \\
\hline & $\begin{array}{l}\text { Quantity } \\
\text { (pounds). }\end{array}$ & Value. & $\begin{array}{l}\text { Quantity } \\
\text { (pounds). }\end{array}$ & Value. & $\begin{array}{l}\text { Quantity } \\
\text { (pounds). }\end{array}$ & Vajue. & $\begin{array}{l}\text { Quantity } \\
\text { (pounds). }\end{array}$ & Value. & $\begin{array}{l}\text { Quantity } \\
\text { (pounds). }\end{array}$ & Value. & $\begin{array}{l}\text { Quantity } \\
\text { (pounds). }\end{array}$ & Value. \\
\hline Total. .................. & 399,000 & 822,000 & 164,000 & $\$ 8,500$ & 124,000 & $\$ 7,000$ & 42,000 & $\$ 3,100$ & 54,000 & $\$ 3,000$ & 15,000 & 8800 \\
\hline 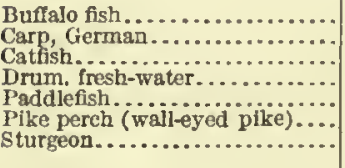 & $\begin{array}{r}43,000 \\
254,000 \\
66,000 \\
4,900 \\
20,000 \\
100 \\
11,000\end{array}$ & $\begin{array}{r}2,200 \\
12,000 \\
6,600 \\
300 \\
800 \\
(1) \quad 600\end{array}$ & $\begin{array}{r}20,000 \\
102,000 \\
21,000 \\
2,300 \\
17,000 \\
(2) \\
2,300\end{array}$ & $\begin{array}{r}1,000 \\
4,500 \\
2,100 \\
100 \\
600 \\
\text { (1) } \\
100\end{array}$ & $\begin{array}{r}11,000 \\
91, m 0 \\
14,000 \\
2,200 \\
3,000 \\
100 \\
3,200\end{array}$ & $\begin{array}{r}500 \\
4,600 \\
1,400 \\
200 \\
200 \\
\text { (1) } \\
200\end{array}$ & 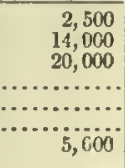 & 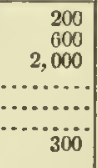 & $\begin{array}{r}9,100 \\
36,000 \\
8,700 \\
200 \\
\ldots\end{array}$ & $\begin{array}{r}500 \\
1,600 \\
900 \\
(1) \\
\cdots \cdots\end{array}$ & $\begin{array}{r}1,000 \\
11,000 \\
3,000 \\
200 \\
\ldots \ldots \\
\cdots\end{array}$ & $\begin{array}{l}\text { (1) } \\
400 \\
{ }^{(1)}{ }^{300} \\
\cdots\end{array}$ \\
\hline
\end{tabular}


NEW HAMPSIIRE.

New Hampshire has but one county bordering upon the Atlantic Ocean, and its fisheries, which are all of the shore and boat class, are of relatively small importance. The principal statistics for 1908 are given in the following statement:

Number of persons employed

79

Capital:

Boats................................. $\$ 13,000$

Apparatus of capture....................... 10,000

Shore and accessory property and cash............. 200

Value of products........................ 53,000

As early as 1888 the Bureau of Fisheries reported that there had been a considerable diminution in the importance of the fisheries of the state, a decrease being evident in the number of persons employed, in the amount of capital invested, and in the quantity and value of the products. This downward tendency has, on the whole, continued, although the heavy dccrease in the quantity of products since 1898 has been accompanied by an increase in their value. Furthermorc, since 1905 the investment in equipment has increased, as shown in the following tabular statement:

\begin{tabular}{|c|c|c|c|c|c|c|}
\hline \multirow[b]{2}{*}{ YEAR. } & \multirow[b]{2}{*}{$\begin{array}{c}\text { Persons } \\
\text { employed, } \\
\text { exclusive } \\
\text { of } \\
\text { shoresmon. }\end{array}$} & \multicolumn{3}{|c|}{ VALUE OY EQUIPMENT. } & \multicolumn{2}{|c|}{ Products. } \\
\hline & & Total. & $\begin{array}{c}\text { Vessels } \\
\text { and } \\
\text { boats, } \\
\text { inelnding } \\
\text { outfit. }\end{array}$ & $\begin{array}{l}\text { Appa- } \\
\text { ratus of } \\
\text { eapture. }\end{array}$ & $\begin{array}{l}\text { Quantity } \\
\text { (pounds). }\end{array}$ & Value. \\
\hline $\begin{array}{l}1908 \ldots \ldots \ldots \\
1905 \ldots \ldots \ldots \\
1902 \ldots \ldots \ldots \\
1898 \ldots \ldots \ldots \\
1888 \ldots \ldots \ldots\end{array}$ & $\begin{array}{r}79 \\
132 \\
147 \\
143 \\
329\end{array}$ & $\begin{array}{r}\$ 23,000 \\
18,000 \\
24,000 \\
25,000 \\
64,000\end{array}$ & $\begin{array}{r}\$ 13,000 \\
8,200 \\
12,000 \\
13,000 \\
41,000\end{array}$ & $\begin{array}{r}\$ 10,000 \\
9,600 \\
11,000 \\
12,000 \\
23,000\end{array}$ & $\begin{array}{r}677,000 \\
1,036,000 \\
1,593,000 \\
3,021,000 \\
3,843,000\end{array}$ & $\begin{array}{r}\$ 53,000 \\
52,000 \\
50,000 \\
49,000 \\
90,000\end{array}$ \\
\hline
\end{tabular}

Of the 79 persons employed in 1908, 78 were proprictors and independent fishermen, and only one was reported as a wage-earner.

The following tabular statement shows the investment in the New Hampshire fisheries in 1908:

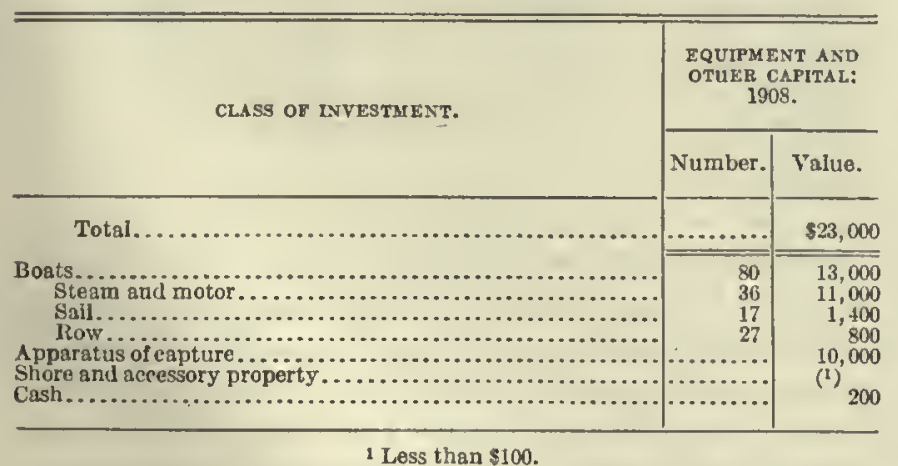

1 Less than $\$ 100$.

Six gill nets, 2,730 lobster pots, 3 moss rakes, and 11 wcirs were reported.

Statistics concerning the fishery products of the state, distributed according to species and apparatus of capture, are given in the tabular statement at the end of this section. In 1908 the value of lobsters constituted 81 per cent of the value of all products. The lobster product has increased rapidly in quantity and more rapidly in value since the canvass of 1888 , as shown below:

\begin{tabular}{|c|c|c|c|}
\hline & \multirow{2}{*}{ TEAR. } & \multicolumn{2}{|c|}{ LOBSTER PRODUCT. } \\
\hline . & & $\begin{array}{l}\text { Quantity } \\
\text { (pounds). }\end{array}$ & Value. \\
\hline 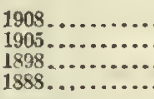 & & $\begin{array}{l}264,000 \\
256,000 \\
109,000 \\
136,000\end{array}$ & $\begin{array}{r}\$ 43,000 \\
33,000 \\
9,400 \\
6,300\end{array}$ \\
\hline
\end{tabular}

In other respeets the fishcries of New Hampshire have suffered a decrease in importance. In 1888 the catch of cod was $1,426,000$ pounds, valued at $\$ 29,000$; that of haddock was $1,069,000$ pounds, valued at $\$ 20,000$; and that of halibut 143,000 pounds, valued at $\$ 12,000$. Compared with these figures the totals for 1908 were very small, as may be seen from the tabular statement given bclow:

\begin{tabular}{|c|c|c|c|c|c|c|}
\hline \multirow{4}{*}{ SPECLES. } & \multicolumn{6}{|c|}{ FISUERY PRODUCTS: 1908.} \\
\hline & \multirow{2}{*}{\multicolumn{2}{|c|}{ Total. }} & \multicolumn{4}{|c|}{ Produet caught by- } \\
\hline & & & \multicolumn{2}{|c|}{ Lines. } & \multicolumn{2}{|c|}{$\begin{array}{l}\text { All other appa } \\
\text { ratus. } 1\end{array}$} \\
\hline & $\begin{array}{l}\text { Quantity } \\
\text { (pounds). }\end{array}$ & Value. & $\begin{array}{l}\text { Quantity } \\
\text { (pounds). }\end{array}$ & Value. & $\begin{array}{l}\text { Quantity } \\
\text { (pounds). }\end{array}$ & Value. \\
\hline Total.... & 677,000 & 853,000 & 211,000 & $\$ 5,500$ & 467,000 & $\$ 48,000$ \\
\hline 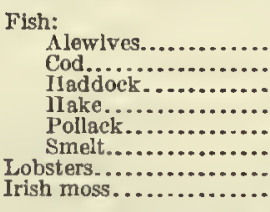 & $\begin{array}{r}121,000 \\
135,000 \\
100,000 \\
13,000 \\
6,300 \\
2,600 \\
264,000 \\
35,000\end{array}$ & $\begin{array}{r}1,800 \\
3,900 \\
2,700 \\
100 \\
100 \\
300 \\
43,000 \\
1,400\end{array}$ & $\begin{array}{r}91,000 \\
100,000 \\
13,000 \\
6,300 \\
\ldots \ldots \ldots \\
\ldots \ldots \ldots\end{array}$ & 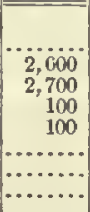 & 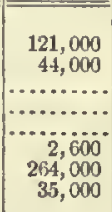 & $\begin{array}{r}1,800 \\
1,400 \\
\ldots . \\
\ldots \ldots \\
\ldots \ldots \\
30 . \\
300 \\
1,000 \\
1,400\end{array}$ \\
\hline
\end{tabular}

1 Includes apparatus, with cateh, as follows: Lobster pots, 264,000 pounds, valued at $\$ 43,000$; pound nets and weirs, 124,000 pounds, valued at $\$ 2.100$; gill nets, 44,000 pounds, valued at $\$ 1,400$; and rakes, 35,000 pounds, valued at $\$ 1,400$.

\section{NEW JERSEY.}

In 1908 New Jersey ranked eighth in value of fishery products, witl a catch valued at $\$ 3,069,000$. Oysters were the leading product, their value forming 45 per cent of the total value of the fishery products of the state; while squeteague, hard clams, and shad were other prominent varieties. Delaware Bay, the Lower Bay, and the numerous coves and inlets along the coast are among the more important fishing grounds of the state.

The following statement gives the principal statistics for the fisheries of the state in 1908:

Number of persons employed................... Capital:

Vessels and boats, including outfit...........\$1, 100,000

Apparatus of capture.................. 345,000

Shore and accessory property and cash......... 269,000

Value of products....................... 3, 069,000 
Comparison with previous canvasses. $-\mathbf{A}$ comparison of the general statistics for 1908 with similar items for previous years shows that there has been a marked decline in the magnitude of the industry since 1897, following a gain between 1891 and 1897. Such a comparison is made in the following tabular statement:

\begin{tabular}{|c|c|c|c|c|c|c|}
\hline \multirow[b]{2}{*}{ YEAR. } & \multirow{2}{*}{$\begin{array}{l}\text { Persons } \\
\text { em-- } \\
\text { ployed, } \\
\text { exclu- } \\
\text { sive of } \\
\text { shores- } \\
\text { men. }\end{array}$} & \multicolumn{3}{|c|}{ VALUE OF EQUIPMENT. } & \multicolumn{2}{|c|}{ PRODUCTS. } \\
\hline & & Total. & $\begin{array}{c}\text { Vessels } \\
\text { ant boats, } \\
\text { including } \\
\text { outfit. }\end{array}$ & $\begin{array}{l}\text { Appa- } \\
\text { ratus of } \\
\text { capture. }\end{array}$ & $\begin{array}{l}\text { Quantity } \\
\text { (pounds). }\end{array}$ & Value. \\
\hline $\begin{array}{l}1908 \ldots \ldots . . \\
1904 \ldots \ldots \ldots \\
1897 \ldots \ldots \ldots\end{array}$ & $\begin{array}{r}7,145 \\
8,293 \\
11,884\end{array}$ & $\begin{array}{r}\$ 1,445,000 \\
1,548,000 \\
1,634,000\end{array}$ & $\begin{array}{r}\$ 1,100,000 \\
1,135,000 \\
1,252,000\end{array}$ & $\begin{array}{r}\$ 345,000 \\
413,000 \\
382,000\end{array}$ & $\begin{array}{r}74,827,000 \\
90,108,000 \\
103,783,000\end{array}$ & $\begin{array}{r}\$ 3,069,000 \\
3,385,000 \\
3,614,000\end{array}$ \\
\hline $1891 \ldots . . . . .$. & 10,107 & $1,519,000$ & $1,198,000$ & 322,000 & $79,116,000$ & $3,520,000$ \\
\hline
\end{tabular}

Persons employed.-The following tabular statement gives statistics as to the persons employed in the fisheries of New Jersey in 1908:

\begin{tabular}{|c|c|c|c|c|c|c|c|}
\hline \multirow{3}{*}{ Cruss. } & \multicolumn{7}{|c|}{ PERSONS EMPLOYED: 1908.} \\
\hline & \multicolumn{4}{|c|}{ Number. } & \multicolumn{3}{|c|}{ Salaries and wages. } \\
\hline & Total. & $\begin{array}{l}\text { Proprie- } \\
\text { tors and } \\
\text { inde- } \\
\text { pendent } \\
\text { fisher- } \\
\text { men. }\end{array}$ & $\begin{array}{l}\text { Sala- } \\
\text { ried } \\
\text { em- } \\
\text { ploy- } \\
\text { ees. }\end{array}$ & $\begin{array}{c}\text { Wage- } \\
\text { earn- } \\
\text { ers. }\end{array}$ & Total. & $\begin{array}{l}\text { Salar } \\
\text { ries. }\end{array}$ & Wages. \\
\hline Total... & 7,231 & ${ }_{14,041}$ & 4 & 3,186 & $\$ 744,000$ & $\$ 1,500$ & 28742,000 \\
\hline $\begin{array}{l}\text { Vessel fisheries........ } \\
\text { Transporting vessels... } \\
\text { Shore and boat fisher- }\end{array}$ & $\begin{array}{r}2,329 \\
115\end{array}$ & $\begin{array}{r}335 \\
39 \\
\end{array}$ & 4 & $\begin{array}{r}1,990 \\
76\end{array}$ & $\begin{array}{r}399,000 \\
20,000\end{array}$ & 1,500 & $\begin{array}{r}398,000 \\
20,000\end{array}$ \\
\hline 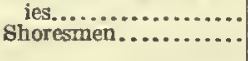 & $\begin{array}{r}4,701 \\
86\end{array}$ & 3,667 & .... & $\begin{array}{r}1,034 \\
86\end{array}$ & $\begin{array}{r}300,000 \\
24,000\end{array}$ & & $\begin{array}{r}300,000 \\
24,000\end{array}$ \\
\hline
\end{tabular}

1 Exclusive of 75 proprietors not fishing.

2 Includes provisions furnished to the value of $\$ 138,000$.

Of the shoresmen, 82 were employed in the shore and boat fisheries and 4 in the vessel fisheries. Including shoresmen, 4,783 persons were engaged in the shore and boat fisheries and 2,333 in the vessel fisheries. The proprietors and independent fishermen outnumbered the salaried employees and wage-earners, owing to the preponderance of independent fishermen among those engaged in the shore and boat fisheries.

Equipment and other capital.-The statistics of capital invested are shown in the next table.

The value of the vessels and their outfits and boats amounted to $\$ 1,100,000$ and formed 64 per cent of the total investment. Contrary to the general rule in coast fisheries, both the number and the value of power vessels and boats were greater than those of sail vessels and sailboats, there being 1,176 of the former class, valued with their outfits at $\$ 849,000$, and 1,002 of the latter, valued with thoir outfits at $\$ 203,000$. Of the total value of craft, including outfit, 60 per cent represented the investment in the vessels of the vessel fisheries; 36 per cent that in the boats of shore and boat fisheries; and 5 per cent that in transporting vessels. Of the investment in shore and accossory property, $\$ 164,000$ pertained to shore and boat fisheries;
$\$ 34,000$ to vessel fisheries; and $\$ 2,200$ to transporting vessels. The cash reported was as follows: $\$ 59,000$ for shore and boat fisheries; $\$ 9,400$ for vessel fisheries; and $\$ 800$ for transporting vessels. The total investment in the shore and boat fisheries was $\$ 932,000$ and that in the vessel fisheries $\$ 727,000$.

\begin{tabular}{|c|c|c|c|}
\hline \multirow{2}{*}{ CLASS OF INVESTMENT. } & \multicolumn{3}{|c|}{$\begin{array}{c}\text { EQUIPMENT AND OTHER CAPITAL: } \\
1908 .\end{array}$} \\
\hline & Value. & Number. & Tonnage. \\
\hline Total.......... & $\$ 1,714,000$ & & \\
\hline Vesscls, including outfit.... & 709,000 & 435 & 4,960 \\
\hline Fishing............... & 658,000 & 391 & 4,446 \\
\hline Steam and motor..... & 546,000 & 255 & 3,221 \\
\hline $\begin{array}{l}\text { Vessels........... } \\
\text { Outfit.......... }\end{array}$ & $\begin{array}{r}453,000 \\
93,000\end{array}$ & & \\
\hline Sail. $\ldots \ldots$ & 111,000 & 129 & $\dddot{1}, 220$ \\
\hline Vessels.$\ldots \ldots \ldots \ldots \ldots \ldots \ldots \ldots \ldots$ & 93,000 & & करो \\
\hline 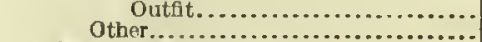 & 18,000 & $\cdots$ & $\cdots$ \\
\hline 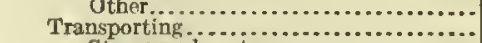 & 52,000 & 44 & $\ddot{500}$ \\
\hline Steam and motor........................ & 36,000 & 23 & 200 \\
\hline $\begin{array}{l}\text { Vessels } \\
\text { Outfit }\end{array}$ & 31,000 & .... & ........... \\
\hline 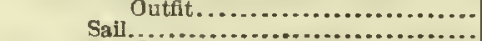 & 5,100 & $\dddot{20}$ & $\because \ddot{3}$ \\
\hline 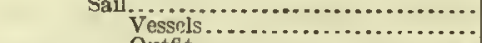 & $\begin{array}{l}16,000 \\
13,000\end{array}$ & & 320 \\
\hline Outfit....................... & 2,800 & & \\
\hline Boats..................................... & 391,000 & 3,843 & .... \\
\hline $\begin{array}{l}\text { Steam and motor } \ldots \ldots \ldots \ldots \\
\text { Sail } \ldots \ldots\end{array}$ & 266,000 & 898 & $-\cdots \cdots$ \\
\hline Row. & $\begin{array}{l}76,000 \\
39,000\end{array}$ & $\begin{array}{r}852 \\
1,654\end{array}$ & (n........ \\
\hline 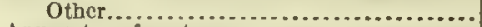 & 9,600 & 439 & .... \\
\hline Apparatus of capture....................... & 345,000 & n............ & 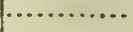 \\
\hline 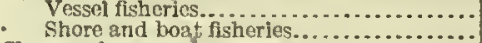 & $\begin{array}{r}26,000 \\
318,000\end{array}$ & & $\cdots$ \\
\hline 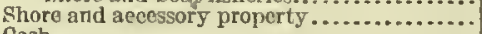 & 200,000 & $\cdots$. & $\cdots$ \\
\hline Cash..................................... & 69,000 & & \\
\hline
\end{tabular}

Apparatus of capture was valued at $\$ 345,000$, the greater part of which amount, $\$ 318,000$, or 92 per cent, is credited to the shore and boat fisheries. The distribution of the principal kinds of apparatus of capture reported between the vessel fisheries and the shore and boat fisheries was as follows:

\begin{tabular}{|c|c|c|c|}
\hline \multirow{3}{*}{ KIND. } & \multicolumn{3}{|c|}{ APPARATUS OF CAPTURE: 1908.} \\
\hline & \multirow{2}{*}{ Total. } & \multicolumn{2}{|c|}{ Used in- } \\
\hline & & $\begin{array}{l}\text { Vessel } \\
\text { fishcries. }\end{array}$ & $\begin{array}{c}\text { Shore and } \\
\text { boat } \\
\text { fisheries. }\end{array}$ \\
\hline 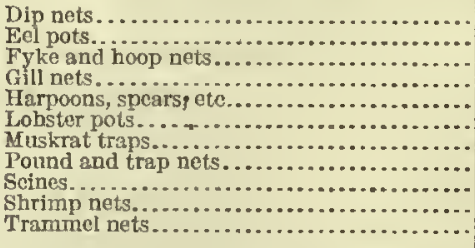 & $\begin{array}{r}183 \\
4,300 \\
1,591 \\
2,243 \\
19 \\
4,191 \\
2,564 \\
350 \\
246 \\
5 \\
2\end{array}$ & 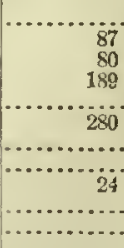 & $\begin{array}{r}183 \\
4,213 \\
1,511 \\
2,054 \\
19 \\
3,911 \\
2,564 \\
350 \\
222 \\
5 \\
2\end{array}$ \\
\hline
\end{tabular}

Products, byspecies.-Table 1, on page 193, gives the products, by species and apparatus of capture.

The leading species, named in the order of quantity taken, were oysters, menhaden, squeteague, king crabs, cod, whiting, sea bass, and shad; while named according to value, they were oysters, squeteague, hard clams, shad, cod, and sea bass.

Products, by class of fisheries.-Table 3, on page 195, gives the statistics of the vessel fisheries, by species and by apparatus of eapture; and Table 2 , on page 194, gives similar statistics for the shore and bont fisheries. The following tabular statement distributes the total 
value of products by species and by class of fisheries, only those products for which a value in excess of $\$ 10,000$ was reported being shown separately:

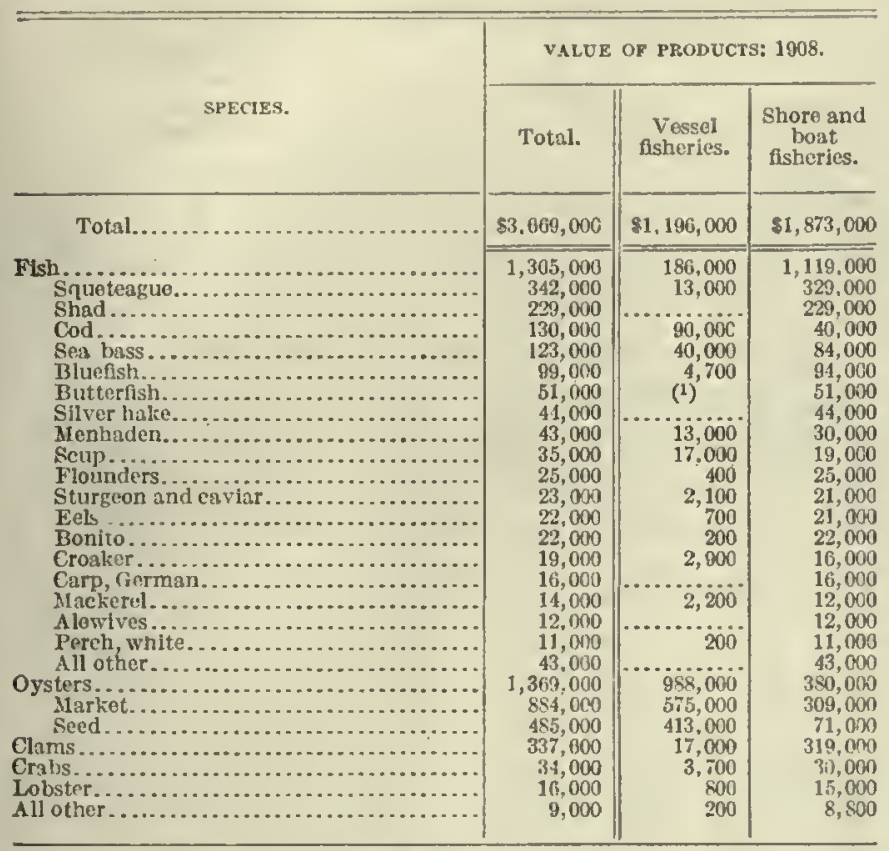

$\therefore$ Lass than $\$ 100$.

Products, by apparatus of capture.-The following tabular statement shows, for each class of fishcries, the distribution by apparatus of capture of the total value of products for the state, only those forms of apparatus which took products having a value in excess of $\$ 10,000$ being shown separately.

\begin{tabular}{|c|c|c|c|}
\hline \multirow{2}{*}{ Kind of crearatus. } & \multicolumn{3}{|c|}{ VALUE OF PRODUCTS: 1908.} \\
\hline & Total. & $\begin{array}{c}\text { Vessel } \\
\text { fisheries. }\end{array}$ & $\begin{array}{l}\text { Shore and } \\
\text { boat } \\
\text { fisheries. }\end{array}$ \\
\hline Total........... & $\$ 3,069,000$ & $\$ 1,196,000$ & $\$ 1,873,000$ \\
\hline 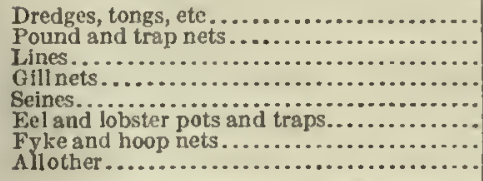 & $\begin{array}{r}1,703,000 \\
539,000 \\
332,000 \\
310,000 \\
108,000 \\
32,000 \\
22,000 \\
23,000\end{array}$ & $\begin{array}{r}1,000,000 \\
137,000 \\
4,400 \\
44,000 \\
1,400 \\
100 \\
\ldots . . .\end{array}$ & $\begin{array}{r}694,000 \\
539,000 \\
196,000 \\
305,000 \\
65,000 \\
30,000 \\
22,000 \\
23,000\end{array}$ \\
\hline
\end{tabular}

Dredges, tongs, etc., pound and trap nets, lines, gill nets, and seines, ranking with respect to the value of the product taken by them in the order named, wero employed in taking fishery products representing 98 per cent of the total value of the product of the state.

Dredges, tongs, etc., show a catch far in excess of that of other apparatus. The product taken by these implements in the vessel fisheries was nearly three times as heavy as that taken in the shore and boat fisheries, but less than twice as valuable.

The eatch with pound and trap nets included $₫$ large number of species. Over one-half of the value of their catcl represented the value of squeteague taken. Butterfish, silver liake, menhaden, and whiting were other important species in the pound and trap net catch. Of the value of the line cateh, more than two-thirds represented the value of sea bass and cod. A little over two-fifths of the product taken with lines was reported for vessel fisheries and almost three-fifths for shore and boat fisheries. In the former elass of fisheries cod was the leading species with respect to value, and sea bass was second in rank, the two together contributing $3,376,000$ pounds, valued at $\$ 128,000$, out of the total line catch of $3,576,000$ pounds, valued at $\$ 137,000$. Of the line catch of the shore and boat fisheries, which aggregated $4,806,000$ pounds and was valued at $\$ 196,000$, sea bass contributed $1,944,000$ pounds, valued at $\$ 76,000$, and bluefish 808,000 pounds, valued at $\$ 44,000$, while the large remainder included a number of species.

Gill nets were used chicfly in the shore and boat fisheries. Much more than half of the catch by these nets consisted of shad.

The value of the catch by seines was less than that of the product taken by any other of the five forms of apparatus discussed. Products taken by seines were reported for both the shore and boat fisheries and the vessel fisheries, $2,582,000$ pounds, valued at $\$ 65,000$, being eredited to the former and $7,067,000$ pounds, valued at $\$ 44,000$, to the latter. In the shore and boat fisheries, the products of greatest value taken by seines were shad, squeteague, and alewives. Of the seine catch reported for the vessel fisheries, menhaden contributed $5,884,000$ pounds, or 83 per cent.

Oysters.-Oysters were the chief fishery product in. New Jersey, as in most of the Middle and South Atlantic states. The total quantity taken in this state was $2,586,000$ bushels, the value of which, $\$ 1,369,000$, represents 45 per cent of the value of all the fishery products of New Jersey. This ratio, however, was less than that of former years, as shown by the following tabular statement:

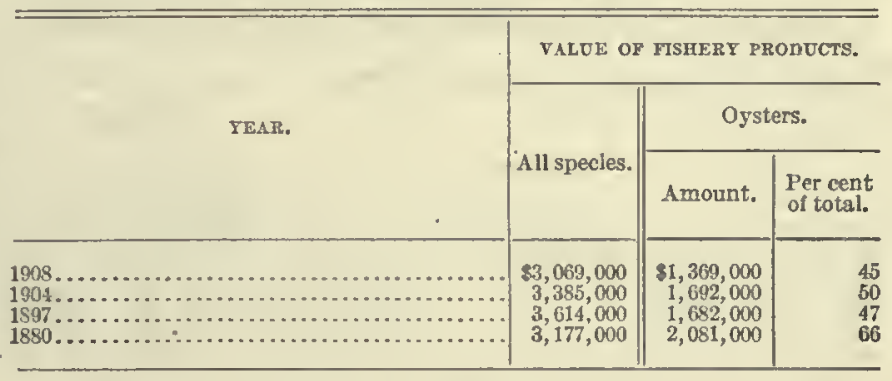

Nearly two-thirds of the oyster product in 1908, or $1,667,000$ bushels, consisted of seed oysters, but the value of these, $\$ 485,000$, was only a little more than one-third of the value of the entire oyster yield. Of the seed oysters, 772,000 bushels, valued at $\$ 236,000$, camo from public areas, and 895,000 bushels, valued at $\$ 248,000$, from private areas. There has been a marked growth since 1904 in the sced-oyster product from private areas. In that year the yield of seed 
oysters was 826,000 bushels, valued at $\$ 393,000$, but of this only 1,300 bushels, valued at $\$ 500$, came from private beds. Between 1904 and 1908, thercfore, the secd oysters from private arcas increased 894,000 bushels in quantity and $\$ 248,000$ in value; while the seed product from public areas decreased 53,000 bushels in quantity and $\$ 157,000$ in value.

In the case of the market oysters essentially all of the product is taken from private areas, only 15,000 bushels, valued at $\$ 12,000$, out of the total market oyster product of 920,000 bushels, valued at $\$ \$ \$ 4,000$, being from public areas in 1908. In quantity the oysters reported for the vessel fisheries exceeded those from the shore and boat fisheries in the proportion of nearly five to one. The vessel catch comprised chiefly seed oysters. The following tabular statement gives the distribution of the oyster product between the vessel fisheries and the shore and boat fisheries and between public and private beds:

\begin{tabular}{|c|c|c|c|c|c|c|}
\hline \multirow{3}{*}{ KIND $\triangle$ ND SOURCE. } & \multicolumn{6}{|c|}{ OYSTER PRODUCT: 1908.} \\
\hline & \multicolumn{2}{|c|}{ Total. } & \multicolumn{2}{|c|}{ Vessel fisherles. } & \multicolumn{2}{|c|}{$\begin{array}{l}\text { Shore and boat } \\
\text { fisberies. }\end{array}$} \\
\hline & $\begin{array}{l}\text { Quantity } \\
\text { (bushels). }\end{array}$ & Value. & $\begin{array}{l}\text { Quanttiy } \\
\text { busbels). }\end{array}$ & Value. & $\begin{array}{l}\text { Quan- } \\
\text { tity } \\
\text { (busb- } \\
\text { els). }\end{array}$ & Value. \\
\hline Total... & $2,586,000$ & $\$ 1,369,000$ & $2,122,000$ & 8988,000 & 464,000 & $\$ 380,000$ \\
\hline Market oysters... & 920,000 & 884,000 & 628,000 & 575,000 & 292,000 & 309,000 \\
\hline $\begin{array}{l}\text { From public areas. } \\
\text { From private areas }\end{array}$ & $\begin{array}{r}15,000 \\
904,000\end{array}$ & $\begin{array}{r}12,000 \\
872,000\end{array}$ & $\begin{array}{r}4,500 \\
623,000\end{array}$ & $\begin{array}{r}2,300 \\
573,000\end{array}$ & $\begin{array}{r}11,000 \\
281,000\end{array}$ & $\begin{array}{r}9,600 \\
299,000\end{array}$ \\
\hline Seed oysters.... & $1,667,000$ & 485,000 & $1,494,000$ & 413,000 & 173,000 & 71,000 \\
\hline $\begin{array}{l}\text { From public areas. } \\
\text { From private areas }\end{array}$ & $\begin{array}{l}772,000 \\
895,000\end{array}$ & $\begin{array}{l}236,00) \\
248,000\end{array}$ & $\begin{array}{l}623,000 \\
871,000\end{array}$ & $\begin{array}{l}173,000 \\
240,000\end{array}$ & $\begin{array}{r}148,000 \\
24,000\end{array}$ & $\begin{array}{r}63,090 \\
8,100\end{array}$ \\
\hline
\end{tabular}

Squeteague.-Squetcague ranked second in value among the products of the New Jersey fisheries. Practically all of the catch of this species was taken in the shore and boat fisheries. The quantity and the value of the catch have increased steadily, as is shown by the following comparison with previous canvasses:

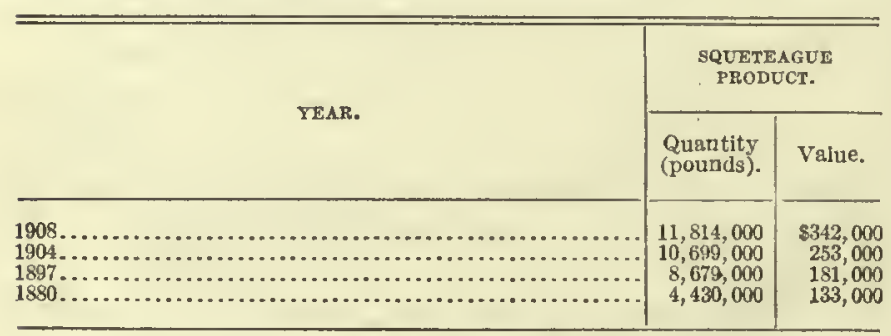

Hard clams.- Hard clams ranked next to squeteague in value, nearly all of the product being from the shore and boat fisheries. The following statement slows that the hard-clam product lias been decreasing in value since 1897 :

\begin{tabular}{|c|c|c|}
\hline \multirow{2}{*}{ YEAR. } & \multicolumn{2}{|c|}{ HARD-CLAM PRODUCT. } \\
\hline & $\begin{array}{l}\text { Quantity } \\
\text { (bushels). }\end{array}$ & Value. \\
\hline $\begin{array}{r}1908 \\
1904 \ldots \ldots \ldots \ldots\end{array} 1{ }_{189}$ & $\begin{array}{l}273,000 \\
271,000 \\
591,000 \\
392,000\end{array}$ & $\begin{array}{r}\$ 318,000 \\
352,000 \\
54,000 \\
196,000\end{array}$ \\
\hline
\end{tabular}

Shad.-This species ranked fourth, with a catch valued at $\$ 229,000$. All of the shad product was taken by the shore and boat fisheries. The decrease from the amounts reported in former years has been considerable, as indicated in the following statement:

\begin{tabular}{|c|c|c|}
\hline \multirow[b]{2}{*}{ TEAR. } & \multicolumn{2}{|c|}{ SHAD PRODUCT. } \\
\hline & $\begin{array}{l}\text { Quantity } \\
\text { (pounds). }\end{array}$ & Value. \\
\hline 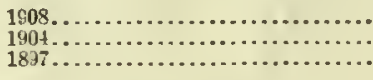 & $\begin{array}{r}3,004,000 \\
4,333,000 \\
13,001,000\end{array}$ & $\begin{array}{r}\$ 229,000 \\
239,000 \\
343,000\end{array}$ \\
\hline
\end{tabular}

Cod.-The cod product of New Jersey in 1908 was $3,767,000$ pounds, valued at $\$ 130,000$. More than three-fifths of this quantity was taken in the vessel fisheries. The total catch of 1904 was far below tliat of 1897 or of 1908 , as may be seen from the comparative statistics which follow.

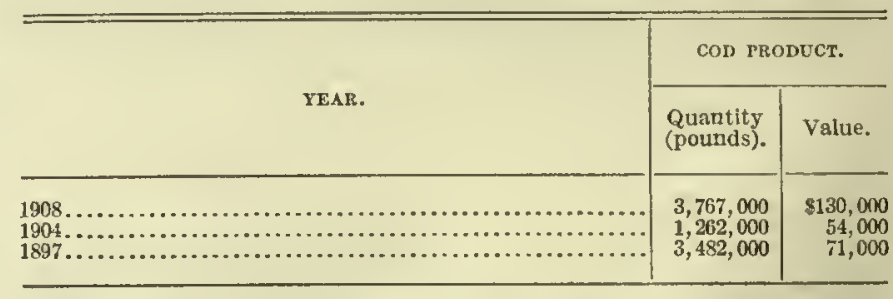

Sea bass.-Another important species was sea bass. About two-thirds of the product was taken in shore and boat fisheries. The catch has steadily increased since 1897, as the following comparison shows:

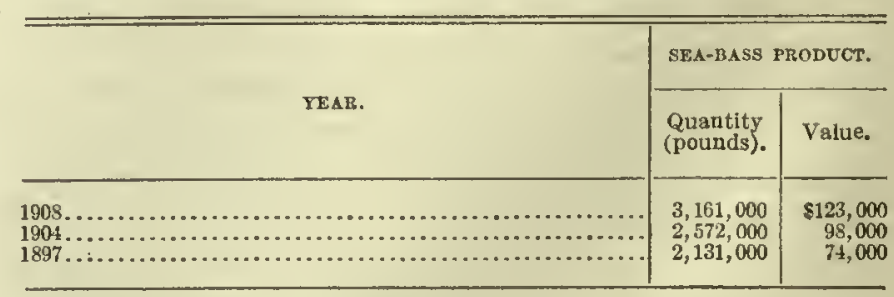


TABLE 1.-NEW JERSEY-FISHERY PRODUCTS: 1908.

\begin{tabular}{|c|c|c|c|c|c|c|c|c|c|c|c|c|c|c|}
\hline \multirow{3}{*}{ SPECIES. } & \multirow{2}{*}{\multicolumn{2}{|c|}{ TOTAL. }} & \multicolumn{12}{|c|}{ PRODUCT CAUGET BY- } \\
\hline & & & \multicolumn{2}{|c|}{$\begin{array}{l}\text { Pound and trap } \\
\text { nets. }\end{array}$} & \multicolumn{2}{|c|}{ Lines. } & \multicolumn{2}{|c|}{ Gill nets. } & \multicolumn{2}{|c|}{ Seines. } & \multicolumn{2}{|c|}{$\begin{array}{l}\text { Fyke and hoop } \\
\text { nets. }\end{array}$} & \multicolumn{2}{|c|}{ All other apparatus. 1} \\
\hline & $\begin{array}{l}\text { Quantity } \\
\text { (pounds). }\end{array}$ & Value. & $\begin{array}{l}\text { Quantity } \\
\text { (pounds). }\end{array}$ & Value. & $\begin{array}{l}\text { Quantity } \\
\text { (pounds). }\end{array}$ & Value. & $\begin{array}{l}\text { Quantity } \\
\text { (pounds). }\end{array}$ & Value. & $\begin{array}{l}\text { Quantlty } \\
\text { (pounds). }\end{array}$ & Value. & $\begin{array}{l}\text { Quantity } \\
\text { (pounds). }\end{array}$ & Value. & $\begin{array}{l}\text { Quantity } \\
\text { (pounds). }\end{array}$ & Value. \\
\hline \multirow[b]{2}{*}{ 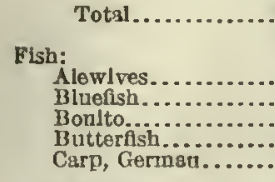 } & $74,827,000$ & $\$ 3,069,000$ & $30,285,000$ & $\$ 539,000$ & $8,382,000$ & 8332,000 & $4,515,000$ & $\$ 310,000$ & $9,649,000$ & $\$ 108,000$ & 449,000 & $\$ 22,000$ & $21,548,000$ & $\$ 1,758,000$ \\
\hline & $\begin{array}{r}1,309,000 \\
1,850,000 \\
578,000 \\
2,054,000 \\
220,000\end{array}$ & $\begin{array}{l}12,000 \\
99,000 \\
22,000 \\
51,000 \\
16,000\end{array}$ & $\begin{array}{r}270,000 \\
204,000 \\
378,000 \\
2,036,000 \\
20,000\end{array}$ & $\begin{array}{r}3,200 \\
12,000 \\
14,000 \\
\$ 1,000 \\
1,800\end{array}$ & $\begin{array}{r}400 \\
871,000 \\
192,000 \\
14,000\end{array}$ & $\begin{array}{r}(2) \\
48,000 \\
7,900 \\
400\end{array}$ & $\begin{array}{r}14,000 \\
737,000 \\
2,800 \\
4,200 \\
165,000\end{array}$ & $\begin{array}{r}100 \\
37,000 \\
100 \\
200 \\
11,000\end{array}$ & $\begin{array}{r}1,015,000 \\
24,000 \\
2,200 \\
200 \\
34,000\end{array}$ & $\begin{array}{l}8,200 \\
1,400 \\
100 \\
(2) \\
2,900\end{array}$ & $\begin{array}{r}2,400 \\
14,000 \\
2,500 \\
800\end{array}$ & $\begin{array}{r}100 \\
800 \\
200 \\
\hdashline 3{ }^{3}\end{array}$ & $\begin{array}{l}6,000 \\
\cdots \cdots\end{array}$ & 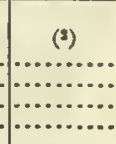 \\
\hline $\begin{array}{l}\text { Catfish.......... } \\
\text { Cod............ }\end{array}$ & $\begin{array}{r}63,000 \\
3,767,000 \\
790,000\end{array}$ & $\begin{array}{r}5,300 \\
130,000 \\
19,000\end{array}$ & $\begin{array}{r}5,500 \\
845,000 \\
457,000\end{array}$ & $\begin{array}{r}400 \\
20,000\end{array}$ & $\mid \because 2,920,0000$ & iiio, 0000 & 22,000 & 1,900 & 31,000 & 2,500 & $\begin{array}{l}4,200 \\
1,000\end{array}$ & $\begin{array}{l}500 \\
100\end{array}$ & 100 & (3) \\
\hline 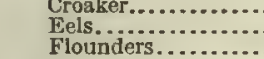 & $\begin{array}{l}790,000 \\
253,000 \\
650,000\end{array}$ & $\begin{array}{l}19,000 \\
22,000\end{array}$ & $\begin{array}{r}457,000 \\
2,700\end{array}$ & $\begin{array}{r}10,000 \\
200 \\
6,500\end{array}$ & $\mid \begin{array}{r}241,000 \\
200 \\
114,000\end{array}$ & $\begin{array}{l}7,000 \\
(2) \\
(4800\end{array}$ & 4,300 & $\because 300^{\circ}$ & $\begin{array}{l}93,000 \\
30,000\end{array}$ & $\begin{array}{l}2,100 \\
2,800\end{array}$ & 22,000 & 2,400 & 193,000 & 10,0000 \\
\hline Haddock. & 20,000 & 600 & 11,000 & 200 & 8,400 & 300 & & & & & & & & \\
\hline $\begin{array}{l}\text { Hake } \\
\text { Horse }\end{array}$ & $\begin{array}{l}181,000 \\
207,000\end{array}$ & $\begin{array}{l}1,600 \\
5,600\end{array}$ & $\begin{array}{l}175,000 \\
207,000\end{array}$ & $\begin{array}{l}1,400 \\
5,600\end{array}$ & 2,000 & (2) & 1,200 & (3) & 2,200 & 100 & 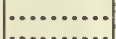 & & & $\because$ \\
\hline $\begin{array}{l}\text { Kinfish ............. } \\
\text { Mackerel............ }\end{array}$ & $\begin{array}{r}35,000 \\
501,000\end{array}$ & $\begin{array}{r}3,400 \\
14,000\end{array}$ & $\begin{array}{r}5,900 \\
460,000\end{array}$ & 9,700 & $20,000^{\circ}$ & $\ddot{2} \ddot{2} 0 \ddot{0} 0$ & $\begin{array}{r}30 \\
37,000\end{array}$ & $\begin{array}{r}300 \\
4,300\end{array}$ & $\begin{array}{r}3,3000 \\
100\end{array}$ & (3) & $\begin{array}{r}3000 \\
2,900\end{array}$ & $\begin{array}{l}100 \\
200\end{array}$ & & $\cdots$ \\
\hline $\begin{array}{l}\text { Menhaden.......... } \\
\text { Mfullet................ }\end{array}$ & $\begin{array}{r}12,417,000 \\
7,600\end{array}$ & $\begin{array}{r}43,000 \\
300\end{array}$ & $5,807,000$ & 28,000 & & & $\begin{array}{r}18,000 \\
1,500\end{array}$ & $\begin{array}{l}100 \\
100\end{array}$ & $\begin{array}{r}6,582,000 \\
6,100\end{array}$ & $\begin{array}{l}14,000 \\
300\end{array}$ & 10,000 & 200 & & (......... \\
\hline & 140,000 & 11,000 & 5,800 & 200 & 21,000 & $1,400^{\circ}$ & 40,000 & 3,600 & 63,000 & 5,000 & 9,500 & $800^{\circ}$ & 200 & (3) \\
\hline $\begin{array}{l}\text { Perch, yellow....... } \\
\text { Pollack............ }\end{array}$ & $\begin{array}{l}17,000 \\
84,000\end{array}$ & $\begin{array}{l}1,300 \\
1,100\end{array}$ & $\begin{array}{r}1,400 \\
81,000\end{array}$ & $\begin{array}{r}100 \\
1,100\end{array}$ & $\begin{array}{r}1,400 \\
500\end{array}$ & $(3)$ & 5,500 & 400 & 6,000 & 500 & 2,200 & 200 & & \\
\hline $\begin{array}{l}\text { Scup................... } \\
\text { Sea bass............. }\end{array}$ & $\begin{array}{l}1,196,000 \\
3,161,000\end{array}$ & $\begin{array}{r}35,000 \\
123,000\end{array}$ & $\begin{array}{l}324,000 \\
131,000\end{array}$ & $\begin{array}{l}9,400 \\
6,900\end{array}$ & $\begin{array}{r}286,000 \\
2,971,000\end{array}$ & $\begin{array}{r}10,000 \\
114,000\end{array}$ & $\begin{array}{r}500 \\
1,400\end{array}$ & (2) & $\begin{array}{r}683,000 \\
46,000\end{array}$ & $\begin{array}{r}16,000 \\
2,100\end{array}$ & $\begin{array}{r}3,000 \\
10,000\end{array}$ & $\begin{array}{l}200 \\
400\end{array}$ & & \\
\hline & $\begin{array}{r}62,000 \\
3,004,000\end{array}$ & 229,000 & $\begin{array}{l}62,000 \\
59,000\end{array}$ & 5,300 & 1,700 & $100^{\circ}$ & $\ddot{2}, 748,000$ & 2008,000 & $\because 7 \ddot{4}, 000 \sigma^{\prime}$ & 15,000 & 21,000 & 1,800 & & \\
\hline Stlver hake.... & $3,708,000$ & 44,000 & $3,522,000$ & 41,000 & 53,000 & 800 & 123,000 & 2,000 & & & 10,000 & 200 & & \\
\hline $\begin{array}{l}\text { Smalt_............... } \\
\text { Spanish mackerei.. }\end{array}$ & 7,500 & 1,500 & & & & & & & 7,500 & 1,500 & & & & \\
\hline Spot. & $\begin{array}{r}7,100 \\
255,000\end{array}$ & $\begin{array}{l}1,800 \\
\mathbf{3}, 100\end{array}$ & $\begin{array}{r}6,000 \\
247,000\end{array}$ & 2,800 & 3,600 & 200 & 800 & 200 & $\because 4,500$ & 200 & & & & \\
\hline $\begin{array}{l}\text { Squeteague.......... } \\
\text { Strlped bass.......... }\end{array}$ & $\begin{array}{r}11,814,000 \\
53,000\end{array}$ & $\begin{array}{r}342,000 \\
7,400\end{array}$ & $\begin{array}{r}10,035,000 \\
10,000\end{array}$ & $\begin{array}{r}231,000 \\
1,100\end{array}$ & $\begin{array}{r}552,000 \\
7,400\end{array}$ & $\begin{array}{r}21,000 \\
800\end{array}$ & $\begin{array}{r}385,000 \\
8,600\end{array}$ & $\begin{array}{r}14,000 \\
1,600\end{array}$ & $\begin{array}{r}815,000 \\
19,000\end{array}$ & $\begin{array}{r}24,000 \\
2,700\end{array}$ & $\begin{array}{r}28,000 \\
7,700\end{array}$ & $\begin{array}{ll}7,300 \\
1,000\end{array}$ & & (n......... \\
\hline $\begin{array}{l}\text { Sturgeon............. } \\
\text { Caviar. }\end{array}$ & 132,000 & 13,000 & 12,000 & 1,200 & & & 120,000 & 12,000 & & & & & & \\
\hline & $\begin{array}{r}9,700 \\
74,000\end{array}$ & $\begin{array}{r}10,000 \\
5,900\end{array}$ & 900 & 1,000 & & & $\begin{array}{r}8,500 \\
29,000\end{array}$ & $\begin{array}{l}9,000 \\
2,600\end{array}$ & 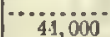 & 3,300 & 4000 & (2) & 4000 & (2) \\
\hline & 112,000 & 3,5 & 5,300 & 100 & 84,000 & $2,400^{\circ}$ & 1,300 & 100 & 22,000 & 900 & 200 & (3) & & ......... \\
\hline All other................. & $\begin{array}{l}11,000 \\
19,000\end{array}$ & $\begin{array}{l}300 \\
400\end{array}$ & $\because 1,000$ & 2000 & $\begin{array}{r}1,000 \\
3,900\end{array}$ & 100 & $2,600^{\circ}$ & (i) $"$ & $1,700^{\circ}$ & 100 & & & & \\
\hline Crabs, hard & 282,000 & 9,100 & 500 & (2) & & & & & & & 20,000 & 200 & 261,000 & 8,900 \\
\hline $\begin{array}{l}\text { Crah } \\
\text { Crab: }\end{array}$ & $\begin{array}{r}63,000 \\
4,607,000\end{array}$ & $\begin{array}{r}6,200 \\
18,000\end{array}$ & $4,583,000^{\circ}$ & i8,000 & 1,000 & 100 & & & 2,000 & 200 & & & $\begin{array}{l}60,000 \\
24,000\end{array}$ & $\begin{array}{r}5,900 \\
100\end{array}$ \\
\hline & 115,000 & 16,000 & & & & & & & & & & & 115,000 & 16,000 \\
\hline & & & 100 & 200 & & & & & & & & & 3,900 & 800 \\
\hline & 100,000 & 3,100 & 100,000 & 3,100 & & & & & & & & & & \\
\hline Terrspin.... & 1,100 & 1,000 & $3300-2>-2$ & & & & & & & & 1800 & ? & 1,100 & 1,000 \\
\hline Mussels.................... & $\begin{array}{r}5,500 \\
287,000\end{array}$ & $\begin{array}{r}300 \\
1,400\end{array}$ & 3,300 & 100 & 400 & (') & & & & & 1,800 & 200 & $\begin{array}{r}100 \\
287,000\end{array}$ & $\stackrel{(3)}{1,400}$ \\
\hline Clams, hard. & $32,184,000$ & 318,000 & & & & & $x_{0}$ & & & & & & $42,184,000$ & 318,000 \\
\hline $\begin{array}{l}\text { Clams, soft.................................. } \\
\text { Clams, surf }\end{array}$ & $\begin{array}{r}205,000 \\
699,000\end{array}$ & $\begin{array}{l}11,000 \\
7,000\end{array}$ & & & & & & & & & & & $\begin{array}{r}205,000 \\
-0900\end{array}$ & 11,000 \\
\hline & & & & & & & & & & & & & & \\
\hline $\begin{array}{c}\text { Oysters, market, from } \\
\text { public areas....................... }\end{array}$ & $? 107,000$ & 12,000 & & & & & & & & & & & 7107,000 & 12,000 \\
\hline $\begin{array}{l}\text { Oysters, market, from } \\
\text { private areas............... }\end{array}$ & $86,330,000$ & 872,000 & & & & & & & & & & & $6,330,000$ & 872,000 \\
\hline ed, from pub- & & - & & & & & & & & & & & & $236,000>>>>$ \\
\hline ed, from pri- & $100,266,000$ & $248, a>->\rightarrow$ & & & & & & & & & & & & 248.090 \\
\hline Skins, mink and muskrat & $\begin{array}{r}0,211 \\
\quad 11,000\end{array}$ & $\begin{array}{r}2,300 \\
2,300\end{array}$ & & & & & & & & & & & $\begin{array}{r}106,266,000 \\
\text { in } 3,000\end{array}$ & $\begin{array}{r}248,060 \\
2,300\end{array}$ \\
\hline
\end{tabular}

1 Yncludes apparatus, with estch, as follows: Dredges, tongs, etc, $21,019,000$ pounds, valued at $\$ 1,703,000$; eel and fobster trans and pots, 299,000 pounds, valned at $\$ 32,000$ dip nets, 113,000 pounds, valued at $\$ 9,600$; mink and muskirat traps, 3,000 pounds, valued at $\$ 2,300$; spears, 9,200 pounds, valued at $\$ 800$; shrimp nets, 3,900 pounds, valued at $\$ s 00$; and minor apparatus, 70,000 pounds, valued at $\$ 9,900$.

3 Less than $\$ 100$.

273,000 bushels.

10895,000 bushels. $76786^{\circ}-11-13$

- 12,000 bushels.
? 15,000 bushels.

904,000 bushels.

772,000 bushels.
119,100 akins. 
TABLE 2.-NEW JERSEY-PRODUCTS OF SHORE AND BOAT FISHERIES: 1908.

\begin{tabular}{|c|c|c|c|c|c|c|c|c|c|c|c|c|c|c|}
\hline \multirow{3}{*}{ SPECIES. } & \multicolumn{2}{|c|}{ TOTAL. } & \multicolumn{12}{|c|}{ Pronver CAUGHT BY- } \\
\hline & \multirow{2}{*}{$\begin{array}{l}\text { Quantity } \\
\text { (pounds). }\end{array}$} & \multirow{2}{*}{ Value. } & \multicolumn{2}{|c|}{$\begin{array}{c}\text { Peund and trap } \\
\text { nets. }\end{array}$} & \multicolumn{2}{|c|}{ Gill nets. } & \multicolumn{2}{|c|}{ Lines. } & \multicolumn{2}{|c|}{ Seines. } & \multicolumn{2}{|c|}{$\begin{array}{c}\text { Fyke and hoop } \\
\text { nets. }\end{array}$} & \multicolumn{2}{|c|}{$\begin{array}{l}\text { All other appa- } \\
\text { ratus.l }\end{array}$} \\
\hline & & & $\begin{array}{l}\text { Quantlty } \\
\text { (peunds). }\end{array}$ & Value. & $\begin{array}{l}\text { Quantity } \\
\text { (pounds). }\end{array}$ & Value. & $\begin{array}{l}\text { Quantity } \\
\text { (pounds). }\end{array}$ & Value. & $\begin{array}{l}\text { Quantity } \\
\text { (pounds). }\end{array}$ & Value. & $\begin{array}{l}\text { Quantity } \\
\text { (peunds). }\end{array}$ & Value. & $\begin{array}{l}\text { Quantity } \\
\text { (pounds). }\end{array}$ & Value. \\
\hline Tetal.... & $49,007,000$ & $\$ 1,873,000$ & $30,285,000$ & 8539,000 & $4,485,000$ & $\$ 305,000$ & $4,806,000$ & $\$ 196,000$ & $2,582,000$ & $\$ 65,000$ & 447,000 & $\$ 22,000$ & $6,402,000$ & 8747,000 \\
\hline 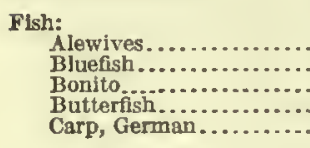 & $\begin{array}{r}1,309,000 \\
1,779,000 \\
574,000 \\
2,054,000 \\
220,000\end{array}$ & $\begin{array}{l}12,000 \\
94,000 \\
22,000 \\
51,000 \\
16,000\end{array}$ & $\begin{array}{r}270,000 \\
204,000 \\
378,000 \\
2,036,000 \\
20,000\end{array}$ & $\begin{array}{r}3,200 \\
12,000 \\
14,000 \\
51,000 \\
1,800\end{array}$ & $\begin{array}{r}14,000 \\
737,000 \\
2,800 \\
4,200 \\
165,000\end{array}$ & $\begin{array}{r}100 \\
37,000 \\
100 \\
200 \\
11,000\end{array}$ & $\begin{array}{r}400 \\
808,000 \\
190,000 \\
14,000\end{array}$ & $\begin{array}{r}(2) \\
44,000 \\
7,800 \\
400\end{array}$ & $\begin{array}{r}1,015,000 \\
17,000 \\
\cdots, \ldots \ldots \\
\cdots 34,000\end{array}$ & $\begin{array}{r}8,200 \\
1,100 \\
\cdots \cdots \cdots \\
\cdots 2,900\end{array}$ & $\begin{array}{r}2,400 \\
14,000 \\
2,500 \\
800\end{array}$ & $\begin{array}{r}100 \\
800 \\
200 \\
200\end{array}$ & $\begin{array}{r}6,000 \\
\cdots \cdots \\
\cdots \cdots\end{array}$ & $\begin{array}{l}(2) \\
\cdots\end{array}$ \\
\hline 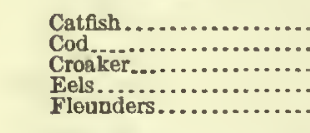 & $\begin{array}{r}63,000 \\
1,417,000 \\
661,000 \\
242,000 \\
638,000\end{array}$ & $\begin{array}{r}5,300 \\
40,000 \\
16,000 \\
21,000 \\
25,000\end{array}$ & $\begin{array}{r}5,500 \\
845,000 \\
457,000 \\
2,700 \\
195,000\end{array}$ & $\begin{array}{r}400 \\
20,000 \\
10,000 \\
200 \\
6,500\end{array}$ & $\begin{array}{r}22,000 \\
\cdots \\
28,0,000 \\
28,00\end{array}$ & $\begin{array}{r}1,900 \\
\cdots \\
1,100\end{array}$ & $\begin{array}{r}571,000 \\
198,000 \\
200 \\
110,000\end{array}$ & $\begin{array}{l}20,000 \\
6,100 \\
(3) \\
4,700\end{array}$ & $\begin{array}{r}31,000 \\
6,000 \\
28,000 \\
33,000\end{array}$ & $\begin{array}{r}2,500 \\
100 \\
2,700 \\
1,600\end{array}$ & $\begin{array}{r}4,200 \\
1,000 \\
\cdots 2,000 \\
271,000\end{array}$ & $\begin{array}{r}2,400 \\
11,000\end{array}$ & $\mid \begin{array}{r}184,000 \\
\cdots\end{array}$ & $\begin{array}{l}16,000 \\
\ldots \ldots\end{array}$ \\
\hline 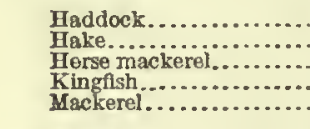 & $\begin{array}{r}20,000 \\
181,000 \\
207,000 \\
35,000 \\
482,000\end{array}$ & $\begin{array}{r}600 \\
1,600 \\
5,600 \\
3,400 \\
12,000\end{array}$ & $\begin{array}{r}11,000 \\
175,000 \\
207,000 \\
5,900 \\
460,000\end{array}$ & $\begin{array}{r}200 \\
1,400 \\
5,600 \\
700 \\
9,700\end{array}$ & $\begin{array}{r}1,200 \\
3,400 \\
18,000\end{array}$ & $\begin{array}{l}(2) \\
300 \\
2,000\end{array}$ & $\begin{array}{r}8,400 \\
2,000 \\
20,000 \\
\end{array}$ & $\begin{array}{l}{ }^{300} \\
\ddot{2}, \ddot{000}\end{array}$ & $\begin{array}{l}2,200 \\
4,300\end{array}$ & 400 & $\begin{array}{r}800 \\
2,800\end{array}$ & 100 & $\begin{array}{l}\cdots \\
\cdots \\
\cdots\end{array}$ & $\because$ \\
\hline 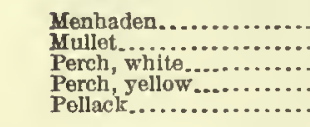 & $\begin{array}{r}6,533,000 \\
7,600 \\
138,000 \\
17,000 \\
84,000\end{array}$ & $\begin{array}{r}30,000 \\
300 \\
11,000 \\
1,300 \\
1,100\end{array}$ & $\begin{array}{r}5,807,000 \\
5,800 \\
1,400 \\
84,000\end{array}$ & $\begin{array}{r}28,000 \\
200 \\
100 \\
1,100\end{array}$ & $\begin{array}{r}18,000 \\
1,500 \\
39,000 \\
5,500 \\
\ldots\end{array}$ & $\begin{array}{r}100 \\
100 \\
3,500 \\
400\end{array}$ & $\begin{array}{r}21,000 \\
1,400 \\
500\end{array}$ & $\begin{array}{l}1,400 \\
100 \\
(2)\end{array}$ & $\begin{array}{r}698,000 \\
6,100 \\
63,000 \\
6,000 \\
6 .\end{array}$ & $\begin{array}{r}1,400 \\
300 \\
5,000 \\
500\end{array}$ & $\begin{array}{r}10,000 \\
9,500 \\
2,200 \\
\ldots \ldots\end{array}$ & $\begin{array}{l}200 \\
3000 \\
200\end{array}$ & $\begin{array}{l}\cdots \ldots \ldots \\
\cdots \cdots \\
\cdots \cdots\end{array}$ & $(3)$ \\
\hline 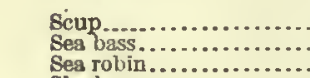 & $\begin{array}{r}583,000 \\
2,088,000 \\
62,000\end{array}$ & $\begin{array}{r}19,000 \\
84,000 \\
200\end{array}$ & $\begin{array}{r}324,000 \\
131,000 \\
62,000\end{array}$ & $\begin{array}{r}9,400 \\
6,900 \\
200\end{array}$ & $\begin{array}{r}500 \\
1,400 \\
\cdots\end{array}$ & (3) & $\begin{array}{r}231,000 \\
1,944,000 \\
\cdots \cdots\end{array}$ & $\begin{array}{r}8,300 \\
76,000\end{array}$ & $\begin{array}{r}25,000 \\
400 \\
\ldots .\end{array}$ & $\begin{array}{c}1,000 \\
(z)\end{array}$ & $\begin{array}{r}3,000 \\
10,000 \\
\end{array}$ & $\begin{array}{l}200 \\
400\end{array}$ & $\begin{array}{l}\ldots \ldots \\
\cdots \ldots \ldots \\
\cdots \ldots\end{array}$ & \\
\hline 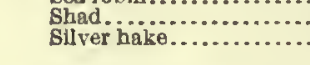 & $\begin{array}{l}3,004,000 \\
3,708,000\end{array}$ & $\begin{array}{r}229,000 \\
44,000\end{array}$ & $\begin{array}{r}59,000 \\
3,522,000\end{array}$ & $\begin{array}{r}5,300 \\
41,000\end{array}$ & $\ddot{2}, 798,000$ & $\begin{array}{r}208,000 \\
2,000\end{array}$ & $\begin{array}{r}1,700 \\
53,000\end{array}$ & $\begin{array}{l}700 \\
800\end{array}$ & $\begin{array}{l}174,000 \\
0.0 .\end{array}$ & 15,000 & $\begin{array}{l}21,000 \\
10,000\end{array}$ & $\ddot{1}, 800$ & & \\
\hline 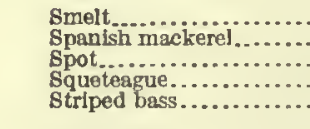 & $\begin{array}{r}7,500 \\
7,100 \\
255,000 \\
11,306,000 \\
53,000\end{array}$ & $\begin{array}{r}1,500 \\
1,800 \\
3,100 \\
329,000 \\
7,400\end{array}$ & $\begin{array}{r}6,000 \\
247,000 \\
10,035,000 \\
10,000\end{array}$ & $\begin{array}{r}1,600 \\
2,800 \\
281,000 \\
1,100\end{array}$ & $\begin{array}{r}800 \\
385,000 \\
8,600\end{array}$ & $\begin{array}{r}134,000 \\
1,600\end{array}$ & $\begin{array}{r}300 \\
3,700 \\
520,000 \\
7,400\end{array}$ & $\begin{array}{r}100 \\
200 \\
20,000 \\
900\end{array}$ & $\begin{array}{r}7,500 \\
4,500 \\
338,000 \\
19,000\end{array}$ & $\begin{array}{r}1,500 \\
\cdots 200 \\
13,000 \\
2,700\end{array}$ & $\begin{array}{r}28,000 \\
7,700\end{array}$ & $\begin{array}{l}1,300 \\
1,000\end{array}$ & $\mid \begin{array}{ll}\cdots \cdots \cdots \\
\cdots \cdots \cdots \\
\cdots \cdots \cdots\end{array}$ & \\
\hline 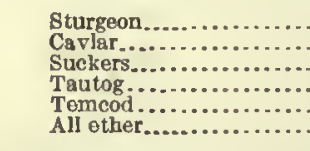 & $\begin{array}{r}123,000 \\
8,700 \\
74,000 \\
112,000 \\
11,000 \\
19,000\end{array}$ & $\begin{array}{r}12,000 \\
8,800 \\
5,900 \\
3,500 \\
300 \\
400\end{array}$ & $\begin{array}{r}12,000 \\
900 \\
5,300 \\
11,000\end{array}$ & $\begin{array}{r}1,200 \\
1,000 \\
100 \\
200\end{array}$ & $\begin{array}{r}11,000 \\
7,700 \\
29,000 \\
1,300 \\
2,600\end{array}$ & $\begin{array}{r}11,000 \\
7,800 \\
2,600 \\
100 \\
(2)\end{array}$ & $\begin{array}{r}84,000 \\
11,000 \\
3,900\end{array}$ & $\begin{array}{r}2,400 \\
300 \\
100\end{array}$ & $\begin{array}{r}44,000 \\
2,200 \\
1,700\end{array}$ & $\begin{array}{r}3,300 \\
900 \\
100\end{array}$ & 200 & (2) & $\begin{array}{l}\ldots \ldots \\
\ldots \ldots \\
\cdots \cdots\end{array}$ & $\begin{array}{ll}(8) \\
(8)\end{array}$ \\
\hline 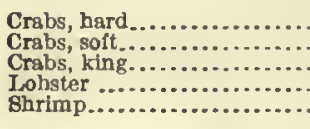 & $\begin{array}{r}186,000 \\
63,000 \\
4,607,000 \\
109,000 \\
4,900\end{array}$ & $\begin{array}{r}5,400 \\
6,200 \\
18,000 \\
15,000 \\
1,000\end{array}$ & $\begin{array}{r}500 \\
4,583,000 \\
1,000\end{array}$ & $\begin{array}{c}\text { (') } \\
18,000 \\
\cdots \\
2000\end{array}$ & & & $\begin{array}{l}1,000 \\
\cdots \\
\cdots\end{array}$ & $\mid \begin{array}{l}\mid \\
\ldots \ldots \ldots \\
\cdots \ldots \ldots\end{array}$ & $\begin{array}{l}2,000 \\
\ldots \ldots \ldots \\
\ldots \ldots\end{array}$ & $\begin{array}{c}200 \\
\cdots \ldots \\
\ldots \ldots \\
\ldots \ldots \\
\ldots \ldots\end{array}$ & $\begin{array}{l}20,000 \\
\cdots \cdots \cdots \\
\cdots \cdots \\
\cdots \cdots \\
\cdots \cdots\end{array}$ & 200 & $\begin{array}{r}165,000 \\
60,000 \\
24,000 \\
109,000 \\
3,900\end{array}$ & $\begin{array}{r}5,200 \\
5,900 \\
100 \\
15,000 \\
800\end{array}$ \\
\hline 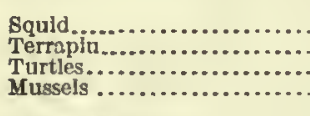 & $\begin{array}{r}100,000 \\
1,100 \\
5,500 \\
3247,000\end{array}$ & $\begin{array}{r}3,100 \\
1,000 \\
300 \\
1,200\end{array}$ & $\begin{array}{r}100,000 \\
3,300 \\
\cdots\end{array}$ & $\begin{array}{l}3,100 \\
100\end{array}$ & & & 4000 & (i) & & & $\dddot{1}, \ddot{800}$ & $\ddot{2} \ddot{00}$ & $\begin{array}{r}\cdots, 100 \\
100 \\
\cdot 247,000\end{array}$ & $\begin{array}{l}1,000 \\
(8) \\
1,200\end{array}$ \\
\hline $\begin{array}{l}\text { Clams, hard .................. } \\
\text { Clams, soft.................. } \\
\text { Clams, surf.............. }\end{array}$ & $\begin{array}{r}42,043,000 \\
6205,000 \\
899,000\end{array}$ & $\begin{array}{r}301,000 \\
11,000 \\
7,000\end{array}$ & & & & & & & & & & & $\begin{array}{r}+2,043,000 \\
-205,000 \\
699,000\end{array}$ & $\begin{array}{r}301,000 \\
11,000 \\
7,000\end{array}$ \\
\hline Oysters, market, from public & 775,000 & 9,600 & & & & & & & & & & & 75,000 & 9,600 \\
\hline $\begin{array}{l}\text { Oysters, market, frem prlvate } \\
\text { areas................ } \\
\text { Oysters, seed, from public } \\
\text { areas, }\end{array}$ & $81,967,000$ & $\begin{array}{r}299,000 \\
63,000\end{array}$ & & & & & & & & & & & $81,967,000$ & 299,000 \\
\hline $\begin{array}{l}\text { areas } \\
\text { areas, seed, from private } \\
\text { skins, mink and muskrat.... }\end{array}$ & $\begin{array}{r}1,038,000 \\
10170,000 \\
113,000\end{array}$ & $\begin{array}{r}63,000 \\
8,100 \\
2,300\end{array}$ & & & & & & & & & & & $\begin{array}{r}1,038,000 \\
10170,000 \\
113,000\end{array}$ & $\begin{array}{r}63,000 \\
8,100 \\
2,300\end{array}$ \\
\hline
\end{tabular}

1 Includes apparatus, witb catch, as follows: Dredges, tougs, etc., $5,919,000$ pounds, valued at $\$ 694,000$; eel and lobster pets and traps, 284,300 pounds, valued at $\$ 30,000$;

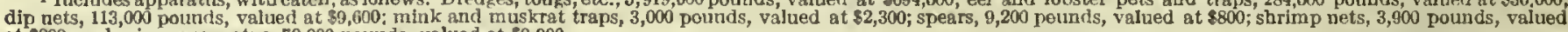
at $\$ 800$; and minor apparatus, 70,000 peunds, valued at $\$ 9,900$.

2 Lass than $\$ 100$. $\$ 255 . \mathrm{mm}$ bushels.

$12,0 \mathrm{~m}$ hushels.

- 281 , 00 bushels.

1024,600 hushels. 
FISHERIES, BY STATES.

TABLE 3.-NEW JERSEY-PRODUCTS OF VESSEL, FISHERIES: 1908.

\begin{tabular}{|c|c|c|c|c|c|c|c|c|c|c|}
\hline \multirow{3}{*}{ SPECrEs. } & \multirow{2}{*}{\multicolumn{2}{|c|}{ TOTAL. }} & \multicolumn{8}{|c|}{ PRONUCT CAUOHT BY- } \\
\hline & & & \multicolumn{2}{|c|}{ Dredges, tongs, etc. } & \multicolumn{2}{|c|}{ Lines. } & \multicolumn{2}{|c|}{ Seines. } & \multicolumn{2}{|c|}{ All otber apparatus. } \\
\hline & $\begin{array}{l}\text { Quantity } \\
\text { (pounds). }\end{array}$ & Value. & $\begin{array}{l}\text { Quantity } \\
\text { (pounds). }\end{array}$ & Value. & $\begin{array}{l}\text { Quantity } \\
\text { (pounds). }\end{array}$ & Value. & $\begin{array}{l}\text { Quantlty } \\
\text { (pounds). }\end{array}$ & Value. & $\begin{array}{l}\text { Quantity } \\
\text { (pounds). }\end{array}$ & Value. \\
\hline Total... & $25,820,000$ & $\$ 1,196,000$ & $15,130,000$ & $\$ 1,009,000$ & $3,570,000$ & $\$ 137,000$ & $7.067,000$ & $\$ 44,000$ & 47,000 & 86,000 \\
\hline 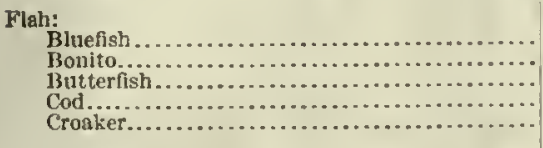 & $\begin{array}{r}71,000 \\
4,100 \\
200 \\
2,349,000 \\
129,000\end{array}$ & $\begin{array}{r}4,700 \\
200 \\
(2) \\
90,000 \\
2,900\end{array}$ & $\begin{array}{l}\cdots \cdots \\
\cdots \cdots \\
\cdots \cdots\end{array}$ & $\begin{array}{l}\cdots \cdots \cdots \\
\cdots \cdots \cdots \cdot \cdot \cdot \\
\cdots \cdots \cdots \cdot \cdot \cdot\end{array}$ & $\begin{array}{r}64,000 \\
1,900 \\
\because 2,349,000 \\
43,000\end{array}$ & $\begin{array}{r}4,400 \\
100 \\
90,000 \\
900\end{array}$ & $\begin{array}{r}7,100 \\
2,200 \\
200 \\
87,000\end{array}$ & $\begin{array}{c}300 \\
100 \\
(2)^{2} \\
2,000\end{array}$ & an. & (n.... \\
\hline 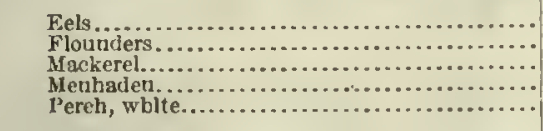 & $\begin{array}{r}11,000 \\
11,000 \\
19,000 \\
5,884,000 \\
1,500\end{array}$ & $\begin{array}{r}700 \\
400 \\
2,200 \\
13,000 \\
200\end{array}$ & & $\begin{array}{l}\cdots \cdots \\
\cdots \\
\cdots \\
\cdots\end{array}$ & $\begin{array}{l}4,400 \\
4 \ldots \ldots\end{array}$ & (2mo & $\begin{array}{r}1,700 \\
5,000 \\
100 \\
5,884,000 \\
.2 .\end{array}$ & $\begin{array}{r}100 \\
200 \\
13,000 \\
2 . \cdots . .\end{array}$ & $\begin{array}{r}9,200 \\
2,000 \\
19,000 \\
1,300\end{array}$ & $\begin{array}{r}600 \\
100 \\
2,200 \\
200\end{array}$ \\
\hline 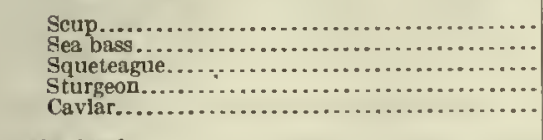 & $\begin{array}{r}613,000 \\
1,073,000 \\
508,000 \\
8,700 \\
1,000\end{array}$ & $\begin{array}{r}17,000 \\
40,000 \\
13,000 \\
1,000 \\
1,100\end{array}$ & & & $\begin{array}{r}55,000 \\
1,027,000 \\
32,000 \\
\cdots\end{array}$ & $\begin{array}{r}1,900 \\
38,000 \\
1,300 \\
\cdots\end{array}$ & $\begin{array}{r}558,000 \\
46,000 \\
476,000 \\
\end{array}$ & $\begin{array}{r}15,000 \\
2,100 \\
11,000 \\
\cdots\end{array}$ & $\begin{array}{l}8,700 \\
1,000\end{array}$ & 1,000 \\
\hline 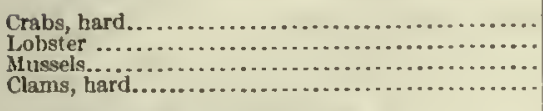 & $\begin{array}{r}95,000 \\
6,100 \\
\quad 40,000 \\
140,000\end{array}$ & $\begin{array}{r}3,700 \\
800 \\
200 \\
17,000\end{array}$ & $\begin{array}{r}95,000 \\
\because 10,000 \\
140,000\end{array}$ & $\begin{array}{l}3,700 \\
17,000\end{array}$ & & & & ........... & $\begin{array}{c}\because, 100 \\
\ldots \ldots\end{array}$ & 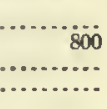 \\
\hline 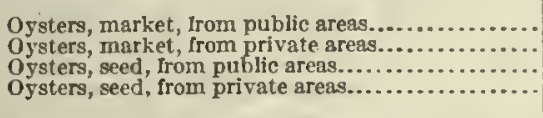 & $\begin{array}{r}832,000 \\
4,363,000 \\
84,364,000 \\
6,096,000\end{array}$ & $\begin{array}{r}2,300 \\
573,000 \\
173,000 \\
240,000\end{array}$ & $\begin{array}{r}532,000 \\
84,363.000 \\
8,304,000 \\
76,096,000\end{array}$ & $\begin{array}{r}2,300 \\
573,000 \\
173,000 \\
240,000\end{array}$ &. & $\cdots$ & & & & $\cdots$ \\
\hline
\end{tabular}

1 Includes apparatus, with catch, as Iollows: Gill nets, 30,000 pounds, valued at $\$ 4,400$; eel and lobster pots and traps, 15,000 pounds, valued at $\$ 1,400 ;$ and fyke and hoop nets, 2,000 pounds, valued at $\$ 100$

Less than $\$ 100$.
\$ $\$ 1,000$ bushels.

5 4,500 bushels.

- 623,000 bushela.

7871,000 buahels.

\section{NEW YORK.}

In the value of fishery products New York ranked third in 1908, being surpassed only by Massachusetts and Virginia. The total value of such products was $\$ 4,594,000$, or 9 per cent of the total for the United States. The chief fishing grounds of the state are Lake Erie, Lake Ontario, the Hudson River, Long Island Sound, and the Atlantic coast region. The first two bodies of water are included in the Great Lakes district, while the remainder constitute the Atlantic coast district. New York is thus peculiar in having both fresh and salt water fisheries of considerable importance and in having fresh-water fisheries in the two natural divisions, the Hudson River being included in the Atlantic coast district.

A summary of the general statistics of the fisheries of the state for 1908 is given in the following statement:

Number of persons employed................ 6,775 Capital:

Vessels and boats, including outfit.......... $\$ 2,058,000$

Apparatus of capture................... $\quad 362,000$

Shore and accessory property and cash ......... 1,413,000 Value of products........................ 4, 594,000

Comparison with previous canvasses.-Prior to the census of 1908 no report covering all of the fisheries of New York had been made for any one year, altliough statistics of the fisheries of Lake Erio and Lake Ontario have been included since 1880 in canvasses of the Great Lakes, and figures for the fisheries of the state along the Atlantic coast have been shown in the reports of the Middle Atlantic states.

In the next table the principal items from the reports on the fisheries of these two districts are given, and composite figures for certain combinations of years are presented as totals for the state.

The number of persons employed as shoresmen and the investment in shore and accessory property and cash capital are excluded from the next table because, owing to the fact that the reports of the Bureau of Fisheries for certain years included with the above items, respectively, the number of men and the amount of capital employed in the wholesale fishery trade and in shore industries related to the fisheries, the statistics secured by that bureau are in these respects not comparable with the census returns.

A comparison of the returns for 1908 with those for 1903-4 shows large decreases in every branch of the industry, including one of 17 per cent in the total amount invested in vessels, boats, and apparatus of capture, and one of 28 per cent in the value of the products. The figures were in fact higher for 1903-4 than for any other canvass, except that the number of vessels was smaller than in 1888-1890 and the quantity of products smaller than in 1880 . 


\begin{tabular}{|c|c|c|c|c|c|c|c|c|c|}
\hline \multirow{3}{*}{ DISTRICT AND YEAR. } & \multirow{3}{*}{$\begin{array}{l}\text { Persons } \\
\text { ern- } \\
\text { ployed, } \\
\text { exclusive } \\
\text { of shores- } \\
\text { men. }\end{array}$} & \multicolumn{6}{|c|}{. EQUTPMENT. } & \multicolumn{2}{|c|}{ PBODUCTS. } \\
\hline & & \multirow{2}{*}{$\begin{array}{l}\text { Total } \\
\text { value. }\end{array}$} & \multicolumn{2}{|c|}{ Vessels. } & \multicolumn{2}{|c|}{ Boats. } & \multirow{2}{*}{$\begin{array}{l}\text { Apparatus } \\
\text { of capture } \\
\text { (value). }\end{array}$} & \multirow{2}{*}{$\begin{array}{l}\text { Quantity } \\
\text { (pounds). }\end{array}$} & \multirow[b]{2}{*}{ Value. } \\
\hline & & & Number. & $\begin{array}{l}\text { Value, in- } \\
\text { cluding } \\
\text { outfit. }\end{array}$ & Number. & Value. & & & \\
\hline 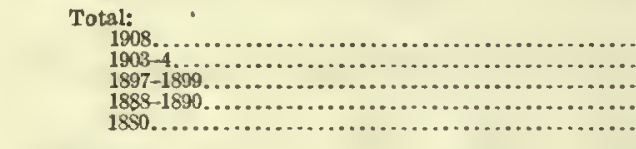 & $\begin{array}{l}6,172 \\
9,732 \\
8,187 \\
7,242 \\
5,650\end{array}$ & $\begin{array}{r}\$ 2,419,000 \\
2,931,000 \\
1,635,000 \\
1,867,000 \\
1,458,000\end{array}$ & $\begin{array}{l}643 \\
711 \\
655 \\
745 \\
541\end{array}$ & $\begin{array}{r}\$ 1,750,000 \\
2,181,000 \\
1,054,000 \\
1,318,000 \\
778,000\end{array}$ & $\begin{array}{l}3,131 \\
5,195 \\
4,510 \\
4,126 \\
3,411\end{array}$ & $\begin{array}{r}\$ 308,000 \\
346,000 \\
293,000 \\
247,000 \\
290,000\end{array}$ & $\begin{array}{r}\$ 362,000 \\
404,000 \\
289,000 \\
301,000 \\
390,000\end{array}$ & $\begin{array}{r}76,485,000 \\
281,844,000 \\
117,516,000 \\
197,754,000 \\
333,523.000\end{array}$ & $\begin{array}{r}\$ 4,594,000 \\
6,418,000 \\
3,634,000 \\
3,604,000 \\
4,381,000\end{array}$ \\
\hline 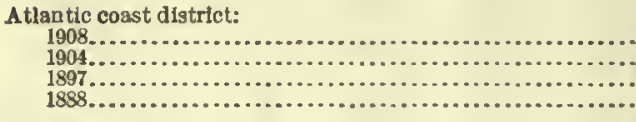 & $\begin{array}{l}5,146 \\
8,496 \\
6,937 \\
5,864\end{array}$ & $\begin{array}{l}2,274,000 \\
2,717,000 \\
1,499,000 \\
1,711,000\end{array}$ & $\begin{array}{l}629 \\
686 \\
643 \\
738\end{array}$ & $\begin{array}{l}1,698,000 \\
2,090,000 \\
1,012,000 \\
1,294,000\end{array}$ & $\begin{array}{l}2,858 \\
4,894 \\
4,089 \\
3,590\end{array}$ & $\begin{array}{l}278,000 \\
321,000 \\
274,000 \\
211,000\end{array}$ & $\begin{array}{l}298,000 \\
306,000 \\
213,000 \\
206,000\end{array}$ & $\begin{array}{r}71,474,000 \\
277,650,000 \\
109,556,000 \\
189,666,000\end{array}$ & $\begin{array}{l}4,390,000 \\
6,231.000 \\
3,392,000 \\
3,348,000\end{array}$ \\
\hline 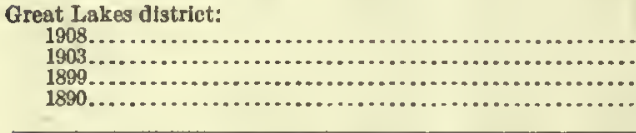 & $\begin{array}{l}1,026 \\
1,236 \\
1,250 \\
1,378\end{array}$ & $\begin{array}{l}145,000 \\
214,000 \\
136,000 \\
156,000\end{array}$ & $\begin{array}{r}14 \\
25 \\
12 \\
7\end{array}$ & $\begin{array}{l}51,000 \\
91,000 \\
42,000 \\
24,000\end{array}$ & $\begin{array}{l}273 \\
301 \\
421 \\
536\end{array}$ & $\begin{array}{l}29,000 \\
25,000 \\
18,000 \\
37,000\end{array}$ & $\begin{array}{l}64,000 \\
98,000 \\
75,000 \\
95,000\end{array}$ & $\begin{array}{l}5,011,000 \\
4,194,000 \\
7,961,000 \\
8,088,000\end{array}$ & $\begin{array}{l}203,000 \\
183,000 \\
2 \pm 2,000 \\
257,000\end{array}$ \\
\hline
\end{tabular}

In the Atlantic Coast district there has been the same tendency toward an increase in the various items up to 1904 and toward a sudden decrease after that date. In the Great Lakes district the number of fishermen has steadily decreased, but up to 1903 the number and value of vessels increased. The number of boats in this district has decreased, but since 1899 their total value has advanced, as a result of the increasing use of motor boats. The amount invested in apparatus of capture in the fisheries of the Great Lakes was less in 1908 than at any previous canvass, but in the value of the products there was an increase from 1903 to 1908 of $\$ 16,000$, or 8 per cent.

Persons employed.- The following table gives the number of persons employed in the fishing industry of New York in 1908:

\begin{tabular}{|c|c|c|c|c|c|c|c|}
\hline \multirow{3}{*}{ DISTEICT AND CLASS. } & \multicolumn{7}{|c|}{ PERSONS EMPLOYED: 1908.} \\
\hline & \multicolumn{4}{|c|}{ Number. } & \multicolumn{3}{|c|}{ Salaries and wages. } \\
\hline & Total. & $\begin{array}{l}\text { Proprictors } \\
\text { and inde- } \\
\text { pendent } \\
\text { fishermen. }\end{array}$ & $\begin{array}{c}\text { Salarled } \\
\text { employees. }\end{array}$ & $\begin{array}{l}\text { Wage- } \\
\text { earners. }\end{array}$ & Total & Salaries. & Wages. \\
\hline Total. ............. & 6,775 & 13,270 & 53 & 3,452 & $\$ 1,177,000$ & $\$ 45,000$ & \& $\$ 1,133,000$ \\
\hline 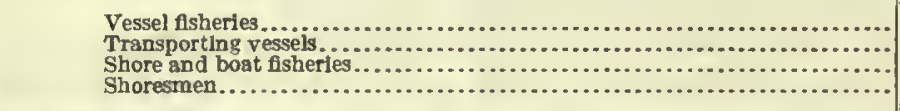 & $\begin{array}{r}2,239 \\
314 \\
3,619 \\
603 \\
\end{array}$ & $\begin{array}{r}501 \\
76 \\
2,693 \\
\end{array}$ & 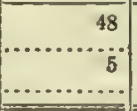 & $\begin{array}{r}1,690 \\
238 \\
921 \\
603 \\
\end{array}$ & $\begin{array}{l}700,000 \\
101,000 \\
231,000 \\
142,000\end{array}$ & $\begin{array}{r}40,000 \\
4,800 \\
\cdots\end{array}$ & $\begin{array}{l}660,000 \\
104,000 \\
227,000 \\
142,000\end{array}$ \\
\hline Atlantic coast district ....................... & 6,749 & . 2,380 & 63 & 3,316 & $1,127,000$ & 45,000 & $1, \overline{082,000}$ \\
\hline 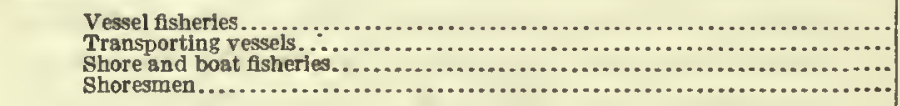 & $\begin{array}{r}2,157 \\
314 \\
2,675 \\
603\end{array}$ & $\begin{array}{r}491 \\
76 \\
1,813 \\
\end{array}$ & 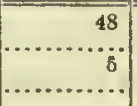 & $\begin{array}{r}1,018 \\
238 \\
857 \\
603\end{array}$ & $\begin{array}{l}665,000 \\
104,000 \\
216,000 \\
142,000\end{array}$ & $\begin{array}{r}40,000 \\
4,800 \\
\ldots . .6 \%\end{array}$ & $\begin{array}{l}626,000 \\
104,000 \\
211,000 \\
142,000\end{array}$ \\
\hline 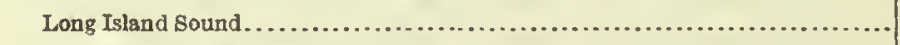 & 1,429 & 588 & 19 & 822 & 269,000 & 17,000 & 252,000 \\
\hline 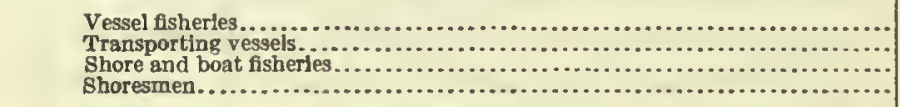 & $\begin{array}{r}453 \\
61 \\
617 \\
298\end{array}$ & $\begin{array}{r}126 \\
22 \\
440 \\
\cdots\end{array}$ & \begin{tabular}{c|c|}
19 \\
$\cdots \cdots$ \\
$\cdots \cdots$
\end{tabular} & $\begin{array}{r}308 \\
39 \\
177 \\
298\end{array}$ & $\begin{array}{r}158,000 \\
15,000 \\
67,000 \\
28,000\end{array}$ & \begin{tabular}{r|}
17,000 \\
$\cdots \cdots$ \\
$\cdots \cdots$
\end{tabular} & $\begin{array}{r}141,000 \\
15,000 \\
67,000 \\
28,000\end{array}$ \\
\hline 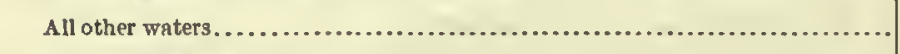 & 4,320 & 1,792 & 34 & 2,494 & 858,000 & 27,000 & 830,000 \\
\hline 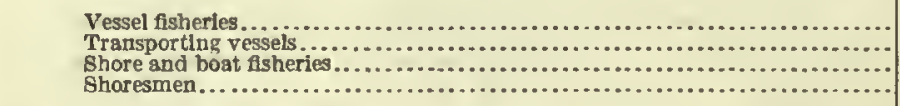 & $\begin{array}{r}1,704 \\
253 \\
2,0.58 \\
305\end{array}$ & $\begin{array}{r}365 \\
54 \\
1,373 \\
\cdots\end{array}$ & 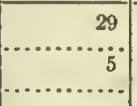 & $\begin{array}{r}1,310 \\
199 \\
680 \\
305\end{array}$ & $\begin{array}{r}508,000 \\
89,000 \\
148,000 \\
113,000\end{array}$ & $\begin{array}{r}23,000 \\
4,500 \\
\ldots \ldots\end{array}$ & $\begin{array}{r}485,000 \\
89,000 \\
143,000 \\
113,000\end{array}$ \\
\hline 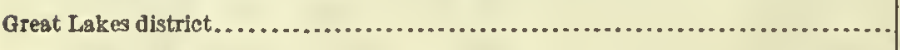 & 1,026 & 890 & $\ldots \ldots$ & 136 & 51,000 & & 51,000 \\
\hline 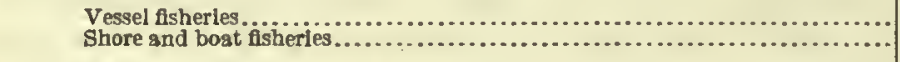 & 82 & 880 & a............... & 72 & $\begin{array}{l}35,000 \\
16,000\end{array}$ & $\cdots \cdots \cdots$ & $\begin{array}{l}35,000 \\
16,000\end{array}$ \\
\hline 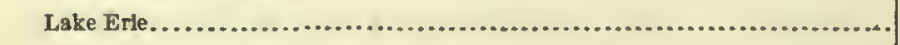 & 730 & .615 & ( $\ldots \ldots \ldots \ldots$ & 115 & 48,000 & . . . . . . . & 48,000 \\
\hline 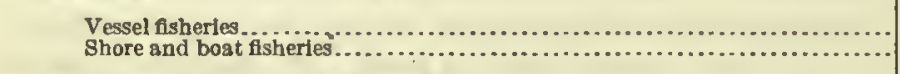 & $\begin{array}{r}82 \\
648\end{array}$ & 605 & 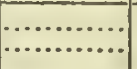 & $\begin{array}{l}72 \\
43\end{array}$ & $\begin{array}{l}35,000 \\
13,000\end{array}$ & $\ldots \ldots \ldots \ldots$ & $\begin{array}{l}35,000 \\
13,000\end{array}$ \\
\hline 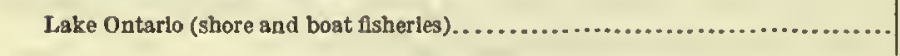 & 296 & 275 & & 21 & 2,900 & & 2,900 \\
\hline
\end{tabular}


Of the total number of persons engaged in the fisheries of the state, including shoresmen, 5,749 , or 85 per cent, were reported for the Atlantic coast district. The shore and boat fisheries are credited with 53 per cent of the total number of persons employed. The number of proprietors and independent fishermen was much higher, relatively, for the Great Lakes district than for the Atlantic coast district, being 87 per cent of all persons employed in the case of the former district and only 41 per cent in the case of the latter.

Equipment and other capital.-The total investment in the fisheries of the state was $\$ 3,832,000$. The amounts represented by the principal items are shown in detail in the following table:

\begin{tabular}{|c|c|c|c|c|c|c|c|}
\hline \multirow{3}{*}{ CLASS OF INVESTMENT. } & \multicolumn{7}{|c|}{ VALUE OF EQUTPLENT AND OTHER CAPTTAL: 1908.} \\
\hline & \multirow[b]{2}{*}{ Aggregate. } & \multicolumn{3}{|c|}{ Atlantic coast distriet. } & \multicolumn{3}{|c|}{ Great Lakes distriet. } \\
\hline & & Total. & $\begin{array}{l}\text { Long Island } \\
\text { sound. }\end{array}$ & $\begin{array}{l}\text { All other } \\
\text { waters. }\end{array}$ & Total. & Lake Erie. & $\begin{array}{c}\text { Lake } \\
\text { Ontario. }\end{array}$ \\
\hline Total............... & $\$ 3,832,000$ & $\$ 3,666,000$ & $\$ 979,000$ & $\$ 2,687,000$ & $\$ 166,000$ & $\$ 131,000$ & $\$ 35,000$ \\
\hline Vessels, including outfit. . & $1,750,000$ & $1,698,000$ & 392,000 & $1,307,000$ & 51,000 & 51,000 & \\
\hline Fisbing................ & $1,406,000$ & $1,354,000$ & 335,000 & $1,019,000$ & 51,000 & 51,000 & (............ \\
\hline & $\begin{array}{l}783,000 \\
664,000\end{array}$ & 732,000 & $\begin{array}{l}305,000 \\
259,000\end{array}$ & $\begin{array}{l}427,000 \\
364,000\end{array}$ & $\begin{array}{l}51,000 \\
42,000\end{array}$ & $\begin{array}{l}51,000 \\
42,000\end{array}$ & (n............. \\
\hline $\begin{array}{l}\text { Vessels.................. } \\
\text { Outfit............... }\end{array}$ & $\begin{array}{l}664,000 \\
119,000\end{array}$ & 110,000 & $\begin{array}{r}259,000 \\
47,000\end{array}$ & $\begin{array}{r}364,000 \\
63,000\end{array}$ & $\begin{array}{r}42,000 \\
9,100\end{array}$ & $\begin{array}{r}42,000 \\
9,100\end{array}$ & .......... \\
\hline Sail & 614,000 & 614,000 & 30,000 & 584,000 & .......... & ......... & \\
\hline Vessels......... & 426,000 & $\$ 26,000$ & 28,000 & 398,000 & ......... & (............. & $\because$ \\
\hline Outfit.......... & 189,000 & 188,000 & 1,800 & 187,000 & ....... & (............... & \\
\hline Other................. & 8,000 & 8,000 & 56 & 8,000 & & (n. & \\
\hline $\begin{array}{l}\text { Transporting.............. } \\
\text { Steam and motor... }\end{array}$ & 344,000 & 344,000 & 56,000 & 288,000 & & & \\
\hline 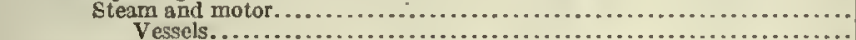 & 209,000 & 209,000 & 39,000 & 171,000 & & (................ & $\cdots \cdot \cdot$ \\
\hline 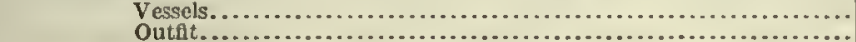 & 173,000 & 173,000 & 32,000 & 141,000 & -........ & . $\ldots \ldots \ldots \ldots$ & an.......... \\
\hline 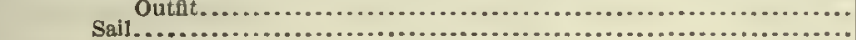 & $\begin{array}{r}37,000 \\
135,000\end{array}$ & $\begin{array}{r}37,000 \\
135,000\end{array}$ & $\begin{array}{r}6,600 \\
\end{array}$ & $\begin{array}{r}30,000 \\
117,000\end{array}$ & n............. & $\because \ldots \ldots \ldots$ & 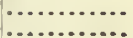 \\
\hline 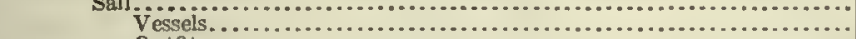 & $\begin{array}{l}135,000 \\
117,000\end{array}$ & $\begin{array}{l}135,000 \\
117,000\end{array}$ & $\begin{array}{l}17,000 \\
15,000\end{array}$ & $\begin{array}{l}117,000 \\
102,000\end{array}$ & & 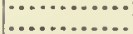 & $\ldots$. \\
\hline Outfit.............. & 18,000 & 18,000 & 2,700 & 15,000 & & (n........... & $\cdots$ \\
\hline Other............... & 300 & 300 & 300 & & & & \\
\hline $\begin{array}{l}\text { Boats........................ } \\
\text { Steam and motor.... }\end{array}$ & 308,000 & 278,000 & 67,000 & 211,000 & 29,000 & 18,000 & $\begin{array}{r}11,000 \\
8,800\end{array}$ \\
\hline 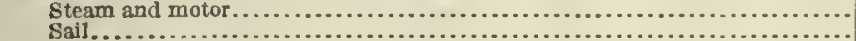 & 187,000 & 162,000 & 41,000 & 120,000 & 25,000 & 17,000 & $\begin{array}{r}8,800 \\
800\end{array}$ \\
\hline 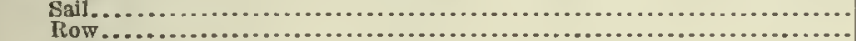 & 42,000 & 40,000 & 12,000 & 28,000 & 1,200 & 300 & 800 \\
\hline 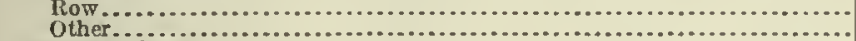 & 61,000 & 58,000 & 11,000 & 47,000 & 2.900 & 1,200 & 7,700 \\
\hline 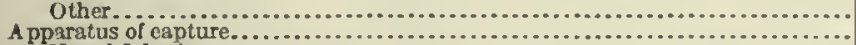 & 18,000 & 18,000 & 2,200 & 16,000 & 100 & & 100 \\
\hline $\begin{array}{l}\text { pparatus of capture............... } \\
\text { Vessel fisheries............. }\end{array}$ & 362,000 & 298,000 & 80,000 & 217,000 & 64,000 & 49,000 & 16,000 \\
\hline $\begin{array}{l}\text { Vessel fisheries................ } \\
\text { Shore and boat fisheries...... }\end{array}$ & 114,000 & 87,000 & 8,700 & 78,000 & 27,000 & 27,000 & \\
\hline Shore and boat fisheries...... & 248,000 & 211,000 & 71,000 & 139,000 & 37,000 & 22,000 & 16,000 \\
\hline 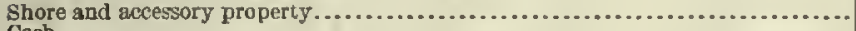 & 665,000 & 647,000 & 183,000 & 464,000 & 19,000 & 11,000 & 7,900 \\
\hline 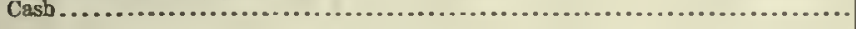 & 747,000 & 745,000 & 258,000 & 487,000 & 2,200 & 2,200 & \\
\hline
\end{tabular}

The number and tonnage of the vessels and the number of the boats were as follows:

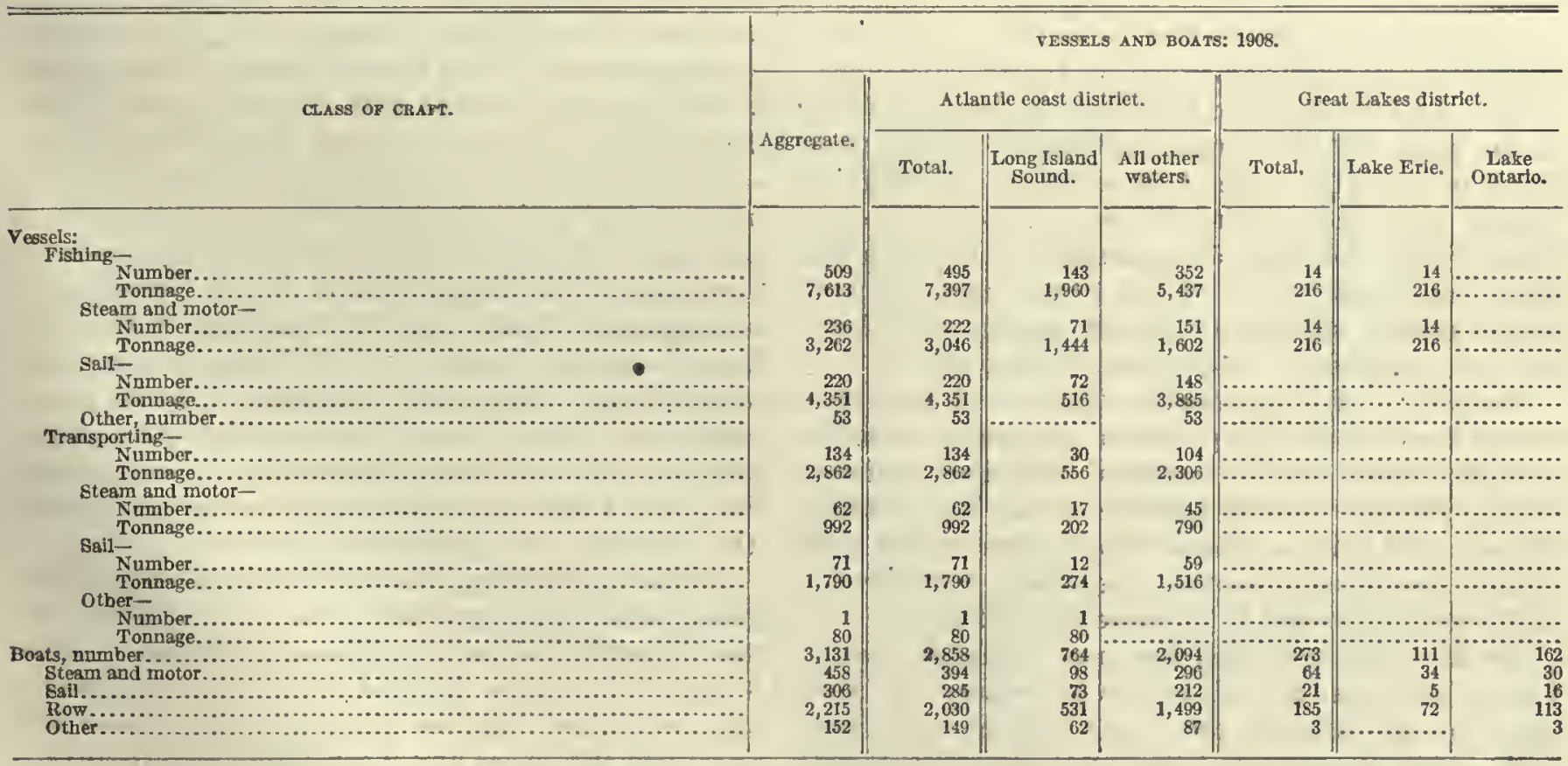


The largest investment was in vessels, 46 per cent of the total capital being invested in fishing and trausporting vessels and their outfits. From 1903-4 to 1908 there was an increase of 3 in the number of fishing vessels, accompanied by a decrease of 2,703 in the net tonnage, while both the number and the tonnage of transporting vessels decreased, the falling off in number amounting to 70 and that in net tonnage to 858 . The total investment in apparatus of capture was $\$ 362,000$, over two-thirds of which pertained to the shore and boat fisheries. In the Great
Lakes district the largest investment was in apparatus of capture, the value of which represented 39 per cent of the total investment for this district.

The investment in shore and accessory property and the cash capital reported, which together represented over a third of the total investment, were confined almost wholly to the Atlantic coast fisheries.

The following table gives detailed statistics concerning the number of the principal kinds of apparatus of capture used:

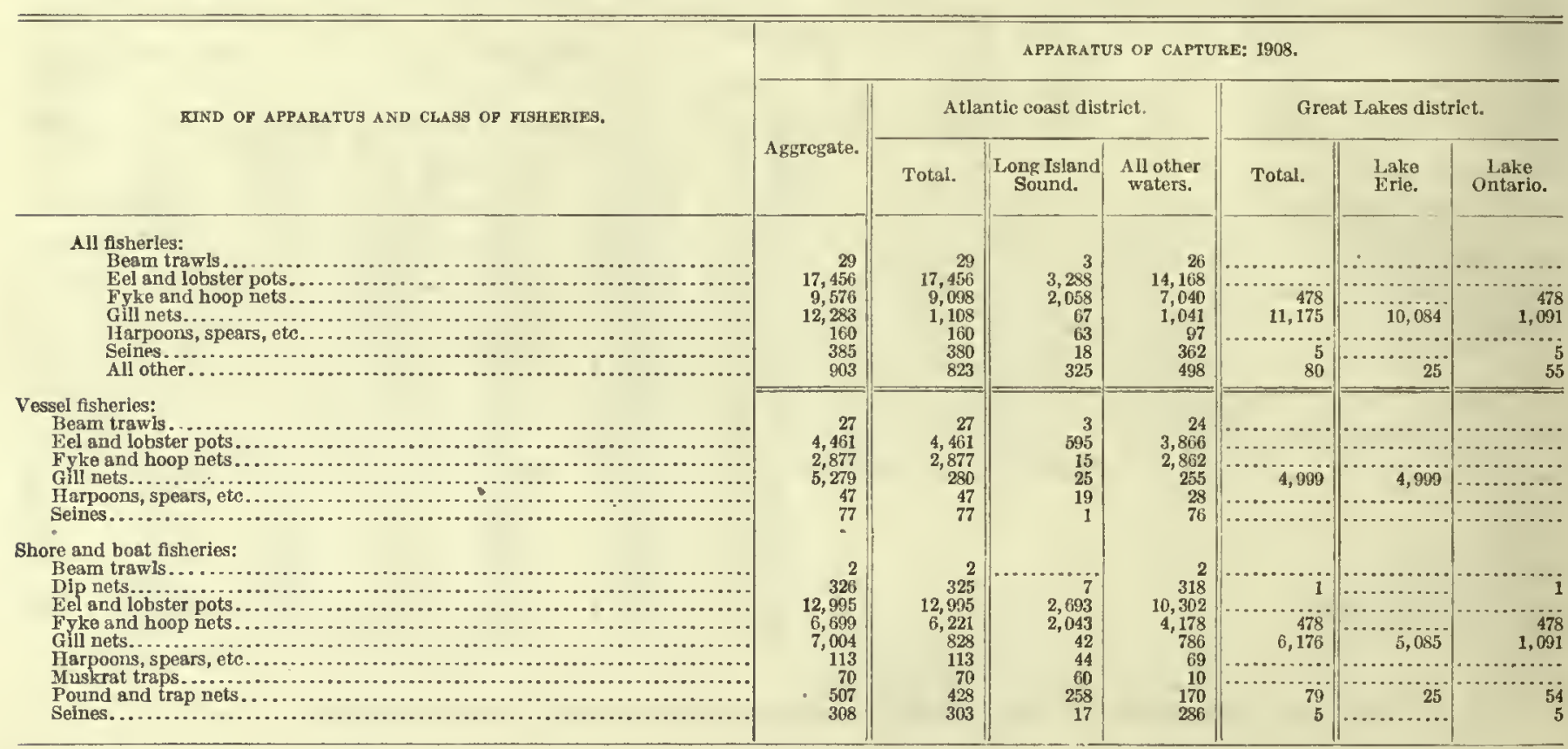

Products, by species.-The products of the New York fisheries in 1908 amounted to $76,485,000$ pounds, valued at $\$ 4,594,000$, and are shown in detail in Table 1 , on page 204. Mollusks contributed nearly twothirds of the total value of all products, the value of oysters alone constituting 56 per cent of the total. The value of the catch of squeteague, which was the most important species of fish proper reported and which ranked second to oysters among all fishery products, represented 10 per cent of the total.

Products, by fishing grounds.-Table 6, on page 207, shows the total fishery products of the state, distributed by species and by districts. Detailed statistics of the products of the Atlantic coast, Long Island Sound, Lake Erie, and Lake Ontario districts, by kind and by apparatus of capture, are shown, respectively, in Tables 2, 3, 4, and 5, on pages 205 to 207.

As all of the mollusks, the most valuable class of fishery products, and all of the salt-water fish were taken on the Atlantic coast, this district is credited with a large proportion of the total value of products. Fish contributed 31 per cent of the total value of products of the Atlantic coast district. The value of squeteague, which is by far the most important species of fish caught, combined with that of bluefish, flounders, and cod, made up nearly three-fourths of the entire value of the fish caught in this district. All the pike perch, lake herring, and whitefish were taken in the Great Lakes district, Lake Erie fumishing much the larger part of the value of each of these. Some species were taken in the Hudson River and also in the Great Lakes; als and German carp were taken principally in the Hudson River, and sturgeon and catfish principally in the Great Lakes. The most important species taken in Lake Erie were pike perch and lake herring. For Lake Ontario the principal specics were catfish and bullheads, pike perch, and sturgeon.

Products, by class of fisheries.-Table 7, on page 208, gives statistics of the fishery products of New York, distributed by species and by class of fisheries. Tables 8 and 10 , on pages 209 and 210 , show the distribution by districts of the products of the vessel fisheries and the shore and boat fisheries, respectively, ranked according to value. 
The following tabular statement slows the distribution, according to species arranged in the order of their value, of the total value of products for each class of fisheries:

\begin{tabular}{|c|c|c|c|}
\hline \multirow[b]{2}{*}{ SPECIES. } & \multicolumn{3}{|c|}{ VALUE OP PRODUCTS: 1908.} \\
\hline & Total. & $\begin{array}{c}\text { Yessel } \\
\text { Asheries. }\end{array}$ & $\begin{array}{c}\text { Shore and } \\
\text { bont } \\
\text { fisheries. }\end{array}$ \\
\hline Total......... & $\$ 4,594,000$ & $\$ 2,860,000$ & $\$ 1,734,000$ \\
\hline 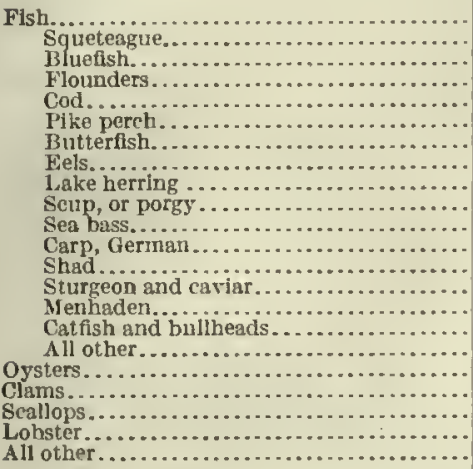 & $\begin{array}{r}1,566,000 \\
451,000 \\
291,000 \\
141,000 \\
99,000 \\
68,000 \\
61,000 \\
57,000 \\
51,000 \\
45,000 \\
35,000 \\
31,000 \\
27,000 \\
23,000 \\
22,000 \\
20,000 \\
140,000 \\
2,553,000 \\
292,000 \\
98,000 \\
57,000 \\
27,000\end{array}$ & $\begin{array}{r}742,000 \\
216,000 \\
268,000 \\
30,000 \\
59,000 \\
38,000 \\
400 \\
11,000 \\
25,000 \\
42,000 \\
16,000 \\
200 \\
(1) \\
18,000 \\
200 \\
16,000 \\
1,952,000 \\
82,000 \\
74,000 \\
18,000 \\
2,800\end{array}$ & $\begin{array}{r}824,000 \\
235,000 \\
22,000 \\
111,000 \\
39,000 \\
30,000 \\
64,000 \\
46,000 \\
26,000 \\
2,600 \\
19,000 \\
31,000 \\
27,000 \\
23,000 \\
4,000 \\
20,000 \\
124,000 \\
601,000 \\
210,000 \\
35,000 \\
40,000 \\
24,000\end{array}$ \\
\hline
\end{tabular}

1 Less than $\$ 100$.

Vessel fisheries are credited with 55 per cent of the weight and 62 per cent of the value of the New York fishery products. Oysters, the most important product for the state as a whole, contributed 68 per cent of the value of the product reported for vessel fisheries of the state as a whole, 70 per cent of the corresponding value for the Atlantic coast district, and 85 per cent of that for the Long Island Sound fisheries. Ninety-seven per cent of the value of the entire eatch reported for vessels represents the value of product secured on the Atlantic coast." The vessels reported for Lake Erie, 14 in number, contributed produets valued at $\$ 73,000$. There were no vessels engaged in fishing on Lake Ontario.

In the shore and boat fisheries, as in the vessel fisheries, oysters were the product of greatest value, representing 35 per cent of the total value of produets. Nearly all the scallops were taken in Long Island Sound; practically all the lake herring eame from the shore and boat fisheries in Lake Erie; and the pike and pickerel almost exclusively from Lake Ontario. The shore and boat fisheries in the Atlantic coast district supplied 93 per cent of the entire eatch reported for this elass of fisheries.

Some species, such as bluefish and scup, were taken almost wholly by the vessel fisheries and others, notably butterfish, earp, sturgeon, and catfish, almost entirely by the shore and boat fisherics. All of the shad produet was from the latter class of fisheries.

Products, by apparatus of capture.-The distribution of the total value of products, arranged in order of the value of their catch, for the state as a whole and for each class of fisheries, is shown in the following tabular statement:

\begin{tabular}{|c|c|c|c|}
\hline \multirow[b]{2}{*}{ - FIND DP APPARATUS, } & \multicolumn{3}{|c|}{ VALUE OF PRODUCTS: 1908.} \\
\hline & Total. & $\begin{array}{l}\text { Vessel } \\
\text { fisheries. }\end{array}$ & $\begin{array}{l}\text { Shore and } \\
\text { bogt } \\
\text { fisheries. }\end{array}$ \\
\hline Total.................. & $\$ 4,594,000$ & $\$ 2,860,000$ & $81,734,000$ \\
\hline 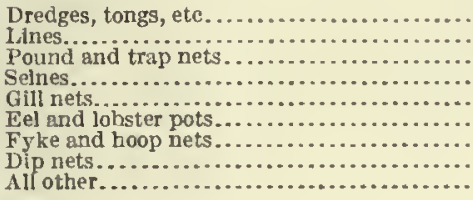 & $\begin{array}{r}2,954,000 \\
442,000 \\
417,000 \\
327,000 \\
246,000 \\
95,000 \\
86,000 \\
9,300 \\
18,000\end{array}$ & $\begin{array}{r}2,100,000 \\
313,000 \\
273,000 \\
118,000 \\
26,000 \\
19,000 \\
12,000\end{array}$ & $\begin{array}{r}854,000 \\
130,000 \\
417,000 \\
54,000 \\
128,000 \\
69,000 \\
67,000 \\
9,300 \\
6,800\end{array}$ \\
\hline
\end{tabular}

The largest eatch was reported for dredges, tongs, ete., which took produets valued at $\$ 2,954,000$, or 64 per cent of the total. Nearly three-fourths of the entire vessel eatch and almost half of the entire shore and boat eatch were taken by these forms of apparatus.

The following tabular statement distributes the value of the catch with dredges, tongs, etc., by species and by class of fisheries:

\begin{tabular}{|c|c|c|c|}
\hline \multirow{2}{*}{ CLASS OP FISHERIES AND SPECIES. } & \multicolumn{3}{|c|}{$\begin{array}{l}\text { VALUE OF PRODUCT TAKEN WITE } \\
\text { DREDGES, TONOS, ETC.: } 1908 .\end{array}$} \\
\hline & Total. & $\begin{array}{l}\text { Long Island } \\
\text { Sound. }\end{array}$ & $\begin{array}{l}\text { All other } \\
\text { waters. }\end{array}$ \\
\hline 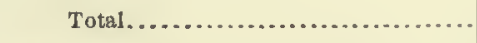 & $\$ 2,954,000$ & $\$ \$ 46,000$ & $\$ 2,108,000$ \\
\hline Vessel flsheries...... & $2,100,000$ & 576,000 & $1,523,000$ \\
\hline 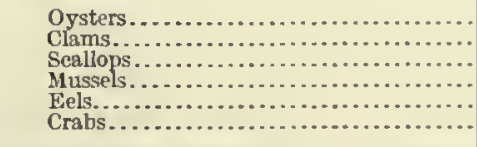 & $\begin{array}{r}1,952,000 \\
82,000 \\
64,000 \\
1,600 \\
400 \\
300\end{array}$ & $\begin{array}{r}499,000 \\
15,000 \\
63,000 \\
\ldots \ldots \\
\cdots\end{array}$ & $\begin{array}{r}1,453,000 \\
67,000 \\
1,000 \\
1,600 \\
400 \\
300\end{array}$ \\
\hline Shore and hoat fisherles......... & 854,000 & 270,000 & 585,000 \\
\hline 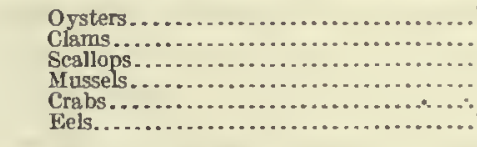 & $\begin{array}{r}601,000 \\
210,000 \\
34,000 \\
6,600 \\
1,000 \\
1,000\end{array}$ & $\begin{array}{r}145,000 \\
91,000 \\
34,000 \\
\cdots \\
\cdots\end{array}$ & $\begin{array}{r}457,000 \\
119,000 \\
200 \\
6,600 \\
1,000 \\
1,000\end{array}$ \\
\hline
\end{tabular}

Lines were next in importance with respect to the value of products taken, more than lalf the entire value of the line eateh representing the value of bluefish, while cod stood next, contributing 22 per cent of the total value.

The value reported for the various products taken with lines is given in the following tabular statement: 


\begin{tabular}{|c|c|c|c|c|c|c|c|}
\hline \multirow{3}{*}{ CLASS OF FISHERIES AND RPECIES. } & \multicolumn{7}{|c|}{ YALUE OF PRODUCT TAKEN WITH LENES: 1908.} \\
\hline & \multirow{2}{*}{ Aggregate. } & \multicolumn{3}{|c|}{ Atiantic coast district. } & \multicolumn{3}{|c|}{ Great Lakes distrlct. } \\
\hline & & Total. & $\begin{array}{l}\text { Long lsland } \\
\text { Sound. }\end{array}$ & $\begin{array}{l}\text { All other } \\
\text { waters. }\end{array}$ & Total. & Lake Erie. & $\begin{array}{c}\text { Lake } \\
\text { Ontario. }\end{array}$ \\
\hline Total................... & $\$ 442,000$ & $\$ 397,000$ & $\$ 5,700$ & $\$ 391,000$ & $\$ 45,000$ & $\$ 5,700$ & $\$ 39,000$ \\
\hline Vessel fisheries. . ... & 313,000 & 313,000 & 2,600 & 310,000 & & & \\
\hline 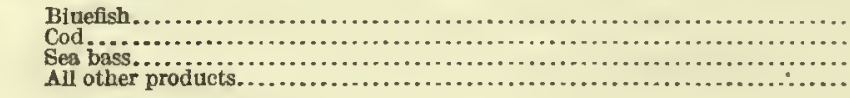 & $\begin{array}{r}243,000 \\
59,000 \\
8,000 \\
2,600\end{array}$ & $\begin{array}{r}243,000 \\
59,000 \\
8,000 \\
2,600\end{array}$ & $\begin{array}{r}100 \\
1,300 \\
1,100 \\
200\end{array}$ & $\begin{array}{r}243,000 \\
58,000 \\
6,900 \\
2,400\end{array}$ & & $\mid \cdots \ldots \ldots \ldots$ & (n............ \\
\hline Shore and boat fisheries..... & 130,000 & 84,000 & 3,100 & 81,000 & 45,000 & 5,700 & 39,000 \\
\hline $\begin{array}{l}\text { Cod } \\
\text { Gea bass } \\
\text { Iladdock }\end{array}$ & $\begin{array}{l}36,000 \\
16,000 \\
11,000\end{array}$ & $\begin{array}{l}36,000 \\
16,000 \\
11,000\end{array}$ & 1,300 & $\begin{array}{l}36,000 \\
15,000 \\
11,000\end{array}$ & & & 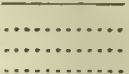 \\
\hline 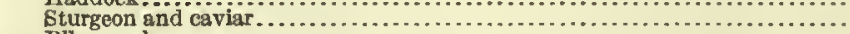 & 10,000 & $\alpha 1,000$ & $\mid \cdots \ldots \ldots \ldots$ & $\ldots . . . .$. & 10,000 & $\ddot{2}, 400$ & 7,700 \\
\hline 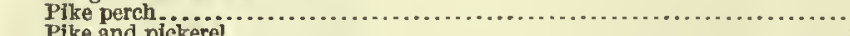 & 8,800 & & $\ldots \ldots \ldots$ & & 8,800 & 2,400 & 6,500 \\
\hline 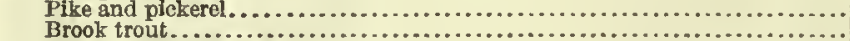 & $\begin{array}{l}7,700 \\
6,300\end{array}$ & (1) & (............ & (1) & 7,700 & .............. & 7,700 \\
\hline 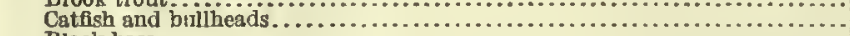 & 6,000 & 100 & & 1000 & 5,900 & 700 & 5,200 \\
\hline 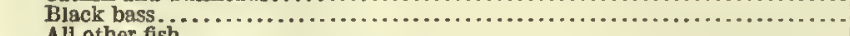 & 5,100 & & & & 5,100 & 100 & 5,000 \\
\hline 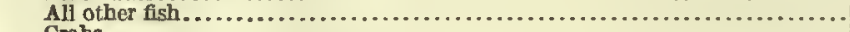 & 18,000 & 17,000 & 1,600 & 15,000 & 1,300 & (3) & 1,200 \\
\hline 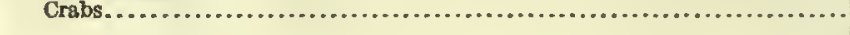 & 4,400 & 4,400 & (............ & 4,400 & ........ & & \\
\hline
\end{tabular}

1 Less than $\$ 100$.

The entire catch with pound and trap nets was reported by the shore and boat fisheries, and its value formed 9 per cent of the total value of products. Squeteague, the chief species thus taken, had a value exceeding that of all other species; flounders and butterfish were also taken in large quantities. The following tabular statement distributes the value of the product taken with pound and trap nets, by species and by districts:

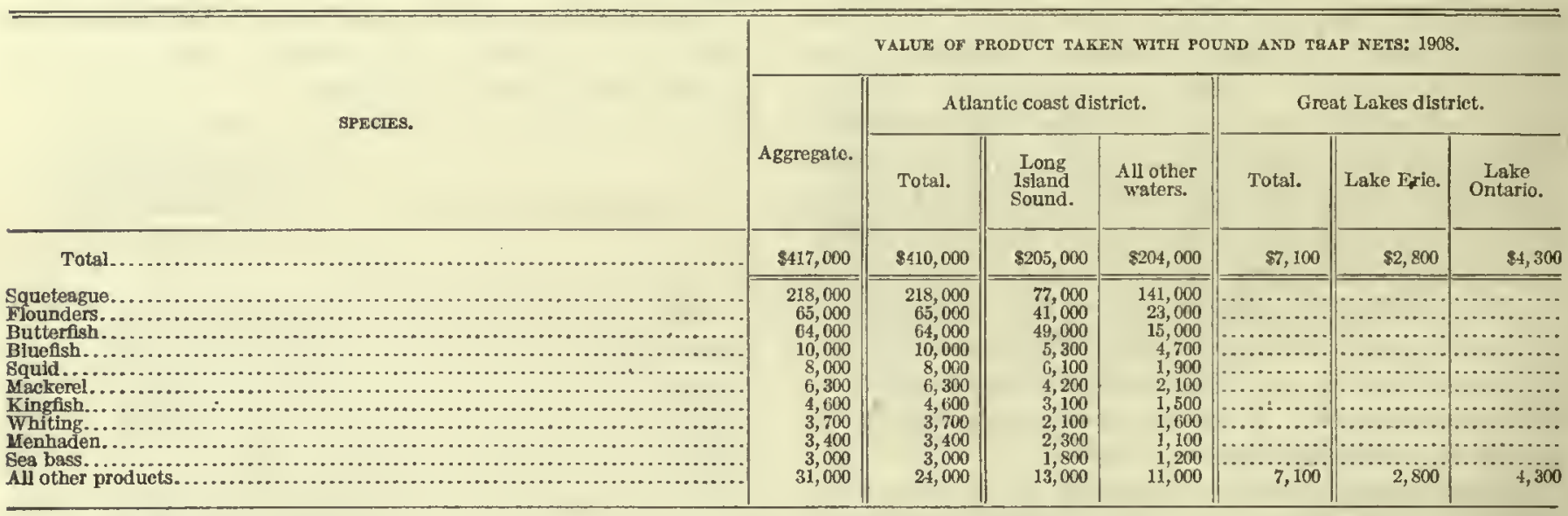

The gill-net catclı amounted to $7,412,000$ pounds, with a value of $\$ 246,000$. Of the 12,283 gill nets reported, 10,084 were used by the Lake Erie fishermen. The most important species taken by these nets were pike perch, for which a value of $\$ 57,000$ was reported; lake herring, for which a value of $\$ 50,000$ was reported; and squeteague, for which a value of $\$ 33,000$ was reported. The value of the gill-net catch, by chief species, by class of fisheries, and by districts, is given in the following tabular statement: 


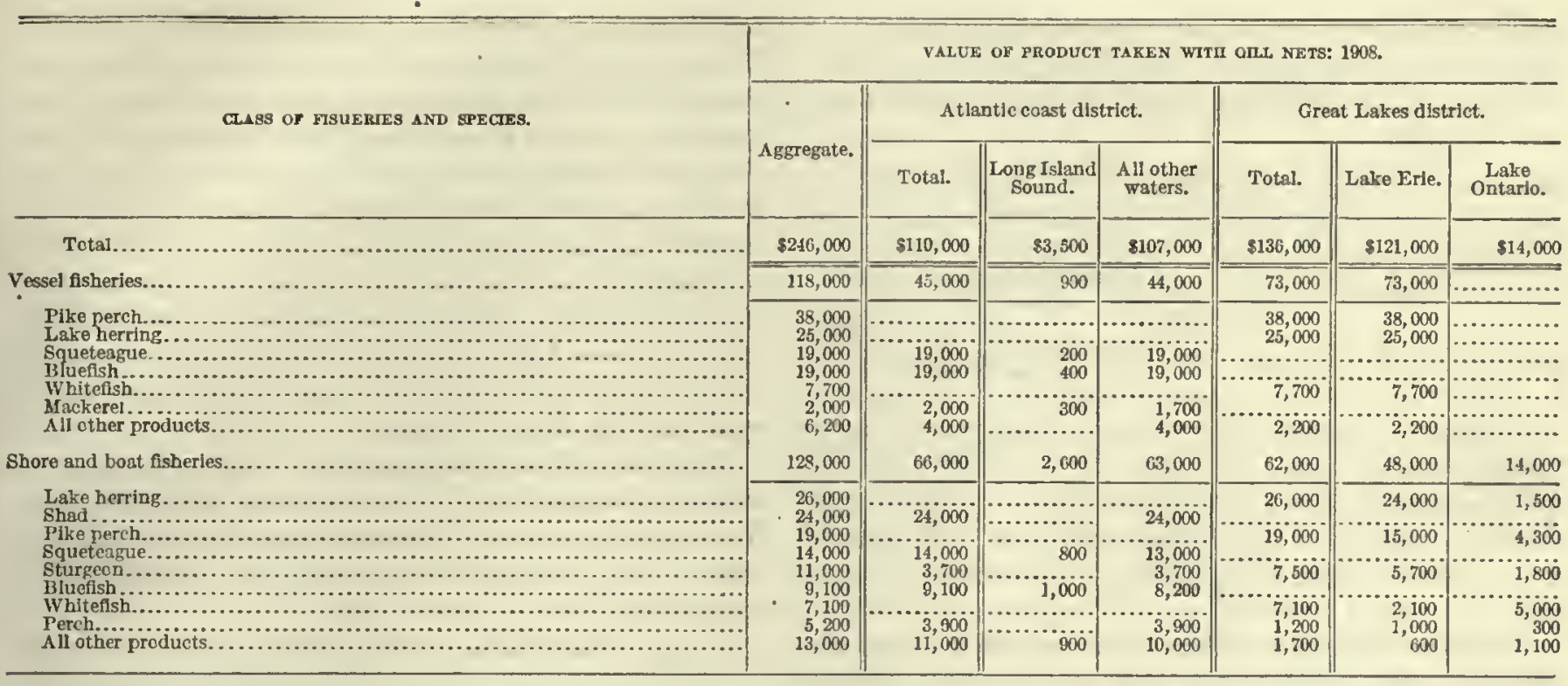

The 385 scines used in 1908 took $18,178,000$ pounds of fish, valued at $\$ 327,000$. Of the total value, 61 per cent was contributed by squeteague, or weakfish, practically all of which product was taken outsida of Long Island Sound by the vessel fishormen. From 1904 to 1908 there was a decrease of $200,511,000$ pounds, valued at $\$ 664,000$, in the seine catch of menhaden, but an increase of 64,000 pounds, valued at $\$ 10,000$, in that of German carp. The value of the seine catch, distributed by chief species, by class of fisheries, and by districts, was as follows:

\begin{tabular}{|c|c|c|c|c|c|}
\hline \multirow{3}{*}{ CLASS OF FISHERIES AND BPECIES. } & \multicolumn{5}{|c|}{$\begin{array}{l}\text { VALUE OF PRODUCT TAKEN WTTL SELNES: } \\
1908 .\end{array}$} \\
\hline & \multirow[b]{2}{*}{$\begin{array}{l}\text { Aggre- } \\
\text { gate. }\end{array}$} & \multicolumn{3}{|c|}{ Atlantic coast district. } & \multirow{2}{*}{$\begin{array}{l}\text { Lake } \\
\text { Onta. } \\
\text { rio. }\end{array}$} \\
\hline & & Total. & $\begin{array}{l}\text { Long } \\
\text { Island } \\
\text { Sound. }\end{array}$ & $\begin{array}{c}\text { All } \\
\text { other } \\
\text { waters. }\end{array}$ & \\
\hline Total... & 8327,000 & 8324,000 & $\$ 2,800$ & $\$ 321,000$ & $\$ 2,700$ \\
\hline Vessel fisheries............ & 273,000 & 273,000 & (1) & 273,000 & $\ldots \ldots \ldots$ \\
\hline 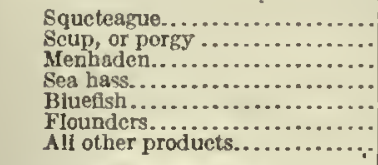 & $\begin{array}{r}197,000 \\
12,000 \\
17,000 \\
7,300 \\
6,000 \\
1,000 \\
1,800\end{array}$ & $\begin{array}{r}197,000 \\
42,000 \\
17,000 \\
7,300 \\
6,000 \\
1,600 \\
1,800\end{array}$ & $\begin{array}{l}(1) \\
\cdots \cdots \cdots \\
\cdots \cdots \cdots \\
\cdots \cdots \cdots \\
\cdots \cdots \cdots \\
\cdots \cdots \cdots\end{array}$ & \begin{tabular}{|r|}
197,000 \\
42,000 \\
17,000 \\
7,300 \\
6,000 \\
1,600 \\
1,800
\end{tabular} & 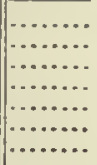 \\
\hline Shore and boat fishcries............ & $54 ; 000$ & 51,000 & 2,800 & 48,000 & 2,700 \\
\hline 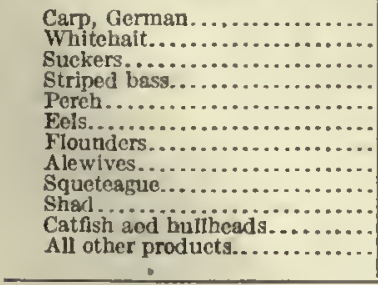 & $\begin{array}{r}23,000 \\
4,600 \\
4,400 \\
3,400 \\
3,300 \\
2,700 \\
2,600 \\
2,400 \\
2,200 \\
1,800 \\
1,300 \\
1,800\end{array}$ & $\begin{array}{r}23,000 \\
4,600 \\
1,7700 \\
3,400 \\
3,300 \\
2,700 \\
2,600 \\
2,400 \\
2,200 \\
1,800 \\
1,300 \\
1,800\end{array}$ & $\begin{array}{c}700 \\
\cdots \\
200 \\
1,400 \\
1,40\end{array}$ & $\begin{array}{r}23,000 \\
4,600 \\
1,700 \\
2,600 \\
3,300 \\
2,700 \\
2,400 \\
2,400 \\
800 \\
1,800 \\
1,300 \\
1,300\end{array}$ & 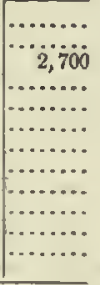 \\
\hline
\end{tabular}

The catch made with pots was confined to the Atlantic coast district. The value of the product taken in this way was $\$ 95,000$, of which $\$ 57,000$ represented the value of lolsters, $\$ 37,000$ the value of ecls, and the remainder that of a few fish and crabs. Detailed statistics as to the value of the catch made with pots, by species, are given in the following tabular statement:

\begin{tabular}{|c|c|c|c|}
\hline \multirow{2}{*}{ CLASS OF FISHERIES AND SPECIES. } & \multicolumn{3}{|c|}{$\begin{array}{l}\text { VALUE OF PRODUCT TAKEN WTTH } \\
\text { POTS: } 1908 \text {. }\end{array}$} \\
\hline & Total. & $\begin{array}{l}\text { Long Island } \\
\text { Sound. }\end{array}$ & $\begin{array}{l}\text { All other } \\
\text { waters. }\end{array}$ \\
\hline Total.................. & $\$ 95,000$ & $\$ 17,000$ & $\$ 78,000$ \\
\hline Vessel fisheries....... & 26,000 & 2,200 & 24,000 \\
\hline 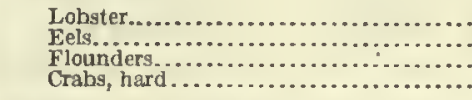 & $\begin{array}{r}18,000 \\
8,300 \\
200 \\
100\end{array}$ & $\begin{array}{r}1,900 \\
300\end{array}$ & $\begin{array}{r}16,000 \\
8,000 \\
200 \\
100\end{array}$ \\
\hline Shore and boat fisheries.................. & 69,000 & 15,000 & 54,000 \\
\hline 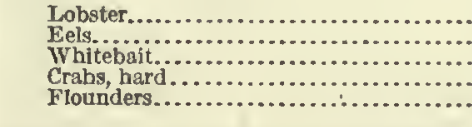 & $\begin{array}{r}39,000 \\
29,000 \\
900 \\
300 \\
100\end{array}$ & $\begin{array}{r}9,600 \\
5,200 \\
(3) \\
6 \cdots\end{array}$ & $\begin{array}{r}29,000 \\
24,000 \\
900 \\
200 \\
100\end{array}$ \\
\hline
\end{tabular}

Flounders were the most important species taken with fyke and hoop nets, the value of the catch amounting to $\$ 56,000$ and constituting 66 per cent of the entire value of the catch taken with this form of apparatus. Detailed statistics as to the value of the fyke and hoop net catch, by species, are as follows:

\begin{tabular}{|c|c|c|c|c|c|}
\hline \multirow{3}{*}{ CLASS OF FISAERIES AND SPECIES. } & \multicolumn{5}{|c|}{$\begin{array}{l}\text { VALUE OF PRODUCT TAKEN WITH FYKE AND } \\
\text { HOOP NETS: 1908. }\end{array}$} \\
\hline & \multirow{2}{*}{$\begin{array}{l}\text { Aggre- } \\
\text { gate. }\end{array}$} & \multicolumn{3}{|c|}{ Atlantic coast dlstriet. } & \multirow{2}{*}{$\begin{array}{l}\text { Lake } \\
\text { Ontario. }\end{array}$} \\
\hline & & Total. & $\begin{array}{l}\text { Long } \\
\text { 1sland } \\
\text { Sound. }\end{array}$ & $\begin{array}{c}\text { All } \\
\text { other } \\
\text { waters. }\end{array}$ & \\
\hline Total... & $\$ 80,000$ & $\$ 73,000$ & $\$ 24,000$ & $\$ 49,000$ & $\$ 13,000$ \\
\hline Vessel fisheries.... & 19,000 & 19,000 & 100 & 19,000 & 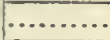 \\
\hline $\begin{array}{l}\text { Flounders................... } \\
\text { All other products............. }\end{array}$ & $\begin{array}{r}19,000 \\
100\end{array}$ & $\begin{array}{r}19,000 \\
100\end{array}$ & 100 & $\begin{array}{l}19,000 \\
(1)\end{array}$ & (…........... \\
\hline Shore and bost fisheries.... & 67,000 & 54,000 & 24,000 & 30,000 & 13,000 \\
\hline 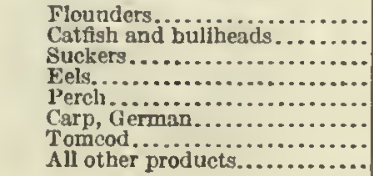 & $\begin{array}{r}37,000 \\
9,700 \\
5,600 \\
4,100 \\
2,900 \\
1,400 \\
1,400 \\
4,300\end{array}$ & $\begin{array}{r}37,000 \\
3,500 \\
3,500 \\
2,200 \\
2,300 \\
1,400 \\
1,400 \\
2,100\end{array}$ & $\mid \begin{array}{r}23,000 \\
\cdots \ldots \ldots . . . \\
\cdots \ldots \ldots \\
(i) \\
\cdots, \ldots 0 \\
300 \\
600\end{array}$ & \begin{tabular}{|r|}
14,000 \\
3,500 \\
3,500 \\
2,200 \\
2,300 \\
1,400 \\
1,000 \\
1,500
\end{tabular} & $\begin{array}{r}6,200 \\
2,200 \\
2,000 \\
000 \\
100 \\
\ldots \\
2,200\end{array}$ \\
\hline & & & & & 2,200 \\
\hline
\end{tabular}


The entire catch with dip nets was reported by the shore and bont fisheries. Statistics as to the value of the catch, by species, are given in the following tabular statement:

\begin{tabular}{|c|c|c|c|c|c|}
\hline \multirow{3}{*}{ SPECIES. } & \multicolumn{5}{|c|}{ VALUE OF PRODUCT TAKEN WITH DIP NETS: 1908.} \\
\hline & \multirow{2}{*}{$\begin{array}{l}\text { Aggre- } \\
\text { gate. }\end{array}$} & \multicolumn{3}{|c|}{ Atlantle coast district. } & \multirow{2}{*}{$\begin{array}{c}\text { Lake } \\
\text { Ontarlo. }\end{array}$} \\
\hline & & Total. & $\begin{array}{l}\text { Long } \\
\text { lsland } \\
\text { Sound. }\end{array}$ & $\begin{array}{c}\text { All } \\
\text { other } \\
\text { waters. }\end{array}$ & \\
\hline Total........... & $\$ 9,300$ & $\$ 9,300$ & $\$ 300$ & $\$ 9,000$ & $\$ 100$ \\
\hline 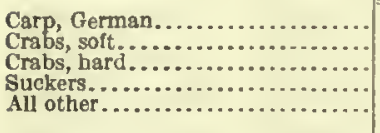 & $\begin{array}{r}4,400 \\
1,100 \\
1,100 \\
900 \\
1,500\end{array}$ & $\begin{array}{r}4,400 \\
1,400 \\
1,100 \\
900 \\
1,500\end{array}$ & $\begin{array}{c}\cdots \\
(1) \\
200\end{array}$ & $\begin{array}{l}4,400 \\
1,400 \\
1,000 \\
900 \\
1,300\end{array}$ & (n) \\
\hline
\end{tabular}

1 Less than $\$ 100$.

Principal species.-Table 9, on page 209, gives the quantity and value of the principal fishery products for 1908 in comparison with the figures for former years for which returns are available. The five leading species, ranked according to value in the respective years, were as follows:

\begin{tabular}{|c|c|c|c|}
\hline 1908 & $1898-09$ & 1890 . & 1880 \\
\hline $\begin{array}{l}\text { Oysters. } \\
\text { Squeteague. } \\
\text { Clams. } \\
\text { Bluefish. } \\
\text { Flounders. }\end{array}$ & $\begin{array}{l}\text { Oysters. } \\
\text { Menhaden. } \\
\text { Bluefish. } \\
\text { Clams. } \\
\text { Sturgeon. }\end{array}$ & $\begin{array}{l}\text { Oysters. } \\
\text { Clams. } \\
\text { Menhaden. } \\
\text { Blueffsh. } \\
\text { Shad. }\end{array}$ & $\begin{array}{l}\text { Oysters. } \\
\text { Menhaden. } \\
\text { Clams. } \\
\text { Sbad. } \\
\text { Squeteague. }\end{array}$ \\
\hline
\end{tabular}

Oysters and clams appear among the five leading species for each of the four years; menhaden and bluefish for three of the years; squeteague and shad for two years; and flounders and sturgeon for one year each.

Oysters.-In 1904 New York ranked first among the states in the value of its oyster product, but in 1908 it held second place, Connecticut ranking first. Although the yield was less than two-thirds the quantity reported for Connecticut, and less than half of that for either Maryland or Virginia, the average price per bushel received by the fishermen was considerably higher. Statistics of oysters taken from New York beds by Connecticut fishermen are given on page 93 . The tabular statement at the foot of this page shows for 1908 the distribution of the quantity and the value of market and seed oysters taken from public and private areas of the state according to the waters from which such products were taken. Of the total yield, 95 per cent, with a value equal to 98 per cent of the total value, was taken from private areas.

Statistics of the oyster catch of New York are available for nine different years between 1880 and 190 . The following tabular statement gives the amount and value of the yield and the average price per bushel for such years:

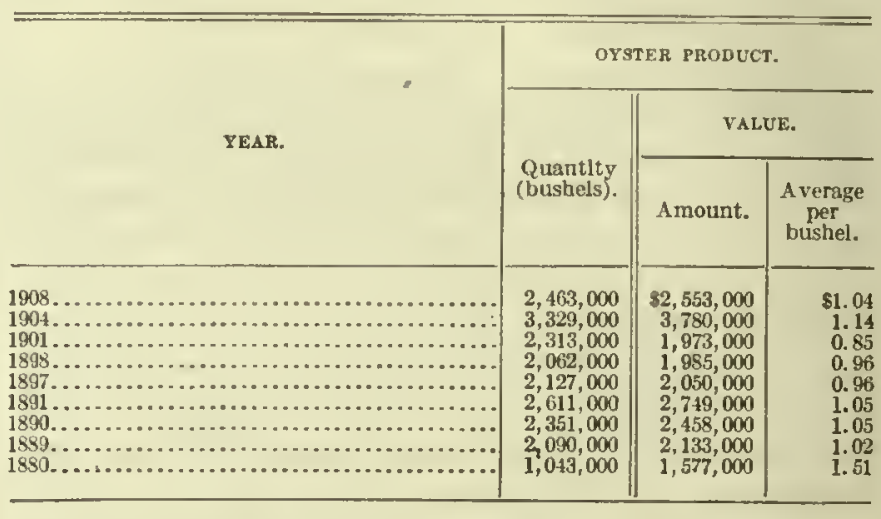

The average catch for the nine years was $2,265,000$ bushels, the average value $\$ 2,362,000$, and the average value per bushel $\$ 1.04$. As compared with these averages the report for 1908 shows increases of $19 \$, 000$ bushels in quantity and $\$ 191,000$ in value, but no change in the average value per bushel. Detailed statisties for the oyster product for 1908 are given in the following tabular statement:

\begin{tabular}{|c|c|c|c|c|c|c|c|c|c|c|c|c|}
\hline \multirow{4}{*}{ KEND AND SOURCE. } & \multicolumn{12}{|c|}{ OYSTER PRODUCT: 1908.} \\
\hline & \multicolumn{4}{|c|}{ Total. } & \multicolumn{4}{|c|}{ Long Island Sound. } & \multicolumn{4}{|c|}{ All other waters. } \\
\hline & \multicolumn{2}{|c|}{ Quantlty. } & \multicolumn{2}{|c|}{ Value. } & \multicolumn{2}{|c|}{ Quantity. } & \multicolumn{2}{|c|}{ Value. } & \multicolumn{2}{|c|}{ Quantity. } & \multicolumn{2}{|c|}{ Value. } \\
\hline & Bushels. & $\begin{array}{c}\text { Per } \\
\text { cent } \\
\text { dls- } \\
\text { tribu- } \\
\text { tlon. }\end{array}$ & Amount. & $\begin{array}{c}\text { Per } \\
\text { cent } \\
\text { dis- } \\
\text { tribu- } \\
\text { tion. }\end{array}$ & Bushals. & $\begin{array}{c}\text { Per } \\
\text { cent } \\
\text { dis- } \\
\text { tribu- } \\
\text { tlon. }\end{array}$ & Amount. & $\begin{array}{l}\text { Per } \\
\text { cent } \\
\text { dis- } \\
\text { tribu- } \\
\text { tion. }\end{array}$ & Bushels. & $\begin{array}{l}\text { Per } \\
\text { cent } \\
\text { dis- } \\
\text { tribu- } \\
\text { tion. }\end{array}$ & Amount. & $\begin{array}{c}\text { Per } \\
\text { cent } \\
\text { dis- } \\
\text { tribu- } \\
\text { tion. }\end{array}$ \\
\hline Total.................... & $2,463,000$ & 100 & $\$ 2,553,000$ & 100 & 770,000 & 100 & $\$ 643,000$ & 100 & $1,693,000$ & 100 & $\$ 1,910,000$ & 100 \\
\hline $\begin{array}{l}\text { From private areas...................... } \\
\text { From publie areas.................... }\end{array}$ & $\begin{array}{r}2,352,000 \\
111,000 \\
\end{array}$ & $\begin{array}{r}95 \\
5 \\
\end{array}$ & $\begin{array}{r}2,490,000 \\
63,000 \\
\end{array}$ & $\begin{array}{r}08 \\
2 \\
\end{array}$ & $\begin{array}{r}745,000 \\
25,000 \\
\end{array}$ & $\begin{array}{r}97 \\
3 \\
\end{array}$ & $\begin{array}{r}631,000 \\
12,000 \\
\end{array}$ & $\begin{array}{r}98 \\
2 \\
\end{array}$ & $\begin{array}{r}1,607,000 \\
87,000 \\
\end{array}$ & $\begin{array}{r}95 \\
5 \\
\end{array}$ & $\begin{array}{r}1,859,000 \\
51,000 \\
\end{array}$ & $\begin{array}{r}97 \\
3 \\
\end{array}$ \\
\hline Market oysters..................... & $1,849,000$ & 75 & $2,173,000$ & 85 & 342,000 & 44 & 375,000 & $\overrightarrow{58}$ & $1,508,000$ & 89 & $1,798,000$ & 94 \\
\hline 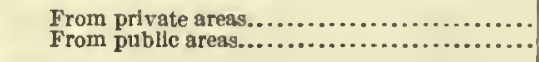 & $\begin{array}{r}1,828,000 \\
22,000\end{array}$ & 74 & $\begin{array}{r}2,155,000 \\
18,000\end{array}$ & $\begin{array}{r}84 \\
1\end{array}$ & $\begin{array}{r}341,000 \\
500\end{array}$ & $(1)^{44}$ & $\begin{array}{r}374,000 \\
500\end{array}$ & $(1)^{58}$ & $\begin{array}{r}1,487,000 \\
21,000\end{array}$ & 88 & $\begin{array}{r}1,780,000 \\
17,000\end{array}$ & 93 \\
\hline Seed oysters..... & 614,000 & 25 & 381,000 & 15 & 429,000 & 56 & 268,000 & 42 & 186,000 & 11 & 112,000 & 6 \\
\hline $\begin{array}{l}\text { From private areas............................ } \\
\text { From public areas......................... }\end{array}$ & $\begin{array}{r}524,000 \\
89,000\end{array}$ & $\begin{array}{r}21 \\
4\end{array}$ & $\begin{array}{r}336,000 \\
45,000\end{array}$ & $\begin{array}{r}13 \\
2\end{array}$ & $\begin{array}{r}404,000 \\
24,000\end{array}$ & $\begin{array}{r}52 \\
3\end{array}$ & $\begin{array}{r}257,000 \\
11,000\end{array}$ & $\begin{array}{r}40 \\
2\end{array}$ & $\begin{array}{r}120,000 \\
66,000\end{array}$ & $\begin{array}{r}7 \\
4\end{array}$ & $\begin{array}{l}79,000 \\
34,000\end{array}$ & $\begin{array}{l}4 \\
2\end{array}$ \\
\hline
\end{tabular}


Clams.- In the yield of hard clams there was a decrease from 1904 to 1908 of nearly 27 per cent. Soft clams, which are used principally in the cod fisheries for bait, decreased 11 per cent in quantity between 1904 and 1908.

Scallops.-The yield of scallops in 1908 amounted to 81,000 gallons, valued at $\$ 98,000$, which represents a decrease of 31,000 gallons in quantity and $\$ 48,000$ in value, compared with the yield of 1904 . The state of New York was second in rank with respect to the value of the scallop product in 1908, the yields in Massachusetts, New York, and Maine contributing, respectively, 38,31 , and 30 per cent of the value of the product of the entire country. The industry in New York is carried on principally at the eastern end of Long Island.

Bluefish.-The bluefish product was taken chiefly with lines in the vessel fisheries. Compared with 1904 there was a decrease in quantity from $11,414,000$ to $3,191,000$ pounds, and a decrease in value from $\$ 557,000$ to $\$ 291,000$.

Butterfish.-There was an increase of 112 per cent in quantity, and an increase of 129 per cent in value in the yield of butterfish for the period from 1904 to 1908.

German carp.-This fish, for which there is an increasing demand, was taken chiefly with seines in the Hudson River. The apparatus to be used in taking German carp in this river and the season in which the fish may be taken are under the control of the State Forest, Fish, and Game Commission. Larger quantities of German carp were caught in 1908 than ever before, the yield of 406,000 pounds, valued at $\$ 31,000$, representing an increase over that in 1903-4 of 115,000 pounds in quantity and $\$ 14,000$ in value.
Cod.-The catch of cod in 1908 was $2,999,000$ pounds, valued at $\$ 99,000$, an increase over that for 1904 of 156 per cent in quantity and of 87 per cent in value.

Flounders.-The flounder catch shows an increase in 1908 compared with 1904 of 154 per cent in weight and 110 per cent in value. A product of $4,629,000$ pounds, valued at $\$ 141,000$, was taken in 1908 , principally in nets.

Menhaden.-The principal uses of the menhaden are for oil and fertilizer, but a few are sold for food. This fish is taken cliefly with seines in the Atlantic Ocean fisheries. Although it continues to lead all others in quantity, there was a large decrease in the catch, that in 1908 being $12,762,000$ pounds, or only about one-seventeenth of that for 1904 . The value of this small catch in 1908 was $\$ 22,000$, or less than onethirtieth of the value for 1904, $\$ 694,000$.

Pike perches.-Under this term are included blue pike, sangers, and wall-eyed pike. The greater part of the product was taken in Lake Erie with gill nets, and the yield of $2,001,000$ pounds, valued at $\$ 68,000$, in 1908 , shows an increase over that for 1903 of 905,000 pounds in quantity and of $\$ 22,000$ in value. The value of blue pike constituted 95 per cent of the total value of pike perch caught in 1908.

Squeteague.-The squeteague taken in 1908 had more than double the value of that caught in 1904. In 1908 the value of this species formed more than onefourth of the value of all fish proper reported for the state. It was surpassed in quantity only by menhaden. The catch was about evenly divided between the shore and boat fisheries, where this fish is taken chiefly in pound and trap nets, and the vessel fisheries, where seines are the principal apparatus used. 
TABLE 1.-NEW YORK-FISHERY PRODUCTS: 1908.

\begin{tabular}{|c|c|c|c|c|c|c|c|c|c|c|c|c|c|c|}
\hline \multirow{3}{*}{ SPECIRS. } & \multirow{2}{*}{\multicolumn{2}{|c|}{ TOTAL. }} & \multicolumn{12}{|c|}{ - PRODUCT CAUOHT BY- } \\
\hline & & & \multicolumn{2}{|c|}{ Lines. } & \multicolumn{2}{|c|}{$\begin{array}{l}\text { Pound and trap } \\
\text { nets. }\end{array}$} & \multicolumn{2}{|c|}{ Selnes. } & \multicolumn{2}{|c|}{ Gill nets. } & \multicolumn{2}{|c|}{$\begin{array}{c}\text { Fyke and boop } \\
\text { nets. }\end{array}$} & \multicolumn{2}{|c|}{ All other apparatus. } \\
\hline & $\begin{array}{l}\text { Quantity } \\
\text { (pounds). }\end{array}$ & Value. & $\begin{array}{l}\text { Quantity } \\
\text { (pounds). }\end{array}$ & Value. & $\begin{array}{l}\text { Quantity } \\
\text { (pounds). }\end{array}$ & Valuc. & $\begin{array}{l}\text { Quantity } \\
\text { (pounds). }\end{array}$ & Value. & $\begin{array}{l}\text { Quantity } \\
\text { (pounds). }\end{array}$ & Value. & $\begin{array}{l}\text { Quantlty } \\
\text { (pounds). }\end{array}$ & Value. & $\begin{array}{l}\text { Quantity } \\
\text { (pounds). }\end{array}$ & Value. \\
\hline Total... & $76,485,000$ & $\$ 4,594,000$ & $7,752,000$ & $=\$ 112,000$ & $11,006,000$ & $\$ 417,000$ & $18,178,000$ & $\$ 327,000$ & $7,412,000$ & $\$ 246,000$ & $2,951,000$ & $\$ 86,000$ & $29,186,000$ & $\$ 3,077,000$ \\
\hline 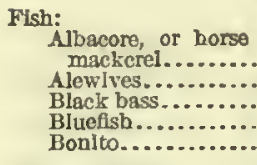 & $\begin{array}{r}10,000 \\
654,000 \\
38,000 \\
3,191,000 \\
102,000\end{array}$ & $\begin{array}{r}400 \\
7,100 \\
5,100 \\
291,000 \\
5,400\end{array}$ & $\begin{array}{r}37,000 \\
2,673,000 \\
74,000\end{array}$ & $\begin{array}{r}5,100 \\
246,000 \\
3,800\end{array}$ & $\begin{array}{r}10,000 \\
187,000 \\
400 \\
134,000 \\
21,000\end{array}$ & $\begin{array}{r}400 \\
2,800 \\
(3) \\
10,000 \\
1,300\end{array}$ & $\begin{array}{r}500 \\
318,000 \\
91,000 \\
6,800\end{array}$ & $\begin{array}{l}\left(^{3}\right) \\
2,400 \\
6,900 \\
300\end{array}$ & $\begin{array}{c}108,000 \\
(b) \\
293,000 \\
\ldots\end{array}$ & $\begin{array}{c}1,600 \\
(3) \\
28,000 \\
\ldots \ldots\end{array}$ & 37,000 & $\begin{array}{l}200 \\
(2)\end{array}$ & $\begin{array}{c}4,300^{\circ} \\
\cdots \cdots \cdots \\
\cdots \cdots \\
\cdots\end{array}$ & $\begin{array}{l}100 \\
\ldots \\
\cdots\end{array}$ \\
\hline $\begin{array}{l}\text { Butterfish.......... } \\
\text { Carp, German .... } \\
\text { Cathish aud buil- }\end{array}$ & $\begin{array}{r}1,229,000 \\
406,000\end{array}$ & $\begin{array}{l}64,000 \\
31,000\end{array}$ & & an. & $\begin{array}{r}1,218,000 \\
4,700\end{array}$ & $\begin{array}{r}64,000 \\
100\end{array}$ & $\begin{array}{r}5,400 \\
271,000\end{array}$ & $\begin{array}{r}300 \\
23,000\end{array}$ & $\begin{array}{r}4,800 \\
35,000\end{array}$ & $\begin{array}{r}300 \\
1,700\end{array}$ & 24,000 & 1,400 & 72,000 & $\dddot{4,400}$ \\
\hline 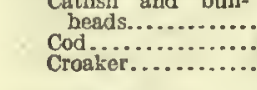 & $\begin{array}{r}247,000 \\
2,999,000 \\
7,500\end{array}$ & $\begin{array}{r}20,000 \\
99,000 \\
200\end{array}$ & $\begin{array}{r}59,000 \\
2,925,000 \\
\cdots \cdots\end{array} \mid$ & $\begin{array}{r}6,000 \\
96,000 \\
\cdots \cdots\end{array}$ & $\begin{array}{l}10,000 \\
51,000 \\
\cdots\end{array}$ & $\begin{array}{r}1,100 \\
1,900 \\
\cdots\end{array}$ & $\begin{array}{r}20,000 \\
2,000 \\
7,500\end{array}$ & $\begin{array}{r}1,300 \\
100 \\
200\end{array}$ & $\begin{array}{r}25,000 \\
19,000 \\
\cdots\end{array}$ & $\begin{array}{r}1,800 \\
900 \\
\cdots\end{array}$ & $\begin{aligned} 129,000 \\
\cdots \cdots \cdots \\
\cdots \cdots\end{aligned}$ & $\begin{array}{r}9,700 \\
\cdots\end{array}$ & $\begin{array}{r}3,200 \\
2,500 \\
\cdots\end{array}$ & $\begin{array}{r}200 \\
100 \\
\cdots\end{array}$ \\
\hline 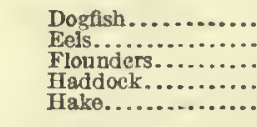 & $\begin{array}{r}42,000 \\
736,000 \\
4,629,000 \\
424,000 \\
39,000\end{array}$ & $\begin{array}{r}600 \\
57,000 \\
141,000 \\
12,000 \\
1,000\end{array}$ & $\begin{array}{r}9,800 \\
113,000 \\
424,000 \\
39,000\end{array}$ & $\begin{array}{r}600 \\
4,100 \\
12,000 \\
1,000\end{array}$ & $\begin{array}{r}42,000 \\
30,000 \\
1,687,000 \\
, 37\end{array}$ & $\begin{array}{r}600 \\
2,400 \\
65,000 \\
\hdashline, \cdots\end{array}$ & $\begin{array}{r}48,000 \\
121,000 \\
\ldots\end{array}$ & $\begin{array}{l}2, \ddot{8} 000 \\
4,200 \\
\cdots \ldots \ldots\end{array}$ & $\begin{array}{r}2,000 \\
50,000 \\
\cdots\end{array}$ & $\begin{array}{r}100 \\
1,900 \\
\cdots\end{array}$ & $\mid \begin{array}{r}100 \\
59,000 \\
2,383,000 \\
\cdots \cdots \cdots \cdots \\
\cdots \cdots \cdots\end{array}$ & $\begin{array}{c}(2) \\
4,100 \\
66,000 \\
\cdots \cdots \cdots \\
\cdots \cdots\end{array}$ & $\mid \begin{array}{r}588,000 \\
276,000 \\
\ldots \ldots \ldots \ldots \ldots\end{array}$ & $\begin{array}{r}47,000 \\
9,700 \\
\therefore \ldots\end{array}$ \\
\hline $\begin{array}{l}\text { Herring, Iake ....... } \\
\text { Kingfish............ } \\
\text { Ling............... } \\
\text { Mackerel. } \\
\text { Mackerel, chub...... }\end{array}$ & $\begin{array}{r}2,044,000 \\
34,000 \\
24,000 \\
10,000 \\
58,000\end{array}$ & $\begin{array}{r}51,000 \\
4,900 \\
400 \\
6,600 \\
2,900\end{array}$ & $\begin{array}{c}\left({ }^{3}\right) \\
100 \\
21,000 \\
16,000 \\
\cdots\end{array}$ & $\begin{array}{l}(2) \\
(3) \\
300 \\
900\end{array}$ & $\begin{array}{r}12,000 \\
33,000 \\
2,600 \\
60,000 \\
57,000\end{array}$ & $\begin{array}{r}300 \\
4,600 \\
32 \\
3,500 \\
2,800\end{array}$ & $\begin{array}{r}800 \\
400 \\
100 \\
1,000\end{array}$ & $\left\{_{100}^{2}\right\}^{200}$ & $\mid \begin{array}{r}2,030,000 \\
600 \\
\cdots \ldots, \ldots 0 \\
30,000 \\
\cdots \ldots \ldots \ldots\end{array}$ & $\begin{array}{r}50,000 \\
100 \\
2,300 \\
2,30\end{array}$ & 1,800 & 100 & 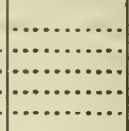 & $\mid \begin{array}{l}\ldots \ldots \ldots \\
\cdots \ldots \ldots \ldots \\
\cdots \ldots \ldots\end{array}$ \\
\hline $\begin{array}{l}\text { Menhaden.......... } \\
\text { Muskallunge...... } \\
\text { Perch, white....... } \\
\text { Perch, yellow...... }\end{array}$ & $\begin{array}{r}12,762,000 \\
19,000 \\
90,000 \\
144,000\end{array}$ & $\begin{array}{r}22,000 \\
1,200 \\
8,700 \\
5,400\end{array}$ & $\begin{array}{l}19,000 \\
\cdots 1,100\end{array}$ & 1,200 & $-\begin{array}{r}2,012,000 \\
3,500 \\
9,300\end{array}$ & $\begin{array}{r}3,400 \\
\cdots \\
400 \\
400\end{array}$ & $\begin{array}{r}9,600,000 \\
31,000 \\
3,200\end{array}$ & $\begin{array}{r}17,000 \\
3,200 \\
200\end{array}$ & $-\begin{array}{r}1,150,000 \\
100 \\
41,000 \\
89,000\end{array}$ & $\begin{array}{l}1,600 \\
(2) \\
3,900 \\
3,100\end{array}$ & $\begin{array}{l}14,000 \\
39,000\end{array}$ & $\begin{array}{l}1,300 \\
1,600\end{array}$ & an. & 100 \\
\hline $\begin{array}{l}\text { Pike and pickerei... } \\
\text { Pike perch (blue } \\
\text { plke)............ } \\
\text { Plke perch (sauger). }\end{array}$ & $\begin{array}{r}90,000 \\
1,904,000 \\
40,000\end{array}$ & $\begin{array}{r}9,600 \\
59,000 \\
2,000\end{array}$ & 23,000 & $\begin{array}{l}7,700 \\
2,300 \\
\ldots \ldots \ldots\end{array}$ & $\begin{array}{l}10,000 \\
30,000 \\
\ldots \ldots\end{array}$ & 1,300 & 100 & $(2)$ & $\begin{array}{r}3,100 \\
1,851,000 \\
40,000\end{array}$ & $\begin{array}{r}55,000 \\
2,000\end{array}$ & $\begin{array}{r}11,000 \\
300\end{array}$ & (2) & $\begin{array}{c}|c| \\
100 \\
\ldots \ldots \ldots \\
\cdots \cdots\end{array}$ & $\begin{array}{c}\text { (अ) } \\
\ldots \ldots \ldots \\
\cdots \cdots\end{array}$ \\
\hline $\begin{array}{l}\text { Pike perch (walj- } \\
\text { eycd pike) ......... } \\
\text { Pollack. ............. }\end{array}$ & $\begin{array}{r}56,000 \\
133,000\end{array}$ & $\begin{array}{l}7,000 \\
3,500\end{array}$ & $\begin{array}{l}52,000 \\
67,000\end{array}$ & $\begin{array}{l}6,500 \\
1,900\end{array}$ & $\begin{array}{r}2,000 \\
50,000\end{array}$ & $\begin{array}{r}200 \\
1,200\end{array}$ & & & $\begin{array}{r}300 \\
10,000\end{array}$ & $\stackrel{(2)}{400}$ & $\begin{array}{l}1,800 \\
\cdots\end{array}$ & 200 & & \\
\hline $\begin{array}{l}\text { Scup, or porgy ..... } \\
\text { Sea bass............ } \\
\text { Sea robin............ } \\
\text { Sbad............... } \\
\text { Skates............ }\end{array}$ & $\begin{array}{r}1,294,000 \\
723 ; 000 \\
53,000 \\
360,000 \\
168,000\end{array}$ & $\begin{array}{r}45,000 \\
35,000 \\
500 \\
27,000 \\
2,100\end{array}$ & $\begin{array}{r}6,200 \\
466,000 \\
\cdots \cdots \cdots \\
\cdots, \ldots, \cdots \\
91,000\end{array}$ & $\begin{array}{r}300 \\
24,000 \\
\cdots \cdots \\
6000\end{array}$ & $\begin{array}{r}52,000 \\
39,000 \\
51,000 \\
6,800 \\
76,000\end{array}$ & $\begin{array}{r}2,400 \\
3,000 \\
500 \\
900 \\
1,600\end{array}$ & $\begin{array}{r}1,235,000 \\
203,000 \\
1,000 \\
27,000 \\
\cdots \ldots . . .\end{array}$ & $\begin{array}{c}42,000 \\
7,300 \\
(3) \\
1,800 \\
\ldots \ldots\end{array}$ & $\begin{array}{r}200 \\
14,000 \\
1,300 \\
323,000 \\
800\end{array}$ & $\begin{array}{l}(3) \\
1,000 \\
(3) \\
24,000 \\
(3)\end{array}$ & $\begin{array}{l}\text { (d) } \\
3,700 \\
\ldots \ldots\end{array}$ & $\begin{array}{c}\text { (3) } \\
400 \\
4.4\end{array}$ & $\mid \cdots \cdots$ & (s) \\
\hline 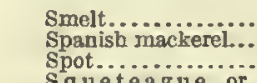 & $\begin{array}{r}4,000 \\
500 \\
109,000\end{array}$ & $\begin{array}{r}900 \\
100 \\
2,600\end{array}$ & & & 69,000 & 1,100 & ${ }_{200}^{(3)}$ & (3) & $\begin{array}{r}2,600 \\
200 \\
39,000\end{array}$ & $\begin{array}{l}600 \\
\left({ }^{3}\right) \\
1,500\end{array}$ & $\begin{array}{r}1,400 \\
\cdots \cdots \\
\cdots\end{array}$ & $\begin{array}{r}300 \\
\ldots \ldots \\
\cdots \cdots\end{array}$ & $\mid \begin{array}{ll} \\
\cdots \cdots \cdots \\
\cdots \cdots \cdots\end{array}$ & $(\cdots \cdots \cdots$ \\
\hline $\begin{array}{l}\text { squet eague, or } \\
\text { weakfish.......... } \\
\text { striped bass........ }\end{array}$ & $11,151,000$ & $\begin{array}{r}451,000 \\
7,600\end{array}$ & $\begin{array}{r}28,000 \\
2,100\end{array}$ & $\begin{array}{r}1,100 \\
300\end{array}$ & $\begin{array}{r}4,319,000 \\
15,000\end{array}$ & $\begin{array}{r}218,000 \\
2,600\end{array}$ & $\begin{array}{r}5,850,000 \\
20,000\end{array}$ & $\begin{array}{r}199,000 \\
3,500\end{array}$ & $\begin{array}{r}955,000 \\
6,700\end{array}$ & $\begin{array}{r}33,000 \\
1,000\end{array}$ & $\begin{array}{r}100 \\
1,400\end{array}$ & ${ }^{(2)}{ }_{200}$ & an. & $\ldots$ \\
\hline 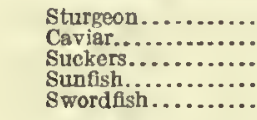 & $\begin{array}{r}105,000 \\
8,100 \\
276,000 \\
31,000 \\
\mathbf{3}, 600\end{array}$ & $\begin{array}{r}16,000 \\
7,500 \\
13,000 \\
900 \\
200\end{array}$ & $\begin{array}{r}39,000 \\
4,900 \\
\cdots \ldots \ldots \\
\cdots\end{array}$ & $\begin{array}{r}6,000 \\
4,000 \\
\cdots \cdots \cdots \\
\cdots \cdots \\
\cdots \cdots \\
\cdots\end{array}$ & $\begin{array}{r}11,000 \\
300 \\
24,000 \\
12,000 \\
\ldots \ldots \ldots\end{array}$ & $\begin{array}{r}1,400 \\
300 \\
800 \\
200 \\
\ldots .\end{array}$ & $\begin{array}{r}500 \\
84,000 \\
400 \\
4.6 .\end{array}$ & $\begin{array}{l}(3) \\
4,400 \\
(2)\end{array}$ & $\begin{array}{r}54,000 \\
2,300 \\
31,000 \\
400 \\
\cdots\end{array}$ & $\begin{array}{c}8,000 \\
3,200 \\
500 \\
\left({ }^{3}\right) \\
\cdots \cdots\end{array}$ & $\begin{array}{r}100 \\
118,000 \\
18,000 \\
\ldots \ldots \ldots\end{array}$ & $\begin{array}{c}(2) \\
5,600 \\
600 \\
\cdots\end{array}$ & $\begin{array}{r}18,000 \\
200 \\
3,600\end{array}$ & (2) $\begin{array}{l}900 \\
200\end{array}$ \\
\hline $\begin{array}{l}\text { Tautog } \\
\text { Tomcod .............. } \\
\text { Trout, brook......... } \\
\text { Trout, lake.......... } \\
\text { Whitebait.......... }\end{array}$ & $\begin{array}{r}81,000 \\
97,000 \\
18,000 \\
20,000 \\
199,000\end{array}$ & $\begin{array}{l}3,100 \\
2,300 \\
6,300 \\
1,400 \\
5,700\end{array}$ & $\begin{array}{r}8,800 \\
\cdots, 0,00 \\
\cdots \cdots \cdots\end{array}$ & $\begin{array}{r}400 \\
\cdots, 300 \\
\cdots \cdots \cdots \\
\cdots \cdots \cdots\end{array}$ & $\begin{array}{r}53,000 \\
16,000 \\
\cdots \cdots \cdots \\
\cdots \cdots \cdots \\
\cdots \cdots\end{array}$ & $\begin{array}{r}1,900 \\
600\end{array}$ & 179,000 & 4,800 & 12,000 & $\begin{array}{r}8000 \\
8.6 .\end{array}$ & $\begin{array}{r}14,000 \\
73,000 \\
8,2000 \\
2,600\end{array}$ & $\begin{array}{r}500 \\
1,400 \\
7000 \\
(3)\end{array}$ & 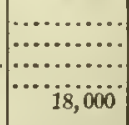 & (n......... \\
\hline $\begin{array}{l}\text { Whitefish } . . . . . . . \\
\text { Whiting........... } \\
\text { All other.......... }\end{array}$ & $\begin{array}{r}179,000 \\
268,000 \\
50,000\end{array}$ & $\begin{array}{r}15,000 \\
3,700 \\
300\end{array}$ & $\begin{array}{r}\cdots \\
2,000\end{array}$ & $\cdots(9)$ & $\begin{array}{r}4,200 \\
268,000 \\
43,000\end{array}$ & $\begin{array}{r}400 \\
3,700 \\
200\end{array}$ & $\begin{array}{r}300 \\
2,000\end{array}$ & ${ }^{(3)} 100$ & $\mid \begin{array}{r}175,000 \\
100\end{array}$ & $\begin{array}{c}15,000 \\
(3)\end{array}$ & 3,100 & 100 & an. & $\cdots \cdots$ \\
\hline 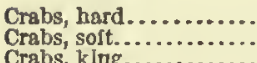 & $\begin{array}{r}580,000 \\
22,000 \\
56,000\end{array}$ & $\begin{array}{l}7,400 \\
2,300 \\
100\end{array}$ & $\begin{array}{r}467,000 \\
\cdots\end{array}$ & $\begin{array}{r}4,700 \\
\ldots \ldots\end{array}$ & $\begin{array}{l}12,000 \\
1 \ldots \ldots 00\end{array}$ & 300 & 38,000 & 500 & 100 & (2) & $\begin{array}{c}6,600 \\
6\end{array}$ & 200 & $\begin{array}{l}56,000 \\
22,000\end{array}$ & $\begin{array}{r}1,800 \\
2,300\end{array}$ \\
\hline 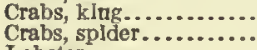 & $\begin{array}{r}56,000 \\
7,200\end{array}$ & $(2)$ & a........ & (........... & $\begin{array}{r}56,000 \\
7,200\end{array}$ & $(2)$ & & & & & & & .................. & (n........... \\
\hline 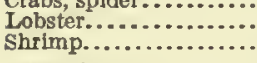 & $\begin{array}{r}423,000 \\
1,500\end{array}$ & $\begin{array}{r}57,000 \\
600\end{array}$ & & & 6,700 & 800 & & & 600 & $\because 00$ & & & $\begin{array}{r}416,000 \\
1,500\end{array}$ & $\begin{array}{r}57,000 \\
600\end{array}$ \\
\hline $\begin{array}{l}\text { Clams, hard } . . . \ldots \ldots \ldots . . \\
\text { Clams, soft............... }\end{array}$ & $\begin{array}{l}1809,000 \\
-656,000\end{array}$ & $\begin{array}{r}223,000 \\
54,000\end{array}$ & & & & & & & & & & & $\begin{array}{l}1809,000 \\
656,000\end{array}$ & $\begin{array}{r}223,000 \\
54,000\end{array}$ \\
\hline f & 167,000 & 14,000 & …........... & an....... & ...... & $\ldots \ldots . . . .$. & ........... & ..... & :.... & a......... & (n.............. & (.......... & 167,000 & $\begin{array}{l}54,000 \\
14,000\end{array}$ \\
\hline Mussels................. & $8,175,000$ & 8,200 & ........... & & & & & & $\cdots$ & & & & $78,175,000$ & 8,200 \\
\hline $\begin{array}{l}\text { Oysters, market, from } \\
\text { pubilic areas......... } \\
\text { oysters, market, irom }\end{array}$ & 151,000 & 18,000 & & & & & & & & & & & - 151,000 & 18,000 \\
\hline $\begin{array}{l}\text { Oysters, market, from } \\
\text { private areas......... } \\
\text { oysters, seed, from }\end{array}$ & $912,705,000$ & $2,155,000$ & & & & & & & & & & & $12,795,000$ & $2,155,000$ \\
\hline $\begin{array}{c}\text { Oysters, seed, from } \\
\text { public areas.......... }\end{array}$ & 10628,000 & 45,000 & & & & & & & & & & & 10628,000 & 45,000 \\
\hline $\begin{array}{l}\text { Oysters, seed, from } \\
\text { private areas......... }\end{array}$ & $113,670,000$ & 336,000 & & & & & & & & & & & $10,670,000$ & 336,000 \\
\hline Scaliops.................. & 12650,000 & 98,000 & & & & & & & & & & & 12650,000 & 98,000 \\
\hline $\begin{array}{l}\text { 8quid.......... } \\
\text { Turties....... }\end{array}$ & $\begin{array}{r}189,000 \\
200\end{array}$ & ${ }_{(3)}^{8,100}$ & (n........ & (n) & $\begin{array}{r}187,000 \\
200\end{array}$ & $\begin{array}{l}8,000 \\
(2)\end{array}$ & & & $\begin{array}{r}2,000 \\
\ldots . . .\end{array}$ & 100 & & & & \\
\hline Skins, muskrat........ & 12100 & (') & & & & & & & & & & & is 100 & (3) \\
\hline
\end{tabular}

1 Ineludes apparatus, with catch, as follows: Dredges, tongs, etc., 27,749,000,pounds, valued at $\$ 2,954,000$; eel and $10 b s t e r$ pots, 915,000 pounds, valued at $\$ 95,000 ;$ beam

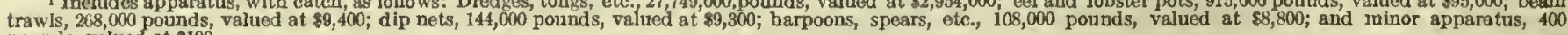
pounds, valued at $\$ 100$.

Less than $\$ 100$.

- Less than 100 pounds.

$\begin{array}{ll}1 & 101,000 \text { bushels. }\end{array}$

22,000 bushels.

$1,822,000$ bushel

1090,000 busbels.
11 524,000 busbels.

1. 81,000 gallons. 
FISHERIES, BY STATES.

TABLE 2.-NEW YORK-FISHERY PRODUCTS OF ATLANTIC COAST DISTRICT, EXCLUSIVE OF LONG ISLAND SOUND: 1908.

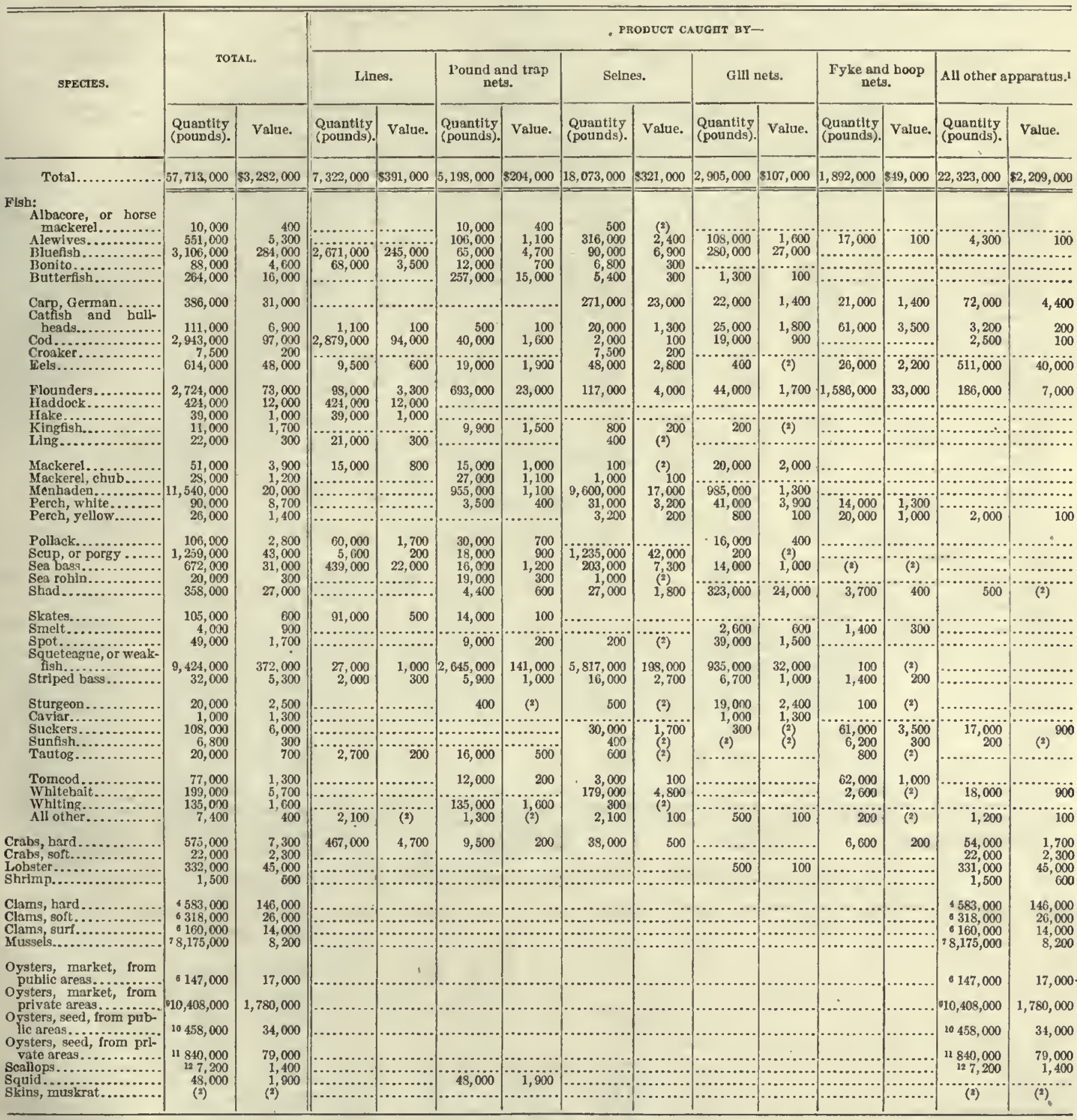

2 Includes apparatus, with catch, as follows: Dredges, tongs, etc. 21,146,000 pounds, valued at \$2,105,000; eel and lobster pots, 776,000 pounds, valued at $\$ 78,000$; dip nets,

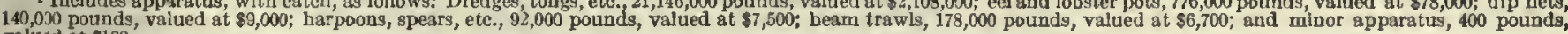
valued at $\$ 100$. 
FISHERIES OF THE UNITED STATES, 1908.

TABLE 3.-NEW YORK-FISHERY PRODUCTS OF LONG ISLAND SOUND: 1908.

\begin{tabular}{|c|c|c|c|c|c|c|c|c|c|c|c|c|c|c|}
\hline \multirow{3}{*}{ SPECTES. } & \multirow{2}{*}{\multicolumn{2}{|c|}{ TOTAL. }} & \multicolumn{12}{|c|}{ PRODUCT CAURHT BY- } \\
\hline & & & \multicolumn{2}{|c|}{$\begin{array}{l}\text { Pound and trap } \\
\text { nets. }\end{array}$} & \multicolumn{2}{|c|}{$\begin{array}{l}\text { Fyke and hoop } \\
\text { nets. }\end{array}$} & \multicolumn{2}{|c|}{ t.lnes. } & \multicolumn{2}{|c|}{ Gill nets. } & \multicolumn{2}{|c|}{ Selnes. } & \multicolumn{2}{|c|}{$\begin{array}{l}\text { All other appa- } \\
\text { ratus. }\end{array}$} \\
\hline & $\begin{array}{l}\text { Quantity } \\
\text { (pounds). }\end{array}$ & Value. & $\begin{array}{l}\text { Quantity } \\
\text { (pounds). }\end{array}$ & Value. & $\begin{array}{l}\text { Quantity } \\
\text { (pounds). }\end{array}$ & Value. & $\mid \begin{array}{l}\text { Quantity } \\
\text { (pounds). }\end{array}$ & Value. & $\begin{array}{l}\text { Quantity } \\
\text { (pounds). }\end{array}$ & Value. & $\begin{array}{l}\text { Quantity } \\
\text { (pounds). }\end{array}$ & Value. & $\begin{array}{l}\text { Quantity } \\
\text { (pounds). }\end{array}$ & Value. \\
\hline Total.. & $13,761,000$ & $\$ 1,109,000$ & $5,673,000$ & 205,000 & 840,000 & $\$ 24,000$ & 111,000 & $\$ 5,700$ & 224,000 & $\$ 3,500$ & 52,000 & $\$ 2,800$ & $0,862,000$ & $\$ 807,000$ \\
\hline 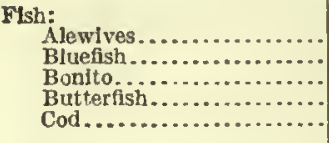 & $\begin{array}{r}103,000 \\
85,000 \\
14,000 \\
96,000 \\
56,000\end{array}$ & $\begin{array}{r}1,700 \\
6,900 \\
900 \\
49,000 \\
1,800\end{array}$ & $\begin{array}{r}81,000 \\
69,000 \\
8,900 \\
961,000 \\
11,000\end{array}$ & $\begin{array}{r}1,700 \\
5,300 \\
600 \\
49,000 \\
400\end{array}$ & $\begin{aligned} 20,000 \\
\ldots \ldots \ldots\end{aligned}$ & $\begin{array}{r}100 \\
\ldots \ldots\end{array}$ & $\begin{array}{r}2,200 \\
5,300 \\
\hdashline 35,000\end{array}$ & $\begin{array}{r}200 \\
300 \\
\hdashline 1,500\end{array}$ & $\begin{array}{r}13,000 \\
3,500\end{array}$ & 1,400 & $\begin{array}{r}1,500 \\
400\end{array}$ & $\begin{array}{l}(2) \\
(2)\end{array}$ & & la... \\
\hline 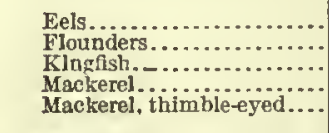 & $\begin{array}{r}77,000 \\
1,906,000 \\
23,000 \\
55,000 \\
30,000\end{array}$ & $\begin{array}{r}6,600 \\
68,000 \\
3,200 \\
2,800 \\
1,800\end{array}$ & $\begin{array}{r}300 \\
993,000 \\
23,000 \\
45,000 \\
30,000\end{array}$ & $\begin{array}{c}\left({ }^{2}\right) \\
41,000 \\
3,100 \\
2,400 \\
1,800\end{array}$ & $\begin{array}{l}797,000 \\
\ldots \ldots \ldots \ldots . . \\
\cdots\end{array}$ & $\begin{array}{l}23,000 \\
\cdots \cdots\end{array}$ & $\begin{array}{r}15,000 \\
100 \\
500\end{array}$ & $\begin{array}{l}800 \\
(2) \\
(2)\end{array}$ & $\begin{array}{r}6,300 \\
400 \\
10,000\end{array}$ & $\begin{array}{l}200 \\
100 \\
300\end{array}$ & $\begin{array}{r}4,500 \\
4, \ldots\end{array}$ & 200 & $\begin{array}{r}77,000 \\
90,000 \\
\cdots\end{array}$ & $\begin{array}{r}6,600 \\
2.700 \\
\cdots \cdots \\
\cdots\end{array}$ \\
\hline 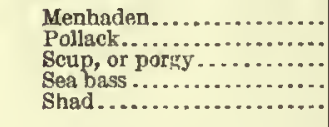 & $\begin{array}{r}1,222,000 \\
27,000 \\
35,000 \\
50,000 \\
2,500\end{array}$ & $\begin{array}{r}2,600 \\
700 \\
1,500 \\
4,200 \\
300\end{array}$ & $\begin{array}{r}1,057,000 \\
19.000 \\
34,000 \\
23,000 \\
2,500\end{array}$ & $\begin{array}{r}2,300 \\
500 \\
1,500 \\
1,800 \\
300\end{array}$ & & & $\begin{array}{r}7,500 \\
600 \\
27,000\end{array}$ & $\begin{array}{r}200 \\
(2) \\
2,300\end{array}$ & $\begin{array}{l}166,000 \\
\cdots \cdots \cdots \cdots \\
\cdots \cdots \cdots \\
\cdots \cdots \cdots\end{array}$ & 300 & 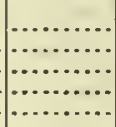 & & & $\begin{array}{l}\cdots \cdots \cdots \\
\cdots \cdots \cdots \\
\cdots \cdots \cdots \\
\cdots \cdots \cdots\end{array}$ \\
\hline 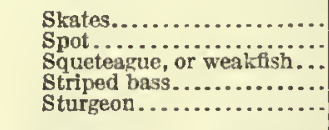 & $\begin{array}{r}63,000 \\
60,000 \\
1,727,000 \\
14,000 \\
5,600\end{array}$ & $\begin{array}{r}1,500 \\
1,000 \\
79,000 \\
2,300 \\
600\end{array}$ & $\begin{array}{r}62,000 \\
60,000 \\
1,674,000 \\
9,500 \\
5,600\end{array}$ & $\begin{array}{r}1,500 \\
1,000 \\
77,000 \\
1,500 \\
600\end{array}$ & & & \begin{tabular}{l}
$(8)$ \\
\hdashline, 500 \\
100
\end{tabular} & $\begin{array}{l}(2) \\
\cdots 100 \\
(2)\end{array}$ & $\begin{array}{r}800 \\
\cdots, 000 \\
19,000 \\
\cdots\end{array}$ & $900^{\circ}$ & $\begin{array}{r}33,000 \\
4,100\end{array}$ & 1,300 & & 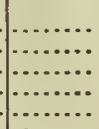 \\
\hline 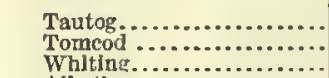 & $\begin{array}{r}61,000 \\
20,000 \\
133,000\end{array}$ & $\begin{array}{l}2,400 \\
1,000 \\
2,100\end{array}$ & $\begin{array}{r}37,000 \\
4,000 \\
133,000\end{array}$ & $\begin{array}{r}1,400 \\
400 \\
2,100\end{array}$ & $\begin{array}{l}13,000 \\
10,000 \\
\ldots \ldots \ldots\end{array}$ & $\begin{array}{l}500 \\
400\end{array}$ & 6,100 & 300 & 1,000 & (2) & $\begin{array}{l}3,600 \\
5,000\end{array}$ & $\begin{array}{l}100 \\
200\end{array}$ & & (....... \\
\hline 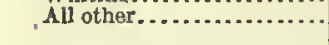 & 122,000 & 1,200 & 118,000 & 1,000 & & & & & 1,300 & (2) & …...... & & 2,800 & $\ddot{2} 00$ \\
\hline $\begin{array}{l}\text { Oysters, market, from public } \\
\text { areas.,.................. } \\
\text { Oysters, market, from prive }\end{array}$ & 3,700 & 500 & & & & & & & & & & & 43,700 & 500 \\
\hline $\begin{array}{l}\text { oyster., seed, from pubilic } \\
\text { areas. . . }\end{array}$ & $\begin{array}{r}2,387,000 \\
8170,000\end{array}$ & 374,000 & & & & & & & & & & & $32,387,000$ & 374,000 \\
\hline 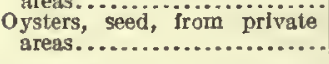 & $72,830,000$ & 257,000 & & & & & & & & & & & $\begin{array}{l}370,000 \\
72,830,000\end{array}$ & $\begin{array}{r}11,000 \\
257,000\end{array}$ \\
\hline 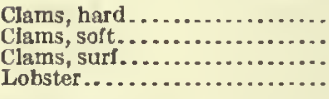 & $\begin{array}{r}8226,000 \\
8338,000 \\
106,500 \\
92,000\end{array}$ & $\begin{array}{r}77,000 \\
29,000 \\
500 \\
12,000\end{array}$ & 6,700 & 900 & & & & & & & & & $\begin{array}{r}8226,000 \\
938,000 \\
196,500 \\
85,000\end{array}$ & $\begin{array}{l}77,000 \\
29,000 \\
590 \\
11,000\end{array}$ \\
\hline 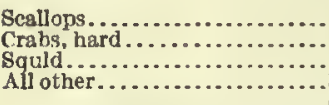 & $\begin{array}{r}11643,000 \\
5,400 \\
141,000 \\
63,000\end{array}$ & $\begin{array}{r}97,000 \\
100 \\
6,200 \\
100\end{array}$ & $\begin{array}{r}3,000 \\
140,000 \\
63,000\end{array}$ & $\begin{array}{l}(3) \\
6,100 \\
100\end{array}$ & & & & & $\begin{array}{r}100 \\
2,000\end{array}$ & (2) & & & $\begin{array}{r}11643,000 \\
2,300 \\
\cdots \ldots \ldots \ldots\end{array}$ & $\begin{array}{l}97,000 \\
(2) \\
\cdots \cdots\end{array}$ \\
\hline
\end{tabular}

1 Includes apparatus, with catch, as follows: Dredges, tongs, etc., $6,603,000$ pounds, valued at $\$ 846,000 ;$ eel and lobster pots, 149,000 pounds, valued at $\$ 17,000 ;$ heam

trawls, 90,000 pounds, valued at $\$ 2,700$; harpoons, spears, etc., 17,000 pounds, valued at $\$ 1,300 ;$ and minor apparatus, 3,000 pounds, valued 8 at $\$ 300$.
2 Less than $\$ 100$.
\$ 500 bushels.

341,000 bushels.

24,000 bushels.
704,000 bushels.

823,000 bushels.
$-34,000$ bushels.

10800 bushels.

1180,000 gallons.

TABLE 4.-NEW YORK-FISHERY PRODUCTS OF LAKE ERIE: 1908.

\begin{tabular}{|c|c|c|c|c|c|c|c|c|}
\hline \multirow{3}{*}{ SPECIES } & \multirow{2}{*}{\multicolumn{2}{|c|}{ TOTAL. }} & \multicolumn{6}{|c|}{ PRODUCT CAUOHT BY- } \\
\hline & & & \multicolumn{2}{|c|}{ Lines. } & \multicolumn{2}{|c|}{ Pound and trap nets. } & \multicolumn{2}{|c|}{ Gill nets. } \\
\hline & $\begin{array}{l}\text { Quantlty } \\
\text { (pounds). }\end{array}$ & Value. & $\begin{array}{l}\text { Quantlty } \\
\text { (pounds). }\end{array}$ & Value. & $\begin{array}{l}\text { Quantity } \\
\text { (pounds). }\end{array}$ & Value. & $\begin{array}{l}\text { Quantity } \\
\text { (pounds). }\end{array}$ & Value. \\
\hline Total....... & $4,188,000$ & $\$ 130,000$ & 53,000 & $\$ 5,700$ & 51,000 & $\$ 2,800$ & $4,084,000$ & $\$ 121,000$ \\
\hline 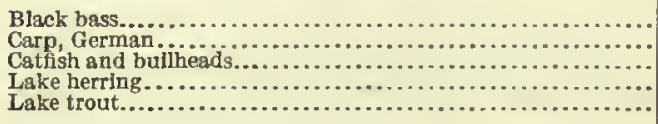 & $\begin{array}{r}1,800 \\
16,000 \\
14,000 \\
2,009,000 \\
6,200\end{array}$ & $\begin{array}{r}100 \\
300 \\
800 \\
49,000 \\
300\end{array}$ & 1,800 & $\left.{ }^{2}\right)^{100}$ & $\begin{array}{r}2,500 \\
200 \\
7,600 \\
.\end{array}$ & (2) $\begin{array}{l}100 \\
200\end{array}$ & $\begin{array}{r}13,000 \\
400 \\
2,001,000 \\
6,200\end{array}$ & $\begin{array}{l}\text { (2) } \\
\text { (2) } \\
49,000 \\
300\end{array}$ \\
\hline 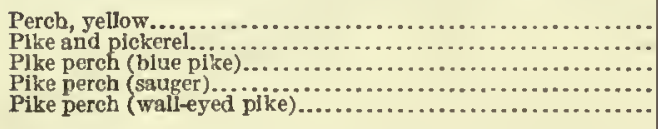 & $\begin{array}{r}83,000 \\
1,700 \\
1,805,000 \\
40,000 \\
2,800\end{array}$ & $\begin{array}{r}2,900 \\
100 \\
54,000 \\
2,000 \\
300\end{array}$ & $\begin{array}{r}1,100 \\
23,000 \\
1,000\end{array}$ & 2,300 & $\begin{array}{r}1,800 \\
12,000 \\
1,3000\end{array}$ & $\begin{array}{r}100 \\
6000 \\
200\end{array}$ & $\begin{array}{r}80,000 \\
1,700 \\
1,770,000 \\
40,000 \\
200\end{array}$ & $\begin{array}{r}2,800 \\
100 \\
51,000 \\
2,000 \\
(2)^{2}\end{array}$ \\
\hline 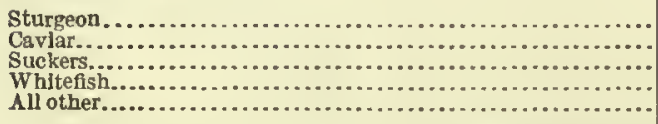 & $\begin{array}{r}42,000 \\
2,400 \\
40,000 \\
123,000 \\
2,100\end{array}$ & $\begin{array}{l}6,600 \\
2,400 \\
1,100 \\
9,800 \\
100\end{array}$ & 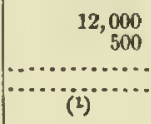 & $\begin{array}{r}2,000 \\
500 \\
\ldots \ldots \ldots . . \\
\cdots(2)\end{array}$ & $\begin{array}{r}4,200 \\
300 \\
19,000 \\
\ldots \ldots \\
1,900\end{array}$ & $\begin{array}{r}600 \\
300 \\
700 \\
\cdots 100\end{array}$ & $\begin{array}{r}25,000 \\
1,700 \\
21,000 \\
123,000 \\
200\end{array}$ & $\begin{array}{r}4,000 \\
1,700 \\
400 \\
9,800 \\
(2)^{9}\end{array}$ \\
\hline
\end{tabular}


FISHERIES, BY STATES.

TABLE 5.-NEW YORK-FISHERY PRODUCTS OF LAKE ONTARIO: 1908."

\begin{tabular}{|c|c|c|c|c|c|c|c|c|c|c|c|c|c|c|}
\hline \multirow{3}{*}{ SPECIES. } & \multirow{2}{*}{\multicolumn{2}{|c|}{ TOTAL. }} & \multicolumn{12}{|c|}{ PRODUCT CAUGHT BY- } \\
\hline & & & \multicolumn{2}{|c|}{ Lines. } & \multicolumn{2}{|c|}{$\begin{array}{l}\text { Pound and trap } \\
\text { nets. }\end{array}$} & \multicolumn{2}{|c|}{ Seines. } & \multicolumn{2}{|c|}{ Gill nets. } & \multicolumn{2}{|c|}{$\begin{array}{c}\text { Fyke and hoop } \\
\text { nets. }\end{array}$} & \multicolumn{2}{|c|}{ Dlp nets. } \\
\hline & $\begin{array}{l}\text { Quantlty } \\
\text { (pounds). }\end{array}$ & Value. & $\begin{array}{l}\text { Quantity } \\
\text { (pounds). }\end{array}$ & Value. & $\begin{array}{l}\text { Quantity } \\
\text { (pounds). }\end{array}$ & Value. & $\begin{array}{l}\text { Quantity } \\
\text { (pounds). }\end{array}$ & Value. & $\begin{array}{l}\text { Quantity } \\
\text { (pounds). }\end{array}$ & Value. & $\begin{array}{l}\text { Quantity } \\
\text { (pounds). }\end{array}$ & Value. & $\begin{array}{l}\text { Quantity } \\
\text { (pounds). }\end{array}$ & Value. \\
\hline Total..... & 823,000 & $\$ 74.000$ & 266,000 & $\$ 39,000$ & 84,000 & $\$ 4,300$ & 54,000 & $\$ 2,700$ & 199,000 & $\$ 14,000$ & 219,000 & $\$ 13,000$ & 1,500 & $\$ 100$ \\
\hline 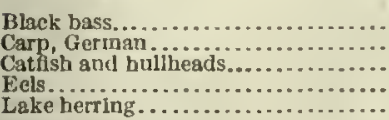 & $\begin{array}{r}36,000 \\
4,700 \\
122,000 \\
44,000 \\
35,000\end{array}$ & $\begin{array}{r}5,000 \\
12,000 \\
2,500 \\
1,700\end{array}$ & $\begin{array}{r}36,000 \\
45,000 \\
300\end{array}$ & $\begin{array}{c}5,000 \\
5,200 \\
(2) \\
\cdots\end{array}$ & $\begin{array}{r}400 \\
2,200 \\
9,500 \\
8,400 \\
4,500\end{array}$ & $\begin{array}{r}(2) \\
100 \\
1,000 \\
500 \\
100\end{array}$ & $\begin{array}{ll}\cdots \\
\cdots \cdots \\
\cdots \\
\cdots \\
\cdots\end{array}$ & $\begin{array}{l}\cdots \\
\cdots \\
\cdots\end{array}$ & $\begin{array}{r}200 \\
1,000 \\
28,000\end{array}$ & $\begin{array}{r}100 \\
1,500\end{array}$ & $\begin{array}{r}2,300 \\
68,000 \\
33,000 \\
1,800\end{array}$ & $\begin{array}{r}100 \\
6,200 \\
2,000 \\
100\end{array}$ & $\mid \begin{array}{l}\cdots \\
\cdots \\
\cdots \\
\cdots \\
\cdots\end{array}$ & ( \\
\hline 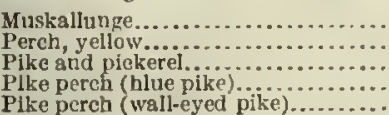 & $\begin{array}{r}19,000 \\
35,000 \\
87,000 \\
100,000 \\
51,000\end{array}$ & $\begin{array}{l}1,200 \\
1,100 \\
9,400 \\
5,000 \\
6,700\end{array}$ & $\begin{array}{l}19,000 \\
65,000 \\
51,000\end{array}$ & $\begin{array}{l}1,200 \\
7,700 \\
6,500\end{array}$ & $\begin{array}{r}7,500 \\
10,000 \\
18,000 \\
500\end{array}$ & $\begin{array}{l}300 \\
700 \\
700 \\
100\end{array}$ & $\mid \begin{array}{l}\cdots \cdots \\
\cdots \cdots \\
\cdots \cdots\end{array}$ & $\mid \begin{array}{l}\cdots \cdots \\
\cdots \cdots \cdots \\
\cdots \cdots \\
\cdots \cdots\end{array}$ & $\begin{array}{r}8,000 \\
1,100 \\
81,000 \\
100\end{array}$ & $\begin{array}{r}300 \\
100 \\
4,300 \\
(2)\end{array}$ & $\begin{array}{r}20,000 \\
11,000 \\
300 \\
1,800\end{array}$ & $\begin{array}{c}600 \\
900 \\
(2) \\
200\end{array}$ & $\mid \begin{array}{ll}\cdots \\
\cdots \cdots \cdots \\
\cdots \cdots \cdots\end{array}$ & $\begin{array}{l}\ldots \\
\ldots \\
\ldots \\
\ldots\end{array}$ \\
\hline 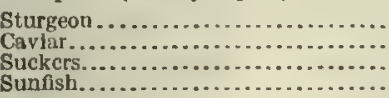 & $\begin{array}{r}37,000 \\
4,700 \\
128,000 \\
24,000\end{array}$ & $\begin{array}{r}5,800 \\
3,800 \\
5,400 \\
600\end{array}$ & $\begin{array}{r}27,000 \\
4,500 \\
\cdots \\
\cdots\end{array}$ & $\begin{array}{c}4,100 \\
3,600 \\
\cdots \\
\cdots\end{array}$ & $\begin{array}{r}800 \\
12,000 \\
12,000\end{array}$ & $\begin{array}{l}100 \\
100 \\
200\end{array}$ & ( & 2,700 & $\begin{array}{r}9,400 \\
200 \\
10,000 \\
400\end{array}$ & $\begin{array}{r}1,600 \\
200 \\
400 \\
(1)\end{array}$ & $\begin{array}{r}57,000 \\
12,000\end{array}$ & 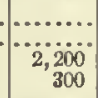 & $\cdots, \ldots$ & ${ }^{\cdots \cdots} 100$ \\
\hline 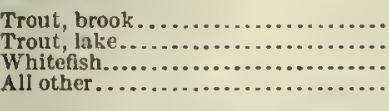 & $\begin{array}{r}18,000 \\
14,000 \\
56,000 \\
3,400\end{array}$ & $\begin{array}{r}6,300 \\
1,100 \\
5,400 \\
100\end{array}$ & $\begin{array}{r}15,000 \\
\cdots \cdots \\
\cdots \\
\cdots\end{array}$ & $\mid \begin{array}{c}6,300 \\
\cdots \cdots \\
\cdots \cdots \\
\cdots \cdots\end{array}$ & $\begin{array}{l}3,200 \\
100\end{array}$ & 400 & & $\begin{array}{l}- \\
\cdots \\
\cdots \\
\cdots\end{array}$ & $\begin{array}{r}6,100 \\
52,000\end{array}$ & $\begin{array}{r}500 \\
5,000 \\
\ldots \ldots\end{array}$ & $\begin{array}{r}8,200 \\
3,200\end{array}$ & ${ }_{100}^{700}$ & $\mid \begin{array}{ll}\cdots \cdots \cdots \\
\cdots \cdots \cdots \\
\cdots \cdots \cdots \\
\cdots \cdots \cdots\end{array}$ & (l) \\
\hline
\end{tabular}

All taken in the shore and boat fisheries.

2. Less than $\$ 100$.

TABLE 6.-NEW YORK-FISHERY PRODUCTS, BY DISTRICTS: 1908.

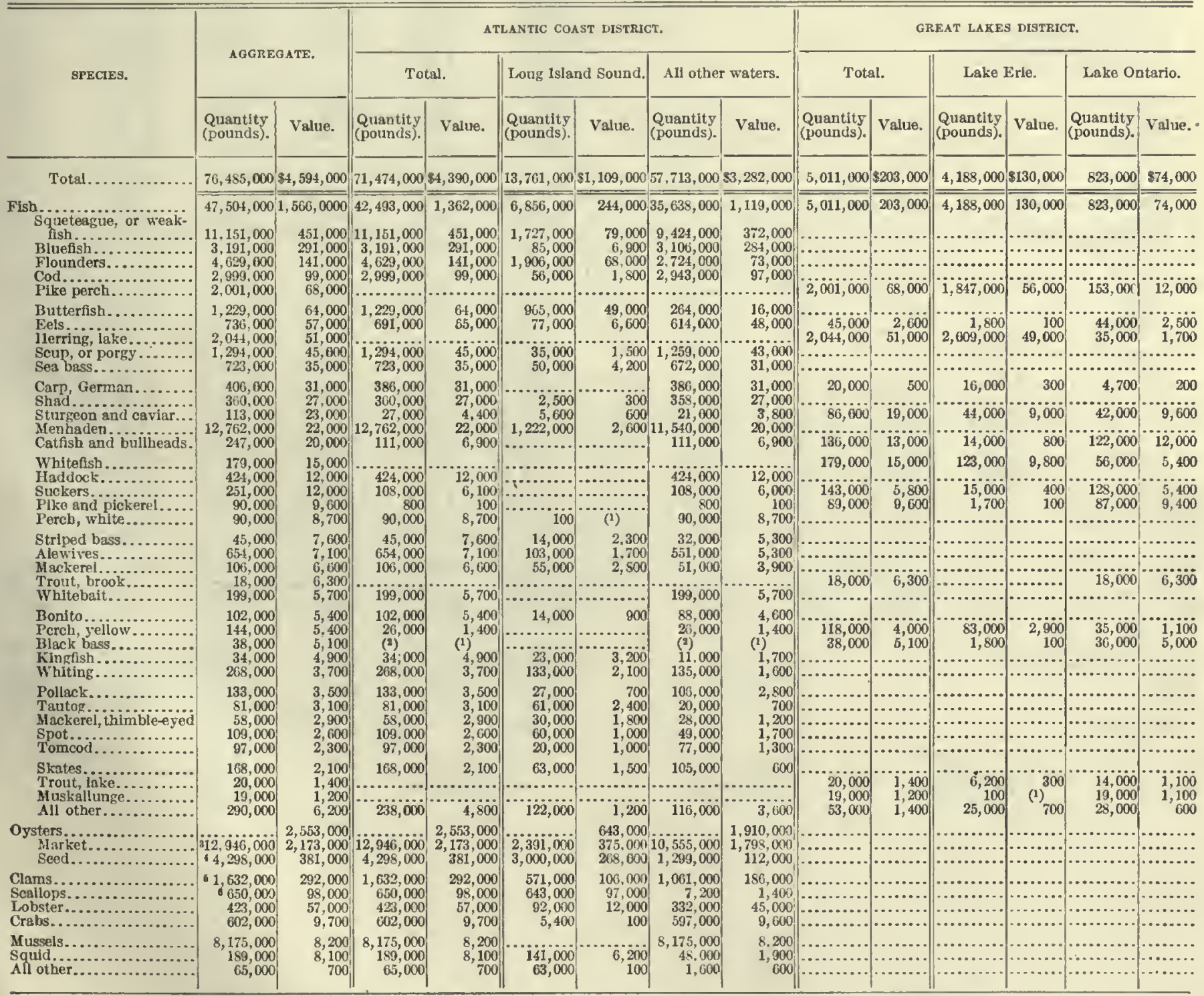


FISHERIES OF THE UNITED STATES, 1908.

TABLE 7.-NEW YORK-PRODUCTS, BY CLASS OF FISHERIES: 1908.

\begin{tabular}{|c|c|c|c|c|c|c|}
\hline \multirow{2}{*}{ - SPECIES. } & \multicolumn{2}{|c|}{ TOTAX. } & \multicolumn{2}{|c|}{ VESSEL FISHERIES. } & \multicolumn{2}{|c|}{ SHORE AND BOAT FISHERIES. } \\
\hline & $\begin{array}{l}\text { Quantity } \\
\text { (pounds). }\end{array}$ & Value. & $\begin{array}{l}\text { Quantity } \\
\text { (pounds). }\end{array}$ & Value. & $\begin{array}{l}\text { Quantity } \\
\text { (pounds). }\end{array}$ & Value. \\
\hline Total..... & $76,485,000$ & $\$ 4,594,000$ & $41,697,000$ & $\$ 2,860,000$ & $34,788,000$ & $\$ 1,734,000$ \\
\hline 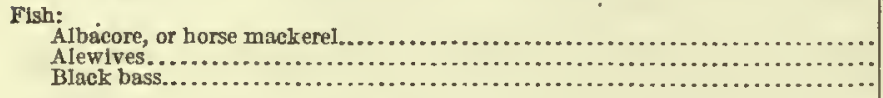 & $\begin{array}{r}19,000 \\
654,000 \\
38,000\end{array}$ & $\begin{array}{l}400 \\
7,000 \\
5,100\end{array}$ & 500 & 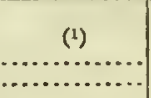 & $\begin{array}{r}19,000 \\
654,000 \\
38,000\end{array}$ & $\begin{array}{r}400 \\
7,000 \\
5,100\end{array}$ \\
\hline 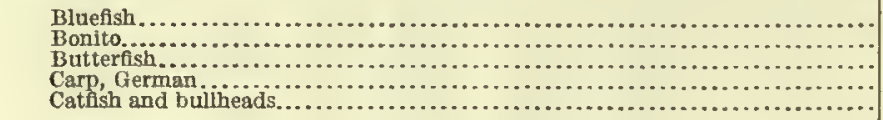 & $\begin{array}{r}3,191,000 \\
102,000 \\
1,229,000 \\
400,000 \\
247,000\end{array}$ & $\begin{array}{r}291,000 \\
5,400 \\
64,000 \\
31,000 \\
20,000\end{array}$ & $\begin{array}{r}2,918,000 \\
11,000 \\
9,500 \\
1,100 \\
1,800\end{array}$ & $\begin{array}{r}268,000 \\
700 \\
400 \\
200 \\
200\end{array}$ & $\begin{array}{r}273,000 \\
99,000 \\
1,222,000 \\
405,000 \\
245,000\end{array}$ & $\begin{array}{r}22,000 \\
4,800 \\
64,000 \\
31,000 \\
29,000\end{array}$ \\
\hline 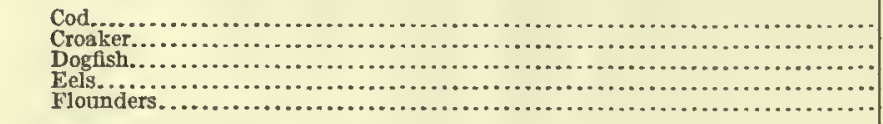 & $\begin{array}{r}2,999,000 \\
7,500 \\
42,000 \\
736,000 \\
4,629,000\end{array}$ & $\begin{array}{r}99,000 \\
200 \\
600 \\
57,000 \\
141,000\end{array}$ & $\begin{array}{r}1,592,000 \\
7,500 \\
1,221,0000\end{array}$ & $\begin{array}{r}59,000 \\
200 \\
i 10,000 \\
39,000\end{array}$ & $\begin{array}{r}1,407,000 \\
42,000 \\
536,000 \\
3,408,000\end{array}$ & $\begin{array}{r}39,000 \\
46,000 \\
111,000\end{array}$ \\
\hline 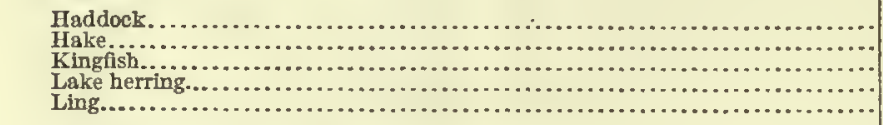 & $\begin{array}{r}424,000 \\
39,000 \\
34,000 \\
2,044,000 \\
24,000\end{array}$ & $\begin{array}{r}12,000 \\
1,000 \\
4,900 \\
51,000 \\
400\end{array}$ & $\begin{array}{r}34,000 \\
1,064,000 \\
2,100\end{array}$ & $\begin{array}{r}1,300 \\
(1) \\
25,000 \\
(1)\end{array}$ & $\begin{array}{r}390,000 \\
39,000 \\
34,000 \\
979,900 \\
22,000\end{array}$ & $\begin{array}{r}11,000 \\
1,000 \\
4,900 \\
25,000 \\
300\end{array}$ \\
\hline 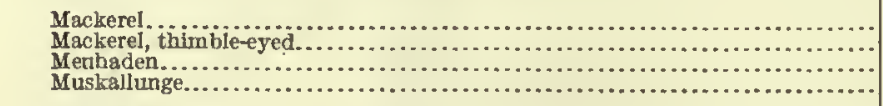 & $\begin{array}{r}109,000 \\
58,000 \\
12,762,000 \\
19,000\end{array}$ & $\begin{array}{r}6,600 \\
2,900 \\
22,000 \\
1,200\end{array}$ & $\begin{array}{r}26,000 \\
10,490,0000 \\
\cdots . . .6 .\end{array}$ & $\begin{array}{c}2,000 \\
18,000 \\
\ldots \ldots \ldots\end{array}$ & $\begin{array}{r}89,000 \\
58,000 \\
2,322,000 \\
19,000\end{array}$ & $\begin{array}{l}4,600 \\
2,900 \\
4,000 \\
1,200\end{array}$ \\
\hline 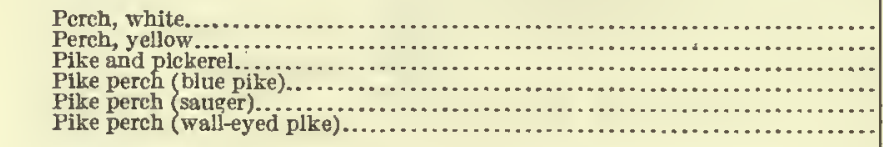 & $\begin{array}{r}99,000 \\
144,000 \\
90,000 \\
1,904,000 \\
49,000 \\
56,000\end{array}$ & $\begin{array}{r}8,700 \\
5,400 \\
9,000 \\
59,000 \\
2,000 \\
7,000\end{array}$ & $\begin{array}{r}100 \\
57,000 \\
800 \\
1,356,000 \\
12,000\end{array}$ & $\begin{array}{l}\text { (1) } \\
1,800 \\
100 \\
38,000 \\
500\end{array}$ & $\begin{array}{r}90,900 \\
87,000 \\
89,000 \\
548,000 \\
28,000 \\
56,000\end{array}$ & $\begin{array}{r}8,700 \\
3,600 \\
9,600 \\
21,000 \\
1,500 \\
7,000\end{array}$ \\
\hline 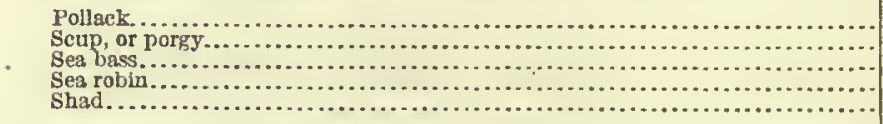 & $\begin{array}{r}133,000 \\
1,294,000 \\
723,000 \\
53,000 \\
360,000\end{array}$ & $\begin{array}{r}3,500 \\
45,000 \\
35,000 \\
509 \\
27,000\end{array}$ & $\begin{array}{r}2,500 \\
1,238,000 \\
455,000 \\
1,000 \\
.\end{array}$ & $\begin{array}{r}100 \\
42,000 \\
16,000 \\
(1)\end{array}$ & $\begin{array}{r}130,000 \\
55,000 \\
268,000 \\
52,000 \\
360,000\end{array}$ & $\begin{array}{r}3,500 \\
2,600 \\
19,000 \\
500 \\
27,000\end{array}$ \\
\hline 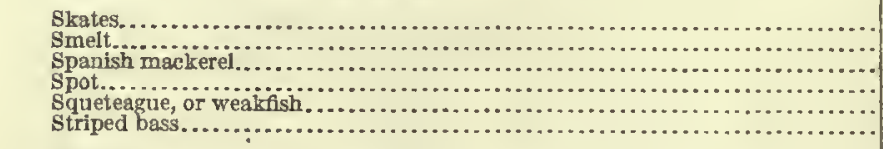 & $\begin{array}{r}168,000 \\
4,000 \\
500 \\
109,000 \\
11,151,000 \\
45,000\end{array}$ & $\begin{array}{r}2,100 \\
900 \\
100 \\
2,600 \\
451,000 \\
7,600\end{array}$ & $\begin{array}{r}100 \\
33,000 \\
6,382,000 \\
1,200\end{array}$ & $\begin{array}{r}(1) \\
1,300 \\
216,000 \\
300\end{array}$ & $\begin{array}{r}168,000 \\
4,000 \\
400 \\
76,000 \\
4,769,000 \\
44,000\end{array}$ & $\begin{array}{r}2,100 \\
900 \\
109 \\
1,400 \\
235,000 \\
7,300\end{array}$ \\
\hline 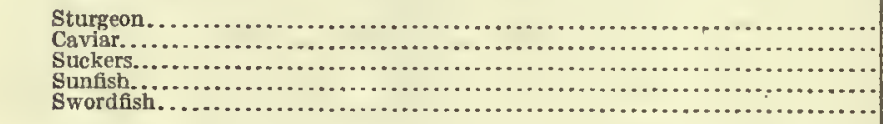 & $\begin{array}{r}105,000 \\
8,100 \\
276,009 \\
31,000 \\
3,600\end{array}$ & $\begin{array}{r}15,000 \\
7,500 \\
13,000 \\
900 \\
200\end{array}$ & $\begin{array}{r}100 \\
5,300 \\
3,500\end{array}$ & (1) & $\begin{array}{r}105,000 \\
8,100 \\
271,000 \\
31,000\end{array}$ & $\begin{array}{r}15,000 \\
7,500 \\
13,000 \\
900 \\
.\end{array}$ \\
\hline 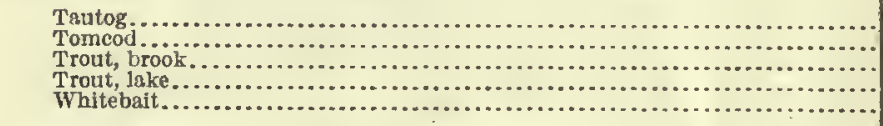 & $\begin{array}{r}81,000 \\
97,000 \\
18,000 \\
20,000 \\
199,000\end{array}$ & $\begin{array}{l}3,100 \\
2,300 \\
6,300 \\
1,400 \\
5,700\end{array}$ & $\begin{array}{r}1,300 \\
1,600 \\
6,100 \\
2,100\end{array}$ & $\begin{array}{r}\text { (1) } \\
100 \\
300 \\
300\end{array}$ & $\begin{array}{r}80,000 \\
95,000 \\
18,000 \\
14,000 \\
197,000\end{array}$ & $\begin{array}{l}3,000 \\
2,200 \\
6,300 \\
1,100 \\
5,600\end{array}$ \\
\hline 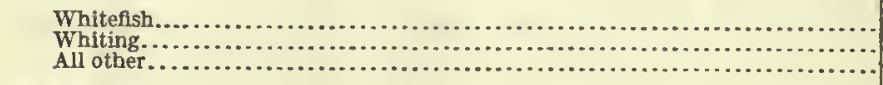 & $\begin{array}{r}179,000 \\
268,000 \\
50,000\end{array}$ & $\begin{array}{r}15,000 \\
3,700 \\
300\end{array}$ & $\begin{array}{r}99,000 \\
300 \\
2,100\end{array}$ & (1) $\begin{array}{r}7,700 \\
100\end{array}$ & $\begin{array}{r}81,000 \\
268,000 \\
48,000\end{array}$ & $\begin{array}{r}7,500 \\
3,700 \\
200\end{array}$ \\
\hline 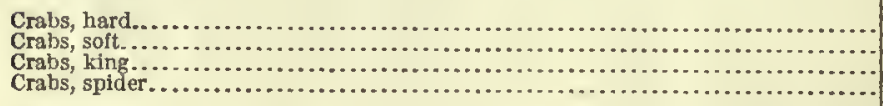 & $\begin{array}{r}589,000 \\
22,000 \\
56,000 \\
7,200\end{array}$ & $\begin{array}{r}7,400 \\
2,300 \\
100\end{array}$ & \begin{tabular}{r|r|}
57,000 \\
\\
$\cdots$ \\
$\cdots$
\end{tabular} & 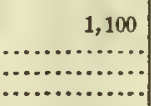 & $\begin{array}{r}523,000 \\
22,000 \\
56,000 \\
7,200\end{array}$ & $\begin{array}{r}6,300 \\
2,300 \\
\quad 100 \\
\text { (1) }\end{array}$ \\
\hline 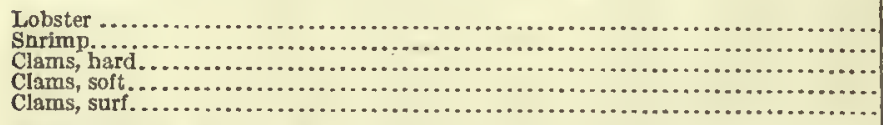 & $\begin{array}{r}423,000 \\
1,600 \\
809,000 \\
8656,000 \\
1157,000\end{array}$ & $\begin{array}{r}57,000 \\
600 \\
223,000 \\
54,000 \\
14,000\end{array}$ & $\begin{array}{r}127,000 \\
241,000 \\
18,000 \\
117,000\end{array}$ & $\begin{array}{r}18,000 \\
70,000 \\
1,800 \\
9,600\end{array}$ & $\begin{array}{r}296,000 \\
1,500 \\
568,000 \\
638,000 \\
49,000\end{array}$ & $\begin{array}{r}40,000 \\
600 \\
153,000 \\
53,000 \\
4,700\end{array}$ \\
\hline 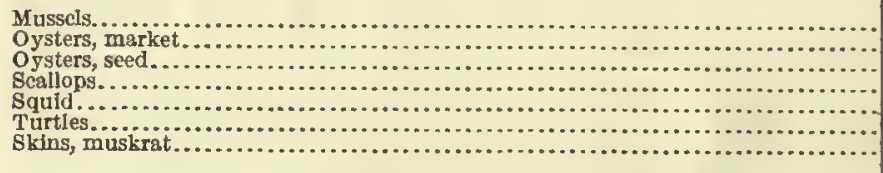 & $\begin{array}{r}8,175,000 \\
12,946,000 \\
4,298,000 \\
\mathbf{3} 650,000 \\
189,000 \\
200 \\
8100\end{array}$ & $\begin{array}{r}8,200 \\
2,173,000 \\
381,000 \\
98,000 \\
8,100 \\
(1) \\
(1)\end{array}$ & $\begin{array}{r}50,000 \\
9,516,000 \\
4,913,000 \\
430,000 \\
\cdots \\
\cdots\end{array}$ & $\begin{array}{r}1,600 \\
1,594,000 \\
358,000 \\
64,000 \\
\cdots\end{array}$ & $\begin{array}{r}8,125,000 \\
3,430,000 \\
286,000 \\
229,000 \\
189,000 \\
200 \\
100\end{array}$ & $\begin{array}{r}6,600 \\
579,000 \\
22,000 \\
35,000 \\
8,100 \\
\text { (1) }\end{array}$ \\
\hline
\end{tabular}


FISHERIES, BY STATES.

TABLE 8.-NEW YORK-PRODUCTS OF VESSEL FISHERIES, BY DISTRICTS: 1908.

\begin{tabular}{|c|c|c|c|c|c|c|c|c|c|c|}
\hline \multirow{3}{*}{ SPECIES. } & \multirow{2}{*}{\multicolumn{2}{|c|}{ AGGREGATE. }} & \multicolumn{6}{|c|}{ ATLANTIC COAST DISTRICT. } & \multirow{2}{*}{\multicolumn{2}{|c|}{ LAKE ERIE. }} \\
\hline & & & \multicolumn{2}{|c|}{ Total. } & \multicolumn{2}{|c|}{ Long Island Sound. } & \multicolumn{2}{|c|}{ All other waters. } & & \\
\hline & $\begin{array}{l}\text { Quantlty } \\
\text { (pounds). }\end{array}$ & Value. & $\begin{array}{l}\text { Quantity } \\
\text { (pounds). }\end{array}$ & Value. & $\begin{array}{l}\text { Quantity } \\
\text { (pounds). }\end{array}$ & Value. & $\begin{array}{l}\text { Quantity } \\
\text { (pounds). }\end{array}$ & Value. & $\begin{array}{l}\text { Quantity } \\
\text { (pounds). }\end{array}$ & Value. \\
\hline Total... & $41,697,000$ & $82,860,000$ & $39,097,000$ & $\$ 2,787,000$ & $6,349,000$ & 8585,000 & $33,747,000$ & $\$ 2,201,000$ & $2,601,000$ & $\$ 73,000$ \\
\hline 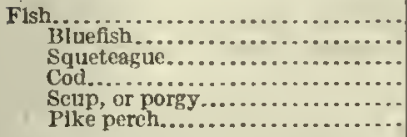 & $\begin{array}{r}27,128,000 \\
2.918,000 \\
6,382,000 \\
1,592,000 \\
1,238,000 \\
1,368,000\end{array}$ & $\begin{array}{r}742,000 \\
268,000 \\
216,000 \\
59,000 \\
42,000 \\
38,000\end{array}$ & $\begin{array}{r}24,528,000 \\
2,918,000 \\
6,382,000 \\
1,592,000 \\
1,238,000\end{array}$ & $\begin{array}{r}669,000 \\
268,000 \\
216,000 \\
59,000 \\
42,000\end{array}$ & $\begin{array}{r}176,000 \\
4,400 \\
3,800 \\
40,000 \\
200\end{array}$ & $\begin{array}{r}7,000 \\
500 \\
200 \\
1,300 \\
(1)\end{array}$ & $\begin{array}{r}24,351,000 \\
2,914,000 \\
6,378,000 \\
1,552,000 \\
1,238,000\end{array}$ & $\begin{array}{r}662,000 \\
268,000 \\
216,000 \\
58,000 \\
42,000\end{array}$ & 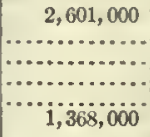 & $\begin{array}{r}73,000 \\
\ldots \ldots \\
\ldots \ldots \\
\cdots \\
38,000\end{array}$ \\
\hline 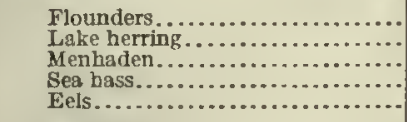 & $\begin{array}{r}1,221,000 \\
1,064,000 \\
10,440,000 \\
455,000 \\
140,000\end{array}$ & $\begin{array}{l}30,000 \\
25,000 \\
18,000 \\
16,000 \\
11,000\end{array}$ & $\begin{array}{r}1,221,000 \\
10,490,000 \\
455,000 \\
140,000\end{array}$ & $\begin{array}{l}30,000 \\
130000 \\
16,000 \\
11,000\end{array}$ & $\begin{array}{r}13,000 \\
6,600\end{array}$ & 1,100 & $\begin{array}{r}1,128,000 \\
10,440,000 \\
442,000 \\
133,000\end{array}$ & $\begin{array}{l}28,000 \\
18,0000 \\
15,000 \\
11,000\end{array}$ & 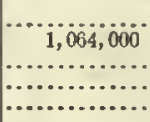 & $\begin{array}{r}25,000 \\
\ldots \ldots\end{array}$ \\
\hline 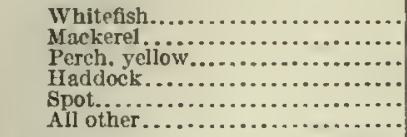 & $\begin{array}{l}99,000 \\
26,000 \\
57,000 \\
34,000 \\
33,000 \\
59,000\end{array}$ & $\begin{array}{l}7,700 \\
2,000 \\
1,800 \\
1,300 \\
1,300 \\
3,000\end{array}$ & $\begin{array}{l}26,000 \\
34,000 \\
33,000 \\
47,000\end{array}$ & $\begin{array}{l}2,000 \\
1,300 \\
1,300 \\
2,600\end{array}$ & $\begin{array}{r}10,000 \\
\ldots \ldots \ldots \ldots \ldots \\
4,400\end{array}$ & 300 & $\begin{array}{r}16,000 \\
34,000 \\
33,000 \\
43,000\end{array}$ & $\begin{array}{r}1,700 \\
1,300 \\
1,300 \\
2,400\end{array}$ & $\begin{array}{r}99,000 \\
\ldots \ldots \ldots \\
\mathbf{5 7}, 000 \\
\cdots \\
12,000\end{array}$ & $\begin{array}{r}7,700 \\
1,800 \\
\cdots \\
\cdots \\
\cdots\end{array}$ \\
\hline 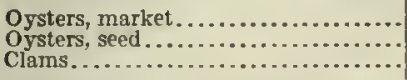 & $\begin{array}{r}29,816,000 \\
\quad 4,013,000 \\
\quad 4376,000\end{array}$ & $\begin{array}{r}1,594,000 \\
358,000 \\
82,000\end{array}$ & $\begin{array}{r}9,516,000 \\
4,013,000 \\
376,000\end{array}$ & $\begin{array}{r}1,594,000 \\
358,000 \\
82,000\end{array}$ & $\begin{array}{r}1,683,000 \\
2,979,000 \\
70,000\end{array}$ & $\begin{array}{r}232,000 \\
267,000 \\
15,000\end{array}$ & $\begin{array}{r}7,833,000 \\
1,033,000 \\
307,000\end{array}$ & $\begin{array}{r}1,362,000 \\
91,000 \\
67,000\end{array}$ & & \\
\hline 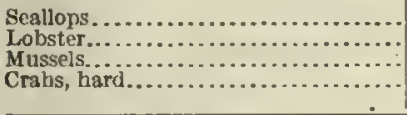 & $\begin{array}{r}430,000 \\
127,000 \\
50,700 \\
57,000 \\
\end{array}$ & $\begin{array}{r}64,000 \\
18,000 \\
1,600 \\
1,100\end{array}$ & $\begin{array}{r}430,000 \\
127,000 \\
50,000 \\
57,000\end{array}$ & $\begin{array}{r}64,000 \\
18,000 \\
1,600 \\
1,100\end{array}$ & $\begin{array}{r}125,000 \\
15,000 \\
\ldots \ldots \ldots\end{array}$ & $\begin{array}{r}63,000 \\
1,900 \\
\cdots \\
\cdots\end{array}$ & $\begin{array}{r}4,800 \\
112,000 \\
50,000 \\
57,000\end{array}$ & $\begin{array}{r}1,000 \\
16,000 \\
1,600 \\
1,100\end{array}$ & & \\
\hline
\end{tabular}

TABLE 9.-NEW YORK-FISHERY PRODUCTS: 1908, 1898-99, 1890, AND 1880.

\begin{tabular}{|c|c|c|c|c|c|c|c|c|}
\hline \multirow{2}{*}{ SPECIES. } & \multicolumn{2}{|c|}{1908} & \multicolumn{2}{|c|}{$1898-99$} & \multicolumn{2}{|c|}{1830} & \multicolumn{2}{|c|}{1880} \\
\hline & $\begin{array}{l}\text { Quantity } \\
\text { (pounds). }\end{array}$ & Value. & $\begin{array}{l}\text { QuantIty } \\
\text { (pounds). }\end{array}$ & Value. & $\begin{array}{l}\text { Quantity } \\
\text { (pounds). }\end{array}$ & Value. & $\begin{array}{l}\text { Quantity } \\
\text { (pounds). }\end{array}$ & Value. \\
\hline 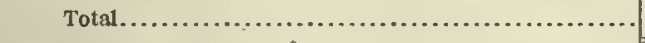 & $76,485,000$ & $\$ 4,694,000$ & $218,458,000$ & $\$ 3,787,000$ & $200,559,000$ & $\$ 4,859,000$ & $333,523,000$ & $\$ 4,381,000$ \\
\hline 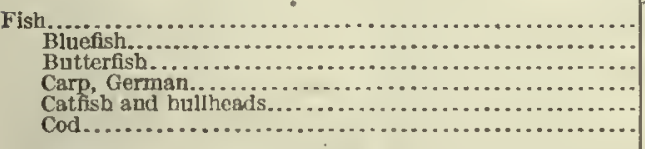 & $\begin{array}{r}47,504,000 \\
3,191,000 \\
1,229,000 \\
406,000 \\
247,000 \\
2,999,000\end{array}$ & $\begin{array}{r}1,566,000 \\
201,000 \\
64,000 \\
31,000 \\
20,000 \\
99,000\end{array}$ & $\begin{array}{r}194,630,000 \\
11,214,000 \\
471,000 \\
297,000 \\
757,000 \\
2,040,000\end{array}$ & $\begin{array}{r}1,436,000 \\
387,000 \\
15,000 \\
12,000 \\
29,000 \\
69,000\end{array}$ & $\begin{array}{r}161,736,000 \\
5,740,000 \\
424,000 \\
865,000 \\
1,939,000\end{array}$ & $\begin{array}{r}1,576,000 \\
250,000 \\
13,000 \\
24,000 \\
79,000\end{array}$ & $\begin{array}{r}\begin{array}{r}318,257,000 \\
3,000,000 \\
\ldots\end{array} \\
3,580,000\end{array}$ & $\begin{array}{r}2,212,000 \\
68,000 \\
\cdots \ldots . . . \cdots \\
67,000\end{array}$ \\
\hline 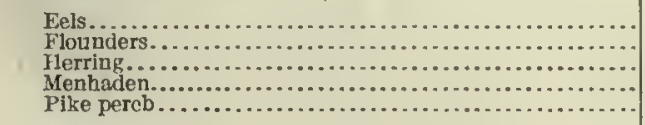 & $\begin{array}{r}736,000 \\
4,629,000 \\
2,0 \$ 6,000 \\
12,762,000 \\
2,001,000\end{array}$ & $\begin{array}{r}57,000 \\
141,000 \\
51,000 \\
22,000 \\
68,000\end{array}$ & $\begin{array}{r}521,000 \\
877,000 \\
3,408,000 \\
163,250,000 \\
1,039,000\end{array}$ & $\begin{array}{r}34,000 \\
25,000 \\
47,000 \\
405,000 \\
43,000\end{array}$ & $\begin{array}{r}1,937,000 \\
1,576,000 \\
2,406,000 \\
128,736,000 \\
826,000\end{array}$ & $\begin{array}{r}110,000 \\
45,000 \\
49,000 \\
341,000 \\
50,000\end{array}$ & $288,931,000$ & \\
\hline 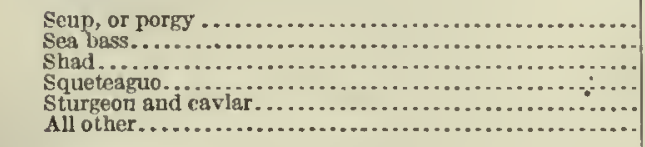 & $\begin{array}{r}1,294,000 \\
723,000 \\
360,000 \\
11,151,000 \\
113,000 \\
3,617,000\end{array}$ & $\begin{array}{r}45,000 \\
35,000 \\
27,000 \\
451,000 \\
23,000 \\
140,000\end{array}$ & $\begin{array}{r}645,000 \\
311,000 \\
1,829,000 \\
2,077,000 \\
1,225,000 \\
4,638,000\end{array}$ & $\begin{array}{r}14,000 \\
14,000 \\
63,000 \\
54,000 \\
105,000 \\
117,000\end{array}$ & $\begin{array}{r}369,000 \\
751,000 \\
3,777,000 \\
2,990,000 \\
2,291,000 \\
7,110,000\end{array}$ & $\begin{array}{r}7,300 \\
41,000 \\
190,000 \\
117,000 \\
84,000 \\
175,000\end{array}$ & $\begin{array}{r}2,734,000 \\
4,000,000 \\
144,000 \\
15,868,000\end{array}$ & $\begin{array}{r}137,000 \\
120,000 \\
8,600 \\
697,000\end{array}$ \\
\hline 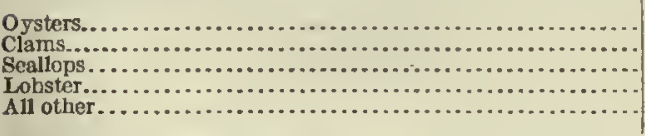 & $\begin{array}{r}117,244,000 \\
1,632,000 \\
650,000 \\
423,000 \\
9,031,000\end{array}$ & $\begin{array}{r}2,553,000 \\
292,000 \\
98,000 \\
57,000 \\
27,000\end{array}$ & $\begin{array}{r}14,436,000 \\
62,321,000 \\
10653,000 \\
332,000 \\
6,085,000\end{array}$ & $\begin{array}{r}1,985,000 \\
267,000 \\
53,000 \\
30,000 \\
16,000\end{array}$ & $\begin{array}{r}36,456,000 \\
75,782,000 \\
11596,000 \\
150,000 \\
15,838,000\end{array}$ & $\begin{array}{r}2,458,000 \\
711,000 \\
71,000 \\
15,000 \\
28,000\end{array}$ & $\begin{array}{r}7,303,000 \\
6,203,000 \\
13.000 \\
1,625,000\end{array}$ & $\begin{array}{r}1,577,000 \\
518,000 \\
\ldots .700 \\
69,000\end{array}$ \\
\hline
\end{tabular}

$12,463,000$ bushels. $22,062,000$ bushels $22,351,000$ bushels.

$76786^{\circ}-11-14$
$\$ 1,043,000$ bushels. 2 204,000 bushels.
2 290,000 bushels.
7 723,000 bushels. : 775,000 bushels.
1082,000 gallons. 1174,000 gallons. 
TABLE 10.-NEW YORK-PRODUCTS OF SHORE AND BOAT FISHERIES, BY DISTRICTS: 1908.

\begin{tabular}{|c|c|c|c|c|c|c|c|c|c|c|c|c|c|c|}
\hline \multirow{3}{*}{ SPECIES. } & \multirow{2}{*}{\multicolumn{2}{|c|}{ AGGREGATE. }} & \multicolumn{6}{|c|}{ ATLANTIC COAST DISTRICT. } & \multicolumn{6}{|c|}{ GREAT LAKES DISTRICT. } \\
\hline & & & \multicolumn{2}{|c|}{ Total. } & \multicolumn{2}{|c|}{$\begin{array}{l}\text { Long Island } \\
\text { Sound. }\end{array}$} & \multicolumn{2}{|c|}{ All other waters. } & \multicolumn{2}{|c|}{ Total. } & \multicolumn{2}{|c|}{ Lake Erie. } & \multicolumn{2}{|c|}{ Lake Ontario. } \\
\hline & $\begin{array}{l}\text { Quantity } \\
\text { (pouads). }\end{array}$ & Value. & $\begin{array}{l}\text { Quantlty } \\
\text { (pounds). }\end{array}$ & Value. & $\begin{array}{l}\text { Quantity } \\
\text { (pounds). }\end{array}$ & Value. & $\begin{array}{l}\text { Quantity } \\
\text { (pounds). }\end{array}$ & Value. & $\begin{array}{l}\text { Quantity } \\
\text { (pounds). }\end{array}$ & Value. & $\begin{array}{l}\text { Quantity } \\
\text { (pounds). }\end{array}$ & Value. & $\begin{array}{l}\text { Quantity } \\
\text { (pounds). }\end{array}$ & Value. \\
\hline Total.... & $34,788,000$ & $\$ 1,734,000$ & $32,377,000$ & $\$ 1,604,000$ & $8,412,000$ & $\$ 523,000$ & $23,965,000$ & $\$ 1,080,000$ & $2,410,000$ & 8130,000 & $1,588,000$ & $\$ 57,000$ & 823,000 & $\$ 74,000$ \\
\hline $\begin{array}{l}\text { Fish } \\
\text { Squete.............. }\end{array}$ & $20,376,000$ & 824,000 & $17,966,000$ & 694,000 & $6,679,000$ & 237,000 & $11,287,000$ & 457,000 & $2,410,000$ & 130,000 & $1,588,000$ & 57,000 & 823,000 & 74,000 \\
\hline weakfish......... & $4,769,000$ & 235,000 & $\begin{array}{l}4,769,000 \\
3,408,000\end{array}$ & $\begin{array}{l}235,000 \\
111,000\end{array}$ & $1,723,000$ & 79,000 & $3.045,000$ & 155,000 & & & & & & \\
\hline $\begin{array}{l}\text { Flounders.......... } \\
\text { Butterfish.......... }\end{array}$ & $\begin{array}{l}3,408,000 \\
1,222,000\end{array}$ & $\begin{array}{r}111,000 \\
64,000\end{array}$ & $\begin{array}{l}3,408,000 \\
1,222,000\end{array}$ & $\begin{array}{r}111,000 \\
64,000\end{array}$ & $\begin{array}{r}1,812,000 \\
965,000\end{array}$ & $\begin{array}{l}65,000 \\
49,000\end{array}$ & $\begin{array}{r}1,590,000 \\
258,000\end{array}$ & $\begin{array}{l}45,000 \\
15,000\end{array}$ & & & & & & \\
\hline Eels................. & 596,000 & 46,000 & 551,000 & 43,000 & 70,000 & 6,000 & 481,000 & 37,000 & 45,000 & 2,600 & 1,800 & 100 & $4 \ddot{4}, 000$ & 2,300 \\
\hline cod................. & $1,407,000$ & 39,000 & $1,407,000$ & 39,000 & 15,000 & 600 & $1,392,000$ & 39,000 & (......... & & & & & ...... \\
\hline $\begin{array}{l}\text { Carp, German..... } \\
\text { Plke perch........ }\end{array}$ & $\begin{array}{l}405,000 \\
633,000\end{array}$ & $\begin{array}{l}31,000 \\
30,000\end{array}$ & 385,000 & $\begin{array}{c}30,000 \\
\cdots\end{array}$ & & ........ & 385,000 & 30.000 & $\begin{array}{r}20,000 \\
633,000\end{array}$ & $\begin{array}{r}500 \\
30,000\end{array}$ & $\begin{array}{r}16,000 \\
480, v x\end{array}$ & $\begin{array}{r}300 \\
18,000\end{array}$ & $\begin{array}{r}4,700 \\
153,000\end{array}$ & $\begin{array}{r}200 \\
12,000\end{array}$ \\
\hline $\begin{array}{l}\text { Shsd ............... } \\
\text { Herring, lake..... }\end{array}$ & $\begin{array}{l}360,000 \\
979,000\end{array}$ & $\begin{array}{l}27,000 \\
26,000\end{array}$ & $\begin{array}{c}360,000 \\
\ldots \ldots \ldots\end{array}$ & 27,000 & 2,500 & 300 & 358,000 & 27,000 & & & $9+4,000$ & 4,000 & & $17 \mathrm{mo}$ \\
\hline Sturgeon and cav- & & & & & & & & & 979,000 & 36,000 & 944,000 & $z+, 000$ & 35,000 & 1,700 \\
\hline Bluefish & 113,000 & 23,000 & 27,000 & 4,400 & 5,600 & 600 & 21,000 & 3,700 & 86,000 & 19,000 & 44,000 & 9,000 & 12,000 & 9,600 \\
\hline $\begin{array}{l}\text { Bluefish........... } \\
\text { Catfish and buli- }\end{array}$ & 273,000 & 22,000 & 273,000 & 22,000 & 81,000 & 6,500 & 193,000 & 16,000 & & & & & & \\
\hline $\begin{array}{l}\text { heads............... } \\
\text { Sea bass......... }\end{array}$ & $\begin{array}{l}245,000 \\
268,000\end{array}$ & $\begin{array}{l}20,000 \\
19,000\end{array}$ & $\begin{array}{l}109,000 \\
268,000\end{array}$ & $\begin{array}{r}6,700 \\
19,000\end{array}$ & & 3,100 & $\begin{array}{l}109,000 \\
231,000\end{array}$ & $\begin{array}{r}6,700 \\
16,000\end{array}$ & 136,000 & 13,000 & 14,000 & 800 & 122,000 & 12,000 \\
\hline Suckers & 251,000 & 12,000 & 108,000 & 6,100 & ............ & .......... & 108,000 & 6,100 & 143,000 & 5,900 & 15,000 & 400 & 128,000 & $\ddot{5}, 400$ \\
\hline Haddock........... & 390,000 & 11,000 & 390,000 & 11,000 & (........... & $\ldots \ldots \ldots$ & 390,000 & 11,000 & - & 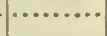 & & & & (n..... \\
\hline $\begin{array}{l}\text { Pike and pickerel.. } \\
\text { Perch, white..... }\end{array}$ & $\begin{array}{l}89,000 \\
90,000\end{array}$ & $\begin{array}{l}9,600 \\
8,700\end{array}$ & $\begin{array}{r}800 \\
90,000\end{array}$ & $\begin{array}{r}100 \\
8,700\end{array}$ & 100 & (1) & $\begin{array}{r}800 \\
90,000\end{array}$ & $\begin{array}{r}100 \\
8,600\end{array}$ & 88,000 & 9,500 & 800 & 100 & 87,000 & 9,400 \\
\hline Whitefisit......... & $\begin{array}{l}81,000 \\
44,000\end{array}$ & 7,500 & 44000 & 7.300 & 14,000 & $\ddot{2} \ddot{3} 00$ & 30000 & & 81,000 & 7,500 & 24,000 & 2,100 & 56,000 & 5,400 \\
\hline $\begin{array}{l}\text { Striped bass........ } \\
\text { Alewlves.......... }\end{array}$ & $\begin{array}{r}44,000 \\
654,000\end{array}$ & 7,100 & 654,000 & 7,100 & $\begin{array}{r}14,000 \\
103,000\end{array}$ & $\begin{array}{l}2,300 \\
1,700\end{array}$ & $\begin{array}{r}30,000 \\
551,000\end{array}$ & $\begin{array}{l}5,000 \\
5,300\end{array}$ & (........ & (....... & $\mid \begin{array}{l}\cdots \ldots \ldots \ldots \\
\cdots \ldots \ldots \ldots\end{array}$ & $\mid \cdots \ldots \ldots$ & a....... & $\cdots \cdots \cdots$ \\
\hline $\begin{array}{l}\text { Trout, brook....... } \\
\text { Whitebait ....... }\end{array}$ & $\begin{array}{r}18,000 \\
197,000\end{array}$ & $\begin{array}{l}6,300 \\
5,500\end{array}$ & & & & & & & 18,000 & 6,300 & & & 18,000 & 6,300 \\
\hline Black bass & 38,000 & 5,100 & 198,000 & (1) & & & (3) & (1) & 38,000 & $\dddot{5}, 100$ & 1,800 & 100 & 36,000 & $\cdots, 000$ \\
\hline $\begin{array}{l}\text { Kingfisb.......... } \\
\text { Bonita.............. }\end{array}$ & $\begin{array}{l}34,000 \\
91,000\end{array}$ & $\begin{array}{l}4,900 \\
4,800\end{array}$ & $\begin{array}{l}34,000 \\
91,000\end{array}$ & $\begin{array}{l}4,900 \\
4,800\end{array}$ & $\begin{array}{l}23,000 \\
14,000\end{array}$ & $\begin{array}{r}3,200 \\
900\end{array}$ & $\begin{array}{l}11,000 \\
76,000\end{array}$ & $\begin{array}{l}1,700 \\
3,900\end{array}$ & …......... & ............ & …...... & ..... & $\ldots \ldots \ldots$ & $\cdots \cdots$ \\
\hline Mackerel. & 80,000 & 4,600 & 80,000 & 4,600 & 45,000 & 2,500 & 35,000 & 2,200 & & & & & & \\
\hline Menh & $2,322,000$ & 4,000 & $2,322,000$ & 4,000 & $1,222,000$ & 2,600 & $1,100,000$ & 1,400 & & & & & & \\
\hline $\begin{array}{l}\text { Whit } \\
\text { Perch }\end{array}$ & $\begin{array}{r}268,000 \\
87,000\end{array}$ & $\begin{array}{l}3,700 \\
3,600\end{array}$ & $\begin{array}{r}268,000 \\
26,000\end{array}$ & 3,700 & 133,000 & 2,100 & $\begin{array}{r}135,000 \\
26,000\end{array}$ & 1,600 & & & & & & \\
\hline Pollack......... & 130,000 & $\begin{array}{l}3,000 \\
3,500\end{array}$ & 130,000 & $\begin{array}{l}1,400 \\
3,500\end{array}$ & 27,000 & 700 & $\begin{array}{r}26,000 \\
103,000\end{array}$ & $\begin{array}{l}1,400 \\
2,800\end{array}$ & 62,000 & 2,200 & 26,000 & 1,100 & 35,000 & 1,100 \\
\hline Tauto & 80,000 & 3,000 & 80,000 & 3,000 & 61,000 & 2,400 & 19,000 & 700 & & & & & & \\
\hline $\begin{array}{l}\text { Mackerel, thimble } \\
\text { eyod.............. }\end{array}$ & 58,000 & 2,900 & 58,000 & & 30,000 & 1,800 & 28,000 & 1200 & & & & & & \\
\hline Seup, or porgy .... & 55,000 & 2,600 & 55,000 & 2,600 & 35,000 & 1,500 & $\begin{array}{l}28,000 \\
21,000\end{array}$ & $\begin{array}{l}1,200 \\
1,100\end{array}$ & & & & & & \\
\hline $\begin{array}{l}\text { Torncod............ } \\
\text { Skates............ }\end{array}$ & $\begin{array}{r}95,000 \\
\cdot \quad 168,000\end{array}$ & $\begin{array}{l}2,200 \\
2,100\end{array}$ & $\begin{array}{r}95,000 \\
168,000\end{array}$ & 2,200 & 18,000 & 900 & 77,000 & 1,300 & $\cdots$ & & & & & \\
\hline 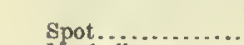 & 100,000 & 2,100 & 168,000 & 2,100 & 63,000 & 1,500 & 105,000 & 600 & & & & & & \\
\hline Muskallunge........ & $\begin{array}{l}76,000 \\
19,000\end{array}$ & $\begin{array}{l}1,400 \\
1,200\end{array}$ & $\begin{array}{r}76,000 \\
\ldots \ldots \ldots\end{array}$ & $\begin{array}{l}1,400 \\
\ldots \ldots\end{array}$ & $\begin{array}{r}60,000 \\
\ldots\end{array}$ & $\begin{array}{r}1,000 \\
\ldots\end{array}$ & 15,000 & 400 & 19,000 & 1,200 & 100 & & 19,000 & 1,200 \\
\hline Trout, lake....... & 14,000 & 1,100 & 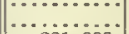 & $\begin{array}{l}\cdots \cdots \\
\cdots \cdots\end{array}$ & (n......... & an. & "......... & ........ & 14,000 & 1,100 & (3) & (1) & 14,000 & 1,100 \\
\hline All other.......... & 268,000 & 5,600 & 221,000 & 4,300 & 119,000 & 1,000 & 102,000 & 3,200 & 47,000 & 1,300 & 19,600 & 700 & 28,000 & 600 \\
\hline Oysters........... & & 601,000 & & 601,000 & & 145,000 & & 457,000 & & & & & & \\
\hline 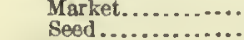 & $\begin{array}{r}3,430,000 \\
: 286,000\end{array}$ & $\begin{array}{r}579,000 \\
22,000\end{array}$ & $\begin{array}{r}3,430,000 \\
286,000\end{array}$ & $\begin{array}{r}579,000 \\
22,000\end{array}$ & $\begin{array}{r}708,000 \\
21,000\end{array}$ & $\begin{array}{r}143,000 \\
1,300\end{array}$ & $\begin{array}{r}2,722,000 \\
265,000\end{array}$ & $\begin{array}{r}436,000 \\
21,000\end{array}$ & & & & & & \\
\hline Clams................. & $=1,256,000$ & 210,000 & $1,256,000$ & 210,000 & 501,000 & $\begin{array}{l}1,300 \\
91,000\end{array}$ & 755,000 & $\begin{array}{r}21,000 \\
119,000\end{array}$ & $\cdots$ & & 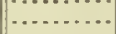 & & & \\
\hline Lobster........... & 296,000 & 40,000 & 296,000 & 40,000 & 76,000 & 10,000 & 220,000 & 29,000 & & & & & . . . . . & $\ldots \ldots$ \\
\hline $\begin{array}{l}\text { Scallops. } \\
\text { Crabs... }\end{array}$ & 220,000 & 35,000 & 220,000 & 35,000 & 217,000 & 34,000 & 2,500 & 400 & & & & & & \\
\hline 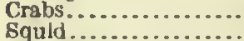 & $\begin{array}{l}545,000 \\
189,000\end{array}$ & $\begin{array}{l}8,600 \\
8,100\end{array}$ & $\begin{array}{l}545,000 \\
189,000\end{array}$ & $\begin{array}{l}8,600 \\
8,100\end{array}$ & $\begin{array}{r}5,400 \\
141,000\end{array}$ & $\begin{array}{r}100 \\
6,200\end{array}$ & $\begin{array}{r}540,000 \\
48,000\end{array}$ & $\begin{array}{l}8,500 \\
1,900\end{array}$ & & & & & & $\ldots$. \\
\hline Mussels.................. & $8,125,000$ & 6,000 & $8,125,000$ & $\begin{array}{l}8,100 \\
6,600\end{array}$ & 141,000 & & $8,125,000$ & 6,600 & $\because$ & & & & & \\
\hline All other............ & 65,000 & 700 & 65,000 & 700 & 63,000 & 100 & 1,600 & 600 & & & & & & \\
\hline & $\begin{array}{l}1 \text { Less tha } \\
2 \text { Less tha }\end{array}$ & 100. & - & & & 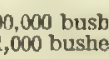 & & & & & 000 & & & \\
\hline
\end{tabular}




\section{NORTII CAROLINA.}

Among the states in which commercial fishing was pursued in 1908, North Carolina ranked eleventh in the value of fishery products. The chicf fishing grounds of the state were Albemarle, Pamlico, and Core Sounds, and their tributary rivers. Among the important rivers were the Cape Fear, New, Roanoke, Shallotte, Newport, North, and Neuse. Many smaller sounds and rivers also contributed to the fishery product of the state.

The following tabular statement gives a general summary of the statistics of the North Carolina fisheries in 1908:

Number of persons employed...................

Capital:

Vessels and boats, including outfit........... \$533,000

Apparatus of capture..................... $\quad 367,000$

Shore and accessory property and cash......... 370,000

Value of products.......................... 1,776,000

Comparison with previous canvasses.-In prior canvasses of the fisheries of North Carolina, the United States Bureau of Fisheries enumerated among the shoresmen employees of the canning and packing industries allied to the fishing industry. These are, however, excluded in the following tabular statement, which shows the general statistics of the fishing industry for certain years:

\begin{tabular}{|c|c|c|c|c|c|c|}
\hline \multirow[b]{2}{*}{ TEAR. } & \multirow{2}{*}{$\begin{array}{c}\text { Persons } \\
\text { em- } \\
\text { ployed, } \\
\text { exclusive } \\
\text { of shores- } \\
\text { men. }\end{array}$} & \multicolumn{3}{|c|}{ VALUE OF EQUIPMENT. } & \multicolumn{2}{|c|}{ PRODUCTS. } \\
\hline & & Total. & $\begin{array}{c}\text { Vessels } \\
\text { and } \\
\text { boats, } \\
\text { including } \\
\text { outft. }\end{array}$ & $\begin{array}{l}\text { Appara- } \\
\text { tus of } \\
\text { capture. }\end{array}$ & $\begin{array}{l}\text { Quantity } \\
\text { (pounds). }\end{array}$ & Value. \\
\hline $\begin{array}{l}1908 \ldots \ldots \ldots \ldots \\
1902 \ldots \ldots \ldots \ldots \\
1897 \ldots \ldots \ldots \ldots \\
1890 \ldots \ldots \ldots \\
1850 \ldots \ldots\end{array}$ & $\begin{array}{r}9,637 \\
11,592 \\
10,120 \\
7,478 \\
4,729\end{array}$ & $\begin{array}{r}8901,000 \\
1,157,000 \\
765,000 \\
634,000 \\
388,000\end{array}$ & $\begin{array}{r}\$ 533,000 \\
583,000 \\
354,000 \\
288,000 \\
162,000\end{array}$ & $\begin{array}{r}\$ 367,000 \\
574,000 \\
411,000 \\
346,000 \\
225,000\end{array}$ & $\begin{array}{r}101,422,000 \\
67,585,000 \\
64,234,000 \\
51,799,000 \\
32,249,000\end{array}$ & $\begin{array}{r}\$ 1,776,000 \\
1,740,000 \\
1,316,000 \\
1,028,000 \\
846,000\end{array}$ \\
\hline
\end{tabular}

An increase in the number of persons employed was shown at each canvass up to and including that of 1902 , and this was accompanied by increases in all the other items given in the above statement. From 1902 to 1908 , however, there was a decline in the number of persons employed and a corresponding decrease in the value of both classes of equipment. The vessels engaged in fishing and transporting show a decrease of $\$ 79,000$ in value since 1902 . Products, on the other hand, continued to increase in both quantity and value.

The following tabular statement distributes, by class of fisheries, the number of persons employed in the years for which canvasses have been made from 1880 to 1908 :

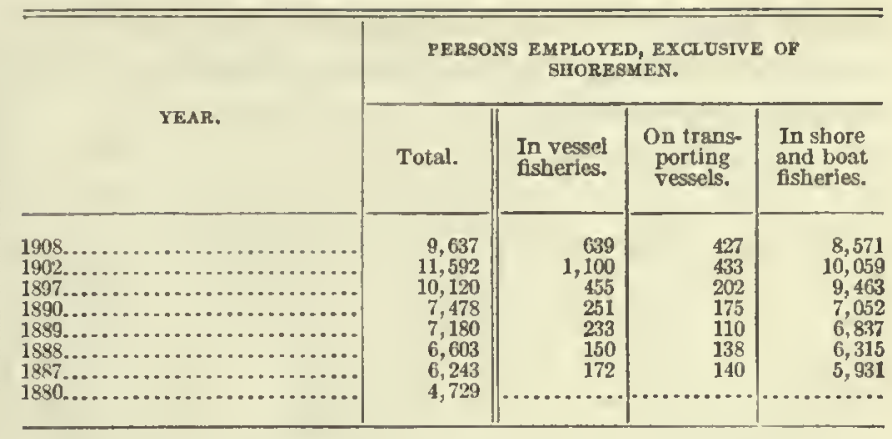

Persons employed.-The distribution of the persons employed is given in the following tabular statement:

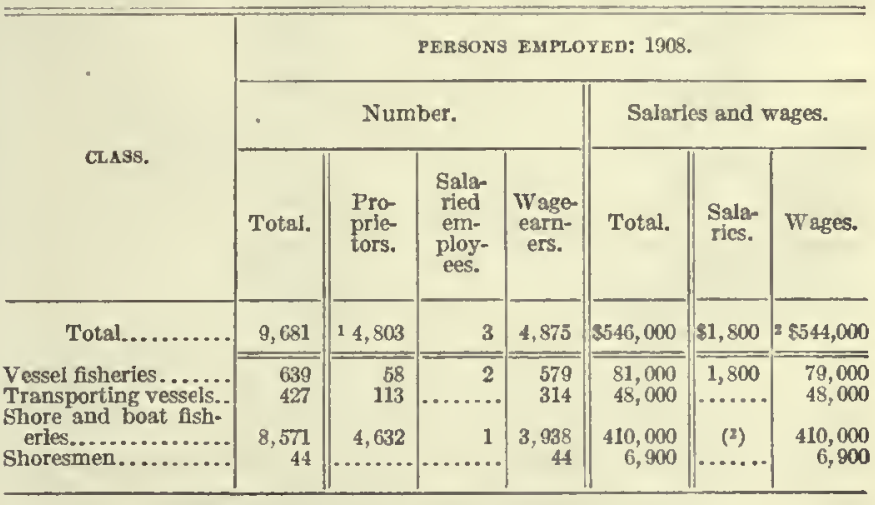

1 Exclusive of 214 proprietors not fishing.

2 Includes provisions lurnished to the value of $\$ 34,000$.

I Less than $\$ 100$.

The vessel fisheries gave employment in 1908 to only a small percentage of the total number of persons reported. The shore and boat fisheries are credited with 8,571 persons, or 89 per cent of the total number, while only 1,066 , or 11 per cent, were engaged in the vessel fisheries and on the transporting vessels. Only 44 shoresmen were reported. By far the larger number of persons reported for vessel fisheries and transporting vessels were wage-earners. For the shore and boat fisheries of North Carolina a larger proportion of wage-earners and a smaller proportion of independent fishermen were reported than for the same class of fisheries in other states.

Many of the persons employed in the industry fished only a part of the year, and during the remainder of the time engaged in farming and other occupations.

Equipment and other capital.-The next tabular statement gives the distribution, by class of investment, of the total capital employed in the fisheries of North Carolina.

The total investment in 1908 in fishing and transporting vessels and their outfits was $\$ 282,000$, which was greater than the investment in boats by $\$ 30,000$. The value of vessels and apparatus of capture pertaining to vessel fisheries was only $\$ 308,000$, or one-half 
as much as the value of the apparatus of capture and boats used in the shore and boat fisheries, which amounted to $\$ 593,000$.

\begin{tabular}{|c|c|c|c|c|}
\hline \multirow{2}{*}{ CLASS OE INVESTMENT } & \multirow{2}{*}{ - } & \multicolumn{3}{|c|}{$\begin{array}{l}\text { EQUIPMENT AND OTHER } \\
\text { CAPITAL: } 1908 .\end{array}$} \\
\hline & & Value. & Number. & Tennage. \\
\hline Total ........... & & $\$ 1,270,000$ & $\cdots \cdot$ & ........ \\
\hline Vessels, lneluding outnt .... & & 282,000 & & \\
\hline 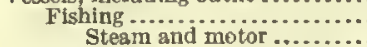 & & 137,000 & 99 & 1,135 \\
\hline $\begin{array}{r}\text { Steam and motor ............. } \\
\text { Vessels ................ }\end{array}$ & & $\begin{array}{l}69,000 \\
59,000\end{array}$ & & 356 \\
\hline Outat ............................ & & 9,500 & & \\
\hline Sail ......... & & 68,000 & 84 & 779 \\
\hline $\begin{array}{l}\text { Vessels : } \\
\text { Outfit .. }\end{array}$ & & $\begin{array}{l}54,000 \\
14,000\end{array}$ & & ….... \\
\hline Transporting ............. & & 145,000 & 200 & $\ddot{1}, \ddot{6}, 00$ \\
\hline $\begin{array}{l}\text { Steam and motor ..... } \\
\text { Vessels........... }\end{array}$ & & 52,000 & & 225 \\
\hline & & & & \\
\hline Sall & & 93,000 & iii & 1,455 \\
\hline Outfit..................... & ….. & $\begin{array}{l}73,000 \\
20,000\end{array}$ & : .......... & \\
\hline 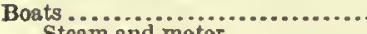 & & 251,000 & 4,984 & , \\
\hline Steam and meter ........... & & $\begin{array}{r}118,000 \\
98,000\end{array}$ & 2.433 & (n........... \\
\hline Rew & $\cdots . .$. & 33,000 & 2,218 & (n................ \\
\hline Other & & 2,600 & & .... \\
\hline $\begin{array}{l}\text { Apparatus of capture ......... } \\
\text { Vessel fisheries . }\end{array}$ & & $\begin{array}{r}367,000 \\
26,000\end{array}$ & & \\
\hline Shere and beat fisheries....... & & 341,000 & & \\
\hline $\begin{array}{l}\text { Shere and accessory property ...... } \\
\text { Cash. }\end{array}$ & & 350,000 & & .............. \\
\hline 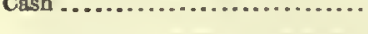 & & 19,000 & & \\
\hline
\end{tabular}

The investment in apparatus of capture in the shore and boat fisheries was nearly thirteen times as great as that in the vessel fisheries. The importance of this item is shown by the fact that in 1902 .it represented 28 per cent and in 1908,27 per cent of the total investment in the fisheries of the state. The decrease from 1902 to 1908 in the value of the investment in apparatus of capture, which was from $\$ 574,000$ to $\$ 367,000$, is chargeable entirely to the shore and boat fisheries, for the value of the apparatus of capture used in the vessel fisheries increased more than $\$ 5,000$.

The numbers of the principal kinds of apparatus of capture employed, all of which, except 16 gill nets, 10 eel pots, 41 seines, and 12 traps, were used in shore and boat fisheries, were as follows:

\begin{tabular}{|c|c|c|}
\hline Bow nets............... & d nets........ & 3,997 \\
\hline Cast nets.............. & s............. & 1,538 \\
\hline 628 & p nets... & 45 \\
\hline 40 & Sto & \\
\hline Fyke nets........... 416 & muskrat, and otter & \\
\hline Gill nets.......... 42,225 & traps. . . . . . . . . & \\
\hline 18 , spears, etc ... 64 & Turtle nets............ & 149 \\
\hline Pots, eel............ 4, 289 & Wheels and slides....... & 25 \\
\hline
\end{tabular}

Products, by species.-The fishery products of the state, distributed by species and by apparatus of capture, are shown in Table 1, on page 215.

The product of the North Carolina fisheries included more than 40 species of fish, besides frogs, crabs, shrimp, terrapin, turtles, clams, and oysters; the skins of mink, muskrats, and otter; whalebone and whale oil; and the hides and oil of porpoises.

Of the important products, shad, oysters, mullet, and clams showed large decreases in 1908 in both quantity and value. Almost the entire increase in the total quantity of products is accounted for by the unprece- dented size of the menhaden catch. Although this amounted to $40,000,000$ pounds more than in 1902 , it caused an increase in value of only $\$ 40,000$. While the catches of some of the other species increased in both quantity and value, the increase in the total value for the state was due chiefly to the general increase in the price per pound received for fishery products.

In the following tabular statement the quantity and value reported for some of the important products are given for 1902 and 1908 :

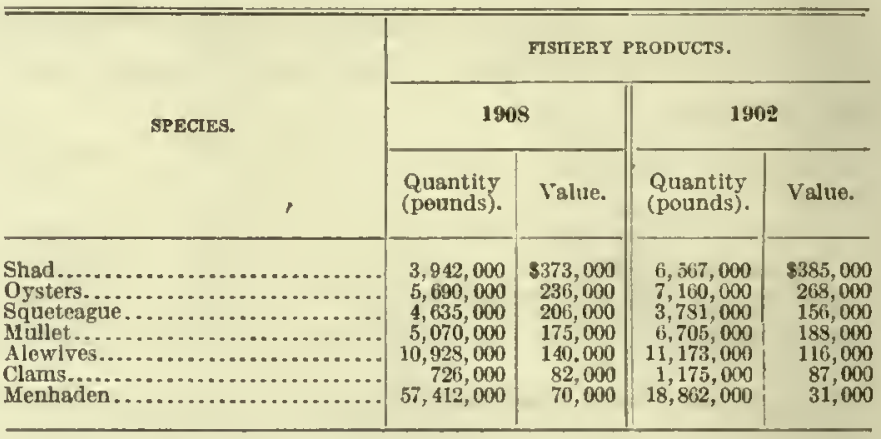

The total weight of the 1908 product was $101,422,000$ pounds and its total value $\$ 1,776,000$. The 40 species of fish reported contributed $94,133,000$ pounds, valued at $\$ 1,406,000$, or 94 per cent of the weight and 79 per cent of the value. Shad constituter the most valuable product and oysters ranked second, the value of the former being $\$ 373,000$, or 21 per cent of the total value reported, and that of the latter $\$ 236,000$, or 13 per cent of the total value. Three species of fish-squetergue, mullet, and, alewives-for which values of $\$ 206,000$, $\$ 175,000$, and $\$ 140,000$, respectively, were reported, ranked next in importance. For no other product was a value as great as $\$ 100,000$ reported; but clams worth $\$ 82,000$ were taken, and crabs and 16 species of fish each added from $\$ 10,000$ to $\$ 70,000$ to the total value of the product.

Products, by class of fisheries. - The products of the shore and boat fisheries and of the vessel fisheries are given in detail, by species and apparatus of capture, in Tables 2 and 3, on pages 216 and 217, respectively.

The next tabular statement distributes, by species, arranged in the order of value, the total value of products for the state as a whole and for each class of fisheries.

The catch of the shore and boat fisheries aggregated $45,556,000$ pounds, or 44 per cent of the total weight, and was valued at $\$ 1,613,000$, or 91 per cent of the total value of the fishery products of the state. Shad contributed 22 per cent of the total value reported for this class of fisheries, representing a larger percentage of the value than any other species. Squeteague, mullet, and oysters each furnished more than 10 per cent of the total value.

The catch of the ressel fisheries was $55,865,000$ pounds, or 55 per cent of the total quantity for the state; but its value was only $\$ 163,000$, or 9 per cent 
of the total value. The values of the menhaden and oyster products each formed about 40 per cent of the value reported for vessel fishcries. Next to these the most raluable product was shad, which had a value of $\$ 13,000$, or 8 per cent of the value credited to this class of fisheries.

\begin{tabular}{|c|c|c|c|}
\hline \multirow[b]{2}{*}{ SPECIES. } & \multicolumn{3}{|c|}{ VALUE OF PRODUCTS: 1908.} \\
\hline & Total. & $\begin{array}{c}\text { Vessel } \\
\text { fisheries. }\end{array}$ & $\begin{array}{l}\text { Shore and } \\
\text { boat } \\
\text { fisheries. }\end{array}$ \\
\hline Total..... & $\$ 1,776,000$ & $\$ 163,000$ & $\$ 1,613,000$ \\
\hline 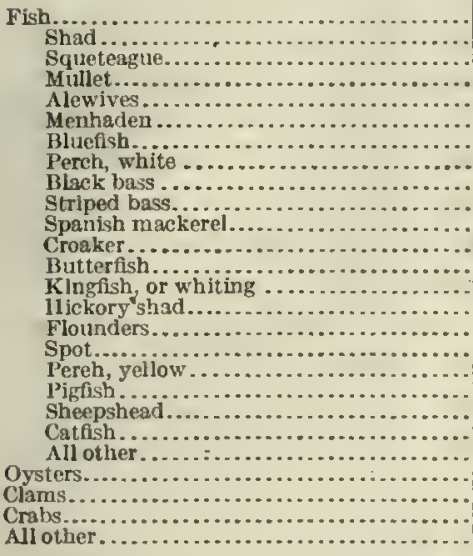 & \begin{tabular}{|r|}
$, 406,000$ \\
373,000 \\
206,000 \\
175,000 \\
140,000 \\
70,000 \\
45,000 \\
44,000 \\
40,000 \\
36,000 \\
34,000 \\
31,000 \\
29,000 \\
28,000 \\
20,000 \\
16,000 \\
16,000 \\
14,000 \\
14,000 \\
12,000 \\
11,000 \\
52,000 \\
236,000 \\
82,000 \\
34,000 \\
18,000
\end{tabular} & 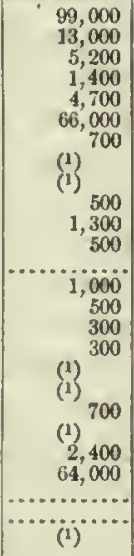 & $\begin{array}{r}1,307,000 \\
360,000 \\
201,000 \\
173,000 \\
136,000 \\
4,000 \\
45,000 \\
44,000 \\
40,000 \\
36,000 \\
33,000 \\
31,000 \\
29,000 \\
27,000 \\
20,000 \\
16,000 \\
15,000 \\
14,000 \\
14,000 \\
11,000 \\
11,000 \\
49,000 \\
172,000 \\
82,000 \\
34,000 \\
18,000\end{array}$ \\
\hline
\end{tabular}

1 Less than $\$ 100$.

The value of fish proper constituted 81 per cent of the total value of the catch in the case of shore and boat fisheries and 61 per cent in the case of vessel fisheries. Two-thirds of the value of the fish taken in the vessel fisheries represented the value of menhaden.

Products, by apparatus of capture.-The following tabular statement shows the distribution by apparatus of capture, arranged in the order of the value of their catch, of the total value of products, for the state as a whole and for each class of fisheries:

\begin{tabular}{|c|c|c|c|}
\hline \multirow[b]{2}{*}{ KIND OF APPARATUS. } & \multicolumn{3}{|c|}{ VALUE OF PRODUCTS: 1908.} \\
\hline & Total. & $\begin{array}{c}\text { Vessel } \\
\text { fisheries. }\end{array}$ & $\begin{array}{c}\text { Shore and } \\
\text { boat } \\
\text { fisheries. }\end{array}$ \\
\hline Total........... & $\$ 1,776,000$ & $\$ 163,000$ & $\$ 1,613,000$ \\
\hline 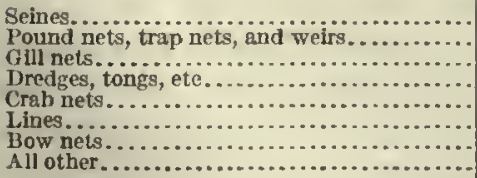 & $\begin{array}{r}591,000 \\
391,000 \\
376,000 \\
307,000 \\
29,000 \\
21,000 \\
16,000 \\
46,000\end{array}$ & $\begin{array}{r}96,000 \\
64,000 \\
700 \\
2,500 \\
(1 ;)\end{array}$ & $\begin{array}{r}495,000 \\
391,000 \\
375,000 \\
243,000 \\
29,000 \\
15,000 \\
16,000 \\
46,000\end{array}$ \\
\hline
\end{tabular}

1 Less than $\$ 100$.

The products caught by seines contributed a larger part of the weight and value of the total fishery products than those taken by any other form of apparatus. Their value constituted 33 per cent of the total value of all products and their weight 70 per cent of the total quantity. The chief species caught by seines were mullet, squeteague, menhaden, black bass, alewives, and shad. Slightly more than five-sixths of the value of the products taken by this form of apparatus was secured from the shore and boat fisheries.

On the basis of the value of the product taken, pound nets, trap nets, and weirs formed the next most important class of fishing apparatus. Since 1880, when only 117 pound nets were used, this kind of apparatus has increased in importance, until in 1908 , 3,997 pound nets, trap nets, and weirs were in use. The value of the product obtained by pound nets, including the comparatively small quantities taken by trap nets and weirs, amounted to $\$ 391,000$, or 22 per cent of the value of all fishery products. These forms of-apparatus were used only in the shore and boat fisheries and principally in the capture of shad and alewives.

Gill nets ranked second in importance with respect to the value of the product taken in 1902 and third in 1908. They were of little consequence in the vessel fisheries, but were extensively used in the shore and boat fisheries for catching shad, squeteague, mullet, bluefish, and numerous less important species. Dredges, tongs, and rakes yielded a product valued at $\$ 307,000$, which consisted of alams, oysters, and crabs. Crab nets, lines, and bow nets followed in rank according to the value of product taken. The use of crab nets and bow nets was confined to the shore and boat fisheries, to which 88 per cent of the value of the catch by lines is also credited. With fyke nets various species of fish, having a total value of $\$ \$, 600$, were taken in the shore and boat fisheries.

Shad.-Shad has always been the chicf product of the fisheries of North Carolina, and in 1908 the total catch was $3,942,000$ pounds, valued at $\$ 373,000$. This catch, however, contributed only 4 per cent of the total weight and 21 per cent of the total value of the fishery products of the state. The quantity was 40 per cent less than in 1902, but the value was only 3 per cent less than in that year. In 1902 the state ranked first in the shad catch, reporting $6,567,000$ pounds, valued at $\$ 385,000$; but in 1908 it was outranked by Virginia, both in the quantity and the value of shad taken. Of the total value of the catch of shad, 96 per cent was that of product obtained in the shore and boat fisheries, principally by means of pound nets and gill nets, though to some extent by seines and other apparatus. The quantity caught in the vessel fisheries, representing 4 per cent of the value, was obtained entirely by the use of seines and gill nets. This fish was taken chiefly in Cape Fear River and its tributaries, in Pamlico, Croatan, Roanoks, and Albemarle Sounds, and in the rivers tributary to these sounds.

Oysters.-The oyster yield ranked second in value, the total product in 1908 being 813,000 bushels, valued at $\$ 236,000$. This represents a decrease, as compared with 1902 , when $1,023,000$ bushels were obtained, having $a$ value of $\$ 268,000$. The average price per bushel, however, increased from 26 cents in 1902 to 30 cents in 1908 . Very little progress has been 
made in the cultivation of oysters in North Carolina. The yield from private areas in 1908 was only 11,000 bushels, valued at $\$ 7,600$ : The following tabular statement presents statisties in respect to the yield of oysters in 1908:

\begin{tabular}{|c|c|c|}
\hline \multirow{2}{*}{ KUND AND SOURCE. } & \multicolumn{2}{|c|}{$\begin{array}{l}\text { OYSTER PRODUCT: } \\
\text { I908. }\end{array}$} \\
\hline & $\begin{array}{l}\text { Quantity } \\
\text { (bushels). }\end{array}$ & Value. \\
\hline Total............. & $8 \mathbf{1 3}, 000$ & $\$ 236,000$ \\
\hline Market.......... & 754,000 & 227,000 \\
\hline 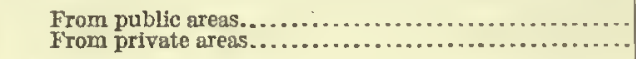 & $\begin{array}{r}744,000 \\
9,500\end{array}$ & $\begin{array}{r}220,000 \\
7,300\end{array}$ \\
\hline Seed....... & 59,000 & 8,800 \\
\hline 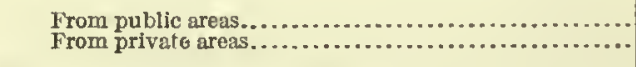 & $\begin{array}{r}57,000 \\
2,000\end{array}$ & 8,500 \\
\hline
\end{tabular}

The total yield of seed oysters from public and private areas in 1908 was only 59,000 bushels, valued at $\$ 8,800$, of which value $\$ 5,000$ represents the value of oysters taken in the vessel fisheries. The total yield of oysters from public areas was 801,000 bushels, valued at $\$ 228,000$, or 99 per cent of the quantity and 97 per cent of the value, of the total yield for the state. Oyster fishing was pursued mainly as a shore and boat fishery, only 27 per cont of the total value of the oyster product being obtained in the vessel fisheries.

Squeteague.-The catch of squeteague, which ranked third in importance in 1908 with respect to value, increased from $3,781,000$ pounds, valued at $\$ 156,000$, in 1902 , to $4,635,000$ pounds, valued at $\$ 206,000$, in 1908. New York and New Jersey were the only states which had a larger and more valuable catch of this fish than North Carolina; Florida had a product slightly larger, but of smaller value. Ninety-six per cent of the total value reported for North Carolina was that of product taken in the shore and boat fisheries; and in this class of fisheries seines, pound nets, and gill nets accounted for all except 4 per cent of the value. Practically all of the value of the catch (over 99 per cent) was that of product sold fresh.

Mullet.-Ninllet ranked fourth in value among the fishery products of North Carolina. The eatch of this state, together with the much larger catch of Florida, represented 90 per cent of the value of the mullet caught in the United States. The quantity taken in North Carolina in 1908, though smaller than that taken in 1902, was greater than the eateh in any previous year. In 1908 the mullet product amounted to $5,070,000$ pounds, valued at $\$ 175,000$, and in 1902 to $6,705,000$ pounds, valued at $\$ 188,000$. Less than 1 per cent of the mullet catch of 1908 was reported by the vessel fisheries. Seines and gin nets were used in the capture of nearly the entire product. The fisher- men sold 54 per cent of the fish fresh and the remainder salted. A little of the roe ( 800 pounds) was salted and sold separately.

Alewives.-The total alewife product in 1908 was $10,928,000$ pounds, valued at $\$ 140,000$, and was the smallest quantity recorded since 1880 , when $15,520,000$ pounds were taken. In 1902 the eatch was $11,173,000$ pounds, valued at $\$ 116,000$, and in 1897 it was $15,790,000$ pounds, valued at $\$ 127,000$. Since 1897 this fish appears to have been less abundant. Like shad, it was caught mostly in the fresh waters; and 97 per cent of the value of the catch was contributed by the product of shore and boat fisheries. Of the total value, 73 per cent represented the value of the catch with pound nets and the remainder the value of that with seines, gill nets, fyke nets, and miscellaneous apparatus. Nearly two-thirds of the alewife product was sold fresh; and with the exception of a small quantity ( 1,200 pounds) which was smoked, the balance was sold salted.

Menhaden.-Of the states showing a menhaden catch, North Carolina ranked third in respect to quantity of product and fourth in respect to value, and was the most southern state in which this fish was taken in any quantity. The catch of $1908-57,412,000$ pounds, valued at $\$ 70,000$-was larger than that of any previous year, and showed an increase since 1902 of more than 204 per cent in quantity and 125 per cent in value. In 1902 the catch was $18,862,000$ pounds, valued at $\$ 31,000$, which was at that time the largest that had ever been taken in the state. This fish, though representing but 4 per cent of the value of all fishery products of the state, constituted 57 per cent of the total quantity. The catch was obtained almost wholly in the vessel fisheries, menhaden contributing 41 per cent of the total value and 96 per cent of the total quantity reported for this class of fisheries. Of the total value of the menhaden catch, only $\$ 4,200$, or 6 per cent, was reported from the shore and boat fisheries. The entire catch in the vessel fisheries was secured by seines, but in the shore and boat fisheries, though seines were the chief apparatus used, about one-fourth of the eatch was taken with gill nets and pound nets.

Other products.-Large inereases since 1902 were shown in the quantity and value of crabs, bluefish, and Spanish mackerel. On the other hand, clams, black bass, striped bass, croakers, and other minor species each showed a decrease from the eatch taken in 1902. The quantity of white perch increased from 941,000 pounds in 1902 to 993,000 pounds in 1908, but the price per pound decreased so that the total value was only $\$ 44,000$ in 1908 , as compared with $\$ 63,000$ in 1902 . This state ranked first in its catch of white perch, which contributed 32 per cent of the value of all white pereh talien in the United States. 
FISHERIES, BY STATES.

TABLE 1.-NORTII CAROLINA-FISHERY PRODUCTS: 1908.

\begin{tabular}{|c|c|c|c|c|c|c|c|c|c|c|c|c|c|c|}
\hline \multirow{3}{*}{ SPECIES. } & \multirow{2}{*}{\multicolumn{2}{|c|}{ TOTAL. }} & \multicolumn{12}{|c|}{ PRODUCT CAOGHT BY- } \\
\hline & & & \multicolumn{2}{|c|}{ Seines. } & \multicolumn{2}{|c|}{$\begin{array}{l}\text { Pound nets, trap } \\
\text { nets, and weirs. }\end{array}$} & \multicolumn{2}{|c|}{ Gill nets. } & \multicolumn{2}{|c|}{ Lines. } & \multicolumn{2}{|c|}{ Fyke nots. } & \multicolumn{2}{|c|}{$\begin{array}{l}\text { All other appa- } \\
\text { ratus. } 1\end{array}$} \\
\hline & $\begin{array}{l}\text { Quantity } \\
\text { (pounds). }\end{array}$ & Value. & $\begin{array}{l}\text { Quantity } \\
\text { (pounds). }\end{array}$ & Value. & $\begin{array}{l}\text { Quantity } \\
\text { (pounds). }\end{array}$ & Value. & $\begin{array}{l}\text { Quantity } \\
\text { (ponuds). }\end{array}$ & Value. & $\begin{array}{l}\text { Quantity } \\
\text { (pounds). }\end{array}$ & Value. & $\begin{array}{l}\text { Quantity } \\
\text { (pounds). }\end{array}$ & Value. & $\begin{array}{l}\text { Quantity } \\
\text { (pounds). }\end{array}$ & Value. \\
\hline Total ... & $101,422,000$ & $\$ 1,776,000$ & $71,069,000$ & $\$ 591,000$ & $14,040,000$ & $\$ 391,000$ & $7,733,000$ & $\$ 376,000$ & 574,000 & $\$ 21,000$ & 231,000 & $\$ 8,600$ & $7,774,000$ & $\$ 339,000$ \\
\hline $\begin{array}{l}\text { ish } \\
\text { Alewives................. } \\
\text { Black bass............. } \\
\text { Bluefish................ } \\
\text { Bonito } \\
\text { Butterfish.................. }\end{array}$ & $\begin{array}{r}10,928,000 \\
511,000 \\
1,256,000 \\
11,000 \\
1,302,000\end{array}$ & $\begin{array}{r}140,000 \\
40,000 \\
45,000 \\
200 \\
29,000\end{array}$ & $\begin{array}{r}2,401,000 \\
45 \overline{5}, 000 \\
55 \overline{5}, 000 \\
\ldots . \ldots \\
98,000\end{array}$ & $\begin{array}{r}34,000 \\
35,000 \\
20,000 \\
3,100\end{array}$ & $\begin{array}{r}8,085,000 \\
20,000 \\
83,000 \\
9,500 \\
1,084,000\end{array}$ & $\begin{array}{r}102,000 \\
2,200 \\
2,500 \\
200 \\
24,000\end{array}$ & $\begin{array}{r}164,000 \\
8,100 \\
601,000 \\
1,100 \\
120,000\end{array}$ & $\begin{array}{r}2,200 \\
600 \\
22,000 \\
(3) \\
2,200\end{array}$ & $\begin{array}{r}7,600 \\
15,000\end{array}$ & $\begin{array}{l}400 \\
500\end{array}$ & $\begin{array}{r}24,000 \\
15,000 \\
1,700\end{array}$ & $\begin{array}{r}300 \\
1,200 \\
100\end{array}$ & $\begin{array}{l}165,000 \\
\cdots \cdots \\
\cdots \cdots\end{array}$ & $\begin{array}{r}1,600 \\
\cdots \cdots \cdots \\
\cdots \cdots \\
\cdots \\
\cdots\end{array}$ \\
\hline $\begin{array}{l}\text { Carp, German......... } \\
\text { Cattish................. } \\
\text { Croaker................. } \\
\text { Dogfish, or bowfin..... } \\
\text { Drum, salt-water..... }\end{array}$ & $\begin{array}{r}228,000 \\
504,000 \\
1,177,000 \\
101,000 \\
343,000\end{array}$ & $\begin{array}{r}7,000 \\
11,000 \\
31,000 \\
1,400 \\
7,200\end{array}$ & $\begin{array}{r}154,000 \\
181,000 \\
626,000 \\
53,000 \\
213,000\end{array}$ & $\begin{array}{r}4,600 \\
3,800 \\
14,000 \\
600 \\
4,600\end{array}$ & $\begin{array}{r}20,000 \\
221,000 \\
225,000 \\
10,000 \\
62,000\end{array}$ & $\begin{array}{r}600 \\
4,300 \\
12,000 \\
100 \\
1,000\end{array}$ & $\begin{array}{r}5,500 \\
28,000 \\
280,000 \\
1,100 \\
49,000\end{array}$ & $\begin{array}{r}200 \\
600 \\
4,700 \\
(1) \\
1,200\end{array}$ & $\begin{array}{r}8,400 \\
37,000 \\
45,000 \\
1,800 \\
17,000\end{array}$ & $\begin{array}{r}300 \\
1,200 \\
900 \\
100 \\
400\end{array}$ & $\begin{array}{r}5,300 \\
20,000 \\
100 \\
30,000 \\
800\end{array}$ & $\begin{array}{l}200 \\
400 \\
(2) \\
300 \\
(1)\end{array}$ & $\begin{array}{r}35,000 \\
16,000 \\
400 \\
5,300 \\
1,500\end{array}$ & $\begin{array}{l}1,100 \\
400 \\
\text { (2) } 200 \\
\text { (3) }\end{array}$ \\
\hline 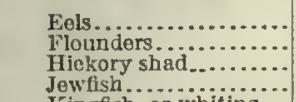 & $\begin{array}{l}258,000 \\
403,000 \\
377,000 \\
1,200\end{array}$ & $\begin{array}{r}5,600 \\
16,000 \\
20,000 \\
100\end{array}$ & $\begin{array}{r}2,500 \\
256,000 \\
167,000 \\
1,200\end{array}$ & $\begin{array}{r}100 \\
10,000 \\
9,000 \\
100\end{array}$ & $\begin{array}{r}5,100 \\
80,000 \\
176,000\end{array}$ & $\begin{array}{r}200 \\
4,100 \\
9,500\end{array}$ & $\begin{array}{l}31,000 \\
23,000\end{array}$ & $\begin{array}{l}1,100 \\
1,100\end{array}$ & $\begin{array}{r}2,200 \\
2,800 \\
400\end{array}$ & $\begin{array}{l}(2) \\
1_{(3)}\end{array}$ & $\begin{array}{l}600 \\
300 \\
100\end{array}$ & $\begin{array}{l}(2) \\
(2) \\
(3)\end{array}$ & $\begin{array}{r}247,000 \\
33,000 \\
10,000\end{array}$ & $\begin{array}{r}5,200 \\
1,000 \\
600\end{array}$ \\
\hline Kingfish, or whiting... & 817,000 & 28,000 & 293,000 & 9,600 & 15,000 & 400 & 486,000 & 17,000 & 10,000 & 700 & 4,000 & 100 & 500 & (2) \\
\hline $\begin{array}{l}\text { Menhaden .............. } \\
\text { Mooufish (ägel-fish, }\end{array}$ & $57,412,000$ & 70,000 & $56,465,000$ & 69,000 & 311,000 & 500 & 636,000 & 600 & & & & & & \\
\hline $\begin{array}{l}\text { or spadefish)......... } \\
\text { Mullet ...... } \\
\text { Mullitet roe, salted...... }\end{array}$ & $\begin{array}{r}53,000 \\
5,070,000 \\
800\end{array}$ & $\begin{array}{r}1,300 \\
175,000 \\
100\end{array}$ & $\begin{array}{r}2,900 \\
3,486,000 \\
800\end{array}$ & $\begin{array}{r}100 \\
124,000 \\
100\end{array}$ & $\begin{array}{r}49,000 \\
8,000\end{array}$ & $\begin{array}{r}1,200 \\
400\end{array}$ & $1,536,000$ & 49,000 & 500 & $\begin{array}{l}(3) \\
\cdots . .\end{array}$ & 3,000 & 100 & 36,000 & 1,400 \\
\hline l'erch, white...... & 993,000 & 44,000 & 152,000 & 19,000 & 365,000 & 17,000 & 87,000 & 3,400 & 8,800 & 900 & 75,000 & $\dddot{3}, 800^{\circ}$ & $\dddot{4}, 800$ & 200 \\
\hline $\begin{array}{l}\text { Perch, yellow..... } \\
\text { Pigfish ............... } \\
\text { P'ike } \\
\text { Pinfish............... } \\
\text { Pompano ......... }\end{array}$ & $\begin{array}{r}360,000 \\
476,000 \\
69,000 \\
373,000 \\
11,000\end{array}$ & $\begin{array}{r}14,000 \\
14,000 \\
3,100 \\
4,300 \\
700\end{array}$ & $\begin{array}{r}227,000 \\
315,000 \\
51,000 \\
203,000 \\
4,200\end{array}$ & $\begin{array}{r}9,600 \\
8,600 \\
2,300 \\
2,300 \\
300\end{array}$ & $\begin{array}{r}97,000 \\
3,000 \\
14,000 \\
128,000 \\
5,900\end{array}$ & $\begin{array}{r}3,300 \\
\quad 100 \\
700 \\
1,400 \\
400\end{array}$ & $\begin{array}{r}21,000 \\
107,000 \\
2,400 \\
41,000 \\
1,000\end{array}$ & $\begin{array}{r}1,000 \\
3,200 \\
100 \\
700 \\
100\end{array}$ & $\begin{array}{r}2,300 \\
50,000 \\
4 \ldots \ldots 0\end{array}$ & $\begin{array}{r}100 \\
2,200 \\
\cdots \cdots \\
\hdashline(2)\end{array}$ & $\begin{array}{r}13,000 \\
100 \\
1,100\end{array}$ & $\begin{array}{l}500 \\
(3) \\
\text { (3) }\end{array}$ & ${ }_{(3)^{300}}^{300}$ & (3) \\
\hline Pomp & 11,000 & 700 & 4,200 & 300 & 5,900 & 400 & 1,000 & 100 & & & & & & \\
\hline $\begin{array}{l}\text { Sea bass.......... } \\
\text { Shad........... }\end{array}$ & & $\begin{array}{r}1,800 \\
3,200 \\
373,000\end{array}$ & $\begin{array}{r}34,000 \\
1,100 \\
401,000\end{array}$ & $\begin{array}{l}1,700 \\
(3) \\
34,000\end{array}$ & 156000 & 144000 & $\begin{array}{r}100 \\
2,000 \\
1,887,000\end{array}$ & $\begin{array}{r}(3) \\
100 \\
186,000\end{array}$ & $\begin{array}{r}5,000 \\
68,000\end{array}$ & 3,100 & & & & \\
\hline 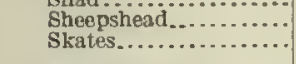 & $\begin{array}{r}3,948,000 \\
24,000\end{array}$ & $\begin{array}{r}r, 000 \\
100\end{array}$ & 219,090 & $\begin{array}{l}34,600 \\
10,000\end{array}$ & $\begin{array}{r}1,563,000 \\
11,000 \\
6,000\end{array}$ & $\begin{array}{r}580 \\
500 \\
100\end{array}$ & $\begin{array}{r}17,000 \\
\ldots \ldots \ldots\end{array}$ & 700 & 1,400 & "ioo" & $\begin{array}{l}6,500 \\
. \ldots \ldots . .\end{array}$ & 600 & $\begin{array}{r}78,000 \\
100\end{array}$ & (2) $^{7,900}$ \\
\hline $\begin{array}{l}\text { Snapper ....... } \\
\text { Spanish macke }\end{array}$ & 13,000 & 300 & & & & & & & $13, \mathrm{c}$ & 300 & & & & \\
\hline 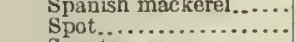 & $\begin{array}{l}457,000 \\
852,000\end{array}$ & $\begin{array}{l}34,000 \\
16,000\end{array}$ & $\begin{array}{l}103,000 \\
584,000\end{array}$ & $\begin{array}{r}8,400 \\
10,000\end{array}$ & $\begin{array}{r}143,000 \\
34,000\end{array}$ & $\begin{array}{r}8,500 \\
000\end{array}$ & $\begin{array}{l}208,000 \\
218,000\end{array}$ & $\begin{array}{r}17,000 \\
4,500\end{array}$ & $\begin{array}{r}2,300 \\
16,000\end{array}$ & $\begin{array}{l}200 \\
500\end{array}$ & $\begin{array}{l}800 \\
200\end{array}$ & $(100$ & $\begin{array}{l}200 \\
400\end{array}$ & (2) \\
\hline $\begin{array}{l}\text { Squeleague } \\
\text { Strawberry bass and }\end{array}$ & $4,635,000$ & 206,000 & $2,425,000$ & 115,000 & 873,000 & 32,000 & $1,090,000$ & 51,000 & 229,000 & 7,900 & 6,000 & 300 & 12,000 & 500 \\
\hline orappie ............... & 24,000 & 1,000 & 6,800 & 300 & 5,500 & 200 & 1,400 & 100 & 2,600 & 100 & 7,700 & 300 & 200 & $\left(^{(3)}\right.$ \\
\hline 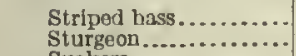 & $\begin{array}{r}510,000 \\
62,000\end{array}$ & $\begin{array}{r}36,000 \\
6,400\end{array}$ & $\begin{array}{r}177,000 \\
34,000\end{array}$ & $\begin{array}{r}12,000 \\
3,800\end{array}$ & $\begin{array}{r}215,000 \\
21,000\end{array}$ & $\begin{array}{r}15,000 \\
1,800\end{array}$ & $\begin{array}{r}38,000 \\
6,000\end{array}$ & $\begin{array}{r}2,700 \\
800\end{array}$ & 6,200 & 500 & 2,400 & 200 & $\begin{array}{r}71,000 \\
800\end{array}$ & $\begin{array}{r}5,700 \\
100\end{array}$ \\
\hline …................ & $\begin{array}{r}63,000 \\
165,000\end{array}$ & & $\begin{array}{r}39,000 \\
113,000\end{array}$ & 1,000 & 9,700 & 400 & 11,000 & 500 & 200 & (a) & $14 \mathrm{mon}$ & & 3,200 & 100 \\
\hline 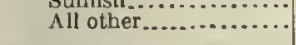 & $\begin{array}{r}10,000 \\
7,200\end{array}$ & $\begin{array}{r}3,600 \\
200\end{array}$ & $\begin{array}{r}113,000 \\
2,000\end{array}$ & $\begin{array}{r}3,700 \\
100\end{array}$ & $\begin{array}{r}14,000 \\
800\end{array}$ & $(2)$ & $\begin{array}{r}13,000 \\
3,200\end{array}$ & $\begin{array}{l}600 \\
100\end{array}$ & $\begin{array}{r}9,900 \\
300\end{array}$ & (3) & 14,000 & 2000 & & \\
\hline Frogs $\ldots . . .$. & $\begin{array}{r}5,400 \\
277,000\end{array}$ & $\begin{array}{r}900 \\
33,000\end{array}$ & & & & & & & & & & & $\begin{array}{r}5,400 \\
276,000\end{array}$ & $\begin{array}{r}900 \\
33,000\end{array}$ \\
\hline & 113,000 & 1,100 & 49,000 & 400 & 55,000 & $400^{\circ}$ & $6,000^{\circ}$ & 200 & 300 & (i) & & & & $\begin{array}{ll}30,000 \\
200\end{array}$ \\
\hline 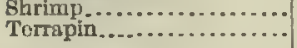 & $\begin{array}{r}371,000 \\
7,700\end{array}$ & $\begin{array}{l}9,000 \\
1,800\end{array}$ & $\begin{array}{r}42,000 \\
4,300\end{array}$ & $\begin{array}{l}1,300 \\
1,200\end{array}$ & & $\dddot{(3)}$ & 200 & 100 & & & & & $\begin{array}{r}328,000 \\
3,200\end{array}$ & $\begin{array}{l}7,700 \\
500\end{array}$ \\
\hline $\begin{array}{l}\text { Turtles.................. } \\
\text { Clams, hard........ }\end{array}$ & $\begin{array}{r}23,000 \\
-726,000\end{array}$ & 82,000 & 9,800 & 300 & & & 700 & (2) & & & & & $\begin{array}{r}13,000 \\
4726,000\end{array}$ & 82,000 \\
\hline 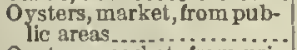 & $5,209,000$ & 220,000 & & & & & & & & & & & $55,209,000$ & 220,000 \\
\hline $\begin{array}{l}\text { Oysters, market, from pri- } \\
\text { vate areas }\end{array}$ & 866,000 & 7,300 & & & & & & & & & & & 866,000 & 7,300 \\
\hline $\begin{array}{l}\text { Oysters, seed, from public } \\
\text { areas................................. }\end{array}$ & 7401,000 & 8,600 & & & & & & & & & & & 7401,000 & 8,500 \\
\hline $\begin{array}{l}\text { Oysters, seed, from private } \\
\text { areas................................. }\end{array}$ & $\checkmark 14,000$ & 300 & & & $\therefore$ & & & & & & & & 814,000 & 300 \\
\hline $\begin{array}{l}\text { Whalebone..... } \\
\text { Skins, mink... }\end{array}$ & $\begin{array}{r}200 \\
\quad 100\end{array}$ & $\begin{array}{l}300 \\
500\end{array}$ & & & & & & & & & & & $\begin{array}{r}200 \\
\quad 100 \\
10500\end{array}$ & $\begin{array}{l}300 \\
500\end{array}$ \\
\hline 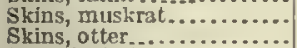 & ${ }_{(8)}^{10500}$ & $\begin{array}{l}800 \\
100\end{array}$ & $\cdots$ & $\ldots$. & & & & & & & & & $\begin{array}{l}20500 \\
\left({ }^{3}\right)\end{array}$ & $\begin{array}{l}800 \\
100\end{array}$ \\
\hline & 48,000 & 1,000 & 48,000 & 1,000 & & & & & & & & & & $\cdots$ \\
\hline 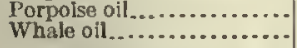 & $\begin{array}{r}21,000 \\
117,500\end{array}$ & $\begin{array}{r}2,200 \\
400\end{array}$ & 21,000 & 2,200 & & & & & & & & & ii 7,500 & $\ddot{400}$ \\
\hline & & & & & & & & & & & & & & \\
\hline
\end{tabular}

1 Includes apparatus, with catch, as follows: Dredges, tongs, ete, $5,907,000$ pounds, valued at $\$ 307,000 ;$ crab nets, 245,000 pounds, valued at $\$ 29,000$; bow nets, 263,000 pounds, valued at $\$ 16,000 ;$ shrimp nets, 328,000 pounds, valuod at $\$ 7,700 ;$ pots, 243,000 pounds, valued at $\$ 5,100 ;$, harpoens, spears, ete., 51,000 pounds, valued at $\$ 2,800$; cast. nets, 46,000 pounds, valued at $\$ 1,900$; wheels and slides, 123,000 pounds, valued at $\$ 1,900$; dip nets, 14,000 pounds, valued at $\$ 1,200 ;$; mink, muskrat, and otter traps,

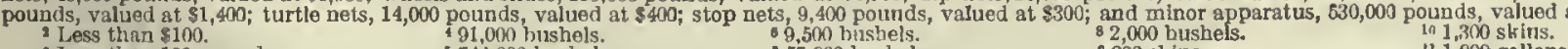


TABLE 2.-NORTH CAROLINA-PRODUCTS OF SHORE AND BOAT FISHERIES: 1908.

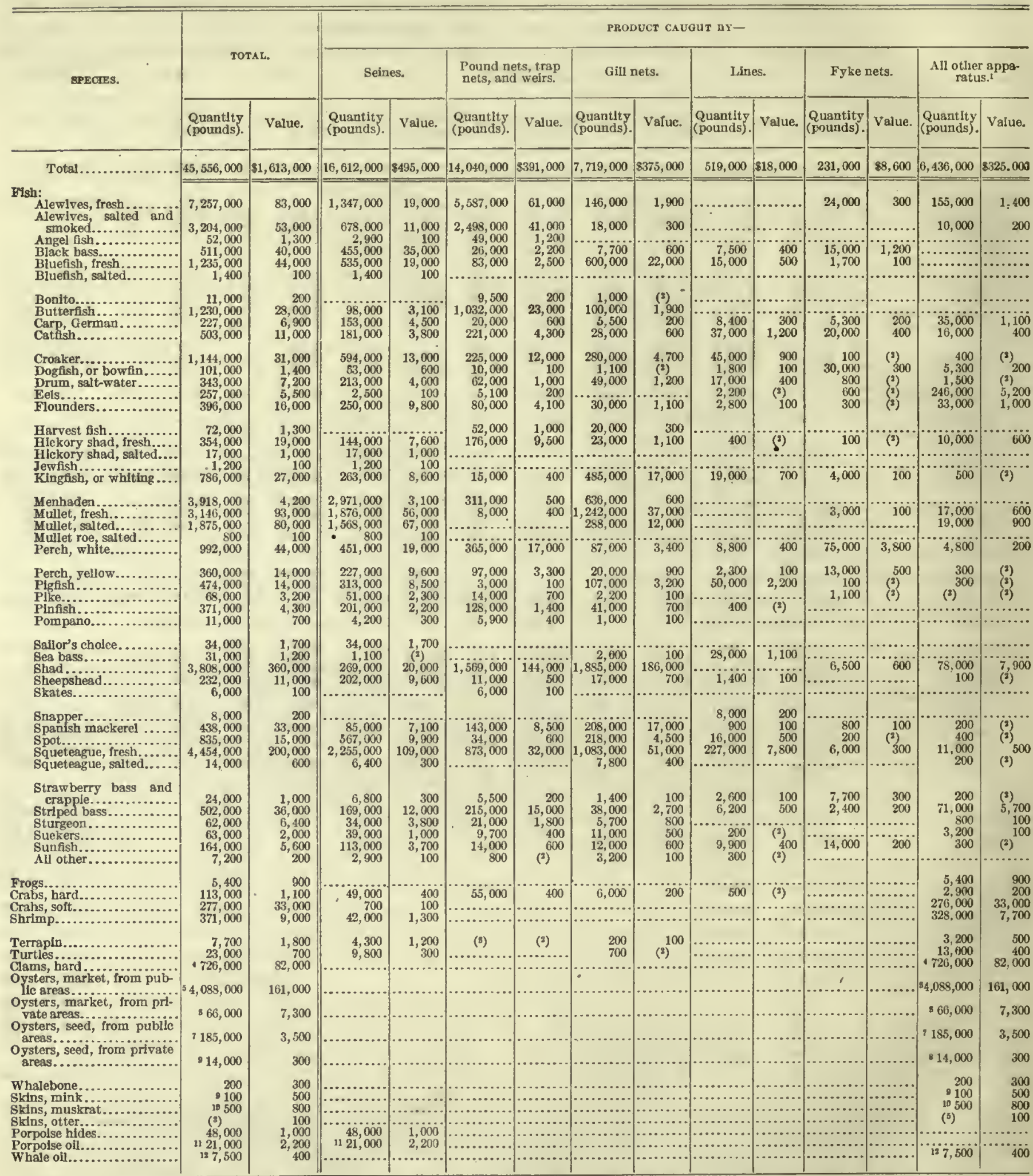

1 Includes apparatus, with catch, as follows: Dredges, tongs, ete., $4,570,000$ pounds, valued at $\$ 243,000 ;$ crab nets, 245,000 pounds, valued at $\$ 29,000$; bow nets, 263,000

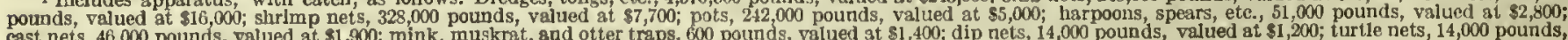
cast nets, 46,000 pounds, valued at $\$ 1,300$; mink, muskrat, sad otter traps, 600 pounds, valued at $\$ 1,400$; dip nets, 
TABLE 3.-NORTH CAROLINA-PRODUCTS OF VESSEL FISHERIES: 1908.

\begin{tabular}{|c|c|c|c|c|c|c|c|c|}
\hline \multirow{3}{*}{ SPECIES. } & \multirow{2}{*}{\multicolumn{2}{|c|}{ TOTAL. }} & \multicolumn{6}{|c|}{ PRODUCI CAUOUT BY- } \\
\hline & & & \multicolumn{2}{|c|}{ Seines. } & \multicolumn{2}{|c|}{ Gill nets. } & \multicolumn{2}{|c|}{ All other apparatus. 1} \\
\hline & $\begin{array}{l}\text { Quantlty } \\
\text { (pounds). }\end{array}$ & Value. & $\begin{array}{l}\text { Quantity } \\
\text { (pounds). }\end{array}$ & Value. & $\begin{array}{l}\text { Quantity } \\
\text { (pounds). }\end{array}$ & Value. & $\begin{array}{l}\text { Quantity } \\
\text { (pounds). }\end{array}$ & Value. \\
\hline Total................... & $55,865,000$ & $\$ 163,000$ & $54,457,000$ & $\$ 96,000$ & 14,000 & $\$ 700$ & $1,394,000$ & $\$ 67,000$ \\
\hline 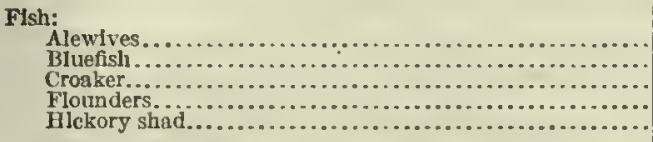 & $\begin{array}{r}467,000 \\
20,000 \\
33,000 \\
6,900 \\
6,000\end{array}$ & $\begin{array}{r}4,700 \\
700 \\
500 \\
300 \\
600\end{array}$ & $\begin{array}{r}467,000 \\
19,000 \\
32,000 \\
6,400 \\
6,000\end{array}$ & $\begin{array}{r}4,700 \\
600 \\
500 \\
300 \\
500\end{array}$ & $\begin{array}{r}\ddot{1}, 0000 \\
300 \\
500\end{array}$ & $(3)$ & 300 & (3) \\
\hline 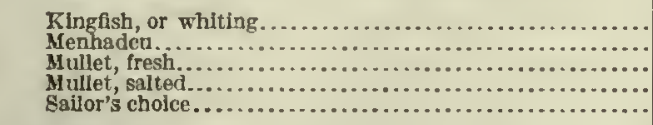 & $\begin{array}{r}30,000 \\
53,494,000 \\
39,000 \\
10,000 \\
5,100\end{array}$ & $\begin{array}{r}1,000 \\
66,000 \\
1,000 \\
400 \\
200\end{array}$ & $\begin{array}{r}30,000 \\
53,494,000 \\
38,000 \\
4,000\end{array}$ & $\begin{array}{r}1,000 \\
66,000 \\
1,000 \\
200\end{array}$ & $\begin{array}{r}400 \\
1,000 \\
6,000 \\
100\end{array}$ & ${ }_{(2)}^{(2)} 200$ & , & $\begin{array}{l}\cdots \\
\cdots \\
\cdots\end{array}$ \\
\hline 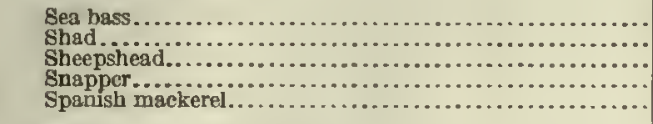 & $\begin{array}{r}41,000 \\
134,000 \\
17,000 \\
5,000 \\
19,000\end{array}$ & $\begin{array}{r}2,000 \\
13,000 \\
700 \\
100 \\
1,300\end{array}$ & $\begin{array}{r}132,0000 \\
17,000 \\
18,0000\end{array}$ & $\begin{array}{l}13,000 \\
700 \\
1,200\end{array}$ & $\begin{array}{r}1,900 \\
200 \\
\cdots \ldots \ldots\end{array}$ & ${ }^{(3)} 200$ & $\begin{array}{r}41,000 \\
\ldots \ldots \ldots \ldots \\
5,000 \\
1,400\end{array}$ & $\begin{array}{r}2,000 \\
100 \\
100\end{array}$ \\
\hline 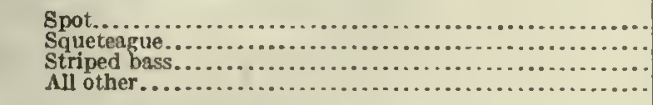 & $\begin{array}{r}17,000 \\
166,000 \\
8,200 \\
10,000\end{array}$ & $\begin{array}{r}300 \\
5,200 \\
500 \\
300\end{array}$ & $\begin{array}{r}17,000 \\
164,000 \\
8,000 \\
5,600\end{array}$ & $\begin{array}{r}300 \\
5,100 \\
500 \\
100\end{array}$ & $\begin{array}{r}200 \\
2,400\end{array}$ & ${ }^{(3)}{ }_{100}$ & $\ddot{2}, 300$ & 100 \\
\hline 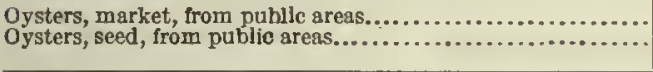 & $\begin{array}{r}3,121,000 \\
i 216,000\end{array}$ & $\begin{array}{r}59,000 \\
5,000\end{array}$ & & & & & $\begin{array}{r}31,121,000 \\
216,000\end{array}$ & $\begin{array}{r}59,000 \\
5,000\end{array}$ \\
\hline
\end{tabular}

1 Includes apparatus, with catch, as follows: Dredges, tougs, etc., $1,337,000$ pounds, valued at $\$ 64,000 ;$ and lines, 56,000 pounds, valued at $\$ 2,500$.

онІо.

The fisheries of Ohio may be grouped in two divisions-those of Lake Erie and those of the Ohio River and its tributaries. The Ohio River fisheries are of very small proportions, the value of the products from this district forming only 2 per cent of the total value of the fishery product of the state.

Of the species taken in the fisheries of the state in 1908 , that for which the greatest value was reported was lake herring, while German carp, blue pike, and other varieties of pike perch followed closely in importance.

The general statistics for the Ohio fisheries for 1908 are summarized in the following tabular statement:

Number of persons employed. 2,054 Capital:

Vessels and boats, including outfit............\$356,000

A pparatus of capture. ................. 423,000

Shore and accessory property and cash......... 343,000

Value of products....................... 840,000

Comparison with previous canvasses.-Statistics of the fisheries of Ohio as a whole are not available for former years, but figures for the Lake Erie fisheries of the state have been reported by the Bureau of Fisheries for certain years, and since the Lake Erie district contributes such a large proportion of the fishery product of the state, these figures give a fairly accurate idea of the fluctuations which have taken place.

As will be seen from the tabular statement given below, this district shows a marked recovery from a retrograde movement which culminated in 1903 . The waters of Lake Erie are so shallow that it would be possible to catch all the fish in them, and such a condition was imminent in 1903 . Warnings of the possible extinction of the fish in this lake were given in 1890 by the Commissioner of Fish and Fisheries, who called attention to an ominous decrease in the product since 1885 .

The increase in fishery products which has taken place during recent years has not, however, extended to the fisheries of the Ohio River distriet, as will be seen from the following tabular statement, which gives statistics of the industry in both districts for 1908 in comparison with certain earlier years:

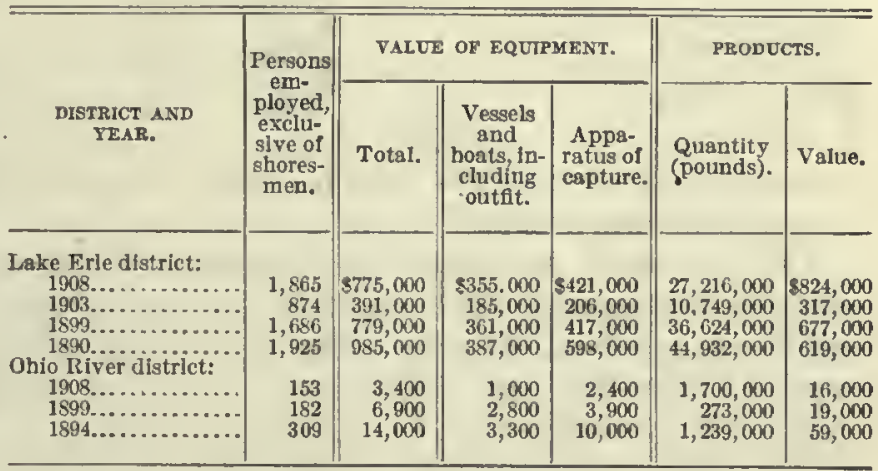

The large increase in the weight of product in the Ohio River district is due entirely to the weight of mussel shells reported in 1908. Except for these produets both the weight and the value of the Ohio River product would have been less than half as much in 1908 as in 1899 , when no mussel-shell products were reported. The falling off in the product of the 
Ohio River distriet after 1894 was due in a large measure to laws restricting fishermen to the use of hooks and lines in interior waters.

Persons employed.-Over 92 per cent of the persons engrged in fisheries in Ohio were employed in the Lake Erie district. Of the 36 shoresmen reported,
25 were engaged in the vessel fisheries and 11 in the shore and boat fisheries. Including shoresmen, therefore, the total number of persons connected with the vessel fisheries was 257 and tho total number conneeted with the shore and boat fisheries 1,739.

The distribution of persons employed was as follows:

\begin{tabular}{|c|c|c|c|c|c|c|c|}
\hline \multirow{3}{*}{ DISTRICT AND CLASS. } & \multicolumn{7}{|c|}{ PERSONS EMIPLOYED: 1908.} \\
\hline & \multicolumn{4}{|c|}{ Number. } & \multicolumn{3}{|c|}{ Salaries and wages. } \\
\hline & Total. & $\begin{array}{l}\text { Proprie- } \\
\text { tors and } \\
\text { independ- } \\
\text { ent fisher- } \\
\text { men. }\end{array}$ & $\begin{array}{c}\text { Salarled } \\
\text { employees. }\end{array}$ & $\begin{array}{l}\text { Wage- } \\
\text { earners. }\end{array}$ & Total. & Salaries. & Wages. \\
\hline 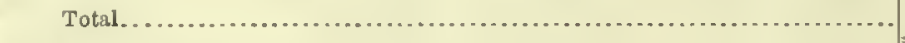 & 2,054 & 1830 & 14 & 1,210 & $\$ 380,000$ & $\$ 11,000$ & $\$ 369,000$ \\
\hline Lake Erle district............. & 1,901 & 733 & 14 & 1,154 & 378,000 & 11,000 & 367,000 \\
\hline 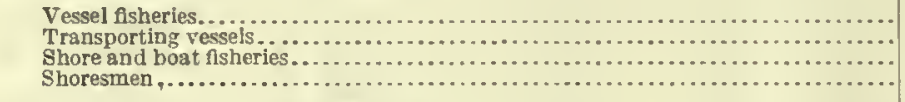 & $\begin{array}{r}262 \\
28 \\
1,575 \\
\$ 36\end{array}$ & $\begin{array}{r}26 \\
707 \\
\cdots+\cdots\end{array}$ & \begin{tabular}{r|r}
8 \\
$\cdots$ \\
$\cdots$
\end{tabular} & $\begin{array}{r}228 \\
28 \\
862 \\
36\end{array}$ & $\begin{array}{r}132,000 \\
15,000 \\
212,000 \\
18,000\end{array}$ & $\begin{array}{r}6,100 \\
5,200 \\
3 . \cdots\end{array}$ & $\begin{array}{r}126,000 \\
15,000 \\
207,000 \\
18,000\end{array}$ \\
\hline 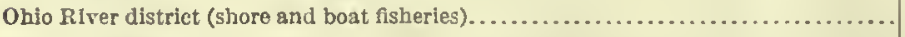 & 153 & 97 & & 56 & 2,100 & & 2,100 \\
\hline
\end{tabular}

1 Excluslve of 22 proprietors not fishing.

2 1nchudes provisions furnished to the value of 89,300

3 Of these, 25 were employed ln vessel fisheries and 11 in shore and boat fisherles.

Equipment and other caprital.-The following tabular statement shows the distribution of the capital invested in the fisheries of the state:

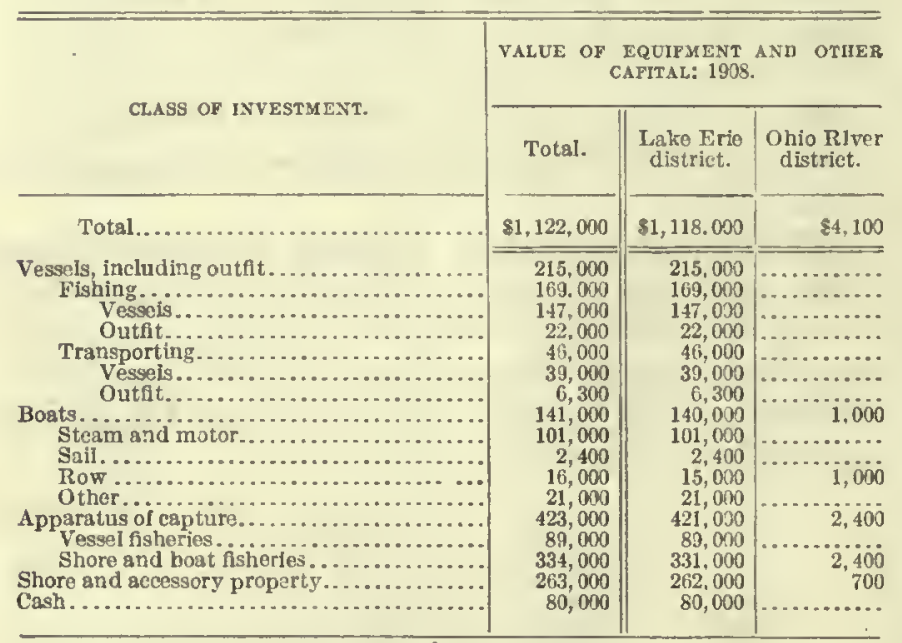

Over 99 per cent of the total investment pertained to the Lake Erie distriet.

Of the value of shore and accessory property, $\$ 62,000$ was reported for vessel fisheries and $\$ 201,000$ for shore and boat fisheries. The entire amount returned under this head, with the exception of $\$ 700$, represented investment in the Lake Erie fisheries.

The vessels reported were exclusively steam craft, and of the boats only 28 , valued at $\$ 2,400$, were sailboats. With the exception of 136 rowboats, all of the boats, as well as all of tho vessels, were used in the Lake Eric fisheries. The number and tomnage of the vessels and the number of the boats were as follows:
Vessels:

Fishing-

Number............................. 42

Tonnage............................... 672

Transporting-

Number............................. 12

Tonnage............................. 190

Boats, number............................. 1,083

Steam and motor......................... 279

Sail................................... 28

Row.............................. 735

Other.................................. 41

The numbers of the prineipal kinds of apparatus reported for the state, of which all except 10 seines and 262 fyke and hoop nets were used in the Lake Erie district and all exeept 18,828 gill nets in the shore and boat fisheries, were as follows:

Fyke and hoop nets......................... 1,226

Gill nets.................................... 25, 030

Harpoons, spears, ete.......................... 83

Pound and trap nets........................ 2, 580

Seines.................................... 266

Trammel nets................................ 521

Traps, muskrat............................. 2,645

Turtle nets.................................. ${ }_{220}$

Products, by species.-Table 1, on page 220, gives detailed statisties as to the products of the fisheries of Ohio, by speeies and by apparatus of capture. On the basis of value, lake herring was the most important fish taken, with German carp ranking second. If the different varieties of pike and pickerel and pike perch by considered together as one item, this class of fish tukes tho lead among the proclucts, with a total weight of $9.743,000$ pounds and a value of $\$ 359.000$. The 
value of the above-named species-lake lierring, carp, pike, pike perch, and pickerel-forms 76 per cent of the total value of the catch, while the remainder of the catch, considered in respect to both weight and value, is fairly well distributed among the other species reported.

Products, by fishing grounds.-Table 2, on page 220, gives detailed statisties regarding the fishery products of Lake Erie district, while Table 3, on page 221, gives similar statistics for the Ohio River district. Among the Ohio River products were three which were not reported for the Lake Erie fisheries, namely, buffalo fish, paddlefish, and the products of the mussel fisheries. The mussel products included mussel shells, pearls, and slugs, and were valued at $\$ 7,000$, or somewhat less than half of the total value of the Ohio River product.

Products, by class of fisheries.--The products of the shore and boat fisheries amounted to 20,511,000 pounds, valued at $\$ 548,000$, and those of the vessel fisheries to $8,405,000$ pounds, valued at $\$ 291,000$. All of the fisheries of the Ohio River district were of the shore and boat class, while for Lake Erie both classes of fisheries were reported. In the vessel fisheries of the latter district the following products were taken:

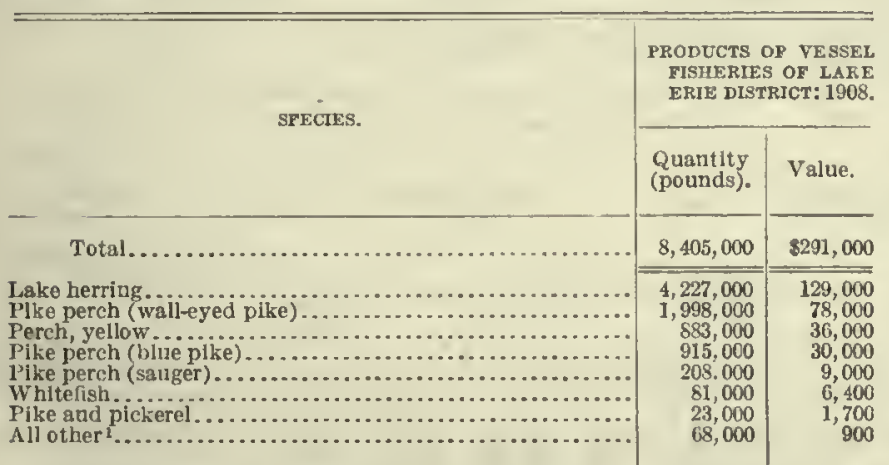

1 Includes products as follows: Suckers, 35,000 pounds, valued at \$500; German carp, 9,800 pouuds, valned at $\$ 200$; drum or sheepshead 16,000 pounds, valued at $\$ 200$; ling or eelpout, white bass, and trout, 7,600 pounds, valued at $\$ 100$.

Products, by apparatus of capture.-Gill nets were not used in the Ohio River fisheries, but in the vessel fisheries of Lake Erie they were the only form of apparatus of capture employed. Pound and trap nets, though used only in the shore and boat fisheries of Lake Erie, took a greater number of species and a heavier catch than any other kind of apparatus. No single species of the 19 which were taken by them sufficiently predominated in weight to form the bulk of the catch; but the different varieties of pike, pickerel, and pike perch taken by pound and trap nets aggregated $5,763,000$ pounds, valued at $\$ 202,000$, and formed over one-half of the weight and about twothirds of the value of the entire catcl by this form of apparatus.

Seines, which were reported for the shore and boat fisheries only, were used in the capture of 13 species. The quantity of products thus taken in tho Ohio
River district was small, amounting to only 20,000 pounds, valued at $\$ 1,600$, while in the shore and boat fisheries of Lake Erie products so caught aggregated $5,761,000$ pounds, valued at $\$ 103,000$. Of these Lake Erie products, 5,708,000 pounds represented German carp and contributed 99 per cent of the total value of the seine catch reported for this district.

Since mussel shells were the principal product of the Ohio River fisheries, the crowfoot dredges used for taking them were the leading apparatus of capture in that district.

Principal species.-Carp was the only one of the leading species for which a considerable increase in catch was shown in 1908, as compared with earlier years. The following tabular statement indicates the relation of the carp catch to the total fishery products of the Lake Erie district of Ohio for certain years:

\begin{tabular}{|c|c|c|c|c|}
\hline \multirow{3}{*}{ YEAR. } & \multicolumn{4}{|c|}{$\begin{array}{l}\text { GERMAN-CARP PRODUCT OF LARE ERIE } \\
\text { DISTRICT. }\end{array}$} \\
\hline & \multicolumn{2}{|c|}{ Quantity. } & \multicolumn{2}{|c|}{ Value. } \\
\hline & Pounds. & $\begin{array}{l}\text { Per cent } \\
\text { of total. }\end{array}$ & Amonrit. & $\begin{array}{l}\text { Per cent } \\
\text { of total. }\end{array}$ \\
\hline $\begin{array}{l}1908 \ldots \ldots \ldots \ldots \ldots \\
1903 \ldots \ldots \ldots \ldots \ldots \ldots \\
1899 \ldots \ldots \ldots \ldots \ldots\end{array}$ & $\begin{array}{l}7,140,000 \\
3,058,000 \\
3,417,000\end{array}$ & $\begin{array}{r}26 \\
28 \\
0\end{array}$ & $\begin{array}{r}8127,000 \\
51,000 \\
47,000\end{array}$ & $\begin{array}{r}15 \\
16 \\
7\end{array}$ \\
\hline
\end{tabular}

The lake-herring catch, though larger than in 1903, retains only a fraction of its earlier importance, as is shown by the following tabular statement, and the decrease in this product accounts, in a large measure, for the decrease in the fishery product of Ohio from 1890 to 1903 :

\begin{tabular}{|c|c|c|c|c|}
\hline \multirow{3}{*}{ YEAR. } & \multicolumn{4}{|c|}{$\begin{array}{l}\text { 'LAKE-MERRING PRODUCT OF LAKE ERIE } \\
\text { DISTRICT. }\end{array}$} \\
\hline & \multicolumn{2}{|c|}{ Quantity. } & \multicolumn{2}{|c|}{ Value. } \\
\hline & Pounds. & $\begin{array}{l}\text { Per cent } \\
\text { of total. }\end{array}$ & Amount. & $\begin{array}{l}\text { Per cent } \\
\text { of total. }\end{array}$ \\
\hline 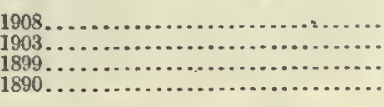 & $\begin{array}{r}4,792,000 \\
1,531,000 \\
19,346,000 \\
27,889,000\end{array}$ & $\begin{array}{l}18 \\
14 \\
53 \\
62\end{array}$ & $\begin{array}{r}\$ 147,000 \\
68,000 \\
253,000 \\
252,000\end{array}$ & $\begin{array}{l}18 \\
21 \\
37 \\
46\end{array}$ \\
\hline
\end{tabular}

The catch of blue pike in 1908 shows a pronounced increase in both quantity and value over those of the preceding two years for which statistics were compiled, as is indicated by the following tabular statement:

\begin{tabular}{|c|c|c|c|c|}
\hline \multirow{3}{*}{ YEAR. } & \multicolumn{4}{|c|}{ BLUE-PIIE PRODUCT OF LAKE ERIE DISTRICT. } \\
\hline & \multicolumn{2}{|c|}{ Quantity. } & \multicolumn{2}{|c|}{ Value. } \\
\hline & Pounds. & $\begin{array}{l}\text { Per cent } \\
\text { of total. }\end{array}$ & Amount. & $\begin{array}{l}\text { Per cent } \\
\text { of total. }\end{array}$ \\
\hline $\begin{array}{l}1908, \ldots \ldots \ldots \ldots \\
1903, \ldots \ldots \ldots \\
1899 \ldots \ldots \ldots \\
1890 \ldots \ldots \ldots \ldots\end{array}$ & $\begin{array}{l}4,004,000 \\
1,733,000 \\
2,213,000 \\
3,995,000\end{array}$ & $\begin{array}{r}15 \\
16 \\
6 \\
9\end{array}$ & $\begin{array}{r}\$ 125,000 \\
68,000 \\
64,000 \\
66,000\end{array}$ & $\begin{array}{r}15 \\
21 \\
9 \\
11\end{array}$ \\
\hline
\end{tabular}


TABLE 1.-OHIO-FISHERY PRODUCTS: 1908.

\begin{tabular}{|c|c|c|c|c|c|c|c|c|c|c|c|c|c|c|}
\hline \multirow{3}{*}{ SPECIES. } & \multirow{2}{*}{\multicolumn{2}{|c|}{ TOTAL. }} & \multicolumn{12}{|c|}{ PRODUCT CAUGHT BY- } \\
\hline & & & \multicolumn{2}{|c|}{ Gill nets. } & \multicolumn{2}{|c|}{$\begin{array}{l}\text { Pound and trap } \\
\text { nets. }\end{array}$} & \multicolumn{2}{|c|}{ Seines. } & \multicolumn{2}{|c|}{$\begin{array}{l}\text { Fyka and hoop } \\
\text { nets. }\end{array}$} & \multicolumn{2}{|c|}{ Lines. } & \multicolumn{2}{|c|}{$\begin{array}{l}\text { All other appa- } \\
\text { ratus.1. }\end{array}$} \\
\hline & $\begin{array}{l}\text { Quantity } \\
\text { (pounds). }\end{array}$ & Value. & $\begin{array}{l}\text { Quentity } \\
\text { (pounds). }\end{array}$ & Value. & $\begin{array}{l}\text { Quantity } \\
\text { (pounds). }\end{array}$ & Value. & $\begin{array}{l}\text { Quantity } \\
\text { (pounds). }\end{array}$ & Value. & $\begin{array}{l}\text { Quantity } \\
\text { (pounds). }\end{array}$ & Value. & $\begin{array}{l}\text { Quantity } \\
\text { (pounds). }\end{array}$ & Value. & $\begin{array}{l}\text { Quentity } \\
\text { (pounds). }\end{array}$ & Value. \\
\hline Total.. & $28,917,000$ & $\$ 840,000$ & $9,400,000$ & $\$ 336,000$ & $9,783,000$ & $\$ 308,000$ & $5,781,000$ & $\$ 105,000$ & $1,714,000$ & $\$ 51,000$ & 118,000 & $\$ 7,700$ & $2,121,000$ & 832,000 \\
\hline 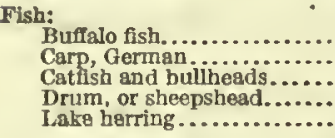 & $\begin{array}{r}9,000 \\
7,158,000 \\
505,000 \\
1,227,000 \\
4,792,000\end{array}$ & $\begin{array}{r}800 \\
129,000 \\
25,000 \\
13,000 \\
147,000\end{array}$ & $\begin{array}{r}57,000 \\
7,200 \\
17,000 \\
4,637,000\end{array}$ & $\begin{array}{r}1,300 \\
300 \\
200 \\
140,000\end{array}$ & $\begin{array}{l}525,000 \\
261,000 \\
989,000 \\
155,000\end{array}$ & $\begin{array}{r}8,700 \\
12,000 \\
9,100 \\
7,300\end{array}$ & $\begin{array}{r}800 \\
5,713,000 \\
14,000 \\
18,000 \\
\ldots .\end{array}$ & $\begin{array}{r}100 \\
102,000 \\
800 \\
600\end{array}$ & $\begin{array}{r}8,100 \\
384,000 \\
130,000 \\
190,000\end{array}$ & $\begin{array}{l}700 \\
7,100 \\
6,200 \\
2,100\end{array}$ & $\begin{array}{r}100 \\
2,300 \\
87,000 \\
8,700\end{array}$ & $\begin{array}{r}(2) \\
200 \\
5,500 \\
800\end{array}$ & $\begin{array}{r}76,000 \\
5,400 \\
5,330\end{array}$ & $\begin{array}{r}9,100 \\
300 \\
100\end{array}$ \\
\hline $\begin{array}{l}\text { Ling or eelpout ............. } \\
\text { Paddlefish }\end{array}$ & 100,000 & 1,300 & 7,700 & 100 & 84,000 & 1,100 & & & 8,800 & 100 & & & $\cdots$ & $\cdots$ \\
\hline $\begin{array}{l}\text { Perch, yellow .............. } \\
\text { Piks and pickerei......... }\end{array}$ & $\begin{array}{l}1,41,000 \\
1,118,000\end{array}$ & $\begin{array}{l}54,000 \\
70,000\end{array}$ & $\begin{array}{r}822,000 \\
52,000\end{array}$ & $\begin{array}{r}3 \ddot{8}, 0000 \\
3,800\end{array}$ & $\begin{array}{r}460,000 \\
786,000\end{array}$ & $\begin{array}{l}13,000 \\
49,000\end{array}$ & $\because \dddot{6,400}$ & & $\begin{array}{r}57,000 \\
266,000\end{array}$ & $\begin{array}{r}1,800 \\
16,000\end{array}$ & $\because, 900$ & $\begin{array}{r}1000 \\
600\end{array}$ & & . \\
\hline 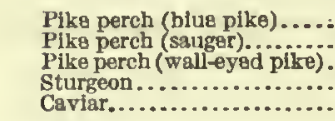 & $\begin{array}{r}4,004,000 \\
2,358,000 \\
2,263,000 \\
8,600 \\
300\end{array}$ & $\begin{array}{r}125,000 \\
71,000 \\
93,000 \\
700 \\
300\end{array}$ & $\begin{array}{r}1,026,000 \\
293,000 \\
1,998,000\end{array}$ & $\begin{array}{l}34,000 \\
13,000 \\
78,000\end{array}$ & $\begin{array}{r}2,902,000 \\
1,826,000 \\
249,000 \\
5,100 \\
300\end{array}$ & $\begin{array}{r}88,000 \\
51,000 \\
14,000 \\
550 \\
300\end{array}$ & $\begin{array}{l}(3) \\
2,400 \\
100 \\
3,300\end{array}$ & $\begin{array}{l}\left({ }^{(2)}\right) \\
(200 \\
{ }_{200}\end{array}$ & $\begin{array}{r}77,000 \\
227,000 \\
15,000 \\
(3)\end{array}$ & $\begin{array}{l}2,600 \\
6,200 \\
1,000 \\
(2)\end{array}$ & $\begin{array}{r}9,800 \\
100 \\
200 \\
()^{(3)}\end{array}$ & $\begin{array}{l}700 \\
\left(\begin{array}{l}2 \\
2 \\
2 \\
2\end{array}\right)\end{array}$ & $(3)$ & $\begin{array}{l}(3) \\
(3) \\
(3)\end{array}$ \\
\hline 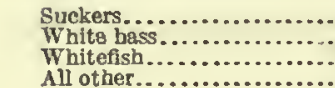 & $\begin{array}{r}1,387,000 \\
172,000 \\
732,000 \\
5,000\end{array}$ & $\begin{array}{r}20,000 \\
8,200 \\
60,000 \\
100\end{array}$ & $\begin{array}{r}45,000 \\
600 \\
337,000 \\
(\varepsilon)\end{array}$ & $\begin{array}{c}600 \\
(3) \\
27,000 \\
(2)\end{array}$ & $\begin{array}{r}1,022,000 \\
128,000 \\
391,000 \\
1,000\end{array}$ & $\begin{array}{r}15,000 \\
6,000 \\
33,000 \\
(2)\end{array}$ & $\begin{array}{r}20,000 \\
1,100\end{array}$ & $\begin{array}{l}400 \\
100\end{array}$ & $\begin{array}{r}298,000 \\
43,000 \\
4,100 \\
4,900\end{array}$ & $\begin{array}{r}4,200 \\
2,000 \\
300 \\
(2)\end{array}$ & 200 & (2) & 1,900 & (2) \\
\hline 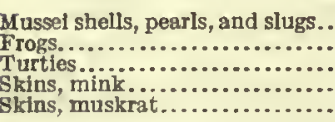 & $\begin{array}{r}1,597,000 \\
4,000 \\
18,000 \\
6100 \\
14,000\end{array}$ & $\begin{array}{r}+7,000 \\
600 \\
900 \\
400 \\
14,000\end{array}$ & & & & & 500 & (3) & & & & & $\begin{array}{r}1,597,000 \\
4,000 \\
18,000 \\
100 \\
14,000\end{array}$ & $\begin{array}{r}7,000 \\
600 \\
900 \\
400 \\
14,000\end{array}$ \\
\hline
\end{tabular}

1 Includes apparatus, with catch, as follows: Harpoons, spears, etc., 9,200 pounds, valued at $\$ 9,700$; trammel nets, 489,000 pounds, valued at $\$ 9,400 ;$ crow foot dredges,

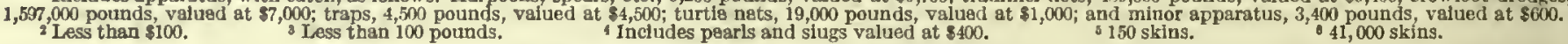

TABLE 2.-OHIO-FISHERY PRODUCTS OF LAKE ERIE DISTRICT: 1908.

\begin{tabular}{|c|c|c|c|c|c|c|c|c|c|c|c|c|c|c|}
\hline \multirow{3}{*}{ SPECIES. } & \multirow{2}{*}{\multicolumn{2}{|c|}{ TOTAL. }} & \multicolumn{12}{|c|}{ PRODUCT CAUGUT HY- } \\
\hline & & & \multicolumn{2}{|c|}{ Gill nets. } & \multicolumn{2}{|c|}{$\begin{array}{l}\text { Pound and trap } \\
\text { nets. }\end{array}$} & \multicolumn{2}{|c|}{ Seines. } & \multicolumn{2}{|c|}{$\begin{array}{c}\text { Fyks and hoop } \\
\text { nets. }\end{array}$} & \multicolumn{2}{|c|}{ Lines. } & \multicolumn{2}{|c|}{$\begin{array}{l}\text { Ail other appa- } \\
\text { ratus.l }\end{array}$} \\
\hline & $\begin{array}{l}\text { Quantity } \\
\text { (pounds). }\end{array}$ & Value. & $\begin{array}{l}\text { Quantity } \\
\text { (pounds). }\end{array}$ & Valus. & $\begin{array}{l}\text { Quantity } \\
\text { (pounds). }\end{array}$ & Value. & $\begin{array}{l}\text { Quantity } \\
\text { (pounds). }\end{array}$ & Value. & $\begin{array}{l}\text { Quantity } \\
\text { (pounds). }\end{array}$ & Valus. & $\begin{array}{l}\text { Quantity } \\
\text { (pounds). }\end{array}$ & Value. & $\begin{array}{l}\text { Quantity } \\
\text { (pounds). }\end{array}$ & Value. \\
\hline Total..... & $27,216,000$ & 8824,000 & $9,400,000$ & $\$ 336,000$ & $9,783,000$ & $\$ 308,000$ & $5,761,000$ & $\$ 103,000$ & $1,665,000$ & $\$ 47,000$ & 84,000 & 54,500 & 524,000 & 525,000 \\
\hline $\begin{array}{l}\text { Fish: } \\
\text { Carp, German............ } \\
\text { Catfish and buliheads..... } \\
\text { Drum, or shespshead...... } \\
\text { laks herring, Iresh........ } \\
\text { lake herring, salted....... }\end{array}$ & $\begin{array}{r}7,140,000 \\
467,000 \\
1,207,000 \\
4,780,000 \\
12,000\end{array}$ & $\begin{array}{r}127,000 \\
21,000 \\
11,000 \\
147,000 \\
400\end{array}$ & $\begin{array}{r}57,000 \\
7,200 \\
17,000 \\
4,625,000 \\
12,000\end{array}$ & $\begin{array}{r}1,300 \\
300 \\
200 \\
139,000 \\
400\end{array}$ & $\begin{array}{c}525,000 \\
261,000 \\
989,000 \\
155,000 \\
\ldots \ldots \ldots \ldots\end{array}$ & $\begin{array}{r}8,700 \\
12,000 \\
9,100 \\
7,300 \\
\ldots \ldots \ldots\end{array}$ & $\begin{array}{r}5,708,000 \\
11,000 \\
13,000 \\
\ldots \ldots \ldots \ldots . \\
\ldots \ldots \ldots \ldots\end{array}$ & $\begin{array}{r}102,000 \\
500 \\
100 \\
\ldots \ldots \ldots\end{array}$ & $\begin{array}{r}373,000 \\
118,000 \\
183,000 \\
\ldots \ldots \ldots \ldots\end{array}$ & $\begin{array}{r}6,400 \\
5,000 \\
1,500 \\
\ldots \ldots \ldots\end{array}$ & $\begin{array}{r}300 \\
64,000 \\
\ldots \ldots \ldots . \\
\ldots \ldots . .\end{array}$ & $\begin{array}{c}{ }^{(2)} \\
3,200 \\
\cdots \ldots \ldots . \\
\ldots \ldots . .\end{array}$ & $\begin{array}{r}476,000 \\
5,400 \\
5,300 \\
\ldots \ldots \ldots\end{array}$ & $\begin{array}{r}9,100 \\
300 \\
100 \\
\ldots \ldots . . . \\
\hdashline .6 .\end{array}$ \\
\hline $\begin{array}{l}\text { ling, or eelpout ............ } \\
\text { Perch, yellow .............. } \\
\text { Pike and pickerel.......... } \\
\text { Piks perch (bius pike)..... } \\
\text { Piks perch (sauger)....... } \\
\text { Pike perch(walleyed pike). }\end{array}$ & $\begin{array}{r}100,000 \\
1,411,000 \\
1,118,000 \\
4,004,000 \\
2,358,000 \\
2,200,000\end{array}$ & $\begin{array}{r}1,300 \\
54,000 \\
70,000 \\
125,000 \\
71,000 \\
93,000\end{array}$ & $\begin{array}{r}7,700 \\
922,000 \\
52,000 \\
1,026,000 \\
293,000 \\
1,998,000\end{array}$ & $\begin{array}{r}100 \\
38,000 \\
3,800 \\
34,000 \\
13,000 \\
78,000\end{array}$ & $\begin{array}{r}84,000 \\
460,000 \\
786,000 \\
2,802,000 \\
1,826,000 \\
249,000\end{array}$ & $\begin{array}{r}1,100 \\
14,000 \\
49,000 \\
88,000 \\
51,000 \\
14,000\end{array}$ & $\begin{array}{l}6,400 \\
\text { (i) } \\
2,400\end{array}$ & $\begin{array}{l}(2)^{400} \\
100\end{array}$ & $\begin{array}{r}8,800 \\
57,000 \\
266,000 \\
77,000 \\
227,000 \\
12,000\end{array}$ & $\begin{array}{r}100 \\
1,800 \\
16,000 \\
2,600 \\
6,200 \\
700\end{array}$ & $\begin{array}{l}1,900 \\
7,400 \\
\dddot{9}, 800\end{array}$ & $\begin{array}{l}100 \\
600 \\
000\end{array}$ & ${ }^{\prime \prime} \ldots$ & $\begin{array}{c}{ }^{2} \\
\cdots \cdots \\
\cdots \cdots \cdots\end{array}$ \\
\hline 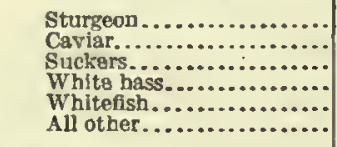 & $\begin{array}{r}5,300 \\
300 \\
1,377,000 \\
172,000 \\
732,000 \\
5,000 \\
\end{array}$ & $\begin{array}{r}500 \\
300 \\
19,000 \\
8,200 \\
60,000 \\
100\end{array}$ & $\begin{array}{r}45,000 \\
600 \\
337,000 \\
(2)\end{array}$ & $\begin{array}{c}600 \\
\left(^{(2)}\right. \\
27,000 \\
(2)\end{array}$ & $\begin{array}{r}5,100 \\
300 \\
1,022,000 \\
128,000 \\
391,000 \\
1,000\end{array}$ & $\begin{array}{r}500 \\
300 \\
15,000 \\
6,100 \\
33,000 \\
\left({ }^{2}\right)\end{array}$ & $\begin{array}{r}78, \ldots 00 \\
1,000 \\
\ldots \ldots \ldots\end{array}$ & $\begin{array}{l}300 \\
100 \\
\cdots\end{array}$ & $\begin{array}{r}\text { (2) } \\
29 i, 000 \\
43,000 \\
4,100 \\
4,000\end{array}$ & $\begin{array}{c}{ }^{(2)} \\
\because 3,800 \\
2,000 \\
300 \\
\left(^{2}\right)\end{array}$ & ()$^{200}$ & $(2)$ & 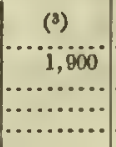 & 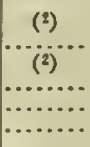 \\
\hline 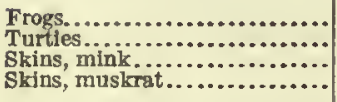 & $\begin{array}{r}4,000 \\
18,000 \\
1,100 \\
14,000\end{array}$ & $\begin{array}{r}600 \\
900 \\
400 \\
14,000\end{array}$ & $\begin{array}{l}\ldots \ldots \ldots \ldots \\
\cdots \cdots \cdots \\
\cdots \cdots \cdots\end{array}$ & & a................ & & 500 & (i) & & & & & $\begin{array}{r}4,000 \\
18,000 \\
1,100 \\
14,000\end{array}$ & $\begin{array}{r}600 \\
900 \\
400 \\
14,000\end{array}$ \\
\hline
\end{tabular}

1 Includes apparatus, with catch, as follows: Harpoons, spears, etc., 9,200 pounds, valued at $\$ 9,700$; trammel nets, 489,000 pounds, valued at $\$ 9,400$; traps, 4,500 pounds,

valued at $\$ 4,500 ;$ turtle nets, 19,000 pounds, valued at $\$ 1,000$; and minor apparatus, 3,400 pounds, valusd at $\$ 600$.
2 Less than $\$ 100$. 
TABLE 3.-OHIO-FISHERY PRODUCTS OF OHIO RIVER DISTRICT: 1908.

\begin{tabular}{|c|c|c|c|c|c|c|c|c|c|c|}
\hline \multirow{3}{*}{ SPECIES. } & \multirow{2}{*}{\multicolumn{2}{|c|}{ TOTAL. }} & \multicolumn{8}{|c|}{ PBODUCT CAUOHT BY- } \\
\hline & & & \multicolumn{2}{|c|}{ Seines. } & \multicolumn{2}{|c|}{ Fyke and hoop nets. } & \multicolumn{2}{|c|}{ Lines. } & \multicolumn{2}{|c|}{ Crowfoot dredges. } \\
\hline & $\begin{array}{l}\text { Quantity } \\
\text { (pounds). }\end{array}$ & Value. & $\begin{array}{l}\text { Quantity } \\
\text { (pounds). }\end{array}$ & Value. & $\begin{array}{l}\text { Quantity } \\
\text { (pounds). }\end{array}$ & Value. & $\begin{array}{l}\text { Quantity } \\
\text { (pounds.) }\end{array}$ & Value. & $\begin{array}{l}\text { Quantity } \\
\text { (pounds). }\end{array}$ & Value. \\
\hline Total... & $1,700,000$ & $\$ 16,000$ & 20,000 & $\$ 1,600$ & 49,000 & $\$ 4,000$ & 35,000 & $\$ 3,200$ & $1,597,000$ & $\$ 7,000$ \\
\hline 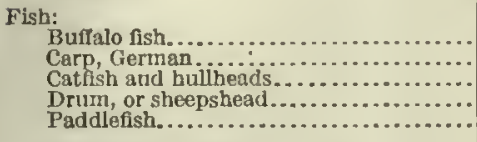 & $\begin{array}{r}9,000 \\
18,000 \\
38,000 \\
20,000 \\
1,600\end{array}$ & $\begin{array}{r}800 \\
1,200 \\
3,700 \\
1,800 \\
100\end{array}$ & $\begin{array}{r}800 \\
5,000 \\
2,500 \\
4,800 \\
1,600\end{array}$ & $\begin{array}{l}100 \\
300 \\
200 \\
500 \\
100\end{array}$ & $\begin{array}{r}8,100 \\
11,000 \\
12,000 \\
6,400 \\
\ldots \ldots \ldots\end{array}$ & $\begin{array}{r}700 \\
700 \\
1,200 \\
600\end{array}$ & $\begin{array}{r}100 \\
2,000 \\
23,000 \\
8,700\end{array}$ & $\begin{array}{l}\text { (1) } \\
200 \\
2,200 \\
800\end{array}$ & 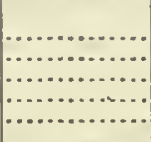 & \begin{tabular}{l} 
\\
\hdashline \\
\hdashline
\end{tabular}$\ldots$ \\
\hline 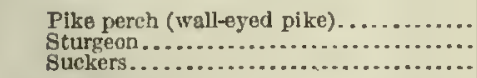 & $\begin{array}{r}2,700 \\
3,300 \\
10,000\end{array}$ & $\begin{array}{l}300 \\
200 \\
700\end{array}$ & $\begin{array}{r}100 \\
3,300 \\
2,100\end{array}$ & $\begin{array}{l}\text { (1) } \\
200 \\
200\end{array}$ & $\begin{array}{r}2,400 \\
\dddot{7}, 900\end{array}$ & $\begin{array}{l}200 \\
300\end{array}$ & $\begin{array}{r}100 \\
200\end{array}$ & (i) & an, & (n) \\
\hline Mussel shells, pearls, and slugs......... & $1,597,000$ & 27,000 & & & & & & & $1,597,000$ & 27,000 \\
\hline
\end{tabular}

Less than $\$ 100$.

OKLAHOMA.

The commercial fisheries of Oklahoma, all of which were of the shore and boat class, were confined to the Arkansas River. The statistics for 1908 are given in the following summary:

Number of fishermen.

Capital. $\$ 50$

Boats-

Number

Value.

3

Apparatus of capture....................... $\$ 10$

Shore and accessory property.................. \$5 $\$ 5$

Products:

Total quantity (pounds) $\ldots \ldots \ldots \ldots \ldots \ldots \ldots \ldots, 700$

Tatal value........................... \$300

Drum, fresh-water-

Pounds.......................... 4,500

Value.............................. $\$ 200$

Buffalo fish-

Pounds................................. 1, 200

Valué.................................. $\$ 50$

Catfish-

Pounds............................. 1,000

Value............................... \$ $\$ 60$

OREGON.

The fishing grounds of Oregon may be grouped in two districts, comprising, respectively, the Columbia River and its tributaries, and the Pacific Ocean together with the rivers emptying into it other than the Columbia. Most of the coast rivers are short, and their descent is so rapid that fishing is confined to within a few miles of the ocean. The Rogue and Umpqua Rivers, however, furnish abundant fishing for the sportsman, but little commercial fishing is done on either river east of the Coast Range. Trout are found in all the mountain streams, while salmon ascend the rivers in small numbers as far east as the Cascade Range. The fishing industry of the state shows a healthy growth, and the product is being rapidly extended to include other species than salmon,
2 Includes pearls and slugs valued at $\$ 400$.

which was for years the only species taken to any extent. The general statistics for 1908 are as follows:

Number of persons employed.....................

4,772

Capital:

Vessels and boats, including outfit.............. \$508,000

Apparatus of capture...................... $\quad 795,000$

Shore and accessory property and cash.......... $\quad 65,000$

Value of products......................... 1,356,000

Comparison with previous canvasses. - The number of persons employed in 1908 was 4,772, as compared with 3,609 reported for 1904 by the Bureau of Fisheries, exclusive of 1,690 employed on shore in canneries, etc. The returns of the Bureau of the Census exclude employees in canneries and include but three shoresmen. During the period between the two canvasses, vessels and boats increased in value from $\$ 369,000$ to $\$ 508,000$, or 38 per cent; apparatus of capture, from $\$ 645,000$ to $\$ 795,000$, or 23 per cent; and products, from $\$ 1,185,000$ to $\$ 1,356,000$, or 14 per cent.

The following tabular statement gives a comparison of the number of persons employed, the capital invested in vessels, boats, and apparatus of capture, and the value of products in 1908, with the figures for certain earlier years for which statistics are available:

\begin{tabular}{|c|c|c|c|c|c|c|}
\hline \multirow[b]{2}{*}{ YEAR. } & \multirow{2}{*}{$\begin{array}{l}\text { Persons } \\
\text { em- } \\
\text { ployed, } \\
\text { exclusive } \\
\text { of shores- } \\
\text { men. }\end{array}$} & \multicolumn{3}{|c|}{ VALUE OF EQUTPMEXT. } & \multicolumn{2}{|c|}{ PRODUCTS. } \\
\hline & & Total. & $\begin{array}{c}\text { Vessels } \\
\text { and boats, } \\
\text { Including } \\
\text { outfit. }\end{array}$ & $\left\{\begin{array}{c}\text { Appara } \\
\text { tus of } \\
\text { capture. }\end{array}\right.$ & $\begin{array}{l}\text { Quantity } \\
\text { (pounds). }\end{array}$ & Vaiue. \\
\hline $\begin{array}{l}1908 \ldots \ldots \ldots \ldots \\
1904 \ldots \ldots \ldots \ldots \\
1899 \ldots \ldots \ldots \ldots \\
1895 \ldots \ldots \ldots \ldots \\
1892 . \ldots \ldots \ldots \ldots \\
1888 \ldots \ldots \ldots\end{array}$ & $\begin{array}{l}4,769 \\
3,609 \\
3,806 \\
4,322 \\
2,822 \\
3,098\end{array}$ & $\begin{array}{r}\$ 1,303,000 \\
1,015,000 \\
762,000 \\
841,000 \\
809,000 \\
724,000\end{array}$ & $\begin{array}{r}8508,000 \\
369,000 \\
275,000 \\
267,000 \\
265,000 \\
287,000\end{array}$ & $\begin{array}{r}\$ 795,000 \\
645,000 \\
487,000 \\
574,000 \\
544,000 \\
438,000\end{array}$ & $\begin{array}{l}28,217,000 \\
27,535,000 \\
22,818,000 \\
38,142,000 \\
28,521,000 \\
25,892,000\end{array}$ & $\begin{array}{r}81,356,000 \\
1,185,000 \\
856,000 \\
1,282,000 \\
872,000 \\
1,034,000\end{array}$ \\
\hline
\end{tabular}

Persons employed.-The distribution of the persons employed in the fisheries of Oregon in 1908, according to the character of their connection with the industry, is shown in the following table for the state as a whole and for the two main fishery districts: 
1 Excluslve of 31 proprietors not fishing.

2 Includes provisions furnished to the value of $\$ 12,000$.

Of the total number of persons employed in the fisheries of the state, 79 per cent were credited to the Columbia River district and 21 per cent to the Pacific coast district. Wage-earners constituted nearly twothirds of the total number employed, and the amount. disbursed in wages was equal to more than one-third of the total value of products. The wage-earners engaged in shore and boat fishing formed 96 per cent of all wage-earners, and received 95 per cent of the total wages paid.

Equipment and other capital.- The distribution of the value of equipment and of the amount of other capital employed in the Oregon fisheries in 1908 is given below.

\begin{tabular}{|c|c|c|c|}
\hline \multirow[b]{2}{*}{ CLASS OF INVESTMENT. } & \multicolumn{3}{|c|}{$\begin{array}{l}\text { VALUE OF EQUTPMENT AND OTHER } \\
\text { CAPITAL: } 1908 .\end{array}$} \\
\hline & Total. & $\begin{array}{l}\text { Columbia } \\
\text { River } \\
\text { district. }\end{array}$ & $\begin{array}{l}\text { Pacific } \\
\text { coast } \\
\text { district. }\end{array}$ \\
\hline Total.... & $\$ 1,368,000$ & $\$ 1,208,000$ & $\$ 160,000$ \\
\hline 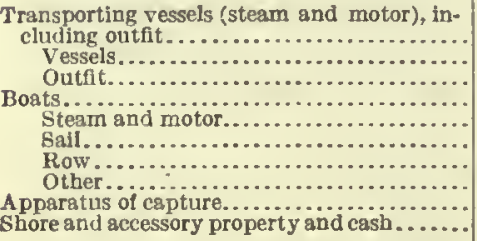 & $\begin{array}{r}140,000 \\
125,000 \\
16,000 \\
367,000 \\
112,000 \\
233,000 \\
18,000 \\
5,400 \\
795,000 \\
65,000\end{array}$ & $\begin{array}{r}114,000 \\
101,000 \\
13,000 \\
316,000 \\
89,000 \\
215,000 \\
6,900 \\
5,100 \\
718,000 \\
59,000\end{array}$ & $\begin{array}{r}26,000 \\
24,000 \\
2,700 \\
51,000 \\
23,000 \\
17,000 \\
11,000 \\
3700 \\
7,000 \\
\mathbf{5}, 300\end{array}$ \\
\hline
\end{tabular}

No vessels were engaged in fishing in the state during the year, all vessels reported being used exclusively for transporting. fish and fish products. Vessels thus engaged numbered 44 , with a total net tonnage of 565 . Seven of these, having a tonnage of 78 , were engaged in the Pacific coast fisheries, while the 37 vessels reported for the Columbia River listrict in 1908 were employed on the Columbir and Willamette Rivers. In 1904 the number of transporting vessels reported was 35 , valued at $\$ 116,000$, and the value of their outfit was $\$ 14,000$. The number of boats reported was 2,312, which comprised 216 steam and motor boats, 1,528 sailboats, 523 rowboats, and 45 scows. Of these several kinds of boats, the Columbia River district reported $198,1,355,191$, and 31 , respectively. The investment in boats of all kinds shows an increase of 54 per cent since 1904 .

The proportion of the eapital invested in apparatus of capture is large, on account of the cxpensive seines and nets used in the salmon fisheries and the great expense of constructing and locating the whecls used on the Columbia River.

The nets, traps, seines, and wheels reported were distributed as follows:

\begin{tabular}{|c|c|c|c|}
\hline \multirow[b]{2}{*}{ KIND. } & \multicolumn{3}{|c|}{ APPARATUS OF CAPTURE: 1908.' } \\
\hline & Total. & $\begin{array}{l}\text { Columbla } \\
\text { River } \\
\text { district. }\end{array}$ & $\begin{array}{l}\text { Pacific } \\
\text { coast } \\
\text { district. }\end{array}$ \\
\hline 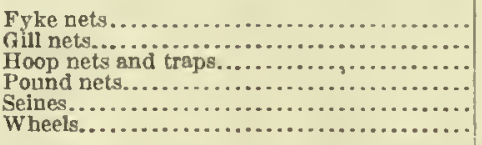 & $\begin{array}{r}35 \\
3,981 \\
2,143 \\
17 \\
100 \\
31\end{array}$ & $\begin{array}{r}35 \\
2,931 \\
1,700 \\
17 \\
58 \\
31\end{array}$ & $\begin{array}{r}1,050 \\
443 \\
42 \\
4 \ldots .\end{array}$ \\
\hline
\end{tabular}

All reported by shore and hoat fisheries.

Gill nets are used principally in the salmon fisheries. The number reported in 1908 represents an increase in the four years between the two canvasses of 1,350 , or 51 per cent, as compared with the number in 19042,631. Thirty wheels were reported in 1904 and 31 in 1908. They were all located on the Columbia River and their catch in 1908 included salmon and sturgeon. The seines reported in 1908 numbered 100, as compared with 50 in 1904. Of those reported in 1908, 58 were in use in the Columbia River district and 42 in other waters. Those employed in the Columbir River fislieries were large seines of an avernge value of nearly $\$ 700$, while the seines used in other waters averaged but $\$ 100$ each in value. No pound nets were reported by the Bureau of Fisheries in 1904 . 
Fyke nets have increased in number, while hoop nets and traps have decreased.

Products, by species. - Table 1, on page 224, shows for 1908 the quantity and value of the fishery products of the state, by species and by apparatus of capture.

The total product increased from $27,533,000$ pounds, valued at $\$ 1,185,000$, in 1904 , to $28,217,000$ pounds, valued at $\$ 1,356,000$, in 1908 , an increase of 3 per cent in quantity and 14 per cent in value. In 1904 there were 15 species of products, as compared with 21 in 1908. Those not reported in carlier canvasses were cultus cod, flounders, sculpin, squeteague, or sea trout, black snapper, sole, and tomeod, some of which were taken in considerable quantities. The value of the salmon catch represented 96 per cent of the total value of products in 1908. The bulk of the Oregon salmon product was of the chinook variety, which contributed 68 per cent of the total weight and 81 per cent of the total valuc of salmon reported for the state.

Products, by fishing grounds.-Tables 2 and 3, on pages 224 and 225 , give tlue fishery products, by species and apparatus of capture, for the Columbia River and Pacific coast districts, respectively, and the following tabular statement shows, for the state as a whole and for the two districts, the distribution by principal species of the total value of products in 1908:

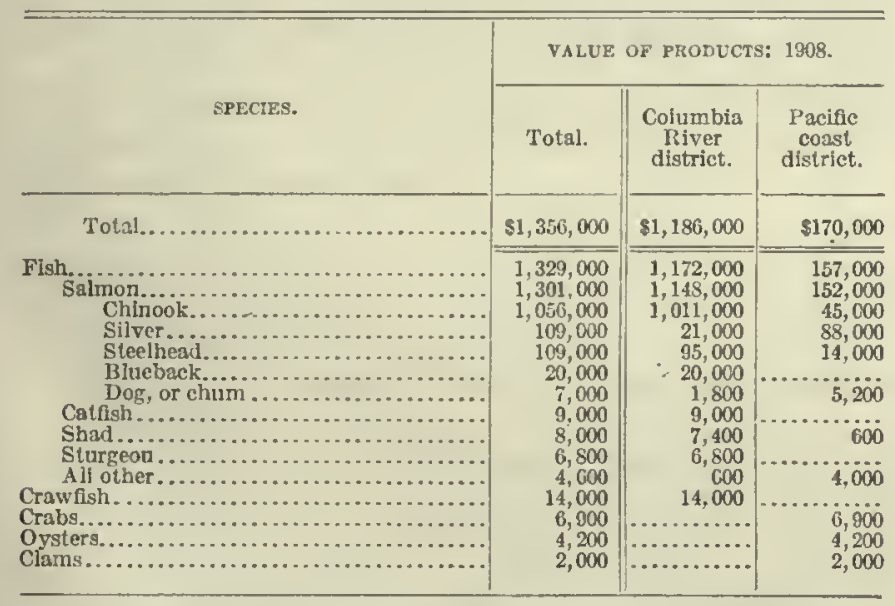

The following tabular statement shows, for 1908 , the fishery products of the state according to fishing grounds:

\begin{tabular}{|c|c|c|}
\hline \multirow{2}{*}{ FISIING GROUND. } & \multicolumn{2}{|c|}{$\begin{array}{c}\text { PISHERY PRONUCTS: } \\
1908 .\end{array}$} \\
\hline & $\begin{array}{l}\text { Quantity } \\
\text { (pounds). }\end{array}$ & Value. \\
\hline Total................ & $28,217,000$ & $\$ 1,35 \mathrm{G}, 000$ \\
\hline 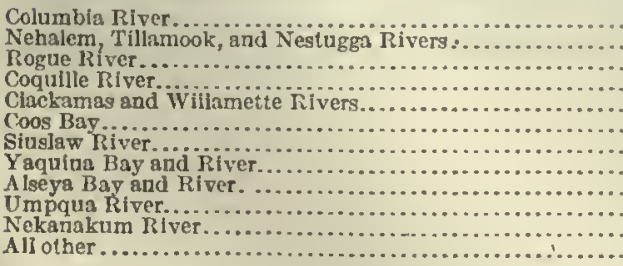 & $\begin{array}{r}20,911,000 \\
2,405,000 \\
990,000 \\
1,293,000 \\
404,000 \\
628,000 \\
845,000 \\
280,000 \\
225,000 \\
140,000 \\
50,000 \\
46,000\end{array}$ & $\begin{array}{r}1,162,000 \\
40,000 \\
37,000 \\
26,000 \\
25,000 \\
20,000 \\
17,000 \\
12,000 \\
8,900 \\
3,200 \\
900 \\
2,900\end{array}$ \\
\hline
\end{tabular}

Products, by apparatus of capture.-Of the total quantity, 22,849,000 pounds were taken with gill nets; and of the gill-net catch, $22,246,000$ pounds, or 97 per cent, represented salmon, valued at $\$ 1,061,000$, or 82 per cent reported for the total salmon catch of the state.

Seines ranked socond both in respect to the quantity and the value of the product taken. In addition to a large amount of salmon, considerable quantities of flounders, herring, and perch of the viviparous variety were included in the seine catch. The catch by wheels is confined to salmon and a few sturgeon.

In the following tabular statement the value of the total fishery product is distributed according to apparatus of capture, for the state and the two districts:

\begin{tabular}{|c|c|c|c|}
\hline \multirow[b]{2}{*}{ KIND OF APPARATUS. } & \multicolumn{3}{|c|}{ VALUE OF PRODUCTS: 1908.} \\
\hline & Total. & $\begin{array}{c}\text { Columbia } \\
\text { River } \\
\text { distriet. }\end{array}$ & $\begin{array}{l}\text { Paciffe } \\
\text { coast } \\
\text { district. }\end{array}$ \\
\hline Total.......... & $\$ 1,350,000$ & $\$ 1,180,000$ & 8170,000 \\
\hline 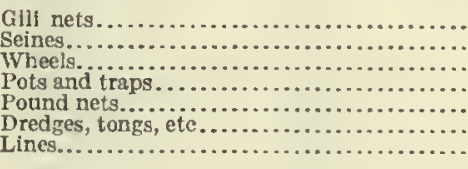 & $\begin{array}{r}1,076,000 \\
152,000 \\
72,000 \\
29,000 \\
18,000 \\
7,200 \\
2,200\end{array}$ & $\begin{array}{r}931,000 \\
142,000 \\
72,000 \\
23,000 \\
18,000 \\
\end{array}$ & $\begin{array}{r}144,000 \\
10,000 \\
6,000 \\
6,200 \\
7,200\end{array}$ \\
\hline
\end{tabular}

Salmon.-As already indicated, salmon constituted the chief fishery product, and represented 95 per cent of the total quantity and 96 per cent of the total value of products reported. The increase between 1904 and 1908 in the quantity reported was 162,000 pounds, or less than 1 per cent, and in the value reported $\$ 150,000$, or 13 per cent. There was a decrease in the quantity caught of the chinook and dog or chum species, although the value of cach increased. Both the quantity and value of blueback, silver, and steelhead salmon increased.

The following tabular statement shows the quantity and value of salmon taken from the different fishing grounds in 1908:

\begin{tabular}{|c|c|c|}
\hline \multirow{2}{*}{ FISAING GROUND. } & \multicolumn{2}{|c|}{$\begin{array}{c}\text { SALMION PRONUCT: } \\
1908 .\end{array}$} \\
\hline & $\begin{array}{l}\text { Quantity } \\
\text { (pounds). }\end{array}$ & Value. \\
\hline Total............. & $26,876,000$ & $\$ 1,301,000$ \\
\hline 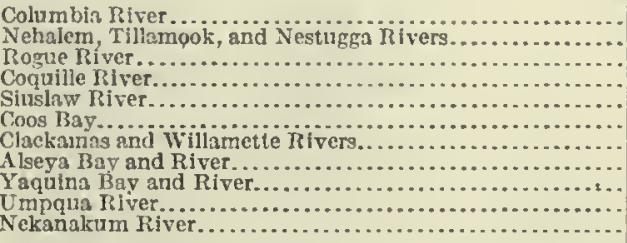 & $\begin{array}{r}20,095,000 \\
2,405,000 \\
990,000 \\
1,277,000 \\
845,000 \\
537,000 \\
263,000 \\
150,000 \\
124,000 \\
140,000 \\
50,000\end{array}$ & $\begin{array}{r}135,000 \\
40,000 \\
37,000 \\
26,000 \\
17,000 \\
17,000 \\
13,000 \\
6,500 \\
4,200 \\
3,200 \\
900\end{array}$ \\
\hline
\end{tabular}

The salmon catcl of the Columbia River alone constituted 75 per cent of the total salmon catch of the state and represented 87 per cent of its total value. The quantity taken from the Coquille River was greater than that taken from Rogue River, but the value of the latter catch was considerably greater. Almost the entire salmon product of the different rivers, excepting 
the Columbia, Clackamas, and Willamette, was used in the canneries, one or more of which are located on each river, except the Alseya and the Nckanakum. The catch of the last-named rivers was delivered to canneries located near by.

Other leading species.-The second in importance of the fishery products was crawfish, but the value of the catch formed only about 1 per cent of the total value of products. In both 1908 and 1904 Oregon ranked first among the states in respect to the value of the crawfish product, Wisconsin holding second rank in both the years named. Catfish, shad, hard crabs, and sturgeon were next in importance in the order named, and each showed a substantial gain since the canrass of 1904 .

TABLE 1.-OREGON-FISHERY PRODUCTS: 1908.

\begin{tabular}{|c|c|c|c|c|c|c|c|c|c|c|}
\hline \multirow{3}{*}{ SPECIES. } & \multirow{2}{*}{\multicolumn{2}{|c|}{ TOTAL. }} & \multicolumn{8}{|c|}{ PRODUCT CAUGUT BY- } \\
\hline & & & \multicolumn{2}{|c|}{ Gill nets. } & \multicolumn{2}{|c|}{ Seines. " } & \multicolumn{2}{|c|}{ Wheels. } & \multicolumn{2}{|c|}{ All other apparatus.' } \\
\hline & $\begin{array}{l}\text { Quantity } \\
\text { (pounds). }\end{array}$ & Value. & $\begin{array}{l}\text { Quantity } \\
\text { (pounds). }\end{array}$ & Value. & $\begin{array}{l}\text { Quantity } \\
\text { (pounds). }\end{array}$ & Value. & $\begin{array}{l}\text { Quantity } \\
\text { (pounds). }\end{array}$ & value. & $\begin{array}{l}\text { Quantity } \\
\text { (pounds). }\end{array}$ & Value. \\
\hline Total... & $28,217,000$ & $\$ 1,356,000$ & $22,849,000$ & $\$ 1,076,000$ & $2,987,000$ & $\$ 152,000$ & $1,355,000$ & $\$ 72,000$ & $1,025,000$ & $\$ 57,000$ \\
\hline 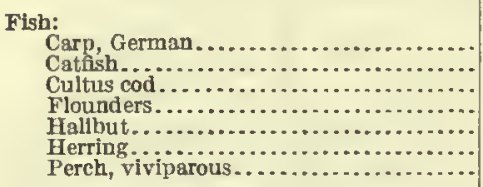 & $\begin{array}{r}30,000 \\
201,000 \\
20,000 \\
23,000 \\
16,000 \\
15,000 \\
26,000\end{array}$ & $\begin{array}{r}300 \\
9,000 \\
800 \\
500 \\
700 \\
300 \\
600\end{array}$ & $\begin{array}{r}30,000 \\
\cdots \\
5,000 \\
9,200 \\
1,700\end{array}$ & $\begin{array}{r}100 \\
200 \\
(2)\end{array}$ & $\begin{array}{r}18,000 \\
64,000 \\
24,000\end{array}$ & $\begin{array}{l}400 \\
100 \\
500\end{array}$ & & & $\begin{array}{r}201,000 \\
20,000 \\
16,000\end{array}$ & $\begin{array}{r}9,000 \\
800 \\
700 \\
700\end{array}$ \\
\hline 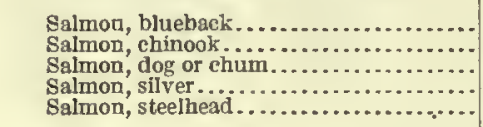 & $\begin{array}{r}403,000 \\
18,176,000 \\
905,000 \\
4,923,000 \\
2,469,000\end{array}$ & $\begin{array}{r}20,000 \\
1,056,000 \\
7,000 \\
109,000 \\
109,090\end{array}$ & $\begin{array}{r}7,700 \\
15,471,000 \\
895,000 \\
4,591,000 \\
1,280,000\end{array}$ & $\begin{array}{r}400 \\
901,000 \\
6,900 \\
102,000 \\
50,000\end{array}$ & $\begin{array}{r}94,000 \\
1,711,000 \\
10,000 \\
274,000 \\
847,000\end{array}$ & $\begin{array}{r}4,100 \\
100,000 \\
100 \\
5,500 \\
42,000\end{array}$ & $\begin{array}{r}291,000 \\
81,000 \\
11,000 \\
218,000\end{array}$ & $\begin{array}{r}16,000 \\
44,000 \\
\cdots 300 \\
10,000\end{array}$ & \begin{tabular}{r}
7,500 \\
175,000 \\
\hdashline 97,000 \\
124,000
\end{tabular} & $\begin{array}{r}300 \\
10,000 \\
900 \\
6,700\end{array}$ \\
\hline 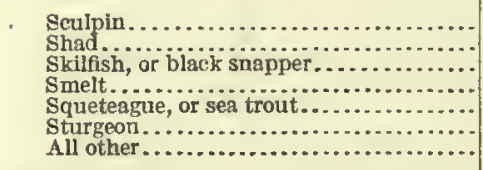 & $\begin{array}{r}8,000 \\
431,000 \\
5,000 \\
30,000 \\
2,000 \\
114,000 \\
3,300\end{array}$ & $\begin{array}{r}300 \\
8,000 \\
200 \\
800 \\
100 \\
6,800 \\
100\end{array}$ & $\begin{array}{r}430,000 \\
28,000 \\
100,000\end{array}$ & $\begin{array}{r}700 \\
\hdashline 5,600 \\
\hdashline\end{array}$ & $\begin{array}{c}1,300 \\
2,100\end{array}$ & $\begin{array}{l}1000 \\
100 \\
12{ }^{2}\end{array}$ & $13,000^{\circ}$ & $1, \ddot{2}, 200$ & $\begin{array}{r}8,000 \\
5,000 \\
2,000 \\
3,300\end{array}$ & 200 \\
\hline 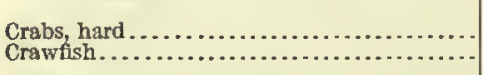 & $\begin{array}{l}200,000 \\
178,000\end{array}$ & $\begin{array}{r}6,900 \\
14,000\end{array}$ & & & & & & & $\begin{array}{l}200,000 \\
178,000\end{array}$ & $\begin{array}{r}6,900 \\
14,000\end{array}$ \\
\hline 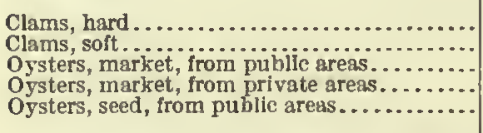 & $\begin{array}{r}8700 \\
30,000 \\
32,300 \\
65,000 \\
31,800\end{array}$ & $\begin{array}{r}100 \\
2,000 \\
800 \\
3,200 \\
200\end{array}$ & & & & & & & $\begin{array}{r}8700 \\
430,000 \\
62,300 \\
85,000 \\
71,800\end{array}$ & $\begin{array}{r}100 \\
2,000 \\
800 \\
3,200 \\
200\end{array}$ \\
\hline
\end{tabular}

1 Includes apparatus, with catch, as follows: Pots and traps, 561,000 pounds, valued at $\$ 29,000 ;$ pound nets, 353,000 pounds, valued at $\$ 18,000$; dredges, tongs, etc. 58,000 pounds, valued at $\$ 7,200$; and lines, 54,000 pounds, valued at $\$ 2,200$.

509 bushels.

600 bushels.

T 300 bushels.

TABLE 2.-OREGON-FISHERY PRODUCTS OF COLUMBIA RIVER DISTRICT: 1908.

\begin{tabular}{|c|c|c|c|c|c|c|c|c|c|c|}
\hline \multirow{3}{*}{ sPECIES. } & \multirow{2}{*}{\multicolumn{2}{|c|}{ TOTAL. }} & \multicolumn{8}{|c|}{ PRODUCT CAUGHT DY- } \\
\hline & & & \multicolumn{2}{|c|}{ Gill nets. } & \multicolumn{2}{|c|}{ Selnes. } & \multicolumn{2}{|c|}{ Wheels. } & \multicolumn{2}{|c|}{ All other apparatus.! } \\
\hline & $\begin{array}{l}\text { Quantity } \\
\text { (pounds). }\end{array}$ & Value. & $\begin{array}{l}\text { Quantity } \\
\text { (pounds). }\end{array}$ & Value. & $\begin{array}{l}\text { Quantity } \\
\text { (pounds). }\end{array}$ & Value. & $\begin{array}{l}\text { Quantity } \\
\text { (pounds). }\end{array}$ & Value. & $\begin{array}{l}\text { Quantity } \\
\text { (pounds). }\end{array}$ & Value. \\
\hline Total... & $21,315,000$ & $\$ 1,186,000$ & $16,643,000$ & $\$ 931,000$ & $2,586,000$ & $\$ 142,000$ & $1,355,000$ & $\$ 72,000$ & 732,000 & $\$ 41,000$ \\
\hline 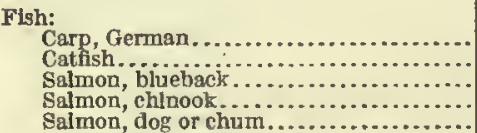 & $\begin{array}{r}30,000 \\
201,000 \\
403,000 \\
16,955,000 \\
147,000\end{array}$ & $\begin{array}{r}300 \\
9,000 \\
20,000 \\
1,011,000 \\
1,800\end{array}$ & $\begin{array}{r}30,000 \\
7,30,700 \\
14,000 \\
147,000\end{array}$ & $\begin{array}{r}860,000 \\
1,800\end{array}$ & $\begin{array}{r}94,000 \\
1,611,000\end{array}$ & $\begin{array}{r}4,100 \\
96,000\end{array}$ & $\begin{array}{r}294,000 \\
819,000 \\
\ldots . . .\end{array}$ & $\begin{array}{r}16,0000 \\
44,000 \\
\ldots . . .\end{array}$ & $\begin{array}{r}201,000 \\
7,500 \\
175,000\end{array}$ & $\begin{array}{r}9,000 \\
300 \\
10,000\end{array}$ \\
\hline 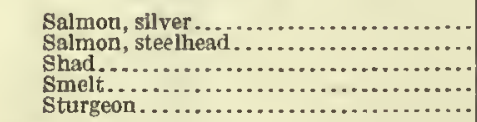 & $\begin{array}{r}839,000 \\
2,013,000 \\
418,000 \\
17,000 \\
114,000\end{array}$ & $\begin{array}{r}21,000 \\
95,000 \\
7,400 \\
300 \\
6,800\end{array}$ & $\begin{array}{r}716,000 \\
858,000 \\
417,000 \\
17,000 \\
100,000\end{array}$ & $\begin{array}{r}18,000 \\
38,000 \\
7,400 \\
300 \\
5,600\end{array}$ & $\begin{array}{r}66,000 \\
813,000 \\
1,300 \\
600 \\
600\end{array}$ & $\begin{array}{l}1,300 \\
40,000 \\
\left(\begin{array}{l}2 \\
(2)\end{array}\right.\end{array}$ & $\begin{array}{r}11,000 \\
218,000 \\
\cdots \\
13,000\end{array}$ & $\begin{array}{r}300 \\
10,000 \\
1,200\end{array}$ & 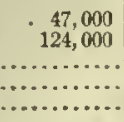 & $\begin{array}{r}900 \\
6,700 \\
\ldots \ldots \ldots \\
\cdots \ldots \ldots \\
\ldots \ldots\end{array}$ \\
\hline 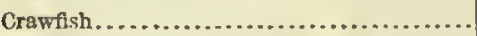 & 178,000 & 14,000 & & & & & & & 178,000 & 14,000 \\
\hline
\end{tabular}

\footnotetext{
1 Includes apparatus, wlth eatch, as follows: Pots and traps, 379,000 pounds, valued at $\$ 23,000$; and pound nets, 353,000 pounds, valued at $\$ 18,000$. $\quad 2$ Less than $\$ 100$.
} 
TABLE 3.-OREGON-IISHERY PRODUCTS OF PACIFIC COAST DISTRICT: 1908.

\begin{tabular}{|c|c|c|c|c|c|c|c|c|}
\hline \multirow{3}{*}{ SPECTES. } & \multirow{2}{*}{\multicolumn{2}{|c|}{ TOTAL. }} & \multicolumn{6}{|c|}{ PRODUCT CAUght BY- } \\
\hline & & & \multicolumn{2}{|c|}{ Gill nets. } & \multicolumn{2}{|c|}{ Seines. } & \multicolumn{2}{|c|}{ All other apparatus. 1} \\
\hline & $\begin{array}{l}\text { Quantity } \\
\text { (pounds). }\end{array}$ & Value. & $\begin{array}{l}\text { Qusntity } \\
\text { (pounds). }\end{array}$ & Value. & $\begin{array}{l}\text { Quantity } \\
\text { (pounds). }\end{array}$ & Value. & $\begin{array}{l}\text { Quantity } \\
\text { (pounds). }\end{array}$ & Value. \\
\hline 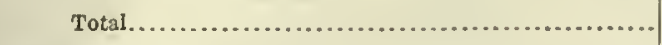 & $6,902,000$ & $\$ 170,000$ & $6,207,000$ & $\$ 144,000$ & 401,000 & $\$ 10,000$ & 294,000 & $\$ 15,000$ \\
\hline 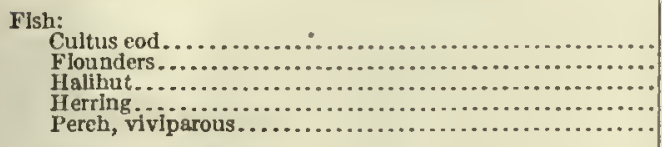 & $\begin{array}{l}20,000 \\
23,000 \\
16,000 \\
15,000 \\
26,000\end{array}$ & $\begin{array}{l}800 \\
500 \\
700 \\
300 \\
600\end{array}$ & $\begin{array}{r}3,000 \\
9,2000 \\
1,700\end{array}$ & $\left.{ }^{2}\right)^{200}$ & $\begin{array}{r}18,000 \\
6,000 \\
24,000\end{array}$ & 100 & $\begin{array}{l}20,000 \\
16,000 \\
0\end{array}$ & $\begin{array}{l}800 \\
700 \\
\cdots\end{array}$ \\
\hline 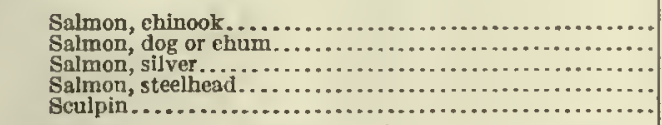 & $\begin{array}{r}1,221,000 \\
758,000 \\
4,084,000 \\
456,000 \\
8,000\end{array}$ & $\begin{array}{r}45,000 \\
5,200 \\
88,000 \\
14,000 \\
300\end{array}$ & $\begin{array}{r}1,121,000 \\
748,000 \\
3,876,000 \\
422,000 \\
\ldots . \cdots\end{array}$ & $\begin{array}{r}41,000 \\
5,200 \\
84,000 \\
13,000\end{array}$ & $\begin{array}{r}100,000 \\
10,000 \\
208,000 \\
34,000 \\
\ldots\end{array}$ & $\begin{array}{r}3,900 \\
100 \\
4,200 \\
1,100 \\
\cdots\end{array}$ & $\ddot{8}, 000$ & $\begin{array}{l}\cdots \\
\cdots \\
\cdots \\
300\end{array}$ \\
\hline 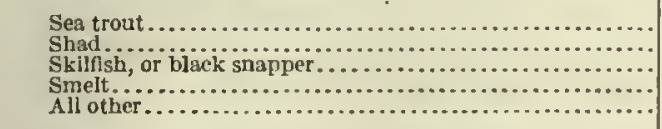 & $\begin{array}{r}2,000 \\
13,000 \\
5,000 \\
13,000 \\
3,300\end{array}$ & $\begin{array}{l}100 \\
600 \\
200 \\
500 \\
100\end{array}$ & $\begin{array}{l}13,000 \\
11,000\end{array}$ & $\begin{array}{c}600^{\circ} \\
3000^{\circ}\end{array}$ & $\dddot{1}, 500$ & $(3)$ & $\begin{array}{l}2,000 \\
\dddot{5}, 000 \\
\dddot{3}, 300\end{array}$ & 100 \\
\hline 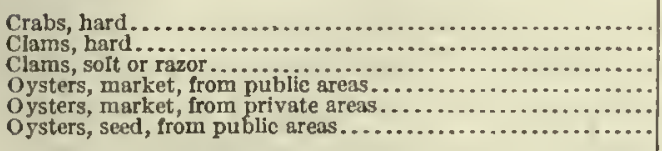 & $\begin{array}{r}200,000 \\
1700 \\
430,000 \\
62,300 \\
75,000 \\
71,800\end{array}$ & $\begin{array}{r}6,900 \\
100 \\
2,000 \\
800 \\
3,200 \\
200\end{array}$ & & & . & \begin{tabular}{ll|}
$\cdots \cdots$ \\
$\cdots \cdots$ \\
$\cdots \cdots$ \\
$\cdots \cdots$
\end{tabular} & $\begin{array}{r}200,000 \\
3700 \\
30,000 \\
2,300 \\
5,000 \\
71,800\end{array}$ & $\begin{array}{r}6,900 \\
100 \\
2,000 \\
800 \\
3,200 \\
200\end{array}$ \\
\hline
\end{tabular}

1 Ineludes apparatus, with catch, as follows: Dredges, tongs, ete., 55,000 pounds, valued at $\$ 7,200$; pots and traps, 182,000 pounds, valued at $\$ 6,000$ : and lines, 54,000

pounds, valued at $\$ 2,200$.
2. Less than $\$ 100$.

100 hushels.

43,700 hushels.

700 bushels.

7300 bushels.

\section{PENNSYLYAN1A.}

The fisheries of Pennsylvania may be grouped in three districts, including, respectively, those of Delaware River and Bay, those of Lake Erie, and those of the Susquelianna River. The following summary presents the chief statistics of the fishing industry for the entire state in 1908:

Number of persons employed.

1,250

Capital:

Vessels and boats, including outfit............... \$280,000

A pparatus of capture.................... 114, 000

Shore and accessory property and cash........... 87,000

Value of products........................ 513,000

Comparison with previous canvasses.-In comparing the statistics as to the products of Lake Erie for 1908 with those for previous years, allowance should be made for the results of a strike lasting seven weeks during the fall season, and for the effects of certain restrictive legislation recently enacted. In 1899 and 1890 large catches of lake herring, amounting to over $10,000,000$ and $8,000,000$ pounds, respectively, made the quantity taken much larger than in succeeding years. The total catch reported for the Delaware River and Bay district in 1908 shows a marked improvement over the downward movement which took place from 1897 to 1904 . The principal data for earlier canvasses are shown in the following comparative summary:

$$
76786^{\circ}-11-15
$$

\begin{tabular}{|c|c|c|c|c|c|c|}
\hline \multirow[b]{2}{*}{ DISTRICT AND YEAR. } & \multirow{2}{*}{$\begin{array}{l}\text { Persons } \\
\text { em- } \\
\text { ployed, } \\
\text { exclu- } \\
\text { sive of } \\
\text { shores- } \\
\text { men. }\end{array}$} & \multicolumn{3}{|c|}{ VALUE OF EQUIPMENT. } & \multicolumn{2}{|c|}{ Products. } \\
\hline & & Total. & $\begin{array}{l}\text { Vessels } \\
\text { and } \\
\text { boats, in } \\
\text { cluding } \\
\text { outfit. }\end{array}$ & 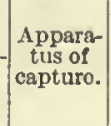 & $\begin{array}{l}\text { Quantity } \\
\text { (pounds). }\end{array}$ & Value. \\
\hline $\begin{array}{l}\text { Total: } \\
\quad 1908 . \ldots \ldots \ldots \\
\quad 1903.4 \ldots \ldots \\
1897-1899 \ldots \ldots\end{array}$ & $\begin{array}{l}1,237 \\
1,172 \\
1,825 \\
\end{array}$ & $\begin{array}{r}8394,000 \\
372,000 \\
321,000 \\
\end{array}$ & $\begin{array}{l}8280,000 \\
268,000 \\
203,000\end{array}$ & $\begin{array}{r}8114,000 \\
105,000 \\
117,000 \\
\end{array}$ & $\begin{array}{l}11,888,000 \\
10,414,000 \\
20,457,000\end{array}$ & $\begin{array}{r}8513,000 \\
473,000 \\
545,000\end{array}$ \\
\hline 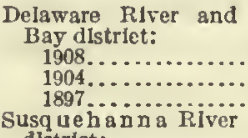 & $\begin{array}{r}514 \\
395 \\
1,115\end{array}$ & $\begin{array}{r}126,000 \\
73,000 \\
135,000\end{array}$ & $\begin{array}{r}116,000 \\
63,000 \\
110,000\end{array}$ & $\begin{array}{r}9,600 \\
10,000 \\
25,000\end{array}$ & $\begin{array}{l}3,987,000 \\
1,630,000 \\
5,331,000\end{array}$ & $\begin{array}{l}254,000 \\
143,000 \\
254,000\end{array}$ \\
\hline $\begin{array}{l}\text { distriet: } \\
1908 \ldots \ldots \ldots \ldots \ldots \\
1904 \ldots \ldots \ldots \ldots \ldots \ldots\end{array}$ & $\begin{array}{l}449 \\
425 \\
346\end{array}$ & $\begin{array}{r}14,000 \\
8,100 \\
6,000\end{array}$ & $\begin{array}{l}4,300 \\
2,800 \\
3,000\end{array}$ & $\begin{array}{l}9,800 \\
5,300 \\
3,000\end{array}$ & $\begin{array}{l}393,000 \\
416,000 \\
273,000\end{array}$ & $\begin{array}{l}26,000 \\
24,000 \\
16,000\end{array}$ \\
\hline 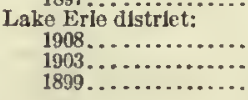 & $\begin{array}{l}274 \\
352 \\
364\end{array}$ & $\begin{array}{l}255,000 \\
291,000 \\
180,000\end{array}$ & $\begin{array}{r}160,000 \\
202,000 \\
90,000\end{array}$ & $\begin{array}{l}95,000 \\
89,000 \\
90,000\end{array}$ & $\begin{array}{r}7,508,000 \\
8,368,000 \\
14,853,000\end{array}$ & $\begin{array}{l}233,000 \\
305,000 \\
276,000\end{array}$ \\
\hline
\end{tabular}

Persons employed.-The statistics concerning the persons employed in the fisheries of Pennsylvania in 1908 are shown in the next tabular statement.

The only vessel engaged in transporting fish was employed on Lake Erie, and the data pertaining to it are included with those of the fishing vessels.

Of the 13 shoresmen, 11 were connected with the vessel fisheries. Thus, including shoresmen, 491 of the total number of persons reported were employed in connection with the vessel fisheries and 759 in connection with the shore and boat fisheries. The excess 
of the number in the shore and boat fisheries over that reported for vessel fisheries was due entirely to the influence of the Susquehanna River district, where all fisheries were of the shore and boat class. In both the Lake Erie district and the Delaware River and Bay district, persons employed in vessel fisheries outnumbered those employed in the shore and boat fisheries.

\begin{tabular}{|c|c|c|c|c|c|c|c|}
\hline \multirow{3}{*}{ DISTRICT AND CLASS. } & \multicolumn{7}{|c|}{ PERSONS EMPLOYEH: 1908.} \\
\hline & \multicolumn{4}{|c|}{ Number. } & \multicolumn{3}{|c|}{ Salaries and wages. } \\
\hline & Total. & $\begin{array}{l}\text { Proprie- } \\
\text { tors and } \\
\text { independ- } \\
\text { ent fish- } \\
\text { ermen. }\end{array}$ & $\begin{array}{c}\text { Sala- } \\
\text { ried om- } \\
\text { ploy- } \\
\text { ees. }\end{array}$ & $\begin{array}{l}\text { Wage- } \\
\text { earn- } \\
\text { ers. }\end{array}$ & Total. & $\begin{array}{l}\text { Saja- } \\
\text { rles. }\end{array}$ & Wages. \\
\hline Total........... & 1,250 & 1561 & 10 & 679 & $\$ 199,000$ & $\$ 6,800$ & $2 \$ 192,000$ \\
\hline $\begin{array}{r}\text { Vessel fish- } \\
\text { erles...... } \\
\text { Shore and } \\
\text { boat fish- } \\
\text { erles...... } \\
\text { Shoresmen. }\end{array}$ & $\begin{array}{r}480 \\
757 \\
13\end{array}$ & 534 & 10 & $\begin{array}{r}223 \\
13\end{array}$ & $\begin{array}{r}177,000 \\
19,000 \\
3,100\end{array}$ & 6,800 & $\begin{array}{r}170,000 \\
19,000 \\
3,100\end{array}$ \\
\hline $\begin{array}{l}\text { Dejaware River and } \\
\text { Bay district........ }\end{array}$ & 520 & 76 & 10 & 434 & 91,000 & 6,800 & 84,000 \\
\hline $\begin{array}{c}\text { Vessel fisheries... } \\
\text { shore and boat } \\
\text { fisheries......... } \\
\text { Shoresmen...... }\end{array}$ & $\begin{array}{r}266 \\
248 \\
6\end{array}$ & $\begin{array}{c}76 \\
\ldots .\end{array}$ & $\cdots$ & $\begin{array}{r}172 \\
6\end{array}$ & $\begin{array}{r}79,000 \\
10,000 \\
1,400\end{array}$ & 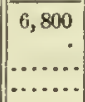 & $\begin{array}{r}10,000 \\
1,400\end{array}$ \\
\hline Lake Erio district.... & 281 & 53 & $\mid \ldots \ldots$. & 228 & 108,000 & $\ldots$ & 105,000 \\
\hline $\begin{array}{l}\text { Vessel fisheries } \\
\text { Shore and boat } \\
\text { fishertes......... } \\
\text { Shoresmen...... }\end{array}$ & $\begin{array}{r}214 \\
60 \\
7\end{array}$ & $\begin{array}{r}27 \\
26 \\
2 \ldots\end{array}$ & (...... & $\begin{array}{r}187 \\
34 \\
7\end{array}$ & $\begin{array}{r}97,000 \\
8,400 \\
1,700\end{array}$ & $\begin{array}{l}\ldots \ldots \\
\cdots \cdots \\
\cdots \cdots\end{array}$ & $\begin{array}{r}97,000 \\
8,400 \\
1,700\end{array}$ \\
\hline $\begin{array}{l}\text { Susquehanna River } \\
\text { distrlct (shore and } \\
\text { boat fisheries)...... }\end{array}$ & 449 & 432 & & 17 & 800 & $\mid \cdots \cdots \cdot$ & 800 \\
\hline
\end{tabular}

1 Exciustre of 30 proprietors not fishing.

Includes provisions furnished to the value of $\$ 21,000$

Equipment and other capital.-The following tabular statement gives the distribution of the total capital invested in the fisheries of Pennsylvania in 1908:

\begin{tabular}{|c|c|c|c|c|}
\hline \multirow[b]{2}{*}{ CLASS OF INVESTMENT. } & \multicolumn{4}{|c|}{$\begin{array}{l}\text { VALUE OF EQUIPMENT AND OTHER } \\
\text { CAPITAL: 1908. - }\end{array}$} \\
\hline & Total. & $\begin{array}{l}\text { Delaware } \\
\text { River } \\
\text { and Bay } \\
\text { district. }\end{array}$ & $\begin{array}{l}\text { Lake Erie } \\
\text { district. }\end{array}$ & $\begin{array}{c}\text { Susque } \\
\text { banna } \\
\text { River } \\
\text { district. }\end{array}$ \\
\hline 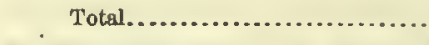 & $\$ 481,000$ & $\$ 183,000$ & $\$ 284,000$ & $\$ 14,000$ \\
\hline 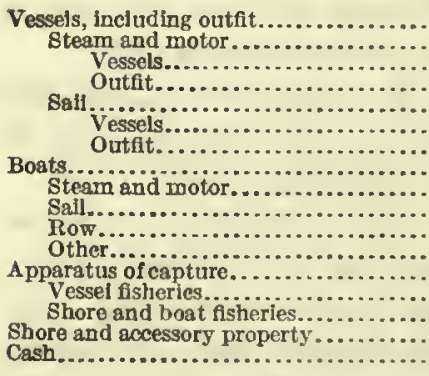 & $\begin{array}{r}254,000 \\
186,000 \\
183,000 \\
23,000 \\
68,000 \\
51,000 \\
17,000 \\
26,000 \\
17,000 \\
600 \\
5,400 \\
3,500 \\
114,000 \\
73,000 \\
41,000 \\
54,000 \\
33,000\end{array}$ & $\begin{array}{r}106,000 \\
38,000 \\
31,000 \\
6,900 \\
68,000 \\
51,000 \\
17,000 \\
10,000 \\
8,300 \\
1,700 \\
7,7000 \\
9,600 \\
3,400 \\
6,200 \\
30,000 \\
28,000\end{array}$ & \begin{tabular}{r}
148,000 \\
148,000 \\
132,000 \\
16,000 \\
$\cdots \ldots . . .$. \\
\hdashline$\ldots . .$. \\
12,000 \\
7,500 \\
600 \\
400 \\
3,200 \\
95,000 \\
70,000 \\
25,000 \\
24,000 \\
5,000
\end{tabular} & 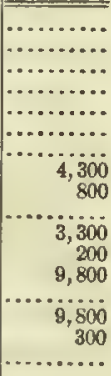 \\
\hline
\end{tabular}

1 Includes one vessel engaged in transporting.
The statisties eoncerning the number and tonnage of the vessels and the number of the boats are as follows:

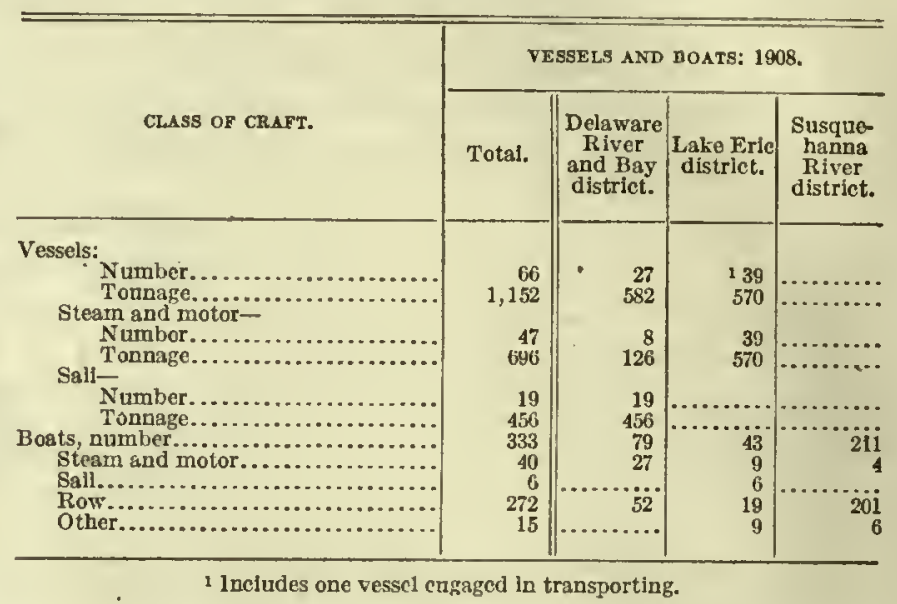

The value of fishing vessels composed over one-half of the total investment. Steam vessels predominated, and steam and motor boats also largely exceeded all other boats in value. The value of apparatus of capture constituted less than a quarter of the investment. Of the value of shore and accessory property, $\$ 20,000$ was credited to the shore and boat fislieries and $\$ 35,000$ to the vessel fisheries. The cash capital amounted to $\$ 3,400$ in the case of the shore and boat fisheries and to $\$ 29,000$ in the case of the vessel fisheries. The total investment in shore and boat fisheries, therefore, was $\$ 90,000$ and that in vessel fisheries $\$ 391,000$.

In the Delaware River and Bay district fishing vessels represented considerably more than half of the total investment, and the value of shore and accessory property and the cash reported, in nearly equal proportions, accounted for the bulk of the remainder. The value of apparatus of capture formed only 5 per cent of the total investment. The total investment in the vessel fisheries of this district was $\$ 161,000$, as compared with $\$ 23,000$ in shore and boat fisheries.

In the Lake Erie district one-half of the total investment was in fishing vessels and one-third in apparatus of capture. A few sailboats were engaged in fishing on this lake, but no sailing vessels. The apparatus of capture reported for the vessel fisheries consisted almost wholly of gill nets. The total investment in the shore and boat fisheries of Pennsylvania on Lake Erie was only $\$ 53,000$, while that in the vessel fisheries was $\$ 230,000$.

In the Susquehanna River district, as already stated, the entire investment was in shore and boat fisheries.

The distribution of the principal kinds of apparatus of capture, by fishery districts and by class of fisheries, is shown in the next tabular statement. 


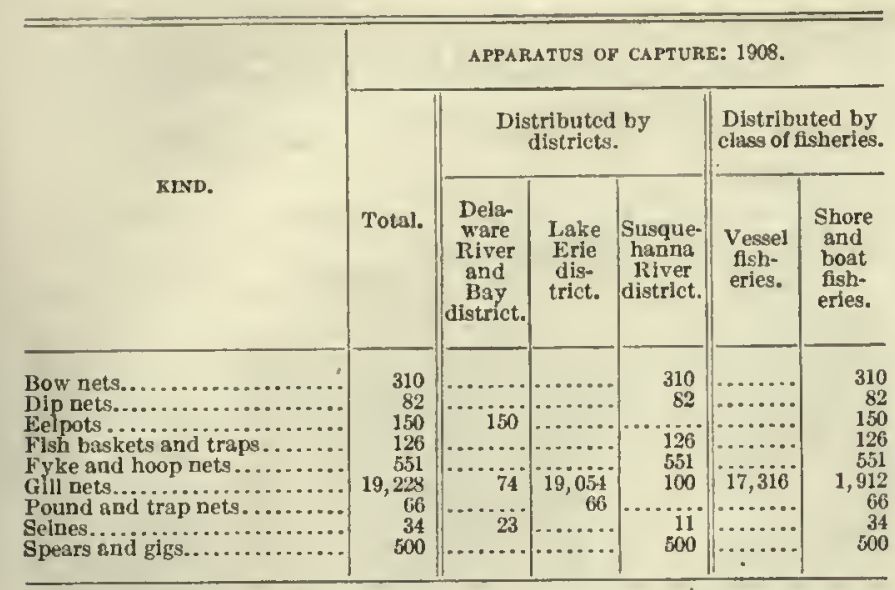

Products, by species.-Table 1, on page 2330 , gives statisties of the quantity and the value of the fishery produets of Pennsylvania, by speeies and by apparatus of eapture. Oysters, blue pike, and lake herring contributed to the total value of the product 34 per cent, 19 per eent, and 18 per eent, respeetively, representing in the aggregate 71 per eent of the total value. Sea bass furnished 9 per cent of the total value, while shad and whitefish each eontributed 7 per eent. Thus six species are shown to aecount for 94 per cent of the value of produets. The remaining 6 per eent was eontributed by 21 speeies. Of the six leading speeies, oysters and sea bass were taken from Delaware River and Bay; blue pike, lake herring, and whitefish from Lake Erie; and shad in nearly equal quantities from the Susquehanna and the Delaware Rivers. Fish proper represented 66 per ecnt of the total value of products and oysters the remaining 34 per cent.

Products, by fishing grounds.-Of the total value of the fishery products for the state, the Delaware River and Bay district furnished 50 per eent, the Lake Erie district 45 per eent, and the Susquehanna River district only 5 per eent. The quantity and value of the fishery produets of the Delaware River and Bay district, distributed by species and by apparatus of capture, are shown in Table 2, on page 230.

Oysters contributed 69 per eent, or more than twothirds, of the total value of the fishery produets of this district. Of the fish proper reported, sea bass, alewives, and shad were the most important as regards quantity. Sea bass and shad exceeded of her species of fish in value also, representing, respeetively, 56 per cent and 26 per cent of the value of all fish eaught, and 17 per cent and 8 per cent of the total value of produets for the distriet, being surpassed only by oysters; the alewife eatch, however, was of eomparatively little value. The sea-bass produet was taken wholly with lines, and the shad and alewives were taken with gill nets and seines.

The statisties of the fishery products of the Lake Erie distriet are given in Table 3, on page 231.

One-half of the Lake Erie eateh was composed of lake herring, but the value of this produet was some- what lower than that of the blue-pike cateh, which eontributed 41 per cent of the value of the Lake Erie produet, as eompared with a corresponding proportion of 39 per eent for lake herring. Whitefish ranked third in both quantity and value, the whitefish eateh representing 16 per eent of the total value of products of this distriet. Practieally the entire amount and value (96 per cent in each case) of the fishery product of the Iake Erie district was contributed by these three varieties of fish. Yellow pereh was the only other speeies that represented more than 1 per cent of either the total quantity or the total value. Gill nets, which were used for securing practically the entire lake-herring cateh and the larger part of the cateh of both pike perch and whitefish, were by far the most important kind of apparatus of eapture employed by the fisheries of this distriet.

Table 4, on page 231, presents, for the Susquehanna River district, statistics of the fishery products similar to those given for the other districts in Tables 2 and 3.

Shad alone represented 79 per eent of the total quantity and 73 per cent of the total value of the Susquehanna River eateh, eels being the only other species of any importance. About two-thirds of the shad product was caught by dip and bow nets and the remainder by seines and gill nets.

The following tabular statement distributes the value of products, by species, for the state and for each distriet:

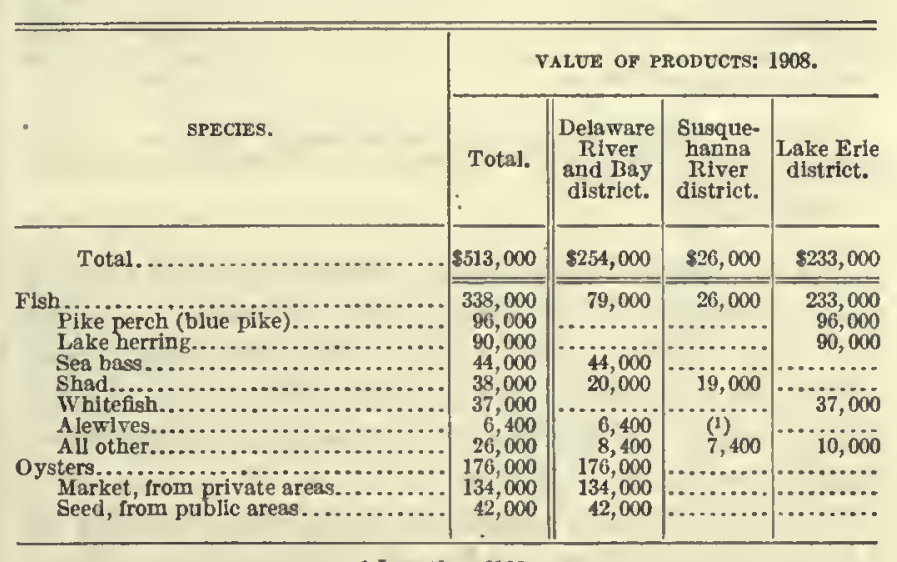

1 Less than $\$ 100$.

Products, by class of fisheries. - The next tabular statement shows the distribution, by species arranged according to value, of the value of products for the state as a whole and for the two elasses of fisheries.

The ressel fisheries account for 84 per eent of the value of all fishery produets of the state and for 76 per cent of that of the total fish catch. Of the products of this class of fisheries, oysters were by far the most important, eontributing 41 per cent of the total value; pike pereh and lake herring were the most important fish products, together representing 39 per eent of the total. Among the products of the shore and boat fisheries, shad, reported exelusively by this class of 
fisheries, had a value nearly as great as the combined value of all other fish.

\begin{tabular}{|c|c|c|c|}
\hline \multirow[b]{2}{*}{ SPECIES. } & \multicolumn{3}{|c|}{ VALUE OF PRODUCTS: 1908.} \\
\hline & Total. & $\begin{array}{c}\text { Vessel } \\
\text { fisheries. }\end{array}$ & $\begin{array}{l}\text { Shore } \\
\text { and boat } \\
\text { fisheries. }\end{array}$ \\
\hline Total............... & $\$ 513,000$ & $\$ 433,000$ & $\$ 80,000$ \\
\hline 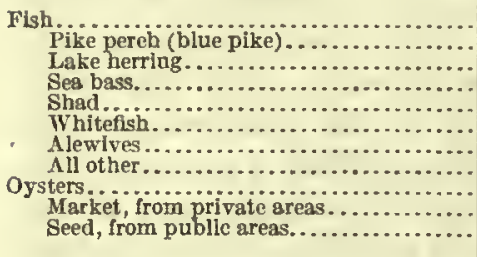 & $\begin{array}{r}338,000 \\
96,000 \\
90,000 \\
44,000 \\
38,000 \\
37,000 \\
6,400 \\
26,000 \\
176,000 \\
134,000 \\
42,000\end{array}$ & $\begin{array}{r}257,000 \\
85,000 \\
83,000 \\
44,000 \\
33,000 \\
310,000 \\
176,000 \\
134,000 \\
42,000\end{array}$ & $\begin{array}{r}80,000 \\
11,000 \\
6,400 \\
38,000 \\
2,600 \\
6,400 \\
16,000 \\
\ldots \ldots \ldots . . . \\
\ldots \ldots\end{array}$ \\
\hline
\end{tabular}

Statistics concerning the products of the vessel fisheries of the Delaware River and Bay district are presented in the following tabular statement:

\begin{tabular}{|c|c|c|}
\hline \multirow{2}{*}{ SPECIES. } & \multicolumn{2}{|c|}{$\begin{array}{l}\text { PRODVCTS OF VESSEL } \\
\text { FISHERIES, DERA } \\
\text { WARE RIVER AND } \\
\text { BAY DISTRICR: 1908. }\end{array}$} \\
\hline & $\begin{array}{l}\text { Quantity } \\
\text { (pounds). }\end{array}$ & Value. \\
\hline Total................... & $2,906,000$ & $\$ 225,000$ \\
\hline 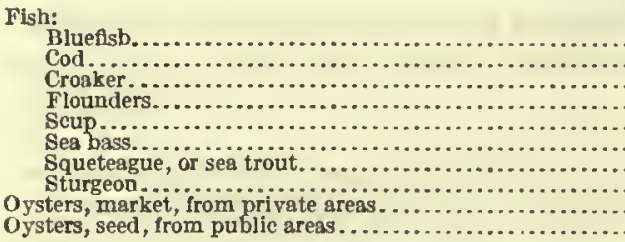 & $\begin{array}{r}7,500 \\
50,000 \\
14,000 \\
4,700 \\
11,000 \\
860,000 \\
12,000 \\
8,400 \\
2906,000 \\
31,032,000\end{array}$ & $\begin{array}{r}800 \\
800 \\
500 \\
200 \\
300 \\
44,000 \\
200 \\
2,600 \\
134,000 \\
42,000\end{array}$ \\
\hline
\end{tabular}

1 Includes apparatus, with catcb, as follows: Dredges, tongs, etc., 1,938,000 pounds, valued at $\$ 176,000$; lines, 959,000 pounds, valued at $\$ 47,000$; and gill nets, $\$, 400$ pounds, valued at $\$ 2,600$.

2 148,000 bushels.

Oysters were the principal species reported for the vessel fisheries of this district and represented 78 per cent of the value of their catch. The remaining 22 per cent of the total value was contributed by eight species of fish proper, all of which, with the exception of sturgeon, were taken with lines.

The next tabular statement gives the statistics of the products of shore and boat fisheries of the Delaware River and Bay district.

The chief products of the shore and boat fisheries of this district were, in point of value, shad and alewives, both fresh and salted. The value of these two species together constituted 90 per cent of the total value of the eatch. Gill nets and seines were the principal apparatus of capture used in this class of fisheries.

Statistics as to the products of the vessel fisheries and the shore and boat fisheries of Lake Erie are presented in Table 3 , on page 231. From a reference to this it will be seen that in both classes of fisheries blue pike, lake herring, and whitefish, in the order named, were the most important products as regards both quantity and value.

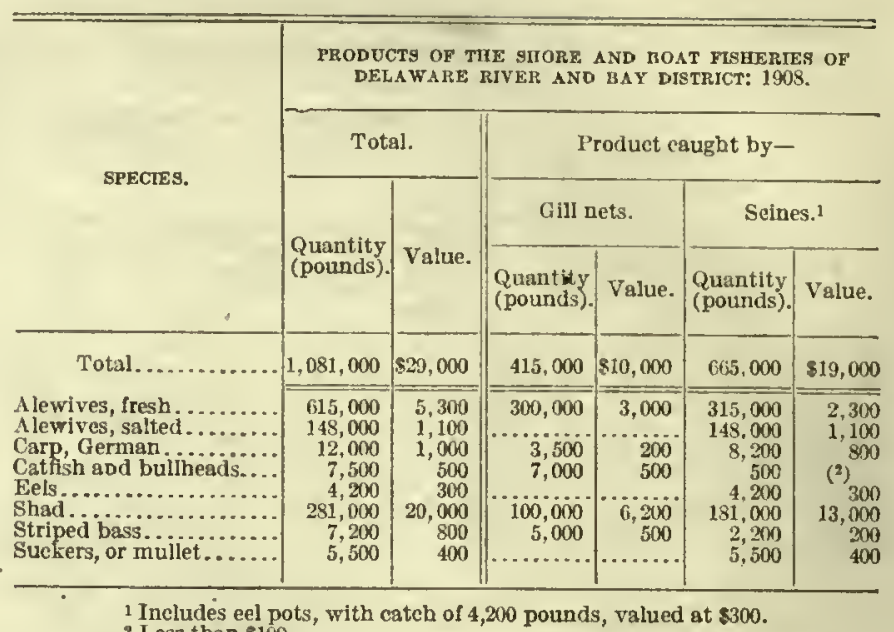

1 Includes eel pots, with catch of 4,200 pounds, valued at $\$ 300$.
2 Less than $\$ 100$.

As already indicated, the Susquehanna River fisheries were all of the shere and boat class.

Products, by apparatus of capture.-The following tabular statement indicates the distribution, by apparatus of capture arranged in the order of the value of their catch, of the value of products for the different fishery districts and for the two classes of fisheries, respectively. Gill nets took products valued at 46 per cent of the total value, and these were the most important form of apparatus in the Lake Erie district, where the catch by lines and pound and trap nets contributed less than 7 per cent of the total value of products. Dredges, tongs, etc., which were used only in the Delaware River and Bay district, took products having a value equal to 69 per cent of the total for this district and 34 per cent of the total for the state. In the Susquehanna River district the largest value of products, 46 per cent of the total for the district; was reported for dip and bow nets, the use of which was confined to this district.

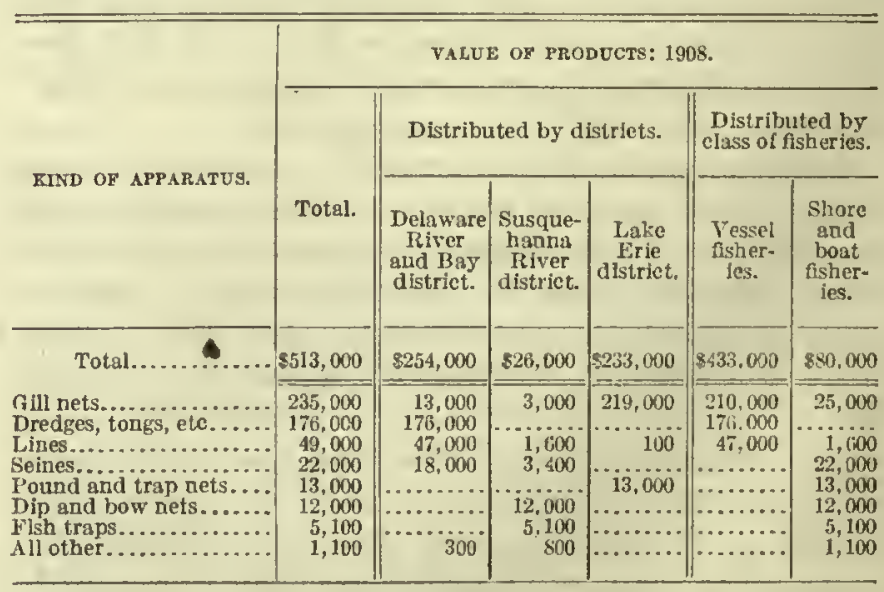

Oysters.-The yield of oysters in 1908, which represented 34 per cent of the total value of products, was larger than that in any previous year. The product was entircly from Delaware Bay; all the market oysters were taken from private beds, and all the seed oysters from public areas. 
The following tabular statement shows the changes in the quantity and value of the yield since 1880:

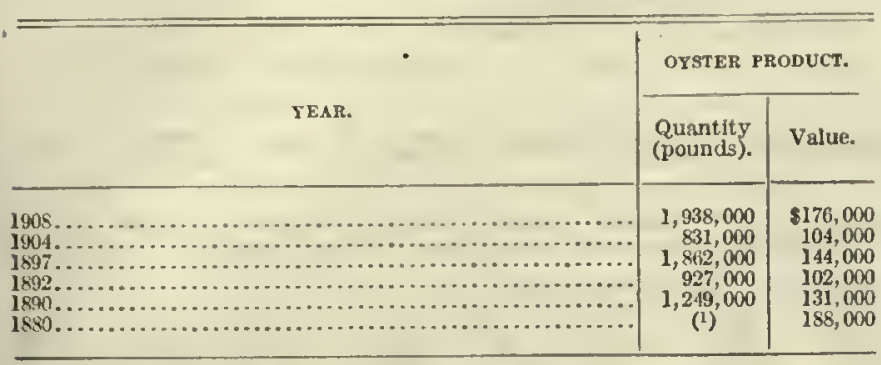

1 Not reported.

Blue pike.-The eatch of blue pike, which ranked first among the fisl proper, was taken wholly on Iake Erie, and contributed 41 per cent to the value of the product from this district. The yield in 1908 was larger than that in any previous year since 1890 and its value greater than that reported for any previous year. The following tabular statement presents the statistics for 1890 and succeeding canvasses:

\begin{tabular}{|c|c|c|c|}
\hline \multirow[b]{2}{*}{ YEAR. } & \multirow{2}{*}{$x^{2}$} & \multicolumn{2}{|c|}{ BLUE-PIKE PRODUCT. } \\
\hline & & $\begin{array}{l}\text { Quantlty } \\
\text { (pounds). }\end{array}$ & Value. \\
\hline 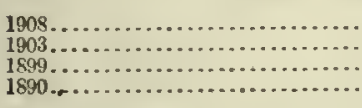 & (n................... & $\begin{array}{l}2,925,000 \\
2,179,000 \\
1,523,000 \\
3,246,000\end{array}$ & $\begin{array}{r}\$ 96,000 \\
79,000 \\
45,000 \\
70,000\end{array}$ \\
\hline
\end{tabular}

Lake herring.--The lake-herring product contributed 18 per cent of the value of all fishery products reported for the state and 39 per cent of that reported for the Lake Erie district. With the exception of a fractional percentage, the entire quantity was taken by gill nets. Of the value of the Lake Erie catch, 92 per cent was credited to vessel fisheries. The catch of this fish las decreased rapidly in quantity since 1899, in which year $10,742,000$ pounds were taken. The following statement, which gives the quantity and value reported for certain earlier years, shows that the lighest value was reached in 1903:

\begin{tabular}{|c|c|c|c|c|}
\hline \multirow{2}{*}{ 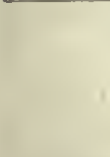 } & \multirow{2}{*}{ YEAR. } & \multirow{2}{*}{ - } & \multicolumn{2}{|c|}{$\begin{array}{l}\text { LAKE-HERRINO } \\
\text { PRODUCT. }\end{array}$} \\
\hline & & & $\begin{array}{l}\text { Quantity } \\
\text { (pounds). }\end{array}$ & Value. \\
\hline $\begin{array}{l}1908 \ldots . . . \\
1900 . \ldots . \\
1899 \ldots \ldots \\
1890 \ldots . . .\end{array}$ & & & $\begin{array}{r}3,790,000 \\
5,750,000 \\
10,742,000 \\
8,013,000\end{array}$ & $\begin{array}{r}\$ 90,000 \\
208,000 \\
134,000 \\
80,000\end{array}$ \\
\hline
\end{tabular}

Sea bass.-This species, the value of which amounted to 9 per cent of the value of all the fishery products of the state, was, like oysters, taken only in the Delaware River and Bay district, where it contributed 17 per cent of the value of the catch. The entire quantity was taken with lines in the vessel fisheries and represented nearly 20 per cent of the value of the catch made by vessel fisheries of the Delawdre River and Bay district. No sea-bass product was reported in 1904, but at previous canvasses the yields were as large as, or larger than, that of 1908, although of somewhat smaller value. The changes in the catch are indicated in the following tabular statement:

\begin{tabular}{|c|c|c|}
\hline \multirow[b]{2}{*}{ YEAR. } & \multicolumn{2}{|c|}{ SEA-RASS PRODUCT. } \\
\hline & $\begin{array}{l}\text { Quantity } \\
\text { (pounds). }\end{array}$ & Value. \\
\hline 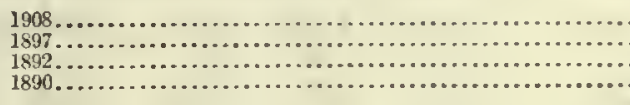 & $\begin{array}{l}860,000 \\
900,000 \\
902,000 \\
803,000\end{array}$ & $\begin{array}{r}\$ 44,000 \\
36,000 \\
38,000 \\
29,000\end{array}$ \\
\hline
\end{tabular}

Shad.-This fish was taken in both the Delaware River and Bay district and the Susquehanna River district, 53 per cent of the total value for the state being credited to the former. Of the total product of fish proper, this species formed 11 per cent in the state, 73 per cent in the Susquehanna River district, and 26 per cent in the Delaware River and Bay fisheries. Seines and gill nets were the principal forms of apparatus of capture used in the sliad fisheries of the Delaware River and Bay district, seines taking about two-thirds of the catch; in the Susquehanna River fisheries, though these two forms of apparatus were used, dip and bow nets were used much more extensively.

The following tabular statement shows that there has been a marked decline in the product of this species since 1890, interrupted only in 1897, when the catch was of greater weight though of less value than in 1892:

\begin{tabular}{|c|c|c|}
\hline \multirow[b]{2}{*}{ YEAR. } & \multicolumn{2}{|c|}{ SKAD PRODUCT. } \\
\hline & $\begin{array}{l}\text { Quantity } \\
\text { (pounds). }\end{array}$ & Value. \\
\hline 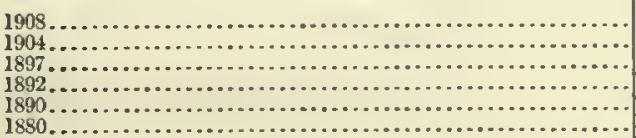 & $\begin{array}{r}593,000 \\
836,000 \\
2,007,000 \\
1,996,000 \\
2,899,000 \\
560,000\end{array}$ & $\begin{array}{r}\$ 38,000 \\
52,000 \\
64,000 \\
110,000 \\
131,000 \\
28,000\end{array}$ \\
\hline
\end{tabular}

Whitefish.-The value of the whitefish catch formed 7 per cent of the value of the total state product and 16 per cent of that of the Lake Erie product. The vessel fisheries of Lake Eric took, by means of gill nets, products valued at 92 per cent of the total value for whitefish. Though greater than the catch in 1903, the quantity taken in 1908 was much less than that reported in any year previous to 1903, while, as the following tabular statement shows, the value in 1908 was practically the same as that in 1880 and that in 1890:

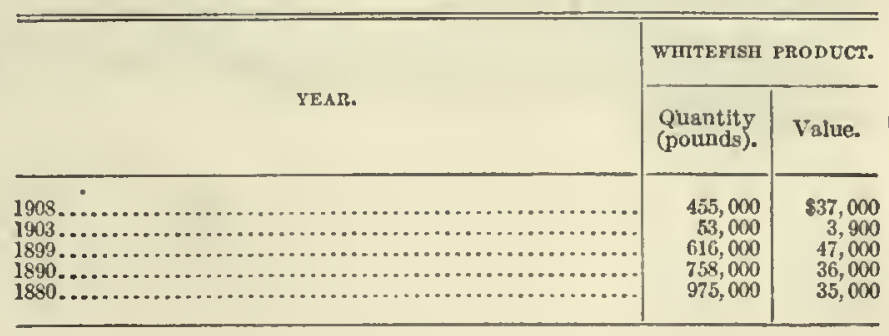


TABLE 1.-PENNSYLVANIA-FISHERY PRODUCTS: 1908.

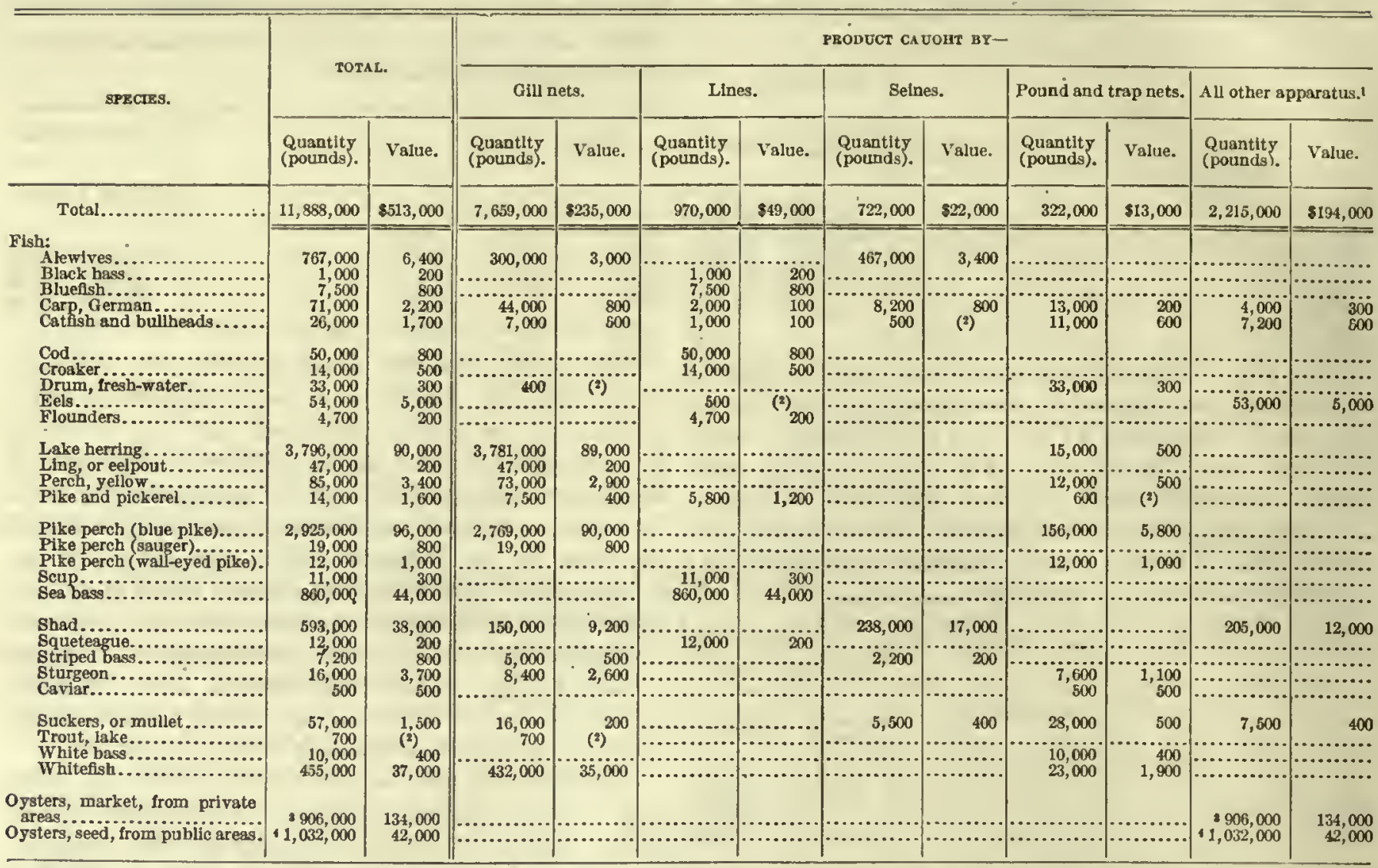

1 Includes apparatus, with catch, as follows: Dredges, tongs, etc., $1,938,000$ pounds, valued at $\$ 176,000 ;$ dip nets and bow nets, 205,000 pounds, valued at $\$ 12,000$

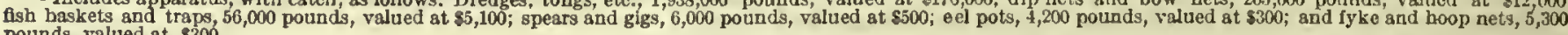
pounds, valued at $\$ 300$.

Less than $\$ 100$.

129,000 bushels.

4148,000 bushels.

TABLE 2.-PENNSYLVANIA-FISHERY PRODUCTS OF DELAWARE RIVER AND BAY DISTRICT: I908.

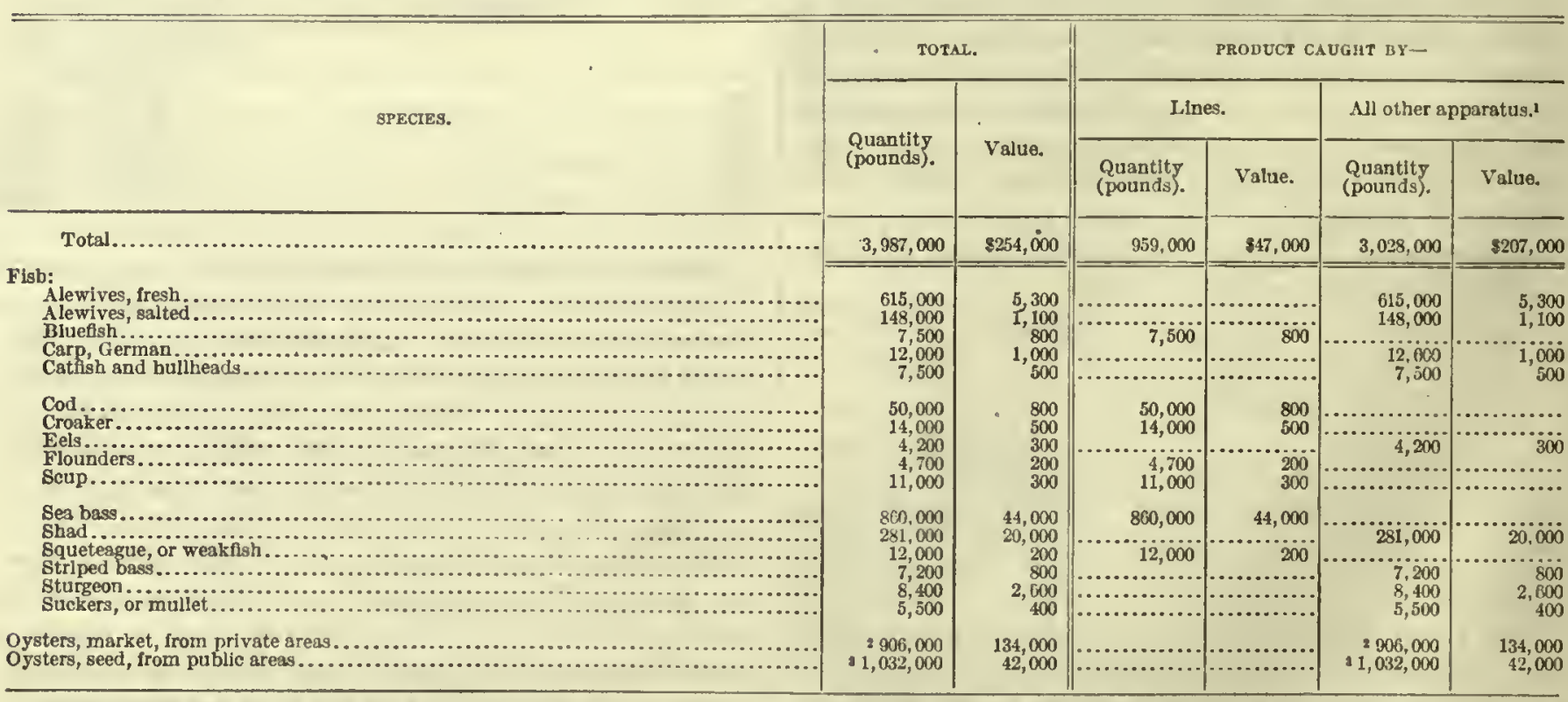

1 Includes apparatus, with catch, as follows: Dredges, tongs, ete., 1,938,000 pounds, valued at $\$ 176,000$ seines, 661,000 pounds, valued at $\$ 18,000$; gill nets, 424,000 pounds, valued at \$13.000; and ecl pots, 4,200 pounds, valued at \$300.

129,000 bushels. 
FISHERIES, BY STATES.

TABLE 3.-PENNSYLVANIA-FISHERY PRODUCTS OF LAKE ERIE DISTRICT: 1908.

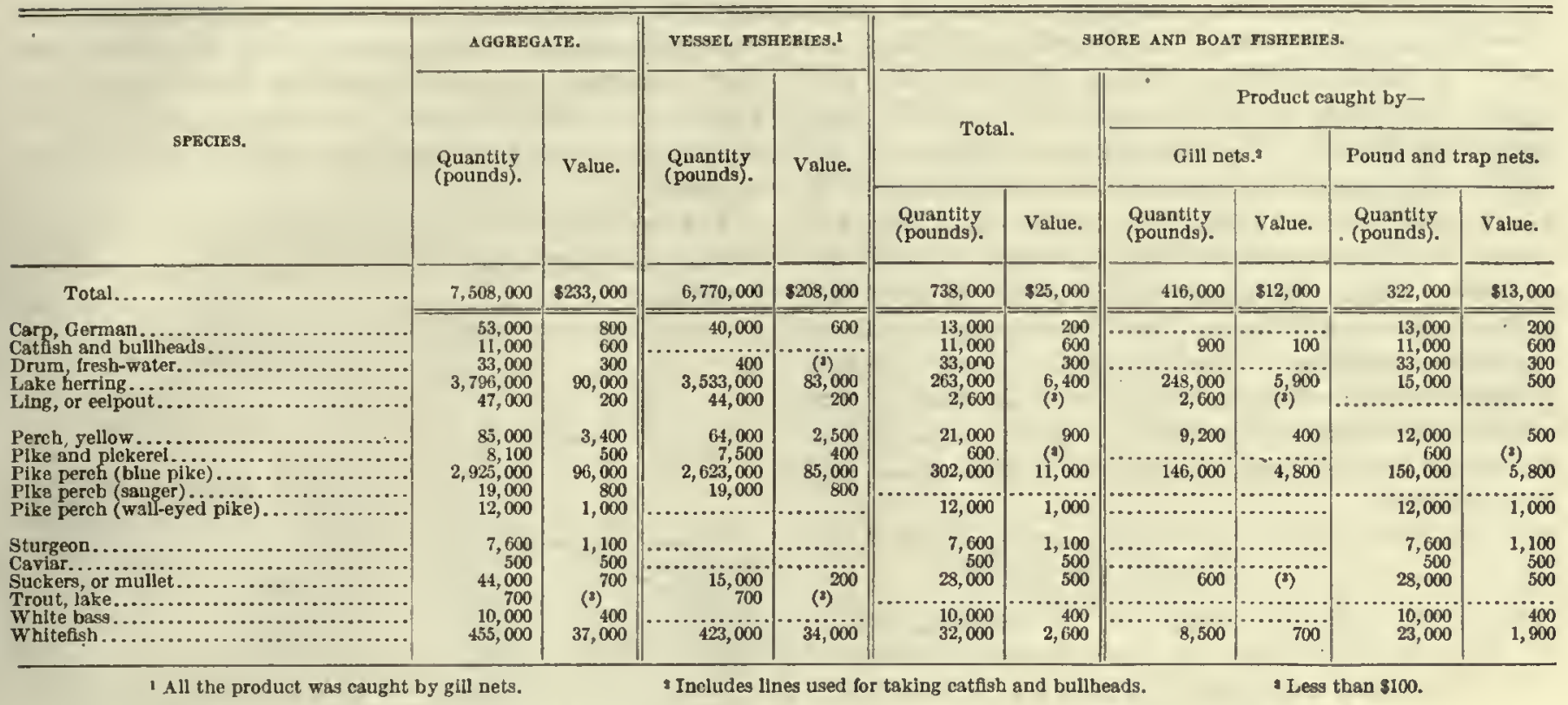

TABLE 4.-PENNSYLVANIA-FISHERY PRODUCTS OF SUSQUEHANNA RIVER DISTRICT: 1908. ${ }^{1}$

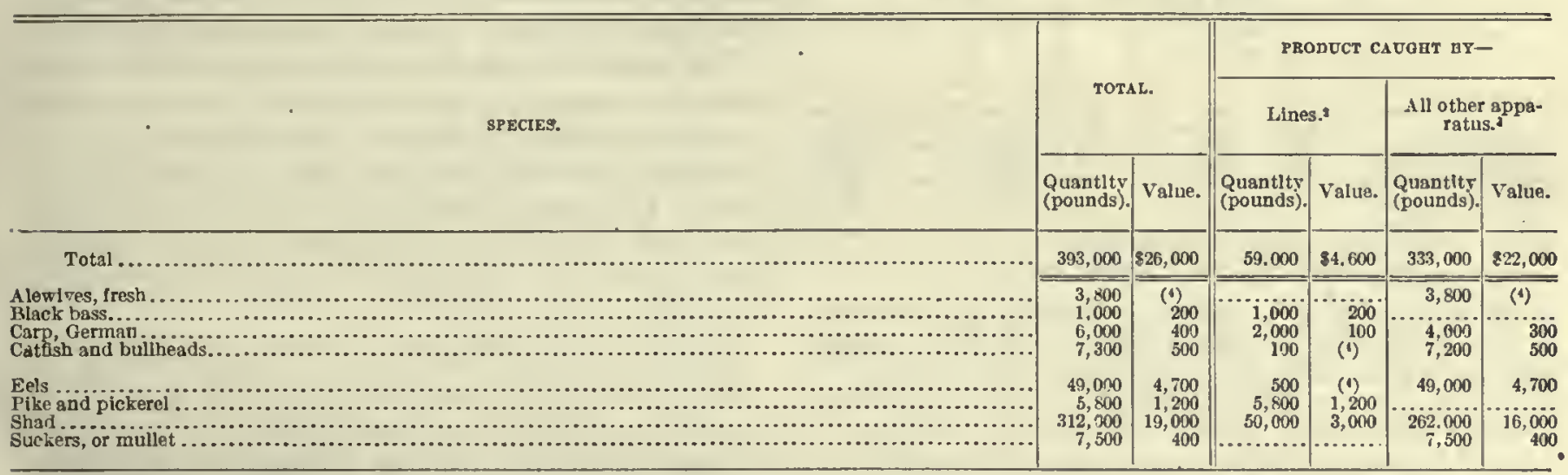

1 All taken in shore and boat fisheries.

Includes gill nets used for taking shad $(50,000$ nounds, valued at $\$ 3,000)$.

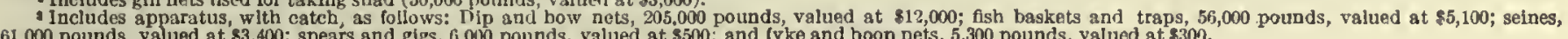

61,000 pounds, valued at $\$ 3,400$ : spears and gigs, 6,000 pounds, valued at $\$ 500$; and (yke and hoop nets, 5,300 pounds, valued at $\$ 300$.
Less than $\$ 100$.

RHODE ISLAND.

The general statistics for the fisheries of Rhode Island, as reported for 1908, are as follows:

Number of persons employed.

Capital:

Vessels and boats, including outfit............... $\$ 647,000$

Apparatus of capture....................... 230,000

Shore and accessory property and cash.......... 627,000

Value of products........................... 1,752,000

Comparison with previous canvasses. -The following tabular statement gives comparative statistics for those years for which figures are available:

\begin{tabular}{|c|c|c|c|c|c|c|}
\hline \multirow[b]{2}{*}{ YEAR. } & \multirow{2}{*}{$\begin{array}{c}\text { Persons } \\
\text { em- } \\
\text { ployed, } \\
\text { excluslve } \\
\text { of shores- } \\
\text { men. }\end{array}$} & \multicolumn{3}{|c|}{ VALUE OF EQUIPMENT. } & \multicolumn{2}{|c|}{ PRODUCTS. } \\
\hline & & Total. & $\begin{array}{c}\text { Vessels } \\
\text { and boats, } \\
\text { including } \\
\text { outfit. }\end{array}$ & $\begin{array}{l}\text { Appara- } \\
\text { tus of } \\
\text { capture. }\end{array}$ & $\begin{array}{l}\text { Quantlty } \\
\text { (pounds). }\end{array}$ & Value. \\
\hline $\begin{array}{l}1908 \ldots \ldots \ldots \\
1905 \ldots \ldots \\
1902 \ldots \ldots \\
1898 \ldots \ldots \\
1889 \ldots \ldots \\
1850 \ldots \ldots\end{array}$ & $\begin{array}{l}1,404 \\
1,708 \\
1,425 \\
1,340 \\
1,284 \\
1,602\end{array}$ & $\begin{array}{r}\$ 877,000 \\
715,000 \\
535,000 \\
437,000 \\
406,000 \\
392,000\end{array}$ & $\begin{array}{r}8647,000 \\
508.000 \\
367,000 \\
287,000 \\
256,000 \\
297,000\end{array}$ & $\begin{array}{r}8230,000 \\
207,000 \\
169,000 \\
151,000 \\
119,000 \\
95,000\end{array}$ & $\begin{array}{r}44,254,000 \\
23,896,000 \\
21,614,000 \\
32,854,000 \\
127,365,000 \\
88,050,000\end{array}$ & $\begin{array}{r}81,752,000 \\
1,547,000 \\
1,156,000 \\
955,000 \\
935,000 \\
881,000\end{array}$ \\
\hline
\end{tabular}

A comparison of the returns for 1908 with those for 1905 shows an increase in the value of equipment and 
in quantity and value of products, and a decrease in the number of persons employed. For the total investment in equipment, the investment in apparatus of capture, and the value of products, the statistics show gains at each canvass, as compared with the one preceding. The variations in quantity are due chicfly to the great fluctuations in the menhaden catch, which was over $112,000,000$ pounds in 1889 , less than $1,000,000$ pounds in 1902 , and ncarly $18,000,000$ pounds in 1908. The total value of products, however, is little affected by the catch of this low-priced fish.

Persons employed.- The distribution of the persons employed in the fisheries of the state is shown in the tabular statement given below. Almost one-half of the total number were employed in the shore and boat fisheries.

\begin{tabular}{|c|c|c|c|c|c|c|c|}
\hline \multirow[b]{3}{*}{ CLASS. } & \multicolumn{7}{|c|}{ PERSONS EMTLOYED: 1909.} \\
\hline & \multicolumn{4}{|c|}{ Number. } & \multicolumn{3}{|c|}{ Salaries and wages. } \\
\hline & Total. & $\begin{array}{c}\text { Pro- } \\
\text { prie- } \\
\text { tors and } \\
\text { inde- } \\
\text { pend- } \\
\text { ent } \\
\text { fisber- } \\
\text { men. }\end{array}$ & $\begin{array}{l}\text { Sala- } \\
\text { rled } \\
\text { em- } \\
\text { ploy- } \\
\text { ees. }\end{array}$ & $\begin{array}{l}\text { Wage- } \\
\text { earn- } \\
\text { ers. }\end{array}$ & Total. & $\begin{array}{l}\text { Sala- } \\
\text { ries. }\end{array}$ & Wages. \\
\hline Total........... & 1,493 & 1565 & 26 & 902 & 5390,000 & $\$ 27,000$ & $2 \$ 363,000$ \\
\hline $\begin{array}{l}\text { Vessel fisherles........ } \\
\text { Transporting vessels... } \\
\text { Shore and boat fisheries } \\
\text { Shoresmen............ }\end{array}$ & $\begin{array}{r}629 \\
49 \\
726 \\
89\end{array}$ & $\begin{array}{r}132 \\
12 \\
421 \\
\ldots \ldots \\
\end{array}$ & $\begin{array}{r}23 \\
\cdots \\
\cdots\end{array}$ & $\begin{array}{r}474 \\
37 \\
302 \\
89\end{array}$ & $\begin{array}{r}225,000 \\
24,000 \\
98,000 \\
43,000\end{array}$ & $\begin{array}{r}23,000 \\
\cdots \ldots \ldots 0 \\
3,90\end{array}$ & $\begin{array}{r}202,000 \\
24,000 \\
94,000 \\
43,000\end{array}$ \\
\hline
\end{tabular}

Equipment and other capital.-Statistics with respect to the distribution of the equipment and other capital reported for the fisheries of the state are as follows:

\begin{tabular}{|c|c|c|c|}
\hline \multirow{2}{*}{ CLASS OF INVESTMENT. } & \multicolumn{3}{|c|}{$\begin{array}{l}\text { EQUTPMENT AND OTHER } \\
\text { CAPITAL: } 1908 .\end{array}$} \\
\hline & Value. & $\begin{array}{l}\text { Num- } \\
\text { ber. }\end{array}$ & $\begin{array}{l}\text { Ton- } \\
\text { nage. }\end{array}$ \\
\hline Total...................................... & $\$ 1,504,000$ & & \\
\hline Vessels, Jncluding outfit .. & 514,000 & 138 & 2,055 \\
\hline Fishlng................. & 464,000 & 119 & 1,817 \\
\hline Steam and motor............ & 460,000 & 112 & 1,828 \\
\hline 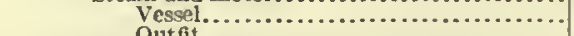 & 372,000 & $\ldots \ldots$. & $\ldots \ldots$ \\
\hline 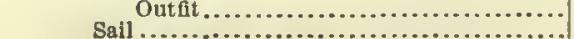 & $\begin{array}{r}88,000 \\
1,700\end{array}$ & $\because \cdots n_{2}$ & $\cdots \cdots$ \\
\hline 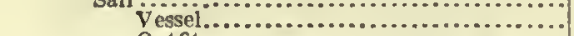 & 1,100 & $\ldots$ & ... \\
\hline 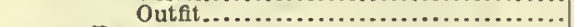 & 600 & & \\
\hline 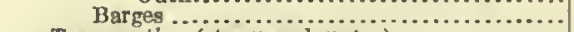 & 2,400 & 5 & $\cdots$ \\
\hline Transporting (steam and motor) ................ & 50,000 & 19 & 208 \\
\hline 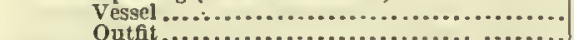 & 41,000 & (.......... & (........ \\
\hline Boats ............... & 133,000 & 815 & \\
\hline 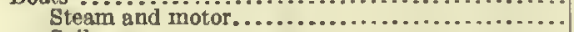 & 110,000 & 232 & $\ldots \ldots$ \\
\hline 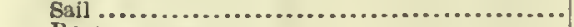 & 3,300 & 17 & .......... \\
\hline Row............ & 18,000 & 550 & \\
\hline Other.............. & 1,400 & 16 & ........ \\
\hline A pparatus of capture................................. & 230,000 & & \\
\hline 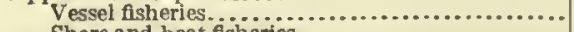 & 111,000 & ....... & -......... \\
\hline Bhore and boat fisheries.......................... & 119,000 & ......... & (........ \\
\hline 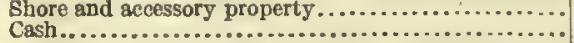 & $\begin{array}{l}451,000 \\
176,000\end{array}$ & & \\
\hline & & & \\
\hline
\end{tabular}

Of the total capital employed in the fishing industry, 43 per cent was invested in vessels and their outfits and boats and 15 per cent in apparatus of capture, while 42 per cent represented the value of shore and accessory property and the amount of cash reported.

Exclusive of shore and accessory property and cash, the investment, credited to fishing and transporting vessels aggregated $\$ 626,000$, of which 82 per cant represented the value of the vessels and 18 per cent the value of apparatus of capture. For the.shore and boat fisheries the corresponding iuvestment was $\$ 251,000$, of which 53 per cent represented the value of boats and 47 per cent the value of apparatus of capture.

The following tabular statement shows the number of the more important kinds of apparatus of capture reported:

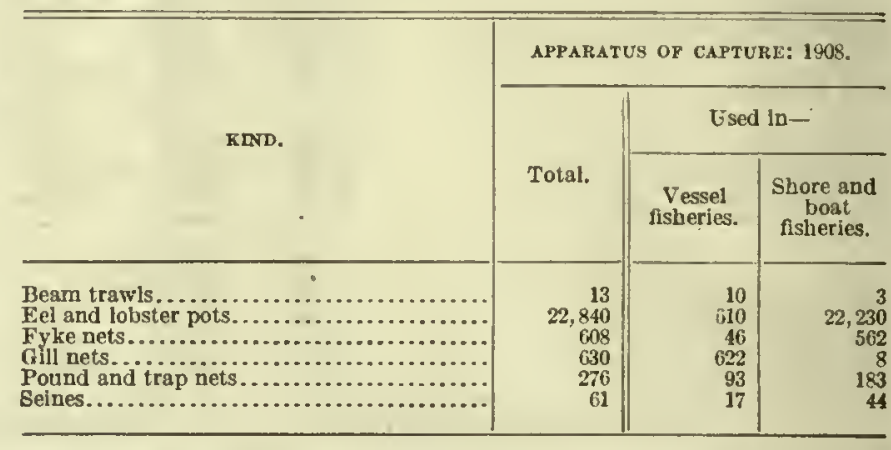

Products, by species.-Table 1, on page 234, gives the weight and value of the fishery products of the state, distributed by species and by apparatus of capture.

The value of the shellfish products of the state, including the squid, constituted 69 per cent of the value of all fishery products. The oyster product, as measured by value, was the most important in the state. In quantity also, if figured at gross weight, the oyster catch largely exceeded the catch of all other fishery products, amounting to nearly 50,000 tons on this basis.

Products, by class of fisheries.-The products of the vessel fisheries are shown, by species and apparatus of capture, in Table 2, on page 235, and the products of the shore and boat fisheries are similarly distributed in Table 3, on page 236. The following tabular statement gives the distribution, according to species, of the total value of products reported for the state and for the vessel fisheries and the shore and boat fisheries, respectively:

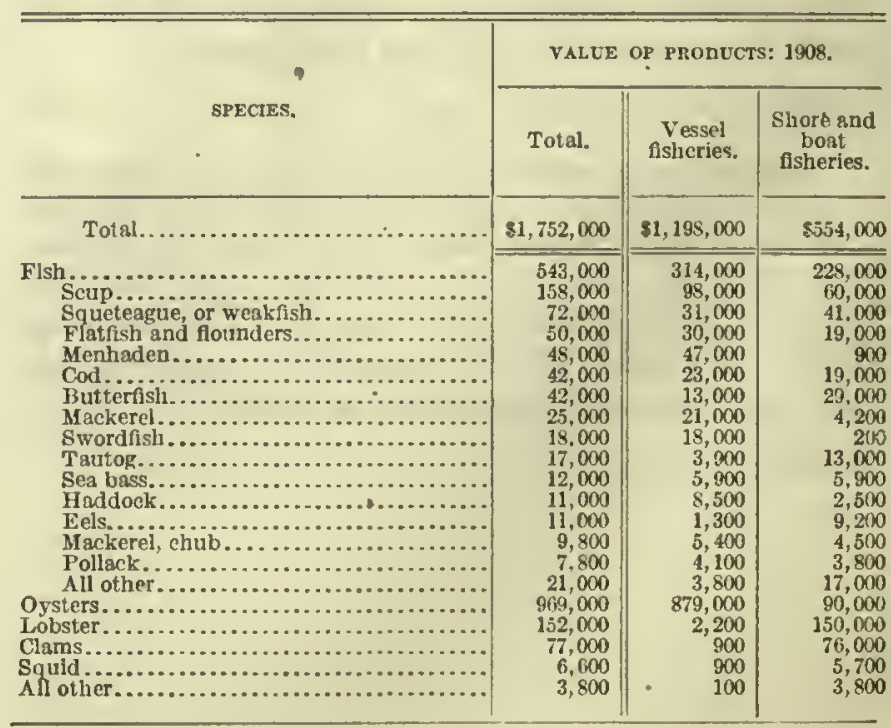


The vessel fisheries contributed a little more than two-thirds of the total value of products, including practically all of the value reported for the menhaden and swordfish catches and 91 per cent of the total value of the oyster product.

Products, by apparatus of capture.-In the following tabular statement the value of products is distributed according to apparatus of capture for all fisheries and for the vessel fisheries and the shore and boat fisheries separately:

\begin{tabular}{|c|c|c|c|}
\hline \multirow[b]{2}{*}{ KINE OF APPARATUS. } & \multicolumn{3}{|c|}{ VALUE OF PRODUCTS: 1908.} \\
\hline & Total. & $\begin{array}{c}\text { Vessel } \\
\text { fisheries. }\end{array}$ & $\begin{array}{c}\text { Shore and } \\
\text { bost } \\
\text { fisherles. }\end{array}$ \\
\hline Total.............................. & $\$ 1,752,000$ & $\$ 1,198,000$ & $\$ 554,000$ \\
\hline 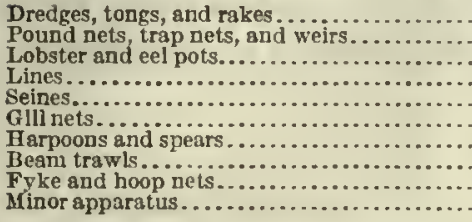 & $\begin{array}{r}1,008,000 \\
388,000 \\
163,000 \\
55,000 \\
40,000 \\
21,000 \\
19,000 \\
14,000 \\
5,800 \\
39,000\end{array}$ & $\begin{array}{r}879,000 \\
196,000 \\
3,600 \\
35,000 \\
33,000 \\
19,000 \\
18,000 \\
12,000 \\
1,600 \\
000\end{array}$ & $\begin{array}{r}129,000 \\
192,000 \\
159,000 \\
20,000 \\
6,900 \\
1,900 \\
1,400 \\
1,500 \\
4,200 \\
38,000\end{array}$ \\
\hline
\end{tabular}

The catch with dredges, tongs, and rakes consisted of oysters, clams, mussels, and scallops, and the value of the products taken in this way represented 58 per cent of the total value reported for all fislieries, nearly three-fourths of the total value reported for the vessel fisheries, and not quite one-fourth of the total value reported for the shore and boat fisheries. In the latter class of fisheries the catch with pound nets, trap nets, and weirs led in value, the principal species taken by these apparatus being scup, squeteague, and butterfish.

Oysters. - The total oyster yield in 1908 was $1,229,000$ bushels, witl a value of $\$ 969,000$, of which $1,223,000$ bushels, valued at $\$ 967,000$, were market oysters, and 5,500 bushels, valued at $\$ 2,500$, were seed oysters. All of the market oysters were from private areas, and of the seed oysters 3,000 bushels were from public areas and 2,500 bushels from private areas. Seven hundred and twenty thousand bushels, valued at $\$ 590,000$, were reported as taken from Rhode Island oyster beds by Connecticut fishermen. Recent canvasses have shown a material increase in the market-oyster product of the state, as indicated by the following tabular statement:

\begin{tabular}{|c|c|c|}
\hline \multirow{2}{*}{ YEAR. } & \multicolumn{2}{|c|}{$\begin{array}{l}\text { MARRET-OYSTER } \\
\text { PEODUCT. }\end{array}$} \\
\hline & $\begin{array}{l}\text { Quantlty } \\
\text { (bushels). }\end{array}$ & Value. \\
\hline 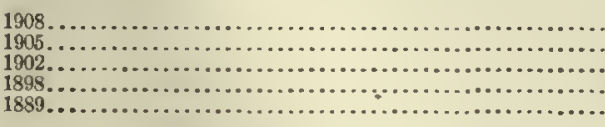 & $\begin{array}{r}1,223,000 \\
755,000 \\
516,000 \\
457,000 \\
203,000\end{array}$ & $\begin{array}{r}\$ 967,000 \\
874,000 \\
561,000 \\
505,000 \\
272,000\end{array}$ \\
\hline
\end{tabular}

Lobster.-The lobster eatch formed an important part of the shellfish products of the state. Comparative figures for a series of years, as given in the following tabular statement, show a general increase in the quantity and value of the lobster product:

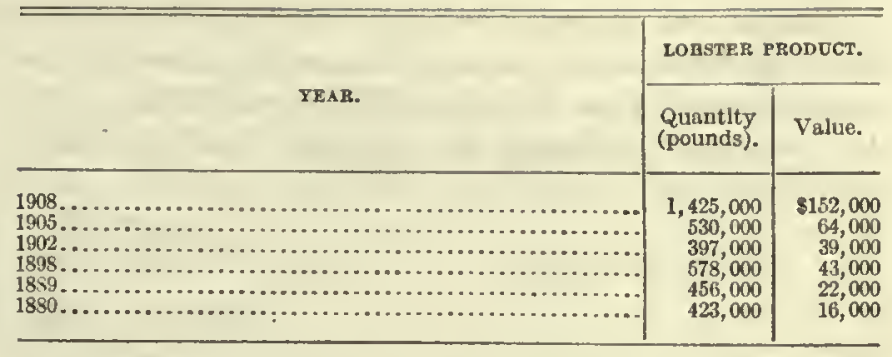

The great increase in the lobster product during recent years, and especially since 1905, is due largely to the work of the Rhode Island Commission of Inland Fisheries, which, as a result of numerous experiments, has devised a method of rearing young lobsters until they become able to care for themselves, and has thus made it possible to increase greatly the number of lobsters inhabiting the waters of the state.

Scup.-This was the leading fish in value, representing 9 per cent of the value of all fishery products and 29 per cent of the value of the catch of fish proper.

The eatch of scup for different years has been as follows:

\begin{tabular}{|c|c|c|}
\hline \multirow[b]{2}{*}{ YEAR, } & \multicolumn{2}{|c|}{ BCUP PROBUCT. } \\
\hline & $\begin{array}{l}\text { Quantity } \\
\text { (pounds). }\end{array}$ & Value. \\
\hline 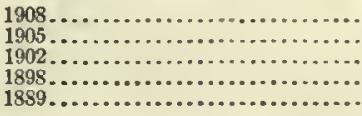 & $\begin{array}{l}4,616,000 \\
5,540,000 \\
6,833,000 \\
6,390,000 \\
6,064,000\end{array}$ & $\begin{array}{r}\$ 158,000 \\
138,000 \\
161,000 \\
76,000 \\
92,000\end{array}$ \\
\hline
\end{tabular}

The figures show a decrease in quantity together with an increase in value since 1905, and a large increase in average value since 1898.

Squeteague.-Of the fish proper, squeteague ranked second with respect to the value of the catch in 1908 . The statistics for the various canvasses since 1880 are as follows:

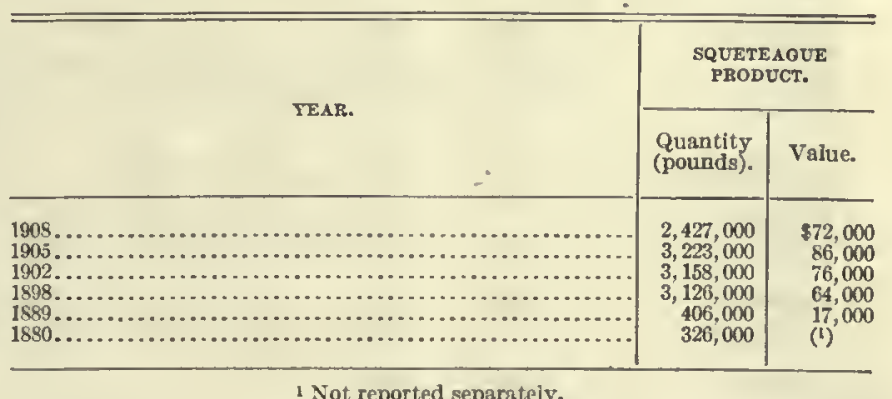

1 Not reported separately.

The largest catch in respect to both quantity and value was reported in 1905 . The decrease in the catch of this species shown in 1908 has been attributed to the fact that, just as the squeteague were beginning to run, target practice took place at Fort Greble, near the mouth of Narragansett Bay. The firing of the heavy guns is believed to have frightened tlie fish away, although it has not been positively decided that firing actually affects the run. 
Flatfish and flounders.-These are important food fishes and the total value of the catch shows an increase for each year, as indicated by the following tabular statement, although the quantity has fluctuated:

\begin{tabular}{c}
\hline \multicolumn{2}{c}{ YEAR. } \\
$\ldots$ \\
\end{tabular}

1 Not reported separately.

Menhaden--Owing to the irregular appearance of this fish in great numbers in coastal waters and the adverse weather conditions, there is great variation in the catch for different years, as the tabular statement in the next column shows.

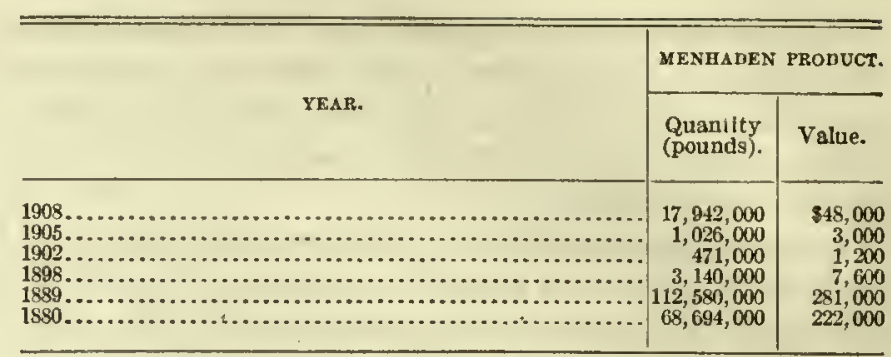

The catch in 1908 shows a heavy increase over that in 1898 and subsequent years, although it did not reach the proportions attained in 1889 and 1880 . Practically all of the catch is consumed in the oil and fertilizer industries. The average values are comparatively steady, ranging from a minimum of $\$ 4.84$ per ton of 2,000 pounds for 1898 to a maximum of $\$ 6.46$ in 1880 , the mean of the averages being $\$ 5.42$ per ton, or substantially the same as the average for 1908.

TABLE 1.-RHODE ISLAND-FISHERY PRODUCTS: 1908.

\begin{tabular}{|c|c|c|c|c|c|c|c|c|c|c|c|c|c|c|}
\hline \multirow{3}{*}{ SPECIES. } & \multirow{2}{*}{\multicolumn{2}{|c|}{ total. }} & \multicolumn{12}{|c|}{ PRODUCT CAUGHT BY- } \\
\hline & & & \multicolumn{2}{|c|}{$\begin{array}{l}\text { Pound nets, traps, } \\
\text { and weirs. }\end{array}$} & \multicolumn{2}{|c|}{ Lines. } & \multicolumn{2}{|c|}{ Selnes. } & \multicolumn{2}{|c|}{ Gill nets. } & \multicolumn{2}{|c|}{$\begin{array}{l}\text { Fyke and hoop } \\
\text { nets. }\end{array}$} & \multicolumn{2}{|c|}{$\begin{array}{l}\text { All other appa- } \\
\text { ratus. }{ }^{1}\end{array}$} \\
\hline & $\begin{array}{l}\text { Quantity } \\
\text { (pounds). }\end{array}$ & Value. & $\begin{array}{l}\text { Quantlty } \\
\text { (pounds). }\end{array}$ & Value. & $\begin{array}{l}\text { Quantity } \\
\text { (pounds). }\end{array}$ & Value. & $\begin{array}{l}\text { Quantity } \\
\text { (pounds). }\end{array}$ & Value. & $\begin{array}{l}\text { Quantity } \\
\text { (pounds). }\end{array}$ & Value, & $\begin{array}{l}\text { Quantity } \\
\text { (pounds). }\end{array}$ & Value. & $\begin{array}{l}\text { Quantity } \\
\text { (pourds). }\end{array}$ & Value. \\
\hline Total.. & $44,254,000$ & $\$ 1,752,000$ & $19,406,000$ & $\$ 388,000$ & $1,828,000$ & $\$ 55,000$ & $10,618,000$ & $\$ 10,000$ & 593,000 & 821,000 & 241,000 & $\$ 5,800$ & $11,538,000$ & $\$ 1,242,000$ \\
\hline 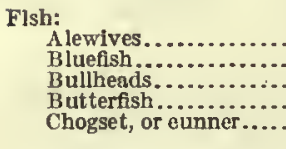 & $\begin{array}{r}288,000 \\
40,000 \\
2,000 \\
1,112,000 \\
5,000\end{array}$ & $\begin{array}{r}4,600 \\
3,700 \\
100 \\
42,000 \\
300\end{array}$ & \begin{tabular}{r}
48,000 \\
28,000 \\
\hdashline $1,101,000$ \\
$\cdots$
\end{tabular} & $\begin{array}{r}700 \\
2,500 \\
42,000 \\
\cdots\end{array}$ & $5,000^{\circ}$ & 500 & $\begin{array}{r}241,000 \\
1,100 \\
1,000 \\
7,000 \\
1,000\end{array}$ & $\begin{array}{r}3,900 \\
100 \\
(2) \\
200 \\
100\end{array}$ & 4,500 & ${ }^{7} 700$ & & 200 & & \\
\hline 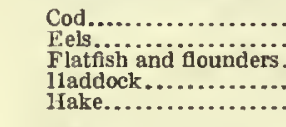 & $\begin{array}{r}1,497,000 \\
149,000 \\
1,891,000 \\
41 \pi, 000 \\
2,300\end{array}$ & $\begin{array}{r}42,000 \\
11,000 \\
50,000 \\
11,000 \\
100\end{array}$ & $\begin{array}{r}514,000 \\
36,000 \\
1,050,000 \\
61,000 \\
1,500\end{array}$ & $\begin{array}{r}14,000 \\
2,300 \\
27,000 \\
1,700 \\
100\end{array}$ & $\begin{array}{r}983,000 \\
76,000 \\
314,000 \\
500\end{array}$ & $\left|\begin{array}{c}28,000 \\
2,200 \\
7,600 \\
(2)\end{array}\right|$ & $\begin{array}{r}1,000 \\
34,000 \\
\ldots . \ldots .\end{array}$ & ${ }_{900}^{1000}$ & 40,000 & 1,800 & 235,000 & 5,600 & $\begin{array}{r}113,000 \\
496,000 \\
\ldots \ldots \ldots \ldots\end{array}$ & $\begin{array}{r}r, \ddot{8}, 00 \\
14,000 \\
\cdots \ldots . .\end{array}$ \\
\hline $\begin{array}{l}\text { Merring ............... } \\
\text { Kingfish............... } \\
\text { Mackerel............. } \\
\text { Maekerel, ehuh........ } \\
\text { Menhaden............. }\end{array}$ & $\begin{array}{r}214,000 \\
1,000 \\
537,000 \\
379,000 \\
17,942,000\end{array}$ & $\begin{array}{r}1,900 \\
100 \\
25,000 \\
9,800 \\
48,000\end{array}$ & $\begin{array}{r}201,000 \\
1,000 \\
116,000 \\
112,000 \\
7,777,000\end{array}$ & $\begin{array}{r}1,900 \\
100 \\
5,200 \\
4,100 \\
22,000\end{array}$ & $\begin{array}{r}70,000 \\
7,000\end{array}$ & $\begin{array}{r}2,700 \\
200\end{array}$ & $\begin{array}{r}10,000 \\
10,000 \\
260,000 \\
9,989,000\end{array}$ & $\begin{array}{r}(2) \\
1,100 \\
5,500 \\
25,000\end{array}$ & $\because 175,000$ & $\begin{array}{r}16,000 \\
1,000\end{array}$ & & & .................... & $\begin{array}{l}\ldots \ldots . . \\
\ldots \ldots . . . \\
\ldots \ldots . . .\end{array}$ \\
\hline 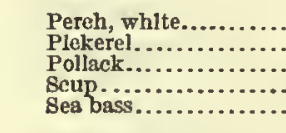 & $\begin{array}{r}15,000 \\
600 \\
26 \%, 000 \\
4,616,000 \\
197,000\end{array}$ & $\begin{array}{r}900 \\
100 \\
7,800 \\
158,000 \\
12,000\end{array}$ & $\begin{array}{r}94,000 \\
4,616,000 \\
184,000\end{array}$ & $\begin{array}{r}2,500 \\
158,000 \\
11,000\end{array}$ & $\begin{array}{c}172,000 \\
13,000\end{array}$ & $\begin{array}{r}3,400 \\
1,200\end{array}$ & 15,000 & 900 & & & 600 & 100 & & \\
\hline 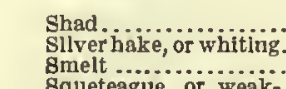 & $\begin{array}{r}4,500 \\
534,000 \\
1,200\end{array}$ & $\begin{array}{r}400 \\
3,600 \\
100\end{array}$ & $\begin{array}{r}1,200 \\
531,000 \\
1,200\end{array}$ & $\begin{array}{r}200 \\
3,600 \\
100\end{array}$ & . & & 500 & 100 & 2,800 & 200 & & & & (n........ \\
\hline 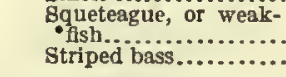 & $\begin{array}{r}2,427,000 \\
34,000\end{array}$ & $\begin{array}{r}72,000 \\
4,700\end{array}$ & $\begin{array}{r}2,326,000 \\
30,000\end{array}$ & $\begin{array}{r}69,000 \\
4,200\end{array}$ & $\begin{array}{r}14,000 \\
1,500\end{array}$ & $\begin{array}{r}500 \\
200\end{array}$ & $\begin{array}{r}62,000 \\
1,000\end{array}$ & $\begin{array}{r}1,400 \\
200\end{array}$ & $\begin{array}{r}26,000 \\
1,500\end{array}$ & $\begin{array}{l}900 \\
100\end{array}$ & & & …......... & (........... \\
\hline 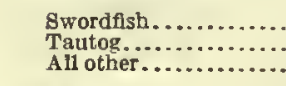 & $\begin{array}{r}308,000 \\
458,000 \\
6,200\end{array}$ & $\begin{array}{r}18,000 \\
17,000 \\
100\end{array}$ & $\begin{array}{r}272,000 \\
1,800\end{array}$ & 9,000 & $\because 71,000$ & $\dddot{0}, 900$ & 9,500 & 300 & $\dddot{2}, 500$ & 100 & & & $\begin{array}{r}308,000 \\
2,500\end{array}$ & $\begin{array}{r}18,000 \\
200\end{array}$ \\
\hline 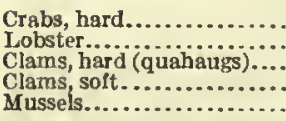 & $\begin{array}{r}146,000 \\
1,425,000 \\
162,000 \\
275,000 \\
3,500\end{array}$ & $\begin{array}{r}2,900 \\
152,000 \\
39,000 \\
38,000 \\
100\end{array}$ & & . & & & & & & & & & $\begin{array}{r}146,000 \\
1,425,000 \\
162,000 \\
275,000 \\
3,500\end{array}$ & $\begin{array}{r}2,900 \\
152,000 \\
39,000 \\
35,000 \\
100\end{array}$ \\
\hline $\begin{array}{l}\text { Oysters, market Irom pri- } \\
\text { vate areas...................... }\end{array}$ & $38,564,000$ & 967,000 & & & & & & & & & & & $38,564,000$ & 967,000 \\
\hline 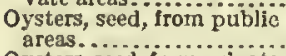 & $\{21,000$ & 1,500 & & & & & & & & & & & 421,000 & 1,500 \\
\hline 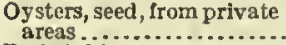 & & 1,000 & & & & & & & & & & & $B 18,000$ & 1,000 \\
\hline 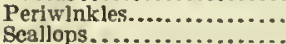 & $\begin{array}{l}81,500 \\
74,000\end{array}$ & $\begin{array}{r}200 \\
600\end{array}$ & & & & & & & & & & & $\begin{array}{l}81,500 \\
74,000\end{array}$ & $\begin{array}{l}200 \\
600\end{array}$ \\
\hline 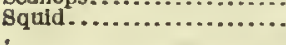 & 292,000 & 6,600 & 292,000 & $\ddot{6}, 600^{\circ}$ & & & & & & & & & & \\
\hline
\end{tabular}

1 Ineludes apparatus, with eatrh, as follows: Dredges, tonys, and rakes, $8,767,000$ pounds, valued at $\$ 1,008,000$; eel and lolster pots, 1,670,000 pounds, valued at $\$ 163,000$;

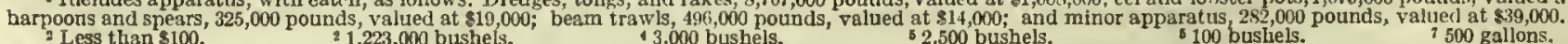


FISHERIES, BY STATES.

TABLE 2.-RHODE ISLAND-PRODUCTS OF VESSEL FISHERIES: 1908.

\begin{tabular}{|c|c|c|c|c|c|c|c|c|c|c|c|c|c|c|}
\hline \multirow{3}{*}{ SPECIE. } & \multirow{2}{*}{\multicolumn{2}{|c|}{ TAL. }} & \multicolumn{12}{|c|}{ PRODUCT CAUGHT BY- } \\
\hline & & & \multicolumn{2}{|c|}{$\begin{array}{l}\text { Pound nets, trap } \\
\text { nets, and weirs. }\end{array}$} & \multicolumn{2}{|c|}{ Lines. } & \multicolumn{2}{|c|}{ Selnes. } & \multicolumn{2}{|c|}{ Gill nets. } & \multicolumn{2}{|c|}{$\begin{array}{l}\text { Fyke and boop } \\
\text { nets. }\end{array}$} & \multicolumn{2}{|c|}{$\begin{array}{l}\text { All other appa- } \\
\text { ratus.? }\end{array}$} \\
\hline & $\begin{array}{l}\text { Quantity } \\
\text { (pounds). }\end{array}$ & Value. & $\begin{array}{l}\text { Quantity } \\
\text { (pounds). }\end{array}$ & Value. & $\begin{array}{l}\text { Quantlty } \\
\text { (pounds). }\end{array}$ & Value. & $\begin{array}{l}\text { Quantity } \\
\text { (pounds). }\end{array}$ & Value. & $\begin{array}{l}\text { Quantlty } \\
\text { (pounds). }\end{array}$ & Value. & $\begin{array}{l}\text { Quantity } \\
\text { (pounds). }\end{array}$ & Value. & $\begin{array}{l}\text { Quantity } \\
\text { (pounds). }\end{array}$ & Value. \\
\hline Total...... & $33,903,000$ & $81,198,000$ & $13,111,000$ & $\$ 196,000$ & $1,227,000$ & 835,000 & $10,328,000$ & $\$ 33,000$ & 557,000 & $\$ 19,000$ & 63,000 & $\$ 1,600$ & $8,615,000$ & $\$ 914,000$ \\
\hline 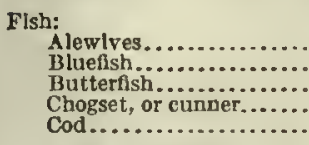 & $\begin{array}{r}32,000 \\
18,000 \\
361,000 \\
3,000 \\
812,000\end{array}$ & $\begin{array}{r}500 \\
1,800 \\
13,000 \\
100 \\
23,000\end{array}$ & $\begin{array}{r}32,000 \\
15,000 \\
357,000 \\
\ldots 9.0 \\
95,000\end{array}$ & $\begin{array}{r}500 \\
1,400 \\
13,000 \\
\cdots 3,000 \\
3,000\end{array}$ & 718,000 & $\mid \begin{array}{r}300 \\
\ldots \ldots \ldots \\
\cdots 20,000\end{array}$ & $\begin{array}{c}\cdots \\
600 \\
\cdots \cdots \cdots \\
\cdots \cdots\end{array}$ & $\begin{array}{r}100 \\
\ldots \ldots \ldots \\
\cdots \ldots \ldots\end{array}$ & $\begin{array}{c}4,000 \\
\ldots \ldots \ldots \\
\ldots \ldots\end{array}$ & $\begin{array}{r}100 \\
\cdots \\
\cdots\end{array}$ & $\because 3,000$ & $\dddot{100}$ & & $\begin{array}{l}\ldots \ldots \ldots \\
\cdots \ldots \ldots \\
\cdots \ldots \ldots \ldots \\
\cdots \ldots \ldots \\
\cdots \ldots \ldots\end{array}$ \\
\hline 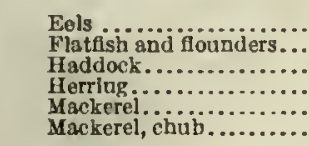 & $\begin{array}{r}14,000 \\
1,179,000 \\
322,000 \\
46,000 \\
438,000 \\
255,000\end{array}$ & $\begin{array}{r}1,300 \\
30,000 \\
8,500 \\
600 \\
21,000 \\
5,400\end{array}$ & $\begin{array}{r}616,000 \\
46,000 \\
51,000\end{array}$ & $\begin{array}{r}15,000 \\
600 \\
2,400 \\
\ldots \ldots\end{array}$ & $\begin{array}{r}50,000 \\
282,000 \\
36,000\end{array}$ & $\begin{array}{r}1,400 \\
6,700 \\
1,400 \\
\ldots \ldots \ldots\end{array}$ & $\begin{array}{r}20,000 \\
16,000 \\
255,000\end{array}$ & $\begin{array}{r} \\
400 \\
\cdots \cdots \\
\cdots \\
\cdots \\
1,100 \\
5,400\end{array}$ & $\begin{array}{r}40,000 \\
334,000 \\
\hdashline\end{array}$ & $\begin{array}{r}1,800 \\
16,000 \\
\cdots\end{array}$ & $\begin{array}{c}60,000 \\
\ldots \ldots . . . \\
\ldots . . . . \\
\ldots . . .\end{array}$ & $\begin{array}{c}\cdots, \ldots, 0 \\
1,500 \\
\cdots \cdots \\
\cdots \cdots \\
\cdots \cdots\end{array}$ & 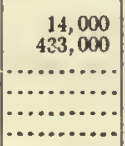 & $\begin{array}{r}1,300 \\
12,000 \\
\cdots \ldots \ldots \\
\cdots \cdots \cdots \\
\cdots \cdots\end{array}$ \\
\hline 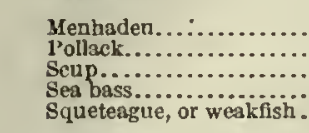 & $\begin{array}{r}17,753,000 \\
134,000 \\
2,908,000 \\
96,000 \\
1,078,000\end{array}$ & $\begin{array}{r}47,000 \\
4,100 \\
98,000 \\
5,900 \\
31,000\end{array}$ & $\begin{array}{r}7,589,000 \\
29,000 \\
2,908,000 \\
89,000 \\
1,023,000\end{array}$ & $\begin{array}{r}21,000 \\
1,000 \\
98,000 \\
5,200 \\
30,000\end{array}$ & $\begin{array}{r}104,000 \\
7,300 \\
4,600\end{array}$ & $\begin{array}{r}3,100 \\
700 \\
200\end{array}$ & 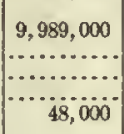 & $\begin{array}{c}25,000 \\
\ldots \ldots \\
\cdots \ldots \ldots \\
\cdots, 000\end{array}$ & $\begin{array}{r}175,000 \\
\cdots \cdots \cdots \\
\cdots \cdots \cdots \\
3,000 \\
\cdots\end{array}$ & $\begin{array}{r}1,000 \\
\cdots \ldots \ldots \\
\cdots \\
100\end{array}$ & & & $\begin{array}{l}\cdots \ldots \\
\cdots \cdots \cdots \\
\cdots \cdots \cdots \\
\cdots \cdots \cdots \\
\cdots \cdots\end{array}$ & $\begin{array}{l}\ldots \ldots \\
\ldots \ldots \\
\ldots \ldots \ldots \\
\ldots \ldots \ldots\end{array}$ \\
\hline 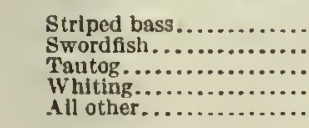 & $\begin{array}{r}1,400 \\
305,000 \\
123,000 \\
105,000 \\
1,500\end{array}$ & $\begin{array}{r}200 \\
18,000 \\
3,900 \\
700 \\
100\end{array}$ & $\begin{array}{r}1,400 \\
102,000 \\
105,000 \\
\cdots\end{array}$ & $\begin{array}{r}200 \\
3,200 \\
700 \\
\cdots\end{array}$ & $\mid \begin{array}{ll}21,000 \\
500\end{array}$ & 80 & $\mid \begin{array}{ll}n \\
\cdots \cdots \cdots \\
\cdots \cdots \cdots\end{array}$ & $\begin{array}{l}\cdots \\
\cdots \cdots \\
\cdots \cdots\end{array}$ & i, 000 & ioj & (n.... & & $\mid \begin{array}{r}\cdots \\
305,000 \\
\cdots \cdots \\
\cdots \cdots \\
\cdots\end{array}$ & $\begin{array}{r}18,000 \\
\cdots \\
\cdots\end{array}$ \\
\hline 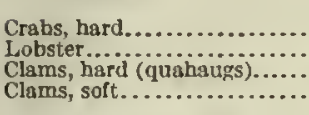 & $\begin{array}{r}4,000 \\
18,000 \\
1,300 \\
4,800\end{array}$ & $\begin{array}{r}100 \\
2,200 \\
300 \\
600\end{array}$ & & & & & & & $\begin{array}{l}\cdots \cdots \\
\cdots \cdots \\
\cdots \cdots\end{array}$ & & & & $\begin{array}{r}4,000 \\
18,000 \\
31,300 \\
14,800\end{array}$ & $\begin{array}{r}100 \\
2,200 \\
300 \\
600\end{array}$ \\
\hline 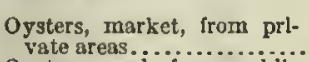 & s $7,814,000$ & 878,000 & & & & & & & & & & & $s 7,814,000$ & 878,000 \\
\hline $\begin{array}{l}\text { Oysters, seed, from public } \\
\text { areas......................... }\end{array}$ & . 2,800 & 200 & & & & & & & & & & & - 2,800 & 200 \\
\hline 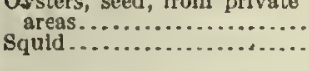 & $\begin{array}{r}718,000 \\
53,000\end{array}$ & $\begin{array}{r}1,000 \\
900\end{array}$ & $\ddot{53,0000}$ & 9000 & & & & & & & & & $\begin{array}{r}r 18,000 \\
\cdots \cdots\end{array}$ & $\begin{array}{r}1,000 \\
\cdots \ldots\end{array}$ \\
\hline
\end{tabular}

1 Includes apparatus, with eatch, as follows: Dredges, tongs, and rakes, $7,835,000$ pounds, valued at $\$ 879,000$; harpoons and spears, 305,000 pounds, valued at $\$ 18,000$; beam trawls, 433,000 pounds, valued at $\$ 12,000$; eel and lobster pots, 37,000 pounds, valued at $\$ 3,600$; and minor apparatus, 6,100 pounds, valued at $\$ 900$.

2 Less than $\$ 100$. 200 bushels.

000 bushels.

$\checkmark 1,116,000$ bushels.

6400 bushel.

72,500 bushels 
TABLE 3.-RHODE ISI,AND-PRODUCTS OF SHORE AND BOAT FISHERIES: 1908.

\begin{tabular}{|c|c|c|c|c|c|c|c|c|c|c|c|c|c|c|}
\hline \multirow{3}{*}{ SPECIES. } & \multirow{2}{*}{\multicolumn{2}{|c|}{ TOTAL. }} & \multicolumn{12}{|c|}{ PRODUCT CAUGHT BY- } \\
\hline & & & \multicolumn{2}{|c|}{$\begin{array}{l}\text { Pound nets, trap } \\
\text { nets, and weirs. }\end{array}$} & \multicolumn{2}{|c|}{ Ilnes. } & \multicolumn{2}{|c|}{ Seines. } & \multicolumn{2}{|c|}{$\begin{array}{c}\text { Fyke and hoop } \\
\text { nets. }\end{array}$} & \multicolumn{2}{|c|}{ Gill nets. } & \multicolumn{2}{|c|}{$\begin{array}{l}\text { All other appa- } \\
\text { ratus. }{ }^{2}\end{array}$} \\
\hline & $\begin{array}{l}\text { Quantity } \\
\text { (pounds). }\end{array}$ & Valıe. & $\begin{array}{l}\text { Quantity } \\
\text { (pounds). }\end{array}$ & Value. & $\begin{array}{r}\text { Quantity } \\
\text { (pounds). }\end{array}$ & Value. & $\begin{array}{l}\text { Quantity } \\
\text { (pounds). }\end{array}$ & Value. & $\begin{array}{l}\text { Quantity } \\
\text { (pounds). }\end{array}$ & Value. & $\begin{array}{l}\text { Quantity } \\
\text { (pounds). }\end{array}$ & Value. & $\begin{array}{l}\text { Quantity } \\
\text { (pounds). }\end{array}$ & Value. \\
\hline Total...... & $10,351,000$ & $\$ 554,000$ & $6,295,000$ & $\$ 192,000$ & 601,000 & $\$ 20,000$ & 320,000 & 86,900 & 178,000 & $\$ 1,200$ & 35,000 & $\$ 1,900$ & $2,922,000$ & $\$ 329,000$ \\
\hline 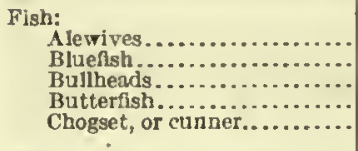 & $\begin{array}{r}250,000 \\
22,000 \\
2,000 \\
751,000 \\
2,000\end{array}$ & $\begin{array}{r}4,100 \\
1,900 \\
100 \\
29,000 \\
200\end{array}$ & $\begin{array}{r}15,000 \\
13,000 \\
744,000 \\
78, \cdots\end{array}$ & $\begin{array}{r}200 \\
1,100 \\
29,000 \\
\cdots\end{array}$ & $\mid \begin{array}{c}1,8 n_{0} \\
\cdots \cdots \\
\cdots \cdots \\
\cdots \cdots\end{array}$ & $\begin{array}{r}200 \\
\cdots \cdots \\
\cdots \cdots\end{array}$ & $\begin{array}{r}241,000 \\
500 \\
1,000 \\
7,000 \\
1,000\end{array}$ & $\begin{array}{l}3,900 \\
(2) \\
(3) \\
200 \\
100\end{array}$ & \begin{tabular}{l}
1,000 \\
\hdashline, 000
\end{tabular} & 100 & $\begin{array}{l}\cdots, 300 \\
\cdots \cdots \\
\cdots \cdots \\
\cdots \cdots\end{array}$ & 700 & ( & a \\
\hline 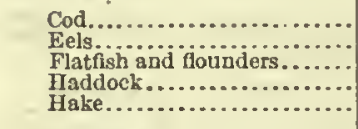 & $\begin{array}{r}684,000 \\
135,000 \\
712,000 \\
93,000 \\
1,800\end{array}$ & $\begin{array}{r}19,000 \\
9,200 \\
19,000 \\
2,500 \\
100\end{array}$ & $\begin{array}{r}419,000 \\
36,000 \\
434,000 \\
61,000 \\
1,800\end{array}$ & $\begin{array}{r}11,000 \\
2,300 \\
12,000 \\
1,700 \\
100\end{array}$ & $\begin{array}{r}205,000 \\
26,000 \\
32,000 \\
\cdots\end{array}$ & $\begin{array}{r}7,400 \\
900 \\
800\end{array}$ & $\mid \begin{array}{r}1,000 \\
14,000 \\
\cdots\end{array}$ & $\begin{array}{l}100 \\
400\end{array}$ & 175,000 & $\begin{array}{l}\dddot{4}, \ldots 00 \\
\cdots \cdots\end{array}$ & & & $\begin{array}{l}98,0000 \\
63,000\end{array}$ & $\begin{array}{l}6,800 \\
1,500 \\
\ldots \ldots\end{array}$ \\
\hline 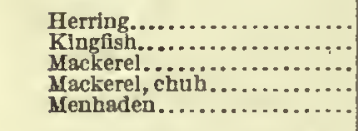 & $\begin{array}{r}169,000 \\
1,000 \\
99,000 \\
124,000 \\
189,000\end{array}$ & $\begin{array}{r}1,300 \\
100 \\
4,200 \\
4,500 \\
900\end{array}$ & $\begin{array}{r}159,000 \\
1,000 \\
65,000 \\
112,000 \\
188,000\end{array}$ & $\begin{array}{r}1,300 \\
100 \\
2,800 \\
1,100 \\
900\end{array}$ & $\mid \begin{array}{r}33,000 \\
7,000 \\
\cdots\end{array}$ & $\begin{array}{r}1,400 \\
200\end{array}$ & $\begin{array}{r}10,000 \\
\cdots, \ldots \ldots \\
5,000 \\
\cdots\end{array}$ & $\begin{array}{c}(2) \\
\cdots \cdots \\
\cdots \cdots \\
200\end{array}$ & & & \begin{tabular}{l}
$\cdots \cdots$ \\
$\cdots \cdots$ \\
\hdashline$\cdots \cdots$ \\
400
\end{tabular} & (2) & & $\begin{array}{l}\cdots \\
\cdots \\
\cdots\end{array}$ \\
\hline 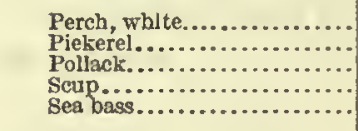 & $\begin{array}{r}15,000 \\
600 \\
132,000 \\
1,708,000 \\
100,000\end{array}$ & $\begin{array}{r}900 \\
100 \\
3,800 \\
60,000 \\
5,900\end{array}$ & $\begin{array}{r}65,000 \\
1,708,000 \\
95,000\end{array}$ & $\begin{array}{r}1,500 \\
60,000 \\
5,300\end{array}$ & $\begin{array}{r}68,000 \\
5,600\end{array}$ & $\mid \begin{array}{c}\cdots \ldots \\
2,300 \\
3, \ldots 00\end{array}$ & 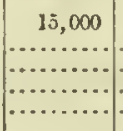 & 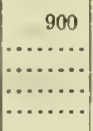 & $\begin{array}{c}c 00 \\
\cdots \cdots \\
\cdots \cdots\end{array}$ & $\begin{array}{l}100 \\
\cdots \cdots \\
\cdots \cdots\end{array}$ & & & & (n) \\
\hline $\begin{array}{l}\text { Shad .................... } \\
\text { Silver hake, or whiting..... } \\
\text { Smelt ..................... } \\
\text { Squeteague, or weakfish.... }\end{array}$ & $\begin{array}{r}3,500 \\
430,000 \\
1,200 \\
1,349,000\end{array}$ & $\begin{array}{r}400 \\
3,000 \\
100 \\
41,000\end{array}$ & $\begin{array}{r}1,200 \\
430,000 \\
1,200 \\
1,303,000\end{array}$ & $\begin{array}{r}200 \\
3,000 \\
100 \\
39,000\end{array}$ & 9,200 & 300 & $\begin{array}{c}500 \\
\cdots \ldots \ldots \\
14,000\end{array}$ & $\begin{array}{l}100 \\
\cdots \cdots \\
100\end{array}$ & & & $\begin{array}{r}1,800 \\
\cdots \cdots \\
\cdots \\
\cdots\end{array}$ & $\begin{array}{l}200 \\
800\end{array}$ & & $\because$ \\
\hline 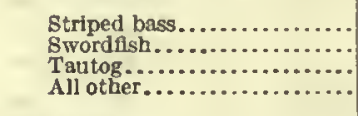 & $\begin{array}{r}32,000 \\
2,800 \\
335,000 \\
6,200\end{array}$ & $\begin{array}{r}4,600 \\
200 \\
13,000 \\
100\end{array}$ & $\begin{array}{r}28,000 \\
170,000 \\
4,800\end{array}$ & $\begin{array}{l}4,000 \\
3,800 \\
3(3)\end{array}$ & $\begin{array}{r}1,500 \\
150,000 \\
1,800\end{array}$ & $\begin{array}{c}6,200 \\
(2)\end{array}$ & $\begin{array}{r}1,000 \\
9,500 \\
9, \ldots\end{array}$ & 200 & & & $\begin{array}{r}1,500 \\
2,500\end{array}$ & 100 & $\mid \begin{array}{r}2,800 \\
2,500 \\
\ldots \ldots \ldots \ldots\end{array}$ & 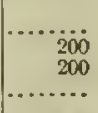 \\
\hline 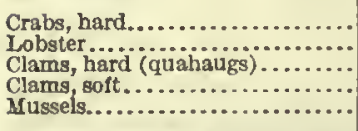 & $\begin{array}{r}142,000 \\
1,406,000 \\
3161,000 \\
271,000 \\
83,500\end{array}$ & $\begin{array}{r}2,800 \\
150,000 \\
39,000 \\
37,000 \\
100\end{array}$ & (n...... & … & & & 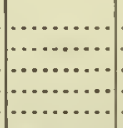 & .... & & & 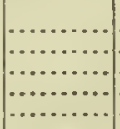 & $\mid \begin{array}{l}\ldots \ldots \ldots \\
\ldots \ldots \ldots \\
\cdots \ldots \ldots \\
\cdots \ldots \ldots \\
\cdots \ldots \ldots\end{array}$ & $\begin{array}{r}142,000 \\
1,406,000 \\
\mathrm{~d} 161,000 \\
1271,000 \\
63,500\end{array}$ & $\begin{array}{r}2,800 \\
150,000 \\
39,000 \\
37,000 \\
100\end{array}$ \\
\hline 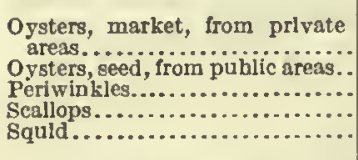 & $\begin{array}{r}749,000 \\
718,000 \\
61,500 \\
84,000 \\
240,000\end{array}$ & $\begin{array}{r}89,000 \\
1,300 \\
200 \\
600 \\
5,700\end{array}$ & ${ }_{240,000}$ & $\cdots, \ldots \ldots$ & $\cdots$ & & 1 & ...... & .. & & $\ldots$ & $\begin{array}{c}\ldots \ldots \ldots \\
\ldots \ldots \ldots \\
\ldots \ldots \ldots \\
\ldots \ldots \ldots\end{array}$ & $\begin{array}{r}749,000 \\
78,000 \\
8,500 \\
4,000 \\
\ldots . \ldots \ldots\end{array}$ & $\begin{array}{r}89,000 \\
1,300 \\
200 \\
600 \\
\ldots . . .\end{array}$ \\
\hline
\end{tabular}

1 Includes apparatus, wlth catch, as follows: Fel and lobster pots, 1,633,000 pounds, valued at $\$ 159,000$; dredges, tongs, and rakes, 932,000 pounds, valued at $\$ 129,000$; beam trawls, 63,000 pounds, valued at $\$ 1,500$; harpoons and spears, 20,000 pounds, valued at $\$ 1,400$; and mlnor apparatus, 274,000 pounds, valued at $\$ 38,000$.

Less than $\$ 100$.
(20,000 bushels. 


\section{SOUTII CAROLINA.}

The value of the fishery products of South Carolina in 1908 was less than the value reported for any other South Atlantic state. Oysters contributed nearly half of the total value, while shad was the most valuable species of fish proper. A canning industry of considerable extent located at Charleston disposed of a large part of the oyster produet, and of small quantities of mullet, shrimp, and clams.

The following statement presents a summary of the statistics of the fishing industry for 1908:

Number of persons employed ............... 2,559 Capital:

Vessels and boats, including outfit ............ \$92,000

Apparatus of capture ................... 16,000

Shore and accessory property and cash ......... 5,400

Value of products........................ 288,000

Comparison with previous canvasses.-From the tabular statement given below, which presents comparative statisties for the years for which canvasses of the South Carolina fisheries have been made, it will be seen that the canvass of 1887 showed a decrease in both quantity and value of products, as compared with the preceding canvass, but that each subsequent canvass has shown an increase in these items. Increases in the number of persons employed and in the capital invested in equipment, which took place between 1880 and 1890, were followed by decreases in 1897, but increases were reported in 1902 and 1908, although the number of persons employed in 1908 was less than the number employed in 1890 .

\begin{tabular}{|c|c|c|c|c|c|c|}
\hline \multirow[b]{2}{*}{ YEAR. } & \multirow{2}{*}{$\begin{array}{l}\text { Persons } \\
\text { em- } \\
\text { ployed, } \\
\text { exclu- } \\
\text { sive of } \\
\text { shores- } \\
\text { men. }\end{array}$} & \multicolumn{3}{|c|}{ VALUE OF EQUIPYENT. } & \multicolumn{2}{|c|}{ PRODUCTS. } \\
\hline & & Total. & $\begin{array}{c}\text { Vessels } \\
\text { and } \\
\text { hoats, in- } \\
\text { cluding } \\
\text { outfit. }\end{array}$ & $\begin{array}{l}\text { Appa- } \\
\text { ratus of } \\
\text { capture. }\end{array}$ & $\begin{array}{l}\text { Quantity } \\
\text { (pounds). }\end{array}$ & Value. \\
\hline $\begin{array}{l}1908 \ldots \ldots \ldots \ldots \ldots \\
1902 \ldots \ldots \ldots \ldots \ldots \\
1897 \ldots \ldots \ldots \ldots \\
1890 \ldots \ldots \ldots \ldots \\
18871 \ldots \ldots \ldots \ldots \ldots \\
1880 \ldots \ldots \ldots \ldots\end{array}$ & $\begin{array}{l}2,530 \\
2,178 \\
1,934 \\
2,577 \\
1,255 \\
964\end{array}$ & $\begin{array}{r}8109,000 \\
82,000 \\
80,000 \\
83,000 \\
59,000 \\
51,000\end{array}$ & $\begin{array}{c}\$ 92,000 \\
62,000 \\
50,000 \\
61,000 \\
46,000 \\
(2)\end{array}$ & $\begin{array}{r}\$ 16,000 \\
19,000 \\
31,000 \\
22,000 \\
13,000 \\
(2)\end{array}$ & $\begin{array}{r}14,104,000 \\
8,174,000 \\
5,280,000 \\
4,945,000 \\
4,076,000 \\
6,143,000\end{array}$ & $\begin{array}{r}\$ 288,000 \\
263,000 \\
210,000 \\
203,000 \\
158,000 \\
213,000\end{array}$ \\
\hline
\end{tabular}

1 Does uot Include fisheries above tidewater. 2 Not reported separately.

Persons employed.-The following tabular statement gives statistics as to the persons employed in 1908:

\begin{tabular}{|c|c|c|c|c|}
\hline \multirow{3}{*}{ cruss. } & \multicolumn{4}{|c|}{ PERSONS EMPLOYED: 1908.} \\
\hline & \multicolumn{3}{|c|}{ Number. } & \multirow[b]{2}{*}{ Wages. } \\
\hline & Total. & $\begin{array}{l}\text { Proprie- } \\
\text { tors and } \\
\text { inde- } \\
\text { pendent } \\
\text { flsher- } \\
\text { men. }\end{array}$ & $\begin{array}{l}\text { Wage- } \\
\text { earners. }\end{array}$ & \\
\hline Total............. & 2,559 & 11,634 & 925 & 2885,000 \\
\hline $\begin{array}{l}\text { Vessel fisheries............ } \\
\text { Transportlng vessels...... } \\
\text { Shore and boat fisherics... } \\
\text { Shoresmen..................... }\end{array}$ & $\begin{array}{r}326 \\
16 \\
2,188 \\
29\end{array}$ & $\begin{array}{r}46 \\
2 \\
1,586 \\
\cdots . . .\end{array}$ & $\begin{array}{r}280 \\
14 \\
602 \\
29\end{array}$ & $\begin{array}{r}38,000 \\
2,100 \\
42,000 \\
2,600\end{array}$ \\
\hline
\end{tabular}

1 Exclusive of 47 proprietors not fishing.

2 Includes provisions furnisbed to the vaiue of $\$ 25$.
All of the shoresmen were einployed in shore and boat fisheries. The independent fishermen in the shore and boat fisheries largely outnumbered those employing wage-earners. The low average amount of wages paid indicates that a large number of the wage-earners were employed for only a part of the time.

Equipment and other capital.-The following tabular statement gives the value of the equipment and the amount of other capital employed, the number and tonnage of vessels, and the number of boats employed in the fisheries of the state:

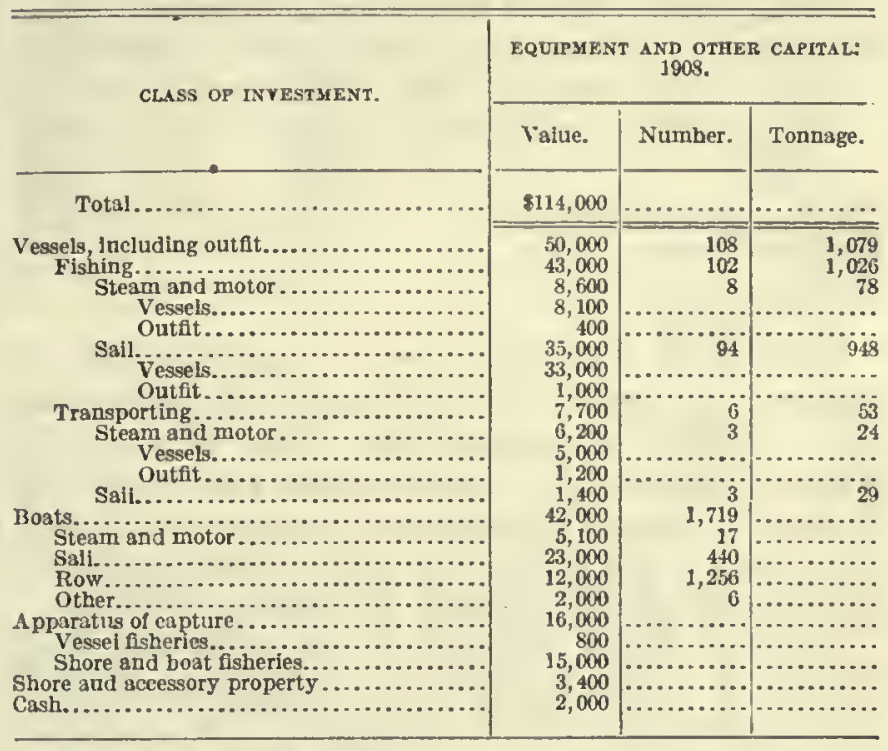

All the cash capital and shore and accessory property pertained to shore and boat fisheries. The total investment was therefore distributed as follows: In shore and boat fisheries, $\$ 63,000$; in vessel fisheries, $\$ 44,000$; and in transporting vessels, $\$ 7,700$.

The investment in fishing ressels and their outfits and that in boats were substantially the same. Together they represented nearly three-fourths of the total capital. Of the investment in apparatus of capture, only a small portion pertained to the vessel fisheries. The numbers of the more important kinds of apparatus reported, all of which with the exception of one seine were employed in the shore and boat fisheries, were as follows:

Bow nets. . . . .............................. 12

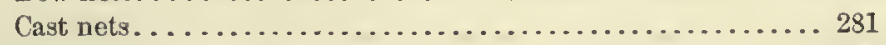

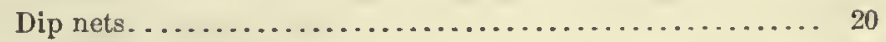

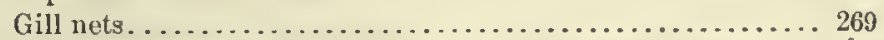

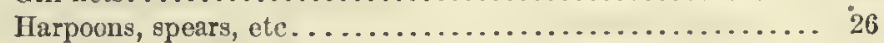

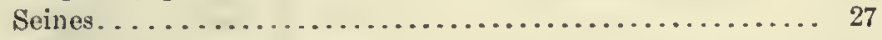

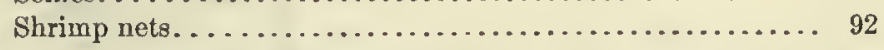

Products, by species.-Table 1, on page 240, gives the fishery products of the state, by species and by apparatus of capture. Though a large number of species are represented, oysters contributed 78 per cent of the total weight and 48 per cent of the total value. The value of the catch of fish proper constituted 43 per cent of the total value of products. Shad was 
the leading species of fish proper, and represented one-third of the value of fish reported and 14 per cent of the value of all products.

Products, by class of fisheries.-The following tabular statement shows the distribution of the value of products, according to species, for the state and for each class of fisheries:

\begin{tabular}{|c|c|c|c|}
\hline \multirow[b]{2}{*}{ SPECIES. } & \multicolumn{3}{|c|}{ VALUE OP PRODUCTS: 1908.} \\
\hline & Total. & $\begin{array}{l}\text { Vessel } \\
\text { fisheries. }\end{array}$ & $\begin{array}{l}\text { Shore } \\
\text { and boat } \\
\text { fisheries. }\end{array}$ \\
\hline Total... & $\$ 288,000$ & $\$(18,000$ & $\$ 220,000$ \\
\hline Fish .... & 123,000 & 22,000 & 101,000 \\
\hline Shad.. & 41,000 & 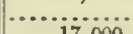 & 41,000 \\
\hline Sea bass. & 22,000 & $\begin{array}{r}17,000 \\
2,000\end{array}$ & $\begin{array}{r}4,400 \\
17,000\end{array}$ \\
\hline $\begin{array}{l}\text { Mullet ........ } \\
\text { Whitting...... }\end{array}$ & 17,000 & ${ }_{200}^{2,00}$ & $\begin{array}{l}17,000 \\
17,000\end{array}$ \\
\hline $\begin{array}{l}\text { Whiting....... } \\
\text { Squeteague.. }\end{array}$ & 8,700 & - 400 & 8,300 \\
\hline All other..... & 15,000 & 1,800 & 13,000 \\
\hline 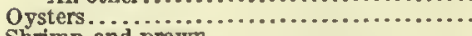 & 137,000 & & 90,000 \\
\hline pand prawn.................. & 19,000 & & 19,000 \\
\hline . & $\begin{array}{l}6,300 \\
3,400\end{array}$ & …....... & 6,300 \\
\hline & & & \\
\hline
\end{tabular}

Statistics of the products of the vessel fisheries of the state, by species and by apparatus of capture, are given in Table 2, on page 240 . The value of the products reported for these fisheries formed 24 per cent of the value of all products. Oysters contributed 68 per cent of the value of the vessel fishery products, and the bulk of the fish catch consisted of sea bass.

Statistics of the products of the shore and boat fisheries of the state, by species and apparatus of capture, are given in Table 3 , on page 241 . This class of fisheries eontributed 76 per cent of the value of all fishery products, but not quite so large a percentage of the total quantity. The value of oysters represented 41 per cent of the value of the shore and boat product, and that of fish proper 46 per cent. All crustaceans and mollusks, other than oysters, were taken in the shore and boat fisheries. Shad was the leading species of fish, and its value formed considerably over one-third of the value of the catch of fish proper. The mullet product and the whiting product were practically equal in value.

Products, by apparatus of capture.-The following tabular statement shows the distribution of the value of products, according to apparatus of capture used, for the state and for each elass of fisheries:

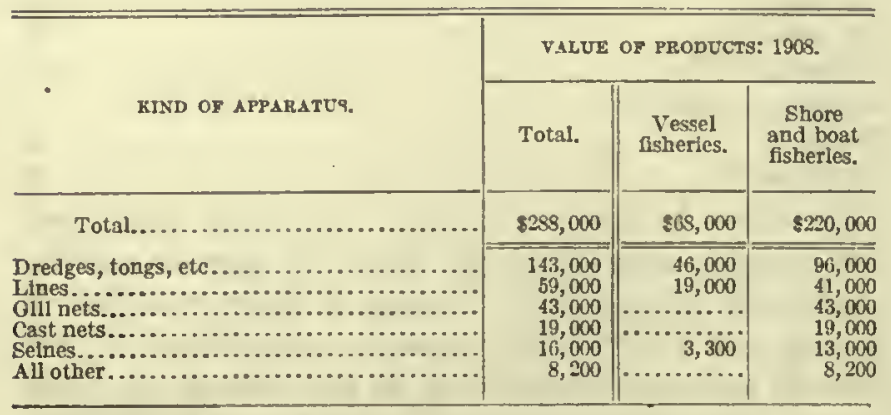

Dredges, tongs, etc., were used in securing the oyster product and most of the unimportant clam product. To this form of apparatus 78 per eent of the total quantity and 50 per cent of the total value of produets are credited.

The value of the products taken by lines formed 20 per cent of the total value of fishery products in the state. Sea bass and whiting, the most important species cauglit by lines, together contributed 65 per cent of the total value of the lins catcli. Over trothirds of the value of the line cateh was reported from the shore and boat fisheries. In this class of fisheries lines took products valued at 19 per cent of the total value; and in vassel fisheries, where the line catch consisted mostly of sea bass, they took products ralued at 28 per cent of the total value.

Gill nets ranked third in value of cateh, contributing 15 per cent of the value of the total fishery product. They were used only in the shore and boat fisherics; the value of the products taken by these nets was slightly greater than the value of the catch by lines in this class of fisheries, the proportions which the values of the two catches represented of the total value of the shore and boat product being 20 per cent and 19 per cent, respeetively. Shad contributed 92 per cent of the value of the gill-net catch.

The catch by cast nets supplied 7 per cent of the value of the state product. Their use was confined to the shore and boat fisheries, the catch with this class of apparatus, which consisted of shrimp, prawn, and mullet, contributing 9 per cent of the total value of products reported for these fisheries.

The value of the product taken by means of seines represented 6 per cent of the value of the state product. Eighty-five per cent of the seine catch in quantity consisted of mullet, and was taken chiefly in the shore and boat fisheries.

Oysters.-All of the oysters reported were market oysters, and the bulk of the product was from public areas, the quantity taken from private areas forming slightly less than 6 per cent of the total. The greater part of the oyster product was used by the canneries. Prices were low in 1908, the average being less than 9 cents per bushel, while some fishermen received as little as 4 cents.

The increase in the yield of oysters has been steady and rapid since 1887, and is largely accountable for the increase shown by the total fishery product of the state since that year.

Though ranking among the leading fishery products of the state in 1880 , oysters did not outrank all other kinds of products until 1897, and the canvass of 1902 was the first in which the quantity of the yield of oysters exceeded that of all other species combined. The quantity of the product in 1908 was more than two and one-fourth times that in 1902. 


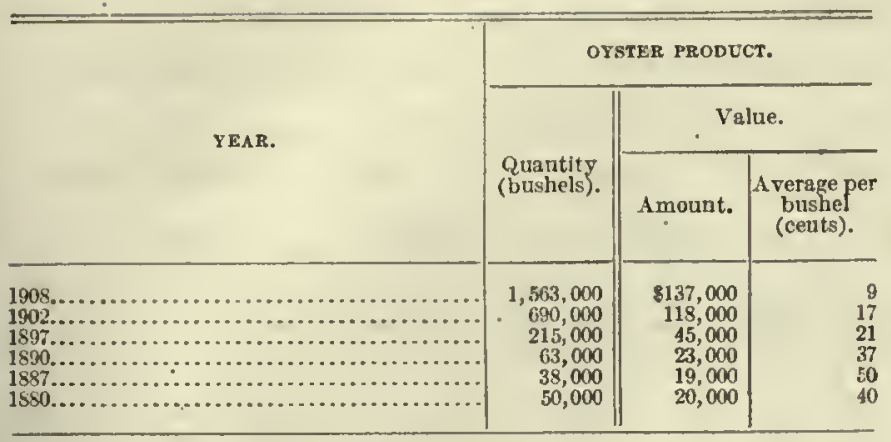

Shad.-Shad ranked second in importance, contributing 14 per cent of the value of the total yield and a third of that of the eatch of fish proper. The entire product was taken in the shore and boat fisheries, and its value composed 19 per cent of the value of the total catch of such fisheries. These fish were caught almost entirely with gill nets. The fluctuations in the quantity and value of the catch for a number of years are shown in the following tabular statement:

\begin{tabular}{|c|c|c|}
\hline \multirow{2}{*}{ YEAR. } & \multicolumn{2}{|c|}{ STLAD PRODUCr. } \\
\hline & $\begin{array}{l}\text { Quantity. } \\
\text { (pounds). }\end{array}$ & Value. \\
\hline 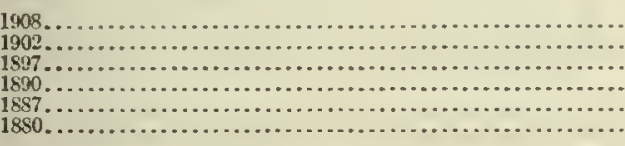 & $\begin{array}{l}464,000 \\
43,000 \\
506,000 \\
563,000 \\
366,000 \\
208,000\end{array}$ & $\begin{array}{r}\$ 11,000 \\
21,000 \\
28,000 \\
41,000 \\
23,000 \\
12,000\end{array}$ \\
\hline
\end{tabular}

Sea bass.-The catch of sea bass was somewhat larger in quantity than that of shad, but its value was only a little over half as great. Though second in importance among the fish proper, sea bass furnished but 8 per cent of the value of all products of the South Carolina fisheries. The value of the sea bass taken in the vessel fisheries, however, constituted 25 per cent of the total value of products and 77 per cent of the value of the fish proper reported for such fisheries. The bulk of the product was taken in the vessel fisheries with lines. The following tabular statement gives statistics of the sea-bass product for those years for which figures are available:

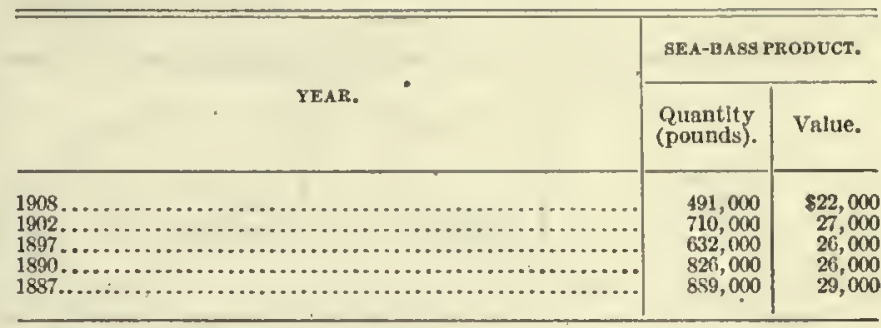

Mullet.-Mullet represented 7 per cent of the value of the total fishery product of the state. Nearly 90 per cent of the value of the catch was reported for the shore and boat fisheries, and over two-thirds of the value represented product taken with seines. Of the total product, nearly a sixth was salted. The product for 1908 shows a large increase over that of former years, as is indicated by the following tabular statement:

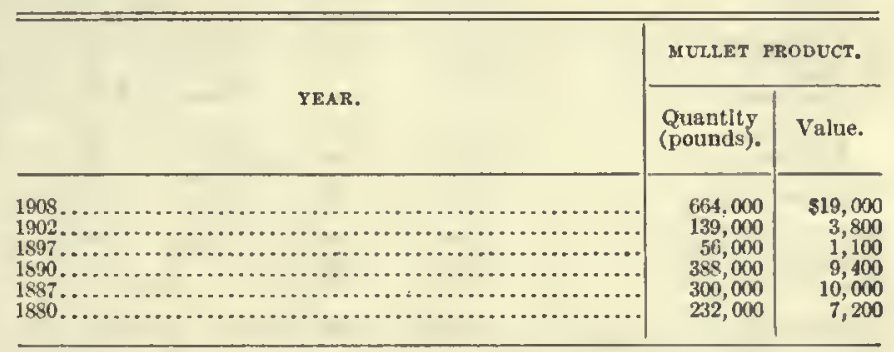

Whiting.-The catch of this species had a value equal to 6 per cent of the value of the total state product. Though in quantity the catch of whiting was less than half as great as that of mullet, in value it ranked little below the latter, as a result of the higher price paid for whiting on the market. This fish was taken almost wholly in the shore and boat fisheries and with lines. The whiting catch in 1908 was considerably less than in former years, as is indicated by the following tabular statement:

\begin{tabular}{|c|c|c|}
\hline \multirow[b]{2}{*}{ 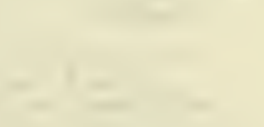 } & \multicolumn{2}{|c|}{ WHITING PRODUCT. } \\
\hline & $\begin{array}{l}\text { Quantity } \\
\text { (younds). }\end{array}$ & Value. \\
\hline 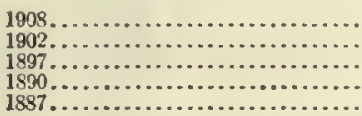 & $\begin{array}{l}274,000 \\
606,000 \\
638,000 \\
521,000 \\
618,000\end{array}$ & $\begin{array}{r}\$ 17,000 \\
30,000 \\
28,000 \\
21,000 \\
19,000\end{array}$ \\
\hline
\end{tabular}


FISHERIES OF THE UNTTED STATES, 1908.

TABLE 1.-SOUTH CAROLINA-FISHERY PRODUCTS: 1908.

\begin{tabular}{|c|c|c|c|c|c|c|c|c|c|c|c|c|}
\hline \multirow{3}{*}{ APECIES. } & \multirow{2}{*}{\multicolumn{2}{|c|}{ TOTAL. }} & \multicolumn{10}{|c|}{ PRODUCT CACGHT BY - } \\
\hline & & & \multicolumn{2}{|c|}{ Lines. } & \multicolumn{2}{|c|}{ Gill nets. } & \multicolumn{2}{|c|}{ Cast nets. } & \multicolumn{2}{|c|}{ Selnes. } & \multicolumn{2}{|c|}{ All ather apparatus. 1} \\
\hline & $\begin{array}{l}\text { Quantity } \\
\text { (pounds). }\end{array}$ & Value. & $\begin{array}{l}\text { Quantity } \\
\text { (pounds). }\end{array}$ & Value. & $\begin{array}{l}\text { Quantity } \\
\text { (pounds). }\end{array}$ & Value. & $\begin{array}{l}\text { Quantity } \\
\text { (pounds). }\end{array}$ & Value. & $\begin{array}{l}\text { Quantity } \\
\text { (pounds). }\end{array}$ & Value. & $\begin{array}{l}\text { Quantity } \\
\text { (pounds). }\end{array}$ & Value. \\
\hline Total.. & $14,104,000$ & $\$ 288,000$ & $1,388,000$ & $\$ 59,000$ & 566,000 & $\$ 43,000$ & 404.000 & 819,000 & 567,000 & $\$ 16,000$ & $11,180,000$ & $\$ 151,000$ \\
\hline 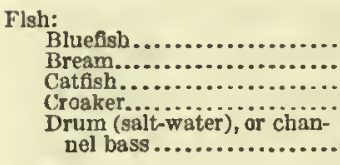 & $\begin{array}{r}7,400 \\
11,000 \\
2 n, 000 \\
85,000 \\
109,000\end{array}$ & $\begin{array}{r}300 \\
300 \\
400 \\
2.800 \\
2,500\end{array}$ & $\begin{array}{r}7,400 \\
6,000 \\
19,000 \\
82,000 \\
107,000\end{array}$ & $\begin{array}{r}300 \\
200 \\
400 \\
2,700\end{array}$ & $\begin{array}{r}300 \\
500\end{array}$ & $\begin{array}{l}\text { (3) } \\
\text { (2) } \\
\text { (2) }\end{array}$ & & & 700 & 100 & $\ddot{5}, 000$ & 200 \\
\hline 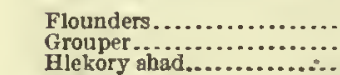 & $\begin{array}{r}4,700 \\
40,000 \\
3,100\end{array}$ & $\begin{array}{r}200 \\
1,000 \\
300\end{array}$ & $\begin{array}{r}100 \\
40,000 \\
.\end{array}$ & $\stackrel{(1)}{1,000}$ & 700 & (2) & & & & & 3,900 & 200 \\
\hline $\begin{array}{l}\text { Mullet........................ } \\
\text { Pompano................. }\end{array}$ & $\begin{array}{r}664,000 \\
4,200\end{array}$ & $\begin{array}{r}19,000 \\
400\end{array}$ & $\begin{array}{r}7,600 \\
4,200\end{array}$ & $\begin{array}{l}100 \\
400\end{array}$ & 81,000 & 2,300 & 9790000 & 3,800 & 484,000 & 13,000 & 200 & \\
\hline 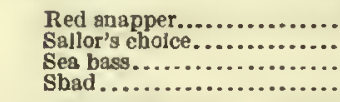 & $\begin{array}{r}12,000 \\
34,000 \\
491,000 \\
464,000\end{array}$ & $\begin{array}{r}400 \\
1,000 \\
22,000 \\
41,000\end{array}$ & $\begin{array}{r}12,000 \\
33,000 \\
483,000\end{array}$ & $\begin{array}{r}400 \\
1,000 \\
21,000\end{array}$ & 449,000 & 40,000 & & & 8,100 & ${ }_{400}^{(2)}$ & $" 15,000$ & $\begin{array}{l}\ldots \ldots . \\
\dddot{1}, 200\end{array}$ \\
\hline 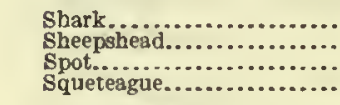 & $\begin{array}{r}72,000 \\
20,000 \\
66,000 \\
183,000\end{array}$ & $\begin{array}{l}1,400 \\
900 \\
1,800 \\
8,700\end{array}$ & $\begin{array}{r}72,000 \\
19,000 \\
28,000 \\
152,000\end{array}$ & $\begin{array}{r}1,400 \\
900 \\
800 \\
7,300\end{array}$ & $\begin{array}{r}22,000 \\
6,400\end{array}$ & $\begin{array}{r}700 \\
300\end{array}$ & & & $\begin{array}{r}300^{\circ} \\
16,000 \\
9,400\end{array}$ & $\begin{array}{r}300 \\
000\end{array}$ & 15,000 & $\begin{array}{l}\cdots \cdots \\
\cdots \cdots \\
\cdots \cdots 0\end{array}$ \\
\hline 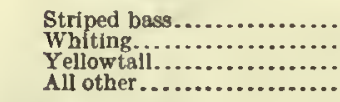 & $\begin{array}{r}5,000 \\
274,000 \\
17,000 \\
2,200\end{array}$ & $\begin{array}{r}300 \\
17,000 \\
600 \\
100\end{array}$ & $\begin{array}{r}2,000 \\
267,000 \\
15,000 \\
2,200\end{array}$ & $\begin{array}{r}100 \\
17,000 \\
500 \\
100\end{array}$ & $\begin{array}{l}500 \\
600\end{array}$ & (2) $^{100}$ & 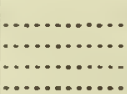 & - & $\begin{array}{r}500 \\
6,000 \\
2,500\end{array}$ & $\begin{array}{l}100 \\
300 \\
100\end{array}$ & 2,000 & $\begin{array}{l}100 \\
\cdots \cdots\end{array}$ \\
\hline 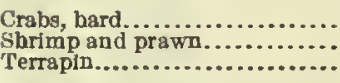 & $\begin{array}{r}33,000 \\
452,000 \\
12,000\end{array}$ & $\begin{array}{r}900 \\
19,000 \\
2,400\end{array}$ & 33,000 & 900 & & & 306,000 & 15,000 & $\begin{array}{r}34,000 \\
1,800\end{array}$ & $\begin{array}{l}300 \\
400\end{array}$ & $\begin{array}{r}111,000 \\
10,000\end{array}$ & $\begin{array}{l}\dddot{3}, 700 \\
1,900\end{array}$ \\
\hline $\begin{array}{l}\text { Clams, hard........................... } \\
\text { Oytuters, market, from public }\end{array}$ & 376,000 & 6,300 & & & & & & & & & 376,000 & 6,300 \\
\hline $\begin{array}{l}\text { areas................................ from private } \\
\text { oyaters, market, }\end{array}$ & $\cdot 10,331,000$ & 129,000 & & & & & & & & & $410,331,000$ & 129,000 \\
\hline 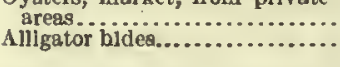 & $\begin{array}{r}6610,000 \\
6100\end{array}$ & $\begin{array}{l}8,000 \\
(2)\end{array}$ & & & & & & & & & $\begin{array}{r}B 610,000 \\
8100\end{array}$ & $\begin{array}{l}8,000 \\
(1)\end{array}$ \\
\hline
\end{tabular}

1 Ineludes apparatus, with eatch, as follows: Dredges, tonss, etc., $11,014,000$ pounds, valued at $\$ 143,000 ;$ shrimp nets, 111,000 pounds, valued at $\$ 3,700 ;$ bow nets, 15,000

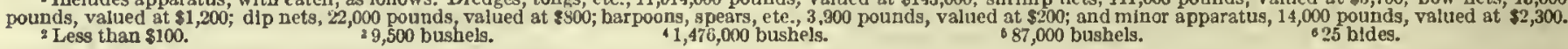

TABLE 2.-SOUTH CAROLINA-PRODUCTS OF VESSEL FISHERIES: 1908.

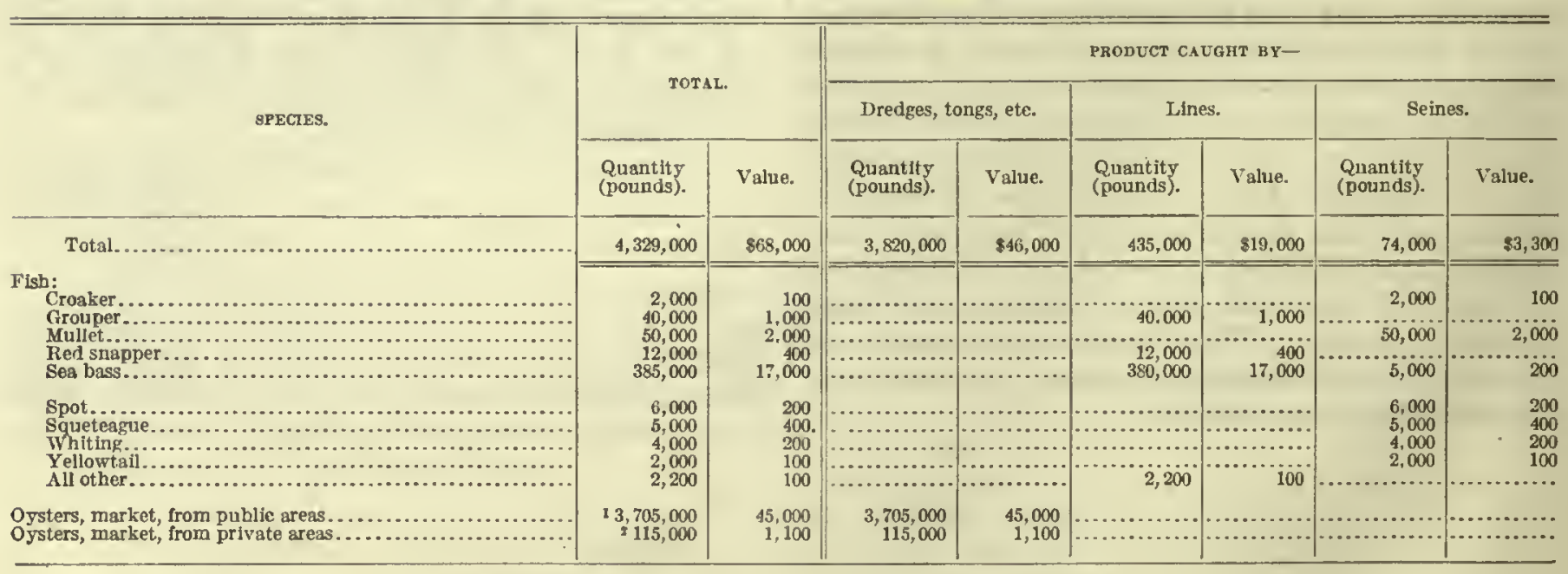


FISHERIES, BY STATES.

TABLE 3.-SOUTH CAROLINA-PRODUCTS OF SHORE AND BOAT FISHERIES: 1908.

\begin{tabular}{|c|c|c|c|c|c|c|c|c|c|c|c|c|}
\hline \multirow{3}{*}{ SPECIES. } & \multirow{2}{*}{\multicolumn{2}{|c|}{ TOTAL. }} & \multicolumn{10}{|c|}{ PRODUCT CAUOHT BY - } \\
\hline & & & \multicolumn{2}{|c|}{ Glll nets. } & \multicolumn{2}{|c|}{ Lines. } & \multicolumn{2}{|c|}{ Cast nets. } & \multicolumn{2}{|c|}{ Seines. } & \multicolumn{2}{|c|}{ All other apparatus. 1} \\
\hline & $\begin{array}{l}\text { Quantity } \\
\text { (pounds). }\end{array}$ & Value. & $\begin{array}{l}\text { Quantity } \\
\text { (pounds). }\end{array}$ & Value. & $\begin{array}{l}\text { Quantity } \\
\text { (pounds). }\end{array}$ & Value. & $\begin{array}{l}\text { Quantity } \\
\text { (pounds). }\end{array}$ & Value. & $\begin{array}{l}\text { Quantity } \\
\text { (pounds). }\end{array}$ & Value. & $\begin{array}{l}\text { Quantity } \\
\text { (pounds). }\end{array}$ & Value. \\
\hline Total....... & $9.776,000$ & 8220,000 & 566,000 & $\$ 43,000$ & 953,000 & $\$ 41,000$ & 404,000 & $\$ 19,000$ & 493,000 & $\$ 13,000$ & $7,300,000$ & $\$ 104,000$ \\
\hline 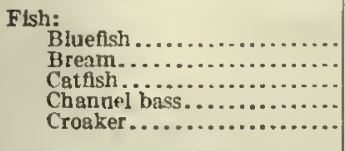 & $\begin{array}{r}7,400 \\
11,000 \\
20,000 \\
25,000 \\
83,000\end{array}$ & $\begin{array}{r}300 \\
300 \\
400 \\
800 \\
2,700\end{array}$ & $\begin{array}{r}500 \\
500 \\
500\end{array}$ & $\begin{array}{l}(3) \\
(2) \\
(2)\end{array}$ & $\begin{array}{r}7,400 \\
6,000 \\
19,000 \\
24,000 \\
82,000\end{array}$ & $\begin{array}{r}300 \\
200 \\
400 \\
700 \\
2,700\end{array}$ & $\begin{array}{l}\cdots \cdots \\
\cdots \cdots \cdots \\
\cdots \cdots\end{array}$ & & $\begin{array}{r}400 \\
500\end{array}$ & (2) & $\begin{array}{l}\cdots \cdots \\
\cdots, 000 \\
\cdots \cdots \cdots \cdots \cdots \\
\cdots \cdots \cdots\end{array}$ & $\begin{array}{l}200 \\
\ldots \ldots \ldots\end{array}$ \\
\hline 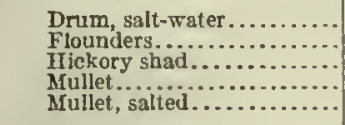 & $\begin{array}{r}83,000 \\
4,700 \\
3,100 \\
525,000 \\
89,000\end{array}$ & $\begin{array}{r}1,700 \\
200 \\
300 \\
14,000 \\
3,100\end{array}$ & $\begin{array}{r}500 \\
700 \\
2,900 \\
76,000 \\
5,000\end{array}$ & $\begin{array}{l}(2) \\
(2) \\
300 \\
2,100 \\
200\end{array}$ & $\begin{array}{r}82,000 \\
100 \\
1,600 \\
1, \ldots .\end{array}$ & $\begin{array}{l}1.700 \\
(2) \\
100\end{array}$ & $\because \ldots \ldots$. & 3,800 & $\begin{array}{r}300 \\
\cdots 3 . \\
350,000 \\
84,000\end{array}$ & $\begin{array}{l}8,200 \\
2,900\end{array}$ & $\begin{array}{r}3,900 \\
200 \\
2\end{array}$ & ${ }^{2}{ }^{200}$ \\
\hline 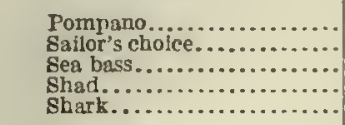 & $\begin{array}{r}4,200 \\
34,000 \\
106,000 \\
464,000 \\
72,000\end{array}$ & $\begin{array}{r}400 \\
1,000 \\
4,400 \\
41,000 \\
1,400\end{array}$ & 449,000 & $\begin{array}{r}40,000 \\
0 .\end{array}$ & $\begin{array}{r}4,200 \\
33,000 \\
103,000 \\
72,000\end{array}$ & $\begin{array}{r}100 \\
1,000 \\
4,200 \\
1,400\end{array}$ & & & $\begin{array}{c}700 \\
3,100 \\
\ldots\end{array}$ & $\begin{array}{r}(2) \\
200 \\
20\end{array}$ & 15,000 & $\begin{array}{l}\cdots \ldots \ldots \\
\cdots \cdots \\
1,200 \\
\cdots\end{array}$ \\
\hline 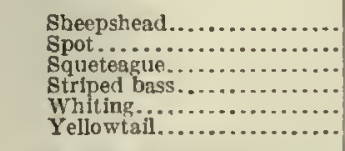 & $\begin{array}{r}20,000 \\
60,000 \\
178,000 \\
5,000 \\
270,000 \\
15,000\end{array}$ & $\begin{array}{r}900 \\
1,000 \\
8,300 \\
300 \\
17,000 \\
500\end{array}$ & $\begin{array}{r}200 \\
22,000 \\
6,400 \\
500 \\
600\end{array}$ & $\begin{array}{l}{ }^{(2)} \\
700 \\
300 \\
100 \\
(2) \\
\end{array}$ & $\begin{array}{r}19,000 \\
28,000 \\
152,000 \\
2,000 \\
267,000 \\
15,000\end{array}$ & $\begin{array}{r}900 \\
800 \\
7,300 \\
100 \\
17,000 \\
500\end{array}$ & (n & n........ & $\begin{array}{r}300 \\
10,000 \\
4,400 \\
500 \\
2,000 \\
500\end{array}$ & $\begin{array}{l}(2) \\
100 \\
200 \\
100 \\
100 \\
(2)\end{array}$ & $\begin{array}{r}15,000 \\
2,000 \\
\cdots\end{array}$ & $\begin{array}{r}\ldots \ldots \\
600 \\
100 \\
\cdots \ldots \ldots \ldots \\
\cdots \ldots \ldots\end{array}$ \\
\hline 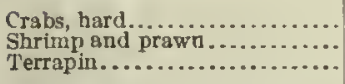 & $\begin{array}{r}33,000 \\
452,000 \\
12,000\end{array}$ & $\begin{array}{r}900 \\
19,000 \\
2,400\end{array}$ & & & $\begin{array}{r}33,000 \\
\cdots \cdots\end{array}$ & $\begin{array}{c}900 \\
\ldots \ldots \ldots \ldots \\
\cdots \ldots \ldots\end{array}$ & $\begin{array}{r}306,000 \\
\cdots \ldots \ldots \ldots\end{array}$ & 15.000 & $\begin{array}{r}34,000 \\
1,800\end{array}$ & $\begin{array}{l}300 \\
400\end{array}$ & $\begin{array}{r}\text { iii, } 000 \\
10,000\end{array}$ & $\begin{array}{l}\ddot{3}, 700 \\
1,900\end{array}$ \\
\hline 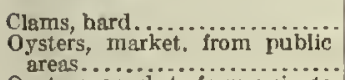 & $\begin{array}{r}76,000 \\
6,626,000\end{array}$ & $\begin{array}{r}6,300 \\
83,000\end{array}$ & & & & & & & & & $\begin{array}{r}276,000 \\
40,626,000\end{array}$ & $\begin{array}{r}6,300 \\
83,000\end{array}$ \\
\hline 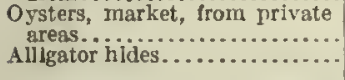 & $\begin{array}{r}496,000 \\
6100\end{array}$ & $\begin{array}{l}6,900 \\
\left({ }^{2}\right)\end{array}$ & & & & & & & & & $\begin{array}{r}496.000 \\
8100\end{array}$ & $\begin{array}{l}6,900 \\
(2)\end{array}$ \\
\hline
\end{tabular}

Includes apparatus, with catch, as tollows: Dredges, tongs, etc., $7,194,000$ pounds, valued at $\$ 06,000 ;$ shrimp nets, 111,000 pounds, valued at $\$ 3,700 ;$ bow nets, 15,000

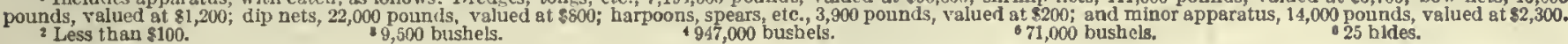
Less than $\$ 100$. 9,500 bushels.
gishols 25 bides.

\section{SOUTII DAKOTA.}

The commercial fisheries of South Dakota, which were never very extensive, showed a decided decline at the canvass of 1908 . Possibly as a result of the stringent laws which during the past few years have restricted fishing without a permit in the inland waters to that with hook and line, the figures shown are smaller than those for any previous year for which statistics are obtainable. The industry was pursued principally on the Missouri River, while by permit and under the supervision of the game warden, fish were taken from Lake Kampeska and the Dakota River. The principal statisties concerning the fishing industry of the state are as follows:

Number of persons employed

33 Capital:

Boats................................. $\$ \$ 400$

Apparatus of capture........................... $\quad 500$

Shore and accessory property................. 100

Value of products......................... 4,200

Of the 33 persons engaged in fishing, 29 were proprietors and independent fishermen and 4 were wageearners, the latter receiving the sum of $\$ 300$ for their services. In 1899 the number of fishermen reported was 72 and in 1894 the number was 121.

$76786^{\circ}-11-16$
The statisties as to equipment and other eapital are given in the following tabular statement:

\begin{tabular}{|c|c|c|}
\hline \multirow[t]{2}{*}{ CLASS OF INVESTMENT. } & \multicolumn{2}{|c|}{$\begin{array}{l}\text { EQUIPMENT AND } \\
\text { OTHER CAPITAL: } \\
1908 .\end{array}$} \\
\hline & Number. & value. \\
\hline Total..... & .... & $\$ 1,000$ \\
\hline 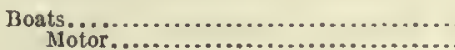 & ${ }_{1}^{27}$ & $\begin{array}{l}400 \\
100\end{array}$ \\
\hline Row ................. & 26 & 300 \\
\hline Apparatus of capture.................. & & 600 \\
\hline 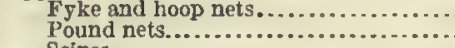 & $\begin{array}{r}49 \\
2\end{array}$ & \\
\hline 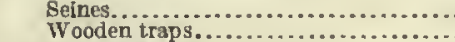 & $\mathbf{2 7}$ & (n............ \\
\hline Shore and accessory poperty........ & & 100 \\
\hline
\end{tabular}

In 1899 the investment in boats, as reported by the Bureau of Fisheries, was $\$ 600$ and the investment in apparatus of capture $\$ 800$. Thus there were decreases in investment between 1899 and 1908 amounting to 33 per cent in the case of boats and 38 per cent in the case of apparatus of capture, these decreases being in keeping with the reduction of over one-half in the number of persons employed.

In 1899 the fishery products of the state were reported as amounting to 136,000 pounds, valued at $\$ 6,900$. The decrease in value of products shown in 
1908, as compared with 1899 , was almost 40 per cent. In 1894, the only other year for which statistics of the fishery products of this state are available, the catch amounted to 417,000 pounds, valued at $\$ 13,000$. The larger part of the catch in each of these former years was taken from the Missouri, Dakota, Vermilion, and Big Sioux Rivers.
The products of the state in 1908 are shown, by species and by apparatus of capture, in the following table. The catch reported with seines and pound nets was confined to Lake Kampeska and the Dakota River, where such fishing was carried on under the supervision of the game warden.

SOUTH DAKOTA-FISHERY PRODUĊTS: 1908.

\begin{tabular}{|c|c|c|c|c|c|c|c|c|c|c|c|c|c|}
\hline \multirow{3}{*}{ BPECIES. } & \multirow{3}{*}{. } & \multirow{2}{*}{\multicolumn{2}{|c|}{ TOTAL. }} & \multicolumn{10}{|c|}{ PRODUCT CAUGHT BY- } \\
\hline & & & & \multicolumn{2}{|c|}{ Sej̉nes. } & \multicolumn{2}{|c|}{ Fyke and hoop nets. } & \multicolumn{2}{|c|}{ Lines. } & \multicolumn{2}{|c|}{ Willow traps. } & \multicolumn{2}{|c|}{ Pound nets. } \\
\hline & & $\begin{array}{l}\text { Quantity } \\
\text { (pounds). }\end{array}$ & Value. & $\begin{array}{l}\text { QuantIty } \\
\text { (pounds). }\end{array}$ & Value. & $\begin{array}{l}\text { Quantity } \\
\text { (pounds). }\end{array}$ & Value. & $\begin{array}{l}\text { Quantity } \\
\text { (pounds). }\end{array}$ & Value. & $\begin{array}{l}\text { Quantity } \\
\text { (pounds). }\end{array}$ & Valne. & $\begin{array}{l}\text { Quantity } \\
\text { (pounds). }\end{array}$ & Value. \\
\hline \multicolumn{2}{|l|}{ Total... } & 70,000 & $\$ 4,200$ & 36,000 & $\$ 1,600$ & 12,000 & $\$ 1,200$ & 11,000 & $\$ 1,000$ & 4,400 & $\$ 400$ & 5,500 & $\$ 100$ \\
\hline \multirow{2}{*}{\multicolumn{2}{|c|}{ 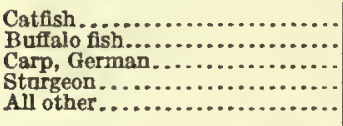 }} & $\begin{array}{r}20,000 \\
32,000 \\
12,000 \\
1,800\end{array}$ & $\begin{array}{r}2,000 \\
-1,200 \\
700 \\
100\end{array}$ & $\begin{array}{r}25,0000 \\
9,000\end{array}$ & $\begin{array}{r}7,000 \\
500\end{array}$ & $\begin{array}{r}11,000 \\
600 \\
1,100\end{array}$ & $\begin{array}{l}1,100 \\
(1) \\
100\end{array}$ & $\begin{array}{l}6,700 \\
1,000 \\
1,300 \\
1,800\end{array}$ & $\begin{array}{l}700 \\
100 \\
100 \\
100\end{array}$ & $\begin{array}{r}2,800 \\
600 \\
1,000\end{array}$ & $\begin{array}{c}300 \\
(1)^{100}\end{array}$ & 5,000 & 100 \\
\hline & & 3,200 & & 2,500 & (1) & ….................. & ?............ & 200 & 100 & & & 500 & (i) \\
\hline
\end{tabular}

${ }^{1}$ Less than $\$ 100$.

TENNESSEE.

The fisheries of Tennessee in 1908 were of the shore and boat class only, and were conducted on the Mississippi River and its tributary waters, comprising chiefly Reelfoot Lake, Open Lake, and Hatchee River; and in the Cumberland and Tennessee Rivers. In this report the fisheries of the last two rivers are considered apart from the others. A summary of the statistics for Tennessee for 1908 is given in the following tabular statement:

Number of persons employed ................... $\quad 427$ Capital:

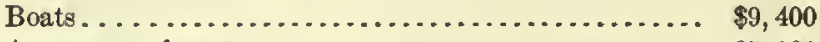

Apparatus of capture ................... 27,000

Shore and accessory property and cash ......... 13,000 Value of products......................... 112,000

Comparison with previous canvasses.-With the exception of the number of persons employed, every item of the data for the fisheries of Tennessee shows a substantial increase in 1908 , as compared with prior years. The following tabular statement presents comparative statistics for those years for which figures are available:

\begin{tabular}{|c|c|c|c|c|c|c|}
\hline \multirow[b]{2}{*}{ TEAR. } & \multirow{2}{*}{$\begin{array}{c}\text { Persons } \\
\text { em- } \\
\text { ployed, } \\
\text { excluslve } \\
\text { of shores- } \\
\text { men. }\end{array}$} & \multicolumn{3}{|c|}{ VALUE OF EQUTPMENT. } & \multicolumn{2}{|c|}{ PRODUCTS. } \\
\hline & & Total. & Boats. & $\begin{array}{c}\text { Appa- } \\
\text { ratus of } \\
\text { capture. }\end{array}$ & $\begin{array}{l}\text { Quantity } \\
\text { (pounds). }\end{array}$ & Valne. \\
\hline $\begin{array}{l}1908 \ldots \ldots \ldots \\
1899 . \ldots \ldots \ldots \\
1894 . \ldots \ldots \ldots\end{array}$ & $\begin{array}{l}427 \\
424 \\
503\end{array}$ & $\begin{array}{r}837,000 \\
31,000 \\
24,000\end{array}$ & $\begin{array}{r}\$ 9,400 \\
7,100 \\
4,900\end{array}$ & $\begin{array}{r}\$ 27,000 \\
24,000 \\
19,000\end{array}$ & $\begin{array}{l}4,506,000 \\
2,775,000 \\
2,445,000\end{array}$ & $\begin{array}{r}8112,000 \\
88,000 \\
83,000\end{array}$ \\
\hline
\end{tabular}

Persons employed.-The fisheries of the Mississippi River district reported 62 per cent of the total number of persons employed and those of the Cumberland and
Tennessee Rivers accounted for the remaining 38 per cent. Only 67 fishermen, or 16 per cent of the total number of persons engaged in the fisheries of the state, were wage-earners, the remainder being proprietors or independent fishermen.

The following tabular statement gives the data concerning persons employed in the fisheries of Tennessee in 1908:

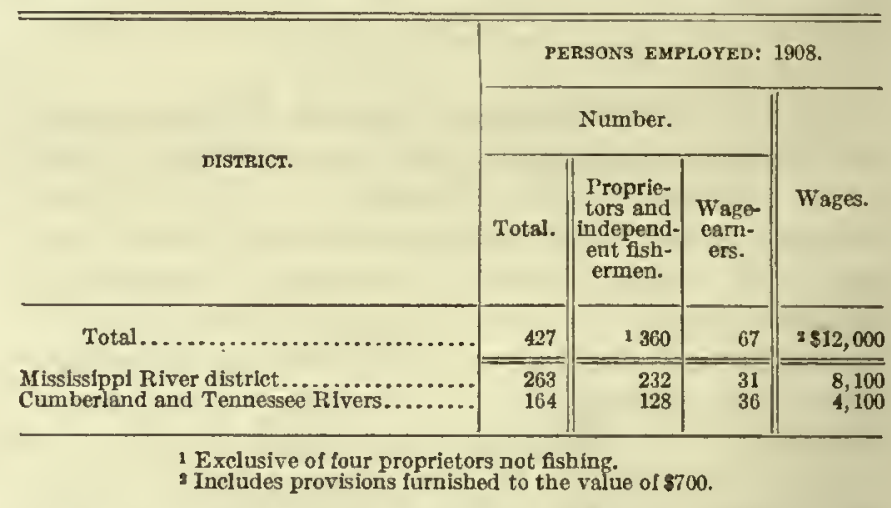

Equipment and other capital.-The distribution of the investment in the fisheries of Tennessee is shown in the following tabular statement:

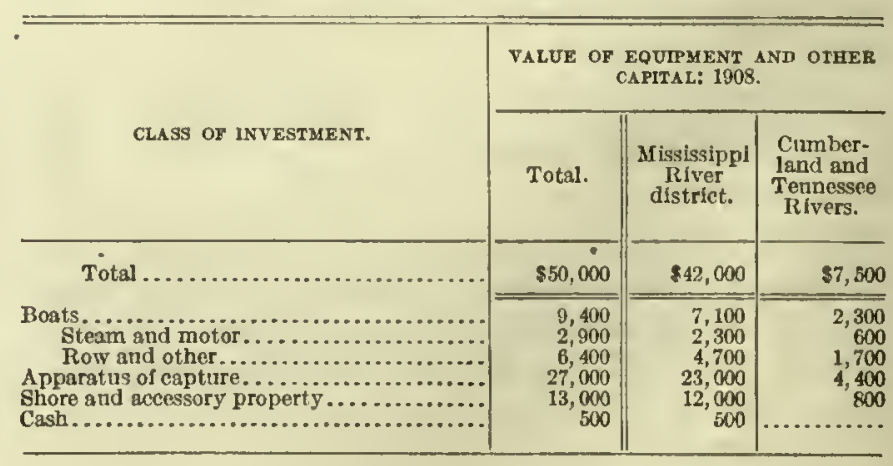


The Mississippi River listriet is credited with 85 per cent of the total investment in the fisheries of the state. The investment in this district included 75 per cent of the total investment in boats for the state, 84 per cent of that in apparatus of capture, 93 per cent of that in shore and accessory property, and the total amount of cash reported. The Mississippi River district reported 10 of the 12 steam and motor boats and 218 of the 387 boats included under the head "Row and other."

The numbers of the more important kinds of apparatus of capture used, all of which, with the exception of 699 fyke and loop nets reported for the Cumberland and Tennessec Rivers, were used in the Mississippi River district, were as follows:

Fyke and hoop nets . . . . . . . . . . . . . .

Pound nets ................................. 19

Seines..................................... 8

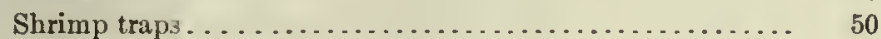

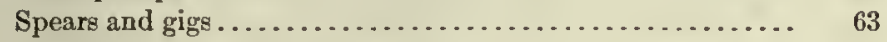

Trammel nets............................... 28

Products, by species. - The distribution of the fishery products of the state, by species and by apparatus of capture, is shown in Table 1 , on page 244.

The most important products in respect to value were buffalo fish, catfish, mussel shells, pearls, and slugs, and black bass; these products representing 62 per cent, or about five-eighths, of the total value of products for the state.

Products, by fishing grounds.-The products of the Mississippi River district and of the Tennessee and Cumberland Rivers are given in detail, by species and apparatus of capture, in Tables 2 and 3 , on page 245 .

The following tabular statement distributes the value of products, by species arranged in the order of value, for the state and for each district:

\begin{tabular}{|c|c|c|c|}
\hline \multirow[b]{2}{*}{ SPECIES } & \multicolumn{3}{|c|}{ VALUE OF PRODUCTS: 1908.} \\
\hline & Total & $\begin{array}{c}\text { Mississippi } \\
\text { River } \\
\text { district. }\end{array}$ & $\begin{array}{l}\text { Cumber- } \\
\text { land and } \\
\text { Tennessee } \\
\text { Rivers. }\end{array}$ \\
\hline Total...................... & $\$ 112,000$ & $\$ 73,000$ & $\$ 39,000$ \\
\hline 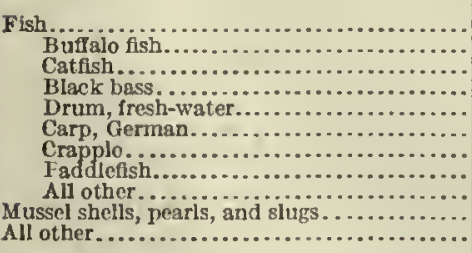 & $\begin{array}{r}97,000 \\
22,000 \\
20,000 \\
13,000 \\
9,500 \\
8,200 \\
7,800 \\
7,500 \\
9,200 \\
14,000 \\
1,200\end{array}$ & $\begin{array}{r}72,000 \\
19,000 \\
11,000 \\
12,000 \\
2,000 \\
6,600 \\
7,600 \\
7,100 \\
5,600 \\
1, \ldots 00\end{array}$ & $\begin{array}{r}25,000 \\
3,200 \\
8,700 \\
100 \\
7,500 \\
1,600 \\
200 \\
300 \\
3,600 \\
14,000\end{array}$ \\
\hline
\end{tabular}

The fish products proper amounted in the aggregate to $2,330,000$ pounds, or 52 per ecnt of the total weight of all fishery products, and were valued at $\$ 97,000$, or 87 per cent of the total value. Of the total value of products reported for the Mississippi River district, the value of fish proper constituted 98 per cent; but the proportion was only 65 per cent in the case of the fisheries of the Cumberland and Tennessee Rivers.
Practically all of the black bass, crappic, and paddlefish, as well as a large part of the buffalo fish, catfish, and German carp, were obtained from the Mississippi River district. The only fish which was more abundant in the Tennessee and Cumberland Rivers than in the Mississippi River was the fresh-water drum, the product of which, however, was less in quantity and value than the catfish product of the first two rivers. The mussel-shell products, including pearls and slugs; contributed 35 per cent of the value of the fishery products of the Cumberland and Tennessce Rivers.

The combined catch of the Mississippi River and its tributary waters, exclusive of the Tennessee and Cumberland Rivers, was $1,993,000$ pounds, valued at $\$ 73,000$, while that of the Tennessee and Cumberland Rivers was $2,513,000$ pounds, valued at $\$ 39,000$. The value reported for the former district formed 65 per cent of the value of all the fishery products of the state.

The following tabular statement gives in detail th9 products of the Reelfoot Isake fisheries in 1908:

\begin{tabular}{|c|c|c|}
\hline \multirow{2}{*}{ SPECEES. } & \multicolumn{2}{|c|}{$\begin{array}{l}\text { FTSHERY PRODUCTS OF } \\
\text { REELFOOT LAKE: } 1908 .\end{array}$} \\
\hline & $\begin{array}{l}\text { QuantIty } \\
\text { (pounds). }\end{array}$ & Value. \\
\hline Total.......................... & $1,147,000$ & $\$ 43,000$ \\
\hline 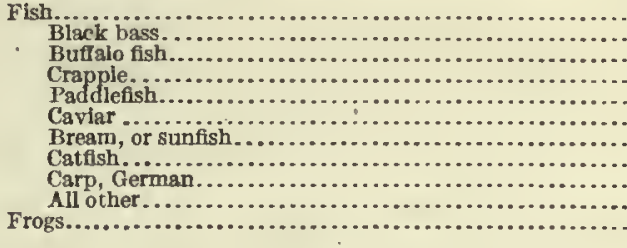 & $\begin{array}{r}1,142,000 \\
174,000 \\
312,000 \\
174,000 \\
142,000 \\
3,000 \\
144,000 \\
82,000 \\
62,000 \\
49,000 \\
5,000\end{array}$ & $\begin{array}{r}42,000 \\
12,000 \\
7,800 \\
7,000 \\
5,700 \\
600 \\
3,500 \\
2,900 \\
1,500 \\
1,000 \\
1,000\end{array}$ \\
\hline
\end{tabular}

Products, by apparatus of capture.-The following tabular statement shows the distribution, by apparatus of capture, of the value of the fishery products reported for the state as a whole and for the two districtsinto which it is divided:

\begin{tabular}{|c|c|c|c|}
\hline \multirow[b]{2}{*}{ KDND OF APPARATUS. } & \multicolumn{3}{|c|}{ VALUE OF PRODUCTS: 1908.} \\
\hline & Total. & $\begin{array}{l}\text { Mississippl } \\
\text { Rlver } \\
\text { distriet. }\end{array}$ & $\begin{array}{l}\text { Cumber- } \\
\text { land and } \\
\text { Tennessee } \\
\text { Rivers. }\end{array}$ \\
\hline Total............ & $\$ 112,000$ & 373,000 & $\$ 39,000$ \\
\hline 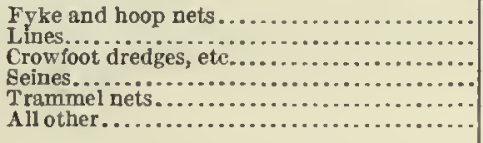 & $\begin{array}{r}45,000 \\
32,000 \\
14,000 \\
8,700 \\
7,600 \\
5,200\end{array}$ & $\begin{array}{r}31,000 \\
21,000 \\
\cdots, 7000 \\
7,000 \\
5,200\end{array}$ & $\begin{array}{r}14,000 \\
11,000 \\
14,000 \\
\cdots, \ldots, \cdots \\
\cdots, \ldots, \cdots\end{array}$ \\
\hline
\end{tabular}

The value of the eatch by fyke and hoop nets represented 40 per cent of the value of all the fishery products of Tennessec. Lines ranked next in value of eatch, taking nearly all of the black bass, the larger part of the catfish, and all of the cels. Crowfoot dredges were used exclusively in the mussel-shell and pearl industries. 
Principal species.-The value of the catch of buffalo fish formed 20 per cent of the value of all fishery products. The quantity of buffalo fish caught decreased from 862,000 pounds in 1899 to 704,000 pounds in 1908 , or 18 per cent, while the value increased from $\$ 19,000$ to $\$ 22,000$, or 19 per cent. Only 15 per cent of the value reported for this fish is credited to the Cumberland and Tennessee Rivers, much the larger part representing the value of product from the Mississippi River and its tributaries.

Catfish ranked second in importance, with a valuo but little less than that reported for buffalo fish. The catch of catfish decreased in quantity and in value between 1899 and 1908.

The mussel-shell and pearl industry was carried on only on the Cumberland and Tennessee Rivers. Although this branch of the state's fisheries was not introduced into Tennessee until after 1899, it has devcloped rapidly, the product for 1908 amounting to $2,170,000$ pounds, valued at $\$ 14,000$. Of the total value, $\$ 9,400$ represented the value of the mussel shells and $\$ 4,200$ that of the pearls and slugs.
The catch of black bass increased from 142,000 pounds, valued at $\$ 8,700$, in 1899 , to 177,000 pounds, valued at $\$ 13,000$, in 1908 . Practically all of this product in $1908,174,000$ pounds, was cauglit in Reelfoot Lake.

Of the fresh-water drum reported, 50 per cent of the total weight and 79 per cent of the total value were credited to tho Cumberland and Tennessee Rivers. This species shows a large decrease in quantity and a sinall decrease in value, the catch in 1899 being 311,000 pounds, valued at $\$ 11,000$, and that in 1908 amounting to 204,000 pounds, valued at $\$ 9,500$.

The German-carp product increased in quantity and value between 1899 and 1908 in Tennessee, as in most of the other states of the Mississippi Valley. A large quantity, representing 91 per cent of the weight and 80 per cent of the valuo of the German carp reported for this state, was caught in the Mississippi River district. The catch of crappio has also increased in quantity and in value while that of paddlefish lias decreased in quantity but increased in value since 1899 .

TABLE 1.-TENNESSEE-FISHERY PRODUCTS: 1908.

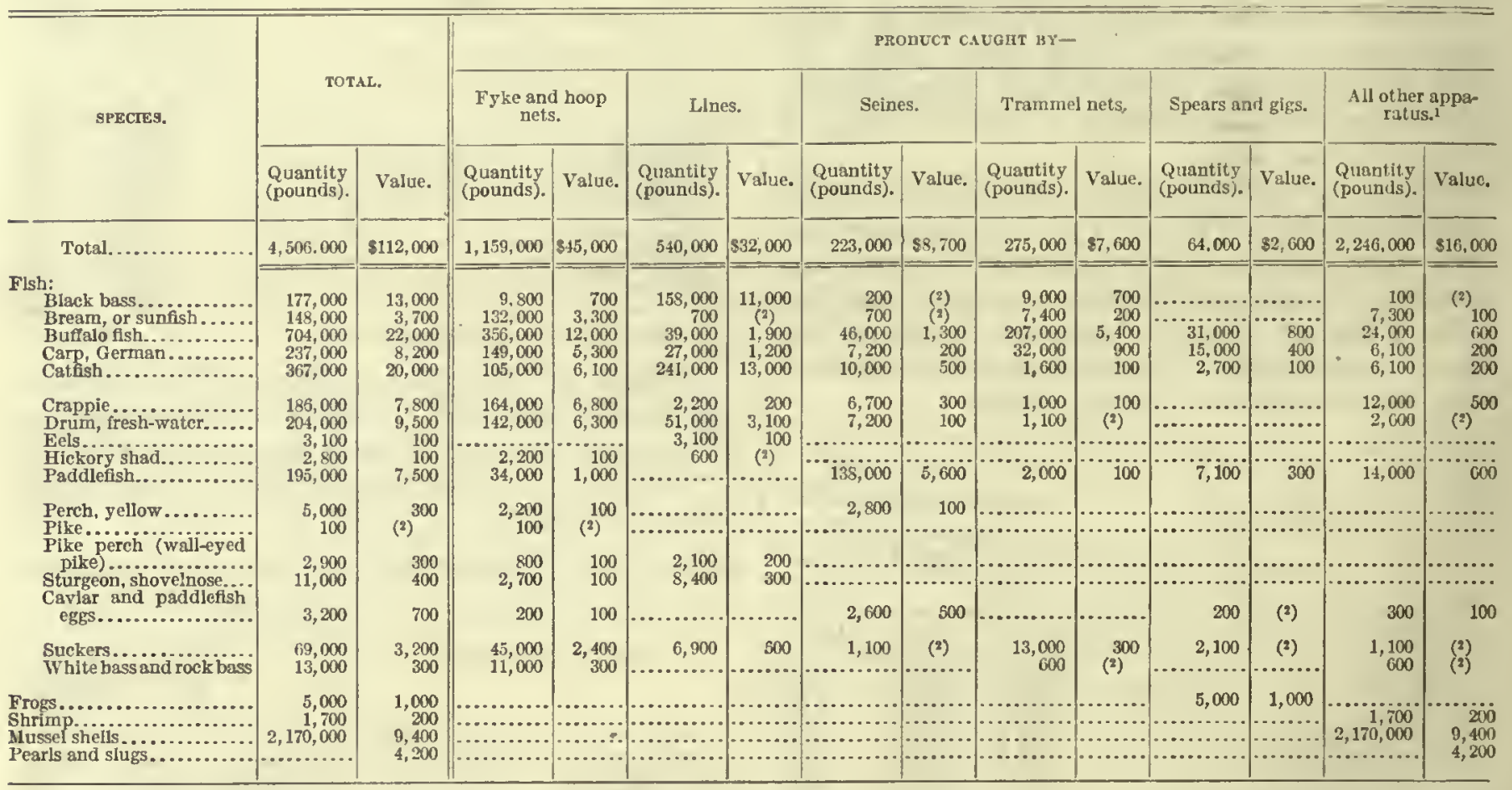

1 Includes apparatus, w1th catch, as follows: Crowloot dredges, etc., 2,170,000 pounds, valued at \$14,000; pound nets, 74,000 pounds, valued at \$2,400; and shrimp traps, 1,700 pounds, valued at $\$ 200$.

2 Less than $\$ 100$. 
FISHERIES, BY STATES.

TABLE 2.-TENNESSEE-FISHERY PRODUCTS OF MISSISSIPPI RIVER DISTRICT: 1908.

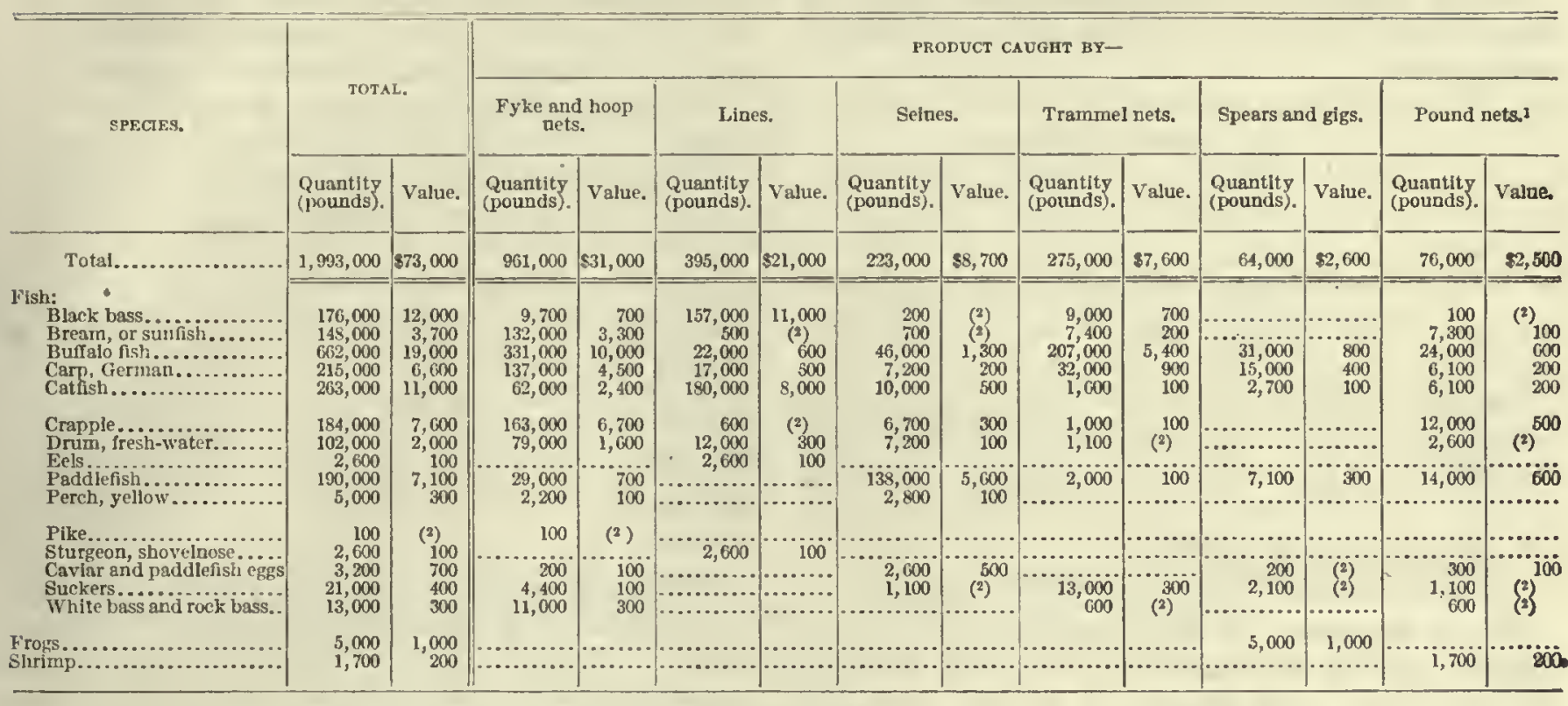

2 Includes shrimp traps, with eatch of 1,700 pounds, valued at $\$ 200$.

2 Less than $\$ 100$.

TABLE 3.-TENNESSEE-FISHERY PRODUCTS OF CUMBERLAND AND TENNESSEE RIVERS: 1908.

\begin{tabular}{|c|c|c|c|c|c|c|c|c|c|}
\hline \multirow{3}{*}{ - } & \multirow{3}{*}{$\begin{array}{l}\text { SPECIES. } \\
\text {. }\end{array}$} & \multirow{2}{*}{\multicolumn{2}{|c|}{ TOTAL. }} & \multicolumn{6}{|c|}{ PBODUCT CAUGHT BY- } \\
\hline & & & & \multicolumn{2}{|c|}{ Fyke and hoop nets. } & \multicolumn{2}{|c|}{ Lines. } & \multicolumn{2}{|c|}{ Crowloot dredges, ctc. } \\
\hline & & $\begin{array}{l}\text { Quantity } \\
\text { (pounds). }\end{array}$ & Value. & $\begin{array}{l}\text { Quantity } \\
\text { (pounds). }\end{array}$ & Value. & $\begin{array}{l}\text { Quantity } \\
\text { (pounds). }\end{array}$ & Value. & $\begin{array}{l}\text { Quantity } \\
\text { (pounds). }\end{array}$ & Value. \\
\hline \multicolumn{2}{|l|}{ Total... } & $2,513,000$ & $\$ 39,000$ & 198,000 & $\$ 14,000$ & 145,000 & $\$ 11,000$ & $2,170,000$ & $\$ 14,000$ \\
\hline \multicolumn{2}{|c|}{ 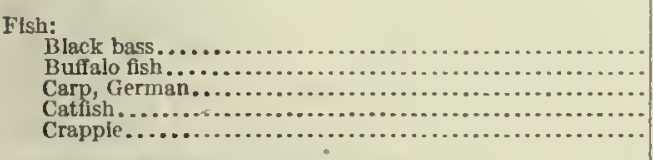 } & $\begin{array}{r}1,100 \\
42,000 \\
23,000 \\
104,000 \\
2,300\end{array}$ & $\begin{array}{r}100 \\
3,200 \\
1,600 \\
8,700 \\
200\end{array}$ & $\begin{array}{r}100 \\
25,000 \\
13,000 \\
43,000 \\
700\end{array}$ & $\begin{array}{r}\text { (1) } 1,900 \\
900 \\
3,700 \\
100\end{array}$ & $\begin{array}{r}1,000 \\
17,000 \\
10,000 \\
61,000 \\
1,600\end{array}$ & $\begin{array}{r}100 \\
1,300 \\
700 \\
5,000 \\
200\end{array}$ & $\begin{array}{l} \\
\cdots \\
\cdots \\
\cdots \\
\cdots \ldots \ldots\end{array}$ & 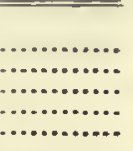 \\
\hline \multicolumn{2}{|c|}{ 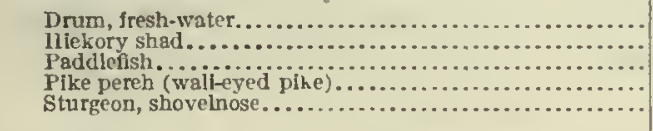 } & $\begin{array}{r}102,000 \\
2,800 \\
5,800 \\
2,900 \\
8,500\end{array}$ & $\begin{array}{r}7,500 \\
100 \\
300 \\
300 \\
400\end{array}$ & $\begin{array}{r}64,000 \\
2,200 \\
5,800 \\
800 \\
2,700\end{array}$ & $\begin{array}{r}4,700 \\
100 \\
300 \\
100 \\
100\end{array}$ & $\begin{array}{r}39,000 \\
600 \\
\cdots, 100 \\
2,100 \\
5,800\end{array}$ & $\begin{array}{l}2,900 \\
(1) \\
200 \\
200\end{array}$ & 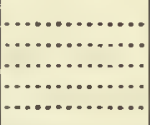 & 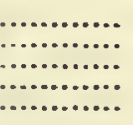 \\
\hline \multicolumn{2}{|c|}{$\begin{array}{l}\text { Suekers } . \ldots \ldots \ldots \ldots \ldots \ldots \ldots \\
\text { All other. }\end{array}$} & $\begin{array}{r}48,000 \\
800\end{array}$ & $\begin{array}{r}2,800 \\
100\end{array}$ & 41,000 & 2,300 & $\begin{array}{r}6,900 \\
800\end{array}$ & $\begin{array}{l}500 \\
100\end{array}$ & & -............. \\
\hline \multicolumn{2}{|c|}{ 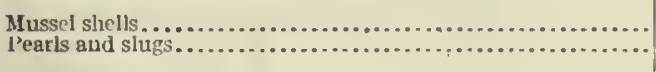 } & $\begin{array}{r}2,170,000 \\
\cdots\end{array}$ & $\begin{array}{l}9,400 \\
4,200\end{array}$ & & & & & $\begin{array}{r}2,170,000 \\
\ldots \ldots\end{array}$ & $\begin{array}{l}9,400 \\
4,200\end{array}$ \\
\hline
\end{tabular}

1 Less than $\$ 100$.

TEXAS.

Although Texas has an extensive coast line, its fishery product in 1908 was smaller thin that of any other Gulf state except Alabama. The principal fishing grounds were Galveston, Corpus Christi, Aransas, and Matagorda Bays, and Sabine Lake. Oysters, red snapper, and squeteague composed two-thirds of the fishery product. 'The principal statistics for 1908 are summarized in the following statement:

Number of persons employed.................... 1,780 Capital:

Vessels and boats, including outfit............. $\$ 387,000$

Apparatus of capture..................... 41,000

Shore and accessory property and cash ............ 26,000

Value of products........................... 446,000

Comparison with previous canvasses.-The canvass of 1908 reveals large increases over 1902 and previous years in all features of the industry. Except for the fact that the canvass of 1897 showed a slight decrease in nearly every item, as compared with that of 1890 , the upward movement has been continuous during the years for which statistics are available. Comparative statistics for these years are as follows:

\begin{tabular}{|c|c|c|c|c|c|c|}
\hline \multirow[b]{2}{*}{ YEAR. } & \multirow{2}{*}{$\begin{array}{c}\text { Persons } \\
\text { employed, } \\
\text { exclisive } \\
\text { of shores- } \\
\text { men. }\end{array}$} & \multicolumn{3}{|c|}{ VALUE OF EQUIP3ENT. } & \multicolumn{2}{|c|}{ PRODUCTS. } \\
\hline & & Total. & $\begin{array}{c}\text { Vessels } \\
\text { and } \\
\text { boats, } \\
\text { including } \\
\text { ontfit. }\end{array}$ & $\begin{array}{l}\text { Appa- } \\
\text { ratus of } \\
\text { capture. }\end{array}$ & $\begin{array}{l}\text { Quantity } \\
\text { (pounds). }\end{array}$ & Value. \\
\hline $\begin{array}{l}1908 \ldots \ldots \ldots \\
1902 \ldots \ldots \\
1897 \ldots \ldots \\
1800 \ldots \ldots \\
1887 \ldots \ldots\end{array}$ & $\begin{array}{l}1,720 \\
1,055 \\
1,140 \\
1,116 \\
901\end{array}$ & $\begin{array}{r}5428,000 \\
212,600 \\
152,000 \\
155,000 \\
126,000\end{array}$ & $\mid \begin{array}{r}\$ 387,000 \\
192,000 \\
130,000 \\
131,000 \\
105,000\end{array}$ & $\begin{array}{r}\$ 41,000 \\
20,000 \\
23,000 \\
24,0100 \\
21,000\end{array}$ & $\begin{array}{r}10,439,000 \\
8,044,000 \\
7,175,000 \\
7,959,000 \\
6,252,000\end{array}$ & $\begin{array}{r}\$ 446,000 \\
354,000 \\
287,000 \\
314,000 \\
256,000\end{array}$ \\
\hline
\end{tabular}


Persons employed.-The following tabular statement gives the distribution of the persons employed in the fisheries of Texas in 1908, and of the wages and salaries paid:

\begin{tabular}{|c|c|c|c|c|c|c|c|}
\hline \multirow[b]{3}{*}{ Class. } & \multicolumn{7}{|c|}{ PERSONS EMPLOTED: 1908.} \\
\hline & \multicolumn{4}{|c|}{ Number. } & \multicolumn{3}{|c|}{ Salarles and wages. } \\
\hline & Total. & $\begin{array}{l}\text { Proprle- } \\
\text { tors and } \\
\text { Inde- } \\
\text { pendent } \\
\text { fisher- } \\
\text { mon. }\end{array}$ & $\begin{array}{l}\text { Sala- } \\
\text { ried } \\
\text { em- } \\
\text { ployees. }\end{array}$ & $\begin{array}{l}\text { Wage- } \\
\text { earn- } \\
\text { ers. }\end{array}$ & Total. & $\begin{array}{l}\text { Sala- } \\
\text { ries. }\end{array}$ & Wages. \\
\hline Total....... & 1,780 & 11,063 & 5 & 712 & $\$ 190,000$ & 87,100 & $2 \$ 183,000$ \\
\hline $\begin{array}{l}\text { Vessel fisheries.... } \\
\text { ghore and bost } \\
\text { fisheries.......... } \\
\text { Shoresmen....... }\end{array}$ & $\begin{array}{r}407 \\
1,313 \\
60\end{array}$ & $\begin{array}{r}163 \\
900 \\
9 . \ldots .\end{array}$ & $\ldots \ldots \ldots$ & $\begin{array}{r}239 \\
413 \\
60\end{array}$ & $\begin{array}{r}71,000 \\
110,000 \\
9,500\end{array}$ & $\begin{array}{l}7,100 \\
\ldots \ldots \\
\cdots \ldots\end{array}$ & $\begin{array}{r}64,000 \\
110,000 \\
9,500\end{array}$ \\
\hline
\end{tabular}

1 Excluslve of two proprietors not fishing.

Includes provisions furnished to the value of $\$ 41,000$

Includes three persons employed on a vessel engaged In transporting.

Of the shoresmen, 37 were employed in the vessel - fisheries and the remaining 23 in the shore and bont fisheries. The total number of persons connected with the ressel fisheries, therefore, was 444 , and the total number connected with the shore and boat fisheries 1,336 . It is apparent that in the shore and boat fisheries more than one-half of those classed as "Proprietors and independent fishermen "were independent fishermen.

Equipment and other capital.--In the following tabular statement statisties are given as to the equipment and the other capital employed in the fisheries of Texas:

\begin{tabular}{|c|c|c|c|}
\hline \multirow{2}{*}{ CLASS OF INVESTMENT. } & \multicolumn{3}{|c|}{$\begin{array}{l}\text { RQUIPMENT AND OTHER CAPITAL: } \\
1908 .\end{array}$} \\
\hline & Value. & Number. & Tonnage. \\
\hline 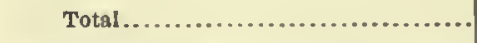 & $\$ 454,000$ & & \\
\hline Vessels (flshing), Iracluding outfit .... & 269,000 & 157 & 1,538 \\
\hline Steam and motor ${ }^{1} \ldots \ldots \ldots \ldots$. & 47,000 & 48 & 349 \\
\hline $\begin{array}{l}\text { Vessels } \ldots \ldots \ldots \ldots \ldots \ldots \ldots \\
\text { Outfit }\end{array}$ & 39,000 & ( $\ldots \ldots \ldots \ldots$ & (n........... \\
\hline $\begin{array}{l}\text { Outfit } \ldots \ldots \ldots \ldots \ldots \ldots \\
\text { Sall } \ldots \ldots \ldots \ldots\end{array}$ & $\begin{array}{r}8,300 \\
222,000\end{array}$ & $\cdots$ & i,is9 \\
\hline 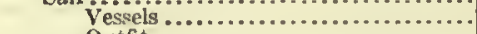 & 181,000 & $\ldots$ & $\ldots . . .$. \\
\hline 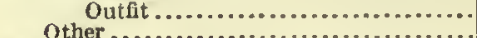 & 41,000 & & (.......... \\
\hline 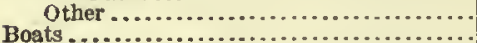 & $\begin{array}{r}900 \\
117,000\end{array}$ & $\begin{array}{r}36 \\
991\end{array}$ & $\ldots \ldots \ldots \cdots \cdots$ \\
\hline 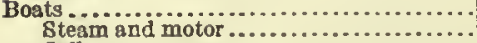 & $\begin{array}{r}117,000 \\
39,000\end{array}$ & $\begin{array}{c}991 \\
97\end{array}$ & 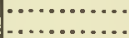 \\
\hline Sall ................................................. & 70,000 & 268 & \\
\hline 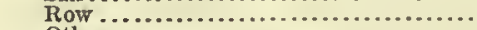 & 7,300 & 594 & ........... \\
\hline other................................... & 1,100 & 32 & ........... \\
\hline Apparatus of capture ...................... & 41,000 & … & \\
\hline $\begin{array}{l}\text { Vessel fisheries } \ldots \ldots \ldots \ldots \ldots \ldots \ldots \\
\text { Shore and bost fisheries }\end{array}$ & 7,100 & -..... & (.......... \\
\hline $\begin{array}{l}\text { Shore and boat fisherles ....................... } \\
\text { Shore and accessory property............... }\end{array}$ & $\begin{array}{r}34,000 \\
7,400\end{array}$ & $\because \ldots .$. & a....... \\
\hline 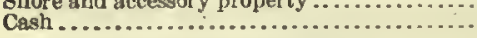 & 19,000 & & \\
\hline
\end{tabular}

1 Includes one vessel of six tons engaged in transporting.

Of the total investment in the Texas fisheries, the value of the various kinds of craft, including the outfits, formed 85 per cent, and of this portion over twothirds represented the value of vessels. The value of the apparatus of eapture used in the shore and boat fisheries was nearly five times as great as that of the apparatus used in the vessel fisheries. Cf the investment in shore and accessory property, $\$ 4,000$ was reported for the vessel fisheries and $\$ 3,500$ for the shore and boat fisheries, while practically all the eash was reported for the ressel fisheries. The total investment in the shore and boat fisheries was $\$ 155,000$, and that in the vessel fisheries $\$ 299,000$. Nets and seines were the most important form of apparatus. The numbers of the more important kinds of apparatus reported, all of which, with the exception of 38 seines, were used in the shore and boat fisheries, were as follows:

Cast nets................................ 332

Dip nets................................... 69

Firearms, guns, etc........................... 137

Fyke nets............................. 455

Gill nets ................................ 219

Mink traps................................. $\quad 30$

Seines.................................... 298

Trammel nets ............................... 19

Turtle nets. ................................. 1

Products, by species. - Table 1, on page 249, gives the fishery products of the state, by species and by apparatus of eapture. A large variety of species are represented in the catch of this state, chief among which are oysters, red snapper, squeteague, and channel bass, or redfish. Theso products together contributed 75 per cent of the value of all fishery products taken in the state, oysters alone representing $3 \mathrm{~s}$ per cent of the value. The only species in the eatch of which Texas led all other states was jewfish.

Products, by class of fisheries.-Table 2, on page 250, gives the products of the vessel fisheries, by species and by apparatus of capture, while Table 3 , on page 250 , gives similar statisties for the shore and boat fisheries. The following tabular statement gives tho distribution, by species, of the total value of products for the fisheries of the state as a whole and for each class of fisheries. Only products for which a total value in excess of $\$ 5,000$ was reported are shown separately.

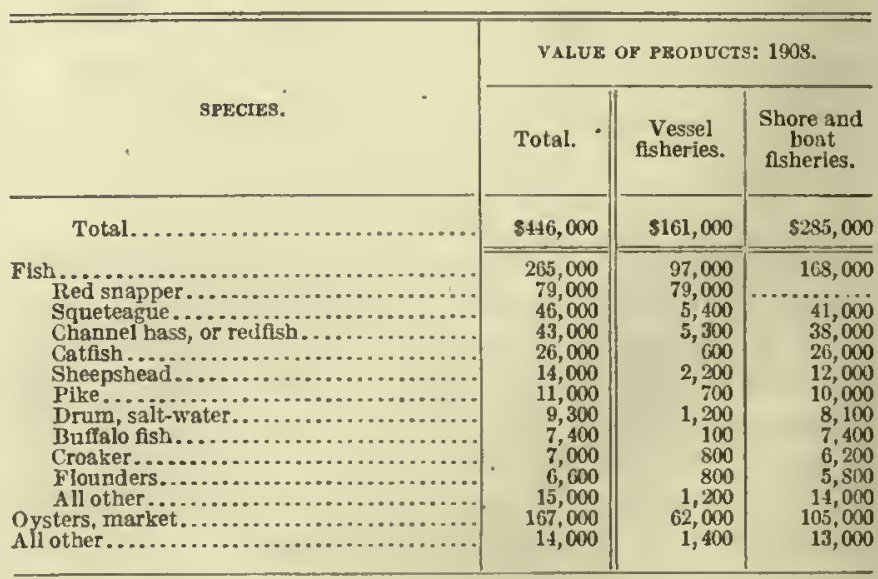

The vessel fisheries took prorluets which represented 36 per cent of the value and a slightly larger pereentage of the weight of the total fishery product. The red snapper ranked first in value among the products of the vessel fisheries, its value forming 49 per cent 
of the total value of products of this class of fisheries, while market oysters ranked second, contributing 39 per cent of the total.

The shore and boat fisheries contributed 64 per cent of the total value of the fishery product of the state and 62 per cent of the total quantity. With the exception of red snapper, every species which entered into the state product was included in the catch of this branch of the fisheries. Oysters were the leading species, their value forming 37 per cent of the value of all shoro and boat products. Squeteague, channel bass, and catfish were the leading species of fish proper reported by the shore and boat fisheries, and comprised 36 per cent of the quantity and furnished 37 per cent of the value of the total product of this class of fisheries. The remainder of the product is evenly distributed.

Products, by apparatus of capture.-The distribution by apparatus of capiure of the value of the products for the state as a whole and for each class of fisheries is shown in the following tabular statement:

\begin{tabular}{|c|c|c|c|}
\hline \multirow[b]{2}{*}{ KIND OF APPARATUS. } & \multicolumn{3}{|c|}{ VALUE OF PRODUCTS: 1908.} \\
\hline & Total. & $\begin{array}{l}\text { Vessel } \\
\text { fisheries. }\end{array}$ & $\begin{array}{l}\text { Shore and } \\
\text { boat } \\
\text { fisheries. }\end{array}$ \\
\hline Total............ & $\$ 446,000$ & $\$ 161,000$ & $\$ 285,000$ \\
\hline 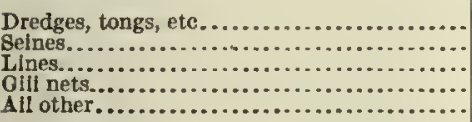 & $\begin{array}{r}167,000 \\
153,000 \\
101,000 \\
7,000 \\
18,000\end{array}$ & $\begin{array}{r}63,000 \\
18,000 \\
80,000 \\
200\end{array}$ & $\begin{array}{r}105,000 \\
135,000 \\
21,000 \\
7,000 \\
17,000\end{array}$ \\
\hline
\end{tabular}

Dredges, tongs, etc., were used exclusively in the oyster industry. Though ranking first with respect to value of catch in the state as a whole, contributing 37 per cent of the total value of products, this class of apparatus ranked second in importance for each class of fisheries, being surpassed in the vessel fisheries by lines and in the shore and boat fisheries by seines. The products taken with seines, which represented 34 per cent of the total value of products for the state, included almost every species taken. The value of squeteague and channel bass constituted over onehalf of the total value of the seine eatch. The value of the catch by lines, which ranked third in importance, formed 23 per cent of the total value of the fishery products of the state. Practically all of the catch in the vessel fisheries was made by lines, dredges, tongs, etc., and seines. The value of the line catch, which consisted chiefly of red snapper, formed 50 per cent of the total value of products for this class of fisheries; that of the catch with dredges, tongs, etc., 39 per cent; and that of the seine catch, 11 per cent. In the shore and hoat fisheries the value of the catch with seines represented 47 per cent, and the value of tho catch with dredges, tongs, etc., 37 per cent of the total value of the catch. Lines rauked third in this class of fisheries, half of the catch with this form of àpparatus being composed of catfish.
Oysters.-The yield of market oysters aggregated 490,000 bushels, with a value of $\$ 167,000$. Of the total quantity, 6.3 per cent was reported for the shore and boat fisheries and 37 per cent for the vessel fisheries. The bulk of the catch was from public areas, only 3,400 bushels, valued at $\$ 1,200$, being from private areas. The entire product reported from private areas was credited to the shore and boat fisheries. The seed oyster product was small, 5,700 bushels, valued at $\$ 400$, being taken from public areas in the vessel fisheries, and 1,800 bushels, valued at $\$ 200$, from public areas in the shore and boat fisheries. The value of the oyster product formed about the same proportion of the total value of products in the two classes of fisheries, the percentages being 37 for the shore and boat fisheries and 39 for the vessel fisheries. The average price per bushel for market oysters was 34 cents. The oyster product for a series of years is shown in the following tabular statement:

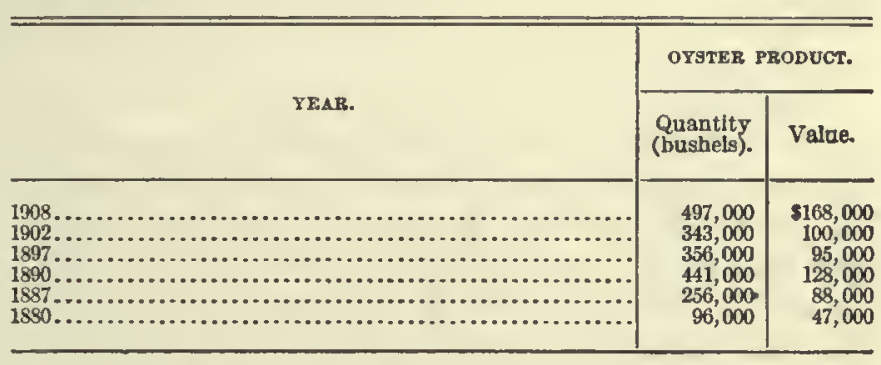

The increase in the oyster yield accounts for a large part of the gain made by the fisheries of the state since 1902 and during previous years. The variations in the fishery products, which are shown in the tabular statement on page 245 , conform in general to the fluctuations in the oyster product.

Red snapper.-The value of the red-snapper catch formed nearly 30 per cent of that of all fish proper, while the weight formed 34 per cent of the total weight. This species was taken entirely with lines and wholly in the vessel fisheries. Its value formed 49 per cent of the value of the entire catch of the vessel fisheries and 81 per cent of the value of all fish proper taken in these fisheries. The growth of the red-snapper fishery since 1890 has been remarkable. In 1902 the value of the catch exceeded that of oysters, but an increase in yield has been accompanied by a decrease in value, while in the case of oysters the value increased at a higher rate than the quantity. The following tabular statement gives statistics of the catch for those years for which figures are available:

YEAR.
$\ldots$


Salt-water drum.-Salt-water drum, channel bass, or redfish, represented 12 per cent of the value of the total product, 4 per cent of the value of the vessel product, and 16 per cent of the value of the shore and boat product. Of the total quantity, 92 per cent was from shore and boat fishcries. Seines took 93 per cent of the product, and over one-half of the remainder was taken with lines. Although the eatch of this product in 1908 was the largest ever reported, the value was the same as in 1897, as the following tabular statement shows:

\begin{tabular}{|c|c|c|}
\hline \multirow{2}{*}{ TEAR. } & \multicolumn{2}{|c|}{$\begin{array}{l}\text { SALT-WATER DRUM, } \\
\text { CHANNEL BASS, OR } \\
\text { REDFTSH PRODUCT. }\end{array}$} \\
\hline & $\begin{array}{l}\text { Quantity } \\
\text { (pounds). }\end{array}$ & Value. \\
\hline 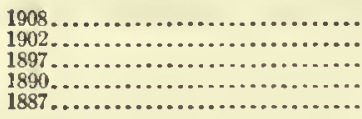 & $\begin{array}{l}1,309,000 \\
1,056,000 \\
1,144,000 \\
1,112,000 \\
1,005,000\end{array}$ & $\begin{array}{r}\$ 52,000 \\
43,000 \\
52,000 \\
48,000 \\
38,000\end{array}$ \\
\hline
\end{tabular}

Squeteague.-The value of squeteague, or sea trout, formed 10 per cent of the value of all fishery products. Though ranking fourth in value among the products in the vessel fisheries, the species represented only 3 per cent of the total value of products of this class of fisheries. In the shore and boat fisheries the value of this fish formed 14 per cent of the value of all products and ranked first among fish proper. Of the total squeteague catch, 90 per cent was reported for the shore and boat fisheries. Seines are credited with 92 per cent of the total quantity and lines with threc- fifths of the remainder. The catch of this fish has been fairly constant for the several years for which statistics are available, as will appear from the following tabular statement:

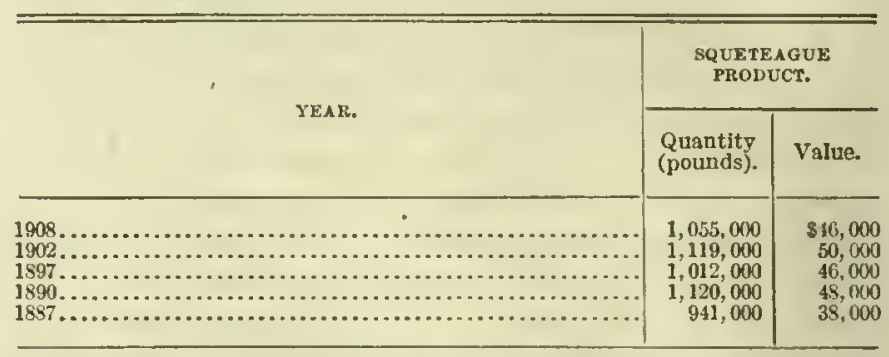

Catfish.-The value of catfish constituted 6 per cent of the total value of the products of the Texas fishcries. This species was caught almost entirely in the shore and boat fisheries, and the value of the catch comprised 9 per cent of the value of products for this class of fisheries. Something less than one-half of the product was taken with seines, while the remainder was taken chiefly with lines. The catch of catfish shows a large increase since 1902, as will be scen from the following tabular statement:

\begin{tabular}{|c|c|c|}
\hline \multirow[b]{2}{*}{ YEAR. } & \multicolumn{2}{|c|}{ CATFISH PRODUCT. } \\
\hline & $\begin{array}{l}\text { Quantity } \\
\text { (pounds). }\end{array}$ & Value. \\
\hline 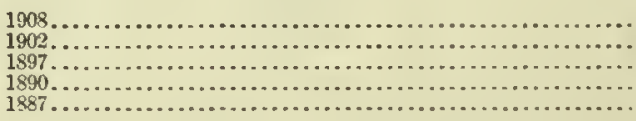 & $\begin{array}{r}560,000 \\
75,000 \\
71,000 \\
45,000 \\
47,000\end{array}$ & $\begin{array}{r}\$ 26,000 \\
3,200 \\
3,000 \\
2,100 \\
2,500\end{array}$ \\
\hline
\end{tabular}


FISHERIES, BY STATES.

TABLE 1.-TEXAS-FISHERY PRODUCTS: 1908.

\begin{tabular}{|c|c|c|c|c|c|c|c|c|c|c|c|c|c|c|}
\hline \multirow{3}{*}{ SPECIES. } & \multirow{2}{*}{\multicolumn{2}{|c|}{ TOTAL. }} & \multicolumn{12}{|c|}{ PRODUCT CAUGHT BY- } \\
\hline & & & \multicolumn{2}{|c|}{ Seines. } & \multicolumn{2}{|c|}{ Lines. } & \multicolumn{2}{|c|}{ Gill nets. } & \multicolumn{2}{|c|}{ Trammel nets. } & \multicolumn{2}{|c|}{ Cast nets. } & \multicolumn{2}{|c|}{$\begin{array}{l}\text { All other appa- } \\
\text { ratus.t }\end{array}$} \\
\hline & $\begin{array}{l}\text { Quantity } \\
\text { (pounds). }\end{array}$ & Value. & $\begin{array}{l}\text { Quantity } \\
\text { (pounds). }\end{array}$ & Value. & $\begin{array}{l}\text { Quantity } \\
\text { (pounds). }\end{array}$ & Value. & $\begin{array}{l}\text { Quantity } \\
\text { (pounds). }\end{array}$ & Value. & $\begin{array}{l}\text { Quantity } \\
\text { (pounds). }\end{array}$ & Value. & $\begin{array}{l}\text { Quantity } \\
\text { (pounds). }\end{array}$ & Value. & $\begin{array}{l}\text { Quantity } \\
\text { (pounds). }\end{array}$ & Value. \\
\hline Total. . & $10,439,000$ & $\$ 446,000$ & $3,655,000$ & $\$ 153,000$ & $2,712,000$ & $\$ 101,000$ & 151,000 & 87,000 & 79,000 & 84,000 & 87,000 & $\$ 3,200$ & $3.755,000$ & $\$ 178,000$ \\
\hline 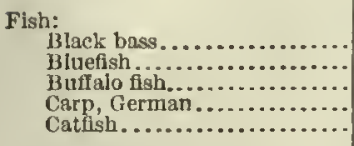 & $\begin{array}{r}17,000 \\
9,700 \\
240,000 \\
2,200 \\
560,000\end{array}$ & $\begin{array}{r}1,200 \\
500 \\
7,400 \\
100 \\
26,000\end{array}$ & $\begin{array}{r}1,500 \\
9,700 \\
131,000 \\
400 \\
259,000\end{array}$ & $\begin{array}{r}200 \\
500 \\
4,100 \\
(3) \\
12,000\end{array}$ & $\begin{array}{r}5,000 \\
32,000 \\
1,300 \\
219,000\end{array}$ & $\begin{array}{r}400 \\
1,700 \\
100 \\
11,000\end{array}$ & $\begin{array}{r}5,200 \\
\cdots \ddot{15}, 000 \\
\cdots \\
3 \overline{3}, 000\end{array}$ & $\ddot{1,700}$ & $\begin{array}{r}5,000 \\
21,000 \\
400 \\
17,000\end{array}$ & $\begin{array}{c}600 \\
(2) \\
800\end{array}$ & & (n.... & $\ddot{41,000}$ & $\ddot{1, i 00}$ \\
\hline 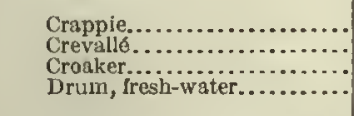 & $\begin{array}{r}40,000 \\
19,000 \\
159,000 \\
13,000\end{array}$ & $\begin{array}{r}2,800 \\
800 \\
7,000 \\
700\end{array}$ & $\begin{array}{r}25,000 \\
18,000 \\
152,000 \\
6,000\end{array}$ & $\begin{array}{r}1,800 \\
800 \\
6,600 \\
400\end{array}$ & $\begin{array}{r}2,100 \\
300 \\
2,700 \\
2,600\end{array}$ & $\begin{array}{l}200 \\
200 \\
100\end{array}$ & $\begin{array}{l}100 \\
3,800 \\
3,000\end{array}$ & $\begin{array}{l}(2)^{200} \\
200\end{array}$ & $\begin{array}{r}13,000 \\
500 \\
700\end{array}$ & $\begin{array}{l}900 \\
\cdots \cdots \\
(2)\end{array}$ & 100 & (2) & 1,000 & $\cdots \cdots$ \\
\hline 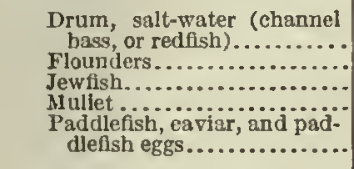 & $\begin{array}{r}1,309,000 \\
140,000 \\
46,000 \\
20,000 \\
33,000\end{array}$ & $\begin{array}{r}52,000 \\
6,600 \\
1,300 \\
900\end{array}$ & $\begin{array}{r}1,215,000 \\
106,000 \\
8,800 \\
17,000 \\
21,000\end{array}$ & $\begin{array}{r}48,000 \\
4,700 \\
300 \\
800\end{array}$ & $\begin{array}{r}51,000 \\
600 \\
37,000 \\
\cdots\end{array}$ & $\begin{array}{l}2,600 \\
(8) \\
1,100 \\
\cdots\end{array}$ & $\begin{array}{r}33,000 \\
2,600 \\
3,000 \\
12,000\end{array}$ & $\begin{array}{r}1,300 \\
100 \\
200 \\
400\end{array}$ & $\begin{array}{r}11,000 \\
700\end{array}$ & $\left(^{700}\right.$ & 300 & $\dddot{(3)}$ & ${ }_{30,000}^{(3)}$ & $\begin{array}{l}\text { (2) } \\
1,700 \\
\cdots \cdots\end{array}$ \\
\hline 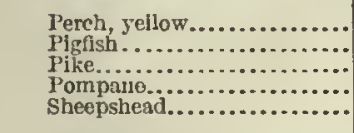 & $\begin{array}{r}1,800 \\
2,600 \\
305,000 \\
18,000 \\
298,000\end{array}$ & $\begin{array}{r}100 \\
100 \\
11,000 \\
1,100 \\
14,000\end{array}$ & $\begin{array}{r}1,100 \\
2,000 \\
304,000 \\
17,000 \\
271,000\end{array}$ & $\begin{array}{r}100 \\
100 \\
11,000 \\
1,000 \\
13,000\end{array}$ & $\begin{array}{r}700 \\
400 \\
200 \\
100 \\
15,000\end{array}$ & $\begin{array}{l}(2) \\
(2) \\
(2) \\
(2) \\
900\end{array}$ & $\begin{array}{r}1,400 \\
600 \\
6,500\end{array}$ & $\begin{array}{l}1000 \\
(2) \\
300\end{array}$ & $\begin{array}{l}(2) \\
2,500\end{array}$ & ${ }_{300}^{(3)}$ & 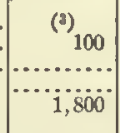 & 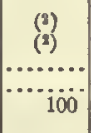 & 200 & $\begin{array}{l}\cdots \cdots \\
\cdots \cdots \cdots \\
\cdots \cdots \\
\cdots(\text { (j) }\end{array}$ \\
\hline 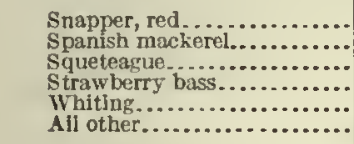 & $\begin{array}{r}2,252,000 \\
42,000 \\
1,055,000 \\
700 \\
9,900 \\
4,900\end{array}$ & $\begin{array}{r}79,000 \\
3,400 \\
46,000 \\
100 \\
500 \\
200\end{array}$ & $\begin{array}{r}18,000 \\
968,000 \\
700 \\
6,300 \\
4,400\end{array}$ & $\begin{array}{r}1,400 \\
42,000 \\
100 \\
300 \\
100\end{array}$ & $\begin{array}{r}2,252,000 \\
24,000 \\
52,000 \\
3,300 \\
200\end{array}$ & $\begin{array}{r}79,000 \\
1,800 \\
2,700 \\
2000 \\
20\end{array}$ & $\mid \begin{array}{r}900 \\
28,000 \\
\cdots \\
\cdots\end{array}$ & $\begin{array}{r}1000 \\
1,400 \\
\cdots \\
\cdots\end{array}$ & $\begin{array}{r}300 \\
6,500 \\
\cdots \\
\cdots\end{array}$ & $\begin{array}{c}\begin{array}{c}(2) \\
400 \\
\cdots\end{array} \\
\cdots \cdots \\
\cdots\end{array}$ & ${ }^{(3)} 100$ & (i) & $\cdots \cdots \cdots$ & $\begin{array}{l}(3)^{\prime} \\
\cdots \cdots\end{array}$ \\
\hline 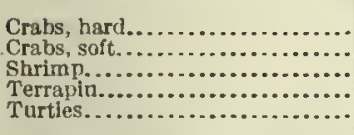 & $\begin{array}{r}199,000 \\
600 \\
118,000 \\
15,000 \\
20,000\end{array}$ & $\begin{array}{l}4,500 \\
200 \\
4,400 \\
1,600 \\
1,000\end{array}$ & $\begin{array}{l}17,000 \\
(3) \\
42,000 \\
15,000 \\
19,000\end{array}$ & $\begin{array}{l}400 \\
(2)^{400} \\
1,600 \\
1,400 \\
900\end{array}$ & $\begin{array}{c}11,000 \\
100 \\
(3)^{3} \\
500\end{array}$ & $\begin{array}{l}300 \\
100 \\
(2)^{2} \\
(2)\end{array}$ & $(3)$ & (a) & 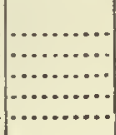 & $\mid \begin{array}{ll}\cdots \\
\cdots \cdots \cdots \\
\cdots \cdots \cdots \\
\cdots \cdots \cdots \\
\cdots \cdots\end{array}$ & $\begin{array}{r}7,100 \\
(8) \\
77,000 \\
\cdots \ldots \ldots \ldots \ldots\end{array}$ & $\begin{array}{c}200 \\
(2) \\
2,800 \\
\ldots \ldots \ldots \\
\ldots \ldots \ldots\end{array}$ & $\begin{array}{r}164,000 \\
500 \\
\ldots . . . \\
400 \\
600\end{array}$ & 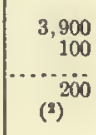 \\
\hline 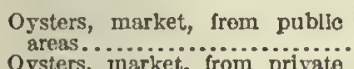 & $43,404,000$ & 166,000 & & & & & & & & & & & $43,404,000$ & 166,000 \\
\hline 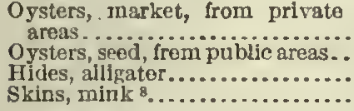 & $\begin{array}{l}524,000 \\
552,000 \\
77,000 \\
\text { (d) }\end{array}$ & $\begin{array}{r}1,200 \\
600 \\
1,400 \\
(2)\end{array}$ & $(3)$ & $(i)$ & & & & & & & & & $\begin{array}{l}24,000 \\
852,000 \\
77,000 \\
(3)\end{array}$ & $\begin{array}{l}1,200 \\
600 \\
1,400 \\
(3)\end{array}$ \\
\hline
\end{tabular}

1 Includes apparatus, with catch, as follows: Dredges, tengs, etc., $3,468,000$ pounds, valned at $\$ 167,000 ;$ dip nets, 164,000 ponnds, ralued at \$4,000; fyke, hoop, and

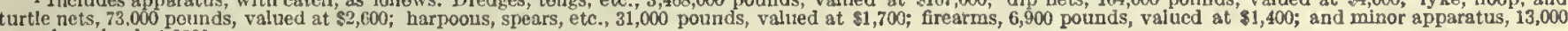
pounds, valued at $\$ 800$. 
TABLE 2.-TEXAS-PRODUCTS OF VESSEL FISHERIES: 1908.

\begin{tabular}{|c|c|c|c|c|c|c|c|c|c|c|}
\hline \multirow{3}{*}{ APECIES. } & \multirow{2}{*}{\multicolumn{2}{|c|}{ TOTAL. }} & \multicolumn{8}{|c|}{ PRODUCT CAUGHT DY- } \\
\hline & & & \multicolumn{2}{|c|}{ Lines. } & \multicolumn{2}{|c|}{ Dredges, tongs, etc. } & \multicolumn{2}{|c|}{ Seines. } & \multicolumn{2}{|c|}{ Harpoons, spears, etc. } \\
\hline & $\begin{array}{l}\text { Quantily } \\
\text { (pounds). }\end{array}$ & Valne. & $\begin{array}{l}\text { Qnantlty } \\
\text { (pounds). }\end{array}$ & Value. & $\begin{array}{l}\text { Qnanlity } \\
\text { (pounds). }\end{array}$ & Value. & $\begin{array}{l}\text { Quantity } \\
\text { (pounds). }\end{array}$ & Valtue. & $\begin{array}{l}\text { Quantity } \\
\text { (pounds). }\end{array}$ & Valne. \\
\hline Total....... & $3,945,000$ & $\$ 161,000$ & $2,297,000$ & $\$ 80,000$ & $1,308,000$ & $\$ 63,000$ & 335,000 & $\$ 18,000$ & 4,900 & $\$ 200$ \\
\hline 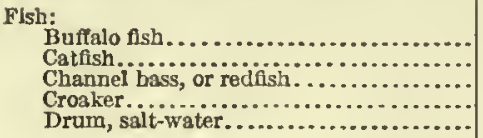 & $\begin{array}{r}1,800 \\
14,000 \\
68,000 \\
16,000 \\
36,000\end{array}$ & $\begin{array}{r}100 \\
600 \\
5,300 \\
800 \\
1,200\end{array}$ & $\begin{array}{r}600 \\
4,300 \\
400\end{array}$ & (i) & & & $\begin{array}{r}1,800 \\
13,000 \\
64,000 \\
16,000 \\
35,000\end{array}$ & $\begin{array}{r}100 \\
600 \\
5,100 \\
800 \\
1,200\end{array}$ & & $\begin{array}{l}\cdots \cdots \\
\cdots \cdots \\
\cdots \cdots\end{array}$ \\
\hline 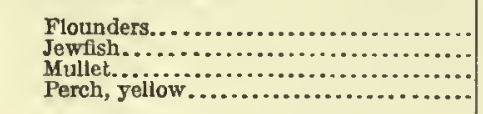 & $\begin{array}{r}17,000 \\
29,000 \\
1,300 \\
1,100\end{array}$ & $\begin{array}{l}800 \\
600 \\
100 \\
100\end{array}$ & $\begin{array}{r}100 \\
29,000\end{array}$ & ${ }^{(b)}{ }_{600}$ & & & $\begin{array}{r}12,000 \\
600 \\
1,300 \\
1,100\end{array}$ & $\begin{array}{l}600 \\
(1)^{100} \\
100\end{array}$ & 4,800 & 200 \\
\hline 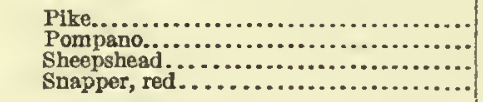 & $\begin{array}{r}16,000 \\
3,900 \\
47,000 \\
2,252,000\end{array}$ & $\begin{array}{r}700 \\
300 \\
2,200 \\
79,000\end{array}$ & $2,252,000$ & $\begin{array}{l}\cdots(1) \cdots \\
79,000\end{array}$ & & & $\begin{array}{r}16,000 \\
3,900 \\
47,000\end{array}$ & $\begin{array}{r}700 \\
300 \\
2,200\end{array}$ & & $\begin{array}{l}\ldots . . \\
\ldots . .\end{array}$ \\
\hline 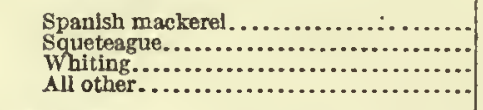 & $\begin{array}{r}2,100 \\
107,000 \\
2,300 \\
300\end{array}$ & $\begin{array}{r}200 \\
5,400 \\
100 \\
(1)\end{array}$ & 3,900 & 200 & & & $\begin{array}{r}2,100 \\
103,000 \\
2,300 \\
300\end{array}$ & $\begin{array}{l}200 \\
5,200 \\
100 \\
(1)\end{array}$ & & $\begin{array}{l}\because \\
\ddot{.}\end{array}$ \\
\hline 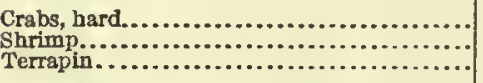 & $\begin{array}{l}7,400 \\
7,900 \\
4,000\end{array}$ & $\begin{array}{l}200 \\
400 \\
300\end{array}$ & 7,000 & 200 & 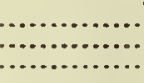 & 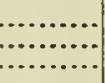 & $\begin{array}{r}400 \\
7,900 \\
4,000\end{array}$ & $\begin{array}{l}(1) \\
400 \\
300\end{array}$ & ……...... & $\ldots$ \\
\hline 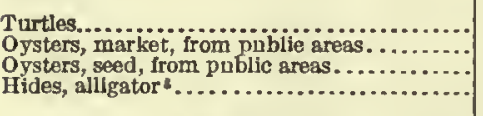 & $\begin{array}{r}2,000 \\
21,269,000 \\
840,000 \\
100\end{array}$ & $\begin{array}{r}100 \\
62,000 \\
400 \\
(1)\end{array}$ & 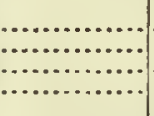 & & $\because 1,269,000$ & $\begin{array}{r}62,000 \\
400\end{array}$ & $\begin{array}{r}2,000 \\
\cdots \cdots \cdots \\
\hdashline(4)^{\cdots \cdots}\end{array}$ & $\begin{array}{r}100 \\
\cdots \ldots . . . \\
(1)^{\cdots}\end{array}$ & (i) & (i) \\
\hline
\end{tabular}

TABLE 3.-TEXAS-PRODUCTS OF SHORE AND BOAT FISIIERIES: 1908.

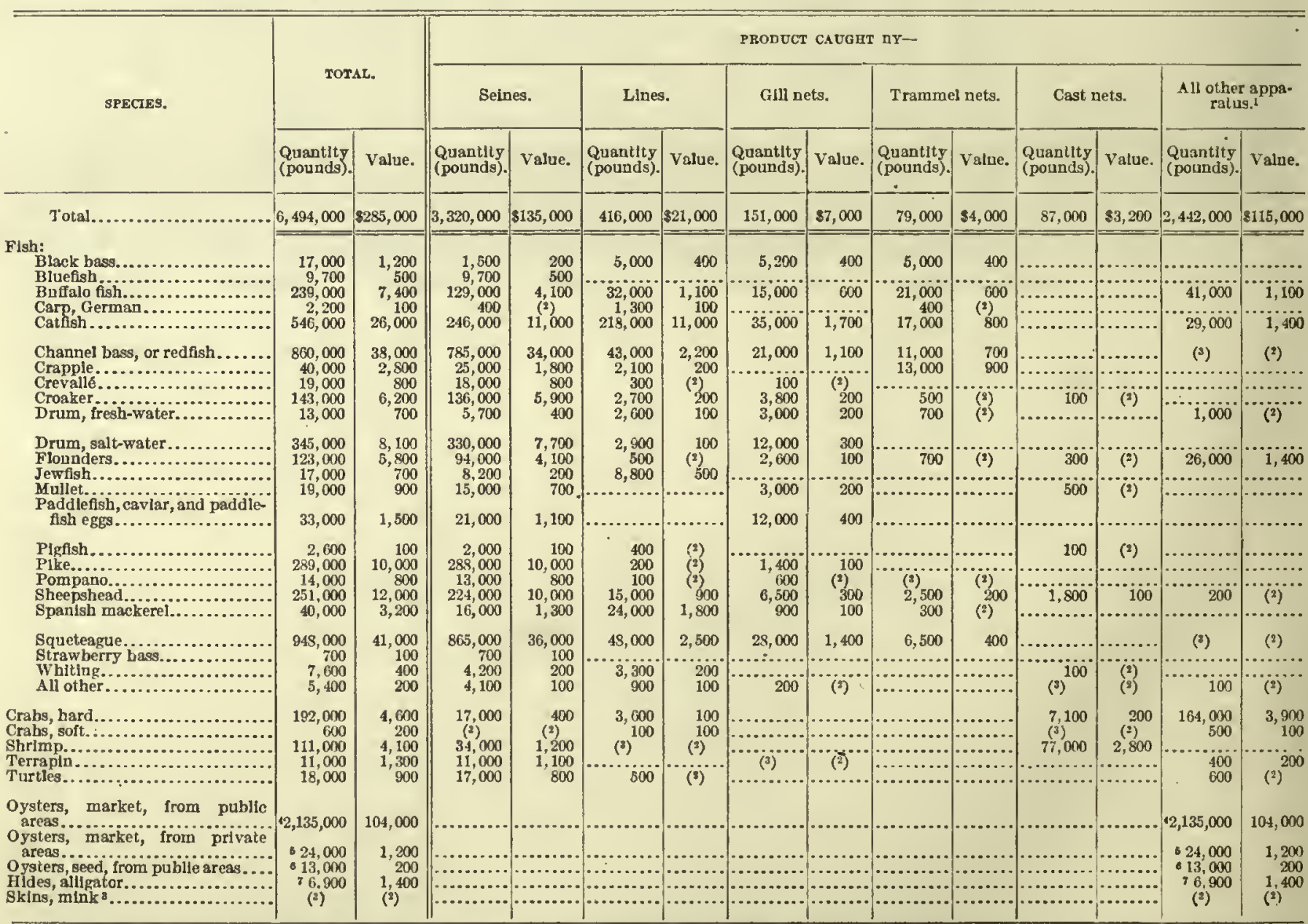

Includes apparatus, with catch, as follows: Dredges, tongs, cle., 2,100,000 pounds, valued at $\$ 105,000 ;$ dip nets, 164,000 pounds, valued at $\$ 4,000 ;$ f $y$ ke, hoop, and turtle

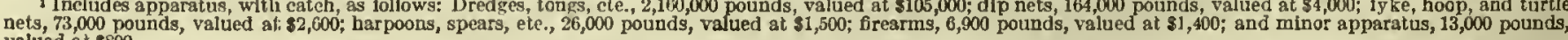
valued at $\$ 800$ 


\section{VIRGINIA.}

In the total value of fishery products Virginia had second place in 1908 among the states in which commercial fisheries were carried on, and in the value of its shad, menhaden, alewife, croaker, caviar, sturgeon, crab, and hard-clam products it ranked first. The taking of oysters was the most important branch of the fishing industry of the state, the product being valued at $\$ 2,348,000$. The shad and menhaden products ranked next in importance, each being valued at between four and five hundred thousand dollars, while clams and crabs followed in rank, the product of each having a value in excess of $\$ 300,000$. Though fisleries are conducted at nearly every available point along the Atlantic coast from North Carolina to the Maryland line, the most important fisheries of the state are in the waters of Chesapeake Bay and its tributaries. This latter district covers an extensive area, comprising not only the waters of Chesapeake Bay, but also Tangier and Pocomoke Sounds and the tidal waters of the Potomac, Wicomico, Rappahannock, York, and James Rivers.

The following statement gives a general summary of the statisties of the industry in Virginia in 1908:

Number of persons employed............... 20,066 Capital:

Vesscls and boats, including outfit. ...........\$2,065, 000

Apparatus of capture.................. $\quad 485,000$

Shore and accessory property and cash....... 434,000

Value of products..................... 4,716,000

Comparison with previous canvasses.-Comparative statistics for years for which figures are available are given in the next tabular statement.

In the total value of equipment and in the quantity of products increases are shown at each canvass from 1891 to 1904 . The value of the product in 1904 was 76 per cent greater than that in 1897 . The figures for
1908, however, show a decrease in every item as compared with the figures for the preceding canvass. In 1908 there were 3,298 fower persons employed, exclusive of shoresmen, than in 1904, a decrease of 14 per cent. The decline in the total value of equipment was $\$ 95,000$, or only 4 per cent. The value reported for fishing and transporting vessels, including outfits, decreased from $\$ 1,502,000$ in 1904 to $\$ 1,332,000$ in 1908 , but as the value of boats increased during the same years from $\$ 591,000$ in 1904 to $\$ 733,000$ in 1008 , the total amount of capital represented by vessels, including outfits and boats, changed very little, namely, from $\$ 2,093,000$ in 1904 to $\$ 2,065,000$ in 1908 , The increase in the number of motor boats has been marked, 1,066 power boats being reported in 1908, as compared with only 38 in 1904 . The value of apparatus of capture decreased $\$ 67,000$, or 12 per cent, while the products showed a decrease from 1904 to 1908 of 16 per cent in value and 12 per cent in quantity.

\begin{tabular}{|c|c|c|c|c|c|c|}
\hline \multirow[b]{2}{*}{ YEAR. } & \multirow{2}{*}{$\begin{array}{l}\text { Persons } \\
\text { em- } \\
\text { ployed, } \\
\text { excluslve } \\
\text { of shores- } \\
\text { men. }\end{array}$} & \multicolumn{3}{|c|}{ TALUE OF EQUTPMENT. } & \multicolumn{2}{|c|}{ PRODUCTs. } \\
\hline & & Total. & $\begin{array}{l}\text { Vessels } \\
\text { and boats, } \\
\text { including } \\
\text { outtit. }\end{array}$ & $\begin{array}{l}\text { Appara- } \\
\text { tus of } \\
\text { capture. }\end{array}$ & $\begin{array}{l}\text { Quantity } \\
\text { (pounds). }\end{array}$ & Value. \\
\hline $\begin{array}{l}1908 \ldots \ldots . \\
1904 \ldots \ldots \ldots \\
1897 \ldots \ldots \ldots \\
1891 \ldots \ldots \ldots \\
1890 \ldots \ldots\end{array}$ & $\begin{array}{l}19,905 \\
23,203 \\
24,252 \\
20,316 \\
16,051\end{array}$ & $\begin{array}{r}\$ 2,550 ; 000 \\
2,645,000 \\
1,859,000 \\
1,763,000 \\
1,424,000\end{array}$ & $\begin{array}{r}\$ 2,065,000 \\
2,093,000 \\
1,408,000 \\
1,403,000 \\
1864,000\end{array}$ & $\begin{array}{r}\$ 485,000 \\
552,000 \\
451,000 \\
361,000 \\
2561,000\end{array}$ & $\begin{array}{l}312,515,000 \\
355,316,000 \\
277,994,000 \\
183,994,000 \\
158,875,000\end{array}$ & $\begin{array}{r}\$ 4,716,000 \\
5,584,000 \\
3,179,000 \\
3,648,000 \\
3,124,000\end{array}$ \\
\hline
\end{tabular}

Persons employed.-In 1908 the fisheries of Virginia gave employment to 20,066 persons. The number of persons employed has gradually declined since 1897 , when it was larger than in any other year for which statistics are available.

The following tablo presents statistics relating to persons employed in 1908:

\begin{tabular}{|c|c|c|c|c|c|c|c|}
\hline \multirow{3}{*}{ DISTRICT AND CLASS. } & \multicolumn{7}{|c|}{ PERSONS EMPLOYED: 1908.} \\
\hline & \multicolumn{4}{|c|}{ Number. } & \multicolumn{3}{|c|}{ Salarles and wages. } \\
\hline & Total. & $\begin{array}{l}\text { Proprietors } \\
\text { and inde- } \\
\text { pendent } \\
\text { ishermen. }\end{array}$ & $\begin{array}{l}\text { Salaried } \\
\text { employees. }\end{array}$ & $\begin{array}{l}\text { Wage- } \\
\text { earners. }\end{array}$ & Total. & Salaries. & Wages. \\
\hline Total...................... & 20,066 & 110,324 & 29 & 9,713 & $\$ 1,316,000$ & $\$ 21,000$ & $3 \$ 1,295,000$ \\
\hline 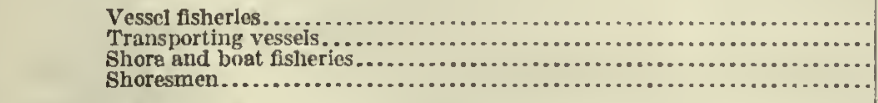 & $\begin{array}{r}3,138 \\
1,133 \\
15,584 \\
161\end{array}$ & $\begin{array}{r}639 \\
343 \\
9,342 \\
\end{array}$ & $\begin{array}{r}15 \\
3 \\
11 \\
\cdots\end{array}$ & $\begin{array}{r}2,534 \\
787 \\
6,231 \\
161\end{array}$ & $\begin{array}{r}455,000 \\
130,000 \\
700,000 \\
32,000\end{array}$ & $\begin{array}{r}13,000 \\
1,000 \\
6,400 \\
\end{array}$ & $\begin{array}{r}442,000 \\
128,000 \\
683,000 \\
32,000\end{array}$ \\
\hline Chesapeaka IBay district.... & 17,416 & 8,913 & 24 & 8,479 & $1,149,000$ & 17,000 & $1,132,000$ \\
\hline 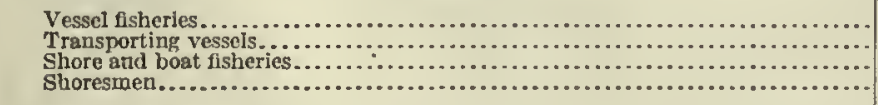 & $\begin{array}{r}2,970 \\
978 \\
13,314 \\
154\end{array}$ & $\begin{array}{r}487 \\
294 \\
8,132\end{array}$ & $\begin{array}{r}15 \\
3 \\
6\end{array}$ & $\begin{array}{r}2,468 \\
681 \\
5,176 \\
154\end{array}$ & $\begin{array}{r}449,000 \\
113,000 \\
557,000 \\
31,000\end{array}$ & $\begin{array}{r}13,000 \\
1,600 \\
3,000 \\
\cdots\end{array}$ & $\begin{array}{r}436,000 \\
111,000 \\
554,000 \\
31,000\end{array}$ \\
\hline Atlantle Ocean district......... & 2,650 & 1,411 & 5 & 1,234 & 167,000 & 3,500 & 163,000 \\
\hline 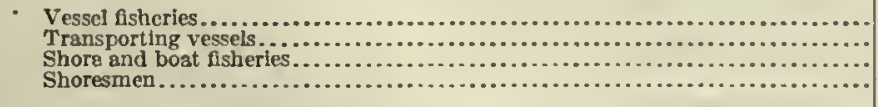 & $\begin{array}{r}218 \\
155 \\
2,270 \\
7\end{array}$ & $\begin{array}{r}152 \\
49 \\
1,210 \\
\end{array}$ & an & $\begin{array}{r}66 \\
106 \\
1,055 \\
7\end{array}$ & $\begin{array}{r}5,600 \\
17,000 \\
143,000 \\
1,100\end{array}$ & 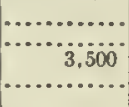 & $\begin{array}{r}5,600 \\
17,000 \\
139,000 \\
1,100\end{array}$ \\
\hline
\end{tabular}


Of the total number of persons employed, 78 per cent were engaged in the shore and boat fisheries and 22 per cent in the vessel fisheries and on transporting vessels. In the vessel fisheries about 80 per cent, and in the shore and boat fisheries about 40 per cent, of the persons employed were wage-earners, the proportion of proprietors and independent fishermen being smaller than in most other states. About 87 per cent of all persons reported were connected with the fisheries of the Chesapeake Bay district, while the remaining 13 per cent were engaged in the fisheries along the Atlantic coast.

Equipment and other capital.-The following tabular statement gives the value of equipment and the amount of other capital invested in 1908, for the state and for each district:

\begin{tabular}{|c|c|c|c|}
\hline \multirow{2}{*}{ CLASS OF INVESTMENT. } & \multicolumn{3}{|c|}{$\begin{array}{l}\text { VALUE OF EQUIPMENT AND OTHER } \\
\text { CAPITAL: 1908. }\end{array}$} \\
\hline & Total. & $\begin{array}{c}\text { Chesapeake } \\
\text { Bay } \\
\text { district. }\end{array}$ & $\begin{array}{l}\text { Atlantie } \\
\text { Ocean } \\
\text { distriet. }\end{array}$ \\
\hline Total..... & $\$ 2,984,000$ & $\$ 2,681,000$ & $\$ 302,000$ \\
\hline Vessels, including outfit. & $1,332,000$ & $1,247,000$ & 85,000 \\
\hline Fishing.................. & 985,000 & 953,000 & 31,000 \\
\hline $\begin{array}{l}\text { Steam and motor... } \\
\text { Vessels }\end{array}$ & 761,000 & 753,000 & 8,500 \\
\hline $\begin{array}{l}\text { Vessels } \\
\text { Outfit. }\end{array}$ & 653,000 & 644,000 & 8,300 \\
\hline Sail............ & $\begin{array}{l}109 ; 000 \\
223,000\end{array}$ & $\begin{array}{l}109,000 \\
2000\end{array}$ & 23000 \\
\hline Vessels. & 192,000 & $\begin{array}{l}270,000 \\
172,000\end{array}$ & $\begin{array}{l}23,000 \\
19,000\end{array}$ \\
\hline Outfit.. & 31,000 & 28,000 & 3,500 \\
\hline Transporting............ & 347,000 & 294,090 & 53,000 \\
\hline Steam and motor... & 119,000 & 95,000 & 25,000 \\
\hline Vessels........... & 107,000 & 85,000 & 23,000 \\
\hline Outfit... & 12,000 & 10,000 & 2,000 \\
\hline Sail.......... & 228,000 & 199,000 & 29,000 \\
\hline Vessels. & 203,000 & 177,000 & 26,000 \\
\hline Outfit... & $\begin{array}{r}25,000 \\
733,000\end{array}$ & $\begin{array}{r}22,000 \\
632000\end{array}$ & 2,500 \\
\hline Stearn and motor... & 331,000 & 266,000 & $\begin{aligned} 101,000 \\
65,000\end{aligned}$ \\
\hline Sail................ & 276,000 & 264,000 & 12,000 \\
\hline Row...... & 112,000 & 101,000 & 11,000 \\
\hline 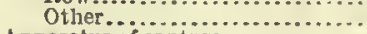 & 14,000 & 1,300 & 13,000 \\
\hline 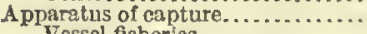 & 485,000 & 433,000 & $\mathbf{5 1}, 000$ \\
\hline Vessel fisberles. . . . . . . . . . & 56,000 & 56,000 & 600 \\
\hline Shore and boat fisheries.... & 428,000 & 378,000 & 51,000 \\
\hline Shore and accessory property.. & 301,000 & 262,000 & 39,000 \\
\hline 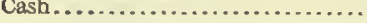 & 133,000 & 106,000 & 26,000 \\
\hline
\end{tabular}

About 90 per cent of the total investment is credited to the Chesapeake Bay district. The investment in vessels, including outfits and boats, represented 69 per cent, that in apparatus of eapture 16 per cent, and that in shore and accessory property, together with the cash capital reported, 15 per cent, of the total investment for the state.

By far the larger number of fishing and transporting vessels were sailing craft, and were employed in the Chesapeake Bay district. Only 120 vessels out of the total of 946 were engaged in fishing and transporting, and only 1,984 boats out of the total of 10,942 were connected with the fisheries of the Atlantic Ocean district. The other vessels and boats, numbering 826 and 8,958 , respectively, were employed in the fisheries of Chesapeake Bay and its tributary waters. While sailing vessels greatly outnumbered steam and motor vessels in the Chesapeake Bay district, the latter class of eraft had a value more than twice that of the former and a tonnage almost half as great. In the Atlantic Ocean district, however, the sailing vessels represented a greater value than the steam and motor vessels, and their total tonnage was more than seven times that of the steam and motor vessels. The following tabular statement gives detailed statisties concerning the number and tonnage of vessels and the number of boats:

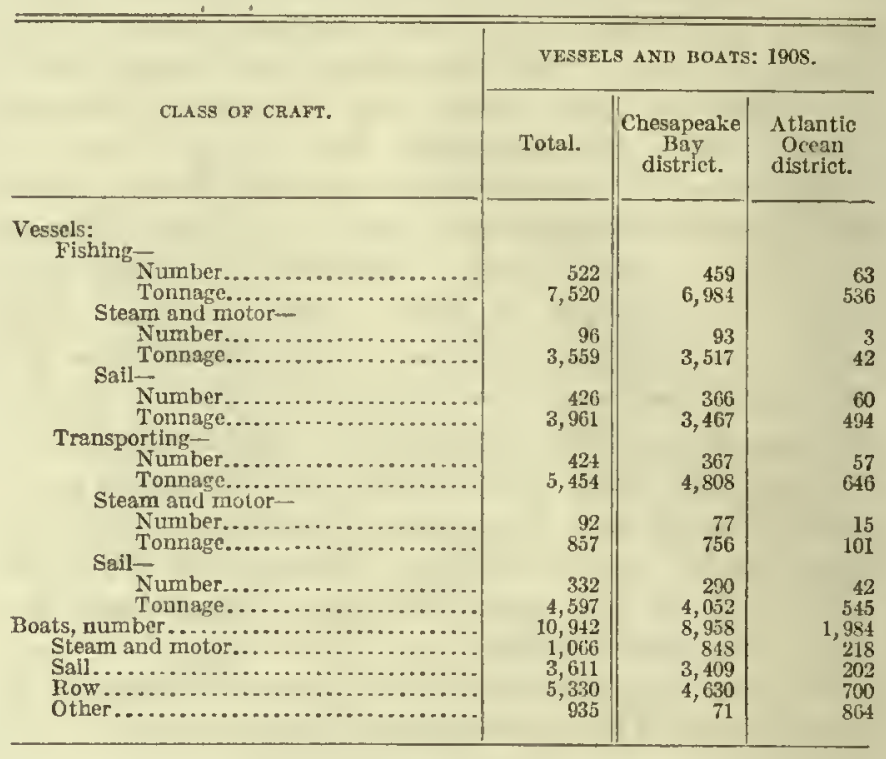

The apparatus of capture reported for the shore and boat fisheries of Virginia largely exceeded in value that reported for the vessel fisheries, the investment in the former case being $\$ 428,000$ and in the latter $\$ 56,000$. The capital represented by this form of investment in the Atlantic Ocean district was only $\$ 51,000$, or 11 per cent of the total investment in apparatus of capture for the state. The number of pound nets used was 1,908 and the number of seines 360 . The latter were used in both vessel and shore and boat fisheries and in both of the districts into which the fishing grounds of the state are divided. The number of gill nets reported was 7,513. Because dredges are considered injurious to the oyster beds, their use in the public areas is restricted by law. They were therefore used comparatively little and often only to clean up the grounds which had previously been worked by tongs. The distribution of the more important kinds of apparatus of capture is shown in the following table:

\begin{tabular}{|c|c|c|c|c|}
\hline \multirow{2}{*}{ DISTEICT AND CLASS OF FLSHERIES. } & \multicolumn{4}{|c|}{ APPARATUS OF CAPTURE: 1908.} \\
\hline & Gill nets. & Pots. & $\begin{array}{l}\text { Pound and } \\
\text { trap nets. }\end{array}$ & Seines. \\
\hline Total.......... & 7,513 & 902 & 1,908 & 360 \\
\hline $\begin{array}{l}\text { Vessel fisheries. ......... } \\
\text { Shore and boat fisheries... }\end{array}$ & $\begin{array}{r}51 \\
7,462 \\
\end{array}$ & $\begin{array}{r}60 \\
812 \\
\end{array}$ & $\begin{array}{r}83 \\
1,825 \\
\end{array}$ & $\begin{array}{r}44 \\
316 \\
\end{array}$ \\
\hline Chesapeake Bay district.... & 6,888 & 869 & 1,865 & 158 \\
\hline $\begin{array}{l}\text { Vessel fisheries. . } \\
\text { Shore and boat fisheries............. }\end{array}$ & $\begin{array}{r}51 \\
6,837\end{array}$ & $\begin{array}{r}60 \\
809\end{array}$ & $\begin{array}{r}83 \\
1,782\end{array}$ & $\begin{array}{r}43 \\
115\end{array}$ \\
\hline Atlantlc Ocean district.... & 625 & 33 & 43 & 202 \\
\hline $\begin{array}{l}\text { Vessel fisheries................... } \\
\text { Shore and bost fisheries......... }\end{array}$ & $\because 25$ & $\ddot{3} 3$ & 43 & 201 \\
\hline
\end{tabular}


Products, by specics.-The fishery products of the state for 1908 are distributed, by species and by apparatus of capture, in Table 1, on page 256.

The value of the fishery produets of Virginia formed 9 per cent of the total value of all fishery products of the United States. Oysters were the most important product, the value of the yield in 1908 forming only a small fraction less than 50 per cent of the value of all fisliery products of the state. Aside from certain species of fish, clams and crabs were the only other important products. The quantity of crabs taken was $25,0 \$ 3,000$ pounds, valued at $\$ 326,000$, and the quantity of clams was $1,969,000$ pounds, valued at $\$ 380,000$.

The product of fish proper amounted in the aggregatc to $249,890,000$ pounds, or 80 per cent of the total weight of fishery products of the state, and was valued at $\$ 1,658,000$, or 35 per cent of the total value. Including nine species tabulated under the head "All other," 42 species of fish were taken in the waters of the state. Of these the most important were shad, menhaden, alewives, squeteague, or sea trout, and croaker. The combined value reported for these five species was $\$ 1,344,000$, or 81 per cent of the value of all fish caught.

Products, by fishing grounds.-The products of the Chesapeake "Bay district are given in detail, by species and by apparatus of capture, in Table 2, on page 257; and Table 3 , on page 258 , gives similar statistics for the Atlantic Ocean district. In the following tabular statement the total value of products is distributed according to species arranged in order of value, for the state as a whole and for each district and each class of fisheries:

\begin{tabular}{|c|c|c|c|c|c|}
\hline \multirow{3}{*}{ SPECTES. } & \multicolumn{5}{|c|}{ YALUE OF PRODUCTS: 1908.} \\
\hline & \multirow[b]{2}{*}{ Total. } & \multicolumn{2}{|c|}{$\begin{array}{l}\text { Distributed by } \\
\text { distriets. }\end{array}$} & \multicolumn{2}{|c|}{$\begin{array}{c}\text { Distributed by class } \\
\text { of fisheries. }\end{array}$} \\
\hline & & $\begin{array}{l}\text { Chesa- } \\
\text { peske } \\
\text { Bap } \\
\text { distriet. }\end{array}$ & $\begin{array}{l}\text { Atlantie } \\
\text { Ocean } \\
\text { distriet. }\end{array}$ & $\begin{array}{l}\text { Vessel } \\
\text { fisheries. }\end{array}$ & $\begin{array}{l}\text { Shore } \\
\text { and boat } \\
\text { fisherles. }\end{array}$ \\
\hline Total.. & $\$ 4,716,000$ & $\$ 4,046,000$ & $\$ 670,000$ & $\$ 1,003,000$ & $\$ 3,707,000$ \\
\hline 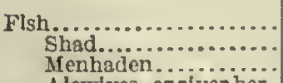 & $\begin{array}{r}1,658,000 \\
486,000 \\
429,000 \\
\end{array}$ & $\begin{array}{r}1,4 S 6,000 \\
481,000 \\
429,000\end{array}$ & $\begin{array}{r}173,000 \\
4,600 \\
100\end{array}$ & $\begin{array}{r}490,000 \\
34,000 \\
419,000\end{array}$ & $\begin{array}{r}1,168,000 \\
452,000 \\
10,000\end{array}$ \\
\hline $\begin{array}{l}\text { A lewives, or river her- } \\
\text { ring................ }\end{array}$ & 171,000 & 168,000 & 3,200 & 22,000 & 149,000 \\
\hline $\begin{array}{l}\text { Squetengue, or sea } \\
\text { trout............... }\end{array}$ & 139,000 & 100,000 & 39,000 & 2,000 & 137,000 \\
\hline Croaker................. & 119,000 & 84,000 & 35,000 & 1,800 & 117,000 \\
\hline $\begin{array}{l}\text { Sturgeon, eavlar, and } \\
\text { sturgeon eggs....... } \\
\text { Striped tass.......... } \\
\text { Catfish................ }\end{array}$ & $\begin{array}{l}49,000 \\
46,000 \\
31,000\end{array}$ & $\begin{array}{l}20,000 \\
46,000 \\
28,000\end{array}$ & $\begin{array}{r}29,000 \\
200 \\
2,900\end{array}$ & $\begin{array}{r}100 \\
2,300 \\
800\end{array}$ & $\begin{array}{l}49,000 \\
44,000 \\
31,000\end{array}$ \\
\hline $\begin{array}{l}\text { Pereh, white......... } \\
\text { Spanish mackerel..... } \\
\text { Butterfish............. } \\
\text { All other............. }\end{array}$ & $\begin{array}{r}2 i, 000 \\
25,000 \\
2 i, 000 \\
114,000\end{array}$ & $\begin{array}{r}24,000 \\
9,100 \\
17,000 \\
79,000\end{array}$ & $\begin{array}{r}2,900 \\
16,000 \\
4,400 \\
35,000\end{array}$ & $\begin{array}{l}\text { (1) } \\
300 \\
8,100\end{array}$ & $\begin{array}{r}26,000 \\
25,000 \\
21,000 \\
106,000\end{array}$ \\
\hline 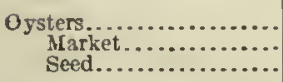 & $\begin{array}{r}2,348,000 \\
1,967,000 \\
381,000\end{array}$ & $\begin{array}{r}2,016,000 \\
1,693,000 \\
323,000\end{array}$ & $\begin{array}{r}332,000 \\
274,000 \\
58,000\end{array}$ & $\begin{array}{r}439,000 \\
384,000 \\
55,000\end{array}$ & $\begin{array}{r}1,909,000 \\
1,583,000 \\
326,000\end{array}$ \\
\hline 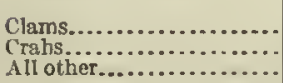 & $\begin{array}{r}380,000 \\
320,000 \\
4,500\end{array}$ & $\begin{array}{r}217,000 \\
320,000 \\
1,600\end{array}$ & $\begin{array}{r}163,000 \\
2,000\end{array}$ & $\begin{array}{r}6,000 \\
73,000\end{array}$ & $\begin{array}{r}374,000 \\
252,000 \\
4,500\end{array}$ \\
\hline
\end{tabular}

3 Less than $\$ 100$.
The combined catch of the fisheries of Chesapeake Bay and its tributary waters was $301,596,000$ pounds, valued at $\$ 4,046,000$, or 97 per cent of the quantity and 86 per cent of the value of the fishery products of the state. The catch of fish proper reported for this district furnished 36 per cent of the total value for the district, and the yield of oysters, the most valuable product, 50 per cent. Next to oysters the shad catch had the largest value, while the menhaden, crab, clam, and herring products also contributed largely to the total value.

The catch of the Atlantic Ocean district, which weighed $10,918,000$ pounds and was valued at $\$ 670,000$, represented only 3 per cent of the total quantity and 14 per cent of the total value of all fishery products of the state. Of the total value of products reported for this district, oysters contributed 50 per cent and clams 24 per cent. Of fish proper, which furnished 26 per cent of the value returned for the district, the principal species taken were squeteague, croaker, and sturgeon. Spanish mackerel ranked next, with a value of $\$ 16,000$, which constituted 64 per cent of the value of all Spanish mackerel taken in the waters of the state.

Products, by class of fisheries.-The products of the vessel fisheries are given in detail, by species and by apparatus of capture, in Tabie 4, on page 258, and the products of the shore and boat fisheries are similarly shown in Table 7, on page 260. As already indicated, the table above shows the distribution, by species arranged in order of value, of the total value of products reported for the state and for each class of fisheries.

The catch of the vessel fisheries aggregated $207,070,000$ pounds, valued at $\$ 1,009,000$, or 66 per cent of the total quantity of fishery products taken in the state and 21 per cent of their total value. Oysters, menhaden, and crabs furnished the largest values. Of the different species of fish proper reported, menhaden represented 90 per cent of the quantity caught in the vessel fisheries.

The combined catch of the shore and boat fisheries of the state aggregated $105,444,000$ pounds, having a value of $\$ 3,707,000$, or 34 per cent and 79 per cent, respectively, of the total quantity and value of all the fishery products of the state. Oysters, shad, and clams were the three most important products of this class of fisheries.

The value of fish constituted 49 per cent of the total value of the products taken in the vessel fisheries and 32 per cent of that of products taken in the shore and boat fisheries. Oysters contributed 44 per cent of the value of the products of the former class of fisheries and 51 per cent of the value of the products of the latter.

Tables 5 and 8 , on pages 259 and 261 show, by species and by apparatus of capture, the products, respectively, 
of the vessel and the shore and boat fisheries of the Chesapeake Bay district, while corresponding statisties for the Atlantic Ocean district are given in Tables 6 and 9, on pages 259 and 262: The following tabular statement gives the distribution, by district and class of fisheries, of the total quantity and value of products reported for the state:

\begin{tabular}{|c|c|c|c|c|}
\hline \multirow{3}{*}{$\begin{array}{l}\text { DISTRICT AND CLASS OF } \\
\text { FISTERIES. }\end{array}$} & \multicolumn{4}{|c|}{ FISHERT PRODUCTS: 1908.} \\
\hline & \multicolumn{2}{|c|}{ Quantity. } & \multicolumn{2}{|c|}{ Value. } \\
\hline & Pounds. & $\begin{array}{l}\text { Per cent } \\
\text { distribu- } \\
\text { tlon. }\end{array}$ & Amount. & $\begin{array}{l}\text { Per cent } \\
\text { distrihu- } \\
\text { tion. }\end{array}$ \\
\hline Total ..................... & $312,515,000$ & 100 & $\$ 4,716,000$ & 100 \\
\hline Chesapeake Bay distrlet.. & $301,586,000$ & 97 & $4,046,000$ & 86 \\
\hline $\begin{array}{l}\text { Vessel fisheries ............. } \\
\text { Shore and boat fisheries .... }\end{array}$ & $\begin{array}{r}206,537,000 \\
95,060,000\end{array}$ & $\begin{array}{l}66 \\
30\end{array}$ & $\begin{array}{r}985,000 \\
3,061,000\end{array}$ & 21 \\
\hline Atlantic Ocean district ... & $10,018,000$ & 3 & 670,000 & 14 \\
\hline $\begin{array}{l}\text { Vessel fisheries ............. } \\
\text { shore and boat fisheries.... }\end{array}$ & $\begin{array}{r}534,000 \\
10,385,000\end{array}$ & (1) 3 & $\begin{array}{r}24,000 \\
646,000\end{array}$ & $\begin{array}{r}1 \\
14\end{array}$ \\
\hline
\end{tabular}

1 Less than 1 per cent.

In both classes of fisheries of the Chesapeake Bay district, oysters contributed the largest value, though nine-tenths of the weight of the produet taken in the vessel fisheries consisted of menhaden. More than 90 per cent of the shad produet of Virginia was eaught in the shore and boat fisheries of Chesapeake Bay and its tributaries.

The only products of the vessel fisheries of the Atlantic Oeean district were oysters, clams, bluefish, sea bass, squeteague, and scup.

Products, by apparatus of capture.-The following tabular statement distributes, by apparatus of capture arranged in the order of the value of the catch, the total value of products reported for the state as a whole and for each district:

\begin{tabular}{|c|c|c|c|c|c|}
\hline \multirow{3}{*}{ KNND OF APPARATUS. } & \multicolumn{5}{|c|}{ VALUE OF PRODUCTS: 1908.} \\
\hline & \multirow{2}{*}{ Total. } & \multicolumn{2}{|c|}{$\begin{array}{l}\text { Distributed by } \\
\text { distriets. }\end{array}$} & \multicolumn{2}{|c|}{$\begin{array}{c}\text { Distributed by class } \\
\text { of fisheries. }\end{array}$} \\
\hline & & $\begin{array}{l}\text { Chesa- } \\
\text { peake Bay } \\
\text { district. }\end{array}$ & $\begin{array}{l}\text { Atlantlc } \\
\text { Ocean } \\
\text { district. }\end{array}$ & $\begin{array}{c}\text { Vessel } \\
\text { fisherles. }\end{array}$ & $\begin{array}{l}\text { Shoro and } \\
\text { boat } \\
\text { fisheries. }\end{array}$ \\
\hline Total..... & $\$ 4,716,000$ & $|\$ 4,046,000|$ & $\$ 670,000$ & $\$ 1,009,000$ & $83,707,000$ \\
\hline 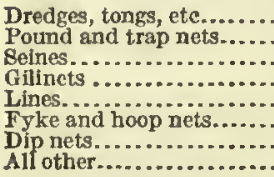 & $\begin{array}{r}2,781,000 \\
833,000 \\
531,000 \\
205,000 \\
190,000 \\
47,000 \\
29,000 \\
99,000\end{array}$ & $\begin{array}{r}2,379,000 \\
732,000 \\
508,000 \\
170,000 \\
179,000 \\
44,000 \\
29,000 \\
4,500\end{array}$ & $\begin{array}{r}403,000 \\
101,000 \\
23,000 \\
35,000 \\
11,000 \\
2,500 \\
95,000\end{array}$ & \begin{tabular}{r}
511,030 \\
58,000 \\
427,000 \\
500 \\
6,400 \\
\hdashline .2. \\
5,600
\end{tabular} & $\begin{array}{r}2,270,000 \\
776,000 \\
103,000 \\
204,000 \\
184,000 \\
47,000 \\
29,000 \\
94,000\end{array}$ \\
\hline
\end{tabular}

The eatch made with dredges, tongs, and rakes, representing mainly the yield of oysters, but also that of clams and crabs, contributed a larger percentage of the value of the products than the catch made with any other elass of apparatus. The value of the products taken in pound and trap nets made this class of apparatus second in importance, these nets being used extensively in both the Atlantic Oeean district and the Chesapeake Bay district, and in the capture of nearly all the species of fish reported. They were employed especially in taking shad and herring, and contributed one-fifth of the total value of the products of the shore and boat fisheries. Seines ranked third in the value of products taken. They were used mostly in the vessel fisheries, 80 per cent of the total value of products reported for them being credited to this class of fisheries. Gill nets and lines were used .very little in the vessel fisheries, while fyke and hoop nets were used only in the shore and boat fisheries. Dip nets were employed only in the shore and boat fisheries of Chesapeake Bay. The greater part of the value of the catch made by means of dip nets represents the value of soft crabs caught, while hard crabs contributed most of the value of the catch by lines.

Oysters.-In 1908 the total yield of oysters from Virginia beds was $5,075,000$ bushels, valued at $\$ 2,348,000$, or about 50 per cent of the value of all the fishery products of the state. The product was distributed by kind and area, as follows:

\begin{tabular}{|c|c|c|c|c|}
\hline \multirow{3}{*}{ KIND AND SOURCE. } & \multicolumn{4}{|c|}{ OYSTER PRODUCT: 1908.} \\
\hline & \multicolumn{2}{|c|}{ Quantity. } & \multicolumn{2}{|c|}{ Value. } \\
\hline & Bushels. & $\begin{array}{l}\text { Per cent } \\
\text { distribu- } \\
\text { tion. }\end{array}$ & Amount. & $\begin{array}{l}\text { Per cent } \\
\text { distribu- } \\
\text { tjon. }\end{array}$ \\
\hline Total....................... & $5,075,000$ & 100 & $\$ 2,348,000$ & 100 \\
\hline Market oysters........... & $3,672,000$ & 72 & $1,967,000$ & 84 \\
\hline $\begin{array}{l}\text { From public areas............... } \\
\text { From private areas .............. }\end{array}$ & $\begin{array}{l}1,369,000 \\
2,303,000\end{array}$ & $\begin{array}{l}27 \\
45\end{array}$ & $\begin{array}{r}645,000 \\
1,322,000\end{array}$ & $\begin{array}{l}27 \\
56\end{array}$ \\
\hline Seed oysters.... & $1,403,000$ & 28 & 381,000 & 16 \\
\hline $\begin{array}{l}\text { From public areas............... } \\
\text { From private areas............ }\end{array}$ & $\begin{array}{r}1,322,000 \\
81,000\end{array}$ & $\begin{array}{r}26 \\
2\end{array}$ & $\begin{array}{r}357,000 \\
24,000\end{array}$ & $\begin{array}{r}15 \\
1\end{array}$ \\
\hline
\end{tabular}

The oyster product eomprised $3,672,000$ bushels of market oysters, valued at $\$ 1,967,000$, and $1,403,000$ bushels of seed oysters, valued at $\$ 381,000$. All tho seed oysters reported, with the exception of 81,000 bushels, were taken from public areas, while 63 per cent of the market oysters were from private areas.

The cultivation of oysters has become an important part of the oyster industry of Virginia. Public reefs have become yearly less productive, and there has been a tendency to enlarge the area available for private beds. As yet the cultivated oysters of Virginia have not brought as high a price per bushel as those from New York and Connecticut, although the natural conditions of the Virginia waters are ideal for eultivation and the state laws afford fairly good protection to private oyster culture.

Though the value of oysters from private areas formed 57 per cent of the total value of the oyster product, the quantity from these areas was less than that from public areas. The average price of market oysters per bushel was 57 cents for those from private 
areas and 47 cents for those from public areas. The average price of seed oysters was 27 conts per bushel.

The following tabular statement, giving the quantity, value, and average price per bushel of Virginia oysters for several years, indicates that the product has been decreasing in quantity since 1901:

\begin{tabular}{|c|c|c|c|}
\hline \multirow{3}{*}{ YEAR. } & \multicolumn{3}{|c|}{ OISTER PRODUCT. } \\
\hline & \multirow{2}{*}{$\begin{array}{l}\text { Quantity } \\
\text { (bushels). }\end{array}$} & \multicolumn{2}{|c|}{ Value. } \\
\hline & & Amount. & $\begin{array}{c}\text { Average } \\
\text { per } \\
\text { bushel. }\end{array}$ \\
\hline 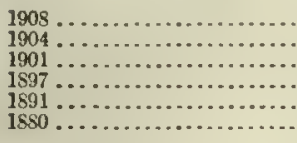 & $\begin{array}{l}5,075,000 \\
7,612,000 \\
7,885,000 \\
7,024,000 \\
6,162,000 \\
6,837,000\end{array}$ & $\begin{array}{r}\$ 2,348,000 \\
3,460,000 \\
2,923,000 \\
2,042,000 \\
2,524,000 \\
2,218,000\end{array}$ & $\begin{array}{r}80.46 \\
0.45 \\
0.37 \\
0.29 \\
0.41 \\
0.32\end{array}$ \\
\hline
\end{tabular}

Tonging was the more usual method of fishing for oysters, but dredges also were used to some extent. Though oyster fishing was carried on extensively in the Atlantic Ocean district by means of vessels and boats, the value of the product obtained from the shore and boat fisheries of Chesapeake Bay and its tributary waters was much greater than that of the entire oyster product of the former district.

Shad.-Shad ranked next to oysters in value and was the most important species of fish caught. The Virginia catch was the largest in the country in 1908, weighing $7,314,000$ pounds and being valued at $\$ 486,000$, or about one-fourth of the entire quantity and value of the shad caught in the waters of the United States. Its value formed 10 per cent of the value of all fishery products of the state. The catch in 1908 was slightly smaller in quantity but greater in value than that in 1904 , which was $7,420,000$ pounds, valued at $\$ 440,000$.

The following tabular statement shows the quantity and value of the catch of shad for certain years from 1880 to 1908 :

\begin{tabular}{|c|c|c|c|}
\hline & \multirow{2}{*}{ - } & \multicolumn{2}{|c|}{ BHAD PRODUCT. } \\
\hline TEAR. & & $\begin{array}{l}\text { Quantity } \\
\text { (pounds). }\end{array}$ & Value. \\
\hline 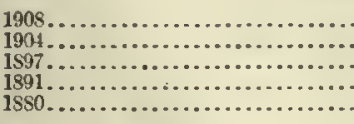 & 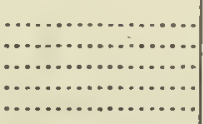 & $\begin{array}{r}7,314,000 \\
7,420,000 \\
11,529,000 \\
6,498,000 \\
3,172,000\end{array}$ & $\begin{array}{r}\$ 486,000 \\
440,000 \\
304,000 \\
207,000 \\
134,000\end{array}$ \\
\hline
\end{tabular}

According to the reports of the fishermen, the decrease of shad in the rivers tributary to Chesapeake Bay, shown in previous reports of the Bureau of Fisheries, continues. This fish is caught mainly by means of pound nets and gill nets in the shore and boat fisheries of Chesapeake Bay and its tributary waters. Less than 1 per cent of the total value of shad represents product taken in the Atlantic coast fisheries.

Menhaden.-The menhaden product of Virginia amounted to $190,089,000$ pounds, valued at $\$ 429,000$, and represented nearly half of the total weight and value of all the menhaden caught in the United States. The catch was considerably less than in 1904, but was larger than in 1897 or any previous year for which statistics are available, as is shown by the following tabular statement:

\begin{tabular}{|c|c|c|}
\hline \multirow{2}{*}{ YEAR. } & \multicolumn{2}{|c|}{ MENHADEN PRODUCT } \\
\hline & $\begin{array}{l}\text { Quantity } \\
\text { (pounds). }\end{array}$ & Value. \\
\hline 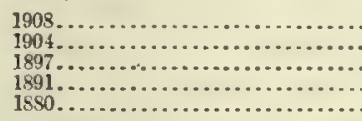 & $\begin{array}{r}190,089,000 \\
247,919,000 \\
178,656,000 \\
105,930,000 \\
88,214,000\end{array}$ & $\begin{array}{r}\$ 429,000 \\
515,000 \\
255,000 \\
198,000 \\
304,000\end{array}$ \\
\hline
\end{tabular}

These fish run in large schools and are caught principally by means of seines. Practically the entire catch was from the Chesapeake Bay district, chiefly from its vessel fisheries.

Clams.-The value of the hard-clam product of Virginia exceeded that reported for any other state, though the New Jersey product exceeded the Virginia product in quantity. In 1908 the Virginia yield was 246,000 bushels, valued at $\$ 380,000$. Up to 1901 the yield was increasing regularly; but since that year, though the value has continued to increase, there has been some fluctuation in the quantity. The following tabular statement gives statistics of the product for certain years from 1890 to 1908 :

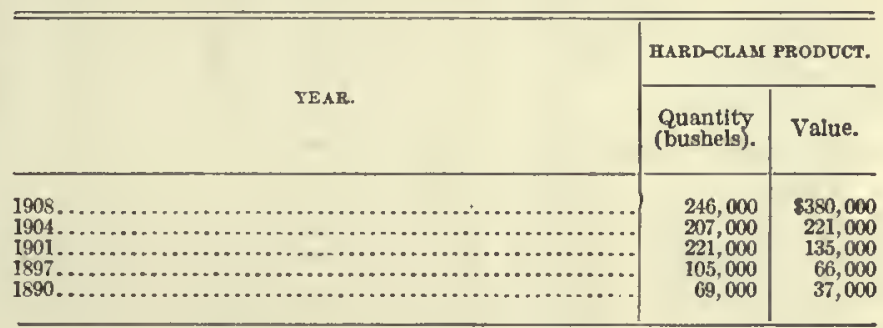

Clams are essentially a product of the shore and boat fisheries. Fifty-seven per cent of the value of the Virginia catch represents the value of clams taken in the Chesapeake Bay district.

Crabs.-Though ranking only fifth with respect to value among the fishery products of Virginia, the total crab product of the statesurpassed in value that of any other state. Virginia ranked first in the yield of hard crabs and second only to Maryland in the yield of soft crabs. In 1908 the total crab product, all of which came from Chesa peake Bay and its tributary waters, was $\$ 25,083,000$ pounds, valued at $\$ 326,000$. This formed nearly 50 per cent of the total quantity and its value more than one-third of the total value of all hard and soft crabs taken in the country. The industry has grown steadily since 1890 ; the product increased 129 per cent in valie from 1901 to 1904 , and 104 per cent in quantity and 19 per cent in value from 1904 to 1908. Statistics as to the yield in earlier years are given in the following tabular statement: 


\begin{tabular}{|c|c|c|c|}
\hline \multirow[b]{2}{*}{ - } & \multirow[b]{2}{*}{ YEAR. } & \multicolumn{2}{|c|}{ CRAB PRODUCT. } \\
\hline & & $\begin{array}{l}\text { Quantity } \\
\text { (pounds). }\end{array}$ & Value. \\
\hline $\begin{array}{l}1998 \ldots \ldots \ldots \\
1904 \ldots \ldots \ldots \\
1901 \ldots \ldots \ldots \\
1897 \ldots \ldots \ldots . \\
1890 \ldots \ldots \ldots\end{array}$ & & $\begin{array}{r}25,083,000 \\
12,267,000 \\
7,402,000 \\
6,400,000 \\
3,025,000\end{array}$ & $\begin{array}{r}\$ 326,000 \\
272,000 \\
119,000 \\
68,000 \\
54,000\end{array}$ \\
\hline
\end{tabular}

Alewives. - The alewife product has long been important among the fishery products of Virginia, and both the quantity and value increased greatly from 1904 to 1908. The catch in 1908, amounting to $37,885,000$ pounds, valued at $\$ 171,000$, was greater in both quantity and value than that reported for any other state, and furnished 42 per cent of the weight and nearly 30 per eent of the value of the total alewife product of the United States. The inerease in the quantity of the eatch since 1904 amounted to almost 160 per cent, and that in the value to 88 per cent.

The following tabular statement gives statistics for certain years from 1880 to 1908 :

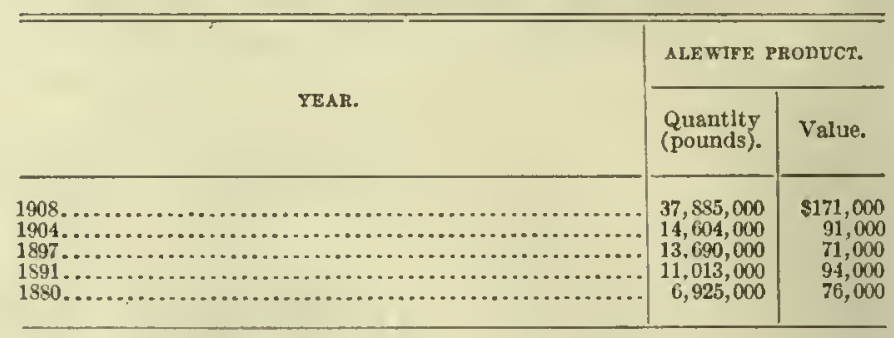

TABLE 1.-VIRGINIA-FISHERY PRODUCTS: 1908

\begin{tabular}{|c|c|c|c|c|c|c|c|c|c|c|c|c|c|c|}
\hline \multirow{3}{*}{ SPECIES. } & \multirow{2}{*}{\multicolumn{2}{|c|}{ TOTAL. }} & \multicolumn{12}{|c|}{ PRODUCT CAUGHT BY- } \\
\hline & & & \multicolumn{2}{|c|}{$\begin{array}{l}\text { Pound and trap } \\
\text { nets. }\end{array}$} & \multicolumn{2}{|c|}{ Seines. } & \multicolumn{2}{|c|}{ Gin nets. } & \multicolumn{2}{|c|}{ Lincs. } & \multicolumn{2}{|c|}{$\begin{array}{l}\text { Fyke and hoop } \\
\text { nets. }\end{array}$} & \multicolumn{2}{|c|}{ An other apparatus.? } \\
\hline & $\begin{array}{l}\text { Quantity } \\
\text { (pounds). }\end{array}$ & Value. & $\begin{array}{l}\text { Quantity } \\
\text { (pounds). }\end{array}$ & Value. & $\begin{array}{l}\text { Quantity } \\
\text { (pounds). }\end{array}$ & Value. & $\begin{array}{l}\text { Quantity } \\
\text { pounds). }\end{array}$ & Value. & $\begin{array}{l}\text { Quantity } \\
\text { (pounds). }\end{array}$ & value. & $\begin{array}{l}\text { Quantity } \\
\text { (pounds). }\end{array}$ & Value. & $\begin{array}{l}\text { Quantity } \\
\text { (pounds). }\end{array}$ & Valuc. \\
\hline Total.. & $312,515,000$ & $\$ 4,716,000$ & $52,560,000$ & 8833,000 & $191,633,000$ & 8531,000 & $3,489,000$ & $\$ 205,000$ & $15,106,000$ & $\$ 190,000$ & $1,279,000$ & $\$ 47,000$ & $48,447,000$ & $\$ 2,910,000$ \\
\hline $\begin{array}{r}\text { Fish: } \\
\text { Alewives......... } \\
\text { Black bass........ } \\
\text { Bluefish ........ } \\
\text { Butterfish....... } \\
\text { Carp, German... }\end{array}$ & $\begin{array}{r}37,885,000 \\
71,000 \\
242,000 \\
725,000 \\
286,000\end{array}$ & $\begin{array}{r}171,000 \\
6,900 \\
14,000 \\
21,000 \\
8,000\end{array}$ & $\begin{array}{r}32,889,000 \\
400 \\
68,000 \\
685,000 \\
22,000\end{array}$ & $\begin{array}{r}138,000 \\
(?) \\
4,600 \\
19,000 \\
1,200\end{array}$ & $\begin{array}{r}3,736,000 \\
62,000 \\
40,000 \\
20,000 \\
230,000\end{array}$ & $\begin{array}{r}20,000 \\
6,200 \\
3,400 \\
1,400 \\
5,700\end{array}$ & $\begin{array}{r}1,105,000 \\
(3) \\
29,000 \\
16,000 \\
12,000\end{array}$ & $\begin{array}{r}9,200 \\
(2) \\
1,500 \\
300 \\
500\end{array}$ & $\begin{array}{r}2,700 \\
100,000\end{array}$ & $\begin{array}{r}200 \\
4,700\end{array}$ & $\begin{array}{r}153,000 \\
5,700 \\
5,200 \\
4,500 \\
16,000\end{array}$ & $\begin{array}{r}3,100 \\
500 \\
100 \\
100 \\
600\end{array}$ & 1,000 & $\begin{array}{r}100 \\
\cdots \cdots \\
\cdots \cdots\end{array}$ \\
\hline 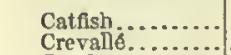 & $\begin{array}{r}738,000 \\
\ldots \quad 80,000\end{array}$ & $\begin{array}{r}31,000 \\
1,800\end{array}$ & $\begin{array}{r}234,000 \\
80,000\end{array}$ & $\begin{array}{r}11,000 \\
1,800\end{array}$ & 162,000 & $\begin{array}{c}7,000 \\
\ldots\end{array}$ & 56,000 & 2,700 & 47,000 & 1,900 & 240,000 & 8,800 & & \\
\hline $\begin{array}{l}\text { Croaker.............. } \\
\text { Drum, sait-water } \\
\text { Eels.............. }\end{array}$ & $\begin{array}{r}4,839,000 \\
78,000 \\
87,000\end{array}$ & $\begin{array}{r}119,000 \\
1,500 \\
4,200\end{array}$ & $\begin{array}{r}4,221,000 \\
61,000 \\
25,000\end{array}$ & $\begin{array}{r}103,000 \\
900 \\
1,400\end{array}$ & $\because 6,000$ & $\begin{array}{l}\because 2,100 \\
200 \\
200\end{array}$ & 61,000 & 1,800 & $\begin{array}{r}306,000 \\
15,000 \\
5,200\end{array}$ & $\begin{array}{r}8,800 \\
600 \\
300\end{array}$ & $\begin{array}{r}1 i i, 000 \\
2,800 \\
5,000\end{array}$ & $\begin{array}{c}2,900 \\
(2) \\
200\end{array}$ & 48,000 & ?.... \\
\hline $\begin{array}{l}\text { Flounders........ } \\
\text { Hlickory shad.... } \\
\text { Hogfish........ } \\
\text { Kingfish, or whit- }\end{array}$ & $\begin{array}{l}189,000 \\
233,000 \\
109,000\end{array}$ & $\begin{array}{r}7,400 \\
6,200 \\
11,000\end{array}$ & $\begin{array}{r}153,000 \\
81,000 \\
46,000\end{array}$ & $\begin{array}{l}5,900 \\
2,500 \\
6,800\end{array}$ & $\begin{array}{l}16,000 \\
84,000 \\
11,000\end{array}$ & $\begin{array}{r}600 \\
2,100 \\
1,600\end{array}$ & $\begin{array}{r}2,800 \\
66,000\end{array}$ & $\begin{array}{r}100 \\
1,600\end{array}$ & $\begin{array}{l}11,000 \\
52,000\end{array}$ & \begin{tabular}{r}
400 \\
\hdashline, 600 \\
2,000
\end{tabular} & $\begin{array}{l}5,300 \\
2,500\end{array}$ & $\begin{array}{l}300 \\
100\end{array}$ & & \\
\hline $\begin{array}{c}\text { Kingtish, or whit- } \\
\text { ing............ }\end{array}$ & 95,000 & 4,800 & 70,000 & 3,700 & 11,000 & 500 & & & 7,200 & 400 & 7,000 & 200 & & \\
\hline $\begin{array}{l}\text { Mfenhaden....... } \\
\text { Minnows....... } \\
\text { Mfoonksh... }\end{array}$ & $\begin{array}{r}190,089,000 \\
2,200 \\
10,000\end{array}$ & $\begin{array}{r}429,000 \\
900 \\
400\end{array}$ & $\begin{array}{c}3,884,000 \\
10,000\end{array}$ & $\begin{array}{c}10,000 \\
\cdots 00\end{array}$ & $\begin{array}{r}186,205,000 \\
2,200\end{array}$ & $\begin{array}{r}419,000 \\
900\end{array}$ & & & & & ….. & & & \\
\hline $\begin{array}{l}\text { Moonkish.......... } \\
\text { Mullet,.......... } \\
\text { Pereh, white.... }\end{array}$ & $\begin{array}{l}10,000 \\
264,000 \\
446,000\end{array}$ & $\begin{array}{r}9,400 \\
27,000\end{array}$ & $\begin{array}{r}10,000 \\
57,000 \\
155,000\end{array}$ & $\begin{array}{l}2,200 \\
9,200\end{array}$ & $\begin{array}{r}37,000 \\
107,000\end{array}$ & $\begin{array}{l}1,300 \\
6,300\end{array}$ & $\begin{array}{r}139,000 \\
82,000\end{array}$ & $\begin{array}{r}5,100 \\
5,400\end{array}$ & $\begin{array}{l}13,000 \\
16,000\end{array}$ & 1,000 & $\begin{array}{r}3,000 \\
85,000\end{array}$ & $\begin{array}{l}\cdots 100 \\
5,000\end{array}$ & $\begin{array}{r}5,800 \\
100\end{array}$ & (?) 200 \\
\hline $\begin{array}{l}\text { Perch, yellow.... } \\
\text { Pike and pick- }\end{array}$ & 118,000 & 5,500 & 45,000 & 2,100 & 40,000 & 1,800 & & 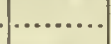 & & & 32,000 & 1,600 & & \\
\hline $\begin{array}{l}\text { ere............ } \\
\text { Pompano....... } \\
\text { Seup............. } \\
\text { Sea bass......... }\end{array}$ & $\begin{array}{l}12,000 \\
20,000 \\
65,000 \\
63,000\end{array}$ & $\begin{array}{l}1,000 \\
3,100 \\
3,500 \\
2,900\end{array}$ & $\begin{array}{r}600 \\
18,000 \\
45,000\end{array}$ & $\begin{array}{l}\left({ }^{(2)}\right) \\
2,800 \\
2,600\end{array}$ & $\begin{array}{r}11,000 \\
\cdots 17,000 \\
15,000\end{array}$ & $\begin{array}{r}900 \\
\cdots 900 \\
900\end{array}$ & $\begin{array}{r}200 \\
1,000\end{array}$ & $\left.{ }^{(2)}\right)$ & $\begin{array}{r}4000 \\
48,000\end{array}$ & $\begin{array}{r}100 \\
100 \\
2,000\end{array}$ & $\begin{array}{r}300 \\
200 \\
1,200\end{array}$ & $\begin{array}{l}(2) \\
(2) \\
100\end{array}$ & & \\
\hline $\begin{array}{l}\text { Shad............. } \\
\text { Sheepshead..... }\end{array}$ & $\begin{array}{r}7,314,000 \\
82,000\end{array}$ & $\begin{array}{r}486,000 \\
5,000\end{array}$ & $\begin{array}{r}5,474,000 \\
82,000\end{array}$ & $\begin{array}{r}341,000 \\
4,900\end{array}$ & $\begin{array}{l}208,000 \\
\cdots \ldots \ldots\end{array}$ & $\begin{array}{c}15,000 \\
\cdots \ldots\end{array}$ & $1,597,000$ & $\mid \begin{array}{c}127,000 \\
\ldots \ldots \ldots\end{array}$ & 400 & (3) & $\begin{array}{c}35,000 \\
\ldots \ldots \ldots\end{array}$ & $\begin{array}{c}3,200 \\
\cdots \ldots . .\end{array}$ & & \\
\hline $\begin{array}{l}\text { Spanish mackerei } \\
\text { Spot............. }\end{array}$ & $\begin{array}{l}276,000 \\
192,000\end{array}$ & $\begin{array}{l}25,000 \\
15,000\end{array}$ & $\begin{array}{r}220,000 \\
78,000\end{array}$ & $\begin{array}{r}19,000 \\
6,300\end{array}$ & 44,000 & 4,200 & $\begin{array}{r}45,000 \\
5,600\end{array}$ & $\begin{array}{r}4,500 \\
500\end{array}$ & $62,000^{\circ}$ & $\dddot{3,500}$ & $\begin{array}{r}11,000 \\
2,700\end{array}$ & $\begin{array}{r}1,200^{\circ} \\
100\end{array}$ & ......... & \\
\hline $\begin{array}{l}\text { Squeteague, or } \\
\text { sea trout....... } \\
\text { striped bass..... }\end{array}$ & $\begin{array}{r}4,491,000 \\
504,000\end{array}$ & $\begin{array}{r}139,000 \\
\mathbf{4 6}, 000\end{array}$ & $\begin{array}{r}3,463,000 \\
160,000\end{array}$ & $\begin{array}{r}103,000 \\
14,000\end{array}$ & $\begin{array}{l}298,000 \\
141,000\end{array}$ & $\begin{array}{l}15,000 \\
13,000\end{array}$ & $\begin{array}{l}61,000 \\
62,000\end{array}$ & $\begin{array}{l}2,700 \\
5,900\end{array}$ & $\begin{array}{r}268,000 \\
33,000\end{array}$ & $\begin{array}{r}11,000 \\
3,500\end{array}$ & $\begin{array}{l}411,000 \\
107,000\end{array}$ & $\begin{array}{r}7,600 \\
10,000\end{array}$ & 100 & (a) \\
\hline $\begin{array}{c}\text { Sturgcon, caviar, } \\
\text { and sturgeon } \\
\text { eggs ............ } \\
\text { Suckers........... }\end{array}$ & $\begin{array}{r}205,000 \\
10,000\end{array}$ & $\begin{array}{r}49,000 \\
500\end{array}$ & 65,000 & 13,000 & $\begin{array}{r}1,100 \\
\ldots \ldots\end{array}$ & 300 & 138,000 & 36,000 & & & $\begin{array}{r}300 \\
10,000\end{array}$ & (') & & \\
\hline $\begin{array}{l}\text { Sunfish............ } \\
\text { All other ........ }\end{array}$ & $\begin{array}{l}58,000 \\
12,000\end{array}$ & $\begin{array}{r}1,200 \\
500\end{array}$ & $\begin{array}{r}400^{\circ} \\
7,200\end{array}$ & (3) & $\begin{aligned} 53,000 \\
500\end{aligned}$ & 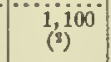 & 200 & (1) & 500 & (3) & $\begin{array}{r}2,500 \\
3,100\end{array}$ & $\begin{array}{l}100 \\
100\end{array}$ & (a............ & \\
\hline 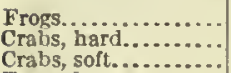 & $\begin{array}{r}3,000 \\
23,001,000 \\
2,082,000\end{array}$ & $\begin{array}{r}700 \\
239,000 \\
8 i, 000\end{array}$ & 140,000 & 700 & & & & & $14,049,000$ & 148,000 & $10,030^{\circ}$ & $200^{\circ}$ & $\begin{array}{r}3,000 \\
8,796,000 \\
2,080,000\end{array}$ & $\begin{array}{r}700 \\
90,000 \\
86,000\end{array}$ \\
\hline 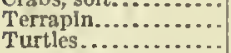 & $\begin{array}{r}2,002,000 \\
24,000\end{array}$ & $\begin{array}{r}400 \\
500\end{array}$ & 13,000 & & & & & (1) & 2,300 & & & & & \\
\hline Clams, hard.......... & $41,969,000$ & 380,000 & 13,000 & 500 & & & & (1) & 0,000 & & & & $41,969,000$ & 380,000 \\
\hline $\begin{array}{l}\text { rket, } \\
\text { areas.. }\end{array}$ & - $9,581,000$ & 645,000 & & & & & & & & & & & $09,581,000$ & 645,000 \\
\hline $\begin{array}{l}\text { Oysters, market, } \\
\text { from private areas. }\end{array}$ & $616,124,000$ & $1,322,000$ & & & & & & & & & & & $016,124,000$ & $1,322,000$ \\
\hline $\begin{array}{l}\text { Oysters, seed, from } \\
\text { puhilic areas....... }\end{array}$ & $79,252,000$ & 357,000 & & & & & & & & & & & $79,252,000$ & 357,000 \\
\hline $\begin{array}{l}\text { Oystcrs, seed, from } \\
\text { private areas........ } \\
\text { scalops................ }\end{array}$ & $\begin{array}{r}856,000 \\
019,000\end{array}$ & $\begin{array}{r}24,000 \\
2,400\end{array}$ & & & & & & & & & & & 856,000 & $\begin{aligned} 24,000 \\
2,400\end{aligned}$ \\
\hline $\begin{array}{l}\text { Skins - mink, musk- } \\
\text { rat, and otter.... }\end{array}$ & 10300 & 400 & & & & & & & & & & & 10300 & 400 \\
\hline
\end{tabular}

1 Includes apparatus, with "catch, as follows: Dredges, tongs, etc., 45,954,000 pounds, valued at \$2,781.000; dip nets, 825,000 pounds, valued at $\$ 29,000$; eel pots, 48,000 pounds, valued at $\$ 2$, 
FISHERIES, BY STATES.

TABLE 2.-VIRGINIA-FISHERY PRODUCTS OF CHESAPEAKE BAY DISTRICT: 1908.

\begin{tabular}{|c|c|c|c|c|c|c|c|c|c|c|c|c|c|c|}
\hline \multirow{3}{*}{ SPECIES. } & \multicolumn{2}{|c|}{ TOTAL. } & \multicolumn{12}{|c|}{ PRODUCT CAUGITT BY- } \\
\hline & \multirow{2}{*}{$\begin{array}{l}\text { Quantity } \\
\text { (pounds). }\end{array}$} & \multirow{2}{*}{ Value. } & \multicolumn{2}{|c|}{$\begin{array}{l}\text { Pound and trap } \\
\text { nets. }\end{array}$} & \multicolumn{2}{|c|}{ Selnes. } & \multicolumn{2}{|c|}{ Lines. } & \multicolumn{2}{|c|}{ Gill nets. } & \multicolumn{2}{|c|}{$\begin{array}{l}\text { Fyke and hoop } \\
\text { nets. }\end{array}$} & \multicolumn{2}{|c|}{ All other apparatus. 1} \\
\hline & & & $\begin{array}{l}\text { Quantity } \\
\text { (pounds). }\end{array}$ & Value. & $\begin{array}{l}\text { Quantity } \\
\text { (pounds). }\end{array}$ & Value. & $\begin{array}{l}\text { Quantity } \\
\text { (pounds). }\end{array}$ & value. & $\begin{array}{l}\text { Quantity } \\
\text { (pounds) }\end{array}$ & Value. & $\begin{array}{l}\text { Quantity } \\
\text { (pounds) }\end{array}$ & Value. & $\begin{array}{l}\text { Quantity } \\
\text { (pounds). }\end{array}$ & Value. \\
\hline Total. . & $301,596,000$ & $84,046,000$ & $49,769,000$ & $\$ 732,600$ & $191,109,000$ & $\$ 508,000$ & $14,836,000$ & $\$ 179,000$ & $3.284,000$ & $\$ 170,000$ & $1,174,000$ & $\$ 44,000$ & $41,425,000$ & $82,413,000$ \\
\hline $\begin{array}{l}\text { Flsh: } \\
\text { Alewives......... } \\
\text { Black bass....... } \\
\text { Bluefish........ } \\
\text { Butterfish....... } \\
\text { Carp, German... }\end{array}$ & $\begin{array}{r}37,713,000 \\
14,000 \\
204,000 \\
600,000 \\
192,000\end{array}$ & $\begin{array}{r}108,000 \\
1,100 \\
11,000 \\
17,000 \\
5,200\end{array}$ & $\begin{array}{r}32,758,000 \\
400 \\
56,000 \\
560,000 \\
22,000\end{array}$ & $\begin{array}{r}136,000 \\
(2) \\
3,700 \\
15,000 \\
1,200\end{array}$ & $\begin{array}{r}3,722,000 \\
7,000 \\
20,000 \\
20,000 \\
145,000\end{array}$ & $\begin{array}{r}20,000 \\
600 \\
1,800 \\
1,400 \\
3,000\end{array}$ & $\begin{array}{r}2,700 \\
94,000\end{array}$ & $\begin{array}{r}200 \\
4,200\end{array}$ & $\begin{array}{r}1,105,000 \\
(2) \\
29,000 \\
16,000 \\
12,000\end{array}$ & $\begin{array}{l}9,200 \\
(2) \\
1,500 \\
300 \\
500\end{array}$ & $\begin{array}{r}127,000 \\
3,700 \\
5,200 \\
4,500 \\
12,000\end{array}$ & $\begin{array}{r}2,400 \\
300 \\
100 \\
100 \\
500\end{array}$ & 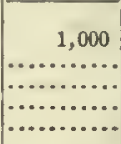 & 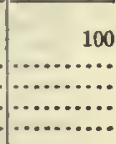 \\
\hline $\begin{array}{l}\text { Catfish.......... } \\
\text { Crevallë......... }\end{array}$ & $\begin{array}{r}641,000 \\
80,000\end{array}$ & $\begin{array}{r}28,000 \\
1,800\end{array}$ & $\begin{array}{r}234,000 \\
80,000\end{array}$ & $\begin{array}{r}11,000 \\
1,800\end{array}$ & 71,000 & 4,300 & 47,000 & 1,900 & 56,000 & 2,700 & 234,000 & 8,600 & $\cdots$. & $\because$ \\
\hline ilt-water & $\begin{array}{r}3,437,000 \\
31,000\end{array}$ & $\begin{array}{r}84,000 \\
600\end{array}$ & $\begin{array}{r}2,897,000 \\
31,000\end{array}$ & $\begin{array}{l}70,000 \\
600\end{array}$ & 76,000 & 2,100 & 292,000 & 7,300 & 60,000 & $\ddot{1}, 800$ & 111,000 & 2,900 & $\cdots$ & $\cdots \cdots$ \\
\hline Eels............... & 84,000 & 4,100 & 25,000 & 1,400 & 5,000 & 200 & 8,200 & 300 & & & 5,000 & 200 & 44,000 & 2,000 \\
\hline Flounders........ & $\begin{array}{r}88,000 \\
233,000\end{array}$ & $\begin{array}{r}3,000 \\
6,200\end{array}$ & $\begin{array}{l}78,000 \\
81,000\end{array}$ & $\begin{array}{l}2,500 \\
2,500\end{array}$ & $\begin{array}{r}2,500 \\
84,000\end{array}$ & $\begin{array}{r}100 \\
2,100\end{array}$ & & & $\begin{array}{r}2,800 \\
66,000\end{array}$ & $\begin{array}{r}100 \\
1,600\end{array}$ & $\begin{array}{l}5,300 \\
2,500\end{array}$ & $\begin{array}{l}300 \\
100\end{array}$ & & $\because$ \\
\hline Klngf & $\begin{array}{r}109,000 \\
24,000\end{array}$ & $\begin{array}{r}11,000 \\
1,100\end{array}$ & $\begin{array}{l}46,000 \\
12,000\end{array}$ & $\begin{array}{r}6,800 \\
500\end{array}$ & $\begin{array}{r}11,000 \\
5,800\end{array}$ & $\begin{array}{r}1,000 \\
300\end{array}$ & 52,000 & 2,600 & & & 7,000 & 200 & & \\
\hline Menhaden....... & $190,049,000$ & 429,000 & $3,844,000$ & 10,000 & $1.86,205,000$ & 419,000 & & & & & & & & ( \\
\hline $\begin{array}{l}\text { MInnows......... } \\
\text { Moonfish........ }\end{array}$ & $\begin{array}{r}2,200 \\
10000\end{array}$ & 900 & & & 2,200 & 900 & & & & & & $\cdots$ & & ..... \\
\hline$\cdots \cdots$ & 181,000 & 6,400 & $\begin{array}{l}10,000 \\
36,000\end{array}$ & $\begin{array}{r}400 \\
1,300\end{array}$ & 24,000 & 900 & 13,000 & 500 & 99,000 & 3,300 & 3,000 & 100 & 5,800 & 200 \\
\hline e..... & 392,000 & 24,000 & 133,000 & 7,900 & 78,000 & 4,800 & 16,000 & 1,000 & 82,000 & 5,400 & 83,000 & $\begin{array}{l}4900 \\
9\end{array}$ & 100 & (2) \\
\hline & & 7,000 & $\$ 5,000$ & 2,100 & $2 \pi, 000$ & & & & & & 01,000 & & & \\
\hline $\begin{array}{l}\text { Plke an } \\
\text { Pompar }\end{array}$ & $\begin{array}{r}3,800 \\
19,000\end{array}$ & $\begin{array}{r}300 \\
3,000\end{array}$ & $\begin{array}{r}6,000 \\
18,000\end{array}$ & $\begin{array}{l}(2) \\
2,800\end{array}$ & 3,000 & 300 & 400 & 100 & $\begin{array}{r}200 \\
1,000\end{array}$ & $\stackrel{(2)}{200}^{(2)}$ & $\begin{array}{l}100 \\
200\end{array}$ & (2) & $\cdots \cdots \cdot$ & (n.......... \\
\hline Seup & $\begin{array}{l}44,000 \\
42,000\end{array}$ & $\begin{array}{l}2,500 \\
1,700\end{array}$ & 41,000 & 2,300 & 2,000 & 200 & 000 & 100 & & & 1,000 & (2) & ........ & : \\
\hline Shad.... & $7,267,000$ & 481,000 & $5,435,000$ & 337,000 & 203,000 & 14,000 & 42,000 & $1, \ldots \ldots$ & $1,597,000$ & 127,000 & 32,000 & 2,900 & …......... & (n........... \\
\hline $\begin{array}{l}\text { Sheenshead... } \\
\text { Spanish mack }\end{array}$ & 1.900 & 200 & 1.500 & 100 & & & 400 & (2) & & & & & & \\
\hline t.... & $\begin{array}{r}99,000 \\
154,000\end{array}$ & $\begin{array}{r}9,100 \\
12,000\end{array}$ & $\begin{array}{l}88,000 \\
48,000\end{array}$ & 7,900 & $\begin{array}{r}200 \\
42,000\end{array}$ & $(2), 100$ & 56,000 & 3,400 & 5,600 & 500 & $\begin{array}{r}11,000 \\
2,700\end{array}$ & 1,200 & - & - \\
\hline Squeteague....... & $3,557,000$ & 100.000 & $2,809,000$ & 75,000 & 212,000 & 12,000 & 125,000 & 3,600 & 56,000 & 2,600 & 355,000 & 6.800 & …......... & 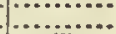 \\
\hline Striped bass..... & 502,000 & 46,000 & 158,000 & 14,000 & 141,000 & 13,000 & 33,000 & 3,500 & 62,000 & 5,900 & 107,000 & 10,000 & 100 & (2) \\
\hline $\begin{array}{l}\text { Sturgeon........ } \\
\text { Cariar and stur- }\end{array}$ & 85,000 & 9,400 & $54, C 00$ & 6,300 & 1,000 & 100 & & & 30,000 & 3,000 & 300 & (2) & ............ & ........ \\
\hline $\begin{array}{l}\text { geon e } \\
\text { Suckers. }\end{array}$ & $\begin{array}{r}8.900 \\
10,000\end{array}$ & $\begin{array}{r}11,000 \\
500\end{array}$ & 5,100 & 5,900 & 100 & 200 & & & 3,700 & 4,600 & & & & \\
\hline All other.. & 12,000 & 500 & 7,600 & 400 & 500 & (2) & 500 & (2) & & & $\begin{array}{r}10,100 \\
3,100\end{array}$ & 100 & & \\
\hline Frogs... & 3,000 & 700 & & & & & & & & & & & 3,000 & 700 \\
\hline & $23,001,00$ & 239, a & 140,000 & 700 & & & $14,049,000$ & 148,000 & & $\ldots .$. & 16,000 & 200 & $8,796,000$ & 90,000 \\
\hline Turtles........ & $\begin{array}{r}2,052,8100 \\
24,000\end{array}$ & $\begin{array}{r}87,000 \\
500\end{array}$ & 18,000 & 300 & & & $\begin{array}{l}2,300 \\
6,000\end{array}$ & $\begin{array}{l}100 \\
200\end{array}$ & 600 & (3) & & & $2,080,000$ & 86,000 \\
\hline Clams, hard.. & $\cdot 1,113,000$ & 217,000 & & & & & & & & & & & $41,113,000$ & 217,000 \\
\hline $\begin{array}{l}\text { Oysters, market, } \\
\text { Irom public areas.. }\end{array}$ & B $8,723,000$ & 591,000 & & & & & & & & & & & $8,723,000$ & 591,000 \\
\hline $\begin{array}{l}\text { Oysters, } \mathrm{market} \text {, } \\
\text { from private areas. }\end{array}$ & 6 $12,833,000$ & $1,102,000$ & & & & & & & & & & & & \\
\hline Oysters, seed, from & 12,030, tout & $1,102,000$ & & & & & & & & & & & {$[12,833,000$} & $1,102,000$ \\
\hline $\begin{array}{l}\text { publie areas. } \\
\text { oysters, seed, from }\end{array}$ & $77,258,000$ & 299,000 & & & & & & & & & & & $7,258,000$ & 299,000 \\
\hline $\begin{array}{l}\text { private areas....... } \\
\text { skins-malnk, muskk }\end{array}$ & 8668,000 & 24,000 & & & & & & & & & & & 568,000 & 24,000 \\
\hline rat, and otter..... & ${ }^{8} 300$ & 400 & & & & & & & & & & & - 300 & 400 \\
\hline
\end{tabular}

1 Includes apparatus, with catch, as follows: Dredges, tongs, etc., 40,527,000 pounds, valued at $\$ 2,379,000 ;$ dlp nets, 828,000 pounds, valued at $\$ 29,000 ;$ eel pots, 44,000 pounds, valued at $\$ 2,000$; mink, muskrat, and otter traps, 300 pounds, valued at $\$ 400$; and minor apparatus, 26,000 pounds, valued at $\$ 2,100$.

Less than $\$ 100$ pounds.

1 $1,246,000$ bushels.

i $1,833,000$ bushels.

81,000 bushels.

$76786^{\circ}-11-17$ 
TABLE 3.-VIRGINIA-FISHERY PRODUCTS OF ATLANTIC OCEAN DISTRICT: 1908.

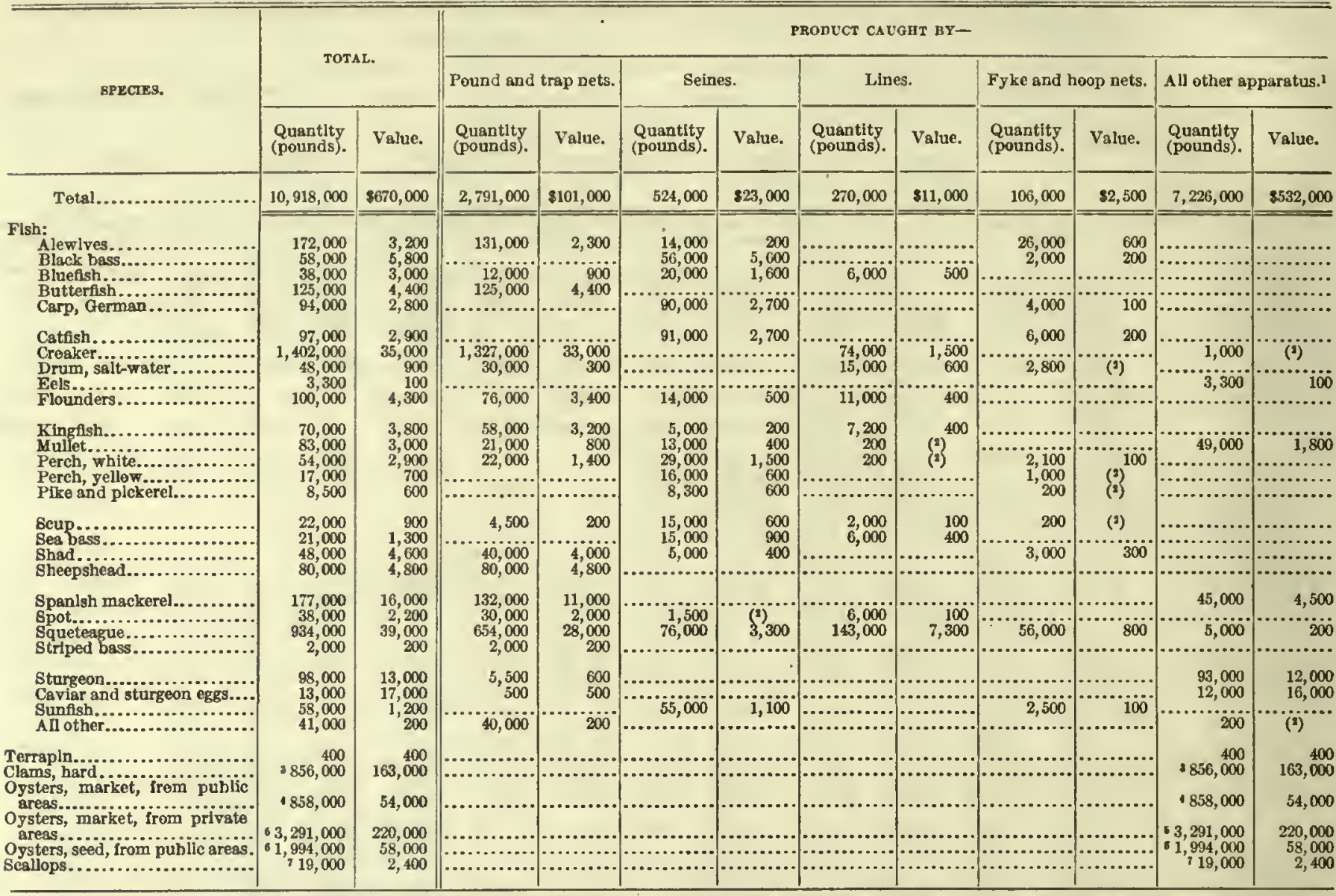

2 Includes apparatus, with catch, as follows: Dredges, tongs, etc., 5,428,000 pounds, valued at $\$ 403,000 ;$ glll nets, 205,000 pounds, valued at $\$ 35,000$; eel pots, 3,300 pounds,

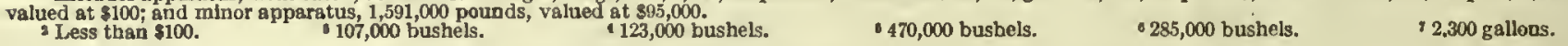

TABLE 4.-VIRGINIA-PRODUCTS OF VESSEL FISHERIES: 1908.

\begin{tabular}{|c|c|c|c|c|c|c|c|c|c|c|}
\hline \multirow{3}{*}{ SPECIES. } & \multirow{2}{*}{\multicolumn{2}{|c|}{ TOTAL. }} & \multicolumn{8}{|c|}{ PRODUCT CAUGHT BY- } \\
\hline & & & \multicolumn{2}{|c|}{ Selnes. } & \multicolumn{2}{|c|}{ Pound and trap nets. } & \multicolumn{2}{|c|}{ Llnes. } & \multicolumn{2}{|c|}{ All ether apparatus. ${ }^{1}$} \\
\hline & $\begin{array}{l}\text { Quantlty } \\
\text { (pounds). }\end{array}$ & Value. & $\begin{array}{l}\text { Quantity } \\
\text { (pounds). }\end{array}$ & Value. & $\begin{array}{l}\text { Quantlty } \\
\text { (pounds). }\end{array}$ & Value. & $\begin{array}{l}\text { Quantity } \\
\text { (pounds). }\end{array}$ & Value. & $\begin{array}{l}\text { Quantity } \\
\text { (pounds). }\end{array}$ & Value. \\
\hline Total... & $207,070,000$ & $\$ 1,009,000$ & $186,361,000$ & $\$ 427,000$ & $7,016,000$ & $\$ 58,000$ & 321,000 & $\$ 6,400$ & $13,371,000$ & $\$ 517,000$ \\
\hline 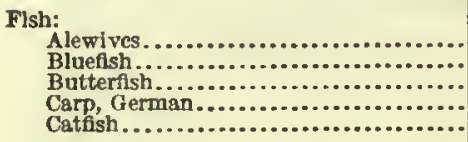 & $\begin{array}{r}6,358,000 \\
37,000 \\
7,500 \\
6,000 \\
22,000\end{array}$ & $\begin{array}{r}22,000 \\
2,900 \\
300 \\
300 \\
800\end{array}$ & $\begin{array}{r}25,000 \\
6,000 \\
9,000\end{array}$ & $\begin{array}{r}3,000 \\
400\end{array}$ & $\begin{array}{r}6,358,000 \\
100 \\
7,600 \\
13,000\end{array}$ & $\begin{array}{r}22,000 \\
()^{2}{ }_{300} \\
400\end{array}$ & $\begin{array}{l}12,000 \\
\ldots \ldots \ldots \\
\ldots \ldots \ldots\end{array}$ & 800 & 0 & $\begin{array}{ll}n \\
\cdots\end{array}$ \\
\hline 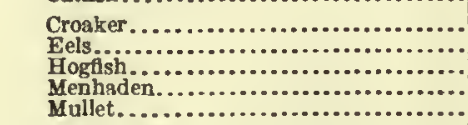 & $\begin{array}{r}93,000 \\
8,300 \\
900 \\
186,205,000 \\
3,000\end{array}$ & $\begin{array}{r}1,800 \\
400 \\
100 \\
419,000 \\
200\end{array}$ & $\begin{array}{r}18,000 \\
186,205,000 \\
3,000\end{array}$ & $\begin{array}{r}419,000 \\
200\end{array}$ & 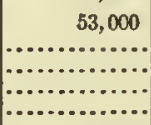 & 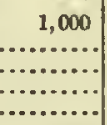 & $\begin{array}{c}40,000 \\
900 \\
\cdots \cdots\end{array}$ & $\begin{array}{r}800 \\
100 \\
\cdots \\
\cdots\end{array}$ & ......, 300 & $\begin{array}{r}200 \\
\cdots \ldots+. \\
\cdots \cdots\end{array}$ \\
\hline 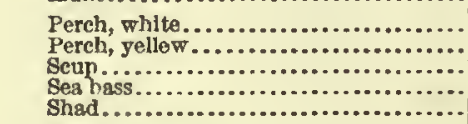 & $\begin{array}{r}8,300 \\
9,000 \\
17,000 \\
63,000 \\
588,000\end{array}$ & $\begin{array}{r}400 \\
400 \\
700 \\
2,900 \\
34,000\end{array}$ & $\begin{array}{r}7,000 \\
9,000 \\
15,000 \\
15,000\end{array}$ & $\begin{array}{l}400 \\
400 \\
600 \\
900\end{array}$ & $\begin{array}{r}1,300 \\
\ldots \ldots \ldots \\
\ldots \ldots\end{array}$ & $\begin{array}{c}100 \\
\cdots \ldots \ldots \ldots \\
34,000\end{array}$ & $\begin{array}{r}\left({ }^{3}\right) \\
2,0000 \\
48,000 \\
\cdots\end{array}$ & $\begin{array}{l}(2) \\
1000 \\
2,000\end{array}$ & 8,500 & (n) \\
\hline 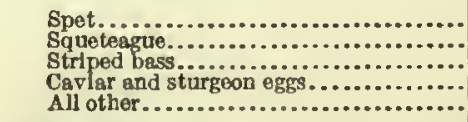 & $\begin{array}{r}3,000 \\
58,000 \\
28,000 \\
100 \\
500\end{array}$ & $\begin{array}{r}300 \\
2,000 \\
2,300 \\
100 \\
(2)\end{array}$ & $\begin{array}{r}88,000 \\
24,000 \\
\end{array}$ & $\begin{array}{l}1,500 \\
2,000\end{array}$ & $\begin{array}{r}1,500 \\
2,000 \\
100 \\
600\end{array}$ & $\begin{array}{l}100 \\
200 \\
100 \\
\left({ }^{2}\right)^{2}\end{array}$ & $\begin{array}{r}3,000 \\
18,000 \\
500 \\
\ldots \ldots \ldots \\
\cdots \ldots . .\end{array}$ & $\begin{array}{r}300 \\
500 \\
100 \\
\cdots \cdots \\
\cdots \\
\cdots\end{array}$ & i, & $\begin{array}{c}\ldots \ldots . \\
\ldots \ldots \\
\ldots \ldots \ldots\end{array}$ \\
\hline 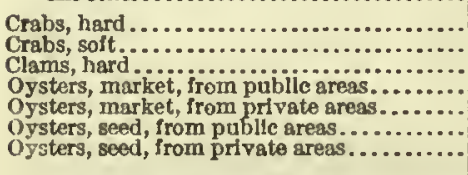 & $\begin{array}{r}6,722,000 \\
115,000 \\
142,000 \\
61,661,000 \\
3,596,000 \\
1,313,000 \\
6105,000\end{array}$ & $\begin{array}{r}70,000 \\
3,600 \\
6,000 \\
113,000 \\
271,000 \\
51,000 \\
4,000\end{array}$ & $\begin{array}{l}\cdots \\
\cdots \cdots \\
\cdots \cdots \\
\cdots\end{array}$ & $\begin{array}{l}\cdots \\
\cdots \\
\cdots\end{array}$ & [..., & …......... & $\begin{array}{r}196,000 \\
400 \\
\cdots \cdots \\
\cdots \cdots \\
\cdots \cdots \\
\cdots\end{array}$ & 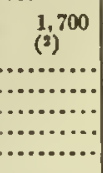 & $\begin{array}{r}6,526,000 \\
114,000 \\
142,000 \\
11,661,000 \\
3,590,000 \\
1,313,000 \\
6105,000\end{array}$ & $\begin{array}{r}68,000 \\
3,800 \\
6,000 \\
113,000 \\
271,000 \\
51,000 \\
4,000\end{array}$ \\
\hline
\end{tabular}

I Includes apparatus, with catch, as follows: Dredges, tongs, etc., 13,171,000 pounds, valued at $\$ 511,000$; glll nets, 9,500 pounds, valued at $\$ 500$; eel pots, 3,300 pounds valuerl at $\$ 200 ;$ and miner apparatus, 188,000 pounds, valued at $\$ 5,400$.

Less than $\$ 100$. Less than 100 pounds.

- 237,000 bushels.

- 514,000 bushels.

188,000 bushels.

15,000 busbels. 
FISHERIES, BY ST ATES.

TABLE 5.-VIRGINIA-PRODUCTS OF VESSEL FISHERIES OF CHESAPEAKE BAY DISTRICT: 1908.

\begin{tabular}{|c|c|c|c|c|c|c|c|c|c|c|}
\hline \multirow{3}{*}{ SPECIES. } & \multirow{2}{*}{\multicolumn{2}{|c|}{ TOTaL. }} & \multicolumn{8}{|c|}{ PRODUCT CAUOUT BX- } \\
\hline & & & \multicolumn{2}{|c|}{ Selnes. } & \multicolumn{2}{|c|}{ Pound and trap nets. } & \multicolumn{2}{|c|}{ Lines. } & \multicolumn{2}{|c|}{ All other apparatus.1 } \\
\hline & $\begin{array}{l}\text { Quantity } \\
\text { (pounds). }\end{array}$ & Value. & $\begin{array}{l}\text { Quantity } \\
\text { (pounds). }\end{array}$ & Value. & $\begin{array}{l}\text { Quantity } \\
\text { (pounds). }\end{array}$ & Value. & $\begin{array}{l}\text { Quantity } \\
\text { (pounds). }\end{array}$ & Value. & $\begin{array}{l}\text { Quantity } \\
\text { (pounds). }\end{array}$ & Value. \\
\hline Total.............. & $206,537,000$ & $\$ 985,000$ & $186,286,000$ & $\$ 424,000$ & $7,016,000$ & $\$ 58,000$ & 301,000 & $\$ 5,300$ & $12,833,000$ & $\$ 198,000$ \\
\hline 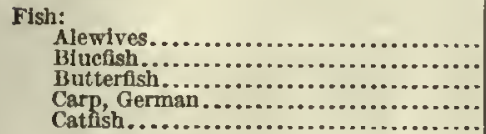 & $\begin{array}{r}6,358,000 \\
11,000 \\
7,500 \\
6,000 \\
22,000\end{array}$ & $\begin{array}{r}22,000 \\
800 \\
300 \\
300 \\
800\end{array}$ & $\begin{array}{r}5,0000 \\
6,000 \\
9,000\end{array}$ & $\begin{array}{r}400 \\
3000 \\
400\end{array}$ & $\begin{array}{r}6,358,000 \\
100 \\
7,500 \\
13,000\end{array}$ & $\begin{array}{c}\begin{array}{c}22,000 \\
(2) \\
300 \\
400\end{array} \\
\ldots . .\end{array}$ & $\begin{array}{c}\ddot{6}, \ddot{0} 000 \\
\ldots \ldots \ldots\end{array}$ & $\begin{array}{r}400 \\
\ldots . . .\end{array}$ & & $\begin{array}{l}\cdots \\
\cdots \\
\cdots\end{array}$ \\
\hline 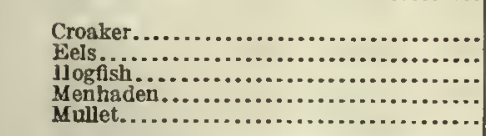 & $\begin{array}{r}93,000 \\
8,300 \\
900 \\
186,205,000 \\
3,000\end{array}$ & $\begin{array}{r}1,800 \\
400 \\
100 \\
419,000 \\
200\end{array}$ & $\begin{array}{r}5,000 \\
\cdots, 36,205,000 \\
3,000\end{array}$ & $\begin{array}{r}200 \\
419,000 \\
200\end{array}$ & 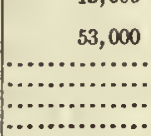 & 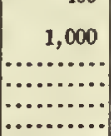 & 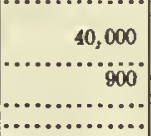 & $\begin{array}{r}800 \\
100 \\
\ldots \ldots\end{array}$ & 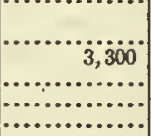 & $\begin{array}{l}200 \\
\cdots \\
\cdots\end{array}$ \\
\hline 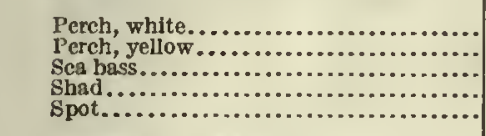 & $\begin{array}{r}8,300 \\
9,000 \\
42,000 \\
588,000 \\
3,000\end{array}$ & $\begin{array}{r}400 \\
400 \\
1,700 \\
34,000 \\
300\end{array}$ & $\begin{array}{r}7,000 \\
9,000 \\
\ldots \ldots . . .6 . \\
\cdots \ldots . . .\end{array}$ & $\begin{array}{r}400 \\
400 \\
\cdots \ldots \\
\ldots \ldots\end{array}$ & $\begin{array}{r}1,300 \\
\ldots, \ldots, \ldots \\
580,000 \\
\cdots\end{array}$ & \begin{tabular}{r|}
100 \\
$3 \ddot{3}, 000$ \\
$\cdots \cdots$
\end{tabular} & $\begin{array}{l}\text { (3) } \\
42,000 \\
3,000\end{array}$ & $\begin{array}{c}\left({ }^{3}\right) \\
1,700 \\
3000\end{array}$ & $\ddot{8}, \overline{500}$ & $\begin{array}{r}\ldots \ldots \\
\cdots \ldots \\
\cdots \ldots\end{array}$ \\
\hline 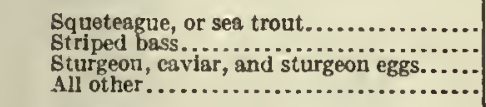 & $\begin{array}{r}27,000 \\
28,000 \\
400 \\
200\end{array}$ & $\begin{array}{l}1,100 \\
2,300 \\
100 \\
(2)\end{array}$ & $\begin{array}{r}13,000 \\
24,000 \\
\cdots \cdots \\
\cdots \cdots\end{array}$ & $\begin{array}{r}700 \\
2,000 \\
\cdots \cdots \\
\cdots\end{array}$ & $\begin{array}{r}1,500 \\
2,000 \\
400 \\
200\end{array}$ & $\begin{array}{r}100 \\
200 \\
100 \\
(2)^{10}\end{array}$ & $\begin{array}{r}12,000 \\
500 \\
\ldots \ldots \ldots \ldots \\
\cdots \cdots\end{array}$ & $\begin{array}{r}300 \\
100 \\
\cdots \cdots\end{array}$ & (1,000 & jo \\
\hline 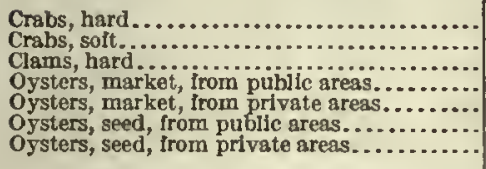 & $\begin{array}{r}6,722,000 \\
115,000 \\
130,000 \\
1,653,000 \\
3,451,000 \\
1,041,000 \\
105,000\end{array}$ & $\begin{array}{r}70,000 \\
3,600 \\
3,800 \\
112,000 \\
263,000 \\
43,000 \\
4,000\end{array}$ & 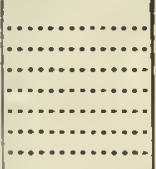 & 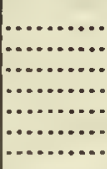 & 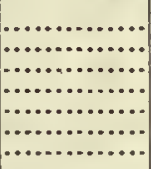 & 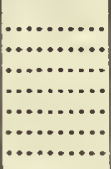 & 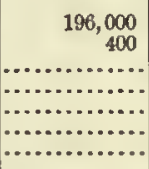 & 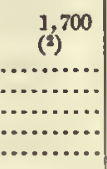 & $\begin{array}{r}6,526,000 \\
114,000 \\
130,000 \\
1,653,000 \\
3,451,000 \\
71,041,000 \\
8105,000\end{array}$ & $\begin{array}{r}68,000 \\
3,600 \\
3,800 \\
112,000 \\
263,000 \\
43,000 \\
4,000\end{array}$ \\
\hline
\end{tabular}

1 Includes apparatus, with catch, as follows: Dredges, tongs, etc., 12,913,000 pounds, valued st $\$ 497,000 ;$ gill nets, 9,500 pounds, valued at $\$ 500$; eel pots, 3,300 pounds,

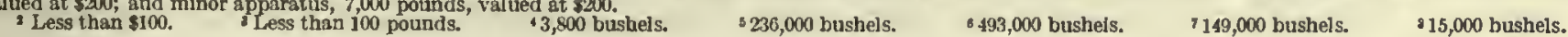

TABLE 6.-VIRGINIA-PRODUCTS OF VESSEL FISHERIES OF ATLANTIC OCEAN DISTRICT: 1908.

\begin{tabular}{|c|c|c|c|c|c|c|c|c|c|c|}
\hline \multirow{3}{*}{ SPECIES. } & \multirow{2}{*}{\multicolumn{2}{|c|}{ TOTAL. }} & \multicolumn{8}{|c|}{ PRODUCT CAUGHT BY- } \\
\hline & & & \multicolumn{2}{|c|}{ Dredges, tongs, etc. } & \multicolumn{2}{|c|}{ Selnes. } & \multicolumn{2}{|c|}{ Lines. } & \multicolumn{2}{|c|}{ Minor apparatns. } \\
\hline & $\begin{array}{l}\text { Quantity } \\
\text { (pounds). }\end{array}$ & Value. & $\begin{array}{l}\text { Quantity } \\
\text { (pounds). }\end{array}$ & Value. & $\begin{array}{l}\text { Quantity } \\
\text { (pounds). }\end{array}$ & Value. & $\begin{array}{l}\text { Quantity } \\
\text { (pounds). }\end{array}$ & Value. & $\begin{array}{l}\text { Quantity } \\
\text { (pounds). }\end{array}$ & Value. \\
\hline Total................ & 534,000 & $\$ 24,000$ & 258,000 & $\$ 14,000$ & 75,000 & $\$ 3,800$ & 20,000 & $\$ 1,100$ & 181,000 & $\$ 5,200$ \\
\hline 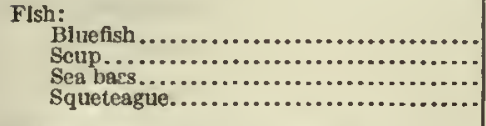 & $\begin{array}{l}26,000 \\
17,000 \\
21,000 \\
31,000\end{array}$ & $\begin{array}{r}2,100 \\
700 \\
1,300 \\
900\end{array}$ & (n. & (n...... & $\begin{array}{l}20,000 \\
15,000 \\
15,000 \\
25,000\end{array}$ & $\begin{array}{r}1,600 \\
600 \\
900 \\
800\end{array}$ & $\begin{array}{l}6,000 \\
2,000 \\
6,000 \\
6,000\end{array}$ & $\begin{array}{l}500 \\
100 \\
400 \\
200\end{array}$ & 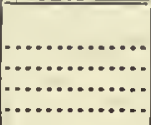 & (n) \\
\hline $\begin{array}{l}\text { Clams, hard................................... } \\
\text { Oysters, market, from pubilic areas........... } \\
\text { Oysters, market, from private areas......... } \\
\text { Oysters, seed, from public areas............ }\end{array}$ & $\begin{array}{r}12,000 \\
38,800 \\
146,000 \\
1272,000\end{array}$ & $\begin{array}{l}2,200 \\
500 \\
8,200 \\
8,300\end{array}$ & $\begin{array}{r}12,000 \\
28,800 \\
146,000 \\
92,000\end{array}$ & $\begin{array}{r}2,200 \\
500 \\
8,200 \\
3,100\end{array}$ & $\begin{array}{l}\cdots \cdots \\
\cdots \cdots \cdots \\
\cdots \cdots \cdots\end{array}$ & ...... & $\begin{array}{l}\cdots \cdots \\
\cdots \cdots \\
\cdots \cdots\end{array}$ & $\begin{array}{l}\cdots \\
\cdots \cdots \\
\cdots \cdots\end{array}$ & $\begin{array}{r}181,000 \\
\\
\cdots\end{array}$ & ;,200 \\
\hline
\end{tabular}


TABLE 7.-VIRGINIA-PRODUCTS OF SHORE AND BOAT FISHERIES: 1908.

\begin{tabular}{|c|c|c|c|c|c|c|c|c|c|c|c|c|c|c|}
\hline \multirow{3}{*}{ SPECIES } & \multirow{2}{*}{\multicolumn{2}{|c|}{ TOTAL. }} & \multicolumn{12}{|c|}{ PRODUCT CAUGHT BY- } \\
\hline & & & \multicolumn{2}{|c|}{$\begin{array}{l}\text { Pound and trap } \\
\text { nets. }\end{array}$} & \multicolumn{2}{|c|}{ Glll nets. } & \multicolumn{2}{|c|}{ Lines. } & \multicolumn{2}{|c|}{ Seines. } & \multicolumn{2}{|c|}{$\begin{array}{c}\text { Fyke and hoop } \\
\text { nets. }\end{array}$} & \multicolumn{2}{|c|}{ All other apparatus. } \\
\hline & $\begin{array}{l}\text { Quantlty } \\
\text { (pounds). }\end{array}$ & Value. & $\begin{array}{l}\text { Quantity } \\
\text { (pounds). }\end{array}$ & Va ue. & $\begin{array}{l}\text { Quantlty } \\
\text { (pounds). }\end{array}$ & Value. & $\begin{array}{l}\text { Quantlty } \\
\text { (pounds). }\end{array}$ & Value. & $\begin{array}{l}\text { Quantity } \\
\text { (pounds). }\end{array}$ & Value. & $\begin{array}{l}\text { Quantlty } \\
\text { (pounds). }\end{array}$ & Value. & $\begin{array}{l}\text { Quantity } \\
\text { (pounds). }\end{array}$ & Value. \\
\hline Total.. & $105,444,000$ & $\$ 3,707,000$ & $45,543,000$ & $\$ 776,000$ & $3,479,000$ & $\$ 204,000$ & $14,785,000$ & $\$ 184,000$ & $5,272,000$ & $\$ 103,000$ & $1,279,000$ & $\$ 47,000$ & $35,085,000$ & $\$ 2,393,000$ \\
\hline $\begin{array}{l}\text { Fish: } \\
\text { Alewives........... } \\
\text { Black bass......... } \\
\text { Bluefish.......... } \\
\text { Butterfish......... } \\
\text { Carp, German..... }\end{array}$ & $\begin{array}{r}31,526,000 \\
71,000 \\
205,000 \\
718,000 \\
280,000\end{array}$ & $\begin{array}{r}149,000 \\
6,900 \\
11,000 \\
21,000 \\
7,700\end{array}$ & $\begin{array}{r}26,531,000 \\
400 \\
68,000 \\
677,000 \\
22,000\end{array}$ & $\begin{array}{r}117,000 \\
\left({ }^{2}\right) \\
4,600 \\
19,000 \\
1,200\end{array}$ & $\begin{array}{c}1,105,000 \\
(3) \\
29,000 \\
16,000 \\
12,000\end{array}$ & $\begin{array}{l}9,200 \\
(2) \\
1,500 \\
300 \\
500\end{array}$ & $\begin{array}{r}2,700 \\
83,000 \\
\cdots\end{array}$ & $\begin{array}{r}200 \\
3,800 \\
\ldots \ldots\end{array}$ & $\begin{array}{r}3,736,000 \\
62,000 \\
15,000 \\
20,000 \\
230,000\end{array}$ & $\begin{array}{r}20,000 \\
6,200 \\
1,300 \\
1,400 \\
5,400\end{array}$ & $\begin{array}{r}153,000 \\
5,700 \\
5,200 \\
4,500 \\
16,000\end{array}$ & $\begin{array}{r}3,100 \\
500 \\
100 \\
100 \\
600\end{array}$ & $\begin{array}{c}1,000 \\
\ldots \ldots \ldots \\
\ldots \ldots \ldots \\
\cdots \cdots\end{array}$ & \begin{tabular}{r}
\multicolumn{1}{c}{100} \\
$\cdots \cdots \cdots \cdots$ \\
$\cdots \cdots \cdots \cdots$ \\
$\cdots \cdots \cdots \cdots$ \\
$\cdots \cdots \cdots$
\end{tabular} \\
\hline 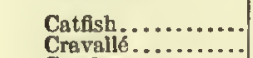 & $\begin{array}{r}716,000 \\
80,000\end{array}$ & $\begin{array}{r}31,000 \\
1,800\end{array}$ & $\begin{array}{r}221,000 \\
80,000\end{array}$ & $\begin{array}{r}11,000 \\
1,800\end{array}$ & 56,000 & 2,700 & 47,000 & 1,900 & 153,000 & 6,700 & 240,000 & $\begin{array}{c}8,800 \\
\cdots\end{array}$ & & \\
\hline $\begin{array}{l}\text { Croaker............. } \\
\text { Drum, sait-water.. } \\
\text { Eels................. }\end{array}$ & $\begin{array}{r}4,745,000 \\
78,000 \\
79,000\end{array}$ & $\begin{array}{r}117,000 \\
1,500 \\
3,800\end{array}$ & $\begin{array}{r}4,171,000 \\
61,000 \\
25,000\end{array}$ & $\begin{array}{r}102,000 \\
900 \\
1,400\end{array}$ & $\begin{array}{r}61,600 \\
\cdots \ldots \ldots \\
\cdots\end{array}$ & $\begin{array}{r}1,800 \\
\ldots \ldots\end{array}$ & $\begin{array}{r}325,000 \\
15,000 \\
5,200\end{array}$ & $\begin{array}{r}7,900 \\
600 \\
300\end{array}$ & $\begin{array}{r}76,000 \\
\ldots . \ldots \ldots\end{array}$ & $\begin{array}{r}2,100 \\
\ldots \ldots\end{array}$ & $\begin{array}{r}111,000 \\
2,800 \\
5,000\end{array}$ & $\begin{array}{l}\ddot{2}, 900 \\
(2) \\
200\end{array}$ & 44,000 & a.............. \\
\hline $\begin{array}{l}\text { Flounders........ } \\
\text { Hickory shad...... } \\
\text { Hogfish............. } \\
\text { Kingfish ............ } \\
\text { Menhaden....... }\end{array}$ & $\begin{array}{r}188,000 \\
233,000 \\
108,000 \\
95,000 \\
3,884,000\end{array}$ & $\begin{array}{r}7,300 \\
6,200 \\
11,000 \\
4,800 \\
10,000\end{array}$ & $\begin{array}{r}153,000 \\
81,000 \\
46,000 \\
70,000 \\
3,884,000\end{array}$ & $\begin{array}{r}5,900 \\
2,500 \\
6,800 \\
3,700 \\
10,000\end{array}$ & $\begin{array}{r}2,800 \\
66,000 \\
\cdots \cdots \\
\cdots \\
\cdots\end{array}$ & $\begin{array}{r}100 \\
1,600 \\
\cdots\end{array}$ & $\begin{array}{r}11,000 \\
\quad 51,000 \\
7,200 \\
\ldots \ldots \ldots\end{array}$ & $\begin{array}{r}400 \\
2,300 \\
400\end{array}$ & $\begin{array}{l}16,000 \\
84,000 \\
11,000 \\
11,000 \\
\cdots \ldots \ldots\end{array}$ & $\begin{array}{r}600 \\
2,100 \\
1,600 \\
500\end{array}$ & $\begin{array}{r}5,300 \\
2,600 \\
\cdots \\
7,000 \\
\cdots\end{array}$ & $\begin{array}{c}300 \\
100 \\
200\end{array}$ & $\cdots$ & $\mid \begin{array}{l}\cdots \cdots \\
\cdots \cdots \cdots \\
\cdots \cdots \cdots \\
\cdots \cdots\end{array}$ \\
\hline $\begin{array}{l}\text { Minnows........... } \\
\text { Moonfish ........... } \\
\text { Mullet............ } \\
\text { Perch, white...... } \\
\text { Perch, yellow...... }\end{array}$ & $\begin{array}{r}2,200 \\
10,000 \\
261,000 \\
438,000 \\
109,000\end{array}$ & $\begin{array}{r}900 \\
400 \\
9,200 \\
26,000 \\
5,100\end{array}$ & $\begin{array}{r}10,000 \\
57,000 \\
154,000 \\
45,000\end{array}$ & $\begin{array}{l}400 \\
2,200 \\
9,200 \\
2,100\end{array}$ & $\begin{array}{r}148,000 \\
82,000 \\
\ldots\end{array}$ & $\begin{array}{l}5,100 \\
5,400\end{array}$ & $\begin{array}{l}13,000 \\
16,000\end{array}$ & $\begin{array}{r}500 \\
1,000\end{array}$ & $\begin{array}{r}2,200 \\
34,000 \\
100,000 \\
31,000\end{array}$ & $\begin{array}{l}1,100 \\
5,000 \\
1,400\end{array}$ & $\begin{array}{r}3,000 \\
85,000 \\
32,000\end{array}$ & $\begin{array}{l}100 \\
5,000 \\
1,600\end{array}$ & $\begin{array}{r}5,800 \\
100\end{array}$ & ${ }_{(2)}^{200}$ \\
\hline $\begin{array}{l}\text { Plke and plckerel.. } \\
\text { Pompano........... } \\
\text { Scup................ } \\
\text { Shad............ } \\
\text { Sheepshead...... }\end{array}$ & $\begin{array}{r}12,000 \\
20,000 \\
48,000 \\
6,726,000 \\
82,000\end{array}$ & $\begin{array}{r}1,000 \\
3,100 \\
2,800 \\
452,000 \\
5,000\end{array}$ & $\begin{array}{r}600 \\
18,000 \\
45,000 \\
4,895,000 \\
82,000\end{array}$ & $\begin{array}{r}\text { (2) } \\
2,800 \\
2,600 \\
307,000 \\
4,900\end{array}$ & \begin{tabular}{r}
200 \\
1,000 \\
\hdashline$, 588,000$ \\
$\cdots, \ldots$.
\end{tabular} & $\begin{array}{c}\text { () } \\
200 \\
127,000 \\
\cdots\end{array}$ & 400 & $(3)$ & $\begin{array}{r}11,000 \\
208,000 \\
2,000 \\
\end{array}$ & $\begin{array}{r}900 \\
200 \\
15,000 \\
\ldots \ldots\end{array}$ & $\begin{array}{r}300 \\
200 \\
1,200 \\
35,000 \\
\end{array}$ & $\begin{array}{l}\text { (3) } \\
100 \\
3,200 \\
\cdots\end{array}$ & a... & 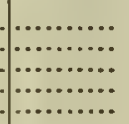 \\
\hline $\begin{array}{l}\text { Spanish mackerel.. } \\
\text { Spot............... } \\
\text { Squeteague........ } \\
\text { Striped bass....... }\end{array}$ & $\begin{array}{r}276,000 \\
189,000 \\
4,433,000 \\
476,000\end{array}$ & $\begin{array}{r}25,000 \\
14,000 \\
137,000 \\
44,000\end{array}$ & $\begin{array}{r}220,000 \\
78,000 \\
3,461,000 \\
158,000\end{array}$ & $\begin{array}{r}19,000 \\
6,300 \\
103,000 \\
14,000\end{array}$ & $\begin{array}{r}45,000 \\
5,600 \\
61,000 \\
61,000\end{array}$ & $\begin{array}{r}4,500 \\
500 \\
2,700 \\
5,800\end{array}$ & $\begin{array}{r}59,000 \\
250,000 \\
33,000\end{array}$ & $\begin{array}{r}3,200 \\
10,000 \\
3,400\end{array}$ & $\begin{array}{r}200 \\
44,000 \\
250,000 \\
117,000\end{array}$ & $\begin{array}{c}\left({ }^{2}\right) \\
4,200 \\
14,000 \\
11,000\end{array}$ & $\begin{array}{r}11,000 \\
2,700 \\
411,000 \\
107,000\end{array}$ & $\begin{array}{r}1,200 \\
100 \\
7,600 \\
10,000\end{array}$ & 100 & $(\cdots \cdots \ldots$ \\
\hline $\begin{array}{l}\text { Sturgeon.......... } \\
\text { Caviar and stur- } \\
\text { geon eggs........ }\end{array}$ & 183,000 & $\begin{array}{l}22,000 \\
27,000\end{array}$ & 60,000 & $\begin{array}{l}6,800 \\
6,300\end{array}$ & $\begin{array}{r}122,000 \\
16,000\end{array}$ & $\begin{array}{l}15,000 \\
21,000\end{array}$ & & & $\begin{array}{r}1,000 \\
100\end{array}$ & $\begin{array}{l}100 \\
200\end{array}$ & 300 & (2) & & \\
\hline $\begin{array}{l}\text { Suckers............. } \\
\text { Sunfish............. } \\
\text { All other......... }\end{array}$ & $\begin{array}{l}10,000 \\
58,000 \\
12,000\end{array}$ & $\begin{array}{r}600 \\
1,200 \\
500\end{array}$ & $\begin{array}{r}400 \\
7,200\end{array}$ & (2) & $\mid \cdots \cdots \cdots$ & (3) & 500 & $(3)$ & $\begin{array}{r}55,000 \\
500\end{array}$ & 1,100 & $\begin{array}{r}10,000 \\
2,500 \\
3,100\end{array}$ & $\begin{array}{l}300 \\
100 \\
100\end{array}$ & $\ldots \ldots \ldots$ & $\begin{array}{l}\cdots \cdots \\
\cdots \cdots \\
\cdots \cdots\end{array}$ \\
\hline 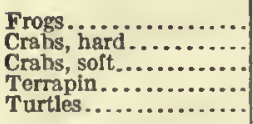 & $\begin{array}{r}3,000 \\
16,279,000 \\
1,967,000 \\
500 \\
24,000\end{array}$ & $\begin{array}{r}700 \\
169,000 \\
83,000 \\
500 \\
500\end{array}$ & $\begin{array}{r}140,000 \\
18,000\end{array}$ & $\begin{array}{r}700 \\
300\end{array}$ & 600 & (2) & $\begin{array}{r}13,853,000 \\
1,900 \\
6,000\end{array}$ & $\begin{array}{r}147,000 \\
100 \\
200\end{array}$ & & & 16,000 & 200 & $\begin{array}{r}3,000 \\
2,270,000 \\
1,965,000 \\
500\end{array}$ & $\begin{array}{r}700 \\
22,000 \\
83,000 \\
500 \\
\ldots . . .\end{array}$ \\
\hline $\begin{array}{l}\text { Clams, hard .......... } \\
\text { Oysters, market, from }\end{array}$ & $11,927,000$ & 374,000 & & & & & & & & & & & $41,927,000$ & 374,000 \\
\hline $\begin{array}{l}\text { puhlic areas........ } \\
\text { oysters, market, from } \\
\text { private areas........ }\end{array}$ & $\begin{array}{l}5,920,000 \\
12,528,000\end{array}$ & $\begin{array}{r}532,000 \\
1,050,000\end{array}$ & & & & & & & & & & & $57,920,000$ & $\begin{array}{r}532,00 \times 0 \\
1,050,000\end{array}$ \\
\hline oysters, seed, from & $7,939,000$ & 306,000 & & & & & & & & & & & $7,939,000$ & 306,000 \\
\hline $\begin{array}{l}\text { Oysters, seed, from } \\
\text { private areas......... }\end{array}$ & 463,000 & 20,000 & & & & & & & & & & & 8463,000 & 20,000 \\
\hline 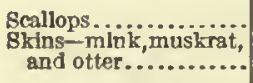 & $\begin{array}{r}\cdot 19,000 \\
10300\end{array}$ & $\begin{array}{r}2,400 \\
400\end{array}$ & & & & & & & & & & & $\begin{array}{r}19,000 \\
10300\end{array}$ & $\begin{array}{r}2,400 \\
400\end{array}$ \\
\hline
\end{tabular}

1 Includes apparatus, with catch, as lollows: Dredges, tongs, etc., $32,783,000$ pounds, valued at $\$ 2,270,000$; dip nets, 828,000 pounds, valued at $\$ 29,000$; eel pots, 44,000

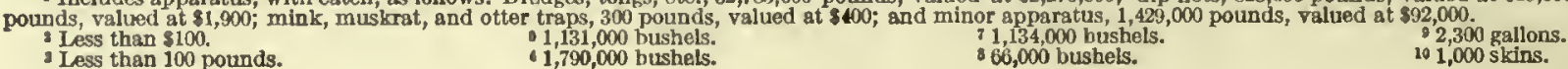

1 241,000 bushels.

$1,790,000$ bushels.

66,000 bushels.

101,000 skins. 
FISHERIES, BY STATES.

TABLE 8.-VIRGINIA-PRODUCTS OF SHORE AND BOAT FISHERIES OF CHESAPEAKE BAY DISTRICT: 1908.

\begin{tabular}{|c|c|c|c|c|c|c|c|c|c|c|c|c|c|c|}
\hline \multirow{3}{*}{ SPECIES. } & \multirow{2}{*}{\multicolumn{2}{|c|}{ TOTAL. }} & \multicolumn{12}{|c|}{ PRODUCT CAUGHT BY- } \\
\hline & & & \multicolumn{2}{|c|}{$\begin{array}{l}\text { Pound and trap } \\
\text { nets. }\end{array}$} & \multicolumn{2}{|c|}{ Llnes. } & \multicolumn{2}{|c|}{ Gill nets. } & \multicolumn{2}{|c|}{ Seines. } & \multicolumn{2}{|c|}{$\begin{array}{c}\text { Fyke and hoop } \\
\text { pets. }\end{array}$} & \multicolumn{2}{|c|}{ All other apparatus, } \\
\hline & $\begin{array}{l}\text { Quantity } \\
\text { (pounds). }\end{array}$ & Value. & $\begin{array}{l}\text { Quantity } \\
\text { (pounds). }\end{array}$ & Value. & $\begin{array}{l}\text { Quantity } \\
\text { (pounds). }\end{array}$ & Value. & $\begin{array}{l}\text { Quantity } \\
\text { (pounds). }\end{array}$ & Value. & $\begin{array}{l}\text { Quantity } \\
\text { (pounds). }\end{array}$ & Value. & $\begin{array}{l}\text { Quantlty } \\
\text { (pounds). }\end{array}$ & Value. & $\begin{array}{l}\text { Quantlty } \\
\text { (pounds). }\end{array}$ & Value. \\
\hline Total... & $95,060,000$ & $\$ 3,061,000$ & $42,752,000$ & $\$ 674,000$ & $14,535,000$ & $\$ 173,000$ & $3,275,000$ & $\$ 170,000$ & $4,823,000$ & $\$ 84,000$ & $1,174,000$ & $\$ 44,000$ & $28,502,000$ & $\$ 1,915,000$ \\
\hline $\begin{array}{l}\text { Fish: } \\
\text { Alewives............ } \\
\text { Black bass ........... } \\
\text { Bluefish............. } \\
\text { Butterfish.......... } \\
\text { Carp, German....... }\end{array}$ & $\begin{array}{r}31,355,000 \\
14,000 \\
193,000 \\
593,000 \\
186,000\end{array}$ & $\begin{array}{r}146,000 \\
1,100 \\
10,000 \\
16,000 \\
4,900\end{array}$ & $\begin{array}{r}26,399,000 \\
400 \\
56,000 \\
552,000 \\
22,000\end{array}$ & $\begin{array}{r}114,000 \\
(2) \\
3,700 \\
15,000 \\
1,200\end{array}$ & $\begin{array}{r}2,700 \\
88,000 \\
\ldots\end{array}$ & $\begin{array}{r}\quad \begin{array}{r}200 \\
3,800 \\
\ldots\end{array} \ldots \\
\cdots\end{array}$ & $\begin{array}{c}1,105,000 \\
(3) \\
29,000 \\
16,000 \\
12,000\end{array}$ & $\begin{array}{c}9,200 \\
(2) \\
1,500 \\
300 \\
500\end{array}$ & $\begin{array}{r}3,722,000 \\
7,000 \\
15,000 \\
20,000 \\
139,000\end{array}$ & $\begin{array}{r}20,000 \\
600 \\
1,300 \\
1,400 \\
2,700\end{array}$ & $\begin{array}{r}127,000 \\
3,700 \\
5,200 \\
4,500 \\
12,000\end{array}$ & $\begin{array}{r}2,400 \\
300 \\
100 \\
100 \\
600\end{array}$ & 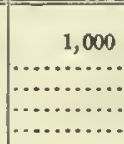 & $\begin{array}{r}100 \\
\cdots \cdots \cdots \\
\cdots \cdots \\
\cdots \cdots \\
\cdots \cdots\end{array}$ \\
\hline 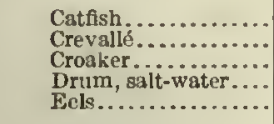 & $\begin{array}{r}619,000 \\
80,000 \\
3,344,000 \\
31,000 \\
76,000\end{array}$ & $\begin{array}{r}28,000 \\
1,800 \\
82,000 \\
600 \\
3,700\end{array}$ & $\begin{array}{r}221,000 \\
80,000 \\
2,844,000 \\
31,000 \\
25,000\end{array}$ & $\begin{array}{r}11,000 \\
1,800 \\
69,000 \\
600 \\
1,400\end{array}$ & $\begin{array}{r}47,000 \\
251,000 \\
100 \\
5,200\end{array}$ & $\begin{array}{c}1,900 \\
\cdots, 500 \\
(2) \\
300\end{array}$ & $\begin{array}{c}56,000 \\
60,000 \\
\ldots \ldots \ldots\end{array}$ & $\begin{array}{l}2,700 \\
\because, 800 \\
\cdots\end{array}$ & $\begin{array}{r}62,000 \\
76,000 \\
\cdots \cdots \cdots\end{array}$ & $\begin{array}{l}3,900 \\
2,100\end{array}$ & $\begin{array}{l}234,000 \\
11 i, 000 \\
\overline{5}, 000\end{array}$ & $\begin{array}{c}8,600 \\
2,900 \\
200\end{array}$ & 41,000 & i,800 \\
\hline 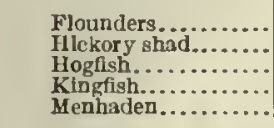 & $\begin{array}{r}88,000 \\
233,000 \\
108,000 \\
24,000 \\
3,844,000\end{array}$ & $\begin{array}{r}3,000 \\
6,200 \\
11,000 \\
1,100 \\
10,000\end{array}$ & $\begin{array}{r}77,000 \\
81,000 \\
46,000 \\
12,000 \\
3,844,000\end{array}$ & $\begin{array}{r}2,500 \\
2,500 \\
6,800 \\
500 \\
10,000\end{array}$ & $\begin{array}{l}51,000 \\
\end{array}$ & $\begin{array}{r}2,500 \\
\cdots \ldots \ldots\end{array}$ & $\begin{array}{r}2,800 \\
66,000 \\
\cdots \cdots \\
\cdots \cdots \\
\cdots \cdots \\
\cdots\end{array}$ & $\begin{array}{r}100 \\
1,600 \\
\cdots \cdots \\
\cdots\end{array}$ & $\begin{array}{r}2,500 \\
84,000 \\
11,000 \\
5,800 \\
\end{array}$ & $\begin{array}{r}100 \\
2,100 \\
1,600 \\
300 \\
\ldots\end{array}$ & \begin{tabular}{r}
5,300 \\
2,500 \\
\hdashline, 000 \\
$7,0$.
\end{tabular} & $\begin{array}{l}300 \\
100 \\
200\end{array}$ & & 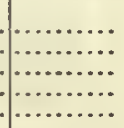 \\
\hline $\begin{array}{l}\text { Minnows............. } \\
\text { Moonfish........... } \\
\text { Mullet. } \\
\text { Perch, white.......... } \\
\text { Perch, yellow...... }\end{array}$ & $\begin{array}{r}2,200 \\
10,000 \\
178,000 \\
384,000 \\
92,000\end{array}$ & $\begin{array}{r}900 \\
400 \\
6,200 \\
24,000 \\
4,400\end{array}$ & $\begin{array}{r}10,000 \\
36,000 \\
131,000 \\
45,000\end{array}$ & $\begin{array}{r}400 \\
1,300 \\
7,800 \\
2,100\end{array}$ & $\begin{array}{r}13,000 \\
16,000 \\
\cdots \cdots\end{array}$ & $\begin{array}{r}500 \\
1,000 \\
\ldots \ldots\end{array}$ & $\begin{array}{r}99,000 \\
82,000 \\
\ldots\end{array}$ & $\begin{array}{r}3,300 \\
5,400 \\
\cdots\end{array}$ & $\begin{array}{l}2,200 \\
21,000 \\
71,000 \\
15,000\end{array}$ & $\begin{array}{r}900 \\
700 \\
4,100 \\
700\end{array}$ & $\begin{array}{r}3,000 \\
83,000 \\
31,000\end{array}$ & $\begin{array}{l}100 \\
4,900 \\
1,500\end{array}$ & $\begin{array}{r}5,800 \\
100 \\
\cdots\end{array}$ & ${ }^{(2)} 200$ \\
\hline 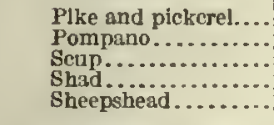 & $\begin{array}{r}3,800 \\
19,000 \\
44,000 \\
6,679,000 \\
1,900\end{array}$ & $\begin{array}{r}300 \\
3,000 \\
2,500 \\
477,000 \\
200\end{array}$ & $\begin{array}{r}600 \\
18,000 \\
41,000 \\
4,855,000 \\
1,500\end{array}$ & $\begin{array}{r}\left({ }^{2}\right) \\
2,800 \\
2,300 \\
303,000 \\
100\end{array}$ & 400 & (i) & \begin{tabular}{r}
200 \\
1,000 \\
\hdashline $1,588,000$ \\
$\cdots$
\end{tabular} & 127,000 & $\begin{array}{r}3,000 \\
2,0000 \\
203,000\end{array}$ & $\begin{array}{r}300 \\
\cdots \\
200 \\
14,000 \\
\cdots\end{array}$ & $\begin{array}{r}100 \\
200 \\
1,000 \\
32,000 \\
\ldots \ldots\end{array}$ & $\begin{array}{l}\left(\begin{array}{l}2 \\
2 \\
2\end{array}\right) \\
(2) \\
2,900 \\
\ldots \ldots \ldots\end{array}$ & 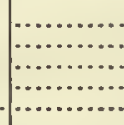 & (n...... \\
\hline $\begin{array}{l}\text { Spanish mackerel.... } \\
\text { Spot.................. } \\
\text { Squeteague.......... } \\
\text { Striped bass........ }\end{array}$ & $\begin{array}{r}99,000 \\
151,000 \\
3,530,000 \\
174,000\end{array}$ & $\begin{array}{r}9,100 \\
12,000 \\
99,000 \\
44,000\end{array}$ & $\begin{array}{r}88,000 \\
48,000 \\
2,807,000 \\
156,000\end{array}$ & $\begin{array}{r}7,900 \\
4,300 \\
75,000 \\
14,000\end{array}$ & $\begin{array}{r}53,000 \\
113,000 \\
33,000\end{array}$ & $\begin{array}{l}33,100 \\
3,300 \\
3,400\end{array}$ & $\begin{array}{r}5,600 \\
56,000 \\
61,000\end{array}$ & $\begin{array}{r}500 \\
2,600 \\
5,800\end{array}$ & $\begin{array}{r}200 \\
42,000 \\
199,000 \\
117,000\end{array}$ & $\begin{array}{r}{ }^{(2)}, 100 \\
11,000 \\
11,000\end{array}$ & $\begin{array}{r}11,000 \\
2,700 \\
355,000 \\
107,000\end{array}$ & $\begin{array}{r}1,200 \\
100 \\
6,800 \\
10,000\end{array}$ & 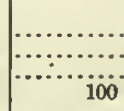 & $(2)$ \\
\hline Sturgeon............ & 85,000 & 9,100 & 54,000 & 6,300 & & & 30,000 & 3,000 & 1,000 & 100 & 300 & (2) & & \\
\hline 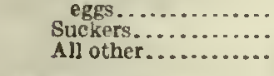 & $\begin{array}{r}8,900 \\
10,000 \\
12,000\end{array}$ & $\begin{array}{r}11,000 \\
500 \\
500\end{array}$ & $\begin{array}{r}5,000 \\
7,600\end{array}$ & $\begin{array}{l}5,800 \\
400\end{array}$ & $\ddot{500}$ & $(2)$ & 3,700 & 4,600 & $\begin{array}{r}100 \\
500\end{array}$ & $\begin{array}{r}200 \\
(2)\end{array}$ & $\begin{array}{r}10,000 \\
3,100\end{array}$ & $\begin{array}{l}6000 \\
100\end{array}$ & & (n... \\
\hline 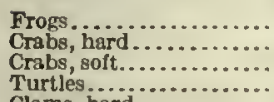 & $\begin{array}{r}3,000 \\
16,279,000 \\
1,967,000 \\
24,000\end{array}$ & $\begin{array}{r}700 \\
169,000 \\
83,000 \\
500\end{array}$ & 140,000 & 300 & $\begin{array}{r}13,853,000 \\
1,900 \\
6,000\end{array}$ & $\begin{array}{r}147,000 \\
100 \\
300\end{array}$ & 600 & (2) & & & $\ddot{16,000}$ & 200 & $\begin{array}{r}3,000 \\
2,270,000 \\
1,965,000 \\
\cdots \ldots \ldots \ldots\end{array}$ & $\begin{array}{r}700 \\
22,000 \\
83,000 \\
\end{array}$ \\
\hline 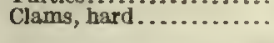 & $11,082,000$ & 213,000 & $\ldots, \ldots, \ldots$ & , n....... & ............. & & . & & & & & & $\because 1,082,000$ & $\ddot{2 i 3}, 000$ \\
\hline $\begin{array}{l}\text { Oysters, market, from } \\
\text { public areas........... } \\
\text { Oysters, market, from }\end{array}$ & $87,070,000$ & 479,000 & & & & & & & & & & & $67,070,000$ & 479,000 \\
\hline $\begin{array}{l}\text { Oysters, market, from } \\
\text { private areas........... } \\
\text { oysters, seed, from pub- }\end{array}$ & $9,382,000$ & 838,000 & & & & & & & & & & & $6,382,000$ & 838,000 \\
\hline $\begin{array}{l}\text { lic areas.............. } \\
\text { Oysters, seed, from pri- }\end{array}$ & $26,217,000$ & 257,000 & & & & & & & & & & & $96,217,000$ & 257,000 \\
\hline $\begin{array}{l}\text { vate areas.................... } \\
\text { Skins-mink, muskrat, }\end{array}$ & - 463,000 & 20,000 & & & & & & & & & & & 463,000 & 20,000 \\
\hline and otter.............. & 300 & 400 & & & & & & & & & & & 300 & 400 \\
\hline
\end{tabular}

1 Includes apparatus, with catch, as follows: Dredges, tongs, etc., $27,614,000$ pounds, valued at $\$ 1,881,000 ;$ dip nets, 822,000 pounds, valued at $\$ 29,000$; eel pots, 41,000 pounds, valued at $\$ 1,800$; mink, muskrat, and otter traps, 300 pounds, valued at $\$ 400$; and minor apparatus, 19,000 pounds, valued at $\$ 1,900$.

2 Less than $\$ 100$. \$1,010,000 bushels. $1,340,000$ bushels.
788,000 bushels. 
TABLE 9.-VIRGINIA-PRODUCTS OF SHORE AND BOAT FISHERIES OF ATLANTIC OCEAN DISTRICT: 1908.

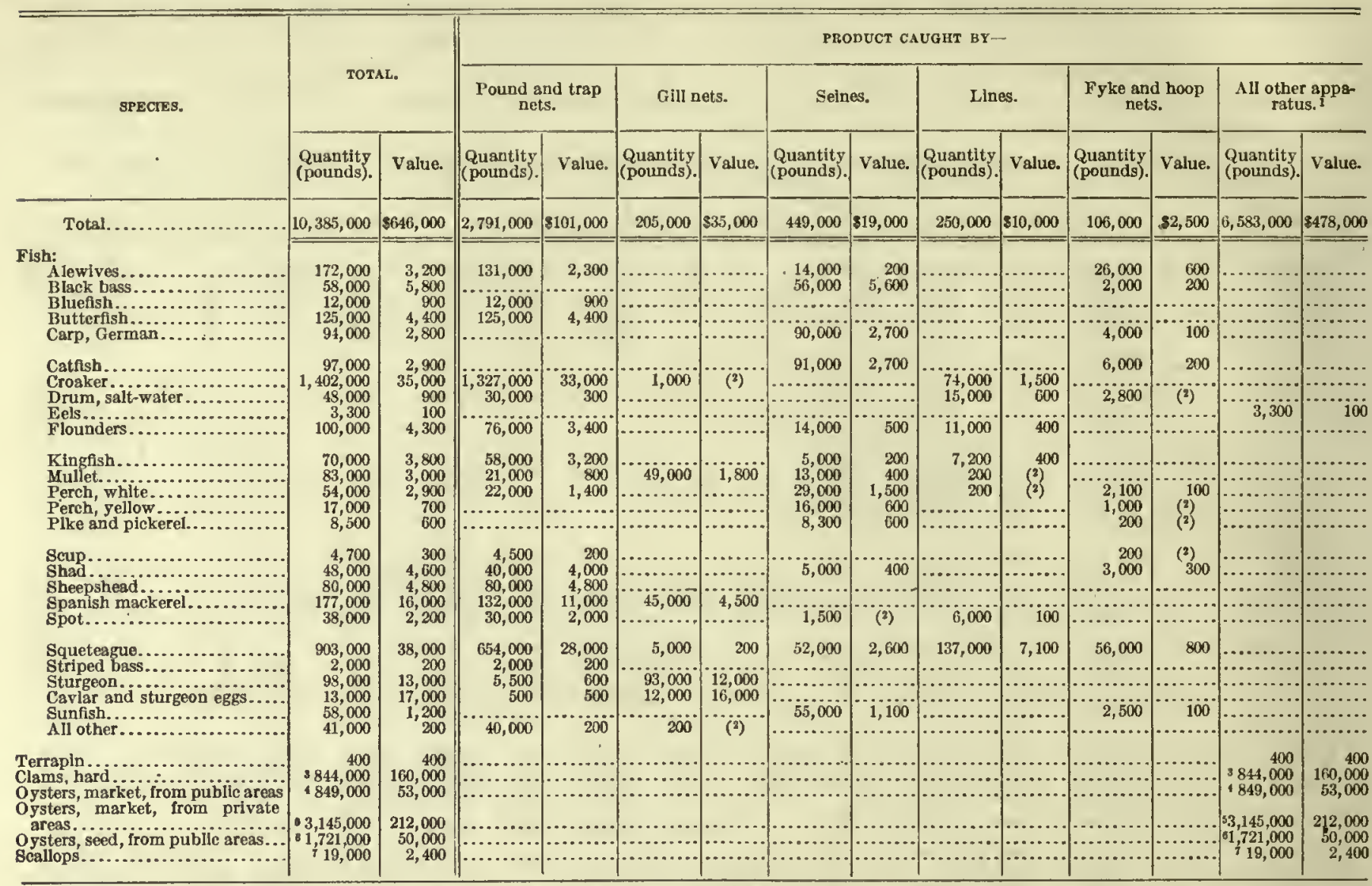

1 Includes apparatus, with catch, as follows: Dredges, tongs, etc., 5,169,000 pounds, valued at $\$ 389,000$; eel pots, 3,300 pounds, ralued at $\$ 100$; and minor apparatus $1,410,000$ pounds,

10,000 pounds, valued at $\$ 90,000$.
2 Less than $\$ 100$.

\section{WASHINGTON.}

Washington ranked fourth among the states in 1908 in the extent of its fisheries, as measured by the value of their products, which was $\$ 3,513,000$, and was exceeded only by Massachusetts, Virginia, and New York. Among the Pacific coast states it ranked first in this respect both at the present census and at the canvasses of 1899 and 1904, while at the canvasses of 1888,1892 , and 1895 it stood second.

In this report the fishing grounds of Washington are divided into two districts: The Pacific Ocean district, which comprises the Pacific Ocean, Puget Sound and other inlets, and all rivers, except the Columbia, flowing into the Pacific Ocean; and the Columbia River.

A summary of the principal statistics relating to the fisheries of the state for the year 1908 is given in the following tabular statement:

Number of persons employed.................. 4,954 Capital:

Vessels and boats, including outfit..........\$1,970,000

Apparatus of capture................... 1, 162,000

Shore and accessory property and cash......... 309,000

Value of products...................... 3,513,000
5449,000 bushels.

- 246,000 bushels.

72,300 gallons.

Comparison with previous canvasses.-The figures for the number of persons employed and the amount reported is the value of the investment in shore and accessory property, together with cash capital, are not comparable with those for previous canvasses, inasmuch as the latter include returns from canneries and packing houses and wholesale dealers. In the following tabular statement, however, which gives a comparative summary for the canvasses of 1888,1892 , $1895,1899,1904$, and 1908, comparable figures have been secured by eliminating shoresmen and the amounts reported for shore and accessory property and cash capital:

\begin{tabular}{|c|c|c|c|c|c|c|}
\hline \multirow[b]{2}{*}{ YEAR. } & \multirow{2}{*}{$\begin{array}{l}\text { Persons } \\
\text { employ- } \\
\text { ed, ex- } \\
\text { clusive } \\
\text { of shores- } \\
\text { men. }\end{array}$} & \multicolumn{3}{|c|}{ VALUE OF EQUIPMENT. } & \multicolumn{2}{|c|}{ PRODUCTS. } \\
\hline & & Total. & $\begin{array}{l}\text { Vessels and } \\
\text { boats, } \\
\text { moluding } \\
\text { outfit. }\end{array}$ & $\begin{array}{l}\text { Apparatus } \\
\text { of capture. }\end{array}$ & $\begin{array}{l}\text { Quantity } \\
\text { (pounds). }\end{array}$ & Valué. \\
\hline $\begin{array}{l}1908 . . \\
1904 . .\end{array}$ & $\begin{array}{l}4,879 \\
6,074\end{array}$ & $\begin{array}{r}83,132,000 \\
2,548,000\end{array}$ & $\begin{array}{r}\$ 1,970,000 \\
859,000\end{array}$ & $\begin{array}{r}\$ 1,162,000 \\
1,690,000\end{array}$ & $\begin{array}{r}100,456,000 \\
88,955,000\end{array}$ & $\begin{array}{r}83,513,000 \\
2,973,000\end{array}$ \\
\hline $1899 .$. & 5,617 & $2,620,000$ & 775,000 & $1,845,000$ & $120,588,000$ & $2,871,000$ \\
\hline $1895 \ldots$ & 5,008 & 872,000 & $\begin{array}{l}331,000 \\
281,000\end{array}$ & $\begin{array}{l}542,000 \\
349,000\end{array}$ & $\begin{array}{l}59,080,000 \\
36,757,000\end{array}$ & $\mid 1,402,000$ \\
\hline $1888 .$. & $\begin{array}{l}2,450 \\
2,854\end{array}$ & 651,000 & 249,000 & 402,000 & $23,362,000$ & 891,000 \\
\hline
\end{tabular}


The fisheries of the state have shown a steady growth, the value of their products having more than quadrupled during the twenty years between 1888 and 1908. The value of vessels and boats has increased steadily sinee 1888 . In the value of apparatus of capture, however, there has been a gradual decrease since 1899, and the number of persons employed in 1908 was smaller than in 1895,1899 , or 1904.

Persons employed.-The following table shows the distribution of the persons employed in 1908 for the state and for the two districts:

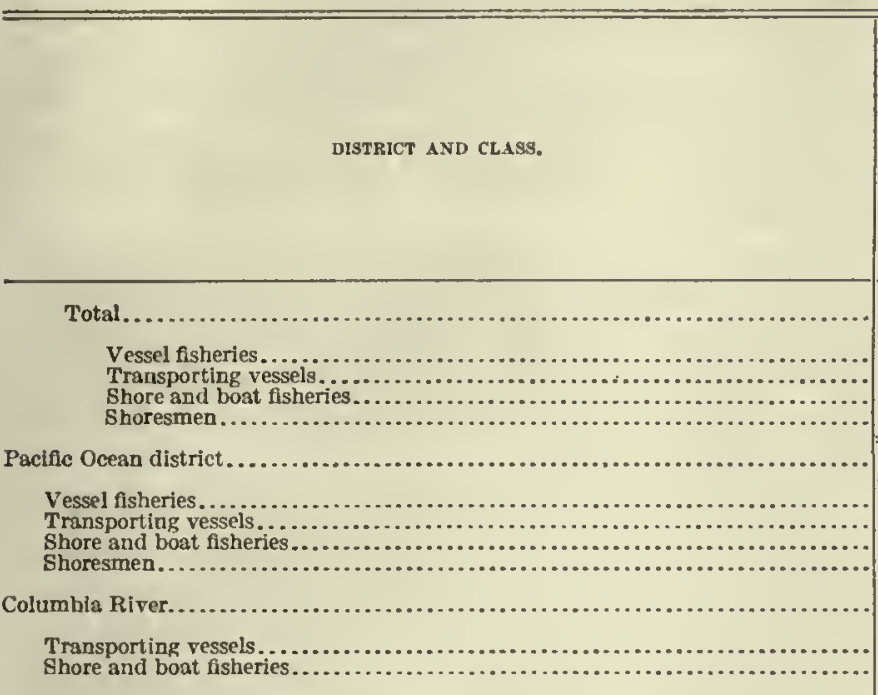

1 Exeluslve of 35 proprietors not fishlng.

The fisheries of the Pacific Occan district gave occupation to approximately seven-tenths of the total number employed in fishing and to three-fourths of the number employed in the shore and boat fisheries.

Equipment and other capital.-The following tabular statement shows in detail the number and value of vessels and boats, the value of shore and accessory property, and the amount of cash invested in 1908, both for the state as a whole and for the two districts:

\begin{tabular}{|c|c|c|c|}
\hline \multirow[b]{2}{*}{ CLASS OF INVESTMENT. } & \multicolumn{3}{|c|}{$\begin{array}{l}\text { VALUE OF EQUTPMENT AND OTHER } \\
\text { CAPITAL: } 1908 .\end{array}$} \\
\hline & Totai. & $\begin{array}{l}\text { Pacific } \\
\text { Ocean } \\
\text { district. }\end{array}$ & $\begin{array}{l}\text { Columbla } \\
\text { River. }\end{array}$ \\
\hline Total... & $\$ 3,441,000$ & $\$ 2,592,000$ & $\$ 850,000$ \\
\hline $\begin{array}{l}\text { Vessels, inciuding outfit... } \\
\text { Fishing................ }\end{array}$ & $1,594,000$ & $1,572,000$ & 21,000 \\
\hline $\begin{array}{l}\text { Fishing........................ } \\
\text { Steam and motor. }\end{array}$ & $\begin{array}{l}1,352,000 \\
1,194,000\end{array}$ & $\begin{array}{l}1,352,000 \\
1,194,000\end{array}$ & \\
\hline Vessels........ & 841,000 & 841,000 & \\
\hline Outôt & 353,000 & 353,000 & \\
\hline Sail $\ldots$ Vessels........... & 157,000 & 157,000 & (n....... \\
\hline Outfit................ & $\begin{array}{r}113,000 \\
44,000\end{array}$ & $\begin{array}{r}113,000 \\
44,000\end{array}$ & …..... \\
\hline $\begin{array}{l}\text { Other.................... } \\
\text { Transporting }\end{array}$ & 1,100 & 1,100 & \\
\hline $\begin{array}{l}\text { Transporting. ......... } \\
\text { Steam and motor.. }\end{array}$ & 242,000 & 220,000 & 21,000 \\
\hline $\begin{array}{c}\text { Steam and motor.. } \\
\text { Vessels......... }\end{array}$ & 235,000 & $\begin{array}{r}213,000 \\
1181,000\end{array}$ & 21,000 \\
\hline $\begin{array}{l}\text { Vessels......... } \\
\text { Outfit......... }\end{array}$ & $\begin{array}{r}200,000 \\
35,000\end{array}$ & $\begin{array}{r}181,000 \\
32,000\end{array}$ & 18,000 \\
\hline Other.... & $\begin{array}{r}35,000 \\
6,900\end{array}$ & 6,900 & $\begin{array}{l}2,900 \\
\ldots \ldots\end{array}$ \\
\hline Boats.................... & 377,000 & 225,000 & 132,000 \\
\hline Steam and mator...... & 120,000 & 57,000 & 62,000 \\
\hline Sal1................... & 95,000 & 9,900 & 85,000 \\
\hline Row.... & 47,000 & 42,000 & 4,900 \\
\hline Other............... & 116,000 & 116,000 & \\
\hline $\begin{array}{l}\text { Apparatus of capture............ } \\
\text { Vessel fisheries }\end{array}$ & $1,162,000$ & $\begin{array}{r}586,000 \\
600\end{array}$ & 576,000 \\
\hline Shore and hoat fisheries............. & $1,102,000$ & 526,000 & $\ddot{5} 76,000$ \\
\hline Shore and accessory property.......... & 220,000 & 120,000 & 100,000 \\
\hline & 89,000 & 89,000 & \\
\hline
\end{tabular}

Of the total capital invested in the fisheries of Washington in 1908, 46 per cent, or somewhat less than one-half, represented the value of fishing and

\begin{tabular}{|c|c|c|c|c|c|c|}
\hline \multicolumn{7}{|c|}{ PERSONS EMPLOYED: 1908.} \\
\hline \multicolumn{4}{|c|}{ Number. } & \multicolumn{3}{|c|}{ Salarles and wages. } \\
\hline Total. & $\begin{array}{l}\text { Proprietors } \\
\text { and inde- } \\
\text { pendent } \\
\text { fishermen. }\end{array}$ & $\begin{array}{l}\text { Salaried } \\
\text { employees. }\end{array}$ & $\begin{array}{l}\text { Wage- } \\
\text { earners. }\end{array}$ & Total. & Salaries. & Wages. \\
\hline 4,954 & 12,058 & 25 & 2,871 & $\$ 1,224,000$ & $\$ 24,000$ & $2 \$ 1,200,000$ \\
\hline 1,109 & 70 & 14 & 1,025 & $\begin{array}{r}685,000 \\
59,000\end{array}$ & 13,000 & 672,000 \\
\hline $\begin{array}{r}3,636 \\
75\end{array}$ & 1,983 & 11 & $\begin{array}{r}1,642 \\
75\end{array}$ & $\begin{array}{r}448,000 \\
32,000\end{array}$ & $\begin{array}{l}11,000 \\
\ldots \ldots\end{array}$ & $\begin{array}{r}437,000 \\
32,000\end{array}$ \\
\hline 3,511 & 1,369 & 22 & 2,120 & $1,085,000$ & 23,000 & $1,062,000$ \\
\hline 1,109 & 70 & 14 & 1,025 & 685,000 & 13,000 & 672,000 \\
\hline $\begin{array}{r}117 \\
2,210 \\
75\end{array}$ & 1,297 & $\dddot{8}$ & $\begin{array}{l}115 \\
905 \\
75\end{array}$ & $\begin{array}{r}55,000 \\
313,000 \\
32,000\end{array}$ & $\because 0,000$ & $\begin{array}{r}55,000 \\
303,000 \\
32,000\end{array}$ \\
\hline 1,443 & 689 & 3 & 751 & 139,000 & 800 & 138,000 \\
\hline $\begin{array}{r}17 \\
1,426\end{array}$ & $\begin{array}{r}3 \\
686\end{array}$ & 3 & $\begin{array}{r}14 \\
737\end{array}$ & $\begin{array}{r}4,200 \\
135,000\end{array}$ & 800 & $\begin{array}{r}4,200 \\
134,000\end{array}$ \\
\hline
\end{tabular}

2 Inciudes provisions furnished to the value or $\$ 187,000$.

transporting vessels, the value of fishing vessels alone forming 39 per cent, or not quite two-fifths. The investment in vessels was mainly in power craft of at least 5 tons register, the value of which constituted 42 per cent, or slightly more than two-fifths, of the total capital employed, while the value of all other classes of vessels formed only 5 per cent of the total. In the fisheries of the Pacific Ocean district 61 per cent, or almost exactly threefifths, of the capital was invested in vessels, as compared with a corresponding percentage of a little over 2 for the Columbia River fisheries, where all of the comparatively small number of vessels employed were engaged in transporting the catch.

Next to the value of vessels, that of apparatus of capture was the largest item of capital, amounting to 34 per cent, or about one-third of the total. By far the largest proportion-68 per cent, or slightly more than two-thirds-of the capital employed in the fisheries of the Columbia River represented the value of apparatus of capture. The value of boats formed 11 per cent of the total investment for the state, that of shore and accessory property 6 per cent, and the amount of cash 3 per cent, all the cash reported being invested in the Pacific Occan district.

Statistics as to the number and tonnage of vessels and the number of boats are given in the next tabular statement.

The vessels engaged in fishing in 1908 comprised 85 steam and 22 sail vessels, with a combined tonnage of 3,991 , and 11 unrigged craft, the valuo of all classes of fishing vessels being $\$ 955,000$. Of these, all of which were used in the Pacific Ocean district, 45 belonged 
to the halibut fleet and eight were employed in the cod fisheries, the remaining 65 being practically all used in making the salmon catch.

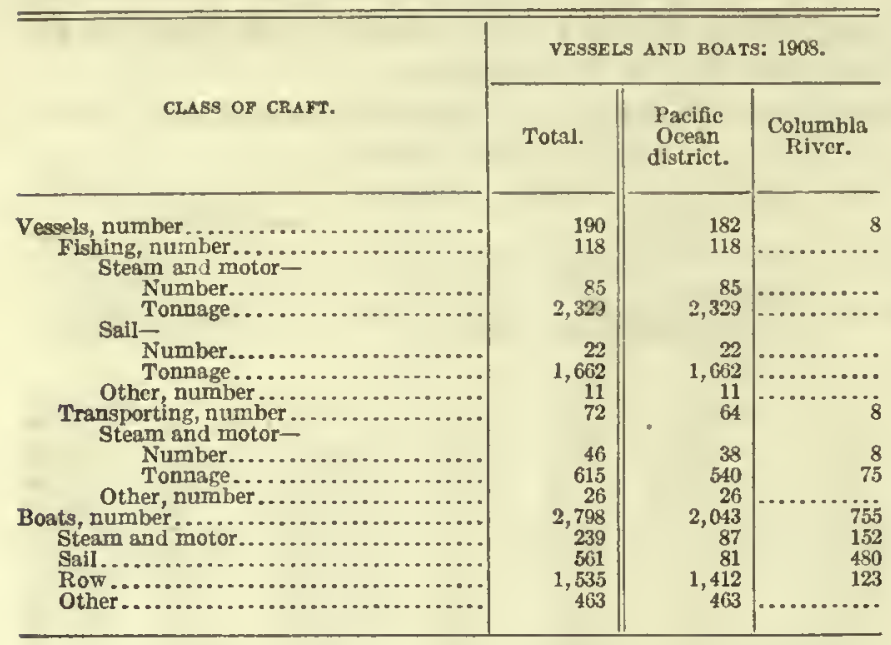

In addition to the vessels engaged in fishing, 46 registered vessels and 26 unrigged barges and scows were used exclusively for transporting the catch. Of this number, only eight were used on the Columbia River. The pound and trap net catch of Puget Sound was credited to the shore and boat fisheries, the tugs used in moving the catch from the traps to the canneries or markets being classified as transporting rather than fishing vessels.

In 1904 there were 50 fishing vessels and 80 transporting vessels reported by the Bureau of Fisheries. The present census therefore shows a large increase in the number and value of fishing vessels reported, and a small decrease in the number and value of vessels engaged exclusively in transporting the cateh.

The number of power boats employed was 239 and their value $\$ 120,000$, as compared with 63 boats, all operated by gasoline and valued at $\$ 44,000$, in 1904 . Of the boats reported in 1908,152 , valued at $\$ 62,000$, were used on the Columbia River, and 87 , valued at $\$ 57,000$, in the other waters of the state. In contrast to this large increase in power boats, there was a material decrease in both the number and the value of other boats reported, including both sail and row boats. The combined number of sail and row boats reported in 1904 was 3,448 , and their value $\$ 310,000$, while in 1908 only 2,096 , valued at $\$ 141,000$, were in use. The sailboat is still employed to a considerable extent on the Columbia River, while practically all the rowboats are in use on Puget Sound and other inland waters. The boats included under the head "Other" are scows or barges of less than 5 tons register.

The amount invested in apparatus of capture in 1908 was $\$ 1,162,000$, as compared with $\$ 1,690,000$ in 1904. This large decrease was caused to a great extent by the fact that gill nets are taking the place of pound nets and seines in the salmon fisheries. The number of pound nets reported showed a decrease, while the number of gill nets reported increased from 1,537 in 1904 to 2,221 in 1908 . The extending of the fisheries so as to inelude in the catch many species of fish which a few years ago were considered of little or no importance has resulted in an increased use of the purse seine. The investment in apparatus of capture is nearly equal for the two districts into which the state is divided, the apparatus reported for the fisheries of the Pacific Ocean district being valued at $\$ 586,000$ and that reported for fisheries of the Columbia River at $\$ 576,000$.

The value of the apparatus employed in the shore and boat fisheries, $\$ 1,102,000$, is greatly in excess of that reported for vessel fisheries, $\$ 60,000$. Of the latter amount, $\$ 45,000$, or slightly more than 75 per cent, represented the value of lines used for the cod and halibut catch.

While the pound net is used more extensively in the salmon fisheries of Puget Sound, the larger gill nets are found in the Columbia River fisheries, for whieh 926 were reported, as compared with 1,295 gill nets returned as used elsewhere in the state. Fish wheels, of which 13 were reported, were in use only on the Columbia River, and their eatch was confined to salmon. The following tabular statement shows statistics as to the number of the more important kinds of apparatus of capture:

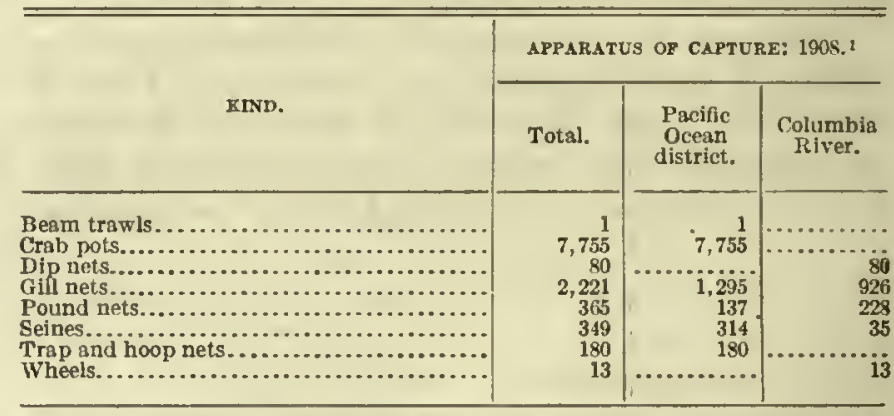

${ }^{1} \mathrm{All}$ used In shore and boat fisheries, except 1 beam trawl, 2 gill nets, and 45 seines.

Products, by species. - Table 1, on page 267, shows in detail the quantity and value of the products, by species and by apparatus of capture, for 1908 . The total products of the Washington fisheries in 1908 amounted to $100,456,000$ pounds, valued at $\$ 3,513$,000 , as compared with $88,955,000$ pounds, valued at $\$ 2,973,000$, in 1904 , an increase of $11,502,000$ pounds, or 13 per cent, in quantity, and $\$ 541,000$, or 18 per cent, in value. The increase reported for halibut alone was very large, amounting to $18,086,000$ pounds, valued at $\$ 879,000$; but this increase was partially offset by the decreases reported for several other spocies, particularly for several varieties of salmon. For cod, herring, and smelt there were marked increases both in the quantity and value of the catch. The black bass, which was formerly caught in limited quantities, is reported to be entirely extinct, none having been taken for the past few seasons. 
Products, by fishing grounds.-Tables 2 and 3, on page 268, give, respectively, for the Pacific Occan district and for the Columbia River, statistics similar to those shown in Table 1. The relative importance of the different species is indicated in the following tabular statement, which distributes the value of products reported for the state and for each district according to species, arranged in order of value:"

\begin{tabular}{|c|c|c|c|}
\hline \multirow[b]{2}{*}{ SPECIES. } & \multicolumn{3}{|c|}{ VALUE OY PRODUCTS: 1908.} \\
\hline & Total. & $\begin{array}{c}\text { Preific } \\
\text { Ocean } \\
\text { district. }\end{array}$ & $\begin{array}{l}\text { Columbia } \\
\text { River. }\end{array}$ \\
\hline Total... & $\$ 3,513,000$ & $\$ 3,018,000$ & $\$ 495,000$ \\
\hline Flsh....... & $3,054,000$ & $2,559,000$ & 495,000 \\
\hline Salmon... & $1,571,000$ & $1,097,000$ & 475,000 \\
\hline Chlnook,$\ldots \ldots \ldots \ldots$ & 565,000 & 250,000 & 315,000 \\
\hline Bluehack, or sockeye.. & 513,000 & 199,000 & 14,000 \\
\hline Silver............... & 255,000 & 200,000 & 54,000 \\
\hline Steelhead................................... & 123,000 & 42,000 & 81,000 \\
\hline 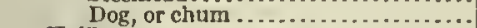 & 115,000 & 105,030 & 11,000 \\
\hline Falibut.......... & $1,236,000$ & $1,236,000$ & \\
\hline Cod, salted. & 124,000 & $-124,000$ & $\cdots \cdots$ \\
\hline Smelt..... & 61,000 & 45,000 & 16,000 \\
\hline 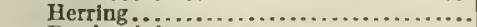 & 21,000 & 21,000 & ........ \\
\hline Perch, viviparous $. . . \ldots \ldots \ldots \ldots \ldots \ldots . .$. & 15,000 & 15.000 & \\
\hline 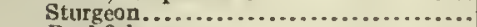 & 6,000 & 3,100 & 2,900 \\
\hline (n. & 5,200 & 5,200 & $\ldots$ \\
\hline 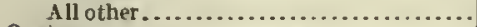 & 15,000 & 13,000 & 1,900 \\
\hline Oysters...$\ldots \ldots \ldots \ldots \ldots \ldots \ldots \ldots \ldots$ & 352,000 & 352,000 & \\
\hline Mlarket, from private areas .................. & 346,000 & 346,000 & (n.......... \\
\hline 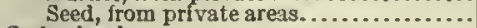 & 6,500 & 6,509 & ............. \\
\hline Crabs, hard................................. & 51,000 & 51,000 & ............. \\
\hline 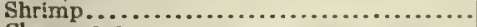 & 22,000 & 22,000 & ........... \\
\hline Clams, razor... & 22,000 & 22,000 & \\
\hline Clams, hard... & 13,000 & 13,000 & ..... \\
\hline
\end{tabular}

Of the products of the Pacific Ocean district fisheries the salmon product was the most important, so far as the amount of the catch is concerned, contributing $44,297,000$ pounds, or not quite one-half of a total eatch of $89,305,000$ pounds. The largest value, however, was reported for the halibut catch, which ranked second in quantity, and represented somewhat more than one-third of the total catch and the total value. The lower average value of the salmon product resulted largely from the fact that the species of salmon for which the largest catch was reported was the dog or chum, which is of comparatively little value. Catches but slightly smaller than that of the latter species were reported for the blueback and for the silver salmon, the value of the blueback catch representing 45 per cent of the total value of products of the salmon fisheries. Oysters ranked next to salmon in value of products, while salted cod also contributed an important product from the standpoint both of quantity and value.

Practically the only important product of the Columbia River fisheries was salmon, which represented 90 per cent of the total catch and contributed 96 per cent of the total value of products reported for this river. Of the different species of salmon, the chinook, which ranked fourth in quantity and second in value in the Pacific Occan district, led both in quantity and value, constituting 53 per cent of the total salmon eatch reported for the Columbia River, and contributing 66 per cent, or practically twothirds, of its value. The silver varicty ranked next to the chinook in quantity, and the steelhead next in value, while insignificant totals were reported for the blueback, which, as has already been shown, was the principal product of the salmon fisheries of the Pacific Ocean and its adjoining waters. There was a fairly large smelt product, but the catches of all other varieties of fish reported for the Columbia River were unimportant both in quantity and value.

Of the total value of products, 87 per cent represented the value of fish proper. The value of the salmon catch constituted 45 per cent, or more than three-sevenths, of the total value of products for the state; 36 per cent, or not quite three-eighths, of the value of the catch reported for the Pacific Ocean district; and 96 per cent, or considerably more than ninetenths, of the value of the Columbia River catch. The halibut catch ranked second in importance, as measured by value, and was confined entirely to the ocean fisheries, its value representing 35 per cent of the total value of products and 41 per cent of the value of products reported for the Pacific Ocean district. The value reported for oysters represented 10 per cent of the total in 1908 . No other product contributed as much as 5 per cent of the total value of products.

The fisheries of the Pacific Ocean district formed by far the more important branch of the state's fisheries, contributing 86 per cent, or more than five-sixtlis, of the total value of products, as compared with 14 per cent credited to the Columbia River. The latter district, however, reported 30 per cent of the total value of the salmon catch.

The following tabular statement shows the distribution of the total catch of the state according to the different waters from which it was taken:

\begin{tabular}{|c|c|c|}
\hline \multirow{2}{*}{ FISHING GROUND. } & \multicolumn{2}{|c|}{ FISUERY PRODUCTS: 1908.} \\
\hline & $\begin{array}{l}\text { Quantity } \\
\text { (pounds). }\end{array}$ & Value. \\
\hline Total.............. & $100,456,000$ & $83,513,000$ \\
\hline 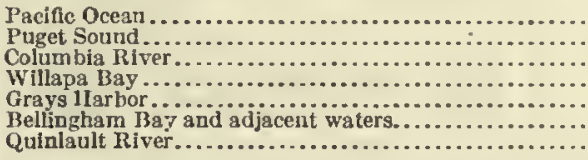 & $\begin{array}{r}35,028,000 \\
46,020,000 \\
11,151,000 \\
2,025,000 \\
3,294,000 \\
1,159,000 \\
780,000\end{array}$ & $\begin{array}{r}1,369,000 \\
1,308,000 \\
495,000 \\
226,000 \\
56,000 \\
36,000 \\
22,000\end{array}$ \\
\hline
\end{tabular}

The largest quantity of product was caught in Puget Sound, although the value of the ocean catch was greater by more than $\$ 60,000$. This is due to the increased activity in the cod and halibut fisheries, which are ocean fisheries, and the decrease in the Puget Sound catch of the more valuable varieties of the salmon.

Products, by class of fisheries. - Statistics relating to the products of the ressel fisheries of the state, by species and by apparatus of capture, are presented in Table 4, on page 269; and similar statistics for the shore and boat fisheries are given in Table 5 , on 
page 269. Statistics as to the products of the shore and boat fisheries of the Pacific Ocean district are given in Table 6, on page 270.

The total catch of the vessel fisheries was $40,171,000$ pounds, valued at $\$ 1,569,000$, representing 40 per cent and 45 per cent, respectively, of the corresponding totals for the state. Halibut was the principal product, forming 75 per cent of the total catch of the vessel fisheries, and contributing 79 per cent of the total value of their products. Cod, salmon, oysters, and shrimp were other products of importance. The bulk of the catch of the vessel fisheries was made by lines, seines, and dredges and tongs, 87 per cent of the quantity being taken by lines. Less than 1 per cent of the total product was caught by gill nets and trawls. The total catch of the vessel fisheries was credited to the Pacific Ocean disirict, no fishing vessels being employed in the Columbia River fisheries.

The shore and boat fisheries produced 60 per cent of the total quantity and 55 per cent of the total value of fishery products of Washington in 1908. Salmon formed the chief product, and of the total salmon catch in the state 92 per cent, representing 95 par cent of the value, was reported by the shore and boat fisheries. Pound nets, gill nets, and seines were the apparatus most extensively used in this class of fisheries.

Of the total quantity reported for the fisheries of the Pacific Ocean district, 55 per cent, with a value equal to 48 per cent of the total value, represented the products of the shore and boat fisheries of these waters, comprising mainly salmon, together with oysters and other shellfish.

Products, by apparatus of capture.-The following tabular statement shows the value of the products taken, by the principal kinds of apparatus of capture used, in 1908:

\begin{tabular}{|c|c|c|c|c|c|}
\hline \multirow{3}{*}{$\begin{array}{l}\text { KrND OF } \\
\text { APPARATUS. }\end{array}$} & \multicolumn{5}{|c|}{ FISHERY PRODUCTS: 1908.} \\
\hline & \multirow{2}{*}{ Totai. } & \multicolumn{2}{|c|}{$\begin{array}{l}\text { Distributed by } \\
\text { districts. }\end{array}$} & \multicolumn{2}{|c|}{$\begin{array}{l}\text { Distributed by class of } \\
\text { fisheries. }\end{array}$} \\
\hline & & $\begin{array}{c}\text { Pacific } \\
\text { Ocean } \\
\text { district. }\end{array}$ & $\begin{array}{l}\text { Columbia } \\
\text { River. }\end{array}$ & $\begin{array}{l}\text { Vessei } \\
\text { fisheries. }\end{array}$ & $\begin{array}{l}\text { Shore and } \\
\text { boat } \\
\text { fisheries. }\end{array}$ \\
\hline Total...... & $\$ 3,513,000$ & $\$ 3,018,000$ & $\$ 495,000$ & $\$ 1,569,000$ & $\$ 1,944,000$ \\
\hline $\begin{array}{l}\text { Lines.............. } \\
\text { Pound nets........ } \\
\text { Gill nets. ............... } \\
\text { Dredges, tongs, etc. } \\
\text { Seines............ } \\
\text { Traps and hoop }\end{array}$ & $\begin{array}{r}1,368,000 \\
868,000 \\
468,000 \\
352,000 \\
333,000\end{array}$ & $\begin{array}{r}1,368,000 \\
703,000 \\
253,000 \\
352,000 \\
256,000\end{array}$ & $\begin{array}{r}165,000 \\
216,000 \\
77,000\end{array}$ & $\begin{array}{r}1,368,000 \\
704,000 \\
96,000\end{array}$ & $\begin{array}{l}868,000 \\
468,000 \\
248,000 \\
237,000\end{array}$ \\
\hline 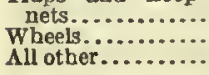 & $\begin{array}{l}51,000 \\
26,000 \\
47,000\end{array}$ & $\begin{array}{r}51,000 \\
335,000\end{array}$ & $\begin{array}{l}\dddot{20}, 000 \\
12,000\end{array}$ & 1,100 & $\begin{array}{l}51,000 \\
26,000 \\
46,000\end{array}$ \\
\hline
\end{tabular}

The line catch was larger in respect both to quantity and value than the catcl credited to any other kin'd of apparatus used in 1908. Halibut represented 86 per cent of the quantity and 90 per cent of the value of products taken by lines, cod and rockfish being the only other kinds of fish included in this catch.

The greater part of the catch reported as taken by pound nets, gill nets, and seines consisted of salmon, although large quantities of herring, smelt, flounders, and shrimp are caught by seines.

Salmon.-Salmon is the principal product of the Washington fisheries both in quantity and value, the catch of 1908 amounting to $54,312,000$ pounds, valued at $\$ 1,571,000$, although this represents a decrease of 20 per cent in quantity and of 19 per cent in value since 1904 , when a catch of $68,252,000$ pounds, valued at $\$ 1,943,000$, was. reported. The several species all shared in these decreases, with the exception of the blueback, or sockeye, and the steelhead. For the former an increase of 9 per cent in quantity was reported, which was accompanied, however, by a decrease of 3 per cent in value, and for the steelhead an increase of 26 per cent in quantity and a gain of 56 per cent in value were reported.

Both in 1908 and 1904 the largest catch reported for any single species was for the silver salmon, although the later canvass shows marked decreases in both the quantity and the value of this species, amounting to 46 per cent and 49 per cent, respectively. Dog salmon was next in importance, so far as the amount of the catch was concerned, followed closely by the blueback and the chinook. Owing to the superior quality of the last-named species, however, the value of the catch was greater than that reported for any other species of salmon, the blueback being a close second in this respect, while for dog salmon, on account of its inferiority as a food fish, the smallest value was reported, in spite of the large catch of this species. The marked falling off, as compared with 1904 , both in the quantity and value of the chinook catch, accompanied by the increase in the catch of the blueback salmon, makes it probable that the latter may in time become the most important product of the salmon fisheries of the state. Both species are largely sold fresh, being frozen and shipped in refrigerator cars to eastern markets.

The following tabular statement distributes the salmon catch of the state according to the different waters from which it was taken:

\begin{tabular}{|c|c|c|}
\hline \multirow{2}{*}{ MSHINC OROUND. } & \multicolumn{2}{|c|}{ SALMON PRODUCT: 1908.} \\
\hline & $\begin{array}{l}\text { Quantity } \\
\text { (pounds). }\end{array}$ & Value. \\
\hline Total.......... & $54,312,000$ & $\$ 1,571,000$ \\
\hline 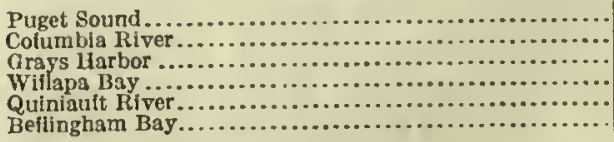 & $\begin{array}{r}37,571,000 \\
10,015,000 \\
3,203,000 \\
1,781,000 \\
780,000 \\
961,000\end{array}$ & $\begin{array}{r}995,000 \\
475,000 \\
45,000 \\
24,000 \\
22,000 \\
11,000\end{array}$ \\
\hline
\end{tabular}


Halibut.-Next to salmon the halibut product is the most important of the fishery products of Washington. The catch of 1908 , a year which was one of the most successful ever experienced by the fisheries of the northwest coast, was the heaviest yet reported, amounting to $30,072,000$ pounds, valued at $\$ 1,236,000$ - an increase since 1904 of 149 per cent in quantity and 246 per cent in value. The growth of the halibut fishery has been more marked than that of any other branch of the Washington fisheries. During the summer months the halibut fleet, which has recently been increased by the addition of a number of splendid steel vessels, operates off Cape Flattery, but as winter approaches it becomes too rough in this locality, and the smaller boats tie up for the winter, while the larger ones go to Alaska, where the fishing grounds are better protected from storms.

TABLE 1.-WASHINGTON-FISHERY PRODUCTS: 1908.

\begin{tabular}{|c|c|c|c|c|c|c|c|c|c|c|c|c|c|c|}
\hline \multirow{3}{*}{ SPECIES, } & \multirow{2}{*}{\multicolumn{2}{|c|}{ TOTAL. }} & \multicolumn{12}{|c|}{ PRODUCT CAUOOHT BY- } \\
\hline & & & \multicolumn{2}{|c|}{ Lines. } & \multicolumn{2}{|c|}{ Pound nets. } & \multicolumn{2}{|c|}{ Gill nets. } & \multicolumn{2}{|c|}{ Seines. } & \multicolumn{2}{|c|}{ Wheels. } & \multicolumn{2}{|c|}{$\begin{array}{l}\text { All other appa- } \\
\text { ratus. } 1\end{array}$} \\
\hline & $\begin{array}{l}\text { Quantity } \\
\text { (pounds). }\end{array}$ & Value. & $\begin{array}{l}\text { Quantity } \\
\text { (pounds). }\end{array}$ & Value. & $\begin{array}{l}\text { Quantity } \\
\text { (pounds). }\end{array}$ & Value. & $\begin{array}{l}\text { Quantity } \\
\text { (pounds). }\end{array}$ & Value. & $\begin{array}{l}\text { Quantity } \\
\text { (pounds). }\end{array}$ & Value. & $\begin{array}{l}\text { Quantity } \\
\text { (pounds). }\end{array}$ & Value. & $\begin{array}{l}\text { Quantity } \\
\text { (pounds). }\end{array}$ & Value. \\
\hline Total & $100,456,000$ & $\$ 3,513,000$ & $35,013,000$ & $\$ 1,368,000$ & $28,860,000$ & $\$ 868,000$ & $16,262,000$ & $\$ 468,000$ & $14,932,000$ & $\$ 333,000$ & 481,000 & $\$ 26,000$ & $4,909,000$ & $\$ 450,000$ \\
\hline $\begin{array}{l}\text { Fish: } \\
\text { Black cod .......... } \\
\text { Cod, salted........ } \\
\text { Cultus cod......... } \\
\text { Flounders........ }\end{array}$ & $\begin{array}{r}168,000 \\
4,648,000 \\
62,000 \\
284,000\end{array}$ & $\begin{array}{r}4,900 \\
124,000 \\
1,400 \\
3,200\end{array}$ & $\begin{array}{r}168,000 \\
4,648,000 \\
62,000 \\
\cdots \ldots \ldots\end{array}$ & $\begin{array}{r}4,900 \\
124,000 \\
1,400 \\
\ldots \ldots\end{array}$ & $\ddot{27,000}$ & 300 & & & 257,000 & 3,000 & & & & \\
\hline $\begin{array}{l}\text { IIalihut........... } \\
\text { Herring . . ....... } \\
\text { Pereh, viviparous.. } \\
\text { Rockfish .......... }\end{array}$ & $\begin{array}{r}30,072,000 \\
2,506,000 \\
661,000 \\
132,000\end{array}$ & $\begin{array}{r}1,236,000 \\
21,000 \\
15,000 \\
5,200\end{array}$ & $\begin{array}{r}30,072,000 \\
\cdots \ldots \ldots \ldots \ldots \\
\cdots 3,000\end{array}$ & $\begin{array}{r}1,236,000 \\
\cdots \ldots \ldots \ldots \\
1,700\end{array}$ & $\mid \begin{array}{c}\cdots \ldots \ldots, \ldots \\
300,000 \\
\cdots \cdots \cdots \cdots \cdots\end{array}$ & $\begin{array}{r}2,300 \\
\cdots\end{array}$ & & & $\begin{array}{r}2,206,000 \\
661,000 \\
69,000\end{array}$ & $\begin{array}{r}19,000 \\
15,000 \\
3,500\end{array}$ & 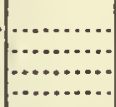 & & & \\
\hline $\begin{array}{l}\text { Salmon, blueback } \\
\text { or sockeye....... } \\
\text { Salmon, chinook }\end{array}$ & $\begin{array}{l}12,501,000 \\
12,336,000\end{array}$ & $\begin{array}{l}513,000 \\
565,000\end{array}$ & & & $\begin{array}{r}10,491,000 \\
5,818,000\end{array}$ & $\begin{array}{l}424,000 \\
242,000\end{array}$ & $\begin{array}{r}649,000 \\
5,385,000\end{array}$ & $\begin{array}{r}27,000 \\
258,000\end{array}$ & $\begin{array}{r}1,269,000 \\
851,000\end{array}$ & $\begin{array}{l}57,000 \\
48,000\end{array}$ & $\begin{array}{r}92,000 \\
282,000\end{array}$ & $\begin{array}{r}5,300 \\
16,000\end{array}$ & & …...... \\
\hline $\begin{array}{l}\text { Salmon, dog or } \\
\text { chum............ } \\
\text { Salmon, silver.... } \\
\text { Salmon, steelhead. }\end{array}$ & $\begin{array}{r}13,055,000 \\
14,080,000 \\
2,339,000\end{array}$ & $\begin{array}{l}115,000 \\
255,000 \\
123,000\end{array}$ & & & $\begin{array}{r}4,230,000 \\
6,991,000 \\
855,000\end{array}$ & $\begin{array}{r}32,000 \\
122,000 \\
41,000\end{array}$ & $\begin{array}{r}3,600,000 \\
5,714,000 \\
726,000\end{array}$ & $\begin{array}{r}30,000 \\
105,000 \\
41,000\end{array}$ & $\begin{array}{r}5,226,000 \\
1,375,000 \\
651,000\end{array}$ & $\begin{array}{l}64,000 \\
28,000 \\
36,000\end{array}$ & 107,000 & 4,800 & $\mid \cdots \ldots \ldots \ldots$ & $\mid \begin{array}{l}\ldots \ldots \ldots \\
\ldots \ldots \ldots\end{array}$ \\
\hline 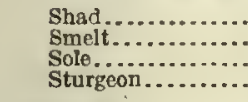 & $\begin{array}{r}100,000 \\
2,897,000 \\
190,000 \\
185,000\end{array}$ & $\begin{array}{r}1,900 \\
61,000 \\
3,800 \\
6,000\end{array}$ & & & $\begin{array}{r}64,000 \\
5,000 \\
80,000\end{array}$ & $\begin{array}{r}1,200 \\
200 \\
2,700\end{array}$ & $\begin{array}{r}500 \\
90,000 \\
97000\end{array}$ & $\begin{array}{c}(2) \\
4,500 \\
\ldots \ldots \\
2,600\end{array}$ & $\begin{array}{r}35,000 \\
1,907,000 \\
185,000 \\
8,100\end{array}$ & $\begin{array}{r}700 \\
45,000 \\
3,600 \\
700\end{array}$ & 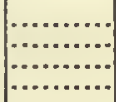 & & $\begin{array}{r}900,000 \\
\cdots\end{array}$ & $\begin{array}{l}12,000 \\
\cdots \cdots\end{array}$ \\
\hline 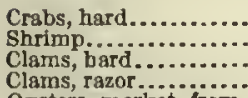 & $\begin{array}{r}2,179,000 \\
247,000 \\
2155,000 \\
+234,000\end{array}$ & $\begin{array}{l}51,000 \\
22,000 \\
13,000 \\
22,000\end{array}$ & $\mid \begin{array}{l}\cdots \\
\cdots \cdots \\
\cdots \cdots\end{array}$ & & & & & $\begin{array}{l}\ldots \ldots \ldots \\
\cdots \ldots \ldots \\
\cdots \ldots \ldots\end{array}$ & $\begin{array}{r}232,000 \\
\ldots \ldots \ldots\end{array}$ & $\begin{array}{r}21,000 \\
\cdots\end{array}$ & ( & & $\begin{array}{r}2,179,000 \\
15,000 \\
155,000 \\
234,000\end{array}$ & $\begin{array}{r}51,000 \\
1,000 \\
13,000 \\
22,000\end{array}$ \\
\hline $\begin{array}{l}\text { Oysters, market, from } \\
\text { private areas......... } \\
\text { oysters, secd, from pri- }\end{array}$ & $1,321,000$ & 346,000 & & & & & & & & & & & $81,321,000$ & 346,000 \\
\hline $\begin{array}{l}\text { Uysters, secd, 1rom pr.- } \\
\text { vate areas............. }\end{array}$ & 104,000 & 6,500 & & & & & & & & & & & 104,000 & 6,500 \\
\hline
\end{tabular}

1 Includes apparatus, with catch, as follows: Dredges, tongs, etc., 1,425,000 pounds, valued at \$352,000; traps and hoop nets, 2,179,000 pounds, $\nabla a 1 u e d$ at $\$ 51,000$; dip nets, 900,000 pounds, valued at $\$ 12,000$; beam trawls, 15,000 pounds, valued at $\$ 1,100$; and minor apparatus, 389,000 pounds, valued at $\$ 34,000$. 
TABLe 2.-WASHINGTON-FisheRY PRODUCTS OF PACIFIC OCEAN DISTRICT: 1908.

\begin{tabular}{|c|c|c|c|c|c|c|c|c|c|c|c|c|}
\hline \multirow{3}{*}{ SPECIES. } & \multirow{2}{*}{\multicolumn{2}{|c|}{ TOTAL. }} & \multicolumn{10}{|c|}{ PRODUCT CAUGHT BY- } \\
\hline & & & \multicolumn{2}{|c|}{ Lines. } & \multicolumn{2}{|c|}{ Pound nets. } & \multicolumn{2}{|c|}{ Selnes. } & \multicolumn{2}{|c|}{ Gill nets. } & \multicolumn{2}{|c|}{ All other apparatus. ${ }^{1}$} \\
\hline & $\begin{array}{l}\text { Quantlty } \\
\text { (pounds). }\end{array}$ & Value. & $\begin{array}{l}\text { Quantity } \\
\text { (pounds). }\end{array}$ & Value. & $\begin{array}{l}\text { Quantity } \\
\text { (pounds). }\end{array}$ & Value. & $\begin{array}{l}\text { Quantity } \\
\text { (pounds). }\end{array}$ & Value. & $\begin{array}{l}\text { Quantity } \\
\text { (pounds). }\end{array}$ & Value. & $\begin{array}{l}\text { Quantity } \\
\text { (pounds). }\end{array}$ & Valuc. \\
\hline 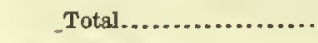 & $89,305,000$ & $\$ 3,018,000$ & $35,013,000$. & $\$ 1,368,000$ & $24,928,000$ & $\$ 703,000$ & $13,379,000$ & $\$ 256,000$ & $11,977,000$ & $\$ 253,000$ & $4,010,000$ & $\$ 439,000$ \\
\hline 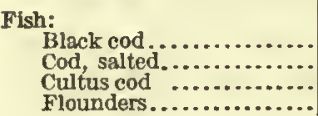 & $\begin{array}{r}168,000 \\
4,648,000 \\
62,000 \\
284,000\end{array}$ & $\begin{array}{r}4,900 \\
124,000 \\
1,400 \\
3,200\end{array}$ & $\begin{array}{r}168,000 \\
4,648,000 \\
62,000\end{array}$ & $\begin{array}{r}4,900 \\
124,000 \\
1,400 \\
\end{array}$ & $2 \pi, 000$ & $\cdots \cdots$ & $\cdots \ldots \ldots \ldots$ & $\cdots, 2,900$ & & & & $\begin{array}{l}\cdots \\
\cdots \\
\cdots\end{array}$ \\
\hline 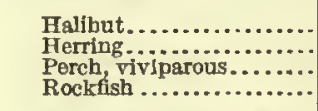 & $\begin{array}{r}30,072,000 \\
2,506,000 \\
661,000 \\
132,000\end{array}$ & $\begin{array}{r}1,236,000 \\
21,000 \\
15,000 \\
5,200\end{array}$ & $\begin{array}{l}30,072,000 \\
\cdots, \ldots, \ldots, \ldots \\
63,000\end{array}$ & $\begin{array}{r}1,236,000 \\
\cdots \ldots \ldots \\
1,700\end{array}$ & $\begin{array}{r}3000,000 \\
\cdots \ldots \ldots \ldots\end{array}$ & 2,200 & $\begin{array}{r}2,206,000 \\
661,000 \\
69,000\end{array}$ & $\begin{array}{r}19,000 \\
15,000 \\
3,500\end{array}$ & & & & \\
\hline $\begin{array}{l}\text { Salmon, blueback or sock- } \\
\text { eye..................... } \\
\text { Salmon, chineok ......... } \\
\text { Salmon, dog or chum..... } \\
\text { Salmon, silver ............ } \\
\text { Salmon, steelhead........ }\end{array}$ & $\begin{array}{r}12,231,000 \\
6,981,000 \\
12,246,000 \\
12,150,000 \\
689,000\end{array}$ & $\begin{array}{r}499,000 \\
250,000 \\
105,000 \\
200,000 \\
42,000\end{array}$ & & $\begin{array}{l}\cdots \\
\cdots \\
\cdots \\
\cdots\end{array}$ & $\begin{array}{r}10,334,000 \\
4,425,000 \\
3,690,000 \\
5,993,000 \\
86,000\end{array}$ & $\begin{array}{r}417,000 \\
161,000 \\
26,000 \\
92,000 \\
3,500\end{array}$ & $\begin{array}{l}1,252,000 \\
39,000 \\
5,226,00 \mathrm{C} \\
1,146,000 \\
199,000\end{array}$ & $\begin{array}{r}57,000 \\
2,000 \\
52,000 \\
22,000 \\
14,000\end{array}$ & $\begin{array}{r}645,000 \\
2,517,000 \\
3,330,000 \\
5,011,000 \\
403,000\end{array}$ & $\begin{array}{l}26,000 \\
88,000 \\
26,000 \\
86,000 \\
25,000\end{array}$ & 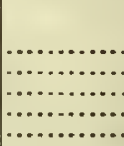 & 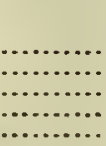 \\
\hline 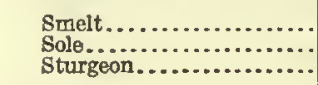 & $\begin{array}{r}1,907,000 \\
190,000 \\
139,000\end{array}$ & $\begin{array}{r}45,000 \\
3,800 \\
3,100\end{array}$ & & & $\begin{array}{r}5,000 \\
68,000\end{array}$ & 1,700 & $\begin{array}{r}1,907,000 \\
185,000 \\
\ldots\end{array}$ & $\begin{array}{r}45,000 \\
3,600\end{array}$ & $\cdots \cdots \cdots$ & $\cdots \cdots, 400$ & & $\begin{array}{l}\text { (n... } \\
\cdots \\
\cdots\end{array}$ \\
\hline 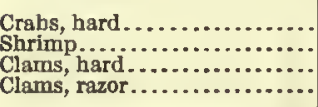 & $\begin{array}{r}2,179,000 \\
247,000 \\
155,000 \\
234,000\end{array}$ & $\begin{array}{l}51,000 \\
22,000 \\
13,000 \\
22,000\end{array}$ & & & $\cdots$ & ( & $\begin{array}{r}232,000 \\
\cdots \ldots \ldots\end{array}$ & $\begin{array}{r}21,000 \\
\ldots \ldots\end{array}$ & (n) & 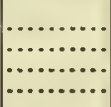 & $\begin{array}{r}2,179,000 \\
15,000 \\
2155,000 \\
5234,000\end{array}$ & $\begin{array}{r}51,000 \\
1,100 \\
13,000 \\
22,000\end{array}$ \\
\hline 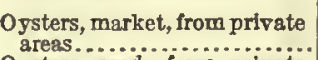 & $1,321,000$ & 346,000 & & & & & & & & & $41,321,000$ & 346,000 \\
\hline $\begin{array}{l}\text { Oysters, seed, from private } \\
\text { areas.................................... }\end{array}$ & 104,000 & 6,500 & & & & & & & & & 104,000 & 6,500 \\
\hline
\end{tabular}

1 Includes apparatus, with catch, as follows: Dredges, tongs, etc., 1,425,000 pounds, valued at $\$ 352,000$; traps and hoop nets, 2,179,000 pounds, valued at $\$ 51,000$; bean trawls, 15,000 pounds, valued at $\$ 1,100$; and minor apparatus, 389,000 pounds, valued at $\$ 34,000$

$\$ 19,000$ bushels. $\quad \$ 23,000$ bushels. $\quad \$ 189,000$ bushels.

TABLE 3.-WASHINGTON-FISHERY PRODUCTS OF THE COLUMBIA RIVER: 1908.

\begin{tabular}{|c|c|c|c|c|c|c|c|c|c|c|}
\hline \multirow{3}{*}{ SPECIES } & \multirow{2}{*}{\multicolumn{2}{|c|}{ TOTAL. }} & \multicolumn{8}{|c|}{ PRODUCT CAUGHT BY- } \\
\hline & & & \multicolumn{2}{|c|}{ Gill nets. } & \multicolumn{2}{|c|}{ Pound nets. } & \multicolumn{2}{|c|}{ Seines. } & \multicolumn{2}{|c|}{ All other apparatus." } \\
\hline & $\begin{array}{l}\text { Quantity } \\
\text { (pounds). }\end{array}$ & Value. & $\begin{array}{l}\text { Quantity } \\
\text { (pounds). }\end{array}$ & Value. & $\begin{array}{l}\text { Quantity } \\
\text { (pounds). }\end{array}$ & Value. & $\begin{array}{l}\text { Qnantity } \\
\text { (poumds). }\end{array}$ & Value. & $\begin{array}{l}\text { Quantity } \\
\text { (pounds). }\end{array}$ & Value. \\
\hline 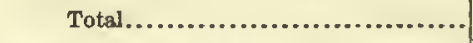 & $11,151,000$ & $\$ 495,000$ & $4,285,000$ & $\$ 216,000$ & $3,932,000$ & $\$ 165,000$ & $1,554,000$ & $\$ 77,000$ & $1,382,000$ & $\$ 38,000$ \\
\hline 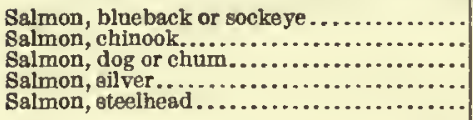 & $\begin{array}{r}270,000 \\
5,356,000 \\
809,000 \\
1,930,000 \\
1,650,000\end{array}$ & $\begin{array}{r}14,000 \\
315,000 \\
11,000 \\
54,000 \\
81,000\end{array}$ & $\begin{array}{r}3,500 \\
2,868,000 \\
270,000 \\
703,000 \\
323,000\end{array}$ & $\begin{array}{r}100 \\
170,000 \\
4,300 \\
19,000 \\
16,000\end{array}$ & $\begin{array}{r}158,000 \\
1,393,000 \\
539,000 \\
997,000 \\
769,000\end{array}$ & $\begin{array}{r}7,500 \\
82,000 \\
6,500 \\
30,000 \\
38,000\end{array}$ & $\begin{array}{r}17,000 \\
812,000 \\
229,000 \\
451,000\end{array}$ & $\begin{array}{r}700 \\
46,000 \\
5,600 \\
23,000\end{array}$ & $\begin{array}{r}92,000 \\
282,000 \\
\cdots \cdots \\
107,000\end{array}$ & $\begin{array}{r}5,300 \\
16,000 \\
4,800\end{array}$ \\
\hline 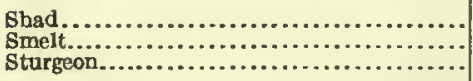 & $\begin{array}{r}100,000 \\
990,000 \\
46,000\end{array}$ & $\begin{array}{r}1,900 \\
16,000 \\
2,900\end{array}$ & $\begin{array}{r}500 \\
90,000 \\
26,000\end{array}$ & $\begin{array}{l}(5) \\
4,500 \\
1,200\end{array}$ & $\begin{array}{r}64,000 \\
12,000\end{array}$ & $\begin{array}{l}1,200 \\
1,000\end{array}$ & 35,000 & 700 & & $\ddot{12,000}$ \\
\hline
\end{tabular}

1 All taken in shore and boat fisheries.

1 All taken in shore and boat fisheries.
Includee apparatus, with catch, as followe: Wheels, 481,000 pounds, valued at $\$ 26,000$; and dip nets, 900,000 pounds, valued at $\$ 12,000$.
Iess than $\$ 100$. 
FISHERIES, BY STATES.

TABLE 4.-WASHINGTON-PRODUCTS OF VESSEL FISHERIES: 1908.

\begin{tabular}{|c|c|c|c|c|c|c|c|c|}
\hline \multirow{3}{*}{ SPECIES. } & \multirow{2}{*}{\multicolumn{2}{|c|}{ TOTAL. }} & \multicolumn{6}{|c|}{ PRODUCT CAUGLT BY- } \\
\hline & & & \multicolumn{2}{|c|}{ Lines. } & \multicolumn{2}{|c|}{ Seines. } & \multicolumn{2}{|c|}{ All othar apparatus. I } \\
\hline & $\begin{array}{l}\text { Quantity } \\
\text { (pounds). }\end{array}$ & Value. & $\begin{array}{l}\text { Quantity } \\
\text { (pounds). }\end{array}$ & Value. & $\begin{array}{l}\text { Quantity } \\
\text { (pounds). }\end{array}$ & Value. & $\begin{array}{l}\text { Quantity } \\
\text { (pounds). }\end{array}$ & Value. \\
\hline Total..... & $40,171,000$ & $\$ 1,569,000$ & $35,013,000$ & $\$ 1,368,000$ & $4,719,000$ & $\$ 96,000$ & 439,000 & $\$ 106,000$ \\
\hline 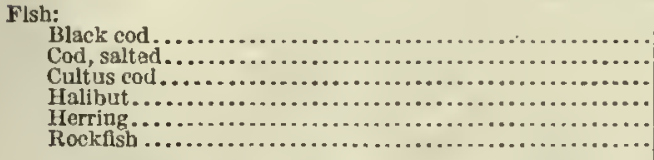 & $\begin{array}{r}168,000 \\
4,648,000 \\
62,000 \\
30,072,000 \\
130,000 \\
63,000\end{array}$ & $\begin{array}{r}4,900 \\
124,000 \\
1,400 \\
1,236,000 \\
1,300 \\
1,700\end{array}$ & $\begin{array}{r}168,000 \\
4,648,000 \\
62,000 \\
30,072,000 \\
633,000\end{array}$ & $\begin{array}{r}4,900 \\
124,000 \\
1,400 \\
1,236,000 \\
1,700\end{array}$ & (130,000 & ( & 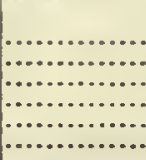 & 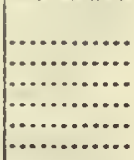 \\
\hline 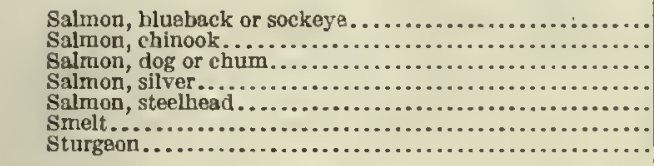 & $\begin{array}{r}664,000 \\
6,000 \\
3,032,000 \\
626,000 \\
24,000 \\
38,000 \\
14,000\end{array}$ & $\begin{array}{r}30,000 \\
400 \\
30,000 \\
11,000 \\
1,800 \\
1,100 \\
200\end{array}$ & $\begin{array}{l}\cdots \cdots \\
\cdots \cdots \\
\cdots \cdots \\
\cdots \cdots\end{array}$ & 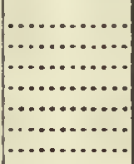 & $\begin{array}{r}664,000 \\
6,000 \\
3,027,000 \\
598,000 \\
24,000 \\
38,000 \\
\ldots .\end{array}$ & $\begin{array}{r}30,000 \\
400 \\
30,000 \\
11,000 \\
1,800 \\
1,100 \\
.\end{array}$ & $\begin{array}{r}\ldots \ldots \\
\mathbf{5}, 000 \\
28,000 \\
\cdots \ldots \ldots \ldots \ldots \\
\cdots \cdots \\
14,000\end{array}$ & 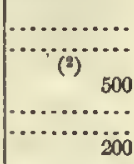 \\
\hline 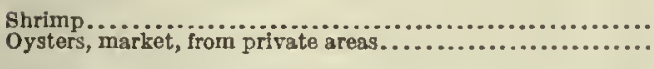 & $\begin{array}{r}247,000 \\
3377,000\end{array}$ & $\begin{array}{r}22,000 \\
104,000\end{array}$ & & & $\begin{array}{l}232,000 \\
\ldots \ldots \ldots\end{array}$ & $\begin{array}{c}21,000 \\
\ldots \ldots \ldots\end{array}$ & $\begin{array}{r}15,000 \\
377,000\end{array}$ & $\begin{array}{r}1,100 \\
104,000\end{array}$ \\
\hline
\end{tabular}

1 Includes apparatus, with catch, as follows: Dredges, tongs, ete., 377,000 pounds, valued at $\$ 104,000 ;$ beam trawls, 15,000 pounds, valued at $\$ 1,100$; and gl1 nats, 47,000 pounds, valued at $\$ 700$.

Less than $\$ 100$

34,000 hushels.

TABLE 5.-WASHINGTON-PRODUCTS OF SHORE AND BOAT FISHERIES: 1908.

\begin{tabular}{|c|c|c|c|c|c|c|c|c|c|c|}
\hline \multirow{3}{*}{ SPECIES. } & \multirow{2}{*}{\multicolumn{2}{|c|}{ TOTAL. }} & \multicolumn{8}{|c|}{ PRODUCT CAUGHT BY- } \\
\hline & & & \multicolumn{2}{|c|}{ Pound nets. } & \multicolumn{2}{|c|}{ Gill nets. } & \multicolumn{2}{|c|}{ Seines. } & \multicolumn{2}{|c|}{ All other apparatus. } \\
\hline & $\begin{array}{l}\text { Quantity } \\
\text { (pounds). }\end{array}$ & Value. & $\begin{array}{l}\text { Quantity } \\
\text { (pounds). }\end{array}$ & Valus. & $\begin{array}{l}\text { Quantity } \\
\text { (pounds). }\end{array}$ & Value. & $\begin{array}{l}\text { Quantity } \\
\text { (pounds). }\end{array}$ & Value. & $\begin{array}{l}\text { Quantity } \\
\text { (pounds). }\end{array}$ & Value. \\
\hline Total......... & $60,285,000$ & $\$ 1,944,000$ & $28,860,000$ & $\$ 868,000$ & $16,215,000$ & $\$ 468,000$ & $10,213,000$ & $\$ 237,000$ & $4,998,000$ & $\$ 371,000$ \\
\hline 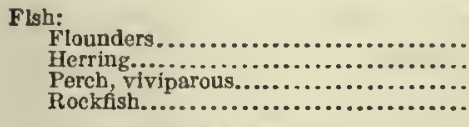 & $\begin{array}{r}284,000 \\
2,376,000 \\
660,000 \\
69,000\end{array}$ & $\begin{array}{r}3,200 \\
20,000 \\
15,000 \\
3,500\end{array}$ & $\begin{array}{r}27,000 \\
300,000 \\
\cdots \cdots \cdots \\
\cdots \cdots\end{array}$ & $\begin{array}{r}300 \\
2,200 \\
\cdots \cdots\end{array}$ & 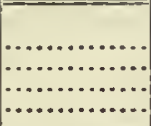 & 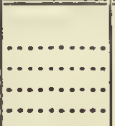 & $\begin{array}{r}257,000 \\
2,076,000 \\
660,000 \\
69,000\end{array}$ & $\begin{array}{r}2,900 \\
17,000 \\
15,000 \\
3,500\end{array}$ & 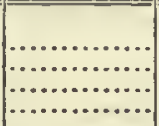 & $\begin{array}{ll} \\
\cdots \cdots \cdots \\
\cdots \cdots \cdots\end{array}$ \\
\hline 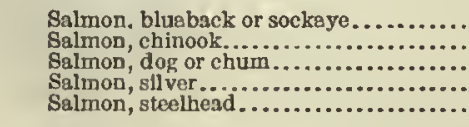 & $\begin{array}{r}11,837,000 \\
12,330,000 \\
10,023,000 \\
13,454,000 \\
2,314,000\end{array}$ & $\begin{array}{r}484,000 \\
565,000 \\
85,000 \\
243,000 \\
121,000\end{array}$ & $\begin{array}{r}10,491,000 \\
5,818,000 \\
4,230,000 \\
6,990,000 \\
855,000\end{array}$ & $\begin{array}{r}424,000 \\
242,000 \\
32,000 \\
122,000 \\
41,000\end{array}$ & $\begin{array}{r}649,000 \\
5,385,000 \\
3,595,000 \\
5,686,000 \\
726,000\end{array}$ & $\begin{array}{r}27,000 \\
258,000 \\
30,000 \\
105,000 \\
41,000\end{array}$ & $\begin{array}{r}605,000 \\
845,000 \\
2,199,000 \\
778,000 \\
626,000\end{array}$ & $\begin{array}{l}28,000 \\
48,000 \\
22,000 \\
17,000 \\
34,000\end{array}$ & 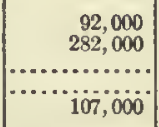 & 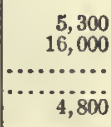 \\
\hline 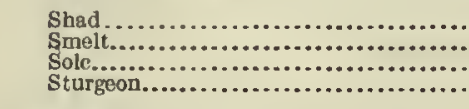 & $\begin{array}{r}100,000 \\
2,859,000 \\
190,000 \\
171,000\end{array}$ & $\begin{array}{r}1,900 \\
60,000 \\
3,800 \\
5,800\end{array}$ & $\begin{array}{r}64,000 \\
5,000 \\
80,000\end{array}$ & $\begin{array}{r}1,200 \\
2,700 \\
2,700\end{array}$ & $\begin{array}{r}500 \\
90,000 \\
93,000\end{array}$ & $\begin{array}{r}(3) \\
4,500 \\
2,400\end{array}$ & $\begin{array}{r}35,000 \\
1,869,000 \\
185,000 \\
8,100\end{array}$ & $\begin{array}{r}700 \\
44,000 \\
3,600 \\
700\end{array}$ & 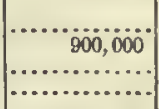 & $\begin{array}{r}\cdots \cdots \\
12,000 \\
\cdots \cdots \cdots\end{array}$ \\
\hline 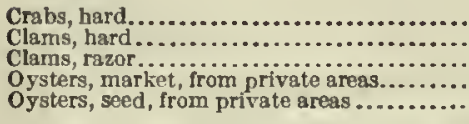 & $\begin{array}{r}2,179,000 \\
\text { s } 155,000 \\
234,000 \\
944,000 \\
104,000\end{array}$ & $\begin{array}{r}51,000 \\
13,000 \\
22,000 \\
242,000 \\
6,500\end{array}$ & 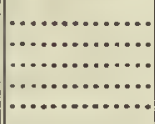 & 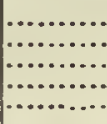 & 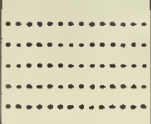 & 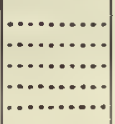 & ' & (n) & $\begin{array}{r}2,179,000 \\
3155,000 \\
234,000 \\
944,000 \\
104,000\end{array}$ & $\begin{array}{r}51,000 \\
13,000 \\
22,000 \\
242,000 \\
6,500\end{array}$ \\
\hline
\end{tabular}

1 Includes apparatus, with catch, as follows: Dredges, tongs, etc., $1,048,000$ pounds, valued at $\$ 248,000 ;$ traps and hoop ncts, $2,179,000$ pounds, valued at $\$ 51,000$; wheels,

481,000 pounds, valued at $\$ 26,000$; dip nets, 900,000 pounds, valued at $\$ 12,000$; and minor apparatus, 389,000 pounds, valued at $\$ 34,000$. 
FISHERIES OF THE UNITED STATES, 1908.

TABLE 6.-WASHINGTON-PRODUCTS OF SHORE AND BOAT FISHERIES OF THE PACIFIC OCEAN DISTRICT: 1908.

\begin{tabular}{|c|c|c|c|c|c|c|c|c|c|c|}
\hline \multirow{3}{*}{ SPECIES. } & \multirow{2}{*}{\multicolumn{2}{|c|}{ TOTAL. }} & \multicolumn{8}{|c|}{ PRODUCT CAUGHT BY- } \\
\hline & & & \multicolumn{2}{|c|}{ Pound nets. } & \multicolumn{2}{|c|}{ Gill nets. } & \multicolumn{2}{|c|}{ Seines. } & \multicolumn{2}{|c|}{ All other apparatus.1 } \\
\hline & $\begin{array}{l}\text { Quantity } \\
\text { (pounds). }\end{array}$ & Value. & $\begin{array}{l}\text { Quantity } \\
\text { (pounds). }\end{array}$ & Value. & $\begin{array}{l}\text { Quantity } \\
\text { (pounds). }\end{array}$ & Value. & $\begin{array}{l}\text { Quantity } \\
\text { (pounds). }\end{array}$ & Value. & $\begin{array}{l}\text { Quantity } \\
\text { (pounds). }\end{array}$ & Value. \\
\hline Total.... & $49,134,000$ & $\$ 1,449,000$ & $24,928,000$ & $\$ 703,000$ & $11,930,000$ & $\$ 252,000$ & $8,659,000$ & $\$ 160,000$ & $3,617,000$ & $\$ 334,000$ \\
\hline 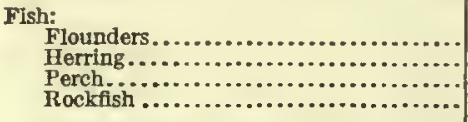 & $\begin{array}{r}284,000 \\
2,376,000 \\
660,000 \\
69,000\end{array}$ & $\begin{array}{r}3,200 \\
20,000 \\
15,000 \\
3,500\end{array}$ & $\begin{array}{r}27,000 \\
300,000 \\
\cdots \ldots \\
\cdots\end{array}$ & $\begin{array}{r}300 \\
2,200 \\
\cdots+\cdots \\
\cdots\end{array}$ & & $\begin{array}{ll} \\
\cdots \cdots \cdots \\
\cdots \cdots \cdots \\
\cdots \cdots\end{array}$ & $\begin{array}{r}257,000 \\
2,076,000 \\
660,000 \\
69,000\end{array}$ & $\begin{array}{r}2,900 \\
17,000 \\
15,000 \\
3,500\end{array}$ & & \\
\hline 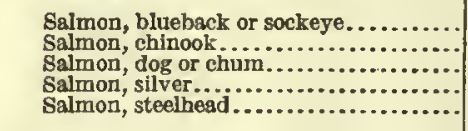 & $\begin{array}{r}11,566,000 \\
6,975,000 \\
9,214,000 \\
11,524,000 \\
664,000\end{array}$ & $\begin{array}{r}470,000 \\
250,000 \\
74,000 \\
189,000 \\
40,000\end{array}$ & $\begin{array}{r}10,334,000 \\
4,425,000 \\
3,690,000 \\
5,993,000 \\
86,000\end{array}$ & $\begin{array}{r}417,000 \\
161,000 \\
26,000 \\
92,000 \\
3,500\end{array}$ & $\begin{array}{r}645,000 \\
2,517,000 \\
3,325,000 \\
4,983,000 \\
403,000\end{array}$ & $\begin{array}{l}26,000 \\
88,000 \\
26,000 \\
86,000 \\
25,000\end{array}$ & $\begin{array}{r}588,000 \\
33,000 \\
2,199,000 \\
549,000 \\
175,000\end{array}$ & $\begin{array}{r}27,000 \\
1,600 \\
22,000 \\
11,000 \\
12,000\end{array}$ & $\begin{array}{ll} \\
\cdots \\
\cdots \cdots \cdots \cdots \cdots \\
\cdots \cdots \cdots \cdots\end{array}$ & (n) \\
\hline 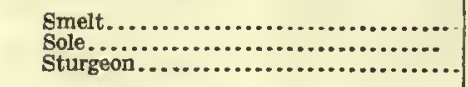 & $\begin{array}{r}1,869,000 \\
190,000 \\
125,000\end{array}$ & $\begin{array}{r}44,000 \\
3,800 \\
2,900\end{array}$ & $\begin{array}{r}5,000 \\
68,000\end{array}$ & $\begin{array}{r}2000 \\
1,700\end{array}$ & $\cdots, 000$ & $\ddot{1, j 00}$ & $\begin{array}{r}1,869,000 \\
185,000 \\
\ldots \ldots .6 \%\end{array}$ & $\begin{array}{r}44,000 \\
3,600 \\
\ldots\end{array}$ & (n) & \\
\hline 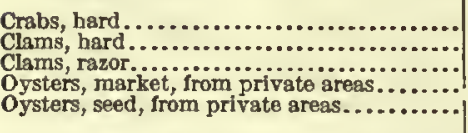 & $\begin{array}{r}2,179,000 \\
2155,000 \\
234,000 \\
1944,000 \\
104,000\end{array}$ & $\begin{array}{r}51,000 \\
13,000 \\
22,000 \\
242,000 \\
6,500\end{array}$ & 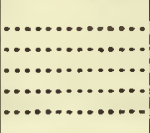 & & .. & (n... & (n. & 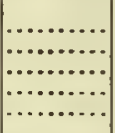 & $\begin{array}{r}2,179,000 \\
2155,000 \\
2234,000 \\
1944,000 \\
104,000\end{array}$ & $\begin{array}{r}51,000 \\
13,000 \\
22,000 \\
242,000 \\
6,500\end{array}$ \\
\hline
\end{tabular}

1 Includes apparatus, with catch, as follows: Dredges, tongs, etc., 1,048,000 pounds, valued at $\$ 248,000$; traps and hoop nets, 2,179,000 pounds, valued at $\$ 51,000 ;$ and

minor apparatus, 389,000 pounds, valued at $\$ 34,000$.
223,000 bushels.

135,000 bushels.

315,000 bushels.

\section{WEST VIRGINIA.}

The commercial fisheries of West Virginia are confined to the Ohio River and are all of the shore and boat class.

The following statement gives a general summary of the fishing industry of the state in 1908:

Number of persons employed. .....................

Capital:

Boats..................................... \$ $\$ 100$

Apparatus of capture........................ 200

Shore and accessory property................ 800 Value of product........................... 000

In 1908 large reductions appear in the number of persons employed, the capital invested, and the quantity and value of fishery products, as compared with 1899 and 1894, for which years statistics are given in the reports of the Bureau of Fisheries. The comparative figures are as follows:

\begin{tabular}{|c|c|c|c|c|}
\hline \multirow{2}{*}{ YEAR. } & \multirow{2}{*}{$\begin{array}{c}\text { Persons } \\
\text { employed. }\end{array}$} & \multirow{2}{*}{$\begin{array}{c}\text { Capital } \\
\text { invested. }\end{array}$} & \multicolumn{2}{|c|}{ PRODUCTS. } \\
\hline & & & $\begin{array}{l}\text { Quantity } \\
\text { (pounds). }\end{array}$ & Value. \\
\hline 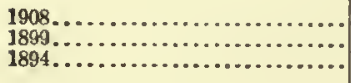 & $\begin{array}{r}8 \\
86 \\
67\end{array}$ & $\begin{array}{r}\$ 1,100 \\
3,600 \\
4,100\end{array}$ & $\begin{array}{r}33,000 \\
161,000 \\
162,000\end{array}$ & $\begin{array}{r}82,000 \\
12,000 \\
8,700\end{array}$ \\
\hline
\end{tabular}

The total value of equipment as reported for 1908 was $\$ 300$, and represented eight rowboats, valued at $\$ 100$, and apparatus of capture valued at $\$ 200$. The latter consisted of lines, two seines, and 22 fyke and hoop nets.
The quantity and value of products, by species, were as follows:

\begin{tabular}{|c|c|c|}
\hline \multirow{2}{*}{ SPECIES. } & \multicolumn{2}{|c|}{$\begin{array}{l}\text { FISHERY PRODU CTS: } \\
1908 .\end{array}$} \\
\hline & $\begin{array}{l}\text { Quantity } \\
\text { (pounds). }\end{array}$ & Vaiue. \\
\hline Total.............. & 33,000 & $\$ 2,000$ \\
\hline 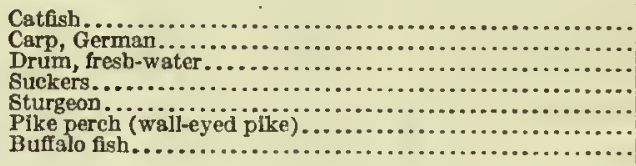 & $\begin{array}{r}9,600 \\
9,800 \\
3,400 \\
6,000 \\
3,000 \\
1,400 \\
300\end{array}$ & $\begin{array}{r}700 \\
400 \\
300 \\
300 \\
200 \\
100 \\
\text { (1) }\end{array}$ \\
\hline
\end{tabular}

1 Less than $\mathbf{8 1 0 0 .}$

WISCONSIN.

The fishery products of Wisconsin were obtained from the Mississippi River and its tributary waters, and from Lake Supcrior and Lake Michigan. The following statement gives a summary of the chief statistics for the fishing industry of this state in 1908:

Number of persons employed.................. 2, 011 Capital:

Vessels and boats, including outfit.......... \$417,000

Apparatus of capture..................... 407,000

Shore and accessory property and cash........ 276,000 Value of products.......................... 1,067,000

Comparison with previous canvasses.-The value of the product in 1908 was larger than that reported in 1899 , in both the river and the lake districts. The comparative summary following shows the more important statistics relating to the fisheries of the two districts in 1899 and 1908. 


\begin{tabular}{|c|c|c|c|c|c|c|}
\hline \multirow[b]{2}{*}{$\begin{array}{l}\text { DISTRICT AND } \\
\text { XEAB. }\end{array}$} & \multirow{2}{*}{$\begin{array}{l}\text { Per- } \\
\text { sons } \\
\text { em- } \\
\text { ployed, } \\
\text { exelu- } \\
\text { sive of } \\
\text { shores- } \\
\text { men. }\end{array}$} & \multicolumn{3}{|c|}{ VALUE OF EQUIPMENT. } & \multicolumn{2}{|c|}{ Pronucts. } \\
\hline & & Total. & $\begin{array}{c}\text { Vessels } \\
\text { and } \\
\text { boats, } \\
\text { including } \\
\text { outfit. }\end{array}$ & $\begin{array}{l}\text { Appara- } \\
\text { tus of } \\
\text { capture. }\end{array}$ & $\begin{array}{l}\text { Quantity } \\
\text { (pounds). }\end{array}$ & Value. \\
\hline $\begin{array}{l}\text { All fisherles: } \\
1908 . \ldots . \\
1899 . . .\end{array}$ & $\begin{array}{l}1,889 \\
1,645\end{array}$ & $\begin{array}{r}8824,000 \\
483,000\end{array}$ & $\begin{array}{r}\$ 417,000 \\
196,000\end{array}$ & $\begin{array}{r}8407,000 \\
257,000\end{array}$ & $\begin{array}{l}30,953,000 \\
36,767,000 \\
\end{array}$ & $\begin{array}{r}\$ 1,067,000 \\
542,000\end{array}$ \\
\hline $\begin{array}{l}\text { Oreat Lakes: } \\
\quad 1908 \ldots \ldots \ldots \ldots \\
1899 \ldots \ldots \ldots \ldots\end{array}$ & $\begin{array}{l}1,284 \\
1,154\end{array}$ & $\begin{array}{l}751,000 \\
468,000\end{array}$ & $\begin{array}{l}383,000 \\
189,000\end{array}$ & $\begin{array}{l}367,000 \\
279,000\end{array}$ & $\begin{array}{l}22,995,000 \\
19,530,000\end{array}$ & $\begin{array}{l}853,000 \\
454,00\end{array}$ \\
\hline $\begin{array}{c}\text { Mississlppl River } \\
\text { district: } \\
1908 \ldots \ldots \ldots \ldots \\
1899 \ldots \ldots \ldots \ldots\end{array}$ & $\begin{array}{l}605 \\
491\end{array}$ & $\begin{array}{l}73,000 \\
15,000\end{array}$ & $\begin{array}{r}34,000 \\
7,000\end{array}$ & $\begin{array}{r}40,000 \\
8,000\end{array}$ & $\begin{array}{r}7,958,000 \\
17,237,000\end{array}$ & $\begin{array}{r}215,000 \\
88,000\end{array}$ \\
\hline
\end{tabular}

The large quantity reported for the Mississippi River district in 1899 consisted chiefly of mussel shells, the food-fish catch in that year being only about a million pounds. A period of great excitement over pearl hunting began in 1896, and this activity, while it lasted, drew fishermen away from their usual pursuits, so that the catch of fish proper was very small.

Persons employed.-The following table gives data concerning the persons employed in the fisheries of Wisconsin in 1908. The number connected with the shore and boat fisheries, including 36 of the shoresmen, was 1,528 , while the number credited to vessel fisheries, including the 86 remaining shoresmen, was 473 . More than one-half of the persons employed in the shore and boat fisheries, and nearly nine-tenths of those employed in the vessel fisheries, were reported for the Lake Michigan district.

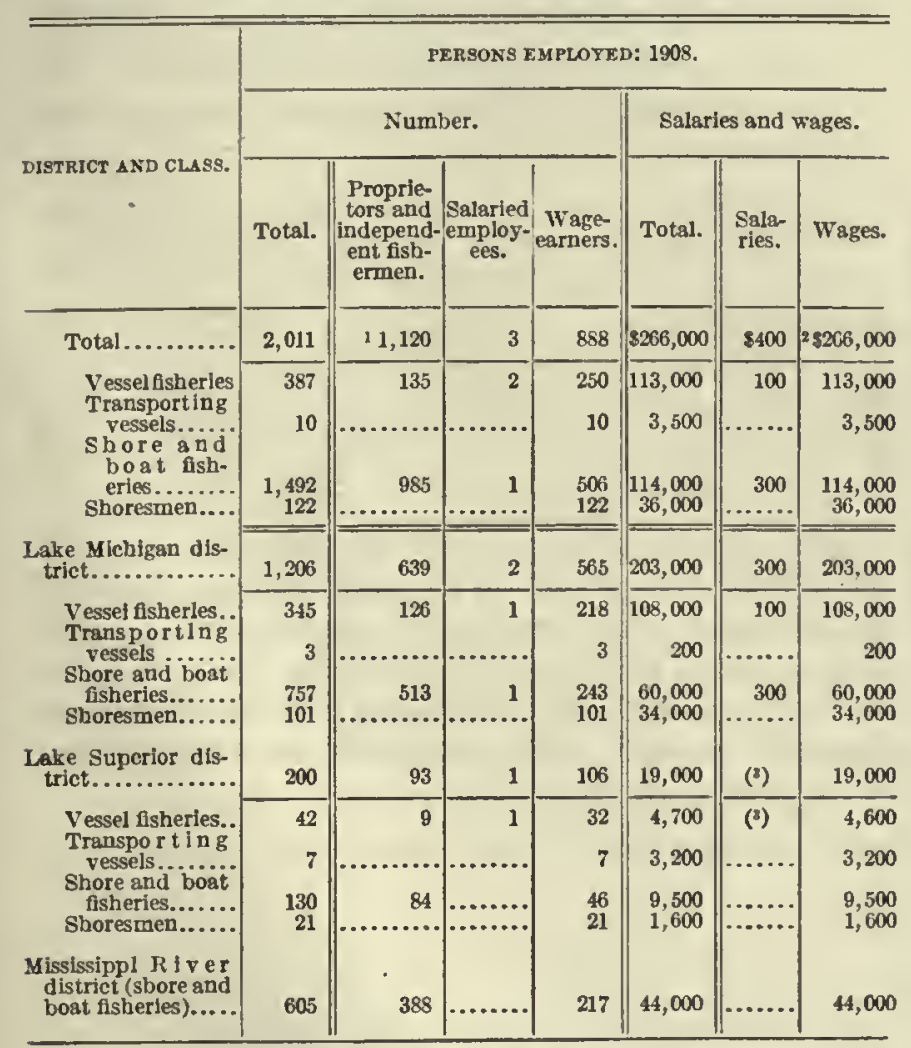

1 Exclusive of 42 proprietors not fishing.

2 includes provisions furnished to the value of $\$ 11,000$.

Less than 8100.

Equipment and other capital.-The following tabular statement gives the distribution, by class of investment, of the total capital employed in the fisheries of the state and of each district in 1908:

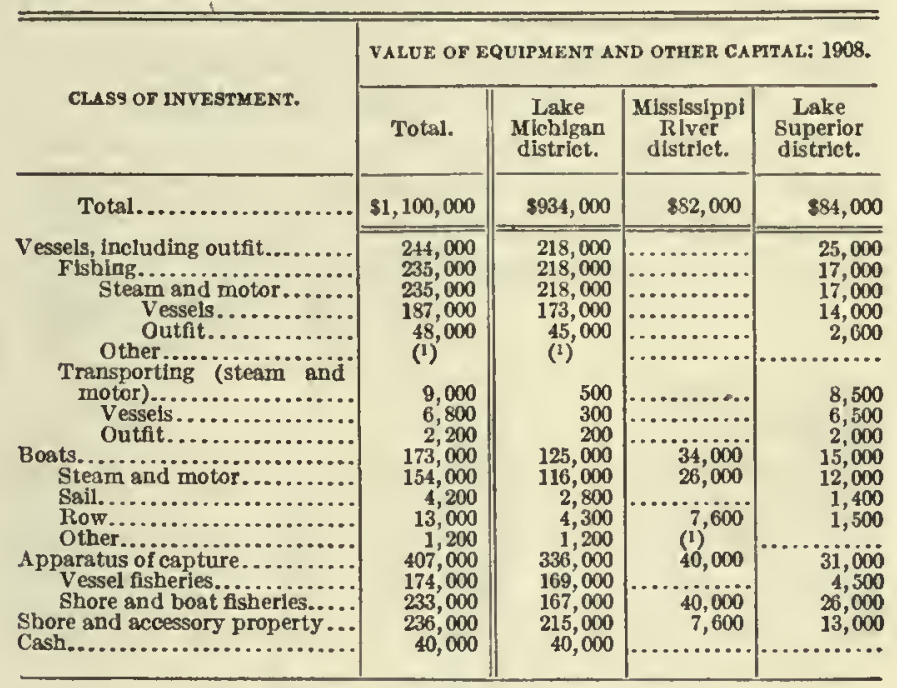

1 Less than $\$ 100$.

The value of vessels and boats, including their outfit, and that of apparatus of capture each formed something over 37 per cent of the total investment, while the value of shore and accessory property, combined with the cash reported, amounted to 25 per cent. Of the value of shore and accessory property $\$ 126,000$ was reported for shore and boat fisheries and $\$ 110,000$ for vessel fisheries and transporting vessels. The amount of cash invested in the shore and boat fisheries was $\$ 20,000$ and that in the vessel fisheries $\$ 19,000$. The shore and boat fisheries were therefore credited with $\$ 553,000$, vessel fisheries with $\$ 533,000$, and transporting vessels with $\$ 14,000$. The investment in the Lake Michigan fisheries represented 85 per cent of the total for the state and comprised $\$ 427,000$ invested in shore and boat fisheries, $\$ 507,000$ in vessel fisheries, and $\$ 500$ in transporting vessels. Of the Lake Superior investment, which formed less than 8 per cent of the total for the state, $\$ 54,000$ pertained to shore and boat fisheries, $\$ 21,000$ to vessel fisheries, and $\$ 8,500$ to transporting vessels.

Nearly one-half of the investment in the Mississippi River district represented the value of apparatus of capture.

The following tabular statement gives statistics concerning the number and tonnage of vessels and the number of boats:

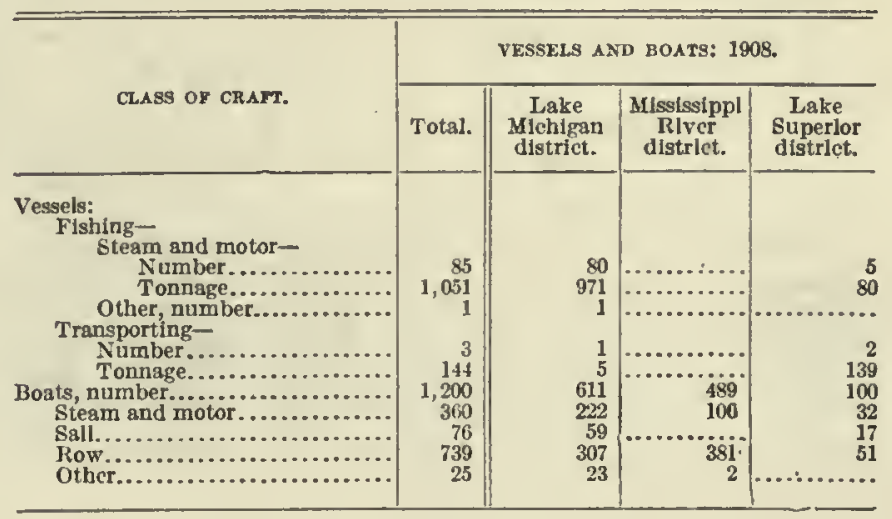


Statistics as to the number of the more important kinds of apparatus of capture are given in the following tabular statement:

\begin{tabular}{|c|c|c|c|c|c|c|}
\hline \multirow{3}{*}{ KIND. } & \multicolumn{6}{|c|}{ APPARATUS OF CAPTURE: 1908.} \\
\hline & \multirow[b]{2}{*}{ Totai. } & \multicolumn{3}{|c|}{ Distributed by districts. } & \multicolumn{2}{|c|}{$\begin{array}{l}\text { Distributed } \\
\text { hy class of } \\
\text { fisherles. }\end{array}$} \\
\hline & & $\begin{array}{l}\text { Lake } \\
\text { Michl- } \\
\text { gan } \\
\text { dis- } \\
\text { trict. }\end{array}$ & $\begin{array}{l}\text { Missis- } \\
\text { sippl } \\
\text { River } \\
\text { dis- } \\
\text { trlet. }\end{array}$ & $\begin{array}{l}\text { Lake } \\
\text { Supe- } \\
\text { rtor } \\
\text { dis- } \\
\text { trict. }\end{array}$ & $\begin{array}{l}\text { Vessel } \\
\text { fish- } \\
\text { ertes. }\end{array}$ & $\begin{array}{l}\text { Shore } \\
\text { and } \\
\text { bost } \\
\text { fish- } \\
\text { erles. }\end{array}$ \\
\hline Crawfish pots.................. & 13,290 & 13,290 & & & 2,000 & 11,290 \\
\hline 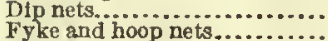 & $\begin{array}{r}5 \\
2,719\end{array}$ & 2,172 & $\ddot{5} \ddot{4} 7$ & & 536 & $\begin{array}{r}5 \\
2,183\end{array}$ \\
\hline 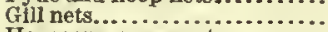 & 30,291 & 28,773 & 425 & 1,093 & 19,070 & 11,221 \\
\hline Harpoons, spears, etc........... & 104 & & 97 & & & \\
\hline Mink and minskrat traps....... & 1,200 & 530 & 670 & $\ldots \ldots$ & a........ & 1,200 \\
\hline Pound and trap nets........... & 619 & 267 & 267 & 85 & 6 & 613 \\
\hline 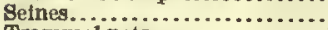 & 384 & 253 & 128 & 3 & 240 & 144 \\
\hline Trammel vets................... & 31 & 7 & 24 & & & 31 \\
\hline
\end{tabular}

All the vessels and all but a small number of the boats were power craft. Of the more important kinds of apparatus of capture, gill nets were most numerous, and were used principally in the vessel fisheries.

Products, by species. - Table 1, on page 274, gives statistics relating to products, by species and by apparatus of capture. Six species-lake trout, herring, buffalo fish, whitefish, yellow perch, and German carp-contributed 84 per cent of the total product for the state, while their value formed 87 per cent of the total value.

Products, by fishing grounds.-Tables 2, 3, and 4, on pages 275 and 276 , give the products, respectively, of the Lake Michigan, the Mississippi River, and the Lake Superior districts. The latter supplied only 5 per cent of the total value of the fishery product of the state. Of the seven species which made up the product of this district, lake herring and trout contributed, respectively, 53 per cent and 40 per cent of the value of the total catch from the district.

Products, by class of fisheries.-Tables 5 and 6, on pages 276 and 277 , give, by species and by apparatus of capture, statistics as to the products of the vessel and the shore and boat fisheries of the state. Similar statistics are given for the vessel fisheries, respectively, of the Lake Michigan and the Lake Superior districts, in Tables 7 and 9 ; and for the shore and boat fisheries of the respective districts, in Tables 8 and 10. The fisheries of the Mississippi River district were all of the shore and boat class.

\begin{tabular}{|c|c|c|c|}
\hline \multirow[b]{2}{*}{ SPECIES. } & \multicolumn{3}{|c|}{ VALUE OF PRODUCTS: 1908.} \\
\hline & Total. & $\begin{array}{c}\text { Vessel } \\
\text { fisheries. }\end{array}$ & $\begin{array}{l}\text { Shore and } \\
\text { boat } \\
\text { fisheries. }\end{array}$ \\
\hline Total....... & $\$ 1,067,000$ & $\$ 425,000$ & 8642,000 \\
\hline 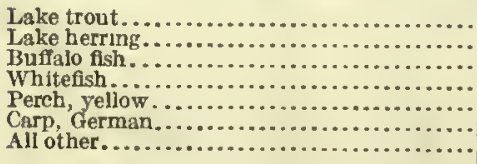 & $\begin{array}{r}340,000 \\
322,000 \\
103,000 \\
56,000 \\
55,000 \\
52,000 \\
137,000\end{array}$ & $\begin{array}{r}200,000 \\
173,000 \\
26,000 \\
15,000 \\
800 \\
11,000\end{array}$ & $\begin{array}{r}140,000 \\
150,000 \\
103,000 \\
30,000 \\
39,000 \\
52,000 \\
127,000\end{array}$ \\
\hline
\end{tabular}

The value of the catch made in the vessel fisheries and that of the catch made in the shore and boat fisheries formed 40 per cent and 60 per cent, respectively, of the value of the total state product. In the product of the vessel fisheries lake trout was the leading species with respect to value and lake herring ranked second, while in the catch reported for the shore and boat fishcries the order of these species was reversed.

Products, by apparatus of capture.--The following tabular statement shows the distribution of the total value of products according to apparatus of capture, for the state, for each class of fisheries, and for the three districts:

\begin{tabular}{|c|c|c|c|c|c|c|}
\hline \multirow{3}{*}{ KIND OP APPARATUS. } & \multicolumn{6}{|c|}{ VALUE OF PRODUCTS: 1908.} \\
\hline & \multirow[b]{2}{*}{ Total. } & \multicolumn{3}{|c|}{ Distributed by districts. } & \multicolumn{2}{|c|}{$\begin{array}{l}\text { Distributed by } \\
\text { class of fisheries. }\end{array}$} \\
\hline & & $\begin{array}{l}\text { Lake } \\
\text { Michl- } \\
\text { gan dis- } \\
\text { trict. }\end{array}$ & $\begin{array}{c}\text { Missis- } \\
\text { sippi } \\
\text { River } \\
\text { district. }\end{array}$ & $\begin{array}{c}\text { Lake } \\
\text { Supe- } \\
\text { rior } \\
\text { district. }\end{array}$ & $\begin{array}{c}\text { Vessel } \\
\text { flsheries. }\end{array}$ & $\begin{array}{l}\text { Shore } \\
\text { and } \\
\text { boat } \\
\text { fish- } \\
\text { eries. }\end{array}$ \\
\hline Total............ & $\$ 1,067,000$ & 8794,000 & $\$ 215,000$ & 858,000 & $\$ 425,000$ & $\$ 642,000$ \\
\hline 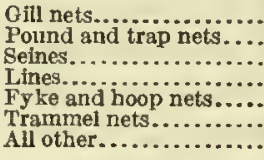 & $\begin{array}{r}533,000 \\
208,000 \\
143,000 \\
92,000 \\
54,000 \\
7,200 \\
31,000\end{array}$ & $\begin{array}{r}494,000 \\
142,000 \\
4,200 \\
85,000 \\
49,000 \\
3,500 \\
17,000\end{array}$ & $\begin{array}{r}7,700 \\
42,000 \\
138,000 \\
4,800 \\
4,500 \\
3,700 \\
14,000\end{array}$ & $\begin{array}{r}32,000 \\
24,000 \\
600 \\
2,400 \\
\cdots \ldots . . \\
\cdots \ldots . . \\
\cdots\end{array}$ & $\begin{array}{r}349,000 \\
6,000 \\
1,300 \\
57,000 \\
6,800 \\
\ldots ., \ldots\end{array}$ & $\begin{array}{r}184,000 \\
202,000 \\
141,000 \\
35,000 \\
47,000 \\
7,200 \\
26,000\end{array}$ \\
\hline
\end{tabular}

Lake trout.-This species, which contributed 32 per cent of the total value of the fishery products of the state, was taken wholly in the lakes, 93 per cent of the quantity reported coming from Lake Michigan. Statistics concerning the catch as reported for the state in previous years are as follows:

\begin{tabular}{|c|c|c|}
\hline ( & \multicolumn{2}{|c|}{ LAEE-TROUT PRONUCT. } \\
\hline TEAR. & $\begin{array}{l}\text { Quantity } \\
\text { (pounds). }\end{array}$ & Value. \\
\hline 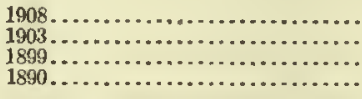 & $\begin{array}{l}4,710,000 \\
5,561,000 \\
3,514,000 \\
3,820,000\end{array}$ & $\begin{array}{r}8340,000 \\
262,000 \\
155,000 \\
176,000\end{array}$ \\
\hline
\end{tabular}

Lake herring.-The value of the lake-herring product in 1908 was nearly 40 per cent greater than that of the largest catch previously reported--the catch of 1899 -though the weight of the latter was greater by 343,000 pounds. The following tabular statement shows the quantity and value of the catch as reported at the various canvasses:

\begin{tabular}{|c|c|c|c|c|}
\hline & \multirow{2}{*}{ YEAR. } & \multirow[b]{2}{*}{. } & \multicolumn{2}{|c|}{$\begin{array}{l}\text { LAKE-HERRING } \\
\text { PEODUCT. }\end{array}$} \\
\hline & & & $\begin{array}{l}\text { Quantity } \\
\text { (pounds). }\end{array}$ & Value. \\
\hline $\begin{array}{l}1908 \ldots \ldots \ldots \ldots \ldots \\
1903 \ldots \ldots \ldots \ldots \ldots \ldots \\
1899 \ldots \ldots \ldots \ldots \ldots \ldots \\
1890 \ldots \ldots \ldots \ldots\end{array}$ & & & $\begin{array}{r}12,124,000 \\
11,801,000 \\
12,467,000 \\
3,798,000\end{array}$ & $\begin{array}{r}\$ 322,000 \\
232,000 \\
236,000 \\
58,000\end{array}$ \\
\hline
\end{tabular}


Buffalo fish. - The buffalo-fish product, all of which was from the Mississippi River district, ranked third in value among the fishery products of the statc. Over 80 per cent of the catch was taken with seines, while pound and trap nets took most of the remainder. The statistics concerning the catch for certain years for which figures are available are as follows:

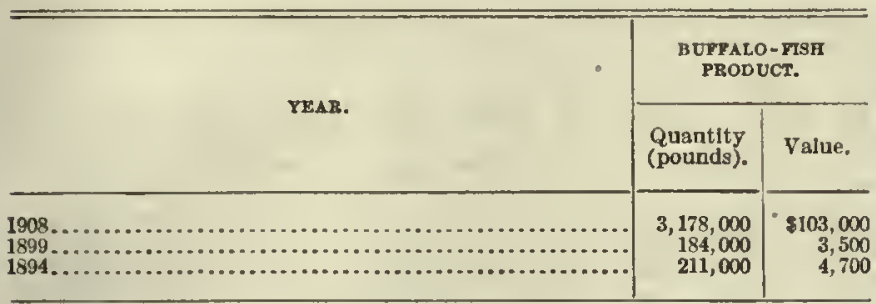

Whitefish.-These fish, which wero taken wholly from the lake waters, ranked fourth among the fishery products of the stato in value, contributing 10 per cent of the value of the total product and 10 per cent of the total weight. Besides the common whitefish, which was sold fresh, sinoked, and salted, three other species were liandled, namely, the blucfin, the longjaw, and the Menominee, the last two being sold in both a fresh and a prepared condition. Whitefish ranked third in value among the products of Lake Superior and fourth among those of Lake Michigan. Over 20 per cent of the total value reported for the species represented product taken in the former district. The whitefish yield was much less in 1908 than in 1890, but considerably more than in the years subsequent to 1890 , as shown by the following tabular statement:

\begin{tabular}{|c|c|c|}
\hline \multirow{2}{*}{ YEAR. } & \multicolumn{2}{|c|}{ WHTEFISH PRODUCT. } \\
\hline & $\begin{array}{l}\text { Quantity } \\
\text { (pounds). }\end{array}$ & Value. \\
\hline 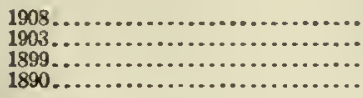 & $\begin{array}{r}1,274,000 \\
1,047,000 \\
633,000 \\
2,188,000\end{array}$ & $\begin{array}{l}\$ 56,000 \\
36,000 \\
20,000 \\
84,000\end{array}$ \\
\hline
\end{tabular}

$76786^{\circ}-11-18$
Yellow perch.-The yellow perch reported had a value nearly equal to that of whitefish and represented 5 per cent of the total value of products for the state. In Lake Michigan, where over 99 per cent of the catch was taken, this fish composed 12 per cent of the total product. Statistics for the entire state are not available for a series of ycars, but as practically the entire catch of this species was taken in Lake Michigan, comparativo figures for this lake are given in the following tabular statement:

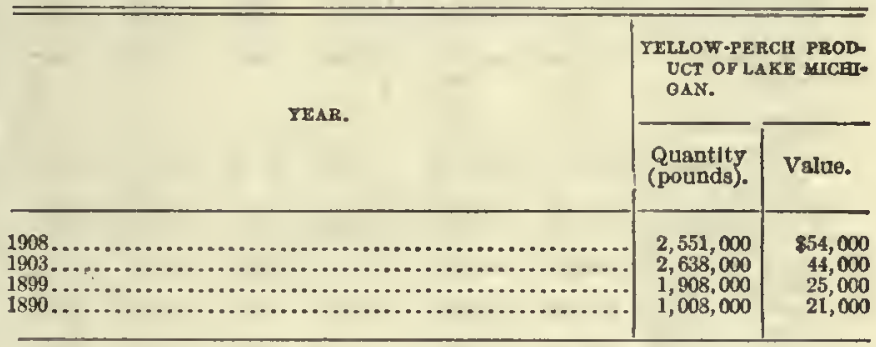

German carp.--This species ranked sixth among the leading species, contributing 5 per cent of the total value. Of the total catch of this fish, 85 per cent was taken in the Mississippi River district and the remainder in Lake Michigan. The carp product has increased almost as much as has that of buffalo fish, and the two combined not only account for the gain in the Mississippi River product since 1890 , but counterbalance the decrease in the catch of certain other species, notably wall-eyed pike and sturgeon. The comparative summary given below is for the Mississippi River district, since statistics for that district only are available for the different years shown.

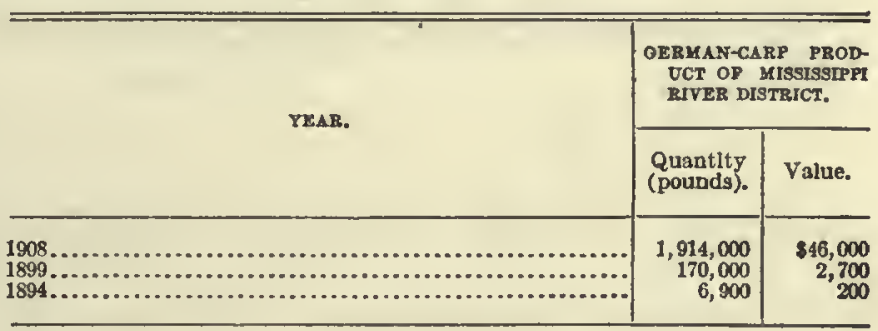


TABLE 1.-WISCONSIN-FISHERY PRODUCTS: 1908.

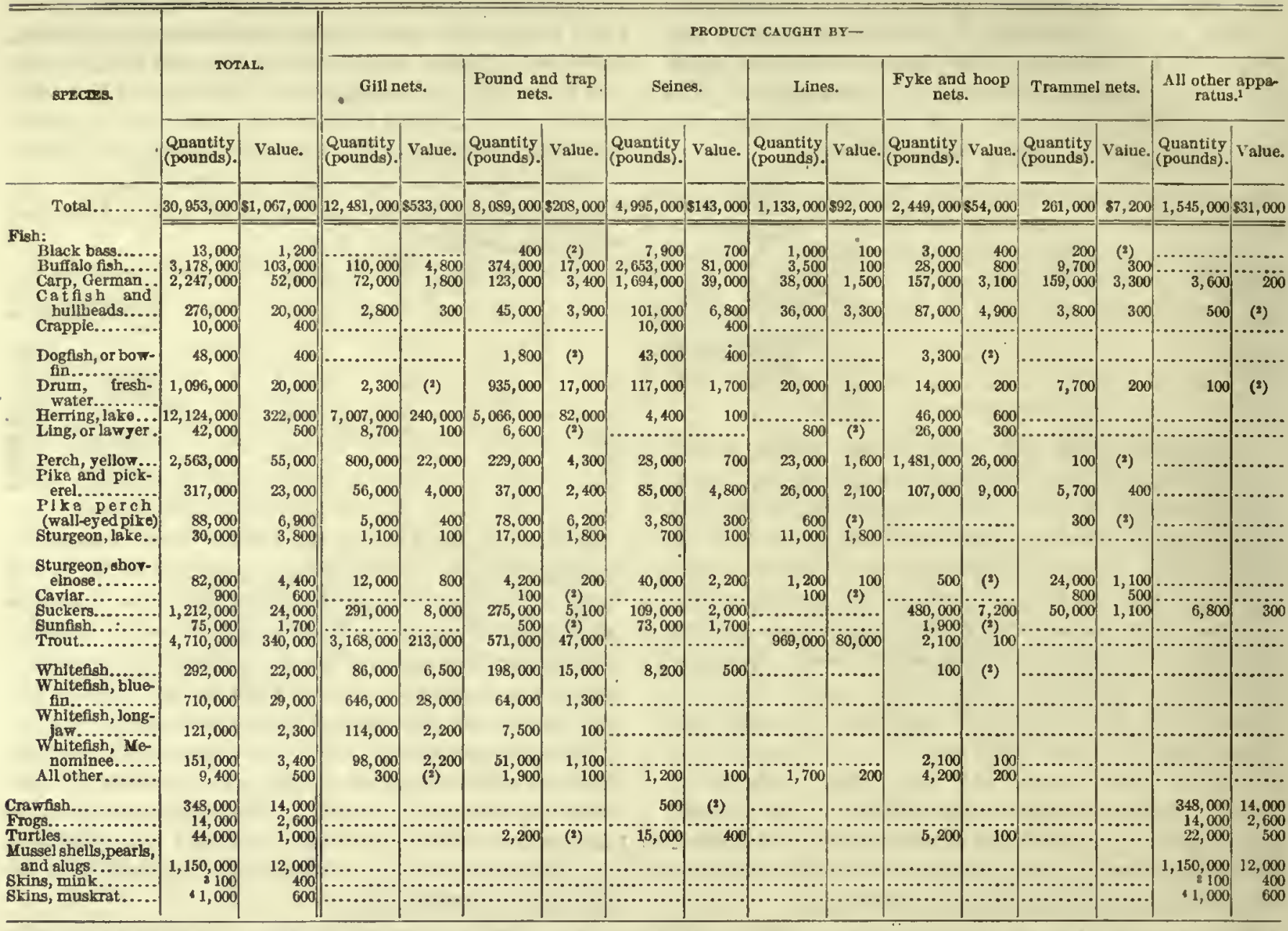

1 Includes apparatus, with catch, as follows: Crawflsh pots, 348,000 pounds, valued at $\$ 14,000 ;$ crowfoot dredges, $1,130,000$ pounds, valued at $\$ 12,000 ;$ mink and musk rat

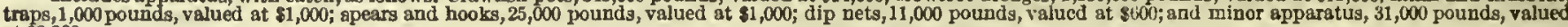
traps, $\$, 000$ 
FISHERIES, BY STATES.

TABLE 2.-WISCONSIN-FISHERY PRODUCTS OF LAKE MICHIGAN DISTRICT: 1908

\begin{tabular}{|c|c|c|c|c|c|c|c|c|c|c|c|c|c|c|}
\hline \multirow{3}{*}{ SPECIES. } & \multirow{2}{*}{\multicolumn{2}{|c|}{ - total. }} & \multicolumn{12}{|c|}{ PRONUCT CAUGUT BY- } \\
\hline & & & \multicolumn{2}{|c|}{ Gill nets. } & \multicolumn{2}{|c|}{$\begin{array}{l}\text { Pound and trap } \\
\text { nets. }\end{array}$} & \multicolumn{2}{|c|}{ ' Lines. } & \multicolumn{2}{|c|}{$\begin{array}{c}\text { Fyke and hoop } \\
\text { nets. }\end{array}$} & \multicolumn{2}{|c|}{ Selnes. } & \multicolumn{2}{|c|}{$\begin{array}{l}\text { All other appa- } \\
\text { ratus.1 }\end{array}$} \\
\hline & $\begin{array}{l}\text { Quantity } \\
\text { (pounds). }\end{array}$ & Value. & $\begin{array}{l}\text { Quantity } \\
\text { (pounds). }\end{array}$ & Value. & $\begin{array}{l}\text { Quantity } \\
\text { (pounds). }\end{array}$ & Value. & $\begin{array}{l}\text { Quantity. } \\
\text { (pounds). }\end{array}$ & Value. & $\begin{array}{l}\text { Quantity } \\
\text { (pounds). }\end{array}$ & Value. & $\begin{array}{l}\text { Quantity } \\
\text { (pounds). }\end{array}$ & Value. & $\begin{array}{l}\text { Quantity } \\
\text { (pounds). }\end{array}$ & Value. \\
\hline Total..... & $21,177,000$ & $\$ 794,000$ & $11,137,000$ & $\$ 494,000$ & $5,967,000$ & $\$ 142,000$ & $1,000,000$ & 385,000 & $2,326,000$ & $\$ 49,000$ & 208,000 & $\$ 4,200$ & 538,000 & $\$ 21,000$ \\
\hline $\begin{array}{l}\text { Fish: } \\
\text { Black bass.................. } \\
\text { Carp, German, fresh ....... } \\
\text { Carp, German, smoked.... } \\
\text { Catish and bullheads...... } \\
\text { Drum, or sheepshead...... }\end{array}$ & $\begin{array}{r}4,500 \\
328,000 \\
4,500 \\
77,000 \\
26,000\end{array}$ & $\begin{array}{r}500 \\
5,700 \\
700 \\
3,400 \\
900\end{array}$ & $\begin{array}{r}8,000 \\
100 \\
300\end{array}$ & $\left.{ }^{13}{ }^{3}\right)^{3}$ & 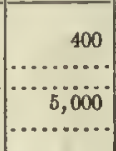 & $\begin{array}{c}(2) \\
\cdots \cdots \\
100\end{array}$ & $\begin{array}{r}1,000 \\
500 \\
4,500 \\
800 \\
\mathbf{5}, 000\end{array}$ & $\begin{array}{l}100 \\
(8) \\
700 \\
100 \\
700\end{array}$ & \begin{tabular}{r}
3,000 \\
96,000 \\
\hdashline 67,000 \\
11,000
\end{tabular} & $\begin{array}{r}100 \\
1,700 \\
3, \ldots 00 \\
3,00\end{array}$ & $\begin{array}{l}\left({ }^{2}\right) \\
84,000 \\
\cdots, \ldots 00 \\
2,000 \\
9,600\end{array}$ & $\ddot{100}$ & $\begin{array}{r}140,000 \\
1,6000 \\
200\end{array}$ & $\ddot{2}, 900$ \\
\hline $\begin{array}{l}\text { Herring, lake, fresh......... } \\
\text { Herring, lake, salted....... } \\
\text { Herring, lake, smoked...... } \\
\text { Ling, or lawyer.............. } \\
\text { Muskallunge.............. }\end{array}$ & $\begin{array}{r}6,911,000 \\
327,000 \\
3,921,000 \\
12,000 \\
1,900\end{array}$ & $\begin{array}{r}236,000 \\
5,200 \\
67,000 \\
500 \\
200\end{array}$ & $\begin{array}{r}5,991,000 \\
10,000 \\
291,000 \\
8,700 \\
200\end{array}$ & $\begin{array}{r}219,000 \\
200 \\
9,900 \\
100 \\
(2)\end{array}$ & $\begin{array}{r}873,000 \\
317,000 \\
3,630,000 \\
6,600 \\
\cdots\end{array}$ & $\begin{array}{r}16,000 \\
5,000 \\
57,000 \\
(2)\end{array}$ & $\begin{array}{l}\ddot{800} \\
200\end{array}$ & (3) & $\begin{array}{r}46,000 \\
\cdots \ldots \ldots \\
26,000 \\
1,100\end{array}$ & $\begin{array}{r}300 \\
100\end{array}$ & 500 & . & 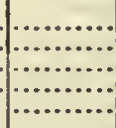 & $\begin{array}{l}\cdots \cdots \cdots \\
\cdots \cdots \cdots \\
\cdots \cdots \cdots \\
\cdots \cdots \cdots\end{array}$ \\
\hline $\begin{array}{l}\text { Perch, yellow.............. } \\
\text { Pike and pickerel........ } \\
\text { Pike perch (wall-eyed pike) } \\
\text { Rock hass } \\
\text { Sturgeon, like, fresh.......... }\end{array}$ & $\begin{array}{r}2,551,000 \\
234,000 \\
4,000 \\
4,800 \\
12,000\end{array}$ & $\begin{array}{r}54,000 \\
18,000 \\
300 \\
200 \\
. \quad 2,000\end{array}$ & $\begin{array}{r}800,000 \\
56,000 \\
4,000 \\
100 \\
\ldots\end{array}$ & $\begin{array}{c}22,000 \\
4,000 \\
300 \\
(?) \\
\cdots\end{array}$ & $\begin{array}{r}229,000 \\
22,000 \\
\quad, 7000 \\
5,000\end{array}$ & $\begin{array}{r}4,000 \\
1,500 \\
\cdots \\
100 \\
700\end{array}$ & $\begin{array}{r}23,000 \\
26,000 \\
\cdots, \ldots \ldots \\
7,0,000\end{array}$ & $\begin{array}{r}1,600 \\
2,100 \\
2\end{array}$ & $\begin{array}{r}1,481,000 \\
104,000 \\
3,000 \\
\ldots \ldots \ldots\end{array}$ & $\begin{array}{r}26,000 \\
8,800 \\
\cdots \\
\cdots\end{array}$ & $\begin{array}{r}16,000 \\
21 ; 000 \\
\cdots \cdots \cdots\end{array}$ & 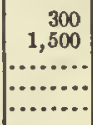 & $\begin{array}{r}100 \\
\mathbf{5}, 000 \\
\cdots \cdots \\
\cdots \cdots\end{array}$ & $\begin{array}{r}\left.{ }^{2}\right)_{300} \\
\cdots \cdots \\
\cdots \cdots\end{array}$ \\
\hline $\begin{array}{l}\text { Sturgeon, lake, smoked..... } \\
\text { Suckers, fresh............... } \\
\text { Suckers, salted............. } \\
\text { Trout, fresh............... } \\
\text { Trout, salted............ }\end{array}$ & $\begin{array}{r}2,500 \\
987,000 \\
64,000 \\
4,302,000 \\
26,000\end{array}$ & $\begin{array}{r}500 \\
20,000 \\
800 \\
316,000 \\
900\end{array}$ & $\begin{array}{r}279,000 \\
3,100 \\
2,895,000 \\
12,000\end{array}$ & $\begin{array}{c}7,800 \\
(2) \\
197,000 \\
500\end{array}$ & $\begin{array}{r}13 i, 000 \\
53,000 \\
476,000 \\
14,000\end{array}$ & $\begin{array}{r}2,900 \\
72,000 \\
400\end{array}$ & $\begin{array}{r}2,000 \\
\cdots \ldots, \ldots \\
929,000 \\
\cdots \ldots \ldots\end{array}$ & $\begin{array}{r}500 \\
78,000\end{array}$ & $\begin{array}{r}474,000 \\
5,800 \\
2,100\end{array}$ & $\begin{array}{r}7,200 \\
100 \\
100 \\
\cdots\end{array}$ & $\begin{array}{r}\begin{array}{r}72,0000 \\
2,300\end{array} \\
\ldots \ldots \ldots \ldots \\
\cdots\end{array}$ & $\dddot{1}, 100$ & $\begin{array}{r}30,000 \\
\cdots \cdots \\
\cdots \cdots\end{array}$ & $\begin{array}{l}\dddot{700} \\
\cdots \\
\cdots\end{array}$ \\
\hline 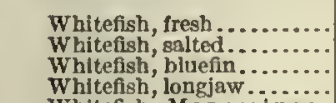 & $\begin{array}{r}113,000 \\
3,900 \\
707,000 \\
8,000\end{array}$ & $\begin{array}{r}11,000 \\
200 \\
29,000 \\
500\end{array}$ & $\begin{array}{r}29,000 \\
200 \\
643,000 \\
8,000\end{array}$ & $\begin{array}{r}3,000 \\
\left(^{2}\right) \\
28,000 \\
500\end{array}$ & $\begin{array}{r}85,000 \\
3,700 \\
64,000 \\
6\end{array}$ & $\begin{array}{r}7,900 \\
200 \\
1,300 \\
\cdots\end{array}$ & & & $\begin{array}{c}100 \\
\cdots\end{array}$ & (3) & $\cdots$ & & & $\begin{array}{l}\cdots \\
\cdots \\
\cdots \\
\cdots\end{array}$ \\
\hline 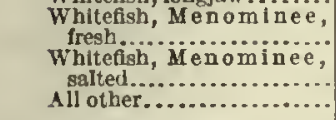 & $\begin{array}{r}90,000 \\
60,000 \\
3,500\end{array}$ & $\begin{array}{r}1,100 \\
100\end{array}$ & $\begin{array}{r}68,000 \\
30,000\end{array}$ & 1,600 & $\begin{array}{r}20,000 \\
30,000 \\
300\end{array}$ & $(2)$ & & & 2,100 & (2) & & & & \\
\hline 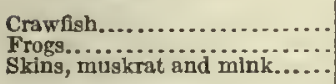 & $\begin{array}{r}348,000 \\
13,000 \\
i 500\end{array}$ & $\begin{array}{r}11,000 \\
2,400 \\
200\end{array}$ & & & & & & & & & .500 & $\begin{array}{l}\text { (2) } \\
\cdots\end{array}$ & $\begin{array}{r}348,000 \\
13,000 \\
1500\end{array}$ & $\begin{array}{r}14,000 \\
2,100 \\
200\end{array}$ \\
\hline
\end{tabular}

1 Includes apparatus, with catch, as follows: Crawfish pots, 348,000 pounds, valued at $\$ 14,000 ;$ trammel nets, 166,000 pounds, valued at $\$ 3,500$; dip nets, 11,000 pounds.

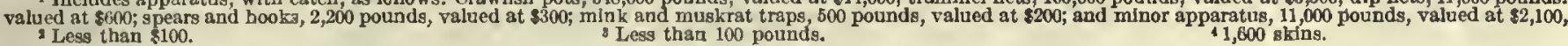

TABLE 3.-WISCONSIN-FISHERY PRODUCTS OF MISSISSIPPI RIVER DISTRICT: ${ }^{1} 1908$.

\begin{tabular}{|c|c|c|c|c|c|c|c|c|c|c|c|c|c|c|}
\hline \multirow{3}{*}{ SPECIES. } & \multirow{2}{*}{\multicolumn{2}{|c|}{ TOTAL. }} & \multicolumn{12}{|c|}{ PRODUCT CAUGHT BY- } \\
\hline & & & \multicolumn{2}{|c|}{ Selnes. } & \multicolumn{2}{|c|}{$\begin{array}{l}\text { Pound and trap } \\
\text { nets. }\end{array}$} & \multicolumn{2}{|c|}{ Glll nets. } & \multicolumn{2}{|c|}{ Lines. } & \multicolumn{2}{|c|}{$\begin{array}{c}\text { Fyke and hoop } \\
\text { nets. }\end{array}$} & \multicolumn{2}{|c|}{$\begin{array}{l}\text { All other appa- } \\
\text { ratus., }\end{array}$} \\
\hline & $\begin{array}{l}\text { Quantity } \\
\text { (pounds). }\end{array}$ & Value. & $\begin{array}{l}\text { Quantity } \\
\text { (pounds). }\end{array}$ & Value. & $\begin{array}{r}\text { Quantity } \\
\text { (pounds). }\end{array}$ & Value. & $\begin{array}{l}\text { Quantity } \\
\text { (pounds). }\end{array}$ & Valne. & $\begin{array}{l}\text { Quantity } \\
\text { (pounds). }\end{array}$ & Value. & $\begin{array}{l}\text { Quantity } \\
\text { (pounds). }\end{array}$ & Value. & $\begin{array}{l}\text { Quantity } \\
\text { (pounds). }\end{array}$ & Value. \\
\hline Total............. & $7,958,000$ & $\$ 215,000$ & $4,773,000$ & $\$ 138,000$ & $1,509,000$ & $\$ 42,000$ & 192,000 & $\$ 7,700$ & 92,000 & $\$ 4,800$ & 123,000 & $\$ 4,500$ & $1,268,000$ & $\$ 17,000$ \\
\hline 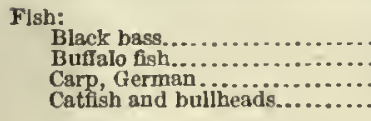 & $\begin{array}{r}8,100 \\
3,178,000 \\
1,914,000 \\
200,000\end{array}$ & $\begin{array}{r}700 \\
103,000 \\
46,000 \\
16,000\end{array}$ & $\begin{array}{r}7,900 \\
2,653,000 \\
1,611,000 \\
99,000\end{array}$ & $\begin{array}{r}81,000 \\
38,000 \\
6,700\end{array}$ & $\begin{array}{r}374,000 \\
123,000 \\
40,000\end{array}$ & $\begin{array}{r}17,000 \\
3,400 \\
3,800\end{array}$ & $\begin{array}{r}110,000 \\
64,000 \\
2,700\end{array}$ & $\begin{array}{r}4,800 \\
1,700 \\
300\end{array}$ & $\begin{array}{r}3,500 \\
33,000 \\
36,000\end{array}$ & $\begin{array}{r}100 \\
700 \\
3,300\end{array}$ & $\begin{array}{l}28,000 \\
61,000 \\
19,000\end{array}$ & $\begin{array}{r}800 \\
1,400 \\
1,900\end{array}$ & $\begin{array}{r}200 \\
9,700 \\
22,000 \\
2,800\end{array}$ & $\begin{array}{l}\text { (2) } 300 \\
600 \\
300\end{array}$ \\
\hline 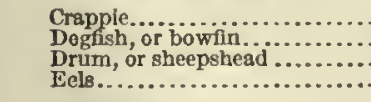 & $\begin{array}{r}10,000 \\
17,000 \\
1,070,000 \\
1,600\end{array}$ & $\begin{array}{r}400 \\
400 \\
19,000 \\
100\end{array}$ & $\begin{array}{r}10,000 \\
43,000 \\
107,000 \\
\ldots\end{array}$ & $\begin{array}{r}400 \\
400 \\
1,700 \\
\ldots \ldots\end{array}$ & $\mid \begin{array}{r}i, 800 \\
935,000 \\
\cdots\end{array}$ & $\begin{array}{c}(8)^{(3)} \\
17,000 \\
\ldots \ldots \ldots\end{array}$ & $\begin{array}{r}2,000 \\
\cdots \ldots \ldots \ldots\end{array}$ & $\ldots \ldots$ & $\begin{array}{r}15,000 \\
1,500\end{array}$ & $\begin{array}{l}300 \\
100\end{array}$ & $\begin{array}{r}2,000 \\
3,000 \\
100\end{array}$ & (8) & $\begin{array}{r}7,800 \\
\cdots\end{array}$ & $\begin{array}{r} \\
200 \\
\cdots\end{array}$ \\
\hline 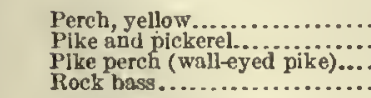 & $\begin{array}{r}12,000 \\
83,000 \\
4,700 \\
800\end{array}$ & $\begin{array}{l}400 \\
4,400 \\
400 \\
()^{3}\end{array}$ & $\begin{array}{r}12,000 \\
64,000 \\
3,800 \\
800\end{array}$ & $\begin{array}{l}400 \\
3,300 \\
300 \\
(3)\end{array}$ & $\begin{array}{r}100 \\
15,000 \\
\cdots \cdots\end{array}$ & $\begin{array}{c}{ }^{(8)} \\
800 \\
. . . .\end{array}$ & 300 & $(3)^{\cdots}$ & 600 & (3) & $\left|\begin{array}{r}\cdots, 000 \\
\cdots \cdots\end{array}\right|$ & $\begin{array}{r} \\
2000 \\
\ldots \ldots \ldots\end{array}$ & $\begin{array}{c}800 \\
300 \\
\ldots . . .\end{array}$ & $\begin{array}{l}(x) \\
(x) \\
\cdots . . .\end{array}$ \\
\hline 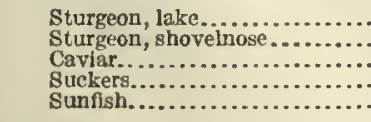 & $\begin{array}{r}6,300 \\
82,000 \\
900 \\
72,000 \\
73,000\end{array}$ & $\begin{array}{r}500 \\
1,400 \\
600 \\
1,500 \\
1,700\end{array}$ & $\begin{array}{r}700 \\
40,000 \\
35,000 \\
73,000\end{array}$ & $\begin{array}{r}100 \\
2,200 \\
1,700 \\
1,700\end{array}$ & $\begin{array}{r}2,600 \\
4,200 \\
11,000 \\
500\end{array}$ & $\begin{array}{l}300 \\
200 \\
\left({ }^{8}\right) \\
200 \\
(8)\end{array}$ & $\begin{array}{r}1,100 \\
12,000 \\
\cdots \\
\cdots\end{array}$ & $\begin{array}{l}100 \\
800\end{array}$ & $\begin{array}{r}1,900 \\
1,200 \\
100 \\
\cdots\end{array}$ & $\begin{array}{c}100 \\
100 \\
(8) \\
0\end{array}$ & 400 & 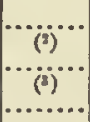 & $\begin{array}{r}24,000 \\
800 \\
26,000\end{array}$ & $\begin{array}{r}\because, 100 \\
500 \\
700\end{array}$ \\
\hline 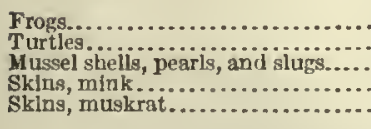 & $\begin{array}{r}1,200 \\
44,000 \\
1,150,000 \\
4100 \\
500\end{array}$ & $\begin{array}{r}200 \\
1,000 \\
12,000 \\
400 \\
100\end{array}$ & 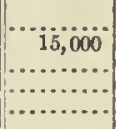 & $\begin{array}{r}400 \\
\cdots\end{array}$ & $\ddot{2}, 200$ & (i) & & & & $\begin{array}{ll}\ldots \ldots \ldots \\
\ldots \ldots \ldots \\
\ldots \ldots \ldots \\
\ldots \ldots \ldots\end{array}$ & $\mid \begin{array}{r}5,200 \\
\cdots \cdots\end{array}$ & $\begin{array}{l}\cdots \cdots \\
\cdots \cdots \\
\cdots \cdots\end{array}$ & $\begin{array}{r}1,200 \\
22,000 \\
1,150,000 \\
100 \\
8500\end{array}$ & $\begin{array}{r}200 \\
500 \\
12,000 \\
400 \\
400\end{array}$ \\
\hline
\end{tabular}

1. All taken in shore and hoat fisherles. traps, 500 pounds, valued at $\$ 700$; spears and books, 23,000 pounds, valued at $\$ 700$; and minor apparatus, 20,000 pounds, valued at $\$ 200$.
$\$ 100$ sklns. 
TABLE 4.-WISCONSIN-FISHERY PRODUCTS OF LAKE SUPERIOR DISTRICT: 1908.

\begin{tabular}{|c|c|c|c|c|c|c|c|c|}
\hline \multirow{3}{*}{ \&PECES. } & \multirow{2}{*}{\multicolumn{2}{|c|}{ Totak. }} & \multicolumn{6}{|c|}{ PRODUCT CAUGHT BY- } \\
\hline & & & \multicolumn{2}{|c|}{ Glll nets. } & \multicolumn{2}{|c|}{ Pound and trap nets. } & \multicolumn{2}{|c|}{ All other apparatus.t } \\
\hline & $\begin{array}{l}\text { Quantlty } \\
\text { (pounds). }\end{array}$ & Value. & $\begin{array}{l}\text { Quantity } \\
\text { (pounds). }\end{array}$ & Value. & $\begin{array}{l}\text { Quantity } \\
\text { (pounds). }\end{array}$ & Value. & $\begin{array}{l}\text { Quantity } \\
\text { (pounds). }\end{array}$ & Value. \\
\hline 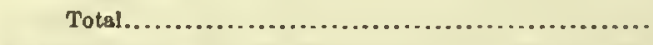 & $1,817,000$ & $\$ 58,000$ & $1,152,000$ & 832,000 & 612,000 & $\$ 24,000$ & 53,000 & 83,000 \\
\hline 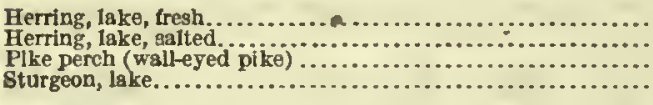 & $\begin{array}{r}135,000 \\
830,000 \\
79,000 \\
9,400\end{array}$ & $\begin{array}{r}1,100 \\
13,000 \\
6,200 \\
800\end{array}$ & $\begin{array}{l}114,000 \\
602,000 \\
1,000 \\
(8)\end{array}$ & $\begin{array}{r}900 \\
9,800 \\
100\end{array}$ & $\begin{array}{r}21,000 \\
224,000 \\
78,000 \\
9,400\end{array}$ & $\begin{array}{r}300 \\
3,300 \\
6,300 \\
800\end{array}$ & $\mid \cdots \ldots \ldots$ & …… \\
\hline 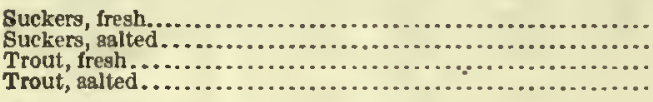 & $\begin{array}{r}30,000 \\
59,000 \\
373,000 \\
9,200\end{array}$ & $\begin{array}{r}500 \\
1,000 \\
23,000 \\
400\end{array}$ & $\begin{array}{r}8,300 \\
252,000 \\
9,000\end{array}$ & $\begin{array}{r}200 \\
15,000 \\
300\end{array}$ & $\begin{array}{r}30,000 \\
50,000 \\
81,000 \\
200\end{array}$ & $\begin{array}{r}500 \\
800 \\
5,000 \\
\left({ }^{2}\right)\end{array}$ & $\begin{array}{r}6000 \\
40,000\end{array}$ & $\begin{array}{r}\text { (j) } \\
2,400 \\
\ldots .\end{array}$ \\
\hline 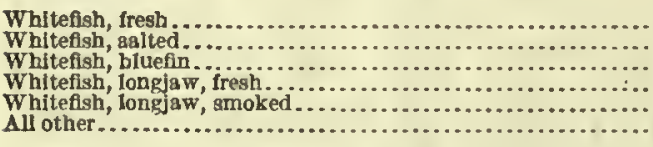 & $\begin{array}{r}168,000 \\
6,100 \\
3,300 \\
111,000 \\
1,900 \\
2,100\end{array}$ & $\begin{array}{r}10,000 \\
200 \\
100 \\
1,700 \\
100 \\
100\end{array}$ & $\begin{array}{r}57,000 \\
500 \\
3,300 \\
104,000 \\
1,900 \\
300\end{array}$ & $\begin{array}{l}3,500 \\
(3) \\
100 \\
1,600 \\
100\end{array}$ & $\begin{array}{r}104,000 \\
5,400 \\
7,500 \\
1,800\end{array}$ & $\begin{array}{r}6,400 \\
200 \\
1000 \\
1000\end{array}$ & $\begin{array}{r}8,000 \\
200\end{array}$ & 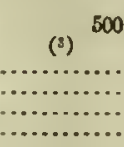 \\
\hline
\end{tabular}

Includes seines, with a certch of 13,000 pounds, valued at $\$ 600$; and lines, with a eatch of 40,000 pounds, valued at $\$ 2,400$. Less than 100 pounds.

Less than $\$ 100$.

TABLE 5.-WISCONSIN-PRODUCTS OF VESSEL FISHERIES: I908.

\begin{tabular}{|c|c|c|c|c|c|c|c|c|c|c|}
\hline \multirow{3}{*}{ SPECIES. } & \multirow{2}{*}{\multicolumn{2}{|c|}{ Total. }} & \multicolumn{8}{|c|}{ PRODUCT CAUGHT BY- } \\
\hline & & & \multicolumn{2}{|c|}{ Gil1 nots. } & \multicolumn{2}{|c|}{ Fyke and hoop nets. } & \multicolumn{2}{|c|}{ Pound and trap nets. } & \multicolumn{2}{|c|}{ All other apparatus. ${ }^{1}$} \\
\hline & $\begin{array}{l}\text { Quantity } \\
\text { (pounds). }\end{array}$ & Value. & $\begin{array}{l}\text { Quantity } \\
\text { (pounds). }\end{array}$ & Value. & $\begin{array}{l}\text { Quantlty } \\
\text { (pounds). }\end{array}$ & Valne. & $\begin{array}{l}\text { Quantity } \\
\text { (pounds). }\end{array}$ & Value. & $\begin{array}{l}\text { Quantity } \\
\text { (pounds). }\end{array}$ & Value. \\
\hline Total...... & $8,863,000$ & $\$ 25,000$ & $7,561,000$ & $\$ 349,000$ & 341,000 & $\$ 6,800$ & 99,000 & $\$ 6,000$ & 862,000 & 863,000 \\
\hline 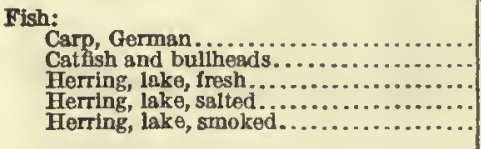 & $\begin{array}{r}61,000 \\
3,200 \\
4,129,000 \\
414,000 \\
59,000\end{array}$ & $\begin{array}{r}800 \\
100 \\
161,000 \\
6,900 \\
5,100\end{array}$ & $\begin{array}{r}8,000 \\
100 \\
4,094,000 \\
414,000 \\
54,000\end{array}$ & $\begin{array}{r}(100 \\
160,000 \\
6,900 \\
4,900\end{array}$ & $\begin{array}{r}8,600 \\
2,800 \\
200 \\
\cdots\end{array}$ & $\begin{array}{c}200 \\
100 \\
()^{2} \\
\cdots\end{array}$ & $\begin{array}{r}35,000 \\
1,000 \\
5,500\end{array}$ & ${ }_{300}^{600}$ & $\begin{array}{r}44,000 \\
200 \\
\cdots \cdots \cdots \\
\cdots \cdots\end{array}$ & 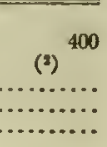 \\
\hline 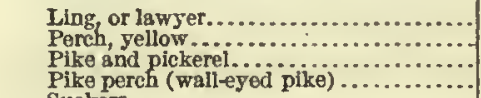 & $\begin{array}{r}10,000 \\
731,000 \\
51,000 \\
2,400\end{array}$ & $\begin{array}{r}100 \\
15,000 \\
3,600 \\
200\end{array}$ & $\begin{array}{r}5,000 \\
460,000 \\
34,000 \\
800\end{array}$ & $\begin{array}{r}100 \\
11,000 \\
2,300 \\
(2)\end{array}$ & $\begin{array}{r}4,900 \\
257,000 \\
15,000\end{array}$ & $\begin{array}{l}\left({ }^{1}\right) \\
4,500 \\
1,200 \\
\ldots, \ldots\end{array}$ & 1,600 & 100 & $\begin{array}{r}100 \\
14,000 \\
1,400 \\
\cdots \cdots\end{array}$ & $\begin{array}{l}\text { (3) } \\
300 \\
100\end{array}$ \\
\hline Suckers................................ & 91,000 & 1,700 & 20,000 & 500 & 51,000 & $700^{\circ}$ & 200 & $(2)$ & 20,000 & \\
\hline $\begin{array}{l}\text { Trout, fresh } \ldots \ldots \ldots \ldots \ldots \ldots \\
\text { Trout, saltod } . \ldots \ldots \ldots\end{array}$ & $\begin{array}{r}2,731,000 \\
4,500\end{array}$ & $\begin{array}{r}200,000 \\
200\end{array}$ & $\begin{array}{r}2,018,000 \\
4,600\end{array}$ & $\begin{array}{r}139,000 \\
200\end{array}$ & & & 43,000 & $\begin{array}{l}3,800 \\
\ldots \ldots\end{array}$ & 671,000 & 57,000 \\
\hline Whitefish & 24,000 & 2,400 & 12,000 & 1,200 & (n) & (n.......... & 12,000 & $\ddot{1}, \ddot{2} 000$ & 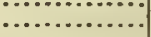 & (n........... \\
\hline 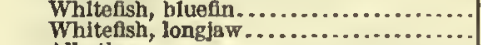 & $\begin{array}{r}388,000 \\
50,000\end{array}$ & $\begin{array}{r}22,000 \\
1,100\end{array}$ & $\begin{array}{r}388,000 \\
50,000\end{array}$ & $\begin{array}{r}22,000 \\
1,100\end{array}$ & a............. & & $\ldots \ldots \ldots$ & & an, & \\
\hline 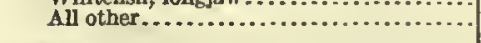 & 4,800 & 100 & 500 & (3) & 1,7000 & 100 & $\ddot{8000}$ & $(3)$ & i, 9000 & (2) ${ }^{\cdots}$ \\
\hline Crawfish....... & 109,000 & 4,700 & & & & & & & 109,000 & 4,700 \\
\hline
\end{tabular}

2 Includes apparatus, with catch, as follows: Lines, 671,000 pounds, valued at \$57,000; crawtsh pots, 109,000 pounds, valued at 24,700 ; and seines, 82,000 pounds, valued at $\$ 1,300$.

Less than $\$ 100$. 
FISHERIES, BY STATES.

TABLE 6.-WISCONSIN-PRODUCTS OF SHORE AND BOAT FISHERIES: 1908.

\begin{tabular}{|c|c|c|c|c|c|c|c|c|c|c|c|c|c|c|}
\hline \multirow{3}{*}{ BPECIES. } & \multirow{2}{*}{\multicolumn{2}{|c|}{ TOTAL. }} & \multicolumn{12}{|c|}{ PRODUCT CAUGnT BY- } \\
\hline & & & \multicolumn{2}{|c|}{$\begin{array}{l}\text { Pound and trap } \\
\text { nets. }\end{array}$} & \multicolumn{2}{|c|}{ Gill nets. } & \multicolumn{2}{|c|}{ Seines. } & \multicolumn{2}{|c|}{$\begin{array}{c}\text { Fylo and hoop } \\
\text { nets. }\end{array}$} & \multicolumn{2}{|c|}{ Llnes. } & \multicolumn{2}{|c|}{$\begin{array}{l}\text { All other appa- } \\
\text { ratus.t }\end{array}$} \\
\hline & $\begin{array}{l}\text { Quantity } \\
\text { (pounds). }\end{array}$ & Value. & $\begin{array}{l}\text { Quantity } \\
\text { (pounds). }\end{array}$ & Value. & $\begin{array}{l}\text { Quantity } \\
\text { (pounds). }\end{array}$ & Value. & $\begin{array}{l}\text { Quantity } \\
\text { (pounds). }\end{array}$ & Value. & $\begin{array}{l}\text { Quantity } \\
\text { (pounds). }\end{array}$ & Value. & $\begin{array}{l}\text { Quantity } \\
\text { (pounds). }\end{array}$ & Value. & $\begin{array}{l}\text { Quantity } \\
\text { (pounds). }\end{array}$ & Value. \\
\hline Total.. & $22,090,000$ & $\$ 642,000$ & $7,990,000$ & $\$ 202,000$ & $4,920,000$ & $\$ 184,000$ & $4,913,000$ & $\$ 141,000$ & $2,108,000$ & $\boldsymbol{H 7}, 000$ & 462,000 & $\$ 35,000$ & $1,697,000$ & $\$ 33,000$ \\
\hline $\begin{array}{l}\text { Fish: } \\
\text { Black bass.................. } \\
\text { Buffalo fish............... } \\
\text { Carp, German, fresh....... } \\
\text { Carp, German, smoked..... } \\
\text { Catfish and bullheads...... }\end{array}$ & $\begin{array}{r}12,000 \\
3,178,000 \\
2,182,000 \\
4,500 \\
273,000\end{array}$ & $\begin{array}{r}1,200 \\
103,000 \\
51,000 \\
700 \\
19,000\end{array}$ & $\begin{array}{r}400 \\
374,000 \\
123,000 \\
43,000\end{array}$ & $\begin{array}{r}\left({ }^{2}\right) \\
17,000 \\
3,400 \\
3, \ddot{3}, 900\end{array}$ & $\begin{array}{r}110,0000 \\
64,000 \\
\cdots \ddot{2}, 700\end{array}$ & $\begin{array}{l}4,800 \\
1,700 \\
300\end{array}$ & $\begin{array}{r}7,900 \\
2,653,000 \\
1,650,000 \\
\because 101,000\end{array}$ & $\begin{array}{r}700 \\
81,000 \\
39,000 \\
6,800\end{array}$ & $\begin{array}{r}2,800 \\
28,000 \\
148,600 \\
\because 84,000\end{array}$ & $\begin{array}{r}300 \\
800 \\
2,800 \\
4,800\end{array}$ & $\begin{array}{r}1,000 \\
3,500 \\
34,000 \\
4,500 \\
36,000\end{array}$ & $\begin{array}{r}100 \\
100 \\
800 \\
700 \\
3,300\end{array}$ & $\begin{array}{r}200 \\
9,700 \\
162,000 \\
4,400\end{array}$ & $\begin{array}{l}\text { (') } \\
300 \\
3,500 \\
400\end{array}$ \\
\hline 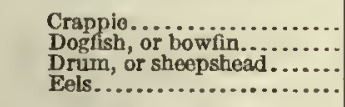 & $\begin{array}{r}10,000 \\
48,000 \\
1,093,000 \\
1,600\end{array}$ & $\begin{array}{r}400 \\
400 \\
20,000 \\
100\end{array}$ & 935,000 & 17,000 & $\ddot{2}, \ddot{0} 000$ & (2) & $\begin{array}{r}10,000 \\
43,000 \\
115,000\end{array}$ & $\begin{array}{r}400 \\
400 \\
1,700 \\
\end{array}$ & $\begin{array}{r}3,300 \\
13,000 \\
100\end{array}$ & (2) & $\begin{array}{r}20,000 \\
1,500\end{array}$ & $\begin{array}{r}1,000 \\
100\end{array}$ & ( 1,800 & $\ddot{200}$ \\
\hline $\begin{array}{l}\text { Herring, lake, fresh ......... } \\
\text { Herring, lake, saltod......... } \\
\text { Herring, lake, smoked ...... } \\
\text { Ling, or lawyer.............. } \\
\text { Muskallunge............. }\end{array}$ & $\begin{array}{r}2,917,000 \\
743,000 \\
3,862,000 \\
32,000 \\
1,300\end{array}$ & $\begin{array}{r}77,000 \\
11,000 \\
62,000 \\
400 \\
100\end{array}$ & $\begin{array}{r}860,000 \\
540,000 \\
3,625,000 \\
6,600 \\
\ldots\end{array}$ & $\begin{array}{r}16,000 \\
8,300 \\
57,000 \\
(2)\end{array}$ & $\begin{array}{r}2,011,000 \\
198,000 \\
237,000 \\
3,700\end{array}$ & $\begin{array}{c}60,000 \\
3,000 \\
5,000 \\
(2) \\
\ldots .\end{array}$ & $\begin{array}{l}4,400 \\
4, \ldots \ldots\end{array}$ & $\ddot{100}$ & $\begin{array}{r}40,000 \\
\cdots \cdots \\
21,000 \\
900\end{array}$ & $\begin{array}{l}300 \\
100\end{array}$ & $\begin{array}{l}700 \\
200\end{array}$ & (i) & 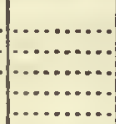 & 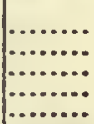 \\
\hline $\begin{array}{l}\text { Perch, yellow .............. } \\
\text { Pike and plckerel...... } \\
\text { Pike perch (walleyed plke). } \\
\text { Rock bass.................. }\end{array}$ & $\begin{array}{r}1,831,000 \\
267,000 \\
86,000 \\
5,500\end{array}$ & $\begin{array}{r}39,000 \\
19,000 \\
6,700 \\
200\end{array}$ & $\begin{array}{r}229,000 \\
37,000 \\
77,000 \\
1,700\end{array}$ & $\begin{array}{r}4,300 \\
2,400 \\
6,100 \\
100\end{array}$ & $\begin{array}{r}340,000 \\
22,000 \\
4,200 \\
100\end{array}$ & $\begin{array}{r}11,000 \\
1,600 \\
300 \\
(3)\end{array}$ & $\begin{array}{r}14,000 \\
84,000 \\
3,800 \\
800\end{array}$ & $\begin{array}{r}400 \\
1,700 \\
300 \\
(3)\end{array}$ & $\begin{array}{r}1,224,000 \\
92,000 \\
\cdots 3,000\end{array}$ & $\begin{array}{r}22,000 \\
7,800 \\
100\end{array}$ & $\begin{array}{r}23,000 \\
26,000 \\
600\end{array}$ & $\begin{array}{l}1,600 \\
2,100 \\
(2)\end{array}$ & $\begin{array}{r}100 \\
5,700 \\
300\end{array}$ & $\begin{array}{l}\text { (9) } \\
(2)^{00} \\
\cdots\end{array}$ \\
\hline 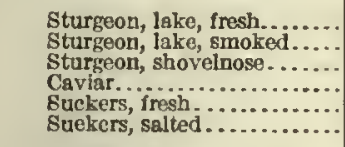 & $\begin{array}{r}28,000 \\
2,500 \\
82,000 \\
900 \\
998,000 \\
123,000\end{array}$ & $\begin{array}{r}3,300 \\
500 \\
4,400 \\
600 \\
20,000 \\
1,900\end{array}$ & $\begin{array}{r}17,000 \\
4,200 \\
100 \\
172,000 \\
103,000\end{array}$ & $\begin{array}{l}1,800 \\
200 \\
(2) \\
3,600 \\
1,500\end{array}$ & $\begin{array}{c}1,100 \\
12,000 \\
\cdots \cdots 00 \\
259,000 \\
12,000\end{array}$ & 7,300 & $\begin{array}{r}40,0000 \\
87,000 \\
2,900\end{array}$ & $\begin{array}{l}2,200 \\
1,300 \\
100\end{array}$ & $\begin{array}{r}424,000 \\
5,800\end{array}$ & 6,500 & $\begin{array}{l}8,900 \\
2,500 \\
1,200 \\
100\end{array}$ & $\begin{array}{r}1,300 \\
500 \\
100 \\
(8)\end{array}$ & $\begin{array}{r}\cdots \\
24,000 \\
800 \\
57,000 \\
\cdots\end{array}$ & $\begin{array}{r}1,100 \\
500 \\
1,400\end{array}$ \\
\hline 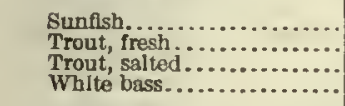 & $\begin{array}{r}75,000 \\
1,943,000 \\
31,000 \\
300\end{array}$ & $\begin{array}{c}1,700 \\
139,000 \\
1,100 \\
(3)\end{array}$ & $\begin{array}{r}500 \\
514,000 \\
14,000 \\
300\end{array}$ & $\begin{array}{l}\left({ }^{2}\right) \\
43,000 \\
400 \\
(2)\end{array}$ & $\begin{array}{r}1,1209,000 \\
17,000 \\
\ldots\end{array}$ & $\begin{array}{r}73,000 \\
700\end{array}$ & $\begin{array}{r}73,000 \\
\ldots \ldots \ldots \ldots \\
\cdots \ldots \ldots\end{array}$ & $\begin{array}{c}1,700 \\
\cdots \cdots\end{array}$ & $\begin{array}{l}1,800 \\
2,100 \\
(3)\end{array}$ & (2) & 298,000 & $\mid \begin{array}{c}23,000 \\
\cdots \ldots \ldots\end{array}$ & & \\
\hline $\begin{array}{l}\text { Whitefish, fresh............. } \\
\text { Whitefish, salted ........... } \\
\text { Whitefish, bluefin......... } \\
\text { Whitefish, longjaw, iresh... } \\
\text { Whitefish, lonfiaw, smoked. } \\
\text { Whitefish, Menominee, fresh } \\
\text { Whlteflsh, Menominee, } \\
\text { salted.................... }\end{array}$ & $\begin{array}{r}257,000 \\
10,000 \\
322,000 \\
69,000 \\
1,900 \\
90,000 \\
61,000\end{array}$ & $\begin{array}{r}19,000 \\
500 \\
6,600 \\
1,000 \\
100 \\
2,300\end{array}$ & $\begin{array}{r}176,000 \\
9,100 \\
64,000 \\
7,800 \\
20,000\end{array}$ & $\begin{array}{r}13,000 \\
400 \\
1,300 \\
100 \\
600\end{array}$ & $\begin{array}{r}73,000 \\
700 \\
258,000 \\
62,000 \\
1,900 \\
68,000 \\
30,000\end{array}$ & $\begin{array}{r}5,300 \\
(2) \\
5,300 \\
900 \\
100 \\
1,600 \\
800\end{array}$ & $\begin{array}{r}8,000 \\
200 \\
\ldots . \ldots\end{array}$ & $\begin{array}{l}(2)^{600} \\
(2 \ldots \\
\ldots\end{array}$ & 2,100 & 100 & & & $\begin{array}{l}\cdots \cdots \\
\cdots \cdots \\
\cdots \cdots\end{array}$ & \\
\hline 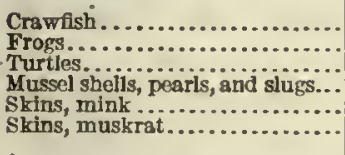 & $\begin{array}{r}239,000 \\
14,000 \\
44,000 \\
1,150,000 \\
1100 \\
11,000\end{array}$ & $\begin{array}{r}9,200 \\
2,600 \\
1,000 \\
12,000 \\
400 \\
600\end{array}$ & 2,200 & (i) & & (n... & $\begin{array}{l}15,000 \\
\cdots\end{array}$ & $\begin{array}{l}\text { (2) } \\
\cdots \\
400\end{array}$ & $\begin{array}{r}\ddot{5}, 2000 \\
\cdots \ldots\end{array}$ & $\ddot{100}$ & & & $\begin{array}{r}238,000 \\
14,000 \\
22,000 \\
1,150,000 \\
1100 \\
1,000\end{array}$ & $\begin{array}{r}9,200 \\
2,600 \\
500 \\
12,000 \\
400 \\
600\end{array}$ \\
\hline
\end{tabular}

1 Includes apparatus, with eatch as follows: Crowfoot dredges, 1,130,000 pounds, valued at $\$ 12,000 ;$ erawtish pots, 238,000 nounds, valued at $\$ 9,200 ;$ trammel nets

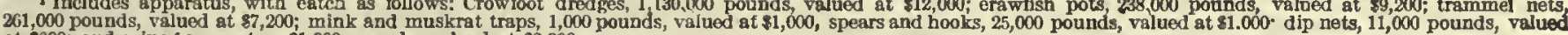
261,000 pounds, valued at 87,$200 ;$ mink and muskrat traps, 1,000
at $\$ 600 ;$ and minor apparatus, 31,000 pounds, valued at $\$ 2,300$

8 Less than $\$ 100$.

- Less than 100 pounds.

- 100 skins.

3,000 skins. 
TABLE 7.-WISCONSIN-PRODUCTS OF VESSEL FISHERIES OF LAKE MICHIGAN DISTRICT: 1908.

\begin{tabular}{|c|c|c|c|c|c|c|c|c|c|c|c|c|c|c|}
\hline \multirow{3}{*}{ SPECTES. } & \multirow{2}{*}{\multicolumn{2}{|c|}{ TAI. }} & \multicolumn{12}{|c|}{ PRODUCT CAUGNT BY- } \\
\hline & & & \multicolumn{2}{|c|}{ Giil nets. } & \multicolumn{2}{|c|}{ Llues. } & \multicolumn{2}{|c|}{$\begin{array}{l}\text { Fyke and hoop } \\
\text { nets. }\end{array}$} & \multicolumn{2}{|c|}{$\begin{array}{l}\text { Pound and trap } \\
\text { nets. }\end{array}$} & \multicolumn{2}{|c|}{ Crawfish pots. } & \multicolumn{2}{|c|}{ Selnes. } \\
\hline & $\begin{array}{l}\text { Quantity } \\
\text { (pounds). }\end{array}$ & Value. & $\begin{array}{l}\text { Ŕuantity } \\
\text { (pounds). }\end{array}$ & Value. & $\begin{array}{l}\text { Quantity } \\
\text { (pounds). }\end{array}$ & Value. & $\begin{array}{l}\text { Quantity } \\
\text { (pounds). }\end{array}$ & Value. & $\begin{array}{l}\text { Quantity } \\
\text { (pounds). }\end{array}$ & Value. & $\begin{array}{l}\text { Quantity } \\
\text { (pounds). }\end{array}$ & Value. & $\begin{array}{l}\text { Quantsty } \\
\text { (pounds). }\end{array}$ & Valoe. \\
\hline Totas.......... & $8,262,000$ & $\$ 414,000$ & $6,964,000$ & $\$ 338,000$ & 670,000 & $\$ 57,000$ & 341,000 & $\$ 6,800$ & 96,000 & $\$ 5,800$ & 109.000 & $\$ 4,700$ & 82.000 & $\$ 1,300$ \\
\hline $\begin{array}{l}\text { Fish: } \\
\text { Carp, German................. } \\
\text { Catfish and huliheads........ } \\
\text { Herring, take, fresh.......... } \\
\text { Herring, lake, smoked........ } \\
\text { Ling, or lawyer .............. }\end{array}$ & $\begin{array}{r}61,000 \\
3,200 \\
4,042,000 \\
59,000 \\
10,000\end{array}$ & $\begin{array}{r}800 \\
100 \\
160,000 \\
5,100 \\
100\end{array}$ & $\begin{array}{r}8,000 \\
100 \\
4,007,000 \\
54,000 \\
5,000\end{array}$ & $\begin{array}{r}100 \\
160,000 \\
4,900 \\
100\end{array}$ & 100 & (i) & $\begin{array}{r}8,600 \\
2,800 \\
200 \\
4,9000\end{array}$ & $\begin{array}{l}200 \\
100 \\
(1) \\
(1)\end{array}$ & $\begin{array}{r}35,000 \\
5,500 \\
\ldots \ldots \ldots\end{array}$ & $\begin{array}{l}500 \\
300 \\
\ldots \ldots\end{array}$ & 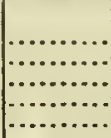 & & 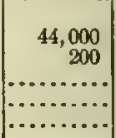 & $\begin{array}{l}{ }^{400} \\
\cdots \cdots \cdots \\
\cdots \cdots \cdots\end{array}$ \\
\hline 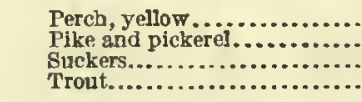 & $\begin{array}{r}731,000 \\
51,000 \\
91,000 \\
2,682,000\end{array}$ & $\begin{array}{r}15,000 \\
3,600 \\
1,700 \\
197,000\end{array}$ & $\begin{array}{r}460,000 \\
34,000 \\
20,000 \\
1,970,000\end{array}$ & $\begin{array}{r}11,000 \\
2,300 \\
500 \\
136,000\end{array}$ & 670,000 & $\ldots \ldots$ & $\begin{array}{r}257,000 \\
15,000 \\
51,000\end{array}$ & $\begin{array}{r}4,500 \\
1,200 \\
700\end{array}$ & 42,000 & 3,800 & & & $\begin{array}{r}14,000 \\
1,400 \\
20,000 \\
2\end{array}$ & $\begin{array}{r}300 \\
100 \\
500 \\
\cdots\end{array}$ \\
\hline 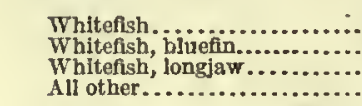 & $\begin{array}{r}22,000 \\
388,000 \\
8,000 \\
4,800\end{array}$ & $\begin{array}{r}2,300 \\
22,000 \\
500 \\
100\end{array}$ & $\begin{array}{r}9,600 \\
388,000 \\
8,000 \\
500\end{array}$ & $\begin{array}{c}1,000 \\
22,000 \\
500 \\
(1)\end{array}$ & $\begin{array}{l} \\
\ldots \ldots \ldots \ldots \\
\cdots \ldots \ldots \ldots \\
\cdots \ldots \ldots \ldots\end{array}$ & $\mid \begin{array}{l}-\cdots \\
\cdots \\
\cdots\end{array}$ & 1,700 & 100 & $\begin{array}{r}12,000 \\
\cdots \\
\cdots \\
800\end{array}$ & $\begin{array}{c}1,200 \\
\cdots \cdots \\
\cdots \\
(1)\end{array}$ & & & ${ }_{1,900}$ & $\begin{array}{ll}\cdots \\
\cdots \cdots \cdots \\
\cdots \cdots\end{array}$ \\
\hline 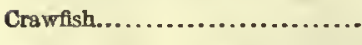 & 109,000 & 4,700 & & & & & & & & & 109,000 & 4,700 & ..... & \\
\hline
\end{tabular}

${ }^{2}$ Less than $\$ 100$.

TABLE 8.-WISCONSIN-PRODUCTS OF SHORE AND BOAT FISHERIES OF LAKE MICHIGAN DISTRICT: 1908.

\begin{tabular}{|c|c|c|c|c|c|c|c|c|c|c|c|c|c|c|c|c|}
\hline \multirow{3}{*}{ SPECIES. } & \multirow{2}{*}{\multicolumn{2}{|c|}{ TOTAL. }} & \multicolumn{14}{|c|}{ PRODUGT CAUOUT BY- } \\
\hline & & & \multicolumn{2}{|c|}{ Gull nets. } & \multicolumn{2}{|c|}{$\begin{array}{l}\text { Pound and trap } \\
\text { nets. }\end{array}$} & \multicolumn{2}{|c|}{$\begin{array}{l}\text { Fyke and hoop } \\
\text { nets. }\end{array}$} & \multicolumn{2}{|c|}{ Lines. } & \multicolumn{2}{|c|}{ Tramme! nets. } & \multicolumn{2}{|c|}{ Seines. } & \multicolumn{2}{|c|}{$\begin{array}{l}\text { All other appa- } \\
\text { ratus.1 }\end{array}$} \\
\hline & $\begin{array}{l}\text { Quantity } \\
\text { (pounds). }\end{array}$ & Value. & $\begin{array}{l}\text { Quantity } \\
\text { (pounds). }\end{array}$ & value. & $\begin{array}{l}\text { Quantity } \\
\text { (pounds). }\end{array}$ & Value. & $\begin{array}{l}\text { Quantity } \\
\text { (pounds). }\end{array}$ & Value. & $\begin{array}{l}\text { Quantity } \\
\text { (pounds). }\end{array}$ & Value. & $\begin{array}{l}\text { Quantity } \\
\text { (pounds). }\end{array}$ & value. & $\begin{array}{l}\text { Quantity } \\
\text { (pounds). }\end{array}$ & Value. & $\begin{array}{l}\text { Quantity } \\
\text { (pounds) }\end{array}$ & Value. \\
\hline Total............ & $12,915,000$ & $\$ 381,000$ & $4,173,000$ & $\$ 156,000$ & $5,871,000$ & $\$ 136,000$ & $1,985,000$ & 842,000 & 330,000 & 828,000 & 166,000 & $\$ 3,500$ & 127,000 & $\$ 2,900$ & 253,000 & $\$ 12,000$ \\
\hline $\begin{array}{l}\text { Fish: } \\
\text { Black bass......... } \\
\text { Carp, German; } \\
\text { fresh. } \\
\text { Carp, German. }\end{array}$ & $\begin{array}{r}4,200 \\
267,000\end{array}$ & $\begin{array}{r}500 \\
4,900\end{array}$ & & & 400 & () & $\begin{array}{r}2,800 \\
87,000\end{array}$ & $\begin{array}{r}300 \\
1,500\end{array}$ & $\begin{array}{r}1,000 \\
500\end{array}$ & $\begin{array}{l}100 \\
\text { (2) }\end{array}$ & 136,000 & 2,700 & $\begin{array}{l}\text { (s) } \\
40,000\end{array}$ & (') & 3,600 & 200 \\
\hline 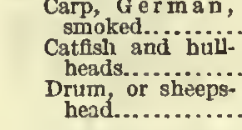 & $\begin{array}{r}4,500 \\
74,000 \\
23,000\end{array}$ & $\begin{array}{r}700 \\
3,200 \\
900\end{array}$ & & & 5,000 & 100 & $\begin{array}{r}65,000 \\
9,600\end{array}$ & $\begin{array}{r}2,900 \\
100\end{array}$ & $\begin{array}{r}4,500 \\
800 \\
5,000\end{array}$ & $\begin{array}{l}700 \\
100 \\
700\end{array}$ & $\begin{array}{r}1,100 \\
2000\end{array}$ & 100 & $\begin{array}{l}1,700 \\
8,000\end{array}$ & $\begin{array}{c}100 \\
\left({ }^{2}\right)\end{array}$ & $\begin{array}{l}500 \\
100\end{array}$ & $\begin{array}{l}\text { (?) } \\
\text { (?) }\end{array}$ \\
\hline $\begin{array}{l}\text { Herring, lake, fresh } \\
\text { Herr in g, lake, } \\
\text { salted ............ }\end{array}$ & $\begin{array}{r}2,869,000 \\
327,000\end{array}$ & $\begin{array}{r}76,000 \\
5,200\end{array}$ & $\begin{array}{r}1,984,000 \\
10,000\end{array}$ & $\begin{array}{r}60,000 \\
200\end{array}$ & $\begin{array}{l}839,000 \\
317,000\end{array}$ & $\begin{array}{r}16,000 \\
5,100\end{array}$ & 46,000 & 600 & & & & & & & & \\
\hline $\begin{array}{l}\text { Herring, lake, } \\
\text { smoked, ........ } \\
\text { Ling, or lawye... } \\
\text { Muskallunge....... }\end{array}$ & $\begin{array}{r}3,862,000 \\
32,000 \\
1,300\end{array}$ & $\begin{array}{r}62,000 \\
400 \\
100\end{array}$ & $\begin{array}{r}237,000 \\
3,700\end{array}$ & $\underset{(2)}{5,000}$ & $\begin{array}{r}3,625,000 \\
6,600\end{array}$ & 57,000 & 21,000 & $\begin{array}{l}300 \\
100\end{array}$ & $\begin{array}{l}700 \\
200\end{array}$ & (1) & & & 2000 & (2) & & (2....... \\
\hline $\begin{array}{l}\text { Perch, yellow...... } \\
\text { Pike and pickerel. } \\
\text { Pike perch (wall- } \\
\text { eyed pike)....... }\end{array}$ & $\begin{array}{r}1,819,000 \\
183,000 \\
4,000\end{array}$ & $\begin{array}{r}39,000 \\
15,000 \\
300\end{array}$ & $\begin{array}{r}340,000 \\
22,000 \\
4,000\end{array}$ & $\begin{array}{r}11,000 \\
1,600\end{array}$ & $\begin{array}{r}229,000 \\
22,000\end{array}$ & $\begin{array}{l}4,300 \\
1,500\end{array}$ & $\begin{array}{r}1,224,000 \\
89,000\end{array}$ & $\begin{array}{r}22,000 \\
7,700\end{array}$ & $\begin{array}{l}23,000 \\
26,000\end{array}$ & $\begin{array}{l}1,600 \\
2,100\end{array}$ & $\begin{array}{r}100 \\
5,000\end{array}$ & $\stackrel{(2)}{.300}$ & $\begin{array}{r}2,500 \\
20,000\end{array}$ & (1) 400 & & ....... \\
\hline $\begin{array}{l}\text { Sturgeo n, lake, } \\
\text { iresh...... } \\
\text { st urgeon, lake, } \\
\text { smoked............... }\end{array}$ & $\begin{array}{r}12,000 \\
2,500\end{array}$ & $\begin{array}{r}2,000 \\
500\end{array}$ & & & 4,900 & 700 & & & $\begin{array}{l}7,000 \\
2,500\end{array}$ & $\begin{array}{r}1,200 \\
500\end{array}$ & & & & & & \\
\hline $\begin{array}{l}\text { Suckers, fresh..... } \\
\text { Suckers, , salted... }\end{array}$ & $\begin{array}{r}896,000 \\
64,000\end{array}$ & $\begin{array}{r}18,000 \\
800\end{array}$ & $\begin{array}{r}259,000 \\
3,400\end{array}$ & (i) & $\begin{array}{r}131,000 \\
53,000\end{array}$ & 2,000 & $\begin{array}{r}423,000 \\
5,800\end{array}$ & $\begin{array}{r}6,500 \\
100\end{array}$ & & & $\ddot{24} \ddot{24}, 000$ & & $\begin{array}{r}52,000 \\
2,300\end{array}$ & $(2)$ & 6,800 & 300 \\
\hline $\begin{array}{l}\text { Trout, fresh....... } \\
\text { Trout, salted...... } \\
\text { Whitefish, fresh } \\
\text { Whit tefish, salted. }\end{array}$ & $\begin{array}{r}1,620,000 \\
26,000 \\
91,000 \\
3,900\end{array}$ & $\begin{array}{r}120,000 \\
900 \\
8,700 \\
200\end{array}$ & $\begin{array}{r}925,000 \\
12,000 \\
19,000 \\
200\end{array}$ & $\begin{array}{r}61,000 \\
500 \\
2,000 \\
(2)\end{array}$ & $\begin{array}{r}433,000 \\
14,000 \\
72,000 \\
3,700\end{array}$ & $\begin{array}{r}38,000 \\
400 \\
6,700 \\
200\end{array}$ & $\begin{array}{r}2,100 \\
100\end{array}$ & $\mid \begin{array}{r}100 \\
\text { (1) }\end{array}$ & 259,000 & 21,000 & & & & 当 & & (........ \\
\hline $\begin{array}{l}\text { Whitefish, bluefin. } \\
\text { Whitefish, Menom- } \\
\text { Inee, Iresh ...... }\end{array}$ & $\begin{array}{r}319,000 \\
89,000\end{array}$ & $\begin{array}{l}6,500 \\
2,300\end{array}$ & $\begin{array}{r}255,000 \\
68,000\end{array}$ & $\begin{array}{l}5,200 \\
1,600\end{array}$ & $\begin{array}{l}64,000 \\
19,000\end{array}$ & $\begin{array}{r}1,300 \\
6000\end{array}$ & 2,100 & 100 & & & & & & & & \\
\hline $\begin{array}{l}\text { Whiteditis, Menom- } \\
\text { inee, salted...... } \\
\text { All other........... }\end{array}$ & $\begin{array}{r}60,000 \\
3,500\end{array}$ & $\begin{array}{r}1,100 \\
100\end{array}$ & 30,000 & 500 & $\begin{array}{r}30,000 \\
300\end{array}$ & (2) 500 & 3,200 & (a) & & & & & & & & : \\
\hline 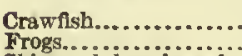 & $\begin{array}{r}239,000 \\
13,000\end{array}$ & $\begin{array}{l}9,200 \\
2,400\end{array}$ & & & & & & & & & & & 600 & (2) & $\begin{array}{r}238,000 \\
13,000\end{array}$ & $\begin{array}{l}9,200 \\
2,400\end{array}$ \\
\hline $\begin{array}{r}\text { 8kins, mink and musk- } \\
\text { rat.......................... }\end{array}$ & 400 & & & & & & & & & & & & & & & \\
\hline
\end{tabular}

1 Includes apparatus, with catch, as follows: Crawnsh pots, 238,000 pounds, valued at $\$ 9,200$; dip nets, 11,000 pounds, valued at $\$ 600$; spears and hooks, 2,200 pounda,

valued at $\$ 300 ;$ mllak and muskrat traps, 500 pounds, valled at $\$ 200 ;$ and minor apparatus, 11,000 pounds, valued at $\$ 2,100$.
: Less than $\$ 100$. 
FISHERIES, BY STATES.

TABLE 9.-WISCONSIN-PRODUCTS OF VESSEL FISHERIES OF LAKE SUPERIOR DISTRICT: 1908.

\begin{tabular}{|c|c|c|c|c|c|c|}
\hline \multirow{3}{*}{ 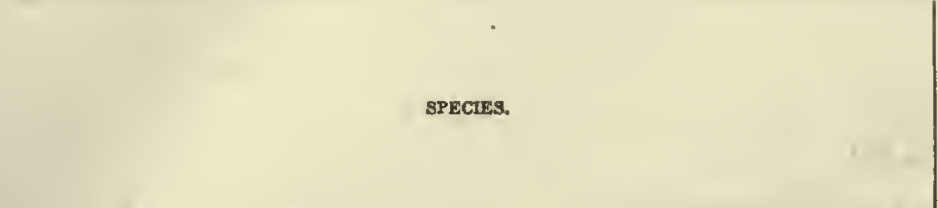 } & \multirow{2}{*}{\multicolumn{2}{|c|}{ TOTAL. }} & \multicolumn{4}{|c|}{ PRODUCT CAUGHT BY- } \\
\hline & & & \multicolumn{2}{|c|}{ Gill nets. } & \multicolumn{2}{|c|}{ An other apparatus.I } \\
\hline & $\begin{array}{l}\text { Quantity } \\
\text { (pounds). }\end{array}$ & Value. & $\begin{array}{l}\text { Quantlty } \\
\text { (pounds). }\end{array}$ & Value. & $\begin{array}{l}\text { Quantity } \\
\text { (pounds). }\end{array}$ & Value. \\
\hline 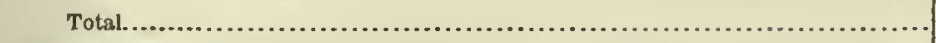 & 601,000 & $\$ 11,000$ & 597,000 & $\$ 11,000$ & 4,100 & $\$ 200$ \\
\hline 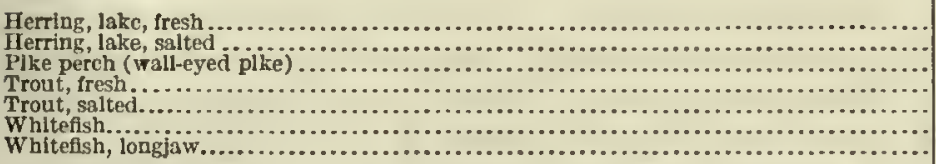 & $\begin{array}{r}87,000 \\
414,000 \\
2,400 \\
49,000 \\
4,500 \\
2,500 \\
42,000\end{array}$ & $\begin{array}{r}500 \\
6,900 \\
200 \\
3,000 \\
200 \\
200 \\
600\end{array}$ & $\begin{array}{r}87,000 \\
414,000 \\
800 \\
47,000 \\
4,500 \\
2,500 \\
42,000\end{array}$ & $\begin{array}{r}6,500 \\
6,900 \\
2,900 \\
200 \\
200 \\
600\end{array}$ & 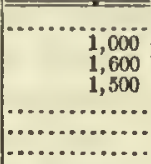 & 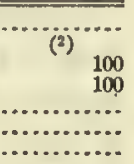 \\
\hline
\end{tabular}

1 Includes pound nets, with a catch of 3,100 pounds, valued at $\$ 200$; and lines, with a catch of 1,000 pounds, valued at $\$ 100$.

Less than $\$ 100$.

TABLE 10.-WISCONSIN-PRODUCTS OF SHORE AND BOAT FISHERIES OF LAKE SUPERIOR DISTRICT: 1908.

\begin{tabular}{|c|c|c|c|c|c|c|c|c|}
\hline \multirow{3}{*}{ SPECIES. } & \multirow{2}{*}{\multicolumn{2}{|c|}{ TOTAL. }} & \multicolumn{6}{|c|}{ PRODUCT CAUOHT BY- } \\
\hline & & & \multicolumn{2}{|c|}{ Pound and trap nets. } & \multicolumn{2}{|c|}{ Glll nets. } & \multicolumn{2}{|c|}{ All other spparatus.1 } \\
\hline & $\begin{array}{l}\text { Quantity } \\
\text { (pounds). }\end{array}$ & Value. & $\begin{array}{l}\text { Quantity } \\
\text { (pounds). }\end{array}$ & Value. & $\begin{array}{l}\text { Quantlty } \\
\text { (pounds). }\end{array}$ & Value. & $\begin{array}{l}\text { Quantlity } \\
\text { (pounds). }\end{array}$ & Value. \\
\hline Total...... & $1,216,000$ & $\$ 47,000$ & 609,000 & $\$ 23,000$ & 555,000 & $\$ 20,000$ & 52,000 & $\$ 2,200$ \\
\hline 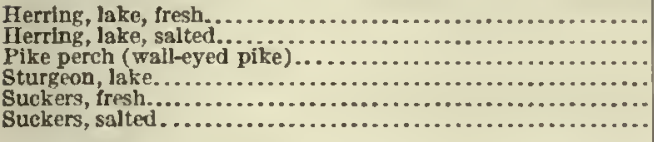 & $\begin{array}{r}48,000 \\
415,000 \\
77,000 \\
9,400 \\
30,000 \\
59,000\end{array}$ & $\begin{array}{r}600 \\
6,200 \\
6,100 \\
800 \\
500 \\
1,000\end{array}$ & $\begin{array}{r}21,000 \\
223,000 \\
77,000 \\
9,400 \\
30,000 \\
50,000\end{array}$ & $\begin{array}{r}300 \\
3,200 \\
6,100 \\
800 \\
500 \\
800\end{array}$ & $\begin{array}{r}27,000 \\
188,000 \\
200 \\
(?) \\
8,300\end{array}$ & $\begin{array}{l}2,800 \\
(2) \\
(2) \\
200\end{array}$ & $\begin{array}{l}\cdots, 400 \\
\cdots \cdots \cdots \\
\cdots \cdots \cdots\end{array}$ & (z) \\
\hline 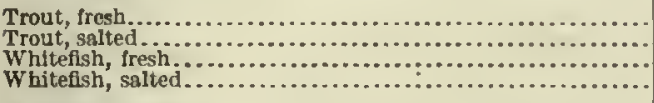 & $\begin{array}{r}324,000 \\
4,700 \\
166,000 \\
6,100\end{array}$ & $\begin{array}{r}20,000 \\
200 \\
10,000 \\
200\end{array}$ & $\begin{array}{r}80,000 \\
200 \\
104,000 \\
5,400\end{array}$ & $\begin{array}{r}5,000 \\
(2) \\
6,400 \\
200\end{array}$ & $\begin{array}{r}204,000 \\
4,400 \\
54,000 \\
500\end{array}$ & $\begin{array}{r}12,000 \\
200 \\
3,300 \\
(2)\end{array}$ & $\begin{array}{r}39,000 \\
8,000 \\
200\end{array}$ & 2,400 \\
\hline 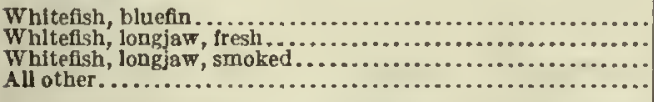 & $\begin{array}{r}3,300 \\
69,000 \\
1,900 \\
2,100\end{array}$ & $\begin{array}{r}100 \\
1,000 \\
100 \\
100\end{array}$ & $\begin{array}{l}7,500 \\
1,800\end{array}$ & ioo & $\begin{array}{r}3,300 \\
62,000 \\
1,900 \\
300\end{array}$ & ${ }_{(3)} \begin{array}{r}100 \\
100\end{array}$ & 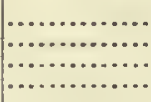 & ( \\
\hline
\end{tabular}

IIncludes lines, with a catch of 39,000 pounds, valued at $\$ 2,400$; and seines, with a catch of 13,000 pounds, valued at $\$ 600$.

2 Less than $\$ 100$.

Less than 100 pounds. 


\section{CHAPTER V.III.}

\section{CANNING AND PRESERVING.}

Comparison with earlier canvasses. -The earliest year for which separate statistics of the industries of canning and preserving fish and oysters are available is 1870. At the census for that year there were reported under the heads "Fish, cured and packed" and "Oysters, canned," 92 establishments which employed in all 2,441 persons and had a combined capital of $\$ 966,000$ and products valued at $\$ 3,064,000$. No figures are obtainable for 1880 , as the reports for the canning and preserving of fish and oysters in that year were included with the reports of other industries. The following table presents a comparative summary of the statistics of establishments engaged in canning and preserving fish and oysters in the United States, exclusive of Alaska, as returned at the censuses of manufactures in 1890,1900, and 1905, and the census of fisheries in 1908. The figures obtained at the censuses of manufactures represent industries classified under the head of "Canning and preserving, fish," and "Canning and preserving, oysters."

Fishery products are preserved to some extent in establishments engaged primarily in the manufacture of other products. It is also true that, in the censuses of manufactures, products other than those of the fisheries are included with industries classified as "Canning and preserving, fish" and "Canning and preserving, oysters." In the census of fisheries for 1908, reports were secured covering only that part of the operations of those establishments which pertained to the fisheries. For these reasons the figures for 1908 are not strictly comparable with those for prior years.

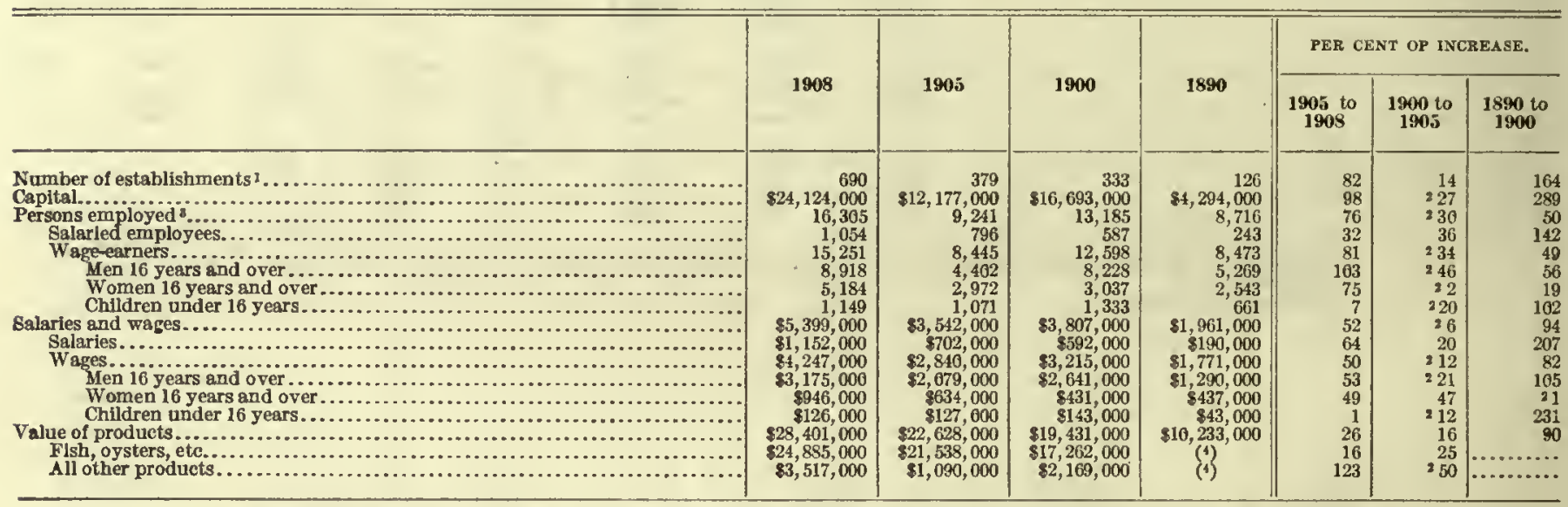

1 Exclusive of the canneries and salteries of Alaska, for statistles of which see Report of the Bureau of Fisheries, Doc. No. 645.

2 Decrease.

Not including proprletors and firm members except In 1890 when they were not reported separately.

In the number of establishments and in the value of products there were increases during each period. From 1905 to 1908 the former increased 82 per cent and the latter 20 per cent. The apparent decreases from 1900 to 1905 in the number of wage-earners and in wages may be attributed to a difference in the methods used at the two censuses for reporting contract labor, which is extensively employed, especially in the salmon canneries. In 1900 contract employees were reported as wage-earners, while in 1905 and in 1908 their number was not reported, the wage item being included under the head of "Miscellaneous expenses" in 1905 and under the liead of "Cost of material" in 1908. From 1905 to 1908 the number of wage-earners increased 81 per cent, but in the amount of wages paid the increase was only 50 per cent. In capital invested there was a decrease of $\$ 4,516,000$ from 1900 to 1905 , which resulted principally from a loss of $\$ 6,312,000$ in Maine, apparently due to a reorganization of some of the larger establishments, and a loss of $\$ 1,012,000$ in Oregon. From 1905 to 1908 the amount of capital increased 98 per cent. The investment of 1908 represents an outlay of $\$ 3,417,000$ for land, $\$ 10,288,000$ for buildings, and cash amounting to $\$ 10,420,000$.

Statistics, by geographic divisions.-The table following shows, for the principal items of the statistics, the distribution by geographic divisions. These divisions correspond with those which appear in the preceding chapters on fishery products. 


\begin{tabular}{|c|c|c|c|c|c|c|}
\hline & $\begin{array}{l}\text { United } \\
\text { States. }\end{array}$ & $\begin{array}{l}\text { Atlantic } \\
\text { coast } \\
\text { divlsion. }\end{array}$ & $\begin{array}{r}\text { Gulf of } \\
\text { Mexico } \\
\text { division. } \\
\text {. }\end{array}$ & $\begin{array}{l}\text { Pacific coast } \\
\text { division. }\end{array}$ & $\begin{array}{c}\text { Great Lrkes } \\
\text { divislon. }\end{array}$ & $\begin{array}{l}\text { Mississlppi } \\
\text { RIver } \\
\text { divislon. }\end{array}$ \\
\hline Number of establishments ${ }^{1}$.. & 690 & 464 & 36 & & & \\
\hline Capital..................... & $\$ 24,124,000$ & $\$ 11,937,000$ & $\$ 2,465,000$ & $\$ 8,713,000$ & $\$ 1,003,000$ & $\$ 5,200$ \\
\hline 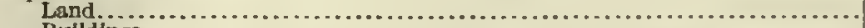 & $\$ 3,417,000$ & $\$ 1,462,000$ & $\$ 242,000$ & $\$ 1,440,000$ & $\$ 271,000$ & $\$ 2,200$ \\
\hline ( & $\$ 10,288,000$ & $\$ 4,878,000$ & $\$ 1,331,000$ & $\$ 3,791,000$ & $\$ 287,000$ & $\$ 1,200$ \\
\hline 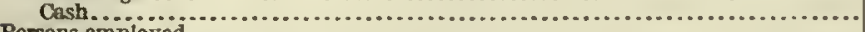 & $\$ 10,420,000$ & $\$ 5,598,000$ & 8893,000 & $\$ 3,483,000$ & $\$ 445,000$ & $\$ 1,800$ \\
\hline 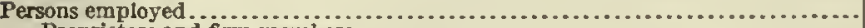 & 17,202 & 11,683 & 3,105 & 2,103 & 296 & 15 \\
\hline 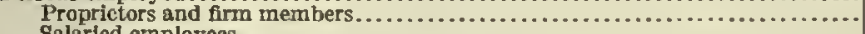 & 897 & 646 & 72 & 90 & 77 & 12 \\
\hline Salaried employees........................................ & 1,054 & 618 & 147 & 244 & 4.5 & \\
\hline 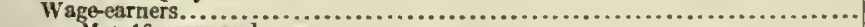 & 15,251 & 10,419 & 2,886 & 1,769 & 174 & 3 \\
\hline 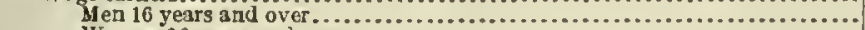 & 8,918 & 6,084 & 1,103 & 1,554 & 174 & 3 \\
\hline 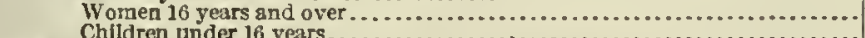 & 5,184 & 3,632 & 1,370 & 182 & & \\
\hline $\begin{array}{l}\text { Children under } 16 \text { years.......... } \\
\text { Balaries and wages. }\end{array}$ & 1,149 & 703 & 413 & 33 & & \\
\hline 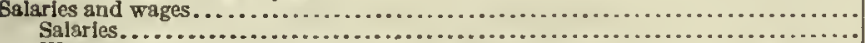 & & & $\$ 620,000$ & $\$ 1,316,000$ & $\$ 142,000$ & $\$ 1,700$ \\
\hline 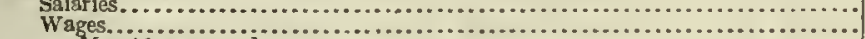 & $\$ 1,152,000$ & $\begin{array}{r}8042,000 \\
82,678,000\end{array}$ & $\begin{array}{l}\$ 130,000 \\
8490,000\end{array}$ & $\begin{array}{l}8333,000 \\
8983,000\end{array}$ & $\$ 87,000$ & $\$ 1,700$ \\
\hline Men 16 years and over................ & $\$ 3,175,000$ & $\$ 1,903,000$ & $\$ 257,000$ & $\$ 919,000$ & $\$ 94,000$ & $\$ 1,700$ \\
\hline Women 16 years and over.......................... & $\$ 946,000$ & $\$ 701,000$ & $\$ 185,000$ & $\$ 59,000$ & .......... & ........ \\
\hline 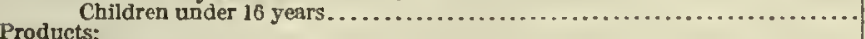 & $\$ 126,000$ & $\$ 74,000$ & $\$ 47,000$ & $\$ 1,900$ & & \\
\hline Products: Quantity (pounds)................ & $468,947,000$ & $359,553,000$ & $26,461,000$ & $73,257,000$ & $9,535,000$ & 137,000 \\
\hline 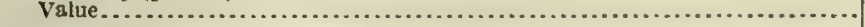 & $\$ 28,401,000$ & $\$ 18,741,000$ & $82,404,000$ & $86,450,000$ & 8788,000 & 819,000 \\
\hline
\end{tabular}

' Exclusive of the canneries and salteries of Alaska, for the statistics of which see Report of the Bureau of Fisheries, Doc. No. 645 .

The Atlantic coast division ranked first in the industry, reporting nearly lialf of the capital and approximately two-thirds of the number of establislments and of the value of products. The Pacific coast division was second in the number of establishments, capital, and value of products, and the Gulf of Mexico division was second in the number of persons employed. The schedule used in the canvass of the packing and canning establishments called for the quantity of fresh fish received at the plants, to be reported in pounds. The data furnished as a result of this inquiry were, however, so incomplete and unsatisfactory that no use could be made of them.

Products, by kind.-The next tabular statement gives the quantity and value of the principal kinds of products prepared, arranged in order of value, together with the proportion which each contributed to the value of all products.

Salmon, sardines, cod, and oysters contributed slightly more than two-thirds of the value of the entire output.

\begin{tabular}{|c|c|c|c|c|}
\hline \multirow{3}{*}{ KUND OF PRODUCT. } & \multicolumn{4}{|c|}{$\begin{array}{l}\text { CANNING AND PRESERVINO, FISII AND OYSTERS- } \\
\text { PRODUCTS: } 1908 \text {. }\end{array}$} \\
\hline & \multicolumn{2}{|c|}{ Quantity. } & \multicolumn{2}{|c|}{ Value. } \\
\hline & Pournds. & $\begin{array}{c}\text { Per cent } \\
\text { distribu- } \\
\text { tion. }\end{array}$ & Amount. & $\begin{array}{l}\text { Per cent } \\
\text { distribu- } \\
\text { tion. }\end{array}$ \\
\hline Total... & $468,947,000$ & 100 & $\$ 28,401,000$ & 100 \\
\hline 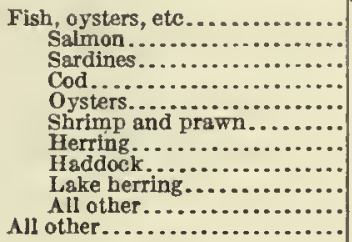 & $\begin{array}{r}340,086,000 \\
57,461,000 \\
72,323,000 \\
60,979,000 \\
46,593,000 \\
3,772,000 \\
18,204,000 \\
12,362,000 \\
6,261,000 \\
62,130,000 \\
128,861,000\end{array}$ & \begin{tabular}{r|r}
73 \\
12 \\
15 \\
13 \\
10 \\
1 \\
4 \\
3 \\
1 \\
13 \\
27
\end{tabular} & $\begin{array}{r}24,885,000 \\
5,966,000 \\
5,311,000 \\
4,557,000 \\
3,428,000 \\
742,000 \\
667,000 \\
594,000 \\
480,000 \\
3,139,000 \\
3,517,000\end{array}$ & $\begin{array}{r}88 \\
21 \\
19 \\
16 \\
12 \\
3 \\
2 \\
2 \\
2 \\
11 \\
12\end{array}$ \\
\hline
\end{tabular}

The following table distributes the value of products by species and by geographic divisions:

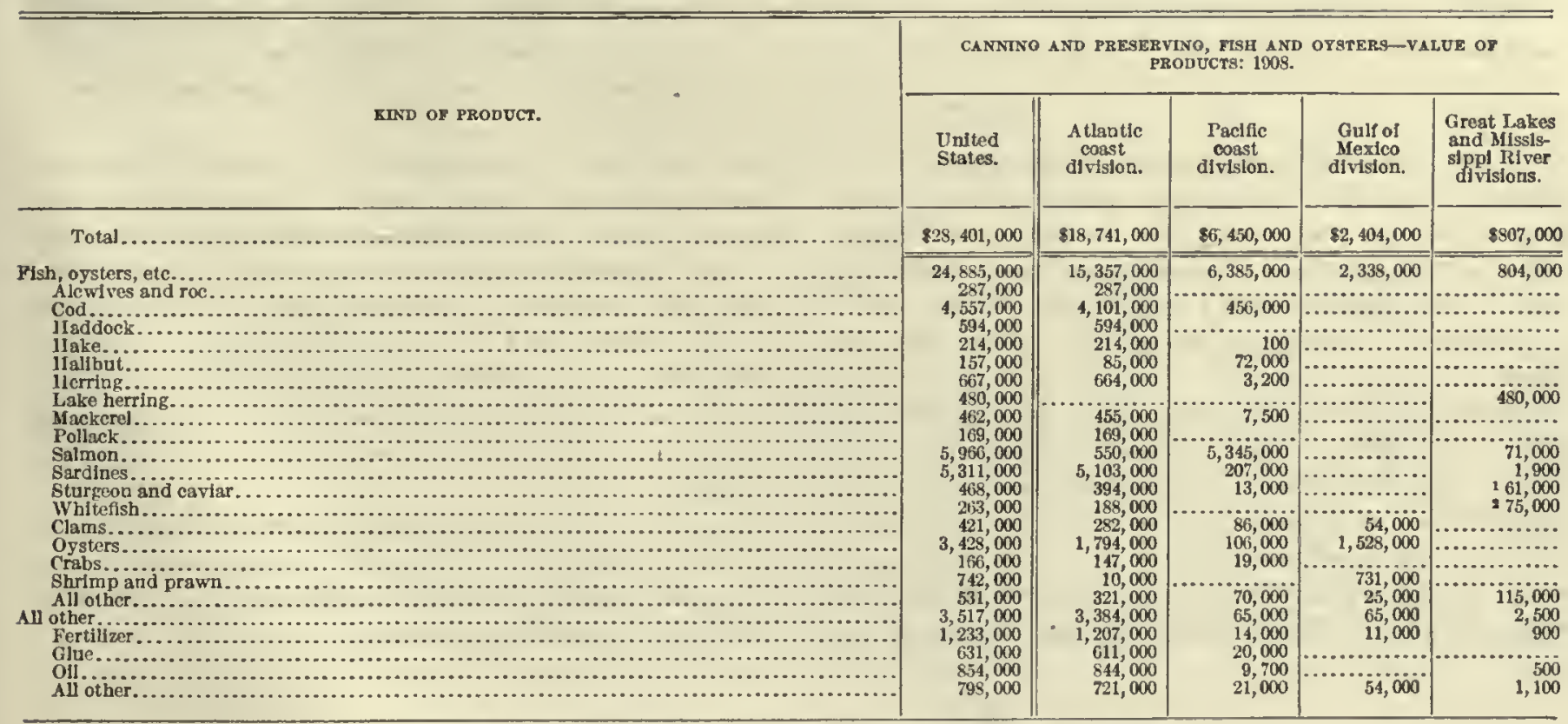


The Atlantic coast division reported 66 per cent of the total value of products; the Pacific coast division, 23 per cent; the Gulf of Mexico division, 8 per cent; the Great Lakes division, nearly 3 per cent; and the Mississippi River division, less than 1 per cent. Of the value of all salmon treated in continental United States, 90 per cent represents the value of salmon prepared by the canneries and packing houses of the Pacific coast states. The Atlantic coast division is credited with 96 per cent of the sardines as measured by value, 90 per cent of the cod, 52 per cent of the oysters, and 84 per cent of the sturgeon prepared in the United States. Nearly all of the hake, mackerel, and herring (exclusive of lake herring), and all of the alewives, haddock, and pollack were put up in the Atlantic coast states. The Gulf states reported 45 per cent of the oyster product and almost the entire shrimp and prawn product. All the lake herring output was from the canning houses of the Great Lakes division.
Table 1, on page 286, gives the value of the food products, by species and by method of treatment. The canned product excecded in value the product treated by any other method used in preparing fishery products for market. Of the total value of food products-\$24,885,000-57 per cent represents canned product; 14 , per cent, boned; 11 per cent, smoked; 10 per cent, salted; 7 per cent, pickled; and 1 per cent, frozen.

Table 2, on page 287 , distributes the quantity and value of all products of the industry according to method of treatment and kind of product, for continental United States and for each geographic division. The by-products of the canneries and packing houses, consisting of fertilizer, oil, glue, etc., had a value in 1908 of $\$ 3,517,000$. On account of the importance of some of these as articles of commerce, they arc shown in detail, by geographic divisions and by states, in the following table:

\begin{tabular}{|c|c|c|c|c|c|}
\hline \multirow{2}{*}{ DIVISION AND STATE. } & \multicolumn{5}{|c|}{$\begin{array}{l}\text { CANNING AND PRESERVING, FISH AND OYSTERS-VALUE OF } \\
\text { PRODUCTS OTHER THAN FOOD PRODUCTS: } 1908 .\end{array}$} \\
\hline & Total. & Fertllizer. & Oll. & $\begin{array}{l}\text { Glue and } \\
\text { isinglass. }\end{array}$ & $\begin{array}{l}\text { All other } \\
\text { products. }\end{array}$ \\
\hline United States.............. & $\$ 3,517,000$ & $\$ 1,233,000$ & 8854,000 & 18782,000 & $\$ 648,000$ \\
\hline Atlantic coast divislon...$\ldots \ldots \ldots \ldots$. & $3,384,000$ & $1,207,000$ & 844,000 & 762,000 & 571,000 \\
\hline 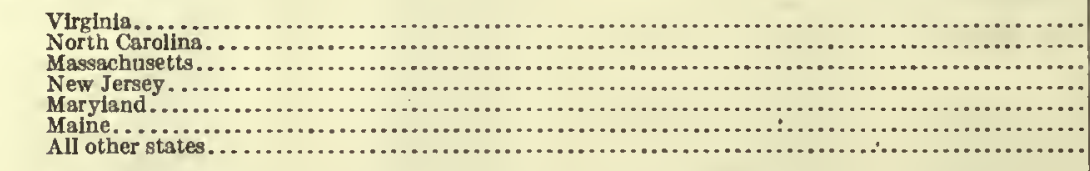 & $\begin{array}{r}1,032,000 \\
116,000 \\
1,249,000 \\
63,000 \\
81,000 \\
143,000 \\
699,000\end{array}$ & $\begin{array}{r}618,000 \\
90,000 \\
77,000 \\
47,000 \\
44,000 \\
19,000 \\
312,000\end{array}$ & $\begin{array}{r}328,000 \\
23,000 \\
123,000 \\
16,000 \\
9,800 \\
20,000 \\
324,000\end{array}$ & 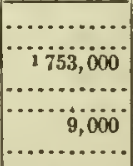 & $\begin{array}{r}87,000 \\
2,100 \\
296,000 \\
\ldots . .700 \\
27,000 \\
95,000 \\
64,000\end{array}$ \\
\hline Paclfic coast divlsion............ & 65,000 & 14,000 & 9,700 & 20,000 & 21,000 \\
\hline 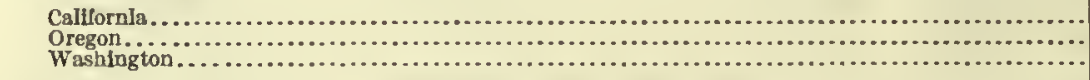 & $\begin{array}{r}34,000 \\
9,400 \\
21,000\end{array}$ & $\begin{array}{l}2,400 \\
3,000 \\
8,800\end{array}$ & $\begin{array}{r}200 \\
6,000 \\
3,500\end{array}$ & $\begin{array}{r}20,000 \\
\cdots \cdots \\
\cdots \cdots\end{array}$ & $\begin{array}{r}11,000 \\
400 \\
9,000\end{array}$ \\
\hline Gulf ol Mexico division. ...................................... & 65,000 & 11,000 & & & 54,000 \\
\hline 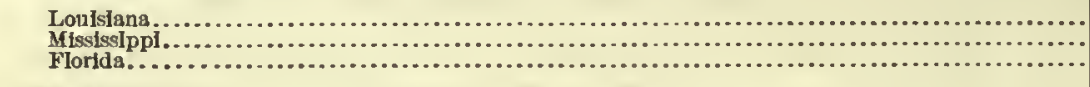 & $\begin{array}{r}32,000 \\
33,000 \\
100\end{array}$ & $\begin{array}{r}1,100 \\
9,700 \\
\cdots\end{array}$ & $\cdots \cdots \cdots \cdots$ & 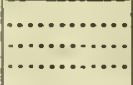 & $\begin{array}{r}31,000 \\
24,000 \\
100\end{array}$ \\
\hline 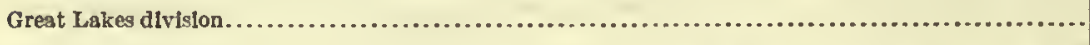 & 2,500 & 900 & 500 & & 1,100 \\
\hline
\end{tabular}

Includes a value ol $\$ 150,000$ reported for Linglass.

Of the total value of products other than food reported by the fish and oyster canneries and packing houses, 35 per cent represents the value of the fertilizer manufactured. The Atlantic coast states contributed 98 per cent and Virginia alone 50 per cent of the value of the fertilizer produced by these establishments.

Another important by-product of this industry was fish oil, for which a value of $\$ 854,000$ was reported, or 24 per cent of the total for products other than food. Virginia led, with an output valued at 38 pcr cent of the value of all fish oil reported by the establishments under consideration. The manufacture of fish glue was confined to three states-Massachusetts, Maine, and California-95 per cent of the value of the output being credited to Massachusetts. All the isinglass reported, valued at $\$ 150,000$, was from Massachusetts.

The preceding statisties are confined to the fish canning and preserving establishments of continental United States, and do not include Alaska. In the remainder of the chapter, which is devoted to a presentation in detail of the data for the leading products, statistics of the Alaskan output have been included.

Salmon.-The table following shows, for the United States, inclusive of Alaska, the quantity and value of the salmon treated in 1908, distributed according to method of treatment by states. 


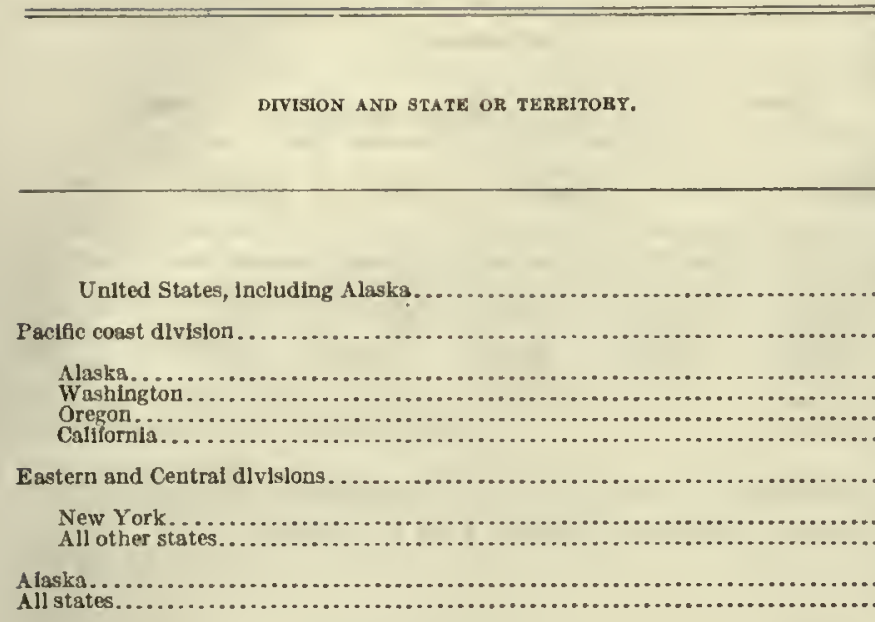

United States, Including Alaska.

Paclfic const division

$$
\text { Alaska..... }
$$

Eastern and Central divislons.

New York

All other states.

\begin{tabular}{|c|c|c|c|c|c|}
\hline Total. & Canned. & Plckled. & Smoked. & $\begin{array}{l}\text { Salted, fn- } \\
\text { cluding } \\
\text { mlld-cured. }\end{array}$ & $\begin{array}{l}\text { Frozen and } \\
\text { fresh. }\end{array}$ \\
\hline \multicolumn{6}{|c|}{ QUANTITY (POUNDS). } \\
\hline $256,414,000$ & $221,107,000$ & - $19,053,000$ & $4,297,000$ & $8,540,000$ & $3,418,000$ \\
\hline $252,982,000$ & $221,107,000$ & $19,053,000$ & 971,000 & $8,434,000$ & $3,418,000$ \\
\hline $\begin{array}{r}198,953,000 \\
28,954,000 \\
21,914,000 \\
3,162,000\end{array}$ & $\begin{array}{r}182,483,000 \\
22,091,000 \\
16,339,000 \\
189,000\end{array}$ & $\begin{array}{r}13,713,000 \\
780,000 \\
3,959,000 \\
600,000\end{array}$ & $\begin{array}{r}48,000 \\
800,000 \\
80,000 \\
42,000\end{array}$ & $\begin{array}{r}1,646,000 \\
4,457,000 \\
2,331,000\end{array}$ & $\begin{array}{r}1,057,000 \\
825,000 \\
1,536,000 \\
\ldots . . .\end{array}$ \\
\hline $3,432,000$ & $\because \ldots \ldots+\ldots$ & n....... & $3,327,000$ & 105,000 & \\
\hline $\begin{array}{r}2,504,000 \\
928,000\end{array}$ & & 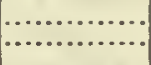 & $\begin{array}{r}2,504,000 \\
823,000\end{array}$ & 105,000 & … \\
\hline $\begin{array}{r}198,953,060 \\
57,461,000\end{array}$ & $\begin{array}{r}182,488,000 \\
38,618,000\end{array}$ & $\begin{array}{r}13,713,000 \\
5,339,000\end{array}$ & $\begin{array}{r}48,000 \\
4,249,000\end{array}$ & $\begin{array}{l}1,646,000 \\
6,893,000\end{array}$ & $\begin{array}{l}1,057,000 \\
2,361,000\end{array}$ \\
\hline
\end{tabular}

Alaska...
SALMON PRODUCT OF CANNERIES AND PACKuNG HOUSES: 1908.

\begin{tabular}{|c|c|c|c|c|c|}
\hline$\$ 16,638,000$ & $\$ 14,132,000$ & $\$ 1,053,000$ & $\$ 678,000$ & $\$ 541,000$ & $\$ 234,000$ \\
\hline $16,017,000$ & $14,132,000$ & $1,053,000$ & 60,000 & 538,000 & 234,000 \\
\hline $\begin{array}{r}10,672,000 \\
2,731,000 \\
2,256,000 \\
359,000\end{array}$ & $\begin{array}{r}10,186,000 \\
2,362,000 \\
1,565,000 \\
20,000\end{array}$ & $\begin{array}{r}353,000 \\
76,000 \\
552,000 \\
72,000\end{array}$ & $\begin{array}{r}4,000 \\
39,000 \\
11,000 \\
6,300\end{array}$ & $\begin{array}{r}79,000 \\
199,000 \\
261,000\end{array}$ & $\begin{array}{r}51,000 \\
55,000 \\
129,000 \\
\ldots \ldots \ldots\end{array}$ \\
\hline 621,000 & 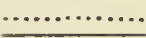 & . & 618,000 & 2,800 & \\
\hline $\begin{array}{l}460,000 \\
161,000\end{array}$ & & & $\begin{array}{l}460,000 \\
158,000\end{array}$ & 2,800 & \\
\hline $\begin{array}{r}10,672,000 \\
5,966,000\end{array}$ & $\begin{array}{r}10,186,000 \\
3,946,000\end{array}$ & $\begin{array}{l}353,000 \\
700,000\end{array}$ & $\begin{array}{r}4,000 \\
674,000\end{array}$ & $\begin{array}{r}79,000 \\
462,000\end{array}$ & $\begin{array}{r}51,000 \\
183,000\end{array}$ \\
\hline
\end{tabular}

VALUE.

Includes a value of $\$ 59,000$ reported for salmon bellies.

Includes a value of $\$ 48,000$ reported for fresh salmon.

cent of the California product was salted, while practically all of that prepared in the Eastern and Central states was smoked. Of the total product of salmon treated in the United States, including Alaska, 86 per cent was canned.

The following tabular statement gives comparative statistics as to the quantity and value of the salmon treated in the United States, inclusive of Alaska, by states, arranged in the order of the value in 1908:

\begin{tabular}{|c|c|c|c|c|c|c|}
\hline \multirow{3}{*}{ BTATE OR TERRITORY. } & \multicolumn{6}{|c|}{ SALMON PRODUCT OF CANNERIES AND PACKINO HOUSES. } \\
\hline & \multicolumn{2}{|c|}{1908} & \multicolumn{2}{|c|}{1905 . } & \multicolumn{2}{|c|}{1900} \\
\hline & $\begin{array}{l}\text { Quantity } \\
\text { (pounds). }\end{array}$ & Value. & $\begin{array}{l}\text { Quantity } \\
\text { (pounds). }\end{array}$ & Value. & $\begin{array}{l}\text { Quantity } \\
\text { (pounds). }\end{array}$ & Value. \\
\hline United States, Including Alaska........... & $256,414,000$ & $\$ 16,638,000$ & $190,529,000$ & $\$ 13,633,000$ & $116,621,000$ & $\$ 9,423,000$ \\
\hline 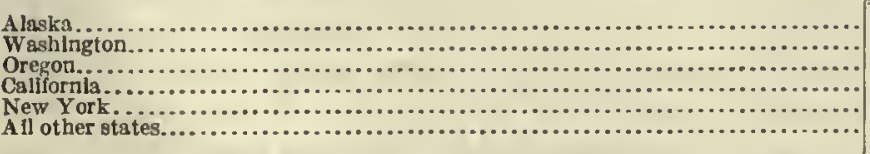 & $\begin{array}{r}198,953,000 \\
28,954,000 \\
21,914,000 \\
3,162,000 \\
2,504,000 \\
928,000\end{array}$ & $\begin{array}{r}10,672,000 \\
2,731,000 \\
2,256,000 \\
359,000 \\
460,000 \\
161,000\end{array}$ & $\begin{array}{r}126,370,000 \\
32,034,000 \\
27,262,000 \\
(1) \\
1,881,000 \\
2,982,000\end{array}$ & $\begin{array}{l}7,731,000 \\
2,909,000 \\
2,392,000 \\
(1) \\
320,000 \\
281,000\end{array}$ & $\begin{array}{r}51,992,000 \\
44,317,000 \\
16,165,000 \\
3,679,000 \\
97,000 \\
371,000\end{array}$ & $\begin{array}{r}3,608,000 \\
3,840,000 \\
1,665,000 \\
270,000 \\
14,000 \\
27,000\end{array}$ \\
\hline
\end{tabular}

The methods of treatment employed vary in the different sections of the country; for instance, 74 per

Included under "All other states."

Sardines.-Since 1875, when the first factory for canning sardines in the United States was started at Eastport, Me., that state has held a practical monopoly of the industry.
The tabular statement following gives the quantity. and value of sardines packed, by states, for 1900, 1905 , and 1908. 


\begin{tabular}{|c|c|c|c|c|c|c|}
\hline \multirow{3}{*}{ ETATE. } & \multicolumn{4}{|c|}{ SARDINES PACKED. } & \multicolumn{2}{|c|}{ • } \\
\hline & \multicolumn{2}{|c|}{$1908^{\circ}$} & \multicolumn{2}{|c|}{1905} & \multicolumn{2}{|c|}{1900} \\
\hline & $\begin{array}{l}\text { Quantlity } \\
\text { (pounds). }\end{array}$ & Value. & $\begin{array}{l}\text { Quantlty } \\
\text { (pounds). }\end{array}$ & Value. & $\begin{array}{l}\text { Quantity } \\
\text { (pounds). }\end{array}$ & Value. \\
\hline Unlted States............ & $72,203,000$ & $\$ 5,309,000$ & $87,225,000$ & $\$ 4,380,000$ & $44,951,000$ & $\$ 4,212,000$ \\
\hline 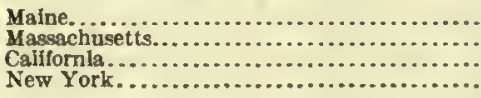 & $\begin{array}{r}68,216,000 \\
2,322,000 \\
1,634,000 \\
32,000\end{array}$ & $\begin{array}{r}4,732,000 \\
369,000 \\
207,000 \\
1,900\end{array}$ & $\begin{array}{l}86,219,000 \\
(2), 000 \\
860,000 \\
146,000\end{array}$ & $\begin{array}{l}4,291,000 \\
(2), 000 \\
78,000 \\
11,000\end{array}$ & $\begin{array}{l}44,420,000 \\
142,000 \\
389,000 \\
\left({ }^{2}\right)\end{array}$ & $\begin{array}{l}4,050,000 \\
84,000 \\
79,000 \\
(3)^{7}\end{array}$ \\
\hline
\end{tabular}

1 Not including 120,000 pounds of "Russian sardines," valued at $\$ 2,100$.

None reported.

Cod.-The cod product treated in 1908 amounted to $66,382,000$ pounds, valued at $\$ 4,692,000$. The following table shows the quantity and value of this product according to the method of treatment, for the United States, including Alaska, and by states:

\begin{tabular}{|c|c|c|c|c|c|}
\hline \multirow{3}{*}{ DIVISION AND STATE OR TERRITORT. } & \multicolumn{5}{|c|}{ COD PACKED : 1908.} \\
\hline & Total. & Boned. & Salted. & Pickled. & $\begin{array}{l}\text { Frozen, } \\
\text { fresh, and } \\
\text { smoked. }\end{array}$ \\
\hline & \multicolumn{5}{|c|}{ QUANTITY (POUNDS). } \\
\hline United States, Inclnding Alaska........ & $66,382,000$ & $32,784,000$ & $27,776,000$ & $5,785,000$ & 37,000 \\
\hline Atlantic coast division ............... & $49,526,000$ & $32,557,000$ & $15,883,000$ & $1,083,000$ & 3,000 \\
\hline 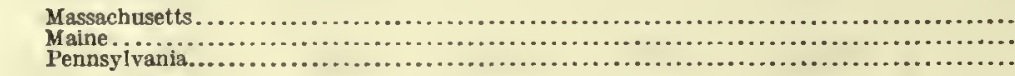 & $\begin{array}{r}41,337,000 \\
8,097,000 \\
91,000\end{array}$ & $\begin{array}{r}31,968,000 \\
589,000 \\
\ldots\end{array}$ & $\begin{array}{r}8,369,000 \\
7,426,000 \\
88,000\end{array}$ & $\begin{array}{r}1,000,000 \\
83,000 \\
\ldots . . .\end{array}$ & 3,000 \\
\hline Pacific coast division ............. & $16,8.56,000$ & 227,000 & $11,893,000$ & $4,702,000$ & 34,000 \\
\hline 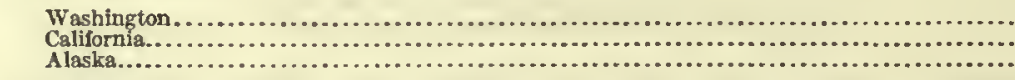 & $\begin{array}{l}4,551,000 \\
6,902,000 \\
5,403,000\end{array}$ & $\begin{aligned} 227,000 \\
\cdots \cdots \\
\cdots \cdots\end{aligned}$ & $\begin{array}{l}4,324,000 \\
2,200,000 \\
5,369,000\end{array}$ & $\ddot{4}, 702,0000$ & 34,000 \\
\hline \multirow[t]{2}{*}{ 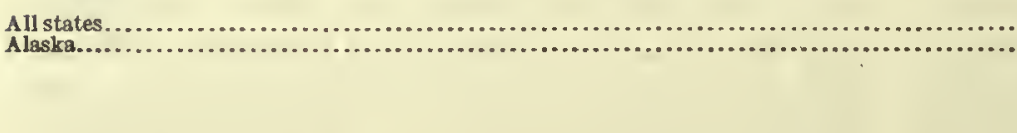 } & $\begin{array}{r}60,979,000 \\
5,403,000\end{array}$ & $\begin{array}{r}32,784,000 \\
\cdots\end{array}$ & $\begin{array}{r}22,407,000 \\
5,369,000\end{array}$ & $\begin{array}{r}5,785,000 \\
\cdots \cdots\end{array}$ & $\begin{array}{r}3,000 \\
34,000\end{array}$ \\
\hline & \multicolumn{5}{|c|}{ VALUE. } \\
\hline United States, including Alaska.............. & $\$ 4,692,000$ & $83,250,000$ & $\$ 1,237,000$ & $\$ 202,000$ & 82,800 \\
\hline Atlantic coast division ....... & $4,101,000$ & $3,238,000$ & 812,000 & 51,000 & 200 \\
\hline 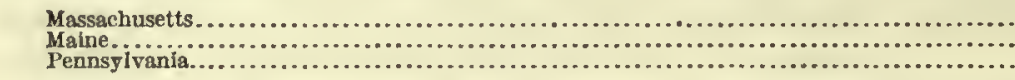 & $\begin{array}{r}3,726,000 \\
365,000 \\
10,000\end{array}$ & $\begin{array}{r}3,179,000 \\
59,000 \\
\ldots\end{array}$ & $\begin{array}{r}497,000 \\
305,000 \\
9,900\end{array}$ & $\begin{array}{r}50,000 \\
1,400 \\
2 .\end{array}$ & ano \\
\hline Paclfic coast dlvision ........ & 591,000 & 12,000 & $\$ 26,000$ & 150,000 & 2,600 \\
\hline 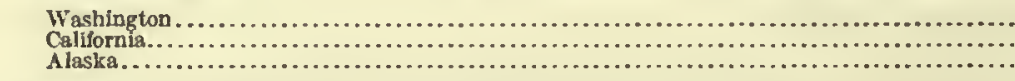 & $\begin{array}{l}229,000 \\
227,000 \\
135,000\end{array}$ & \begin{tabular}{r|r}
12,000 \\
$\cdots \cdots \cdots$ \\
$\cdots \cdots \cdots$
\end{tabular} & $\begin{array}{r}217,000 \\
77,000 \\
132,000\end{array}$ & 150,000 & 2,600 \\
\hline 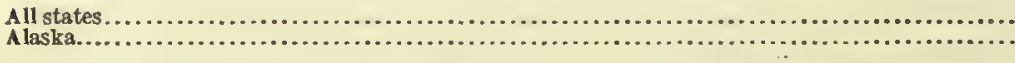 & $\begin{array}{r}4,557,000 \\
135,000\end{array}$ & $\begin{array}{r}3,250,000 \\
-\ldots\end{array}$ & $\begin{array}{r}1,105,000 \\
132,000\end{array}$ & 202,000 & $\begin{array}{r}200 \\
2,600\end{array}$ \\
\hline
\end{tabular}

The value reported for 1908 represents an increase of $\$ 1,678,000$, or more than 50 per cent, over the value reported for 1905 , which was $\$ 3,013,000$. In 1900 the product was valued at $\$ 3,109,000$. The next table shows, by geographic divisions and by states, the quantity and value of cod reported by canning and packing establishments in the United States, including Alaska, for 1900, 1905, and 1908.

No figures are shown for Alaska for 1905, but a comparison of the figures for 1900 and 1908 reveals an increase of 685 per cent in the quantity and of 382 per cent in the value of the cod prepared by the canneries and salteries of this territory.
The product of Massachusetts represented 62 per cent of the total quantity and 79 per cent of the total value of cod treated in canneries and packing houses. Maine reported a value of $\$ 365,000$; Washington, $\$ 229,000$; California, $\$ 227,000$; Alaska, $\$ 135,000$; and Pennsylvania, $\$ 10,000$. There seems to be a rapidly growing demand for boned cod. While but 49 per cent of the total amount in 1908 was boned, the value of the product thus treated formed 69 per cent of the total value. In Washington nearly all of the cod was salted, and in California about two-thirds was pickled and the rest salted. 


\begin{tabular}{|c|c|c|c|c|c|c|}
\hline \multirow{3}{*}{ DIVISION AKD BTATE OR TEREITOBY. } & \multicolumn{6}{|c|}{ COD PACKED. } \\
\hline & \multicolumn{2}{|c|}{1908} & \multicolumn{2}{|c|}{1905} & \multicolumn{2}{|c|}{1800} \\
\hline & $\begin{array}{l}\text { Quantity } \\
\text { (pounds). }\end{array}$ & Value. & $\begin{array}{l}\text { Quantity } \\
\text { (pounds). }\end{array}$ & Value. & $\begin{array}{l}\text { Quantity } \\
\text { (pounds). }\end{array}$ & Value. \\
\hline United States, Including Alaska.............. & $66,382,000$ & $\$ 4,692,000$ & $48,758,000$ & $\$ 3,013,000$ & $65,419,000$ & $\$ 3,109,000$ \\
\hline Atlantic coast divislon .. & $49,526,000$ & $4,101,000$ & $40,620,000$ & $2,655,000$ & $57,088,000$ & $2,628,000$ \\
\hline 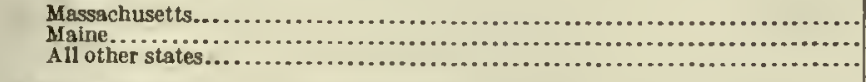 & $\begin{array}{r}41,337,000 \\
8,097,000 \\
91,000\end{array}$ & $\begin{array}{r}3,726,000 \\
365,000 \\
10,000\end{array}$ & $\begin{array}{r}37,913,000 \\
2,682,000 \\
24,000\end{array}$ & $\begin{array}{r}2,511,000 \\
141,000 \\
2,200\end{array}$ & $\begin{array}{r}48,501,000 \\
8,535,000 \\
52,000\end{array}$ & $\begin{array}{r}2,545,000 \\
80,000 \\
3,100\end{array}$ \\
\hline Pacific coast division .......... & $16,856,000$ & 591,000 & $8,138,000$ & 359,000 & $8,330,000$ & 480,000 \\
\hline 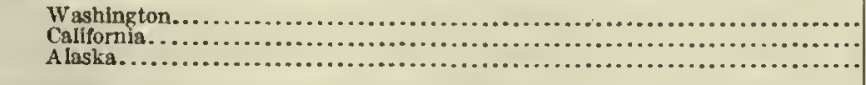 & $\begin{array}{l}4,551,000 \\
6,902,000 \\
5,403,000\end{array}$ & $\begin{array}{l}229,000 \\
227,000 \\
135,000\end{array}$ & $\begin{array}{r}877,000 \\
7,261,000 \\
\cdots\end{array}$ & $\begin{array}{r}49,000 \\
309,000 \\
\cdots\end{array}$ & $\begin{array}{r}954,000 \\
6,688,000 \\
688,000\end{array}$ & $\begin{array}{r}45,000 \\
407,000 \\
28,000\end{array}$ \\
\hline 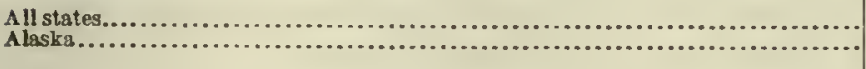 & $\begin{array}{r}60,979,000 \\
5,403,000\end{array}$ & $\begin{array}{r}4,557,000 \\
135,000\end{array}$ & $\begin{array}{r}48,758,000 \\
\ldots \ldots \ldots \ldots\end{array}$ & $3,013,000$ & $\begin{array}{r}64,731,000 \\
688,000\end{array}$ & $\begin{array}{r}3,081,000 \\
28,000\end{array}$ \\
\hline
\end{tabular}

Oysters.-The following table gives the cannedoyster product, by states, for 1908:

\begin{tabular}{|c|c|c|}
\hline \multirow{2}{*}{ DIVISION AND STATE. } & \multicolumn{2}{|c|}{$\begin{array}{l}\text { OYSTERS CANNED: } \\
1908 .\end{array}$} \\
\hline & $\begin{array}{l}\text { Quantity } \\
\text { (pounds). }\end{array}$ & Value. \\
\hline United States....... & $46,593,000$ & $\$ 3,428,000$ \\
\hline A tlantic coast division .. & $25,924,000$ & $1,794,000$ \\
\hline 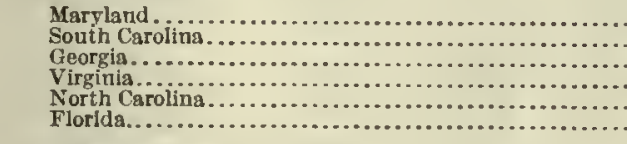 & $\begin{array}{l}7,651,000 \\
9,426,000 \\
4,853,000 \\
1,856,000 \\
1,055,000 \\
1,083,000\end{array}$ & $\begin{array}{r}599,000 \\
525,000 \\
374,000 \\
163,000 \\
70,000 \\
62,000\end{array}$ \\
\hline Gulf of Mexico division.... & $20,220,000$ & $1,528,000$ \\
\hline 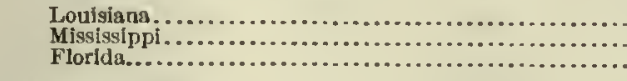 & $\begin{array}{l}9,969,000 \\
7,835,000 \\
2,422,000\end{array}$ & $\begin{array}{l}770,000 \\
625,000 \\
134,000\end{array}$ \\
\hline Pacific coast division $. . . . . . \ldots \ldots \ldots . .$. & 444,000 & 106,000 \\
\hline 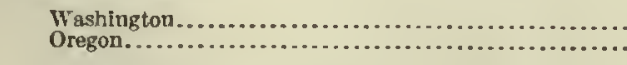 & $\begin{array}{r}413,000 \\
30,000\end{array}$ & $\begin{array}{r}100,000 \\
6,100\end{array}$ \\
\hline
\end{tabular}

Louisiana held first place in the value of oysters canned, followed by Mississippi, Maryland, and South Carolina, in the order named. In 1905 Mississippi ranked first, Maryland second, South Carolina third, and Louisiana fourth. In 1900 Maryland was first and Mississippi second. The next tabular statement shows the quantity and value of the canned oyster product for 1900,1905 , and 1908 , by states ranked according to the value reported in 1908 .

The value of the canned oyster product was $\$ 371,000$ less in 1908 than in 1905, but it was greater than in 1900 by $\$ 1,893,000$, or 123 per cent. The decrease from 1905 to 1908 occurred principally in Mississippi and North Carolina.

Shrimp and prawn.-In 1908, as in earlier years, practically all these crustaceans were packed in Louisiana and Mississippi, the former reporting 54 per cent and the latter 44 per cent of the total value of product.

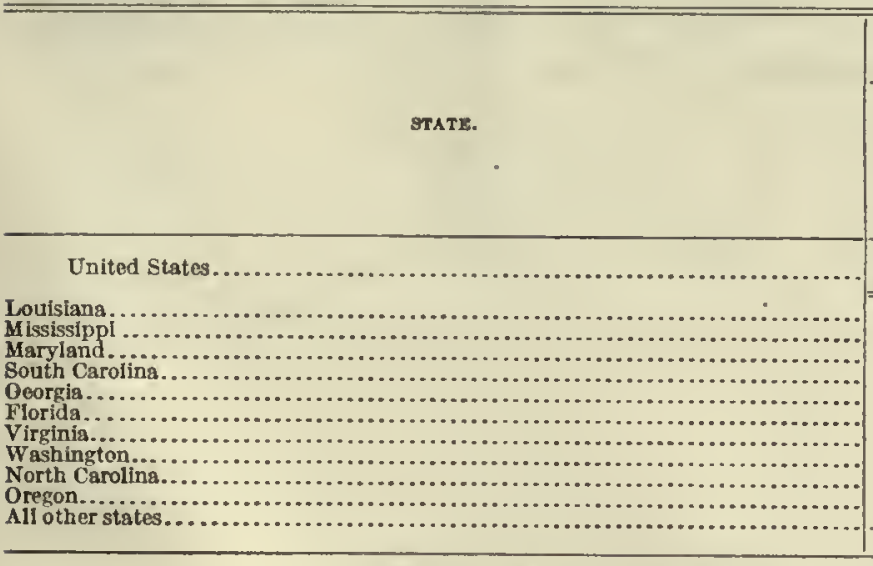

1 lncluded In the total for "All other states."

\begin{tabular}{|c|c|c|c|c|c|}
\hline \multicolumn{6}{|c|}{ OYSTERS CANNED. } \\
\hline \multicolumn{2}{|c|}{1908} & \multicolumn{2}{|c|}{1905} & \multicolumn{2}{|c|}{1900} \\
\hline $\begin{array}{l}\text { Quantity } \\
\text { (pounds). }\end{array}$ & Value. & $\begin{array}{l}\text { Quantity } \\
\text { (pounds). }\end{array}$ & Value. & $\begin{array}{l}\text { Quantity } \\
\text { (pounds). }\end{array}$ & Value. \\
\hline $46,593,000$ & $\$ 3,428,000$ & $59,249,000$ & $\$ 3,799,000$ & $20,792,000$ & $\$ 1,536,000$ \\
\hline $\begin{array}{r}9,969,000 \\
7,835,000 \\
7,651,000 \\
9,426,000 \\
4,853,000 \\
3,505,000 \\
1,856,000 \\
413,000 \\
1,055,000 \\
30,000 \\
\ldots . . . . . .\end{array}$ & $\begin{array}{r}770,000 \\
625,000 \\
599,000 \\
525,000 \\
374,000 \\
195,000 \\
163,000 \\
100,000 \\
70,000 \\
6,100\end{array}$ & $\begin{array}{r}7,126,000 \\
21,952,000 \\
6,666,000 \\
9,251,000 \\
4,794,000 \\
1,802,000 \\
\text { (1) } \\
\text { (3) } \\
2,526,000 \\
\text { (1) } \\
5,132,000\end{array}$ & $\begin{array}{r}507,000 \\
1,341,000 \\
549,000 \\
530,000 \\
257,000 \\
126,000 \\
(1) \\
(3) \\
144,000 \\
(1) \\
346,000\end{array}$ & $\begin{array}{c}1,273,000 \\
6,078,000 \\
6,916,000 \\
(1) \\
(1) \\
1,504,000 \\
(1) \\
50,000 \\
(1) \\
(3) \\
4,972,000\end{array}$ & $\begin{array}{l}72,000 \\
495,000 \\
570,000 \\
(1) \\
(1) \\
96,000 \\
(1) \\
17,000 \\
(1) \\
\text { (3) } 286,000\end{array}$ \\
\hline
\end{tabular}

None reported.
The tabular statement following gives the quantity and value of the preserved shrimp and prawn product in 1908, distributed by method of treatment and by states. 


\begin{tabular}{|c|c|c|c|c|c|c|}
\hline \multirow{3}{*}{ STATE. } & \multicolumn{6}{|c|}{ SHRIMP AND PRAWN PRESERVED: 1908.} \\
\hline & \multicolumn{2}{|c|}{ Total. } & \multicolumn{2}{|c|}{ Canned. } & \multicolumn{2}{|c|}{ Drled and pickled. } \\
\hline & $\begin{array}{l}\text { Quantity } \\
\text { (pounds). }\end{array}$ & Value. & $\begin{array}{l}\text { Quantity } \\
\text { (pounds). }\end{array}$ & Value. & $\begin{array}{l}\text { Quantity } \\
\text { (pounds). }\end{array}$ & Value. \\
\hline United Ststes.. & $3,772,000$ & $\$ 742,000$ & $3,273,000$ & $\$ 657,000$ & 500,000 & $\$ 85,000$ \\
\hline 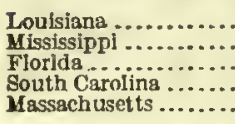 & $\begin{array}{r}1,986,000 \\
1,704,000 \\
75,000 \\
8,300 \\
400\end{array}$ & $\begin{array}{r}103,000 \\
329 ; 000 \\
9,000 \\
1,000 \\
100\end{array}$ & $\begin{array}{r}1,644,000 \\
1,625,000 \\
3,500 \\
400\end{array}$ & \begin{tabular}{r}
334,000 \\
322,000 \\
\hdashline$\cdots 00$ \\
100
\end{tabular} & 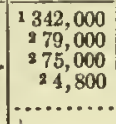 & $\begin{array}{r}69,000 \\
6,600 \\
9,000 \\
500 \\
\ldots .\end{array}$ \\
\hline
\end{tabular}

3 Dried.

Pickled.

The quantity and value of the preserved shrimp and prawn product, as reported at the canvasses of 1900 , 1905, and 1908, are shown at top of next column.

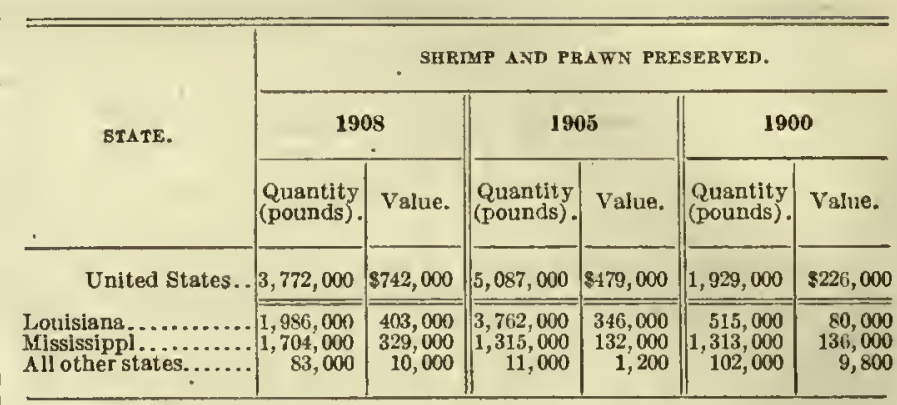

Although the quantity preserved in the United States in 1908 was less than in 1905 , the value of the product showed a large increase. Compared with the figures for 1900 , there is shown an increase of 96 per cent in quantity and 228 per cent in value.

TABLE 1.-CANNING AND PRESERVING, FISH AND OYSTERS-VALUE OF FOOD PRODUCTS: 1908.

\begin{tabular}{|c|c|c|c|c|c|c|c|}
\hline \multirow{2}{*}{ KIND OF PRODUCT. } & \multicolumn{7}{|c|}{ CANNINO AND PRESERVING, FISH AND OYSTERS-VALUE OF FOOD FRODUCTS: 1908.} \\
\hline & Total. & Canned. & Boned. & Smoked. & $\begin{array}{l}\text { Salted, } \\
\text { including } \\
\text { mild-cured. }\end{array}$ & Pickled. & $\begin{array}{c}\text { Frozen } \\
\text { and fresh. }\end{array}$ \\
\hline Total .. & $\$ 24,885,000$ & $814,142,000$ & $\$ 3,526,000$ & $\$ 2,818,000$ & $82,386,000$ & $\$ 1,694,000$ & $\$ 318,000$ \\
\hline 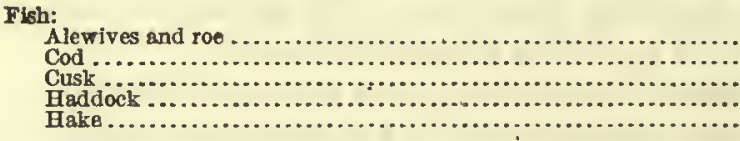 & $\begin{array}{r}287,000 \\
4,557,000 \\
76,000 \\
594,000 \\
214,000\end{array}$ & 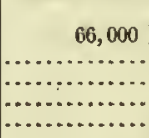 & $\begin{array}{r}3,250,000 \\
11,000 \\
68,000 \\
35,000\end{array}$ & $\begin{array}{r}7,400 \\
\cdots \ldots, \ldots \ldots \\
308,000 \\
\cdots\end{array}$ & $\begin{array}{r}1,105,000 \\
65,000 \\
183,000 \\
179,000\end{array}$ & $\begin{array}{r}214,000 \\
202,000 \\
1,000 \\
35,000 \\
100\end{array}$ & ....... \\
\hline 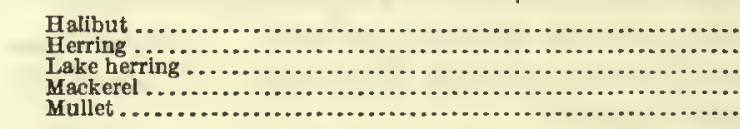 & $\begin{array}{r}157,000 \\
667,000 \\
180,000 \\
462,000 \\
64,000\end{array}$ & $\begin{array}{r}8,400 \\
48,000 \\
3,000\end{array}$ & $\begin{array}{r}123,000 \\
\ldots \ldots \ldots . . .\end{array}$ & $\begin{array}{r}114,000 \\
451,000 \\
426,000 \\
13,000\end{array}$ & $\begin{array}{l}20,000 \\
16,000 \\
61,000\end{array}$ & $\begin{array}{r}1200 \\
74,000 \\
4,600 \\
402,000\end{array}$ & $\begin{array}{l}22,000 \\
10,000 \\
33,000\end{array}$ \\
\hline 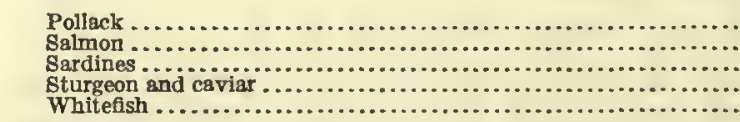 & $\begin{array}{r}169,000 \\
5,966,000 \\
5,311,000 \\
468,000 \\
263,000\end{array}$ & $\begin{array}{r}3,946,000 \\
5,307,000 \\
3,400\end{array}$ & 40,000 & $\begin{array}{r}200 \\
674,000 \\
100 \\
453,000 \\
257,000\end{array}$ & $\begin{array}{r}128,000 \\
462,000 \\
2,100 \\
4,100\end{array}$ & $\begin{array}{r}200 \\
700,000 \\
1,900 \\
\cdots \cdots \\
200\end{array}$ & $\begin{array}{r}183,000 \\
12,000 \\
1,900\end{array}$ \\
\hline 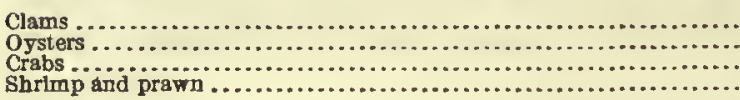 & $\begin{array}{r}421,000 \\
3,428,000 \\
166,000 \\
742,000\end{array}$ & $\begin{array}{r}412,000 \\
3,428,000 \\
166,000 \\
657,000\end{array}$ & .................. & ............ & 69,000 & $\begin{array}{r}8,600 \\
\ldots \ldots \ldots\end{array}$ & $\ldots . .$. \\
\hline All other $. . . . \ldots \ldots \ldots \ldots \ldots \ldots . . . . . .$. & 391,000 & 97,000 & & 113,000 & 92,000 & 34,000 & 56,000 \\
\hline
\end{tabular}

3 Value of halibut fins. 
TABLE 2.-CANNING AND PRESERVING, FISH AND OYSTERS-PRODUCTS, BY GEOGRAPHIC DIVISIONS, METHOD OF TREATMENT, AND KIND: 1908.

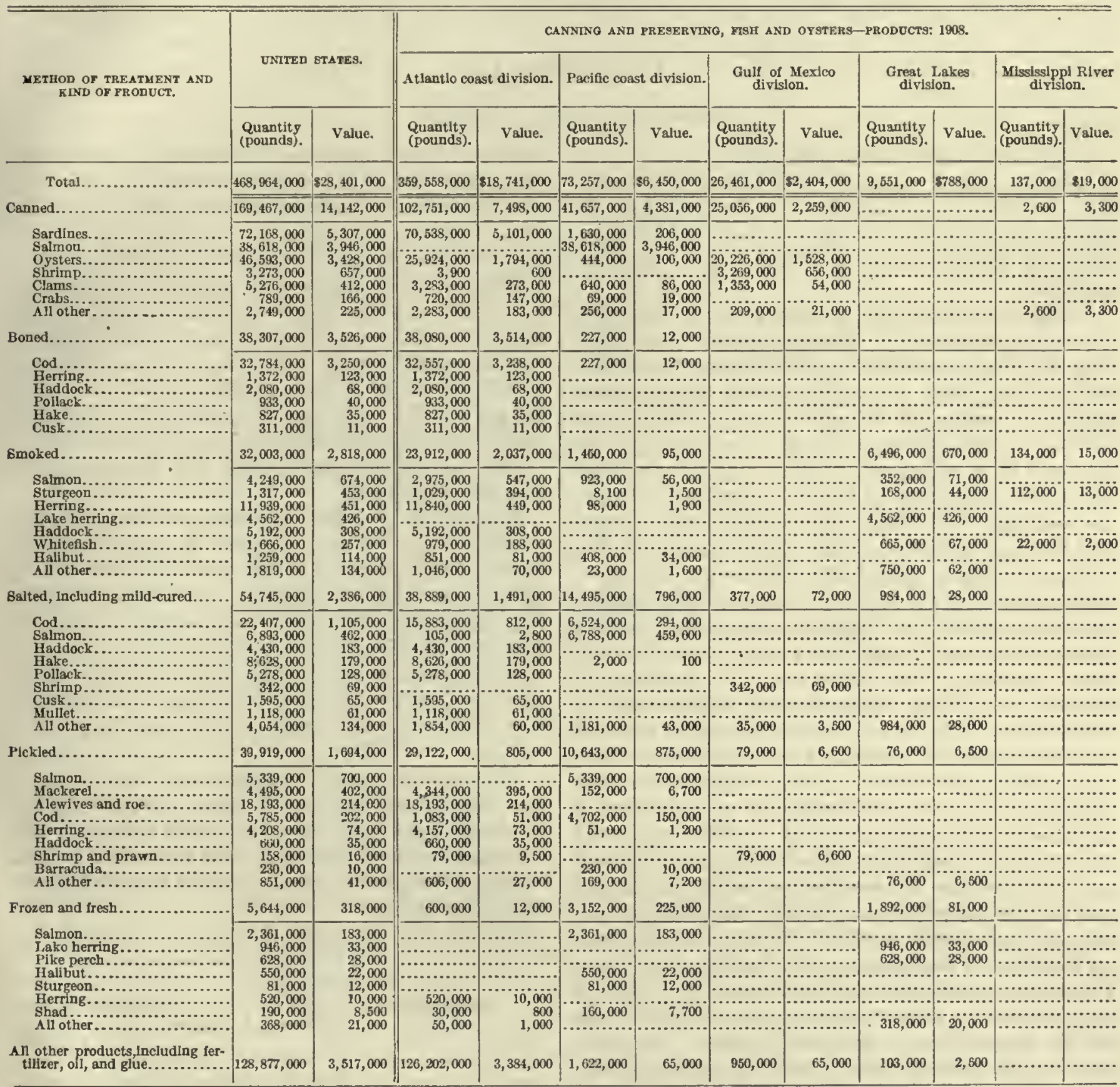




\section{CHAPTER IX.}

\section{EXPORTS AND IMPORTS. ${ }^{1}$}

Comparison with domestic production.-The exports of domestic fishery products for the fiscal year ended June 30,1908 , were valued at $\$ 6,166,193$, and the imports for consumption for the same period were valued at $\$ 13,135,724$, or $\$ 6,969,531$ more than the exports.

Fresh fish formed but a small part of either the exports or the imports. The exports and imports of fresh fish were essentially to and from near-by countries, and so far as they are distinguishable and reported separately amounted in value to only $\$ 87,379$ and $\$ 1,772,164$, respectively. When these amounts are deducted from the gross exports and imports there remain the large sums of $\$ 6,078,814$ and $\$ 11,363,560$, representing, respectively, the value of the exports and imports of fishery products other than fresh fish during the fiscal year 1908. Obviously, therefore, any comparison of exports and imports with domestic production must deal with the products of the fish canning and preserving industry rather than with the main products of the fisheries. The statistics of domestic production, exports, and imports may be correlated so as to show in a general way the value of the fishery products available for consumption. Such a comparison is, however, necessarily defective, not only because the values of products in the census of the fisheries are those reported by the fishermen or the manufacturers, while the values of products exported and imported, are the commercial values at the port and may be therefore considerably different, but also because there is no record of the value of the stock on hand at the beginning and at the end of the year. Furthermore, the statistics for exports and imports are those for the fiscal year ended June 30, while those for the fisheries are for the calendar year. The products of fish canning and preserving establishments, however, inclusive of those of Alaska, had a value of $\$ 35,902,847$ in 1908 . As a considerable amount of fish was cured or preserved by the fishermen, this should be added to the products of the fish canning and preserving establishments, for comparative purposes; and as these exports and imports of fishery products include oil, whalebone, and sponges, the amounts reported for these products by the fisheries should be also added. The sum secured by making these combinations, $\$ 38,910,295$, represents the value

\footnotetext{
1 The figures used in this chapter have been taken from "Commerce and Navigation of the United States," Bureau of Statistica, Department of Commerce and Labor.
}

for the domestic production which is in a general way comparable with the figures for the exports and imports of fishery products other than fresh fish. This total comprises the products of the fish canning and preserving industry in continental United States, $\$ 35,902,847$; fish salted and smoked by fishermen, $\$ 1,948,635$; fish oil, whale oil, and sea-elephant oil, $\$ 298,717$; whalebone, $\$ 215,226$; and sponges, $\$ 544,870$. The excess of the value of imports over that of exports, $\$ 6,969,531$, added to the above total, gives the sum of $\$ 45,879,826$ for the United States consumption of fishery products other than fresh fish, of which amount 15 per cent represented imports and. 85 per cent the domestic production.

Comparison of exports and imports.-In 1890 and previous years the total exports of fishery products exceeded the imports, and the balance of trade was in favor of the United States; but by 1895 the balance had shifted and the.imports exceeded the exports, and since the latter year the balance of trade has uniformly been against the United States. The difference increased rapidly, until in 1907 and 1908 the debit balance of trade was in excess of the total value of the exports.

The following tabular statement gives the values of the imports and exports of fishery products for certain years since 1875, and the resulting balances. This statement includes the value of all fish, whether fresh, canned, or otherwise treated, fish and whale oil, whalebone, and sponges.

\begin{tabular}{|c|c|c|c|c|}
\hline \multirow[b]{2}{*}{ FISCAL TEAR. } & \multicolumn{4}{|c|}{ VALUE OF FISHERY PRODUCTS. } \\
\hline & Imports. & Exports. & $\begin{array}{l}\text { Excess of } \\
\text { imports } \\
\text { over } \\
\text { exports. }\end{array}$ & $\begin{array}{l}\text { Excess of } \\
\text { exports } \\
\text { over } \\
\text { imports. }\end{array}$ \\
\hline 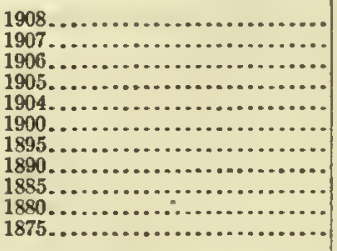 & $\begin{array}{r}\$ 13,135,724 \\
13,224,049 \\
12,599,201 \\
11,530,487 \\
11,052,236 \\
8,230,121 \\
6,237,287 \\
5,815,284 \\
5,247,404 \\
3,813,299 \\
3,350,748\end{array}$ & $\begin{array}{r}86,166,193 \\
6,238,570 \\
8,100,879 \\
7,096,340 \\
8,368,016 \\
6,163,113 \\
5,408,870 \\
7,336,993 \\
5,891,164 \\
5,114,926 \\
4,716,655\end{array}$ & $\begin{array}{r}\$ 6,969,531 \\
6,985,479 \\
4,498,322 \\
4,434,147 \\
2,684,220 \\
2,067,008 \\
828,417 \\
\ldots \ldots \ldots \ldots \ldots \\
\ldots \ldots \ldots \ldots \ldots \\
\ldots \ldots \ldots \ldots . . .\end{array}$ & 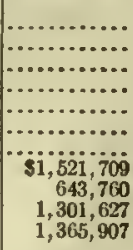 \\
\hline
\end{tabular}

In the case of whale oil the excess of imports over exports did not begin until 1900; whalebone exports, on the other hand, have always exceeded imports, but by varying amounts. It will be seen that the growth in the debit balance is due chiefly to a marked increase in the value of imports. Table 1, on page 291, 
gives the quantity and value of the exports of domestic fishery products, distributed by kinds, for the fiscal years 1890,1900 , and 1908; and Table 2 , on page 291 , gives for the same years the value of the domestic exports, by country to which exported. The quantity and value of the imports reported for the fiscal years 1890,1900 , and 1908 are distributed according to kind of product and country from which imported in Table 3 , on page 292 ; and the value of imports for these years is shown by country from which imported in Table 4, on page 293.

The exportation and importation of fishery products are governed largely by the location of the source of supply or market, shipping conditions, the direction of trade routes, etc.

The imports of salmon, which were valued at $\$ 229,881$, were all from near-by North American countries and the greater part were entered at North Atlantic and at northern border and lake ports. Manifestly, the proximity of the Canadian supply to the Eastern states made such importation cheaper than the transportation of the domestic product from the Paeifie coast. Similar situations, together with shipping conditions and the location of trade routes, account for the exportation of domestic cod, haddock, hake, pollack, and lierring to the West Indies and the Central American states, while quantities many times larger were imported from Europe, Canada, the West Indies, and elsewhere. In the case of sponges part of the imports consisted of various species not produced on the coast of Florida, although the largest portion came from the West Indies and comprised varieties very similar to those produced in Florida. On account of the location of trade routes New York is the center of both exportation and importation of this product. Oysters were imported, while they formed the most important fishery product exported next to salmon. Herring, the fish most extensively imported, had only a small value as an export, as explained above. Among other fishery products imported in large quantities were anchovies and sardines, pickled mackerel, of which only a small amount was exported, and lobsters, which formed no part of the exports of fishery products. Miscellaneous kinds of fresh fish and shellfish from Canada and other countries owe their interchange with like American products principally to differences in species, but also to the direction of the trade routes.

Exports.-Although the United States exported fishery products worth $\$ 6,166,193$ in 1908 , the production as a wloole was less than the consumption, and the fish importations, valued at $\$ 13,135,724$, did not overstock the market. Of the total value of the exports in 1908, 66 per cent represented the value of salmon, either canned, cured, or fresh, and 11 per cent that of oysters.

The preeminence of salmon among exports was maintained in each of the years for which statistics are given, the quantities differing only slightly. There has been, however, a marked change in the form in which the salmon has been exported; in 1890 praetically the entire quantity was canned, but in 1908 only 60 per cent of the amount exported was thus prepared. Although less salmon was exported in 1908 than in 1890 , the value of the smaller exportation was greater by $\$ 758,176$. On the other hand, the value of the oyster exports deereased.

The fishery products exported to the United Kingdom had a greater value than those exported to any other country, although the value of the exports to Germany was nearly as great. The former country is credited with 26 per cent and the latter with 25 per cent of the total value of our exports of fishery products. The German trade was much smaller, relatively, in 1900 and 1890, while the purchases of the United Kingdom for those years constituted 40 and 50 per cent, respectively, of the total value of the exports of fishery products of the United States.

The exports to the United Kingdom in 1908 were composed prineipally of canned salmon and comprised about half of that commodity exported. This country also took nearly a third of the oyster exports. The exports to Germany consisted almost wholly of cured salmon, over 86 per cent of the total exports of which went to that country. Of the exported whalebone, over 98 per cent represents product purchased by France.

The total exports to North American countries have gradually, though slightly, decreased since 1890 . The value of the exports to Canada, including Newfoundland, $\$ 431,800$, was larger in 1908 than that of the exports to any other country of this continent, forming 41 per cent of the total value of fishery products exported to countries of North America. Though this represents a decrease in both amount and percentage of the total since 1900, it is nearly twice as great as the corresponding value in 1890 . In 1890 the West Indies received a much larger share of our exported fishery products than did Canada, but since then the exports to these islands have steadily decreased, and a decrease has been manifest since 1900 even in the case of Cuba, despite the close political relations between that island and the United States during the past 10 years. But in view of the fact that there has been an increase as compard with 1890 in the value of the fishery products imported from the West Indies, it seems probable that the home demand rather than any loss of markets caused the decrease in the exportations to these islands. The exports of fishery products to the Central American states were much larger than in 1900 and 1890, this increase being in line with the increase in general trade with these states. Mexico, especially since 1900 , also shows a large increase in imports of fishery products from the United States, which was the result of the increased importation of canned salmon. 
The export trade in fish with South America has developed rapidly, especially that with Chile and Argentina, salmon being the principal kind exported. Of the great gain made in exports of fishery products to Brazil between 1890 and 1900, about one-half has been lost since the latter year. During the years from 1900 to 1908 the export trade with Asia, Oceania, and Africa also receded from the high-water mark of 1900.

Imports.-The aggregate value of fishery products imported into the United States in 1908 was $\$ 13,135,724$, of which amount the sum of $\$ 12,292,770$ represents the value of food-fish imports, including shellfish. Herring, the chief article imported, supplied 20 per cent of the latter value. The proportions that other leading commodities represented of the total value of the food-fish imports (including shellfish) were as follows: Anchovies and sardines, packed in oil or otherwise treated, 18 per cent; fresh fish, 14 per cent; canned or preserved mackerel, 12 per cent; lobsters, 11 per cent; and preserved cod, haddock, hake, and pollack, 7 per cent. Thus these commodities, together with herring, account for 83 per cent of the total value of food-fish and shellfish imports.

The bulk of the herring product, 97 per cent, was pickled or salted and of the quantity thus treated, 37 per cent came from the Netherlands and a slightly greater proportion, which, however, was of smaller value, from the United Kingdom. Anchovies and sardines, packed in oil or otherwise treated, came chiefly from Norway and France. The value of fresh fish imported was more thanotwenty times that of the fresh fish exported. The most important source of supplies of these latter imports was Canada, which also formed the principal market for our fresh fish exports.

Of the value reported for mackerel, 42 per cent represents imports from the United Kingdom, and 34 per cent imports from Norway. Lobsters were brought chiefly from Canada, while a substantial quantity came from British South Africa. Preserved cod, haddock, hake, and pollack were imported chiefly from Canada.

The proportions which the specified kinds of imports have represented of the total food-fish imports have been nearly the same in previous years, although herring has gained somewhat more rapidly than any of the other classes of fishery products. Not one of the classes of food-fish products for which statistics are presented shows a decrease in importation in 1908, as compared with 1890 .

In respect to whale and fish oil, imports from Newfoundland and Labrador led, but the increase in the value of the imports from Norway is to be noted, as is their high grade. The growth of such imports from Japar was also remarkable. The value of the total importation of sponges, of which 77 per cent represents the value of sponges obtained from the British West Indies and Cuba, was less in 1908 than in either 1890 or 1900.

Canada supplied the greatest value of imports of fishery products, contributing 37 per cent of the total in 1908 , the same proportion in 1900 , and 51 per cent in 1890. Imports from Europe furnished 54 per cent of the value of the imports in 1908; but the European country which led in this respect, the United Kingdom, though ranking second to Canada, supplied imports valued at less than half of the value of the Canadian product. The value of imports from the United Kingdom formed 17 per cent of the total value of our imports of fishery products in both 1908 and 1900 and 9 per cent in 1890.

Norway and Sweden, next in importance, supplied 15 per cent of the total value of the imports in 1908 , and the Netherlands 9 per cent. The value of the imports from the Netherlands formed in 1908 about the same proportion of the total value as in 1900 , but a slightly larger proportion than in 1890 , while for Norway the increase shown was more rapid than for any of the other leading countries. Of the total value of imports from Norway and Sweden in 1908, $\$ 1,927,412$ represents the value of importations from Norway and $\$ 95,874$ that of importations from Sweden.

While imports from Canada, the United Kingdom, Norway and Sweden combined, and the Netherlands have increased in value absolutely and relatively since 1890, those from France have lost both in absolute and in relative value since 1900 . The imports from Belgium and the West Indies have also fallen of in value since 1900 . The values credited to these three countries in 1908 are, however, greater than the corresponding figures for 1890 . In 1890 imports from France ranked second in value, those from Canada being first. In 1900 the former were surpassed only by those from the United Kingdom and Canada; while in 1908 France ranked fifth. This loss of position was due, especially, to a decrease in the importation of sardines.

The great increase in the value of the Norwegian imports was made up largely of increases in the value of anchovies, as well as in the values of mackerel and miscellaneous fish. Pickled or salted herring accounted chiefly for the increase in value shown for the United Kingdom, but there was also a large gain in the value of imports of miscellaneous fish from that country. The increase in the value of Canadian imports was common to all commodities except dried or smoked herring, but was most pronounced in the case of fresh fish, preserved cod, haddock, hake, and pollack, miscellaneous shellfish, and lobsters. 
EXPORTS AND IMPORTS.

'TABLE 1.-EXPORTS OF DOMESTIC FISHERY PRODUCTS: 1908, 1900, AND 1890.

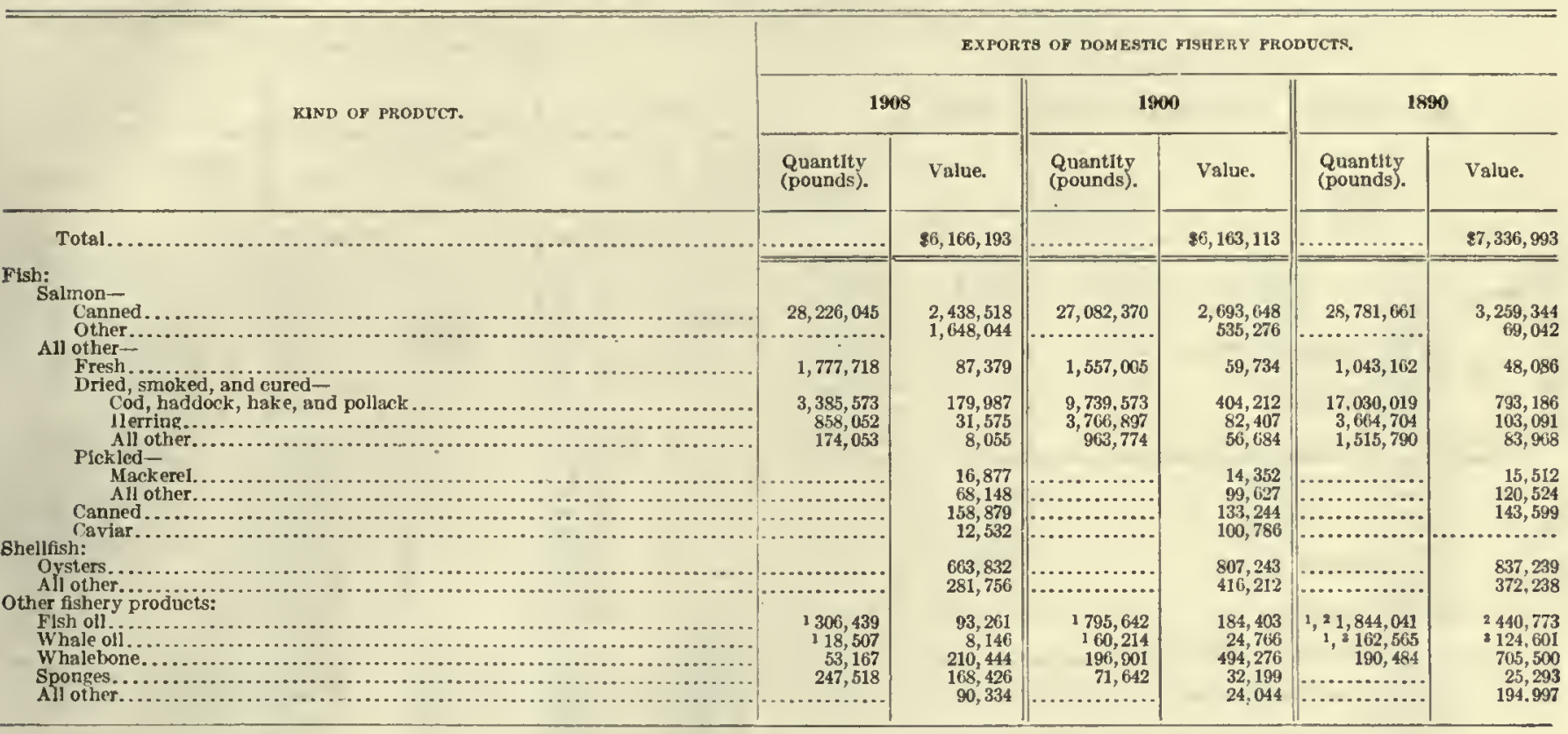

1 Gallons.

2 Includes whale oll.

Sperm oll. Whale oll included with fish oll.

TABLE 2.-VALUE OF EXPORTS OF DOMESTIC FISHERY PRODUCTS, BY COUNTRY TO WHICH EXPORTED: I908, 1900, AND 1890 .

COUNTRY TO WHCH EXPORTED, FIEHERY PROUUCTS.

\begin{tabular}{|c|c|c|c|}
\hline \multirow{2}{*}{ (a) } & \multirow{2}{*}{\multicolumn{2}{|c|}{1900}} & \multirow[b]{2}{*}{1890} \\
\hline & & & \\
\hline All countries..... & $\$ 6,166,193$ & $\$ 6,163,113$ & $\$ 7,336,993$ \\
\hline Europe...... & $3,604,806$ & $3,533,975$ & $4,82 n, 7^{7} 0$ \\
\hline (rermany........ & $1,520,674$ & 574,144 & 650,290 \\
\hline 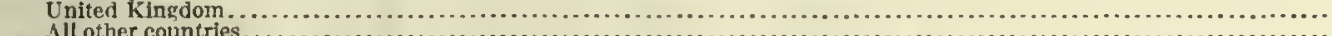 & I, 597,769 & $2,489,498$ & $3,849,099$ \\
\hline 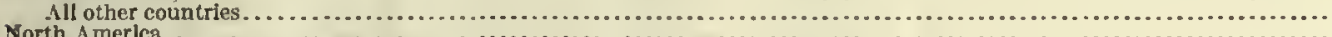 & 456,363 & 470,343 & 321,408 \\
\hline 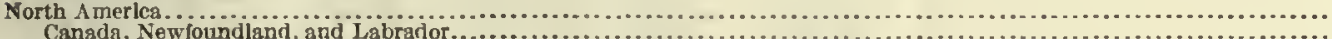 & $1,084,384$ & $1,094,720$ & $1,217,886$ \\
\hline 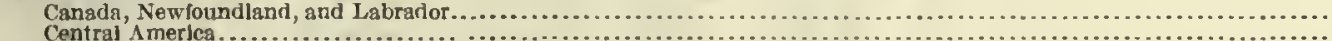 & 454,291 & 516,062 & 228,067 \\
\hline 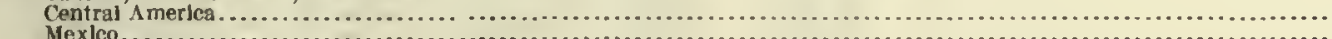 & 177,699 & 44,880 & 62,935 \\
\hline Mexlco & 163,853 & 66,577 & 39,379 \\
\hline 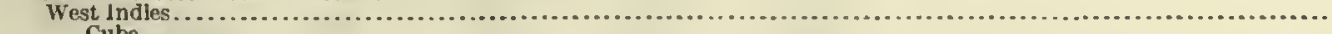 & 271,325 & 467,039 & 887,130 \\
\hline 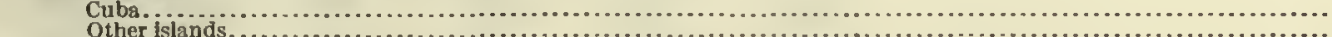 & 73,054 & 90,163 & $\begin{array}{r}56,005 \\
831,125\end{array}$ \\
\hline 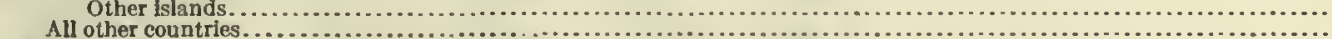 & 198,271 & 376,876 & 831,125 \\
\hline 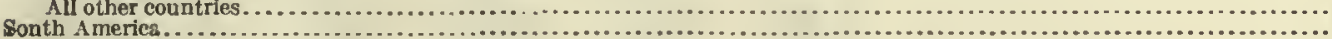 & 17,216 & 162 & \\
\hline 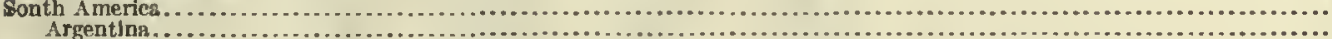 & 658,904 & 455,978 & $\begin{array}{r}275,868 \\
30.826\end{array}$ \\
\hline 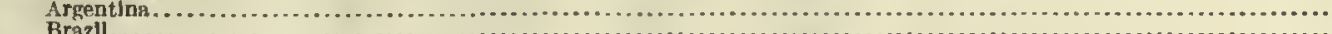 & 100,907 & 45,295 & 30,826 \\
\hline 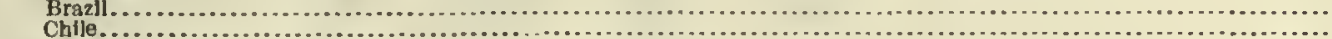 & 77,790 & 155,039 & $\begin{array}{l}11,225 \\
33,336\end{array}$ \\
\hline 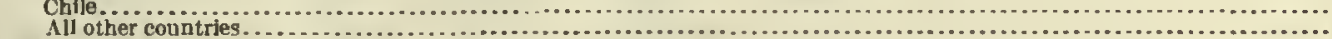 & $\begin{array}{l}316,760 \\
163,447\end{array}$ & $\begin{array}{r}89.888 \\
165.756\end{array}$ & $\begin{array}{r}33,336 \\
200,481\end{array}$ \\
\hline Asta & 141,175 & 284,374 & 254,971 \\
\hline 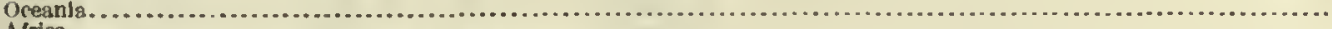 & 615,318 & 683,498 & 691,779 \\
\hline 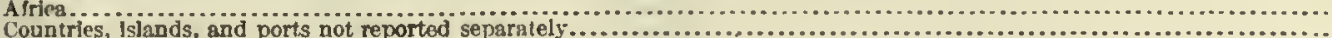 & 61,606 & 110,568 & $\begin{array}{l}41,742 \\
33,950\end{array}$ \\
\hline untries, ISIawos, and ports not reportio se paratery & & & \\
\hline
\end{tabular}


TABLE 3.-IMPORTS OF FISHERY PRODUCTS, BY KIND AND GOUNTRY FROM WHICH IMPORTED: 1908, 1900 , AND 1890.

\begin{tabular}{|c|c|c|c|c|c|c|}
\hline \multirow{3}{*}{ KIND OP PRODUCT AND COUNTRY FROM WHCH IMPORTED. } & \multicolumn{6}{|c|}{ IMPORTS OF FISHERY PRODUCTS. } \\
\hline & \multicolumn{2}{|c|}{1908} & \multicolumn{2}{|c|}{1900} & \multicolumn{2}{|c|}{1890} \\
\hline & $\begin{array}{l}\text { Quantity } \\
\text { (pounds). }\end{array}$ & Value. & $\begin{array}{l}\text { Quantity } \\
\text { (pounds). }\end{array}$ & Value. & $\begin{array}{l}\text { Quantity } \\
\text { (pounds). }\end{array}$ & Value. \\
\hline Total............. & & $\$ 13,135,724$ & 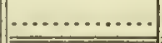 & $\$ 3,230,121$ & & $35,815,284$ \\
\hline 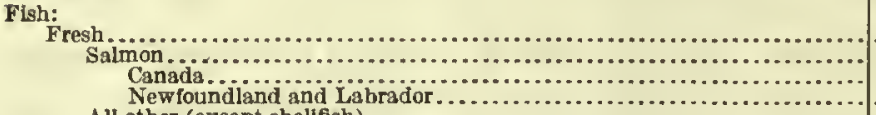 & $\begin{array}{l}1,140,381 \\
1,140,381\end{array}$ & $\begin{array}{r}1,772,164 \\
120,032 \\
120,032\end{array}$ & $\begin{array}{r}1,199,079 \\
1,195,922 \\
3,157\end{array}$ & $\begin{array}{r}1,245,542 \\
115,069 \\
114,880 \\
189\end{array}$ & $\begin{array}{r}853,963 \\
853,963 \\
\ldots . . .\end{array}$ & $\begin{array}{r}880,203 \\
88,648 \\
88,648 \\
\end{array}$ \\
\hline 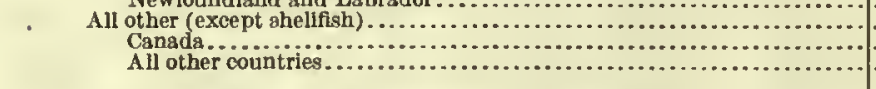 & & $\begin{array}{r}1,652,132 \\
1,639,946 \\
12,186\end{array}$ & 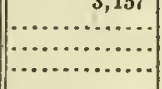 & $\begin{array}{r}1,130,473 \\
1,126,498 \\
3,975\end{array}$ & $\begin{array}{r}41,727,190 \\
40,372,180 \\
1,355,010\end{array}$ & $\begin{array}{r}791,555 \\
765,787 \\
25,768\end{array}$ \\
\hline 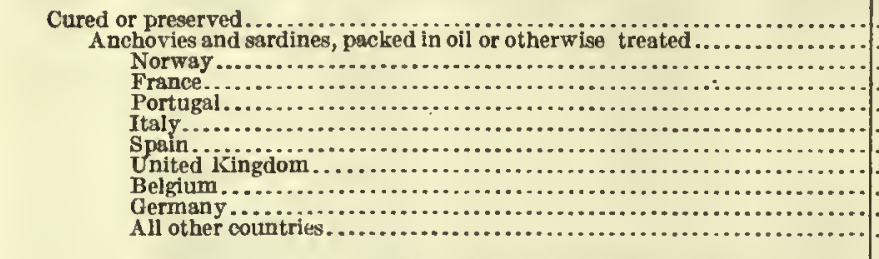 & 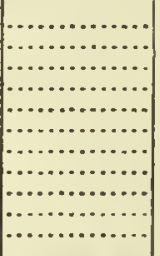 & $\begin{array}{r}8,671,876 \\
2,219,549 \\
772,411 \\
761,669 \\
318,290 \\
121,259 \\
66,874 \\
62,994 \\
31,153 \\
24,078 \\
60,821\end{array}$ & 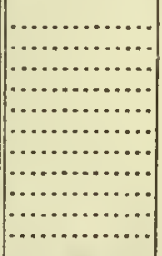 & $\begin{array}{r}5,181,275 \\
1,483,768 \\
156,247 \\
1,189,125 \\
110,434 \\
29,059 \\
2,363 \\
20,469 \\
51,065 \\
6,909 \\
17,197\end{array}$ & 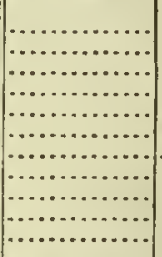 & $\begin{array}{r}3,710,382 \\
728,108 \\
114,415 \\
625,109 \\
20,060 \\
7,007 \\
35,454 \\
11,953 \\
5,664 \\
8,446\end{array}$ \\
\hline 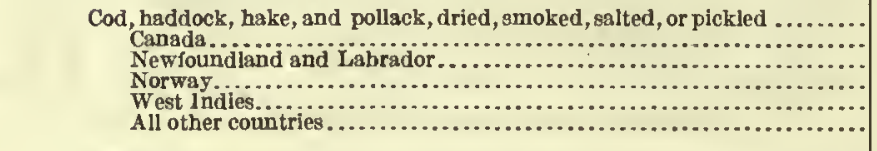 & $\begin{array}{r}15,831,540 \\
12,959,677 \\
1,819,577 \\
901,335 \\
105,000 \\
45,951\end{array}$ & $\begin{array}{r}870,757 \\
679,237 \\
93,499 \\
86,285 \\
9,022 \\
2,714\end{array}$ & $\begin{array}{r}14,395,483 \\
9,885,426 \\
1,916,167 \\
1671,946 \\
43,525 \\
1,878,419\end{array}$ & $\begin{array}{r}543,172 \\
351,564 \\
82,676 \\
143,048 \\
2,724 \\
63,160\end{array}$ & $\begin{array}{r}12,750,312 \\
8,642,981 \\
2,249,082 \\
1108,759 \\
\ldots . .7 . \ldots . . \\
1,749,490\end{array}$ & $\begin{array}{r}409,388 \\
290,362 \\
76,710 \\
15,552 \\
30,764\end{array}$ \\
\hline 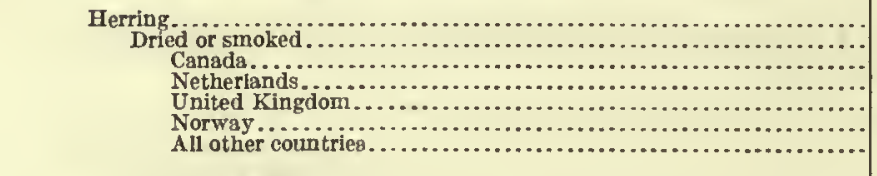 & $\begin{array}{r}73,163,909 \\
2,035,135 \\
1,090,734 \\
799,828 \\
75,524 \\
51,886 \\
17,163\end{array}$ & $\begin{array}{r}2,479,273 \\
67,788 \\
31,055 \\
31,211 \\
2,769 \\
1,990 \\
763\end{array}$ & $\begin{array}{r}36,374,217 \\
5,130,813 \\
4,605,133 \\
69,123 \\
299,322 \\
138,719 \\
118,516\end{array}$ & $\begin{array}{r}1,482,568 \\
127,555 \\
107,800 \\
3,661 \\
12,043 \\
1,037 \\
3,014\end{array}$ & $\begin{array}{r}31,590,573 \\
6,502,573 \\
5,608,964 \\
96,670 \\
10,130 \\
1701,288 \\
85,521\end{array}$ & $\begin{array}{r}1,021,962 \\
140,144 \\
107,611 \\
2,854 \\
448 \\
127,373 \\
1,858\end{array}$ \\
\hline 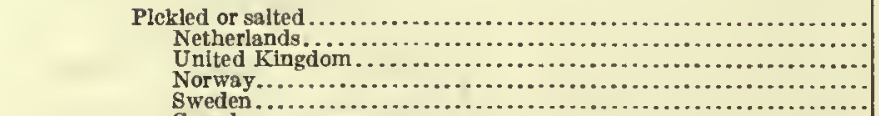 & $\begin{array}{r}71,128,774 \\
26,359,077 \\
27,326,546 \\
9,359,233 \\
512,440\end{array}$ & $\begin{array}{r}2,411,485 \\
1,030,863 \\
1,006,368 \\
209,826 \\
12,652\end{array}$ & $\begin{array}{r}31,243,404 \\
12,191,397 \\
8,960,272 \\
15,352,369 \\
\ldots\end{array}$ & $\begin{array}{r}1,355,013 \\
674,665 \\
375,586 \\
1199,327\end{array}$ & $\begin{array}{r}25,088,000 \\
7,893,200 \\
2,035,000 \\
15,541,800\end{array}$ & $\begin{array}{r}881,818 \\
470,133 \\
73,113 \\
117,100 \\
\end{array}$ \\
\hline 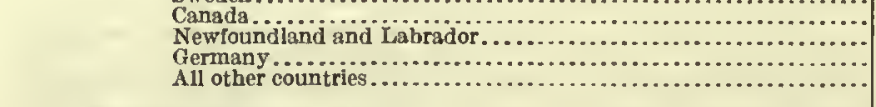 & $\begin{array}{r}5,170,344 \\
1,904,470 \\
413,990 \\
82,674\end{array}$ & $\begin{array}{r}105,524 \\
29,309 \\
14,254 \\
2,689\end{array}$ & $\begin{array}{r}3,351,547 \\
943,545 \\
356,888 \\
87,386\end{array}$ & $\begin{array}{r}57,416 \\
23,169 \\
21,491 \\
3,359\end{array}$ & $\begin{array}{r}4,606,800 \\
2,806,600 \\
2,158,200 \\
46,400\end{array}$ & $\begin{array}{r}88,218 \\
58,056 \\
73,107 \\
2,091\end{array}$ \\
\hline $\begin{array}{r}\text { Mackerel, pickled or salted } \\
\text { United Kingdom } \\
\text { Norway } \\
\text { Sweden } \\
\text { Sw. }\end{array}$ & $\begin{array}{r}20,956,891 \\
9,997,749 \\
5,403,247 \\
577,258\end{array}$ & $\begin{array}{r}1,439,359 \\
608,679 \\
.488,195 \\
51,322\end{array}$ & $\begin{array}{r}18,546,554 \\
13,630,662 \\
12,273,537\end{array}$ & $\begin{array}{r}1,276,900 \\
855,440 \\
1233,943\end{array}$ & $\begin{array}{r}14,087,400 \\
4,782,400 \\
1609,000\end{array}$ & $\begin{array}{r}1,010,670 \\
316,953 \\
48,465 \\
\ldots\end{array}$ \\
\hline 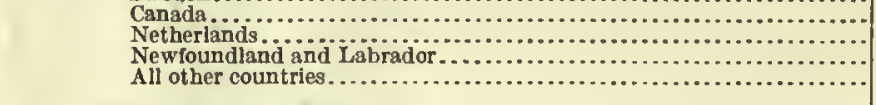 & $\begin{array}{r}3,277,799 \\
1,650,180 \\
33,400 \\
17,258\end{array}$ & $\begin{array}{r}209,782 \\
78,192 \\
1,756 \\
1,433\end{array}$ & $\begin{array}{r}2,054,621 \\
676,971 \\
1,400 \\
9,363\end{array}$ & $\begin{array}{r}140,927 \\
45,805 \\
60 \\
725\end{array}$ & $\begin{array}{r}8,567,600 \\
125,4000\end{array}$ & $\begin{array}{r}641,360 \\
232 \\
3,651\end{array}$ \\
\hline 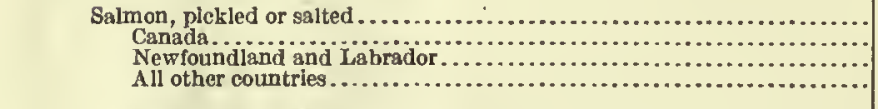 & $\begin{array}{r}1,079,168 \\
1,017,884 \\
56,700 \\
4,584\end{array}$ & $\begin{array}{r}109,849 \\
106,629 \\
3,003 \\
217\end{array}$ & $\begin{array}{r}736,658 \\
404,397 \\
231,661 \\
600\end{array}$ & $\begin{array}{r}54,236 \\
29,608 \\
24,587 \\
41\end{array}$ & $\begin{array}{r}789,200 \\
395,400 \\
393,800 \\
\ldots \ldots \ldots\end{array}$ & $\begin{array}{r}67,149 \\
34,313 \\
32,836 \\
\ldots \ldots \ldots\end{array}$ \\
\hline 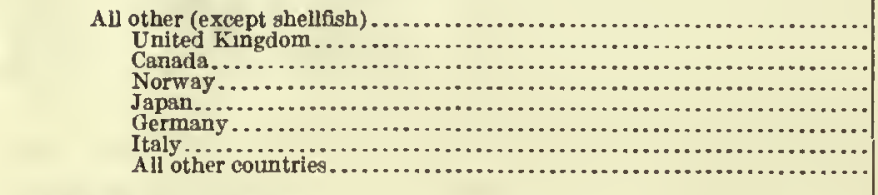 & 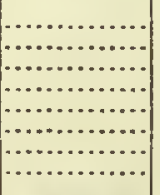 & $\begin{array}{r}1,553,089 \\
394,781 \\
294,695 \\
214,487 \\
162,310 \\
138,857 \\
128,625 \\
219,334\end{array}$ & 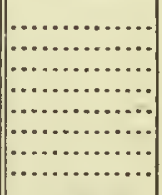 & $\begin{array}{r}340,631 \\
51,467 \\
63,465 \\
185,926 \\
3,077 \\
25,962 \\
10,733 \\
100,001\end{array}$ & 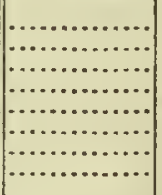 & $\begin{array}{r}473,105 \\
7,823 \\
357,448 \\
117,474 \\
1,076 \\
13,158 \\
3,716 \\
72,410\end{array}$ \\
\hline 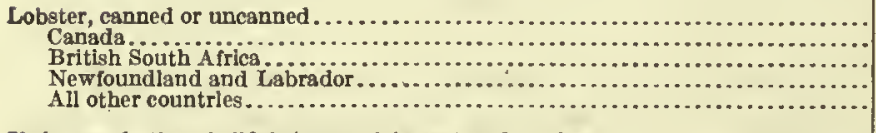 & $\begin{array}{r}8,212,945 \\
8,063,752 \\
136,173 \\
5,310 \\
7,710\end{array}$ & $\begin{array}{r}1,401,449 \\
1,375,315 \\
22,879 \\
1,504 \\
1,751\end{array}$ & $\begin{array}{r}7,497,227 \\
7,328,853 \\
143,815 \\
.17,419 \\
7,140\end{array}$ & $\begin{array}{r}931,219 \\
915,360 \\
10,993 \\
3,431 \\
1,435\end{array}$ & 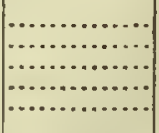 & $\begin{array}{r}568,150 \\
491,282 \\
\cdots, 7006 \\
76,046 \\
822\end{array}$ \\
\hline 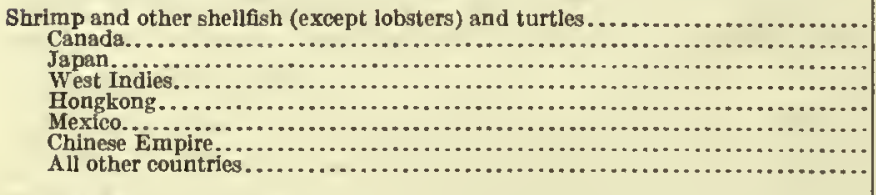 & (n........ & $\begin{array}{r}333,606 \\
135,958 \\
90,515 \\
29,430 \\
22,182 \\
22,166 \\
17,419 \\
15,906\end{array}$ & 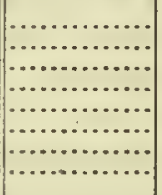 & $\begin{array}{r}62,415 \\
16,345 \\
3,804 \\
3,573 \\
5,278 \\
11,565 \\
15,794 \\
6,056\end{array}$ & 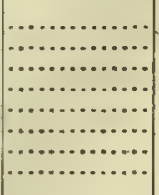 & $\begin{array}{r}131,100 \\
109,239 \\
11 \\
50 \\
1,540 \\
1,420 \\
10,015 \\
8,825\end{array}$ \\
\hline 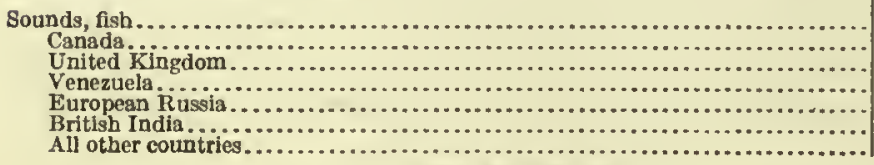 & 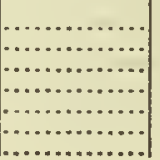 & $\begin{array}{r}113,675 \\
62,365 \\
22,721 \\
13,907 \\
6,706 \\
4,113 \\
3,863\end{array}$ & 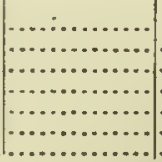 & ( $)$ & 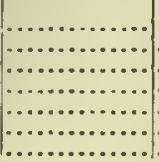 & $\begin{array}{l}\ldots \ldots \ldots \\
\ldots \ldots \ldots \\
\ldots \ldots \ldots \\
\ldots \ldots \ldots \\
\ldots \ldots \ldots\end{array}$ \\
\hline
\end{tabular}


TABLE 3.-IMPORTS OF FISHERY PRODUCTS, BY KIND AND COUNTRY FIOM WHICH IMPORTED: 1908, 1900, AND 1890-Continued.

\begin{tabular}{|c|c|c|c|c|c|c|}
\hline \multirow{3}{*}{ KIND OF FRODUCT AND COUNTRY FHOM WHCH IMFORTED. } & \multicolumn{6}{|c|}{ IMPORTS OF FISUERY PRODUCTE. } \\
\hline & \multicolumn{2}{|c|}{1908} & \multicolumn{2}{|c|}{1900} & \multicolumn{2}{|c|}{1890} \\
\hline & $\begin{array}{l}\text { Quantity } \\
\text { (pounds). }\end{array}$ & Value. & $\begin{array}{l}\text { Quantity } \\
\text { (pounds). }\end{array}$ & Value. & $\begin{array}{l}\text { Quantlty } \\
\text { (pounds). }\end{array}$ & Value. \\
\hline 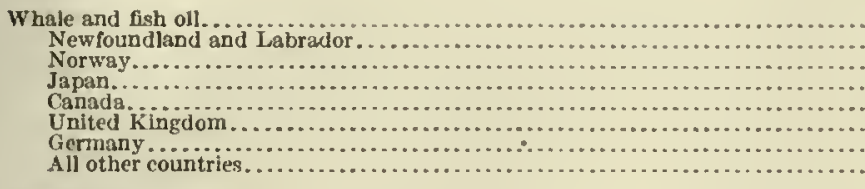 & $\begin{array}{r}1,221,065 \\
573,019 \\
254,790 \\
221,993 \\
140,555 \\
20,823 \\
9,008 \\
877\end{array}$ & $\begin{array}{r}408,113 \\
154,663 \\
153,873 \\
47,722 \\
35,243 \\
11,411 \\
4,683 \\
518\end{array}$ & $\begin{array}{r}851,372 \\
204,213 \\
265,710 \\
40 \\
349,556 \\
2,434 \\
27,529 \\
1,890\end{array}$ & $\begin{array}{r}\$ 273,367 \\
48,339 \\
2133,938 \\
10 \\
76,170 \\
1,121 \\
13,193 \\
596\end{array}$ & $\begin{array}{r}1267,379 \\
11,578 \\
2147,824 \\
6,300 \\
67,847 \\
4,293 \\
26,397 \\
3,140\end{array}$ & $\begin{array}{r}\$ 85,436 \\
2,730 \\
56,977 \\
1,828 \\
12,857 \\
1,602 \\
8,541 \\
901\end{array}$ \\
\hline 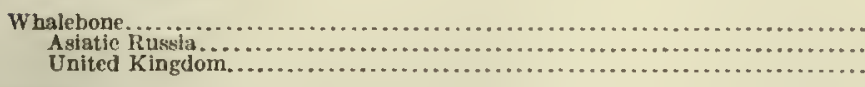 & $\begin{array}{r}9,054 \\
8,899 \\
155\end{array}$ & $\begin{array}{r}43,633 \\
43,560 \\
73\end{array}$ & & & $\begin{array}{r}19,040 \\
\cdots \\
(j)\end{array}$ & $\begin{array}{r}23,295 \\
\ldots \ldots \cdots\end{array}$ \\
\hline 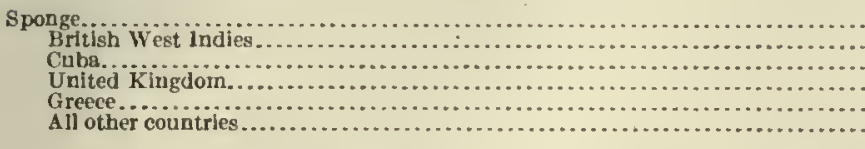 & $\mid$ & $\begin{array}{r}391,208 \\
174,961 \\
125,779 \\
50,827 \\
26,190 \\
13,451\end{array}$ & | & $\begin{array}{r}536,303 \\
293,016 \\
133,033 \\
79,466 \\
18,135 \\
12,653\end{array}$ & 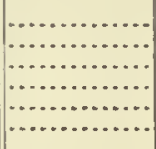 & $\begin{array}{r}416,718 \\
214,883 \\
26,741 \\
115,205 \\
48,131 \\
11,758\end{array}$ \\
\hline
\end{tabular}

1Gallons.

Norway and Sweden.

Not reported.

TABLE 4.-VALUE OF IMPORTS OF FISHERY PRODUCTS, BY COUNTRY FROM WHICH IMPORTED: 1908, 1900 , AND 1890.

\begin{tabular}{|c|c|c|c|}
\hline \multirow{2}{*}{ COUNTRY FROM WHCH IMPORTED. } & \multicolumn{3}{|c|}{ VALUE OF IMPORTS OF FTSUERY PRODUCTS. } \\
\hline & 1908 & 1900 & 1890 \\
\hline All countries.... & $\$ 13,135,724$ & $\$ 8,230,121$ & $\$ 5,815,284$ \\
\hline Europe ........ & $7,120,849$ & $4,420,482$ & $2,157,527$ \\
\hline 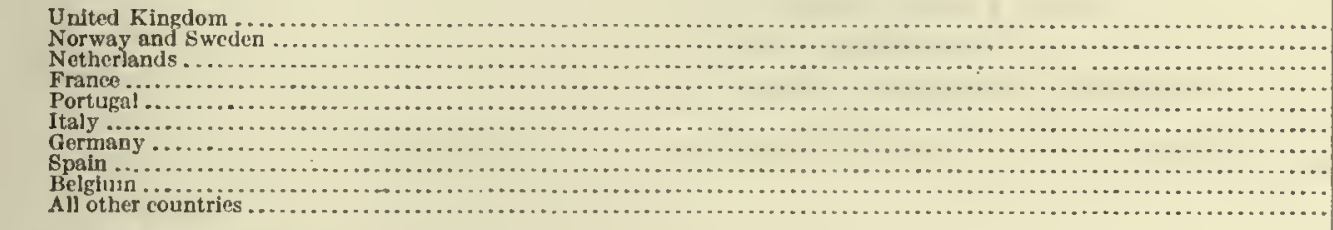 & $\begin{array}{r}2,170,057 \\
2,023,286 \\
1,162,712 \\
788,711 \\
346,646 \\
253,261 \\
191,207 \\
85,737 \\
31,587 \\
73,645\end{array}$ & $\begin{array}{r}1,400,280 \\
753,838 \\
758,678 \\
1,196,862 \\
110,434 \\
39,939 \\
70,914 \\
2,690 \\
56,141 \\
30,703\end{array}$ & $\begin{array}{r}551,423 \\
287,359 \\
479,388 \\
634,587 \\
20,060 \\
12,696 \\
103,079 \\
57 \\
13,854 \\
55,024\end{array}$ \\
\hline North America............ & $5,485,447$ & $3,720,942$ & $3,567,827$ \\
\hline 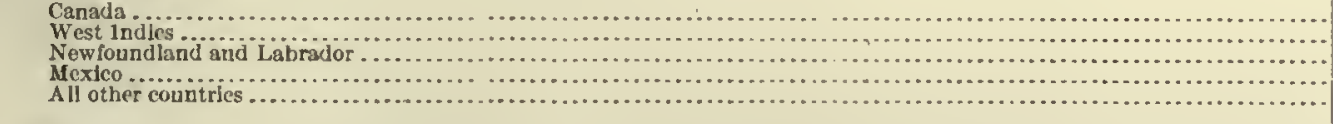 & $\begin{array}{r}4,797,133 \\
342,857 \\
293,932 \\
47,805 \\
3,720\end{array}$ & $\begin{array}{r}3,000,678 \\
436,486 \\
189,737 \\
23,920 \\
70,121\end{array}$ & $\begin{array}{r}2,988,288 \\
256,059 \\
281,739 \\
3,888 \\
37,853\end{array}$ \\
\hline Asia.... & 483,769 & 74,907 & 66,110 \\
\hline 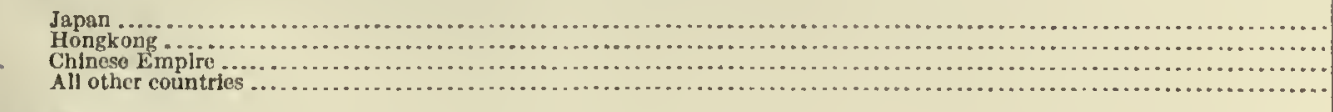 & $\begin{array}{r}310,011 \\
63,912 \\
56,326 \\
53,520\end{array}$ & $\begin{array}{r}7,282 \\
21,181 \\
46,105 \\
339\end{array}$ & $\begin{array}{r}2,915 \\
9,618 \\
53,498 \\
79\end{array}$ \\
\hline 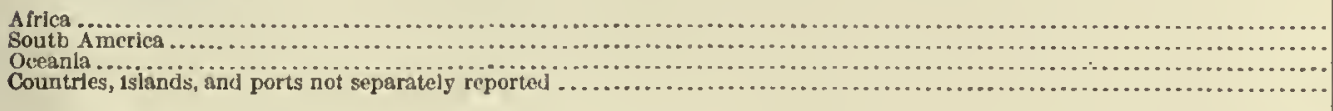 & $\begin{array}{r}24,599 \\
14,783 \\
277\end{array}$ & $\begin{array}{r}32,460 \\
1,102 \\
228\end{array}$ & $\begin{array}{r}357 \\
23,460\end{array}$ \\
\hline
\end{tabular}





\section{APPENDICES.}

APPENDIX A.-THE FISHERIES OF ALASKA IN 1908.

APPENDIX B.-SCHEDULES:

SHORE AND BOAT FISHERIES.

VESSEL FISHERIES.

PACKING HOUSES AND CANNERIES.

APPENDIX C.-INSTRUCTIONS TO SPECIAL AGENTS. 



\section{APPENDIX A.}

\section{THE FISHERIES OF ALASKA IN 1908.}

By Mularn C. Marsi, Agent at the Salmon Fisheries of Alaska, and John N. Coвb, Aseistant Agent.

\section{SUMMARIZED STATISTICS.}

As in the reports for previous years, the District of Alaska is considered in the four geographic sections generally recognized, as follows: Southeast Alaska, embracing all that narrow strip of mainland, and the numerous islands adjacent, from Portland Canal northweetward to and including Yakutat Bay; central Alaska, the region on the Pacific, or south side, from Yakutat Bay westward, including the Aleutian chain; western $A$ laska, the shores of Bering Sea, and islands in this sea; and aretic Alaska, from Bering Strait to the Canadian border.

With the exception of aretic Alaska and a portion of western Alaska, practically all of the fiehing localities were visited by one or the other of the agents. Statisties of the yield of fur seals from the Pribilof Islands were obtained through the courtesy of the agent at the fur seal islands, while figures for the other aquatic furs (except the coast fur seals and zea otter) and skins, also the whalebone and walrue ivory, were obtained from the customhouse records at Juneau. Considerable commercial fishing is carried on in the Yukon River and its tributaries, where fish wheele, nets, and spears are employed, but unfortunately it has been found impossible so far, owing to the short time available each season and the few agents employed, to extend the inspection work over this large region, or to secure data showing the extent of the fisheries there.

As in previous years, by far the greater part of the fishery produets of Alaska are marketed outside the district, but a steadily increasing local demand is noticeable, especially in the case of the hitherto somewhat neglected minor species.

\section{PERSONS ENGAGED.}

The number of persone engaged in the fisheries of Alaska in 1908 was 13,337 , of whom 4,976 were engaged direetly in fishing, 7,740 in the canneries, salteries, and at other shore work, and 621 employed on the transporting vessels. This total is a gain of 585 over the number employed in 1907. The fact that the fishermen act as sailors on the transporting ships to and from the salmon canneries and ealteries explains the small number of transporters shown in the table. Owing to the impossibility of the agents visiting aretic Alaska in the limited open season, thus making lt difficult to secure accurate data, no attenpt has been made to show the number of men employed and the investment in the fisheries of this region, although certain of the products are shown in the proper table.

Persons engaged in the Alaska fisheries in 1908.

\begin{tabular}{|c|c|c|c|c|}
\hline OCCUPATION AND RACE. & $\begin{array}{c}\text { Southeast } \\
\text { Alaska. }\end{array}$ & $\begin{array}{l}\text { Central } \\
\text { A laska. }\end{array}$ & $\begin{array}{l}\text { Western } \\
\text { Alaska. }\end{array}$ & Total. \\
\hline \multicolumn{5}{|l|}{ Fishermen: } \\
\hline Whites... & 1,193 & 663 & 1,554 & 3,410 \\
\hline \multirow{3}{*}{ Japanese } & $1,2 \subseteq 8$ & 103 & 138 & 1,539 \\
\hline & 27 & .... & ........ & 27 \\
\hline & 2,518 & 766 & 1,692 & 4,976 \\
\hline \multicolumn{5}{|l|}{ Shoresmen: } \\
\hline Whites................ & 519 & 307 & 1,003 & 1,829 \\
\hline Indians........... & 886 & $\begin{array}{l}165 \\
393\end{array}$ & $\begin{array}{l}430 \\
860\end{array}$ & $\begin{array}{l}1,481 \\
2,018\end{array}$ \\
\hline Japanese........... & 43.5 & 374 & 1,603 & 2,412 \\
\hline Total... & 2,605 & 1,239 & 3,896 & 7,740 \\
\hline \\
\hline $\begin{array}{l}\text { Whites.... } \\
\text { Indians... }\end{array}$ & $\begin{array}{r}268 \\
40\end{array}$ & $\begin{array}{r}144 \\
2\end{array}$ & $\begin{array}{r}165 \\
7\end{array}$ & 572 \\
\hline \multirow{3}{*}{ Grand total. } & 303 & 146 & 172 & 691 \\
\hline & & & & \\
\hline & 0,420 & 2,151 & 5,760 & 13,337 \\
\hline
\end{tabular}

1NVESTMENT.

The total investment in the fisheries was $\$ 10,319,784$, an increase of $\$ 1,103,756$ over 1907 . The item of cash capital was eliminated in the 1906 report, and this procedure has been followed ever since.

INVESTMENT IN THE ALASKA FISHERIES IN 1908.

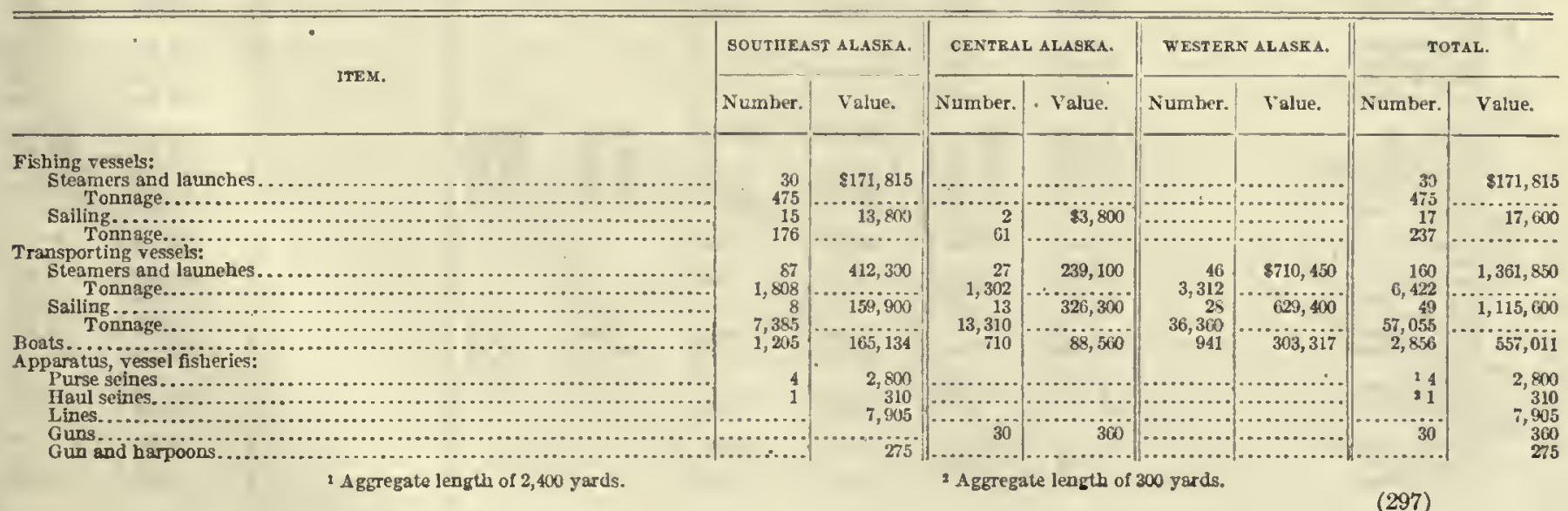


INVESTMENT IN THE ALASKA FISHERIES IN 1908-Continued.

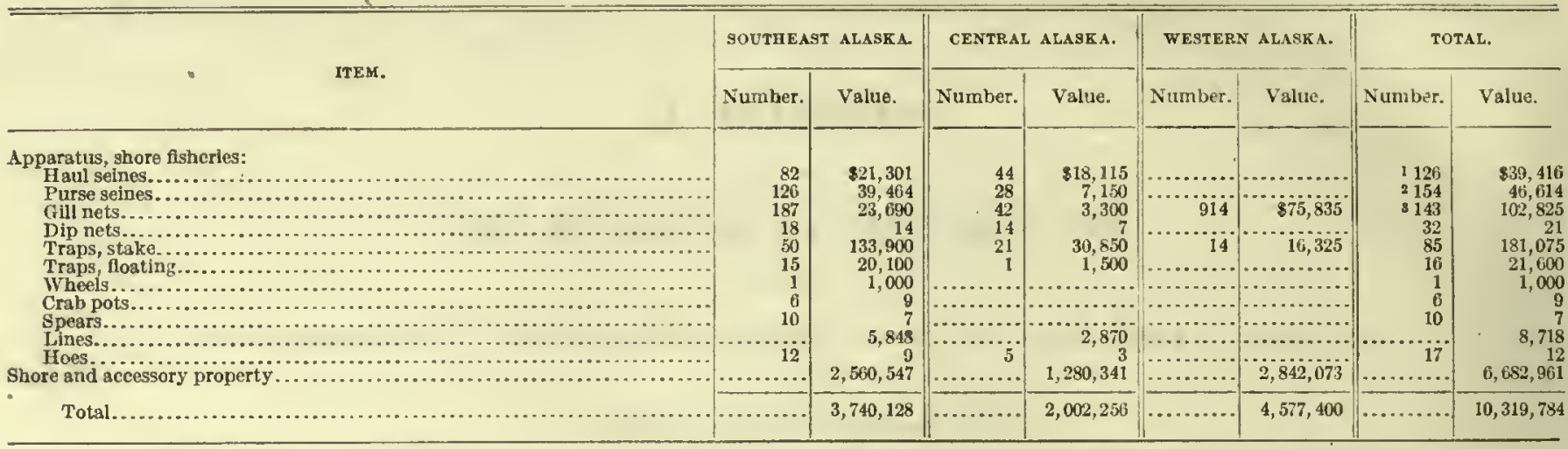

1 Aggregate length of 60,452 jards.

PRODUCTS.

The total quantity of products was $217,813,415$ pounds, valued at $\$ 11,847,443$, a gain of $39,455,114$ pounds and $\$ 1,687,260$ over 1907 . Except for fertilizer, oil, furs, and hides, the weights are round weights, or the weight of products when first taken from the water; the prepared products weights are shown in the subsidiary tables
3 Aggregate length of 265,056 yards.

PRODUCTS OF ALASKA FISHERIES IN 1908.

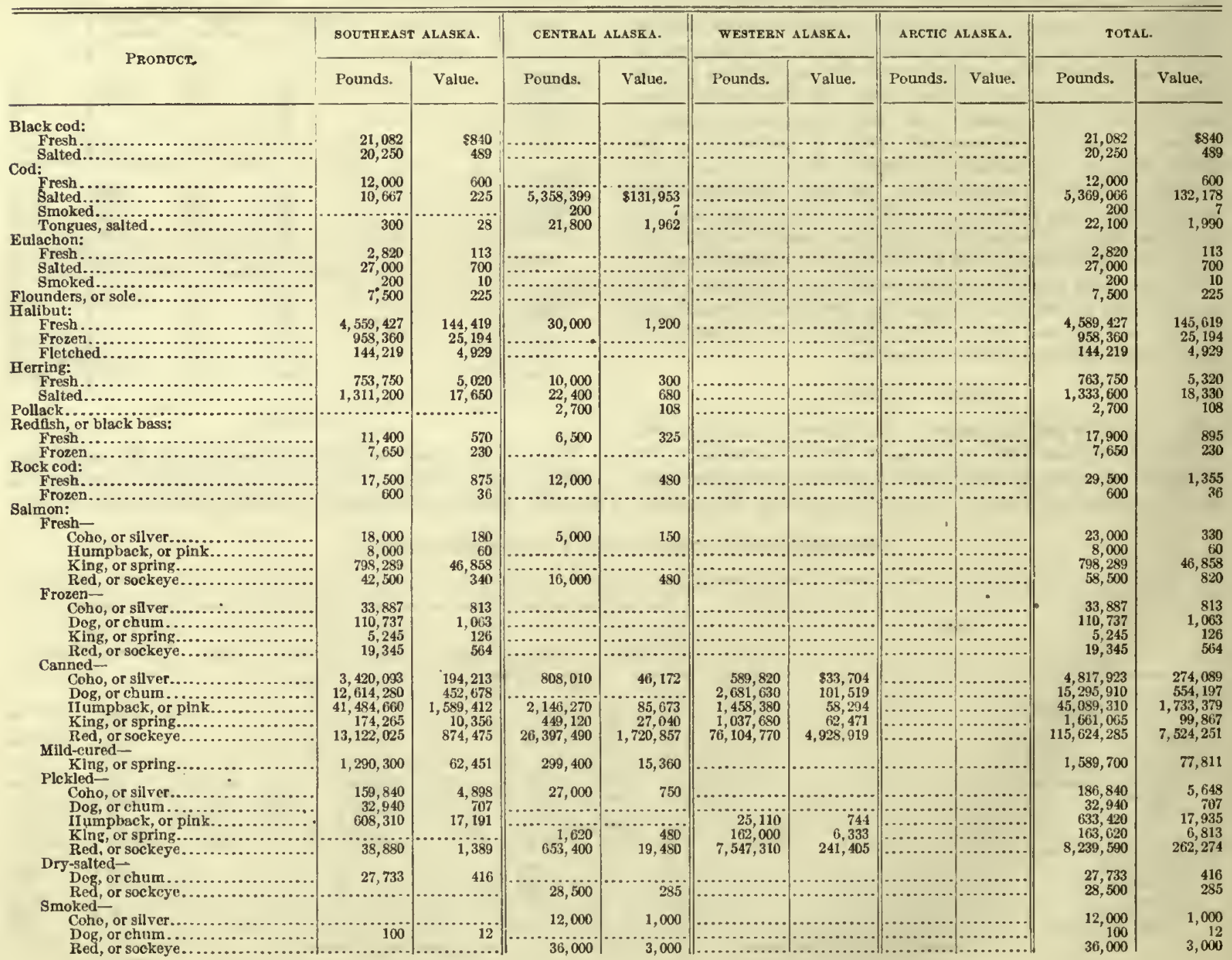


APPENDIX.

PRODUCTS OF ALASKA FISHERIES IN 1908-Continued.

\begin{tabular}{|c|c|c|c|c|c|c|c|c|c|c|}
\hline \multirow{2}{*}{ PRODUCT. } & \multicolumn{2}{|c|}{ SOUTUEAST ALASKA. } & \multicolumn{2}{|c|}{ CENTRAL ALASKA. } & \multicolumn{2}{|c|}{ WESTER A ALASKA. } & \multicolumn{2}{|c|}{ ARCTIC A LASEA } & \multicolumn{2}{|c|}{ TOTAL. } \\
\hline & Pounds. & Value. & Pounda. & Value. & Pounds. & Value. & Pounds. & Value. & Pounds. & Value. \\
\hline \multicolumn{11}{|l|}{ Salmon bclles, salted: } \\
\hline 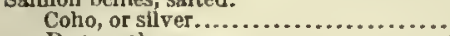 & 36,100 & $\$ 380$ & 181,450 & $\$ 3,155$ & & & & & 217,550 & $\$ 3,535$ \\
\hline Dog, or chum................. & 111,150 & 699 & $\ldots \ldots \ldots$ & 年 & & & & & 111,150 & 699 \\
\hline Iumpback, or pink................. & $2,260,325$ & 27,660 & 38,000 & 480 & 45.600 & $\cdots$ & & & $2,298,325$ & 28,140 \\
\hline 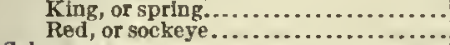 & 33,250 & 386 & $\cdots 1,691,000$ & $\cdots 24,770$ & 60,000 & 1,080 & (n.......... & ...... & & 26,236 \\
\hline Salmon eggs................................. & 15 & 3 & $\ldots, 09,0 . \ldots$ & .............. & $\ldots, \ldots . .$. & ....... & & & $1,104,200$ & $\begin{array}{r}20,600 \\
3\end{array}$ \\
\hline \multirow{2}{*}{\multicolumn{11}{|c|}{$\begin{array}{l}\text { Trout: } \\
\text { Dolly Varden- }\end{array}$}} \\
\hline & & & & & & & & & & \\
\hline 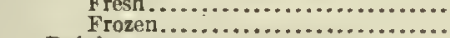 & $\begin{array}{r}39,200 \\
8.000\end{array}$ & $\begin{array}{r}1,340 \\
180\end{array}$ & $\begin{array}{l}13,000 \\
\ldots \ldots \ldots\end{array}$ & 650 & & & & & $\begin{array}{r}52,200 \\
8,000\end{array}$ & $\begin{array}{l}1,990 \\
180\end{array}$ \\
\hline Rainbow & 8.000 & 480 & & & & & & & 8,000 & 480 \\
\hline $\begin{array}{l}\text { Steelhead }- \\
\text { Fresh } . . . \ldots \ldots \ldots \ldots \ldots . . . \ldots .\end{array}$ & 2,900 & 116 & & & & & & & 2,900 & 116 \\
\hline Frozen........................ & 30,681 & 982 & & & & & $\cdots$ & & 30,681 & 992 \\
\hline \multicolumn{11}{|l|}{$\begin{array}{l}\text { Whitefish } \\
\text { Fertilizer: }\end{array}$} \\
\hline Herring . . . . . . . . . . . . . . . . . . . & $1,496,000$ & 24,000 & & & & & & & $1,496,000$ & 24,000 \\
\hline Salmon................................. & 374,090 & 6,000 & $\cdots \cdot{ }^{\prime}$ & & & & ....... & ..... & 374,000 & 6,000 \\
\hline \multicolumn{11}{|l|}{ Ofl: Whale } \\
\hline Herring. & 819,000 & 21,000 & & & & & & & 1819,000 & 21.600 \\
\hline Salmon........ & 204,750 & 5,400 & & & & & & & 204,750 & 5,400 \\
\hline Whale......................... & $1,232,850$ & 49,036 & & & & & .......... & .... & $1,232,850$ & 49,036 \\
\hline 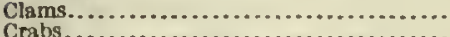 & 6,000 & 300 & 2,000 & 50 & & & .. & & 18,000 & 350 \\
\hline \multicolumn{11}{|l|}{ Aquatic furs and skins: } \\
\hline Beaver..................... & 743 & 3,730 & 252 & 1,332 & 235 & 1,399 & ...... & & 1,280 & 6,461 \\
\hline \multicolumn{11}{|l|}{ Otter- } \\
\hline Land... & 1,495 & 5,411 & 1,637 & 5,982 & 200 & 667 & & & 83,332 & 12,060 \\
\hline \multicolumn{11}{|l|}{ Seal- } \\
\hline Fur......................... & 1,992 & 8,350 & 804 & 2,680 & 89,784 & 448,920 & .. & & 1092,580 & 459,950 \\
\hline 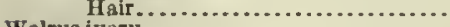 & 4,620 & 945 & .............. & .............. & 14,796 & 2,405 & & & 1119,116 & 3,350 \\
\hline 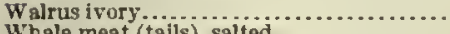 & 3 & 3 & (............. & & n............ & n........... & 13,742 & 89,390 & 13,745 & 9,393 \\
\hline 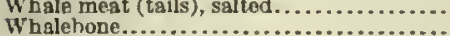 & 1.000 & $\begin{array}{r}35 \\
2.259\end{array}$ & $\cdots \cdots \cdot$ & & $\cdots \cdots \cdots$ & & 53.331 & 300500 & $\begin{array}{r}1,000 \\
63,640\end{array}$ & 35 \\
\hline \multirow[t]{2}{*}{ 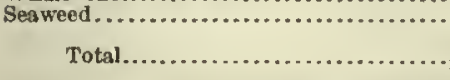 } & 810 & 203 & $\cdots$ & & 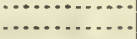 & (n............... & $\begin{array}{r}23,431 \\
\ldots . . .6 .\end{array}$ & . & $\begin{array}{r}0.5,640 \\
810\end{array}$ & $\begin{array}{r}202,601 \\
203\end{array}$ \\
\hline & $89,635,468$ & $3.636,642$ & $38,289,750$ & $2,105,741$ & $89,821,024$ & $5,895,168$ & 67,173 & 209,892 & $217,813,415$ & $11,847,443$ \\
\hline $\begin{array}{l}\text { 1 Represents } 109,200 \\
\text { Represents } 27,300 \\
\text { Represents } 164,380 \\
\text { Rapresents } 850 \text { bus }\end{array}$ & $\begin{array}{l}\text { allons. } \\
\text { ilons. } \\
\text { rallons. } \\
\text { iels. }\end{array}$ & & $\begin{array}{l}\text { Represe } \\
\text { Represe } \\
\text { Represe } \\
\text { Represe }\end{array}$ & $\begin{array}{l}\text { nts } 8,800 \mathrm{cra} \\
\text { nts } 1,280 \mathrm{ski} \\
\text { nts } 31,712 \mathrm{sk} \\
\text { nts } 1,333 \mathrm{skt}\end{array}$ & & $10 \mathrm{R}$ & $\begin{array}{l}\text { epresents } \\
\text { Represents } \\
\text { Represents }\end{array}$ & $\begin{array}{l}2 \text { skins. } \\
5,430 \text { skin } \\
, 472 \text { skins }\end{array}$ & & \\
\hline
\end{tabular}




\section{APPENDIX B.}

\section{SCHEDULES.}

\section{SHORE AND BOAT FISHERIES.}

[Albshore and boat fisheries must be reported on this schedule. If packing houses or canneries are operated under the same ownership, a report should lso be medeon Schedule $\mathrm{E} E 3-249$. Vessel fisheries should not beincluded fn this report but should be reported on Schedule EE2-248.]

Name of company or individual operating the fishery......

Post office (give city, street, and number).

Location.

County

State

(Give name or deseription of water upon which fishing operations are conducted.)

Wasmingtox, D. C., January 4, 1909

The act of Congress of June 7, I906, authorizes the Director of the Census, in cooperatiof with the Bureau of Fisheries, to take a census of the fishing industry.

The information returned on this schedule should cover the business ycar most nearly conforming to the year ending December 31. 1908. All questions that require a fixed timc, such as cash on hand and values of property, should be of the date of the beginning of the year covered by the report.

All answers will be held absolutely confinential. No publication will be made in the Census reports disclosing the operations of individuals or companies in any particular, and the information will be used only for the statistical purposes for which it was given.

The canvass will be made under the superviston of Mr. W. M. Steuart, chief statistician for manufactures.

\section{S. N. D. NoRTH,} Director of the Census.

Extract from act of Congress, March 3, 1899:

SEction 22.- * * * And every president, treasurer, secretary, director, agent, or other officer of every corporation, and every establishment of productive industry whether conducted as a corporate body, limfted liability company, or by private individuals, from which answers to any of the schedules, inquiries, or statistical interrogatories provided for by this act are herein required, who shall, if thereto requested by the Director, supervisor, enumerator, or special agent, williully neglect or refuse to give true and complete answers to any inquirics authorized by this act, or shall willfully give falsc information, shall be guilty of a misdemeanor, and upon conviction thereof shall be fined not exceeding ten thousend

\section{CERTIHCATE.}

This is to certify that the information contained in this schedule is complete and correct to the best of my knowledge and belief, and covers the perfod irom........., $190 . . .$, to........, $190 \ldots$.

(Signature of speclal agent.)

(Signature of the person furnishing the information.)

Each question shonld be answered; if any inquiry is not applicable and no answer can be made, write the word "None."

1. CAPITAL INVESTED-OWNED AND BORROWED: The answer must show the total amount of capital, both owned and borrowed. All the items of fixed and live capital may be taken at the amounts carried on the books. If land or bulldings are rented, that fact should be stated and the value given. The value of all items of live capital, bills recelvable, unsettled ledger accounts, materials, products, and cash on hand, etc., should be given as of the beginning
of the business year reported.

\begin{tabular}{|c|c|c|c|c|c|}
\hline ITEM. & $\begin{array}{l}\text { Num- } \\
\text { ber. }\end{array}$ & Value. & ITEM. & $\begin{array}{l}\text { Num- } \\
\text { ber. }\end{array}$ & Value. \\
\hline Motor boats... & & \$..... & Cunner nets, cunner & & $\$ \ldots$. \\
\hline Saliboats......... & & & traps, snap nets........ & & \\
\hline Rowboats.... & & & 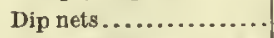 & & .... \\
\hline Scows........... & & & Dredges, tongs, rakes, & & \\
\hline A balone outfita... & & & forks, nippers, scrapes, & & \\
\hline Bag nets................ & & & grabs, shovels......... & & \\
\hline Beam trawls, otter trawls & & & Eel pots and traps...... & 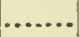 & . \\
\hline Bow nets................ & & & Firearms, guns, rifles, & & \\
\hline Cast nets........... & & & bomb guns............ & & \\
\hline Crewfish pots...... & & & Fyke nets, boop nets.... & & $\ldots$. \\
\hline
\end{tabular}

\begin{tabular}{|c|c|c|c|c|}
\hline ITEM. & $\begin{array}{c}\text { Num- } \\
\text { ber. }\end{array}$ & Value. & $\begin{array}{c}\text { Num- } \\
\text { ber. }\end{array}$ & Value. \\
\hline $\begin{array}{l}\text { Glll nets, drift nets, set } \\
\text { nets, stake nets........ }\end{array}$ & & s. & 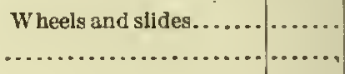 & $\$ \ldots$ \\
\hline Harpoons,spears, eel gigs & & & & \\
\hline Houl and other seines.... & & & 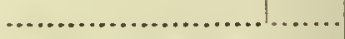 & \\
\hline 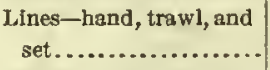 & & & \multirow{6}{*}{$\begin{array}{l}\text { Land, buildings, machinery, } \\
\text { tools, Implcments, and all } \\
\text { fixed capital for wbich sepa- } \\
\text { ratevalues are not given...... } \\
\text { Cash, bills receivable, unsettled } \\
\text { ledger accounts, materials on } \\
\text { band, and sundrles not re- } \\
\text { ported above.................... }\end{array}$} & \\
\hline Lobster pots and traps... & & & & \\
\hline Otter and muskrat traps & & & & \\
\hline Paranzelia nets......... & & ........ & & \\
\hline $\begin{array}{l}\text { Pound nets, trap nets, } \\
\text { weirs................... }\end{array}$ & & & & \\
\hline Reeí nets................ & & & & \\
\hline Shrimp nets............. & & & \multirow{5}{*}{$\begin{array}{l}\text { Total.................... } \\
\text { (If more than one blank is } \\
\text { filled out for the same lndivid- } \\
\text { ual or company, the last two } \\
\text { ltems may be reported on one } \\
\text { blank.) }\end{array}$} & \\
\hline $\begin{array}{l}\text { Spongeapparatus, hooks, } \\
\text { water glasses, and div- } \\
\text { ing equipment.......... }\end{array}$ & & & & \\
\hline Stop nets............... & & .......... & & \\
\hline Trammel netg............ & $\ldots$ & ......... & & \\
\hline Turtle nets.............. & & & & \\
\hline
\end{tabular}

2. PROPRIETORS, FIRM MEMBERS, LND INDEPENDENT FISHER-

MEN: Number

If any of the proprietors or firm members reported above

were not personally engaged in fishing, give the number Number..........
not so engaged:

3. SALARIED EMPLOYEES: Number

A mount paid in salaries,

\$...........

(Salaried officers, managers, clerks, etc.)

\begin{tabular}{|c|c|c|}
\hline $\begin{array}{l}\text { 4. WAGE-EARNERS (not including employees } \\
\text { reported above). }\end{array}$ & Number. & $\begin{array}{l}\text { Total amount } \\
\text { paid in wages } \\
\text { during year. }\end{array}$ \\
\hline 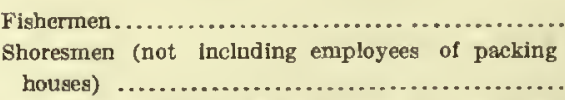 & & s..... \\
\hline 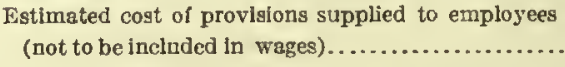 & & \\
\hline
\end{tabular}

5. QUANTITY AND VALUE OF YEAR'S CATCII: Report all fishery produets, including aquatic mammals, reptiles, shellifish, sponges, etc., taken during by each kind of apparatus. If the "pounds" is not known and can not be estimated, give tho "bushels" or "number" and state what unit of measure is used.

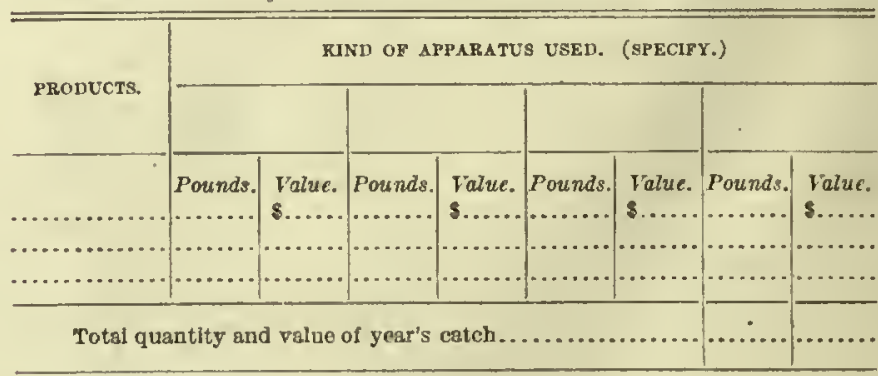

REMARKS: 
VESSEL FISHERIES.

(All vessel fisheries must be reported on this schedule. If packing houses or cannerles are operated under the same ownership, a report should also bo made on Schedule EE3-249. Shore and boat fishories should not bo included in this report, but should be reported on schedule EE 1-247.]

Name of company or Indlvidual for whom this report is mads ..................

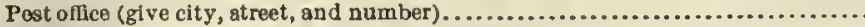
County ............

Name of vessel.

State............

Hailing port.

Fishing port.

Wasmington, D. C., January 4, 19199.

The act of Congress of June 7,1906 , authorizes the Director of tha Census, in cooperation with the Bureau of Fisheries, to take a census of the fishing Industry

The information returned on this schedule should cover the business year most nearly conforming to the year endlng December 31, 1908. All questions that require a tixed time, such as cash on hand and values of property, should bo of the dats of the beginning of the year covered by the report.

All answers will be held absolutely confidential. No publleatlon will bo made in the Census reports disclesing the operations of individuals or companles in any particular, and the information will be used ondy for the statistical purposes for which it was given.

The eanvass wlll be made under the supervision of Mr. W. M. Steuart, chlef statistician for manulactures.

S. N. D. NoRTH, Director of the Census.

Extract from act of Congress, Marcb 3, 1899:

Section 22. - * * "And every president, treasurer, secretary, director, agent, or other offeer of every corporation, and every estahishment of productive industry, whether conducted as a corporate body, limited liability company, or by private indivlduals, Irom which answers to any of the schedules, inquirles, or statisticai interrogatories provlded for by this act are herein required, who shall, If thereto requested by the Director, superviser, enumerator, or special agent, will fully neglect or reluse to glve true and complets answers to any inquities authorized by this act, or shall will fully give false information, ahsil bo guity of a misdemeanor, and upon cenvictlon thereof shall bo fined not exceoding.ten thousand CERTIFICATE.

This is to certily that the information contained in this schedule is complete and correct to the best of my knowledge and belief, and covers the period from .................., $190 \ldots$ to................., $190 .$.

(Signature of special agent.)

(Signaturs of the person furnlshing the information.)

Each question should be answered; if ang inquiry is not epplicabie and no answer can be made, write the word "None."

1. CAPITAL INVESTED-OWNED AND BORROWED: The answer must show the total amount of capital, both owned and borrowed. All the iterns of fixed and live capital may be taken at tho amountscarried on the books. It land or buildings are rented, or vessels are chartered, that lact should be stated an the value given. The value of all items of live capital, bills recelvable, un given as of the beginning of the business year reported.

\begin{tabular}{|c|c|c|c|c|c|}
\hline ITEM. & Num- & Value. & ITEM. & Num: & Valuo. \\
\hline Fishing [Steam or metorl & & & Purse seines............. & & s...... \\
\hline ressels [Sail............. & & & Spongeapparatus, hooks, & & \\
\hline Transporting $\left\{\begin{array}{c}\text { Steam or } \\
\text { motor } 1 . .\end{array}\right.$ & & & $\begin{array}{l}\text { water glasses, and div- } \\
\text { Ing equlpment......... }\end{array}$ & & \\
\hline Sail...... & & & Trammei nets............ & .. & \\
\hline Beats carried on vessels. . & & & Trap nets..................... & & \\
\hline $\begin{array}{l}\text { Outfit (provisions, fuei, } \\
\text { aalt, lce, halt)........... }\end{array}$ & & & 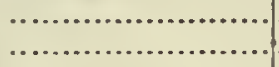 & & \\
\hline Beam trawls, otter trawls & & & ….................... & & \\
\hline $\begin{array}{l}\text { Dredges, tongs, hoes, } \\
\text { rakes, forks, nlppers, } \\
\text { acrapes, grabs, ahovels. }\end{array}$ & & & $\begin{array}{l}\text { Land, bulldings, mach } \\
\text { tools, implements, an }\end{array}$ & $\begin{array}{l}\text { alnery, } \\
\text { ad ail }\end{array}$ & \\
\hline Eel pots and traps....... & & & fixed capital, for whlch & sepa- & \\
\hline $\begin{array}{l}\text { Firearms, guns, rifles, } \\
\text { bomb guns............. }\end{array}$ & & & $\begin{array}{l}\text { rate vaiues are not given } \\
\text { Cash, bilis receivable, uns }\end{array}$ & settled & $\cdots$ \\
\hline Fyke nets, hoop nets.... & & & ledger accounts, materi & lais on & \\
\hline $\begin{array}{l}\text { Gill nets, drift nets, set } \\
\text { nets, atake nets........ }\end{array}$ & & & $\begin{array}{l}\text { hand, and sundrles } \mathrm{n} \\
\text { ported above........... }\end{array}$ & lot re & \\
\hline Harpoons, apears......... & & & Total.............. & ........... & \\
\hline Haui and other aeines... & & & (Ifmore than one blanki & is filled & \\
\hline $\begin{array}{c}\text { Lines-hand, trawi, and } \\
\text { set................... }\end{array}$ & & & $\begin{array}{l}\text { out for the same individ } \\
\text { company, the last two iter }\end{array}$ & $\begin{array}{l}\text { lual or } \\
\text { cns may }\end{array}$ & \\
\hline Lobster pots and traps.. & & & & & \\
\hline Paranzella nets.......... & & & & & \\
\hline
\end{tabular}

1 Mark "Aux." II equlpped with both sail and mechanical motive power.
2. PROPRIETORS, FIRM MEMBERS, AND INDEPENDENT FISHERMEN: Number...........

If any of the propristors or firm members reported above

were not personaliy ongaged in flshing, give the number Number.

3. SALARIED EMPLOYEES: Number.......... Amount paid in salaries, (Salarlod officers, managers, clerks, etc.)

\begin{tabular}{|c|c|c|}
\hline $\begin{array}{l}\text { 4. WAGE-EARNERS (not including omplogees } \\
\text { reported above). }\end{array}$ & Number. & $\begin{array}{l}\text { Total amount } \\
\text { paid in wages } \\
\text { during year. }\end{array}$ \\
\hline 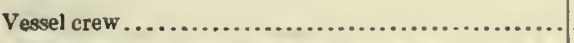 & & \\
\hline Shoresmen (net including employees ol packing houses) & 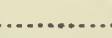 & \\
\hline $\begin{array}{l}\text { Estlmated cost of provisions supplied to employees (n } \\
\text { cluded in wages) } \ldots \ldots \ldots \ldots \ldots \ldots \ldots \ldots \ldots \ldots \ldots \ldots \ldots\end{array}$ & to to be in- & \\
\hline
\end{tabular}

5. QUANTITY AND VALUE OF YEAR'S CATCH: Report all fishery products, Including aquatlc mammais, reptlles, shellish, sponges, otc., takon during the year. Giva tho name and total quantity and value of each species caught by each kind ol appara tus. If the "pounds" is not known and can not be estimat
give tha "busheis" or "number" and state what unit of measure is used.

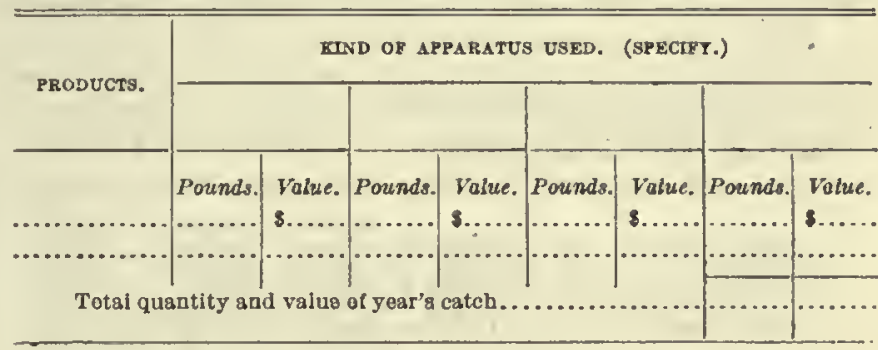

Remarks:

\section{PACKING HOUSES AND CANNERIES.}

[Establishmonts engaged in thecanning and preserving of flsh and in the manufacture of lertilizer, olis, etc., Irom sams must b9 reperted on thls schedule. If fishing operations ars conducted under thB sams ownership, a repert must also be made on the schedules provided lor this purpose. Vessel fisheries must be reported on Schedule EE2-248 and shore or boat fisheries on Schedule EE1-247.]

Nama of company or individual operating the estabilshment.

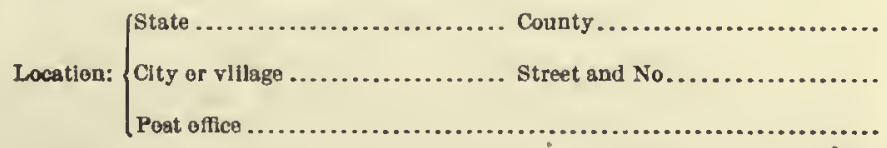

Generai ofice at.

(Establishments operated under the same ownership and located in different states must be reported separataly.)

Washivatos, D. C., January 4, 1909.

The act of Congress of June 7,1906 , authorizes the Director of the Census, in cooperation with the Bureau of Fisheries, to take a census of the fishing industry.

Tho information returned on thls schedule should cever tho business year most nearly conforming to the year ending December 31,1908 . Ail questions that reguire a fixed time, such as cash on hand and values of property, should be of the date of the beginning of the year covered by the report.

All answers will be held absolutely confidenilal. No publication will bo mado in tha census reports disclosing the operations of Individuais or companies in any partlcular, and the information will be used only for the statistical purpases for which it wos given.

Tha canvass wlil bo made under the supervision of Mr. W. M. Stouart, chlef statistician for manufactures.

S. N. D. NoRTH, Director of the Census.

Extract from act of Congress, March 3, 1899:

Section 22.- * * "And every president, treasurer, secretary, director, agant, or other offeer of every corporation, and avery astabilishment of productive industry, whother conducted as a corperate body, limited liabllity company, or by prlvate Individuals, from which answers to any of the schedules, inquiries, or statistical interrogatories provided for by this act are herein required, who shall, if thereto requested by the Director, supervisor, enumerator, or speciai agent,
willfully neglect or roluse to give true and complets answers to any inquiries athorized by this act, or shail willfully give false informatlon, shall be guilty of a misdemsanor, and upon conviction thereof shall bo fined not exceeding ten thou. aand doliars, to which may be added imprisonment for a period not exceeding one year." 


\section{CERTIFICATE.}

This is to certify that the information contained in this schedule is complete and correct to the best of my knowledge and belief, and covers the period from $\ldots . . . . ., 190$, to ........., 190 , during wblch period the plant was in active operation......... days.

(Signature of special agent.) (Signature of the person furnishing the information.) Each question should be answered; if any inquiry is not applicable and no answer can be made, write the word "None."

1. CAPITAL INVESTED, OWNED, AND BORROWED: The answer must show the total amount of capital, both owned and borrowed. Alt the items of fixed and live capital may be taken at the amounts carried on the books. If land or buildings are rented, that fact should be stated and the value given. The value of all items of live capital, hills receivable, unsettled ledger accounts, materials, products, and cash on hand, etc., should be given as of the beginning of the business year reported.

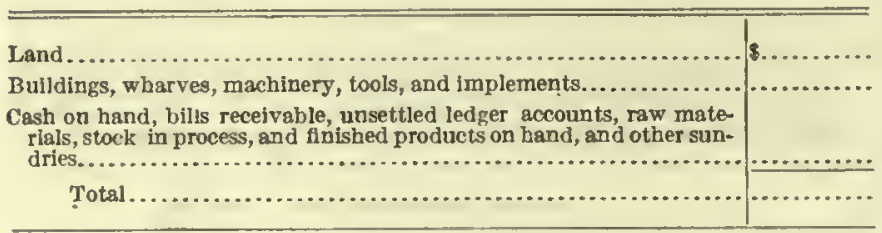

2. PROPRIETORS AND FIRM MEMBERS: Number.........

3. SALARIED EMPLOYEES: Number....... Amount paid in salaries, $\$ . . .$. (Salaried officers, managers, clerks, etc.)

\begin{tabular}{|c|c|c|c|c|}
\hline $\begin{array}{l}\text { 4. WAGE-EARNERS, IN- } \\
\text { CLUDING P I E C E - } \\
\text { WORKERS: Do not in- } \\
\text { clude salaried employees } \\
\text { reported above. }\end{array}$ & $\begin{array}{l}\text { Average } \\
\text { number } \\
\text { employed } \\
\text { during } \\
\text { the year. }\end{array}$ & $\begin{array}{l}\text { Greatest } \\
\text { number } \\
\text { employed } \\
\text { at any } \\
\text { one time } \\
\text { during } \\
\text { the year. }\end{array}$ & $\begin{array}{l}\text { Least } \\
\text { number } \\
\text { employed } \\
\text { at any } \\
\text { one time } \\
\text { during } \\
\text { the year. }\end{array}$ & $\begin{array}{l}\text { Total } \\
\text { amount } \\
\text { pald in } \\
\text { wages } \\
\text { during } \\
\text { the year. }\end{array}$ \\
\hline Men 16 years and over.... & & & & s.......... \\
\hline Wornen 16 years and over.. & & & & ... \\
\hline Children under 16 years.... & ............ & $\ldots \ldots \ldots \ldots$ & (n.......... & (........... \\
\hline 'Total. & & & & \\
\hline
\end{tabular}

To obtain the average number employed during the year, take the average number employed each month, add, and divide by 12 . Salaries and wages should include board or rent furnished as part compensation. Foremen receiving wages and performing work similar to that of the men over whom they have charge are to he reported as wage-earners. If books do not show the separate amount of wares paid to men, women, and chlidren, apportion the total wages for the year upon the basis of an average pay roll.

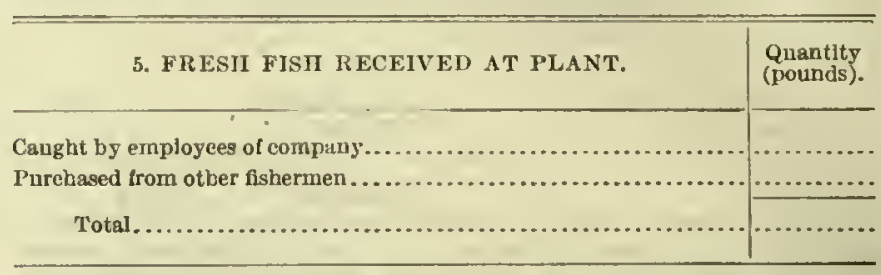

6. PRODUCTS OF PACKING HOUSE OR CANNERY.

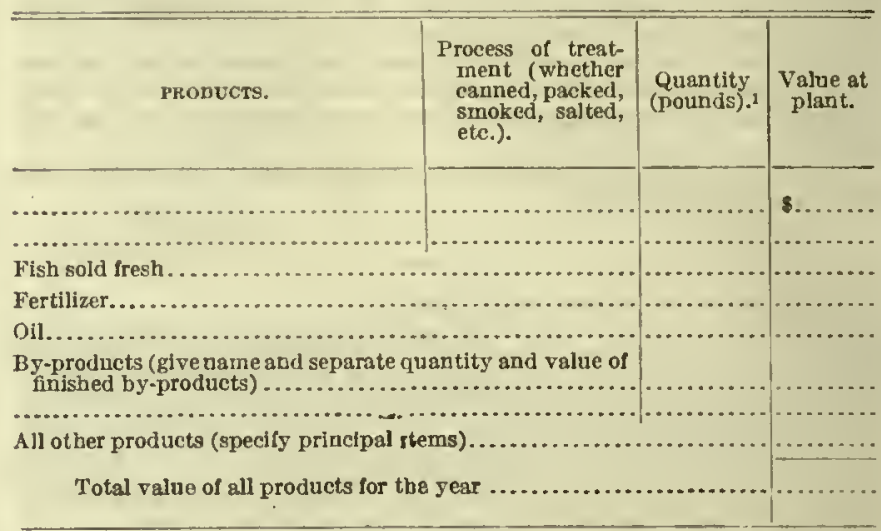

1 If the quantity ls not given in pounds, state specifically the unit of measure used. If number of cans is renorted, give size of cans, for example, "half-pound," "one If number "cans is renorted, je size of cans, slor is used state number of cans of each size. If number of cases ls reported, give number and size of cans in case.

Remarks: 


\section{APPENDIX C.}

\section{INSTRUCTIONS TO SPECIAL AGENTS.}

\section{GENFRAL}

In conformity with the act of Congress of June 7,1906 , the census of the fishing industry is to be made by the Director of the Census in cooperation with the Commissioner of Fisheries. The object of this cooperation is to avoid a duplicate canvass and insure, uniformity and agreement in the reports of the two bureaus. To secure such a result and to minimize the work of correspondence, correction, and revision, the utmost pains must be taken to obtain correct information for all branches of the investigation.

The census is to be made under the immediate supervision of the chief statisticiau for manufactures, and all employees engaged in field work must follow the instructions of that official.

Industries and period covered.-The census must cover, in addition to all varieties of seafood and fish products, shellfish, whales, seals, turtles, crabs, shrimp, alligators, and sponges. It will inelude also the pearl mussel fisheries of the rivers of the country. All commereial fisheries, vessels engaged in fishing, and vessels engaged in transporting fish from the fishing grounds, which operate from the ports of the continental United States, Alaska, or Porto Rico, must be reported. Vessels engaged in fishing or transporting fish for a portion of the year and in other work for the remainder of the I2 months must be reported, and in such cases the report must cover the operations of the entire year. Vessels engaged in transporting fish from port to port as regular freight must not be reported. The census also covers the operations of establishments engaged in canning or preserving fish or in the manuficture of fertilizer, oil, etc., from sea products.

Dealers in fish produets, either wholesale or retail, who are not also engaged in catching or in eanning or preserving fish, should not be reported. It is difficult in many instances to separate the statisties for the mercantile portion of the industry; but the following rules should be applied whenever practicable:

1. When dealers in fish or fish products are also engaged in canning or preserving fish or in catching fish, no attempt should be made to separate these statistics-the en tire establishment should be included in the census report, except as provided in Rule 2.

2. If an establishment is engaged primarily in the purchase and sale of fish or fish products and incidentally in catching fish or in canning and preserving the same, the statistics for the mercantile portion should be segregated and the census report relate exclusively to the fishing or canning and preserving branch of the establishment.

3. In cases where the purchase and sale of fish or fish produets is combined with the canning or preserving of fish or with catching fish, and a combined report is made, as indicated in Rule 1 , the report must show separately the quantity received and the quantity and value of products disposed of in connection with the wholeale or retail branch of the establishment.

4. The freezing of fish or the shucking of oysters when done by merchants is considered as a portion of the mercantile business and should not be reported. If the same establishments are engaged in the catching of fisl or the canning and preserving of the same, the statistics for the entire establishment should be included, as indicated in Rule 1.

For census purposes the term "commercial fishery" includes all frhing operations conducted for profit-i. e., for the sale of the catch, but it does not include the operations of individuale, clubs, etc., eatching fish for their own consumption or for eport.
The census reports must cover the year ending December $3 I$, 1908 , or the fishing season which most ncarly conforms to this calendar year. The fishing season covers different periods in different sections of the country and the reports must be prepared to meet local conditions. The period eovered by each report must be given on the title-page of the schedule.

Daily reports and correspondence.-The canvass will be made by the regular employees of the Census Office and the employees of the Bureau of Fisheries detailed for this purpose. Each employee detailed for field work must make a report on a form provided for this purpose for every day on which he is actually employed. At the elose of each day the daily report must be forwarded by registered mail in the return penalty envelope addressed to the Director of the Census.

Day's work.-The relative efficiency of each employee engaged in field work will be determined by the number and completeness of the schedules secured, and each daily report must account for the work of the day. Inquiries concerning schedules or further instructions must be made by letter and not on the daily report forms, Employees must give sufficient notice of the date they will complete the district to which they are assigned, so that, if necessary, they may be assigncd to other territory without loss of time.

Schedules.-Fishing and the allied industry of packing and canning will be reported on the following schedules:

Schedule EE1-247.-To be used in reporting shore or boat fisheries. If shore or boat fisheries are conducted in connection with vessel fisheries or with eanneries or packing houses, reports should also be made on schedules EE2-248 and EE3-249. If it is necessary to make the report on two or more schedules, care should be taken that no amounts are duplicated. The vast majority of the reports will be prepared on schedules EEI-247 and EE2-248.

Schedule EE2-248.- To be used in reporting fisheries conducted with vessels which have been documented. As indicated by the schedule, it was designed for the purpose of securing a separate report for each vessel. If several vessels are operated under the same ownership and it is impracticable to obtain a separate report for each, a consolidated report may be made on one blank covering the catch of all the craft, provided they operate from the same fishing port. In preparing consolidated reports of the catch of two or more vessels, a separate sehedule must be prepared for each vessel and answers made to the first four inquiries. The entire catch may then be reported under inquiry 5 of any one of the sehedules for fishing vessels. Inquiry 5 of the remaining fishing vessels should be ansiwered by referring to the schedule on which the catch is reported.

Schedule EE3-249.-To be used in reporting packing houses, canneries, and fish curing establishments. Reports must not be made for wholesale or retail dealers in fish unless such dealers are also engaged in fishing. The packing of fresh fish in ice, freezing fish, shucking oysters, or picking crab meat must not be reported when dono by dealers, but when these industries are carried on by fishermen, statistics for them must be included in the reports, as indicated above.

In cases where oyster fishermen shuck the oysters before selling them, the agent must report separately under "Remarks" the number and wages of the employees engaged exelusively in shucking. They must also report, by estimate, if necessary, both the value of the oysters in the shell and their value after being shucked. 
The three schedules are prepared for the purpose of collecting statistics which will enable the office to make a separate presentation of data for shore fisheries, for vessel fisheries, and canning or packing establishments, respectively, the totals for each branch of the industry to be presented by states. Therefore it is important that eeparate reports be prepared; if, however, two or more branches are conducted under the same ownership and it is impossible to secure separate reports, a consolidated report may be prepared, but in such cases a full description of the conditions must be given under "Remarks" on the last page of the schedule and percentages furnished which will enable the office to make the separation if necessary. Great care must be taken to avoid duplication of statistics in the preparation of the separate reports.

Districts and lists.-The entire country has been divided into districts and one or more special agents will be assigned to each district. Before starting the canvass each agent must know the extent of his district, and must not visit points outside his district without specific directions to do so. Each agent will be held accountable for a thorough and rapid canvass of the district to which he has been assigned. To assist in locating the fisheries, vessels, and establishments to be canvassed, each agent will be furnished with-

1. List of localities where fishing is conducted.

2. List of vessels.

3. Index card for each vessel.

4. List of canneries, etc.

5. Index card for each cannery.

The number at the top of the index card must be written in the upper right-hand corner of the schedule and the card must accompany the schedule when it is sent to the office. When an establishment is to be omitted or a cross reference is to be made, the card with an explanatory note on it should be sent to the office with the daily report. The index numbers of all cards accompanying the daily report should be given in the left-hand margin of the daily report. The list of fishing vessels includes the name and address of the owner in each case, and the agent will find that these addresses include many localities not included in the list of localities. It is expected that the agent will be able to secure the reports for most of the vessels at the fishing grounds or fishing ports, and will therefore confine himself to his list of localities until he has secured as many of the reports as possible, after which the owners of the remaining vessels should be visited. This is a general rule and may be waived by the agent if he finds he can conduct the canvass more economically and advantageously otherwise. He should, of course, secure reports from all fishermen in or surrounding a given locality, so as to avoid revisiting the same neighborhood. The lists are not complete and must not be accepted as representing all of the localities nor all of the interests to be enumerated. As the lists were obtained from records that are several years old, the accuracy of the canvass will depend to a very large degree on the diligence of the agents, and they should constantly be on the alert to discover other points at which fishing is conducted and other establishments engaged in the fishing industry. Every name on the agent's list, however, must be accounted for; if a vessel or establishment has changed ownership or gone out of existence, the name and a memorandum of the facts must be given on the agent's daily report.

Each agent will be furnished with a statement of the order in which he will be expected to visit the different points in his district. This order should be followed unless the agent finds that railroad connections and local conditions make a change advisable. In such a case the character and necessity of the change must be stated on the agent's daily report.

Method of canvassing.- It is recognized that the fishing industry differs from all other industries covered by the census, in that it is not conducted during the entire year, and that there are many small unimportant operators. While it is essential that a thorough canvass be made of the industry, the special agent must exercise discretion in securing reports of the operations of the small fishermen and those who are absent at the time of the visit.

On entering a locality where shore fishing is conducted, the agent should first obtain from the principal fishermen and fish dealers a complete list of the fishermen in that vicinity. A rapid canvass should then be made of, and reports obtained from, the fishermen in the immediate vicinity. As these reports are obtained, inquiries should be made regarding fishermen who are absent or who are not easily accessible, and partial reports prepared for them. These partial reports should be corrected if better information is afterwards obtained from dealers or other fishermen. When reports for practically all of the fishermen have been prepared, the agent, instead of making visits to unimportant points in the neighborhood or waiting for other fishermen to return, should complete the can vass of the locality by the use of the estimates he has obtained. The operations of a group of fishermen may be included in one schedule if an accurate estimate of the entire catch can be obtained. The estimated reports should, if possible, be the result of interviews with more than one person, so as to avoid the possibility of exaggerated statements, and should contain under "Remarks" a statement of the conditions under which they were obtained.

In cases where reports are prepared in the manner suggested in the preceding paragraph the agent will probably find it necessary to retain all or some of the schedules for a locality until he leaves the vicinity, so that if better information shall be obtained after the report has been wholly or partially prepared he can substitute it, and so that he can avoid duplication in the reports. If the schedules are thus retained to be sent in later, a memorandum should be made on each schedule showing the date of the daily report on which it was reported.

In visiting a locality the agent should not ask "Is there any commercial fishing here?" but he shculd ask "Was there any fishing here during 1908?" There are localities where fishing is carricd on at certain seasons only, and at the time the agent calls there may be no one fishing. Cases will be found where shore fishermen live in one state and fish in the waters of another state. For example, shore fishermen living in New Jersey may go into Virginia waters at a certain season to fish. In such cases the fishing must be reported by both the agent in Virginia and the agent iu New Jersey. When the report covers operations in different states, full explanation must be made under "Remarks" on the last page of the schedule. This explanation must give the names or description of the different localities in which the fishing covered by the schedule was carried on and the quantity of the catch in each locality.

In preparing reports for a number of fishermen operating out of the same port, care must be taken to avoid duplication. Each schedule must be complete and distinct, so that a uniform tabulation can be made in the office.

It is especially difficult to obtain statistics for fishing vessels that are absent from the home ports for considerable periods. For this reason it will generally be advisable to obtain reports for the fishing vessels of a locality first, and while the shore fisheries and establishments are being enumerated other vessels may come in. There are comparatively few ports from which such vessels operate, and the special agents must resort to every possible means to obtain information concerning them.

If an agent finds that the canvass of a district to which he has been assigned can not be finished because vessels operating from points in it are out at the fishing grounds, he should not remain indefinitely in the district, but must advise the office of the probable number and size of the vessels from which he has not been able to obtain reports, and await instructions. However, if he is satisfied from inquiry that the vessels are comparatively unimportant, he should obtain all available information concerning them, prepare for each a partial report containing the name and address of the owner, the name, net tonnage, and value of the vessel, and general information concerning the character and extent of the catch, and forward same to the office with proper letter of explanation. The necessity of romaining in a locality awaiting the return of vessels is left largely to the discretion of the agent.

Remote localities. - While the entire country bordering on waters from which commercial fishing operations can be carried on must be covered, agents may find that some fishing operations are carried 
on in remote localities not accessible by railroad or boat, and that no exact information concerning them can be obtained without a long, expensive trip by the use of livery. If in such cases the agent can secure satisfactory information that the year's catch was comparatively unimportant, he should not incur the expense of the trip, but should obtain the best information possible from persons who are familiar with the operations of the fishermen, preparo a repert, and give explanation under "Remarks."

In cases where the fisherman is absent when the agent calls and it is evident from a personal inspection that his operations for the year were unimpertant, the information should be obtained from some one familiar with the value of the boats, equipment, and the year's catch.

General report.--Each agent will be required to furnish a gencral statement of conditions and recent develepments in the fishing inclustry in the district to which he is assigned. Detailed answers to the following inquiries will develop these conditions, and the agent must submit the questions to the principal fishermen of each locality and make such memoranda as will enable him to make a full report when the canvass of the district is finished.

1. Has the past scason been an average one, an unusually good one, or an unusually poor one?

2. Has there been any general change in the apparatus used for catching fish in the last two or three years? If so, describe briefy.

3. What are the principal nationalities of the fishermen?

4. Has there been any considerable change in the nationality of the fishermen in the last few years? If so, describe briefly.

5. What kinds of fish, if any, are being caught in smaller quantities in the last few years?

6. What kinds of fish, if any, are being caught in greater quantities in the last few years?

7. What kinds of fish, if any, have been caught for the first time in the neighborhood in the last year or two?

8. What conditions, if any, exist that make the fishing unusually difficult or unprofitable?

9. Are these conditions increasing or decreasing?

10. IIas any disease affected the fish during the past year? If so, describe briefly the extent and nature of the disease and the kind or kinds of fish affected.

11. Describe briefly the nature and extent of loss of life and preperty during the year.

In addition to the foregoing inquiries, the agent is at liberty and will be expected to ask such other questions as will tend to elicit valuable information as to the conditions of the industry in the section of the country in which he is working.

\section{Schedule for Vessel Frsheries EE2-248.}

Title-page.-The name and post-office address is not necessarily that of the owner of the vessel. It may be the name and address of the person or company operating the fishery, as in some cases the ressels are chartered and the owner is not connected with fisheries.

Fishing port.-The term "fishing port" is generally understood by vessel fishermen, and means the port at which the catch is ordinarily landed. As a rule, the homes of the fishermen are at the fishing port.

Hailing port.-The hailing port of a vessel is the port at which it is documented in the customhouse and from which its official papers issue.

Name of vessel.-The full name of the vessel should be given. For example, if the name of the vessel is Charles Bacalester it should be so reported, and not as the Mfacalester. If the name of the vessel has been changed during 1908, that fact should be noted under "Remarks."

Net tonnage.-The net tonnage is given in the efficial papers of a vessel and is also cut on the vessel itself. The owuer or captain will generally know the net tonnage.

Certificate. - The certificate should show the time covered by the report. If the vessel was sold or destroyed during the year, the fact should be noted under "Remarks." A space is provided for the signature of the person furnishing the information for the report

$$
76786^{\circ}-11-20
$$

and the schedule sheuld erdinarily be signed; but if for any reason it is impracticable to ebtain a signature, it may be omitted. In such cases the agent should supply the name of the person who furnished the information. If the post-office address of the person furnishing the information is different from that given on the face of the schedule, it should be reported.

Capital invested.-The answer to this inquiry should cover the entire investment. If vessels are chartered or buildings or apparatus are rented, they should nevertheless be reported. If such vesscls or apparatus are included in another fisherman's report, an explanation should be made under "Remarks," so that the duplication may be eliminated. The amount reported should be the value of vessels, buildings, and apparatus at the beginning of the year covered by the report. All vessels equipped with mechanical propelling power are considered as "steam " or "motor." A vessel having both sails and steam power weuld be classed as "steam."

The term "transporting vessels" includes all vessels connected with the fishery, but not actually engaged in fishing. Fer example, it includes towbeats engaged in hauling vessels carrying fish, vessels used as cold-storage barges or to live on, watch beats, and lay boats. If a transperting vessel is not connected with vessel fisheries, that fuct should be stated. It might be connected with a cannery or packing house or even with a shore fishery. Vessels engaged in both fishing and transporting should be reported as fishing vessels, but the fact that they were also engaged in transporting should be noted under "Remarks." The value of eutfit is, strictly speaking, not an item of capital but an item of expense. The answer to this inquiry, therefore, should shew the total outlay for outfit during the year. Many vessels will, of course, be fitted with a new supply of provisions, fuel, bait, etc., several times a year. Care should be taken that the answer does not show the value of only one complete outfit for the vessel. It is believed that the list of apparatus given on the schedule will cover practically all the kinds in general use. Nevertheless, blank lines have been added, and if the agent finds any apparatus in use that is not included in the list, be should report it on one of these lines and should, in addition, give a general description of the apparatus under "Remarks," with a diagram, if necessary. If shore and vessel fisheries are carried on under the wame ownership, it will be necessary to fill out more than one blank, but it is not necessary to divide the value of shore and accessory property and cash, etc. The value of these items may be reported on any one schedule and reference to that schedule made on the other schedules.

In some states private or cultivated oyster beds are loased for a term ef years or actually owned by the operators. This, hewever, is net the universal practice, and as it will be impossible to obtain the total value of all oyster beds, this item must not be included in the values reported for answer to inquiry 1.

Proprietors, firm members, and independent fishermen.-Stockholders of corporations should not be reported unless they are also employees of the company. A person fishing on shares, delivering a part of the catch to another person and selling the remainder, should not be considered as an independeut fisherman; in this case the persen to whom a part of the catch was delivered sheuld be considered the proprietor. It is desired to shew in the report the total number of persons engaged in fishing. For this reason it is necessary to indicate whether the proprietor was actually engaged in fishing. In the great majerity of cases the proprietor will be found to be so engaged, but in cases where he is not, this fact should be indicated in the space provided. If the ownership of the vessel is in shares, a number of which are held by parties whe take no part in its management, these parties should be reported as "shareholders." Persons reported in inquiries 2, 3, and 4 should not be duplicated when more than one schedule is secured for operations carried on under the same ownership.

Salaried employees. - There will probably be comparatively few cases where it will be necessary to answer this inquiry. It applies only to large companies having a managing office in which recerds of the fishing are kept by salaried empleyees. Persons reported in this inquiry should net be reported on another schedule. 
Vessel crew.-The regular crew, including the fishermen on the vessel, should be reported as "vessel crew." If the captain or any other member of the crew has been reported as a proprietor, he should not be reported here. Where fishermen are working on shares, it will be necessary to estimate the annual wages. Where board is provided for fishermen as part compensation, the value of provisions thus used should not be included in wages, but should be reported separately as provided for in the schedule.

Quantity and value of catch.-The total catch should be reported. The number of pounds should be obtained if possible, but in cases where it is impossible to estimate the weight the quantity should be reported by some other unit of measurement, the unit used being specified. If the quantity is reported in barrels, casks, boxes, bas kets, or similar measure, the size of the unit should be stated. It will probably be necessary in most cases to report the quantity of oysters, clams, etc., in bushels. When oysters are reported, a statement should be made showing whether they were taken from public or from private beds. The quantities and values of market and seed oysters must be reported separately.

The prices of fish and fish products vary greatly, according to the season or the state of the market. Agents must familiarize themselves with the prices prevailing in the section of the country in which they are employed, and in every instance check the quantities and values reported so as to verify the average price and see that it is in harmony with actual conditions. In cases where fishing operations are conducted in connection with a packing house or cannery, the two operations being carried on by two different sets of employees, the entire catch of fresh fish should be reported on the schedule for "Vessel fisheries" or "Shore and boat fisheries," as the case may be, and the products of the packing house or cannery should be reported on the schedule provided for the purpose. The two schedules should be attached to each other when sent to the office.

In cases where fishermen salt or smoke a part of their catch, the same employees being engaged in both the fishing and the salting or smoking, the entire report should be made on a schedule for "Shore and boat fisheries" or for "Vessel fisheries," as the case may be. In such cases each kind of fish caught by each kind of apparatus should be reported in the condition it was when it left the fishermen's hands-for example, "fresh cod," "salted cod," or "smoked herring." If the fishermen are employed in connection with a cannery, the fish will leave their hands fresh, and should be reported in this way. If they salt or smoke a part or all of their catch, the fish so treated should be reported as they leave their hands; that is to say, as salted or smoked. In reporting fresh fish the weight before being cleaned, commonly known as "round weight," should be given.

When it is necessary for the fisherman to estimate the quantity and value of the catch, the total quantity and the total value should be entered and the attention of the informant called to such entries before the echedule is signed.

In reporting a traneporting veesel, it is of course unnecessary to answer the question relating to the catch.

It is the intention of the office to publish separately the quantities and values of each spccies of fish caught during 1908. It is possible that some difficulty will be encountered in obtaining complete returns in this detail, and for this reason the attention of the agents is particularly called to this phase of the inquiry. It will be the natural inclination of the fishermen, in giving an estimated report, to mention only the principal kinds of fish caught, but the agents must use every effort to obtain a complete list of the species taken during the year, together with their quantities and values.

It is frequently found that, while fishing operations may be carried on particularly for the capture of a certain species of fish, still other varietics will almost invariably be taken. These other varieties may not appear to the fishermen to be of much importance, but it is believed that the quantities thus caught will in the aggregate be considerable.

The last report of the Bureau of Fisheries for the state in which the agent is working will show, by counties, the quantities and values of each epecies of fish caught during the year covered by the report, and it will therefore be well for the agent to familiarize himself with this list.

\section{Schedule for Shore and Boat Fisheries EE1-247.}

If several fishermen work together in a sort of partnership arrangement, one report should be made for them. When a fisherman works on shares - that is, keeps a part of his catch and delivers the other part to his employer-he should not be considered as an independent fisherman.

The instructions for filling the schedule for "Vessel fisheries" will cover most of the inquiries on the schedule for "Shore and boat fisheries." Special attention is, however, called to the following points:

Locations.-The location reported should be the point on shore from which the fishing operations are conducted. In many cases a fishing camp is established as a base of operations.

Waters where fishing is conducted.-The answer to this ouestion should give the name of the body of water where the fishing is conducted, as, for example, the name of the river, inlet, bay, or sound.

Tagc-earners.-Only employees actually connected with the fishing should be reported as wage-earners. Shorcsmen should include all shore employees directly connected with the catching of fish; for example, it would include persons engaged in mending nets.

\section{Screnute for Packing Houges and Canneries Ee3-249.}

This schedule is intended to cover all packing, preserving, and curing of fish. The operations are not necessarily conducted in buildings, but fish may be salted or otherwise preserved on the beach or even on the deck of the fishing vessel. If the packing or curing is done by the fishermen, the report should be made as indicated under "Quantity and value of catch," above.

If an individual or company operates plants in different states, a separate report should be made for the plants in each state, as it is desired to present statistics separately for the several states.

Wage-earners.-To obtain the avcrage number of wage-earners employed during the year, the average number employed during the various months should be added and the total divided by 12 . The word "none" should not be used in answer to the inquiry as to the least number cmployed at any one time in the case of an establishment that had no employees for a part of the year, but the smallcst number employed at any one time should be given.

Fresh fish received at plant.-This should include all fish received at the plant. Spoiled fish received by a fertilizer plant should be reported. If imported fish were received at a plan $\varepsilon$, that fact should be stated. If partially treated fish are received at the plant and the process completed, the quantity of partially treated fish received at the plant should be reported separately from the quantity of fresh fish received.

Products.--Under this head should he reported the kind, quantity, and value of fish or sea products, and the nature of the process of treatment (canned, packed, smoked, salted, made into fertilizer, etc.). If the quantity can not be reported in pounds, it should be reported in other terms, and the unit of measurement should be stated. If barrels or casks are reported, their size should be stated. If canned goods are reported in number of cans, the number of cans of each size should be stated; if number of cases are reported, the size of the cans and the number of cans to each case should be given. If canned oysters are reported in pounds, the agent must be careful that the weight given represents the actual contents of the cans. The contents of a 1-pound can of oysters may weigh 10 ounces. Therefore in this case sixteen 1-pound cans of oysters should be reported as 10 pounds. If by-products are reported, the various kinds should be named or described, and the quantities and values of the principal by-products should be reported separately.

The difference between the weight of the green fish and the finished product of the cannery depends largely upon the process employed and the character of the finished product. This variation, however, must be carefully noted at the time of preparing the reports, and when it is excessive or apparcntly insufficient, a proper memorandum of explanation should be given under "Remarks" on the last page of the schedule. 


\section{LIST AND DESCRIPTION OF KINDS OF FISH.}

Abalone (Haliotis).-A mollusk found on the coast of California, especially abundant in the neighborhood of San Diego. It is also called "sea-ear," "ormer-shell," "car-shell," etc. Different species are known as red abalone, black abalone, and rough abalone. The shells are largely sold for commercial purposes, many being shipped to Europe. The flesh is salted and dried and used for food by the Chinese.

AlBACORE. - See Horse mackerel.

ALEWIFE (Pomolobus pseudoharengus and $P$. xstivalis).-These two species are generally known indiscriminately as alewives, and are found in waters adjacent to the sea. $P$. pseudoharengus is never found south of the Neuse River, in North Carolina. It is known along the Potomac as "branch herring;" on the Albemarle as the "big-eyed herring" and the "wall-eyed herring;" in New England as "alewife," and on the Connecticut as "ellwife" and "ellwhop." It appears in the rivers three or four weeks earlier than the "glut herring" or the "shad." P. xstivalis is found from the Carolinas to the Gulf of Maine. It is known in the Chesapeake and Albemarle as "glut herring;" in the Ogeechee as "English herring;" in the St. Johns as "herring," and in Massachusetts and during the later runs in the Rappahannock as the "blueback;" also known as "black-belly," "saw-belly," and "kyack." It is less abundant than $P$. pseudoharengus, and much less valuable as a food fish. Both species average about a half pound in weight and 8 to 10 inches in length. They are caught in nets, seines, weirs, etc., and are of very great importance as food fish. They are also used for bait. The name is also applied to the menhaden (Brevoortia tyrannus) in Delaware, Maryland, and Virginia.

Alfione (Rhacochilus toxoles). - A food fish found on the California coast from Cape Mendocino to San Pedro. It is also called "perch" and "sprat." It reaches a length of 18 inches and a weight of 5 pounds. It is the most important of the surf-fishes.

Alligator (Alligator mississippiensis). -The alligator is found in the strearns and swamps of the Southern states, and more or less numerously along the coast from South Carolina to Texas. It is also called "cayman." Alligators attain a length of 12 feet, and average about 10 feet. 'They are captured for their hides, oil, ivory, flesh, skeletons, and eggs.

AMBer-Fish (Seriola). - A food fish found from Cape Cod to Cape Hatteras. It is known as "jack-fish" on the Carolina coast, and "amber-fish," "shark's pilot," and "rudder-fish" elsewhere. The average length is 24 inches; average weight, 7 pounds. Another species found on the California coast is known as "yellow-tail."

ANcuovy (Engraulididx).--These are small fishes of the genus Anchoria common on the Atlantic coast from Cape Cod to Texas; also on the coast of southern California, and the genus Engraulis common from Alaska to Lower California. The silver anchovy (Anchovia browni) is the common Atlantic species. It is also known as "gardine" and "spearing," and with other anchovies enters into the composition of "white bait." The California anchovy (Engraulis mordax) is the largest and most valuable food species. It is mostly preserved in oil or made into fish paste. The name is also applied to preparations of other fish, especially young herring and sprat.

ANGEL-FISH.-1. A name applied to the moonfish, "or spadefish (Chotodipterus faber), from Florida to Clarleston. 2. Small, beautifully tinted fish (Holacanthus), found in tropical waters, especially among coral reefs. They are sold for exhibition in aquaria and also for food.

ATkA-Fish (Pleurogrammus monopterygius). - A fine food fish found among the Aleutian Islands. The average weight is about 2 pounds and average length about 16 inches. Also known as "Atka mackerel."

"Barracuda (Sphyroena argentea).-An excellent food fish caught on the California coast from San Francisco southward. It reaches a length of about 5 feet and a weight of about 12 pounds. It is caught with hand lines and by trolling, and when dried and salted makes excellent food. The great barracuda ( $S$. barracuda), also known as "picuda" or "becuna," is found on our coast from Pensacola to Charleston and is the largest of the geuus, reaching a length of 6 feet. Smaller species (S. borcalis and S. guachaucho) are found as far north as Cape Cod, but are not highly valued as food fish.

BAss.-See Black bass, Calico bass, Redfish, Rock bass, Sea bass, Striped bass, and White bass.

The "yellow bass" or." "brassy bass" (Morone interrupta) is found throughout the lower course of the Mississippi; the "mud bass" (Acantharchus pomotis) in the coastwise streams from New Jersey to North Carolina; the "silver bass" (Ifiodon tergisus) in the Ohio Valley and northward to the upper Missouri. The "Otsego bass" is the whitefish (Coregonus clupeaformis) of Otsego Lake, New York; the "little bass," the little roncador (Genyonemus lineatus) of San Francisco.

Beluga (Delphinapterus leucas).-A whale abundant in the north Atlantic, north Pacific, and Arctic Oceans. Specimens are occasionally taken as far south as Cape Cod. It is also called "white whale," "whitefish," "porpoise," "dauphin blanc," "marsoon," etc. It attains a length of 15 feet and is captured for its oil and skin. The oil is sold under the name of "porpoise-jaw oil;" the skin is made into leather.

BIO-EYED MACKEREL.-See Chub mackerel.

BILL-FISH.-A name applied to the gar-pike (Lepisosteus osseus), to the garfish (Tylosurus marinus), and to the spearfish (Tetrapturus imperator).

BLAcK Bass (Microptcrus salmoides and M. dolomieu).-These two species are known, respectively, as "large-mouth black bass" and "small-mouth black bass." The former is found generally in sluggish waters from Dakota to New York and south to Florida and Mexico. It is known in the Great Lakes region as "Oswego bass," in Indiana as "moss bass," in Kentucky as "jumper," in North Carolina as "chub" and "welshman," and in the Southern states as "trout," "green bass," and "bayou bass." The small-mouth bass is generally found in clear running streams from Dakota to the St. Lawrence, and south to South Carolina, Alabama, and Arkansas. In the Southern states it is also called "jumper," "perch," "trout," "mountain trout," etc. Each species is from 1 to 21 feet in length and weighs from 2 to 8 pounds. They are caught with hook and line and furnish a considerable quantity of excellent food. The name is also applied to the black rockfish (Sebastodes mystinus and S. melanops) in Puget Sound.

BLACKFIN.-A whitefish (Leucichthys nigripinnis) found in Lake Michigan; also called "bluefin."

BuAckfish (Globicephalus melas).-An important and abundant emall whale found on the Atlantic coast as far south as New Jersey. It is also called "pilot whale," "grind whale," etc. Its average length is from 15 to 18 feet; average weight, 1,000 pounds. It is captured by being stranded on the shore and by harpooning, and is valuable for its oil. Fishermen sometimes use this whale for food and bait. The name is also applied to the sea bass (Centropristes striatus) south of Cape Hatteras and about Marthas Vineyard, and to the tautog (Tautoga onitis) on the coast of New York and ivew Jersey.

BuAcK HoRse (Cycleptus elongatus).-A sucker found in the larger streams of the Mississippi Valley. It is also called "gourdseed sucker," "Missouri sucker," "sweet sucker," and "suckere]." It reaches a length of $2 \frac{1}{2}$ feet and a weight of from 5 to 12 pounds. A good food fish.

Blenny (Blenniidx). - A fish of little economic value, found on the Atlantic, Pacific, and Gulf coasts, sometimes sold in the market as "eels."

BLINKa.-One-year-old mackerel, graded fourth in the markets. BLISTER.-A very young oyster.

BLOATE18. - A fat herring or mackerel.

BlUевасK.-1. An important salmon (Oncorhynchus nerka) found on the Pacific coast from the Columbia River northward. In the 
upper Columbia and in Alaska it is called "redfish;" in the lower Columbia, "blueback;" in Puget Sound, "sockeye;" and in the Fraser River, "suk-kegh." It averages about 8 pounds in weight and ranks next to the Chinook salmon in value at the canneries. 2. The name is also applied to the "glut herring" (Pomolobus æstivalis) in Massachusetts and in the later runs of the Rappahannock.

Blue CoD.-See CuItus cod.

BLUEFIN (Leucichthys nigripinnis). - One of the whitefishes found in Lake Michigan; also called "blackfin."

BLUefish (Pomatomus saltatrix). - A very gamy food fish found on the Atlantic and Gulf coasts. On the coast of the New England and Middle states it is called "bluefish;" in Rhode Island, "horsemackerel;" south of Cape Hatteras, "skipjack;" in North Carolina, Virginia, and Maryland, "tailor" and "greenfish;" in the Gulf of Mexico, "bluefish." Young bluefish are called "snapping mackerel," "snappers," and "salt-water tailors" in some parts of New England; "blue snappers" about New Bedford, and "skip mackerel" about New York. Bluefish vary in weight from 1 to 20 pounds, according to season and locality. Large numbers are caught during the summer months with nets, traps, seines, and hand lines. The name is improperly applied to the squeteague (Cynoscion regalis) from southern New Jersey to Virginia, to the black sea-bass (Centropristes striatus) at Newport and New Bedford, to the "greenfish" (Girella nigricans) on the California coast sou th of Monterey, and to the bonito (Sarda sarda) in the markets.

BuUfFish мuмmichog.-See Mullet.

BLUNT-Nosed shiner (Selene vomer).-A familiar food fish found along the Atlantic coast from Florida to Cape Cod and in the Gulf of Mexico. It is known in various places as "hogfish;" in North Carolina, as "moonfish" or "sunfish;" in Florida, as "moonfish;" at Woods Hole, as "humpbacked butterfish;" and in the New York market and Narragainsett Bay, as "pug-nosed shiner." It is from 8 to 12 inches long.

Boccaccio. - See Rockfish.

Bontro (Sarda sarda). - A food fish found in the Atlantic Ocean. It weighs from 2 to 10 pounds, and is caught with hand lines and in nets. The name is also applied to all the larger scombroids, and to the cobia (Rachycentron canadum) in the Chesapeake.

Bowfin (Amiatus calva). $-\Lambda$ fresh-water food fish found in the Great Lakes and in the streams which flow into the south Atlantic and the Gulf of Mexico. It is also called "dogfish," "gawyer," "mud-fish," "grindle," etc., in different localities. It reaches a weight of 10 to 12 pounds, and is caught with hook and line. It is used for food in some states.

Bowhend (Balæna mysticetus).-A whale of great commercial importance found in the Aretic regions. It is the most valuable of all whales. It yields large quantities of oil. It has the fineste and longest baleen.

BresM.-A name used in many localities, generally with some descriptive prefix, for the common fresh-water sunfish. At Charleston the sailor's choice (Lagodon rhomboides) is known as "salt-water bream." The golden shiner (Abramis crysoleucas) is also called "bream" in some localities, as is the rockfish (Sebastes marinus).

Brook trout.-See Speckled trout.

BUFFALO FISH, RED OR BIG-MOUTKED B UFFALO (Ictiobus cyprinella); Black or Monarel buFralo (I. uTus); and SMall-MoUthed or WHITE BUfFalo ( $I$. bubalus).-These fresh-water suckers are common to the waters of the Mississippi Valley and sometimes weigh 30 to 40 pounds. They are caught with nets and hand lines. "Buffalo carp" is a name sometimes erroneously applied to them.

Bullfrog (Rana catesbiana).-A very familiar fresh-water amphibian found in nearly all localities in the United States. It is the largest of the frogs, sometimes reaching a length of 8 inches along back. The hind quarters are used extensively for food.

BuLL-HEAd. -See Horned pout.

Bursot (Lota maculosa).-A fresh-water fish found in most of the lakes and streams in the northern part of the United States. In various localities it is called "ling," "lawyer," "lake cusk," "cel- pout," "dogfish," "chub-el," "fresh-water cod," "mother of eels," "aleby trout," etc. It reaches a length of 30 inches.

BUTTERFish (Poronotus triacanthus). - A food fish found on the Atlantic coast from Maine to Florida. It is called "butterfish" in Massachusetts and New York, "harvest-fish " in New Jersey, "dollarfish" in Maine, "sheepshead" and "skipjack" about Cape Cod, "pumpkin-seed" in Connecticut, and "starfish" at Norfolk. It has an average length of 7 to 8 inches, and is caught in traps and pounds.

Cabrilla. - A name applied indiscriminately to several serranoid fishes of the southern coast of California. They are also called "rock bass," "kelp salmon," "Johnny Verde," "lockee cod" (Chinese), etc. They are from 1 to 2 feet long, weigh 2 to 5 pounds, and are used extensively for food.

Calico bass (Pomoxis sparoides). - A food fish found in the Great Lakes, in the Mississippi Valley, and in the streams of the Carolinas and eastern Georgia. In Lake Erie and in Ohiogencrally it is called "strawberry bass" or "grass bass;" in Lake Michigan, "barfish;" in Illinois, "calico bass;" in the South, "goggle-eye" or "goggleeyed perch;" also sometimes called "bitter-head," and "lamplighter." It averages from 1 to 2 pounds in weight, and is caught with hook and line.

Canderish.-See Eulachon. The black candlefish (Anoplopoma fimbria) is found on the Pacific coast from Montcrey northward.

Caperin (Mallotus villosus).-A small fish of the smelt family found in the north Atlantic as far south as Maine, in Bering Sea, and in the Arctic Ocean. It reaches a length of about 12 inches. It is valuable food for other fish, especially the cod, and is used extensively for bait. They are caught in seines and dip nets, generally at night. The name is incorrectly applied to the silverside (Menidia notata) in the vicinity of Boston.

Carp (Cyprinus carpio). - A fresh-water food fish of great interest to fish culturists, now found in ponds and streams in nearly every state of the Union. As a result of domestication several varieties have arisen, the principal ones being the "scale carp," heavily scaled, the "mirror carp," with a few series of very large scales, and the "leather carp," naked. The size varies with the temperature and clearness of the water, the abundance and nature of the food supply, the kind of bottom, etc. They live to a ripe old age, and sometimes attain a weight of more than 40 pounds. Also known as "German carp."

CA Trish (Siluridx).-The American species include the sea catfishes of the Atlantic coast, the channel cats of all the rivers east of the Rocky Mountains, the horned pout widely distributed through the brooks and ponds of the states, and the diminutive mad toms. The various species are distinguished by the common names of "channel cat," "blue cat," "Mississippi cat," "mud cat," "flannelmouth," "horned pout," "bull-head," "minister," "goujon," "bashaw," "gaff-topsail," etc. They vary in length from 1 to 5 feet and in weight from 2 to 150 pounds. They are caught by means of nets, traps, hand lines, and jugging, and are largely used for food.

Cavalua. See Crevallé.

Cero. - See Spanish mackerel.

Cetaceans.-Marine mammals, more or less fishlike in form, found in all seas, such as whales, dolphins, porpoises, etc.

Channel-1asa. - Sce Red-drum.

Chicken hatibut. $-\Lambda$ name applied to small or young halibut. They are sold at a slightly higher price per pound than the commonsized fish. The name is also incorrectly applied to the summer flounder (Paralichthys dentatus).

Chinook salmon.-See Quinnat.

Chooset (Tautogolabrus adspersus).--This fish is found mostly in bays and harbors on the coast north of New York. It is also called "cunner," "sea perch," "perch," "bergall," "nippers," "baitstealer," etc. It is similar to the tautog in appearance and is generally associated with it; it is from 8 to 10 inches long, and weighs about 1 pound. It is caught in bag nets and with book and line, and in some localities used for food. 
Cavb.-This name is given most frequently to various species of the Cyprinidx. They are found in all parts of the United States, but have no great value as food fish. The name is also applied to the tautog (Tautoga onitis) in New Jersey and in the Chesapeake, to the spot (Leiostomus xanthurus) at Charleston, S. C., and to the large-mouth black bass (Micropterus salmoides) in North Carolina.

Chu в мackeret (Scomber japonicus). - A food fish of much less value than the common mackerel, which it closely resembles. It is found irregularly along the Atlantic and Gulf coasts and in the Pacific as far north as Monterey. It is also called "thimble-eye," "big-eyed mackerel," "bull mackerel," "easter mackerel," "tinker mackerel," and "little mackerel." It reaches a length of about 1 foot, and on account of its small size very little attention is paid to it where the common mackerel is found.

Cloar-Fish.-See Round robin.

Cisco (Leucichthys artedi).-One of the lesser whitefishes, found in the Great Lakes and neighhoring waters. Other names are "lake herring," "Michigan herring," etc. The usual length is a little more than 12 inches. It belongs to the salmon family. The name is also applied to a related species of less economic importance.

Сия 4.-A name given to bivalve mollusks largely used for food and bait; found on all our coasts. Various species, most of which are edible, are known by the names of "soft clam," "long clam," "butter-fish," "mananose," "nanninose," "squirt clam," "quahaug," "hard clam," "surf clam," "sea clam," "hen clam," "beach clam," "dipper," "skimmer," "painted clam," "cuneata clam," "round clam," "little-neck clam," "gapers," "tellens," "flat clam," "razor clam," "razor-fish," "knife-handle," "bullnose," etc. The fishing or digging of these bivalves forms an important industry in both the Atlantic and Pacific states. Dredges, rakes, tongs, hoes, forks, and baskets are used in gathering them. Large quantities are salted or pickled and sold for bait.

Conia (Rachycentron canadum). - One of the mast important food fishes of Maryland and Virginia, and found less abundantly along the entire coast from Cape Cod southward. It is called "bonito" and "coalfish" in the Chesapeake; "sergeant-fish" in southern and eastern Florida; "ling" and "snooks" in western Florida; and "crab-eater." It averages from 2 to 3 feet in length.

CoD (Gadus callarias).- One of the most important food fishes of the United States. It is caught most extensively along the coasts of the Middle states, New England, and British America. It varies in weight from 3 to 75 pounds. It is caught with hand lines, trawls, nets, etc., and is sold fresh, pickled, salted, and dried. Food preparations, such as boneless and desiccated fish, are also made from cod. The sounds are used in the manufacture of glue. The Alaska cod (Gadus macrocephalus) is an important food fish found from Bering Sea to Oregon.

The skilfish (Anoplopoma fimbria) is known as the "black cod." The redfish (Sebastodes melanops) is known as the "red cod."

The cultus cod (Ophiodon elongatus) is always called "codfish" where the true cod is unknown.

CoNch (Strombus gigas).-A large sea snail found on the Atlantic coast and extensively gathered and sold for ornaments, for the manufacture of porcelain and lime, and for medicinal purposes. The animal is used as food in Key West. A valuable pearl is sometimes derived from it.

Crab.- A general term applied to various kinds of decapod crustaceans found along the entire coast. The different epecies vary much in size, habit, and use, and are designated blue, fiddler, green, hermit, horseshoe, jonab, kelp, king, lady, mud, oyster, red, rock, sand, sea, soldier, spider, stone, etc. The edible crabs have names applied by the catchers, describing the different.conditions of the shell. While shedding they are known as "hard-shell," "comer," "buster," "peeler," and "shedder;" while growing a new shell, "soft-shell," "paper-shell," "buckler," and "hardshell." The gathering of crahs is an important industry along the entire Atlantic coast. They are caught with scrap nets, dip nets, pots, seines, trawle, hand lines, spears, and tongs, and are used for food, bait, and fertilizers. The fertilizers are sold as "cancerine."

Crappie (Pomoxis annularis). - A fresh-water food fish found in the Mississippi Valley. Local names are "bachelor," "new light," "campbellite," "sac-a-lait," "chinquapin perch," etc. It is sometimes confounded with the calico bass (Pomoxis sparoides).

Crayfisi, or Crawfish.-A decapod crustacean found in most of the fresh-water streams of North America. It is sometimes called the "spring lobster." The principal supply is obtained at New Orleans, in the Potomac, and near the Great Lakes, and the principal markets are New York and New Orleans.

Crevalué (Caranx hippos). - A food fish veryabundanton the east Florida and Gulf coasts, and occasionally found as far north as Cape Cod. Iocal names are "crevalle," "horse crevalle," "horsemackerel," etc. The average weight is 12 pounds. The name is also applied to the cero (Scomberomorus cavalla).

Croaker (Micropogon undulatus). - A food fish found mostly in the South, but sometimes caught as far north as New York. Local names are "crocus" and "ronco." It averages about 10 inches in length. Large quantities are caught in the Gulf with hand lines and seines, and sell at low prices.

Also a local name for blue surf-fish (Embiotoca jacksoni) at San Diego, and for the fresh-water drum (Aplodinotus grunniens) in northern Indiana.

Couтcr.-The spawn of the oyster; also materials used to form the spawning bed for oysters.

Cultus coD (Ophiodon elongatus). - A common food fish found on the Pacific coast from Sitka to Santa Barbara. Common names are "codfish", "ling," "bastard cod," "buffalo cod," "blue cod," etc. It averages about 8 pounds in weight, and is caught on hooks and in sweep nets.

Cuneata cLa (Gnathodon cuneatus). - This clam is found in large quantities in the Gulf of Mexico and is used as an article of food. The shell is used for road making. The famous shell roads of the South are constructed of these shells, taken from Lakes Pontchartrain and Salvador.

\section{Cunner. - See Chogret.}

Cusk (Brosme brosme). - A deep-water food fish found in the Atlantic Ocean north of Cape Cod.

CutrLe-Fisu (Cephalopoda).-Mollusks found in large numbers all along the coast. The "common squid," "octopus," "calamary," "sea arrow," etc., are different species found in particular localities. They are caught in fish pounds, seines, weirs, and trawls, and with fishhooks; large numbers are also taken by driving them on shore by "torching." Some are caught with a peculiar arrangement of hooks called a "squid jig." Different species vary in length from a few inches to 50 feet. They are important as a bait for many useful fish and as food for man. Oil, "cuttle bone," a dentifrice, india ink, etc., are also obtained from them.

DACE.-A common name applied to different species of the Cyp. rinidx family, generally modified by some descriptive prefix, as "horned dace," "red dace," etc.

Din MOND-BACK. - See Terrapin.

Dogrish (Squalus acanthias). - A shark found abundantly in the north $A$ tlantic, sometimes ranging south to Cuba. On the Pacific coast is found $S$. sucklii. It reaches a length of 3 feet. They are captured for their livers and skins, the former producing large quantities of oil, and the latter, when dried, beiug used for polishing purposes. The names "smooth-dogfish," "horned dogfish," etc., are applied to related species. The name dogfish is also applied to the bowfin (Amialus calva) in the region of the Great Lakes and to the burbot (Lota maculosa) about Lake Erie.

Dolphin.-1. Cetaceans abundant everywhere in temperate and tropical seas; also known by the names of "porpoise," "cowfish," "herring-hogs," "puffers," etc. Dolphins are from 5 to 15 feet long and weigh from 100 to 500 pounds. They are captured in nets, by harpooning, and by driving them ashore, and are used for bait and 
for the oil and leather they produce. 2. A pelagic fish (Coryphæna hippurus) sometimes found on our coasts.

Drum (Pogonias chromis).-1. A large food fish found plentifully in the south Atlantic Ocean and Gulf of Mexico and occasionally taken as far north as Cape Cod. The young and adult fish are respectively known as "striped drum" and "black drum." The average weight is 20 pounds. They are caught in seines and gill nets and with hook and line. The flesh is coarse, but sweet and tender. The large and silvery scales are used in the manufacture of "fishscale jewelry." 2. The fresh-water drum (Aplodinotus grunniens) is found in all large bodies of water from the Great Lakes to the Rio Grande. It is known as the "sheepshead" on the Great Lakes; as "perch," "white perch," and "gray perch" on the Ohio River; as "crocus" on the lakes of northern Indiana; as "drum" and "thunder-pumper" in the Southern states; and as "gaspergou" in Arkansas, Louisiana, and Texas. "Jewel-head" is sometimes heard. It reaches a length of 4 feet and a weight of from 40 to 60 pounds. It is a food fish, but not of fine quality. 3. Redfish or red drum (Scirnops ocellatus).

DuN-FisH.-Cod or other fish that are slack-salted and dried or cured in a dark room until they turn an amber or dun color. They are much esteemed for food.

Eex (Anguilla chrisypa).-A very common food fish found in all parts of the United States east of the Rocky Mountains in both fresh and salt waters. Eels are caught in weirs, nets, traps, pots, baskets, and with spears and hand lines, and are sold fresh and canned. The skin is used for mechanical purposes.

Eulachon (Thaleichthys pacificus). - A small fish common in the rivers and coast waters of the north Pacific. The Indian name "oolican" (hoolakins) is often used. The trade name is "candlefish." On the Columbia River the name "smelt" is used. The length averages a little less than 1 foot. It is an excellent food fish, and is also of importance for the oil it yields, which is used as a substitute for cod-liver oil.

Finback (Balænoptera physalus).-This is a large whale common to all seas. It attains a length of about 70 feet, and is captured by stranding or by the use of the bomb lance. It yields very little oil or baleen. Other species are found in the north Atlantic and on the Pacific coast.

Fratrish.-A name applied to a large group of fishes which have the body much compressed, both eyes on one side of the head, the blind side colorless and usually lowermost in the water. It is the common name given to the family of flounders (Pleuronectidx).

Flounder (Pleuronectid $x$ ).-The family of flounders is composed of the turbots (Bothin $x$ ), the halibuts (Hippoglossinx), the plaices (Pleuronectinæ), and probably the soles (Soleid $x$ ). The name is variously applied to the flat fishes found on all our coasts, as "American sole," "bastard halibut," "Monterey halibut," "winter flounder," " starry flounder," "rough limanda," "diamond flounder," "long-finned sole," "sand-dab," "rough dab," "Greenland turbot," "pole flounder," "craig flounder," "spotted sand flounder," etc. They are of all sizes and vary in shape; caught in weirs, pounds, seines, and nets, and with hand lines and gaffs, and sold for food and bait.

Fur seaL (Collorhinus ursinus).-A fur-bearing sea mammal found from California northward; especially abundant upon the Pribilof Islands. Its skin is of great commercial value. Its flesh is not used for food except by the natives.

Garfish (Tylosurus marinus).-A fish of little economic importance common on the Atlantic and Gulf coasts from Maine to Texas. It often ascends rivers for great distances. It is also called "needlefish" in the Gulf of Mexico, "garfish" on the Altantic coast, and "tea-snipe," "silver gar," and "billfish" in different localities. It is about $2 \frac{1}{2}$ feet long and weighs about 2 pounds. Other species are known as "peedle-fish" and "houndfish" or "agujon."

GAR-P1KE (Lepisosteus osseus).-A destructive fish found in the Great Lakes, throughout the Mississippi Valley, and in most of the streams of tho Southern states. Other names often used are "gar," "'billfish," "swordfish," "long-nosed gar-pike," etc. It reaches a length of 5 or 6 feet. The flesh is tough and not edible.

The short-nosed gar ( $L$. platystomus) is smaller than the preceding und has the same geographic distribution, but is less common northward.

The alligator gar (L.tristachus) is found in all waters tributary to the Gulf of Mexico as far north as the Ohio River. It attains a length of 10 feet, but averages about 2 feet. It is of no valne as a food fish.

Gaspereav.-The Canadian name for the alewife (Pomolobus pseudoharengus).

GoldFish (Carassius auratus). - A small fresh-water fish, closely allied to the carp, native to eastern China. They are used only as ornaments for aquaria. The name is also applied to a California damsel-fish (Hypsypops rubicundus).

Goony.-See Spot.

Gooserish (Lophius piscatorius).-A large sluggish fish found on the north Atlantic coast from Nova Scotia to Cape Lookout. Local names are "angler," "fishing frog," monkfish," "bellows-fish," "molligut," "all-mouth," "wide-gape," "kettleman," etc. It reaches a length of 4 feet and a weight of 40 pounds. Although palatable, it is seldom used for food, being principally used as bait for lobster pots.

Grampus (Grampus griseus).-A large dolphin taken on tho Atlantic coast. It is also called "cowfish." It attains a length of 15 to 20 feet, and is valuable for the oil it yields. A smaller species $(G$. stearnsii) is found on the California coast.

Grayline (Thymallus signifer).-A beautiful fish found in Alaska. 1t averages 10 or 11 inches in length and half a pound in weight. Varieties are found in Montana (T. montanus) and Michigan (T. tricolor) and are of great interest to anglers.

Gray Whale (Rhachianectes glaucus). - A large whale found along the Pacific coast; also called "devilfish," "hard-head," "gray back," "rip sack," "mussel digger," etc. It averages 35 or 40 feet in length, and is captured for its oil and baleen.

Green turtue (Chelonia midas). - This turtle is found on the coast from Long Island Sound to Florida and along the Gulf coast. In the different localities it varies in size, from 8 pounds at Beaufort, $N$. C., to 1,000 pounds at Cedar Keys, Fla. The flesh of this turtle forms the basis of the well-known turtle soup; the eggs are valuable for food and for the oil they yield. A closely related species is found on the coast of southern California.

GriLsE. - $A$ young salmon on its first return to fresh water, usially in its second year of life. It then weighs from 2 to 6 pounds, and is of great value as a food fish. See Salmon.

Grouper (Epinephelus). - A food fish found off the south Atlantic coast and in the Gulf. The different species are known as "red grouper," "brown snapper," red-bellied suapper," "black grouper," "jewfish," "warsaw," "spotted hind," "banded grouper," "rockfish," etc. They vary in size greatly, the "jewfish" exceeding 100 pounds. All are caught with hook and line. The name "grouper" is also applied to the rock cod of southern California and to the tripletail of the St. Johns River.

Grunt.-The name of several small Hæmulidæ quite common off the south Atlantic and Gulf coasts, and sometimes found on the California coast. Different species are known as "black grunt," "red-mouth grunt," "flannel-mouthed porgy," "pigfish," "hogfish," "sailor's choice," "sargo," "pork-fish," ete. All are caught with hook and line and are valued as food fish. They make a peculiar grunting noise when taken out of the water.

MADDock (Melanogrammus aglifinus).--A food fish found in the Atlantic north of the Delaware capes; called "dickie" in some localities. It a verages in weight from 4 to 6 pounds. It is extensively caught for a fresh food fish, and is also salted, pickled, and dried. When slack-salted and smoked it is sold under the name of "haddie." The sounds are used in the manufacture of glue. Trawls and hand lines are used in catching them.

HAKE (Urophycis). - Not true hakes, A food fish found off the Atlantic coast from Newfoundland to Cape Hatteras. Different 
species are known as "old English hake," "squirrel hake," "white hake," "ling," "king hake," "codling," etc. They are often prepared under the trade name of "boneless fish." They average from $1 \frac{1}{2}$ to 2 feet in length and 3 to 8 pounds in weight, and are caught near muddy bottoms with trawls and hand lines and in weirs and traps. They are eaten fresh, and are salted and dried, and pickled in barrels. The sound, or air bladder, is of great commercial importance in the manufacture of isinglass. The name is also applied to the kingfish (Menticirrhus saxatilis) on the coast of New Jersey and Delaware. The California hake (Merluccius productus) and the New England whiting (Merluccius bilinearis) or "silver hake" are true hakes.

Halibut (Ifippoglossus hippoglossus).-The largest and most valuable of the flat fishes; found in the North Atlantic and Pacific Occans. It is one of the largest species used for food, sometimes weighing over 300 pounds. The average weight is from 50 to 75 pounds. It is caught with trawls and hand lines. There are three grades of halibut. The "white," which has its underside immaculate, is considered best and brings the highest price; the "gray" is blotched on the under side and sells for a third less; the "sour" is tainted, and brings only about one-fourth as much as the "white." Small young fish, weighing from 10 to 20 pounds, are called "chickens," and are much sought after by epicures. Halibut are sold fresh and are also cured and smoked. The napes are pickled. An oil used for currying purposes is made from the head, and the reidue is used as a fertilizer under the name of "chum." See Flounder.

Hallotis.-See Abalone.

HawkS-n1L, tURTLE (Chelonia imbricata).-This turtle is found on the Atlantic coast south of North Carolina and throughout the Gulf. It is also called the "tortoise-shell turtle." It reaches a weight of about 300 pounds. It is of no value for food, but is caught for the hornlike scales or plates which cover its bony shell, which form the "tortoise shell" of commerce. A closely related species is found on the Pacific coast.

HERring (Clupea harengus).-A very important food fish found in the north Atlantic as far south as Sandy Hook; it is never found in brackish or fresh waters. "Sperling" and "brit" denote differenees in the age of the fish. They weigh from one-half to 1 pound; average length, 10 inches. They are caught in pounds, traps, weirs, and gill nets, and by "torching." As a food fish they are used fresh, ealted, pickled, smoked, and canned; used also extensively for bait in the cod, haddock, halibut, and hake fisheries.

The name is also applied to the Gulf menhaden (Brevoortia patronus) on the Texas coast and to the menhaden (B. tyrannus) in southern Florida. The hickory shad (Dorosoma cepedianum) is called "thread herring" in North Carolina. Tho "big-eyed herring" (Elops saurus) appears in America north to the Carolinas and Gulf of California. The California herring (Clupea pallasi) is found the entire length of the Pacific coast. The Rocky Mountain whitefish (Coregonus williamsoni) is called "mountain herring" in Utah. For "lake herring" and "Michigan herring," see Cisco; for "branch herring," "big-eyed herring," "wall-eyed herring," "glut herring," "English herring," "spring herring," and "summer herring," see Alewife; for "fall herring," see Mattowacca.

IIocFism (Lachnolaimus maximus). -A much-esteemed food fish found about the Florida reefs, where it is caught by line fishermen. It a verages 3 to 5 pounds in weight. The name is also applied to the log perch (Percina caprodes), to the pigfish (Orthopristis chrysopternes), and to the blunt-nosed shiner (Selene voiner).

HORNED POUT (Ameiurus nebulosus). - $\mathbf{A}$ catfish found in the fresh waters of the Eastern, Northern, and Southern states, and in California. It is also called "bull-head," "bull-pout," "minister," etc. It averages about 12 inches in length and $1 \frac{1}{2}$ pounds in weight.

HorNEY-HEAD, - A small dace (IIybopsis kentuckiensis), found abundantly in rivers from New York to Alabama and in the West.

Horsefish.-See Blunt-nosed shiner. The name is also applied to the sauger (Stizostedion canadense).
Horsefoot. - A local name for the horseshoe crab or king crab.

HonsE-MACKeneL (Thynnus thynnus). - The largest of the mackerel family, found on the Atlantic coast to Newfoundland and on the California coast to Monterey Bay. Also called "tunny," "tuna," and "albacore." The average length is about 8 feet. A good fond fish and yields much oil, etc. The name is also applied to the bluefish (Pomatomus saltatrix) in Rhode Island; to the jurel (Caranx chrysos) at Fort Macon; to the crevalle (Caranx hippos); to the California hake (Merluccius productus) on the Pacific coast; and to several Pacific coast species of little importance.

Horseshoe crab (Limulus polyphemus).-A crustacean found on the Atlantic coast in large numbers; also called "king crab," "horsefoot," etc. It is caught by hand and in pounds and weirs, and is used for both bait and food, but most extensively for fertilizing purposes.

Huмpвлек (Megaptera nodosa).-A whale found in both the Atlantic and Pacific Oceans. It attains a length of 50 feet. It is valuable for its oil, but the baleen is short and of poor quality.

HUMPBACKED RUTTERFISII, - See Blunt-nosed shiner.

JACK.-A name applied to the common pickerel (Esox reticulatus) in the South, to the bocaccio (Sebastodes paucispinis) on the Pacific coast, and to the wall-eyed pike (Stizostedion vitreum) in the South.

JACK-FISH. - See Jurcl.

JACK SALMON. - Sce Wall-eyed pike.

Jewrisf (Stereolepis gigas).-The largest food fish found on the Pacific coast, sometimes reaching a weight of 500 pounds. It is also called "black sea-bass." The name is also applied to the black gromper (Garrupa nigrita) in Florida and Texas, and to the tarpon (Tarpon atlanticus) in Georgia and Florida.

JuREL (Caranx chrysos). - A food fish found along the Atlantic and Gulf coasts. It is known about Pensacola as "jurel" and "hardtail;" along the Florida coast as "jack-fish" and "skipjack;" in South Carolina as the "horse crevalle;" " at Fort Macon as the "horsemackerel;" and about New York and on the coast of New Jersey as the "yellow mackerel." They measure from 12 to 18 inches in length, and are caught in seines.

Kilier Whale (Orca orca).-A whale from 15 to 30 feet long that abounds in both the Atlantic and Pacific Oceans, but is seldom captured. The Makah Indians of Washington consider them choice food. The jaws, studded with strong, conical teeth, are sold as curiosities.

King Crab.-See Horseshoe crab.

KIngFish (Menticirrhus saxatilis). $-\Lambda$ food fish found on the coasts of the Middle and South Atlantic states, and occasionally on the Gulf coast. It is called "hake" in New Jersey, "tomcod" in Connecticut, "black mullet" in the Chesapeake, "sca mink" in North Carolina, and "whiting" in the South. Also a common name for the cero (Scomberomorus cavalla).

King mon.-See Quinnat.

LaDYFisf (Albula vulpes).-A fish of wide distribution in temperate and tropical waters; found on the Atlantic coast as far north as Cape Cod, in the Gulf of Mexico, and on the Pacific coast to San Dicgo. On account of its beautiful color it sells readily, but is not much esteemed as a table fish.

LAKE HERRING.-See Cisco.

LAKE TROUT (Cristivomer namaycush). - The trout found in the Great Lakes and in the smaller lakes of the Northern states. In different localities the individuals vary greatly in color, size, and shape, and are known by the local names "salmon trout," "namaycush," "togue," "tuladi," "Mackinaw tront," "lake salmon," "black trout," "reef trout," "longe," ete. The "siscowet" is another variety of this species.

LAMPREY (Petromyzonid $x$ ). -A fish of little commercial value, found in nearly all the fresh and brackish waters of the United States. It is also known by the names "lamper eel," "nine-eye," etc.

LANT (Ammodytes americanus). - I small fish found on the north Atlantic coast, probably as far south as Maryland, and A. personatus 
in California and Alaska. It is also known as the "fand eel" and "kand-lance," because it frequently imbeds itself in the sand. The average length is about 10 inches.

LiNG.-A local name given to the hake (Urophycis) in the Gulf of St. Lawrence and south of Cape Cod; to the burbet (Lota maculosa) in Lake Ontario, the lakes of western New York, and in the New York market; to the mutton-fish (Zoarces anguillaris) in different localities; to the cobia (Rachycentrom canodum) in western Florida; and to the cultus cod (Ophioden elongatus) about Pnget Sonnd.

LoBsten (Hontarus americanus). - A decapod crustacean of great economic importance, found on the A tlantic coast from Delaware to Labrador. It averages about 11 inches in length and about 2 pounds in weight, but the size varics with localities and scasons. It is caught in pots and traps especially constructed for this fishery.

The "spiny lobster" of California and Florida is a different species; it averages $3 \frac{1}{2}$ pounds in weight.

LoogerHeAD (Thalassochelys caretta).-A turtle of small economic value, found in the Atlantic as far north as Massachusetts and in the Gulf of Mexico. It reaches a weight of 1,500 pounds, but those taken average only about 50 pounds. They are caught by divers. Only a small number are sold for food, as the flesh is not palatable, but the eggs are bighly esteemed. An inferior quality of oil is obtained from this turtle.

LUMP-FLSH (Cyclopterus lumpus). - An unwieldy fish, widely distributed throughout the north Atlantic, ranging on the coast as far south as Chesapeake Bay. The average weight is about 5 pounds. It is of little economic value, but on account of its bright colors is often found in the markets.

Mackeree (Scomber scombrus).-A very important food fish, found in the north Atlantic sonth to Cape Hatteras. They range from 9 to 18 inches in length and $\frac{1}{2}$ to 3 pounds in weight, and are caught in purse seines, pounds, weirs, gill nets, etc., and with hook and line. They are sold fresh, salted, pickled, and canned, and are cometimes used for bait. Small mackerel are known as "spikes" (5 to 6 inches long), "blinkers" (7 to 8 inches long), and "tinkers" (9 inches long). See Atka mackerel, Spanish mackerel, chub mackerel, horse-mackerel.

Mademorsblie.-See Yellowtail.

MANATEE (Trichechus latirostris).-A sirenian found on the Florida coast in very small numbers; also called "sea-cow." They are from 6 to 8 feet long, and are caught in rope nets and with spears and javelins. On account of their scarcity they have become very valuable as specimens. They are also converted in to food, oil, and leather.

Maroate-FI8H (Hæmulon album).-A grunt found in Eouthern Florida; known also as "porgy," "market-fish," etc. The largest measure about 16 inches in length. They are canght mostly for bait, but in some places they are sold for food.

MARKET-FiSH. -See Margate-fish.

Marshbaxker.-See Mfenhaden.

Mattowacca (Dotosoma cepcdianum). - A poor food fish found on the $A$ tlantic coast from Cape Cod to Florida, ascending rivers. It is called "hickory shad" and "hicks," particularly in the South; "tailor shad," "tailor berring," and "fresh-water tailor" in the Potomac; and "forerunner" and "fall herring" in some rivers, in allusion to the time of its run and that of the "white shad." It averages 12 to 15 inches in length and 2 to 3 pounds in weight.

Medialura (Medialuna californiensis).-An excellent food fish found on the California coast south of Point Conception; also called "half-moon:" It reaches a weight of 3 or 4 pounds and a length of about a foot.

Menhadex (Brevoortia tyrannus). $-\Lambda$ fish of the herring family, found along the Atlantic seaboard from Maine to Florida, sometimes as far inland as brackish water extends. It is known by a great number of local names, the most common being "pogy," "hardhead," "hard-head shad," "bony fish," "whitcfish," "mossbunker," "bunker," "cheboy," "marshbanker," "alewife," "oldwife," "ellwife," "pilcher," "green-tail," "bug-fish," "bug-shad," "bug-head," "fat-back," "yellowtail," "shiner," "herring," etc. The average length is 10 to 12 inches; average weight two-thirde of a pound to 1 pound. They are caught in purse seines, haul seines, gill nets, set nets, and weirs. They are of economic importance mainly for the oil and guano which are produced from them; they are also used as bait for mackerel, cod, halibut, haddock, sea-bass, etc. As a food fish they are sold fresh and salted and canved. "Fishmeal," a food for domestic animals, is also made from them. Another species (B. patronus) is found on the Gulf const.

Menominee (Coregonus quadrilateralis).-Sce Whitefish.

Merluccio (Merluccius productus). - A poor food fish found on the Pacific coast from Santa Barbara northward. It is also called "hake," "horse-mackerel," etc. It averages 5 to 6 pounds in weight.

Missouri sucker.-Sec Black horse.

MOON-EYE (Hiodon tergisus).-A beautiful fresh-water food fish found in the Lake region and in the larger tributaries of the Mississippi. It is also called "silver bass" and "toothed herring." It weighs from 1 to 2 pounds, and is caught with hook and line and in dip nets. Also a common name for the cisco (Argyrosemus hoyi) of Lake Michigan.

Moonfish (Chxtodipterus faber). $-\mathrm{A}$ food fish caught on the Atlantic coast from Woods Hole southward, in the Gulf of Mexico, and on the California coast. In the northern parts of the Gulf of Mexico it is called "spadefish;" from Florida to Charleston "angcl-fish;" and at Beaufort, N. C., "porgee" and "pogy." The average length is not more than 8 inches. A local name for the blunt-nosed shiner (Selene vomer) in North Carolina and Florida.

Mossiunker.-See Menhaden.

MULLet (Afugil cephalus and M. curema).-Two species of mullet are found on the Atlantic coast, known as tho "striped mullet" and the "white mullet." The former is the larger and has 8 instead of 9 rays in the anal fin and 42 instead of 38 scales between the gill openings and base of the caudal fin. The "striped mullet" is found on the Atlantic coast from Cape Cod to Brazil and on the coast of southern California, ascending streams; the "white mullet," from Cape Cod southward. Local names are "bluefish mummichog," " "jumping mullet," "sand mullet," fat-back," "silver mullet," "big-eyed mullet," "blue-hack mullet," "liza," or "josea." M. cephalus is the most important of all the food fishes of the Sonth, and greatly surpasses $M$. curema both in numbers and in economic importance. It averages about 1 foot in length and 1 pound in weight, but sometimes reaches a weight of 4 to 5 pounds and a length of 24 inches. It is caught in haul seines, gill nets, cast nets, pound nets, etc., and is sold fresh and salted; the roc is also very valuable food, and is sold fresh, salted, smoked, and dried.

For "black mullet," see King-fish; for "ground mullet," see Whiting. Many suckers of the genus Moxostoma are called "mullet," "white mullet," "sucking mullet," etc.

Ifummichoo (Pociliid $x$ ). - These fish are fond in the brackish waters along the Atlantic, Pacific, and Gulf coasts, near the mouths of rivers, and in many of the fresh-water streams and lakes. Along the eastern coast they are known as "mayfish," "killifish," and "fundalus;" on the Gulf as "sac-a-lait;" and in the interior as "minnows." They are all small fish, rarely exceeding 4 inches in length. They are not commonly used for food, but are of much importance as food for larger fish and for bait.

Mubrallunoe (Esox masquizongy). - A rare food fish found in the Great Lakes and Northwest, sometimes appearing in the Ohio. The average length is about 6 feet; average weight, 40 pounds. It is canght in pound nets, with hook and line, and by trawling. Another species ( $E$. ohiensis) is abundant in Chautauqua Iake.

Musseu (Mytilus edulis).-A black, thin-shelled, salt-water mollusk, found on the Atlantic coast as far sonth as North Carolina and on the Pacific coast to Monterey. They are not used extensively for food, but in New York they are pickled and sold to a local trade. The shells are used as a cultch for young oysters, for paint holders, and for ornamente. Large quantities of another genus (Modiola) are 
sold to farmers along the New Jersey and Long Island cossts for fertilizer trade. The fresh-water mussels (Unionidx) are of much value as food for mammals and birds. The shells are used in making pearl buttons.

IIUtTon-FISH (Zoarces anguillaris). - A food fish found on the Atlantic coast from Delaware to Lahrador. It is also called the "eelpout," "mother-of-eels," "congo eel," "ling," and "lamper eel." It reaches a length of about 20 inches and a weight of 3 pounds. The name is also given to the snapper (Lutianus analis) of Florida.

NaMAYcush. - See Lake tront.

NANN1NOSE.-See Clam.

Narwhal (Monodon monoceros).-A dolphin found along the northern coast of Alaska and in the Arctic Ocean; also known as the "unicorn." It is 10 to 14 leet long, and bears a tusk 9 feet long. It is captured for its tusks, oil, and flesh.

NORWAY ILADDOCK.-See Rosefish.

Octorus.-See Cuttle-fish.

OtDWIFE.-See Menhaden.

Oswego bass. - See Black baes.

OTTER (Ifustelidx).-The fresh-water otter (Lutra canadensis) is widely distributed over the United States. 'The sea-otter (Enhydris marina), highly prized for its skin, is found in the North Pacific. Both are rare.

Oyster (Ostrea virginica). - The most important bivalve found on the coast. There are two classes, "native" and "plants." The former are found on the entire coast; the latter in localities where the cultivation of the oyster is particularly profitahle. Oysters are obtained by dredging, raking, and tonging, and are very extensively used in the canning industry. The shells are used in manufacturing lime and cement and for building highways. Native oysters will open about 1 gallon to the bushel; plants do somewhat better. Oystere are graded as "extras," "boxes," "culls," and "cullinteens," according to age, the "cullinteens" being the youngest.

PADdle-Fish (Polyodon spathula). - A ganoid fish, allied to the sturgeon, found in all the larger streams of the Mississippi Valley. It reaches a length of 3 or 4 feet. It is a poor food fish, but the roe is extensively used for caviar. Local names are "spoonbill," "duckbill cat," and "shovelfish."

PEARL OYster. - An oyster found on the California coast and in the Gulf of California. The shells are used in manufacturing various useful and beautiful articles.

Perce (Perca Ravescens).-This fish, the true perch, is found throughout the Great Lakes region and the rivers of New England and the states east of the Alleghenies as far south as Georgia. "Yellow perch" and "ringed perch" are names in common use; "striped perch" is used at Lake Vincent. Its usual length is about 1 foot and its weight generally less than 2 pounds. It is of moderate value as a food fish, and is caught with hook and line and in pound nets and gill nets.

The name "perch" is also given to the large-mouth black bass (Micropterus salmoides) and to the small-mouth black bass ( $\boldsymbol{M}$. dolomieu) in the Southern states; to the chogset (Tautogolabrus adspersus) in localities in Massachusetts; to the fresh-water drum (Aplodinotus grunniens) in the Ohio River; and to the surf-fishes (Embiotocidx) on the Pacific coast. "Black perch" is applied to the triple-tail (iobotes surinamensis) in South Carolina, and to the blue surf-fish (Embiotoca jacksoni) on the Pacific coast. "Chinquapin perch" is applied to the crappie (Pomoxis annularis) in the lower Mississippi; "gray perch" to the fresh-water drum (Aplodinotus grunniens) in the Ohio River; "log perch" to a darter (Percina caprodes); "pike perch" to the wall-eyed pike (Stizostedion vitreum); "red perch" to the rosefish (Sebastes marinus) on the coast of Maine; "ringed perch" to the perch (Perca flavescens); "river perch" to a surf-fish (Iyslerocarpus traski) of California; "Sacramento perch" to a sunfish (Archoplites interruptus) of the Sacramento and San Joaquin Rivers; "silver perch" to the yellowtail (Bairdiella chrysura) in New Jerey; "etriped perch" to the perch (Perca flavescens) at Lake Vincent; "white perch" to a surf-fish (Phanerodon furcatus) on the California coast; to a bass (Morone americuna) on the Atlantic coast; to the fresh-water drum (Aplodinotus grunniens) in the Ohio River; and "yellow perch" to the perch (Perca Ravescens).

Periwinkle. $-\Lambda$ common name for the sea snail (Littorina) and whelk (Fulga), which are used for bait and sometimes for food on the north Atlantic coast. It also constitutes $\alpha$ large portion of the food supply of various fishes.

Pickerel (Esox reticulatus).-A food fish found in streams and ponds along the Atlantic coast from Maine to Alabama. In the Southern states it is usually called "jack." It reaches a weight of 7 or 8 pounds; averages about half as much.

The name "pickerel" is also applied to the true pike (Esox lucius) in the upper lakes; to the "wall-eyed pike" (Stizostedion vitreum) in Lake Erie and Saginaw Bay; and to the sauger (Stizostedion canadense). The wall-eyed pike ( $S$. vitreum) is also called "yellow pickerel" about Lake Erie. The brook pickerels (E. americanus and $E$. vermiculatus) are found, respectively, along the Atlantic coast and in the Mississippi Valley. "Salt pickerel" and "medium pickerel" are trade names.

Prafisr.-A name applied to the genus Orthopristis of the family of grunts, found on the southern coast.

Prke (Esox lucius).-A food fish found in the Great Lakes region; also called "pickerel." It is distinguished from allied species by ito color, which is uniform brown, green, or black, with numerous elongate white blotches upon the sides. It averages 4 to 8 pounds in weight. They are caught with hook and line and in gill nets and pound nets. The name "pike" is also applied to the wall-eyed pike or pike perch (Stizostedion vitreum) in the upper lakes, and to the Sacramento pike (Ptychocheilus oregonensis) in the Columbia and Sacramento Rivers. "Gray pike," "sand pike," "ground pike," etc., are names for the sauger (Stizostedion canadense).

Prke perches (Stizostedion vitreum and S. canadense).-The "wall-eyed pike" (S. vitreum) otherwise known as "glass-eye," "pike perch," "yellow pike," "dory," and "blue pike " on the Great Lakes; as "salmon," "jack," "okow," "blowfish," and "green pike" in other localities. It is found in the large streams and ponds east of the Missouri; it is an excellent food fish and may reach a weight of 20 pounds. The sauger or sand-perch ( $S$. canadense) is smaller and less important as a food fish. It is especially abundant in the Great Lakes, but extends to Montana, Tennessee, and Arkansas.

Pilot-fish (Naucrates duetor).-A pelagic fish of no economic importance, and seldom taken on our coast. It is about 12 inches long, and is generally found in the company of ships and sharks.

P1Nrisu.-See Sailor's choice.

PrAice.-A flat fish found on both coasts of America. The winter flounder (Pseudopleuronectes americanus) is a common food fish of New England. Other species are known as "rusty-dab," "eelback flounder," "craig-fluke," "pole-flounder," "flukes" on the Atlantic coast; as "great starry flounder," "slippery sole," etc., on the Pacific coast. See Flounder. The true plaice (Pleuronoctes platessa) is a European species not found in American waters.

PogY.-A name applied to the menhaden (Brevoortia) tyrannus north of Cape Cod, to the moonfish (Chxtodipterus faber) and the scup (Stenotomus chrysops) along the southern coast, and to the surf-fish (Damalichthys argyrosonnus) on the coast of Oregon.

Pollack (Pollachius virens). - A food fish of importance, found mainly off the New England coast. It sometimes occurs as far south as Virginia. The average weight is about 10 pounds. They are caught with seines, nets, and hand lines. For food they are sold fresh, salted, and dried. The sounds are used in the manufacture of glue, the livers are sold in large quantities for the manufacture of oil, and the tongues are cut out and sold fresh.

Pompano, or Pampano (Trachinotus carolinus).-An excellent food fish, found on the Atlantic coast from Cape Cod to the Gulf, being very common on the Florida coasts. They average 8 to 10 
inches in length and 1 to 2 pounds in weight. Other species found on our eastern coast are the "old-wife," or "gaff-topsail pompano;" the "round pompano," or "Indian River permit;" the "permit" or "great pompano," which is frequently not distinguished from the "common pompano" ( $T$. carolinus) by the fishermen. The poppyfish (Palometa simillima) is miscalled the "California pompano." It is a delicate food fish.

Poroes, or Porgy.-A name given to the surf-fish (Damalichthys argyrosomus) in Oregon and Washington; to the moonfish (Chretodipterus faber) at Beaufort, N. C.; to the scup (Stenotomus chrysops) in New York and along the southern coast; to the sailor's choice (Lagodon rhomboides) in the St. Johns River and at Cedar Keys; and to several sparoids of the Gulf.

PoRk-Fisn (Anisotremus virginicus).-See Grunt.

Porpolse (Phocana communis), - A cetacean found on the north Atlantic and north Pacific coasts, ascending rivers. It is known as "harbor porpoise," "herring-hog," "puffer," "snuffer," "snuffing pig," etc. It reaches a length of 4 or 5 feet. They are captured in pounds, seines, and mackerel gill nets. They are not used for food, but an oil is obtained from their jaws which is much used for mechanical purposes. The skin is tanned and made in to leather. The name is also applied rather indiscriminately to many dolphins.

PrAwn.-See Shrimp.

PuMprin-8Eed.-A name applied to the sunfish (Eupomotis gibbosus) of the brooks of New York and New England, and to the butterfish (Poronotus triacanthus) in Connecticut.

Quahaug (Venus mercenaria).-An edible clam, found very abundantly from Cape Cod to Florida. It is also called "hard clam," "round clam," "bull-nose," "little neck," etc. They are gathered by raking.

QUEEN-FISH (Seriphus politus).-A small food fish of excellent quality found on the Pacific coast south of Tomales Bay. It is also called "kingfish." The average weight is about half a pound.

QUiLL-BACK.-A sucker (Ictiobus velifer) found abundantly in the Mississippi Valley.

Quinnat (Oncorhynchus tschawytscha). -The species of the salmon family mostly used for canning. It is found on the Pacific coast from Nonterey northward. It is also called "chinook salmon," "king salmon," "Columbia River salmon," "salmon," etc. The average weight is 16 to 22 pounds.

RACER.-A shad that has spawned and is lean and worthless.

RAY (Raix).-A general name given to a large group of fishes found on all our coasts. They are also called "skates," "torpedoes," "devil-fishes," etc. They sometimes attain an enormous size, measuring 3 feet across the back and 10 feet in length. They are caught on trawls and in seines, and some are used for food; oil is obtained from the livers of some, and the skin is sometimes manufactured in to leather called "shagreen."

RAzor-sHell (Ensis directus).-1 long, slender clam which is a common inhabitant of sand bars and sand flats in New England where the water is pure. It is also called "razor-fish," "razorclam," "knife-handle," etc. It is sometimes used for food, and its shells are sold for ornaments. The California razor-shell is a different species (Solen sicarius).

RED DRUM. - The redfish (Scirnops ocellatus). Also known as "channel-bass."

RED-EYE.-See Rock bass and Warmouth.

REDFIN.-A name applied to the common shiner (Notropis cornutus).

REDFish (Scixnops ocellatus).-1. A much-esteemed food fish found on the coast from Cape Cod to the Rio Grande. It is commonly known as the "red drum." In Chesapeake Bay and south to Cape Hatteras it is called the "drum;" in the Carolinas, Florida, and the Gulf, "bass," "spotted bass," "red bass," "sea bass," "reef bass," and "channel bass;" in Florida and the Gulf states, "redfish" and "red horse;" and at various places, "spot." It grows to a length of 5 feet or more and a weight of 75 pounds; average weight, 10 pounds. They are taken with spears, gill nets, and bottom lines.
2. The redfish of California (Pimelometopon pulcher) is found from Point Conception to Cerros Island. It is also called "fat-head" and "sheepshead." It reaches a weight of 12 to 15 pounds, but is not a valuable food fish.

3. The blueback salmon (Oncorhynchus nerka) is also called "redfish" in the upper Columbia and in Alaska.

4. The redfish (Sebastodes melanops). A food fish found from southeastern Alaska to California. It is also known as "red cod," "red rockfish," etc. See Rockfish.

RED HORsE.-1. A name applicd to several species of suckers found in the waters of the West and South. They are all poor food fishes.

2. The redfish (Scixnops ocellatus) of Florida aud the Guli.

RED SNAPPER (Lutianus aya). - A valuable food fish found off the Florida coast and in the Gulf of Mexico. It attains a weight of 40 pounds, but averages only about half as much. It is caught with hand lines, and is sold fresh.

RoAcr (Semotilus corporalis). - The largest chub found east of the Rocky Mountains. It is abundant in the streams of the New England and Middle states east of the Alleghenies. Also called "fallfish," "chub," "dace," etc. It reaches a length of 18 inches, but is of no special importance as a food fish. A local name for the spot (Leiostomus xanthurus) in the Chesapeake region.

Robin.-A name applied to the sailor's choice (Lagodon rhomboides) about Cape Hatteras.

Rock. -See Striped bass.

Rock BAss (Ambloplites rupestris). - A small food fish everywhere abundant in lakes, ponds, and larger streams throughout the Great Lakes region and the Mississippi Valley. It is called "rock bass" in the Lake region and "goggle-eye" and "red-eye" farther south. It seldom exceeds $I \frac{1}{2}$ pounds in wreight. The name is also given to the sea bass (Centropistes striatus) at New Bedford, Mass., and to several other serranoid fishes of the Pacific coast.

ROCK COD.-See Rockfish.

RockFisH (Scorpænidæ).-These fish are caught in enormous quantities on the Pacific coast, especially from Santa Barbara to San Francisco. There are a large number of specios, known to the fishermen as "priest fish," "rock cod," and "rockfish," with many qualifying prefixes, as "black," "black-banded," "brown," "grass," "green," "orange," "red," "yellow," "yellow-backed," "yellowtail," etc.; also called "garrupa," "grouper," "scorpene," "sculpin," "scorpion," "tree-fish," "flyfish," "corsair," "Spanish flag," "reina," "black bass," "jack," "tomcod," "bocraccio," etc. They average 15 inches in length and 2 or 3 pounds in weiglit, but some reach a length of 3 feet and a weight of 12 pounds. They are caught in seines and with hook and line. The name is also applied to the striped bass (Roccus lineatus) along the Atlantic coast; to the groupers (Epinephelus) about Key West and in the Gulf of Mexico; to the $\log _{0}$ perch (Percina caprodes).

ROCE TROUT (Hexagrammos).-A group of fishes of considerable importance on the Pacific coast. They are the true greenlings. The different species are known as "sea trout," "starling," "boregata," "bodieron," "red rock trout," etc. The size varies greatly, the average being 18 inches long and $2 \frac{1}{2}$ pounds in weight.

RoNCADOR (Roncador stearnsi). $-\Lambda$ food fish of excellent quality, found from Santa Barbara southward; also called "croaker." It reaches a length of over 2 feet and a weight of 6 to 8 pounds. Related species are known as "red roncador," "little roncador," "yellow-finned roncador," etc.

ROSEFISH (Sebastes marinus). $-\Lambda$ brilliantly colored fish found off the north Atlantic coast as far soutli as New York. It is also called "red perch," "redfish," "Norway haddock," "snapper," "hemdurgan," "bream," etc. The average length is about 12 inches; average weight, $1 \frac{1}{2}$ pounds. It is caught on trawl lines.

Round RoBIN (Decapterus punctatus). $-\mathrm{A}$ food fish found along the coast from the Gulf to Woods Hole. It is also called "cigarfish" and "scad." It reaches a length of 12 inches.

RUDDER-FISH (Kyphosus sectatrix). $-\mathrm{A}$ small fish abundant about Key West. The banded rudder-fish (Seriola zonata) is found from Cape Cod to Florida. 
RunNer (Elagatis bipinnulatus).-A food fish abundant on the western and southern coasts of Florida. It is also called "skipjack," "yellowtail," and "shoemaker." It reaches a length of $2 \frac{1}{2}$ feet.

Sacramento Perch (Archoplites interruptus). $-\boldsymbol{A}$ eunfish of the Sacramento and an excellent food fish.

Sacramento Pike (Ptycochelius oregonensis and $P$. grandis).-A chub of the Sacramento and Columbia. It is also known as "bigmouth," "box-head," "yellow-belly," "chappaul," and "squawfish." It reaches a length of 5 feet or more.

Sarblina (Salvelinus aureolus).--The Sunapee trout of Maine and New Hampshire.

SAILOR's crorce (Lagodon rhomboides). -A food fish found on the Atlantic coast south of Cape Hatteras and in the Gulf. It is also called "robin," "pinfish," "salt-water bream," "squirrel-fish," "porgy," "вcup," "yellowtail," "shiner," "chopa spina," etc. It averages about 10 inches in length and 6 ounces in weight, and is caught with hook and line and in cast nets and seines The name is also applied to the pigfish (Orthopristis chrysopterus) in South Carulina.

Salmon (Salmo salar).-This is the salmon of the Atlantic coast. It is found along the coast of the New England states. At different ages the fish are known as "parrs," "smolts," "grilse," "kelts," and "salmon." The adults weigh from 15 to 40 pounds. They are caught with nets, seines, and hand lines, and by spearing. The landlocked salmon, or fresh-water salmon, or Sebago salmon (S. sebago), is found in fresh waters, generally landlocked.

The blueback salmon (Oncorhynchus nerka) is found on the Pacific coast from the Columbia River northward. The California salmon, or clinook salmon, or quinnat (O. tschawytscha), is found from Monterey to Alaska. The dog salmon (O. keta) ranges from the Sacramento River to Bering Strait. The humpbacked salmon, or lost salmon (O. gorbuscha), ranges from the Sacramento River to Alaska. The silver salmon, or white salmon $(O$. kisutch $)$, is found in all rivers from the Sacramento River to Bering Strait.

The California yellowtail (Seriola dorsalis) is also known as the "white salmon" on the Pacific coast, as is also the chub (Ptychocheilus lucius) of the Colorado River. The name "kelp salmon" is applied to the cabrilla (Paralabrax clathratus) at Monterey; "lake salmon," to the lake trout (Cristivomer namaycush) in the lakes of nortliern New York; and "salmon" and "jack salmon," to the "wall-cyed pike" (Stizostedion vitreum) in the streams of the South. See Trout.

SARnine.-The California sardine (Sardinia carulea). The name is erroneously applied to various other small fishes of the herring family, and is also given to canned herring prepared after the manner of the French sardines.

SaUoer (Stizostedion canadense).-This fish is found in the Great Lakes region, and in the upper Mississippi, upper Missouri, and Ohio Rivers. It is known locally as the "gray pike," "sand pike," "ground pike," " pickering," "pickerel," "horsefish," etc. It is a small fish, not exceeding 18 inches in length. See Pike perches.

Scallor (Pecten irradians).-An edible bivalve found off the coasts of Long Island, Rhode Island, and southern Massachusetts in paying quantities; less numerous South. It is obtained by dredging and raking. The poweriul central muscle by which the animal opens and closes its shell forms the edil)le portion. The shells are of commercial value. The rims or refuse are used for fertilizers.

Sculpin (Cottidx). - Several specics of sculpin are found on the Atlantic and Pacific coasts and in inland waters, but none are of particular value as food fish. Those on the Atlantic are called "grubby," "puffing-grubby," "daddy sculpin," "bull-head," "sea-robin," "sea toad," "pigfish," "sea-raven," etc.; those on the Pacific, "drummer," "salpa," "johnny," "biggy-head," "cabezon," etc.; and those in the lakes and streams of the Northern states, "bull-heads," "miller's thumb," "goblins," "blobs," "mufflejaws," etc. Nost of the species are of small size.

Scup (Stenotomus chrysops). - This fish is found along the Atlantic coast from Cape Cod to South Carolina; , abundant North. Common local names are "scuppaug," "paugy," "porgy," "pogy," "fair maid," etc. They are caught in pounds and traps and with hook and line.

Sea Bass (Centropristes striatus).-A food fish found from Vineyard Sound to the castern part of the Gulf of Mexico. It is known south of Cape Hatteras as the "blackfish;" in the Middle states as "black Will," "black Harry," and "hannahills;" about New Bedford and Newport as "bluefish;" and at New Bedlord also as "rock bass." The average length in New England is about 15 inches; average weight, $1 \frac{1}{2}$ pounds. In the South they are much smaller, averaging about three-fourths of a pound in weight. They are caught with hand lines and in pounds and traps. The white seabass (Cynoscion nobilis) is found on the Pacific coast from Cape Mendocino to San Diego. It is an important food fish, and averages 15 pounds in weight. The redfish (Scionops ocellata) is called "sea bass" in the Carolinas, Florida, and the Gulf.

Sea-elephant (Mirounga angustirostris).-A marine mammal, 12 to 14 feet long, found on the Pacific coast. The oil is of commercial value, and the tongues are sometimes salted and used for food.

Sea herrina.-The common herring (Clupea harengus) of the north Atlantic.

SEA-HoRse (Hippocampus hudsonius and $H$. ingens).-A curious fish found on the eastern coast south of Cape Cod and on the Pacific coast. Few specimens are taken, and they are sold for curiosities.

Seal (Pinnipedia).-The seal tribe embraces the walrus, eared seals, and earless seals. They are found in the northern part of the Atlantic and Pacific Oceans and in the Arctic Ocean. They are captured for their oil, skins, and flesh. The fur-seal fishery is the most important. See Fur seal.

SeA-Lion (Eumetopias jubata).-A seal found on the Pacific coast from the Farallone Islands to the Pribilof Islands. The males are about 15 feet long, and weigh about 1,000 pounds; the females are about half as large as the males. They are killed with guns and lances, and are used by the natives for food, oil, leather, etc. The California sea-lion (Zalophus californianus) is found on the California coast from San Diego to San Francisco.

Sea ronin (Prionotus carolinus).- This fish is lound along the eastern coast south of Cape Cod. They are alsb called "gurnards," "wing-fish," "sea bat," etc. They attain a length of 15 to 18 inches and a weight of about a pound. The name is also applied to the toadfish (Opsanus tau) in the Gulf.

SeA sHad.- Small immature shad that feed about bays and the mouths of rivers during the summer after the ascent of the main body of breeders.

SEA sNaILs (Gasteropoda).-An asymmetrical mollusk bearing a single shell. They are found on all our coasts, and are known as "periwinkles," "whelks," "wilks," "winkles," "wrinkles," "conchs," "drills," "borers," "helmet-shells," "abalones," "ormer-shells," "sea-ears," "limpets," "wood-lice," "lobster tails," "sea-bugs," etc. They are not extensively used for food in this country, but are used for bait in numerous fisheries.

SeA Trout. A name given to the white sea-bass (Cynoscion nobilis) on the Pacific coast; to the white trout (Cynoscion nothus) along the southern coast; to the spotted rock trout or greenling (Hexagrammos decagrammus) south of San Francisco; and to the squeteague (Cynoscion regalis) on the Atlantic coast. It is also a trade name for sea herring.

SEEKONKS.-Oysters (mainly seed) growing in the Seekonk River, Rhode Island.

Sergeavt-Fisir.-See Cobia.

Shan (Alosa sapidissima).-A very important food fish found on all the coasts and in some inland waters; the great fisheries are in the rivers of the Atlantic slope. It is called "white shad," in distinction from other "shad." The average weight is about 4 pounds; average length about 2 feet. It is caught in nets, seines, and weirs, and is sold fresh, cured, and pickled.

The names "mud shad," "gizzard shad," "winter shad," "stink shad," "hickory shad," and "white-eyed shad " apply to a different 
species (Dorosoma ccpedianum). The menhaden is called "hardhead shad" about Cape Ann, "bug shad" in Virginia, and "yellowtail shad" from North Carolina to Florida.

Sharks (Notidani).--Numerous species of sharks are found on the Atlantic and the Pacific coasts. They are sometimes called "dogfish," "angel-fish," "porbeagle," "swingle-tail," "bonnet-head," "hammer-head," etc. They are captured with hook and line and with harpoons; sometimes they are taken in nets set for other fieh. Sharks are valuable for their livers, from which oil is extracted; their bodies are used mainly for fertilizing purposes.

Sheepshead (Archosargus probatocephalus.). - A choice food fish caught off the eastern coast of the United States from Cape Cod to Texas. The weight varies from 2 to 12 pounds, according to locality; the average size is about 4 pounds. They are caught with hand lines, seines, and nets, and by spearing. The name is also applied to the butter-fish (Poronotus triacanthus) about Cape Cod, to the freshwater drum (Aplodinotus grunniens) in the Great Lakes, and to the redfish (Pimelometopon pulcher) south of Point Conception, California.

SHEEPSW OOL.-The highest grade of Florida commercial sponges.

SHiner.-A common name applied to the redfin (Notropis cornutus) from New England to Kansas and Alabama; to the menhaden (Brevoortia tyrannus) in southern Florida; to some of the surf-fishes (Embiotocidx) on the Pacific coast; and to the sailor's choice (Lagodon rhomboides) about Cedar Keys. The blunt-nosed shiner (Selene vomer) is so called about New York and Narragansett Bay. The golden shiner (Abramis chrysoleucus) is found in the rivers east of the Great Plains.

Serimp.-A decapod crustacean found in large numbers on all our coasts and in many inland waters. The usual length is about 2 inches, but some attain a larger size. They are caught in dip nets, purse nets, ete., and are used for food and bait. Prawns are generally larger than shrimps, often attaining a length of 7 inches.

SilverFish.-See Tarpon.

SILver HAKE (Merluccius bilinearis). -This fish is found on the Atlantic coast north of Virginia. It is also called "New England whiting." The average length is 1 foot. It is caught in weirs, nets, and with hand lines, and is used for food and bait.

Silversines (Atherinid $x$ ).-A small food fish, found along the Atlantic and Pacific coasts. Different species are known as "sand smelt," "green smelt," "anchovy," "merit-fish," "sardine," "California smelt," "little smelt," "brit," etc. They range from 7 to 18 inches in length and are caught in seines.

Sirenians.-Large marine mammals, more or less fishlike in form, such as manatees, sea-cows, ete.; found in warm seas.

Siscowet.-See Lake trout.

SкAте.-See Ray.

SkILFISH (Anoplopoma fimbria). - A common food fish from Unalaska to Monterey. It is also known as "beshow," "coalfish," and "black cod."

Skipjack.-A local name applied to the skipper (Scombresox saurus) along the Atlantic and Gulf coasts; to the inland alewife (Pomolobus.chrysochloris) in the Mississippi Valley from the Great Lakes to the Gulf; to the bluefish (Pomatomus saltatrix) south of Cape Hatteras; to the bonito (Sarda chilensis) on the Pacific coast; to the runner (Elagatis bipinnulatus) about Key West; to the butterfish (Poronotus triacanthus) about Cape Cod; to the cuitlass-fish (Trichiurus lepturus); to the jurel (Caranx chrysos) along the east Florida coast; and to the leather jacket (Oligoplites saurus) on the Atlantic coast.

Skip Mackerel. - A name applied to the bluefish about New York.

Suelt (Osmerus mardax). - A very choice food fish found on the Atlantic coast from Virginia to the St. Lawrence and landlocked in many New England lakes. Also called "American smelt" and "frostfish." When sent to market unfrozen they are known as "green" smelts. The average length is 8 to 10 inches. The Pacific smelt (O. thaleichthys) is found from San Francisco to Alaska. The surf smelt (Mesopus pretiosus) is found from Monterey to Alaska.
The eulachon or candlefish (Thaleichthys pacificus) is an excellent food fish found from the Columbia River to Skagway, where it is called "smelt." Some of the silversides (Atherinidx) are wrongly called "smelts;" this is especially true of Atherinopsis californiensis, which is widely known as "smelt," "blue smelt," and "California smelt."

Smolt. - A name applied to an immature salmon when it has become a uniform bright silvery color.

SNappers (Lutianidx).--The red snapper (Lutianus aya) is the most important of these fishes. It is a large fish, bright red in eolor, and is found from Long Island southward, but is most abundant on the coasts of Georgia, Florida, and the Gulf states. The gray snapper or mangrove snapper ( $L$. griseus), also known in Florida as "lawyer," is a most common species. The mutton snapper ( $L$. analis), the dog snapper, or jocu (L. jocu), the schoolmaster, or caji ( $L$. apadus), the silk snapper ( $L$. vivanus), the lane snapper ( $L$. synagris), are all fishes of food value common in the West Indies and southern Florida.

The red grouper (Ephinephelus morio) is called "brown snapper" and "red-bellied snapper" in Florida; the rosefish (Sebastes marinus) is called "snapper" on the North Atlantic coast; the bluefish (Pomatomus saltatrix) is called "snapper" and "blue snapper" ou the New England coast; and the cod that live near the shore away from the ledges are called "black snappers."

Sole (Soleidx). -The American sole, or hog-choker (Achirus fasciatus) is common from Boston to Galveston. See Flounder.

Spadefish.-See Moonfish.

SPANISH Mackerel (Scomberomorus maculatus).-A very choice food fish found on the Atlantic coast south of Cape Cod and in the eastern part of the Gulf of Mexico. The average length is about 20 inches; average weight about 3 pounds. In California the Monterey Spanish mackerel (S. concolor) is a most excellent food fish. They are caught on troll lines and in gill nets and pound nets.

The cavalla ( $S$. cavalla) is a West Indian species, but often taken in small numbers on the southern New England coast. It is also known as "kingfish." The name "cero" is often applied to the Spanish mackerel.

SPECKLED Trout (Salvelinus fontinalis).-An excellent food fish found in cold lakes and streams of the Atlantic watershed, in the headwaters of the Mississippi, and in the Great Lakes region. It is the American "brook trout." The varieties differ much in size and appearance in different regions. It is our gamiest fish, and is generally caught with hook and line.

The rainbow trout (Salmo irideus) of California and the Dolly Varden trout (Salvelinus malma) of the mountains are sometimes known as "speckled trout."

Sperm whale (Physeter macrocephalus).-One of the most valuable of the whales; found in both the Atlantic and Pacific Oceans. It is also called "cachelot." The males reach a length of 70 fect, the females much less. They are captured for their oil and spermaceti. An intestinal substance called "ambergris" is also very valuable.

SPONOE.-The sponge of commerce is found off the Florida coast. The grades generally rank sheepswool, yellow, velvet, grass, and glove; but different men in the business grade them differently.

Spот (Leiostomus xanthurus).-A food fish found along the coast from Cape Cod to Texas. It is called "goody" in New Jersey, "roach" in the Chesapeake, "chub" at Charleston, S. C., "masooka" on the St. Johns, "chopa blanca" at Pensacola, "Lafayette", etc. It is about 6 inches long, and is taken with hook and line and in gill nets.

Sprat.-1. A local New England name for the young alewife. 2. See Alfione.

Squeteane (Cynoscion regalis). - An excellent food fish found in abundance along the Atlantic coast from Cape Cod to Florida. It is known as "drummer" about Cape Cod; "yellowfin" about Buzzards Bay; "weakfish" in New York and New Jersey; "bluefish " in Delaware and Virginia; "gray trout," "sun trout," "shad trout," "sea trout," and "salt-water trout" in the Middle and South A tlan- 
tic states; and "squeteague," "squit," "chickwit," etc., in various places. It averages about $2 \frac{1}{2}$ pounds in weight, though some individuals attain a weight of 30 pounds. They are caught in seines and gill nets and with hook and line. The sounds are of commercial value. The spotted squeteague (Cynoscion nebulosus) is found from New Jersey to Texas, and is somewhat larger than the preceding. The California "bluefish" is Cynoscion parvipinnis. The great "white sea-bass" of California is Cynoscion nobilis.

Squid.-See Cuttle-fish.

STARFIS11.-A star-shaped animal consisting of a central disk from which radiate five arms or "fingers;" found all along the coast and known as "five-finger," "sea-star," "star," etc. It is of importance only on account of the great damage it does to oyster beds.

StrA WDERRY BA99.-See Calico bass.

Stripen bass (Roccus lineatus).- One of the choicest food fishes found along the Atlantic and Gulf coasts; it often ascends rivers for several miles. In the North it is generally called the "striped bass;" in the South "rockfish" and "rock." Large specimens are called "green-head" and "squid-hound" by New Englanders. The average length is about 3 feet; average weight about 20 pounds. They are caught in weirs, traps, gill nets, and seines, and with hook and line. The name is sometimes applied to the white bass (Roccus chrysops) of the Great Lakes region.

Sturgeon (Acipenseridx). - A food fish found on the A tlantic and Pacific coasts and in many inland waters. The various species are known as "lake sturgeon," "white sturgeon," "shovelnose," etc. The Atlantic sturgeon attains a length of 5 to 12 feet and a weight of 400 to 500 pounds. They are caught in drift nets, pound nets, weirs, and seines, and by spearing and "gaffing." They are sold fresh, pickled, and smoked, for food; "caviar" is manufactured from their eggs; the skin is made into leather; the sounds are used in the manufacture of glue and isinglass; a valuable oil is sometimes obtained from the parts not used for food; and the refuse is used for fertilizing purposes.

Sucker (Catostomidx). - A food fish, of which some 58 species are found in most of the fresh waters of the United States. The different species are known as "May sucker," "mud sucker," "chub sucker," etc., "rabbit-mouth," "harelip," "split-mouth," "red horse," "mullet," "creek-fish," "black horse," "buffalo-fish," "moogadee," etc. They vary in size, all attaining a length of at least a foot. They are caught with hook and line, spears, nets, snares, etc.

SUK-KEGH.-See Blueback.

SULPHUR-BotTom WHALE (Sibbaldius sul fureus). - The largest known cetacean, reaching a length of 100 feet. It is found in the Pacific Ocean, and is captured only by the use of the bomb lance. It is valuable for its oil and baleen.

Sunfise (Eupomotis gibbosus).-A food fish found in the Great Lakes region, the upper Mississippi Valley, and the coastwise streams from Maine to Georgia. It is also known as "sunny," "pumpkinseed," "bream," etc. It averages about a pound in weight and is caught with hook and line. Related species are known as "sunfish," "long-eared sunfish," "blue sunfish," etc.

The ocean sunfish (Mola mola) is found off the entire coast of the United States; also called "headfish." It reaches a weight of 500 pounds, and yields a large quantity of valuable oil.

SuRF-Fish (Embiotocidæ). - A food fish found in large numbers along the Pacific coast. The general name "perch" is applied to them every where along the coast; they are also called "pogy" and "porgy" on the Oregon coast, "surf-fish" south of Monterey, and "minny," "sparada," "moharra," etc., along their northern range. The largest attain a weight of 4 pounds; the average is about I pound. See Alfione.

Suroeon-FIse (Teuthis hepatus). - This is the Tang common from Carolina to Florida. It is a good food fish. Also known as "lancetfish," "doctor-fish," etc.

SweLL-FISH (Tetraodontidx). - The different species are known as "globe-fishes," "puffers," "swell-toad," etc. They are common on the Atlantic coast.
SwordFish (Xiphias gladius).-One of the best food fishes found the entire length of the Atlantic coast, and rarely off the California coast. The average weight is from 300 to 400 pounds. It is captured with harpoons, and is sold fresh, pickled, and salted. The swords are sold as curiosities.

TAILOR.-The "salt-water tailor" is the bluefish (Pomatomus saltatrix) of North Carolina, Virginia, and Maryland. The "freshwater tailor" is the mattowacca (Clupea mediocris) of the Potomac.

TARPON (Tarpon atlanticus). -An immense herring-like fish found in the western Atlantic and Gulf of Mexico. It is also called "jewfish" in Georgia and Florida; "grand écaille," or "grandy-kye," and "savanilla" in Texas; and "silver-fish" at Pensacola. It attains a length of 6 feet and a weight of 75 pounds, and is caught on hooks and in seines. It is seldom used for food, but the scales, which are from 1 to 3 inches in diameter, are sold for ornaments.

Tautoo (Tautoga onitis). $-\mathrm{A}$ food fish found along the east coast from Maine to South Carolina. On the New York coast it is called "blackfish;" in New Jersey, "blackfish," "tautog," and "chub;" on the Virginia coast, "Moll" and "Will George;" at the mouth of the Chesapeake, "salt-water chub;" and in North Carolina, "oysterfish." The average weight is about 2 pounds; average length, about 15 inches. It is caught on hooks, and in pounds, weirs, and nets.

Ten-Pounder (Elops saurus).-A game fish found in America north to the Carolinas and Gulf of California. Also known as "bigeyed herring," "bony-fish," "piojo," "John Mariggle," etc.

Terrapin.-The salt-water terrapin (Malaclemmys palustris) is very highly prized for food. It is found in salt marshes along the coast from Massachusetts to Texas, but those which enter into commerce are principally from Chesapeake Bay and the Carolina coast. They are also called "Balt-marsh turtle" and "diamond-back." The average weight is 4 or 5 pounds. They are taken in dredges, seines, and nets.

The fresh-water terrapins are generally distributed south of the forty-first parallel of latitude. The most common used for food are the "red-bellied terrapin" (Pseudemys rugosa), the "mobilianer" ( $P$. mobiliensis), and the "yellow-bellied terrapin" (P. scabra).

ThIMBLE-EYE. - See Chub mackerel.

Truefise (Latilidx).-A food fish found along the Atlantic and Gulf coasts, and on the Pacific coast south of Monterey. The California species (Caulolatilus princeps) is also known as the "whitefish " and "blanquillo." The Atlantic species (Lopholatilus chamxleonticeps) is abundant at the edge of the Gulf stream southward from Nantucket. All are caught with hook and line.

Tinker mackerel. - See Chub mackerel.

Toou E.-See Lake trout.

Tomcon.-The Atlantic tomcod (Microgadus tomcod) ranges from New York to Newfoundland, often ascending rivers. It is also known as the "frostfish." The Pacific tomcod ( $M$. proximus) is found from Monterey northward. Each species reaches a length of about 1 foot and a weight of about one-half pound. They are taken in great numbers in seines and sweep nets, and with hook and line. The name is also applied to the kingfish (Menticirrhus saxatilis) on the Connecticut coast, and to the bocaccio (Sebastodes paucispinis) on the California coast.

TorTorse.-See Turtle.

Triple-TaIl (Lobotes surinamensis).-A food fish, found on the Atlantic coast as far north as Cape Cod, abundant South. It is known in South Carolina as "black perch," and on the St. Johns River as "grouper." It attains a length of from 2 to 3 feet, and is caught with hook and line. The scales are sold at a high price for ornaments.

Trout.-A common name given to the divisions of the salmon family formed by the genus Salmo of western America, the genus Sulvelinus or charrs, and the genus Cristivomer or Great Lakes trout. Salmo is represented by three series - the cutthroat trout (S. clarkii), the rainbow trout ( $S$. irideus), and steelhead trout ( $S$. rivularis). Salvelinus is represented in America by some seven species, and Cristivomer by two. See Lake trout, Speckled trout, Rock trout, Squeteague, Black bass, and Salmon. 
TRUNKFish (Ostraciid $)$.-Different species are known as "cuckold," "cowfish," "horned trunkfish," "spotted trunkfish," etc. They are a tropical fish found in small numbers on the Florida coast.

TunNy.-See Horse-mackerel.

Turвot.-See Flounder. The true turbot (Bothinx) is not found on the American coast.

TurTLEs.-See Green turtle, Hawks-bill turtle, Loggerhead, and Terrapin.

UNiCORN.-See Narwhal.

WaLL-EYen PIKE.-See Pike perch.

Walrus (Odontobrenus rosmames and O. obesus).-A marine mammal, found in the north Atlantic and Pacific Oceans. It attains a length of 16 feet and a woight of 2,000 pounds; averages about onefourth less. They are captured by means of the rifle, harpoon, and lance, and are valuable for their oil, tusks, hide, and flesh.

WARMOUTH (Chrnobryttus gulosus). - A small food fish, found abundantly in sluggish waters from Virginia to Texas, sometimes as far north as Lake Michigan. It is also called "perch," "sunfish," "goggle-eye," "red-eye," etc. The average weight is about 1 pound.

WHITE BASS (Roccus chrysops).-A food fish, found abundantly in the Great Lakes region and in the Ohio and upper Mississippi, chiefly in deep and still waters. It is also called "striped bass." Its usual weight is from 1 to 3 pounds. It is caught on hooks, and ranks high as a food fish.

Whitefish (Coregonus).-They form one of the most important. groups of fresh-water fishes of America. The common whitefish (Ce elupeaformis) is the most valued of the tribe, although the others ar highly esteemed as a food. It is found in the Great Lakes region and is known as "humpback," "bowback," and "highback" whitefish; also as "Otsego bass" in the neighborhood of Otsego Lake, N. Y. It is caught chiefly in gill nets, and averages less than 4 pounds in weight. Other economic species are the Rocky Mountain whitefish (C. williamsoni); the Menominee whitefish (C. quadrilateralis) also locally known as "round whitefish," "frostfish," "shadwater," "pilot fish," "chivey," "blackback," etc. The whitefishes belong to the salmon family. The name is also applied to the bluefish (Pomatomus saltatrix) on the Hudson; to the menhaden (Brevoortia tyrannus) in western Connecticut; to the tilefish (Caulolatilus princeps) in California; and to the beluga (Delphinapterus leucas) by whalers.
WHITE PERCH (Morone americana).-This bass is an important food fish, found very abundantly along the Atlantic coast from South Carolina to Nova Scotia; it also occurs in brackish waters in the mouths of rivers, and is sometimes landlocked in fresh-water ponds. It is the common "perch" of the fisheries of the Middle Atlantic states. The average length is 8 to 9 inches. It is caught with seines, nets, hook and line, etc., and is used very extensively for food. The name is also applied to the fresh-water drum (Aplodinotus grunniens) in the Ohio River, and to the porgee (Damalichthys argyrosomus) on the California coast.

Whitivo (Menticirrhus saxatilis). - - This fish is otherwise known as the "kingfish" and "sea-mink"; it is abundant from Cape Ann to Pensacola. The sand-whiting ( $M$. americanus), also known as "deep-water whiting," is abundant from Chesapeake Bay to Texas. The surf-whiting ( $M$. littoralis), also called the "silver-whiting," is common from the Carolinas to Texas. The California whiting ( $M$. undulatus) is also known as the "sand-sucker." On the coast of Florida they are variously known as "kingfish," "barb," "bullhead whiting," and "ground mullet." They attain a length of 10 inches and a weight of $1 \frac{1}{2}$ pounds. They are caught with hook and line and in seines, and are a food fish of considerable importance. The name is also applied to the harvest-fish (Peprilus paru) at Norfolk, Va., and to the silver hake (Merluccius bilinearis) on the New England coast.

WoLf-Fisn (Anarhichas lupus).-A large fish found off the New England coast north of Nantucket Shoals. It is also called "catfish." The average length is about 4 feet; average weight about 25 pounds. It is caught on hooks and in seines, and is sold fresh, salted, and dried and smoked.

Yeltowtatl (Bairdiella chrysura).-An excellent food fish found on the Atlantic coast from Cape Cod to Texas; it is especially abundant South. It is called "filver perch" on the coast of New Jersey, and "mademoiselle" at Pensacola. It averages 8 inches in length. The name is also applied to the menhaden (Brevoortia tyrannus) from North Carolina to Florida; to the runner (Elagatis bipinnulatus) at Pensacola; to the sailor's choice (Lagodon rhomboides) in the Indian River region; to the amber-fish (Seriola dorsalis) on the California coast south of Santa Barbara; and to the green rockfish (Sebastichthys flavidus) at Monterey. 


\section{IN DEX.}

Abalone, comparison with previous census, 26; quantity and value, by geographic divisions, 28; by apparatus of capture, 32 ; by states, 42 .

Africa, value of exports of domestic fishery products to, 291; of imports, 293.

Alabama, summary of fisheries, 13; persons employed, not including shoresmen, 18; quantity and value of products, 25, 34; detailed statistics, 79-82.

Alaska, salmon product of canneries and packing houses, 283; rank in value, 283; cod packed, 284, 285.

Albacore, or horse mackerol, origin of name, 9; quantity and value, by geograplic divisions, 26 ; by apparatus of capture, 30 ; by states, 34 .

Alewives, origin of name, 9 ; rank in value, 24 ; quantity and value, by geographic divisions, 26 ; by apparatus of capture, 30 ; by states, 34 ; detailed statistics regarding, 47. See also Alewives and roe.

Alewives and roe, canned and preserved, value, by geographic divisions, 281, 287; by method of treatment, 286,287 ; quantity, 287

Alligator hides. See Hides.

Amber-fish, or jack-fish, quantity and value, by geographic divisions, 26 ; by apparatus of capture, 30 ; by states, 34 .

Anchovies, quantity and value, by geographic divisions, 26 ; by apparatus of capture, 30 ; by states, 34 . See also Anchovies and sardines.

Anchovies and sardines, imports, by country from which imported, 292. See also Sardines.

Angel-fish. See Moonfish, angel-fish, or spadefish.

Apparatus of capture, variety of, $8,21,22$; value, by geographic divisions, 11,22 ; by Atlantic coast state groups, 11; in states on Chesapeake Bay, 12; on Great Lakes, 12; by commercial fisheries, 19; by states, 21, 79-279; detailed statistics, 22 ; products by, 29, 30, 44, 46. See also Apparatus of capture and outfit.

Apparatus of capture and outfit, comparison with former censuses, 10. See also Outfit.

Argentina, value of exports of domestic fishery products to, 291.

Arkansas, summary of fisheries, 13; persons employed, not including shoresmen, 18; quantity and value of products, 25,34 ; detailed statistics, 82-84.

Asia, value of exports of domestic fishery products to, 291; of imports, 293

Asiatic Russia, imports of fishery products, 293.

Atlantic coast district, exclusive of Long Island Sound, fishery products of 205

Atlantic coast division, summary of statistics, 11 ; by $\Lambda$ tlantic coast state groups, 11; persons employed, salaries, and wages, by main branches of industry, 14, 16; per cent of persons engaged in fishing, 15; capital invested in vessels and boats, 20, 22,23 ; average tonnage of vessels, 21,23 ; number, 23 ; products, by species, 26 ; by class of fisheries and apparatus of capture, 29; canning and preserving, fish and oysters, summary, by geographic divisions,
281 ; value of products, 281, 287; of byproducts, 282; cod packed, 284, 285; oysters canned, 285 .

Atlantic Ocean district, fishery products of, $108,151,258,259,262$.

Barracuda, quiantity and value, by geographic divisions, 26 ; by apparatus of capture, 30; by states, 34; pickled, 287.

Bass, black, quantity and value, by geographic divisions, 26; by apparatus of capture, 30 ; by states, 34 .

- crappie and strawberry, quantity and value, by geographic divisions, 27 ; by apparatus of capture, 30 ; by states, 35 . rock, quantity and value, by geographic divisions, 27 ; by apparatus of capture, 30 ; by states, 38 .

- sea, quantity and value, by geographic divisions, 27 ; by apparatus of capture, 30 ; by etates, 39 .

- striped, quantity and value, by geographic divisions, 28; by apparatus of capture, 32 ; by states, 40 .

- white, quantity and value, by geographic divisions, 28; by apparatus of capture, 32 ; by states, 40 .

Beam trawls, number and value, 22; quantity and value of products caught by, by geographic divisions, 29 ; by states, 45 .

Belgium, imports of fishery products, 292 , 293.

Black bass. Sce Bass.

Black cod. See Cod.

Bluefish, rank in value, 24 ; quantity and value, by geographic divisions, 28 ; by apparatus of capture, 30 ; by states, 34 ; detailed statistics regarding, 48 .

13oat fisheries. Sce Shore and boat fisheries.

Boate, comparison with former censuses, 10 ; use of term, 20; value, by geographic divisions, 20,22, 23; number and tonnage, 23 . detailed statistics, by states, 79-279.

- row, value, by geographic divisions,

22, 23; number and tonnage, 23.

sail, value, by geographic divisions, 22 , 23 ; number and tonnage, 23.

- steam and motor, value, by geographic divisions, 22, 23; number and tonnage, 23 . See clso Vesecls and boats, including outfit.

Bonito, quantity and value, by geographic divisions, 26 ; by apparatus of capture, 30 ; by states, 34 .

Bowfins. Sce Dogfish, or bowfins.

Brazil, value of exports of domestic fishery products to, 291 .

Bream and sunfish, use of term, 9 ; quantity and value, by geographic divisions, 26 by apparatus of capture, 30 ; by states, 34 . British India, imports of fishery products, 292.

British South Africa, imports of fishery products, 292.

British West Indies, imports of fishery products, 293.

Brook trout. See Trout.

Buffalo fish, rank in value, 24 ; quantity and value, ly geographic divisions, 26 ; by apparatus of capture, 30; by states, 35 ; detailed statistics regarding, 48 .

Bureau of Fisheries, cooperation in canvass, 7,8 .
Butterfieh, use of term, 10; quantity and value, by geographic divisions, 26 ; by apparatus of capture, 30 ; by states, 35 .

California, summary of fisheries, 13; persons employed, not including shoresmen, 18 ; value of apparatus of capture, 21 ; quantity and value of products, 25, 34; detailed statistics, 84-91; canning and preserving, fish and oysters, value of by-products, 282; salmon product of canneries and packing houses, 283; rank in value, 283 ; sardines packed, 284; cod packed, 284 285.

Canada, imports of fishery products, 292, 293. See also Canada, Newfoundland, and Labrador.

Canada, Newfoundland, and Labrador, value of exports of domestic fishery products to, 291.

Canning and preserving, fish and oysters classification of establishments engaged in 9; comparison with former censuses, 280; statistics, by geographic divisions, 280 ; products, by kind, 281; by species, 281,287 ; by-products, 282 ; food products, 286 .

Capital, amount, by geographic divisions, 11,22 ; by $\Lambda$ tlantic coast state groups, 11 in states on Chesapeake Bay, 12; on Great Lakes, 12; leading items of, 19 ; states reporting more than $\$ 2,000,000,19$. See also Capital, not including shore and accessory property and cash and Equipment and other capital.

Capital, not including shore and accessory property and cash, comparison with former censuses, 10.

Carp, German, rank in value, 24 ; quantity and value, by geographic divisions, 26 ; by apparatus of capture, 30 ; by states, 35 ; detailed statistics regarding, 49 .

Cash, use of term, 19; amount invested in commercial fisheries, 19. See also Shore and accessory property and cash.

Catfish, origin of name, 9 ; rank in value, 24 ; quantity and value, by geographic divisions, 26 ; by apparatus of capture, 30 by states, 35; detailed statistics regarding, 51 .

Caviar, quantity and value, by geographic divisions, 28; by apparatus of capture, 32 by states, 41 ; exports of, 291. See also Sturgeons and caviar.

Central America, value of exports of domestic fishery products to, 291 .

Central division. See Eastern and central divisions.

Chesapeake Bay, persons employed, 12, 16; capital, and value of products, 12 .

Chesapeake liay district, fishery products of $150,257,259,261$.

Chile, value of exports of domestic fishery products to, 291.

Chinese Empire, imports of fishery products, $292,293$.

Clame, rank in value, 24 ; comparison with previous census, 26; detailed statistics regarding, 52; canned and preserved, value, by geographic divisions, 281, 287; by method of treatment, 286, 287; quantity, 257. 
Clams, hard, pounds of meat per bushel, 9; quantity and value, by geographic divislens, 28; by apparatus of capture, 32 ; by states, 42 .

- razer, pounds of meat per bushel, 9; quantity and value, by geographic divisions, 28; by apparatus of capture, 32; by states, 42 .

- soft, pounds of meat per bushel, 9; quantity and value, by geographic divisions, 28 ; by apparatus of capture, 32 ; by states, 42 .

- surf, pounds of meat per bushel, 9; quantity and value, by geographic divisions, 28; by apparatus of capture, 32 ; by states, 42 .

Cobia, quantity and value, by geographic divisions, 26 ; by apparatus of capture, 30 ; by states, 35 .

Cockles, winkles, and conchs, pounds of meat per bushel, 9; quantity and value, by geographic divisions, 28 ; by apparatus of capture, 32 ; by states, 42 .

Cod, rank in value, 24 ; quantity and value by geographic divisions, 27; by apparatus of capture, 30 ; by states, 35 ; detailed statistics regarding, 52 ; canned and preserved, value, by geographic divisions, 281, 287; by states, 284,285 ; by method of treatment, 286, 287; quantity, 281, 284, 285, 287.

- black, quantity and value, by geographic divisions, 26 ; by apparatus of capture, 30 ; by states, 34 .

- cultus, quantity and value, by geographic divisions, 27 ; by apparatus of capture, 30 ; by states, 36 . See also Cod, haddock, hake, and pollack.

Cod, haddock, hake, and pollack, exports of, 291 ; imports, by country from which imported, 292.

Colorade, persons empleyed, not including shoresmen, 18.

Columbia River district, fishery products of, $224,268$.

Conchs. See Cockles, winkles, and conchs.

Connecticut, summary of fisheries, 13 ; persons employed, not including sheresmen, 18 ; capital, 19; quantity and value of products, 25, 34; detailed statistics, 91-06.

Crabs, length of season, 17 ; rank in value, 24 ; comparison with previous census, 26 ; detailed statistics regarding, 54; canned and preserved, value, by geographic divisions, 281, 287; by method of treatment, 286,287 ; quantity, 287.

- hard, quantity and value, by geographic divisions, 28; by apparatus of capture, 32 ; by states, 41 .

- king, quantity and value, by geographic divisions, 28 ; by apparatus of capture, 32 ; by states, 41 .

- soft, quantity and value, by geegraphic divisions, 28; by apparatus of capture, 32 ; by states, 41 .

- spider, quantity and value, by geographic divisions, 28 ; by apparatus of capture, 32 .

- stone, quantity and value, by geographic divisions, 28 ; by apparatus of capture, 32 ; by states, 41 .

Crappie and strawberry bass: See Bass.

Crawfish, comparison with previous census, 26 ; quantity and value, by geographic divisions, 28 ; by apparatus of capture, 32 ; by states, 41 .

Crevallé, quantity and value, by geographic divisions, 27 ; by apparatus of capture, 30 ; by states, 35 .

Croaker, quantity and value, by geographic divisions, 27 ; by apparatus of capture, 30 ; by states, 35 .

Crustaccans, quantity and value, 24; cemparison with previous census, 26 .

Cuba, value of exports of domestic fishery products to, 291; of imports, 293.
Cultus cod. See Ced.

Cumberland and Tennessee Rivers, fishery products of, 245.

Cunner, quantity and value, by geographic divisions, 27 ; by apparatus of capture, 30 by states, 36 .

Cusk, quantity and value, by geographic divisions, 27; by apparatus of capture, 30 by states, 36 ; canned and preserved, value; by method of treatment, 286,287 ; by geographic divisions, 287; quantity, 287:"

Delaware, summary of fisheries, 12,13 ; persons employed, not including shoresmen, 18; quantity and value of products, 25,34 ; detailed statistics, 96-99.

Delaware River and Bay district, fishery products of, 230.

Detroit River. See Lake St. Clair and St. Clair and Detroit Rivers.

District of Columbia, persens employed, not including shoresmen, 18.

Dogfish, or bewfins, quantity and value, by geographic divisions, 27 ; by apparatus of capture, 30 ; by states, 36 .

Dredges, tongs, rakes, etc., value, 22; quantity and value of products caught by, by geographic divisions, 29; by species, 31 by states, 45 .

Drum, origin of name, 9; quantity and value, by geographic divisions, 27 ; by apparatus of capture, 30 ; by states, 36 .

Eastern and central divisions, salmon product of canneries and packing houses, 283.

Eelpout. See Ling, or eelpout.

Eels, quantity and value, by geographic divisions, 27 ; by apparatus of capture, 30 ; by states, 36 .

Employces. See Persons employed and Salaried employees.

Equipment and other capital, amount, by geographic divisions, 22; by states, 79-279. See also Capital.

Eurepe, value of exports of domestic fishery products to, 291; of imports, 293.

European Russia, imports of fishery products, 292.

Exports, comparison with imports, 288; value of $288,289,291$; by country to which exported, 291.

Fertilizer, value, by geographic divisions, 281,282 ; by states, 282. See also Fertilizer, oil, and glue.

Fertilizer, oil, and glue, quantity and value, by geographic divisions, 287.

Firm members, use of term, 14.

Fish, confusion in common names of, 9 ; distribution, 24; comparison with previous census, 26; quantity and value, by species, 26,30 ; by geographic divisions, 26 ; by apparatus of capture, 30 ; by states, 34 79-279; canned and preserved, value, by geegraphic divisione, 281, 237; by kind, 281,287 ; by method of treatment, 286,287 ; quantity, 287; experts of, 291; imports, by kind and country from which imported, 292

Fish oil. See Oil.

Fisheries, general, difficulty attending census of, 7 ; comparison with former censuses, 10; summary, 13; products, by apparatus of capture and geographic divisions, 29 ; by states, 79-279; detailed statistics, 47-78.

Fishermen, exclusive of shoresmen, comparison with former censuses, 10; prevailing nationality, 17; detailed statistics, by states, $79-279$.

Fishery products, quantity and value, 24; detalled statistics, by states, 79-279; values of imports and exports, 283; exports, by kind, 291; by country to which exported, 291; imports, by kind, 292; by country from which imported, 292, 293. See also Products.
Fishing vessels. See Vessels.

Florida, summary of fisheries, 13; persons employed, not including shoresmen, 18 ; capital, 19; value of apparatus of capture, 21 ; quantity and value of products, 25,34 ; detaled statistics, 100-110; canning and preserving, fish and oysters, value of byproducts, 282 ; oysters cauned, 285; shrimp and prawn preserved, 286.

Flounders, uso of term, 9 ; rank in value, 24 ; quantity and value, by geographic divisions, 27 ; by apparatus of capture, 30 ; by states, 36; detailed statistics regarding, 56. Food fish, quantity and value, 24 ; comparison with previous census, 26. See also Fish.

Food producte, canning and preserving, fieh and oysters, value, 286. See also Products. France, imports of fishery products, 292, 293. Fregs, comparison with previous census, 26 ; quantity and value, by geographic divisions, 28 ; by apparatus of capture, 32 ; by states, 41

Fyke and hoop nets. See Neta.

Geographic divisions, summary of fisheries by, 11; persons employed, 14, 15; tonnage of vessels, 21; equipment and other capital, 22; number, tonnage, and value of vessels and boats, 23; products, 26, 29 , 47-78; canning and preserving, fisl and oysters, summary, 281; products, 281, 287; by-products, 282 ; salmon product of canneries and packing houses, 283; cod packed, 284, 285; oysters canned, 255.

Georgia, summary of fisheries, 13; persons employed, net including shoresmen, 18 quantity and value of producta, 25,34 ; detailed statistics, 110-113; oysters canned, 285.

German carp. See Carp, German.

Germany, value of exports of demestic fishery products to, 291; of imports, 292, 293. Gill nets. See Nets.

Glue, value, by geographic divisions, 281 , 282; by states, 282 . See also Fertilizer, oil, and glue.

Great Lakes and Mississippi River divisions, canning and preserving, fish and oysters, value of products, 281. See also Mississippi River division.

Great Lakes division, summary of atatistics, 11; persens employed, by main branches ef industry, 14; by lakes and rivers, 16; salaries and wages, 14; per cent of persens engaged in fishing, 15; capital invested in vessels and boats, 20 , 22; average tonnage of vessels, 21, 23; number, 23; producto, by species, 26 ; by class of fisheries and apparatus of capture, 29; canning and preserving, fish and oysters, summary, by geegraphic divisions, 281; value of products, 281, 287; of by-products, 282. See also Great Lakes and Mississippi River divisions.

Greece, imports of fishery producto, 293.

Grouper, quantity and value, by geographic divisions, 27; by apparatus of capture, 30 ; by states, 36 .

Grunts, quantity and value, by geographic divisions, 27; by apparatus of capture, 30 ; by states, 36 .

Gulf of Mexice district, fisbery products of, $107,136,137,183,181$

Gulf of Mexico division, summary of statis. tics, 11; persons cmployed, salaries, and wages, by main branches of industry, 14. per cent of persens engaged in fisbing, 15 ; capital invested in vessels and boats, 20 , 22,23 ; average tonnage of vessels, 21,23 ; number, 23 ; products, by species, 26 ; by class of fisheries and apparatus of capture, 29; canning and preserving, fish and oysters, summary, by geographic divisions, 281 ; value of products, 281, 287; of byproducts, 282; oysters canned, 285. 
Haddock, rank in value, 24; quantity and value, by geograpbic divisions, 27; by apparatus of capture, 30 ; by states, 36 ; detailed statistics regarding, 56; canned and preserved, value, by geograpbic divisions, 281, 287; by method of treatment, 286 , 287; quantity, 281, 287. See also Cod, haddock, hake, and pollack.

Hake, rank in value, 24 ; quantity and value, by geographic divisions, 27 ; by apparatus of capture, 30 ; by states, 36 ; detailed statistics regarding, 57; canned and preserved, value, by geographic divisions, 281,287 ; by method of treatment, 286 , 287; quantity, 287.

- silver, quantity and value, by geographic divisions, 27 ; by apparatus of capture, 32 ; by states, 39 . See also Cod, baddock, hake, and pollack

Halibnt, origin of name, 9 ; rank in value, 24; quantity and value, by geographic divisions, 27 ; by apparatus of capture, 30 ; by states, 36 ; detailed statistics regarding, 57 ; canned and preserved, value, by geographic divisions, 281, 287; by method of treatment, 286, 287; quantity, 287.

Hard clams. See Clams.

Hard crabs. Sce Crabs.

Harpoons, spears, etc., value, 22; quantity and value of products caught by, by geographic divisions, 29 ; by species, 31 ; by states, 45 .

Haul seines. See Seines.

Herring, origin of name, 9; quantity and value, by geographic divisions, 27 ; by apparatus of capture, 30 ; by states, 37 ; detailed statistics regarding, 58; exports of, 291 ; imports, by country from which imported, 292 ; canned and preserved, value, by geographic divisions, 281, 287 ; by method of treatment, 286, 287; quantity, $281,287$.

- lake, rank in value, 24; quantity and value, by geographic divisions, 27 ; by apparatus of capture, 30 ; by states, 37 ; detailed statistics regarding, 59 ; canned and preserved, value, by geographic divisions, 281, 287; by method of treatment, 286, 287; quantity, 281, 287.

- salt-water, rank in value, 24

Hickory shad. See Shad.

Ilides, alligator, comparison with previous census, 26; quantity and value, by geographic divisions, 28; by apparatus of capture, $32 ;$ by states, 43 .

-.. porpoise, comparison with previous census, 26; quantity and value, by geographic divisions, 28; by apparatus of capture, 32 ; by states, 43 . See also Hides, pelts, and skins.

Hides, pelts, and skins, comparison with previous census, 26.

Hogfish. See Pigfish, or hogfish.

Hongkong, imports of fishery products, 292, 293.

Hoop nets. See Fyke and hoop nets.

Horse mackerel. See Albacore, or horse mackerel.

Idaho, persons employed, not including shoresmen, 18

Illinois, summary of fisheries, 13; persons employed, not including shoresmen, 18; value of apparatus of capture, 21 ; quantity and value of products, 25,34 ; detailed statistics, 113-120.

Imports, comparison with exports, 288; value of, $288,290,292$; by kind of product, 292 ; by country from which imported, 292, 293 .

Independent fishermen. See Proprietors and independent fisbermen.

Indiana, summary of fisheries, 13; persons employed, not including shoresmen, 18; quantity and value of products, 25,34 ; detailed statistics, 120-123.
Iowa, summary of fisheries, 13 ; persons employed, not including shoresmen, 18; quantity and value of products, 25,34 ; detailed statistics, 124-126.

Irish moss, quantity and value, by geographic divisions, 28; by apparatus of capture, $32 ;$ by states, 44 .

Italy, imports of fishery products, 292, 293.

Jack-fish. See Amber-fish, or jack-fish.

Japan, imports of fishery products, 292, 293.

Jewfish, origin of name, $9 ;$ quantity and value, by geographic divisions, 27 ; by apparatus of capture, 30 ; by states, 37 .

Jurel, quantity and value, by geographic divisions, 27; by apparatus of capture, 30 ; by states, 37 .

Kansas, persons employed, not including shoresmen, 18; quantity and value of products, 25, 34; fisheries of, 126, 127.

Kentucky, summary of fisheries, 13 ; persons employed, not including shoresmen, 18 ; quantity and value of products, 25,34 ; detailed statistics, 127-130.

King crabs. See Crabs.

Kingfish, origin of name, 9. See also Whiting and kingfish.

Labrador. See Canada, Newfoundland, and Labrador.

Ladyfish, quantity and value, by geographic divisions, 27 ; by apparatus of capture, 30 ; by states, 37 .

Lake Erie, persons employed, 12, 16; capital, and value of products, 12

Lake Erie district, fishery products of, 172, $206,220,231$.

Lake herring. See Herring.

Lake Huron, persons employed, 12,16 ; capital and value of products, 12

Lake Huron district, fishery products of, 171. Lake Michigan, persons employed, 12, 16 ; capital, and value of products, 12

Lake Michigan district, fishery products of, $119,123,170,275,278$

Lake Ontario, including Niagara and. St Lawrence Rivers, persons employed, 12, 16; capital, and value of products, 12.

Lake Ontario district, fisbery products of, 207.

Lake St. Clair and St. Clair and Detroit Rivers, persons employed, 12, 16; capital, and value of products, 12 .

Lake St. Clair district, fishory products of, 172.

Lake Superior, persons employed, 12, 16; capital, and value of products, 12

Lake Superior district, fishery products of 171, 178, 276, 279.

Lake trout. See Trout.

Lines, hand, trawl, and set, value, 21, 22; quantity and value of products caught by by geographic divisions, 29 ; by species, 30 ; by states, 45 .

Ling, or eelpout, quantity and value, by geographic divisions, 27 ; by apparatus of capture, 30 ; by states, 37 .

Livers, quantity and value, by geographic divisions, 28 ; by apparatus of capture, 32 by states, 43 .

Lobster, rank in value, 24 ; comparison with previous census, 26 ; quantity and value, by geographic divisions, 28 ; by apparatus of capture, 32 ; by states, 41 ; detailed statistics regarding, 61 ; imports, by country from which imported, 292.

- spiny, comparison with previous census, 26 ; quantity and value, by geographic divisions, 28; by apparatus of capture, 32 by states, 41 ; detailed statistics regarding, 62 .

Long Island Sound, fishery products of, 206. Louisiana, summary of fisheries, 13 ; persons employed, not including shoresmen, 18 ; quantity and value of products, 25,34 ; detailed statisties, 130-137; canning and preserving, fish and oysters, value of by-products, 282 ; oysters canned, 285 . shrimp and prawn preserved, 286.

Mackerel, rank in value, 24 ; quantity and value, by geographic divisions, 27 ; by apparatus of capture, 30 ; by states, 37 detailed statistics regarding, 62 ; canned and preserved, value, by geographic divisions, 281, 287; by method of treatment 286,287 ; quantity, 287; exports of, 291; imports, by country from which imported, 292.

- Spanish, quantity and value, by geographic divisions, 28 ; by apparatus of capture, 32 ; by states, 39 .

Maine, summary of fisheries, $13 ;$ persons employed, not including shoresmen, 18 ; capital, 19; value of apparatus of capture, 21; quantity and value of products, 25,34 detailed statistics, 138-145; canning and preserving, fish and oysters, value of byproducts, 282; sardines packed, 284; cod packed, 284, 285

Market oysters. See Oysters.

Maryland, summary of fisheries, 12,13 ; persons employed, not including shoresmen, 18; capital, 19; value of apparatus of capture, 21; quantity and value of producte, 25, 34; detailed statistics, 145-152; canning and preserving, fish and oysters, value of by-products, 282 ; oysters canned, 285.

Massachusette, summary of fisheries, 13; persons employed, not including sboresmen, 18; capital, 19; value of apparatus of capture, 21; quantity and value of products, 25 , 34; detailed statistics, $152-$ 164; canning and preserving, fisb and oysters, value of by-products, 282 ; sardines packed, 284; cod packed, 284, 285; shrimp and prawn preserved, 286.

Menbaden, origin of name, 9 ; rank in value, 24 ; comparison with previous census, 26 quantity and value, by geographic divisions, 27 ; by apparatus of capture, 30 ; by states, 37 ; detailed statistics regarding, 63.

Menhaden fisheries, comparison with former censuses, 10.

Mexico, value of exports of domestic fishery products to, 291; of imports, 292, 293.

Míchigan, summary of fisheries, 13; persons employed, not including shoresmen, 18 capital, 19; value of apparatus of capture 21; quantity and value of products, 25,34 detailed statistics, 165-173.

Middle Atlantic states, fisheries of, 11; persons employed, salaries, and wages, 16.

Mink skins. See Skins.

Minnesota, summary of fisheries, 13; persons employed, not including shoresmen, 18; quantity and value of products, 25,34 detailed statistics, 173-178.

Minnows, quantity and value, by geographic divisions, 27 ; by apparatus of capture, 30 ; by states, 37 .

Mississippi, summary of fisheries, 13; persons employed, not including shoresmen, 18; quantity and value of products, 25,34 detailed statistic8, 178-184; canning and preserving, fisb and oysters, value of byproducts, 282; oysters canned, 285 ; shrimp and prawn preserved, 286.

Mississippi River district, fishery products of, 118, 130, 136, 177, 183, 187, 245, 275.

Mississippi River division, summary of statistics, 11; persons employed, salaries, and wages, by main branches of industry, 14; per cent of persons engaged in fishing, 15: capital invested in vessels and boats, $20,22,23$; average tonnage of vessele, 21, 23 ; number, 23 ; products, by species, 26 ; by class of fisheries and apparatus of cap- 
ture, 29; canning and preserving, fish and oysters, summary, by geographic divisions, 281; value of products, 287. See also Great Lakes and Mlssissippi River divisions.

Missouri, summary of fisheries, 13; persons employed, not including shoresmen, 18; quantity and value of products, 25,34 ; detailed statistics, 185-187.

Missouri River district, fishery products of, 126, 187.

Molluske, pounds of meat per bushel, 9; rank in value, 24; comparison with previous census, 26.

Montana, persons employed, not including shoresmen, 18

Moonfish, angel-fish, or spadefish, quantity and value,, by geographic divisions, 27; hy apparatus of capture, 30 ; by states, 37 . Motor boats. See Steam and motor boats.

Mullet, rank in value, 24; quantity and value, by geographic divisions, 27 ; hy apparatus of capture, 30; by states, 37 . detailed statistics regarding, 64; canned and preserved, value, by method of treatment, 286, 287; hy geographic divisions, 287; quantity, 287.

Muskallunge, quantity and value, by geographic divisions, 27; by apparatus of capture, 30 ; by states, 38 .

Muskrat skins. See Skins.

Mussel shells. See Shells.

Mussel shells, pearls, and slugs, rank in value of product, 24; comparison with previous census, 26. See also Pearls and slugs.

Mussels, pounds of meat per bushel, 9; quantity and value, by geographic divisions, 28 ; by apparatus of capture, 32 ; by states, 42 ; detailed statistics regarding, 65 .

Mutton-fish, quantity and value, by geographic divisions, 27 ; by apparatus of capture, 30 ; by states, 38 .

Names, confusion in regard to, 9 .

Nehraska, persons employed, not including shoresmen, 18; quantity and value of products, 25, 34; fisheries of, 188.

Netherlands, imports of fishery products, $292,293$.

Nets, value of all classes, 21 ; quantity and value of products caught by, by geographic divisions, 29.

- fyke and hoop, rank in apparatus of capture, 21 ; number and value, 22 ; quantity and value of products caught by, by geographic divisions, 29; by species, 31 ; by states, 44

- gill, rank in apparatus of capture, 21; number and value, 22 ; quantity and value of products caught by, hy geographic divisions, 29; by species, 30 ; by states, 44 .

- trammel, number and value, 22 ; quantity and value of products caught by, by geographic divisions, 29; by species, 31 ; by atates, 45 . See also Pound nets, trap nets, and weirs.

Nevada, persons employed, not including shoresmen, 18

New England states, fisheries of, 11; persons employed, salaries, and wages, 16.

New Hampshire, persons employed, not including shoresmen, 18; quantity and value of products, 25, 34; fisheries of, 189.

New Jersey, summary of fisheries, 13; persons employed, not including shoresmen, 18; quantity and value of products, 25,34 ; detailed statistics, 189-195; canning and preserving, fish and oysters, value of byproducts, 282 .

New Mexico, persons employed, not including shoresmen, 18.

New York, summary of fisheries, 13; persons employed, not including shoresmen, 18; capital, 19; value of apparatus of capture, 21; quantity and value of products, 25,34 . detailed statistics, 195-210; salmon prod- uct of canneries and packing houses, 283 ; rank in value, 283; sardines packed, 284 . Newfoundland. See Canada, Newfoundland, and Labrador and Newfoundland and Labrador.

Newfoundland and Labrador, imports of fishery products, 292, 293. See also Canada, Newfoundland, and Labrador.

Niagara River. See Lake Ontario, including Niagara and St. Lawrence Rivers.

North America, value of exports of domestic fishery products to countries of, 291; of imports, 293.

North Carolina, summary of fisheries, 13; persons employed, not including shoresmen, 18; value of apparatus of capture, 21; quantity and value of products, 25,34 detailed statistics, 211-217; canning and preserving, fish and oysters, value of hyproducts, 282 ; oysters canned, 285.

North Dakota, persons employed, not including shoresmen, 18.

Norway, imports of fishery products, 292, 293. See also Norway and Sweden.

Norway and Sweden, imports of fishery products, 293. See also Sweden.

Oceania, value of exports of domestic fishery products to, 291; of imports, 293.

Ohio, summary of fisheries, 13; persons employed, not including shoresmen, 18 ; value of apparatus of capture, 21 ; quantity and value of products, 25,34 ; detailed statistice, 217-221.

Ohio River district, fishery products of, 118, $123,129,221$.

Oil, value, hy geographic divisions, 281, 282; by states, 282 .

- fish, quantity and value, by geographic divisions, 28; by apparatus of capture, 32; by states, 43 ; exports of, 291. - porpoise, quantity and value, by geographic divisions, 28; by apparatus of capture, 32 ; by states, 43.

- sea-elephant, quantity and value, by geographic divisions, 28; by apparatus of capture, 32 ; by states, 44 .

- seal, quantity and value, by geographic divisions, 28; by apparatus of capture, 32 by states, 44 .

- sperm, quantity and value, by geographic divisions, 28; hy apparatus of capture, 32 ; hy states, 44 .

- whale, comparison with previous census, 26; quantity and value, by geographic divisions, 28; by apparatus of capture, 32 ; by states, 44 ; exports of, 291.

- whale and fish, imports, by country from which imported, 293. See also Fertilizer, oil, and glue.

Oklahoma, persons employed, not including shoresmen, 18; quantity and value of products, 25, 34; fisheries of, 221.

Oregon, summary of fisheries, 13; persons employed, not including shoresmen, 18; value of apparatus of capture, 21 ; quantity and value of products, 25,34 ; de tailed statistics, 221-225; canning and preserving, fish and oysters, value of byproducts, 282; salmon product of canneries and packing houses, 283 ; rank in value, 283 ; oysters canned, 285.

Otter skins. See Skins.

Outfit, use of term, 20; value, by geographic divisions, 23. See also Apparatus of capture and outfit and Vessels and hoats, including outfit.

Oyster fisheries, comparison with former censuses, 10.

Oysters, pounds of meat per bushel, 9 length of season, 17; rank in value, 24 ; comparison with previous census, 26 ; detailed statistics regarding, 66 ; canned and preserved, value, by geographic divisions, 281,287 ; by states, 285 ; by method of treatment, 286, 287; quantity, 281, 287; exports of, 291 .

Oysters, market, from private and public areas, quantity and value, by geographic divisions, 28; hy apparatus of capture, 32 ; by states, 42 .

- seed, from private and public areas, quantity and value, by geographic divisions, 28; by apparatus of capture, 32 ; by states, 42 .

Pacific coast district, fishery products of, 225.

Pacific coast division, summary of statistics, 11; persons employed, salaries, and wages, by main branches of industry, 14; per cent of persons engaged in fishing, 15; capital invested in vessels and hoats, 20 , 22,23 ; average tonnage of vessels, 21,23 ; number, 23; products, hy species, 26 ; by class of fisheries and apparatus of capture, 29 ; canning and preserving, fish and oysters, summary, by geographic divisions, 281; value of products, 281, 287; of hy-products, 282; quantity and value of salmon, 283; cod packed, 284, 285; oysters canned, 285 .

Pacific Ocean district, fishery products of, 268,270 .

Paddlefish, quantity and value, by geographic divisions, 27; by apparatus of capture, 30 ; by states, 38 .

Pearl fishing, method of, 66 .

Pearls and slugs, value, by geographic divisions, 28 ; by apparatus of capture, 32 ; by states, 43. See also Mlussel shells, pearls, and slugs.

Pelts. See Hides, pelts, and skins.

Pennsylvania, summary of fisheries, 13; persons employed, not including shoresmen, 18; value of apparatus of capture, 21 ; quantity and value of products, 25, 34; detailed statistics, 225-231; cod packed, 284. See also Susquehanna River fisheries.

Perch, origin of name, 9 ; quantity and value, hy geographic divisions, 27; by apparatus of capture, 30 .

- pike, rank in value, 24; quantity and value, by geographic divisione, 27; by apparatus of capture, 30 ; by states, 38 ; detailed statistica regarding, 68; frozen and fresh, quantity and value, by geographic divisione, 287. 38. 38 .

Permit quantity and value, by geographic divisions, 27; by apparatus of capturo, 30 ; hy states, 38 .

Persons employed, number, by geographic divisions, 11, 14; in Atlantic coast division; 11, 16; in states on Chesapeake Bay, 12, 16; on Great Lakes, 12,16 ; salaries and wages, by geographic divisions and by main branches of industry, 14; per cent distribution, 15; comparison with former censuses, 18; detailed statistics, by states, 79-279.

Persons employed, not including shoresmen, comparison with former censuses, 18 ; detailed statistice, by states, 79-279.

Pickerel. See Pike and pickerel.

Pigfish, or hogfish, origin of name, 9; quantity and value, by geographic divisions, 27; by apparatus of capture, 30 ; by states, 38 .

Pike, Sacramento, quantity and value, by geographic divisions, 27 ; by apparatus of capture, 30 ; by states, 38 .

Pike and pickerel, quantity and value, by geographic divisions, 27 ; by apparatus of capture, 30 ; by states, 38 .

Pike perch. See Perch.

Pinfieh. See Sailor's choice, or pinfish. 
Pollack, rank in value, 24; quantity and value, by geographic divisions, 27; by apparatus of capture, 30 ; by states, 38 ; detailed statistics regarding, 69 ; canned and preserved, value, by geographic divisions, 281,287 ; by method of treatment, 286 , 287; quantity, 287. See also Cod, haddock, hake, and pollack.

Pompano, origin of name, 10; quantity and value, by geographic divisions, 27 ; by apparatus of capture, 30 ; by states, 38 .

Porgy, quantity and value, by geographic divisions, 27; by apparatus of capture, 30 ; by states, 38 .

Porkfish, quantity and value, by geographic divisions, 27; by apparatus of capture, 30 ; by states, 38 .

Porpoise hides. See Hides.

Porpoise oil. See Oil.

Portugal, imports of fishery products, 292, 293.

Pote and traps, number and value, 22 ; quantity and value of products caught by, by geographic divisions, 29; by species, 31 ; by states, 45 .

Pound nets, trap nets, and weirs, variation in value, 21; rank in apparatus of capture 21 ; number and value, 22 ; quantity and value of products caught by, by geographic divisions, 29; by species, 30 ; by states, 44.

Prawn. See Shrimp and prawn.

Preserving. See Canning and preserving.

Products, comparison with former censuses, 10; value, by geographic divisions, 11,22 , 29; by Atlantic coast state groups, 11; in states on Chesapeake Bay, 12; on Great Lakes, 12; by commercial fisheries, 19 ; by species, $24,26,30,34$; by states, $25,34,44$ 79-279; by general classes, 26 ; by class of fisheries, 29 ; by apparatus of capture, 29 30,44 ; detailed statistics, 47-78; canning and preeerving, fish and oysters, by kind 281 ; quantity and value, 281, 282, 287; values of imports and exports, 288; exports, by kind, 291; by country to which exported, 291 ; imports, by kind and country from which imported, 292. See also Fishery products and Food products.

Property. See Shore and accessory property and cash.

Proprietors and independent fishermen, use of term, 14; number, by geographic divisions and by main branches of industry, 14 ; in $A$ tlantic coast division, 16 ; per cent distribution and per cent of total persons employed, 15; detailed statistics, by states, 79-279.

Purse seinee. Sce Seines.

Rakes. See Dredges, tongs, rakes, etc.

Razor clams. See Clams.

Red snapper. See Snapper.

Redfish, or rosefish; quantity and value, by geographic divisions, 27 ; by apparatus of capture, 30 ; by states, 38 .

Rhode Island, summary of fisheries, 13; persons employed, not including shoresmen, 18; value of apparatus of capture, 21 ; quantity and value of products, 25,$34 ;$ detailed statistics, 231-236.

Rock bass. See Bass.

Rockfish, quantity and value, by geographic divisions, 27; by apparatus of capture, 30 ; by states, 38 .

Roe. See Alewives and roe.

Rosefieh. See Redfish.

Round robin, quantity and value, by geographic divieions, 27 ; by apparatus of capture, 30 ; by states, 38 .

Rowboats. See Boats.

Sacramento pike. See Pike.

Sailboats. See Boats.
Sailor's choice, or pinfieh, quantity and value, by geographic divisions, 27 ; by apparatus of capture, 30 ; by states, 39

St. Clair River. See Lake St. Clair and St. Clair and Detroit Rivers.

St. Lawrence River. See Lake Ontario, including Niagara and St. Lawrence Rivers. Salaried employees, number, by geographic divisions and by main branches of industry, 14 ; in $\Lambda$ tlantic coast division, 16 ; per cent distribution and per cent of total persons employed, 15; detailed statistics, by states, 79-279.

Salaries, amount, by geographic divisions and by main branches of industry, $14 ;$ in Atlantic coast division, 16 ; by states, $79-$ 279 .

Salmon, rank in value, 24; quantity and value, by geographic divisions, 27 ; by apparatus of capture, 30 ; by states, 39 ; detailed statistics regarding, 69 ; canned and preserved, value, by geographic divisione, 281,287 ; by states, 283 ; by method of treatment, 283, 286, 287; quantity, 281, 287 ; exports of, 291 ; imports, by country from which imported, 292

Salt-water herring. See Herring.

Sardines, quantity and value, by geographic divisions, 27; by apparatus of capture, 30; by states, 39 ; canned and preserved, value, by geographic divisions, 281, 287; by states, 283,284 ; by method of treatment, 286, 287; quantity, 281, 287. See also Anchovies and sardines.

Scallop rims. See Scallops and scallop rims. Scallops, pounds of meat per bushel, 9; quantity and value, by geographic divisions, 28; by states, 42 . See also Scallops and scallop rims.

Scallops and scallop rims, comparison with previous census, 26; quantity and value, by geographic divisions, 28 ; by apparatus of capture, 32 ; by states, 42 .

Scup, quantity and value, by geographic divisions, 27; by apparatus of capture, 30 ; by states, 39

Sea bass. See Bass.

Sea grass, quantity and value, by geographic divieions, 28; by apparatus of capture, 32 ; by states, 44

Sea robin, quantity and value, by geographic divisions, 27 ; by apparatus of capture, 30 ; by states, 39 .

Sea-elephant oil. See Oil.

Seal oil. See Oil.

Seal skins, See Skins.

Seed oysters. See Oysters.

Seines, rank in apparatus of capture, 21; number and value, 22 ; quantity and value of products caught by, by geographic divisions, 29; by species, 30 ; by states, 44 .

- haul, rank in apparatus of capture, 21; number and value, 22 .

- purse, rank in apparatus of capture, 21; number and value, 22 .

Shad, origin of name, 9 ; rank in value, 24 ; quantity and value, by geographic divisions, 27 ; by apparatus of capture, 30 ; by states, 39; detailed statistics regarding, 71; frozen and fresh, quantity and value, by geographic divisions, 287.

hickory, origin of name, 9; quantity and value, by geographic divisions, 27 ; by apparatus of capture, 30 ; by states, 37 . Shark, quantity and value, by geographic divisions, 27 ; by apparatus of capture, 32 ; by states, 39 .

Sheepshead, origin of name, 9; quantity and value, by geographic divisions, 27; by apparatus of capture, 32 ; by states, 39 . Shellfish, exports of, 291.

Shells, mussel, comparison with previous census, 26; quantity and value, by geo- graphic divisions, 28; by apparatus of capture, 32 ; by states, 43 . See also Mussel shells, pearls, and slugs.

Shore and accessory property, use of term, 19 value, by commercial fisheries, 19. See also Shore and accessory property and cash

Shore and accessory property and cash value, by geographic divisions, 11,22 by $\Lambda$ tlantic coast state groups, 11 ; in states on Chesapeake Bay, 12; on Great Lakes, 12. See also Cash.

Shore and boat fisheries, salaries and wages 14, 16; persons employed, 14; per cent of total number, 15; number, in $A$ tlantic coast division, 16; in Chesapeake Bay district, 16; capital invested in, 19; average tonnage of vessels, 21, 23; number and value of apparatus of capture, 22 ; of products, 29; detailed statistics, by states, 79-279.

Shoresmen, use of term, 14; salaries and wages, 14,16 ; number omployed, 14 ; per cent of total number, 15; number, in Atlantic coast division, 16 ; in Chesapeake Bay district, 16.

Shrimp and other shellfish (except lobster) and turtles, imports, by country from which imported, 202. See also Turtles.

Shrimp and prawn, rank in value, 24 ; comparison with previous census, 26 ; quantity and value, by geographic divisions, 28; by apparatus of capture, 32 ; by states, 41 . detailed statistics regarding, 72 ; canned and preserved, value, by geographic divisions, 281,287 ; by states, 285 ; by method of treatment, 286, 287; quantity, 281, 287. Silver hake. See Hake.

Skates, quantity and value, by geographic divisions, 27; by apparatus of capture, 32 ; by states, 39

Skins, detailed statistics regarding, 73 .

- mink, comparison with previous census, 26; quantíty and value, by geographic divisions, 28 ; by apparatus of capture, 32 . by states, 43 .

muskrat, comparison with previous census, 26; quantity and value, by geographic divisions, 28; by apparatus of capture, 32 ; by states, 43 .

otter, comparison with previous census, 26 ; quantity and value, by geographic divisions, 28 ; by apparatus of capture, $3 \dot{2}$; by states, 43 .

seal, comparison with previous census 26; quantity and value, by geographic divisions, 28; by apparatus of capture, 32 ; by states, 43. See also Hides, pelts, and skins. Slides. See Wheels and slides.

Slugs. See Pearls and slugs and Mussel shells, pearls, and slugs.

Smelt, quantity and value, by geographic divisions, 28 ; by apparatus of capture, 32 ; by states, 39 .

Snapper, rank in value, 24; quantity and value, by geographic divisions, 28 ; by apparatus of capture, 32 ; by states, 39 ; detailed statistics regarding, 74 .

red, quantity and value, by geographic divisions, 28 ; by apparatus of capture, 32 ; by states, 39; detalled statistics regarding, 74

Soft clams. See Clams.

Soft crabs. See Crabs.

Sounds, quantity and value, by geographic divisions, 28; by apparatus of capture, 32 ; by states, 43 ; imports, by country from which imported, 292.

South America, value of exports of domestic fishery products to, 291; of imports, 293. South Atlantic states, fisheries of, 11; persons employed, calaries, and wages, 16. South Carolina, summary of fisheries, 13; persons employed, not including shoresmen, 18; quantity and value of products, 
25,34 ; detailed statistics, 237-241; oysters canned, 285; shrimp and prawn preserved, 286.

South Dakota, persons employed, not including shoresmen, 18; quantity and value of products, 25, 34; fisheries of, 241 , 242.

Spadefish. See Moonfish, angel-fish, or spadefish.

Spain, imports of fishery products, 282, 293.

Spanish mackerel. See Mackerel.

Spears. See Harpoons, spears, etc.

Sperm oil. See Oil.

Spider crabs. See Crabs.

Spiny lobster. See Lobster.

Sponge apparatus, value, 22; quantity and value of products caught by, by geographic divisions, 29.

Sponge fisheries, comparison with former censuses, 10.

Sponges, rank in value, 24 ; comparison with previous census, 26; quantity and value, by geographic divisions, 28; by apparatus of capture, 32 ; by states, 43 ; detailed statistics regarding, 74; exports of, 291; imports, by country from which imported, 293.

Spot, quantity and value, by geographic divisions, 28; by apparatus of capture, 32 ; by states, 39 .

Squeteague, rank in value, 24 ; quantity and value, by geographic divisions, 28 ; by apparatus of capture, 32 ; hy states, 40 ; detailed statistics regarding, 74 .

Squid, comparison with previous census, 26; quantity and value, by geographic divisions, 28 ; by apparatus of capture, 32 ; by states, 43.

States, fisheries by, 13, 25, 47-78; persons employed, 18; capital, 19; value of apparatus of capture, 21 ; detail summary, 34 ; products, by apparatus of capture, 44; detailed statistics, 79-279; canning and preserving, fish and oysters, value of by-products, 282 ; salmon product of canneries and packing houses, 283; sardines packed, 284; cod packed, 284, 285; oysters canned, 285; shrimp and prawn preserved, 286.

Steam and motor boats. See Boats.

Stone crabs. See Crabs.

Strawberry bass. See Crappie and strawberry bass.

Striped bass. See Bass.

Sturgeons, quantity and value, by geographic divisions, 28; by apparatus of capture, 32 ; by states, 40 ; detailed statistics regarding, 75; smoked, and frozen and fresh, quantity and value, by geographic divisions, 287. See also Sturgeons and caviar.

Sturgeons and caviar, canned and preserved, value, by geographic divisions, 281,287 ; by method of treatment, 286, 287; quantity, 287. See also Caviar.

Suckers, quantity and value, by geographic divisions, 28; by apparatus of capture, 32 ; by states, 40 .

Sunfish. See Bream and sunfish.

Surf clams. See Clams.

Surf-fish, or viviparous perch, origin of name, 9; quantity and value, by geographic divisions, 28; by apparatus of capture, 32 ; by states, 40 .

Susquehanna River district, fishery products of, 231.

Susquehanna River fisheries, persons employed, 12, 16; capital, and value of products, 12.

Sweden, imports of fishery products, 292. See also Norway and Sweden.

Swordfish, quantity and value, by geographic divisions, 28; by apparatus of capture, 32 ; by atates, 40 .
Tautog, quantity and value, by geographic divisions, 28; by apparatus of capture, 32 ; by states, 40 .

Tennessee, summary of fisheries, 13; persons employed, not including shoresmen, 18; quantity and value of products, 25,34 detailed statistics, 242-245.

Tennessee River. See Cumberland and Tennessee Rivers.

Terrapin, quantity and value, by geographic divisions, 28; by apparatus of capture; 32 ; by states, 43 . See also Terrapin and turtles.

Terrapin and turtles, comparison with previous census, 26 . See also Turtles.

Texas, summary of fisheries, 13 ; persons employed, not including shoresmen, 18; quantity and value of products, 25,34 ; detailed statistics, $245-250$.

Tomeod, quantity and value, by geographic divisions, 28; by apparatus of capture, 32 ; by states, 40 .

Tongs. See Dredges, tongs, rakes, etc.

Tonnage, by classes of vessels, 21 ; by geographic divisions, 21, 23.

Trammel nets. See Nets.

Transporting vessels. See Vessels.

Trap nets. See Pound nets, trap nets, and weirs.

Traps. See Pots and traps.

Trout, use of term, 9 .

brook, quantity and value, by geographic divisions, 28 ; by apparatus of eapture, 32 ; by states, 40 .

- lake, rank in value, 24 ; quantity and value, by geographic divisions, 28; by apparatus of capture, 32 ; by states, 40 ; detailed statistics regarding, 60 .

Turtles, quantity and value, by.geographic divisions, 28 ; by apparatus of capture, 32 ; by states, 43 . See also Terrapin and turtles and Shrimp and other shellfish (except lobster) and turtles.

United Kingdom, value of exports of domestic fishery products to, 291; of imports, $292,293$.

Utah, persons employed, not including shoresmen, 18

Venezuela, imports of fishery products, 292. Vermont, persons employed, not including shoresmen, 18 .

Vessel crew, use of term, 14.

Vessel fisheries, salaries and wages, 14, 16 persons employed, 14; per cent of total number, 15; number, in Atlantic coast division, 16; in Chesapealse Bay district, 16; capital invested in, 19,20 ; average tonnage of vessels, 21, 23; number and value of apparatus of capture, 22 ; of products, 29 ; detailed statistics, by states, 79-279.

Vessels, comparison with former censuses 10; use of term, 19; classes of, 20; capital invested in, 20, 22; average tonnage, 21,23 number and value, by geographic divisions, 23; detailed statistics, by states, 79-279.

fishing, capital invested in, 20, 22; average tonnage, 21, 23; number and value, by geographic divisions, 23.

- transporting, salaries and wages, 14, 16 persons employed, 14; per cent of total number, 15; number, in Atlantic coast division, 16; in Chesapeake Bay district, 16; capital invested in, 20,22 ; a verage tonnage, 21, 23; number and value, by geographic divisions, 23. See also Vessels, including outfit, and Vessels and boats, including outfit.

Vessels, including outfit, capital invested in, by geographic divisions, 22.

Pessels and boats, including outfit, value, by geographic divisions, 11; by Atlantic coast state groups, 11 ; in states on Chesa- peake Bay, 12; on Great Lakes, 12; by commercial fisheries, 19; detailed statistics, by states, 79-279. See also Boats.

Virginia, summary of fisheries, 13; persons employed, not including shoresmen, 18 ; capital, 19; value of apparatus of capture, 21 ; quantity and value of products, 25 34 ; detailed statistics, 251-262; canning and preserving, fish and oysters, value of by-products, 282; oysters canned, 285.

Wage-earners, number, by geographic divisions and by main branches of industry, 14; in Atlantic coast division, 16; per cent distribution and per cent of total persons employed, 15; general statistics regarding, 17; by states, $79-279$.

Wages, amount, by geographic divisions and by main branches of industry, 14; in Atlantic coast division, 16 ; general statistics regarding, 17 ; by states, 79-279.

Washington, summary of fisheries, 13; persons employed, not including shoresmen, 18; capital, 19; value of apparatus of capture, 21; quantity and value of products, 25, 34; detailed statistics, 262-270; canning and preserving, fish and oysters, value of by-products, 282 ; salmon product of canneries and packing houses, 283; rank in value, 283; cod packed, 284, 255; oysters canned, 285.

Weirs. See Pound nets, trap nets, and weirs.

West Indies, value of exports of domestic fishery products to, 291; of imports, 292, 293.

West Virginia, persons employed, not including shoresmen, 18; quantity and value of products, 25, 34; fisheries of, 270.

Whale fisheries, comparison with former censuses, 10.

Whale oil. See Oil.

Whale products, quantity and value, 24; comparison with previous census, 26 ; detailed statistics regarding, 76 .

Whalebone, comparison with previous census, 26; quantity and value, by geographic divisions, 28; by apparatus of capture, 32 ; by states, 43 ; exports of, 291 ; imports, by country from which imported, 293.

Whaling apparatus, quantity and value of products caught by, by geographic divisions, 29.

Wheels and slides, number and value, 22; quantity and value of products caught by, by geographic divisions, 29 ; by states, 45 . White bass. See Bass.

White perch. See Perch.

Whitefish, origin of name, 9 ; rank in value, 24 ; quantity and value, by geographic divisions, 28 ; by apparatus of capture, 32 ; by states, 41; detalled statistics regarding, 77 ; canned and preserved, value, by geographic divisions, 281, 287; by method of treatment, 286, 287; quantity, 287.

Whiting, origin of name, 9. See also Whiting and kingfish.

Whiting and kingfish, quantity and value, by geographic divisions, 28; by apparatus of capture, $32 ;$ hy states, 41 .

Winkles. See Cockles, winkles, and conchs. Wisconsin, summary of fisheries, 13; persons employed, not including shoresmen, 18; value of apparatus of capture, 21 ; quantity and value of products, 25,34 ; detailed statistics, 270-279.

Wyoming, persons employed, not including shoresmen, 18.

Yellow perch. See Perch.

Yellowtail, quantity and value, by geographic divisions, 28; by apparatus of capture, 32 ; by states, 41 . 

RETURN TO the circulation desk of any University of California Library or to the

NORTHERN REGIONAL LIBRARY FACILITY Bldg. 400, Richmond Field Station University of California

Richmond, CA 94804-4698

ALL BOOKS MAY BE RECALLED AFTER 7 DAYS

- 2-month loans may be renewed by calling (510) 642-6753

- l-year loans may be recharged by bringing . books to NRLF

- Renewals and recharges may be made 4 days prior to due date.

DUE AS STAMPED BELOW

\section{J JUN 072001}

6481567 
No 834922

U.S. Bureau of the 1908

census. B2fi

Fisheries of the

United States, 1908.

UNIVERSITY OF CALIFORNIA

DAVIS 
